Universidade de São Paulo

Faculdade de Arquitetura e Urbanismo

Caroline Gabriel Pedro

Pietro Maria Bardi, cronista em revista: 1976-1988

São Paulo

2014 

Caroline Gabriel Pedro

\section{Pietro Maria Bardi, cronista em revista: 1976-1988}

Dissertação apresentada como requisito à obtenção do grau de Mestre em Arquitetura e Urbanismo, no Programa de Pós-Graduação em Arquitetura e Urbanismo, Área de Concentração História e Fundamentos da Arquitetura e do Urbanismo da Faculdade de Arquitetura e Urbanismo da Universidade de São Paulo

Luciano Migliaccio orientador

São Paulo 2014 
Autorizo a reprodução e divulgação total ou parcial deste trabalho, por qualquer meio convencional ou eletrônico, para fins de estudo e pesquisa, desde que citada a fonte. e-mail: carolpedro@usp.br

Pedro, Caroline Gabriel

Pietro Maria Bardi, cronista em revista: 1976-1988 |

Caroline Gabriel Pedro — São Paulo, 2014. 803 p. : II.

Dissertação (Mestrado - Área de Concentração História e

Fundamentos da Arquitetura e do Urbanismo) — FAUUSP.

Orientador: Luciano Migliaccio.

1. Revistas 2. Artes 3. Crítica de Arte 4. Bardi, Pietro Maria (1900-1999)

5. Museu de Arte de São Paulo Assis Chateaubriand.

I. Título.

CDU7 
Agradeço imensamente ao meu orientador, Luciano Migliaccio, pela paciência confiança e oportunidade; a todos os que se preocuparam, facilitaram e tornaram possível a realizaçáo desta pesquisa, a Paula Alzugaray, ao querido Eduardo Cruz, e a Dílico Covizzi, aos funcionários dos acervos consultados (especialmnete a Lucila, da FAU, Natan e Beatriz, da BMA) aos entrevistados, Fábio Magalhães e Mino Carta, toda a equipe do Centro Universitário Maria Antonia, (especialmente Lara’nja, Gabi, Ana Avelar, João e Tuca) além da incrível Suzana e da Val, minha mais recente aquisição.

Agradeço também a toda milha família, que mais uma vez me apoiou nessa empreitada desde o início, principalmente à minha mãe, Hildes, que é o meu maior anjo, e a Clayton, meu maior amor. 

Dedico este trabalho à princesinha Marina, que não me sai da cabeça. 



\section{Resumo}

Pietro Maria Bardi, "cronista" de arte, arquitetura, design (e de muitos outros temas) e galerista experiente na Itália, veio ao Brasil em 1947, aos 47 anos. Trouxe consigo sua segunda esposa, Lina Bo Bardi, e uma coleção de arte a ser exposta no Ministério da Educação e Saúde, no Rio. Foi tão logo convidado por Assis Chateaubriand, diretor da cadeia de jornais Diários Associados, (Diário de S. Paulo etc.) a organizar um Museu de Arte "Antiga e Moderna," que resultou no Museu de Arte de São Paulo-Masp. Tinha por intenção criar um museu vivo organizando, vinculados ao Masp, o Instituto de Arte Contemporânea-IAC, e a Escola de Propaganda, embriāo da atual Escola Superior de Propaganda e MarketingESPM, as primeiras tentativas, no Brasil, de uma escola de design e de publicidade. Suas iniciativas buscavam atrair público e tornar a arte acessível, contribuído para que fosse produzida com qualidade pelos brasileiros para os próprios brasileiros, através da conscientização de apreciadores e patrocinadores dessas manifestaçóes. Assim, Bardi, ciente do papel da publicidade, percebia a importância de divulgar tudo relativo às iniciativas do Masp e à arte. Usava como veículos a rede dos Diários, a Habitat (a revista do Masp), a Mirante das Artes \& etc. (a revista homônima de sua galeria) e periódicos diversos, principalmente os geridos pelas famílias Carta e Alzugaray. Esses textos brasileiros do diretor e criador do maior museu da América Latina ainda não foram oficialmente compilados nem analisados, especialmente em virtude da dificuldade em acessá-los. Esta pesquisa, um primeiro passo para essa importante e trabalhosa tarefa e concentrou-se em seus artigos publicados nos magazines Casa Vogue, Homem Vogue, Arte Vogue, Senhor Vogue, Senhor e Istoé, no intervalo de 1976 à 1988, período que compreende sua primeira aparição como colaborador nas revistas de Vogue, até a fusão, em I988, das revistas Senhor e Istoé, da Editora Três.

\section{Palavras-chave}

Revistas; Artes; Crítica de Arte; Bardi, Pietro Maria (I900-I999);

Museu de Arte de São Paulo Assis Chateaubriand. 



\section{Abstract}

Pietro Maria Bardi was a journalist and author who wrote about art, design and architecture (along with many other subjects) and an experienced gallerist in Italy. He came to Brazil in 1947, at the age of 47 . He brought his second wife, Lina Bo Bardi, and a collection of art to be exhibited in the Health and Education Administration, in Rio de Janeiro. Later Bardi was invited by Assis Chateaubriand, the Diários Associados's director, to create an Ancient and Modern Art Museum. This resulted in the creation of the São Paulo Art Museum-Masp. He wanted to create a "living" museum, by which he meant a museum with a more interesting and interactive experience. He combined the Contemporary Art Institute-IAC, the first Brazilian design school, with an advertising school, all under one roof. His goal was to make all kinds of art accessible to everybody, contributing to its creation and quality, by brasilians for brasilians, he did this with the conscientiousness of a connoisseur and with the sponsorship of the art community. Thus, Bardi, conscious of the role of marketing realized the true importantance of advertizing everything related to Masp's exhibitions and other initiatives. Alongside the Chateaubriand's media, Bardi also advertised and wrote article in the Habitat (the Museum magazine) and Mirante das Artes \& etc. (the homonym magazine of his art gallery) magazines and other periodicals like the ones directd by Carta and Alzugaray families. These brazilian articles on art and other related topics, produced by the creator and director of the most important latin american art museum, were never compiled or analysed, most likely because of the difficulty to access them. This research is intended to be the first step of this important and laborious task and focuses on Bardi's writings published in Casa Vogue, Homem Vogue, Arte Vogue, Senhor Vogue, Senhor e Istoé magazines, between 1976 and 1988 , from his first showing as collaborator in Vogue to the merger of Senhor e Istoé magazines, of Editora Três.

Keywords

Magazines; Arts; Art Criticism; Bardi, Pietro Maria (1900-1999);

Museu de Arte de São Paulo Assis Chateaubriand 

I

- IntroduÇão

Trajeto da pesquisa

7

7 I.I. Bardi: cronista, galerista, cronista

I2 I.2. O boicote das mídias

I4 I.3. A retomada da comunicação

I5 I.4. Os Carta

I9 I.5. Alzugaray

20 I.6. Editora Três e Encontro Editorial

2I

2I

23

25

27

28

35

2.6. Istoé

2.6.I. Istoé, até 1988

2.6.2. Istoé Senhor, a partir de I988

$4 \mathrm{I}$

$4 \mathrm{I}$

- Capítulo 2 Revistas

2.I. Vogue Brasil

2.2. Casa Vogue

2.3. Arte Vogue

2.4. Homem Vogue

2.5. Senhor Vogue

2.5.I. Senhor

- Capítulo 3 Assuntos recorrentes

I.I. Arte

I.I.I. Pintura

I.I.2. Escultura

I.I.3. Arquitetura, urbanismo, engenharia

I.I.4. Design

I.I.5. Propaganda, marketing

I.I.6. Moda

I.I.7. Artesanato

I.I.8. Mercado da arte, colecionismo 
53 I.2 O Museu do Bardi

I.2.I. Assis Chateaubriand

I.2.2. Lina Bo Bardi

I.2.3. A criação do Masp

I.2.4. A montagem do acervo

I.2.5. Os cursos no Masp

I.2.6. As exposiçóes

I.2.7. As publicaçóes relacionadas ao Museu

I.2.8. Bardi, amigo

66 I.3 Outras iniciativas

I.3.I. Francesco Matarazzo

I.3.2. Bienais

I.3.3. Patrocinios

I.3.4. Bardi ao avesso da crítica

75

- Conclusấo

79 - ApÊndice

80 Diagrama: Linha do tempo

8I Quadro \# I Casa Vogue

83 Quadro \#2 Homem Vogue

84 Quadro \#3 Senhor

98 QuAdro \#4 IstoÉ

99 - Anexo A Textos de P.M. Bardi em colaboraçóes regulares ou pontuais

63I - Anexo B Outros autores em colaboraçóes regulares de P.M. Bardi

657 - Anexo C Sobre P.M. Bardi

691 - Anexo D Arte Vogue

78I - Bibliografia 


\section{Introdução}

Pietro Maria Bardi, "cronista" de arte, de arquitetura (e de muitos outros temas) e galerista experiente na Itália, veio ao Brasil em I947, aos 47 anos. Trouxe consigo uma coleção de arte, que logo foi exposta no Ministério da Educação e Cultura, no Rio, já com intuito de organizar um Museu de Arte "Antiga e Moderna," que desde 1946 já vinha sendo delineado a convite de Assis Chateaubriand, diretor da cadeia de jornais e emissoras Diários Associados. Desse convite surgiu o Museu de Arte de São Paulo-Masp. O acervo do museu foi montado entre 1947 e 1953, tornando-se o principal da América Latina. Esse acervo foi selecionado por Bardi no Brasil, entre colecionadores, pelo amor ou pela dor do mecenato, e na Europa pós-guerra. Suas iniciativas avançaram também, por exemplo, no campo da educação, quando criou, vinculado ao Masp, o Instituto de Arte Contemporânea-IAC, e posteriormente a Escola de Propaganda do Museu, embriáo da atual Escola Superior de Propaganda e Marketing-ESPM. IAC e Escola de Propaganda eram, na visão de Bardi, escolas que fariam a "arte" acessível a toda a população, produzida com qualidade pelos próprios brasileiros para os brasileiros.

Através da rede de comunicações disponibilizada por Chateaubriand, Bardi pôde veicular suas intenções e ideias, quase sempre relacionadas ou ao Museu ou a um projeto de modernização do Brasil. Sua opinião sobre arquitetura, artes visuais e até política foram também divulgadas, ao longo de seus mais de cinquenta anos de atuação no Brasil, em periódicos diversos, ou de produção própria (Habitat, Revista Mirante das Artes \& etc.) ou, após a morte de Chateaubriand, em publicaçóes ligadas à família Carta ${ }^{\mathrm{I}}$ (Homem Vogue, Casa Vogue, Arte Vogue, Senhor Vogue, Senhor, Istoé Senhor e Istoé)

O levantamento de sua participação nos periódicos acima relacionados foi possível pela própria autocitação que Bardi costumeiramente fazia em seus textos. A princípio, seriam colocados todos os textos de Bardi publicados em

I Outras publicações que deram a Bardi espaço de colaboração permanente, se houveram, não foram encontradas até o final desta pesquisa. 
Senhor Vogue, Senhor, Istoé e Istoé Senhor, que resultaria no período de 1976 a 1993. Porém, como era de seu feitio indicar tudo o que ele estava produzindo nas outras publicações, (talvez por autoafirmação de si/do Masp, talvez por consciência da importância da comunicação, talvez pela proximidade temporal da produção desses textos, provavelmente por tudo isso somado) acabaram entrando nesta seleção a Homem Vogue e a Casa Vogue, além de artigos avulsos em Vogue Brasil \# I (maio 1975; Editora Três; cf. Anexo A, p.Ioo) e \#II5 (fev. 1985; Carta Editorial; cf. Anexo C, p.666) e Status \#I36 (nov. 1979; Editora Três; cf. Anexo A, p.652). Deste modo, foi necessário restringir a pesquisa a pouco mais de uma década de contribuição com as publicações dos Carta, (Carta Editorial e Editora Três) de 1975 a 1988, para que fossem incluídas todas as publicações dessa fase, mesmo quando pontuais.

Desta maneira, o período de seleção vai de 1975, quando foi publicado o primeiro artigo em Vogue, a 1988, quando houve a fusão dos títulos Istoé e Senhor. O recorte funcionou como um limitante, dado o volume de textos encontrados, tendo-se em conta que no período pós-fusão havia grande repetição de temas desta primeira amostragem. O segundo período, de 1988 a 1992 (quando são encontrados os últimos artigos de Bardi publicados ${ }^{2}$ em Casa Vogue e Istoé) deverá ser disponibilizado e analisado em pesquisa futura: outra ponta a ser amarrada no corpo de pesquisa relativo a Bardi.

O corpo analítico desta monografia resume-se a dois capítulos. No primeiro, a história pessoal de Bardi é contada rapidamente, numa tentativa de ligar sua atuação italiana, como jornalista e galerista, com a brasileira, como diretor de museu e "cronista" da arte. Também no primeiro capítulo, esta pesquisa se propóe a contar brevemente a história das principais publicaçóes relacionadas à história jornalística e artística da família Carta, visto ainda não existir tal fonte. Além da comparação entre todos os expedientes das revistas levantadas, uma entrevista a Mino Carta foi essencial para que algumas dúvidas fossem sanadas.

No segundo capítulo é apresentada uma breve história de cada uma das publicaçóes, como eram apresentados os textos de Bardi, algumas interrelaçóes

2 O último artigo publicado de Bardi na Istoé foi no volume \#II99 (23 set. 1992) e em Casa Vogue, o último artigo foi no volume \#2 de i990. (Importante ressaltar que a coleção de Casa Vogue disponível para consulta em acervos públicos está incompleta, e certamente esse não foi o último artigo de fato.) Oficialmente, entretanto, seu nome aparecerá no expediente, entre os colaboradores de Istoé, até a edição \#I255 (20 out. 1993). Em Casa Vogue, aparecerá no expediente até o volume \#2 de 1993. (Considerando-se que o vol. \#3 não esteve disponível para consulta e no volume \#4 já não constava o nome de Bardi no expediente.) 
com os outros títulos, além da exposição de alguns recursos empregados por Bardi para se relacionar com o público específico de cada título.

Já no terceiro capítulo, procurou-se fazer também um levantamento dos principais temas discutidos por Bardi durante o período de recorte nas fontes levantadas, além da análise de alguns aspectos do discurso de Bardi como cronista no Brasil.

No apêndice, pode-se consultar um diagrama ilustrativo da linha do tempo dessas publicações. Ele foi construído numa tentativa de tornar mais rapidamente inteligível o encontro e fusão dos títulos de relevância para esta pesquisa, localizando-as visualmente entre si e relativamente a alguns outros títulos de relevância na história das publicaçôes brasileiras.

No apêndice, ainda, podem-se consultar os quadros que relacionam todos os títulos dos textos de Bardi encontrados nas publicaçôes dentro do período considerado, informando a editora, os diretores da edição (normalmente os Carta ou os Alzugaray, como será visto) além outras informaçóes pertinentes às contribuições. Esses quadros servem como uma espécie de índice para os Anexos, onde estão todos os textos encontrados em ordem cronológica.

No Anexo A encontram-se todos os textos assinados e atribuídos a Bardi nas revistas Istoé pré-fusão, Casa Vogue, Homem Vogue, Senhor Vogue e Senhor, e em publicaçóes para as quais o próprio Bardi menciona como havendo contribuído, mas de maneira pontual (Vogue Brasil e Status)

Algumas das colaboraçóes de Bardi contaram com outros autores e, numa tentativa de não quebrar essa relação de afinidade intelectual, além de estabelecer relaçôes com o contexto histórico, esses textos não foram descartados, estando disponíveis para consulta no Anexo B.

O Anexo C compreende textos, nestas publicaçóes, que abordem como tema a figura de Bardi, seja por outros autores, seja por ele mesmo.

Os seis volumes da publicação Arte Vogue, avulsa nos dois primeiros números e anexada à Casa Vogue nos quatro números seguintes, foram consultados em sua integridade. Alguns trechos da Arte Vogue, assinados ou não por Bardi, entretanto, foram reproduzidos no Anexo D, na íntegra, dado sua pertinência relativa ao discurso de Bardi ou simplesmente por terem sido entendidos de grande importância para outras pesquisas, buscando-se, assim, facilitar-lhes o estudo. Os textos de Arte Vogue que não foram aqui reproduzidos estão relacionados em índice próprio também no Anexo $\mathrm{D}$, tendo em mente também a divulgação para futuras pesquisas. Entretanto, dada a 
importância temática e formal desta publicação, é considerada merecedora de atenção exclusiva em pesquisa consecutiva mais aprofundada.

O principal objetivo é que todo esse conteúdo se torne acessível, já que, infelizmente, não foram ainda digitalizados nem disponibilizados em conjunto.

\section{Trajeto da pesquisa}

Como não raro, o resultado desta pesquisa está completamente distante do que se propôs em seu início. A princípio, pretendia-se levantar como a obra de Roberto Sambonet se modificou a partir de sua permanência no Brasil, entre I949 e I954, sabendo-se que seu contato com Pietro Maria Bardi teve fundamental importância, e como sua estadia pode ter se refletido em artistas e designers que com ele conviveram. Seria uma continuação mais aprofundada da pesquisa realizada para o Trabalho Final de Graduação, \{Pedro, 20Io\} com a introdução de informaçôes inéditas em relação ao TFG disponíveis principalmente no acervo do Instituto Lina Bo e Pietro Maria Bardi. Constatou-se, então, a impossibilidade de consultar tal arquivo, além da falta de novas informaçôes em outros locais.

Assim, esta dissertação seguiu outro caminho a partir de algumas constataçóes. Primeiro, era bastante presente a figura de Pietro Maria Bardi nos rumos que Sambonet tomou enquanto esteve no Brasil, e mesmo depois de seu retorno à Itália. Ao que Enrico Morteo, arquiteto, crítico e historiador de design italiano, um dos principais estudiosos da obra de Sambonet, declarou certa vez, em uma palestra na FAUUSP: "Foi de grande vantagem para Sambonet a capacidade para abandonar preconceitos e excessos de sua cultura europeia para se dedicar a atividades inéditas sugeridas por Bardi e que tornam sua abordagem tão original." \{Morteo, E. 2009\} Soma-se a isso o fato de boa parte do que se tem sobre Sambonet no Brasil estar relacionado com o Museu de Arte de São Paulo-Masp, com as publicações que Bardi dirigia ou participava e, numa rápida análise, com o próprio Bardi. Numa disciplina sobre design deste programa de Pós-Graduação, ministrada pelo professor Dr. Marcos da Costa Braga, era necessário que se desenvolvesse uma monografia a ver com o tema da pesquisa, mas ainda, até aquele período, não fora possível de se realizar dada a impossibilidade mencionada de se acessar as novas informaçôes no Instituto, constatando-se que não haveria tempo hábil para o desenvolvimento da monografia a ver com Sambonet, se se dependesse do acesso ao 
tal acervo. A partir da sugestão do professor da disciplina, foi elaborada uma monografia sobre os textos que Bardi havia escrito sobre design, selecionados de alguns periódicos, que se tornou a luz no fim do túnel para o desfecho desta dissertação. Por último, constatou-se então que simplesmente não existe nenhuma compilação nem estudo sobre essa obra "periódico-permanente" de Bardi como já existe para a obra escrita de Lina Bo Bardi, sua esposa. Constatou-se também, surpreendentemente, que não existe nenhum estudo sobre o percurso de boa parte dessas publicaçóes em si, de modo que, exposto como se segue, configura-se um relatório inédito.

Sob a instrução do orientador, Luciano Migliaccio, foram levantados então todos os textos encontrados publicados não por coincidência, como se verá, pelas editoras da família Carta, assinados ou atribuídos a Bardi, entre I975 e 1988.

As publicações foram consultadas em diversos acervos de São Paulo: fauUsp, feausp, ECAusp, Biblioteca Mario de Andrade, Editora Três. O objetivo era levantar todos os textos no período de recorte, em todas essas publicaçôes, mas alguns dos volumes das publicaçóes Casa Vogue e Homem Vogue não foram encontrados. Constatou-se que os outros possíveis acervos que talvez os possuíssem (Carta Editorial, Editora Globo Conde Nast, Arquivo Público do Estado de São Paulo, Museu de Arte de São Paulo, Instituto Lina Bo e Pietro Maria Bardi) não estão ainda organizados ou simplesmente não os possuem. Espera-se que sejam encontrados e disponibilizados o mais breve possível para preencher essa lacuna.

Outras etapas dessa pesquisa deverão ser a disponibilização dos textos faltantes do período pós-fusão (I988-I993), disponibilização e análise mais aprofundada de Arte Vogue, confirmação da participação ou não de Bardi em $O$ Cruzeiro, além da análise mais precisa desses escritos à luz das teorias defendidas e operadas por Bardi ao longo de sua vida, incluindo-se o período na Itália. 


\section{Capítulo 1 Colaboração: Bardi em Carta}

A relação de Pietro Maria Bardi com os membros da família Carta se inicia em 1946. Bardi faz uma breve parada no Brasil, em dezembro daquele ano, para se encontrar com Assis Chateaubriand e discutir mais detalhes sobre o Museu. Mino Carta conta que, na noite de 24 de dezembro de 1946, ele, com 12 anos, e seu irmão, Luis Carta, com Io anos, passavam a noite de natal com o pai na casa de um amigo da família. Conheceram ali Pietro Maria Bardi e Lina Bo, sua segunda esposa, recém-chegados de Buenos Aires. O casal poderia ter voltado direto da exposição que inauguraram na Argentina para a Europa, mas fizeram parada no Brasil para se encontrar com Assis Chateaubriand, que pretendia empreender um museu. ${ }^{3}$

Nos anos 1970, quando Bardi retoma comunicação com a sua audiência, através das publicações da família Carta, isso se dá justamente na época da primeira exposição de Mino Carta no Masp, em 1975. Neste mesmo ano é publicado artigo em Vogue \#I (maio 1975).

Assim, segue-se um breve relato da história pessoal de Bardi, dos Carta e Alzugaray, e da história das editoras com as quais Bardi se envolveu, canais de comunicação a ele disponibilizados após o falecimento de Assis Chateaubriand.

\section{I.I. Bardi: cronista, galerista, cronista}

Pietro Maria Bardi conta sua vida diversas vezes como se conta uma anedota. A biografia de Bardi será (incontavelmente) apresentada pelos textos que ele escreveu, disponibilizados em anexo. Entretanto, será apresentado um breve resumo, de modo a ligar essa personagem a outras importantes para o entendimento de como aconteceram as colaboraçóes de Bardi com os periódicos selecionados.

Mino Carta, declaração verbal em II fev 2014. 
A formação fundamental de Bardi foi feita num autodidatismo improvisado, logo após abandonar o ensino elementar por ter repetido três vezes o terceiro ano e trabalhando assim cedo (cerca de I3 anos) como contínuo num escritório de advocacia. Ali percebeu a importância de saber ler e escrever e passa a estudar a biblioteca do advogado que o contratara. A seguir, trabalhando como operário-aprendiz no Arsenal Marítimo, o maior contato que teve com magazines e arte era através da revista L'Eroica, que circulava na regiáo. Aos 17 anos, envia seu primeiro artigo, sobre o pintor Francesco Gamba, para a revista Gazzetta di Genova, que é publicado, e outro, logo a seguir, para a publicação Avanti! sobre o utilitarismo de Jeremy Bentham ${ }^{4}$ que, além de publicado, foi remunerado. Entretanto, logo com o início da I Guerra é chamado ao ofício bélico. Ali percebe o provincianismo do italiano-médio que não se interessava por assuntos além-paese ou, inclusive, por aprender a escrever. Começa então a exercer função de transcritor das cartas dos recrutas analfabetos. Ao ser dispensado, com 2I anos, logo consegue um lugar como repórter no Il Giornale di Bergamo. \{TENTORI, 2000, p.19-24\}

A essa altura, Bardi já era definitivamente letrado e suficientemente culto para adentrar no campo que em breve se arriscaria: o das artes. Mas não sem antes treinar o seu lado mais "obstinado." Em diversos momentos, Bardi criticou velada ou abertamente certas incoerências que ele via em relação ao fascismo (do qual era simpatizante), e mesmo sofrendo as consequências de seu posicionamento, manteve esse tipo de postura aparentemente por toda a vida, conforme se pode verificar em seus textos publicados no Brasil (cf. Anexos): "aderindo talvez à revolução de Mussolini, sempre usei a liberdade de polemizar, com bastante severidade e irreverência, tanto que acabei sendo posto em desgraça." \{BARDI, Senhor \#363, 7 mar. 1988, p.73\}

A adesão de Bardi ao Fascismo não foi sem críticas aos aspectos do regime que considerava retrógados ou violentos. Como redator do Giornale di Bergamo foi vítima da violência de grupos fascistas por se recusar a publicar um artigo elogioso sobre a Marcha sobre Roma, em 1922. Sucessivamente tentou estimular o regime a adotar uma política favorável aos arquitetos racionalistas polemizando contra o mau gosto da Itália oficial com o Tavolo degli Orroris e apoiando o projeto modernista para o nova estação ferroviária

4 Jeremy Bentham, (I748-I832) filósofo e jurista inglês. Bardi frequentemente menciona esse seu artigo, conforme se verá.

5 A Mesa dos horrores foi uma grande fotomontagem com tudo o que Bardi considerava de pior na arquitetura classicizante produzida principalmente 
de Florença de Giovanni Michelucci. Esse tipo de posicionamento crítico aparentemente contraditório poderá ser observado em diversos artigos que Bardi viria a escrever no Brasil: ao mesmo tempo em que simpatizava com os beneméritos mecenas da sociedade dos quatrocentôes paulistas, criticava-lhes a falta de gosto, e tentava, a seu modo educar-lhes justamente a respeito do que ele considerava "bom" gosto, além da importância da arte. Ao mesmo tempo em que criticava o provincianismo brasileiro em relação à aquisição de obras de arte nacional e sua consequente supervalorização em leilóes locais, contribuía como podia para esse mercado (p.ex., adquirindo obras de jovens artistas brasileiros que náo haviam ainda atingido valor de mercado ou promovendo feiras de antiquários no vão do Masp) e sempre elogiava as inciativas a respeito do comércio de arte; ao mesmo tempo em que criticava "as madames artistas," incentivava que as atividades artísticas fossem apreciadas, estudadas, ensinadas, comercializadas, adquiridas e - por que não? - realizadas por um sempre crescente número de interessados. Seu esforço era por uma apreciação refletida, inequívoca e clara das atividades pré-artesanais, artesanais e artísticas - munindo-se de conceitos que ele também estendeu ao design, que gera objetos destinados a alguma utilidade, produzidos em escala industrial - e sua consequente justa valorização.

Voltando à formação de Bardi, seu aprofundamento no campo da arte se daria crescentemente desde o supracitado artigo sobre Francesco Gamba até assumir a Galleria d'Arte di Roma, passando pelas Galleria L'Esame e Galleria Bardi, ambas em Milão.

Mesmo dedicando-se a atividades de comercialização e exposição das obras de artistas daquele momento, e distanciando-se dos grandes jornais, Bardi nunca se afastou da atividade periodista, fundando as próprias revistas:

Começo minha carreira, diria, de galerista, o que deve ter sido no ano de 25, me parece. Adquiro a Galleria L'Esame do renomado escritor Enrico Somaré, e abro a Galeria Bardi. Debuto no inarticulado mercado da arte contemporânea, depois no da arte antiga, e, pelo vício do papel impresso, fundo meu quinzenal de arte, Belvedere (disseram-me que uma coleção deste jornal foi vendida recentemente por mil dólares) devotado às mudanças. (...) Nos primeiros anos da década de 30 me chamam da Capital para dirigir a Galleria d'Arte de Roma, oficial. ${ }^{6}$ Para ter minha plataforma de discussão, fundo e

para os órgãos e monumentos do partido naquele momento, na Itália.

6 "Galeria pública implantanda - como diz cada um de seus folhetos e boletins - 'sob os auspícios do Sindicato Nacional 
dirijo com Massimo Bontempelli a revista Quadrante, e promovo a campanha da arquitetura racional. \{BARDI, Vogue Brasil \#II5, fev. I985, passim\}

Depois de colaborar e dirigir diversos jornais italianos e lançar as próprias revistas de suas galerias, Bardi escreverá ainda em outros títulos: no L’Ambrosiano (1930-1933) que ele dirigiu; no Meridiano di Roma (1936-1938) onde ele defendeu persistentemente a nova arquitetura até terminar "com a imposição de silêncio a Bardi" \{TENTORI, 2000, p.I30\}; nas revistas Il Vetro (contribuiçóes anônimas, por algum tempo) e Lo Stile antes de embarcar para o Brasil.

Uma observação: Bardi organiza a exposição de pinturas de Renato Scarpelli, acontecida na Galleria dell'Esame, recém-adquirida de Enrico Somaré, em Milão,7 em dezembro de 1926. Segundo Tentori, Scarpelli era amigo bergamasco de Bardi e irmáo do diretor do Giornale di Bergamo. \{TENTORI, 2000, p.28-3I Neste caso, há um indício para o estabelecimento de um paralelo ao inverso: na Itália, os contatos pessoais de Bardi no jornalismo facilitaram sua atuação como galerista, assim como, no Brasil, sua atuação como galerista e, principalmente, diretor do Masp, facilitaria sua inserção como "paginista," "cronista" das revistas com as quais viria a colaborar permanente ou pontualmente.

No Brasil, na época da chegada de Bardi em 1946, soma-se ainda o fato do mercado editorial ser gerido por praticamente só estrangeiros, a maioria dos quais italianos como ele: a conterraneidade parece ter sido um grande facilitador para sua colaboração com os Carta, especialmente após a perda do canal dos Diários com a morte de Chateaubriand, em i968. Alíás, toda a experiência de Bardi adquirida em sua carreira como articulista - ele contribuiu, entre 1920 e 1926, com o Giornale di Bergamo, a Rivista di Bergamo, a Gazetta di Genova, o Il Popolo de Bérgamo, Il Secolo e Corriere della Sera, de Miláo, e foi redator do Indipendente de Savona e do Il Popolo de Bérgamo - não foi ignorada por Chateaubriand, que, além de chamá-lo para a empreitada do Museu, o convidou também para a direção geral dos Diários Associados:

Aos vinte e poucos anos, renomado jornalista graças àquela spirito-
saggine e, também, por ter produzido alguns furos de repercussão
internacional, me vi até disputado pelos grandes jornais de Milão.

Fascista de Belas-Artes.”' \{TENTORI, 2000, p.44\}

7 A galeria localizava-se na via Brera 7 e foi adquirida com o fundo recebido pela demissão de Bardi do Corriere della Sera, após discordar de Ugo Ojetti. 
Passei a ser redator do Il Secolo e, depois, do Corriere della Sera. Deixei esta Meca do carreirismo para me dedicar a um outro vício mais preferido, o de mexer com as coisas de arte. (Revelo estas historietas jornalísticas por terem elas exercido uma espécie de reflexo em minha temporada brasileira: quando o caro amigo Chateaubriand descobriu minhas antigas andanças no campo do papel impresso fez questão de que o recém-chegado de um país derrotado na guerra tivesse uma participação verde-amarela, investindo-o nada mais nada menos na condição de diretor-geral dos Diários Associados. Durante certo tempo a exerci muito a contragosto e sem brilho: mas como o Capitão mandara.) \{BARDI, Senhor Vogue \#II, fev. 1979, p.79-80\}

Bardi menciona o fato novamente em Senhor \#206, 27 fev. 1985, p.8I “...o amigo Assis me incumbiu até da direção geral dos Diários Associados” e em Senhor \#24I, 30 out. 1985, p.II6: “...por pouco tempo eu tive o cargo de diretor-geral [dos Diários Associados], vindo a conhecer até segredos, que não revelei no meu livro Sodalicio com Assis Chateaubriand."

No começo do Masp, através da rede de comunicaçóes disponibilizada por Chateaubriand, Bardi tinha carta branca para veicular suas intençóes e tudo mais o que o convinha, principalmente as iniciativas relacionadas ao Museu - e são inúmeros os artigos de Bardi publicados nos Diários disponibilizados pela Biblioteca do Masp. Entranto, Bardi sentia e declarava sofrer certo boicote por parte das outras cadeias de informaçôes, como Folha e Estado. Ele tinha contato claramente muito próximo a Chateaubriand: este sim malquisto pelos concorrentes nas comunicaçóes, entre outros motivos, pelo dado uso que ele fazia do poder político de seus Diários e Emissoras Associados. E, antes disso, Bardi fora afiliado ao partido fascista italiano e teve contato próximo Mussolini. Isso se deu na época não militarizada do fascio, mas, de fato, continuou após sua militarização e políticas de discriminação racial. Entrentanto, conforme nos descreve Francesco Tentori, apesar de sua associaçáo ao partido, Bardi sempre esteve ligado com grupos pró-semitas, como o de Quadrante, onde se encontravam Ernesto Rogers, Adriano Olivetti, Masino (judeus) e Bontempelli (pró-judeus), e, ao que tudo indica, nunca deixou de se relacionar ou expor artistas por questôes raciais na Itália e, posteriormente, no Brasil. \{TENTORI, 200o, p.I5\} Assim, a colaboração de talentos de qualquer proveniência mostra o desligamento de Bardi das questóes raciais. Com o fim da II Guerra e a derrota do fascismo, Bardi nunca negou sua associação anterior ao partido e, ao contrário, não parecia se importar em lembrar o fato, normalmente assegurando sua tentativa de afirmar a arquitetura racionalista como a 
oficial de Mussolini, como em todas as vezes em que menciona o Tavolo degli Orrori.

O próprio Bardi declara que, com o passar do tempo foi afastando-se cada vez mais do partido, até ser expulso: "É bom saber que, por não concordar com certas novidades do fascismo (acreditava nos seus princípios) era dissidente cada vez que vinham à tona sujeitinhos insuportáveis e decretaram-me fora do partido.” \{BARDI, Vogue Brasil \#II5, fev. 1985, passim\}

Apesar disso, a associação semântica de $\mathrm{Bardi}^{8}$ ao fascismo seria sempre reforçada negativamente por seus arquicríticos no Brasil.

\section{I.2. O boicote das mídias}

Um exemplo dessa associação foi logo no recém-inaugurado Museu de Arte de São Paulo, quando, numa conferência de Flávio de Carvalho, em que este pediu a opinião do "professor" Bardi, que estava na plateia: outro participante na plateia, o crítico do Estado de S.Paulo Ciro Mendes, interrompeu a fala da F.C. e começou a acusar Bardi de "carcamano, fascista," ao que Bardi respondeu da maneira mais irrefletida: "agarrei-o pelo colete e lhe dei um murro de mandá-lo para o hospital."

Outro problema era a proximidade de Bardi com Assis Chateaubriand. Este, associado ou não a Bardi, não media esforços para que se realizassem suas intençóes: e elas frequentemente eram realizadas, inclusive de maneiras pouco ortodoxas e muito criticadas. A utilização de sua cadeia de jornais para exortar forçadamente os "mecenas" iniciais do Museu, principalmente os escolhidos da "sociedade dos quatrocentôes," mostra a resolução em montar um acervo público a partir da riqueza que se encontrava nas mãos dessa oligarquia. $(\mathrm{Ou}$ ex-aristocracia, para maior exatidão.) Sobre esse fato, Bardi escreveu:

\footnotetext{
De vez em quando recebia no Masp pessoas eminentes alegando, por conveniência, um ou outro motivo, desenformando receitas moralísticas, para retirar seus nomes como doadores de quadros: não queriam ser considerados em relaçôes com o Exator. Pela minha posição de cúmplice em várias caçadas de dinheiro para erguer o monumento (a palavra é muito apropriada) do Masp, era procurado também para estas estratégias. \{BARDI, Vogue Brasil \#115, fev. 1985, p.II5-I62\}
}

8 Interessante notar que a figura de Lina sempre fora associada aos comunistas, desde sua época na Itália, mantendo-se no Brasil, mesmo ela sendo casada com uma figura per suposto fascista, de modo que isso provavelmente a livrou de algumas antipatias neste país.

9 Não raro esse episódio ser narrado por Bardi em seus artigos, como se verá. 
Mino Carta formula por sua vez uma opinião positiva sobre estas iniciativas de Chateaubriand e de Bardi que obrigariam a oligarquia paulista a sair do seu provincianismo e de uma atitude parasitária que exploraria o resto da sociedade sem contribuir em nada para o seu avanço. ${ }^{\circ}$

Chatô e Bardi formaram uma dupla afinadíssima, e aquele soube como municiar a operação. À época, com ímpeto udenista, houve quem alegasse que o dono dos Associados não hesitava em chantagear alguns graúdos paulistanos para obrigá-los a financiar esta ou aquela obra. É razoável supor que ele conhecesse a fundo as mazelas da sociedade bandeirante, de sorte a explorá-las a bem do seu plano, conhecia também, e a respeito não sobra dúvida, o provincianismo e o narcisismo de damas e cavalheiros. O que de mais retumbante, e de seguro registro nas colunas sociais, poderia haver além da doação de um Picasso, ou de um Goya, à cidade de Piratininga? \{Mino CARTA, Carta Capital\#799, I6 set 2011, Editorial 2\}

Sobre Chateaubriand, Bardi escreveria (sempre elogiosamente) ainda:

Ele era um cidadão único. Não era de família rica e o que conseguiu acumular foi resultado do seu trabalho e de uma visão toda sua da sociedade - pensava que os meios provêm de que os possui. Assim, se tornou praticante de uma filosofia própria: pedia a quem tinha para concretizar suas várias campanhas em favor da agricultura, da criança e da aviação, as mais mais conhecidas sem contar o Masp. (...) Como São Francisco de Assis, achava que quem possuía demais podia empregar uma parte em benefício dos outros, visando sempre o bem comum. (...) Era um mestre imbatível na arte de convencer possíveis doadores de obras para o museu, falando não em nome da instituição, mas sim do Brasil. \{BARDI, Istoé \#I202, I4 out. 1992, p.75\}

Assim, não é de se surpreender que as obras do acervo do Masp recém-montado fossem acusadas de falsas ${ }^{\text {II }}$ pela mídia local, nem que se tentasse desacreditar a competência de Bardi. Não bastasse sua associação a Chateaubriand e ao fascismo para sofrer o acusado boicote de todas as mídias que rivalizavam com os Diários, Bardi não se retraía nem se deixava intimidar, se indispondo pessoalmente se assim achasse necessário, e contribuindo ainda mais para a situação. Aliás, seu temperamento explosivo, por si só, já era suficiente para que se criassem inimizades no decorrer de sua vida. ${ }^{12}$

IO Mino Carta, declaração verbal em ir fev 2014.

II Bardi resolveu a questão usando luvas de pelica ao expor as obras do Masp em importantes instituiçôes de Arte na Europa e Estados Unidos, atestando assim a autenticidade de todas.

I2 Além do episódio com Ciro Mendes, Tentori menciona alguns outros, com Ugo Ojetti, os irmão Bernocchi e Marcello Piacentini. \{TENTORI, 20oo, passim\} 
Enfim, isso tudo somado fez com que a fama de Bardi, ao menos nesses meios, fosse desacreditada. ${ }^{13}$ Assim, após a morte de Assis Chateaubriand, visto Bardi não ser exatamente bem-vindo nos outros meios, é muito provável que a recíproca fosse verdadeira e que ele mesmo náo se sentisse à vontade para escrever nessas outras publicaçóes. Até estreitar relaçóes com a família Carta, como se verá a seguir.

\section{I.3. A retomada da comunicação}

No Brasil, o mercado editorial de periódicos, nas décadas de 1950 e 60, (início das atividades do Masp) era representado principalmente por alguns "conglomerados." No Rio de Janeiro, os Nascimento Brito (Jornal do Brasil) os Bloch (Manchete) e Roberto Marinho (O Globo). Em São Paulo, os Civita (Abril) os Mesquita (O Estado de S. Paulo) os Frias (Folha de S. Paulo) os Levy (Gazeta) além, é claro, de Assis Chateaubriand (Os Diários e Emissoras Associados). E Bardi se utilizava justamente dos Diários Associados para se comunicar com o público do Museu e divulgar suas intençóes.

Em 1968, com o falecimento de Chateaubriand, Bardi fica órfăo desses canais de comunicação outrora disponibilzados pelo "Capitão," dada sua relação intranquila com os herdeiros de Assis (Gilberto Chateubriand, principalmente).

Na década de 1970, esses conglomerados ainda existiam, além de grupos menores, todos então às voltas com a ditadura militar em seu auge no Brasil. Este seria o ambiente jornalístico no qual Bardi re-entraria quando inicia sua colaboração com as publicações das editoras Três, Encontro Editorial e Carta Editorial, em 1975. E Bardi participaria por dezesseis anos desse mercado, tendo acompanhando, portanto, o processo de redemocratização. O elo entre Bardi e todas essas editoras de publicações aparentemente distantes (Senhor e Casa Vogue, por exemplo) foi a sua relação pessoal com os membros da família Carta, relação que se inicia em 1946, como se verá, mas fica oficialmente mais próxima com a exposição de Mino Carta no Masp, justamente em 1975 .

As revistas geridas independentemente pela família Carta enquadram-se, pode se dizer, num projeto de modernizaçáo do Brasil, e esse projeto de modernização não era exclusivo dos Carta nem inédito. Nahum Sirotsky, por

I3 Nota-se que a figura de Lina não foi associada à de Chateaubriand, como aconteceu com a de Bardi, e as alcunhas atribuídas ao marido, como "falsário" etc., não foram a ela estendida. 
exemplo, o idealizador da primeira revista Senhor (1959-1964), tinha em mente essa modernização através da abordagem cultural e informação qualitativa e aprofundada também, e pensava a realidade brasileira justificando a ideia para sua publicação da seguinte maneira:

(...) A fórmula editorial de Senhor partia da realidade do nível de ignorância das chamadas elites do país. Então, como provavelmente ainda agora, só uns poucos se interessavam por textos de ficção ou mesmo por publicações especializadas. As elites pensavam e viviam casuisticamente, em função do dia. Não tinham visão nacional dos seus próprios problemas e, muito menos, das questôes nacionais ou internacionais. E isto resultava em falta de criatividade em todos os setores da vida brasileira. É mais do que provável que tudo o que aconteceu no Brasil desde então decorra diretamente de tal verdade. \{SIROTSKY, Senhor \#I, I976, p.77-79\}

Esse ponto de vista tinha muito a ver com a postura assumida pelo próprio Bardi em relação à arte, sua apreciação e realização, conforme encontrado em seus textos. Os Carta, dadas suas raízes, sua história como imigrantes cultos no Brasil, e as publicações que vieram a dirigir, provavelmente sentiam o mesmo que Sirotsky e Bardi. Afinal, pelo menos as publicaçóes objetos desta pesquisa eram direcionadas à classe $\mathrm{A}$ e aos formadores de opinião, conforme se verá. Aliás, tal como Bardi, a famiglia Carta também possuía um pé no jornalismo e outro na arte.

\section{I.4. Os Carta}

Giannino Carta, ${ }^{14}$ italiano, da Genova como Bardi, formou-se em Direito e Filosofia, lecionou História da Arte (1933-1940) e contribuiu com diversos jornais e revistas, como Secolo XXI, Gazzetta del Popolo, (Turim) Illustrazione Italiana, La Settimana Illustrata antes de mudar-se para o Brasil, em agosto de 1946, com a esposa, Clara Becherucci Carta, escritora, e seus dois filhos, Mino e Luis Carta. É na noite de Natal de 1946 que a família conhece Pietro Maria Bardi e Lina Bo, ${ }^{15}$ e se estabelece uma relação que durará o resto da vida de Bardi. No Brasil, Giannino trabalhou em diversos jornais até assumir posto

I4 Os dados biográficos de Giannino Carta foram, em sua maioria, retirados de "Giannino Carta," O Estado de S.Paulo, 3I out 1964, p.8, artigo publicado em virtude seu falecimento repentino. (Autor não identificado.)

Mino Carta, declaração verbal em II fev 2014. 
permanente em 1948 no Estado de S.Paulo, e em revistas como Anhembi. ${ }^{16}$ Também aqui lecionou História da Arte, na Universidade de São Paulo e, paralelamente a tudo, pintava nas horas vagas, tendo realizado uma exposiçáo em São Paulo. Em 1956, volta para a Itália com toda a família, por um período, ao assumir a subdiretoria do Gazzeta del Popolo. Retorna "para casa” em i960, (depois dos filhos, que já haviam retornado ao Brasil) e logo um mês depois reassume antigo posto no Estado. Enquanto esteve na Itália, foi correspondente do Estado e, sempre que no Brasil, do Corriere della Sera.

Seu primogênito, Mino Carta, nascido em 1934 Demetrio Giuliano Gianni Carta, também em Genova, chegou ao Brasil com quase doze anos. Matriculou-se no curso de Direito do Largo São Francisco, mas não chegou a concluí-lo. Assim como o pai, seguiu carreira como jornalista e, paralelamente, a de pintor. "Eu queria frequentar os dois ambientes, algo nada incomum na Itália. ${ }^{{ }^{17}}$ Em 1954, Sérgio Milliet o convidou a participar das celebraçôes do IV Centenário de São Paulo, e ali, foram expostas duas de suas telas, juntamente com outras de artistas como Pancetti, Portinari e Tarsila do Amaral. Sua primeira individual aconteceu em 1957, em Miláo, organizada pelo crítico Luigi Carluccio, futuro presidente da Bienal Internacional de Veneza. Entre os visitantes, Carlo Carrà, que o convidou a trabalhar com ele. A partir de I960, já de volta ao Brasil, deixou a atividade pictórica por catorze anos. Volta a pintar sem intenção de expor, mas "foi Pietro Maria Bardi quem docemente me forçou a mudar de ideia um ano depois," e ele expóe, em 1975, sua primeira de três individuais no Masp. Esta primeira com trinta telas sobre a Lapa de Baixo, localização do edifício da Editora Três. As molduras dessa exposição foram executadas por Giuseppe Baccaro, ${ }^{18}$ que possuía uma marcenaria em Olinda. ${ }^{19}$ Mino recebia e acatava conselhos dos dois: Bardi o aconselhava a, por exemplo, pintar figuras, quando nada mais exceto paisagens o ocorria.

I6 Criada e dirigida por Paulo Duarte, (I899-I984) escritor e jornalista ligado aos Mesquita e ao Estado de S.Paulo, circulou de 1950 a 1962. Mino Carta também colaboraria com essa publicação tempos depois.

I7 Como Bardi, por exemplo, que acabou conseguindo realizar as duas coisas até o final de sua vida. Os dados biográficos de Mino Carta foram retirados do artigo "Pintura e resistência," de Rosane Pavam, Carta Capital, I2 ago $201 \mathrm{I}$.

I8 Mino e Baccaro (Itália I930- ) foram muito amigos. Baccaro "acabou 'enlouquecendo’ pois foi pego pela polícia fumando um baseado, nada além disso. Virou vegetariano e foi embora para Olinda. Na minha primeira exposição do Masp, ele tinha uma marcenaria em Olinda que abrigava menores, e as minhas molduras foram feitas ali.” Mino Carta, declaração verbal em II fev 2014. 
Já Baccaro aconselhou a Mino a trocar o óleo pela acrílica, menos tóxica, o que o permitiu pintar em casa. E ele se deu bem com a nova matéria. Neste momento, Baccaro e Bardi o colocaram em contato com o marchand Antonio Maluf, ${ }^{20}$ para representá-lo comercialmente. As outras individuais no Masp aconteceriam em 1983, com o Bardi ainda diretor, e em maio de 1994, com cem telas curadas por Jacob Klintowitz, quando Bardi já era presidente honorário.

Luis Carta, que havia voltado aos vinte anos para a Itália com os pais e irmão, no final da década de I950. Trabalhava ali como correspondente das revistas Visão e Manchete, dirigidas por Nahum Sirotsky - que criaria a primeira Senhor no ano seguinte. Mino Carta ${ }^{21}$ garante que o Adolpho Bloch, o fundador da Bloch Editores, que lançou a revista Manchete em 1952, foi pessoalmente a Roma convidar Luis para trabalhar na publicação. E a certa altura, provavelmente depois dessa visita, Luis recebe de Nahum uma carta timbrada da Manchete com os seguintes dizeres:

"Rio de Janeiro, Io de setembro de 1958

Ilmo. Sr. Luis Carta

ROMA - Itália

Velho Carta,

Hoje foi para mim um grande dia: o Adolpho [Bloch] me disse que pretende contratá-lo para trabalhar no Brasil. A ideia não podia ser melhor. Pelo trabalho que você faz na Settimana posso avaliar suas qualidades de secretário, pelo seu texto e reportagens em Manchete sei que é um dos melhores repórteres jovens que eu conheço.

O Adolpho quer saber, com a maior urgência, quando você se disporia a vir para o Brasil e trabalhar conosco. Um bom cargo de direção o aguarda. E você estaria de volta ao país que você tanto gosta.

Responda, velho Carta, com a maior pressa possível, e não perca a oportunidade que lhe oferecem.

Um abraço do Nahum Sirotsky

P.S.: Adolpho e Lucy ${ }^{22}$ lhe enviam um abraço"

\{Luis Carta, Senhor \#I, abr. 1978, p.63\}

E Luis chegou no mesmo dia em que Nahum deixou a Manchete. Luis trabalhou cerca de um ano na Manchete indo para o Rio segunda cedo e voltando sexta-feira, todas as semanas, pois sua esposa não queria se mudar de São

20 Maluf foi o marchand de Mino até se aposentar, em I990.

2I Mino Carta, declaração verbal em ir fev 2014.

22 Lucy Mendes Bloch, esposa de Adolpho e editora da Manchete e da revista Jóia. 
Paulo. ${ }^{23}$ Com o tempo isso acabou ficando pesado. Sabendo do caso, Victor Civita o convidou para ser diretor editorial da Editora Abril, em São Paulo, convite que ele aceitou prontamente. "Naquela época a Abril era muito diferente do que acabou virando. A principal revista era a Manequim. E o Luis aceitou, foi para lá na primeira metade de 1959.”24 Ali, Luis atuou, por exemplo, como diretor de Claudia, que publicava assuntos como moda, etiqueta e receitas - na mesma linha do que viria a seguir, quando Luis editaria a Vogue e seus apêndices a partir de 1975, sendo que em Casa Vogue, a gastronomia a princípio ocupava matéria dedicada e, a seguir, encarte dedicado ${ }^{25}$ às receitas temáticas e à história dos ingredientes e elementos culinários. Seu irmão, Mino Carta, também assumiu cargos de direção de publicaçóes na Abril, assim que pretendeu-se o lançamento da Quatro Rodas.

Como jornalista, Mino começou fazendo a cobertura da copa no Brasil para os jornais italianos Il Messaggero de Roma e Il Secolo XXI de Gênova. Colaborou com a revista Anhembi e, na temporada que passou na Itália, com vinte e poucos anos, foi redator de La Gazzetta del Popolo e Il Messaggero. "Quando houve a ideia da Quatro Rodas, os dois loucos [Victor Civita e Luis Carta] me chamaram, e eu voltei para o Brasil." Na Abril de Victor Civita, esteve presente na fundação de diversos títulos. A Quatro-Rodas, ${ }^{26}$ lançada em agosto de 1960, foi criada a partir da insinuação de um diretor de montadora ("Por que o Brasil não tem uma revista automobilística?" perguntou um diretor da Volkswagen à VC num almoço) e o crescimento expressivo da indústria automobilística nos quatro anos anteriores ao lançamento eram bons indicadores do que viria a seguir. Numa Kombi pela Dutra, Mino e Roberto Civita (filho de Victor, dirigia) foram marcando num mapa e classificando todas as

23 Mino Carta, declaração verbal em II fev 2014.

24 Mino Carta. Idem.

25 Em 1978, os encartes Comer e Beber tinham a mesma frequencia e peso que a Arte Vogue, dirigida por Bardi, sendo que ambos eram trimestrais.

26 Um registro anedótico da entrevista que fiz a Mino Carta. Me deparei com uma sala sem computador. Havia, sim, uma máquina de datilografar, um garrafa de cerveja (importada, suponho, mas não observei o rótulo), o telefone wireplus. No decorrer da entrevista, perguntei ao Mino "Foi você que fez a Quatro Rodas, não?" e obtive a resposta "Sim, sem saber dirigir, até hoje...” Essa aversão às tecnologias pode ser lida como engessamento dinossáurico frente a um mundo tão "acessível," mas eu interpretei, afinal, como uma sensibilidade ao mundo real, ao mundo (no que me toca) da cultura e das pessoas. Explico: havia uma taça para compartilhar a cerveja comigo, mas eu, umbilicada no "mundo" pelo celular, só a percebi quando estava me despedindo de Mino. 
paradas possíveis (postos, restaurantes, borracharias) compilado e publicado no número inaugural, que vendeu bastante. Mino era o diretor de redação.

Em II de setembro de 1968 é lançado o primeiro número de Veja, após o teste com treze bonecos feitos por jornalistas recrutados por anúncio e selecionados após um curso de jornalismo da própria Abril. A ideia surgiu depois que Roberto e Mino foram aos Estados Unidos e Europa participar de todos os processos de produção das principais revistas desses mercados. Mino é também diretor de redação nessa publicação e, sob sua direção, o título sofreu diversas vezes com a censura. Seu contrato previa que os Civita "definiam o tipo de revista que queriam, mas depois seriam leitores da revista. A discussão seria sempre a posteriori, nunca a priori, ou seja, não poderiam influenciar a pauta e coisa e tal," de modo que a redação teria liberdade de ponto de vista, independente de pressões políticas. O último número de Veja em que aparece como diretor de editora e de redação é o de 2I de janeiro de $1976 .{ }^{27}$ Poucos meses após a sua saída forçada da Veja, Mino estaria dedicando-se à Istoé.

\section{I.5. Alzugaray}

O Domingo era ator na Argentina. Veio para o Brasil para rodar o filme do Jardel. ${ }^{28}$ Conheceu uma brasileira, se apaixonou pela brasileira e se casou com a brasileira. Naquela época, as revistas da Abril que mais vendiam eram as de fotonovelas: Ilusão, Noturno e Capricho. A Capricho vendia setecentos mil exemplares. E o Domingo resolveu ficar e trabalhar com isso. Ele amava mais o dinheiro que a arte - e não veja isso como uma crítica. Ele morava no Rio, escrevia o texto, dirigia a fotonovela e atuava na fotonovela. Ele vinha periodicamente entregar esse material ao Luis [Carta].

Em 196I, o Victor Civita chamou o Domingo para São Paulo, para dirigir dentro da Editora Abril todas as revistas de fotonovelas. E

27 Mino declarou na imprensa brasileira que pediu demissão da Abril após Richard Civita lhe contar, numa partida de tênis, que, dada a crise financeira pela qual a Abril passava em meados da década de 70, (e a pedra no sapato da ditadura que era Mino, contratado pela Abril em termos de liberdade absoluta em relação aos diretores da editora) a Caixa Econômica Federal havia oferecido um empréstimo de US\$ 50 milhôes, desde que Mino saísse da editora. Em homenagem a Roberto Civita, \{MARANHÃO, 5 jun. 20I3, p.IOI\} a Veja publica a outra versão da história, dizendo que o patriarca Victor Civita demitira Mino temendo que Roberto não soubesse lidar com a senioridade de Carta, visto que ambos se desentendiam com frequência, o que já estava ameaçando a estabilidade (financeira) de Veja. Nenhum empréstimo foi mencionado alegando-se que o balanço financeiro veio através de outras operaçôes de marketing da própria revista.

28 Jardel Filho, nascido Jardel Frederico Bôscoli. Atuou junto a Domingo em Meus amores no Rio, 1959. \{IMDB $\}$ 
quando eu cheguei ao Brasil, o Domingo foi uma das primeiras pessoas que eu conheci. ${ }^{29}$

\section{I.6. Editora Três e Encontro Editorial}

A Editora Três nasceu em 1972, e o nome Três era porque foram três sócios: o Domingo Alzugaray, ${ }^{30}$ o Luis Carta e o Fabrizio Fasano, que era o sócio majoritário e que ficou por dois anos, até 1974. Quando ele saiu, o nome continuou. ${ }^{3 \mathrm{I}}$

A editora era responsável pela publicação das revistas Status, Planeta, e, a partir e 1975, as licenciadas de Vogue (por inciativa de Luis Carta) além de outras.

Depois dos meus problemas com a censura na Veja, os dois disseram "Vem trabalhar com a gente, vamos fazer uma revista anódina e inodora." E o jeito para eu virar sócio deles foi fazendo uma nova editora. Foram cinquenta mil cruzeiros de cada um e formamos a Encontro Editorial.

Na Editora Três, com o passar do tempo, passou a haver algumas diferenças entre o Luis e o Domingo. O Luis queria uma editora pequena, num lugar bem decorado e o Domingo queria dinheiro. $\mathrm{O}$ Luis desligou-se da Editora Três e da Encontro Editorial ${ }^{32}$ em agosto de 1976 e fez a sua própria editora, a Carta Editorial e mudou-se para a avenida Brasil, onde a editora existe até hoje. Levou consigo as publicaçôes que ele havia trazido para o Brasil, como as Vogue. E nos disse "Vocês fiquem com a minha parte, podem dividir entre vocês," e nunca reivindicou a parte dele, os cinquenta mil cruzeiros iniciais. ${ }^{33}$

29 Mino Carta, declaração verbal em II fev. 2014

30 A esposa de Domingo Alzugaray, Cátia, sempre aparece junto ao marido em todas as publicaçóes e iniciativas nas quais Domingo esteve envolvido.

3I Mino Carta, declaração verbal em II fev. 2014

32 Luis Carta permanece no expediente como diretor até o volume \#8 (dez. 1976) enquanto a Istoé foi mensal. Ele sai coincidentemente quando a censura perde sua severidade e não significaria grandes problemas para Mino Carta.

Mino Carta, declaração verbal em II fev. 2014 


\section{Capítulo 2 \\ Revistas}

Segue-se uma breve análise de todos ${ }^{34}$ os títulos de revistas - publicações de periodicidade variável (semanal a semestral) - com as quais Pietro Maria Bardi oficialmente ${ }^{35}$ contribuiu a partir de 1975 até 1992.

\section{I. Vogue Brasil}

A licença das publicações Vogue, da Condé Nast, foram editadas no Brasil por iniciativa de Luis Carta a partir de 1975, a princípio pela Editora Três. Com o sucesso das licenças da Condé Nast no Brasil, e querendo manter-se pequeno, direcionado a classe A (Domingo Alzugaray queria que a Editora Três fosse grande) decidiu fundar a sua própria editora em 1976, a Carta Editorial, dedicada, a princípio, exclusivamente às licenças de Vogue, onde elas permaneceram até 20Io, quando foram vendidas para a Editora Globo. (Hoje, Ediçóes Globo Condé Nast.)

Quando Luis Carta traz os títulos de Vogue, da Condé Nast, para o Brasil, o faz enxergando o nicho das questóes do gosto e com o propósito de promover uma atualização internacional do gosto especialmente das classes média e alta no Brasil. Com a revista destinada ao público feminino (Vogue Brasil), ao público masculino (Homem Vogue, edição brasileira de Vogue's Men) e às questôes da casa (Casa Vogue, edição brasileira de Vogue Living), sempre abordando temas que contribuíssem para a conscientizaçáo e apreciaçáo de todas essas manifestaçôes que Bardi localizaria sem dificuldades dentro do

34 Nấo se descobriram outros títulos: caso tenham existido, eles não foram encontrados a tempo de aparecer nesta compilação.

35 Bardi não contribuiu regularmente com a Vogue Brasil, assim como não contribuiu regularmente com a Status. Entretanto, a Vogue Brasil entrou nesta análise por ter sido lançada ao mesmo tempo e dentro do mesmo projeto que Casa Vogue e Homem Vogue, que não é o caso da Status. 
baluarte da Arte. E Luis Carta sozinho consegue, com essas publicaçóes, sustentar uma editora.

Em anúncio de julho de 1977, dois anos após a estréia de Vogue, Casa Vogue e Homem Vogue no Brasil, eram publicadas as seguintes revista sob a chancela Vogue:

Vogue: ou melhor, a mais autorizada revista do mundo, em sua fórmula brasileira, para tratar de moda e de beleza da mulher e para indicar tudo o que está em Voga no campo das artes, da cultura, do estilo de vida. II revistas anuais (dez/jan. uma única edição de verão)

Homem Vogue: a mais nova e importante revista masculina brasileira que apresenta como pontos centrais, reportagens, ficção, moda, economia, política e estilo de vida do homem de sucesso. A cultura, o bom gosto são os elementos de sustentação desta revista, expressão brasileira da mais sofisticada publicação internacional. II ediçôes anuais

Casa Vogue: a mais rica e completa resenha do design e da decoração brasileira e estrangeira. Todas as propostas mais recentes do mercado do móvel, da decoração e do acessório. (dez/jan. uma única edição)

Beleza Vogue: Uma edição anual com tudo o que há de novo, de melhor e de mais apropriado na área da beleza. ${ }^{36}$

Arte Vogue: duas ediçóes anuais dedicadas à Arte. A única revista da linha Vogue, do mundo todo, dedicada exclusivamente ao assunto. Uma iniciativa brasileira para dar merecido valor à Arte e aos artistas locais.

O primeiro volumes de Vogue Brasil data de maio de 1975. Os primeiros volumes das outras duas publicaçóes principais sob a chancela Vogue (Homem Vogue e Casa Vogue) não foram encontrados em nenhum dos acervos disponíveis para consulta e, dadas a data e a ordenação numérica, (bastante caótica, no caso de Casa Vogue antes de 1979) é suposto terem sido lançados simultaneamente, em maio de 1975 também.

Tampouco foram encontrados, em todas as coleçôes, os volumes localizados no intervalo que compreende a transição da licença de Vogue da Editora Três para a Carta Editorial, transição esta acontecida no segundo semestre de 1976.

36 Beleza Vogue e Arte Vogue eram vendidas em volumes avulsos, mas, neste anúncio, foram publicaçóes a serem dadas como brinde aos assinantes de combos Vogue, como se verá no item sobre Arte Vogue a seguir. 
É de interesse para este levantamento o período no qual Bardi colaborou com essas publicaçôes. Por hipótese, acredita-se que a colaboração oficial de Bardi com Homem Vogue e Casa Vogue deva ter acontecido a partir do primeiro volume pós-transição até a extinção do título (Arte Vogue e Homem Vogue, esta pela fusão com Senhor) ou até Bardi se ausentar dessa atividade, considerando o problema de saúde que o acometeu a partir de 1992 (Casa Vogue, neste caso). Todos os artigos levantados foram numerados de acordo com a sequência encontrada, sabendo-se que outros devem interpor-se a eles. (cf. Quadros I, p.8I; e Quadro 2, p.83)

Bardi contribuiu com a Vogue Brasil de modo pontual. No número \# I (cf. Anexo A, p.roo) ele conta um pouco de sua biografia, explica porque não é crítico, mas "apenas" um cronista. Sabe-se que ele contribuiu com um número em entre novembro e dezembro de 1976, num artigo sobre Wesley Duke Lee.37

A edição \#II5, de fevereiro de 1985, foi especial, comemorativa dos dez anos da publicação no Brasil e foi dedicada a Bardi, que comemorava 85 anos quase ao mesmo tempo. Nesta, ele conta mais detalhadamente sua vida na Itália, suas relações com artistas, com Chateaubriand, tem mais espaço para demonstrar toda a sua erudição. Além disso, outros contribuíram escrevendo sobre o Bardi. A própria Lina dá o seu depoimento quase impessoal, contando o passado dela em torno da personagem-Bardi, na Itália ainda a ser modernizada. Não menciona a relação dos dois, apesar da sugestão de Luis Carta "como aguentá-lo," e conclui falando de seu projeto arquitetônico então mais recente: o SESC Pompeia. (cf. Anexo C, p.686) ${ }^{38}$ Apesar do extenso ensaio fotográfico com Bardi na Casa de Vidro feito especialmente para esta edição, Lina e Bardi aparecem juntos apenas nas fotografias da década de I940.

\subsection{Casa Vogue}

Casa Vogue era dirigida para profissionais da área de arquitetura, arquitetura de interiores, decoração, e também para amadores. As revistas eram ricamente ilustradas e possuíam a colaboração de profissionais de diversas áreas: arquitetura, teatro, artes visuais, design, moda, jornalismo, seguindo a mesma linha

37 “Arte Vogue no Brasil, dá prá fazer? Deu.” Istoé \#24, 8 jun. 1977, p.49.

38 Apesar do texto ser autobiográfico, de autoria de Bardi, portanto, entendeu-se ser mais pertinente colocá-lo não no Anexo $\mathrm{A}$, onde estão os textos de autoria de Bardi, mas no Anexo C, onde estão os outros textos dedicados a Bardi por outros autores, inclusive os da edição \#iıs de Vogue Brasil. 
da Vogue Brasil. Alguns dos colaboradores de Casa Vogue foram: Antonio Bivar (o dramaturgo, em sua fase de jornalista) Alik Kostakis (colunista social) Attilio Baschera (designer de estampas, que viria a constar como "Assessor de estilo" da publicação na década de 90) Alberto Guzik (crítico de teatro) Radha Abramo (historiadora da arte) e Ruy Ohtake (arquiteto)

Em Casa Vogue, (ignorando-se as falhas da coleção consultada) as colaboraçôes de Pietro Maria Bardi (cf. Quadro \#I em apêndice) até I984 não eram regulares. Às vezes eram poucos parágrafos dentro de um artigo de outro autor sobre uma determinada construção, (\#2I fev. 1977) ou então sobre temas como decoração (\#2 mar-abr 1982) tecidos e estamparia (\#30 nov. 1977). A maior recorrência, nesta fase, seria sobre colecionismo em geral, expondo elogiosamente - coleçóes de particulares (\#7 jul-ago-set I979; \#5 set-out 1983, em virtude de publicação sobre a coleção de João Marinho) de antiquários (\#8 out-nov-dez 1979; \#3 mai-jun 1989) e iniciativas na área, (\#36 jun.1978) além da análise de obras de arquitetura (\#38 ago. 1978)

No número \#39, no editorial do último número da Arte Vogue incorporada ao final da Casa Vogue, Bardi avisa que a revista deixará de existir e que, a partir de fevereiro do ano seguinte (1979) passará a publicar no "coirmão" Senhor Vogue. E Bardi não fará nenhuma colaboração a Casa Vogue novamente, até $1984,{ }^{39}$ apesar de continuar a aparecer no expediente, entre os colaboradores.

A partir do número \#2 de 1984 (março-abril) a seção destinada a Bardi passou a ser publicada sob a rubrica P.M. Bardi, ${ }^{40}$ ao que ele declara no olho do texto, desta vez sem título e que tratou de diversos assuntos: "O diretor de Casa Vogue me homenageia com uma página para, de agora em diante, conversar a respeito de algumas coisas: comunicar, discutindo, formal ou informalmente, a aventura do cotidiano." \{BARDI, Casa Vogue \#2, mar-abr I984, p.68\}

Ele assume, mais uma vez, a variedade de assuntos que abordaria e sempre abordou em todas as publicaçôes com as quais contribuiu.

39 Novamente, vale lembrar que a coleção consultada não é completa. Os números faltantes para afirmar com certeza este hiato de Bardi em Casa Vogue são 198I \#3 (mai-jun); 1982 \#4 (jul-ago), \#5 (set-out) e \#6 (nov-dez)

40 Vale lembrar que a rubrica homônima dedicada a P.M. Bardi já existia em Senhor desde maio de 1982, como se verá no tópico sobre a Senhor Vogue, a seguir. 


\subsection{Arte Vogue}

Arte Vogue é uma publicação dedicada às artes, foi dirigida por Bardi sendo a única da chancela no mundo direcionada ao tema. A publicação será abordada brevemente, pois ela resume em si muito do que Bardi acredita, argumenta, critica e defende. Entretanto, dado o volume de informação que ela, em todos os seus volumes, carrega, fica evidente sua importância e sua análise mais aprofundada é altamente sugerível para tema de pesquisa futura.

A ideia para Arte Vogue é contada por artigo em Istoé\#24 (maio 1977)

Arte Vogue nasceu, muito apropriadamente, do sucesso de uma exposição - a de Wesley Duke Lee, em dezembro do ano passado. O pintor do Realismo Mágico perpetrou uma mostra tão bem-sucedida que todos os seus belos trabalhos foram vendidos num único dia. A razão? Segundo o próprio Wesley, a entrevista que P.M. Bardi fizera em Vogue Brasil, a da moda e da mulher, publicara uma semana antes. "É impressionante a sua penetração no meio artístico" - afirmou Wesley a Luís Carta. Foi o empurrão. Carta conversou com outros artistas: "Dá prá fazer?" Sondou publicitários. Convidou Bardi. E em menos de cinco meses Arte Vogue estava nas bancas.

No total, Arte Vogue contou com seis números. Os dois primeiros foram publicaçôes Vogue independentes, de lançamento semestral em maio e novembro de 1977. A ideia inicial é que todos os números seriam semestrais, publicados em maio e novembro de cada ano. Entretanto, os quatro últimos foram incorporados a Casa Vogue, trimestralmente em março, junho, setembro e dezembro de 1978, antes de ser engavetada.

A empreitada do primeiro volume de Arte Vogue, lançada em maio de 1977, custou I,5 milhão de cruzeiros. A revista tinha preço de capa de sessenta cruzeiros, sendo necessária a venda de no mínimo 25 mil unidades para cobrir os custos: e foi essa a tiragem da revista. Naquela época, somando-se as tiragens das três Vogue principais, o público atingido somava cerca de trezentas mil pessoas. Luis Carta acreditava ser possível que 25 mil delas se interessassem pela publicação. Mas não foi feito investimento publicitário externo, esperando-se que a divulgação fosse baseada no boca a boca da intelectualidade. Na Casa Vogue de junho, um mês depois do lançamento, encontra-se uma página inteira apenas com os dizeres "Um novo Vogue ... só de Arte" e com a capa do primeiro número de Arte Vogue. Luis Carta queria fazer um teste. Talvez náo alcançando as vendas esperadas para o início da empreitada, ele passou a anunciar a Arte Vogue como revista promocional, utilizando-se dela para impulsionar as assinaturas combinadas: ganharia como brinde a 
publicação quem assinasse simultaneamente a Vogue Brasil e Casa Vogue, ou então, quem assinasse Vogue Brasil, Casa Vogue e Homem Vogue - neste último combinado, o assinante receberia além de Arte Vogue a Vogue Beleza.

Partindo-se da suposição quase óbvia de que os custos dos números avulsos não foram compensadores, os quatro números finais, subsequentes, foram incorporados trimestralmente à Casa Vogue durante o ano de 1978. A cada edição, entretanto, foi se reduzindo o número de páginas dedicadas à publicação, até que ela deixasse de existir.

Avulso, promocional ou incorporado, a empreitada não deve ter sido tão rentável, como já esperava Luis Carta desde o primeiro número. "Luis Carta, tradicionalmente capaz de irônicas tiradas, acha que Arte Vogue pode ser 'um sucesso ou um fracasso.' Mas obviamente se inclina com a maior parte de seu peso para a segunda alternativa" $\{\text { Istoé \#24, } 8 \text { ju. 1977, p.49 }\}^{4 \mathrm{I}}$

A coordenação da edição ficou a cargo de Fernando Lion e a da comunicação visual a cargo de Antônio Marcos Silva, sendo composta por Silvio Lancellotti, Maria Bonomi, Lina Bo Bardi, Lúcio Grinover, Alexandre Wollner, Olney Krüse e José Mindlin.

O primeiro número de Arte Vogue teve, de capa a capa, I64 páginas. No editorial, Bardi apresenta as intenções da publicação e os assuntos a serem abordados: "A revista chega para intervir num campo fértil de atividades, inovaçôes, extravagâncias discussóes tão intensas que parecem anuviar o semblante tradicional da contínua busca do conceito e do tabu da arte - o belo." \{BARDI, Arte Vogue \#I, maio 1977, p.7\}

No mesmo editorial, Bardi, ironicamente, ${ }^{42}$ se explica pela quantidade ou ocupação das páginas (quase todas) ilustradas (em quadricromia): "A comunicação visual às vezes prevalecerá sobre a escrita - em função, é claro, das novas preferências impostas pela mudança dos gostos e pelo desejo de ver, mais do que ler."

As contribuições envolveram diversos assuntos, de panorama da arte no Brasil e no mundo a Design, de colecionismo à criação do Ministério da Cultura, de roubo de obras sacras a Design. ${ }^{43}$

\footnotetext{
4I Artigo publicado logo após o lançamento da Arte Vogue \#I. Percebeu-se que uma publicação/editora anunciava as iniciativas da outra em diversos momentos.

42 Refere-se a outras publicaçóes que, baseadas no semanário francês Paris Match, davam mais importância à informação fotográfica que à informação impressa, como Manchete (Bloch) e Contigo! (Abril)

cf. Anexo D, p.692.
} 
O número \#2, ainda avulso, teve I48 páginas, de capa a capa. Apesar da redução de um caderno (I6 páginas), a grande variedade de temas continuou. ${ }^{44}$ No editorial, a notícia de que a iniciativa de publicação dedicada exclusivamente a Arte havia se multiplicado no país, mencionando, entre outros, o Jornal das Artes.

No número \#3 de Arte Vogue, quando ela é transformada em caderno especial da Casa Vogue, Luis Carta apresenta a mudança da seguinte maneira:

A partir deste mês decidimos juntar em uma única revista duas de nossas publicaçóes. Arte Vogue passa a ser um caderno especial de Casa Vogue. E é justo que assim seja, que arte sempre foi algo intimamente ligado à nossa vida e que é sonho de todos trazer para dentro das próprias paredes algo de realmente bom, de valor, artístico. $\mathrm{O}$ caderno sairá este ano quatro vezes (e não duas vezes apenas como em 1977) e seu responsável único continuará sendo o professor Pietro Maria Bardi, o que é mais do que uma simples garantia de qualidade. \{CARTA, Casa Vogue \#33, mar. 1978, p.27\}

Aparentemente, Alexandre Wollner contribuiria com a Arte Vogue \#3 analisando o desenho da identidade visual de algumas empresas. Esta seção aparece no índice, mas não existiu neste volume. Existiu, entretanto, efetivamente nos números \#i e \#5. Provavelmente seria uma colaboração constante.

Em Arte Vogue \#4, \#5 e \#6, as seçôes vão ficando cada vez menos descritivas. O maior conteúdo foi o de arquitetura e arte em AV \#4 (Cebolão e Ioo Artistas); arquitetura e design em AV \#5 e intercâmbio de obras e bienal em AV \#6. Mesmo assim, o número de páginas caiu drasticamente em relação ao inaugural.

\subsection{Homem Vogue}

Na Itália, desde meados da década de 1960 já circulava a L'Uomo Vogue, publicação destinada ao público masculino, que abordava temas afins à moda, como comportamento, personalidades, arte, arquitetura, design, tecnologia, prescindindo do erotismo da figura feminina como tema principal da revista. A edição brasileira ${ }^{45}$ manteve essa linha, apresentando projeto gráfico

44 cf. Anexo D, p.725

45 Homem Vogue foi licensiada para a Editora Três até o número \#16 (set. 1976). Não foi possível a consulta dos números \#I7 ao \#2I, mas no número \#22 passou a ser publicada pela Carta Editorial. A editora foi reponsável pelo título até o \#33, último volume antes da fusão com o título Senhor, também da Carta Editorial naquele momento. 
elaborado, moderno, e conteúdo que contava com colaboração de diversos jornalistas, artistas, fotógrafos, músicos, personalidades da época, oriundos de diversas áreas, como Lívio Rangan (da Rhodia, tratava das questóes da moda e estilo), Ibrahim Sued (colunista social, que também abordava questôes de comportamento - quase sempre feminino), Rudi Crespi (diretor da Vogue Brasil e Vogue México, casado com Consuelo Crespi, modelo e editora das Vogue americana e italiana, era correspondente da Homem Vogue e seus textos tratavam de atualidades em geral, inclusive arte), José Duarte Aguiar (arquiteto, escrevia também sobre questóes da atuação profissional), Samuel Wainer (tio de Nahum Sirotsky, escrevia sobre estilo e comportamento, normalmente ligados a personalidades da imprensa), Ciro del Nero (cenógrafo, escrevia sobre critica de teatro), Carlos Lemos, Paulo Francis, Luis Fernando Veríssimo, Wesley Duke Lee, Sílvio Lancellotti, Macalé, Attilio Baschera, Vinícius de Moraes, Ciccillo Matarazzo (!) e, como não poderia ser diferente, Mino Carta e Pietro Maria Bardi.

As contribuiçôes de Bardi para Homem Vogue, (também aqui se ignorando as falhas da coleção), abordavam as questôes do (bom) gosto e da arte abrangente-bardiana. Normalmente, os assuntos problematizados tinham mais a ver com o universo masculino, e eram tratados com o costumeiro tom professoral-sarcástico empregado em seus textos. Aliás, talvez o cinismo fosse até mais carregado em Homem Vogue que em Casa Vogue, por exemplo. Bardi chegou, inclusive, a escrever uma ficção, "O Grande Incêndio" em Homem Vogue \#25B (jun-jul 1977, p.92-96 (Caderno de Ficção), cf. Anexo A, p.ı19)

Infelizmente, a coleção acessada para o levantamento desta pesquisa não está completa. Nos acervos da USP, Mackenzie, Biblioteca Mário de Andrade, ${ }^{46}$ Biblioteca do Masp, Arquivo Público do Estado, Carta Editorial e Editora Globo Condé Nast ${ }^{47}$ não possuem absolutamente nenhum volume. A Editora Três, por coincidência, tem encadernada parte da coleção, incompleta, portanto, e que foi a base desta pesquisa. No total foram encontradas contribuições de Bardi em seis dos doze volumes consultados.

46 Às vésperas da entrega desta monografia, o bibliotecário da Hemeroteca da Mário de Andrade consultado meses antes sobre a existência dos números da Homem Vogue da década de 1970 informa que o título havia sido encontrado no acervo, que estava sendo organizado. Não informou a tempo, entretanto, quais os números das ediçôes disponíveis.

47 No acordo feito entre a Carta Editorial e a Editora Globo em virtude da venda das publicaçóes com a licença da Condé Nast, o acervo das Vogue seria transferido para a Globo. A Carta Editorial informa que o acervo saiu de lá e foi devidamente encaminhado à Globo, mas a Globo informa nunca tê-lo recebido. 


\subsection{Senhor Vogue}

E é já na Carta Editorial que Luis tem a ideia de fundir Homem Vogue com a Senhor do "velho" amigo Nahum, surgindo, então, a Senhor Vogue, em abril de 1978. A numeração do título, relativa à Homem Vogue, foi reiniciada, pois o corpo da publicação sofreu grande reformulação. O título completo Senhor Vogue durará 2I volumes, seguindo apenas como Senhor, a partir do número \#22 (jan. 1980; a numeração, neste caso, não foi reiniciada)

A Senhor Vogue, assim que surgiu, ainda manteve muito da Homem Vogue: design de capa, colaboradores e algumas seçóes. A tipografia do título "senhor" era a mesma do anterior "homem" e manteve-se assim até o número \#I2 (mar 1979). No número \#I3 (abr. 1979), o logo é redesenhado aparentando algo mais "clássico" e "empresarial." Esse logo sofre um leve redesenho quando perde "Vogue" (\#22, jan. 1980) e já dava sinais do que viria a seguir: a partir do número \#58 (28 abr. 1982) o logo adotado, novamente redesenhado, é mantido praticamente o mesmo até o último número da publicação (\#380, 4 jul. 1988) e também depois de sua a fusão com a Istoé, sendo o mesmo até o último número da Istoé Senhor (\#1173, 25 mar. 1992), que, novamente, seguiu apenas como Istoé.

À parte as migraçôes de colaboraçôes a causa da mudança de Homem Vogue para Senhor Vogue e Senhor, estando neste grupo o próprio Bardi, as revistas levantadas, dirigidas pelos Carta e pelos Alzugaray, frequentemente compartilhavam colaboradores. Por exemplo, Alberto Guzik (crítico de teatro) aparecia no expediente de Casa Vogue e Senhor Vogue; Daniel Más (jornalista) em Status, Senhor Vogue, Casa Vogue (sendo que nesta assinava a sessão "As paredes de Casa Vogue," onde eram apresentados artistas, seus ateliês, obras e resumos biográficos); Renato Magalhães Gouvêa (galerista, antiquário) Senhor, Casa Vogue (nesta viria a constar como consultor em artes); Radha Abramo (historiadora da arte) constava em Casa Vogue e seu marido, Cláudio Abramo (jornalista) em Senhor. Isso apenas para mostrar que essa interrelação entre afinidades intelectuais e relações pessoais nas revistas geridas pelos Carta não era exclusiva de Bardi. A ele, entretanto, se reservava visivelmente muito mais espaço e inserçóes nessas publicaçóes quando analisadas em seu conjunto, além de uma liberdade de abordagens que não se estendia aos outros.

Bardi já colaborava com a Homem Vogue antes da fusão com a Senhor de Sirotsky. Ao contrário de Lívio Rangan e Silvio Lancellotti, os únicos que continuaram a figurar como colaboradores com a mudança de publicação, seu nome só irá aparecer oficialmente a partir do volume \#II, onde Pietro Maria 
Bardi é o tema de capa e da reportagem (autobiográfica) principal. Entretanto, Bardi havia contribuído nos volumes 4, 5, 6, 7 e Io sem constar oficialmente no expediente.

Enquanto a publicação ainda intitulava-se Senhor Vogue, Bardi ainda não constava oficialmente no expediente nos números iniciais, \#4 (jul. 1978, sobre o mercado da arte), \#s (ago. 1978, sobre o projeto de Luigi Vietti para o Helvetia Contry Club em Indaiatuba, o texto é publicado na seção "Entre homens," herdada da Homem Vogue antes da reformulação para Senhor Vogue), \#6 (set. 1978, sobre a preservação das obras, acervos e, por extensão, memória do Brasil), \#7 (out. 1978, sobre as relaçôes entre arte e indústria e o pioneirismo no da Rhodia ao promovê-las, no Brasil, com uma colaboração assinada por José Hugo Celidônio ${ }^{48}$ ) e \#IO (jan 1979, sobre a importância não ignorável da moda para a sociedade contemporânea, sendo que esta é a única vez ao longo de todos os seus anos de colaboração com a Senhor em que Bardi não assina o texto principal, sendo este uma nota do artigo principal de Marco Antonio de Menezes sobre Pierre Cardin)

O número \#II (fev. 1979), com Bardi na capa, seu nome figurando oficialmente no expediente, um longo de texto autobiográfico (23 páginas) seguido por um caderno sobre artes (mais I4 páginas) inaugura o caderno sobre arte a ser editado por Bardi a cada número. No índice do volume \#II apresenta-se a seguinte oficialização da colaboração:

\footnotetext{
Senhor apresenta-se este mês com uma novidade importante: um caderno de arte - que será mensal ${ }^{49}$ - editado por P.M. Bardi. E precedido, neste número, por um artigo autobiográfico do próprio Bardi que, modéstia à parte, (nossa e do autor) é uma joia. Uma vida de criatividade, vivida com inteligência e humor.
}

E no editorial, assinado por Luis Carta, aparece o seguinte: a vida é na verdade algo a ser encarado com extrema ironia: juntar
numa só matéria elementos tão díspares e conflitantes (...) requer
também uma dose de senso de humor. Qualidade aliás das mais raras,
com raras exceçóes. Exceção para mim definitiva é a de um homem
que entra nestes dias no seu octogésimo ano de vida: Pietro Maria
Bardi, a quem o Brasil muito deve (e esta é a típica frase da qual ele

48 José Hugo Celidônio colaborava com a Casa Vogue regularmente sobre culinária e sua seção passa a ser, em abril de I978, um caderno trimestral, "Comer e Beber," tal como "Arte Vogue," editada por Bardi. Esses cadernos foram publicados trimestralmente até que o caderno de Celidônio passa a ser mensal e o de Bardi, infelizmente desaparece.

49 Mensal, pois até então a periodicidade da revista era mensal, e que passará a ser semanal acompanhando a alteração da periodicidade da revista. 
ri com sardônica indiferença) e que a partir deste mês mudou sua seção de artes da revista Casa Vogue para Senhor. Dedicamos a Bardi a capa da revista e uma matéria que ele - com medo de más interpretaçóes - escreveu de próprio punho contando de sua vida e - desculpe, professor - de sua obra: uma carreira absolutamente fulgurante e altamente movimentada. Na Itália, primeiro, onde ele se apresentava como inovador na arquitetura e na pintura. Sua resistência ao estilo neo-triunfalista do fascismo e que ele combateu até a hostilização total. Depois o convite de Chateaubriand, o museu e o marco que é na vida deste país, as compras - controvertidas às vezes - que fez em benefício do nosso patrimônio artístico e, finalmente, sua preocupação constante em dar oportunidade aos novos e ter uma visão da arte não como um exercício gratuito, mas sempre ligada às coisas práticas da vida. (...) Um promotor, um animador, um renovador. Um homem com senso de humor, acima de tudo. \{LUIS CARTA, Senhor \#I, fev. 1979, p.47\}

De fato, depois da oficialização da colaboração do Bardi com a revista, a partir do número \#II, apenas os números \#I9 e \#2I, de outubro e dezembro de I979, não contarão com o texto de Bardi. A colaboração contará sem outras falhas até depois da fusão, em 1988, de Senhor com a Istoé.

E a seção destinada à Bardi tem, enquanto a publicação ainda carrega Vogue, (dos volumes \#I2 a \#20) grande número de páginas, sempre superior a dez, de modo que sua seção ocupa mais de IO\% da revista. Além disso, a partir do número \#I2, a seção de Bardi aparece no índice como "Senhor e as Artes, , $^{\circ}$ por Pietro Maria Bardi” até o número \#49 (3I dez. 198I). No volume \#50 (I5 jan. 1982) passa a aparecer no índice apenas "Senhor e as Artes," e neste caso o nome de Bardi apareceria na página do próprio texto. Talvez por um erro de revisão, a rubrica apareceu no índice do número \#58 (28 abr. 1982) como "Senhor e as Artes," se manteve assim na página do texto, mas o nome de Bardi simplesmente não apareceu nem no índice, nem no próprio texto. No número seguinte, (\#59, 5 maio 1982) o índice ainda mostrava a seção "Senhor e as Artes," mas desta vez, no texto, no lugar da referida rubrica, apareceu apenas "P.M. Bardi" com o mesmo corpo tipográfico da rubrica até então. A partir do número \#60 (II maio I982) a rubrica passou a ser "P.M. Bardi" tanto no índice quanto no texto. ${ }^{\text {II }} \mathrm{E}$ Bardi tem consciência do significado desses canais de comunicação, a ponto de ser escolhidos entre uma das personalidades mais

50 A grafia varia de revista para revista, encontrando-se, tanto no índice quanto na página do texto, "O Senhor e as Artes," "O Senhor \& as Artes" e "Senhor \& as Artes."

5I A Casa Vogue adotaria a mesma rubrica "P.M. Bardi" a partir do número \#2 de 1984 (março-abril), como visto antes. 
influentes entre as donas-de-casa e reconhecer a importância do espaço que lhe é destinado em Senhor:

...em dezembro passado, quando vi na Senhor, a revista que semanalmente publica a página "P.M.Bardi," meu semblante ao lado dos de Carlos Drummond de Andrade, Sobral Pinto, Cora Coralina, Chico Xavier e até do Papa. (Motivo: personalidades indicadas, através da uma pesquisa realizada ouvindo-se donas da casa, para indicar sujeitos ad-hoc.) \{BARDI, Vogue Brasil\#II5, fev. 1985, p.II6-I62, grifo nosso\}

Adotar a rubrica "P.M. Bardi" faz sentido considerando-se que a diversidade de assuntos abordados era muito ampla. Uma seção inteira "inespecífica" o suficiente para carregar "apenas" o nome de Bardi se justificaria dentro da crença bardiana de que praticamente tudo pode ser arte. Mesmo fugindo do tema (como quando escreve sobre a indústria de pinceis no Brasil; Senhor \#43, 8 out. 198I, p.72), ainda assim o tema é ligado à arte ou ao gosto. Os textos de Bardi frequentemente se diversificam na temática, e quase todos escorregam para reminiscências pessoais, às vezes tratando de assuntos políticos (apoio a um determinado candidato, que ele espera/solicita que apoie as questôes da Arte; Senhor \#264, 8 abr. 1986, p.76) ou em voga (alguma publicaçáo que ele recomenda, morte de um afeto ou desafeto). Para completar, o próprio Bardi escreve também em Senhor incontáveis vezes sua abordagem do tema Arte está longe de ser a tradicional, como será visto em tópico a seguir.

Assim sendo, é compreensível porque suas colaboraçôes em Senhor inicialmente eram inseridas sob a rubrica "Senhor e as Artes" mas passou a ser “P.M. Bardi," mantendo-se em Istoé Senhor e Istoé e estendendo-se a Casa Vogue.

\subsection{Senhor}

A Senhor Vogue, conforme já visto anteriormente, perde a alcunha Vogue a partir do número \#22 (jan. 1980), sendo editada pela Carta Editorial até o número \#34 (jan. 198I), quando passa a ser da Editora Três.

Sirotsky escreveu no primeiro número de Senhor Vogue (abr. 1978) sobre o seu primeiro projeto para a primeira Senhor, da década de 1959, os seguintes dizeres:

\footnotetext{
Estávamos em 1958. O Brasil se industrializava. A tendência à urbanização me parecia irreversível. Tudo indicava que a nova classe de empresários e técnicos iria necessitar de uma publicação semanal que a mantivesse informada sobre a economia nacional e a internacional. Anos antes, em São Paulo, eu havia tido provas do interesse pela
} 
economia num programa de televisão que eu apresentava na TV Tupi. A Visão, quinzenária, era bem sucedida. Por acaso revelei minhas ideias a um amigo (...) que se dispôs a me apoiar financeiramente. Parti para obter apoio em outros setores.

Minha ideia era a de um semanário que fizesse cuidadosa cobertura dos fatos econômicos, interpretando-os, procurando mostrar o seu significado, as suas possíveis repercussôes e reflexos sobre a vida brasileira. A revista também se preocuparia com as repercussóes sobre a economia dos fatos políticos, culturais em geral, científicos e tecnológicos. \{Sirotsky, Senhor Vogue \#I, 1976, p.77-79\}

A primeira Senhor, de Sirotsky, entretanto, acabou não saindo de acordo com essa primeira ideia, pois os investidores, o grupo Delta, tinham outros planos: fazer uma revista que fosse um cartão de visitas, um portfolio das possibilidades gráficas do grupo, que editava, entre outras publicaçôes, enciclopédias. \{Sirotsky, Senhor \#I, 1976, p.77\} Mas anos depois, quando Luis Carta conclui a fusão dos títulos Homem Vogue e Senhor, a ideia fundamental de Sirotsky é quase atingida em sua completude. Ela será realmente alcançada a partir da edição \#4I (IO set. 198I), quando a Senhor passa a disponibilizar um caderno que correspondia à edição brasileira da The Economist: publicação que até hoje não tem pretensôes de ser a mais vendida do mundo, mas sim a mais aprofundada e informativa, buscando ser acessível inclusive para não-especialistas nos diversos assuntos abordados. Bardi elogia a publicação inglesa: "Nas páginas da seção The Economist, sempre instrutivas também para leigos em economia, em recente edição de Senhor, descubro um artigo dedicado a Le Corbusier..." \{BARDI, Senhor \#315, 3I mar 1987, p.68\}

A revista Senhor passa a ter oficialmente a The Economist como modelo "filosófico," de jornalismo, se aproximando inclusive visualmente cada vez mais da revista de economia inglesa.

Jorge da Cunha Lima, em janeiro de 1979, numa laudatória declaração em sua seção, "O Senhor em Vogue," confirma essa inclinação da publicação brasileira: inclinação esta datada de mais de dois anos e meio antes da efetiva publicação da The Economist vinculada a Senhor:

No início de 1978 demos andamento a um projeto da Carta Editorial que visava a criar uma revista para o empresário brasileiro, que não fosse chata como as revistas técnicas, nem frívola como as "chamadas" revistas masculinas. Acreditávamos que o empresário, mais do que os costumeiros problemas de "caixa," estava sofrendo na pele as consequências da modernização da sociedade brasileira. Ele era parte do poder, sabíamos que a reflexão é um instrumento tão indispensável à conquista do poder quanto o crédito bancário é indispensável à 
consolidação das empresas. E sabíamos que ambos implicam em esforços ingentes. (...) Buscamos produzir uma revista que, nas suas características mensais, isto é, distante da notícia fulminante do Telstar, se constituísse num duto entre o empresário e o poder (em todas as suas dimensôes) e entre a realidade e o empresário. Acreditávamos firmemente que um poder desvinculado da realidade é belo e inútil como um barco fora da água. Sabíamos que a realidade nem sempre é o condimento mais digestivo para ser servido no intervalo de reflexão de um homem que trabalha mais de dez horas por dia. (...) $\{$ LIMA, Senhor Vogue \#IO, jan 1979, p.98\}

\section{E Francisco Alberto Madia de Souza, um ano e três meses após o lançamento} do título em 1978, escreve sob a rubrica "Jornal de marketing" os seguintes dados e objetivos:

Decididamente em nenhum momento passou por esta Carta Editorial a ideia de concorrer com outros veículos em termos quantitativos. Nestes três anos de existência desenvolvemos e implantamos as revistas, Vogue, Casa Vogue e Senhor Vogue, voltadas para a classe A - hoje, um contingente de aproximadamente setecentas mil famílias brasileiras que possuem uma renda mensal familiar igual ou superior a Cr\$ 30 mil. Essas setecentas mil famílias detêm quase $80 \%$ da renda nacional e, mais do que isso, praticamente a totalidade das disponibilidades para efeito de consumo. E nesse target, indiscutivelmente as nossas três revistas são líderes de mercado.

Hoje vamos falar um pouco desta revista. Senhor Vogue. Com quarenta mil exemplares de tiragem e uma circulação oscilando entre 32 mil a 35 mil exemplares, Senhor Vogue está presente nos trezentos municípios mais importantes do país, que detêm mais de $90 \%$ da renda nacional, e em algumas grandes cidades do exterior. Lida, basicamente pela classe política, empresarial, pelo $\mathrm{I}^{\mathrm{o}}$ escalão das empresas públicas e privadas, por homens que têm o invejável poder de decidir em última instância, de dar a palavra final. E todas essas afirmaçóes acabam de ser comprovadas por pesquisa realizada pelo IPPM - Instituto Paulista de Pesquisa de Mercado - entre cem assinantes desta revista, tendo sido os entrevistados sorteados dentro da metodologia mais recomendável no sentido de garantir total fidedignidade às informaçóes obtidas.

Por essa pesquisa ficamos sabendo que hoje a revista Senhor Vogue é uma das revistas de maior índice de leitores por exemplar do país: 34,9 . Esse índice resulta principalmente do local onde a revista fica nas residências - no living - e de sua transferência para escritórios e outros tocais de grande movimento. A pesquisa revelou ainda que a família 
leitora tem uma renda média de Cr\$ 79.200,00 que correspondiam no momento da pesquisa - jan/mar 79, a US\$. 3400, e que ainda $77 \%$ dos entrevistados já foram ao exterior, quase todos mais de uma vez.

Finalmente, e além de outras informaçóes relevantes, a pesquisa revelou que mais de dois terços dos pesquisados são sócios de algum clube (Harmonia, Jockey, Paulistano, Country, Iate, entre outros), 91\% possuem imóveis, $19 \%$ motorista particular, quase I0\% grau Master, Pós-Graduação ou equivalente, e ainda, que para $53 \%$ dos entrevistados Senhor Vogue é a única revista masculina que eles leem. \{MADIA DE SOUZA, Senhor Vogue \#15, 29 jun 1979, p.29\}

Todos os textos de Bardi em Senhor Vogue/Senhor foram disponibilizados no Anexo A. Senhor Vogue/Senhor representa $86 \%{ }^{52}$ das publicaçôes com contribuições de Bardi. Representa também, ou melhor, por isso mesmo, a maior variedade de temas abordados.

\subsection{Istoé}

No que se refere a esta pesquisa, a história da Istoé pode ser dividida em quatro fases:

- A primeira, de maio de 1976 a edição \#163, de 6 de fevereiro de 1980, período em que a publicação esteve sob responsabilidade da Encontro Editorial, dos Alzugaray e Carta, intervalo onde aparecem dez textos assinados por Pietro Maria Bardi; ${ }^{53}$

- A segunda, da edição \#164, de I3 de fevereiro de 1980, à \#369, de I8 de janeiro de 1984, quando passa ser publicada pela Caminho Editorial, de Fernando Moreira Salles, ligado ao grupo Unibanco;

- A terceira, do volume \#370, de 25 de janeiro de 1984, à \#60I, de 29 de junho de 1988, quando foi publicada pelo grupo da Gazeta Mercantil;

- A quarta e última fase, da edição \#982, de II de julho de I988, à edição \#I255, de 20 de outubro de I993, compreende o período que se inicia com o título retornando às mãos da família que a originou (Alzugaray, com Mino Carta) e termina com a última colaboração oficial de Bardi.

52 368/428 volumes com contribuições de Bardi. O cálculo considerou apenas o volume em si, ignorando número de inserçóes, quando encontram-se mais de uma contribuição de Bardi por volume, e independente do número de páginas dedicadas a Bardi. Exceção foi feita às quatro ediçóes de Arte Vogue incorporadas à Casa Vogue que foram consideradas volumes independentes.

Disponibilizados no Anexo A. 


\subsection{Istoé, até I988}

A Istoé foi lançada em maio de 1976, afinal, dada a preocupação da família e amigos de Mino Carta depois de sua saída da Abril. Segundo Mino, "o Luis e o Alzugaray fizeram a Istoé anódina e inodora [e mensal] por causa dos problemas anteriores com a censura na Veja. ${ }^{34}$ Entretanto, a partir do arrefecimento da censura em março de 1977 , a Istoé passa a ser semanal e a tratar novamente dos assuntos mais caros a Mino: política além de atualidades, ao ponto de que a seção de artes, a princípio com diversos articulistas, vai perdendo espaço para a de política. (Por outro lado, todas as seçóes sáo cada vez melhor organizadas, incluindo a de artes.)

A rubrica Artes Plásticas, em Istoé, passa a acontecer a partir do volume \#2. Neste, foi assinada por Roberto Marinho de Azevedo e se intitulava "O universo político-onírico de João Câmara, artista de verdade." (p.34-35) Na mesma edição, houve outro espaço (p.II6-II9) para artes visuais, concedido ao artista Rodolfo Mesquita, que ali publicou seu texto "Prenez Garde a le Dessin” e vários desenhos e caricaturas. O texto de apresentação anuncia o seguinte:

Tomem nota deste nome: Rodolfo Mesquita, desenhista, 24 anos. Um artista importante. Já fez uma exposição individual em Olinda, na Fundação da Casa da Criançass e participou de duas coletivas. Este ano ganhou o II Prêmio Jornal do Brasil e agora programa uma individual no Museu de Arte de São Paulo. Arredio, avesso a fotografias, aqui se explica numa série de desenhos exclusivos para Istoé e num breve texto, intitulado "Prenez Garde a le Dessin."

Em dezembro de 1976, Bardi publica em um grande espaço do volume \#8 da revista (oito páginas) um texto sobre Chateaubriand (cf. Anexo A, p.Ios, “Os últimos dias do Cidadão Chatô,” título que faz citação ao Cidadão Kane). A Istoé passa a ser semanal a partir do volume \#II (9 mar 1977) e Bardi passa a constar oficialmente como colaborador no expediente a partir do volume \#I2 (I6 mar 1977), quando publica uma resenha sobre o que chama de "urbanística," praticamente prevendo a futura criação do Estatuto da Cidade e dos Planos Diretores. Até outubro de 1977, Bardi publicará outros oito textos (todos disponíveis no Anexo A), no início sob a rubrica "Cultura: Arquitetura" e na sequência sob a rubrica "Cultura: Artes." Os textos versariam principalmente sobre arquitetura, (\#15, 6 abr. 1977; \#16, I3 abr. 1977; \#17, 20 abr.

54 Mino Carta, declaração verbal em II fev 2014.

55 Eis mais um indício de que as relaçóes pessoais entre Pietro Maria Bardi, Giuseppe Baccaro e os Carta resultavam em artigos nas publicaçôes da famiglia. 
1977, \#25, I5 jun. 1977; \#29, I3 jul. 1977), sobre Urbanismo (\#32, 3 ago. 1977), sobre a arte de Fábio Magalhães (o mesmo que depois, na década de 1990, o substituiria na direção do Masp, \#44, 26 out. 1977), e também, sob a rubrica "Memória," texto sobre Ciccillo Matarazzo (\#I8, 27 abr. 1977). Bardi não fará mais contribuições a Istoé até que se dê a fusão deste título com a Senhor, em 1988.

Apesar da ausência de colaborações de Bardi, as informaçóes relativas a artes e arquitetura seguirão sendo publicadas assinadas por Roberto Marinho de Azevedo, José Nogueira, Silvio Lancellotti, Geraldo Ferraz, Nirlando Beirão, Ruy Sampaio, Geraldo Edson de Andrade, Gardênia Garcia, Pancho Gomes, Moacir Jupiassu, Dagomir Marquezi, Giuseppe Baccaro, Mário Schenberg, Cecília Prada, Margarita Sansone, Milton Hatoum, Fernando Sandoval, entre outros.

No volume \#I5I (I4 nov 1979) a Encontro Editorial mantém como diretor Mino Carta, saem os Alzugaray e entram, em seu lugar, Armando V. Salem, Fernando Sandoval, Raymundo Faoro e Tão Gomes Pinto.

No editorial do volume \#I62 (30 jan 1980), há a informação da perda do Jornal da República, empreitado por Mino Carta seis meses antes. Com o fracasso do jornal, Mino resta com uma dívida de US $\$ 1,5$ milhão à época. Como saída para saldá-la, o título do jornal é vendido juntamente com o de Istoé para Fernando Moreira Salles, e esperava-se que fosse dada sequência a ambas as publicações. O Jornal da República é, entretanto, definitivamente engavetado. Já a Istoé, a partir do expediente do volume \#I64 (I3 fev 1980) tem a Encontro Editorial substituída pela Caminho Editorial, figurando como diretor-presidente Fernando Moreira Salles e como diretores Antônio Fernandes De Franceschi, Armando V. Salem e Mino Carta. Mino constará no expediente até o volume \#228 (6 maio de $198 \mathrm{I})^{56}$ mas declarou $^{57}$ ter saído definitivamente do corpo editorial da Istoé em fevereiro, exatamente um ano após a venda do título, assim que cumprido o acordo feito com os Moreira Salles. O nome de Bardi entre os colaboradores é mantido até o volume \#I78, de 2I de maio de 1980, mesmo não tendo contribuído com nenhum artigo para esta Istoé da Caminho Editorial e saído junto com Mino Carta, em fevereiro também. Até esta fase do título, sua contribuição efetiva foi infinitamente

56 A partir do volume \#229 (I3 maio 198I) constarão apenas Fernando Moreira Salles, Antônio Fernandes De Franceschi e Armando V. Salem. 
menos frequente que em Senhor e nas outras publicaçóes da famiglia Carta, acontecendo mesmo apenas no início da publicação.

A Caminho Editorial, do Moreira Salles, segue como responsável pela publicação até o volume \#369 (I8 jan 1984). A partir do volume \#370 (25 jan 1984) é assumida pela Gazeta Mercantil ${ }^{58}$ de Luiz Fernando Levy. Seu pai Herbert Victor Levy, passa a figurar como diretor-presidente a partir do volume \#375 (29 fev 1984) e Luiz Fernando como vice-presidente. A publicação seguirá sob a edição da Gazeta Mercantil até o volume \#60I (29 jun I988). Este período da Istoé-Gazeta Mercantil foi infeliz na história da publicação, que, se não decaiu em seriedade e comprometimento jornalístico, perdeu muito em qualidade gráfica.

\subsubsection{Istoé Senhor, a partir de 1988}

Dada então qualidade decadente da Istoé, surge a oportunidade e Domingo Alzugaray recompra o título para sua Editora Três, mas funde com o título Senhor, que passa a ser Istoé Senhor, a partir de in de julho de I988. Somam-se assim a tiragem, assinantes e anunciantes de uma com a reputação e qualidade gráfica mantida pela outra: "para atribuir à decadente Istoé a linha editorial e qualidade que Senhor conseguiu manter ao longo dos anos." \{Editorial, Istoé \#II74, I abr. I992, p.II\}

A numeração das ediçôes de Istoé Senhor não é completamente reiniciada, mas passa a ser \#982: o número seguinte ao resultado da soma dos volumes já editados dos dois títulos anteriores: \#380, no caso de Senhor, e \#6or, da Istoé.99

"Bardi ficou inventando vários logos, ficava trazendo vários desenhos para a Istoé, quando o título foi recomprado. Era muito vivo." ${ }^{\prime 60} \mathrm{O}$ logo anterior, entretanto, foi mantido.

Nesta ocasião, por conta da manutenção do corpo colaborativo de Senhor, Pietro Maria Bardi continua a aparecer entre os colaboradores, mantendo-se a habitual seção a ele reservada na Senhor, sem hiatos.

58 Esta foi uma transição silenciosa, dado que nenhum aviso aos leitores e patrocinadores foi dado no editorial ou em nota de qualquer tipo, como aconteceu na transição anterior e aconterá na próxima, quando for recomprada pela Editora Três.

59 A última edição da Senhor antes da fusão foi a \#380, de 4 de julho de 1988; a da Istoé, \#60I, de 29 de junho. A Istoé Senhor \#982 é de II de julho. Assim, houve um gap de uma semana na readaptação da Istoé, anunciado em nota no editorial da Istoé \#6oI.

60 Mino Carta, declaração verbal em ir fev 2014. 
Istoé Senhor é publicada até março de 1992. A partir do volume \#II74 (I abr. 1992), a alcunha Senhor é abandonada e a publicação segue, outra vez, apenas como Istoé.

A seção "P.M. Bardi" não foi publicada apenas nos volumes retrospectivos, os últimos publicados no final dos anos I990 (\#IIIO, 26 dez. 1990) e I99I (\#II6I, 25 dez. I99I) e Bardi colabora religiosamente em todos os volumes até o \#II95 (26 ago. 1992) Foi por volta dessa data que ele sofre um aneurisma nas $\operatorname{costas}^{61} \mathrm{e}$, mesmo tendo sido operado com sucesso, a partir daí seus problemas de saúde só piorariam, comprometendo, em poucos anos, inclusive a sua lucidez.

Depois de três edições em hiato, foi publicado no número \#II99 da Istoé (23 set. 1992) o último artigo de Bardi, sobre o Grupo Cobra, onde uma nota informa o seguinte: "Pietro Maria Bardi já está se recuperando e esta semana decidiu ocupar o seu espaço tradicional. Por algum tempo, ele manterá uma colaboração saltuária, até o momento em que poderá retomá-la semanalmente." Infelizmente esse retorno não aconteceu. Seu nome, entretanto, continuaria a aparecer no expediente por quase um ano depois disso (até Istoé \#I255, 20 out. 1993).

Os 2I4 artigos levantados de Bardi, publicados em Istoé Senhor e Istoé pós-fusão, não foram incluídos nesta pesquisa dada a repetição temática e argumentativa do autor em relação a suas contribuiçóes do período pré-fusão. Reconhece-se, entretanto, a importância de sua disponibilização e análise em pesquisa futura.

6I Lina Bo Bardi havia falecido há pouco tempo: cinco meses antes de Bardi entrar nessa que Mino Carta chamou de "espiral de decadência mental: esclerose.” (declaração verbal em II fev 20I4) 


\section{Capitulo 3 \\ Assuntos recorrentes}

Neste capítulo serão analisados os assuntos recorrentes nos textos jornalísticos publicados por Bardi, na tentativa de identificar seus interesses principais e a evolução do seu pensamento em relação aos campos considerados.

\section{I.I. Arte}

"Afinal, quem se interessa pelas artes deve mexer em todos os setores interligados à vida." \{BARDI, Casa Vogue \#6, nov-dez 1986, p.II4\}

Sem dúvida, o assunto que aparece em quase todos os textos de Pietro Maria Bardi é o seu entendimento sobre arte. Mesmo que apenas uma linha, praticamente em todos eles, a questão é colocada.

\footnotetext{
Várias vezes, nesta página, os assuntos escorregam por caminhos que não correspondem ao rigor de um enquadramento na manifestação Arte. Os novos conceitos pertinentes ao labirinto desta imensa atividade, de qualquer modo, não vencem o rigor que herdamos e consolidamos academicamente. Agora se admite no recinto, ao lado das produçôes elitistas, inúmeras outras de complemento ou, como opinam os críticos, marginais. \{BARDI, Senhor \#I05, 23 mar. 1983, p.82\}
}

Este último trecho foi retirado de um artigo que, ao final, defende a acepção de Arte estendida "à produção dos filmes publicitários para TV, produçôes nas quais se somam engenhosidade, invençáo e técnica, ou seja, Arte." (grifo nosso) Percebe-se em diversos momentos que a questão, para Bardi, transcende a discussão sobre o Belo. Ele mesmo explica:

\footnotetext{
A renovação da função museográfica é evidente. Levar em conta a realidade é oportuno. A tradicional e burocrática celebração da "beleza," como ciência e arte do produzir, não está mais em cena, pois o "bonito" foi posto de lado. O que vale agora é outro critério, pois o gosto é levado para outros caminhos. (...) Então, nada mais singular que um museu de arte se interesse por acontecimentos relacionados e
} 
determinadores das mudanças da estética hodierna, considerando fato de arte o redigir um cotidiano, naturalmente pensando até em criatividade. A palavra estética, que vem do grego, significa fatos sensíveis. Benedetto Croce a definia como a "ciência do aprendizado sensível, teoria das artes liberais... Arte do bem pensar, arte do raciocínio por analogia." \{BARDI, Senhor \#254, 28 jan. 1986, p.72\}

O esforço de Bardi em expandir a definição de arte existe porque ele se sente pessoalmente responsável como diretor do Masp "para nós, que manuseamos objetos nos recintos mal definidos de museus, cabe-nos algumas responsabilidades na definição da arte.”\{BARDI, Senhor \#96, I9 jan. 1983, p.69\}

E Bardi segue em frente. Ele definitivamente despreza a distinção entre artes maiores e menores, de Belas Artes. Ele, inclusive, não faz distinção definitiva entre Arte e outras áreas como a produção técnica e o desenho do produto industrial. Aliás, seria mais adequado dizer que ele faz uma indistinção, por exemplo, entre arte e design, quando ele associa a importância da contemplação sensível, da utilidade e a das condiçôes de difusão e produção técnica no julgamento sobre um determinado objeto. De modo que, para ele, a arte surge sempre da resolução técnica de alguma necessidade cotidiana, e ele aceita, com alguma reserva, quase toda a produção humana, funcional ou não, como sendo potenciais manifestaçôes artísticas.

A questão atualmente é mais discutida, como nos mostra André Stolarski:

Decerto, nem tudo é arte, a priori porém, qualquer coisa pode sê-lo. A arte em geral é o nome da novidade de que Duchamp foi mensageiro. Esse nome substitui a denominação genérica 'belas-artes,' que corresponde à situação que encarnavam a Academia, a Escola e o sistema das belas-artes antes que sua falência fosse declarada pelas vanguardas históricas. \{deDuve, 2010 em Stolarski, 2012, p.57\}

E Stolarski complementa:

"Nem tudo é arte, mas a priori pode sê-lo." Essa abertura, essa novidade fundamental produziu, de dentro da arte, todas as condiçóes para a produçáo de uma indiferenciação profunda, anterior a qualquer outra consideração, cujas consequências não pararam de reverberar por toda parte desde então. \{Stolarski, 20I2, p.57\}

E esse assunto era já há muito familiar a Bardi. E “desde então," parece que Bardi, sempre que retoma o assunto, faz um convite à sensibilidade: há algo a ser sentido além de racionalizado e visto.

[na] exposição de uma escultora figurativa, Oxana, (...) foi observado um interesse bastante acentuado do público. Estamos ainda num período de transição. A escultura de Oxana não é para ver, mas para entender, com a simplicidade instintiva e o amor que ela pôs no criá-la. 
Faz parte da bagagem, um dia de volta, do Romantismo. Não tenho receio em dizer que, sem se comover, náo adianta ver. \{BARDI, Senhor \#94, 5 jan. 1983, p.64; grifo nosso\}

Por isso, não há um julgamento de valor quando, na Vitrina das formas, ele expóe deliberadamente uma máquina de escrever Olivetti ao lado de um vaso pré-histórico. Há sim o reconhecimento do trabalho humano de acordo velado com as velhas utilitas e venustas - e firmitas, sempre que pertinente. E há também a manutenção deste discurso, se não ao longo de todos os anos em que tratou do assunto, pelo menos no período que compreende os escritos analisados neste levantamento. Por exemplo:
A Vitrina das formas reunia objetos de arte e de uso de todos os tempos, desde a Babilônia até este século já em declínio. Servia para lembrar ao admirador de Rembrandt e de Picasso que a história da arte era composta também de objetos de uso cotidiano e não somente de contemplação, dignos da mesma consideração e de contemplação. (...) A tecnologia e o design representam fatos da vida em que o homem pôs talento, jeito, cultura, tenacidade, arte. \{BARDI, Senhor \#26, maio I980, p.IIO-III\}

Para completar esse raciocínio, Bardi frequentemente alude à ampliação através da formação de um público que saiba "considerar" e "contemplar" essa(s) arte(s). Escrever nos jornais dos Diários Associados, publicar as revistas do Museu (Habitat) e da Galeria (Mirante), colaborar nas revistas dos Carta faz parte desse projeto de conscientização da arte. As exposiçóes didáticas e a própria Vitrina das formas também se incluem nesse propósito, sendo estas algumas de suas contribuições pessoais para a formação de um público mais amplo possível para a arte. Mas, sem dúvida, a peça-chave dessa espécie de filosofia pessoal são os cursos: o curso de história da arte, de museografia, o IAC, Escola de Propaganda. Tudo lado a lado com as exposiçóes de arte em si.

Outro exemplo: quando menciona a criação do IAC, ele fala sobre ensino, design e liga isso à exposição de Max Bill:

\footnotetext{
Recuamos trinta anos, àqueles tempos em que o Museu abriu o Instituto de Arte Contemporânea, uma escola dirigida por Lina Bardi e que objetivava pôr em linha o então incógnito Design. Pensávamos chamar atenção para uma atividade que na própria Europa, depois da extraordinária empresa que foi a Bauhaus de Gropius e de Mies van der Rohe, andava se impondo. Para explicar a iniciativa Design, convidamos para uma grande exposição Max Bill, que teve um modesto sucesso em comparação com sua personalidade. \{BARDI, Senhor \#47, 3 dez. I98I, p.72\}
} 
Ao mesmo tempo em que, no discurso de Bardi, o campo de abrangência do conceito arte é ampliado pelo conceito de estética mencionado acima (ciência do aprendizado sensível), ele por outro lado, também é delimitado: para Bardi, arte depende, além do talento (entendido aqui como intuição e sensibilidade pessoal e rigor técnico, no caso da produção das manifestaçôes artísticas "tradicionais"), de muito bom-senso, tanto daquele que produz quanto daquele que vai apreciar a arte. E o bom-senso entra, explícita ou implicitamente, nos debates sobre o gosto: que sim, se discute, e muito. Para Bardi, o bom-senso ou bom-gosto é crônico e tópico: ele existe de fato pela simples pertinência e relação de algo com seu momento e seu local.

Às vezes, o retorno à magnificência do Parthenon é decisão de um tal que mexe o dia todo com produtos elétricos, sendo entáo difícil estabelecer sintonia entre os tempos e os gostos, bem como descobrir as motivaçôes de uma escolha de ordem estética. \{BARDI, Senhor \#89, I dez. 1982, p. 76$\}$

E em muitas outras vezes isso é formalizado. Por exemplo, quando ele comenta sobre a arquitetura "foliona" que é o estilo Mediterrâneo, quando fala da moda, da propaganda e do design copiando modelos americanos e europeus, quando fala das Bienais que copiam o modelo de Veneza. Um caso:

O erro de base, [produzido pela Bienal de São Paulo] em nosso parecer, é o genérico da condução da vida brasileira, o olhar demasiado para fora e náo prestar atençáo no que se faz, no que se quer e o que se pode inventar aqui dentro das fronteiras pátrias. A observação nada tem a ver com o espírito de nacionalismo (...) trata-se na verdade em se pensar e resolver (tesourando, naturalmente, o que de bom e útil se produz lá fora) com a própria cabeça e conforme as exigências das próprias necessidades morais e materiais. \{ALENCASTRO, Arte Vogue \#2, nov. 1977, p.36-37.

Ou quando ele explica a criação dos cursos do Masp: "volto meus pensamentos para os primeiros passos dados pela Escola [de Propaganda], inaugurada para provocar uma autonomia face ao hábito de copiar, quase servilmente, os sistemas norte-americanos." \{BARDI, Senhor \#74, I8 ago. 1982, p.68\}

Mais uma vez, para Bardi, essa experimentação estética e muito pessoal, mas, ao mesmo tempo, é perfeitamente ensinável, no fazer e no apreciar, aduzindo que o bom-senso, mais que discutível, pode ser apreensível. Isso náo apenas nos textos aqui disponibilizados, mas em suas realizaçóes, sempre pertinentes à filosofia da educação para a Arte e, afinal, para a Vida. ${ }^{62}$

62 Vale observar que Bardi não faz apologia a um estilo ou outro. Ao contrário, aceita de todos, com parcimônia, e sempre dá a entender sua antecipaçáo à tendências, 
Ao final, quando Bardi, faz mais apologias e também mais críticas, é quase sempre quando ele fala sobre o mercado de arte (desbalanceado por questôes de bairrismo) ou sobre fazer arte desinteressadamente, apenas como passatempo por questóes mais de ego que de vocaçáo: ele despreza a atitude das "madamas" que se aproximam para tentar uma individual no Masp; opóe-se à arquitetura que não se encaixa em tradiçóes locais, repudia as Bienais, ultrapassadas em sua essência. Apesar de apelar pela "modernização" sem preconceitos, Bardi desconsidera a arte hodierna, das "novidades excêntricas," que ele entende como "vazia"

$$
\begin{aligned}
& \text { Corriqueiro constatar-se, sendo até mesmo ingênuo repetir o slogan, } \\
& \text { que os tempos mudaram. O mesmo se poderá dizer daquilo que nesta } \\
& \text { seara é abordado com frequência, isto é, o lazer-negócio "arte" cada } \\
& \text { vez mais encalhado no rochedo do Indeterminado. Quem nele mexe } \\
& \text { está sujeito a defrontar-se com muitas surpresas e, assim sendo, deve } \\
& \text { se adaptar à poluição das novidades excêntricas que vão relegando } \\
& \text { a Tradiçáo ao banco dos castigos, os conservacionistas convidados a } \\
& \text { fazer boa cara diante de um jogo que não vai, procurando conciliar e } \\
& \text { justificar. Se os tempos são estes que fazer? Seria idiotice não mani- } \\
& \text { pular o computador ou não ver televisão. \{BARDI, Senhor \#67, } 30 \text { jun. } \\
& \text { I982, p.69\} }
\end{aligned}
$$

"Por isso, indo fotografar na Bienal, encontrando o carrinho para transporte interno de 'telas já eram,' abandonado num canto, o dignificamos como obra de arte." \{Arte Vogue\#2, nov. 1977, p.43\}

Isto posto, não raramente, ele faz muitos elogios ao saber-fazer, ao saber adaptar-se, à estética do popular, e até do kitsch, que ele dá a entender ser genuíno, sensível e sincero, tópico e crônico:

$$
\begin{aligned}
& \text {...para tomar conhecimento da existência de coisas que nos confortam } \\
& \text { no dia-a-dia, como deve ser (...) até mesmo em favela - porque não? - } \\
& \text { onde certa vez, e ao longo de uma pesquisa, encontrei folhinhas, oleo- } \\
& \text { grafias, vasos de flores, santas ceias de Leonardo, numa palavra, artes } \\
& \text { como quaisquer outras, às quais seria pueril não atribuir valor, pois se } \\
& \text { trata de estética popular. \{BARDI, Senhor \#26, maio I980, p.IIO-III\} }
\end{aligned}
$$

Não à toa ele conseguiu enxergar valor em artistas de rua como Agostinho Batista de Freitas, "um artista que descobri traçando desenhos no passeio em frente do prédio da Light, recebi muitas críticas" \{BARDI, Senhor \#286, 9 set. I986, p.76\}

Seguem-se algumas pinceladas desse discurso, relacionadas por tema, de acordo com os mais mencionados acima descritos.

como no caso da valorização do art nouveau e do kitsch antes que virassem febre. 


\section{I.I.I. Pintura}

Bardi costuma falar muito de pintores em geral, reconhecendo ser essa a atividade mais difundida como artística. Os artistas brasileiros que ele mais menciona elogiosamente são Wesley Duke Lee e Alfredo Volpi. Entretanto, Bardi sente uma "estagnação" por parte dos artistas-pintores, e escreve em tom de denúncia: "Os pintores de hoje se acomodaram na profissão produtora não mais de prazeres hedonísticos, engajada nos caprichos do bom burguês que nela encontrou novo caminho para investir dinheiro..." \{BARDI, Senhor \#64, 9 jun. 1982, p.65\}

Sobre a pinacoteca do Masp, Bardi declara:

O Museu de Arte de São Paulo apresenta um acervo quase exclusivo de pinturas. Infelizmente, quando o sr. Chateaubriand decidiu formá-lo, não aceitou o plano inicialmente proposto qual o de reunir peças das várias manifestaçóes da arte, para compor um panorama informativo se não completo, coisa impossível, pelo menos capaz de satisfazer didaticamente o visitante. O II SNAGA, levado a efeito em maio, possibilitou ao Masp apresentar o que lhe falta, desde o móvel até a ourivesaria, desde a arqueologia até o design e quantas outras produçôes do homem de ontem e de hoje. \{BARDI, Casa Vogue \#36A, junho de I978, p.80-8I\}

\section{I.I.2. Escultura}

Bardi em diversos momentos mostra seu desconforto em relação à supervaloração da pintura comparada às outras manifestaçóes artísticas. E essa comparação ele faz normalmente quando vai falar da escultura:

No quadrante das artes plásticas a escultura é, certamente, a que menos atenção e consideração recebe. Serve para monumentos, medalhas, quase sempre ingrediente de celebraçóes, raro o emprego na arquitetura, ainda não aceita pelos senhores colecionistas, adeptos em geral somente da pintura. \{BARDI, Senhor \#94, 5 jan. 1983, p.64\}

E ele menciona o que entende como sendo a origem do descaso

(...) arquitetura e escultura. Estas artes são íntimas uma com a outra, desde a Antiguidade: o escultor contribuindo no preparo da aparência exterior ou no modelar os elementos. A coluna, a base e o capitel são obras de escultor, obedecendo às prescrições estéticas. O Partenon é grandiosa obra de escultura, sem contar o que lhe está próximo, o Erectêion. E a autêntica fábula plástica da arquitetura da Índia? \{BARDI, Senhor \#97, 26 jan. 1983, p.69\}

Nos anos 20, quando Le Corbusier lança o jejum da machine-à-habiter, a decoração, os acabamentos de fachada vão desaparecendo. 
É o tempo da arquitetura dita hospitalar: paredes lisas, rigidamente imaculadas, portas sem relevos, tudo calculado para não "embelezar" nada. Também para o mestre franco-suíço o jejum não durou por longo tempo: a Capela de Ronchamp é mais um bloco escultórico do que propriamente uma arquitetura. \{BARDI, Senhor \#96, 19 jan. 1983, p.69\}

\section{I.I.3. Arquitetura, urbanismo, engenharia}

Sendo esta profundamente ligada à escultura, e como todas as outras manifestaçôes artísticas, Bardi defende a genuinidade no fazer, desvinculando as "novas" ordens/estilos de um passado superado. E isso Bardi carrega desde a Itália, sempre relembrando a todos de sua mesa dos horrores e da iniciativa que teve de apresentá-la a Mussolini. ${ }^{63}$ Afinal, "a arquitetura é o cartão de visita de uma nação: basta dar um passeio entre os prédios das administraçôes estaduais em qualquer região [do Brasil] para que se tenha uma ideia de tal cartão.” \{Bardi, Arte Vogue \#I, maio 1977, p.47\}

A importância que Bardi dá à Arquitetura tem a ver, nas entrelinhas, com o impacto visual da obra na vizinhança. Essa preocupação está de acordo com o raciocínio que ele faz sobre as questôes de pertinência crônica e tópica, da técnica e da expressão de qualquer projeto.

Também, Bardi questiona a ausência de profissionais capacitados para projetos no Brasil, normalmente deixados a cargo de amadores, e faz a seguinte analogia:

[Os estetas de Brasília, que] na pior das hipóteses, são eles os aprovadores do empreendimento. Que pensar dos mesmos? Evidentemente: trata-se de laboriosos burocratas, certamente bem intencionados, porém, pais de família que náo deixariam operar um parente por um enfermeiro, ao invés de um médico. Mas é assim. Quando se trata de um assunto pertinente à estética, forma-se o fatal grupo de trabalho que se reúne, palreia e consome inumeráveis cafezinhos, pontualmente se esquecendo de procurar a colaboração dos competentes na matéria. \{BARDI, Arte Vogue \#I, maio 1977, p.47\}

63 Às vezes, Bardi deixa transparecer que a empreitada fora bem-sucedida. $\mathrm{Na}$ época, o discurso pró-arquitetura racionalista de Bardi causou-lhe a sua expulsão do partido. Mas ele entende o sucesso daquela exposição ao destempo: "Os críticos italianos, agora que o fato se tornou história, consideram aquela exposição o marco inicial da luta por uma arquitetura mais coerente com os tempos." \{BARDI, Senhor Vogue \#5, ago 1978, p.I8, 20\} 
De modo que esse descaso gera resultados como: "Fácil ainda constatar, na metrópole, a aplicação de estilos do passado remanejados, sem que se saiba por que e como." \{BARDI, Senhor \#89, I dez. 1982, p.76\}

Resumidamente, os principais pontos de observação de Bardi em relação à arquitetura podem ser consultados na simulação de mesa redonda (“Arquitetura agora”) publicada em Arte Vogue \#2, nov. 1977, p.76-80 (cf. Anexo D, p.73I) Como o texto não está assinado, é possível que tenha havido a colaboração de outro autor.

\begin{abstract}
Arquiteturas? É justamente a classificação que me intrigou na lembrança, o estabelecer o quanto de estética é possível descobrir nas construçôes da danada utilidade das armas. Por consequência também nas obras viárias, portuárias, industriais e, hoje em dia, nos monumentos hidrelétricos, nas centrais atômicas, e até nos próprios implantes para o lançamento dos mísseis, isto é, atividades atribuídas aos engenheiros, não só da construção mas dos mais variados ramos. Todavia eles também dependem dos arquitetos. Uma barragem é uma obra de engenharia e, ao mesmo tempo, é uma arquitetura. A atribuição da arquitetura, como se sabe, é geralmente reservada as obras religiosas, aos palácios e palacetes, as moradias. No meu livro [Arquitetura e Engenharia no Brasil] trato também dos refúgios populares, até das favelas, dado que as primeiras ilustraçôes se referem às cabanas dos americanos. \{BARDI, Casa Vogue \#4, jul-ago I985, p.76\}
\end{abstract}

\title{
I.I.4. Design
}

Bardi, além de incentivar o desenvolvimento de um design local, o faz comparando o design com a arquitetura - que, para ele, eram de feitura similar:

o design [no Brasil] tem sua história bem singular, como bem o demonstra a construção da máquina do engenho de açúcar, que passou de horizontal a vertical através de várias e inteligentíssimas correçóes. (...) quem conhece o assunto, nota que o design brasileiro contemporâneo deve ainda trabalhar bastante para desvencilhar-se da inventiva estrangeira. É bem verdade, como disse com exatidão Lúcio Costa referindo-se à arquitetura, que a nossa está atrelada à locomotiva da arquitetura internacional, chegando os tempos em que tutto il mondo é paese. \{BARDI, Senhor \#76, I set. 1982, p.65\}

O design é uma das formas (Bardi diria) artísticas de expressão hodierna. Como já mencionado no tópico Arte, a Vitrina das Formas é um dos exemplos dessa visão de Bardi e do quanto esse raciocínio não era (é) bem aceito:

Em 50, quando inauguramos a Vitrine das formas, coloquei, num sintético panorama histórico que ia desde as pedras do Neolítico até as produçóes de Oitocentos, uma máquina de escrever para 
representar nosso século. Objeto de arte? O “mundo" não gostou, achou excêntrica e ofensiva a iniciativa, sem contar as condenaçôes pelo “mau gosto." \{BARDI, Senhor \#96, I9 jan. 1983, p.69\}

\section{I.I.5. Propaganda, marketing}

Entre outras coisas, pensei em criar uma série de escolas, uma delas dedicada à Propaganda, a qual vingou ao longo do tempo e hoje presta inestimáveis serviços sob o título de Escola Superior de Propaganda e Marketing. \{BARDI, Senhor \#I43, I4 dez. I983, p.79\}

Agora vejo que o grande Center Shop de São Bernardo do Campo expóe nada menos que um conjunto de objetos antigos da coleção de Gilbert C. Asmar. Ao mesmo tempo o Morumbi Shopping pede ao Masp que arme uma exposição de arte. Os tempos da cultura, e neste caso o marketing estão em plena e promissora união e evolução. \{BARDI, Senhor \#74, I8 ago I982, p.68\}

\section{I.I.6. Moda}

As questóes de moda e de gosto foram tratadas principalmente por Pietro Maria Bardi em Homem Vogue, enquanto existiu. Mas em Senhor também encontramos esse tipo de discurso:

Lógico que um supermercado se vale de todos os meios para incentivar as atividades comerciais. Nos primeiros anos de ação do Masp consegui convencer a alta direção do Mappin quão importante era colaborar conosco para o lançamento (pura ingenuidade) da moda brasileira $^{64}$ que criamos e apresentamos na Pinacoteca: as vitrinas do Mappin que davam para a Praça Ramos de Azevedo, em São Paulo, mostraram as produções. Naturalmente a generosa ideia não logrou sucesso, pois a importação da moda continuou como dantes. De qualquer jeito estava lançada a semente arte na técnica do mercado. \{BARDI, Senhor \#74, I8 ago 1982, p.68\}

Moda, propaganda e design (vitrinas) e arte (pinturas) e nacionalização normalmente se somam nesse discurso.

Aliás, Bardi sempre valorizou a Moda como forma de expressáo humana e, portanto, como Arte. Os dois desfiles do início dos anos 1950 (de

64 Por algum motivo, as iniciativas do Museu de Arte de São Paulo em relação à moda, em I95I e 1952, são escassamente relembradas. Numa rápida busca despretensiosa pela rede, as inciativas da Rhodia, sob a coordenação de Lívio Rangan, especialmente nas Fenits de 1962 e 1963, são frequentemente mencionadas como inauguradoras no setor. Vale lembrar que os desfiles de moda no Masp aconteceram na época em que as outras mídias, segundo Bardi, boicotavam as iniciativas ligadas a Chateaubriand. 
Christian Dior e de Moda Brasileira) são o indício mais óbvio do pioneirismo e interesse de Bardi pelo tema. E isso, obviamente também, entra em consonância com o projeto de Luis Carta em Vogue.

A moda - dizem - é um disperdício de meios econômicos que bem poderiam ser aplicados no atendimento das desventuras humanas. Será mesmo? (...)

Numa sociedade integrada como a que já está entregando seu modelo aos contestadores do século 2I, cujas vanguardas se preparam; numa sociedade como a nossa parece impossível uma mudança, dizia justamente Cardin, pois a moda é peça típica da manifestação social. A humanidade está por demais saturada de indivíduos que cultivam a auto-estima, para de golpe ou paulatinamente renunciar à sua aparência. Não creio que vá desaparecer logo o mito da auto-estima, condensado no dito popular: é o traje que faz o monge...

As mulheres de hoje querem se diferenciar umas das outras (...). E os homens não estão indo pelo mesmo caminho? (...) a moda é um componente existencial coletivo: a gente se exprime através do jeito de vestir (até Oscar Wilde, que náo precisava de sinais para marcar sua presença, colocava um cravo verde na lapela.) Estou falando da moda em geral e não de excêntricos ou excêntricas. Estas últimas foram definidas numa recente entrevista do costureiro Valentino como "saindo do boudoir para subir no palco..." A moda é uma dinâmica cultural, a expressão de arte mais típica de um determinado tempo. Reconstruímos a história pelo documento do costume, índice de civilização e de distinção dos grupos étnicos e até políticos: (...) As mudanças do sistema-moda (hoje aceleradas pelo consumismo desenfreado) demonstram a vivência cultural da gente. Como é o caso espetacular do império sempre mais amplo da moda neste século de metropolização crescente dos habitantes vindos do campo. Em qualquer aldeia, por mais modesta, se vocês falarem de Pierre Cardin todas as moças saberão quem ele é. A moda, através da TV e dos demais meios de comunicaçôes, divulga os figurinos apenas propostos por, Paris, até aos mais remotos sertôes. E se tirássemos de Paris o mecanismo por eles armado, o que aconteceria por lá? Das esquerdas se aponta a moda de extrema compostura e tremenda elegância dos chineses. Mas é uma moda, e corresponde à civilização milenar de um povo. E tẫo "moda" como as invençôes que a cada estaçâo Pierre Cardin espalha pelo mundo. Concluímos com o artista francês, nascido em Veneza, que a situação da moda continua de pé, sem abalos. \{BARDI, Senhor Vogue\#Io, jan. 1979, p.87\}

\section{I.I.7. Artesanato}

Uma das maiores virtudes dos objetos artesanais, para Bardi, é a sua legitimidade, serem genuinamente o que são, a expressão pura do saber-fazer, sem 
interferência externa de teóricos e críticos. São os maiores representantes da estética da resolução de problemas cotidianos, por "inumeráveis operações desempenhadas pela mão e pela cuca."

Essa "briga" de Bardi foi iniciada junto com a abertura do Masp em Sao Paulo, em 1947. E, como é de seu feitio, imodestamente, ele reconhece o pioneirismo:

Aliás, devo confessar que, se alguma virada me é atribuída, foi pela consideração que sempre demonstrei pelas artes classificadas nos manuais de "menores." Por exemplo, o artesanato, o que de maravilhoso o povo, sem ajuda dos críticos, realiza numa e em mil atividades. (...) organizei no Masp não sei quantas exposiçôes de produtos populares brasileiros, todas manifestaçôes pontualmente ignoradas, até que os órgãos burocráticos do design industrial descobrem que o artesanato é o pré-design, como se vê numa publicação da Federação das Indústrias de São Paulo, Artesanato e Desenho Industrial. Afinal, o Masp náo só produziu o que de mais documentado se refere ao artesanato, como abriu a primeira Escola de Desenho Industrial no Brasil, em 1950. \{BARDI, Senhor \#266, 22 abr. 1986, p.76\}

\section{I.I.8. Mercado da arte, colecionismo}

Mexer no setor publicações de assuntos de arte sempre foi empresa complicadíssima, pois relatar e comentar o trabalho de arquitetos, pintores, escultores, e tantos outros adeptos às artes, até não sei bem quando, era considerado um exercício não digo marginal, porém, não muito digno de ampla atençấo: eram poucos, para não dizer raros, tanto os produtores como os apreciadores. Quando o presidente Dutra inaugurou o Museu de Arte de São Paulo, em 1947, a cidade era órfã de galerias, havendo uma única, do francês sr. Beneteau, num corredor próximo à Barão de Itapetininga; as lojas dos aprendizes do antiquariato eram em seus próprios apartamentos. Nos leilóes do pioneiro José Felice Florestano, quase sem público, arrematavam-se obras importantes por ninharias.

A ultra-ativa cidade, apelidada sem saber por que, de, "Athenas do Brasil" nestes últimos decênios mudou, e o esplêndido lazer das artes não é mais como uma Cinderela, mas obtém distinção excepcional. Os jornais cotidianos dão páginas e páginas às artes, (em '47, a inauguração do Masp não recebeu menção do maior jornal paulista, registrando somente a vinda do presidente Dutra sem acenar ao motivo da visita) e hoje, os leilóes tornaram-se praga, o mercado é vivo, a produção pictórica e escultórica supera em volume a música popular, e assim por diante.

A Metrópole é até sede de uma Bienal que recebe Cr\$ I bilhão para mostrar aos leigos as últimas provas da transvanguarda, exaltada pelos, 
“críticos" que tacham os simples cronistas de obscurantistas, por ocasião da festa bilionária (com mais alguns quebrados, em milhóes). A premissa serve para anotar que, apesar do boom realmente notável, o que é que falta? Uma publicação periódica especializada.

Quando nós, cronistas, precisamos verificar eventos do final de Oitocentos, e começo de Novecentos, procuramos as extremamente raras coleçôes da Ilustração até o agitador Klaxon. Lembro-me que, expondo o caso acima a um colega, o Luís, da família Carta, este concordou e decidiu uma açáo, colocando nas bancas a Vogue-Arte. \{BARDI, Senhor \#I46, 4 jan. I984, p.64\}

O desenvolvimento do mercado da arte no Brasil é constantemente abordado por Bardi em seus textos, de todas as publicaçóes, mas principalmente nos textos da Revista Senhor ${ }^{65}$ que, além de ser publicação direcionada também para "homens de negócio," é a que compreende o maior período e duração de sua colaboração tâo assídua:

Senhor é uma revista que enfoca os mais diversos assuntos e atividades que vão desde os de caráter político, econômico e social até os relativos às artes, objeto desta página, dando, assim, significado e interesse ao valor das produçóes que representam uma realidade no setor dos bens. \{BARDI, Senhor \#I38, 9 nov. 1983, p.76\}

Entretanto, profundamente ligado a este assunto está o colecionismo. E Bardi raramente fala de um sem mencionar o outro. Ele mesmo explica:

Os antiquários e os colecionadores constituem o protoplasma dos museus: o que neles se reúne provém daqueles senhores. É esta na verdade a história de todos os museus. Por isso o colecionador que pode ser também, aliás é, um investidor, às vezes um marchant-amateur, outros um apaixonado por um por um hobby qualquer, desempenha uma função de primeira plana na cultura, qual a de salvar do esquecimento coisas que no futuro representarão a história. \{BARDI, Casa Vogue \#36A, jun. 1978, p.8o-8I\}

E Bardi, marchand experiente num país como a Itália, já sabia das possibilidades que o mercado representava para a constituição de Museus. Quando ele vem montar o Masp, sente falta desse tipo de representação e no Brasil das décadas de 1940 e 50, e passa a se esforçar (por escrito, no que diz respeito a esta monografia) para fomentar mais essa importante atividade:

65 No miolo da publicação, começa a vir anexado o caderno Senhor S.A., que trata de questôes de mercado. Ali se publicam, ao longo do período que exisitiu, diversas notícias sobre transaçóes comerciais por antiquários e leiloeiros, fornecendo dados mais aprofundados e estimativas, inclusive a respeito de colecionismos de peças de vidro, carros, pintura etc. 
Notando a ausência de um ambiente de algum valor, eu, Lina e o arquiteto Gian Carlo Palanti, tivemos a errada ideia de abrir aqui na pauliceia uma filial do meu Studio d'Arte Palma que, enquanto se instalava o Masp, mantinha funcionando em Roma. Não deu certo e decorridos dois anos acabamos fechando, à espera de tempos mais propícios e alimentando a esperança do aparecimento de mais interessados na história das artes. \{BARDI, Casa Vogue \#3, mai-jun 1982, p.I2O-I2I\}

E continua

Era indispensável para fortalecer a estrutura do Masp contar com o concurso do mercado e fomentar o colecionismo. Se começava da estaca zero, porém, o entusiasmo e o maquiavélico pigliare l'impresa do dr. Assis parecia um exemplo a ser seguido. Em São Paulo, naqueles anos finais de 40, finalmente ocorreu um fato novo: o casal Fiocca inaugura a Galeria Domus, ali na avenida Vieira de Carvalho, colaborando na organizaçáo o sr. Bonino, que com eles tinha chegado de Nápoles. Novidade na cidade ainda um pouco sonolenta em termos de comércio de arte. Bonino animou-se tanto com a atividade que logo fundou em Buenos Aires a sua própria sede, para, mais tarde, abrir a Bonino carioca, hoje dirigida por Giovanna Bonino, e uma outra galeria em Nova York. A Domus, por falta de movimento, fechou. Deveriam transcorrer duas décadas para o mercado de arte se articular. \{BARDI, Senhor Vogue \#4, jul. 1978, p.58-69\}

Com Luís Carta, editor e, ao mesmo tempo, realizador, no Brasil, de uma revista de importância internacional como Vogue, nos empenhamos numa publicação que representou um fato singular. Edição de uma organização reconhecida como das maiores, continha ensaios de história e crônicas dos movimentos ilustrados como devem ser, além de consideração por cada problema, não apenas circunscritos às, "lanas caprinas", mas de amplo interesse; em suma, uma publicação de interesse público. Felizmente, Vogue Arte deu vida à Casa Vogue, dirigida por Andrea Carta, a mais interessante revista de arquitetura que temos e que completa agora oito anos. Finalmente uma publicação prestigiosa e bem considerada. \{BARDI, Senhor \#I46, 4 jan. I984, p.64\}

\section{I.2 O Museu do Bardi}

A forte ligação de Bardi com o Masp era facilmente perceptível, não só pelos relatos de quem conheceu Bardi, mas pelo próprio Bardi ao se referir ao museu. Este é o segundo assunto que Bardi mais menciona, sob inúmeros argumentos: a figura Chateaubriand, a fundação do Museu, a montagem do 
acervo, os cursos que aconteceram no Masp, as exposiçôes e as publicaçóes relacionadas às exposições ou à história do Museu.

Vale lembrar que muito do que Bardi fez acontecer no Masp, ele já havia feito antes, no Studio d'Arte Palma.

\begin{abstract}
Nesses anos todos, a única queixa do velho mestre Pietro Maria Bardi é o Masp carregar o sisudo nome de "museu." Ele diz, carrancudo (...): "isto aqui é mais um laboratório; museu dá sempre a impressão de coisa estática, e o Masp é dinâmico, vivo.” Bardi não pára um instante há meses, preparando os festejos dos trinta anos do Masp, que ele comemora como se fosse seu próprio aniversário. Afinal, é diretor do museu desde a fundação, em 1947. E há quem diga que, pela ordem de importância, as primeiras aquisiçôes feitas pelo fundador, Assis Chateaubriand, foram um Rembrandt, um Picasso e Pietro Maria Bardi. \{Jupiassu, Istoé\#45, 2 nov. 1977, p. 59\}
\end{abstract}

\title{
I.2.I. Assis Chateaubriand
}

Bardi tem um profundo respeito por Assis Chateaubriand. Ao se referir a Assis, ele utiliza os seguintes termos: animador, patrão, capitão, jornalista, mago, Hearst do Brasil, mecenas e controlador das riquezas e comportamentos das classes produtoras, caput magister, o incentivador, inesquecível, amigo, deus ex-máquina, ${ }^{66} \mathrm{o}$ supremo, "o generoso, o esplêndido brasileiro de sempre, difícil e irrequieto, eu sei, mas realizador," entre outros.

Assis Chateaubriand, antes de empreender o Museu, buscou promover grandes avanços, por exemplo, na aviação brasileira, arrecadando doaçôes utilizando-se do poder político, ou melhor, da pressão política dos seus Diários e Emissoras Associados. Experiência adquirida e treinada, o mesmo foi feito pelo Masp alguns anos depois, o que não agradava muitos de seus doadores. Apesar disso, a importância fundamental de Assis Chateaubriand no processo de criação do Museu é sempre que retomada por Bardi, sua admiração pela capacidade realizadora de Chateaubriand, inclusive pelo ostracismo a que este foi "condenado" pelos grandes conglomerados. "Condenação" não acontecida por acaso:

\footnotetext{
Lamento o silêncio dos contemporâneos para com Assis. ${ }^{67}$ (...) O dr. Assis me dizia ser ele consumado professor do sistema e de ter formado o patrimônio dos Diários Associados e depois das estaçóes
}

66 Em grafias variáveis, entre portuguê e latim.

67 Anos depois, em 20II, Mino Carta lamentará o silêncio contemporâneo em relação a Bardi. \{CARTA, Carta Capital\#799, I6 set 20II, Editorial 2\} 
de rádio e de TV, através de negociaçóes de conveniência, ao mesmo tempo de utilidade para o contraente e para sua cadeia. Só um contabilista sem preconceitos teria capacidade para reconstituir como um único empresário conseguiu ser o dono de 35 cotidianos, espalhados nas capitais, desde o Amazonas até o Rio Grande do Sul: um domínio singular à maneira de Hearst nos Estados Unidos.

Uma das liçôes que o B. aprendeu ${ }^{68}$ com Chateaubriand foi a de conseguir dos capitalistas responsáveis por indústrias, fazendas, comércio e tantas outras empresas, meios para serem aplicados na cultura. Para Assis as pressóes tinham o respaldo de seu poderio.

Todos sabem como foram deflagradas as campanhas de Assis: aviação, evento em que quem não doava pelo menos um aviáo de treinamento aos aeroclubes podia esperar sua efígie na primeira página de um Jornal vestido de penitenciário, como se deu com o conde Chiquinho. A novidade era: todos deviam contribuir para as iniciativas do Empreendedor. \{BARDI, Vogue Brasil \#II5, fev. 1985, p.II6-I62\}

E, por vezes, Bardi respondia em defesa de Chateaubriand:

De vez em quando encontrei personagens da política no gabinete de Assis Chateaubriand, do qual falei numa das últimas crônicas, e que agora o livro de Samuel Wainer pinta como chantagista, exercício, pelo que pude seguir no caso do Masp, não interesseiro. \{BARDI, Senhor \#363, 7 mar. 1988, p.73\}

Chateubriand incomodou muita gente, especialmente quando necessitava da boa-vontade de terceiros para realizar suas empreitadas. Por outro lado, no caso do Masp, legou ao Estado o acervo inteiro que hoje é avaliado em mais de um bilhão de dólares dólares. ${ }^{69} \mathrm{E}$ é esse o cálculo maquiavélico de Bardi: reforçando a todo o tempo os méritos do acervo, que ao fim, foi legado público, Bardi também justifica os meios empregados, condignificando esse lado da memória de Assis Chateaubriand.

$\mathrm{Na}$ década de 90, Bardi também é acusado, inclusive pelo filho de Chateaubriand, de "roubar" e fazer negociaçôes escusas utilizando seu cargo de Diretor do Masp e sua atuação concomitante como dono da galeria Mirante das Artes. E Bardi, quando respondia, lembrava que, como diretor técnico do Museu, não recebia salário e, apesar disso, era ele mesmo o maior doador do Masp: era dele a biblioteca à disposição de todos, e muitas obras do acervo foram pessoalmente doadas por ele, "juntamente com as instalaçôes da

68 Aqui, Bardi fala de si mesmo usando a terceira pessoa do singular.

69 O acervo, hoje público, custou menos de quatro milhōes de dólares. Foi pago em parte com o dinheiro que Chateaubriand tirava dos Diários, e em parte com a ajuda da Caixa Econômica, com autorização do presidente Juscelino Kubitschek. Feito impressionante, considerando-se, as políticas de investimentos e desvios nacionais. 
lanchonete que serve aos frequentadores, ao museu." \{BARDI, Senhor Vogue \#II, fev. 1979, p.76-98\} Já G.C. nunca havia contribuído em nada com o Masp.

No que diz respeito a esta pesquisa, interessa o período em que Bardi não contava mais presença de Chateaubriand no Museu, de modo que ele, quando falava do Museu, usava normalmente a primeira ou terceira pessoa do singular para falar de si mesmo, e também a terceira do singular para falar de Chateaubriand explicitamente. ${ }^{\circ}$ Raramente encontra-se a primeira do plural para o projeto em conjunto que foi o Masp.

\section{I.2.2. Lina Bo Bardi}

Observa-se que Bardi, mesmo se referindo à criação do Museu usando a primeira pessoa do singular, provavelmente raciocinava o sujeito sendo ele e Lina, o casal Bardi, conforme deixou transparecer no seguinte trecho:

Mas quero confessar que realizei com prazer, nesta minha nova Nação, velhos sonhos entrevistos na antiga pátria: aqui as ocasiōes, a facilidade de atingir os propósitos, esta onda de cordialidade com polêmicas e até batalhas possibilitam propósitos e convicçôes. Digo isto por Lina, a arquiteta com quem sou casado. Afinal, os dois construímos, do nada, um museu, bem ou mal, fazendo-o reconhecido no exterior ativando intercâmbios. \{BARDI, Senhor \#3II, 3 mar. I987, p.68, grifo nosso\}

Nas poucas vezes em que Bardi fala de Lina objetivamente, ele o faz reconhecendo a importância dela não apenas nas empreitadas conjuntas, relacionadas ao Masp (Habitat, IAC, projeto do Masp) mas também nos projetos em que ele não esteve, até onde se sabe, diretamente envolvido:

Tentativas de contribuir para criar um ambiente favorável ao trânsito das artes foram numerosas. Alguém lembra a revista Habitat, sem dúvida fato essencial para discutir problemas, dirigida por Lina Bardi, o arquiteto que se incumbiu de todas as construçóes do Masp e responsável pela restauração do Solar do Unhão, em Salvador, bem assim pela fundação do MAM da Bahia. \{BARDI, Senhor Vogue \#II, fev. 1979, p.76-84\}

\section{I.2.3. A criaçấo do Masp}

O Masp não é uma instituição que cultiva ortodoxamente o conceito da "Arte pela Arte" de oitocentesca preferência. Para sua direção a

70 É preciso conferir se o estilo no singular era também adotado nos artigos que Bardi escreveu sobre o Museu enquanto Chateaubriand era vivo. 
preocupação constante, após trinta anos de ininterrupto trabalho, foi e continua a ser a de envolver a arte na realidade da vida, nas suas mais profissionais que contribuem diuturnamente para a descoberta, estudo, conservação, valorização do objeto de arte, operando na senda da formação e ativação da cultura. \{BARDI, Casa Vogue\#36A, junho de 1978 , p.80-8I

Bardi carregava essa ideia do Studio d'Arte Palma e das outras experiências anteriores no mercado da arte italiano:

(...) o Studio d'Arte Palma, que se constituiu em importante centro de concentração de exame e ação de problemas das artes plásticas: conservação, restauração, comércio, estudos, galeria e tudo quando se refere à arte.

E complementa: em 1946, (...) eu era interessado no mercado de arte, tanto (...) que na praça Dom José Gaspar abria a filial do meu Studio d'Arte Palma, de Roma." \{BARDI, Senhor \#192, 2I nov. 1984, p.84-85\}

Pode-se dizer que, mesmo quando Bardi fala de si mesmo, ele fala do Museu. E o inverso é verdadeiro. Ele representava a instituição desde seu início (o "Museu do Bar" = MAM-SP; $;^{71}$ o "Museu do Bardi" = Masp, na gíria da década de 1950) era reconhecido como a personagem "Museu de Arte" nos textos de autores seus contemporâneos e ele se reconhecia como a figura do Masp também.

Sobre a centralização da Arte em São Paulo, Bardi conta (e elogia Assis Chateaubriand)

A política que foi anunciada pelo secretário de Cultura do governo Montoro, João Pacheco Chaves, é a de intensificar a ação no Interior. Mais que oportuna a decisão, pois até hoje tudo se concentra nas capitais e pouco, para náo dizer muito pouco, se destina aos outros centros. Quando se abriu o Museu de Arte de São Paulo, seu fundador, Assis Chateaubriand, se preocupou com este problema. Foram tomadas várias iniciativas nos anos 50 , na tentativa de constituir um museu em Marília e outro em Pinhal, porém sem resultados. De fato, os tempos não eram propícios. Nos anos 60 o sr. Chateaubriand dedicou-se à criação de museus regionais, filiados ao Masp. Conseguiu-se alguma coisa em Campina Grande, na Paraíba, em Feira de Santana, na Bahia, em Porto Alegre e em outras cidades. \{BARDI, Senhor \#IIo, 27 abr. 1983, p. 85$\}$

Não há outra menção a esses acervos ou museus ao longo dos outros artigos.

7I Museu de Arte Moderna de São Paulo, década de I950, dirigido pelo Conde Matarazzo. 


\section{I.2.4. A montagem do acervo}

A montagem do acervo do Masp, quando considerados os "mecenas" brasileiros, foi feita a partir de doaçóes espontâneas dos próprios artistas e de alguns colecionadores. Entretanto, tem-se notícia dos doadores ma non troppo, pressionados por Chateauriand, conforme já visto no item sobre o boicote das mídias.72

No exterior, Bardi selecionou as obras num pós-guerra muito propício a esse tipo de negociação. Chegou, inclusive a ser acusado de exportação clandestina, no caso da obra de Giorgione. \{BARDI, Vogue Brasil \#II5, p.II5-I62: Curiosidades e sorte\}

Essa seleção foi paga com verba dos Diários Associados e do governo brasileiro, quando da pressão dos credores de Nova York, em virtude da exposição.

Enfim, não se intimidou, comprando muitas obras do mesmo autor, pensando numa futura troca por outros autores tão importantes quanto:

(...) várias vezes [fui] repreendido: a presença às vezes excessiva de alguns mestres, como é o caso por exemplo dos treze Renoir, seis Modigliani e dezesseis Portinari. Justificativa: o entendimento com o inesquecível sr. Chateaubriand, quando juntos formamos a Pinacoteca, era de reunir pinturas de alguns autores cujo custo era bem conveniente, para em um segundo tempo aproveitar da alta dos valores, vendendo ou trocando com telas de outros artistas para equilibrar o acervo. Desaparecido o Fundador, a diretoria do Masp não quis dar sequência à ideia dos iniciadores na iniciativa. \{BARDI, Vogue Brasil \#II5, fev. 1985, p.136-I37\}

Bardi ao longo dos anos dos textos disponibilizados, menciona ter-se equivocado apenas uma vez a respeito de uma autoria:

Eu mesmo adquiri para o Masp um retrato de Ticiano em que todas as evidências e modos eram do mestre e, no entretanto, alguns anos depois convenci-me de que se tratava de obra de Páris Bordon.

Quero dizer que julgar autores de obras de arte é tarefa complicada, e algumas vezes pode-se errar. \{BARDI, Senhor \#I39, I6 nov. I983, p.93\}

Fato é que, se algum equívoco foi sobre uma obra falsa ou se ele sentiu ter errado no valor de alguma negociação, isso ele nunca mencionou. Menciona sim que Assis errou ao negociar obras sem antes consultá-lo:

Assis Chateaubriand me pediu para armar uma pinacoteca às pressas.

(Neste momento lembro que um dia será preciso contar a história do Masp.) Trabalhar com aquele caput magister não era fácil. Não

72 Alguns indivíduos o procuraram para desvincularem seus nomes como doadores de quadros em BARDI, Vogue Brasil\#II5, fev. 1985, p.II6-I62. 
dispunha de dados certos, perplexo às vezes pelo fato do incentivador comprar a Moema, de Victor Meirelles, pagando por ela o equivalente a três obras de Van Gogh, ou adquirindo dois Canaletto, falsificados grosseiramente, por uma soma astronômica. Conciliando, usando de diplomacia, nem eu sei bem como se conseguiu fazer o Brasil navegar no mare magnum do mercado internacional. Em 48, segurando no Masp algumas obras-primas excepcionais, no estrangeiro, as referências ao nosso favor circulavam cordiais e curiosas; e, nem o propheta in patria, vimo-nos alvos de denúncias as mais díspares das quais a menor era de importar, sic et simpliciter, pinturas falsas. Seja como for o Brasil, aliás, um brasileiro, levantava o problema de participar inteligentemente do mercado de arte, no momento mais propício, quando na Europa vitoriosos e derrotados deviam reconstruir suas economias. \{BARDI, Senhor Vogue \#4, jul. 1978, p.58-69\}

Menciona também sua intuição certeira na aquisição do Rafael, de autoria negada por um especialista anterior:

Alguém que insere em seu currículo esta surpresa da Vogue, como atividade quase emergente, deveria resumir afortunadas descobertas de obras de arte, não para se destacar no seu comércio e no cargo de diretor do Masp, mas para contar as numerosas aquisiçóes, geralmente de objetos sem habituais "documentações de autenticidade." Isto levaria a ocupar muito espaço, últil talvez somente para especialistas no assunto. Já dei noticia, no rascunho biográfico, do caso do Giorgione, agora se escolhe uma peça de Rafael. Cada obra do Masp, como de resto cada obra que adquiri ao longo da carreira, tem seu currículo. A obra do Masp que, me parece, possa despertar a curiosidade do leitor, é o painel de Rafael. Em 54 eu devia expor a mostra “Cem Obras-primas do Masp” na Tate Gallery. Chegando em Londres, adverti o diretor que devia acrescentar mais uma, pois tinha adquirido a "Ressurreição," pintada pelo Mestre de Urbino. Foi na manhã de Páscoa, na Knoedler, em New York, a loja excepcionalmente aberta naquele dia para três brasileiros (dr. Assis, Walter Moreira Salles e B.) tomarem conhecimento da existência de uma pintura absolutamente desconhecida: tinha vindo no dia anterior da Inglaterra, achada em Rossie Priory, proposta à National Gallery de Londres, e por este museu recusada, pois lá as peças da Renascença italiana deviam ser aprovadas por Bernard Berenson, o qual negou a autoria.

$\mathrm{O}$ veto do mestre suscitou as reservas imagináveis. Conseguiu-se, todavia, juntar às cem pinturas do Masp a Ressurreição, declarando-a de autoria de Rafael. Sozinho, pesquisando, descobri então que a pintura era lembrada por Crowe e Cavacasell e numa monografia, de I884, dedicada ao pintor, e mais: no Ashmolean Museu de Oxford existem, no patrimônio Lawrence, os desenhos preparatórios de duas figuras da pintura.

A crítica europeia perplexa: Brasil docet?

Até que o mestres do mestres, mestre mesmo, Roberto Longhi, celebra 
a descoberta brasileira no documentado ensaio na revista Paragone.

\{BARDI, Vogue Brasil \#115, fev. 1985\}

E, por causa da experiência de Bardi (que ele mesmo se encarregava de divulgar), ele era frequentemente perguntado para tratar de assuntos como autoria ou tendências de valorização de obras e artistas. E ele ensinava:

Dias atrás me perguntaram quais os autores novos para comprar com visos de investimento. Difícil responder a perguntas desta ordem. Aconselha-se a considerar com muita atenção as obras, e mais especialmente o caráter do autor, servindo-se dos olhos e não dos ouvidos, pois nas orelhas se aninham sempre sentenças soltas e muito do agrado dos interessados. \{BARDI, Senhor \#65, I6 jun. I982, p.69\}

\section{I.2.5. Os cursos no Masp}

Os cursos implementados do Pietro Maria Bardi e Lina Bo no Masp pretendiam contribuir para a formação do gosto. Sobre isso, Bardi escreve:

Disso [a formação do gosto] eu mesmo tive plena consciência quando, entre outros departamentos de ensino, como Música, Dança, Fotografia, Paisagismo, Desenho Industrial etc., abri, nos anos 50, no Masp, a Escola de Propaganda, ainda em plena atividade, evoluindo de acordo com os tempos, sob o título Escola Superior de Propaganda e Marketing. \{BARDI, Senhor \#I3I, 2I set. 1983, p.69\}

Todos eles foram propostos para fundamentar teoricamente os jovens e futuros apreciadores da arte em suas diversas manifestaçóes. Além da importância da Escola de Propaganda, tem-se a pioneira escola de design (IAC), dirigida por Lina Bo Bardi:

Instituto de Arte Contemporânea, uma escola dirigida por Lina Bardi e que objetivava pôr em linha o então incógnito Design.

Pensávamos chamar atenção para uma atividade que na própria Europa, depois da extraordinária empresa que foi a Bauhaus de Gropius e de Mies van der Rohe, andava se impondo. Para explicar a iniciativa Design, convidamos para uma grande exposição Max Bill, que teve um modesto sucesso em comparação com sua personalidade. \{BARDI, Senhor \#47, 3 dez. I98I, p.72\}

\section{I.2.6. As exposiçóes}

As exposiçóes de Arte do Masp sempre foram táo variadas quanto foi variado o que Bardi pensava como Arte. Desde pinturas e esculturas a engenhos de açúcar e arquitetura. O Masp, através da figura de Bardi, sempre apoiou, 
(emprestando obras, p.ex.) as iniciativas de exposiçóes e eventos culturais externos ao Museu:

O Masp aceita cooperar com o entusiasmo daqueles que buscam inovações. No mais moderno supermercado agora o usuário, e sem dúvida os que se interessam pelo fato arte, podem ver uma exposiçấo de arte italiana desde o século XVI até o século XIX, alinhando peças raríssimas relacionadas com a descoberta e história da América: uma alegoria de Niccolò Frangipani e outra de Francesco De Mura. Exposiçōes de arte em supermercados são um fato importante, pois constituem mais um elemento para melhor difusão da cultura. Certamente será imitada, como sempre acontece entre nós.

Mais uma vez é preciso que se diga que o sistema da exposição deve obedecer a uma inteligente síntese, e não a simples enchimento.

\{BARDI, Senhor Vogue \#20, nov. 1979, I04-II \}

\section{I.2.7. As publicaçôes relacionadas ao Museu}

Entre as primeiras publicaçóes relacionadas ao Museu, encontra-se a revista Habitat: "Quando o sr. Chateaubriand teve a audaciosa ideia de dar vida a um museu, para sucitar interesse em torno da novidade, eu e Lina resolvemos fundar uma revista dedicada às artes. Surgiu o ${ }^{73}$ Habitat." \{BARDI, Vogue Brasil \#I, maio I975, p.I76; cf. Anexo A\}

E este tipo de publicação não era novidade para Bardi: enquanto na Galleria d'Arte di Roma, Bardi havia publicado a revista Quadrante, anonimamente, Il Vetro e Lo Stile e, depois, publicação homônima no Studio d'Arte Palma.

Procurou-se utilizar os meios favoráveis para suscitar a participação do público, especialmente da juventude, pondo em prática as experiências que haviam me ocupado na direção de galerias na Itália, a difusão de publicaçôes sendo essencial: lanço a revista Habitat, então muito mais difundida no estrangeiro do que no Brasil; anos depois a Mirante das Artes \& etc. e, finalmente, a tentativa da Arte Vogue, periódicos por mim dirigidos, sendo este último de um padrão agora próprio da Casa Vogue. \{BARDI, Vogue Brasil \#II5, fev. 1985, p.II5-I62\}

Há também, claro, inúmeras referências a publicações sobre as exposições acontecidas no Masp.

73 Normalmente, Bardi sempre se refere às revista no masculino, pois como é em italiano: il magazine. 


\section{I.2.8. Bardi, amigo}

Além do óbvio relacionamento com Assis Chateaubriand, Luis Carta e Mino Carta, frequentemente, Bardi descreve sua relaçâo pessoal, de intimidade, com arquitetos, artistas e personalidades de um modo geral.

\section{Mussolini}

Sobre Mussolini, quando Bardi o menciona, normalmente conta o episódio em que teve a "cara de Bronze" de convidá-lo para abrir a exposição em defesa do MIAR: "Mussolini a quem, mais tarde, eu mesmo, como se pode constatar nas papeladas registradas neste novo livro, tive oportunidade de explicar a besteira daquela arquitetura e de convencê-lo a mudar de opinião.” \{BARDI, Senhor \#197-198, 26 dez. 1984, p.I00\}; "Mussolini tinha aderido à proposta de mudar a direção no construir, ordenando oficialmente a publicação de meu manifesto polêmico, síntese do meu livro Rapporto sull'Architettura." \{BARDI, Senhor \#294, I3 nov. 1985, p.88\}

\section{Ezra Pound}

Com um artigo intitulado "Ezra Pound: evocaçôes: No centenário do poeta, retalhos de uma velha amizade," Bardi pincela o que foi a relação dos dois

Pound, nos anos 30, quando morava em Rapallo, na Ligúria, foi me procurar em Roma, fautor da polêmica por mim desencadeada em favor da nova arquitetura, então apelidada de racionalista, cujo cônsul era Le Corbusier. Ele veio me ver na Galleria d'Arte.

Pound havia acompanhado aquilo que, meio século depois, este cronista se permite definir a audácia de uma exposição, (uma das minhas pichaçôes) e vinha, sem saber de mim, para me abraçar e se solidarizar. De fato cumprimentava alguém que, como diretor de uma entidade oficial, tinha denunciado o atraso estético do regime, tendo a cara de bronze de convidar, para inaugurar o grupo Movimento Italiano Arquitetura Racional, o próprio Mussolini. (...) Com Ezra Pound ativei ampla correspondência que um dia irei publicar. Trata-se de longas e pitorescas cartas. Li uma carta dele endereçada a Mussolini, saída dos sequestros dos arquivos italianos feitos pelos aliados, em que o Poeta o incita a prestigiar minha campanha em favor da renovação da arquitetura. \{BARDI, Senhor \#294, I3 nov. 1985, p.88\}

\section{Le Corbusier}

Conheci o Batalhador ab antiquo: o primeiro encontro deu-se no navio Patris II, que em I93I levava para a Grécia parte dos congressistas para assinar a chamada Carta de Atenas. (...) Depois de Atenas, convidei Le Corbusier a palestrar em Roma, superando o veto da 
polícia que o tinha fichado como nada menos que comunista, por ter projetado um edifício em Leningrado. Aliás, num capítulo, revelo as tentativas do Ativista para servir ao Fascismo: fatos inéditos e curiosos, úteis, penso eu, para um currículo. (...) A lembrança leva em conta o Brasil. O delineador do risco do Ministério de Educação e Saúde apareceu aqui, pela primeira vez, em I929. Quem o convidou foi um mecenas de primeira hora, Paulo Prado, do qual no livro consegui publicar parte das cartas de Corbú. (...) [Em] 1936 (...) Lúcio Costa, Mestre orientador e propulsor da nova Arquitetura no Brasil.” Foi (...) que convenceu o ministro Gustavo Capanema a chamar Le Corbusier. $\mathrm{Na}$ então Capital, o Inventor da "máquina-para-morar" pronunciou seis conferências. Por mais que possa parecer estranho, todos os grandes desenhos de parede que ele entáo realizou para ilustrar as conferências são de minha propriedade pois, em 1950, quando organizei sua exposição individual no Masp, sabendo que tinha levado os desenhos para Paris, o contatei e comprei os mesmos. (...) Le Corbusier sabia administrar as suas contas e no livro revelo alguns episódios justamente para fazer seu perfil, sem a preocupação costumeira do panegírico. Preocupei-me em dar realce à sua obra espetacular, a página mais viva da arquitetura deste Século, da qual também o Brasil se beneficiou: Brasilia docet. \{BARDI, Senhor \#I97-I98, 26 dez. I984, p.IOo\}

\section{Pier Luigi Nervi}

Em consequência do falecimento de Nervi, Bardi publica sobre o início da relação dos dois. Aconteceu após o episódio em que Bardi publica no L'Ambrosiano artigo elogioso ao projeto do estádio de Florença projetado e calculado pelo "arquiteto" P.L. Nervi, este recorre a Bardi:

Procurou-me: nervosíssimo, quase me investindo, reprovou a publicação, pois ele "não era um arquiteto, mas um engenheiro." Alinhou uma série de razóes entre as quais uma de ordem fiscal face à publicidade dada a sua firma "Nervi e Nebbiosi" etc. Como resultado da controvérsia, o reclamante deu esta definição lapidar: "L'architetto è um muratore che sa il latino."

Levei o homem na conversa, (...) Nervi acalmou-se. Descobrimos que na mocidade tínhamos tido um encontro ao jogarmos futebol no mesmo campo, em Savona. Conversa vai, conversa vem, ficamos em paz um com o outro após longas horas de troca de ideias, ponto de partida para uma amizade que começada depois de 1930 só agora termina com seu desaparecimento. \{BARDI, Senhor Vogue \#I2, mar. I979, p.83-97\} 


\section{Luigi Vietti}

"O amigo Vietti que após longos decênios acabei por encontrar aqui no Brasil, para realizar um projeto destinado à implantação do Helvetia Country Club, em Indaiatuba, a vinte quilômetros de Campinas, Estado de São Paulo. \{BARDI, Senhor Vogue \#5, ago. 1978, p.I8, 20\}

Vietti náo mudou nada. Calmo, sorridente, ponderado nos julgamentos, sempre disposto a procurar soluçôes eficientes. Encontramo-nos na chácara dos Moroni, ao pé do Pico do Jaraguá, na capital paulista, oportunidade em que evocamos os tempos da polêmica italiana, como falamos também dos seus trabalhos. Vietti ficou conhecido quando venceu, como urbanista inovador, o concurso destinado a estabelecer o plano diretor da zona oriental da cidade de Gênova, o que lhe valeu participar de vários outros projetos, como os de Cortina d'Ampezzo, Portofino etc. O mais famoso é o da ordenação da Costa Esmeralda, na Sardenha, obra que todos conhecem. (Vejam Casa Vogue, edição de fevereiro deste ano.)

Disse que Vietti foi um dos nossos companheiros que trabalharam para a elevação do nível da arquitetura italiana, desfraldando a bandeira do Racionalismo, enquanto eu insistia na fórmula "contra o desperdício decorativo," fato que nos trouxe o apelido de partidários da "arquitetura hospitalar" e, politicamente, a denúncia de querer importar a "arquitetura soviética. \{BARDI, Senhor Vogue \#5, ago. 1978, p.20\}

\section{Giorgio Morandi}

Fui honrado por Giorgio Morandi, no sentido de escrever o prefácio da plaquette preparada para comemorar seu septuagésimo aniversário, pois dele adquirira várias obras e o defendia nos anos 20. \{BARDI, Vogue Brasil \#I, maio 19775, p.177\}

Com relação ao tempo o que me comove é o seguinte: quando, em 1957, Giorgio Morandi comemorou seus setenta anos, a Galleria del Milione (a sucessora da Bardi, em 33) perguntou ao Mestre quem escolheria como autor de um livro-brinde dedicado a ele. Respondeu: "Bardi."

Telegrafam-me, embarco para a Itália, e escrevo a lembrança. Obrigado, Morandi! Nestes últimos anos o morandismo é até insuportável, pois chegam a lhe dedicar um museu, as cotaçóes de suas obras no mercado sobem ao nível do exagero, as mesmas precipitações dos recém-chegados, possíveis peixes no barril, o que faz pensar que quando o B. viajava de Miláo para Bolonha, e almoçava com Morandi na trattoria da Cesarina, aprendia; "Sa? Ieri all'Accademia (onde ensinava gravura) sono andato a uma ricorrenza: mi sono portato l'orbace e l'ho vestito lá, non mi pareva bello attraversare la città vestito di nero." \{BARDI, Vogue Brasil \#II5, fev 1985, p.II5-162\} 
Me honro de ter, em 46, doado uma pintura de Morandi à Tate Gallery, de Londres, justamente para chamar a atenção sobre o artista bolonhês. Fui bom amigo dele e negociei muitas de suas telas. Mas estas são as vicendas do traficar as produçóes dos artistas. \{BARDI, Senhor \#177, 8 ago. 1984, p.77-79\}

\section{Wesley Duke Lee}

Desde que o conheço, Wesley não desistiu de provar e reprovar, de abrir e seguir caminhos atuais. Bastaria o seu Retrato de Tiradentes que está na Pinacoteca do Masp, para documentar um espírito superador de modos e maneiras, realizador de anseios espirituais, evocativos de história. \{BARDI, Senhor \#302-303, 30 dez. 1986, p.68\}

\section{Tarsila do Amaral}

Todos sabem que o acervo do Mirante das Artes é meu. Aliás, as duas telas da Tarsila, Antropofagia e Abaporu, esta última vendida recentemente por trezentos milhôes de cruzeiros, foram adquiridas pelo Mirante diretamente da grande pintora, ambas sendo comercializadas mais tarde. Trata-se de um exemplo eloquente de quando se acredita num artista. Comprei quando Tarsila não conseguiu vendê-las, notadamente a preços ultranormais. \{BARDI, Senhor \#I77, 8 ago. 1984, p. $77-79\}$

Tanto que fui eu mesmo que a adquiri [a obra $O$ Abaporu] da autora, em tempos bem antigos, quando os compradores de Tarsila não se contavam nem nos dedos da mâo \{BARDI, Senhor \#323, 26 maio I987, p.68\}

\section{Lasar Segall}

"Lasar Segall, meu conhecido desde a Europa, me explicou: — Bardi, não faça caso, pois eu também passei por isso; continue o seu trabalho; os cães ladram e a caravana passa." [Conselho de Segall a Bardi, quando das acusaçóes de obras falsas no acervo do Masp] \{BARDI, Vogue Brasil \#I, maio I975, p.I77.\}

\section{Silvio Santos}

(...) conheci Sílvio somente na ocasião em que, no teatro Anhembi, dirigiu a escolha de uma beldade brasileira, incumbida de voar para a corrida das misses Universo, e eu, a seu convite, participei do júri. Declarando não ter smoking, o SBT providenciou e me vestiu na fatídica farda, necessária para o julgamento. Sílvio conversou comigo para agradecer minha presença durante os intervalos: tal qual como é no palco. Sua palavra, descobri, sem um acento a mais nem a menos, a pronúncia simples e arguta como de costume na tevê, mostra um domínio calculado de economia nas entrelinhas. 
Mas o que mais me surpreendeu em Sílvio foi a trajetória de sua vida e fez com que me aproximasse dele. (...) me alegrou, pois confirma que o querer oferece o vencer. E o vencer de Sílvio teve o dom que Horácio definia ore rotundo, isto é, se o meu latim ainda está certo: voz harmoniosa, para dizer convencedora, persuasiva. Os italianos acrescentariam: cerello fino. \{BARDI, Senhor \#366, 28 mar. 1988, p.Ioo\}

\section{Claudio Abramo}

Eu nunca tive com ele contatos muito frequentes, todavia sabia bastante de sua formação cultural e, naturalmente, política. Esta, nos seus tempos de começo de vida, sendo um daqueles que compreendiam a urgência das mudanças, não tinha outra referência: fazer compreender as vozes que apregoam a última reação a um estado de contrastes sociais que o século 20 deveria liquidar.

O livrinho foi publicado e logo, na vida militar, deu-me as primeiras dores de cabeça, pois me ficharam como "subversivo."

Penso que Cláudio, nos tempos do seu noviciado trotskista, mesmo sem guerras permeando o cenário, deve ter tido também seus arrebatamentos. Os jovens que se lançam na vida, se não têm índole de puxa-saco, são atraídos pela contra- corrente. E Cláudio, pelo que sei, empenhou-se em manter-se em posiçóes claramente de crítica, de consideraçóes de justo senso popular. Sua palavra, no exercício da profissão, sempre venceu, alinhada a um caráter inflexível. \{BARDI, Senhor \#336, 25 ago. 1987, p.82\}

\section{I.3 Outras iniciativas}

Pietro Maria Bardi, além de constantemente falar sobre a heterogeneidade do conceito Arte, além de tudo o mais relacionado ao Museu, tem uma terceira esfera de preferência de assuntos, que diz respeito aos seus afetos e desafetos. Matarazzo e as Bienais são, sem dúvida, os mais criticados. A falta de apoio público ou privado a Cultura em geral, mas principalmente a Arte, também são focos de atenção. Mas quando acontecem os patrocínios, Bardi dedica ainda mais espaço a notícia e ao patrocinador.

\section{I.3.I. Francesco Matarazzo}

Deve-se creditar a Ciccillo, imitador e correligionário do mago Assis, fatos notáveis como o da fundação do Museu de Arte Moderna e da Bienal: o primeiro foi por ele próprio posterior e inopinadamente 
extinto, ${ }^{74}$ ocasionando não-tranquilas reações dos sócios; a segunda depois foi deixada à matroca. (...) Encontrei-me inúmeras vezes com Ciccillo. Com tão cordial e ao mesmo tempo respeitoso relacionamento, certamente nunca me passou pela cabeça exercer aquela profissão tão comum na diplomacia provinciana, qual seja a do puxa-saquismo condimentado com "traiçôezinhas" e nunca se dizer realmente o que se pensa. Mesmo tendo com Ciccillo as mais cordiais relaçóes, jamais deixei de censurar - e o fiz por palavras, atos e escritos - o tipo de política que exercitava em relação às artes locais, como ainda apontava erros cometidos pelo carrossel dos seus inumeráveis assessores.

Para mim, a constituição do MAM, pouco depois de São Paulo passar a contar com um museu moderno, (pinacoteca com Picasso, Chagall etc; seção didática para explicar as coisas a um público ainda desinformado; sala de exposiçóes onde eram exibidas, em retrospectivas, obras de Anita, de Fiori, ou Calder, ou Morandi etc; auditório para conferências, abordando temas de arte, de poesia, para se ouvir música, como para se ver cinema etc.) foi um gesto típico de amizade de onça, tanto mais agravante pelo fato de Ciccillo procurar instalar o novo museu no mesmo prédio e pavimento onde já estava funcionando o Masp, gerando, quase sempre, não pouca confusão.75 $\{\mathrm{BARDI}$, Istoé \#I8, 27 abr. I977, p.40\}

E Bardi faz questão de lembrar que Ciccillo Matarazzo "não deixou um centavo para a entidade que presidiu durante anos e que lhe deu fama de mecenas, justo ele que era riquíssimo." [BARDI, Arte Vogue \#2, nov. 1977, p. $38-43\}$

\section{I.3.2. Bienais}

Conforme já visto no tópico "Exposiçôes," Bardi defende em seus escritos uma linha de curadoria e projeto expositivo que busque a síntese e a coerência. Basicamente, todas as ressalvas que ele faz às Bienais de São Paulo baseiam-se nesse entendimento.

Esta das Bienais é uma macaquice de "país em formação." (...)

Grupinhos de estetas abrem logo depois, no mesmo prédio dos Diários Associados, um maspinho e, para proclamar que São Paulo era a Atenas da América do Sul, caputmagister o sr. Ciccillo Matarazzo, fabricaram um carro antes dos bois: uma Bienal Internacional.

74 Bardi refere-se ao episódio em que Ciccillo, após disputas internas no MAM, ter transferido todo seu acervo para o MAC-USP, em 1963.

75 Os dois Franciscos (de Assis e Matarazzo) disputavam o "título" de maior mecenas do Brasil, além do patrimônio dos Penteado (Yolanda, que acabou casando-se com Ciccillo). Matarazzo só não competiu com Ciccillo nas comunicações pois a ditadura getulista impedia não brasileiros de possuírem meios de comunicaçóes. 
Ciccillo atravessa o Oceano, desembarca em Veneza, descobre o regu-

lamento daquela Bienal, novidade de 1893 , transfere-a para a Pauliceia, e a macaquice tem início. \{BARDI, Senhor \#I36, 26 out. I983, p.II8\}

E com o título sugestivo "Um convite à indigestão: A Bienal de São Paulo não imita mais Veneza. Imita a Alemanha," Bardi faz mais críticas:

Tudo corre bem e mal. Agora a Bienal é autre, pois seguindo as imitaçóes, o novo diretor prof. Walter Zanini, descobre a Quadrienal de Kassel. Veneza já era, as luzes vêm da Alemanha, propondo novas problemáticas do não-figurativo, indefiníveis, pelo menos para os “obscurantistas," isto é, os tapados que não entendem, (...) nós, obscurantistas, não sabemos interpretar. \{BARDI, Senhor \#136, 26 out. I983, p.II8\}

Os problemas com o sistema de premiação adotado pela Fundação Bienal, sempre alertada por Bardi a respeito de sua obsolescência, culminaram no seguinte:

O que aconteceu durante o ato de comunicação dos premiados da XIV Bienal é por demais conhecido graças ao noticiário da imprensa em geral. Portanto, não vale a pena retornar ao assunto. A culpa não é do júri que fez o possível para contentar os vários países participantes; a culpa reside no sistema de premiaçôes, superadíssimo.

Os artistas não são cavalos de corrida. Chagall é melhor que Léger, ou mesmo que Braque? Só o defunto ingênuo dono das Bienais [Matarazzo] (não deixou um centavo para a entidade que presidiu durante anos e que lhe deu fama de mecenas, justo ele que era riquíssimo) poderia ter pensado em graduaçôes stakanovistas. Nos tempos em que os júris opinavam sobre pinturas e esculturas figurativas o critério funcionava, incorretamente, mas funcionava; hoje com aquela onda, aliás tempestade, de conceitualismos, pensar em primeiro, segundo ou terceiro valor, é ridículo. Assim e diante do ocorrido, só resta esperar que o próximo conselho diretor da Bienal suprima aquele sistema obsoleto e sem interesse. \{BARDI, Arte Vogue \#2, nov. 1977, p.38-43\}

\section{I.3.3. Patrocinios}

Pietro Maria Bardi sempre deu espaço a discussōes que envolvessem o investimento em Arte e em Cultura. Abriu espaço no Masp e, em seguida, em Arte Vogue, para a criação do Ministério da Cultura, por exemplo. \{Mesa Redonda, Arte Vogue \#I, maio 1977, p.48-53\} E ainda discutia iniciativas como a Lei Sarney de incentivo a Cultura.

Independente disso, Bardi possuía também grande consciência do papel da propaganda. Sempre que pertinente, fazia elogios nominais e agradecia a 
todos os que patrocinavam atividades em prol da cultura e sua divulgação. As atividades elogiadas não necessariamente tinham a ver com o Masp, e inúmeros são os casos onde ele faz menções a esses patrocinadores em seus artigos, nessas mídias com as quais ele contribuía.

A entidade que Bardi mais elogia é o SESC "Fábrica da" Pompeia. Ele poderia inclusive ser acusado de favoritismo, dado que o projeto é de Lina. Talvez fosse sim por favoritismo, mas antes de tudo, o SESC (re)apresentava também tudo o que Bardi planejava para o Masp: algo que não é engessado, que é vivo, que tem a participação assídua da população de diversas faixas sociais e escolares.

De todo modo, depois da morte Assis Chateaubriand, Bardi tem muitos motivos para se preocupar com a falta de patrocínios do Museu. E é muito possível que ele buscasse, com esses "free-ads," com a publicação de textos elogiosos a contribuidores e "mecenas" seus contemporâneos, mais investimentos no Masp ou, genericamente, no campo cultural. E a lógica é cíclica:

- a promoção da açáo em si, veiculando publicaçóes e exposiçóes patrocinadas;

- a promoção de si mesmo, numa espécie de fidelização do investidor em sua figura, atestando de que qualquer investimento em suas iniciativas seria não apenas garantido por sua competência, contatos internacionais e eficiência, comprovadas em inúmeros dos casos que Bardi mesmo conta em seu espaço nesses veículos;

- Esses investimentos teriam ainda repercurssão nesses meios aos quais Bardi tinha acesso, como a Senhor (de audiência elitizada, formadora de opiniáo), divulgando e fazendo aparecer esses nomes, marcas, empresas em revistas de importância e circulação, o que seria uma espécie de promessa de "free-ad" aos próximos que se habilitassem nesse tipo de investimento cultural (desde que Bardi ficasse sabendo, claro), o que retorna para a divulgação, inicialmente, da ação cultural em si. A cultura sendo propagada com a ajuda da propaganda.

Devo lembrar os que contribuíram para a realização de exposiçóes e de publicaçóes de livros e catálogos. Para começar cito o Banco Safra, que ofereceu ao Masp o primeiro catálogo geral digno do acervo, oferecendo depois o mesmo ao Museu de Arte Sacra e ao Museu Paulista da USP.

Particular registro para o Banco Sudameris que já publicou sete livros de minha autoria na "Coleção Arte e Cultura," dedicados a $O$ Modernismo no Brasil; Arte da Prata no Brasil; Arte da Cerâmica no Brasil; Mestres, Artifices, Oficiais e Aprendizes no Brasil; A Madeira, 
Desde o Pau-Brasil até a Celulose; Lembrança do Trem de Ferro; sendo o último A Comunicação, de Cabral à Informática, com notável vantagem econômica para o Masp. Um outro banco, o Francês e Brasileiro, nos patrocina os "Concertos Sinfônicos ao Meio-dia," duas vezes por mês. Várias são as contribuições que recebemos, entre elas destacam-se da Kodak Brasileira, American Express, Hoechst, Lufthansa, Banca Commerciale Italiana, Pirelli S.A., Banco Itaú, Fondazione Giovanni Agnelli da Itália, Estúdios Eldorado, Fortuna Com. Internacional Ltda., IM Arte e Artesanato, Associaçấo Brasileira de Cimento Portland, Rhodia, Consulado Geral da França, MPM Propaganda, Cromex Resinas, e também as doaçóes vindas através de serviços prestados a particulares pelo Departamento de Restauro e Conservação do Masp, além da atuaçáo deste relator como garoto propaganda, revertendo o cachê para a caixa do Masp. \{BARDI, Vogue Brasil \#II5, fev. 1985, p.II5-162\}

E ele provavelmente tinha interesse em fazer esse tipo elogio, em publicação como a Senhor, a procura de outros investidores, principalmente após a morte de Assis Chateaubriand.

E ele elogiava diversas iniciativas particulares. São encontrados textos elogiosos ao Banco Sudameris, para o qual Bardi organiza uma coleção de títulos referentes a diversas das atividades que ele considera artísticas, elogia a Rhodia também, especialmente depois de sua iniciativa de Natal, que foi depois recorrentemente copiada ${ }^{76} \mathrm{E}$ não é só ele. Em artigo revista Senhor, que faz chamada aos empresários sobre o retorno financeiro de se investir em cultura com o título "Um investimento garantido: Empresários e políticos descobrem o óbvio: financiar obras de interesse cultural dá lucro” existe uma análise do idealizador da ideia sobre o projeto:

Aos poucos, a comunidade empresarial está sentindo a necessidade
de investir em projetos culturais de caráter institucional. (...) Talvez
pelo equívoco arraigado de que "gastar" em cultura equivale a
jogar dinheiro fora. Ou, no mínimo, fazer caridade. Mas já existem
exemplos convincentes que provam o contrário. Algumas empresas,
como a Rhodia, Banco da Bahia, Sudameris, Olivetti, Mercedes-
Benz, Eletropaulo, Construtora Fortes, já ultrapassaram o nível das
campanhas institucionais comuns, veiculadas por métodos tradicio-
nais e partiram para o financiamento de livros culturais, o que faz
dupla vantagem: além de divulgar assuntos que dificilmente seriam
editados pelo mercado, projeta a imagem da empresa com resultados
surpreendentes. O Livro de São Paulo, por exemplo, que a Rhodia
editou em in79 - uma síntese do que restou da cidade depois das
sucessivas "febres" imobiliárias - representou um retorno publicitário
quatro vezes maior do que o custo. Pois a imprensa, sensibilizada com

76 cf. Anexos A e C; BARDI; CELIDÔNIO, Senhor Vogue \#7, out. I978, p.98-Io5. 
a iniciativa, abriu grandes espaços para comentar a publicação da obra, uma das muitas ideias que partiu da iniciativa da empresa montada pelo escritor e jornalista Jorge Cunha Lima. "Se a Rhodia fizesse uma campanha institucional comum," diz Cunha Lima, "gastaria quatro vezes mais e não teria a mesma repercussão. E nem a mesma permanência, pois decorridos três anos esse livro que documenta as sobras da cidade de São Paulo já se tornou histórico, pois muitos dos lugares que fotografamos e comentamos foram mais tarde demolidos ou descaracterizados." \{DUCLÓS, Senhor \#60, I2 maio 1982, p.64\}

Além das empresas, Bardi elogia diversos galeristas e colecionadores também (João Marino é o mais recorrente), através de sua ativa figura no campo cultural.

\section{I.3.4. Bardi ao avesso da critica}

Lembrando que Pietro Maria Bardi foi um autodidata, talvez percorrer esse caminho "torto" até trabalhar com artes tenha contribuído para que ele não se reconheça como crítico. Sobre sua capacidade de avaliar uma obra de arte, ele não nega sua competência, muitas vezes a enfatiza, mas sempre se desvinculando de uma atividade "crítica." Como no caso da aquisição de Ressurreição, de Raphael, quando quadro, sem documentos ou registros até entáo, havia tido autoria negada por Bernard Berenson, "o papa da Renascença” e a obra não foi comprada pela Tate Gallery. Numa negociaçáo que poderia ser um grande fracasso, Bardi o "noviço no sacerdócio," com critérios, pode-se dizer, subjetivos, (e nâo teóricos, como no caso de Berenson) avalizou e o resultado já sabemos:

Presente no local o sr. Assis Chateaubriand, Walter Moreira Salles e o Bardi. Mutismo absoluto, ar de arapuca. Eu deveria decidir-me antes de sair. Devo declarar que nunca julguei obras de arte lendo papeladas ou escutando conversas interesseiras: uma obra deve investir, convencer, enamorar, encantar de imediato. Sem fazer blague, desde a entrada eu já havia decidido. Talvez eu nem soubesse por que mas disse sim, convencido de estar adquirindo uma das mais surpreendentes pinturas de Rafael. \{BARDI, Senhor \#116, 8 jun. 1983, p.73\}

Sei julgar suas produçôes, pois me preparei seriamente para avaliar com consciência e competência. Adquiri as pinturas do amigo Giorgio Morandi numa época em que ninguém as queria nem de graça.

Nunca comprei terrenos, paredes, muros, bônus e bilhetes de loteria; só comprei obras de arte. Descobri-as e continuo descobrindo-as. Fui perito de conspícuos acervos entre os quais o de Pellerano, em Buenos Aires, lá pelos anos 30, época em que tive oportunidade de conhecer como turista o Brasil. Publiquei razoável número de livros, vários dos 
quais traduzidos até em cinco idiomas, sendo os mais elaborados The

Arts in Brazil, 1956, e Profile of the New Brazilian Art, 1964, monografias que penso sejam essenciais para que o estrangeiro conheça o que se passou aqui como atividade das artes. O Profile foi editado contemporaneamente em Amsterdá, Londres e Nova York. \{BARDI, Senhor Vogue \#II, fev. 1979, p.76-98; cf. Anexo A\}

Apesar de tudo, Bardi recusa o título de crítico: "Repito: não sou nem historiador nem crítico, mas um simples conhecedor, avaliador também dos que chutam na assim chamada crítica." \{BARDI, Vogue Brasil \#II5, fev. 1985, p.II5I62\} Prefere o de perito e, acima de todos, o de cronista.
Por ocasiáo da publicaçáo do livro que dediquei ao Trem de ferro, rei dos ventos, vários jornais e revistas, ao informarem sobre minha biografia, incorreram num lapso, afirmando que o cronista desta página foi, antigamente, diretor do Corriere della Sera. Esclareço que pertenci ao big milanês simplesmente como redator, aliás repórter. Aproveito esta correção para desmentir outra informação que não corresponde à verdade, isto é, ser o Bardi um "crítico de arte." Considero-me um cronista das artes e, como tal, dirigi revistas, penso eu, não de pouca valia, também no Brasil, como Habitat, Mirante das Artes e Vogue-Arte. \{BARDI, Senhor \#I46, 4 jan. 1984, p.64\}

E essa autotitulagem é, sempre que possível, reforçada:

Insisto em minha posição de cronista de arte, registrador dos fatos, tentando adivinhar certezas em matéria tâo fluida e imprecisa. (...) Cuido ser honesto declarar (...) que não sou crítico de arte. (Nem mesmo um crítico "c" microscópico.) Possivelmente um crítico de fatos que penso cabeça-para-baixo, táo do agrado na opiniáo de todos. \{BARDI, Vogue Brasil\#I, maio 1975, p.I48\}

Até porque os críticos de arte, desde o início da fundação do Masp, acusaram Bardi de "falsário," e outros termos nada elogiosos:

Vim vi defendere, omnes leges, omniaque jura permittunt, que é como dizer: todas as leis permitem valer-se da força contra quem usa a força. Assim, respondi às críticas, não recorrendo a força; com migalhas de ironia desenhadas no Habitat, sob o pseudônimo de Alencastro. \{BARDI, Vogue Brasil \#I, maio 1975, p.176\}

Num episódio em que Bardi (pr)escreve que os críticos de arte tenham mais calma tomando chá de camomila, depois que Sheila Leirner escreve sobre a exposição de Masp "Um século de escultura no Brasil” sem tê-la visitado:

Lembro-me que uma das numerosas e ilustres "críticas de arte" locais, na exposição, "Um século de escultura" declarou-se horrorizada pelos figurativos, pois no seu elucubrar, "não estavam mais em moda" o que me levou a recordar a famosa definição de um inovador 
custe-o-que-custe: "Miquelângelo não interessa ao Brasil.” \{BARDI, Senhor \#94, 5 jan. 1983, p.64\}

E, em defesa de Sheila Leirner, o diretor da Associação Brasileira dos Críticos de Arte, Pedro Manuel, publica carta em repúdio à atitude de Bardi. Ao que Bardi treplica na revista Senhor:

Caro Pedro Manuel, o Masp não é um “espaço.” Sem modéstia, ensinou todos vocês a verem, pela primeira vez, as obras de arte antigas e modernas, bem como contribuiu para que São Paulo desvestisse a capa da indiferença que a própria Semana de Arte Moderna não conseguira lhe tirar. Se cometemos alguns erros, em contrapartida combinamos muitas atividades que nos conferem o direito de acalmar burlescamente uma associada da entidade máxima da Crítica de arte local, de quem não conhecemos ainda a posição, pois, quando assina os alvarás é quase sempre dando o contra, sem cordialidade, como no citado episódio da Escultura, evento do qual falou sem visitar. Fato realmente lamentável e, portanto, merecedor da Camomila prescrita. Fico apenas, e no momento, com a Camomila. Outros remédios guardo para a próxima ocasião. \{BARDI, Senhor \#6I, I9 maio I982, p.65\}

Os exemplos enfim, são inúmeros. E Bardi não economiza em mordacidade para com a atuação "profissional” de crítico de arte:

No Reino das Artes os ministérios são numerosos e, felizmente, não são eles dependentes do monarca e muito menos regidos por um estatuto. Produtores, marketingadores, historiadores, colecionadores, especuladores, penetras, amadores, prima-donas, segundos homens etc. etc., todos operam com total independência ou, quando é preciso, juntos, porém não sem antes jurar com a mão pousada num código qualquer. Pelo visto, deixei de incluir na turma acima citada os críticos, uma categoria que desejo enfocar nesta página. O motivo é que vários amigos e inimigos (cada ministério é prenhe de antagonismos) pensam que este redator é um "crítico." \{BARDI, Senhor \#I39, I6 nov. I983, p.93\}

Como conseguir o título de crítico de arte? Simples: existe uma associação paralela, a dos artistas, e basta pedir a inscrição anexando como comprovante um recorte de jornal que tenha publicado algumas colunas sobre o assunto. Obtida a caderneta prossegue a compilação de pareceres, que é facílimo, pois a demanda das bienais, salóes, salóezinhos, galerias é tão inflacionária que tem lugar para todos. Constituído seu mini-império, dispóe e organiza sua estratégia, (sempre através da publicidade) conquista posiçôes na imprensa que lhe permitem a emissão de bulinhas e bênçãos, às vezes - genus irritabile criticum - censuras e anátemas, de acordo com as amizades e os interesses. \{BARDI, Arte Vogue \#2, nov. 1977; cf. Anexo D\} 
Nunca se vê nos jornais um definido interesse pela crítica de inumeráveis manifestaçôes que interessam diretamente à necessidade de arrumar o gosto, a compostura estética, a não ofensa aos olhos etcetera. Temos muitos críticos e até associaçóes de críticos. Não que eles não intervenham para observar falhas e incongruências, porém, nunca se viu uma açáo concorde, o que se chamaria de campanha nacional. Dizem que isso depende de numerosos outros fatores e contingências. Claro, mas é interessante ir até a raiz para um exame mais cuidadoso. Entre o caminho que leva ao bosque repleto de fantasmas utópicos e o caminho em direção ao gramado florido, deve existir uma estrada de permeio. Há que procurá-la. Não é difícil encontrá-la, pois já existe uma indicação: bom-senso." \{BARDI, Arte Vogue \#I, maio 1977, p.47\} 
Conclusão 
Com o falecimento de Assis Chateaubriand, em 1968, Pietro Maria Bardi perde os canais de comunicaçôes oficiais do Masp e só consegue recuperar algo similar quase oito anos depois, em 1976. Isso porque ele estreita relaçóes com os membros da família Carta, que já o conheciam havia mais de vinte anos. Por tradição, a família Carta trabalhava no campo do jornalismo ou mercado editorial. Mino e Luis trabalharam com as revistas da própria editora, com as de outras editoras e, antes de tudo, com o jornalismo propriamente dito. $\mathrm{O}$ pai dos dois, Giannino Carta, também foi jornalista. Além do avô materno. A família também tinha ligaçóes com a arte: Giannino pintava nas horas vagas, e Mino seguiu-lhe o exemplo. E provavelmente em alguma ocasião relacionada com a individual de Mino Carta no Masp, surgiu a oportunidade de Bardi retomar um canal mais amplo de divulgação do Masp. Assim, a relação pessoal de Bardi com a família Carta, especificamente com Mino e Luis Carta, teve o papel fundamental para que Bardi desse seguimento a sua comunicação com o público que ele pretendia do Masp. O levantamento feito através das revistas preenchem uma parte da história das publicaçôes no Brasil, além da relaçáo Bardi-Carta estar inserida na questão da modernização proporcionada pela imigração italiana no Brasil, a partir de todo o material inédito levantado nessas publicaçóes, boa parte disponibilizada nos Anexos.

Também foi possível preencher uma lacuna da biografia de Pietro Maria Bardi: sua colaboração e produção escrita no Brasil através dos meios disponibilizados pela família Carta, a partir de 1975, dada sua relação pessoal anterior, de modo que ele pôde continuar a divulgar o Museu de Arte de São Paulo (exposiçôes, iniciativas, inscriçôes, eventos e intençôes), cumprindo também com a finalidade de contribuir para a formaçáo de um gosto e de um público modernos no contexto das grandes transformaçóes sociais e culturais a que estava sendo submetido o país.

Os textos aqui disponibilizados reconstituem um certo tipo de pensamento, proveniente da formação italiana de Bardi justamente numa época como a do surgimento da Bauhaus, dos CiAms e outras teorias modernas.

As publicações dos Carta eram normalmente destinadas a um público com um grau socioeconômico mais elevado. $\mathrm{O}$ tipo de audiência variava de revista para revista (homens vs. mulheres vs. profissionais liberais vs. empresários vs. donas-de-casa etc.) E Bardi, aparentemente, soube comunicar-se com todas elas, ao longo dos quase vinte anos de colaboração com essas publicações,

Os escritos de Bardi cronista adquirem assim uma grande relevância para podermos compreender o sentido da sua ação como diretor do Masp e 
como operador cultural em São Paulo e no Brasil depois da morte de Assis Chateaubriand e o deslocamento do museu na nova sede da Avenida Paulista.

Os textos reunidos, contudo, não dizem respeito só a estes importantes aspectos da personalidade do crítico italiano. Eles representam uma fonte da maior importância para conhecer o contexto da produção artística e do mercado das artes no Brasil. O mapeamento das participaçóes de Bardi na mídia impressa permite perceber com maior clareza a rede cultural e seus posicionamentos em relação aos desdobramentos políticos e à pauta colocada pela ditadura militar e pelo processo de democratização posteriormente.

Junto com os livros publicados pelo autor, os escritos permitem que se acompanhe a evolução do seu pensamento em relação aos problemas da arte na sociedade contemporânea. Os textos aqui disponibilizados, escritos por Bardi ou outros colaboradores sob sua direção, ${ }^{77}$ são certamente fonte importante para a reconstruçáo do ambiente e do mercado da arte no Brasil, mais especificamente do Mercado da Arte em São Paulo, nas décadas de 1970 e I980; acusam os desafetos intelectuais de Bardi, principalmente os provenientes da Fundação Bienal, ${ }^{8}$ e apontam também para afinidades intelectuais entre Bardi e outros autores; ${ }^{79}$ além de reconstituirem também a repercusão das bienais, no meio artístico.

Seu pensamento certamente nunca foi sistemático e teoricamente fundamentado, mas que, não por isso, faltou de relevância e de impacto no contexto da época, devido sobretudo à incansável atividade de jornalista e à capacidade como tal de formar a opiniáo e o gosto do crescente público da metrópole aos mais diversos níveis, não excluso a reflexão poética dos artistas, a formação da pedagogia das artes e de suas instituiçóes, o sistema expositivo em formação, de que o Masp era parte fundamental, o colecionismo e o mercado.

77 Especialmente no caso das Arte Vogue.

78 Sheila Leirner, Pedro Manuel, Gilberto Chateaubriand, Aracy Amaral

79 Entre eles, Jacob Klintowitz, Radha Abramo, Fábio Magalhães, Alexandre Wollner, Mino Carta, Giuseppe Baccaro. 
Apêndice 
Diagrama: LinHa DO TEMPO dos títulos, contribuições e colaborações de P.M.Bardi

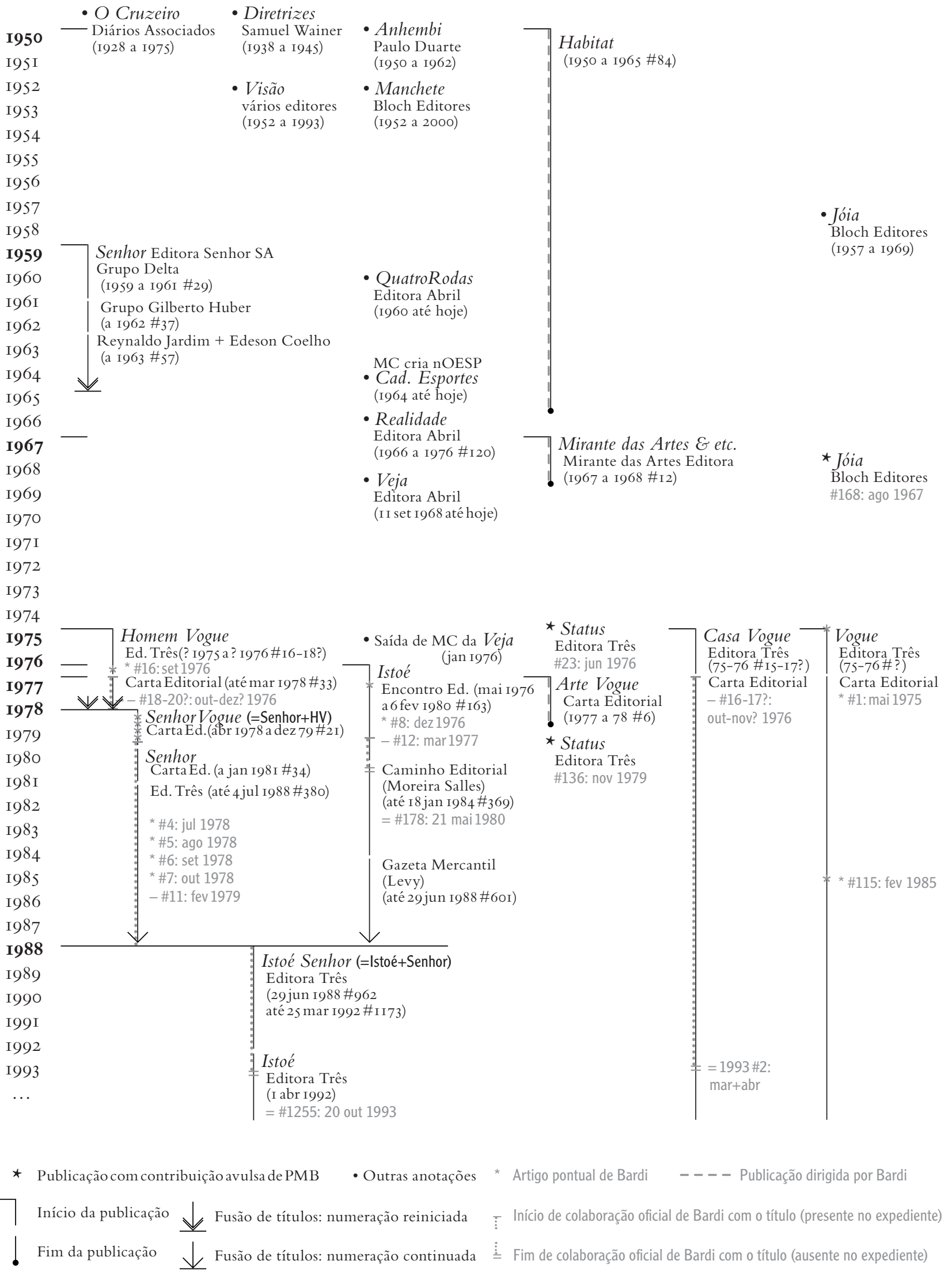


Quadro \#1 CASA Vogue (levantamento em coleção incompleta:relação dos vol.consultados)

\begin{tabular}{|c|c|c|c|c|c|}
\hline editora & diretores editora & \# & data & “artigo de Bardi;” observações & $\begin{array}{c}\# \\
\text { Bardi } \\
\end{array}$ \\
\hline \multicolumn{6}{|c|}{ CASA VOGUE } \\
\hline \multirow{5}{*}{$\begin{array}{l}\text { Editora } \\
\text { Três }\end{array}$} & \multirow{5}{*}{$\begin{array}{l}\text { Luis Carta, } \\
\text { Domingo Alzugaray }\end{array}$} & $6 / \mathrm{A}$ & $\operatorname{dez} 1975$ & \multirow{5}{*}{ sem contribuições de Bardi } & \\
\hline & & 9/A & mar 1976 & & \\
\hline & & $12 / \mathrm{A}$ & jun 1976 & & . \\
\hline & & $14 / \mathrm{A}$ & ago 1976 & & \\
\hline & & $16 / \mathrm{B}$ & set 1976 & & \\
\hline \multirow{28}{*}{$\begin{array}{l}\text { Carta } \\
\text { Editorial }\end{array}$} & \multirow{9}{*}{$\begin{array}{l}\text { Luis Carta, } \\
\text { Fabrizio Fasano, } \\
\text { Mino Carta }\end{array}$} & $18 / \mathrm{A}$ & dez 1976 & $\begin{array}{l}\text { início da colaboração oficial de Bardi (expediente); } \\
\text { sem contribuiçôes de Bardi }\end{array}$ & - \\
\hline & & $20 / \mathrm{A}$ & jan 1977 & sem contribuições de Bardi & . \\
\hline & & $21 / \mathrm{A}$ & fev 1977 & $\begin{array}{l}\text { "Arquitetura corrente e inteligente: P.M. Bardi fala } \\
\text { desta casa" (Projeto residencial de Ugo di Pace para } \\
\text { Vera Andraus; pequeno texto em "0 mundo só ama } \\
\text { os originais," entrevista com Ugo di Pace, por Maiá } \\
\text { Mendonça) }\end{array}$ & [1] \\
\hline & & $22 / \mathrm{A}$ & mar 1977 & \multirow{2}{*}{ - sem contribuições de Bardi } & \\
\hline & & $23 / \mathrm{A}$ & abr 1977 & & \\
\hline & & $24 / \mathrm{A}$ & mai 1977 & $\begin{array}{l}\text { sem contribuiç̃̃es de Bardi } \\
\text { [Arte Vogue \#1 avulsa] }\end{array}$ & \\
\hline & & $25 / \mathrm{A}$ & jun 1977 & \multirow{3}{*}{ sem contribuições de Bardi } & \\
\hline & & $26 / \mathrm{A}$ & jul 1977 & & \\
\hline & & $27 / \mathrm{A}$ & ago 1977 & & \\
\hline & \multirow{11}{*}{$\begin{array}{l}\text { Luis Carta, } \\
\text { Fabrizio Fasano, } \\
\text { Mino Carta, } \\
\text { Ricardo Amaral }\end{array}$} & $28 / \mathrm{A}$ & set 1977 & "A arte de conservar com amor: Coleção João Marino" & [2] \\
\hline & & $29 / \mathrm{A}$ & out 1977 & sem contribuições de Bardi & $\cdot$ \\
\hline & & $30 / \mathrm{A}$ & nov 1977 & $\begin{array}{l}\text { "Tecidos que animam e complementam qualquer tipo } \\
\text { de ambiente" } \\
\text { [Arte Vogue \#2 avulsa] }\end{array}$ & [3] \\
\hline & & $31 / \mathrm{A}$ & $\begin{array}{c}\text { dez } 1977+ \\
\text { jan } 1978\end{array}$ & sem contribuições de Bardi & \\
\hline & & $32 / \mathrm{A}$ & fev 1978 & $\begin{array}{l}\text { sem contribuição de Bardi; } \\
\text { artigo sobre a coleção Bardi }\end{array}$ & \\
\hline & & $33 / \mathrm{A}$ & mar 1978 & $\begin{array}{l}\text { "0 colecionador salva do esquecimento aquilo que no } \\
\text { futuro representará a história;" } \\
\text { [Arte Vogue \#3: incorporada à Casa Vogue] }\end{array}$ & [4] \\
\hline & & $34 / \mathrm{A}$ & abr 1978 & & \\
\hline & & $35 / \mathrm{A}$ & mai 1978 & ontribulçoes de Bardl & \\
\hline & & $36 / \mathrm{A}$ & jun 1978 & [Arte Vogue \#4: incorporada à Casa Vogue] & \\
\hline & & $37 / \mathrm{A}$ & jul 1978 & sem contribuições de Bardi & \\
\hline & & $38 / \mathrm{A}$ & ago 1978 & "Um projeto polêmico de Ugo di Pace" & [5] \\
\hline & \multirow{3}{*}{$\begin{array}{l}\text { Luis Carta, } \\
\text { Fabrizio Fasano, } \\
\text { Ricardo Amaral, } \\
\text { Francisco Alberto } \\
\text { Madia de Souza } \\
\end{array}$} & $39 / \mathrm{A}$ & set 1978 & $\begin{array}{l}\text { sem contribuições de Bardi; } \\
\text { [Arte Vogue \#5: incorporada à Casa Vogue] }\end{array}$ & \\
\hline & & $41 / \mathrm{A}$ & nov 1978 & sem contribuições de Bardi & \\
\hline & & $42 / \mathrm{A}$ & dez 1978 & [Arte Vogue \#6: incorporada à Casa Vogue] & \\
\hline & \multirow{4}{*}{$\begin{array}{l}\text { Luis Carta, } \\
\text { Fabrizio Fasano, } \\
\text { Ricardo Amaral, } \\
\text { Francisco Alberto } \\
\text { Madia de Souza, Rudi } \\
\text { Crespi, José Hugo } \\
\text { Celidônio }\end{array}$} & 1 & jan 1979 & sem contribuições de Bardi & \\
\hline & & 2 & fev 1979 & sem contribuições de Bardi & \\
\hline & & 3 & mar 1979 & $\begin{array}{l}\text { "Propriedade, compostura, inteligência. Uma casa do } \\
\text { arquiteto Raul di Pace" }\end{array}$ & [6] \\
\hline & & 4 a 5 & $\begin{array}{c}\text { abr a mai } \\
1979 \\
\end{array}$ & \multirow[b]{2}{*}{ sem contribuições de Bardi } & \\
\hline & $\begin{array}{l}\text { Luis Carta, } \\
\text { Ricardo Amaral, } \\
\text { Francisco Alberto } \\
\text { Madia de Souza, Rudi } \\
\text { Crespi, José Hugo } \\
\text { Celidônio } \\
\end{array}$ & 6 & jun 1979 & & \\
\hline
\end{tabular}




\begin{tabular}{|c|c|c|c|c|c|}
\hline editora & diretores editora & \# & data & "artigo de Bardi;" observações & $\begin{array}{c}\# \\
\text { Bardi }\end{array}$ \\
\hline & \multirow{2}{*}{$\begin{array}{l}\text { Luis Carta, } \\
\text { Francisco Alberto } \\
\text { Madia de Souza, Rudi } \\
\text { Crespi, Alice Carta, } \\
\text { Domingo Alzugaray, } \\
\text { Catia Alzugaray } \\
\end{array}$} & 7 & $\begin{array}{c}\text { jul+ago+set } \\
1979 \\
\end{array}$ & $\begin{array}{l}\text { "Seara do colecionador: uma coleção de modernos, } \\
\text { de Enrica Profili" }\end{array}$ & [7] \\
\hline & & 8 & $\begin{array}{l}\text { out+nov+dez } \\
\quad 1979\end{array}$ & "Antiqua, simbiose de dois momentos" & {$[8]$} \\
\hline & \multirow{2}{*}{$\begin{array}{l}\text { Luis Carta, Rudi Crespi, } \\
\text { Alice Carta, } \\
\text { Domingo Alzugaray, } \\
\text { Catia Alzugaray } \\
\end{array}$} & 1 a 6 & $\begin{array}{c}\text { jan+fev a } \\
\text { nov+dez } 1980\end{array}$ & \multirow{4}{*}{ sem contribuições de Bardi } & \\
\hline & & 1 & jan+fev 1981 & & \\
\hline & \multirow{4}{*}{$\begin{array}{l}\text { Luis Carta, } \\
\text { Rudi Crespi, } \\
\text { Domingo Alzugaray, } \\
\text { Catia Alzugaray }\end{array}$} & 2 a 6 & $\begin{array}{c}\text { mar+abr a } \\
\text { nov+dez } 1981\end{array}$ & & \\
\hline & & 1 & jan+fev 1982 & & \\
\hline & & 2 & mar+abr 1982 & $\begin{array}{l}\text { "Um contato com artes exóticas: na casa de uma } \\
\text { designer" }\end{array}$ & [9] \\
\hline & & 3 & mai+jun 1982 & "Visita a um antiquário" & [10] \\
\hline & $\begin{array}{l}\text { Luis Carta, } \\
\text { Rudi Crespi }\end{array}$ & 1 a 4 & $\begin{array}{c}\text { jan+fev a } \\
\text { jul+ago } 1983\end{array}$ & sem contribuições de Bardi & $\cdot$ \\
\hline \multirow{33}{*}{$\begin{array}{l}\text { Carta } \\
\text { Editorial }\end{array}$} & \multirow{11}{*}{$\begin{array}{l}\text { Luis Carta, } \\
\text { Rudi Crespi, } \\
\text { Andrea Carta, } \\
\text { Ricardo Kowarick }\end{array}$} & 5 & set+out 1983 & "Coleção Arte Brasileira" & [11] \\
\hline & & 6 & nov+dez 1983 & \multirow{2}{*}{ - sem contribuições de Bardi } & \multirow{2}{*}{. } \\
\hline & & 1 & jan+fev 1984 & & \\
\hline & & 2 & mar+abr 1984 & [sem título: início seção P.M. Bardi] & [12] \\
\hline & & \multirow{2}{*}{3} & \multirow{2}{*}{ mai+jun 1984} & "Comunicação no Brasil" & \multirow{2}{*}[13]{} \\
\hline & & & & "A casa do Morumbi: em meio ao verde" & \\
\hline & & 4 & jul+ago 1984 & [sem título: SP 2000] & [14] \\
\hline & & 5 & set+out 1984 & "Cuidado ao destruir" & [15] \\
\hline & & 6 & nov+dez 1984 & "Sem mais problemas" & [16] \\
\hline & & 1 & jan+fev 1985 & "Gentoteca: uma solução?" & [17] \\
\hline & & 2 & mar+abr 1985 & "Arquitetura e Arte" & [18] \\
\hline & \multirow{20}{*}{$\begin{array}{l}\text { Luis Carta, } \\
\text { Andrea Carta, } \\
\text { Ricardo Kowarick }\end{array}$} & 3 & mai+jun 1985 & "Como desenhar uma cadeira?" & [19] \\
\hline & & 4 & jul+ago 1985 & "Engenharia, arquitetura e arte" & [20] \\
\hline & & 5 & set+out 1985 & "...E, por que não? Os tronos" & [21] \\
\hline & & 6 & nov+dez 1985 & "No baile das artes" & {$[22]$} \\
\hline & & 1 & jan+fev 1986 & "Arquitetura e engenharia na construção" & [23] \\
\hline & & 2 & mar+abr 1986 & "Antenção às paredes" & [24] \\
\hline & & 3 & mai+jun 1986 & "Excessivamente kitsch" & {$[25]$} \\
\hline & & 4 & jul+ago 1986 & "A moda objeto de arte" & [26] \\
\hline & & 5 & set+out 1986 & "0 mercado das artes" & [27] \\
\hline & & 6 & nov+dez 1986 & "Revisando a moral" & {$[28]$} \\
\hline & & 1 & jan+fev 1987 & "A propósito dos tapetes..." & [29] \\
\hline & & 2 & mar+abr 1987 & "As cadeiras" & {$[30]$} \\
\hline & & 3 & mai+jun 1987 & "0 assunto é mobiliário" & {$[31]$} \\
\hline & & 4 & jul+ago 1987 & "Fotografia: arte mecânica e figurativa" & {$[32]$} \\
\hline & & 5 & set+out 1987 & "Questão de estilo" & {$[33]$} \\
\hline & & 6 & nov+dez 1987 & "A conservação da madeira" & [34] \\
\hline & & 1 & jan+fev 1988 & "Esperanto arquitetônico" & [35] \\
\hline & & 2 & mar+abr 1988 & "Reflexões ao ar livre" & {$[36]$} \\
\hline & & 3 & mai+jun 1988 & "Obras autênticas & [37] \\
\hline & & 4 & jul+ago 1988 & $\begin{array}{l}\text { "Arte ao ar livre;" último texto encontrado dentro do } \\
\text { recorte temporal desta pesquisa }\end{array}$ & [38] \\
\hline & \multirow[t]{2}{*}{$\begin{array}{l}\text { Andrea Carta, Ricardo } \\
\text { Kovwarick, Idel Arcuschin, } \\
\text { Edison Augusto Garcia, } \\
\text { João Carrascosa, } \\
\text { Hiluz Del Priore } \\
\end{array}$} & 2 & mar-abr 1990 & $\begin{array}{l}\text { "0 que é decoração?;" último texto de Bardi encon- } \\
\text { trado dentro das coleçôes (incompletas) consul- } \\
\text { tadas; fora do recorte temporal desta pesquisa, não } \\
\text { será disponibilizado em anexo; Bardi continua a } \\
\text { aprecer no expediente }\end{array}$ & [39] \\
\hline & & 4 & jul+ago 1993 & Bardi não aparece mais no expediente. & {$[=]$} \\
\hline
\end{tabular}

Os números de Casa Vogue faltantes (quando existirem) são: 19751 a 5; 1976 7, 8, 10, 11, 13, 15, 17, 19?;

1978: 40 (out.); 19824 a 6 (jul-ago a nov-dez); 19885 e 6 (set-out e nov-dez);

1990 1, 3 a 6 (jan-fev, mai-jun a nov-dez); 1991: todos; 19921 (jan-fev); 19933 (mai-jun) 
QuAdro \#2 Homem VOGUE (levantamento em coleção incompleta:relação dos vol.consultados)

\begin{tabular}{|c|c|c|c|c|c|}
\hline editora & diretores editora & \# & data & “artigo de Bardi;” observações & $\begin{array}{c}\# \\
\text { Bardi }\end{array}$ \\
\hline \multicolumn{6}{|c|}{ HOMEM VOGUE } \\
\hline \multirow[t]{2}{*}{$\begin{array}{l}\text { Editora } \\
\text { Três }\end{array}$} & \multirow[t]{2}{*}{$\begin{array}{l}\text { Luis Carta, } \\
\text { Catia Alzugaray, } \\
\text { Domingo Alzugaray, } \\
\text { Rudi Crespi }\end{array}$} & $10 / \mathrm{A}$ & abr 1976 & $\begin{array}{l}\text { a contagem das colaborações de Bardi será } \\
\text { baseada apenas nos volumes acessados, todos aqui } \\
\text { relacionados - inclusive quando não houver Bardi } \\
\text { scritti. É muito provável que existam outros artigos } \\
\text { de Bardi nos números ausentes. }\end{array}$ & . \\
\hline & & $16 / \mathrm{A}$ & set 1976 & "Revivals e Histerismo" & [1] \\
\hline \multirow{11}{*}{$\begin{array}{l}\text { Carta } \\
\text { Editorial }\end{array}$} & \multirow{9}{*}{$\begin{array}{l}\text { Luis Carta, } \\
\text { Fabrizio Fasano, } \\
\text { Mino Carta }\end{array}$} & $21 / B$ & fev+mar 1977 & $\begin{array}{l}\text { "Bom gosto (I) e considerações sobre o mau gosto } \\
\text { (II);" O nome de Bardi consta no expediente, mas } \\
\text { suspeita-se que ele tenha entrado quando houve } \\
\text { a mudança de editora, entre outubro e novembro } \\
\text { de } 1977, \text { como acontecido em todas as outras } \\
\text { publicaçôes da Carta Editorial. }\end{array}$ & $\overline{-}$ \\
\hline & & 23/B & $\begin{array}{c}\text { abr+mai } \\
1977 \\
\end{array}$ & "Como ler a fórmula de Einsten?" & [3] \\
\hline & & $25 / B$ & jun+jul 1977 & $\begin{array}{l}\text { "No decor matrimonial" } \\
\text { "0 Grande Incêndio: } \\
\text { São Paulo, } 26 \text { de maio de 2089" }\end{array}$ & [4] \\
\hline & & $27 / \mathrm{B}$ & ago 1977 & Vogue Homem volta a ser mensal & \\
\hline & & 28/B & set 1977 & "A futilidade é o protoplasma da moda: seja elegante" & [5] \\
\hline & & \multirow{2}{*}{ 29/B } & \multirow{2}{*}{ out 1977} & "Hábito, vício, mania da simetria" & \multirow{2}{*}{ [6] } \\
\hline & & & & "0 purgatório paradisíaco do marquês Von Bayros" & \\
\hline & & $30 / \mathrm{B}$ & nov 1977 & & . \\
\hline & & $31 / \mathrm{B}$ & dez 1977 & & \\
\hline & \multirow{2}{*}{$\begin{array}{l}\text { Luis Carta, } \\
\text { Fabrizio Fasano, } \\
\text { Mino Carta, } \\
\text { Ricardo Amaral }\end{array}$} & $32 / B$ & jan+fev 1978 & & \\
\hline & & 33/B & mar 1978 & último número de Homem Vogue & \\
\hline
\end{tabular}

Senhor Vogue de abril de 1978 em diante: cf. Quadro \#3

Legenda: - início de colaboração oficial de Bardi com o título (presença no expediente); = fim de colaboração oficial; [x] ordenação provisória dos volumes consultados com contribuições de Bardi, prevendo-se que seja alterada quando a coleção do título for completa

Os números de Homem Vogue faltantes (quando existirem) são:

todos os de 1975 a janeiro de 1977: 1 a 9,11 a 15 e 17 a 20

É provável que alguns desses volumes não tenham existido, pois a numeração bimestral ora era par, ora ímpar. 
QuAdro \#3 SEnHor (levantamento me coleção completa)

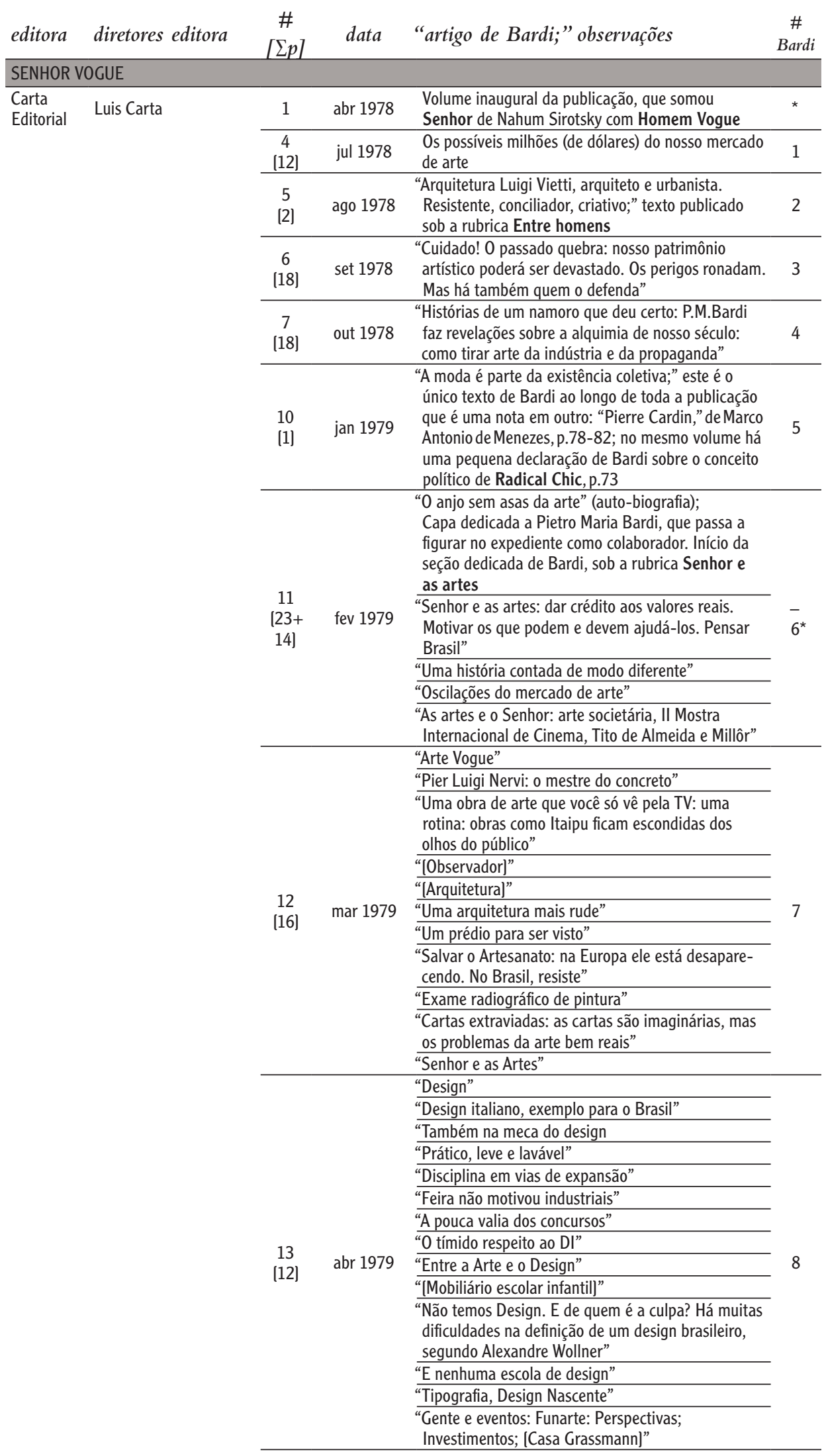




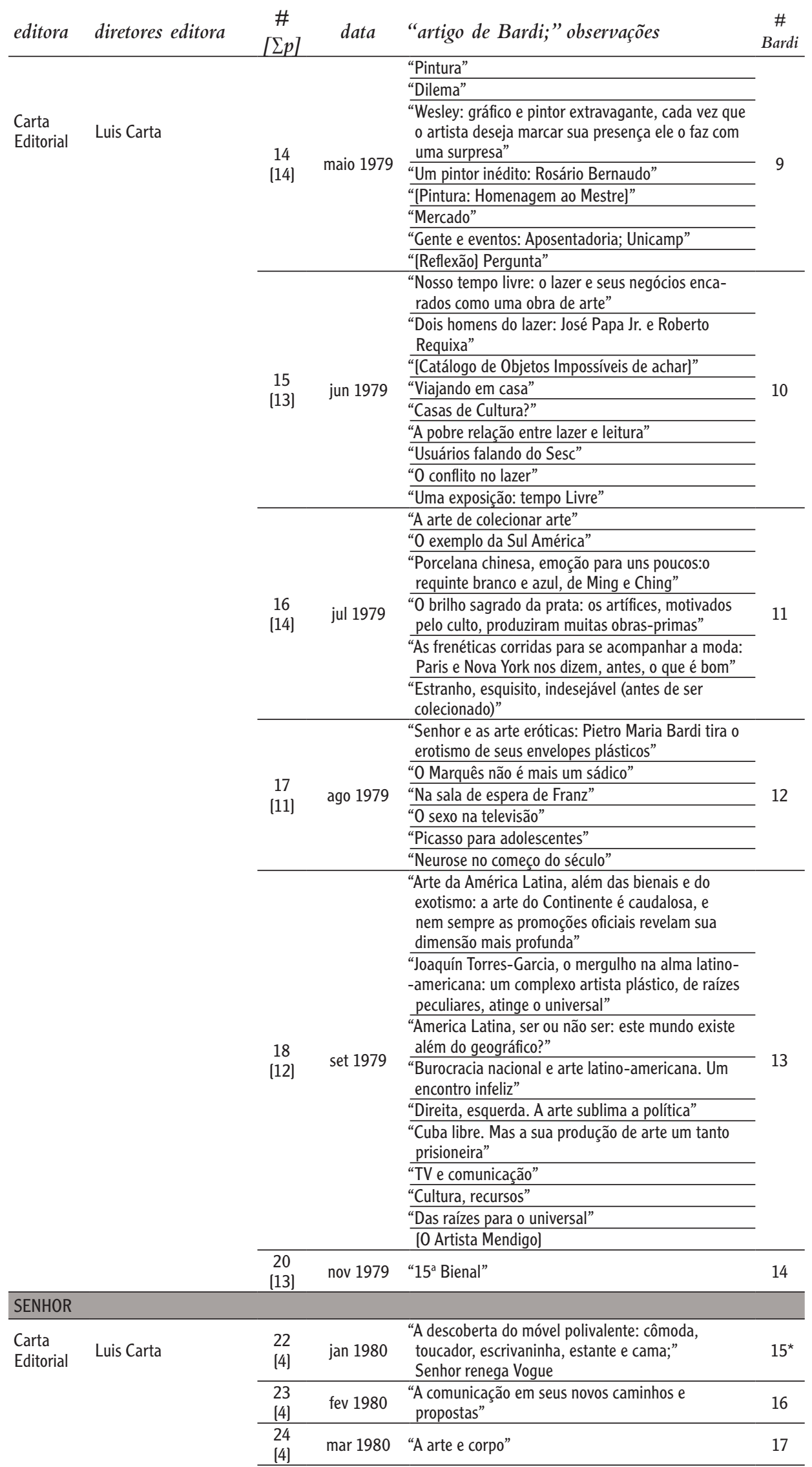




\begin{tabular}{|c|c|c|c|c|c|}
\hline editora & diretores editora & $\begin{array}{c}\# \\
{[\Sigma p]}\end{array}$ & data & “artigo de Bardi;” observações & $\begin{array}{c}\# \\
\text { Bardi }\end{array}$ \\
\hline \multirow[t]{10}{*}{$\begin{array}{l}\text { Carta } \\
\text { Editorial }\end{array}$} & \multirow[t]{10}{*}{ Luis Carta } & $\begin{array}{l}25 \\
{[5]}\end{array}$ & abr 1980 & $\begin{array}{l}\text { "Brasil 21: uma revista voltada para o futuro dá } 500 \\
\text { mil por seu logotipo" } \\
\text { "Made in England: em São Paulo, o lirismo de um } \\
\text { estadista cáustico e a crítica de um pintor lírico" }\end{array}$ & 18 \\
\hline & & $\begin{array}{l}26 \\
{[4]}\end{array}$ & maio 1980 & $\begin{array}{l}\text { "Um museu não pode abrigar só pinturas e escul- } \\
\text { turas: } 0 \text { sucesso da Feira de Trocas do Masp, em } \\
\text { São Paulo, com sua exposição de quinquilharias e } \\
\text { antiguidades" }\end{array}$ & 19 \\
\hline & & & & $\begin{array}{l}\text { "Deixa comigo que eu vou mostrar uma novidade: a } \\
\text { magia de Wesley, do tufão da Rex ao mapa-mundi } \\
\text { de agora" }\end{array}$ & \multirow[b]{2}{*}{20} \\
\hline & & $\begin{array}{l}27 \\
{[5]}\end{array}$ & jun 1980 & $\begin{array}{l}\text { "Questões de mercado: que se deve comprar para } \\
\text { encher paredes vazias: senhores, fujam dos críticos, } \\
\text { conheçam os artistas e aprendam a conviver com } \\
\text { seu trabalho. Isso ensina mais do que os textos - } \\
\text { Jacob Klintowitz" }\end{array}$ & \\
\hline & & $\begin{array}{l}28 \\
{[2]}\end{array}$ & jul 1980 & $\begin{array}{l}\text { "0 erotismo de Zaragoza: e o texto lúcido e lógico de } \\
\text { Jacob Klintowitz" }\end{array}$ & 21 \\
\hline & & $\begin{array}{l}29 \\
{[2]}\end{array}$ & ago 1980 & $\begin{array}{l}\text { "As quermesses de arte. Arte? As festinhas cheias de } \\
\text { medalhas inúteis, e os leilões regados a whisky e } \\
\text { champagne" }\end{array}$ & 22 \\
\hline & & $\begin{array}{l}30 \\
{[2]}\end{array}$ & set 1980 & $\begin{array}{l}\text { "À descoberta dos simbolistas: um elo esquecido } \\
\text { mas importante na longa corrente da história da } \\
\text { arte" }\end{array}$ & 23 \\
\hline & & $\begin{array}{l}31 \\
{[4]}\end{array}$ & out 1980 & $\begin{array}{l}\text { "Os italianos no Brasil: no Museu de Arte de São } \\
\text { Paulo, uma comovedora exposição sobre a vida, } \\
\text { a arte e a cultura dos imigrantes que ajudaram a } \\
\text { fazer o Brasil" }\end{array}$ & 24 \\
\hline & & $\begin{array}{l}32 \\
{[2]}\end{array}$ & nov 1980 & $\begin{array}{l}\text { "O Antigo e nós: os problemas do tempo na cultura e } \\
\text { as fórmulas que usamos para solucioná-los" }\end{array}$ & 25 \\
\hline & & $\begin{array}{l}33 \\
{[1]}\end{array}$ & dez 1980 & "Bienal, Trienal, Quadrienal..." & 26 \\
\hline $\begin{array}{l}\text { Carta } \\
\text { Editorial }\end{array}$ & $\begin{array}{l}\text { Luis Carta, } \\
\text { Domingo Alzugaray }\end{array}$ & $\begin{array}{l}34 \\
{[2]}\end{array}$ & jan 1981 & $\begin{array}{l}\text { "Academie-vangarde: ou, como descambar rapida- } \\
\text { mente para o ocaso" }\end{array}$ & 27 \\
\hline \multirow[t]{8}{*}{$\begin{array}{l}\text { Editora } \\
\text { Três }\end{array}$} & \multirow[t]{8}{*}{$\begin{array}{l}\text { Domingo Alzugaray, } \\
\text { Cátia Alzugaray, } \\
\text { Silvio Lancellotti }\end{array}$} & $\begin{array}{l}35 \\
{[2]}\end{array}$ & fev 1981 & $\begin{array}{l}\text { "Assunto: caricatura: ou, o sucesso de um desenhista } \\
\text { brasileiro numa grande exposição em países de } \\
\text { além Cortina de Ferro;" } \\
\text { a revista passa a ser editada pela Editora Três }\end{array}$ & $28^{*}$ \\
\hline & & $\begin{array}{l}36 \\
{[2]}\end{array}$ & mar 1981 & $\begin{array}{l}\text { "O mercado assinatural: comprar para estocar. Essa } \\
\text { é a tese do chamado colecionador. Quer dizer, do } \\
\text { comerciante. Mas isso não ofende a arte?" }\end{array}$ & 29 \\
\hline & & $\begin{array}{l}37 \\
{[1]}\end{array}$ & abr 1981 & $\begin{array}{l}\text { "Siron, Nardin, Caciporé e (por que não?) Bardi: } \\
\text { dentre os premiados pela Associação Paulista dos } \\
\text { Críticos de Arte, versão- } 81,0 \text { escriba que assina } \\
\text { esta seção:justa homenagem a três artistas solitá- } \\
\text { rios, inquietos, contestadores. E ao velho professor, } \\
\text { que diz: 'grazie"” }\end{array}$ & 30 \\
\hline & & $\begin{array}{l}38 \\
{[2]}\end{array}$ & maio 1981 & $\begin{array}{l}\text { "A importância da memória nacional: no Masp, mais } \\
\text { uma exposição fundamental: os arquivos de São } \\
\text { Paulo, enfim livres dos ataques do descaso, do pó } \\
\text { e dos cupins" }\end{array}$ & 31 \\
\hline & & $\begin{array}{l}39 \\
{[2]}\end{array}$ & jun 1981 & $\begin{array}{l}\text { “E os leilões, chegarão fim? Se não chegarem, que o } \\
\text { comprador inexperiente se acautele. Mas o 'boom' } \\
\text { deve entrar em baixa fatal” }\end{array}$ & 32 \\
\hline & & $\begin{array}{l}40 \\
{[2]}\end{array}$ & jul 1981 & $\begin{array}{l}\text { "As aquarelas-memória de Miguelzinho: nestas } \\
\text { aquarelas, um pouco da história de S.Paulo, esque- } \\
\text { cidas como Miguelzinho, seu autor, num canto deste } \\
\text { país sem memória" }\end{array}$ & 33 \\
\hline & & $\begin{array}{l}41 \\
{[1]^{*}}\end{array}$ & 10 set 1981 & $\begin{array}{l}\text { "Museus, um cabidão de empregos? No lançamento } \\
\text { da correspondência de dois pioneiros da abertura } \\
\text { cultural, um alerta para o abandono de nossos } \\
\text { museus;" a publicação passa a ser quinzenal } \\
\text { e a apresentar o caderno com a chancela The } \\
\text { Economist; * a seção do Bardi ocupará apenas } \\
\text { uma página a partir desse volume }\end{array}$ & $34^{*}$ \\
\hline & & 42 & 24 set 1981 & $\begin{array}{l}\text { "Michelangelo, séc. xx: Sérgio Ferro recaia um } \\
\text { mestre, descobrindo novas interpretações, numa } \\
\text { proposta singular e polêmica" }\end{array}$ & 35 \\
\hline
\end{tabular}




\begin{tabular}{|c|c|c|c|c|c|}
\hline editora & diretores editora & $\begin{array}{l}\# \\
{[\Sigma p]}\end{array}$ & data & “artigo de Bardi;" observações & $\begin{array}{c}\# \\
\text { Bardi }\end{array}$ \\
\hline \multirow[t]{29}{*}{$\begin{array}{l}\text { Editora } \\
\text { Três }\end{array}$} & \multirow[t]{29}{*}{$\begin{array}{l}\text { Domingo Alzugaray, } \\
\text { Cátia Alzugaray, } \\
\text { Silvio Lancellotti }\end{array}$} & 43 & 18 out 1981 & $\begin{array}{l}\text { "Brasil, um grande exportador de pincéis: o filho de } \\
\text { um madeireiro se propôs um dia a fabricar pincéis. } \\
\text { Seu sonho é hoje uma realidade" }\end{array}$ & 36 \\
\hline & & 44 & 22 out 1981 & $\begin{array}{l}\text { "Os pára-quedistas da arte: eles existem aos montes, } \\
\text { expõem em qualquer lugar, promovendo uma } \\
\text { confusão dos diabos com seu amadorismo" }\end{array}$ & 37 \\
\hline & & 45 & 5 nov 1981 & $\begin{array}{l}\text { "Pelas trilhas de minas: os caminhos da Arte mineira } \\
\text { estão no Masp. Lá perfilam-se os figurativos, os } \\
\text { românticos, futuristas e até os tradicionalistas" }\end{array}$ & 38 \\
\hline & & 46 & 19 nov 1981 & $\begin{array}{l}\text { "Quando a arquitetura esquece sua função: é normal } \\
\text { surgirem projetos arquitetônicos revolucionários, } \\
\text { mas que se esquecem de sua função primeira: } \\
\text { servir de abrigo às pessoas." }\end{array}$ & 39 \\
\hline & & 47 & $3 \operatorname{dez} 1981$ & $\begin{array}{l}\text { "As memórias da cidade: "paulista não é homem } \\
\text { muito dado a diversões... um homem mais dado à } \\
\text { luta que um bom viveur, accomodado às facilidades } \\
\text { da terra e da boa fortuna."” }\end{array}$ & 40 \\
\hline & & 48 & 17 dez 1981 & $\begin{array}{l}\text { "0 manifesto de Piracicaba: os salões de Arte estão- } \\
\text {-se tornando frequentes no Brasil e refletindo o } \\
\text { mundo cheio de labirintos de nosso tempo, inventor } \\
\text { de poéticas imprevistas" }\end{array}$ & 41 \\
\hline & & 49 & 31 dez 1981 & $\begin{array}{l}\text { "Um nordeste menos autêntico: a qualidade da cerâ- } \\
\text { mica popular começou a cair com o consumismo. } \\
\text { Hoje, há exaustão de fontes anteriormente ativas } \\
\text { e originais" }\end{array}$ & 42 \\
\hline & & 50 & 15 jan 1982 & $\begin{array}{l}\text { "Uma pesquisa difícil: enquanto a pintura provoca } \\
\text { delírios, a escultura continua quase esquecida, } \\
\text { reservada apenas aos monumentos públicos e às } \\
\text { recordações funerárias" }\end{array}$ & 43 \\
\hline & & 51 & 28 jan 1982 & $\begin{array}{l}\text { "Audácias de um Pasquim do Império: A reedição de } \\
\text { um jornal pioneiro na sátira política e dos costumes, } \\
\text { que sacudiu a São Paulo provinciana de 1876" }\end{array}$ & 44 \\
\hline & & 52 & 11 fev 1982 & $\begin{array}{l}\text { "0 "poster" japonês contemporâneo: Vendo de perto } \\
\text { a arte japonesa, os críticos podem analisar sua } \\
\text { influência na formação da escola nipo-brasileira" }\end{array}$ & 45 \\
\hline & & 53 & 25 fev 1982 & $\begin{array}{l}\text { "Pintura para pintura: o prazer dos críticos é desco- } \\
\text { brir a possível vocação, a intimidade, a emoção, } 0 \\
\text { secreto intransmissível da arte de pintar" }\end{array}$ & 46 \\
\hline & & 54 & 11 mar 1982 & $\begin{array}{l}\text { "Os artistas são pitonisas? } 0 \text { pintor Francisco de } \\
\text { Mello une homens e máquinas, com um desenho } \\
\text { escrupuloso" }\end{array}$ & 47 \\
\hline & & 55 & 25 mar 1982 & $\begin{array}{l}\text { "Conselhos ao colecionador: num documento sobre } \\
\text { a arte russa de vanguarda, um "expert" publica as } \\
\text { suas regras para se formar um acervo;" a publi- } \\
\text { cação passa a ser semanal }\end{array}$ & $48^{*}$ \\
\hline & & 56 & 8 abr 1982 & $\begin{array}{l}\text { "Um apelo para manter a obra de Chateaubriand: } \\
\text { aos } 35 \text { anos, o Masp deve continuar recebendo o } \\
\text { apoio das classes produtoras, como acontece desde } \\
\text { a sua fundação" }\end{array}$ & 49 \\
\hline & & 57 & 21 abr 1982 & "Quanto vale o passado?" & 50 \\
\hline & & 58 & 28 abr 1982 & "Adhemar e o Masp: sem ingratidão" & 51 \\
\hline & & 59 & 5 maio 1982 & $\begin{array}{l}\text { "A escultura, sem histeria;" } \\
\text { último volume onde os textos de Bardi encontram- } \\
\text {-se sob a rubrica "Senhor e as Artes" }\end{array}$ & $52^{*}$ \\
\hline & & 60 & 12 maio 1982 & $\begin{array}{l}2 \text { "No campo movediço da Cultura;" a seção de Bardi } \\
\text { passa a se intitular "P.M.Bardi" }\end{array}$ & 53 \\
\hline & & 61 & 19 maio 1982 & "Os nervos abalados da Crítica" & 54 \\
\hline & & 62 & 26 maio 1982 & 2 "As confusões do 'Espaço"” & 55 \\
\hline & & 63 & 2 jun 1982 & "Só o futebol é que merece viajar?" & 56 \\
\hline & & 64 & 9 jun 1982 & "A pintura mural" & 57 \\
\hline & & 65 & 16 jun 1982 & "As leis do mercado de arte" & 58 \\
\hline & & 66 & 23 jun 1982 & "Vantagens do mecenato" & 59 \\
\hline & & 67 & 30 jun 1982 & "0 preço da vanguarda" & 60 \\
\hline & & 68 & 7 jul 1982 & "A Memória e o egoísmo" & 61 \\
\hline & & 69 & 14 jul 1982 & "A Bienal da imitação" & 62 \\
\hline & & 70 & 21 jul 1982 & "Mestres do retrato" & 63 \\
\hline & & 71 & 28 jul 1982 & "Pela janela do mundo" & 64 \\
\hline
\end{tabular}




\begin{tabular}{|c|c|c|c|c|c|}
\hline editora & diretores editora & $\begin{array}{c}\# \\
{\left[\sum p\right]}\end{array}$ & data & "artigo de Bardi;" observações & $\begin{array}{c}\# \\
\text { Bardi } \\
\end{array}$ \\
\hline \multirow[t]{52}{*}{$\begin{array}{l}\text { Editora } \\
\text { Três }\end{array}$} & \multirow[t]{52}{*}{$\begin{array}{l}\text { Domingo Alzugaray, } \\
\text { Cátia Alzugaray, } \\
\text { Silvio Lancellotti }\end{array}$} & 72 & 4 ago 1982 & $\begin{array}{l}\text { "Os leilões melancólicos: livrar-se dos preconceitos } \\
\text { é um bom início para quem quer modificar a rotina } \\
\text { artística em São Paulo" }\end{array}$ & 65 \\
\hline & & 73 & 11 ago 1982 & "Os antiacadêmicos do Rio" & 66 \\
\hline & & 74 & 18 ago 1982 & "Supermercado de arte" & 67 \\
\hline & & 75 & 25 ago 1982 & "Coisas da indústria antiga e moderna" & 68 \\
\hline & & 76 & 1 set 1982 & "A trégua chega aos museus" & 69 \\
\hline & & 77 & 8 set 1982 & "Nos jardins da memória" & 70 \\
\hline & & 78 & 15 set 1982 & "Coisas do patrimônio" & 71 \\
\hline & & 79 & 22 set 1982 & "Histórias de falsários" & 72 \\
\hline & & 80 & 29 set 1982 & "Mais uma viagem do Masp" & 73 \\
\hline & & 81 & 6 out 1982 & "Uma dupla muito agitada" & 74 \\
\hline & & 82 & 13 out 1982 & $\begin{array}{l}\text { "0 verdadeiro milagre da Virgem: uma festa em } \\
\text { Aparecida do Norte e algumas reflexões sobre a } \\
\text { permanência da Arte" }\end{array}$ & 75 \\
\hline & & 83 & 20 out 1982 & "A arte da falsificação" & 76 \\
\hline & & 84 & 27 out 1982 & "0 crime das cinco letras" & 77 \\
\hline & & 85 & 3 nov 1982 & $\begin{array}{l}\text { "Manchas e rabiscos: Wallinho Simonsen, a reve- } \\
\text { lação de uma maturidade" }\end{array}$ & 78 \\
\hline & & 86 & 10 nov 1982 & "A solidariedade urbana" & 79 \\
\hline & & 87 & 17 nov 1982 & "0 cansaço do figurativo" & 80 \\
\hline & & 88 & 24 nov 1982 & "Uma nova política cultural" & 81 \\
\hline & & 89 & 1 dez 1982 & "Uma arquitetura tropical" & 82 \\
\hline & & 90 & $8 \mathrm{dez} 1982$ & "Os salões do fim do século" & 83 \\
\hline & & 91 & 15 dez 1982 & "A arte maior de uma ourives" & 84 \\
\hline & & 92 & 22 dez 1982 & "Arte na hora do chá" & 85 \\
\hline & & 93 & 29 dez 1982 & "Conservar, para sobreviver" & 86 \\
\hline & & 94 & 5 jan 1983 & "A escultura avança" & 87 \\
\hline & & 95 & 12 jan 1983 & "Vênus na casa de massagem" & 88 \\
\hline & & 96 & 19 jan 1983 & "Os escultores-arquitetos" & 89 \\
\hline & & 97 & 26 jan 1983 & "0 talento em poliedro" & 90 \\
\hline & & 98 & 2 fev 1983 & "A vez de Brasília" & 91 \\
\hline & & 99 & 9 fev 1983 & "Estética do investimento" & 92 \\
\hline & & $\begin{array}{c}100+ \\
101\end{array}$ & 16 fev 1983 & “Falando de privilégios" & 93 \\
\hline & & 102 & $2 \operatorname{mar} 1983$ & $\begin{array}{l}\text { "Amor à tipografia;" } \\
\text { primeiro volume semanal }\end{array}$ & 94 \\
\hline & & 103 & $9 \operatorname{mar} 1983$ & "Arte para encher os olhos" & 95 \\
\hline & & 104 & $16 \operatorname{mar} 1983$ & "0 vírus do Kitsch" & 96 \\
\hline & & 105 & 23 mar 1983 & "0 valor da 'Arte menor"” & 97 \\
\hline & & 106 & 30 mar 1983 & "Uma Feira precipitada" & 98 \\
\hline & & 107 & 6 abr 1983 & "Surpresas nas edições de arte" & 99 \\
\hline & & 108 & 13 abr 1983 & "A arte do tropeço" & 100 \\
\hline & & 109 & 20 abr 1983 & "A revolução dos brinquedos" & 101 \\
\hline & & 110 & 27 abr 1983 & $\begin{array}{l}\text { "Os heroicos museus do Interior: esperanças para } \\
\text { uma atividade maldita" }\end{array}$ & 102 \\
\hline & & 111 & 4 maio 1983 & "Cinquenta retratos do Brasil" & 103 \\
\hline & & 112 & 11 maio 1983 & "Um pintor da aventura humana” & 104 \\
\hline & & 113 & 18 maio 1983 & 3 "Uma visão científica da arte" & 105 \\
\hline & & 114 & 25 maio 1983 & 3 "A outra farsa de Hitler" & 106 \\
\hline & & 115 & 1 jun 1983 & "Arquitetura: um passo atrás" & 107 \\
\hline & & 116 & 8 jun 1983 & $\begin{array}{l}\text { "A obra que surpreendeu a rainha: cinco séculos de } \\
\text { Rafael, um pintor sem mistérios" }\end{array}$ & 108 \\
\hline & & 117 & 15 jun 1983 & "Aventuras de Manet em São Paulo" & 109 \\
\hline & & 118 & 22 jun 1983 & "Um faro infalível: histórias do maior editor da Itália" & 110 \\
\hline & & 119 & 29 jun 1983 & $\begin{array}{l}\text { "0 direito histórico da Arte: no Brasil, um problema } \\
\text { idêntico ao dos mármores da Acrópole" }\end{array}$ & 111 \\
\hline & & 120 & 6 jul 1983 & $\begin{array}{l}\text { "Os caprichos da Arquitetura: uma arte que dificil- } \\
\text { mente chega ao consenso" }\end{array}$ & 112 \\
\hline & & 121 & 13 jul 1983 & $\begin{array}{l}\text { "0 boom do tempo livre: criatividade artística agora } \\
\text { é moda na sociedade de massas" }\end{array}$ & 113 \\
\hline & & 122 & 20 jul 1983 & $\begin{array}{l}\text { "Vestir com liberdade: da tragédia do colarinho à } \\
\text { democracia dos jeans" }\end{array}$ & 114 \\
\hline & & 123 & 27 jul 1983 & $\begin{array}{l}\text { "As manias do público: quais são os critérios artís- } \\
\text { ticos dos visitantes dos museus?" }\end{array}$ & 115 \\
\hline & & 124 & 3 ago 1983 & "Uma arte quase secreta" & 116 \\
\hline
\end{tabular}




\begin{tabular}{|c|c|c|c|c|c|}
\hline editora & diretores editora & $\begin{array}{c}\# \\
{[\Sigma p]}\end{array}$ & data & “artigo de Bardi;" observações & $\begin{array}{c}\# \\
\text { Bardi } \\
\end{array}$ \\
\hline \multirow[t]{34}{*}{$\begin{array}{l}\text { Editora } \\
\text { Três }\end{array}$} & \multirow[t]{34}{*}{$\begin{array}{l}\text { Domingo Alzugaray, } \\
\text { Cátia Alzugaray, } \\
\text { Silvio Lancellotti }\end{array}$} & 125 & 10 ago 1983 & $\begin{array}{l}\text { "Um paisagista em Curitiba: Paul Garfunkel reafirma, } \\
\text { em nosso século, uma tradição artística que vem } \\
\text { desde Maurício de Nassau e que se tomou, com o } \\
\text { tempo, num importante patrimônio da História do } \\
\text { Brasil" }\end{array}$ & 117 \\
\hline & & 126 & 17 ago 1983 & "0 terno combate de Segall" & 118 \\
\hline & & 127 & 24 ago 1983 & $\begin{array}{l}\text { "Vanguarda: o Brasil na trincheira: uma infiltração } \\
\text { de jovens artistas em Nova York" }\end{array}$ & 119 \\
\hline & & 128 & 31 ago 1983 & $\begin{array}{l}\text { "A histeria nacionalista: redutos conservadores } \\
\text { arrepiam-se com a 'morte' da identidade cultural" }\end{array}$ & 120 \\
\hline & & 129 & 7 set 1983 & $\begin{array}{l}\text { "0 vale-tudo dos estilos: indefinições da arquitetura } \\
\text { numa época fechada para as reformas estéticas" }\end{array}$ & 121 \\
\hline & & 130 & 14 set 1983 & $\begin{array}{l}\text { "Uma nova correspondência: nas cartas a Oneyda } \\
\text { Alvarenga, as ideias de Mário de Andrade sobre as } \\
\text { artes plásticas" }\end{array}$ & 122 \\
\hline & & 131 & 21 set 1983 & $\begin{array}{l}\text { "Um museu recém-nascido: a Propaganda não pode } \\
\text { ser vista como uma arte 'menor" }\end{array}$ & 123 \\
\hline & & 132 & 28 set 1983 & $\begin{array}{l}\text { "A democratização da arte: perguntas da Sociologia } \\
\text { para um mercado que se fortalece" }\end{array}$ & 124 \\
\hline & & 133 & 5 out 1983 & $\begin{array}{l}\text { "Itália de todos os mundos: no Masp, plano geral de } \\
\text { um país de descobridores" }\end{array}$ & 125 \\
\hline & & 134 & 12 out 1983 & $\begin{array}{l}\text { "Emoções de um colecionador: uma arte contra } \\
\text { muitos preconceitos, à procura das obras esque- } \\
\text { cidas dos brasileiros anônimos do passado" }\end{array}$ & 126 \\
\hline & & 135 & 19 out 1983 & $\begin{array}{l}\text { "Mudanças no ensino das artes: aprender com } \\
\text { liberdade, uma opção capaz de romper com o } \\
\text { pedantismo" }\end{array}$ & 127 \\
\hline & & 136 & 26 out 1983 & $\begin{array}{l}\text { “Um convite à indigestão: a Bienal de São Paulo não } \\
\text { imita mais Veneza. Imita a Alemanha” }\end{array}$ & 128 \\
\hline & & 137 & 2 nov 1983 & “Uma profissão sem diploma” & 129 \\
\hline & & 138 & 9 nov 1983 & "Cresce o mercado de arte" & 130 \\
\hline & & 139 & 16 nov 1983 & $\begin{array}{l}\text { "Nos labirintos da estética: a difícil missão de } \\
\text { escrever sobre arte numa época confusa" }\end{array}$ & 131 \\
\hline & & 140 & 23 nov 1983 & $\begin{array}{l}\text { "Reflexos da informática: uma revolução que está } \\
\text { isolando os 'obscurantistas"” }\end{array}$ & 132 \\
\hline & & 141 & 30 nov 1983 & $\begin{array}{l}\text { "Os jovens e a pintura: surpresa: nenhuma obra da } \\
\text { transvanguarda no Prêmio Pirelli" }\end{array}$ & 133 \\
\hline & & 142 & 7 dez 1983 & $\begin{array}{l}\text { "Chega de adular a cultura: a tecnologia brasileira é } \\
\text { que está precisando de um museu" }\end{array}$ & 134 \\
\hline & & 143 & $14 \mathrm{dez} 1983$ & $\begin{array}{l}\text { "A decadência do plágio: esforços a favor da criativi- } \\
\text { dade da propaganda no Brasil }\end{array}$ & 135 \\
\hline & & 144 & 21 dez 1983 & $\begin{array}{l}\text { "Memórias do 'rei dos ventos:' as aventuras dos } \\
\text { trens brasileiros e sua galeria de heróis" }\end{array}$ & 136 \\
\hline & & 145 & 28 dez 1983 & $\begin{array}{l}\text { "Os críticos dos trópicos: arte na imprensa, um setor } \\
\text { aberto à xingação e ao ataque pessoal" }\end{array}$ & 137 \\
\hline & & 146 & 4 jan 1984 & $\begin{array}{l}\text { "Uma árvore na horta: o mercado de arte no Brasil } \\
\text { precisa de uma publicação especializada de } \\
\text { interesse público" }\end{array}$ & 138 \\
\hline & & 147 & 11 jan 1984 & $\begin{array}{l}\text { "Rumo à maximetrópole: São Paulo tenta imaginar } \\
\text { como vai ser sua cultura, no fim do século" }\end{array}$ & 139 \\
\hline & & 148 & 18 jan 1984 & "Patrimônio e iniciativa" & 140 \\
\hline & & 149 & 25 jan 1984 & "São Paulo, arte e futuro" & 141 \\
\hline & & 150 & 1 fev 1984 & "A arte antes de Cabral" & 142 \\
\hline & & 151 & $8 \mathrm{fev} 1984$ & "Um arquiteto de vanguarda" & 143 \\
\hline & & 152 & $15 \mathrm{fev} 1984$ & $\begin{array}{l}\text { "Uma chance para dois estilos: quem se interessa } \\
\text { por enfeites decorativos antigos?" }\end{array}$ & 144 \\
\hline & & 153 & 22 fev 1984 & $\begin{array}{l}\text { "A safra da arte religiosa: maravilhas do catálogo do } \\
\text { Museu de Arte Sacra" }\end{array}$ & 145 \\
\hline & & 154 & 29 fev 1984 & $\begin{array}{l}\text { "Tambores internacionais: os milagres do Masp, uma } \\
\text { sociedade sem fins lucrativos cercada de incom- } \\
\text { preensão e atacada pelos que justificam gastos } \\
\text { públicos exagerados em promoções de pequena } \\
\text { repercussão cultural" }\end{array}$ & 146 \\
\hline & & $\begin{array}{c}155+ \\
156 \\
\end{array}$ & $\begin{array}{c}7+14 \mathrm{mar} \\
1984 \\
\end{array}$ & "Aventuras de Manet em São Paulo" & 147 \\
\hline & & 157 & 21 mar 1984 & "A arquitetura do índio" & 148 \\
\hline & & 158 & 28 mar 1984 & "Nossa memória pede socorro" & 149 \\
\hline & & 159 & 4 abr 1984 & $\begin{array}{l}\text { "Uma questão de prestígio: As viagens internacionais } \\
\text { do acervo do Masp" }\end{array}$ & 150 \\
\hline
\end{tabular}




\begin{tabular}{|c|c|c|c|c|c|}
\hline editora & diretores editora & $\begin{array}{c}\# \\
{[\Sigma p]}\end{array}$ & data & “artigo de Bardi;” observações & $\begin{array}{c}\# \\
\text { Bardi }\end{array}$ \\
\hline \multirow{33}{*}{$\begin{array}{l}\text { Editora } \\
\text { Três }\end{array}$} & \multirow{33}{*}{$\begin{array}{l}\text { Domingo Alzugaray, } \\
\text { Cátia Alzugaray, } \\
\text { Silvio Lancellotti }\end{array}$} & 160 & 11 abr 1984 & $\begin{array}{l}\text { "A arte é para poucos? 0s eternos grupinhos, do } \\
\text { informal ao abstracionismo" }\end{array}$ & 151 \\
\hline & & 161 & 18 abr 1984 & "Marketing: arte e agilidade" & 152 \\
\hline & & 162 & 25 abr 1984 & 4 "A medalha inesperada" & 153 \\
\hline & & 163 & 2 maio 1984 & 4 "A descoberta de novos mundos" & 154 \\
\hline & & 164 & 9 maio 1984 & 4 "Um artista sem rótulos" & 155 \\
\hline & & 165 & 16 maio 1984 & 4 "Um colecionador autêntico" & 156 \\
\hline & & 166 & 23 maio 1984 & 4 "Raros tesouros brasileiros" & 157 \\
\hline & & 167 & 30 maio 1984 & 4 "Molecagem com o Belo" & 158 \\
\hline & & 168 & 6 jun 1984 & $\begin{array}{l}\text { "Simbolismo, uma escola que sai do esquecimento: } \\
\text { Acusada por algum tempo de ser uma cópia } \\
\text { malfeita da Renascença, ela só recentemente foi } \\
\text { ressuscitada pela crítica e pelo interesse do público" }\end{array}$ & 159 \\
\hline & & 169 & 13 jun 1984 & $\begin{array}{l}\text { "E como sobremesa, uma bíblia do massacre: no } \\
\text { álbum de cartuns de Hugo Corrêa, o julgamento do } \\
\text { gosto humano pela criminalidade guerreira implica } \\
\text { uma condenação carregada de ironia" }\end{array}$ & 160 \\
\hline & & 170 & 20 jun 1984 & 4 "A poética da embalagem" & 161 \\
\hline & & 171 & 27 jun 1984 & 4 "A Holanda nordestina" & 162 \\
\hline & & 172 & 4 jul 1984 & $\begin{array}{l}\text { "Milagres da arte popular: o Masp faz uma expo- } \\
\text { sição de pintores primitivos, apesar da má vontade } \\
\text { de certos especialistas" }\end{array}$ & 163 \\
\hline & & 173 & 11 jul 1984 & "No coração do passado" & 164 \\
\hline & & 174 & 18 jul 1984 & "Tendências da panelinha" & 165 \\
\hline & & 175 & 25 jul 1984 & $\begin{array}{l}\text { "A arquitetura da terra: Inspirações do caboclo à } \\
\text { disposição da curiosidade urbana" }\end{array}$ & 166 \\
\hline & & 176 & 1 ago 1984 & $\begin{array}{l}\text { "A vez das enciclopédias: onde está o nosso Giovanni } \\
\text { Treccani?" }\end{array}$ & 167 \\
\hline & & 177 & 8 ago 1984 & $\begin{array}{l}\text { "Eu não entendo mais nada: o maior conhecedor de } \\
\text { arte do Brasil entrevista a si mesmo e declara-se } \\
\text { perplexo com a evolução do mundo das artes" }\end{array}$ & 168 \\
\hline & & & & "A conquista do supérfluo" & \\
\hline & & 178 & 15 ago 1984 & $\begin{array}{l}4 \text { "Como salvar os museus? Uma atividade que sofre } \\
\text { tanto quanto os acervos" }\end{array}$ & 169 \\
\hline & & 179 & 22 ago 1984 & 4 "Balanço de um valente" & 170 \\
\hline & & 180 & 29 ago 1984 & $\begin{array}{l}\text { "A civilização do futuro: A arte do ano } 2000 \text { deverá } \\
4 \text { contribuir para a difusão de princípios úteis a uma } \\
\text { sociedade contaminada pelo consumo" }\end{array}$ & 171 \\
\hline & & 181 & 5 set 1984 & "Ambiguidades da crítica" & 172 \\
\hline & & 182 & 12 set 1984 & $\begin{array}{l}\text { "A Semana quase futurista: antropofágias brasileira } \\
\text { do mito Marinetti, a partir do evento de } 1922 \text { e dos } \\
\text { calafrios que o ídolo provocou quatro anos depois, } \\
\text { numa visita que trocou o Pão de Açúcar pela favela" }\end{array}$ & 173 \\
\hline & & 183 & 19 set 1984 & $\begin{array}{l}\text { "O novo academismo: um debate sobre as energias e } \\
\text { o cansaço do Figurativo" }\end{array}$ & 174 \\
\hline & & 184 & 26 set 1984 & $\begin{array}{l}\text { "Cultura não é sobremesa: a importância do } \\
\text { intercâmbio artístico para o desenvolvimento das } \\
\text { relaçôes entre o Brasil e o Japão" }\end{array}$ & 175 \\
\hline & & 185 & 3 out 1984 & $\begin{array}{l}\text { "Ossos e nervos do Copa: a pesquisa fotográfica de } \\
\text { Olney Krüse nas salas e corredores de um edifício- } \\
\text {-símbolo do Rio antigo ajuda a desmascarar a } \\
\text { moda da poluição visual" }\end{array}$ & 176 \\
\hline & & 186 & 10 out 1984 & $\begin{array}{l}\text { "0 relâmpago dos pincéis: A convivência com uma } \\
\text { fábrica que fornece a matéria-prima da pintura na } \\
\text { era industrial provoca algumas reminiscências do } \\
\text { tempo dos mestres" }\end{array}$ & 177 \\
\hline & & 187 & 17 out 1984 & $\begin{array}{l}\text { "Astúcias da arte num tempo de política: uma } \\
\text { reunião acadêmica na Universidade Mackenzie, } \\
\text { com vaias, aplausos, uma medalha e considerações } \\
\text { múltiplas sobre a capacidade da cultura de abrir } \\
\text { todas as portas" }\end{array}$ & 178 \\
\hline & & 188 & 24 out 1984 & $\begin{array}{l}\text { "Lembrança de Le Corbusier: como surgiu uma } \\
\text { estética anti-sensual de um olhar fascinado?" }\end{array}$ & 179 \\
\hline & & 189 & 31 out 1984 & 4 "0 encanto das pequenas obras" & 180 \\
\hline & & 190 & 7 nov 1984 & $\begin{array}{l}\text { "0 pacifismo e os encantos da mocidade: uma } \\
\text { homenagem em meio à Autobiografia, de Bertrand } \\
\text { Russell: para meditar sobre a crise e renovar o } \\
\text { otimismo" }\end{array}$ & 181 \\
\hline & & 191 & 14 nov 1984 & $\begin{array}{l}4 \text { "Um estímulo à criação: a arte do design nos } \\
\text { pequenos objetos" }\end{array}$ & 182 \\
\hline
\end{tabular}




\begin{tabular}{|c|c|c|c|c|c|}
\hline editora & diretores editora & $\begin{array}{c}\# \\
{[\Sigma p]}\end{array}$ & data & "artigo de Bardi;" observações & $\begin{array}{c}\# \\
\text { Bardi } \\
\end{array}$ \\
\hline \multirow[t]{29}{*}{$\begin{array}{l}\text { Editora } \\
\text { Três }\end{array}$} & \multirow[t]{29}{*}{$\begin{array}{l}\text { Domingo Alzugaray, } \\
\text { Cátia Alzugaray, } \\
\text { Silvio Lancellotti }\end{array}$} & 192 & 21 nov 1984 & $\begin{array}{l}\text { "A arte da mesquinharia: o cronista reage a } \\
\text { 'mentiras' e 'maledicências' e esclarece uma história } \\
\text { que envolve Tarsila, o Masp e o Abaporu" }\end{array}$ & 183 \\
\hline & & 193 & 28 nov 1984 & $\begin{array}{l}\text { "A fábrica de valores: cada época tem o Sócrates } \\
\text { que merece" }\end{array}$ & 184 \\
\hline & & 194 & 5 dez 1984 & $\begin{array}{l}\text { "Um pulo internacional: ecos da Escola de Pans, na } \\
\text { exposição do Masp" }\end{array}$ & 185 \\
\hline & & 195 & $12 \operatorname{dez} 1984$ & $\begin{array}{l}\text { "Notas meridionais: sobre um artista em dois } \\
\text { mundos" }\end{array}$ & 186 \\
\hline & & 196 & $19 \operatorname{dez} 1984$ & $\begin{array}{l}\text { "As luzes de Paris: um debate com o presidente do } \\
\text { Centro Georges Pompidou" }\end{array}$ & 187 \\
\hline & & $\begin{array}{c}197+ \\
198 \\
\end{array}$ & $26 \operatorname{dez} 1984$ & $\begin{array}{l}\text { "As aulas de Le Corbusier: uma evocação dos } \\
\text { mestres da arquitetura" }\end{array}$ & 188 \\
\hline & & 199 & 9 jan 1985 & $\begin{array}{l}\text { "Uma síntese da gravura: o gesto criador de uma } \\
\text { arte múltipla” }\end{array}$ & 189 \\
\hline & & 200 & 16 jan 1985 & $\begin{array}{l}\text { "O labirinto da comunicação: um balanço de Pero } \\
\text { Vaz de Caminha à informática" }\end{array}$ & 190 \\
\hline & & 201 & 23 jan 1985 & $\begin{array}{l}\text { "O papel histórico da nossa vanguarda: um balanço } \\
\text { do trabalho dos pioneiros que colocaram a arte } \\
\text { brasileira no rumo da modernidade" }\end{array}$ & 191 \\
\hline & & 202 & 30 jan 1985 & $\begin{array}{l}\text { "A arte nas máquinas: a construção de Cumbica: } \\
\text { arte e engenharia andando juntas" }\end{array}$ & 192 \\
\hline & & 203 & 6 fev 1985 & $\begin{array}{l}\text { "Uma nova pedra: uma resposta a cartas apócrifas } \\
\text { cheias de acusaçỗes. E uma advertência" }\end{array}$ & 193 \\
\hline & & 204 & 13 fev 1985 & $\begin{array}{l}\text { "0 arrepio contemporâneo: o que é o novo e o que é } \\
\text { o bom? A arte percorre estranhos caminhos antes } \\
\text { de impregnar a sociedade" }\end{array}$ & 194 \\
\hline & & 205 & 20 fev 1985 & $\begin{array}{l}\text { "A pintura como denúncia: a importância da obra de } \\
\text { Cândido Portinari" }\end{array}$ & 195 \\
\hline & & 206 & 27 fev 1985 & $\begin{array}{l}\text { "Uma chuva de homenagens: agradecimentos de um } \\
\text { paulista assumido no mês do seu aniversário" }\end{array}$ & 196 \\
\hline & & 207 & $6 \operatorname{mar} 1985$ & $\begin{array}{l}\text { "Uma aventura indispensável: a história de um } \\
\text { empréstimo em Nova York" }\end{array}$ & 197 \\
\hline & & 208 & 13 mar 1985 & $\begin{array}{l}\text { "Os especialistas inúteis: a difíicil caçada das obras- } \\
\text {-primas internacionais" }\end{array}$ & 198 \\
\hline & & 209 & 20 mar 1985 & $\begin{array}{l}\text { "0 sono das artes plásticas: Um setor que pouco se } \\
\text { envolveu com a denúncia social no Brasil" }\end{array}$ & 199 \\
\hline & & 210 & 27 mar 1985 & $\begin{array}{l}\text { "A arquitetura em Cumbica: algumas soluções } \\
\text { criativas expostas no Masp" }\end{array}$ & 200 \\
\hline & & 211 & 3 abr 1985 & $\begin{array}{l}\text { "São Jerônimo liberado: a restauração de uma obra } \\
\text { com cinco séculos de idade" }\end{array}$ & 201 \\
\hline & & 212 & 10 abr 1985 & $\begin{array}{l}\text { "Um balanço da vanguarda: o Chase Manhattan } \\
\text { Bank e a renovação das artes plásticas" }\end{array}$ & 202 \\
\hline & & 213 & 17 abr 1985 & $\begin{array}{l}\text { "A obra dos penetras: uma visão otimista sobre a } \\
\text { inflação de talentos nas artes" }\end{array}$ & 203 \\
\hline & & 214 & 24 abr 1985 & $\begin{array}{l}\text { "A central de boatos: problemas com um código } \\
\text { herdado da Colônia" }\end{array}$ & 204 \\
\hline & & 215 & 1 maio 1985 & $\begin{array}{l}\text { "A cultura de Alagoas: alguns perfis do Brasil } \\
\text { imperial e republicano iluminam a leitura de um } \\
\text { aprendiz de História" }\end{array}$ & 205 \\
\hline & & 216 & 8 maio 1985 & $\begin{array}{l}\text { "O pânico do futuro: enquanto os artistas se } \\
\text { afundam na abstração, os cientistas preparam o } \\
\text { Apocalipse" }\end{array}$ & 206 \\
\hline & & 217 & 15 maio 1985 & $\begin{array}{l}\text { "Artes de um escrivão público: agradar a artistas } \\
\text { e críticos tem sido um dos muitos fardos de um } \\
\text { diretor de museu. Mas o importante é saber } 0 \\
\text { momento adequado para investir numa obra pouco } \\
\text { conhecida" }\end{array}$ & 207 \\
\hline & & 218 & 22 maio 1985 & $\begin{array}{l}\text { "Intervenção na arquitetura: um exemplo de recupe- } \\
\text { ração artística e histórica em Gênova” }\end{array}$ & 208 \\
\hline & & 219 & 29 maio 1985 & $\begin{array}{l}\text { "A importância do cálculo: uma visão 'excêntrica:' a } \\
\text { arte da matemática na arquitetura” }\end{array}$ & 209 \\
\hline & & 220 & 5 jun 1985 & $\begin{array}{l}\text { "A prontidão dos penetras: como enfrentar a astúcia } \\
\text { aos vendedores de obras falsas" }\end{array}$ & 210 \\
\hline & & 221 & 12 jun 1985 & $\begin{array}{l}\text { "Design: o vôo dos pioneiros: uma conferência no } \\
\text { Instituto Tecnológico da Aeronáutica desencadeia } \\
\text { reflexões sobre a arte de projetar aviões. Ideias que } \\
\text { vão render uma exposição no Masp" }\end{array}$ & 211 \\
\hline
\end{tabular}




\begin{tabular}{|c|c|c|c|c|c|}
\hline editora & diretores editora & $\begin{array}{l}\# \\
{\left[\sum p\right]}\end{array}$ & data & “artigo de Bardi;" observações & $\begin{array}{c}\# \\
\text { Bardi } \\
\end{array}$ \\
\hline \multirow{28}{*}{$\begin{array}{l}\text { Editora } \\
\text { Três }\end{array}$} & \multirow{28}{*}{$\begin{array}{l}\text { Domingo Alzugaray, } \\
\text { Cátia Alzugaray, } \\
\text { Silvio Lancellotti }\end{array}$} & 222 & 19 jun 1985 & $\begin{array}{l}\text { "Um passeio pelo Brasil: fotos tiradas antes de } 1900 \\
\text { revelam um país desconhecido" }\end{array}$ & 212 \\
\hline & & 223 & 26 jun 1985 & $\begin{array}{l}\text { "0 manso leão das artes: o Imposto de Renda e a } \\
\text { participação cívica dos empresários na cultura } \\
\text { nacional" }\end{array}$ & 213 \\
\hline & & 224 & 3 jul 1985 & $\begin{array}{l}\text { "Algumas pistas para cercar o trabalho de Renoir: as } \\
\text { cinco obras do mestre, expostas no Masp, são indis- } \\
\text { pensáveis para qualquer retrospectiva internacional. } \\
\text { A opinião é de experts de Paris e Londres" }\end{array}$ & 214 \\
\hline & & 225 & 10 jul 1985 & $\begin{array}{l}\text { "Um assalto estético: as chances do design brasileiro } \\
\text { no mercado internacional" }\end{array}$ & 215 \\
\hline & & 226 & 17 jul 1985 & $\begin{array}{l}\text { "0 dinheiro da arte: o mecenato e a formação do } \\
\text { patrimônio do Masp" }\end{array}$ & 216 \\
\hline & & 227 & 24 jul 1985 & $\begin{array}{l}\text { "0 ofício da crítica: o exemplo das mostras didáticas } \\
\text { no Exterior" }\end{array}$ & 217 \\
\hline & & 228 & 31 jul 1985 & $\begin{array}{l}\text { "A aventura da tecnologia: memórias de uma } \\
\text { atividade que não pode prescindir do estímulo do } \\
\text { governo e das empresas privadas. E que desperta } \\
\text { muita curiosidade no público" }\end{array}$ & 218 \\
\hline & & 229 & 7 ago 1985 & $\begin{array}{l}\text { "Uma saída criativa: } 0 \text { trabalho cultural aos } \\
\text { publicitários" }\end{array}$ & 219 \\
\hline & & 230 & 14 ago 1985 & $\begin{array}{l}\text { "A possível viagem: novos rumos para o mercado de } \\
\text { arte no Brasil" }\end{array}$ & 220 \\
\hline & & 231 & 21 ago 1985 & $\begin{array}{l}\text { "A pátria dos estrangeiros: um país sem revan- } \\
\text { chismos antropológicos não pode recriar velhos } \\
\text { preconceitos contra os imigrantes" }\end{array}$ & 221 \\
\hline & & 232 & 28 out 1985 & $\begin{array}{l}\text { "Um terremoto artístico: memórias da Trienal } \\
\text { Internacional de Milão" }\end{array}$ & 222 \\
\hline & & 233 & 4 set 1985 & $\begin{array}{l}\text { "Pimenta no vatapá: um novo espaço para o debate } \\
\text { cultural" }\end{array}$ & 223 \\
\hline & & 234 & 11 set 1985 & $\begin{array}{l}\text { "O sonho da cidade ideal: os tumultos do progresso } \\
\text { criaram a necessidade de reformas totais no espaço } \\
\text { urbano. Mas como adequar desejos e aspirações a } \\
\text { uma realidade cada vez mais negativa?" }\end{array}$ & 224 \\
\hline & & 235 & 18 set 1985 & $\begin{array}{l}\text { "As trapaças da arte: perdas e danos de um negócio } \\
\text { cheio de armadilhas" }\end{array}$ & 225 \\
\hline & & 236 & 25 set 1985 & $\begin{array}{l}\text { "Um convite à aventura: relato de uma viagem ao } \\
\text { purgatório tropical” }\end{array}$ & 226 \\
\hline & & 237 & 2 out 1985 & $\begin{array}{l}\text { "Uma arquitetura exemplar: bons exemplos de } \\
\text { design num supermercado de São Paulo" }\end{array}$ & 227 \\
\hline & & 238 & 9 out 1985 & $\begin{array}{l}\text { "Roteiro de uma ousadia: onde está a história da } \\
\text { arte brasileira deste século?" }\end{array}$ & 228 \\
\hline & & 239 & 16 out 1985 & $\begin{array}{l}\text { "A antiguidade da vanguarda: excessos e conveniên- } \\
\text { cias da Bienal paulistana" }\end{array}$ & 229 \\
\hline & & 240 & 25 out 1985 & $\begin{array}{l}\text { "0 nó da tradição: a contribuição do artesanato à } \\
\text { cultura brasileira" }\end{array}$ & 230 \\
\hline & & 241 & 30 out 1985 & $\begin{array}{l}\text { "0 aprendizado do ursinho: as memórias de um } \\
\text { jornalista íntimo dos homens que mandaram no } \\
\text { Brasil nas últimas décadas" }\end{array}$ & 231 \\
\hline & & 242 & 6 nov 1985 & $\begin{array}{l}\text { "A saúde do patrimônio: } 0 \text { acervo cultural corre } \\
\text { perigo em todos os países, mas já existe um esforço } \\
\text { inicial para mudar a situação" }\end{array}$ & 232 \\
\hline & & 243 & 13 nov 1985 & $\begin{array}{l}\text { "Ezra Pound: evocações: no centenário do poeta, } \\
\text { retalhos de uma velha amizade" }\end{array}$ & 233 \\
\hline & & 244 & 20 nov 1985 & $\begin{array}{l}\text { "Nota } 10 \text { ou nota zero? } 0 \text { labirinto dos julgamentos } \\
\text { sobre arte" }\end{array}$ & 234 \\
\hline & & 245 & 27 nov 1985 & $\begin{array}{l}\text { "A estética internacional: a geleia geral da arte, vista } \\
\text { pelos seus mais importantes incentivadores" }\end{array}$ & 235 \\
\hline & & 246 & $4 \mathrm{dez} 1985$ & $\begin{array}{l}\text { "0 boom dos catálogos: as empresas fazem o levan- } \\
\text { tamento peça por peça, dos acervos dos museus } \\
\text { brasileiros" }\end{array}$ & 236 \\
\hline & & 247 & $11 \mathrm{dez} 1985$ & $\begin{array}{l}\text { "A multiplicação da novidade: a improvisação e a } \\
\text { astúcia nos negócios artísticos" }\end{array}$ & 237 \\
\hline & & 248 & $18 \mathrm{dez} 1985$ & $\begin{array}{l}\text { "Uma realidade indigesta: o pioneirismo do Masp no } \\
\text { esforço de mostrar a arte brasileira no que ela tem } \\
\text { de mais contundente e representativo" }\end{array}$ & 238 \\
\hline & & 249 & 25 dez 1985 & $\begin{array}{l}\text { "Reunião do mestre distante: minibiografia afetiva } \\
\text { de Lasar Segall e sua obra" }\end{array}$ & 239 \\
\hline
\end{tabular}




\begin{tabular}{|c|c|c|c|c|c|}
\hline editora & diretores editora & $\begin{array}{l}\# \\
{\left[\sum p\right]}\end{array}$ & data & "artigo de Bardi;" observações & $\begin{array}{c}\# \\
\text { Bardi } \\
\end{array}$ \\
\hline \multirow{27}{*}{$\begin{array}{l}\text { Editora } \\
\text { Três }\end{array}$} & \multirow{27}{*}{$\begin{array}{l}\text { Domingo Alzugaray, } \\
\text { Cátia Alzugaray, } \\
\text { Silvio Lancellotti }\end{array}$} & $\begin{array}{c}250+ \\
251 \\
\end{array}$ & $\begin{array}{l}31 \text { dez } 1985+ \\
7 \text { jan } 1986\end{array}$ & $\begin{array}{l}\text { "0 nervosismo das vanguardas: um trabalho difícil } \\
\text { para historiadores e críticos" }\end{array}$ & 240 \\
\hline & & 252 & 14 jan 1986 & $\begin{array}{l}\text { "A redação vai ao museu: as artes do Jornal da Tarde } \\
\text { expostas no Masp" }\end{array}$ & 241 \\
\hline & & 253 & 21 jan 1986 & $\begin{array}{l}\text { "As vestes de um pioneiro: uma noite inesquecível na } \\
\text { Universidade Mackenzie" }\end{array}$ & 242 \\
\hline & & 254 & 28 jan 1986 & $\begin{array}{l}\text { "A fantasia do cotidiano: a renovação histórica das } \\
\text { atividades culturais" }\end{array}$ & 243 \\
\hline & & 255 & 4 fev 1986 & $\begin{array}{l}\text { "Um homem cordial: a arte do encontro, segundo } 0 \\
\text { embaixador Jayme de Barros" }\end{array}$ & 244 \\
\hline & & 256 & 11 fev 1986 & $\begin{array}{l}\text { "Um mundo em mudança: do abstrato ao concreto: } \\
\text { desafios da arte contemporânea" }\end{array}$ & 245 \\
\hline & & 257 & 18 fev 1986 & $\begin{array}{l}\text { "Socorro ecológico: um banco, um poeta e um alerta } \\
\text { sobre o Pantanal" }\end{array}$ & 246 \\
\hline & & 258 & 25 fev 1986 & $\begin{array}{l}\text { "Uma tela esfaqueada: as relações entre as } \\
\text { vanguardas e a pintura regional" }\end{array}$ & 247 \\
\hline & & 259 & 4 mar 1986 & $\begin{array}{l}\text { "A volta ao clássico: arquiteto vai mudar o que } 0 \\
\text { Beaubourg tem de mais moderno" }\end{array}$ & 248 \\
\hline & & 260 & 11 mar 1986 & $\begin{array}{l}\text { "As brigas com a estética: a necessidade de } \\
\text { pesquisar os movimentos artísticos deste século e } \\
\text { decifrar seus inúmeros labirintos" }\end{array}$ & 249 \\
\hline & & 261 & 18 mar 1986 & $\begin{array}{l}\text { "Estilos misturados: a arte encontra a técnica, e } \\
\text { vice-versa, na ciranda de revoluções estéticas } \\
\text { ocorridas neste século" }\end{array}$ & 250 \\
\hline & & 262 & 25 mar 1986 & $\begin{array}{l}\text { "0 tecido da memória: datas, nomes, encontros e } \\
\text { surpresas: o difícil e gratificante balanço de experi- } \\
\text { ências entrelaçadas pelo tempo" }\end{array}$ & 251 \\
\hline & & 263 & 1 abr 1986 & $\begin{array}{l}\text { "0 destino das cidades: a importância da memória } \\
\text { nos planos de renovação urbana" }\end{array}$ & 252 \\
\hline & & 264 & 8 abr 1986 & $\begin{array}{l}\text { "Uma decisão política: reflexões sobre a candidatura } \\
\text { Ermírio de Moraes" }\end{array}$ & 253 \\
\hline & & 265 & 15 abr 1986 & $\begin{array}{l}\text { "Uma antiga amizade: a participação da Itália na } \\
\text { construção do Brasil" }\end{array}$ & 254 \\
\hline & & 266 & 22 abr 1986 & $\begin{array}{l}\text { "Sem a ajuda dos críticos: as mil atividades do povo, } \\
\text { decantadas pelos artistas de aldeia que agem } \\
\text { simplesmente, dispensando os currículos" }\end{array}$ & 255 \\
\hline & & 267 & 19 abr 1986 & $\begin{array}{l}\text { "0 fiasco da aposentadoria: a informação não ó raio } \\
\text { laser, mas apenas simples saber" }\end{array}$ & 256 \\
\hline & & 268 & 6 maio 1986 & $\begin{array}{l}\text { "Como ocupar o espaço: preencher paredes, sem } \\
\text { critério, pode transformar-se num problema esté- } \\
\text { tico de difícil solução" }\end{array}$ & 257 \\
\hline & & 269 & 13 maio 1986 & $\begin{array}{l}\text { "0 caçador de temas: o rastro de Picasso nos } 360 \\
\text { desenhos apresentados no Brasil" }\end{array}$ & 258 \\
\hline & & 270 & 20 maio 1986 & $\begin{array}{l}\text { "Brasil-Itália, um espaço cultural cada vez maior: } \\
\text { um entendimento já disseminado no cotidiano } \\
\text { e que agora alcança dimensões inéditas com a } \\
\text { programação de múltiplos eventos" }\end{array}$ & 259 \\
\hline & & 271 & 27 maio 1986 & $\begin{array}{l}\text { "A estética do favor: uma viagem à irrealidade dos } \\
\text { textos de apresentação das obras artísticas" }\end{array}$ & 260 \\
\hline & & 272 & 3 jun 1986 & $\begin{array}{l}\text { "Uma nova ruptura: copiar velhas vanguardas é } \\
\text { academismo barato. Mas optar pelo figurativo pode } \\
\text { ser um gesto polêmico" }\end{array}$ & 261 \\
\hline & & 273 & 10 jun 1986 & $\begin{array}{l}\text { "Um resgate polêmico: restaurar obras de arte inco- } \\
\text { moda sempre os conservadores. Mas o processo é } \\
\text { irreversível" }\end{array}$ & 262 \\
\hline & & 274 & 17 jun 1986 & $\begin{array}{l}\text { "Uma injeção publicitária: a campanha da DPZ para } \\
\text { o Masp: a confluência de atividades comuns no } \\
\text { território da arte" }\end{array}$ & 263 \\
\hline & & 275 & 24 jun 1986 & $\begin{array}{l}\text { "Um gesto iluminado: evocações da participação } \\
\text { fundamental de um empresário nos eventos } \\
\text { culturais" }\end{array}$ & 264 \\
\hline & & 276 & 1 jul 1986 & $\begin{array}{l}\text { "Os paroquianos da cultura: } 0 \text { vôo rasteiro dos } \\
\text { candidatos que não conhecem as verdadeiras } \\
\text { necessidades de uma área desamparada" }\end{array}$ & 265 \\
\hline & & 277 & 8 jul 1986 & $\begin{array}{l}\text { "Uma semente no Recife: o papel dos museus nas } \\
\text { invenções culturais" }\end{array}$ & 266 \\
\hline
\end{tabular}




\begin{tabular}{|c|c|c|c|c|c|}
\hline editora & diretores editora & $\begin{array}{l}\# \\
{\left[\sum p\right]}\end{array}$ & data & “artigo de Bardi;” observações & $\begin{array}{c}\# \\
\text { Bardi } \\
\end{array}$ \\
\hline \multirow{26}{*}{$\begin{array}{l}\text { Editora } \\
\text { Três }\end{array}$} & \multirow{26}{*}{$\begin{array}{l}\text { Domingo Alzugaray, } \\
\text { Cátia Alzugaray, } \\
\text { Silvio Lancellotti }\end{array}$} & 278 & 15 jul 1986 & $\begin{array}{l}\text { "Respeito à memória: o difícil trabalho de conser- } \\
\text { vação dos centros históricos, um desafio para todas } \\
\text { as cidades do mundo" }\end{array}$ & 267 \\
\hline & & 279 & 22 jul 1986 & $\begin{array}{l}\text { "Um hobby histórico: os colecionadores de antigui- } \\
\text { dade e sua colheita minuciosa da peças esquecidas" }\end{array}$ & 268 \\
\hline & & 280 & 29 jul 1986 & $\begin{array}{l}\text { "A corrida para o diploma: observações de um } \\
\text { penetra no mundo mágico do jornalismo, onde um } \\
\text { canudo pode valer mais do que a sensibilidade" }\end{array}$ & 269 \\
\hline & & 281 & 5 ago 1986 & $\begin{array}{l}\text { "Arte, coração da indústria: a alquimia das cores no } \\
\text { território da tecnologia" }\end{array}$ & 270 \\
\hline & & 282 & 12 ago 1986 & $\begin{array}{l}\text { "A estética das vitrinas: a popularidade de uma arte } \\
\text { delicada" }\end{array}$ & 271 \\
\hline & & 283 & 19 ago 1986 & $\begin{array}{l}\text { "Um escândalo americano: um exemplo artístico } \\
\text { do começo do século que deveria ser imitado nos } \\
\text { nossos tempos de provocações vazias" }\end{array}$ & 272 \\
\hline & & 284 & 26 ago 1986 & $\begin{array}{l}\text { "0 jogo dos estilos: as oscilações da arquitetura no } \\
\text { território brasileiro" }\end{array}$ & 273 \\
\hline & & 285 & 2 set 1986 & $\begin{array}{l}\text { "0 clima da arquitetura: como abrir as janelas da } \\
\text { arte para o sol" }\end{array}$ & 274 \\
\hline & & 286 & 9 set 1986 & $\begin{array}{l}\text { "O barril dos peixes: } 0 \text { árduo trabalho de costurar } \\
\text { conceitos adversos na obra comum da arte: afinal, } \\
\text { quem são os primitivos?" }\end{array}$ & 275 \\
\hline & & 287 & 16 set 1986 & $\begin{array}{l}\text { "Um sarau na Alemanha: obras de artistas brasileiros } \\
\text { viajam graças ao apoio de uma empresa que já } \\
\text { aplica a Lei Sarney" }\end{array}$ & 276 \\
\hline & & 288 & 23 set 1986 & $\begin{array}{l}\text { "Contrastes da forma: uma exposição que é um } \\
\text { banquete modernista" }\end{array}$ & 277 \\
\hline & & 289 & 30 set 1986 & $\begin{array}{l}\text { "Pós-moderno para quê? Um tema entre a excessiva } \\
\text { superficialidade e a promessa de humanizar as } \\
\text { manifestações artísticas" }\end{array}$ & 278 \\
\hline & & 290 & 7 out 1986 & $\begin{array}{l}\text { "A renovação da arte: a didática histórica sobre } \\
\text { manifestaç̃̃es artísticas que podem mudar velhos } \\
\text { conceitos" }\end{array}$ & 279 \\
\hline & & 291 & 14 out 1986 & $\begin{array}{l}\text { "Conselho aos investidores: o delicado terreno do } \\
\text { mercado de arte, onde deve prevalecer a sensatez e } \\
\text { a sensibilidade" }\end{array}$ & 280 \\
\hline & & 292 & 21 out 1986 & $\begin{array}{l}\text { "0 arrepio do inédito: estamos próximos a uma } \\
\text { revolução, que poderá jogar o modernismo para o } \\
\text { espaço. } 0 \text { que será?" }\end{array}$ & 281 \\
\hline & & 293 & 28 out 1986 & $\begin{array}{l}\text { "A vocação da memória: quarenta anos do Masp: } \\
\text { o resumo de um trabalho que entrou em contato } \\
\text { direto com os museus do Exterior" }\end{array}$ & 282 \\
\hline & & 294 & 4 nov 1986 & $\begin{array}{l}\text { "A cultura das raízes: por que não um Globo Cultural, } \\
\text { para divulgar e incentivar uma produção ainda } \\
\text { marginalizada pela mídia brasileira?" }\end{array}$ & 283 \\
\hline & & 295 & 11 nov 1986 & $\begin{array}{l}\text { "0 resgate romântico: o novo edifício de esportes } \\
\text { do Sesc Pompeia enriquece o esforço brasileiro em } \\
\text { favor da memória" }\end{array}$ & 284 \\
\hline & & 296 & 18 nov 1986 & $\begin{array}{l}\text { "0 poder econômico da arte: o mercado brasileiro } \\
\text { deve abrir os olhos para o potencial que existe nos } \\
\text { objetos artísticos. Para isso, é preciso optar pelo } \\
\text { comércio de alto nível" }\end{array}$ & 285 \\
\hline & & 297 & 25 nov 1986 & $\begin{array}{l}\text { "Uma arte amazônica: um livro sobre o Museu } \\
\text { Goeldi, de Belém, para os brasileiros conhecerem } \\
\text { melhor seus mistérios" }\end{array}$ & 286 \\
\hline & & 298 & $2 \operatorname{dez} 1986$ & $\begin{array}{l}\text { "0 ouro da natureza: o difícil garimpo da Arte, entre } \\
\text { a emoção e a História" }\end{array}$ & 287 \\
\hline & & 299 & $9 \operatorname{dez} 1986$ & $\begin{array}{l}\text { "A verdade é uma escultura: memórias de dois } \\
\text { artistas pouco reconhecidos" }\end{array}$ & 288 \\
\hline & & 300 & $16 \operatorname{dez} 1986$ & $\begin{array}{l}\text { "Os segredos da estética: um acervo que funciona } \\
\text { como impulso e revelação" }\end{array}$ & 289 \\
\hline & & 301 & $23 \mathrm{dez} 1986$ & $\begin{array}{l}\text { "Os mitos da arquitetura: qual a diferença entre } \\
\text { admirar o Partenon e dormir embaixo da ponte?" }\end{array}$ & 290 \\
\hline & & $\begin{array}{c}302+ \\
303\end{array}$ & $\begin{array}{c}30 \operatorname{dez} 1986+ \\
6 \text { jan } 1987\end{array}$ & $\begin{array}{l}\text { "Um criador de imagens: a exposição de Wesley } \\
\text { Duke Lee é um milagre no meio da infinidade de } \\
\text { ofertas do mercado artístico" }\end{array}$ & 291 \\
\hline & & 304 & 13 jan 1987 & $\begin{array}{l}\text { "Cultura além da paróquia: depois da Lei Sarney, } \\
\text { esta é a hora de os nossos editores levarem ao } \\
\text { Exterior a cultura brasileira" }\end{array}$ & 292 \\
\hline
\end{tabular}




\begin{tabular}{|c|c|c|c|c|c|}
\hline editora & diretores editora & $\begin{array}{l}\# \\
{[\Sigma p]}\end{array}$ & data & “artigo de Bardi;” observações & $\begin{array}{c}\# \\
\text { Bardi } \\
\end{array}$ \\
\hline \multirow{25}{*}{$\begin{array}{l}\text { Editora } \\
\text { Três }\end{array}$} & \multirow{25}{*}{$\begin{array}{l}\text { Domingo Alzugaray, } \\
\text { Cátia Alzugaray, } \\
\text { Silvio Lancellotti }\end{array}$} & 305 & 20 jan 1987 & $\begin{array}{l}\text { "Labor para historiadores: se é trabalhoso decifrar } \\
\text { Vênus e Cupido, o que estará reservado aos pesqui- } \\
\text { sadores de um Kandinsky" }\end{array}$ & 293 \\
\hline & & 306 & 27 jan 1987 & $\begin{array}{l}\text { "0 caso Rembrandt: testemunho pessoal sobre uma } \\
\text { leviandade" }\end{array}$ & 294 \\
\hline & & 307 & 3 fev 1987 & $\begin{array}{l}\text { "Uma convidada especial: ela se chama propaganda. } \\
\text { Começou a ser ensinada no Masp e estará na festa } \\
\text { de seu quadragésimo aniversário" }\end{array}$ & 295 \\
\hline & & 308 & 10 fev 1987 & $\begin{array}{l}\text { "0 direito a memória: discute se nacionalmente, na } \\
\text { Itália, a conservação de museus. Um tema, aliás, } \\
\text { que também afeta o Brasil" }\end{array}$ & 296 \\
\hline & & 309 & 17 fev 1987 & $\begin{array}{l}\text { "Flashes do futuro: entre o excesso de novidades, } \\
\text { algumas obras são exemplos do avanço das artes } \\
\text { em múltiplas direções" }\end{array}$ & 297 \\
\hline & & 310 & 24 fev 1987 & $\begin{array}{l}\text { "Evocações de um monumento: um conjunto } \\
\text { bancário recentemente inaugurado sintetiza a } \\
\text { comunhão da arquitetura com técnicas urbanas } \\
\text { sofisticadas" }\end{array}$ & 298 \\
\hline & & 311 & 3 mar 1987 & $\begin{array}{l}\text { "Um modesto craque: a medalha de ouro da Itália, } \\
\text { por benemerêncta cultural: uma vitória da obsti- } \\
\text { nação e do trabalho" }\end{array}$ & 299 \\
\hline & & 312 & 10 mar 1987 & $\begin{array}{l}\text { "A vez do figurativo: com a mostra do pintor Franco } \\
\text { Cilia, o Masp abriu mais um espaço na discussão } \\
\text { que envolve o complexo panorama da pintura neste } \\
\text { final de século" }\end{array}$ & 300 \\
\hline & & 313 & 17 mar 1987 & $\begin{array}{l}\text { "Memórias da revolução: um livro sobre o } \\
\text { Impressionismo procura levantar as dificuldades } \\
\text { iniciais do movimento" }\end{array}$ & 301 \\
\hline & & 314 & $24 \operatorname{mar} 1987$ & $\begin{array}{l}\text { "A descoberta do passado: uma exposição para } \\
\text { comemorar o cinquentenário da Secretaria do } \\
\text { Patrimônio Histórico e Artístico Nacional, marco da } \\
\text { recuperação da memória brasileira" }\end{array}$ & 302 \\
\hline & & 315 & 31 mar 1987 & $\begin{array}{l}\text { "O Picasso da arquitetura: memórias de Le Corbusier } \\
\text { e a sua obra cheia de contradições" }\end{array}$ & 303 \\
\hline & & 316 & 7 abr 1987 & $\begin{array}{l}\text { "Chega de rotina: romper com o pesadelo da } \\
\text { mesmice resgata o papel da arte e reinventa a } \\
\text { emoção de estar vivo" }\end{array}$ & 304 \\
\hline & & 317 & 14 abr 1987 & $\begin{array}{l}\text { "0 delírio das artes: um fenômeno comercial? Mas } \\
\text { há bons sinais por trás disso" }\end{array}$ & 305 \\
\hline & & 318 & 21 abr 1987 & $\begin{array}{l}\text { "Evocação romântica: ao falar dos velhos edifícios de } \\
\text { São Paulo, os cronistas mostram a arte no início da } \\
\text { industrialização" }\end{array}$ & 306 \\
\hline & & 319 & 28 maio 1987 & $\begin{array}{l}\text { "A desordem tolerada: os que querem rever o } \\
7 \text { pós-moderno das vanguardas históricas criam } \\
\text { confusões na arte" }\end{array}$ & 307 \\
\hline & & 320 & 5 maio 1987 & $\begin{array}{l}\text { "A síndrome dos gênios: } 0 \text { que há por trás da santa } \\
\text { loucura dos artistas" }\end{array}$ & 308 \\
\hline & & 321 & 12 maio 1987 & $\begin{array}{l}70 \text { espaço do gesto criador: visita ao repousante } \\
\text { caos de um ateliê de artista" }\end{array}$ & 309 \\
\hline & & 322 & 19 maio 1987 & $\begin{array}{l}\text { "Uma visita de Leonardo: a IBM anfitriona o como- } \\
7 \text { vente encontro de um gênio do passado com a alta } \\
\text { tecnologia de hoje" }\end{array}$ & 310 \\
\hline & & 323 & 26 maio 1987 & $\begin{array}{l}70 \text { mercado enlouqueceu: quantos Abaporus vale um } \\
\text { Van Gogh?" }\end{array}$ & 311 \\
\hline & & 324 & 2 jun 1987 & $\begin{array}{l}\text { "Solidário às vaias: como Hugo Borger, diretor do } \\
\text { museu de Colônia, o diretor do Masp é a favor do } \\
\text { intercâmbio de exposições" }\end{array}$ & 312 \\
\hline & & 325 & 9 jun 1987 & $\begin{array}{l}\text { "A união pela arte: na Nigéria, onde existem } 200 \\
\text { dialetos diferentes, as manifestações artísticas } \\
\text { refletem uma unidade cultural" }\end{array}$ & 313 \\
\hline & & 326 & 16 jun 1987 & $\begin{array}{l}\text { "Os empresários têm cultura: Sarney disse o } \\
\text { contrário e se equivocou. Confundiu inculto com } \\
\text { maus administradores de indústrias" }\end{array}$ & 314 \\
\hline & & 327 & 23 jun 1987 & $\begin{array}{l}\text { "Princípio de conversa: o Ministério da Cultura, que } \\
\text { nasceu sob suspeita, mostra que está aí para ficar" }\end{array}$ & 315 \\
\hline & & 328 & 30 jun 1987 & $\begin{array}{l}\text { "A arte de fazer 'clic:' em seu livro, Notas, Stefania } \\
\text { Bril interpreta a criação dos principais fotógrafos } \\
\text { do mundo" }\end{array}$ & 316 \\
\hline & & 329 & 7 jul 1987 & $\begin{array}{l}\text { "A propaganda merece: os } 30 \text { anos da MPM e } \\
\text { lembranças dos tempos pioneiros" }\end{array}$ & 317 \\
\hline
\end{tabular}




\begin{tabular}{|c|c|c|c|c|c|}
\hline editora & diretores editora & $\begin{array}{c}\# \\
{\left[\sum p\right]}\end{array}$ & data & “artigo de Bardi;” observações & $\begin{array}{c}\# \\
\text { Bardi }\end{array}$ \\
\hline \multirow{27}{*}{$\begin{array}{l}\text { Editora } \\
\text { Três }\end{array}$} & \multirow{27}{*}{$\begin{array}{l}\text { Domingo Alzugaray, } \\
\text { Cátia Alzugaray, } \\
\text { Silvio Lancellotti }\end{array}$} & 330 & 14 jul 1987 & $\begin{array}{l}\text { "Arte para ver e usar: o design precursor da mulher } \\
\text { do futuro" }\end{array}$ & 318 \\
\hline & & 331 & 21 jul 1987 & $\begin{array}{l}\text { "Telas que valem ouro: as companhias de seguro } \\
\text { descobrem um belo negócio: o mercado de arte" }\end{array}$ & 319 \\
\hline & & 332 & 28 jul 1987 & $\begin{array}{l}\text { "Conversa pessoal: recordações de uma antiga } \\
\text { amizade com Gilberto Freyre" }\end{array}$ & 320 \\
\hline & & 333 & 4 ago 1987 & $\begin{array}{l}\text { "0 benefício da confusão: a arte incorpora o compu- } \\
\text { tador, ao mesmo tempo em que sente saudades } \\
\text { do figurativo. Quem vencerá: a vanguarda ou o } \\
\text { academismo?" }\end{array}$ & 321 \\
\hline & & 334 & 11 ago 1987 & $\begin{array}{l}\text { "0 estilo faraônico: Brasília toma ao pé da letra, na } \\
\text { sua arquitetura, o padrão de vida local" }\end{array}$ & 322 \\
\hline & & 335 & 18 ago 1987 & $\begin{array}{l}\text { "São José não é Canudos: visita à cidade onde } \\
\text { Euclides escreveu Os Sertões e construiu uma } \\
\text { ponte" }\end{array}$ & 323 \\
\hline & & 336 & 25 ago 1987 & $\begin{array}{l}\text { "A insubmissão do 'radical:' Abramo, que nunca } \\
\text { aderiu aos poderosos, nos convidava a refletir sobre } \\
\text { a realidade em que vive o ser humano" }\end{array}$ & 324 \\
\hline & & 337 & 1 set 1987 & $\begin{array}{l}\text { "Os sucessos da antiarte: Paul Klee na carroceria de } \\
\text { um automóvel. Por que não?" }\end{array}$ & 325 \\
\hline & & 338 & 8 set 1987 & $\begin{array}{l}\text { "Um vôo pela memória: de Bartolomeu de Gusmão } \\
\text { a uma precursora crônica em defesa do aeroporto } \\
\text { de Cumbica" }\end{array}$ & 326 \\
\hline & & 339 & 15 set 1987 & $\begin{array}{l}\text { "Mão dupla para a África: Pierre Verger, em livro e } \\
\text { numa mostra em preparação, antecipa os } 100 \text { anos } \\
\text { da Libertação" }\end{array}$ & 327 \\
\hline & & 340 & 22 set 1987 & $\begin{array}{l}\text { "A 'escolinha' deu certo: trinta anos de ensino de } \\
\text { propaganda e marketing" }\end{array}$ & 328 \\
\hline & & 341 & 29 set 1987 & $\begin{array}{l}\text { "A melodia do Ukiyo-ê: exatidão, detalhes, inspi- } \\
\text { ração: a gravura japonesa em sua melhor expressão" }\end{array}$ & 329 \\
\hline & & 342 & 6 out 1987 & $\begin{array}{l}\text { Os } 40 \text { anos de uma ousadia: como é que o Masp, } \\
\text { graças a Assis Chateaubriand, garimpou ouro na } \\
\text { terra do café }\end{array}$ & 330 \\
\hline & & 343 & 13 out 1987 & $\begin{array}{l}\text { Cem anos, com exclamação: o Museu de Arte de } \\
\text { São Paulo comemora o centenário de nascimento } \\
\text { do arquiteto Le Corbusier }\end{array}$ & 331 \\
\hline & & 344 & 20 out 1987 & $\begin{array}{l}\text { "'Cansado de quê?:' as homenagens dos amigos nos } \\
40 \text { anos do Masp retemperam a alma de um velho } \\
\text { galerista" }\end{array}$ & 332 \\
\hline & & 345 & 27 out 1987 & $\begin{array}{l}\text { "Fragmento por fragmento: a escultura de Margarida } \\
\text { de Brabante é recomposta em Gênova" }\end{array}$ & 333 \\
\hline & & 346 & 3 nov 1987 & $\begin{array}{l}\text { "A arte do cotidiano: ela está nas ruas, nos } \\
\text { prédios... Não visa lucros a seu criador mas servir } \\
\text { à comunidade" }\end{array}$ & 334 \\
\hline & & 347 & 10 nov 1987 & $\begin{array}{l}\text { "Rumo às artes do Sul: na visão subjetiva dos } \\
\text { artistas de Santa Catarina, a transformação histó- } \\
\text { rica da sua gente" }\end{array}$ & 335 \\
\hline & & 348 & 17 nov 1987 & $\begin{array}{l}\text { "Parado no tempo: para o arquiteto Manuel Siqueira } \\
\text { Marques, a fotografia é uma arte menor" }\end{array}$ & 336 \\
\hline & & 349 & $24 \operatorname{dez} 1987$ & $\begin{array}{l}\text { "SOS Morumbi: do bairro que nasceu com vocaçã } \\
\text { para santuário ecológico sobrou um bosque, onde } \\
\text { queriam erguer uma delegacia" }\end{array}$ & 337 \\
\hline & & 350 & 1 dez 1987 & $\begin{array}{l}\text { Lembrem-se de Delacroix: a burocracia dos salões } \\
\text { desfavorece a arte }\end{array}$ & 338 \\
\hline & & 351 & $8 \operatorname{dez} 1987$ & $\begin{array}{l}\text { A sátira pela imagem: quando a fotografia serve à } \\
\text { polêmica e à provocação }\end{array}$ & 339 \\
\hline & & 352 & $15 \mathrm{dez} 1987$ & $\begin{array}{l}\text { "Le Corbusier, modernista: rabiscos inéditos de uma } \\
\text { visita ao Rio de Janeiro e uma conferência que } \\
\text { abalou o Brasil" }\end{array}$ & 340 \\
\hline & & 353 & $22 \mathrm{dez} 1987$ & $\begin{array}{l}\text { "A leitura pelo desenho: a pedagoga Angela Lago } \\
\text { não usa texto em seus livros. E ensina às crianças o } \\
\text { mundo real através da fantasia" }\end{array}$ & 341 \\
\hline & & 354 & 5 jan 1988 & $\begin{array}{l}\text { "A interiorização da arte: impressões de uma visita } \\
\text { ao museu de Ribeirão Preto, instalado na fazenda } \\
\text { de um 'rei do café"” }\end{array}$ & 342 \\
\hline & & 355 & 12 jan 1988 & $\begin{array}{l}\text { "As marés e as rochas: nas artes, tudo o que ó novo } \\
\text { será fatalmente imaturo?" }\end{array}$ & 343 \\
\hline & & 356 & 19 jan 1988 & $\begin{array}{l}\text { "Fora das metrópoles: piedade, no interior de São } \\
\text { Paulo, abre sua Casa da Cultura" }\end{array}$ & 344 \\
\hline
\end{tabular}




\begin{tabular}{|c|c|c|c|c|c|}
\hline editora & diretores editora & $\begin{array}{c}\# \\
{\left[\sum p\right]}\end{array}$ & data & “artigo de Bardi;" observações & $\begin{array}{c}\# \\
\text { Bardi }\end{array}$ \\
\hline \multirow{24}{*}{$\begin{array}{l}\text { Editora } \\
\text { Três }\end{array}$} & \multirow{9}{*}{$\begin{array}{l}\text { Domingo Alzugaray, } \\
\text { Cátia Alzugaray, } \\
\text { Silvio Lancellotti }\end{array}$} & 357 & 26 jan 1988 & $\begin{array}{l}\text { "Um tempo de dúvidas: a verdadeira sensibili- } \\
\text { dade artística sofre a imposição da ideologia da } \\
\text { modernidade" }\end{array}$ & 345 \\
\hline & & 358 & 2 fev 1988 & $\begin{array}{l}\text { "Em tempo: Le Corbusier: um livro imprescindível } \\
\text { para lembrar um centenário que já passou - mas, } \\
\text { que importa, se o personagem é eterno?" }\end{array}$ & 346 \\
\hline & & 359 & 9 fev 1988 & $\begin{array}{l}\text { "Lembranças de Assis: o que um livro sobre } \\
\text { Chateaubriand tem a oferecer ao País" }\end{array}$ & 347 \\
\hline & & 360 & $15 \mathrm{fev} 1988$ & $\begin{array}{l}\text { "0 arquivo e a Constituinte: para estudar nossa } \\
\text { história recente será preciso ir aos Estados Unidos?" }\end{array}$ & 348 \\
\hline & & 361 & 22 fev 1988 & $\begin{array}{l}\text { "À flor da pele: também no Brasil a moda já é } \\
\text { celebrada como arte" }\end{array}$ & 349 \\
\hline & & 362 & 29 fev 1988 & $\begin{array}{l}\text { "0 destino dos estilos: o tempo os apaga numa } \\
\text { contínua superposição de formas. } 0 \text { Neoclássico é } \\
\text { um caso exemplar dessas transformações" }\end{array}$ & 350 \\
\hline & & 363 & 7 mar 1988 & $\begin{array}{l}\text { "Casa sem goteira: livre das infiltrações de água, o } \\
\text { Masp já pode receber de volta o acervo que enviou } \\
\text { à Europa" }\end{array}$ & 351 \\
\hline & & 364 & 14 mar 1988 & $\begin{array}{l}\text { "Uma difícil missão: a Bienal de Arte de São Paulo } \\
\text { carece de uma revolução que Alex Periscinoto terá } \\
\text { de realizar" }\end{array}$ & 352 \\
\hline & & 365 & 21 mar 1988 & $\begin{array}{l}\text { "Candidatos ao Olimpo: no mercado de artes, } \\
\text { investir em nomes consagrados sai caro. Melhor é } \\
\text { se antecipar à fama" }\end{array}$ & 353 \\
\hline & \multirow{15}{*}{$\begin{array}{l}\text { Domingo Alzugaray, } \\
\text { Catia Alzugaray, } \\
\text { Mino Carta }\end{array}$} & 366 & 28 mar 1988 & $\begin{array}{l}\text { "0 dom da voz: } 0 \text { apresentador e empresário Sílvio } \\
\text { Santos conversa nas ruas como fala nos palcos. Foi } \\
\text { nas ruas, aliás, que ele aprendeu a ser persuasivo e } \\
\text { se convenceu de que o querer oferece o vencer" }\end{array}$ & 354 \\
\hline & & 367 & 4 abr 1988 & $\begin{array}{l}\text { "Notas de viagem: Niemeyer lança um olhar inteli- } \\
\text { gente em direção da Ponte Vecchio e percebe que a } \\
\text { contribuição árabe está por toda parte" }\end{array}$ & 355 \\
\hline & & 368 & 11 abr 1988 & $\begin{array}{l}\text { "0 tesouro do Caribe: Fica em Cuba um dos mais } \\
\text { ricos acervos artísticos da AL" }\end{array}$ & 356 \\
\hline & & 369 & 18 abr 1988 & $\begin{array}{l}\text { "0 futuro do passado: } 0 \text { antiquariato: peças antigas, } \\
\text { gosto atual" }\end{array}$ & 357 \\
\hline & & 370 & 25 abr 1988 & $\begin{array}{l}\text { "A arte na mesa: um livro mostra o interesse de } \\
\text { artistas antigos e contemporâneos com a não } \\
\text { menos nobre arte de cozinhar" }\end{array}$ & 358 \\
\hline & & 371 & 2 maio 1988 & $\begin{array}{l}\text { "0 ouro que sobrou: imagens do apogeu pré-colonial } \\
\text { na América do Sul" }\end{array}$ & 359 \\
\hline & & 372 & 9 maio 1988 & $\begin{array}{l}\text { "Relíquias africanas: com a exposição África Negra, } \\
\text { o Masp presta sua homenagem ao centenário da } \\
\text { Lei Áurea" }\end{array}$ & 360 \\
\hline & & 373 & 16 maio 1988 & $\begin{array}{l}\text { "Prêmio para um autodidata: por seu trabalho } \\
\text { à frente do Masp, Pietro Maria Bardi recebe a } \\
\text { distinção de doutor honoris causa" }\end{array}$ & 361 \\
\hline & & 374 & 23 maio 1988 & $\begin{array}{l}\text { "Memória negra: inaugurada há pouco em Salvador, } \\
\text { a Casa do Benin será um espaço permanente de } \\
\text { reflexão sobre a influência africana na etnografia } \\
\text { brasileira" }\end{array}$ & 362 \\
\hline & & 375 & $\begin{array}{l}30 \text { maio } \\
1988\end{array}$ & $\begin{array}{l}\text { "A emoção marcada a ferro: não há equívoco maior } \\
\text { do que considerar a gravura uma arte menor. Estão } \\
\text { aí para provar Bonomi, Grassman..." }\end{array}$ & 363 \\
\hline & & 376 & 6 jun 1988 & $\begin{array}{l}\text { "A missão do solitário: sugestão à Bienal deste } \\
\text { ano: uma bela homenagem a Volpi, silencioso } \\
\text { revolucionário" }\end{array}$ & 364 \\
\hline & & 377 & 13 jun 1988 & $\begin{array}{l}\text { "Mestre do figurativo: mal compreendido à sua } \\
\text { época, Lasar Segall nada fica a dever aos maiores } \\
\text { expressionistas alemães" }\end{array}$ & 365 \\
\hline & & 378 & 20 jun 1988 & $\begin{array}{l}\text { "Arquitetura prêt-à-porter: o uso de pré-moldados } \\
\text { nas obras públicas de Salvador" }\end{array}$ & 366 \\
\hline & & 379 & 27 jun 1988 & $\begin{array}{l}\text { "Inspiração oriental: a arte japonesa está em } \\
\text { exposição no Masp" }\end{array}$ & 367 \\
\hline & & 380 & 4 jul 1988 & $\begin{array}{l}\text { "A fusão e a confusão: o Ecletismo na arquitetura } \\
\text { nem sempre dá uma boa mistura”; útlimo número } \\
\text { do título, antes da fusão com a Istoé. Bardi seguirá } \\
\text { contribuindo semanalmente com a Istoé Senhor }\end{array}$ & 368 \\
\hline
\end{tabular}


QuAdRo \#4 IstoÉ (levantamento em coleção completa)

\begin{tabular}{|c|c|c|c|c|c|}
\hline editora & diretores editora & \# & data & "artigos Bardi;” observações & $\begin{array}{c}\text { \# } \\
\text { Bardi }\end{array}$ \\
\hline \multicolumn{6}{|l|}{ ISTOÉ } \\
\hline \multirow{14}{*}{$\begin{array}{l}\text { Encontro } \\
\text { Editorial }\end{array}$} & \multirow{2}{*}{$\begin{array}{l}\text { Catia Alzugaray, } \\
\text { Domingo Alzugaray, } \\
\text { Luis Carta, } \\
\text { Mino Carta }\end{array}$} & 1 & maio 1976 & & \\
\hline & & 8 & dez 1976 & "Os últimos dias do cidadão Chatô" & 1 \\
\hline & \multirow{11}{*}{$\begin{array}{l}\text { Catia Alzugaray, } \\
\text { Domingo Alzugaray, } \\
\text { Mino Carta }\end{array}$} & 9 & jan 1977 & $\begin{array}{l}\text { Luis Carta sai da publicação, vendendo sua parte } \\
\text { aos Alzugaray }\end{array}$ & \\
\hline & & 11 & 9 mar 1977 & $\begin{array}{l}\text { a censura chega ao fim, permitindo que a publi- } \\
\text { cação torne-se semanal a partir deste número }\end{array}$ & * \\
\hline & & 12 & 16 mar 1977 & $\begin{array}{l}\text { "A Urbanística: reflexão sobre qualidade de } \\
\text { vida;" Bardi passa a figurar oficialmente entre os } \\
\text { colaboradores }\end{array}$ & $\overline{2}$ \\
\hline & & 15 & 6 abr 1977 & "Nas fachadas, a nova moda foliona" & 3 \\
\hline & & 16 & 13 abr 1977 & "A casa concha que pode ser feita por você mesmo" & 4 \\
\hline & & 17 & 20 abr 1977 & "0 'pot-porri' que se chama de mediterrâneo" & 5 \\
\hline & & 18 & 27 abr 1977 & "Don Cicillo, um Matarazzo nas artes" & 6 \\
\hline & & 25 & 15 jun 1977 & "Alquimia Arquitetônica" & 7 \\
\hline & & 29 & 13 jul 1977 & "Evocações de Le Corbusier no Brasil" & 8 \\
\hline & & 32 & 3 ago 1977 & "Verde" & 9 \\
\hline & & 44 & 26 out 1977 & "Sem abstracionismos" & 10 \\
\hline & $\begin{array}{l}\text { Armando V. Salem, } \\
\text { Fernando Sandoval, } \\
\text { Mino Carta, Raymundo } \\
\text { Faoro, Tão Gomes Pinto } \\
\end{array}$ & 151 & 14 nov 1979 & Catia e Domingo Alzugaray saem da editora & \\
\hline \multirow{3}{*}{$\begin{array}{l}\text { Caminho } \\
\text { Editorial }\end{array}$} & \multirow[t]{2}{*}{$\begin{array}{l}\text { Fernando Moreira Salles, } \\
\text { Antônio Fernando De } \\
\text { Franceschi, Armando V. } \\
\text { Salem, Mino Carta. }\end{array}$} & 164 & 13 fev 1980 & $\begin{array}{l}\text { o título foi vendido à Caminho Editorial, relacio- } \\
\text { nada ao grupo Unibanco, por causa do fracasso } \\
\text { financeiro deixado pelo Jornal da República } \\
\text { (US\$ } 1,5 \text { milhão, na época) } \\
\text { Saem do corpo diretivo editorial Fernando Sandoval, } \\
\text { Raymundo Faoro, Tão Gomes Pinto }\end{array}$ & * \\
\hline & & 178 & 21 mai 1980 & último expediente com o nome de Bardi & $=$ \\
\hline & $\begin{array}{l}\text { Fernando Moreira Salles, } \\
\text { Antônio Fernando De } \\
\text { Franceschi, Armando } \\
\text { V. Salem }\end{array}$ & 228 & 13 mai 1981 & $\begin{array}{l}\text { o nome de Mino Carta sai do expediente neste } \\
\text { número. Ele, porém, declarou ter saído em feve- } \\
\text { reiro, assim que cumprido o acordo de participar da } \\
\text { transição da revista por um ano }\end{array}$ & \\
\hline \multirow{3}{*}{$\begin{array}{l}\text { Gazeta } \\
\text { Mercantil }\end{array}$} & Luiz Fernando Levy & 370 & 25 jan 1984 & o título é passado para o grupo da Gazeta Mercantil & * \\
\hline & \multirow[b]{2}{*}{$\begin{array}{l}\text { Herbert Levy, } \\
\text { Luiz Fernando Levy }\end{array}$} & 375 & 29 fev 1984 & [análise detalhada do expediente até este número] & \\
\hline & & 601 & 29 jun 1988 & $\begin{array}{l}\text { último número da Gazeta Mercantil; } \\
\text { a circulação do título é interrompida por uma } \\
\text { semana }\end{array}$ & * \\
\hline \multicolumn{6}{|c|}{ ISTOÉ SENHOR } \\
\hline \multirow[b]{2}{*}{$\begin{array}{l}\text { Editora } \\
\text { Três }\end{array}$} & \multirow{2}{*}{$\begin{array}{l}\text { Domingo Alzugaray, } \\
\text { Catia Alzugaray, } \\
\text { Mino Carta }\end{array}$} & {$[982$} & 11 jul 1988 & $\begin{array}{l}\text { "Natureza viva: a arte do ikebana nos arranjos florais } \\
\text { do mestre japonês Sen'hei" }\end{array}$ & $\overline{-}$ \\
\hline & & $\begin{array}{c}982 \\
a \\
1199]\end{array}$ & $\begin{array}{l}11 \text { jul } 1988 \text { a } \\
23 \text { set } 1992\end{array}$ & $\begin{array}{l}\text { los } 214 \text { artigos de Bardi nesse período pós-fusão } \\
\text { deverão ser compilados e analisados em pesquisa } \\
\text { futura] }\end{array}$ & $\begin{array}{l}11 \mathrm{a} \\
224\end{array}$ \\
\hline \multicolumn{6}{|l|}{ ISTOÉ } \\
\hline \multirow{4}{*}{$\begin{array}{l}\text { Editora } \\
\text { Três }\end{array}$} & & 1174 & 1 abr 1992 & cioè, o Senhor é renegado & * \\
\hline & $\begin{array}{l}\text { Domingo Alzugaray, } \\
\text { Catia Alzugaray, } \\
\text { Mino carta }\end{array}$ & 1199] & 23 set 1992 & $\begin{array}{l}\text { "Cores do subjetivismo: no Masp, obras do Grupo } \\
\text { Cobra revelam a intenção de se chegar à gênese } \\
\text { dos sentimentos;" } \\
\text { uma nota informa que Bardi "está se recuperando" } \\
\text { e poderá voltar a contribuir quando quiser (o que } \\
\text { não acontece) }\end{array}$ & 224] \\
\hline & $\begin{array}{l}\text { Domingo Alzugaray, } \\
\text { Catia Alzugaray }\end{array}$ & 1247 & 25 ago 1993 & $\begin{array}{l}\text { Mino Carta sai da publicação pois se divergiu de } \\
\text { Domingo Alzugaray em questões de posiciona- } \\
\text { mento político. Bardi, segundo ele, saiu ao mesmo } \\
\text { tempo, mas já não havia contribuído por meses e, } \\
\text { assim mesmo, constou no expediente por um pouco } \\
\text { mais de tempo }\end{array}$ & \\
\hline & $\begin{array}{l}\text { Domingo Alzugaray, } \\
\text { Catia Alzugaray, } \\
\text { José Carlos Bardawll, } \\
\text { Tão Gomes Pinto }\end{array}$ & 1255 & 20 out 1993 & último expediente com o nome de Bardi & $=$ \\
\hline
\end{tabular}

Legenda: - início de colaboração oficial de Bardi com o título (presença no expediente); = fim de colaboração oficial 


\section{Anexo $A$}

\section{Textos de P.M. Bardi}

em colaborações regulares ou pontuais 
Vogue Brasil \#I, maio I975, p.I48-I49,I76-I77

EU, CRÍTICO?

Pietro Maria Bardi, o genial criador do Museu de Arte de São Paulo, o mais importante do Brasil, fala pela primeira vez de como é difícil superar as desconfianças dos que querem criticar seu trabalho, eo dos outros e se diz, ele próprio, "cronista da arte, registrador dos fatos, tentando adivinhar certezas fluidas e imprecisas."

$$
\sim
$$

Com frequência sou procurado aqui no Museu por diversas mocinhas (rapazes, menos) e mesmo senhoras, as quais, não sabendo conscientemente como preencher as ociosas horas de que dispóem, pintam. Vêm me mostrar telas, desenhos ou gravuras, Mais gravuras, visto ser esta a manifestação preferida pelas mulheres que tentam seus passos no terreiro das artes. Chegam, se apresentam, e pedem um parecer a respeito da arte que produzem. Digo-lhes, então, que me dedico mais a problemas de história. Nem sou crítico patenteado pela respectiva associação de classe. Porém as carinhosas não aceitam o argumento. Atacam de frente, cobrindo-me de guirlandas e confetes. A única saída é das uma de cavalheiro. Admito, então: um pouquinho entendo, se não de estética pelo menos de técnica. De fato, fiz um curso intensivo numa das escolas noturnas de Jaboticabal do Rio Negro, aliás presidida por um excelente professor acadêmico.

- O senhor é papa, não esconda sua sabedoria, faça-me o favor de examinar atentamente minhas pinturas, pois se as mesmas nada valerem só me resta voltar a tricotar; diga-me francamente; aliás, confesso-lhe que há meses que me atormento com isto; comecei na Escola Brasil; uma voz misteriosa e insistente me incitou o amigar-me com as tintas e os pincéis; minha arte explodiu.

Afinal uma comparação com tão elevada hierarquia espiritual não deixa inoperante o mais compassado dos insensíveis. Passamos a ver, ou melhor, a contemplar os trabalhos em pauta. A autora explica as temáticas; gentilmente peço silêncio, para náo quebrar a linha do meu pensamento andante e chegante que remói no meu cérebro e de lá, fugidiamente, vai direto ao coração, provocando o costumeiro frisson da emoção

A interlocutora se inquieta e reclama.

Contesta-me dizendo que o sistema

“consideração-emoção" é papalvice. Tem

lido - aprendeu inglês na UCBEU - as

últimas prosas (claras e leves como a água de Lindoia) do Art International, garante-me que hoje a "tipologia das imagens permite uma ampla liberdade criativa, através de uma extrema comunicatividade semântica, procurando um itinerário de pesquisa de identidade em nível existencial ou psiquiátrico." Porém tem mais. Ela declara que a próxima revolução vai enterrar o velho lugar-comum Arte e Vida que a turma dos velhos artistas gostava de repetir em coro com os velhos mestres cantores e os agarramoscas bonitos, novos e ricos, indicando que esta profecia é de um autêntico papa: Ad Reinhardt, o autor de The Next Revolution in Art. Ad discorda até de várias piadas, como: "A arte, de qualquer jeito, é uma maneira de viver" (de Kooning, I95I); "Pintar é viajar de noite sem saber para onde se vai" (Motherwell, 1959); "Um bom quadro que não representa nada é uma coisa que não existe" (Rothko, Gottlieb, 1947).

Imaginava que minha interlocutora fosse mais simples e de poucas leituras. No entanto ali estava ela a me dizer que já sabia ser a moda da última semana a pesquisa da identidade. Armada de teorias recentes Adorno, Altusser, Barthes, Marcuse: puro material arqueológico - ajeitava-se para operar no grito da hora. Eu refletia, respeitosamente, com Verdi: La donna é mobile qual piuma al vento 1 muta di accento e di pensier. O certo é que milhares de metidas-em-arte mudam por demais de pele.

Todavia tratava-se de raciocinar sobre o valor das coisas apresentadas, por acaso espalhadas pelo cháo, ao lado de uma Tarsila brilhante de cor e de alma. O que fazer, o que dizer?

É o momento em que o crítico, ou o presumido tal, se sente perplexo em relação à crítica. A fixação gráfica desta situação é devolvida ao amigo Saul Steinberg. (Combinei com ele a realizaçáo de uma 
individual no Museu em 1950 que batizamos Saul no Deserto: a crítica, então, estava empenhada em descobrir as origens do Grupo Santa Helena, e os artistas, na cópia de Max Bill, o qual, meses antes, tinha apresentado sua primeira mostra fora da Suíça.) Gostaria de desaparecer numa cortina de fumaça como em Fausto. Mas os olhos implacáveis da postulante me fulminam na base de raios laser. Assim, velhaco, pronuncio monossilabicamente um "bom," logo me apressando em corrigir: - Uma pintura é como uma música: julga-se quando se contempla muitas vezes. Tinha articulado um pensamento: se digo "ruim," a interlocutora se enfurece e, da altaneira posiçáo de papa, sou relegado à condição de Belzebu; pensei ainda quando e como a tal iria curricular meu elogio. (O Bardi disse que sou artista de primeira, tanto assim que vai desmontar a Pinacoteca para expor minhas telas, com um coquetel que a Alik Kostakis vai clichetear em página inteira; e mais: o Bardi vai escrever um ensaio, ele tem um olho como ninguém!) Diante de tal acontecimento, sinto-me um velhaco vulgar. Eu, crítico?

Esta profissão é ingrata. Quem maneja paleta para elaborar pintura de cavalete, ferramenta para escultura ornamental, recentemente guindada à condição de múltiplo ou de objeto industrializado, (a praça está poluída, agora, destas novidades I890) quem espreme pipi conceitualista, (sem referência ao conceitualismo, que é tendência séria) se sente gênio antes de começar. O crítico não concorda? Então é um pobre coitado, ignorante, atrasado.

Antigamente, nos anos em que iniciei minhas atividades de distribuidor de elogios e de reprimendas - arrependo-me de tanta ingenuidade por ter escrito sem experiência — as aventuras da crítica corriam mais placidamente. Apesar dos caprichos que o art nouveau inovava na Europa, o academismo estava de pé, e por consequência o parecer sobre uma pintura era dado conforme os cânones bíblicos de Roger de Piles, do Raphael Mengs e dos cupinchas desses luminares. Não se trapaceava no jogo. Se o artista desenhava uma cabeça, a anatomia devia ser absoluta, Vesálio à mão. (Todo o mundo sabe que ele foi um anatomista famoso)
Tempos ingratos: os próprios impressionistas eram maltratados até pelos porteiros, contempladores das cromolitografias representando as Quatro estaçôes ou o Banquete de cardeais e damas em decoté.

La Belle Epoque, a ideia acadêmica, conservadora e provinciana, não era facilmente desmantelável. Um episódio: o senhor Cesare Sforni voltando de Paris a Florença com o Camponês de Van Gogh foi chamado de louco pela família e vizinhança, e confinado. $\mathrm{Na}$ minha pátria de origem, a Itália - "aluna da poesia e mestra das artes" - era o slogan para inglês ver e aprender que pisando a terra do Sole mio a arte era táo caseira como a tiririca - falou-se em impressionismo com lamentável atraso. Em geral, os italianos descobrem as vanguardas durante as celebraçóes dos cinquentenários. O único movimento vivo foi o dos futuristas, e nasceu em Paris. Ao aparecer o trabalho dos marinettistas, nasceu também o apodítico "também o meu menino é capaz de fazer um destes scarabocchi," evoluindo o conceito chamado em causa Picasso \& companhia. (Infelizmente este conceito é emitido comumente em São Paulo, diante de obras modernas.)

Quando o sr. Chateaubriand teve a audaciosa ideia de dar vida a um museu, para sucitar interesse em torno da novidade, eu e Lina resolvemos fundar uma revista dedicada às artes. Surgiu o Habitat. A primeira reflexão foi sobre o fato crítico.

$\mathrm{O}$ ambiente não aconselhava operar em moldes por demais rigorosos: afloravam suscetibilidades e desconfianças; as opiniôes francas implicavam, em contrapartida, reaçóes perturbadoras a um trabalho museográfico que pedia, antes de tudo, diplomacia cerimoniosa, e não modos tranchants. Atiramos a crítica mansarda. (Vem-me à mente um outro fato a considerar: aquele que Roberto de Oliveira Campos batizou de forma lapidar, no tocante à economia brasileira, de "nacionalismo temperamental," fato que parece agora exorcizado junto ao escapismo e ao paternalismo.) Os primeiros números da revista inseriam produçóes se não entre as mais consoantes com as exigências do tempo, pelo menos não demasiadamente puxadas para esquemas superados. 
As críticas ao Museu e depois ao Habitat se desencadearam à moda paulista: soltos os boatos no bem adubado campo da credibilidade sempre pronta a desabafar uma fatiazinha de inveja, as iniciativas começaram a ser alvo de mexericos, calúnias e difamaçóes. O espirituoso manipulador dos Diários Associados me dizia peremptório: - Faça das tripas coração. Não era fácil o transplante: o professor Zerbini não tinha ainda estudado esta cirurgia. Por sua vez, os clínicos recomendavam engolir brometos em fortes doses, alternando com tragos de sapos ferreiros fêmeas.

Em certo momento a crítica censurou serem falsas as obras do Museu; em adendo, um jovem (já candidato a uma cátedra qualquer de história da arte) decretou que Michelangelo náo interessava ao Brasil; que um certo P.M. Bardi efetivamente existia na Itália, mas o aqui desembarcado de um porão de navio cargueiro era um sócio; e assim por diante.

Lasar Segall, meu conhecido desde a Europa, me explicou: — Bardi, não faça caso, pois eu também passei por isso; continue o seu trabalho; os cães ladram e a caravana passa.

Lembrei me então que no ginásio (não curtido em um ano) aprendi um dito que me acompanhou e que me tem sido útil ao longo das minhas jornadas: Vim vi repellere licet; depois de intensa pesquisa descobri que esta afirmaçáo de Ulpiano (Roma, I70-228) foi aperfeiçoada pelo jurisconsulto Paulo. Vim vi defendere, omnes leges, omniaque jura permittunt, que é como dizer: todas as leis permitem valer-se da força contra quem usa a força. Assim, respondi às críticas, não recorrendo à força; com migalhas de ironia desenhadas no Habitat, sob o pseudônimo de Alencastro.

O bafo começou a irritar. Foi quando decidi levar parte da Pinacoteca recém-formada para um tour de exposiçóes pela Europa, começando por Paris. As Cem Obras do Museu de Arte de Sáo Paulo foram admiradas e comentadas por centenas de milhares de visitantes no Orangerie do Louvre, tendo o privilégio de uma inauguração pelo entáo presidente da República e Senhora Vincent Auriol; depois seguiram-se as exposiçóes no Palais des Beaux-Arts de Bruxelas; no Central Museum de Utrecht, no Kunsthalle de Dusseldorf; no Kunstmuseum de Berna; na tate Gallery de Londres, no Palazzo Reale de Milão e, finalmente, no Metropolitan Museum of Art de Nova York. Concluída a festa internacional, as obras voltaram respaldadas por autoridades críticas como as de Venturi, Longhi, Chastel e muitos outros. Foram, então, apresentadas no Museu Nacional de Belas-Artes do Rio de Janeiro.

Reinstalado o acervo na cidade de São Paulo, a via crucis-Crítica recomeçou; na verdade enfraquecida pelo surgimento de novos e mais palpitantes assuntos e faltas dos mesmos, como o melancólico desaparecimento do Museu de Arte Moderna, a criação do Museu de Arte Contemporânea, da FAAP, as verbas da bienal e tantas outras bagatelas que deram lugar aos epidêmicos boatos.

A crítica, incomodando a filosofia, é um tribunal que julga o bom e o não-bom das produçôes que lhe são submetidas. $\mathrm{O}$ praticante desta tarefa (melhor se conhece Kant e Hegel, no pensamento dos professores da matéria, a dupla considerada batuta no assunto) deve ser possivelmente nutrido de sabedoria, ter aprendido a nadar no seco, antes de se jogar n'água, saber o que significa lógico-transcendental e lógico-objetivo, dando lugar a uma questão importantíssima: o de jure da validez do conhecimento insolúvel no terreno de facto. Confesso jamais ter conseguido compreender tais arabescos da filosofia; (avançando a opinião de que não tendo o cérebro de um Benedetto Croce é oportuno renunciar) é por isso que não me dediquei à crítica, optando por modestas e cordiais aproximçóes para com os elementos que me pareciam merecedores de apoio. (Em abono a este ponto direi que fui honrado por Giorgio Morandi, no sentido de escrever o prefácio da plaquette preparada para comemorar seu septuagésimo aniversário, pois dele adquirira várias obras e o defendia nos anos 20.) Mas pensei em crítica, mais propenso a raciocinar diante deste complicado assunto da arte nos moldes Fritz Saxl, um dos mestres do glorioso Warburg Institut. Começava ele suas aulas assim: "Não sou um filósofo, 
nem sou capaz de falar de filosofia. É o material histórico concreto que sempre me atrai, seja no campo da literatura, seja no da arte ou da religiáo. Mas quaisquer que sejam as particularidades dos temas de pesquisas, todos eles têm um aspecto em comum que apresenta um valor tão generalizado e fundamental para nosso inteiro trabalho, e somos inclinados a aceitá-lo sem prestar demasiada atenção ao seu caráter problemático...” Assim, prudente em relação à atitude dos demais críticos-filósofos, filósofos-críticos - insisto em minha posição de cronista de arte, registrador dos fatos, tentando adivinhar certezas em matéria tão fluida e imprecisa.

Já sei que por tão sincera declaração o Sindicato dos Críticos irá, certamente, aprovar na ordem do dia uma moção contra o Bardi, "sempre o desmancha-prazeres, o viciado do contra, o náo se adapta aos nossos meios. Culpado crônico de todas as oposiçóes ao situacionismo, distribuidor de dardos de curare, cunhador de ferroadas impiedosas, leitor obstinado de Arnobio e de Schoppenhauer."
Quando me retiro para minha fazenda no Morumbi, ouvindo os sariguês pisar no teto, acariciando meu cachorro fila e os gatos sem raça, vendo colibris bebendo groselha nas garrafinhas disfarçadas entre os galhos dos hibiscos, neste mundo distante das arquiteturas ilhas gregas (o último estilo presente de grego incorporado aos inúmeros das grandes construtoras); longe das comissóes obrigadas a julgar, isto é criticar milhares de produtos de transbordante amadorismo; fechando o circuito do televisor quando aparecem as desmoralizantes aberturas das novelas ou o coçar nos violóes e cantos acompanhantes; afastado das obrigaçóes sociais, penso na crítica. Talvez como vulpes ad uvam.

Cuido ser honesto declarar - como já afirmei à prezada amiga no comecinho destas despretensiosas notas - que não sou crítico de arte. (Nem mesmo um crítico "c" microscópico.) Possivelmente um crítico de fatos que penso cabeçapara-baixo, tão do agrado na opinião de todos. E aqui faço ponto final, fazendo continência, ironicamente discreta, àquele exército de que nos fala Schiller.

\section{Homem Vogue \#I6A, setembro de 1976, p.54-57}

\section{REVIVALS E HISTERISMO \\ Como o colecionador brasileiro vai adotando modismo que vem de fora, sem compreender nada do que se passa, confundindo tudo. Há mais bom gosto numa favela do que na casa de um rico}

Também no Brasil os revivals emergem e se enraízam com a mesma pontualidade despontada na Europa e nos Estados Unidos graças às facilidades das comunicaçóes escritas, faladas e figuradas.

Para exemplificar: os dois mais recentes foram o art nouveau, alguns anos atrás e, em seguida, o art déco. Objetos que na véspera dos booms eram jogados fora por serem tidos como de mau gosto voltam a ser desempoeirados, lustrados e monetariamente valorizados.

Revivals de origem romântica de uma burguesia ansiosa de sensaçóes culturais de mais fácil acesso histórico, já que a lembrança se restringe aos tempos dos avós?

Corrida atrás de proposiçóes puramente modísticas, sem nenhum entendimento dessas "recomposiçóes de tempo," homenagem ou reverência ao tempo transcorrido? Reação às demais iniciativas que extrapolam para uma rua sem saída?

É bem possível que tais interrogaçóes convirjam para uma síntese: os revivals determinam o fluxo e refluxo da vida já que se verificam no curso da história, na sua realidade e na sua expressividade artística como na recuperação do labor, da inteligência das certezas ou das utopias que foram se acumulando nos ombros da humanidade.

Hoje os revivals mais falados são os de períodos históricos menores: o art nouveau e o art déco, partículas que, pensando bem, são quase divertissements para uns poucos estetas.

De fato, se pensarmos na Renascença, no Neoclássico e mesmo politicamente nos revivals cesaristas que ensanguentaram a Europa, voltaremos a considerar 
a vida como reflexo condicionado de experiências vividas ao longo da história onde se pode atingir o belo, o verdadeiro, o bem, o mal, enfim tudo que justifique a continuidade de viver.

Como foi dito, os surtos de arte de fins e começo do século que proliferaram no Brasil, resultaram na descoberta de preciosas minas de objetos dos estilos então na moda.

Tais objetos eram de importação feita por nossos viajantes já que os que daqui não saíam estavam naturalmente à la page quanto às produçóes de alhures.

Fotografias de ambiente do citado período ilustram presença de decoraçốes caprichadas bem naquele estilo chamado "fitinha" e no outro chamado de "geométrico." Além dos ambientes, havia arquitetura as quais se pouco notáveis pelo menos estavam entrosadas com as propostas da época. Infelizmente as poucas coisas existentes há umas duas dezenas de anos, hoje praticamente desapareceram. Aliás, tenho em minha coleção o esplêndido portão de um palacete art nouveau que retirei, da rua Major Sertório, em Sáo Paulo, lembrando-me de que o vendedor tomou-me como excêntrico ou mesmo fabricante de casas de periferia.

A cidade mais rica em arquitetura e objetos de revivals é o Rio de Janeiro depois, diria, Belém do Pará e São Paulo. No Rio e em São Paulo era o Mappin que ditava a moda; em Belém a Casa Pekin. No Recife poucas coisas são encontradas no que se refere a Gallé, Richard, Daum, Lalique, nomes que constituíam o forte das importaçóes como nos fins dos setecentos e começo dos oitocentos era a porcelana de Macau.

É confortador constatar o interesse despertado nos centros culturalmente mais prósperos no que diz respeito à conservação do que resta dos mais coerentes estilos contemporâneos. Numerosos são os colecionadores que se tornaram também estudiosos do assunto, como o casal Adolfo Leirner que realizou no museu a exposição "Tempo dos Modernistas" particularmente dedicada ao art déco, reveladores da participação brasileira na atualidade, através de figuras familiares afins: Antonio Gomide, sua irmã Regina com seu marido John
Graz. Estas notas visam chamar atenção sobre um problema cultural da mais alta importância qual o da conservação e carinho que devem ser dedicados à história.

Muitas vezes ouço dizer que a arte começa com Picasso ou então que a arte é a do dia; a palavra "passado" riscada com uma cruz.

Recordemos que tivemos papas que transformaram o Coliseu numa pedreira, déspotas que destruíram catedrais, aventureiros que fundiram os tesouros das civilizaçóes americanas, loucos que martelaram a Pietà de Micheiangelo, ladróes que roubam, para fazer chantagem, obras de Piero e Rafael; como vemos, o mundo infelizmente é uma miscelânea de malandros, indiferentes, coitadinhos, mas também de gente digna. Estas notas são endereçadas a estes últimos.

Eu me pergunto: qual a escola de uma elite ou de uma massa? Infelizmente os problemas de estética são mais pertinentes aos possuidores de contas correntes bancárias onde o saldo com muitos cifróes permite uma estrutura bastante folgada; quem luta para manter cheia a panela de arroz e feijáo não quer se preocupar com o assim chamado belo.

Porém é bem mais fácil observar bom gosto numa favela que numa casa de rico. Longe de mim brincar com o leitor. Digo francamente que uma dessas casinhas construídas em mutirão e espalhadas pela periferia, do ponto de vista da arquitetura, me interessam muito mais que aquelas colmeias chamadas de estilo mediterrâneo e que a ignorância local engole como um uísque falsificado mas engarrafado em frasco original.

Esta digressão é para voltar ao caso dos revivals. Existem revivals que o curso da história propóe, como outros que desaparecem, como dizem os italianos, a vacca, isto é, sem a maturidade emanada de uma reflexão crítica acontecimentos geralmente brotados e propostos às sociedades desinformadas, degustadoras mais do fachadismo que do conteúdo.

Naturalmente não se trata de revivals a serem levados a sério, apesar do histerismo macacal que campeia soltamente por este país afora. 
No Brasil foi registrado o lançamento de inumeráveis pseudo-revivals. Aliás, a crônica da arquitetura das grandes cidades mostra muito bem a sorte que tiveram os mais diferentes estilos humorísticos em sua maioria. Para circunscrever o assunto a São Paulo, todos estão lembrados da onda do colonial mexicano, dos tetos pontiagudos para "neve" escoar e aqui introduzidos pelos alemães, ao passo que os italianos impingiam imitaçóes renascentistas e os árabes faziam florescem contrafaçóes de arcos.

E assim por diante até que apareceu o grande movimento de E o Vento Levou, de mediterrâneo, dos portais das vertentes, das ilhas gregas e quantas outras fanfarronadas de alguns vivaldinos coadjuvantes por decoradores cuja experiência se baseia páginas do Home and Garden, aliás uma bíblia que a grã-finagem recebe por via aérea.

Como disse no começo destas notas, quando passou a moda do art nouveau e do art déco, as famílias jogaram fora os objetos para substituí-los por outros que a moda prescrevia através da publicidade. Ninguém considerou que um vidro de Gallé ou uma prata de época era uma obra de arte digna de atenção e conservação. Evidente falta de gosto e informação.

As oscilaçóes de gosto neste século devem ser registradas na escala Richter. A última movimentação estética na metrópole está extinguindo até os recentes revivals importados do fim da Belle Époque: dizem que "cansaram," como anualmente se cansam das linhas dos automóveis e das boates em voga. Parece que quando os abalos se acalmarem teremos mais uma moda, a da arte a moda, a da arte oriental. Existem compradores que estão fazendo ponte-aérea com os portos franqueados da China e das capitais do Pacífico, dali importando uma gama de coisas de gosto e idade duvidosos. Num certo sentido é um revival, pois o Brasil nos tempos da colônia e mesmo pouco depois recebeu muita coisa daquele continente. Deve-se saudar a iniciativa dos que homenageiam o Oriente. Todavia é necessária uma recomendação: não tragam quinquilharias, já temos montanhas produzidas aqui. Fazemos um convite: tratem os compradores de segurar ao nosso paupérrimo patrimônio de arte estrangeira, obras de real valor, e deixem nos bazares as bugigangas de enfeite. Sabe-se que as senhoras estão interessadas na movimentação orientalista. Já se antevê nas casas ricas, estátuas de Cakya Mouni em companhia das de Cristo, o que é esplêndido nessa interessante ampliação teológica do embrassons nous ecumênico.

Mas é bom repetir: cuidem de que esse revivalzinho geográfico não provoque o do histerismo das xícaras de café, das miniaturas das garrafas de licores, dos leques e de muitos outros colecionismos sui generis.

\section{Legenda}

P.54-55 Escultura, mármore assinado E. Battiglia, fins do século i9. Col. Mirante das Artes, São Paulo gailarina, estátua criselefantina de J.R. Colinet, Col. Mirante das Artes, São Paulo

p.56-57 Grupo de estátuas criselefantinas de vários artistas franceses. Col. Mirante das Artes, São Paulo g Painel em veludo de Regina Gomide Graz, gorgorão e changeant prateado. Col. Mirante das Artes, São Paulo g Móvel assinado Gallé, e vaso encamisado em várias camadas de vidros coloridos. No fundo, tapeçaria flamenga do século I7. Col. Mirante das Artes, São Paulo

\section{Istoé\#8, dezembro de 1976, p.80-87 (Cultura: Arquitetura)}

\section{Os últimos dias do CIDAdÃo Chatô}

Assis Chateaubriand,o nosso Cidadão Kane, segundo Pietro Maria Bardi, realizador de uma das ideias mais felizes do próprio Chatô, o Museu de Arte paulista. (chamada no índice)

O nosso Cidadão Kane chamava-se Assis Chateaubriand, o Chatô. Antes de mais nada, jornalista e dono da maior cadeia de jornais e emissoras do País, de rádio e TV. Depois embaixador, imortal da Academia de Letras, pioneiro em muitas atividades e protagonista de muitas aventuras, nem todas boas.

Em 1960, aos 69 anos, sofreu um derrame cerebral que o deixou entrevado numa cadeira de rodas por mais oito, mas não o curou do seu vício maior, o de escrever: para 
tanto, dispunha de uma máquina especial, em engenho fantástico em que as teclas eram conectadas a fios presos nas suas máos. Levava dez horas para escrever um artigo. Há trinta anos ele sonhava em criar em São Paulo um museu de arte. Realizou o sonho convocando uma autoridade mundial em artes plásticas, o professor Pietro Maria Bardi. Trinta anos depois, Bardi ainda dirige o museu que organizou e está escrevendo um livro em que evoca o nosso Kane. Aqui publicamos a introdução e um capitulo desta evocação.

On doit des égards aux vivants; on ne doit aux morts que la verité. - Voltaire, Lettre sur Oedipe

Este é o segundo livro que dedico a Chateaubriand. O primeiro, The Arts in Brazil: A New Museum at São Paulo, (editores: Milione de Milão e Abraams de Nova York, 1956) é a história, até aquela época, da comum empresa de criar o Museu de Arte de São Paulo, fundado em 1947. Trazia na dedicatória uma fotografia do Amigo, considerada irreverente pela classe que gosta das badalaçóes conformistas: Chateaubriand vestido em terno branco, nesses tempos apreciados pelos elegantes dos trópicos, no momento em que ia pôr na cabeça um chapéu de papel, igual àqueles que fazem os moleques para brincar de soldado, ou os pintores de parede para se salvaguardarem dos respingos da tinta.

Tinha, pelo contrário, razóes de sobra para acreditar que aquela página agradaria ao efigiado, do humor e de tudo, até da ironia, o que estivesse além da barreira da normalidade. Julgador de língua solta, homem de espírito, cordialíssimo e, quando calhava, irreverente, brilhante e caloroso, um "quanto basta" para projetar- se com originalidade; de outro lado ponderador consciente de situações, solícito, cortês e até pedante aceitador de tradições.

Disto tudo emergia uma figura que se contradizia com naturalidade: construtor do amanhá, com os pés enlameados do mecanismo do deixa estar burguês, paladino de várias morais, políticas e sociais, e ao mesmo tempo cunhador de sistemas julgados ortodoxos até um certo ponto. Às vezes o considerei como um utilitarista mesmo se a sua ciência de conduta humana não fosse perfeitamente "exata como a matemática." Um generoso. Se, às vezes, houve deviaçôes, isto se deveu ao seu viver aleatório pela estrada dos perigos e riscos, à sua vida característica de instabilidade e inconstância. É lógico, portanto, que este homem, dotado de uma personalidade tão premente e capaz de infatigáveis e tão desconcertantes iniciativas - um daqueles raros que realizam uma empresa de manhá, pensando noutra para a noite - estivesse sempre presente no palco, com uma proposta e uma ação não congênita a uma sociedade de ideais modestos e de tradição conservadora dos proveitos profundamente edonísticos, aparecendo ele, ora como Barrabás, ora como monge penitente. Suportado amado, bem disse dom Helder: aquém do bem e além do mal.

Não me teria supreendido se visse Chateaubriand tomar parte num daqueles fire-walk no Oriente para demonstrar a incombustibilidade do corpo humano; na realidade o vi passar, como uma salamandra, sobre pedras bem mais quentes que aquelas do deus Anguilla de Tui Na Galita da ilha de Suva, em torno do qual girava uma fama-mito, forçando-o a aceitar reprovas e aplausos, permanecendo indiferente a umas e outras.

Imperturbável produtor da vida, meteu-se pelo caminho que lhe era destinado, com o prazer e menosprezo de ter vestido togas de advogado becas de professor, fardas de acadêmico e de embaixador e até de coronel honorário, tight de senador, ao invés de um esplêndido uniforme de cangaceiro costurado pelas gentis mãos de muitas Marias Bonitas.

Escrevo cangaceiro também com a convicção que o meu caro Amigo teria me aprovado ao primeiro instante, e sei muito bem que os moleiróes - aquela companhia que leva rosas à Deusa Ignávia - acharão a definição sem graça. Mas a minha é sim uma narrativa purgada pelas hipocrisias que o bom biógrafo é obrigado a omitir do seu trabalho. E mais: este livro o escrevo para o meu prazer, como penhor de reconhecimento a um homem que tive a ocasião de encontrar, para com ele criar coisas que sobrepujem as nossas pessoas, a despeito dos brancos-de-pés-redondos 
que tentaram, inutilmente fazer-nos malograr em nossa iniciativa.

O cinismo, a ambição, a timidez

"No entanto, o Enfermo começava a descobrir, com estupro, que a mente não estava tisnada."

"O único ponto a favor do seu cinismo era a coragem que se vangloriava possuir a grande."

Domingo sem data, desses que recuam na memória e parecem envolvidos nas faixas que o búlgaro Javacheff Christo usa para empacotar monumentos, entregando-os ao silêncio. Calor denso e opaco. Os colibris da imensa gaiola em frente à Casa Amarela repousam. A cidade náo se mexe, o dia é mesmo consagrado à inatividade.

Encontro Chateaubriand imóvel, deitado na cama dotada de baldaquim e manivelas para ajustar mais confortavelmente as posiçóes do corpo doente. $\mathrm{O}$ enfermeiro, o bravo e paciente Honorato, sentado ao lado, à espera do início da nossa conversação. $\mathrm{O}$ Animador se exprime com gestos, articula as palavras com o esforço de quem náo se dá por vencido. (Criança, quis domar um potro, emaranhando-se no bridão, arrastado mato a dentro persistiu até vencer a fúria do animal.) Vem o café, o Honorato, com uma colher, serve ao dr. Assis e, depois, enxuga-lhe os lábios. Os braços não têm mais ação, a não ser o direito ligeiramente articulável, a máo encapuzada numa luva de couro deixa entrever o dedo indicador, o pulso preso a um elástico ajustado verticalmente do teto: consegue leves provimentos, o dedo percorre o teclado da Olivetti elétrica em busca das letras, conseguindo ao longo de horas compor o artigo que a cada dia ainda escreve para os Diários.

Hoje, mais um. Convidou-me para o almoço. Desejava eu verificar certas citaçóes e completar nomes que, nem através da palavra penosa, nem da composição datilográfica, conseguia acertar. Chateaubriand está lúcido, a memória invejável, o humor de sempre: alternando a risada convulsa e o rosto carregado de dor. Às vezes, poucas lágrimas quando se sentia impotente pela inexorabilidade do mal, ou quando um dos filhos lhe movia processos, publicando a queixa.
Agora o Jornalista pensa só no assunto da sua coluna. Tenta comunicar-me que vai escrever uma nota sobre cinismo e maquiavelismo. Possivelmente o Lima Duarte a vai ler em homenagem a um hóspede ao qual reserva "um jantar do arco-da-velha," para criar notícia. Nossa amizade se estruturou no convívio do bate-papo cultural, desde o primeiro encontro. Ele gostava de história; eu me acantonava no refúgio de um diletante daquele gostar, na definição de Lessing. Em certos momentos imaginávamo-nos transpostos numa severa aula de academia arcádica, mas por momentos mesmo, pois o fato do dia nos recolocava na crônica. O tema, porém, implicava uma excursão nos tempos que se foram.

Sendo o meu presumível gosto pela história, na opinião do Patrão, comprovado por ter publicado, precisamente em 1917, um ensaio dedicado a Geremia Bentham, ${ }^{ }$ele aproveita para revelar-me as extraordinárias empresas de um carioca que andava espalhando a notícia de que fora encarregado por Stalin de colaborar na reelaboração da Constituição russa, da mesma forma como o jurista inglês tinha aceito a incumbência de redigi-la para Catarina, na base do bem e útil casados à maneira epicureia para proporcionar felicidade aos súditos.

Partindo de uma destas ocasióes, o nosso especular se prolongava, sempre através das dificuldades vocais do colóquio, sem dar sinais de querer parar. Assim, por meu turno, conto a história de don Michele Cimorelli, o fanfarrão napolitano que se dizia amigo íntimo de Napoleão, dando como verídico de que o imperador mandava buscá-lo secretamente para lhe ajeitar o plano da batalha de Austerlitz. O futuro vencedor o acolhe assim: - Miché, damne n'occhio a stu campo. ${ }^{2} \mathrm{O}$ estrategista desenrola os mapas, de lápis vermelho corrige as fesserie, estabelece os pontos de ataque e defesa, recomenda de não se mudar nada, e retorna a Nápoles. A espionagem austríaca informa, então, ao seu estado-maior a

I Jeremy Bentham, (I748-I832) filósofo e jurista inglês, em sua grafia italiana. Bardi sempre menciona esse seu artigo, de I9I7.

2 
presença de don Michele; exclamação, em coro: - Estamos fritos! (A expressáo era outra, e vulgar.) Chateaubriand, hilariante, exulta. Da próxima vez lhe levarei, para que o leia, o capítulo Cimorelli dos Aneddoti de Benedetto Croce.

$\sim$

Enquanto o Animador dá uma cochilada, vencido pelo cansaço e pelo calor, corro os olhos pelo ambiente. Fundara e mantinha um museu, mas em sua casa não havia nem arte, nem decoração. Muitos livros nas prateleiras de duas estantes, onde despontava uma quase completa Camiliana. (Homenagem ao português que, como ele, gostava de escavar-se para contar suas aventuras e participação na vida crepitante.) Um retrato seu, pendurado contra o lambris, pintado por uma velha amiga, simpática, mas pobre de capacidade pictórica, tanto assim que a imagem mais se assemelhava a Totó que ao Capitão. (Muitos hóspedes perguntavam por que guardava em sua casa a cara do popular cômico italiano.) A peça mestra, montada num cavalete de três pernas, inclinado: uma estampa em cores de Os girassóis de van Gogh.

No dormitório, um "tableau imbecil," como dizia Picasso: jovem camponesa em costume transilvânico. (As motivaçóes que o levavam a pendurar molduras sempre foram, para mim, indecifráveis. Só num caso descobri o movente: um dia mandou ao museu um lindo Retrato de Dama de Vestier, adquirido na exposição "Retrato Francês, de Fouquet a Prudhon." Soube, mais tarde, que a dama setecentista se parecia com uma sua conhecida. Desentendimentos com a senhora tinham provocado a doação; a reconciliação, uma reentrée em casa, e depois a definitiva colocação no acervo maspiano.)

Nas paredes: fotografias com vistas de fazendas, batismo de avióes de sua campanha para dar asas ao Brasil, inaugurações de emissoras de rádio, senhoras, bois, amigos, diplomas de prêmios ganhos em concursos agrícolas. Eram recordaçôes, em parte transferidas do seu gabinete de trabalho. Uma espirituosa foto de figuras camufladas de índios, que do teto da Tupi ameaçavam com flechas, burlescamente, certos fiscais encarregados de fechar a emissora, já tinha visto na salinha de direção da antiga e mixuruca sede dos Diários, naquele meio-andar obtido graças a um tapume de madeira, no fundo da redação, onde atualmente está o restaurante Costa do Sol, bem em frente ao grande edifício dos Diários à rua 7 de Abril.

Esta era a "pinacoteca" de Chateaubriand. Foi o maior comprador de obras de Portinari. Doou-as todas ao museu, inclusive a Série Bíblica que, outrora, figurava no auditório da Tupi no Sumaré. Apreciava muito o Candinho.

Manhã de bate-papo. O trabalho começa depois do almoço. Tinha dado ordens ao Honorato para que tudo saísse certo. (Quando convidava, em outros tempos, como hoje, alla buona, dizia: - Pegue no armário aquele foie-gras, apanhe o Chateauneuf-du-Pape; quem foi à feira? Hoje, como sobremesa, quero olhos-de-sogra. Um dia vocês viráo comer orelhas de porco com feijão branco conforme uma receita de dom Pedro que o Eça tanto criticou, injustamente, quando o imperador foi a Lisboa.)

Um espetáculo vê-lo nas fazendas, nos bons tempos em que, dando voltas ao redor $\mathrm{da}$ mesa, saboreava os pratos, felicitando a dona da casa e o pessoal do forno e fogão.

- Chateaubriand, e Maquiavel e nossos amigos do cinismo?

- O senhor tem o Cozinheiro Nacional?

Nova digressáo. Possuía um exemplar. Um dia me pediu emprestado para copiar a receita da cobra refogada, carne de sabor mais fino que o da enguia. Queria também copiar o menu do "banquete brasileiro:" 4 sopas, 19 pratos, 5 pratinhos, I2 empadas e uma série de especialidades, para se chegar ao digerível "terceiro serviço," queijos e doces.

Chateaubriand é levado até à máquina. Começa a dedilhar. $\mathrm{O}$ aparelho que guia a máo assemelha-se a um daqueles capuchos que encobriam as cabeças dos falcóes nas caçadas medievais. A testa inclinada, os olhos atentos para melhor ver a tecla a ser batida. Da poltrona ao fundo, observo o Dominador: agita-se para baixar a letra no ponto certo da folha. Bate lentamente como um aprendiz. Jamais se servira antes da máquina, escrevia rápido a mão, meio 
hieroglífico meio taquigráfico. (Certa vez, indo ao México, fui portador de uma carta sua ao nosso embaixador; nenhum de nós conseguiu decifrar o que estava escrito.) As pausas monótonas, as linhas correndo até o retorno automático do carro, o leve zumbido da corrente elétrica se junta aos raros piupius de colibris. Quando um automóvel passa pela rua, o barulho é o de um furacão.

Pensava nas semanas em que Chateaubriand superava a crise mais aguda da paralisia. Não se tinha ainda dado conta do seu estado físico, mas já reagia para resistir e imprimir um impulso capaz de arrancar para sua nova corrida, com destemor acima de qualquer previsão: sede de viver e prepotência vigorosa. (Os urubus agourentos acabavam de levantar voo à procura de outros pastos, e já o Indomável pensava como passar seu dia na pactuação com as possibilidades; lembrava de Ivan Iljitsch no conto de Tolstoi.)

Homem difícil de ser derrotado. O professor Ackermann valeu-se de todos os recursos de sua ciência para aliviá-lo. Em contrapartida ele contribuiu com forças hauridas não se sabe de onde. Penso na sua imensa força de vontade que não conhecia limites.

Tristes aqueles meses. Os boateiros velhacos soltavam notícias catastróficas. O nojo dos interesses que sempre circundam as esperanças de heranças envenenou o ar com nuvens de miasmas vencedoras de todos os repelentes. No entretanto o Enfermo começava a descobrir, com estupor, que a mente, milagrosamente, não estava tisnada. (No evanescente da confusão do raciocínio, dir-me-ia mais tarde, provou a adiçáo de números, invertendo depois os adendos; dando certa a soma, disse para si: bom.) Sua memória, contando com os recursos de todas as membranas do cérebro, estava sempre pronta, como antes, para dar conta do recado. Readquiriu o comando de si mesmo e de seus empreendimentos. E, fenômeno a ser escrito com o carvão branco nos anais da neuropatologia, começou até a pensar em viagens. Contrariando o conselho dos médicos, acompanhado por enfermeiros, reiniciou o seu vaivém entre o Rio e São Paulo. (Quando ainda dono da saúde, de vez em quando fazia esta ponte aérea duas vezes por dia.)

Até pouco antes do jantar as folhas saltavam da máquina. Dos escritos fervilhava sua dialética espirituosa, como sempre de confissão. Estava eu um pouco cético sobre o resultado da combinação cinismo-maquiavelismo. (Diz Chateaubriand que cinismo é atitude adotada na linguagem comum para indicar certos descaramentos, desprezo do conforto e das convençôes humanas.) Eu receava que surgissem lembranças de leituras do seu tempo de doutorado. Chateaubriand, após a fundação dos Diários, com a Guerra no meio, não teve muito empenho para acompanhar a evolução da cultura europeia. Julguei que marcava passo com o remueur d'idées Emile Faguet que frequentemente citava, sustentando teses em que se evidenciavam preferências positivistas. Conhecimento sumário do "Príncipe," menos de outro dioscuro italiano, Guicciardini. Autores difíceis de serem lidos e cujos pensamentos não são fáceis de serem assimilados, que não são reduzíveis ao pigliare l'impresa e ao il fine giustifica i mezzi. (Ficou surpreso quando observei que esta última fórmula não era tâo maquiavélica, como Hegel demonstrou citando o jesuíta Busembaum: "quando o fim é lícito, também os meios são lícitos," mais adequada ao maquiavelismo.)

O Amigo enfrentava com argúcia a demonstração das ideias, às vezes assentindo com a cabeça, outras contradizendo. Não era daqueles que contemporizavam quando era hora de refletir e calcular consequências. (Observei, certo dia, ao Artilheiro, que não deveria publicar a última nota de uma série excessivamente impetuosa, pontuando num alvo carregado de incógnitas e de zonas vulneráveis; lembrei-lhe que Descartes, ao ser informado da condenação de Galileu, prudentemente se absteve de publicar suas observaçóes. Era a época em que Chateaubriand assinava "macaco elétrico,” não economizando machadadas.)

Ao apoderar-se de um conceito, pulverizava-o à sua maneira, amoldando-o segundo a própria conveniência dialética. Desta forma se autodenunciava desprezador, para ele um cínico. Não escondia 
qualquer parcela de mordacidade, e quanto mais corrosiva melhor. Náo esperava a ocasião propícia para mostrar-se descarado, como prescrevia-se no Ginásio Cinosarge, insistindo sobre o cinismo. Sabia levar água ao seu moinho, ambicioso, não respeitava as regras de uma discutível ética vigente na praça. $\mathrm{O}$ único ponto a favor do seu cinismo era a coragem de que se vangloriava possuir a grande.

Os tímidos procuram interromper o círculo do pânico ostentando superioridade e prepotência. Tudo somado, era um tímido que tudo armava para superar a timidez. Sei que isso pode parecer paradoxal a quem o conhecia superficialmente. Eu que o vi tratar com indivíduos de pouca conversa, autênticos cínicos, frios manobradores de negócios, caras de argentários escondidas por trás de um grave ar de águias, aguçando as garras, bem posso testemunhar sobre a timidez de Chateaubriand.

Por este motivo o espírito de Maquiavel mal se adaptava a ele. Aconselha o Secretário florentino a colorir o próprio "parecer ser," e a "ser um grande simulador e dissimulador: e tấo simples são os homens e tanto eles obedecem às necessidades presentes que aquele que nos engana sempre encontrará os que vão se deixar enganar."

— Só vocês italianos sabem ser maquiavélicos.

Respeitava e tinha profunda admiração por quem considerava intelectualmente superior. Um desses afortunados podia convencê-lo do impossível, com facilidade. Se a amizade se confundia com a admiração, o tipo ganhava o templo dos tabus. (Dispunha de um variado número de templos e também de cárceres para hospedar divindades e meia-divindades, ou aqueles de se atirar ao fogo. Para o Polemista nato, a Divina Comédia era o poema ideal porque nele cada contemplado ocupa um lugar definido na base dos próprios méritos ou deméritos. Os templos do Julgador correspondiam, aproximadamente, aos circuitos dantescos, mais tangenciados para o Inferno do que para o Paraíso; o Purgatório reservado a um número razoável de pecadores. Porém, as passagens de uma zona para outra dependiam das conveniências; à brasileira: reconciliação após a disputa. Considerava especialmente mau o avarento. Generoso distribuidor de bens, lógico que desta figura tivesse horror. Fomos, uma tarde, visitar um supermilionário que tinha prometido, após ingentes esforços e as advertências de praxe, doar uma obra de arte importante para o museu.

- É o carioca mais avarento, o pior.

Nem lhe conhecia o nome. O carro chega à porta de uma modesta residência. Entramos, admitidos na presença da "vítima." Eu, como "professor de arte," poderia escolher qualquer dos quadros pendurados na parede. Após examiná-los, o doador, para mostrar outros, convidou-me a subir as escadas que levava ao andar superior. Foi naquele momento que assisti a uma cena de feuilleton: o homem galgava os degraus arrastando- se. Era cardíaco. E o nosso Dante o repreendeu:

- Mas, meu Deus do céu, por que não manda instalar um elevador?

Lembrei a Chateaubriand aquele antigo episódio e a conversa voltou para os problemas do cinismo. $\mathrm{O}$ avarento é um cínico?

- Então o Senhor permita-me, às vezes de mãos furadas, é um cínico? Chateaubriand, o cínico é um taciturno, um misantropo, odeia as comodidades, julga e age pensando ser ele o único a possuir no bolso, e não o interlocutor, a pedra filosofal. O senhor gosta de ideias brilhantes e hoje inventou esta: muito bem, mas o fato é que o senhor não é um cínico mas, digamos, isto sim, que seja um indiferente da moral, que deseja superá-la e até mesmo pisoteá-la, nos casos extremos...

— Mas isto é cinismo.

— Nem por sonho.

\section{Legenda}

p.78 Chatô segundo Wesley Duke Lee, numa obra de pintura-ambiente intitulada "Consideraçôes...," fotografada por Lew Parrella.

p.82 Chatô, já entrevado numa cadeira de rodas, visita uma feira de gado $\mathbf{E m}$ dias melhores, com Danuza Leão, na Festa do Algodão @ Num churrasco em 44 e com Nelson Rockefeller em 47 
p.83 Com Ademar, em Paris, comemorando Santos Dumont Imortal na Academia de Letras, com a senhora Vitorino Freire p.84 O senador Chatô com JK, na revoada dos beija-flores, em $1956 \mathbf{g}$ Voltando de Nova York em 54, e numa photographia de 37

Casa Vogue \#2I, fevereiro de I977, p.8I

ARQuiteTuRa CORRENTE E INTEligente:

P.M. Bardi fala desta casa [em "O mundo só ama os originais;"

Entrevista a Ugo di Pace, por Maiá Mendonça, p.76-8I, I03]

Enquanto as construçóes dos arranha-céus andam se desenvolvendo nos modos do international style ou dos assim chamados estilos "mediterrâneo," “...e o vento levou," e outros ainda mais amenos (aproveitando da situação e que o ridículo tomou férias) as outras construçóes, as unifamiliares, apresentam, nas expressóes melhores, características singulares a serem consideradas elementos corretos da arquitetura contemporânea. Um desenhar que procede do racionalismo de um Rietvelt, Le Corbusier e Neutra, andou criando, nos novos e antigos jardins paulistas, formas interessantes, livres, bem estudadas na planta, dando por resultado não mais a representação ostensiva $\mathrm{da}$ fachada ainda preocupação dos comitentes encabulados em indicar status, mas o organismo funcional, que é o que se pede a um arquiteto consciente. De fato a ele se demanda oferecer condiçóes de boa moradia e não de monumentalidade.
Vejo, de vez em quando, persuasivas construçôes, de aparência externa simples, que logo deixam entrever uma oportuna distribuição interna, elaboradas machines-à-habiter, porém alegradas de requinte e consequente pingo de extravagância. Noto, bem acondicionado, este conceito (do desligamento dos velhos cânones próprios dos palacetes ainda oitocentistas e do insistir na procura de novos caminhos) na casa de Vera Andraus: jouet-à-habiter. Cada ambiente é ajeitado com e na intimidade, não se importando com a aparência - materiais à vista, respeito e integração da natureza, justa medida dos espaços considerados participantes do espaço total - confortável. Afinal: uma residência onde a gente, não mais inquilina da simetria, se sente em casa, na de hoje, pensando que a Arquitetura se não é a princesa das artes, como pretendia Vitruvio, é arte nobre, quando é praticada com coerência e inteligência.

Homem Vogue \#2IB, fevereiro-março de 1977, p.I6 (Entre Homens)

BOM GOSTO (I) E CONSIDERAÇỐES SOBRE MAU GOSTO (II)

Nem todos carregam na vida a cornucópia do bom gosto, pois ela é pesada para a grande maioria: contém uma quantidade de coisas, cada uma delas entrelaçada a outra, exigentes, pernósticas, seríssimas, formando um estilo apoiado, antes de tudo, no caráter. Se um carregador não tiver caráter, que não carregue a cornucópia, mas apanhe o tambor do mau gosto. (E será mais feliz, pois este é a tiririca das relaçóes humanas, e ninguém faz caso às excentricidades do bom gosto.) A cornucópia não está mais em moda. Há, porém, solitários que a defendem do desprezo geral. Outro dia, um do tambor, disse-me: "Imagine, Bardi; há imbecis que propóem abolir as businas dos automóveis; como eu poderia chamar os meus empregados para me abrirem o portão da garagem"?

Quando abrimos o Mirante das Artes há uns dez anos, uma das primeiras exposiçôes inaugurais foi dedicada ao Art Nouveau. $\mathrm{O}$ insucesso foi digno de se escrever com carvão branco. Ainda o Art Nouveau era considerado "mau gosto," tanto que o respeitável público classe A desempoeirou peças de Gallé e de Daum para vendê-las ao excêntrico que, em 1947, adquiriu para o Museu de Arte de São Paulo dois grandes e belíssimos vasos daquele excelente gosto então castigado; e para a sua coleção particular um portão floreal que estava à venda como restos de demolição de um prédio Art Noveau à rua Major Sertório.

Geralmente quem opina sobre arte é sempre alguém fora do ramo. Mexer 
neste complicado labirinto dito Arte continua sendo assunto de poucos, cultivados e interessados nas oscilaçóes do gosto. Julgar é difícil, pois precisa-se conhecer a história e prever o que vai acontecer. É impossível explicar isto a quem tem língua na boca para falar.

Agora ouço pronunciar a palavra kitsch em lugar de mau gosto. É evidente o mau gosto dos que não sabem que as duas locuçóes se referem a duas coisas distintas. Perder tempo com estas senhoras e, na verdade menos com os senhores, que bolaram de mau gosto a minissaia para depois, uma vez que a moda a prescreveu, minissaiar até se as pernas não eram as de Marlene Dietrich; perder tempo não vale a pena. Todavia é bom recomendar aos senhores e às senhoras, quando frente às produçóes das artes (a moda é o protoplasma da arte) procurar ajeitar a boca à do siri mudo.

II

A propósito de mau gosto: em 48 a grã-finagem de São Paulo se reuniu no antigo
Trianon para um baile excepcional. Seu título era Baile do Mau Gosto, um juri presidido por Alberto Cavalcanti, que voltava ao Brasil após trinta e cinco anos de ausência, foi incumbido de outorgar prêmios vistosos às fantasias mais originais. Raríssimos os gringos convidados; Lina e eu fomos da turminha admitida.

Nunca tinha assistido antes a espetáculos similares, pois sempre detestei reunióes sociais onde se perde tempo ouvindo bobagens. De qualquer modo difícil era recusar um convite vindo do Chateaubriand. Na verdade o Baile interessou à Lina para um ajuste de contas: desejava caricaturar certa senhora da alta que se tinha comportado conosco contrariando as prescriçóes do Monsenhor della Casa. A mascarada foi perfeita porquanto mau digerida. O primeiro foi decretado para a arquiteta Lina Bardi; um belíssimo faqueiro até hoje usamos e, me parece, oferecido por Baby Pignatari.
Demorou, mas agora a constatação de que a Urbanística não é mais uma ciência-arte restrita aos limites de uma cidade vai ganhando terreno. Há já quem fale em território mais amplo, como se deu no caso de se considerar, ao invés de São Paulo, a Grande São Paulo. Com um pouco mais de reflexão e vai contemplar-se, um dia, num único plano urbanístico o território do Estado. O que não daria em nada, se o plano não for parte do nacional, com todas as implicaçóes de ordem demográfica, econômica e, em última análise, política.

Será possível, um dia, mexer-se nesse projeto? Aquele que, através de um mutirão, produz uma das inúmeras casinhas nas vilas, na ou longe da periferia, à espera do asfalto-luz-água, é também contribuidor da Urbanística, assim como é o presidente que manda riscar de estradas a Amazônia: todos contribuem para sistematizar, desfrutar e organizar o território. E o poder econômico livre, ou quase livre, para erguer os espigóes onde bem entender, ou poluir o ar de um vilarejo, ou para despejar veneno nos rios? Dizem: são as etapas e os tributos ao progresso, meta inarredável da humanidade, que não cuida de salvar vidas da fome, mas prossegue na fabricação de ingredientes bélicos. $(\mathrm{O}$ senhor Carter quer vetar o projeto nuclear do Brasil, mas promete contratos de bilhóes e bilhôes de dólares para os Estados Unidos exportarem mais armamentos.)

$\mathrm{O}$ que tem a ver tudo isso com a Urbanística? Muito: o aparelhar um território para o conforto de seus habitantes significa, antes de tudo, pensar no homem e saber e definir o que o homem quer. Náo se trata de desenhar o traçado das ruas de um dos numerosos parques dos Cisnes, Vertentes e Portais, e bolar (e infelizmente construir) as favelas de luxo. Trata-se de resolver o problema das favelas. Depois a posição e a tristeza da vida desses povoados até a ofensa a eles votada pelos demais, exageradamente abastados, a Urbanística é a responsável pela qualidade da vida. Produto de um sistema corrente de leis e de costumes, herança ainda de tempos incrivelmente atrasados, (também produziram-se profetas 
de tempos que devem mudar) a Urbanística, nas escolas comunais, está nas mãos do burocrata que recebe ordens do poder.

No que se refere às circunstâncias da cidade, demonstramos no ano passado, numa exposição realmente dramática, no Masp, quais as condiçóes da Urbanística na Grande São Paulo: penosas, a começar pela carência de verdes, das tragédias das inundaçōes, das crianças abandonadas à própria sorte, da cultura sem donos e sem freguesia.

Tratou-se, sem dúvida, de uma denúncia: o povo pôde escrever, numa parede especialmente reservada, o que pensava. E disse coisas duras. Porém tudo ficou como estava. Não se discutiu; os jornais hospedeiros de reclamaçóes populares para os buracos das ruas (especialmente se na rua mora um pistolão) não comentaram; os repórteres de televisão, geralmente ocupados no pedir opinióes, se vence o Palmeiras ou o Coríntians, não apareceram; e cosi fan tutti. Parece que, no Brasil, os problemas da cidade são problemas resolvidos. (Por quem manda.)

Homem Vogue \#23B, abril-maio de 1977, p.I4 (Entre Homens)

Como ler a FóRmula de Einsten

"Gosto," "não gosto," "gosto menos," "gosto mais," "gostaria se," "verdadeiramente é menos que zero.” São algumas opiniôes que geralmente se ouve de fulanos que julgam uma obra, ou mini, ou náo-obra de arte. $\mathrm{O}$ registro dos pareceres é o mais variado. A frase mais comum, quando o objeto é passível de julgamento, é uma pintura de autor não canônico no compor figuras, é: "Também meu filhinho é capaz de pintar assim.” E, às vezes, trata-se de obra-prima de Picasso, ou - para não sair do gramado local - de um autêntico como nosso venerando e amado Volpi.

Julgar depende de mil e uma coisas: cultura, ambiente, humor e gosto. Náo bom gosto: encontrei, na minha longa experiência, perfeitíssimos Lord Brummel, aqueles que podem atravessar Londres (não digo São Paulo porque as calçadas não permitem) sem serem notados, tão impecáveis e discretos eram em sua elegância, isto é, na medida esteticamente calculada e certa; e, todavia, órfãos desta quimera que se apelida de gosto, não entendendo bulhufas deste outro divertissement que se apelida Arte. O caso é generalizado, espraiando muito mais do que se pensa. É comum ouvir-se a frase "de arte eu não entendo," e observar-se um pessoal indiferente, fechado em si, os olhos desviados daquilo que se apresenta. E se trata de gente, às vezes, culta e alinhada, que sabe escolher uma gravata, sugerir uma linha de corte ao alfaiate, personagem que você encontra no Salão do Automóvel, preocupadíssimo com a escolha de um carro de nova linha,

pois a do ano precedente já está fora da moda, discutindo a cor dos assentos.

Curioso: a mesma gente não vai ver exposiçôes de pintura (é verdade que a inflação das exposiçóes e da pintura quase supera a monetária) nem se a patroa dos mesmo é enfronhada no processo estético (ou mini, ou a-estético) e insiste. Preferem a boate, o coquetel em casa dos amigos, a jogadinha inocente ou de máo na carteira.

Há algum tempo chegou no Masp, ilustre grã-fino, inteligente, um desses tipos tão ricos de simpatia que enche uma catedral. Confessou-nos que ganhou como presente de casamento um quadro que jamais pendurou na parede, pois o achava "horrível." Desembrulhada a peça, perguntei-lhe: por que o acha horrivel? Resposta: porque náo gosto.

Iniciada a confissão o tal acabou elucidando que "de arte não entende." Mostrei-lhe a fórmula da relatividade de Einstein que sempre trago no bolso: conhece estes números e letras? Respondeu-me: Não, o que representam?

Então, cordialmente, concluí: para julgar é necessário conhecer.

Sei que o postulante andou espalhando: o diretor do Masp é pessoa esquisita. Fiquei contente por ser verdadeira tal inquinação. 


\section{Istoé \#15, 6 de abril de 1977, p.46 (Cultura: Arquitetura)}

\section{NAS FACHADAS, A NOVA MODA FOLIONA}

Bem ou mal, a arquitetura brasileira sempre foi ajeitada nos moldes da europeia, estilizando-se do barroco ao neoclássico, do melange oitocentista até o racionalismo, segundo os ditames vindos de fora. As iniciativas visando a uma autonomia não foram numerosas, e se deram somente na arquitetura espontânea, aquela sem consulta do Vignola para resolver problemas de função e não de estética; a estética aparecendo consequência.

O casarão do padre Inácio, perto de Cotia, próximo a São Paulo, antes das modificaçóes e restauros, representava um organismo a ser inscrito na das construçôes como invenção aqui brotada; como esse casarão jesuítico, tantas casas podem ser inscritas na história daqueles tempos, quando ainda não haviam chegado os desenhos das igrejas preparados pela repartição romana da Companhia de Jesus, preocupada com o efeito, sem ter em conta que o destino do produto era o trópico, e não Portugal. E a mãe-pátria operava na mesma: desenhava arquitetura não para a que então se constituía em povo novo, mas para português ver e, eventualmente, lá confessar seus pecados e receber gratia plena.

Fantasia. O caboclo sem cachorro com gato mesmo, arrumou sua maloca, economizando madeira e aperfeiçoou o invento da terra batida, até a impermeabilizou, no litoral com óleo de baleia; como coisas de arte (porque esta devia estar presente, conforme as prescriçōes), caprichou nas cruzes e símbolos da Paixão, esculpiu a Nossa Senhora e o Cristo deposto, sem nunca saber que era fachada. Ainda o barroco disputava a palma com os maneiristas da Renascença. Felizmente, entre uma floresta e outra, matando uma sucuri aqui e uma onça acolá, a existência era árdua, audaciosa e sadia. Sadia também no que se referia às construçóes.

Depois, as coisas mudaram. Desembarcou o arquiteto de Lisboa. Vieram os séculos do desenvolvimento, até a chegada dos fugitivos dona Maria e d. João vi, e o barroco foi à glória, seguido posteriormente do neoclássico, e o restante da história já é fato conhecido.

Tempos modernos: importam-se os modos do racionalismo e da reação contra o enfeite decorativo da fachada. (A planta é a mesma de sempre, automaticamente copiada das precedentes.) Então: vamos tirar até a última moldura, qualquer friso, para que a fachada fique lisa e branca. Nem as janelas podem ter um leve tímpano. A ordem é pureza de linha.

E os anos passam. A decoração fachadesca jogada porta afora, olha lá, entrou pela janela. E, nos anos em que o símbolo da arquitetura é o cilindro misterioso de uma usina nuclear, eis a farra de caprichar janelas. Nem no último carnaval viu-se tanta fantasia, aliás parece que as construtoras esperam o evento nacional dos gladiadores do samba, que, por sua vez, está obscurecendo os gladiadores da bola, para se inspirar no brilho das fachadas da nova arquitetura não mais mediterrânea, porém francamente foliona.

\section{Legenda}

Nas nossas fachadas, o estilo

tropical-mediterrâneo-carnavalesco

Istoé \#I6, I3 de abril de 1977, p.46 (Cultura: Arquitetura)

A CASA-CONCHA, QUE PODE SER FEITA POR VOCÊ MESMO

A moradia dos pobres sempre foi problema sem solução, apesar de ter implicado inúmeros profetas, inventores, legisladores, sonhadores e burocratas. As soluções não saíram, pois o problema não é de construção do abrigo, ou do familistérío de Fourier, ou uma daquela piada siglada BNH; o problema é outro: mudar o panorama econômico e, por consequência, mexer no político, instaurar uma consciência coletiva e criativa de um outro modo de vida. O que é pedir demais ao homo sapiens, capaz, de ir e voltar da Lua, e incapaz de liquidar as favelas.

Por isso, cada vez que recebo um convite para um congresso-conversa dedicado às habitaçóes populares, ou recebo um volume sobre a industrialização da construção, (o último foi de Paulo Bruna - Arquitetura, 
Industrialização e Desenvolvimento, editora Perspectiva) penso mais uma vez no desperdício de tantas energias que, empolgadas na técnica, perdem de vista o problema básico, escondendo a cabeça na areia, para o corpo não ser visto, à imitação do avestruz.

Quimera. Digo isto a um jovem arquiteto, autor de um projeto de domos populares.

Encontrei muitos elementos desta categoria, de generosos visionários e reformadores de mentalidade. Sérgio Prado me parece invulnerável aos ataques fatais e tentadores da situação, entusiasta por convicção de estar no concreto de uma convicção calculada e experimentada, e por ter viajado muito, visto, conhecido e avaliado o que se produz e se pensa nos centros de discussão europeus. (Não que, no Velho Mundo, as soluções de problemas brilhem, mas, pelo menos, foram colocadas.)

A proposta de Sérgio Prado é um domo que nada tem a ver com a estrutura da casa há milênios, feita de paredes e cobertura. Tem, sim, os dois elementos, mas são de uso variado, de montar, desmontar, aumentáveis e componíveis ao gosto: um passo adiante da machine-à-halbiter de Le Corbusier. (Na Universidade de Sttutgart, Alemanha, um grupo de trabalho está empenhado em soluçóes parecidas.) Composta de elementos pré-fabricados alla buona, com materiais leves, não produzidos por operários especializados mas por gente do mutirão. Dispóem-se as peças que podem ser feitas dos mais diversos materiais: madeira, ferro, cimento, fibras naturais, materiais de fácil usinagem, palha prensada, derivado de lixo industrial inoxidável, soldam-se as peças com nata de cimento ou resinas, ajeita-se a defesa dos agentes atmosféricos.

Conchas. O sistema de construção é estudado para que qualquer um possa fazer, mesmo sem preparo técnico, suficiente preparo tradicional de um artesanato-prático-nativo qualquer. (Aécio Gil Borsoi, cm Pernambuco, há uns dez anos, propôs um sistema similar, bastante econômico, com o emprego da taipa e elementos pré-fabricados artesanalmente.) O sistema proposto, devido à sua simplicidade, permite que esses conhecimentos específicos dos usuários sejam absorvidos e desenvolvidos. Este ponto é fundamental, pois o custo de uma obra é composto por duas grandes verbas iguais: o material e a mão-de-obra; (em 1975, os custos desta habitação industrializada, totalmente equipada, luz, água, equipamentos correspondia a menos de I/3 do mínimo previstos pelo BNH) por esta razáo o sistema proposto permite ao morador construir sua casa pela metade do custo, sem ter que fazer economia ou utilizar materiais não adequados ao projeto.

A forma circular, esférica, do domo propóe um espaço único, central, amplo, que confere um aspecto de individualidade, do indivisível. O espaço é organizado, dividido em duas áreas principais: a entrada, luminosa, aberta, coletiva, onde se encontra a sala, cozinha, o convívio, e, passando como num caracol, chega-se ao espaço individual, do recolhimento. Há uma soluçáo de continuidade entre esses extremos. O primeiro, o coletivo, é claro, aberto (para fora e para cima), o segundo é, naturalmente, escurecido, íntimo. A planta tem referências a conchas (proteçãointeriorização) e a comunicação-exteriorização (cornetas-alto-falantes).

À parte escura, íntima, corresponde o silêncio e, à medida que se progride, amplifica-se o som, a luz, o espaço: a porta é alta; à saída da casa corresponde uma abertura, ampla, a indicar que a partir desse ponto tudo aumenta, projeta-se; os dois elementos correspondem à introversão e à extroversão, o íntimo e o coletivo.

\section{Legenda}

O projeto de Sérgio Prado, no papel e já executado: dois espaços, o íntimo e o coletivo.

Istoé \#I7, 20 de abril de I977, p.46 (Cultura: Arquitetura)

O "Pot-POURRI" QUE SE CHAMA DE MEDITERRÂNEO

Conversava recentemente com um ingênuo que dizia morar em um novo prédio implantado numa certa vertente, quando, por coincidência, recebi uma carta em que o missivista me dizia ter lido num diário de São Paulo o lançamento de um novo arranha-céu em "estilo mediterrâneo." O plano e a localização agradaram-lhe 
e, ato contínuo, procurou o corretor de plantão o qual exibiu reluzente maqueta do edifício. E por ser completamente leigo em assuntos de estética, perguntou se sabia de alguma notícia a respeito daquele estilo.

O corretor, exibindo lábia propícia à circunstância, fez saber que, ao longo das costas do mar para onde convergem três continentes, a arquitetura é marcadamente mediterrânea, caracterizando-se pela simplicidade, pelo arcado das janelas, pela espaçosidade, pela altura das paredes e por numerosas outras particularidades, coisas que todas as pessoas cultas conhecem.

Para não passar por inculto, o curioso, articulando o providencial pois não, despediu-se, e lembrou-se de pedir luzes ao colunista. Queria alinhar-me entre pessoas incultas, pois apesar de ter nascido a uma centena de metros das águas que Platão chamava de "estanho dos sapos," nunca ouvira falar de um "estilo mediterrâneo." As costas deste mar são habitadas por povos de raças diferentes e cujas manifestaçóes construtivas mudam de terra para terra, dando origem a tipologias diversificadas, tanto na antiguidade como na contemporaneidade.

Conjuntação. Na própria Itália, os trulli das Apúlias, apesar de ter sido esta região uma colônia grega, nada apresentam de similar com a construção que se vê na Grécia. Estou confrontando moradias populares e não monumentos, pois parece que as ordens arquitetônicas estão fora da cogitação do corretor: nas mansôes, nos prédios de trinta andares etiquetados de "mediterrâneos" na desvairada São Paulo e, brevemente, no Rio Janeiro (pelo menos lá existe mar que não é mar mas sim oceano, com idas e horizontes, e não as chiare dolci fresche acque do rio Pinheiros) não são vistos tímpanos e colunas.

Eu apelidaria de "estilo mediterrâneo" (naturalmente com a premissa de alguns "pseudo") a certas fachadas. Na verdade, trata-se de um pot-pourri dos estilos, ainda correntes, como "E o Vento Levou..." o "colonial norte-americano," o "georgiano" como os imobiliaristas os chamam.

Pelo menos nestes partos cesáreos dos nossos escritórios que se dedicam à elaboração das fachadas para deleite dos ignorantes, são mostrados elementos que de longe nos transpóem a sombra da Acrópole de Atenas, que definiria a "arquitetura mediterrânea."

Mas o que têm a partilhar com Péricles e com Ictino aqueles executivos de negócios e fachadistas estereotipados, que tapeiam descaradamente, inserindo slogans mediterrâneos - "agora novo mediterrâneo," "mediterrâneo de luxo," "mediterrâneo autentico" - em páginas inteiras para enlear, entre outros, o desprovido leitor que me escreve? Há alguns anos, quando o desenvolvimento ainda não era computado eletronicamente, estilo era o "colonial." Muito mais sério.

\section{Legenda}

Estilo "mediterrâneo:" tudo vale

Istoé \#I8, 27 de abril de I977, p.40-4I (Memória)

Don Cicillo, um Matarazzo nas artes

Era um Matarazzo e gostava de arte. A soma de bom gosto e dinheiro costuma apresentar um único resultado matemático: o mecenato. E assim foi Francisco Matarazzo Sobrinho: um Mecenas bem-sucedido. Em I95I, achou que São Paulo merecia safar-se de seu inculto torpor provinciano - e criou a Bienal. Desde então, Bienal e Cicillo se tornaram nomes quase sinônimos. Ele era a Bienal. E a Bienal era Cicillo. No domingo, dia I7, aos 79 anos, ele morreu. O crítico e museólogo Pietro Maria Bardi conta quem foi esse homem.

$$
\sim
$$

Presume ser ainda muito cedo para se emitir um juízo bastante adequado sobre a breve história das atividades culturais em Sáo Paulo, muito particularmente no que se refere à Bienal e, por analogia, ao seu fundador e animador, o Franciscano Cicillo, figura querida e respeitada na pauliceia efervescente do pós-guerra.

Desde que começou a tomar corpo a iniciativa de Assis Chateaubriand, com quem combinei a criação do Museu de Arte de São Paulo lá pelos idos de I946, e com sua inauguração em outubro do ano seguinte, portanto, ao longo de trinta anos, tive ensejo de várias vezes me encontrar com Cicillo. Este, por seu turno, também resolveu interessar-se 
pela solução dos complicados problemas das artes de uma cidade que, depois dos primeiros passos da Semana de 22, apresentava-se na cena como corista do "Nabucco" de Verdi: cantando "partian, partian, partian," porém sem sair do local.

Deve-se creditar a Cicillo, imitador e correligionário do mago Assis, fatos notáveis como o da fundação do Museu de Arte Moderna e da Bienal: o primeiro foi por ele próprio posterior e inopinadamente extinto, ocasionando não-tranquilas reaçóes dos sócios; a segunda depois foi deixada à matroca.

Com bar. Como disse, encontrei-me inúmeras vezes com Cicillo. Com tão cordial e ao mesmo tempo respeitoso relacionamento, certamente nunca me passou pela cabeça exercer aquela profissão tão comum na diplomacia provinciana, qual seja a do puxa-saquismo condimentado com "traiçôezinhas" e nunca se dizer realmente o que se pensa. Mesmo tendo com Cicillo as mais cordiais relaçóes, jamais deixei de censurar - e o fiz por palavras, atos e escritos - o tipo de política que exercitava em relação às artes locais, como ainda apontava erros cometidos pelo carrossel dos seus inumeráveis assessores.

Para mim, a constituição do MAM, pouco depois de Sáo Paulo passar a contar com um museu moderno, (pinacoteca com Picasso, Chagall etc; seção didática para explicar as coisas a um público ainda desinformado; sala de exposiçóes onde eram exibidas, em retrospectivas, obras de Anita, de Fiori, ou Calder, ou Morandi etc; auditório para conferências, abordando temas de arte, de poesia, para se ouvir música, como para se ver cinema etc.) foi um gesto típico de amizade de onça, tanto mais agravante pelo fato de Cicillo procurar instalar o novo museu no mesmo prédio e pavimento onde já estava funcionando o Masp, gerando, quase sempre, não pouca confusão.

A cidade, na época, não contava sequer com uma galeria de arte, com raros ateliês de pintores contemporâneos - os poucos existentes eram acadêmicos. Um grande artista como Lasar Segall ficava isolado na rua Afonso Celso; a Pinacoteca do Estado, bem pobrezinha, sobrevivia sem publicaçóes especializadas. Eis, na verdade, o quadro por demais triste mas imperante na urbe piratininga em relação à arte; por outro lado, a situação cultural era um pouco melhor, tanto assim que alguns entusiastas apelidavam, ignorantemente, a metrópole de "Atenas do Brasil." Repetindo: para mim, dois museus, e, no mesmo local, era uma aldeianada, e ainda soa nos meus ouvidos a assertiva de alguns que intitulavam um museu, onde existia um bar, de Museu do Bar e o outro o Museu do Bardi.

Mastigar. Depois presenciamos a destruição do Trianon, a construção do mostrengo arquitetônico do Ibirapuera, dos carros carnavalescos do IV Centenário e quantos outros acontecimentos aos quais Cicillo emprestou seu entusiasmo e para os quais conseguiu vultosas verbas dos poderes públicos. Numa cascata cadenciada e rotineira foram rolando as Bienais, que, na verdade, se constituíram em fato de grande importância pela charmosa voluntariedade da entáo esposa do animador, dona Yolanda, que conseguiu, juntamente com o saudoso Arturo Profili, alinhar exposiçóes dos mais famosos nomes.

Algumas Bienais foram efetivamente excepcionais, apesar do ofensivo slogan dos "Io km de pintura," bem assim da apresentação de quantidade desproporcional de produçáo de artistas locais improvisados.

Um fato positivo foi o intercâmbio com a Bienal de Veneza e na qual foram apresentados inúmeros elementos, especialmente das turminhas devotadas à situação, sendo que Lasar Segall somente figurou em Veneza após sua morte, e assim mesmo graças à minha iniciativa, já que nunca tinha sido contemplado pelos manda-chuvas que nunca viram com bons olhos seu relacionamento estreito com o Masp.

Ao passo que a Missão Francesa de I8ı6 obrigava os alunos da Academia a estudar ao longo de cinco anos, a Missáo das Bienais oferecia a fórmula do Abstrato para se tornarem artistas com impressionante rapidez, cogumelando a praça de iludidos.

Escrevi na revista Habitat que na política das artes, em São Paulo, se estava pondo o carro antes dos bois. Doutro lado, o maior sociólogo norte-americano, Harold Rosenberg, no Art News, sob o 
título "Vanity Fair," tendo assistido à inauguração de uma Bienal e vendo um autêntico poleiro de senhoras exibindo toaletes vistosas, banalizando com frívolas conversas e dando as costas às obras expostas, chegou à conclusão de que Sáo Paulo devia ainda mastigar (como deve ainda) para assim poder armar um status cultural no setor.

Panorama. As Bienais, a meu ver, se aprofundaram mais no prestígio advindo das festas, festividades, merendas, coquetéis etc., do que na função didática precípua de explicar aos visitantes o que estavam vendo (sem se falar daquelas monitoras instruídas para dizer besteirinhas configuradas em xerox. Às Bienais faltou a comunicação, o ensinar. Pensava-se que um público enamorado das naturezas mortas de Pedro Alexandrinho poderia entender o Cubismo de Léger.

Sei, naturalmente, que este depoimento não irá agradar aos felizardos que, pelas mesmas razóes acima ditas, têm opinião contrária. Todavia, permito-me afirmar que, se as verbas vultosas que Cicillo, magistralmente, conseguiu dispor ao longo de anos tivessem sido concentradas num plano mais propício a uma cidade ainda tímida em relação aos problemas das artes, um plano sem vedetes, ponderado através de pesquisas e amadurecido como empreendimento de real utilidade, certamente nos dias que correm as coisas estariam encaminhadas para melhor.

Ao invés, tivemos o contínuo surgir de minimuseus (que gentilmente chamam de Maspinhos) sem públicos, a Bienal em crise, novas e opulentas repartiçóes públicas de pesquisa náo-pesquisantes, e os leilóes onde os apostadores da loteria artística continuam, semanalmente, a comprar assinaturas a peso de ouro, desprezando as obras dos jovens talentos. Este é o panorama.

Cicillo deixa como legado um organismo. dotado de conspícuos meios financeiros, para o incentivo das artes e da literatura. Presidido por uma personalidade da estatura do prof. Lucas Nogueira Garcez, esta instituição contribuirá, sem dúvida, para ativar a cultura e recordar o nome de um benemérito que, com o sr. Chateaubriand, muito se esforçou para levantar o interesse pelas artes. Os dois voluntariosos, caso se dessem as mãos naqueles idos dos anos 40, certamente poderiam ter feito coisas do arco-da-velha pela cidade de São Paulo.

Mas isto é uma outra história. Hoje, aqui, limito-me tão-somente a reverenciar a memória de um homem de bem.

\section{Legenda}

Cicillo em seu mundo, com sua mulher, Balbina, a última foto, com o ainda governador Juscelino; e cercado de obras de arte

\section{Homem Vogue \#25B, junho-julho de 1977, p.io (Entre Homens)}

\section{NO DECOR MATRIMONIAL}

Dias atrás assisti a um comercial de um casal que praticamente ainda estava em lua-de-mel. O pomo da discórdia era que a mulher queria um fogáo belo, enquanto o marido queria apenas um fogão funcional. Evidente o costumeiro contraste entre quem torce pela beleza e quem por ela pouco se importa, preferindo mais solidez, o robusto, o racional, o econômico etc. $\mathrm{O}$ casal, afinal, vai para a mesma cama e, ao invés de praticar amor, continua discutindo até chegar à conclusão de que o fogão é perfeito esteticamente e ao mesmo tempo perfeito tecnicamente. Assim: desquite evitado e marketing para ingênuos digerir.

Esta disputa é comum nas famílias. Uns só veem o exterior das coisas enquanto outros se preocupam só com o funcional.
Ainda na TV, outro casal: a mulher que foge do marido, tira do carro dele (uma Mercedes) uma montanha de malas e passa-as para o seu, um Fiat-I47. E antes de dar a arrancada a mulher pergunta: "Náo vai dizer nada?" Ele perplexo: "Como é que coube toda a bagagem?” Trata-se, evidentemente, de um sujeito que nem sabe o que é poesia, arte e afins, tão frio que náo leva em conta a estética, o lado da beleza, mas tão-somente a praticidade. No último Salão do Automóvel, mais uma disputa de casal, qual a troca de um carro. Ele se dispunha a trocar porque o motor dava evidentes sinais de velhice e consumia combustível em demasia; ela por achar que de há muito a máquina estava fora de moda, repetindo o slogan: "Cada ano troque o seu 
automóvel.” (Entre parênteses: uma das bases do consumismo norte-americano.) Assim queria o zerinho-zerinho para se pavonear, pouco se importando quanto à mecânica do veículo, o gasto do combustível e outros assuntos tão correntes em nossos dias, mas que para ela pouca importância tem. Briga. Quando o casal enfim se pôs de acordo e tudo parecia pacífico, ele, distraidamente, falou ser a cor cinza a mais conveniente e prática, pois a poeira quase não aparece. Ela recomeçou a lide. Queria um carro de cor vermelha, maculada de filetes brancos. Para náo provocar escândalo no stand apinhado de público, ele anuiu. Mas veio à tona o som da buzina: ela não queria o som comum dos automóveis, mas sim uma buzina que emitisse os acordes da Traviata, de Verdi, para assim se destacar quando em tráfego e chamar atenção, como uma dama da Classe A.

Dizem-me que histórias deste gênero são comuns nas mansóes onde quem manda é o decorador. A maioria dos elementos desta benemérita categoria de déspotas discute, às vezes ao longo de meses, para conciliar as duplas já que o dono quer isto e a dona aquilo, particularmente quando se trata de pintura que fica bem (ou mal) sobre o sofá de três ou então de quatro lugares, milimetricamente. Em geral o paciente esteta deixa os dois se cansar das gritarias e, quando se reconciliam em nome do bom gosto e da praticidade, o homem do décor, diplomaticamente, pronuncia a única frase latina que sabe: "De gustibus non est disputandum."

Homem Vogue \#25B, junho-julho de 1977, p.92-96 (Caderno de Ficçáo)

O Grande InCÊndio: Sáo Paulo, 26 de Maio de 2089

Ninguém conseguiu saber, ao certo, como se deu o princípio daquele incêndio, que ficou na lembrança de muitos, como uma catástrofe, a ponto de ser comparada como a que destruiu Pompeia. Ocorrendo o aniversário da imensa fogueira, houve comemoração com mais gala do que aquele evento do passado, pois ocorria o centenário e, apesar destas festas não estarem mais na moda, as autoridades fizeram questâo de rememorar o Grande Incêndio da Antiga Pauliceia. A iniciativa foi da secçáo local do PCP, sendo orador oficial o secretário geral Toni Parhzmekew, o qual, em seu quilométrico discurso, recomendou ao proletariado ter muito cuidado no uso do fogo, advertindo também que os descuidos podem até mandar pelos ares a central nuclear de Engenheiro Zagafohu. (A antiga Campinas, rebatizada em 2068 com o nome do inventor do cigarro a combustão automática, inodoro e incombustível.) O medo de fogo, depois do GI, é ainda sério: metade da população ingere mantimentos frios e leva no bolso um mini-extintor nuclear, as TVs diariamente repetindo filmes de propaganda, ensinando como prevenir-se contra incêndio; proibição, por lei, do uso de fósforos; (o isqueiro agora tornou-se objeto de museu) cada vila possui seu posto de bombeiros. Mas nem todo mal aparece para chatear: após o GI, os donos do vapor decretaram vários e oportunos feriados e assim o dia do GI ficou sendo a data da tragédia; o Dia do fim do GI; o Sétimo Dia do GI; o Dia da Comemoração das Vítimas do GI; e mais dias, que náo se sabe se por acaso ou por manipulação interesseira, que coincidem com quintas-feiras, possibilitando assim convenientes pontes.

No discurso do Toni, estas regalias de feriados foram apontadas como conquistas sociais. Não faltou censura à lenda de que a coincidência das quintas-feiras pudesse ser atribuída à Providência, como bem espalham as mixurucas reminiscências dos nostálgicos carolas. Veementemente Sua Excelência (os títulos deferidos aos eminentes foram mantidos, pois, apesar de todos serem iguais, chefes são sempre chefes), o secretário, assim se manifestou:

"Companheiros dos Campos, das Oficinas, da Burocracia, das Milícias, do Bem-Estar, acuso como mentirosos e como fascistas os ainda ignorantes que acreditam nas bagatelas da superstição. O negócio das quintas-feiras é mera coincidência materialista, uma vez que Karl Marx falou muito claramente a respeito. Se vocês querem saber mais sobre o crepitar das chamas do fatal GI, eu lhes digo que não foram só as imagens das igrejas que não se queimaram. Salvou-se também a única cópia do $O$ Capital, que a então metrópole dos herdeiros da Colônia e dos imigrados, famélicos em acumular 
dinheiro, possuía. Aquela bíblia foi o único objeto preservado do fogo, como uma imaculada salamandra. Não acreditem em fantasias, sejam materialistas, unidos no credo marxista. Cada um de vocês deve se sentir como um bombeiro, apagando as chamas destruidoras de possíveis oposiçôes, alimentando, porém, no coração, a flama do amor para com a Situaçáo.”

Como de praxe foi entoado o hino (aprovado pelo Comitê Central) com as seguintes estrofes:

\section{Juventude, Juventude, Primavera de futuro, Etc.}

Depois iniciou-se o desfile em formação militar, em passo marcial ritmado no passo de ganso, e encabeçado por Sua Excelência montado num cavalo vermelho. O cortejo passou diante do palácio do PCP (em estilo mediterrâneo, pois este estilo é secularmente oficializado por lei própria na cidade, sendo raros os arquitetos diversionistas os quais, mais por descuido do que por mau gosto, modificam a proporção dos arquinhos abaixando-os um pouco mais) e depois o cortejo passou diante do monumento erigido ao GI e em cujo pedestal foi colocada uma lápide recordativa do evento. Um prático de história do passado comentava que os atrasados do século anterior homenageavam servindo-se de coroas de flores de matéria plástica (quando foi descoberta esta horrível coisa) e, hoje, vendo triunfar a profecia de Marx, (todos artistas) mostraram o troféu preparado pelo Núcleo da Criação do único partido do poder, simbolizado por um conjunto de extintores naturalmente vermelhos, entrelaçados por duas fitas, sendo uma verde-amarela e a outra branca-vermelha-preta, para assim lembrar as cores da bandeira em voga nos tempos do GI. Deposto o trambolho, criticado, por espírito de porco, por um cronista dono de coluna dedicada à arte estética (sem dúvida será censurado e cassado pelo Núcleo onde está inscrito, pois não compreendeu o simbolismo-educativo do objeto criado para imortalizar o acontecimento) o povo foi dispersado e encurralado nos estádios (o maior, depois de um século, foi denominado Coringão de Vicente Matheus, que foi a principal figura dos tempos do
GI, e presidido por um bis-bis-bisneto do procer pebolista) onde os times estavam esperando para começar o jogo, a disputar não mais durante noventa minutos, pois a poderosa classe da bola, através de uma greve, obteve sua reduçáo para 60 minutos com intervalo de meia hora.

Depois de assistir à partida fui para meu familistério, jantei no refeitório (por motivo dos festejos tivemos, extramente, doces e pinga marca ${ }^{\circ}$ Centenário) reentrando em casa. Minha companheira e o filho estavam me esperando. Eles náo participaram da oceânica reunião, tendo pronto um falso certificado do médico da zona testemunhando a ausência, na eventualidade de um dedo-mole espionar e, consequentemente, ter de pagar a multa. (Disseram-me que nos tempos em que imperava um sistema político denominado Democracia, o eleitor que não votava pagava um bocado de dinheiro, e ainda era fichado como imprestante cidadão.)

Relatei aos membros da família o que tinha se passado com riqueza de detalhes e observaçóes, já que se tratava de um assunto importante: aquelas concentrações populares se bem que rotineiras e cansativas. Para puxar conversa os interlocutores me perguntaram peremptórios: "Afinal podemos saber como foi possível o fogo arrasar uma grande cidade?"

Sou um modesto professor das Escolas Coletivas onde se ensina o que os grêmios dos alunos nos impóe. (Às vezes me pedem para comentar matérias que desconheço; eles não entendem o que Sócrates afirmava sobre sua ignorância e, então, me xingam e me metem na cabeça duas orelhas de burro, para finalmente me confinarem, como castigo, atrás do quadro-negro.) Do GI náo sei se existem documentos probantes, aqueles que ainda são apelidados de fontes. Circula a convicção de que muitas cartas foram manipuladas pela Situação, quase sempre empenhada em demonstrar que a daquele tempo era formada de parvos muito presunçosos que administravam bestamente as cidades, convencidos que estavam de que milhóes de automóveis podiam perfeitamente 
circular na Piratininga das ruas construídas para tráfego de mulas e cavalos.

Os Arquivos são vetados aos não pertencentes à elite dos escrivãos da história oficial, sabedores que são de como se puxa a água para o moinho do patrão. Assim a história do GI é compilada de conjecturas como o impreciso ouvi dizer ou por aproximaçôes. (Um Gregorovius ou um Pastor hoje seria cassado e seus livros queimados.) Difícil estabelecer as causas, apesar do PCP ter instituído inúmeras CPI. (Iguaizinhas às do século 20, pululantes de elementos que mandavam as soluçóes às calendas gregas, para embolsar o mais possível, generosos jetôes.) O GI sempre foi e tem tido o ar de um mistério.

Ninguém o sabe, mas sou espírita. Aliás, em casa ninguém sabe. Assim, quando a heresia vem à tona na Escola, prorrompo em sonoras gargalhadas, pantagruélicas mesmo, para que meu anátema seja claro e merecedor de aplausos, pois não quero responder a uma qualquer comissão de inquisição, a qual, sem dúvida, me torturaria para que confessasse o possível delito. Sou espírita independente, solitário, secreto.

Recapitulei isto tudo para meus coinquilinos náo suspeitarem do conto que pretendo escrever e que aqui pela primeira vez relato, responsabilizando a Alma do Além com a qual converso e a quem confio como se fosse eu mesmo (produzindo o costumeiro sinal do Não) como confiar no Regime, pois náo quero ter dor de cabeça e ser tranquilamente aposentado.

Minha cara Esposa, aliás, Companheira, por ser produto do Amor Livre, meu caro Filho, produto também do Amor Livre, o negócio do GI, mais ou menos, assim se passou: corria o ano de 1989 e o Brasil estava no apogeu de sua potencialidade, pois descobriu que plantar café ainda era a solução para equilibrar a balança dos pagamentos, continuando São Paulo, o maior produtor da rubiácea, politicamente marginalizado mas, todavia, sempre mais engolfado no dinheiro. (Mal distribuído, porém muito, quase dava para acender charuto com notas de 500 como nos tempos da borracha da Amazônia.) A Burguesia, desde a Classe A até a Classe Q, gozando de favores dignos de um sibarita. Nas ruas, a cada cem metros, uma boate, a filial de um banco, um botequim, um estacionamento. Uma nuvem permanente de bióxido de carbono alegrava a cidade, juntamente com uma sinfonia de buzinas e de ruídos de motores. A Burguesia, feliz e desvairada, identificava o status pelo $\mathrm{cm}^{2}$ dos cilindros do carro. Qualquer imbecil fazia questão de auto-transportar os meninos para a escola, mesmo que a distância fosse de apenas uma quadra. Tinha o gosto masoquista das filas, ao longo de horas, mesmo que fosse para rodar na Anchieta ou na Imigrantes, indo e voltando da praia, pois weekend era também status. As ruas, as praças, as calçadas, literalmente tomadas pelos senhores automobilistas. Estes, pouco se importavam em gastar uma hora para vencer o trajeto que, pedibus calcantibus, podiam fazer em dez minutos. Quando os governantes, iludidos a respeito dos sentimentos do paulopolitano, ofereceram os ônibus para executivos, e lá de Brasília propuseram mutiróes de transporte, os mais abastados se revoltaram. E as coisas continuaram: as madames de Mercedes ou galaxiadas, adorando consumir gasolina, solidárias com os fornecedores do invento de quatro rodas e 200 cavalos, reclamantes dos 80 horários já que éramos o país dos fittipaldis, idealizadores do Supersucar que, pontualmente, chegam no $2 \mathrm{I}^{\mathrm{O}}$ lugar nas corridas internacionais, porém produzindo na curta mente do truste mais consumidores de doces.

São Paulo tinha razões de levar a sério, aliás, a mania do automobolismo, pois Fittipaldi era nosso. (E o petróleo continuava dos árabes.) Assim, prosperavam os mobrais para formar turmas de novatos do volante. A leitura nos jornais de segundas-feiras do elevado número de mortos, dos mutilados, dos feridos nos domingos, eletrizava as gentes, sinal evidente pago pela civilização ao turismo. Era obrigação se movimentar, acionar, desportivar (é saúde). São Paulo não contente por várias primazias mundiais, ambicionava, absolutamente, ganhar a Taça da Poluição, a Taça do Tempo Perdido Inutilmente, a Taça da Vaidade Automotiva e outras taças de menor peso. Era um período de insensatez, do descuido e do não saber para onde ir. 
E foi assim que, comportadamente, São Paulo provocou o desastre do Gl.

Parece que o fato se deu da seguinte maneira: quem diz que a faísca não piscou na Pamplona ou na Augusta, mas o fato é que na noitinha de 26 de maio do ano fatal, São Paulo, sufocado pelo calor de 36 graus, segundo os boletins meteorológicos, mas que na realidade andava na casa dos 42 ou talvez 44 , (senegalesco mesmo) tendo a seca liquidado quase tudo pela falta de água e quantos outros males que afligem o viver cotidiano, como a greve dos lixeiros com detritos acumulando-se nas calçadas e provocando um fedor danado; uma noitinha em que o paulopolitano deixa o trabalho e volta para a casa, ocupando as ruas transformadas em garagem a céu aberto, trombando, blasfemando e vomitando palavróes do mais alto caláo e lançados contra todos os volantistas. Logo que o caos ficou caótico, a um determinado momento vem à falta, a força elétrica, escurecendo a cidade. Os telefones emudecem. Os guardas de trânsito, desatentos, como sempre, preocupam-se mais em computar mais e mais multas e a chamar a atenção dos transgressores, sem qualquer possibilidade de informar o plantão do que está ocorrendo e o plantão, por sua vez, ao secretário de Trânsito, este ao prefeito e, palmilhando ainda os canais competentes, chegar ao governador, o qual, por acaso, estava despachando no palácio de verão dos campos jordanianos.

Os que viram ou imaginaram ver as primeiras chamas e ouviram as primeiras explosóes pensavam que o lógico seria a declaraçáo de estado de calamidade pública, mas parece que os possíveis proponentes morreram.

Volto à maldita fagulha. Dizem que ela foi provocada por um fusca ao rasgar o para-lama de um caminháo-tanque de gasolina. Descuido dos respectivos condutores: primeiras inculpaçóes seguidas de trocas de sonoros fdp e, finalmente, sopapos e pancadarias. Sendo o espetáculo dos mais atraentes para um povinho que, por causa da censura, desertava dos teatros, formou-se vasta assistência tumultuante, como sempre dividida em duas facçóes: a que defendia o caminhonista e a outra o fusquista, gerando uma balbúrdia e uma barafunda dos diabos dignas de serem inscritas em caracteres de ouro nos anais do Município, infelizmente não documentada fotograficamente pela ausência de repórter.

O tráfego parou e bloqueando todas as estradas próximas e longínquas, engarrafamento, veículos buzinando em atendimento a uma antiga lei antirruídos. (Era um tempo em que as leis impressas eram usadas nas privadas.) Instantes de noite apocalíptica, fim do mundo que os cronistas chamam de dantesca sem saber quem é o Dante e a Comédia. Inúmeros salvadores da pátria (temos o bizzeffe, sibillos premiados) avançam fórmulas de panaceias para resolver o caso, quando - e é aqui se dá o princípio da história - com fumaças e faíscas saindo do cofre do caminhão. Outros dizem: de uma perua encostada no caminhão. Alguém recorre ao extintor que o regulamento de trânsito obriga a todos terem no carro, mas como este aparelho sempre foi tido como sem serventia e mais fruto de uma das muitas marmeladas mini-nacionais (como no caso dos cintos de segurança) o fogo propagou-se e se tornou senhor da situação, atingindo veículos vizinhos. $\mathrm{O}$ pessoal, impotente, foge, as chamas abrasam o inflamável. Em poucos instantes explode, derramando rios crepitantes e provocando explosóes em cadeia. Começam a pegar fogo os sobrados, os prédios. Não era a primeira vez: inteiros arranha-céus se incendiavam, mas o Andraus e o Joelma, em comparação com aquela noite, eram café-pequeníssimos. Quantos mortos? Milhóes. Foi a labareda do Século, obscurecendo a façanha de Nero. Nunca a palavra tragédia foi tão adequada. Dizem que contemporaneamente em outras ruas se deu o mesmo, tanto que os boatos dos raros sobreviventes contavam que tinha lá a mão de alguma organização terrorista, não se sabe se da direita, da esquerda ou mesmo centrista. Os boatos foram infinitos. (Naquele ano ainda era esta a comunicação corrente, mais autorizada.)

Sei que vocês, agora, querem que me pronuncie a respeito das culpas e dos culpados. Mas como é possível conjeturar? Lapalissiano: o prefeito deveria ver e saber que com toda aquela massa de carros nas 
ruas, mais próprias para carros de boi, era marchar para o colapso; mas o prefeito de então dependia diretamente do governador, este por sua vez diretamente do presidente, equiparado a um rei de nomeaçáo direta de Deus. Por isso os puxa-sacos do prefeito espalharam o boato de que se tratava de vontade divina, serpeando per li rami até os dois que brigaram não se sabe se na Augusta ou na Pamplona, dando origem ao chamado castigo divino.

E o Corpo de Bombeiros? - pergunta o Filho da minha Companheira.

Dizem que os bombeiros chegaram com atraso por um chamado telefônico, num e em outro ponto, nada pondendo fazer contra a intensidade do fogo, a confusão, a falta de água, sem contar que inúmeras viaturas, deles bombeiros, foram queimadas. Naturalmente, de qualquer cidadezinha do Grande São Paulo, avisados não se sabe como, partiram as secçôes locais dos bombeiros a todo vapor. Vieram ainda de Santos, de Campinas (perdão, de Engenheiro Zagafohu), de Ribeirão Preto e, no dia seguinte, até do Rio de Janeiro, mas toda a frota nada pôde fazer, a não ser em alguns bairros da periferia, através da implosão de prédios para circunscrever as chamas.

Depois: vocês imaginaram o que significava trabalhar num inferno com atmosfera de Ioo graus positivos? Não tenho mais élan para evocar a catástrofe. Felizmente na Nova Era, depois da Revolução de 202I (nosso esclarecido governo a festejou dando uma semana inteira de folga e com larga distribuição de bandeirinhas) o urbanista que desenhou a Nova São Paulo criou estradas de cem metros de largura, sem cruzamentos, arborizadas para o transeunte se sentir à vontade como numa praça, ambiente (não meio ambiente) sem automóveis, pois como previa a CIA em 1977, o petróleo, dez anos mais tarde, e isto foi em 1987, esgotou-se, e o automóvel passou a virar sucata. Vocês sabem como se vive a son aise na nova São Paulo, adorável cidade, não mais metrópole, florida, comunitária (um por todos e todos por um) a cidade da solidariedade, mais bonita que Brasília, e comparável somente à Cidade do Sol de Tommaso Campanella.

- Pode ser, concluiu, que o

GI foi uma necessidade.

\section{Istoé \#25, I5 de junho de 1977, p.6I (Cultura: Artes)}

ALQUIMIA ARQUITETÔNICA

$\mathrm{Na}$ Universidade de Stuttgart existe um grupo interdisciplinar que está trabalhando num projeto: fornecer ao usuário de arquitetura a moradia ideal ao seu gosto. O grupo (composto por Heinz Dirlerwanger, Eduard Geisler, Jürgen Joedicke e Vitorio Magnano Lampugnani) não está, aparentemente, fazendo nada de mais original. Mas. na realidade, está, pois suas pesquisas semânticas e semiológicas se completam com o emprego de computadores. $\mathrm{O}$ resultado do projeto vindo do computador não se propóe modificar a função do arquiteto, mas provê-lo. A hipótese dos proponentes é que uma pessoa (F) reaja de uma determinada maneira $(\mathrm{Rx})$ a um determinado modo arquitetônico (A). Ao mesmo tempo, supóe-se que a relação não seja condicionada exclusivamente por variantes pertinentes ao mesmo signo (VA) - ou seja, por características arquitetônicas de cada tipo - mas também por variantes que se referem ao contexto material no qual o signo se encontra $(\mathrm{Vc})$ e também por variantes que se referem ao consumidor (Vf). Por exemplo, sexo, idade, nível social, condições psíquicas, motivaçóes, implicaçóes pessoais. Eis a fórmula:

$\mathrm{Rx}=\mathrm{F}(\mathrm{VA}, \mathrm{Vc}, \mathrm{Vf})$

Não se assustem com a aparente complicação: o que o grupo de Stuttgart propóe é que se chegue à definição de uma relação estético-emotiva entre usuário e arquitetura. Que se respeite o gosto de quem, afinal, vai - e deve - ser o beneficiário da obra.

\section{Istoé \#29, I3 de julho de 1977, p.57 (Cultura: Artes)} Evocaçóes de Le Corbusier no Brasil

Os cultores da arte que deveria ser a principal, se Vitruvio ainda tem algum valor, isto é, a arquitetura, sabem o que foi e o que Unificou a Carta de Athenas. 
Organizado pelo animador Siegfried Giedion, o congresso do "Ciam" acolheu os nomes mais prestigiosos do tempo. (Le Corbusier, Aalto, van Eesteren, Sert, Pollini, Teragni, Rothe, Sirkus, Papadaki, Bottoni, Hubacker, Sise, Karantinos, Moholy-Nagi, Brukalski conjuntamente a Fernand Léger, Christian Zervos dos Cahiers d'Art, o dr. Winter, do antigo L'Esprit Nouveau, Badovici, Morthon Shand da Architectural Review e, entre muitos outros, este cronista.)

A recordação é porque estreitei lá na Grécia minha amizade com Le Corbusier - e pela primeira vez ouvi-o falar de "modernismo construtivo" no Brasil. À sombra do Parthenon, um dia, "Corbu" acenou ao jovem Gregori Warchavchik que ele tinha conhecido em Roma, quando praticava junto com Marcello Piacentini, como o condutor da reação contra o pout-pourri dos estilos nos trópicos. $\mathrm{O}$ mestre contou que tinha conhecido o russo em Sáo Paulo quando devia desenhar uma casa para Paulo Prado - este descrito como batalhador e financiador de uma "semana" dedicada à renovação das artes, ocorrida há uns dez antes.

Passaram-se mais quinze anos, a Guerra, a Europa desfeita, eu desembarcando no Rio de Warchavchik e também de Lasar Segall, a respeito do qual tinha escrito em minha revista Quadrante. Gostei muito dos dois protagonistas, ambos ligados por laços de parentesco, pois se casaram com as irmãs Klabin, dando origem a um clã que tentou bastante despertar São Paulo do seu sono provinciano. Logo depois, em 1947, eu inaugurava o Museu, iniciativa do mecenas e controlador das riquezas e comportamentos das classes produtoras, o sr. Assis Chateaubriand.

Mantendo intensa correspondência com Le Corbusier, aproveitando uma ideia do Institute of Contemporary Art de Boston, combinei, em I95I, apresentar (montagem espetacular de Lina) a exposição "O Mundo de Le Corbusier," compreendendo, além da arquitetura, sua pintura e sua escultura, não me esquecendo de sua filosofia racionalista que eu mesmo tentei definir no ensaio Leitura crítica de Le C.

Penso que jamais fora instalada uma mostra de artista contemporâneo num recinto geralmente sagrado, como o é a pinacoteca. (Sistema que ainda utilizo, escandalizando naturalmente os conservadores pernostificados na fórmula "a arte pela arte.”) De qualquer modo, os convidados de honra - o presidente Dutra, alguns de seus ministros, Nelson Rockefeller e Henry Georges Clouzot - apreciaram a audácia, pois, afinal, tributava-se uma homenagem ao autor do "risco" do edifício do então Ministério da Educação e Saúde.

O inventor da novidade machine-à-habiter e da construção sobre piloti ficou radiante; todavia, mais uma vez, seu caráter imprevisível e sofredor da mesquinhez desmancha-a-festa deu galho: ex-abrupto, telegrafou-me e encarregou- me de reclamar do governo brasileiro os honorários a que tinha direito pelas prestaçóes e representaçóes que foram combinadas ao tempo do "risco."

Bem a par do comportamento do amigo, prudentemente dirigi-me a Gregori para consultar o Lúcio Costa, o qual, justamente indignado, respondeu dando provas que o reclamante fora pago durante a famosa estadia. Aplaquei o suíço e, sabedor que ele gostava de gestos práticos, comprei-lhe pessoalmente todos os desenhos das célebres conferências às quais se atribui o despertar do sono arquitetônico carioca simbolizado nas fachadas da avenida Rio Branco. Recebidos os desenhos, propus-lhe escrever a monografia $L e C$. au Brésil. Mais uma vez, as exigências monetárias totalmente fora de propósitos aconselharam-me a desistir do projeto.

Não sei como o mestre foi considerado sob o ponto de vista da tintura política ao tempo em que o Brasil foi contagiado pela escarlatina fascista. (Doença prescrita e ainda não diagnosticada historicamente, superficialmente definida reacionária por uma burguesia ou por reformadores de doutrinas por demais superficiais nos pronunciamentos.) Disseram-me que, desembarcando do Rio de Janeiro, Le Corbusier não teve empecilhos de cunho estado-novistas. Esteve à vontade, sempre acolhido com a cordialidade que não teve na Itália.

\section{Legenda}

"Corbu:" pendor pecuniário g Masp, (I957) a fixação geométrica 
Istoé \#32, 3 de agosto de 1977, p.57 (Cultura: Artes)

VERDE

De vez em quando fala-se do verde em São Paulo. A última foi quando a autoridade competente ameaçou multar com cinquenta mil cruzeiros a cada árvore cortada indevidamente. Lembrou-se que a metrópole paulistana está carente de dois milhóes de árvores, possuindo tão-somente duzentas mil - muitíssimo abaixo dos índices recomendados pelos especialistas internacionais em saúde. Parece que os arrojados grupos financeiros vão atender ao apelo para plantar árvores, porém estão à procura de uma espécie particular de planta, aquela que o Pinóquio encontrou no seu caminho desvairado: a árvore que, como fruto, dá moedas de ouro e que nem precisa ser adubada. De qualquer maneira, um aplauso ao prefeito Olavo Egídio Setúbal, que incorporou ao patrimônio da municipalidade parte da Fazenda do Carmo.

Casa Vogue \#28A, setembro de 1977, p.52-55 (A coleção deste mês)

A ARTE DE CONSERVAR COM AMOR: Coleção Joáo Marino

$\mathrm{Na}$ edição \# I da revista Arte vogue, Mino Carta apresentou com grande sucesso o eng. João Marino como colecionador. Eu mesmo combinei o encontro para inaugurar as páginas que iremos dedicar, na nova revista, a quem cultiva o inteligente hobby de juntar objetos pertencentes à crônica e à história do labor dos artistas.

Escolhi este colecionador por vários motivos, sendo o principal o gosto de Marino em recolher coisas de singular interesse, estudando-as convenientemente, conservando-as com amor, e - fato que entre nós que manipulamos no campo se dá alguma importância - colocando-as à disposiçáo para que outros saibam e apreciem. Anos atrás São Paulo contava com a Sociarte, uma entidade de amantes da arte, que reunia periodicamente na casa de cada um dos seus membros, interessantes tertúlias para saborear as mais recentes aquisiçôes de cada um.

Conheci Marino quando organizei a exposição "Imagem do Brasil," complemento da "BrazilExport 73," realizada em Bruxelas, uma manifestação arquivada na clandestinidade por causa dos barulhos que lá se deram por parte de agitadores a serviço de uma política assás interessada em mudar o lema da nossa bandeira, isto é, desordem e desprogresso. Precisava de alguém unicums do arte-fazer brasileiro para compor sua alvorada ainda incerta, implicada no tardio renascimento, e ajeitar os rumos do barroco. Outros colecionadores haviam prometido ceder algumas peças de destaque; aliás, o catálogo divulgado na ocasião do certame contém ilustraçôes correspondentes a peças que, na última hora, alguns colecionadores desprovidos de senso patriótico ou portadores do pernicioso vírus boato recusaram o empréstimo. Ao contrário dessas figuras, João Marino cedeu para a exposição de Bruxelas a escultura Nossa Senhora, que considero relíquia excepcional da arte brasileira do primeiro século, bem como outros objetos de sua coleçáo, e nos ofereceu com aquela simplicidade que lhe é inata e muito própria de quem se sabe detentor de um patrimônio idealmente pertencente à comunidade. (Detesto aqueles colecionadores ciumentos que diariamente telefonam para saber se a bolsa de valores está em alta, colecionadores que propalam a decisão de deixar tudo para um museu e, depois, fica-se sabendo que as viúvas, logo após o funeral, transformaram suas mansões em mercadinhos.)

Quantas vezes precisei, no Museu de Arte de Sáo Paulo, para uma aula, de um objeto original para melhor inteligência dos alunos, para que tocassem com as mãos e então recorria ao Marino o qual, ele mesmo e rapidamente levava a peça. $\mathrm{O}$ colecionador deve ser desprendido, franquear sua casa àqueles que desejam ver, discutir, "socializar" o que recolheu, saber que poucos homens festejam o centenário, gente que gosta mais de descobrir do que possuir, que mostra um achado com os olhos enternecidos, se entusiasma, refaz a história, admira os artífices, se empolga.

Foi por tudo isso que Inaugurei a série de colecionadores de Arte Vogue com o acervo do eng. João Marino, que os leitores de Casa Vogue têm agora a oportunidade de conhecer. 


\section{Legenda}

p.53 Sobre a cômoda de jatobá, do início do século I8, proveniente de Oeiras, a imagem da Madona com Menino de autoria de Frei Agostinho de Jesus, de barro cozido, do início do século I7

p. 54 Jarro de barro para guardar farinha de mandioca, Ubatuba, Sáo Paulo; arcaz de sacristia, madeira vinhático, século I8, proveniente de Minas Gerais; sobre o arcaz, à esquerda, Nossa Senhora Menina, imagem paulista, de barro cozido, final do século I6 e, à direita, imagem paulista de barro cozido, datada de I677; ao fundo, quadros de Alfredo Volpi das décadas de 60 e 70 Três imagens paulistas datadas respectivamente I678, I676 e I598 e um par de tocheiros de ferro do século I6, também paulista Divino de madeira policromada, século I8, proveniente do Vale do Paraíba Duas caixas de esmolas com cabo, representando as almas do purgatório: arte popular baiana, ambas do século I8 p. 55 Nossa Senhora Menina, imagem de barro cozido do século I6, proveniente de Bertioga, São Paulo g Cristo da Paciência, imagem de madeira, século I8. Proveniente de Minas Gerais Pequeno arcaz de madeira sucupira e jacarandá, século 17, proveniente de Pernambuco; em cima do arcaz, Santo Antonio Abade, imagem de madeira do século I8, das Missóes do Rio Grande do Sul

Homem Vogue \#28B, setembro de 1977, p.I4 (Entre Homens)

A FUTILIDADE É O PROTOPLASMA DA MODA: SEJA ELEGANTE

Problemas de, ou do Gosto? Existem inúmeros. Aparecem a cada instante, sejam eles complicadíssimos ou simplérrimos ou mesmo fúteis (o fútil é o protoplasma da moda, a moda é o protoplasma do estilo); todos são percebidos somente por alguns pernósticos encabulados em repartir, verticalmente, o cabelo em quatro, pessoal cacete que arruma a mesa de comando de seu escritório dispondo os lápis e as canetas bem alinhadinhas, milimetrando as posiçóes, ajustando as cores e as nuances dos utensílios.

Eis um problema de gosto. Conheci um destes pacientes que contratou um pintor conceitualista, um daqueles que geometrizam tudo conforme o ditado de Platão, para arrumar sua escrivaninha: sendo, como disse, homem de comando, devia chamar a atenção dos auxiliares e assim iniciá-los na consideraçáo dos problemas da harmonia, da beleza, em última análise, do comportamento estético.

Quando adentrava a sala deste chefe, sabedor ele de ser eu um metido, mais ou menos, nos problemas dos quais ele estava certo de militar nas fileiras dos seguidores do Baumgarten (vejam numa enciclopédia) me olhava atentamente para me apanhar em eventuais falhas de gosto, geralmente: cor do paletó e ajuste sincronizado da gravata, colarinho enrugado ou detalhe fora da moda do mês, bigodes mal aparados e não exatamente balanceados e outros quejandos que afligem os pretensiosos árbitros da Beleza.

Outro dia vi, numa galeria, um colega tomando nota a respeito das obras do artista expositor, rabiscando nas margens de um jornal, sendo a caneta cor de pistache, igual à usada nos sorvetes; aproximando-me do rapaz notei que seu traje era um xadrez (escocês na origem, manipulado numa daquelas tecelagens que xerocam tudo que se desenha em Paris) cinza, contrastante demais com os sapatos de cor amarela com fivela dourada, náo apresentando a dobra no terminai da calça, um toque prescrito por Homem Vogue. Reflexão: será que o rapaz está em condiçôes de julgar coisas da estética? Pode, pois a Constituição não contempla, nem veta. Por outro lado, não existe nenhuma portaria contrariante, e cada cidadão pode se vestir como quiser. (No Brasil, afora a elegância das africanas, circula entre brancas uma elegância, isto é, gosto importado de países onde todos os anos a neve cai.)

Veja o leitor onde transam os problemas de gosto, e quantos corolários lá se entrosam. Quando o fruidor dorme, nada tem a observar (se um sonha, isso é com o psicanalista que dá sua mágica explicação), porém logo que acorda surgem os casos. $\mathrm{O}$ mais engraçado foi um tal que no momento de escolher a gravata do dia ficou indeciso pela cor e a padronagem, 
então se deixou levar pelo assunto gosto-náo-gosto que acabou perdendo a hora de um casamento na catedral onde, aliás, serviria como padrinho e certamente seria notado como um arbiter eleganciorum.

\section{Homem Vogue \#29B, outubro de 1977, p.28 (Entre Homens)}

HÁBITO, VÍCIO, MANIA DA SIMETRIA

A simetria, isto é, a relação entre duas partes que em filosofia se define "relação entre $x$ e $y$ ” e também "entre $y$ e $x$," foi a inspiradora da Arquitetura em todos os tempos, desde Stonohenge até o Partenon, desde o Coliseu até às Catedrais e - para uma referência nacional - ao Palácio do Ipiranga, em São Paulo: acesso central, ala à direita e ala à esquerda, imitação do organismo humano sintetizado ao círculo-alegoria de Leonardo.

Após um certo tempo o conceito de ajeitar simetria na operação arquitetura é posto em discussão; todavia, a maioria dos arquitetos e dos mestres de obra continua balanceando as fachadas simetricamente. Se, por acaso, o organismo interno não precisa de uma ou mais janelas, no aspecto externo aparecerão postiças, decisão que vem de longe, pois a anomalia já era notada nos Pensées de Pascal, o qual observa que a simetria é fundada sobre a figura humana, motivo pelo qual a simetria é vista em largura e náo em altura e profundidade.

Como sair desta prescrição quando o arquiteto toma o lápis para desenhar a fachada, o subconsciente envasado pelo tradicional, também sabendo de antemão que o comitente gosta (por hábito, vício ou mania) da ordem simétrica? Até a dona de casa, quando convida, quer número par de hóspedes para compor a mesa simetricamente. E quando o ricaço quer, em sua casa, algumas colunas e frontão, portal de entrada com dois elementos; e não um, porém dois lampióes (naturalmente imitados daquelas carroças antigas, mas não com o pavio a óleo e sim com lâmpada e bateria elétrica) uma de cada lado; e um tapete exatamente no centro, responsabilizando o mordomo pela sua simétrica colocação? É só refletir um minuto, e logo se notará a escravidão que a grande fala das ilustres ordens arquitetônicas gregas nos transmitiu.

Eu era ainda menino quando vi reformar uma simples casinha de campo que tinha uma porta à frente, porém bem de lado; pois bem, desmanchou-se a fachada para recompô-la. Deu-se até uma festa para celebrar a inovação estética que resultou, por consequência, de se entrar diretamente no living e náo no hall como estava prescrito nos manuais. Por espírito de contradição comecei a apreciar o assimétrico, e o descobria com muito prazer nas antigas casas dos camponeses, despreocupados com a estética, e seguidores de princípios práticos e convenientes para resolver o viver em moradias. A uma operária de olaria que tinha construído uma casinha, organizando um mutirão, no Embu, perguntei-lhe, há alguns anos, por que tinha planejado a entrada diretamente na cozinha: "Porque é o lugar da casa onde passo mais tempo. E nesta casinha, a porta estava do lado, e náo era por acaso."

Isso vale para os que ignoram os complicadíssimos problemas de um assunto que parece táo simples, a simetria, não para os físicos e, como estou vendo nas relações do seminário a ela dedicado recentemente em Veneza, pela Fundação Cini, até para os negócios da espiritualidade, intervindo o caro e saudoso Roger Bastide sustentando que no plano sacro e profano, a religiáo constitui o domínio da simetria.

Mas a nota é de simetria pauperum, e para notar que o cânone persiste. É o mando da tradição, que náo se muda de um século para outro, apesar de se constatar as incongruências daquele repartir de organismos de um lado e do outro iguais, na maioria das vezes, para satisfazer funçôes diversas. No seminário veneziano acima lembrado, o problema foi posto sob o ponto de vista filosófico. É curioso que nem um dos participantes levantou o caso da simetria no campo da Arquitetura, num tempo em que a assimetria está captando simpatias e justificativas por parte dos mestres das mais recentes geraçôes. 
Homem Vogue \#29B, outubro de 1977, p.II2-IIS

O PURGATÓRIO PARADISÍACO DO MARQUÊS VON BAYROS

(Pornografia, uma armadilha da moral!)

Há uns vinte anos, num bric-à-brac paulista, isto é, dos templos do artefazer dos anônimos, onde os objetos em desuso ou jogados estâo, melancolicamente, à espera de nós, os enamorados das aventuras da forma e do invento encontrei uma velha pasta repleta de aquarelas. Temas eróticos, mas non troppo. Apesar da assinatura ilegível, fácil foi decifrar que o pintor era vienense, e do começo do século. As pesquisas do caso não foram fáceis, pois o produtor era daqueles encaminhados nas veredas onde a cada esquina, se encontram estátuas ofertadas a um Tabu, não deram certo.

(Qualquer artistazinho colocador de quadros nos Salóes, naturezas mortas e até nus, porém acadêmicos e pudibundos tem sua estensiva biografia e renome; os operadores das coisas proibidas, caçados pelos censores e condenados pelos tribunais, são clandestinos.)

Os franco-atiradores nos alvos sexuais trabalham para uma maçonaria fechada e severa, que admite os clérigos através de dificultosos exames, pois gosta do secreto, e só se sabe dela através de boatos indiscretos. $\mathrm{O}$ colecionador de espécimens amatórios é, em geral, um senhor com fama de competente notado nas reunióes sociais como zeloso observador da Moral de fachada, e pode ser visto na Igreja recebendo sua hóstia, sem sequer pensar em revelar ao confessor suas deviaçóes do direito canônico.

Finalmente, depois de muito tempo da minha descoberta, por acaso vendo uma ilustração "permitida" numa revista alemá, com esclarecida legenda, descubro o artífice das aquarelas Franz von Bayros. A partir deste momento, para nós práticos no reconstruir personalidades que pisam no Jardim das Artes, tudo torna-se rotina: trata-se de combinas as letras de um joguinho de palavras cruzadas. Anos após Franz foi desvelado e revelado. Agora todos o conhecem, pois hoje em dia não mais se fecham as portas dos quartos onde estão em cena alunas de Ninon de Lenclos. Nos tempos do ilustre Von Bayros o intercâmbio amoroso era, aos olhos da Moral corrente, bem complicado.

(Boldini quase foi esbofeteado pelo barão parlemitano Ignacio Florio, rei do vinho Marsala, pois ousou, ao pintar o retrato da Baronesa, mostrar uma minúscula secção de suas pernas, tendo sido obrigado a recobrir aquela "indecência" com saias, ocultando até as pontas dos sapatinhos de cetim. Duros tempos do próprio Boldini, rei do retrato: na primeira Bienal de Veneza, em I895, ele apresentou, prepotentemente, a figura $d a$ elegantissima adolescente Errazuriz, com meias pretas e respectivas ligas, aparecendo apreciável porçãozinha de coxas: o escândalo foi clamoroso devido a essa semvergonhice "morbidamente picante." O Boldini era um Von Bayros disfarçado, porém encobridor dos desejos que lhe fervilhavam em sua cabeça.)

Franz, sem dúvida, deu risadas ao assistir à tempestade veneziana: uma inépcia, negocinho de moleques, para ele desenhista das peladas à procura do prazer indiscriminado, que considerava único bem possível e fundamento de outra faceta da Moral, à rebours, provavelmente uma das inúmeras inibiçóes coladas nos seres humanos.

Folheando o volume Die Purpurschnecke Erotische Zeichnungen, (Gala Verlag Hamburg) recentemente dedicado a Von Bayros, os encontros desconcertantes são assustadores, pois a inventiva está na sala de espera daquele divertissement que o austero Catão, o Censor, teria apelidado de pornografia. Franz, sem se salvar do Inferno, orquestra com dignidade os comportamentos condenados terrenamente; ambienta-os com requinte, divertindo-se nos subentendidos e na alusão mais que no prosaico: uma arte franca no contar delícias, até envolvida de um certo ascetismo. A nevrose não deixa de dominar as cenas.

(Sem nevrose não se comunica nada neste purgatório; por outro lado, Leonardo também não fora neurótico sublimando sua ou seu Gioconda?)

Franz desenhava para os que conseguiam arrancar do arabesco das linhas motivo para saber melhor, e pôr as novidades 
na batedeira da fantasia para fantasticar suavidades. Naturalmente se fala dos que têm à cabeceira os Ragionamenti, de Messer Aretino, julgando o Decameron, manual romanceado, por demais reticente. Trata-se de degustadores de apetites sensíveis, sensualísticos com pingos de luxúria: uma categoria que não mais é a maçonaria acima indicada, pois a comercialização do erotismo tornou-se inflacionária, alcançando níveis de perversidade vulgar, generalizando atividades demais que, sem a reserva e o gosto do proibido, acabam por tornarem-se monstruosas.

Os desenhos de Von Bayros não são mais propriedades das elites apreciadoras de Lucrecio e de Saffo, desprezadores horrorizados das ruas noturnas de Amsterdam e dos catálogos da senhora alemã que industrializou os objetos de consumo para pobres diabos encabulados na ars de Eva.

(Este boom da Pornô não será uma armadilha da Moral? Há quem se lembre do confeiteiro que empregou um boy dizendo-lhe que poderia comer tantos doces quantos quisesse, à vontade; e o rapaz, no primeiro dia, tanto engoliu que teve indigestâo, vômitos e baixou hospital; voltando ao trabalho, o garoto nem mais olhava para os suculentos doces.)
Von Bayros é parcimonioso, saboreador, continuador dos franceses das Fêtes Galantes. Seu jeito é o de um clássico: olha Giorgione, Ticiano e Cranach para se aperfeiçoar no acariciar o nu feminino, convencido de que precisa não sair da representação clássica, isto é, dar às figuras da sua comédia sem véus, a solidez e a graça que os acontecimentos particulares dos encontros amorosos exigem. Olhou também para os chineses, desenrolando os metros e mais metros daquelas cenas que ensinam e propiciam as experiências, rolos então importados por Bing, o rei do art nouveau.

(A sua sobrinha, historiadora de arte e não das últimas, quando herdou os preciosos bens de Satanaz, os queimou à maneira de Savonarola.)

Franz foi o mais atento enciclopédico dos negócios em pauta, apaixonado registrador do sublime da ciência do Amor e da Felicidade, recolhida nos esconderijos libertinos, anotador dos impulsos imaginativos dos quais resulta difícil o relato.

Franz von Bayros era marquês, nasceu em I866 em Agran, Zagobria, morreu em Viena em 1924. Foi muito ativo, não desenhou outros temas a não ser o preferido dos problemas da cama.

Istoé \#44, 26 de outubro de 1977, p.80 (Cultura: Artes)

SEM ABSTRACIONISMOS

Desenhista e arquiteto. Fábio Magalhães participou, em Paris, de um projeto de escola de arquitetura chefiado por Oscar Niemeyer e pelo saudoso Eron de Alencar; de lá, transferiu-se para os Estados Unidos; viajou para o Japáo, foi parar no Peru, onde, ao lado de escavaçóes arqueológicas, trabalhou com comunicação, cinema e TV. Nos cinco anos de peregrinaçóes Fábio não teve tempo de continuar a traçar seus desenhos de signo arguto, temas onde o homem é o protagonista, e que nenhum abstracionismo ou conceitualismo vai jogar fora das telas e dos papéis.
Voltando a Sáo Paulo, retomou seu não esquecido pendor para reproduzir gente, saborear fisionomias, ajeitar posições e situaçôes: trabalhos; trabalhos que começaram a ser mostrados, desde o dia I8, (e até o dia I ${ }^{\circ}$ de novembro) na Seta, em São Paulo, a galeria das descobertas na vanguarda nacional.

\section{Legenda}

Desenho de Fábio Magalhães: apôs as peregrinaçóes
A moda vai, a moda vem. Certo dia desaparece o costume de usar determinada coisa e, a partir daí, nasce a proposta de mudá-la para outra coisa. A moda está inserida no mecanismo de mutaçáo perpétua, e que independe dos visos de monotonia. Assim como o progresso acelera sua corrida, as oscilaçôes do gosto a seguem. A moda, 
interligada a um recíproco influxo com a arte, a moral e a economia, é fenômeno obscuro, estruturando-se nos instintos estéticos coletivos, sem possibilidade de acertar as origens, às vezes imposiçóes artificiosas, outras limpidamente lógicas, aceitas como um alívio pois supera empecilhos e tiranias, também elas impostas em tempos passados pela moda. Ficar fora da prepotente não dá, e exagerá-la idem; resta esperar por uma nova voga, pois assim parece ser nosso destino.

Você chega à casa e vê o insólito: tem uma mesinha e, por associaçáo, em cima da mesma um abat-jour; recobre a mesa com uma toalha colorida que vai até o chão com suas dobras geométricas, uma plástica que lembra uma escultura, uma arte que hoje vai se emparelhando com a tapeçaria.

Alguma coisa acontece na decoraçáo: insatisfaçôes por ver mesas por demais funcionais, um incontido desejo de animar o ambiente, com propósitos de distinção. Sáo todos ingredientes da moda. Esta de toalhas mais parece um revival já que a um tempo este elemento era tido como batuta.

O uso é antigo, provavelmente surgido nos primeiros passos do Cristianismo como mostram as figuraçóes da Última Ceia no mais primitivo dos mosaicos de Ravena. No começo era de uso litúrgico e a toalha, quase sempre de linho, passou a ser usada nas casas, recebendo ornamentaçôes geométricas, rendadas. É na Renascença que a toalha se torna objeto de uso familiar, dando uma nota de requinte. Nas coleçóes dedicadas a este elemento caseiro ou em museus, pode-se ver como a fantasia dos artesãos conseguiu dar à toalha motivos alegres, alusivos em geral à caça, afinal como fato ligado à gastronomia. Será no Setecentos, depois da invenção e difusão da estamparia sobre tecido, que a decoração da toalha registrará alguma novidade, porém de escassa duração. No Oitocentos é a volta ao branco, com desenhos obtidos na diferenciação dos pontos.

Nas andanças das preferências hoje, a toalha, após superar o hábito do branco, é colorida. Os desenhistas de tecidos fornecem à indústria ricas e requintadas mostras, permitindo um vasto leque para escolha. Escolher é ato de arte.
Pode ser que o desuso das toalhas tenha começado nos Estados Unidos, através o lançamento do serviço dito "à americana:" pequenos retângulos ou arredondados para receber pratos e talheres, um dos tantos casos de simplificação dos problemas da vida que levou o pessoal à circunstância do comer arranchado e até mesmo de pé, como os animais e aves. Aquele uso norte-americano propiciou uma reformulação em termos de tampos de mesa, geralmente de madeira, posteriormente de mármore e mais tarde de cristal e de plástico ou como é mais comum dizer-se, de fórmica. Atribui-se, em parte, ao uso do material transparente a propensão à volta das toalhas, pois comer vislumbrando pernas e pés, certamente é constrangedor especialmente para as senhoras que náo sabem como fazer, pois além de comer ficam com a preocupação de se manterem compostas. Um fato de elegância.

A toalha assim está voltando ao favor das famílias enquanto o serviço "à americana” fica mais comum nas lanchonetes, um lugar onde se come correndo e mal digerindo.

Que a vida tende à estandardização não resta dúvida se bem que exista o permanente desejo de fugir da mesma.

Para não fugir ao assunto: a toalha dá um ar de festa à mesa, compóe e ajeita o convívio, proporcionando intimidade e o que o dito popular afirma: "o olho quer a sua parte."

\section{Legenda}

p. $57 \mathrm{Um}$ cantinho aconchegante da sala de estar. Paredes forradas com tecido chintz-bambu da Trama. A mesa nostálgica, cheia de retratos e recordaçóes, está vestida com dois tecidos da Trama: pássaros e bambu, tendo como xale o mesmo motivo da parede. A poltrona, forrada com flores subindo uma escada de bambu, completa o ambiente.

p. 58 Um jantar à luz de velas: mesa redonda, vestida com chintz da Trama, com azáleas em seu composé. Cadeiras de jardim e paredes forradas com azáleas maiores dáo o toque final. I Uma mesa de jantar quadrada, arrumada com tecidos da Trama imitando palha. 
O xale deve ser sempre num dos composés do tecido: as almofadas das cadeiras também: tudo com muito charme e muita bossa. Sobre a mesa, arranjos também de palha, inclusive os pratinhos para ostras. Os talheres, com rabo de bambu natural, são da Lolo Lacerda Soares Artesanato (Fone: 2II-729I). A foto foi feita no restaurante SeaSnack, Alameda Lorena, I884, São Paulo.

p. 59 Mesa de canto, vestida com chintz de tons turquesa e azul profundo, com motivos de cegonhas e, em seu composé, motivos florais. A parede do fundo está forrada com o mesmo motivo do xale da mesa: cegonhas e bambu. Sobre o sofá de plástico branco e brilhante, diversas almofadinhas nos composés do tecido. Mesa decorada com conchas. Tecidos da Trama. I Um cantinho de leitura todo forrado com tecidos rosa com flores num rosa mais escuro: aconchegante em todos os detalhes. A mesa vestida com uma saia de dois composés, formando babados, completa a intimidade exigida pela leitura de um bom livro. Os tecidos são da Trama: Rua Consolação, 3055-A, fones: 853-I250, 88I-2553 e 88I-2542.

Casa Vogue \#36A, junho de I978, p.80-8I

OCOLECIONADOR SALVA DOESQUECIMENTO AQUILO QUENO FUTURO REPRESENTARÁA HISTÓRIA

O diretor do Masp, Pietro Maria Bardi, e o II Salão Nacional de Antiguidades $e$ Galerias de Arte

O II Salão de Antiguidades e Galerias de Arte, ${ }^{3}$ que se distinguiu pela organização atenta e eficaz, merece nota especial sob o ponto de vista museugráfico, uma vez que foi apresentado num museu, fato bastante inédito, capaz de suscitar apreciaçóes e palpites os mais diversos, porém, no geral favoráveis à tardia iniciativa de um ativo grupo de profissionais que só merecem encômios.

O Masp não é uma instituição que cultiva ortodoxamente o conceito da "Arte pela Arte" de oitocentesca preferência. Para sua direção a preocupação constante, após trinta anos de ininterrupto trabalho, foi e continua a ser a de envolver a arte na realidade da vida, nas suas mais profissionais que contribuem diuturnamente para a descoberta, estudo, conservação, valorização do objeto de arte, operando na senda da formação e ativação da cultura. Os antiquários e os colecionadores constituem o protoplasma dos museus: o que neles se reúne provém daqueles senhores. É esta na verdade a história de todos os museus. Por isso o colecionador que pode ser também, aliás é, um investidor, às vezes um marchant-amateur, outros um apaixonado por um por um hobby

3 O II Salâo aconteceu de i9 a 28 de maio de 1978 e foi a primeira vez que uma exposição de iniciativa de terceiros aconteceu dentro do do Masp. \{Casa Vogue \#36 p.65\} qualquer, desempenha uma função de primeira plana na cultura, qual a de salvar do esquecimento coisas que no futuro representarão a história.

Foi confortante ver o público, por sinal bem numeroso, aos milhares mesmo, no Masp, entrando nos estandes e conversando com os antiquários e os galeristas, examinando peças, informando-se, ativando relaçóes sem dúvida promissoras. Os que interessam pela arte puderam ver reunida uma quantidade de objetos, especialmente nacionais, um conjunto que nenhum museu do país reúne: um museu provisório para durar duas semanas.

Esta observação nos leva a uma outra consideração: o Museu de Arte de São Paulo apresenta um acervo quase exclusivo de pinturas. Infelizmente, quando o sr. Chateaubriand decidiu formá-lo, náo aceitou o plano inicialmente proposto qual o de reunir peças das várias manifestaçóes da arte, para compor um panorama informativo se não completo, coisa impossível, pelo menos capaz de satisfazer didaticamente o visitante.

O II SNAGA, levado a efeito em maio, possibilitou ao Masp apresentar o que lhe falta, desde o móvel até a ourivesaria, desde a arqueologia até o design e quantas outras produçóes do homem de ontem e de hoje.

Outra observação a ser feita: nossos museus são pobres, cada um fazendo milagres para sobreviver carentes de um plano de governo 
para solucionar o problema. No Salão realizado no Masp, riquíssimo de memórias nacionais, foi possível admirar-se autênticas obras-primas dignas de serem transferidas para um museu, isto é, num recruto onde todos pudessem apreciar. Assim a apreciação do que foi mostrado no Masp teve apenas o sabor das rosas de Malherbe.
O confortante é ter-se a esperança de que antes ou depois os colecionadores, benemerentíssimos, adquirentes das relíquias, as destinem, um dia, aos museus. Este é o pensamento de quem, permanentemente, acredita num espírito público eque considera a cultura acima dos interesses individuais e sem egoísmos.

Senhor Vogue \#4, julho de 1978, p.58-69 Os POSSÍVEIS MILHÓEs (DE DÓlARES) DO NOSSO MERCADO DE ARTE Pietro Maria Bardi fala de quadros, de cotaçóes, de investimentos

A valorização das obras de arte é de tirar o fôlego. Um exemplo: o quadro $O$ Conde-Duque de Olivares, de Velazquez, foi comprado pelo Masp, de São Paulo, em $1948,{ }^{4}$ por 65 mil dólares. Hoje vale cinco milhōes. Outro: A bailarina de I4 anos, de Degas, custou, em I949, 45 mil dólares. Hoje custaria quatro milhóes. Arte, portanto, é também investimento, além de manifestação cultural. Há que considerar sempre esses dois aspectos quando se fala de mercado de arte. A projeção do artista criador e sua posição na sociedade, de um lado, e os mecanismos de marketing da produção artística. Mecanismos que obedecem a técnicas, mais ou menos hábeis, e que devem ser expurgados da especulação pura e simples, das falsificaçôes, da supervalorização dos nomes consagrados e da subvalorizaçáo dos jovens.

Um Tal arruma sua fortuna, troca o Fusca por um Mercedes, muda da casinha geminada para um palacete ou apartamento com piscina, apela para o decorador e este lhe arranja os ambientes. O que precisa para dar singularidade e chic à moradia é não se esquecer de que uma certa coisa, (palpável e ao mesmo tempo impalpável) denominada arte, deve não só estar presente, mas sobretudo receber carinho.

$\mathrm{O}$ Tal que pode muito bem ser mestre na arte dos negócios não teve tempo ou mesmo vocação para se instruir na "arte pela arte," ou no exercício das artes aplicadas a um setor qualquer; pode ser que nem tenha pensado em consultar o painel

4 O retrato do Conde-Duque veio de Londres e entrou oficialmente para o acervo em cerimônia do I4 de maio de 1948. Folha de S.Paulo, São Paulo, I5 maio i948. Caderno único, p.4. eletrônico da Bolsa de Valores, ou uma máquina, atribuindo-lhe importância de produto de arte. Ao longo da minha vida transei cordialmente com gente extraordinária, porém impermeável, de corpo e mente fechados diante de espetáculos ou coisas em que genialidade, inventiva, gosto e quantas outras particularidades se interligam com a arte. — Não entendo de arte, é a exclamação mais corrente. De qualquer jeito, o Tal quando vê sapatos com tiras prateadas que o tornam mais bonito, troca os de laço; ao escolher um carro compra um daqueles de linha elegante; quanto às joias, seleciona as mais deslumbrantes; e assim por diante, praticando uns tantos atos que, somados, determinam o geral da arte.

A passagem entre o resolver os probleminhas acima lembrados e os problemas de maior porte que implicam participação de cultura, preferências estéticas, gosto-não-gosto, satisfação, originalidade e tudo mais que sirva para julgar e resolver é passagem que apresenta um conjunto não pequeno de obstáculos. Na maioria das vezes, o Tal se resigna a fazer o que os demais fazem: é o fenômeno da moda. No que se refere ao nosso assunto, é a moda que governa a vontade dos Tais quando decidem dar brilho às suas casas, ao colecionar obras de arte, talvez (em sua maioria) com intençôes confessas ou disfarçadas de investimento monetário. Hoje, no Brasil, o número de Tais que descobrem que a arte merece alguma consideração cresce numa progressão que coincide, felizmente, com um certo otimismo econômico, apesar das dificuldades próprias de um país em vias de acelerado desenvolvimento, permanecendo a inflaçáo e a expectativa das reformas sociais e políticas. 
Quem possui sobras de numerário tem preocupaçóes em aplicá-las convenientemente, visto que a Bolsa se tornou um local de joguinho de especuladores, algumas vezes despudorados, e os imóveis ostentando ar de crise, o Tal está descobrindo, às vezes sem mesmo "entender de arte," ali buscar um refúgio para que o capital não se deteriore. Por outro lado, a história deste mercado, ativo no mundo inteiro, confirma ser o objeto antigo ou moderno disputado em leilóes que alcançam importâncias surpreendentes. Pinturas de Leonardo, Rembrandt, Cézanne, vendidas a milhóes de dólares, gravuras de Picasso vendidas a dezenas e dezenas de milhares de dólares. Quando se pensa quanto é pago por um selo das Ilhas Maurício, ou por um ícone bizantino, ou mesmo um vaso grego assinado, parece, e isto é demonstrável, que as produçôes dos artistas e os objetos raros procedentes da história, detêm valores estáveis, e sempre em alta.

No Brasil, como vimos, o mercado de arte é de data recente. Prevê-se que - com a superação da atual situação na busca de tempos melhores - aqui irá acontecer o mesmo que se deu nos Estados Unidos no fim do século passado: desenvolvimento industrial, mais riqueza, mais cultura deram como resultado um interesse considerável em relação à arte. Tanto assim que aquele país possui hoje patrimônio incomensurável de arte, aumentando constantemente, como bem se vê através dos ressonantes leilóes internacionais e nos boletins dos museus, sem se falar das crônicas registradas em Los Angeles: o que poderão gastar os trustes da Fundação Getty está na base de nada menos que setenta milhóes de dólares por ano, uma montanha de dinheiro capaz de abalar o mercado internacional.

Oferecidas aos leitores algumas consideraçóes de ordem geral, vamos agora dar uma olhada na situação brasileira, de passado recente até os nossos dias. A sociedade, a dos que dispôem de meios para aplicá-los no chamado produto arte, não deixa de pagar seu tributo face às consequências provocadas pelo nascente marketing que se consubstancia nos ramos propaganda e public relations. Deixemos de lado, por um momento, os artistas que já se foram, as assinaturas que motivam os investimentos considerados mais promissores. Por enquanto, são os vivos que interessam. Um pintor, presente nos coquetéis e, consequentemente, nas crônicas sociais, independentemente da qualidade daquilo que produz, consegue posição privilegiada; posição inversa é a do artista que náo sabe ou náo quer se promover, por timidez inata ou não, humildade e outras qualidades, e por falta de conhecimento dos canais que o levam às reunióes mundanas, ou quem sabe por detestar certos ambientes onde se gosta de posar em grupo empunhando um copo de uísque.

No mercado de arte nacional o uísque teve e continua tendo sua importância. (vernissages sem aquelas garrafas não rendem, nem funcionam.) Espertos, aliás espertalhões, inventaram o sistema que apropriadamente denominam de reunióes fechadas, onde os que pertencem à faixa de A a B se encontram, transbordando para o plano de reunióes públicas de fascinante marketing, configuradas em autênticos leilóes-espetáculo.

Esta invenção tem sido muito aplaudida em Sáo Paulo, onde a gente que pode está sempre disposta a procurar diversóes noturnas. $\mathrm{O}$ metteur-en-scène foi um tal de José Paulo Domingues [da Silva], na anágrafe do século Paolo Businco, foragido da Itália por trapaças e aqui refugiado primeiro praticando o comércio de panetones e sapatos femininos e, posteriormente, no setor arte.

$\mathrm{O}$ aventureiro, estudando o ambiente com a atenção psicológica muito própria dos que farejam e sabem como se dá um golpe, inaugurou um tipo de leiláo diferente: não mais aqueles conciliábulos de uns quatro gatos pingados reunidos pelo saudoso e querido José Florestano Felice, 5 com vistas à disputa de móveis, bibelôs e quadros, mas elegantes concentraçóes no mais chic dos salóes de recepção da cidade, a Maison de France, onde os convidados engravatados, as senhoras ostentando "longos," disputavam sofregamente o serviço de buffet em que generosamente corria o líquido

$5 \quad$ Atuou como leiloeiro oficial a partir de sua nomeação, em 1939, pela Junta Comercial de SP. Faleceu em Io de março de I976. \{Folha de S.Paulo\} 
indispensável e proveniente das cinco maiores marcas, licores capitosos, canapés e petiscos, coisas capazes de satisfazer ao mais exigente paladar, cigarros e charutos de marcas famosas, tudo isto servido em ambiente perfumado com spray de lavanda.

A empresa se denominou "Collectio." Contava com os serviços do leiloeiro escolhido, o bonário Irineu Ângulo, que logo se popularizou pelo seu modo caseiro de ilustrar as peças em disputa, conquistando a simpatia que até hoje desfruta. (Seu prestígio junto a outras camadas da populaçáo aumentou recentemente quando passou a figurar num "comercial" de TV, não para anunciar uma obra-prima, mas "vendendo" os serviços de um banco privado, aliás, como já o fizera anteriormente para a Philips o nosso Aldemir Martins. O pintor Rebolo não se transformou em ator de novela?) Atraentes, elegantérrimas e decotadíssimas moças de minissaias percorriam o festivo saláo para recolher o final dos lances, enquanto o Businco, altaneiro e impecável, como autêntico cerimoniário, percorria com os olhos aquela alegre arena, tudo supervisionando para que o negócio corresse às mil maravilhas.

Tal comportamento se repetia em cada festa-leiláo, o que lhe valeu, dentro de táo pouco tempo, alcançar o status de grande conhecedor, autêntico mestre em relaçóes públicas e de amizades onde se alinhavam até figuróes. Numa palavra, o Tal montou uma bem azeitada máquina de marketing que lhe valeu amplos créditos bancários, dobrando vários banqueiros ao demonstrar que era o dono absoluto de um vitorioso mercado.

Audaciosamente adquiriu um prédio de esquina na avenida Brigadeiro Luís Antônio e encarregou o arquiteto $\grave{a}$ la mode, Ennes Silveira Mello, de reformá-lo e ali instalar a sede própria da empresa, ampliando assim suas bem calculadas especulaçôes e maquinaçôes.

O Businco foi hábil, pois para reforçar sua posição e dar maior consistência à mercadoria oferecida a um público em parte desconfiado face ao saltitar dos valores, o valente contrato o crítico de arte do Jornal do Brasil, Roberto Pontual, apelidado na época de "Trombeta da Collectio," para explanar, quadro por quadro, e embromar a assistência. Amparado pela imprensa que recebia generosa centimetragem de publicidade, recebido, festejado, louvado, o João Paolo tornou-se o Pelé do mercado de arte: agrupou quase todos os mercadores de arte, fundou uma fictícia associação de classe autonomeando-se presidente, fez generosas doaçóes de obras a universidades. Sabia, na verdade, bem orquestrar e conquistar confiança.

Businco foi quem, aproveitando a descrença em relação à Bolsa de Valores, procurou provar que a melhor solução em termos de investimento era a de adquirir obras de arte. Foi mais longe ainda, pois chegou ao cúmulo de tapear banqueiros, ao efetivar operaçóes financeiras que resultaram desastrosas não para ele, Domingues-Businco, que vendo tamanha facilidade em ganhar e obter dinheiro, não teve dúvida em extrapolar para negócios imobiliários e turísticos.

Quando morreu, no apogeu de sua efêmera glória, ${ }^{6}$ as coisas foram aclaradas: deixara colossal rombo nos bancos, junto aos quais penhorara não uma mas várias vezes a mesma obra, pois jamais as deixava em custódia garantidora, a preços mais que generosos. $\mathrm{Na}$ esteira de suas acrobacias financeiras deixou não poucas vítimas, porém nenhum artista ou marchand. Reconstruído o capítulo da sua fantástica existência, deve se reconhecer que foi este arremedo in minimis do conde Cagliostro o animador do mercado da pintura brasileira. Provavelmente sem ser um inusitado descobridor da mentalidade ambiente, não se teria hoje o progresso que o setor bem ou mal experimenta. A lição, modificada e felizmente náo repelida nos lados menos canônicos, tem como herança os promotores dos grandiosos coquetéis, em estrondosas exposiçóes de pinturas de terceira ordem, fortemente apoiadas por caudais de press-releases, autêntica convocação da classe, geralmente a B. Os turistas criticam estas concentrações, mas o certo é que elas

6 Faleceu aos 46 anos, vítima de um colapso cardíaco, em Sáo Paulo, em 27 de dezembro de 1973, três anos após fundar a Collectio. \{Folha de S.Paulo\} 
dão resultados e não se pode desprezar o sistema inventado pelo falecido trapalhão.

Com o tempo, o mercado se acomodará mais nos moldes tradicionais dos centros europeus e norte-americanos: (não que lá não existam fatos lamentáveis como o episódio tupiniquim; será suficiente lembrar, por exemplo, que lá as falsificações são feitas em grande estilo) leilóes onde existe, por parte da assistência, um simples gesto de levantar a máo quando fazem o lance percebido pelo leiloeiro, que se limita a bater o martelo para liquidar, em poucos instantes, arremates formalizando a venda de milhóes de dólares.

\section{Valores internos e de fora}

Sem dúvida, as preferências dos colecionadores de pintura e logicamente investidores (não será uma das metrópoles mais subservientes ao deus Dinheiro a mancar) através do tempo irão se apurando para determinar posiçóes mais equilibradas.

Deve-se considerar o que representou até aqui para o mercado de arte o fator das oscilaçóes do gosto, isto é, o mudar de opiniôes a respeito dos autores; opiniốes geralmente não controladas, e não precedidas de exames mais atentos. Nestes últimos anos, foi curioso assistir-se a um fenômeno próprio de um ambiente que julga sem muitas convicçóes estéticas, os olhos quase sempre dirigidos para o que fazem os outros. Quando se começou a falar em Di Cavalcanti ou em Volpi, como mereciam estes dois mestres até então não muito considerados, face à desabalada corrida para ter uma de suas telas nas paredes domésticas, a falação resultou num verdadeiro delírio. $\mathrm{Na}$ oportunidade em que os valores aumentavam na relação direta, também, da inflação, artistas jovens (os futuros Di e Volpi) não recebiam atenção, pois a moda canalizava o pessoal para Mulatas e Bandeirinhas.

Uma das questôes temáticas de contínuas discussóes é a da posição dos valores das obras nacionais, tanto no Brasil quanto no estrangeiro. Há alguns anos, constituiu surpresa saber-se que o sr. Nelson Rockefeller tinha vendido a brasileiros os Portinari que havia comprado nas suas andanças entre nós. $\mathrm{O}$ mesmo se deu com outros colecionadores multinacionais ou simples turistas que, sabendo dos preços alcançados pelas pinturas dos Candinho, Di, Tarsila e de outros dos nossos pintores mais celebrados, decidiram delas se desfazer. (O mesmo caso se deu em relação aos Frans Post, comentado nesta reportagem.) Marchands e curiosos se encarregaram de comprar quantas telas puderam encomendar, especialmente em Paris, berço do modernismo nacional. Acontece que hoje em dia, adquiridos todos ou quase, os Vicente do Rego Monteiro, Ismael Nery, Segall e até artistas menores, na verdade a pintura brasileira retornou à casa. (O fenômeno não é só nosso: cada nação tem uma tendência natural para gostar e valorizar os próprios artistas.)

Ingenuamente alguém pergunta: — Se pusermos em leilão em Londres ou em Nova York, uma tela de Di, quanto alcançaria?

Preço bem modesto, se por acaso náo estiverem na sala dois brasileiros ao corrente do mercado interno.

Aflora à mente uma outra pergunta: - Por que não se opera para valorizar nossa arte no estrangeiro?

A resposta comporta uma explicação. Antes de tudo, o mecanismo para impor um artista é extremamente complicado. Depende de circunstâncias, experiências que não se improvisam e meios financeiros. Às vezes, a iniciativa chega ser fato até político: é mais fácil impor uma assinatura (o mercado no tocante à pintura é a assinatura) de fora num país novo do que o inverso. (Assim se deu nos Estados Unidos, que souberam posteriormente inverter a situação: hoje impondo à Europa as suas assinaturas.) Pela minha experiência no setor posso dizer que quando, em 1946, doei à Tate Gallery de Londres a primeira Natureza morta, de Giorgio Morandi, (mestre cujas obras se vendiam então, na Itália, a duzentos dólares, e que nos anos vinte custavam apenas cinco dólares) o diretor considerou-o um excelente pintor completamente desconhecido, não suspeitando que no futuro, hoje, aquela obra seria disputada no mercado internacional por nada menos que cinquenta, sessenta mil dólares. Porém, se um italiano chegou 
a alcançar estes valores, deve-se inferir qual foi o lento, intenso e estratégico trabalho exercido. Apesar da singularidade da arte, deve-se operar num círculo de atividades inteligente que ajudam na afirmação. Penso que temos possibilidade de projetar, um dia, alguns artistas brasileiros do passado e do presente no mercado estrangeiro, tudo dependendo do aclaramento do problema arte em nossa terra. Por enquanto, os artistas latino-americanos rumam em direção à Europa e aos Estados Unidos, pois não encontram nos próprios países um ambiente adequado. Assim, vimos os nacionais Arthur Luís Piza e Roland Cabot vencer em Paris como elementos de primeira plana. O chileno Roberto Matta, ${ }^{7}$ o colombiano Ómar Rayo, ${ }^{8}$ [Fernando] Botero ${ }^{9}$ ou mesmo [José Luis] Cuevas, ${ }^{\text {IO }}$ [Wilfredo] Lam, ${ }^{\text {II }}$ [Julio] Le Parc, ${ }^{12}$ para citar apenas alguns.

O que é necessário ativar-se é o intercâmbio. Hoje que o Brasil está intercambiando indústria, agricultura e comércio com o mundo inteiro, numa época em que as naçôes vão se ajustando ao sistema dos vasos comunicantes, parece-me ter soado a hora de pensar que a arte é fato a ser seriamente considerado. Pouca, para não dizer rara, a arte de fora que pinga no Brasil. (Infelizmente, quando se descobrem em casa algumas coisas de fora, logo se pensa

7 Emigrou para Europa em 1933. Trabalhou no atelier de Le Corbusier. (I9II-2002)

8 Pintor colombiano, radicou-se em Nova York na década de 1960. (I928-2010)

9 Pintor, escultor e desenhista colombiano, passou longa temporada na Europa (déc. 1950) e depois nos EUA. (I932-)

Pintor, desenhista, escritor, gravurista, escultor e ilustrador mexicano. (I93I-)

II Wifredo Oscar de la Concepción Lam y Castilla, pintor cubano, mudou-se para Paris em 1938. (1902-I982)

I2 Escultor e pintor argentino, vai para Paris em 1958. (1928- ) em transformá-las em libras esterlinas na Sotheby's ou na Christie's, empobrecendo ainda mais nosso já parco patrimônio.) No II Salão de Antiquários e Galerias de Arte, o marchand carioca Jean Boghici expôs uma fileira de obras de Joaquín Torres García, ${ }^{\mathrm{I3}}$ (o mestre número um da arte latino-americana, que não venceu em sua própria pátria, o Uruguai, mas em Paris) pinturas da melhor qualidade. (Esperamos que as mesmas fiquem no Brasil.)

\section{Considerar os jovens}

Considerando que o problema é de ambiente, necessariamente de cultura, penso nos jovens, notadamente aqueles que começam. Parece-me ser este o problema de base das artes no Brasil: devemos ampará-los. Estamos ainda na era dos Salóes e dos prêmios de viagem dos idos de Pedro II. Não se considerou a evolução e as necessidades diferentes para o labor arte. É a consequência de vários fatos que começam pela ignorância, do náo estar a par da operosidade dos novos, encabulando-se na convicção por demais materialista de empregar o dinheiro nas assinaturas que, na ilusão deles, terão um futuro promissor e sem discussão (mutatis mutandi, não poderá acontecer como no tempo dos Impressionistas, os quais pouco faturaram em vida, quando alguns acadêmicos como o hoje esquecido [Jean-Louis Ernest] Meissonier faturavam fortunas com disputas entre rainhas e reis do aço?)

A estruturação de uma consciência favorável ao exercício e fortalecimento $\mathrm{da}$ arte deveria ser iniciativa política, através de decisóes e leis bem estudadas. (Curioso: foi providenciada a aposentadoria dos abastados futebolistas e, ainda há poucos dias, a dos artistas de teatro; não se pensou nos artistas plásticos.) $\mathrm{A}$ proposta de uma lei para reservar $\mathrm{I} \%$ dos gastos em obras públicas, a ser destinado à colaboração de artistas, foi impedida por aqueles consultores jurídicos que provavelmente elaboram leis de auxílio a atletas e às nefandas torcidas.

Numa sociedade onde cada um deve resolver seus próprios casos, seria útil para os artistas brasileiros (aqueles que

I3 Pintor uruguaio. (I874-I949) 
realmente têm valor) chegar afinal a um entendimento com as galerias. Náo se conta ainda com uma categoria em condiçóes de contratar, como se dá no estrangeiro, os artistas, conciliando os interesses das partes. Geralmente as relaçóes entre galerias e artistas são mais de contraste que de entendimento. (Lembro-me do que acontecia em Paris, quando Picasso denunciava a figura do marchand como um inimigo. Paul Rosenberg escrevia ao mestre em 2-I2-I8: Enfaisant allusion aux raports d'artistes et de marchands, vous parliez de lutte de classe. Il y a lutte de classe entre mauvais ouvriers et mauvais patrons, mais pour des gens qui ont le moral élevé, il n'y aura jamais lutte, mais toujours conciliation.) ${ }^{\mathrm{I}}$

Pergunta: será possível localmente, daqui algum tempo, náo evocar cartas deste teor? O mestre "marxista" partiu para o Além deixando aos filhos dezenas e dezenas de milhóes de dólares, falava de luta de classe: eis um parêntese a abrir para desejar que entre nós o marchand tivesse uma posição determinante para a afirmação da arte dos jovens. Para isso, se precisaria de elementos do estofo de um Rosenberg ${ }^{\text {Is }}$ ou de um [Léopold] Zborowsky que, à custa de sacrifícios duríssimos, amenizou a dura situação de Modigliani e de outros dos seus contratados protegidos.

Parece-me que o marchand de pintores, feitas as exceçóes que sempre existem, não se distingue pelas iniciativas no que se refere à valorizaçáo dos novos. Por outro lado, o próprio comércio dos já afirmados e dos mais ou menos afirmados que engrossam as listas dos leilóes, (catálogos esdrúxulos, mais folhetos que catálogos, com todos os visos de provisório) ainda não têm o status que se espera, no que se refere à promoção.

I4 "Referindo-se às relações entre artistas e marchands, você citou a luta de classes. Há luta de classes entre maus trabalhadores e maus patrôes, mas entre pessoas que têm a moral elevada jamais haverá luta, mas sempre conciliação.” (tradução nossa)

I5 Paul Rosenberg foi galerista e, juntamente com DanielHenry Kahnweiler, marchand de Braque e Picasso. (I88I-I959)
Para sermos justos só a "Collectio" sabia promover: lembremos daquele rico álbum dedicado aos novos, que representou vistosa valorização da arte nacional.

Ainda não se pensou numa maciça ação de marketing. ( $\mathrm{Na}$ Itália funcionam casas que anunciam vistosamente em revistas e jornais. Uma delas, a Sant'Erasmo, apresenta a "Operação de quadros de autor a prazo: vocês contemplam, e a obra de arte trabalha por vocês. Os quadros de autor são um investimento seguro. Nos últimos vinte anos os aumentos foram de $15 / 20 \%$ ao ano.")

No setor promoçáo, deve-se considerar positiva a ação dos que se dedicam a gravuras. Entre eles, Raquel [Arnaud] e Mônica [Filgueiras de Almeida], do Gabinete de Artes Gráficas de São Paulo, que experimentam o sistema de venda por correspondência. Depois de alguns anos se vende gravura com resultados positivos através de ambulantes, sendo iniciadora do sistema Yara [Forte] Cohen. O desejo de ter arte em casa está interessando à juventude, o que é um bom sinal de cultura. Os jovens a custo de dinheiro transam com gráfica, cartazes de exposiçôes, álbuns, múltiplos. A preços acessíveis, podem começar a colecionar animando um mercado em formaçáo que representa válido apoio a muitos pintores, escultores e técnicos.

Reitero a necessidade de ajudar os jovens. É sabido que a compreensão por parte daqueles que porfiam no campo das artes, mas distanciados das fórmulas aceitas, provocando polêmicas contra elas, mesmo os inscritos na categoria que no começo do século foram inquinados de vanguardistas, na verdade é atitude de poucos. Basta repassar a vida de alguns mestres de recente passado para saber das hostilidades que os acompanharam e atrapalharam. Não só entre nós, mas em ambientes como Paris, Londres, Nova York, também não compreenderam os artistas de mais talento, descobertos, às vezes após o desaparecimento, o valor de suas obras elevando-se a tal nível que o preço de uma única peça teria servido para a subsistência de uma vida inteira.

Difícil saber-se quem tem o privilégio de enxergar qual o futuro de um artista, 
tentando convencer o comprador de pintura ou de escultura a raciocinar, considerando a possibilidade de um emprego de capital nas produçóes dos jovens. No Brasil existem jovens que, a médio ou a longo prazo, fatalmente encontrarão um honroso lugar entre os assim chamados clássicos procuradíssimos; todavia, o colecionador ou o investidor não se dispóe a arriscar, e insiste nos valores que reputa não só certos mas em alta, mesmo se arriscando a cair nas armadilhas dos falsificadores. A tendência do ambiente, em geral, é a de procurar os autores já consagrados, deixando de lado os novos, sejam eles jovens, maduros ou já entrados na pré-senilidade. Falemos agora de um fato desagradável: a falsificação. O mecanismo mercantil necessita de vários adendos. Um deles é a peritagem. Desenvolvendo as transaçóes, é fatal que personagens dotados de poucos escrúpulos penetrem no campo para traficar com suas vistas voltadas para a sempre rentável atividade da falsificação. $\mathrm{O}$ caso é comum nos mercados do mundo inteiro, como periodicamente a imprensa registra. Ativo na Europa e nos Estados Unidos, pode-se dizer que náo existe obra de autor de renome que não tenha sido falsificada: logo que um artista alcança bons preços, o falsário se agita e os capangas se encarregam de tapear o primeiro otário que encontram. Os elementos acabam sendo identificados; bons de lábia levam sempre na conversa aqueles ingênuos que querem fazer negócios convenientes.

Uma questão desagradável: as crescentes falsificações. Precisamos de boa peritagem

No Brasil a história dos falsos começa quando os abastados italianos querem obras dos seus pagos: um grupinho de patrícios os abastece de mercadoria que com o tempo acabará nas lojas de bric-à-brac. São destes últimos anos os escândalos dos Di Cavalcanti, Volpi, Bonadei, Guignard, Djanira, executados por desonestos amanuenses. Às vezes as falsificaçôes fáceis de serem detectadas, bem assim de outros artistas que circulam lastreadas com expertises ou atestados de garantia assinados (às vezes também com assinaturas reconhecidas em notário que ignoram estarem chancelando coisas falsas) por peritos reais ou fantasmagóricos. São fatos que perturbam o mercado, deslustram uma atividade por todos os títulos fascinante e deixam em desconforto aqueles que realmente fazem da arte um negócio sério e respeitável.

Qual a maneira de corrigir as distorsôes? Antes de tudo é aconselhável adquirir nas galerias que têm responsabilidade em todos os níveis e que podem realmente responder quanto a eventuais erros. De outro lado será indispensável constituir (e a própria associação de classe deveria pensar nisso) um comitê de peritos prudentes, capazes e sobretudo independentes. Será isso possível?

Os peritos deveriam ser especializados nos vários ramos, um pouco como acontece na França com os seus commissaires priseurs. Para supervisionar náo somente o ramo pintura, mas a ouriversaria, o mobiliário, notadamente quando se trata do colonial. (São Paulo é riquíssimo de navetas aos modos das caravelas do século i7 e fabricadas no século 20 , aliás, ontem.) Um dos casos que mais preocupam é o aparecimento impressionante de obras do Aleijadinho. (O que acontece com este mestre é o mesmo que no século I9 ocorreu com Rafael, na Itália: cada um que possuía uma cópia do mestre cuidava ser dono de um original; não sei quantas Madonna della Seggiola me apresentaram para obter uma expertise, sonhando pressurosos com milhóes de dólares.) $\mathrm{O}$ mesmo se dá com o mestre mineiro: parece que o número das estátuas e talhas saídas do seu atelier representa extenso caudal. (Viu-se, na exposição a ele dedicada no MAм carioca, evidente pseudos.)

A conversa deverá agora sugerir consideraçôes face ao problema do atribuicionismo, uma das pragas que infestam a história da arte. (Recentemente, vi uma expertise referente a um Pancetti de propriedade de uma rica nordestina, porém boa vendedora de panaceia; os termos do dito documento eram simplesmente penosos, pois estava na cara que se tratava de um falso vulgar.) Como na Itália era comum vender-se retratos de Garibaldi feitos por Tintoretto, às vezes comerciantes novatos de antiguidades náo oferecem Nossa Senhora de Fátima do século I8? 
De vez em quando, nestes últimos dez anos, ao longo dos quais os objetos de arte emergiram e provocaram incomum atenção do ponto de vista mercantil, fui procurado por jornalistas da imprensa especializada em assuntos econômicos a fim de conversar sobre a situaçáo dos valores que acabaram se afirmando nos leilóes e nas crescentes transaçóes comerciais.

Procuraram o diretor do Masp pelos seguintes fatos: ser ele um veterano e constante interessado pelos problemas de mercado de obras de arte, e ao mesmo tempo por ser possuidor de certa experiência internacional; por ser o responsável por uma das maiores aquisiçóes de que se tem notícia, qual a do atual acervo do Masp; e, finalmente, por ter sido convidado e investido da condição de perito para solucionar um pleito judicial que envolvia duas pinturas de Vermeer, a do Museu Boymans de Rotterdam e a do senhor W. van Beuningen, ${ }^{16}$ face ao impasse estabelecido entre os peritos Coremans e De Coen. Recordo esses fatos para o leitor saber que esta reportagem é redigida por alguém que se dedicou assiduamente ao estudo do problema com atenção, palmilhando tanto no terreno de areia movediça das teorias, como patinando no campo da realidade comercial.

\section{O encontro com a São Paulo das artes}

Quando, em I946, o sr. Chateaubriand ofereceu-me a excelente oportunidade de criar um museu, eu era presidente do Studio d'Arte Palma, de Roma, conhecido como a mais viva organização de estudos, restauro e comércio da Itália. Chegando ao Brasil e envolvido num acontecimento incomum, a primeira providência foi a de obter informaçóes quanto ao que se passava no campo das artes.

Vale a pena recordar que o interesse pelos problemas históricos eram bem conduzidos pelas iniciativas do Serviço do Patrimônio

I6 Existiram dois colecionadores de obras de Vermeer envolvidos em situaçóes de falsificação: Willem van der Vorm e Daniël George van Beuningen. (N.A.)
Histórico e Artístico Nacional que reunia elementos extraordinários. (Um lembrete: por que o IPHAN não reimprime a coleção de sua importantíssima revista?) Pelo contrário, a atividade da arte moderna me pareceu modesta a julgar pelos poucos ateliers e galerias comerciais. São Paulo tinha a Galeria Itá, do francês Auguste Louis Beneteau, comerciante de pinturas acadêmicas francesas procedentes dos leilóes do Hotel Drouot; raros eram os metidos no antiquariato, como pequenas eram as lojas e apartamentos de sabor bric-à-brac; assistia-se a um certo fervor jornalístico como eco das reaçóes da Semana de 22; e alguns colecionadores de arte antiga (lembro o dr. Ephin Mindlin) e de moderna, mais numerosos. Admirava-se, naqueles anos pacatos, na casa de Paulo Prado a coleção de Léger, Chagall, Delaunay, Modigliani; (depois emigrados para o estrangeiro) junto aos herdeiros da benemérita d. Olívia Guedes Penteado outra bela coleção (o Lipchitz e o Léger, então generosamente doados ao Masp pelo casal Carolina [filha de D. Olívia] e Goffredo [Teixeira] da Silva Telles); algumas peças ainda podiam ser encontradas em poder de Oswald de Andrade. Outros quadros, especialmente de pintura italiana, decoravam as casas dos condes Crespi e Matarazzo. Contava-se, como fábula, das preciosidades do conde Siciliano, leiloadas pelo francês Zirlis. Difícil era ver as casas de outros peninsulares que fizeram fortuna no Brasil, pois corria o boato de que o diretor do novo museu era um valido do sr. Chateaubriand, o qual teria pedido como doação eventuais peças assinaladas. ( $\mathrm{O}$ boato era pura invencionice e mais fruto de mentes viciadas, aliás como ainda hoje se usa.)

As coleçôes mais ou menos ocasionais foram formadas, geralmente, durante as visitas dos viajantes à Europa, ou nas tendas dos comerciantes de fora que aqui aportaram. Entre eles, o Pardini e o Carlo Cuoco, este importador de telas italianas lá pelos idos de 1920, abrindo exposiçóes em armazéns vazios. Segundo uma lenda, certa feita, o sr. Cuoco deu uma festa, durante a qual cada convidado foi homenageado com um quadro. Lembro-me de ter visto sua coleção num belo casarão da avenida Brigadeiro Luís Antônio, posteriormente 
adquirido de "porteira fechada" pelo sr. Sérgio Pinho Melláo. A coleçáo mais falada pertencia ao amável senador e poeta Freitas Valle, abrigada na celebrada Villa Kyrial, decorada por Augustin Salinas, irmão do pintor Pablo Salinas. (De ambos se recorda uma visitadíssima exposição no salão nobre da antiga sede da Prefeitura na rua Libero Badaró, o Palacete Prates. $)^{17}$ Era o tempo dos bons negócios cafeeiros e dos passos acelerados da industrialização, e São Paulo começava a contar com moradias requintadas; o Liceu de Artes e Ofícios em atividade, alguns artistas recebendo incumbências. John Graz, aqui chegado da Suíça, dois anos antes da Semana, acompanhado de Antônio Gonçalves Gomide e de sua irmã Regina, com a qual viria a se casar, depois de ter estrelado com uma exposição numa loja desocupada da rua Barão de Itapetininga, improvisou-se em decorador, desenhando móveis e pintando murais coerentes com o art-déco então em seus inícios. Outro aconselhador de bom gosto tornou-se o arquiteto Rino Levi, com o arranjo das casas de Roberto Cochrane Simonsen. Valiosa também foi a contribuição de Gregori Warchavchik que tentou desenhar móveis à la Bauhaus, apresentando na São Paulo apegada ao estilo Mappin \& Webb as novidades do racionalismo.

De Paris tinha chegado rica sobra de peças art-nouveau. (Nestes últimos anos tem sido desempoeirada ao ensejo do revival.) As casas, seguindo a moda, se enfeitavam de coisas. Visitei a de Inácio da Costa Ferreira, o popular desenhista caricatural Ferrignac, delegado de polícia e posteriormente feito secretário da Segurança Pública: um minimuseu repleto de uma infinidade de objetos curiosos.

I7 Os irmãos Salinas expuseram em I9Io na Casa Verde, (situada na rua São Bento) em igıı no Palacete Martinico, (situado na pça. Antonio Prado) em I9I2 na Casa Mascarani (e em I9I9 no Palacete Guanabara. (situado na av. São João) \{Rossi, M.S. I999, p.83-II9.\} Não foram encontradas informaçóes referentes à referida exposição dos irmáos Salinas no Palacete Prates. (N.A.)
O comércio engatinhava: galerias abertas e que se fechavam com a mesma facilidade; entre as mais ativas, a "Jorge;" outra, do toscano Manlio Nello Benedetti, que conseguiu colocar pinturas de Fabbricatore, Irolli, Casciaro, Dalbono e outros napolitanos. Reverenciado pela nascente e rica sociedade paulista, o desenvolto pintor e conde [Bigio Luigi] Gerardenghi, pontificava como um árbitro num apartamento do então chique Hotel São Bento, sediado no arranha-céu Martinelli, protegido dos Fracarolli que o incumbiram de decorar o Cassino do Parque Balneário Hotel, em Santos. Girardenghi combinava-se com um outro simpático italiano Carlo Prina, tradutor de Trilussa. [poeta italiano] Os personagens peninsulares estavam sempre em cena, sendo o mais conhecido, Ernesto Altini, ${ }^{18}$ capaz de reproduzir qualquer pintura de artistas procurados pela freguesia, mercador ambulante pelas Américas, desaparecido tempos depois na Argentina.

Destaque tinham os irmãos Ângulo, parentes do Irineu, hoje o príncipe dos leiloeiros paulistas, operosos na rua José Bonifácio $\mathrm{n}^{\circ} \mathrm{1} 3$, especializados em numismática e em prata portuguesa, mas também promotores da arte de Benedito Calixto, Campão, Campos Ayres, Oscar Pereira da Silva, Pedro Alexandrino e de outros na crista, gratos à burguesia que considerava a Semana como uma palhaçada, não se apercebendo que o Modernismo despontava, ganhando marcante posição.

Várias são as crônicas do tempo. Gestas de Emílio Basile, hábil organizador de leilóes, sendo um histórico: o de [Egidio Pinotti] Gamba, do Moinho Minetti \& Gamba, que durou uns quinze dias, tantas eram as coisas trazidas da Europa.

I8 Segundo Rosalva Altini-Weber, sua filha, Ernesto Altini trabalhou no MoMA, como curador no Masp e no Museu David Carneiro, em Curitiba, e, finalmente, no Museu de Belas Artes de Buenos Aires. Disponível em <http://www.saatchionline. $\mathrm{com} /$ rosalvaltini $>$. Acesso em out 20I3. Não foram encontradas, ainda, informaçóes sobre a declarada atuação junto ao Masp. (n.a.) 
No Rio os casos foram outros. Bastaria lembrar as casas dos Guinle para que se tenha uma pálida ideia dos autênticos tesouros por eles importados de Paris. O Rio podia ser comparado a Buenos Aires, sem qualquer discussão o centro cultural mais europeu destas landes colombianas. Lá existiam os autênticos colecionadores, bastando lembrar a figura de Antônio Santamarina, e que a casa Wildenstein ${ }^{19}$ ali mantém uma filial há mais de meio século.

\section{Milhões de dólares}

Assis Chateaubriand me pediu para armar uma pinacoteca às pressas. (Neste momento lembro que um dia será preciso contar a história do Masp.) Trabalhar com aquele caputmagister não era fácil. Não dispunha de dados certos, perplexo às vezes pelo fato do incentivador comprar a Moema, de Victor Meirelles, pagando por ela o equivalente a três obras de Van Gogh, ou adquirindo dois Canaletto, falsificados grosseiramente, por uma soma astronômica. Conciliando, usando de diplomacia, nem eu sei bem como se conseguiu fazer o Brasil navegar no mare magnum do mercado internacional. Em 48, segurando no Masp algumas obra-primas excepcionais, no estrangeiro, as referências ao nosso favor circulavam cordiais e curiosas; e, nem o propheta in patria, vimo-nos alvos de denúncias as mais díspares das quais a menor era de importar, sic et simpliciter, pinturas falsas. Seja como for o Brasil, aliás, um brasileiro, levantava o problema de participar inteligentemente do mercado de arte, no momento mais propício, quando na Europa vitoriosos e derrotados deviam reconstruir suas economias. Em poucos anos as transas mercantilmente transcuráveis dos vendedores italianos acima lembrados cederam lugar a um fato de importância mundial. Em 53, na Orengerie do Louvre, o presidente da França, M. Vicent Auriol, inaugurava a exposição de "Ioo chef-d'oeuvres," do Museu de Arte de São

I9 Apesar de sua galeria situar-se no Rio, Georges Wildenstein contribuiu para a formação da pinacoteca do Masp, tanto que é hoje homenageado com uma das salas do Museu, no segundo andar.
Paulo; a manifestação seguiu um roteiro generoso, apresentando-se nos museus da Bélgica, Holanda, Suíça, Alemanha, Milão, Londres, Nova York. Minha convicção era a de levantar o problema do colecionismo. Tinha observado que o brasileiro não brinca em serviço no que se refere à descoberta e percepção de negócios rentáveis. Tem bom senso, sabe prever, realizar às vezes com audácia. Não fui futurólogo.

Era indispensável para fortalecer a estrutura do Masp contar com o concurso do mercado e fomentar o colecionismo. Se começava da estaca zero, porém, o entusiasmo e o maquiavélico pigliare l'impresa do dr. Assis parecia um exemplo a ser seguido. Em São Paulo, naqueles anos finais de 40, finalmente ocorreu um fato novo: o casal [Ana Maria (Nina) e Pasquale] Fiocca inaugura a "Galeria Domus," ali na avenida Vieira de Carvalho, colaborando na organização o sr. [Alfredo] Bonino, que com eles tinha chegado de Nápoles. Novidade na cidade ainda um pouco sonolenta em termos de comércio de arte. Bonino animou-se tanto com a atividade que logo fundou em Buenos Aires a sua própria sede, para, mais tarde, abrir a Bonino carioca, hoje dirigida por Giovanna Bonino, [esposa de Alfredo] e uma outra galeria em Nova York. ${ }^{20}$ A “Domus," por falta de movimento, fechou. ${ }^{21}$ Deveria transcorrer duas décadas para o mercado de arte se articular.

Os tempos eram de estranho desinteresse para com a arte.

Organizei a primeira retrospectiva de Portinari no museu no mesmo ano em que o pintor se candidatou à uma cadeira de senador, precisando de gaita para atender

20 A Bonino, em Copacabana, funcionou de 1960 até os anos 80 , e foi a primeira trabalhar exclusivamente com arte no Rio. $\{$ Bueno, M.L. 2005\}

2I A Domus funcionou de 1947 a 1953. Boa parte dos colecionadores dessa arte contemporânea era estrangeira. Ernesto Wolff, cliente da Domus, em I958, abre a galeria São Luis e convida Nina Fiocca a dirigi-la. \{Bueno, M.L. 2005\} 
à demanda eleitoral. Eu tinha certeza de um sucesso financeiro, mas na verdade resultou em total fracasso. As únicas telas vendidas foram por mim adquiridas - a Trilogia dos Retirantes - por vinte contos e pagas em prestaçóes de cinco contos cada, e pensando-se em termos de dólares, ao todo uns três mil dólares. (Seu valor, hoje, é estimado em quinhentos mil dólares.)

Não poucos seriam os casos a serem rememorados. Irritante o pouco interesse demonstrado para com os artistas nacionais ainda no decênio pós a Segunda Guerra Mundial, vinte e tantos anos depois da Semana de 22; resolvida numa revolta sem consequências, deixando os raros bons protagonistas em suas lutas diuturnas para sobreviver, sem o conforto dos adquirentes: Anita, Di, Vicente do Rego Monteiro, Tarsila do Amaral, Graz, Gomide, Guignard, Victor Brecheret, Regina Graz, Cícero Dias e quantos outros que lutaram nem sempre recebendo a devida consideração. Faltava certamente ambiente.

Iato para apenas evocar os nacionais. Registrar o que se passou com os artistas estrangeiros certamente nos possibilitará chegar à conclusão de que a praça não dispunha da menor informaçáo quanto ao que se passava no além-mar. (Um fato que me ocorre. Em 48, no Salão do Ministério da Educação e Saúde, organizei uma grande exposição da arte italiana da primeira metade do século 20. Figuravam obras-primas de Giorgio Morandi, Gino Severini, Carlo Carrà, Ardengo Soffici, de Pisis, de Chirico, Felice Casorati, a preços por assim dizer de banana. Os Morandi na base de duzentos, trezentos dólares por peça, valores que hoje podem ser cifrados em torno de cinquenta, sessenta mil dólares por peça. O único Morandi então vendido foi por mim recomprado pelo atual valor.
Graças às circunstâncias da guerra, emigraram para o Brasil razoável número de artistas de valor, mas que por falta de ambiente náo soubemos dar a eles o devido valor. Penso em Maria Helena Vieira da Silva, que viveu em Santa Tereza durante o período da guerra, sem jamais ter recebido a atençáo de que era justamente merecedora.

É o caso de lembrar do que se passou com Lasar Segall. Não poucas foram as dificuldades que atrapalharam sua adaptação ao meio; não fora a valiosa ajuda que obteve em virtude do casamento com Jenny Klabin, que lhe possibilitou viver independentemente face à apatia dos que se interessavam pelas coisas da arte. E que dizer de Ernesto de Fiori?

Também em época mais recente, de boom, deixamos escapar do país elementos que certamente teriam dado boas contribuiçóes e prestado serviços à causa da cultura nacional. Basta pensar nos italianos Giuliano Vangi, hoje um dos mais notados da escultura europeia, o pintor Gastone Novelli, o designer e pintor Roberto Sambonet, o espanhol Joan Ponç, que voltou à sua Barcelona. $\mathrm{O}$ mesmo aconteceu em outros campos, também da ciência. No campo do teatro não soubemos segurar Luciano Salce e Adolfo Celi, para citar apenas dois nomes. E no cinema? Alberto Cavalcanti poderia depor.

Concluindo este trecho: trata-se de pensar seriamente em organizar e potenciar tudo que interessa à arte nacional, provendo-a de ambiente, meios, solidariedade, procurando formar uma torcida. Torcida não fanática, mas seriamente empenhada no problema cultura, já que resolvemos muito bem o problema do futebol. (Observo que nos dias de Copa Mundial, os componentes da seleção canarinha tiveram o apelido de heróis.)

\section{O Que SE VENDE No BRAsil, p.64}

$\mathrm{O}$ que se vende e o que não se vende de arte no Brasil? Vende-se, especialmente, arte popular. (Não mais original, pois se descobriu a maneira de trazer do Nordeste cerâmicas, bordados, palhas, pinturas, tudo na base da pechincha e da tutaméa junto aos artesáos, para vender nas grandes metrópoles aos turistas e aos amadores a preços exorbitantes e de corar um frade de pedra.) Outro tipo de arte que se vende em São Paulo é a da Praça da República ou do Embu. (Este seria, na fantasia daquele Município, a "cidade das artes.") Trata-se de uma mercadoria que satisfaz perfeitamente a pequena burguesia! 
Giuseppe Baccaro: A VAlorizaÇão COMEÇOU COM JusCelino, p.64-65

$\mathrm{Na}$ intenção de oferecer uma reportagem franca e aberta, pedimos a Giuseppe Baccaro - o mais ativo dos marchands no fim dos anos 60 e começo dos 70, hoje dedicando-se em Olinda a conspícuas obras de filantropia e educação - que respondesse a algumas perguntas. Eis seus pontos de vista:

B Quando pensa que começou a valorização da obra de arte?

GB Parece-me que ela começou no governo de Juscelino, quando da construçáo de Brasília e a implantação de um capitalismo nacional de porte que criou fortunas rápidas e consequente necessidade de aparatos que evidenciassem a ascensão social. O clima nacionalístico favorecia a procura de obras de brasileiros, filhos ricos de imigrantes que substituíam os objetos de decoração trazidos na viagem, mudavam de mansôes, exercitavam um estilo de vida. Vendia-se também muito tapete persa e móveis coloniais, mas as pinturas sempre deram mais o que falar, permitindo uma movimentação mundana e uma subliteratura em volta. Então começou a procura do melhor em arte brasileira, sem que soubessem do que se tratava. Ao rico, como sempre, interessava apenas que fosse o melhor. Mas isto devia ser provado pela qualidade decorativa, pois caso contrário seria irreconhecível. Vendiam-se, portanto, quase só obras pigmentadas, de preferência com temática folclórica sem comprometimento com a realidade social. Isso explica a fortuna de Di Cavalcanti e a miséria de Goeldi. Surgiram alguns comerciantes, eu entre eles, para satisfazer os desejos desses compradores. Limitei-me em pôr no mercado Tarsila, Anita e Gomide; depois Portinari, Ismael e Visconti, lutando para impor o Grassmann. Não descobri artistas. Tudo não passou de uma transferência de obras, do remediado para o rico. O trabalho não tinha nada de meritório, ao contrário. Hoje, ausente do mercado desde I97I, tenho a desagradável sensaçáo de ter sido um caçador de bichos raros para zoológicos grã-finos.

B Acha que os valores de Mercado correspondem aos valores reais?

GB A noção de valor venal é a alma da sociedade capitalista, a categoria em cujo manuseio emprega e esgota o seu saber todo. Como resultado, no mercado de arte, o valor de um quadro depende do poder do dono da casa onde se encontra enforcado. Mais amplamente, é o resultado de um acordo entre colecionadores de poder econômico. Se $99 \%$ das obras de arte dos cinquenta artistas brasileiros de renome estão nas mãos dos capitalistas, suas cotaçóes não podem baixar de maneira nenhuma, a menos que não reduza o próprio poder econômico dos donos. Mesmo assim as baixas seriam proporcionais. Somente a mudança do sistema que poderia permitir o surgimento de outra ideia de valor para a obra de arte. O que garante seu valor venal é a sua localização. Pode-se acrescentar: quaisquer obras que sejam as obras. Os equívocos não são esclarecidos com opiniōes de entendidos. O discurso estético, no Brasil, tem desenvolvimento próprio, e bastante confuso. Aqui ricocheteiam as ultimíssimas teorias euroamericanas. Uma visão e linguagem críticas nacionais, propostas por algum raro crítico, caiu no vazio. Atualmente as conversas sobre arte são mais de surdos, ou melhor, de cegos. Acredito que daqui a dez anos haverá muito bric-à-brac e leiloeiros vendendo obras de arte de espólios, falências e concordatas. Aí, fulanos que hoje vendem a cem mil tentarão inutilmente oferecer por quinhentos. Espero que nesse meio tempo muita obra digna esteja nos museus à vista do povo.

B Qual o papel dos marchands e leiloeiros na valorização?

GB A maioria deles é instrumento desse jogo em que a localizaçáo de obras garante seu valor. Eles não têm acervo consistente e em geral ganha apenas nas transferências, venda por venda, enquanto o colecionador capitalista ganha em todas e todos juntos armam jogadas maiores.

A constatação de que qualquer alta de preços beneficia, em bloco, toda a classe de colecionadores é óbvia, mas não parece tão evidente assim na hora de um leilão, por exemplo. A encenação e o deslumbre encobrem a operação real que está sendo levada a efeito pela venda particular. Às vezes se cria até a sensação enganadora de que um golpe baixo está sendo praticado 
contra o coitado do rico que compra. Mas é bom saber que no ato em que um único Di Cavalcanti é vendido 30\% a mais da cotação média, num leiláo bem promovido, os Di Cavalcanti em poder de dois terços dos capitalistas sobem também na mesma proporção. Se a obra passa de trezentos para quatrocentos mil, significa que a burguesia que detém todas as obras está valorizando seus capitais móveis em quinhentos milhôes de cruzeiros. Sem contar a imediata repercussão que isso provoca nas cotaçôes do acervo inteiro. Existe, portanto, uma Bolsa Artística que funciona sorrateiramente ao lado da Bolsa de Valores, com enormes quantias em movimento. Chega de brincar com a arte pois esta não é mais o objeto meio fresco e indefinível de que tratam as babozeiras dos manuais de estética. Finalmente, tomou forma e peso como testa de ferro das fortunas dos ricos. Mas é oportuno que corram rios de palavras indecifráveis sobre ela. Que as idiotices sobre a Beleza, que o boato de seu valor educativo e social continuam confundindo as cabeças. O fato real é que $99 \%$ - e quem sabe mais - de toda arte representativa do Brasil se encontra nas máos de $\mathrm{I} / 50.000^{\circ}-\mathrm{e}$ quem sabe menos - da população brasileira, a chamada "elite econômica," a única que soube refrear o desenfreado anseio de comunicação da arte na camisa de força do dinheiro. Tanto acúmulo bem merece suas encenaçóes. Todo dia a farsa da sensibilidade das elites que sequestram os miseráveis Portinari, os pobres Guignard e de Pancetti, é encenada pelos meios de comunicação de massa. É ali que dançam todos juntos: os críticos, os cronistas mundanos, os banqueiros, os decoradores, os plásticos de nomeada (cirurgióes e artistas), os falsos instituidores de caridade, as superdamas das lapinhas para o Natal dos Pobres... Não há dúvida: para defender o artista é preciso defender a sua obra. Não há meio termo: se é justa a destinação atual da obra de arte, as afirmaçôes de nossa própria cultura sobre seu valor educativo e social são carentes de solução.

O ARTISTA NÃO É UM SONHADOR, p.66

Pergunta dirigida ao arquiteto Cesar Luis Pires de Mello, colecionador brilhante e um dos fundadores da Galeria Cosme Velho, de São Paulo.

B Você acha que o Brasil tem hoje um mercado de arte em desenvolvimento seguro?

CL O interesse do público pelas artes plásticas no Brasil é inegável. A confirmaçâo está na crescente afluência do público às exposiçóes, aos museus e às galerias. Está, também, no crescente aumento do número de colecionadores.

B O colecionador, mais avisado e informado, procura segurança e garantia através da origem boa e da crítica séria. Acha que as galerias estão atentas e preocupadas em melhor organizar-se e fornecer material bom e seguro ao comprador?

CL Temos hoje em dia um bom número de galerias, bem instaladas, com fichários e documentação e, portanto, em condição de garantir a seriedade do mercado.

B E os outros?

CL Com o aumento dos colecionadores e interessados, o artista deixou de ser aquele sonhador boêmio que só em momentos de inspiraçấo produzia. E hoje ele um consciente e laborioso operário de arte que em seu atelier trabalha em mil e uma experiências. Assim essa operosidade resulta num conjunto de artistas e marchands os quais asseguram um desenvolvimento natural do mercado de arte.
DESCONFIANÇA MARCA OS NOVOS, p.67

Perguntamos a Guy de la Chevalerie, da galeria Jardim das Artes, especializada em artistas de fora, qual a aceitação dos pintores no mercado. Ele nos disse que: "Nestes últimos anos houve um movimento de nacionalismo em todos os setores, entre os quais pode ser infelizmente incluído o das artes. O colecionador se orgulha mais de possuir um Di de 500 mil cruzeiros do que um Picasso de igual valor. Os fortes colecionadores, (os investidores) porém, começam a perceber que investir numa pintura de valor internacional é mais seguro que investir numa pintura nacional supervalorizada. De um modo geral, o público 
compra valores estabelecidos, desconfiando dos novos pintores no mercado."

\section{Legenda}

p.58 Edgar Degas, $A$ bailarina de 14 anos 9 Velazquez, $O$ Conde de Olivares

p.59 José Antônio van Acker, Marinha (1976) Um dos pintores ainda não bem considerados

p.6o Gregório Gruber, Figura (1973) Um dos hiperrealistas em franca ascensão

p.6I-62 Marcelo Grassmann, Desenho (1952) Um dos maiores gravadores brasileiros, com mercado sempre em alta Giorgio Lucchesi, Natureza morta (I890) Adquirida pelo colecionador Alfredo Masetti, São Paulo. Uma das pinturas disputadas nos anos 20 pelos nascentes colecionadores da coletividade italiana Convite para leilão da Coleção José Gonçalves com palavras de Décio Abramo, sem legenda

p.63-64 Emiliano Di Cavalcanti (I8971977) O pescador. Um dos mestres que continuam na crista do mercado I fotografia de Giuseppe Baccaro

Casa Vogue \#38A, agosto de 1978 , p.84-87 UM PROJeto POlÊMico de UGo di PaCe

Novos rumos no setor da arquitetura das casas unifamiliares, uma tentativa de adeus à tradição que, todavia, persiste nesses edifícios da burguesia, diferenciados entre um e outro pela aplicação dos elementos estilísticos nas fachadas. De vez em quando, entre uma e outra construçáo rica de pomposa colunata ou de elementos que aludem ao colonial, órfãs de perspectivas funcionais e de respeito ao bom gosto e ao bom senso, surgem combinaçóes de muros que logo de início denunciam a rebeliáo à ordem generalizada do edifício convencional, anônimo. É normal que o encontro provoque surpresa e perplexidade. Porém, aos poucos, as formas não mais habituais vão ganhando, aqui e acolá, simpatias, pondo em cheque o classicismo, aliás, o pseudoclassicismo e os derivados manipulados pelo culturalismo considerados como sobrevivência de tempos passados. Apesar da atividade das vanguardas da arquitetura, paralela às de todas as outras artes, a resistência às inovaçóes continua bastante firme. Os períodos de transição são assim, notando-se que o presente, p.66 Uma das pinturas disputadas nos anos 20 pelos nascentes colecionadores italianos. Natureza morta (I89o) de Giorgio Lucchesi. Adiquirida pelo colecionador Alfredo Masetti, Sáo Paulo

p.67 Esplêndida escultura de Victor Brecheret. Coleção da Galeria Fernando Millan, São Paulo.

No mercado de arte, o maior volume de transaçóes é feito na área da pintura, seguida da gráfica. A escultura parece ser a parente pobre da arte do pincel. Nunca teve popularidade e a pouca que tinha a perdeu depois do ocaso do Barroco, liquidado com a vinda da Missão Francesa em I8I6, que se dedicou quase exclusivamente à pintura, liquidado, também, pelo declínio das práticas religiosas. O Brasil, riquissimo de imagens esculpidas, pátria do grande Aleijadinho, foi obrigado a convidar escultores estrangeiros, como aconteceu com a encomenda feita a um francês para o Cristo Redentor do Corcovado.

p.68 Wesley Duke Lee, Figura deitada (I964) Um pintor que teve mercado sempre constante

mais que período de transição, é período de revivement do panorama: a provoca-lo, após o caso das propostas dos mestres europeus e americanos estão grupos e personalidades isolados a operar livremente, fora das regras gerais. Quem passa por Sáo Paulo, à rua Cônego Eugênio Leite, entre a rua Atlântica e alameda Gabriel Monteiro da Silva, vê, alinhado às construçôes parietais interseccionadas por duas elevaçóes verticalmente cilíndricas: uma antifachada da qual, porém, entrando para visitar a construçáo, logo se entende qual a sua função, de um jeito iconoclasta e polêmico. O projetista, um dos participantes do empenho de renovar o código arquitetônico, preocupado com a utilizaçáo do espaço a ser criado, desinteressou-se por completo do resultado exterior, fixado exclusivamente na realização interna. Os semicilindros são, de fato, torres cilíndricas que abrigam as duchas dos banheiros. É indispensável ler as plantas para se informar do conceito da casa. Numa área de 600 metros quadrados de terreno e 450 metros construídos, o construtor conseguiu criar 
amplos espaços para o living, sem prejudicar os demais setores, as áreas de repouso e de atendimentos das funçóes, digamos, maquinísticas, para lembrar a superada definição de lembrar a superada definição de Le Corbusier. O verde, o pingo de natureza que se tornou implícito nas construçóes de hoje, a animação do décor por meio de objetos de arte bem escolhidos e combinados com os elementos de mobiliário modernos completam ambientes planejados para se morar convenientemente.

\section{Legenda}

p.86 Ugo di Pace conseguiu reservar amplos espaços param living, a área de estar da casa sem com isso sacrificar outras dependências, de utilidade funcional ou de lazer. I A parte externa da casa náo chega a ser desconcertante, como se poderia pensar, dadas as premissas do projeto, mas não houve realmente, da parte do arquiteto, qualquer preocupação formalista que lhe determinasse opçóes contraditórias com o aproveitamento dos espaços interiores.

Senhor Vogue \#5, agosto de 1978, p.I8, 20 (Entre homens)

Arquitetura Luigi VietTI, ARQUiteTo E URbanista. Resistente, conciliador, criativo

Eis uma ocasião para mim única: a de lembrar um tempo, já bastante recuado neste século, em que me vi envolvido numa das raras polêmicas da arte italiana ao longo dos vinte anos do regime mussoliniano. Polêmica que começou de um jeito que, curiosamente, me faz lembrar também o que aconteceu no Brasil ao tempo da ação dos Modernistas: état d'esprit pareil.

Na Itália, a situação da Arquitetura era mais ou menos igual à do Brasil: vigorava o ecletismo, isto é, o uso e aplicaçáo dos estilos do passado, porém readaptados naturalmente na fachada, pois o organismo funcional parecia não ser tarefa dos incumbidos da estética da construção. Constatado o atraso que em geral o país apresentava, desencadeou-se a polêmica, liderada pelo grupo "Movimento Italiano Architettura Razionale.” A iniciativa culminou numa exposição aberta na Galleria d'Arte de Roma, então por mim dirigida, apresentando conjuntamente projetos e fotografias de algumas realizaçôes de jovens arquitetos, o Tavolo degli Orrori, uma ampla fotomontagem de minha autoria em que se ridicularizavam os monumentos e os palácios de autoria dos "mestres" em evidência, todos pomposamente distinguidos com o galardão de membros da Real Academia da Itália.

Os críticos italianos, agora que o fato se tornou história, consideram aquela exposição o marco inicial da luta por uma arquitetura mais coerente com os tempos. Luta na qual se uniram elementos cansados da estagnação da construçáo, engenheiros, jovens recentemente formados e egressos das faculdades, bem como todos aqueles que não concordavam com o ensino e a vigência de um gosto passadista, em grande parte devido ao fato de que o arquiteto náo era o profissional que hoje se conhece, mas um simples licenciado das escolas de belas artes, com diploma de "desenho arquitetônico," cabendo ao engenheiro a parte pertinente à construção.

Nem todos os participantes da manifestação aderiram ao Racionalismo ortodoxo, porém, todos acreditavam que o panorama deveria de qualquer jeito mudar.

Entre os que participaram da reação estava um arquiteto que naquele tempo andava se afirmando na profissáo, Luigi Vietti, o amigo Vietti que após longos decênios acabei por encontrar aqui no Brasil, para realizar um projeto destinado à implantaçáo do Helvetia Country Club, em Indaiatuba, a vinte quilômetros de Campinas, Estado de São Paulo.

Vietti não mudou nada. Calmo, sorridente, ponderado nos julgamentos, sempre disposto a procurar soluçóes eficientes. Encontramo-nos na chácara dos Moroni, ao pé do Pico do Jaraguá, na capital paulista, oportunidade em que evocamos os tempos da polêmica italiana, como falamos também dos seus trabalhos. Vietti ficou conhecido quando venceu, como urbanista inovador, o concurso destinado a estabelecer o plano diretor da zona oriental da cidade de Gênova, o que lhe valeu participar de vários outros projetos, como os de Cortina d'Ampezzo, Portofino etc. O mais famoso é o da ordenação da Costa Esmeralda, na Sardenha, obra que todos conhecem. (Vejam Casa Vogue, edição de fevereiro deste ano.) 
Disse que Vietti foi um dos nossos companheiros que trabalharam para a elevação do nível da arquitetura italiana, desfraldando a bandeira do Racionalismo, enquanto eu insistia na fórmula "contra o desperdício decorativo," fato que nos trouxe o apelido de partidários da "arquitetura hospitalar” e, politicamente, a denúncia de querer importar a "arquitetura soviética.” (Por coincidência, fiz uma viagem à Rússia, integrando uma comitiva de arquitetos europeus que visitaram aquele país sob o patrocínio da revista francesa Architecture d'Aujourd'hui, da qual eu era redator.) O racional, para Vietti, está em resolver a função orgânica de uma construção, mas combinando-a com a preocupação do agradável, melhor dizendo, da elegância, apesar desta palavra soar de forma equívoca algumas vezes.

Quem procura um arquiteto - e não brilha de uma viva cultura estética (o que acontece de vez em quando) - prentende justamente habitar ambientes, além de praticáveis, de bom gosto.

Nem sempre o encontro entre o arquiteto e o futuro morador é dos mais tranquilos, pois é sabido que quem encomenda tem um ponto de vista firmado do que deseja, de suas necessidades. Tem imposiçóes e sugestôes, (raramente confia no contratado, limitando-se a declarar que irá ver quando a casa estiver pronta) especialmente quando as senhoras desfilam um festival de palpites. $\mathrm{O}$ arquiteto, dono do assunto técnico e artístico, deve escutar, discutir, resolver e conciliar. E para contentar a madame ou o dono, não pode correr o risco de construir, como dizia Flaubert, um sobrado esquecendo a escada... Assim, o bom arquiteto deve ser diplomata, maneiroso, hábil conversador para, tendo em vista o interesse do resultado, convencer e vencer finalmente. Vietti é mestre na arte de conseguir convencer e vencer. Senhor de um estilo que evita a excentricidade, alcançando o saudável de linhas harmoniosas, o bonito, como se diz aqui no Brasil para classificar moradias confortáveis, luminosas, entrosadas com a natureza. Isto é: a arquitetura que afinal se tornou normal no Oriente, consagrando o trabalho dos pioneiros europeus e americanos, como Le Corbusier, Mies van de Rohe, Frank Lloyd Wright e Richard Neutra.

Vietti será hóspede de São Paulo, ou melhor, de Giorgio Moroni, para apresentar o projeto do novo núcleo de lazer do Helvetia Country Club, apresentação esta que se realizará no Museu de Arte de São Paulo, às 18 horas do dia I9 de setembro próximo.

Senhor Vogue \#6, set 1978, p.I06-II3

CUIDADO! O PASSADO QUEBRA

Nosso patrimônio artístico poderá ser devastado.

Os perigos rondam. Mas há também quem o defenda

Na edição de julho passado de Senhor Vogue publiquei ampla reportagem dedicada aos senhores que se interessam pela bagatela chamada Arte e brilham como amadores, investidores, mercadores, falsários e quantas outras "qualificaçôes" deferidas aos sentados no sofá da Musa Pintura, a mais cortejada neste Brasil que vai para a frente. Nestas novas páginas gostaria de excursionar pelo campo da Musa Antiquária, isto é, encontrar aqueles senhores que se interessam por objetos que os tempos passados nos deixaram como herança, algumas vezes obras-primas ou simples bugigangas, os dois extremos suscetíveis de recordaçôes, dignos de melhor atenção e de conservação, pois constituem o patrimônio mais certo de nossa História.
Os torcedores da memória nacional

A incumbência, em termos gerais é, como poucos sabem, delegada pela Federação ao Instituto do Patrimônio Histórico e Artístico Nacional, órgão que faz o que pode nos limites das verbas que recebe, resistindo quanto pode diante das pressóes de que é alvo por parte do poder econômico que, por exemplo, náo lhe permitiu sequer sustar a destruição do palacete que foi residência do patrono do Exército, o duque de Caxias, para ali levantar um belo prédio de apartamentos.

Penso que os mais ativos colaboradores do IPHAN sejamos nós torcedores da memória nacional, museólogos, colecionadores, estudiosos, pesquisadores, antiquários. 
Os colecionadores e os antiquários são verdadeiros colaboradores das autoridades no que se refere à conservação e à defesa do patrimônio. Isto não só no Brasil, mas em todos os países. São eles que, muitas vezes, atuam como guardiães, para salvar da destruição obras de arquitetura, talhas, imagens, bibliotecas e arquivos. Por outro lado, há o problema dos objetos que desaparecem, especialmente das igrejas, por vendas que os padres combinam, ou em consequência de roubos. Tanto num quanto noutro caso, o patrimônio toma as providências cabíveis, seja através do tombamento das obras, atribuindo responsabilidades precisas ao clero, seja obtendo a necessária proteção.

O Patrimônio tem os meios legais, o pessoal necessário para resolver a defesa e a conservação da memória brasileira? Desde o tempo do inesquecível Rodrigo Mello Franco de Andrade, ${ }^{22}$ o Patrimônio vem desempenhando um papel constante e zeloso, nem sempre satisfatório e que nos permite perguntar: por que o governo não se decide a salvar convenientemente a memória nacional? Basta lembrar que, ainda na década de 30, a Bahia assistia à destruição da Sé de Salvador para dar passagem a uma linha de bonde que os baianos apelidaram de Marinetti. (O fato ridículo é que a destruição foi realizada depois da competente permissão do papa.)

Também o pálido interesse geralmente demonstrado pela História é fator a ser considerado em termos de colecionadores. O jornal O Estado de S.Paulo, no ano passado, denunciou em editorial um caso típico: em Londres, foi leiloado um lote de correspondência de dom Pedro I, alcançando preço modesto em libras esterlinas. Nenhum brasileiro em Londres, em cuja embaixada temos adidos culturais, se interessou pela compra, feita afinal por um comerciante de autógrafos parisiense, do qual acabei adquirindo os documentos, talvez imbuído de carità di patria.

22 Rodrigo Mello Franco de Andrade foi presidente do IPHAN desde a sua fundação, em 1937, até 1968, quando se aposentou. Disponível em <https://www.ufmg.br/frmfa/ historico/>. Acesso em 26 jan 2014.

\section{A barreira alfandegária}

Maior interesse é demonstrado peles antigos objetos de arte nacional, ativando um consistente mercado. Às vem concentrando a preocupação de possuir peças raras de custo exagerado como é o caso das paisagens de Frans Post que, pela corrida descontrolada para possuí-los, atingem valores francamente só para brasileiros ricos verem.

Porém, à parte as extravagâncias, o interesse pelos objetos históricos existe e prospera. Isto ficou claro no recente II Salão Nacional de Antiquários, realizado no Masp. Para quem conhece as manifestaçôes similares promovidas nos centros europeus, o referido certamente apresentou um conjunto de peças do mais alto padráo. Prevaleceram as obra nacionais, fato que se repete tanto em Londres quanto $m$ Florença, porém não faltaram obras estrangeiras, entre as quais as orientais, a prata inglesa, alguma pintura europeia, a cerâmica pré-colombiana. Tudo demonstra que o antiquariado esta se movimentando para encontrar outros setores de mercado além do nacional.

Caso algum dia as autoridades fazendárias se disponham a um gesto de lucidez e decretem a abolição da perseguição que movem contra os objetos de arte que chegam aos terminais marítimos, aéreos e terrestres do país, o mercado se fortalecerá não apenas em benefício da economia nacional, mas sobretudo enriquecendo o patrimônio cultural. (Logo após a última guerra, os antiquários da Itália derrotada, na mais precária situação financeira, obtiveram consideráveis créditos e permissóes para importar, concentrando as compras no mercado londrino; como consequência, houve a ativaçáo do mercado com o exterior, que resultou em benefícios para a balança comercial italiana.) Não é possível que um painel de Rafael seja barrado em nossas alfândegas como se fosse um simples lote de perfumes franceses.

É do interesse da nação a abertura dos portos, para que cheguem até nós objetos de arte antigos e contemporâneos. Gesto de alta relevância cultural para o Brasil vem de praticar o dinâmico e combativo parlamentar paulista Israel 
Dias Novaes ${ }^{23}$ ao encaminhar à mesa da Câmara dos Deputados um projeto de lei que restabelece as condiçóes de importação de obras de arte vigentes até 1974 , pois até aquele ano o imposto incidente fixava-se em $2 \%$ enquanto o decreto lei I.364 elevou-o para Ioo\%.

$23 \mathrm{Na}$ época, 1978, Israel Dias Novaes foi presidente vitalício da Academia Paulista de Letras e foi eleito deputado federal em 1975. Em 1978, ano deste artigo de Bardi, Novaes seria considerado o melhor deputado federal em todo o Brasil. \{Academia Paulista de Letras\}
O país já tão pobre de obras de arte viu-se de um momento para outro privado de um intercâmbio artístico. $\mathrm{Na}$ justificativa de sua propositura o deputado Novaes enfatiza que essa elevação de alíquota teve caráter abrangente e visou a favorecer nossa balança comercial. Seu erro foi incluir obras de arte como pinturas, desenhos, gravuras, estampas, litografias, estátuas, esculturas, objetos de arte antigos com mais de cem anos. Propóe, com sua iniciativa, o retorno à situação anterior de uma alíquota de $2 \%$ sobre esse tipo especial de importaçáo para uma retomada do desenvolvimento artístico do país.

Valor da arte é função do desejo de tê-la , p.Io6-IO7

Depoimento de Amim Brunetti Atta; cf. Anexo B, p.632

Os PIONEIROS E AS PIONEIRAS, p.IO8-IO9

Elas serviam chá aos santos padres em troca...

$\mathrm{Na}$ reportagem dedicada à arte contemporânea restrita principalmente à pintura produzida pelos que são chamados de "clássicos" nacionais, tivemos ocasião de lembrar a recente formação do mercado, lembrando as iniciativas dos importadores estrangeiros de coisas de arte, bem assim outras determinadas pelas nossas elites que transcorriam temporadas em Paris. Em geral o que traziam bem espelhava o gosto acadêmico pela pintura, com atenção voltada para as telas decorativas, sem demonstrar interesse particular para com os mestres das vanguardas, exceção feita a alguns amadores mais informados, destacando-se dentre eles, Paulo Prado, Olívia Guedes Penteado e Oswald de Andrade. No setor antiquário se importaram obras de arte de alguma importância, como se deu, por exemplo, com as famílias Guinle no Rio e Matarazzo em São Paulo. Porém, em geral o que se importou confirma o opiniấo de que o gosto não era dos mais refinados. $\mathrm{O}$ problema de um interesse pelo antiquariado e para com a arte, nos anos 20, era apenas aparente, começando a ter os primeiros elementos curiosos pelo passado e descobridores de possíveis negócios.

Quem conhece todas estas histórias do advento do objeto antigo é um personagem de destaque e autor do primeiro livro sobre o mobiliário colonial, o veterano romancista e pintor José de Almeida Santos.

Procurei-o em sua casa repleta de recordaçôes. Lembrou seus colegas pioneiros do mercado de antiquário. Contou que os iniciadores foram, em São Paulo, o prof. Mello e Castro, ${ }^{24}$ sobrinho-neto da marquesa de Santos; no Rio, Baerlain, ${ }^{25}$ personagem lendário. Dos antigos, alguns ainda existem na praça. Como o Francisco [Roberto], ${ }^{26}$ que ainda recentemente

24 Náo conseguiu-se descobrir o nome exato. É possível que seja filho de Maria de Castro Canto e Mello, (sobrinha da marquesa) com Brasílico de Aguiar e Castro (filho da marquesa) em seu segundo casamento.

25 John Emanuel Baerlein, engenheiro elétrico e civil, nascido em Portugal em I896, fundou a John Baerlein e Cia., rebatizada de Baerlein construtora, no Rio de Janeiro. | Fernando Baerlein, Relojoaria da Bolsa, r. Ouvidor 54 almanak administrativo, mercantil e industrial p.I347 (I9I8)

Coincidentemente, na av. Cidade Jardim, além de Francisco Roberto havia outro antiquário Francisco, o de sobrenome Schwarcz, acusado de envolvimento no roubo da Igreja Matriz do Pilar, em Ouro Preto, 
abriu uma grande loja na avenida Cidade Jardim, e o rei das miudezas, o popular [José Claudino da] Nóbrega, ali na alameda Casa Branca quase esquina da rua Estados Unidos. Existiam outros na São Paulo que ambicionava ser a capital artística do país. Almeida Santos lembra o André Levy, o Stroppel, o Basile, o popular Florestano, o astuto Moysés, e uma razoável patrulha de mulheres que se improvisaram de colecionadoras, mas que vendiam "os excedentes." Entre elas Leonor Sampaio Moreira, Narciza Espíndola, Eliza Benjakar e Zezé Botelho.

Uma outra dessas colecionadoras- marchands era famosa por arranjar mercadorias. Passeava de carro com o Max, um satélite de Moysés, o Jayme. Madame descia na porta das igrejas, entrava, olhava os objetos que interessavam e a seguir, já no carro, mandava Max recolhê-los. Às vezes o colecionador cometia enganos e a colecionadora mandava devolver ou trocar o objeto trazido. Ela tinha outras duas amigas: serviam chás aos cônegos em suas casas e em permuta "compravam" castiçais, tocheiros, imagens, âmbulas, navetas, cálices, turíbulos, santos-óleos, paramentos agaloados de prata dourada.

que chegou a ser preso, mas que negou participação e logo foi solto. Esse caso foi, por algum motivo, proibido pela censura de ser veiculado em qualquer meio. Até hoje, os autores desse crime, um dos maiores da história de roubo a museus do Brasil, nunca foram encontrados nem punidos. "Habeas do antiquario..." Folha de S.Paulo; "Sinos repicam em protesto." Folha de S.Paulo; Werneck. Roubo de peças sacras... Defesa Civil do Patrimônio Histórico e Artístico Nacional. O roubo, mercado e catalogação oficial de peças sacras será tema de entrevista ao leiloeiro Antonio Leon Filho, o Leone, em Arte Vogue \#I, p.26-28. Curiosamente, o entrevistado estaria ele próprio envolvido, em fevereiro de 2007 , com o roubo de obras de arte: cinco gravuras de Friedrich Hagedorn, pertencentes ao acervo da Biblioteca Nacional, além de outras, peças em outubro de 2007.
Pergunto ao memorialista se além das madames, naturalmente, havia os que compravam os "excedentes," isto é, autênticos colecionadores. Sim, havia: ele, Guilherme Guinle e o Mariano Carneiro da Cunha, no Rio; Calmon, na Bahia; em São Paulo, alguns amadores: Octales Marcondes, Heitor Portugal, Alcides Vidigal, Aristides Lara e o embaixador Macedo Soares, Jacó Guariglia, Oto Bier, Pignatari, José Gonçalves, Júlio Pinotti, Benjamin Mendonça e outros. Lá pelos anos 30, José Almeida Santos consegue publicar na Folha de S.Paulo uma coluna especializada em antiquariado. Foi convidado por seu amigo Benedito Bastos Barretos, o popular Belmonte. Retomou o gosto de escrever, hábito que tinha deixado para se consagrar à profissão de antiquário, deixando de ser redator e gerente de $O$ Impão, de Amadeu Amaral e Jairo Góis, uma publicação que tinha como colaboradores Guilherme de Almeida, Menotti e o jovem Di Cavalcanti.

O Rio e São Paulo foram as duas cidades que mais atenção deram a nossa história das artes. Os poucos colecionadores operaram contactando com os museus, depósitos promíscuos de poucas coisas de valor e de bric-à-brac, sem disposição harmoniosa, sem critério didático. Os diretores se consideravam "donos" do acervo público ali existente, sem fichário. No livro de [José de] Almeida Santos, Mobiliário Artístico Brasileiro, existem dois desenhos: "Casa Para Morar" e "Casa Para Atrapalhar" que dão ideia da influência perniciosa dos museus na interpretação particular de colecionador desavisado. De vez em quando algumas exposiçóes dos artistas dos quais se falava eram realizadas. Bastará lembrar a de Antônio Parreiras ${ }^{27}$ que esteve em São Paulo com uma mostra na rua Barão de Itapetininga, recebendo uma única "reserva." O futuro comprador era Mário Salaberry, ${ }^{28}$ preposto de leiloeiro.

27 Antônio Diogo da Silva Parreiras, (Niterói RJ I860-I937) ilustrador, desenhista e pintor academicista

28 Mário Salaberry (ora grafado Salaberri) era ator. Viveu no Rio com a esposa e atriz Zilka Salaberry. Em 1949, tentou abrir 
Ao fechar a exposição, Parreiras não teve confirmação da compra. Voltou com os quadros para Niterói, onde morava. Oscar Pereira da Silva, naquele tempo, não podia abrir exposiçóes por falta de dinheiro para confecção das molduras.

$\mathrm{O}$ amigo Pedro de Oliveira Ribeiro Neto, ${ }^{29}$ historiador e primeiro diretor do Museu de Arte Sacra de São Paulo, lembra que no Brasil dos anos 30 ainda se tinha facilidade em encontrar objetos de arte antigos e adquiri-los, inclusive para exportação, sem qualquer providência que o impedisse. Quantas não foram as igrejas e capelas levadas de Minas e
a Companhia Mário Salaberry
de teatro, no Conservatório
Dramático e Musical. Morreu
em I7 nov 195I, em Pernambuco, num acidente automobilístico.
"Campanha contra... " A Noite,
I949; "Faleceu o ator teatral Mario
Salaberry." Folha de S.Paulo, I95I.
29 Pedro Antônio de Oliveira
Ribeiro Neto, 1908-1989.

da Bahia, nessa época, para colecionadores estrangeiros, principalmente dos Estados Unidos, e lá expostas como arte, que era coqueluche local, sem contar as pratas e móveis vendidos na Argentina.

Pedro disse ao repórter: "Quem, naquela época, já entendia de alguma coisa, no Brasil, pôde realmente conseguir peças invejáveis, por preços ridículos. Em geral as coleçôes, quando não são de objetos previamente escolhidos, dependem de oportunidade de herança ou de encontro de peças do mesmo gênero, evidentemente agrupadas por pessoas de gosto e sensibilidade especiais. Assim, quem as herda ou adquire, em geral vai pesquisar e anexar outras peças no gênero, de interesse artístico ou histórico. No meu caso foi o que aconteceu, pois meus pais e avós já guardavam peças artísticas ou históricas há várias geraçóes. Com o acervo ao qual me habituei a vida toda, não foi difícil, há cinquenta anos, aperfeiçoá-lo, sem que ninguém se incomodasse com as peças que encontrei à venda e comprei com os meus parcos salários de moço."

$\overline{\text { ESTES VETERANOS, incansáveis pesquisadores e garimpeiros de obras de arte, estão na linha }}$ de defesa do patrimônio brasileiro, p.Io6-IO7

José Almeida dos Santos, veterano dos antiquários, autor de Mobiliário Colonial Brasileiro.

Eduardo Etzel, possuidor de duas mil peças, das quais I 388 cedidas ao Museu de Arte Sacra de São Paulo.
O paulista Francisco Roberto, descobridor de extraordinária seara de imagens, colecionador emérito.

José Claudino da Nóbrega, o mais popular dos antiquários de São Paulo, Brasil-trotter incansável.

IMPORTÂNCIA DA SOCIARTE, p.II2

Não podemos deixar de mencionar o esforço que um grupo de colecionadores vem fazendo desde 1967 para o desenvolvimento do colecionismo da chamada pintura acadêmica brasileira: a Sociarte, entidade paulista que tinha à sua frente o médico Argemiro Siqueira, ao lado de Américo Ribeiro dos Santos, João da Cruz Vicente de Azevedo, Duilio Crispim Farina, Noedu Correa, Augusto Veloso e outros. Os associados realizam reunióes mensais alternada nas casas de cada um. Mais de uma centena de reunióes e exposiçôes foram realizadas, sendo a mais recente a dedicada a Castagneto. Após um decênio de atividades o entusiasmo é o mesmo, havendo reunióes semanais na sede à rua Pedro Taques, continuando o precípuo objetivo de congregar os amantes da arte e o de enaltecer parcelas do nosso patrimônio artístico. A Sociarte é atualmente presidida por Augusto Veloso.

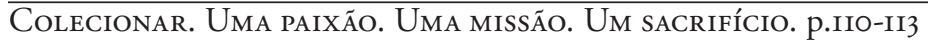

Falemos de história do colecionismo. Trata-se de um capítulo indispensável para evidenciar a história da burguesia que estruturou o Brasil. Eis um assunto para os jovens que agora, numerosos, 
ascendem à carreira frequentando as Faculdades de Ciências Humanas.

Dom João VI, o primeiro colecionador

Pode ser que o colecionador mais antigo no Brasil tenha sido dom João vi quê trouxe às pressas de Portugal objetos de arte existentes na corte reinol. A ele se deve acrescentar a figura de Lebreton que desembarcou no Rio chefiando a Missão de I8I6, com uma quadraria. Ao longo do Oitocentos não se tem notícias de juntadores de obras de arte. O teatrólogo Arthur Azevedo possuía rico conjunto de gravuras que deixou ao governo do Maranhão, conjunto esse irrecuperável. (Pode ser que algum historiador nos corrija.) É do Novecentos a descoberta propriamente dita do colecionar. Tímida nos primeiros decênios, adolescente entre as duas guerras, juvenil depois da segunda.

Nesta reportagem é quase impossível oferecer-se um quadro completo deste saudável hobby brasileiro. Nossa intenção é de assinalar alguns dos beneméritos, bem sabendo que tanto no Rio quanto em São Paulo, Bahia, Recife, Curitiba e em outras capitais e até em centros menores existem elementos desconhecidos dos quais gostaríamos, proximamente, em Casa Vogue ou em Arte Vogue de registrar o labor. Assim rogamos a benevolência dos eventualmente esquecidos, sem dúvida, reconhecemos, em número considerável, (antigos e novos; de arte brasileira ou internacional; de coisas modestas ou então de alto valor; de etnografia e de arte popular; armazenadores e descriminadores de peças; ocasionais e contumazes etc.) todos aqueles que se congregam no operar para preservar documentos de história, incentivar artes, contribuindo assim na tarefa de enobrecer nossa História.

\section{No Rio de Janeiro}

Lolly Hime, no Rio de Janeiro, obteve para esta reportagem alguns depoimentos de colecionadores cariocas que aqui reproduzimos:

Francisco de Paula Machado, presidente do Jockey Club do Rio e possuidor de uma singular coleção de pesos de papeis franceses, várias peças procedentes de um leilão do antigo rei Farouk. Quando jovem foi influenciado por seu tio Guilherme Guinle, colecionador de apurado gosto do antigo e do moderno, o qual, ao falecer e ciente do interesse do sobrinho, doou-lhe a coleçâo inteira: peças, entre as inúmeras do século I9, das manufaturas Baccarat, Clichy e St. Louis.

Marcos Carneiro de Mendonça, outro colecionador que em sua casa, em Cosme Velho, conserva uma preciosa Brasiliana que será futuramente transformada em Fundação. Casado com a poetisa Anna Amélia, é considerado profundo pesquisador de documentos, possuindo entre esses uma carta em que o enviado especial de dom João vi ao Brasil, o diplomata Charles Stewart, então a serviço da Inglaterra em Portugal, enviou ao rei para debater a questão do reconhecimento de nossa independência. Este precioso documento, entre tantos de igual importância, faz parte do arquivo desse estudioso de nossa História.

Antônio de Avellar Fernandes coleciona há quarenta anos porcelana europeia. Tem peças do Reinado e do Império bem como possui significativo grupo de xícaras que vai desde o século I8 até o começo do século I9, representando 32 manufaturas europeias. Complemento curioso é uma pequena coletânea de xícaras com marcas falsas, como Sèvres, Meissen, Nápoles e Viena.

O casal José Willemsens coleciona particularmente móveis, pratas portuguesas e louças da Companhia das índias, muitas delas herdadas por seus antepassados. $\mathrm{Na}$ coleção destacam-se pinturas do século I9 representando vistas do Rio como até produçóes de Fabergé, e um famoso serviço da Companhia das Índias, o dos galos, entre os que vieram com a corte de dom João vi, o mesmo se dando com um grupo de imagens barrocas paulistas e mineiras.

O prof. Jorge Rezende prefere ser tido como um colecionador amador já que: "Busco a seleção do objeto, a cada peça rara, as trocas, a homogeneidade. Tudo representa um ato de amor. Solicitam-me, também, que discuta o porquê do gosto pelas espevitadeiras. Não sei. Talvez porque tenha herdado uma, inglesa, peça de família, que me estimulou a procurar outras, da mesma época. Difícil é apenas começar." Coleciona 
ainda pintura brasileira, imagens barrocas, porcelanas, raridades e particularmente espevitadeiras, acima mencionadas.

Cândido de Paula Machado é considerado um dos bons colecionadores de mobiliário brasileiro disposto em sua casa segundo as regras de uma estética e de convivência no cotidiano. Difícil descrever, porém cabe destaque o arcaz almofadado em losangos de Sergipe, várias cadeiras dom João vi, os aparelhos da Companhia das Índias, a balaustrada de antiga igreja da Bahia, os móveis-miniaturas, as pratas, as mesas-credências entre as quais uma atribuída ao Aleijadinho. A quadraria é bem rica: entre as pinturas, documentos importantes de Emilius Bauch, austríaco, paisagista do Rio no Oitocentos. A respeito do colecionismo ele declara: "Para mim, o objeto de arte é a, materialização de uma cultura, de uma civilização, que introduzimos em nossa vida como uma dimensão enriquecedora na busca da harmonia. A sua procura, o seu encontro, são prazeres maiores até do que a sua posse."

O empresário dr. Leonídio Ribeiro, presidente da Sul América Cia. Nacional de Seguros e também da Fundação Estadual dos Museus do Rio, antigo colecionador de pinturas nacionais, nos declarou: "A arte é parte integrante de todo ser humano que tem condiçóes de desenvolver sua sensibilidade. No meu caso, o gosto foi herdado. A pintura foi o caminho através do qual estabelecia ligação com o universo das artes. Considero-me possuidor de uma boa coleção e, na Sul América, acredito que, em mais alguns anos, teremos o melhor acervo de pintores brasileiros do país. Entendo ser dever de todo empresário apoiar e incentivar as diferentes expressóes de cultura do seu povo."

Outro empresário, Celso da Rocha Miranda, ama ir à procura de livros, mas confessa modestamente náo merecer ser incluído entre os colecionadores pois, segundo ele, nunca o foi. "Colecionador é quem busca raridades. Creio que o que possuo em livros é o que restou de meio século de leitura, ou referem-se a algum assunto específico." Apesar de não se confessar colecionador, Rocha Miranda possui uma biblioteca e tem raros documentos sobre a História brasileira, naturalmente alguns documentos inéditos: boa safra sobre o período da transferência da família real para o Brasil, acontecimento ainda pouco estudado sobre o qual ele gostaria de aprofundar seus próprios conhecimentos, divulgando suas conclusóes a respeito, com a correspondência de Lord Strangford, o diplomata inglês que acompanhou a família real ao Brasil, quando revela os surpreendentes motivos que protelaram por três anos a assinatura dos tratados de I8Io. Enquanto ele recolhe bibliografias e fontes de nossa História, sua esposa Maria Luiza, (Malu) prefere colecionar arte antiga nacional e contemporânea. Na belíssima casa da rua Marquês de Sáo Vicente, o barroco encanta, e póe diante dos estudiosos problemas de atribuicionismo, como as duas credências provenientes de Bom Jesus do Matosinho, parecendo ser produto de artesão espanhol. Nas paredes obras de Marie Laurencin, Boucher, Rugendas, Castagneto, Marieschi, Portinari, Greuze, Djanira, Guignard. Duas estantes abrigam uma rica coleçáo de araras, em porcelana de Saxe e Meissen. Entretanto, o casal Rocha Miranda orgulha-se de sua maior coleção, a que cultiva em sua propriedade de Petrópoles: oito mil orquídeas.

Precisaríamos falar de inumeráveis outros colecionadores. Como de Eva Rapaport, cuja paixão é a arte antiga europeia. Ela pode ser uma das poucas entre os que se interessam pela arte de outros países. $(\mathrm{O}$ mesmo que se nota na rica mansão de Ema Klabin, em São Paulo.) Também Antônio Sanchez Larraigoti tem preferência por apreciáveis peças europeias. A embaixatriz Gilda Sarmanho possui uma selecionada coleção de pré-colombianos e pratas da Rússia. (No setor do pré-colombiano o paulista Oscar Landmann se destaca como colecionador de fama internacional.) A embaixatriz Esther Lago coleciona arte oriental. (Formou excelente coleção de arte chinesa quando, com seu marido, nosso embaixador, lá viveu durante anos.) Famosa é a coleção da embaixatriz Elsa Souza Leão. Mário Peixoto, o enfant prodige do cinema que em 33 realizou Limite, gosta de antiquariado, pretendendo deixar na Ilha Grande, onde vive há 34 anos um Museu do Litoral Fluminense. Outros colecionadores? Paulo Geyer, Josefina Jordan, Ivo Pitanguy, 
Carmen Mayrink Veiga, Maria Cecília Fontes, Guiomar e Gustavo Magalhães.

\section{Coleções de todos os tipos}

Além daqueles que juntam o colonial, temos notícia dos que se dedicam ao colecionismo de vários e às vezes surpreendentes setores. Seria impossível anotar todos (bastante numerosos mas escondidos) aqueles que recolhem em silêncio e não mostram suas coisas.

Coleciona leques d. Maria dos Passos Castro; pratos brasonados, Sebastião Ribeiro Lowndes; xícaras brasonadas, Antônio de Avellar Fernandes; joias antigas, Celso Cirilo; candelabros chanukiot. (Em São Paulo, surpreendente coleçáo de objetos hebreus como a do dr. Leon Feffer, cujos filhos Fanny e Max também são colecionadores.)

Fernando Leão, no Rio, é apontado como atento interessado no art-déco. (Em São Paulo, Fúlvia e Adolfo Leirner apresentam belíssimo conjunto dessa época, como são hoje os mais estudiosos especialistas deste estilo e do precedente art-nouveau.) Singular a coleção de Augusto de Lemos, do Rio, que junta somente pinturas do excelente pintor Sigaud. Na antiga capital existem residências que poderiam ser um dia consideradas e merecedoras de um testemunho público para que os pósteros venham a saber como se vivia nestes tempos correntes, numa amável convivência com obras de arte. Em Nova York muitos são os que visitam a mansão-museu da Quinta Avenida, que um dia foi do colecionador Frick. Pensa-se, em termos nacionais, nas casas de boa arquitetura e de interiores de gosto apurado, como a do banqueiro Walter Moreira Salles, na Gávea, a de Plácido Gutierrez, por exemplo. Os que juntam preciosidades operam para enriquecer os museus. Na vizinha Petrópolis, dom Pedro Henrique conserva documentos de sua ilustre família e objetos do mais alto valor para a História que, sem dúvida, irão um dia completar os componentes que formam o Museu Imperial.

\section{$\mathrm{Na}$ ativa São Paulo}

São Paulo rivaliza com o Rio. Na Pauliceia foram formadas coleçóes vultosas.
Recentemente se dispersaram as peças juntadas diligentemente por Octales Marcondes Ferreira. (Conjunto que bem enriqueceria o acervo do Museu da Casa Brasileira; algumas peças passaram a integrar o acervo do Palácio dos Bandeirantes, pois os governos presididos por Abreu Sodré e Paulo Egydio se empenharam oportunamente na sua decoração; entre outras peças, foi adquirindo o painel Tiradentes, de Portinari, por quatro milhões de cruzeiros, o preço mais alto alcançado por uma pintura nacional.)

Lembramos que o patrimônio artístico se enriqueceu bastante através do que foi trazido por abastadas famílias israelitas antes da guerra, como os Arnhold, em Sáo Paulo, portadoras de coleçóes excepcionais; Ernesto Wolf, dono de um relevante conjunto de vidros antigos, além de pinturas, desenhos e gravuras; e quantos outros dos quais náo temos notícias. Não devemos nos esquecer a contribuição dos galeristas e antiquários. Lembramos Stanislaw Herstal, autor da mais completa iconografia de dom Pedro I e do primeiro álbum de imagens antigas brasileiras; o alemão Sprengel, moldureiro de Goering e depois antiquário; a sra. Giorgetti; (seu filho Carlos é hoje um dos mais conceituados antiquários nacionais) Ugo di Pace, que deixou o objeto antigo para se tornar construtor. A lista deve ser completada com o ativíssimo romeno Jean Boghici, o italiano Franco Terranova, que fundou com José de Carvalho a Petite Galerie carioca; Biagio Motta, fundador da Documenta, C.O K. Reichenheim, com a sua discreta Connoisseur, recentemente escolhido para representar em São Paulo a Sotheby's Parke Bernet. (No Rio representada por Walter Geyerhahn.) E que dizer de Benjamin Steiner, que deixou o jornalismo para se tornar um dos pesquisadores mais preparados das artes de fim e princípio do século?

Voltando aos colecionadores paulistas: de relógios, singular a coleção do saudoso Roberto Selmi-Dei e de Dimas de Mello Pimenta; em termos de máquinas, instrumentos de astronomia, autômatos, o arquiteto Ludovico Martino; Milton Guper recolhe objetos oitocentescos de diversões; a cerâmica de Saramenha tem seu dono e estudioso em Paulo Vasconcellos; 
os automóveis históricos foram a paixão de Roberto Lee e que constituem o acervo do atraente Museu de Caçapava.

Aqui caberia uma notícia sobre os cultores da bibliografia, assunto tão complexo que vai merecer uma reportagem à parte. Figuram em primeira plana Yan de Almeida Prado, Rubens Borba de Moraes, José [Ephim] Mindlin e a viúva de Carlos Rizzini.

\section{Nas capitais}

O Brasil é imenso e para saber-se de tudo que interessa à área da arte não é fácil. Sabe-se das atividades, geralmente através de notícias de crônica. Como a do Recife, onde Abelardo Rodrigues, hábil rastreador, conseguiu reunir 762 peças de arte colonial motivando a famosa disputa entre os Estados da Bahia e de Pernambuco para a compra da coleção. $\mathrm{Na}$ Bahia, a cidade mais apegada à memória nacional, com seu exemplar Museu de Arte Sacra, aberto pelo eminente historiador e monge dom Clemente da Silva Nigra, e seu Museu do Unhão, realizado pela arquiteta Lina Bo Bardi no governo Juracy Magalhães, com suas igrejas e conventos, sua patrulha de artistas sob a proteção de Jorge Amado; em Salvador, os colecionadores sempre foram ativos. Entre eles o antigo ministro da Educação Clemente Mariani, a família Catarino, Mirabeau Sampaio, a família Costa Pinto, cuja coleçáo é hoje acervo de um museu.

Em Minas existem numerosos colecionadores, entre eles, Geraldo Parreiras, que reuniu apreciável acervo que, há pouco tempo, seus herdeiros não tiveram dúvidas em dele se desfazer, vendendo-o ao governo do Estado pela respeitável soma de 27 milhóes.
Em Maceió, é a riquíssima coleção do pintor Pierre Chalita. Em Curitiba, destaca-se Newton Carneiro, não só como colecionador, mas também como um dos nossos mais brilhantes historiadores do período colonial, tanto assim que brevemente vai publicar uma monografia dedicada a Johann Moritz Rugendas..$^{30}$ No Paraná, também uma coleção única no gênero: a dos herdeiros do marquês italiano Vittelleschi, de relíquias arqueológicas etruscas. Certamente outros nomes faltam neste rápido panorama.

\section{E Brasília?}

E na capital? Eis um problema cultural merecedor de imediata atenção. Brasília não pode permanecer como uma amostra de arquitetura para impressionar apenas, mas deve formar seus centros culturais, emergir de alguns institutos para apresentar, antes de tudo, a História e a Civilização nacionais. As poucas coisas existentes no Palácio do Itamaraty são, na verdade, muito poucas.

Por que os colecionadores não se reúnem e oferecem a Brasília os materiais capazes e úteis para formar um núcleo museográfico, futuro Museu Nacional?

\section{"Infelizmente, os doadores são moscas brancas"}

Sabe-se, por experiência, que os doadores não passam de moscas brancas; de qualquer jeito, por que o embaixador Wladimir do Amaral Murtinho, responsável pela decoração do Palácio do Itamaraty e hoje secretário de cultura de Brasília, não pensa nesta possibilidade?

30 De fato, Newton Carneiro publicou o título Rugendas no Brasil pela editora Kosmos, no Rio de Janeiro, em 1979.

A arte é negociada, p.IIo

Depoimento de Paulo Vasconcellos; cf. Anexo B, p.632

Os ANTIQUÁRIOS, p. II3

O presidente da Associação Brasileira de Antiquários, Danton Vampré Jr., prestou a Senhor Vogue o seguinte depoimento sobre a posição do antiquário no Brasil: "Ao terminar o II Salão Nacional de Antiguidades e Galerias de Arte no
Masp, constatei que o comércio de antiguidades está passando por transformações importantes. No encontro dos antiquários abriu-se o diálogo tão almejado, fortaleceu-se o espírito de classe e foi provocada a conscientização da posição do antiquário 
ao apresentar ao público um comércio esclarecido e sério. Acredito, pelo que pude observar, que já temos, como no estrangeiro, quase que somente antiquários especializados, preservadores de objetos de arte e responsáveis perante seus clientes; também o trabalho criterioso de pesquisa e seriedade de muitos desses antiquários têm dado uma nova dimensão ao comércio de antiguidades, tornando-o no presente um comércio conceituado e de padrão Internacional.”

Um destaque (merecido) p.III

Texto de Amim Brunetti Atta; cf Anexo B, p.633

ATENÇÃo PARA OS “CLÁSSICOS” p. II3

O colecionismo das pinturas brasileiras mais em voga, a das dez, doze assinaturas que estão entrando para fazer parte ao antiquariado, é particularmente vivo no Rio e em Sáo Paulo. Muitos dos seus adeptos sem possibilidade de registro, sejam aqueles que conservam o que adquirem e os que promovem o fluxo das obras, nas suas transas de troca, venda, reposiçóes. $(\mathrm{O}$ que é normal no setor.) No Rio sabe-se de conjuntos interessantes como os de Cesar Mello Cunha que, ao lado dos nacionais, alinha De Chirico, Morandi, Baumeister, Guttuso; ele nos declarou: "Descobrir uma obra de arte é uma das minhas poucas atividades que me proporcionam satisfação; encontrar um quadro, móvel ou objeto que me agrade plenamente e que possa adquirir é para mim uma imensa alegria."

Registremos aqui entre as numerosas coleçôes de Drault Ernany, de Jorge Veiga, de Gilberto Chateaubriand, (400 peças de I22 autores) de Adolpho Bloch, de Manchete, que reuniu um dos maiores acervos de nacionais entre os períodos 40 e 70. Em São Paulo, Arthur de Camargo Pacheco, dono da conceituada galeria Cosme Velho, reuniu grupos bem escolhidos de nacionais, particularmente de Volpi. (Numerosos os que possuem Volpi, entre eles, Ladi Biezus, Marco Antonio Mastrobuono, ${ }^{3 \mathrm{I}}$ João Marino, também colecionador de modernos, Alfredo Nagib Rizkallah,32 Torquato [Saboia] Pessoa. ${ }^{33}$ )

Francisco Matarazzo o, presidente do MAM e das Bienais, colecionou exemplarmente para integrar o acervo do MAC peças entre as poucas de mestres contemporâneos europeus em São Paulo, e merece registro como façanha, naturalmente depois da do Masp.

\section{Legenda}

p.IO7 $\mathrm{O}$ mercado ainda não descobriu a arte da fotografia, uma nova fonte de colecionismo e, ao mesmo tempo, de recuperação de documentação de vida após as descobertas de Daguerre e do nosso Hércules Florence, até então reserva dos pintores. Aqui está uma rara fotografia em que aparecem figuras do patriciado paulista. Da esquerda para a direita: Sílvio Prado, Antonieta Arinos e Antônio Prado Júnior. (Coleção particular, São Paulo) 9 Trameau do século ı8, chinoiserie. Coleção de Amin [Brunetti] Atta, Rio de Janeiro p.Iog Art-déco e art-nouveau foram dois revivais que chamaram a atenção numerosos interessados. Existem em Sáo Paulo e no Rio de Janeiro peças muito bem escolhidas, como esta escultura em vidro da coleção Miroglio \& Yufon $\int$ A antiga pintura brasileira é rara, como raros são seus colecionadores. Mas aqui está O Natal, de pintor pernambucano do século i8, coleção de José dos Santos, de Pernambuco

32 Biezus foi presidente da Bovespa de 1976 a 200I. "Discussão da Lei das S.A.s...” OESP, 2I mar. $200 \mathrm{I}$.

Foi membro da comissão de arte do MAM-sP, juntamente com Ladi Biezus, Cesar Luis Pires, Emídio Dias Carvalho, Edo Rocha, Paulo Antonácio, Sônia Guarita e José Zaragoza. 
p.III Esfera armilar pescada em Parati e integrada à coleção de Paulo Vasconcelos, S.P.
p;II3 Celso da Rocha Miranda: livros g Cândido de Paula Machado: mobiliário brasileiro José Willemsens: móveis, pratas 9 Francisco de Paula Machado: pesos de papéis

Senhor Vogue \#7, outubro de I978, p.98-IO5

Histórias DE UM NAMORO QUE DEU CERTO

P.M.Bardi faz revelaçóes sobre a alquimia de nosso século:

como tirar arte da indústria e da propaganda

A estética, a par de todos os demais adendos da filosofia, mudou de rumo, e continua a mudar e vai se manifestando através de propostas e contrapropostas, por vezes aos saltos, que descombinam sua tradicional presença no campo das artes.

Este campo era, até há um século, ainda cultivado por inquilinos reconhecidos por suas patentes e diplomas, pessoal de ofício, chefiados por seus monstros sagrados, status indiscutível, reverenciados: o mundo das artes que já é história. Se alguém procurar considerá-lo é denegrido, recebendo as invectivas de "acadêmico" e de "passadista." Após a aventura dos Cubistas e Futuristas parece que as artes anelam por novidades.

O fato que contribuiu para as mudanças da estética foi o advento da indústria. Antes o utensílio era o produto de um trabalho manual, do artesão e do artista. Agora, o útil e o que se usa, vêm das fábricas, das máquinas, dos computadores impostos pelo Marketing e pela publicidade. As duas últimas açóes comandam um fenômeno típico do progresso: a moda, que se tornou um propulsor acelerado e incontrolável.

Há, é natural, aqueles que lamentam que as coisas não andam mais como antigamente, atitude a ser inscrita nas surpresas de La Palisse, sem refletir que cada um de nós somos elementos da massa e também se não compra vestidos em supermercados ou se não anda de fusca: as exceçóes dos que chegam à elite confirmam a regra geral de que o mundo vai se adaptando, cada vez mais, à estandartização da vida. O impulso provém da civilização industrial à qual são transferidos, se não por completo, pelo menos ingentes dispositivos da atividade arte.

O artista, solitário ou não, existe e vai existir sempre, implícito participante da criação, apesar do labor de um concorrente,

o cientista e suas equipes técnicas que, a um certo momento, coloca no ar um Concorde, maravilhosa obra de arte.

Picasso ou Matisse, para se tornarem populares, valeram-se e se valem das reproduçóes fotomecânicas. Os escultores se adaptaram à produção de múltiplos. $\mathrm{O}$ projetista de uma batedeira elétrica pode ser chamado de escultor. Os pintores de maior aceitação são os anônimos que desenham Imprimés para tecidos. Hoje em dia os artistas que estão mais em evidência são os designers, participantes do fato industrial.

Neste caderno dedicado à Rhodia há ilustraçóes que, direta ou indiretamente, permitem compreender qual a participação da indústria no desenvolvimento da estética.

Eu mesmo, creio ter colaborado em algumas manifestaçóes patrocinadas pela Rhodia. Uma foi quando esta indústria se interessou pelo revival do Art-Nouveau, marcando época a primeira tentativa brasileira de evocar aquele movimento surgido na França. Elaborei, como redator, um belo número da revista Jóia. ${ }^{34}$ A matéria serviu para o lançamento de um desfile de moda promovido pela Rhodia e realizado em várias capitais europeias. Após este revival, de repercussão internacional, a Rhodia teve a ideia, inédita, de convocar artistas brasileiros para desenhar imprimés, decisão importante, pois naqueles tempos tudo era importado. Foi a primeira vez que nossos pintores de cavaletes se dedicaram a este tipo de atividade. Após apresentaçáo em desfile todos os modelos foram doados ao Museu de Arte de São Paulo, que os conserva para oferecê-los, um dia, a um Museu do Costume. A Rhodia é ativa também no setor da editoria que visa ao conhecimento da história nacional

34 Jóia \#167, agosto de 1967 , Bloch Editores. 
devido ao especial interesse demonstrado pelo superintendente das comunicaçóes e relaçóes públicas da empresa, o dr. Luiz Seraphico, conhecido professor universitário e especialista em relaçôes públicas, que une à sensibilidade estética o conhecimento de opiniāo à qual as manifestaçóes são dirigidas. A ele devem ser creditadas as importantes iniciativas e, entre elas, o volume que teve por tema Capitanias de Mar e Serra, com texto de Julita Scarano e aquarelas de Thomas Ianelli. Este livro foi apresentado, em noite de gala, no Masp.

Um outro livro de sua autoria apresentado também no Masp, por ocasiāo da mostra "Artistas e Artífices do Brasil, séculos I6-I8," com o título Arte Colonial: Mobiliário, visualiza o mundo ideológico do Brasil colonial. O sentido dessas promoçôes de nível cultural responde à avidez de conhecimento, principalmente dos mais jovens, e demonstra a intimização da Rhodia com o Brasil. Para este ano a Rhodia está preparando uma história das comunicaçóes viárias no Brasil: a abertura de estradas, a audácia das Bandeiras, do lento entrelaçar dos territórios, do advento das estradas de ferro, a era do asfalto e da aviação. Será uma publicação que, pelas pesquisas, texto de fácil compreensão e farta ilustração, inédita, se constituirá em mais uma contribuição desta indústria para o enriquecimento da bibliografia no setor. Seu lançamento, a exemplo das publicaçóes precedentes, será feito no Museu de Arte de São Paulo reunindo o grande público que sempre acorre às promoçóes da Rhodia, visando a uma participação tangível à nossa cultura. É notável o espírito da Rhodia na comunicação da sua imagem visando, constantemente, ao aculturamento do seu fruidor.

Entre inúmeras iniciativas a que surpreendeu e causou impacto foi a série de anúncios evocadores de histórias do povo brasileiro: breves contos dedicados às atividades populares; uma publicidade de utilidade pública apreciando, com discrição, o nome da empresa.

Problemas comuns, soluçóes artísticas originais, p.IOO, IO2

O segredo: não mexer no trabalho do artista

Texto de José Hugo Celidônio; cf. Anexo B, p.633

\section{Legenda}

p.98-Ioo Nas fotos de Manduca Leal, trabalho Rhodia em casa própria:

o Museu de Arte de São Paulo

p.Ior Nas foto dessa página, as aquarelas que Thomaz Ianelli produziu com exclusividade para a Rhodia, em 1976. Elas estão publicadas em Capitanias de Mar e Serra, distribuído como brinde de fim de ano pela empresa. Uma bela maneira de se livrar do lugar-comum dos presentes frívolos que não identificam e dos objetos que vão diretamente para o esquecimento.

p.IO2 Luiz Antonio Seraphico, assessor de comunicaçôes e relaçôes públicas da Rhodia p.ro3 No livro sobre Mobiliário Colonial, a própria Rhodia se encarregou de fazer uma exaustiva pesquisa e preparar o texto, assessorada por uma agência de propaganda e pelos principais colecionadores do país. Disso resultou uma obra única, da qual nenhum interessado no assunto pode prescindir. Quem fatura com isso é a empresa

p.I04-IO5 A propaganda faz o nome sem falar do produto Textos do cronista Luís Fernando Veríssimo, o principal ingrediente de uma campanha que ficou famosa. As histórias do povo brasileiro, embora não dissessem uma palavra sobre as atividades da Rhodia, formaram uma imagem muito forte de ligação entre ela e o país em que está instalada

Senhor Vogue \#Io, janeiro de I979, p.82

A MODA É PARTE DA EXISTÊNCIA COLETIVA

No almoço que o Luis Carta ofereceu a Pierre Cardin, falou-se um pouco de tudo, mas predominantemente de moda. $\mathrm{O}$ que mais me interessou foi um fato que seria discutido melhor se as mesas, em vez de serem retangulares, fossem redondas: a nascente aversão das esquerdas políticas pela moda. Ou melhor: pela haute costure. A moda - dizem - é um disperdício de meios econômicos que bem 
poderiam ser aplicados no atendimento das desventuras humanas. Será mesmo?

Numa sociedade integrada como a que já está entregando seu modelo aos contestadores do século 2I, cujas vanguardas se preparam; numa sociedade como a nossa parece impossível uma mudança, dizia justamente Cardin, pois a moda é peça típica da manifestação social. A humanidade está por demais saturada de indivíduos que cultivam a auto-estima, para de golpe ou paulatinamente renunciar à sua aparência. Náo creio que vá desaparecer logo o mito da auto-estima, condensado no dito popular: é o traje que faz o monge...

As mulheres de hoje querem se diferenciar umas das outras, ajeitando um penteado de capricho diverso, a cor da roupa, uma maquilagem carregada ou não, e assim por diante. E os homens não estão indo pelo mesmo caminho? Sábado, durante uma das minhas aulas do Curso de Museugrafia, frente a um auditório quase totalmente feminino e constatando que as alunas davam sinais de impaciência ao se defrontarem com noçôes sobre metais, contei-lhes do almoço com Cardin: como num passe de mágica, o murmúrio quase chegou às raias do alarido. Minhas palavras foram absorvidas da maneira mais absoluta. $\mathrm{O}$ que isso significa?

Significa que a moda é um componente existencial coletivo: a gente se exprime através do jeito de vestir (até Oscar Wilde, que náo precisava de sinais para marcar

Senhor Vogue \#II, fevereiro de 1979, p.76-98 P.M. BARDI: O ANJO SEM ASAS DAS ARTES

Senhor apresenta-se este mês com uma novidade importante: um caderno de arte - que será mensal - editado por P.M. Bardi. E precedido, neste número, por um artigo autobiográfico do próprio Bardi que, modéstia à parte, (nossa e do autor) é uma joia. Uma vida de criatividade, vivida com inteligência e humor. (chamada no índice)

Seria muito complicado alguém condensar o que foram as múltiplas atividades exercidas por P.M. Bardi nos vários campos a que se dedicou, mais particularmente o jornalismo $e$ as artes. Assim, pedimos ao diretor e cofundador (juntamente com Assis Chateaubriand) sua presença, colocava um cravo verde na lapela.) Estou falando da moda em geral e não de excêntricos ou excêntricas. Estas últimas foram definidas numa recente entrevista do costureiro Valentino como "saindo do boudoir para subir no palco..." A moda é uma dinâmica cultural, a expressão de arte mais típica de um determinado tempo. Reconstruímos a história pelo documento do costume, índice de civilização e de distinção dos grupos étnicos e até políticos: na França, os contestadores não vestem o blusão preto e não deixam crescer a barba? As mudanças do sistema-moda (hoje aceleradas pelo consumismo desenfreado) demonstram a vivência cultural da gente. Como é o caso espetacular do império sempre mais amplo da moda neste século de metropolização crescente dos habitantes vindos do campo. Em qualquer aldeia, por mais modesta, se vocês falarem de Pierre Cardin todas as moças saberão quem ele é. A moda, através da TV e dos demais meios de comunicaçôes, divulga os figurinos apenas propostos por, Paris, até aos mais remotos sertóes. E se tirássemos de Paris o mecanismo por eles armado, o que aconteceria por lá? Das esquerdas se aponta a moda de extrema compostura e tremenda elegância dos chineses. Mas é uma moda, e corresponde à civilização milenar de um povo. E tão "moda" como as invençóes que a cada estação Pierre Cardin espalha pelo mundo. Concluímos com o artista francês, nascido em Veneza, que a situação da moda continua de pé, sem abalos. do Museu de Arte de Sáo Paulo um depoimento, para contar o que fez na Itália e o que fez e ainda está fazendo no Brasil. $O$ depoimento serve para apresentar as páginas mensais que Senhor Vogue vai dedicar às artes e das quais Bardi será o editor.

Até agora Senhor Vogue medalhou suas capas com ilustraçóes de caras dos assim classificados da produção, da política, da economia. Apresenta agora um simples oriundo daquela península que enviou para as Américas a multidão de camponeses 
e operários que andou fundando paesi e città, como contava uma antiga cançáo. ${ }^{35}$

Pensando em ver minha cara estampada e pendurada nas ruas, estou certo de que isto vai satisfazer alguns dos Prousts nacionais que, de vez em quando, me acusam nada menos de ter surrupiado e vendido uma obra pertencente ao museu que organizei com o sr. (aliás Senhor) Chateaubriand. Afinal eles podem imaginar o Bardi "procurado pela policia." (Contra as calúnias dos tais tentei reagir, mas no Brasil "o direito de defesa é um dos aspectos mais discutidos," disse recentemente o Odylo Costa, filho, durante solene sessão do Conselho Federal de Cultura, “...hoje consagrado na lei, embora - devo dizer como jornalista - sempre maliciosamente ludibriado pelo pessoal do jornal...") Assim, eis uma ocasião, conforme pedido do amigo Luis Carta, de oferecer um retrato do Bardi mais próprio e mais semelhante, penso bem diferente daquele pintado pelos fofoqueirinhos ativos nos laboratórios de boatos.

Permito-me, entâo, vir à presença dos leitores de $S V$ para decifrar um pouco da minha quase octogenária crônica.

35 A canção se intitula Trenta giorni di nave a vapore, (Trinta dias de barco a vapor) por ser de domínio público, tem algumas versôes que se diferem. Eis uma delas: "Trenta giorni di nave a vapore| fino in America noi siamo arrivati|fino in America noi siamo arrivati| abbiam trovato né paglia né fieno| abbiam dormito sul nudo e terreno| come le bestie abbiam riposà| E l'America l'è lunga e l'è larga*| l'è circondata da monti e da piani| e con l'industria dei nostri italiani| abbiam fondato paesi e città| e con l'industria dei nostri italiani| abbiam fondato paesi e città." (Trinta dias de navio a vapor| na América chegamos| não encontramos nem palha nem feno| dormimos sobre chão nu| como os animais repousamos $\| \mathrm{E}$ a América é grande* ("larga" pode ser traduzida como "generosa" ou "liberal") e longa| é cercada de montes e planícies| e com a indústria dos nossos italianos| fundamos vilas e cidades. Tradução nossa.)
Confesso: relato-a muito a contragosto; mais por passatempo. (Quem pode contar seriamente uma biografia são as sumidades que vão - ou aspiram - ver seus nomes nomenclaturados em ruas, avenidas, praças, viadutos, pontes e escolas em razão do status, ou pela amizade da família do finado com algum vereador.)

\section{O gosto de ser autodidata}

Menino sem letras, pois não consegui ser admitido no quarto ano do primário, depois de haver repetido três vezes o ano inferior, decidi-me aos dez anos ser rampollo independente da família. Trabalhei como office-boy, tarefa gostosa pois nos permite estar sempre na rua; depois como aprendiz e operário mecânico no Arsenal da minha cidade, La Spezia. A desastrosa derrota de Caporetto, na Primeira Guerra Mundial, quando a Itália, traindo a Intesa, reivindicava a posse de Trento e Trieste, me transplantou para uma bateria de artilharia de montanha onde os soldados deviam cumprir o apresentar-armas, sustentando um canhão que pesava mais de cem quilos. Tinha dezessete anos.

Pode ser que ao longo da duração da bagunça conflagratória tenha melhor considerado o lema que ornava o brasão da família: Io son gentil benché di spada armato. (Sou amável, embora armado de espada.) Tinha aprendido que a vida é luta e que a principal tarefa é aprender a se defender. Assistindo e participando daqueles massacres dei-me conta da exemplar estupidez que são as guerras. Por outro lado, além dos dizeres do emblema familiar, me parecia persuasivo outro dito que costumo ainda repetir: Vim vi repellere licet..$^{36}$ Esqueci-me de dizer que quando mergulhei no trabalho enfrentei e resolvi, a meu modo, o problema de não ser ignorante, estudando com férrea disciplina nas escolas noturnas. Aos domingos andava descobrindo, com avidez, na biblioteca municipal, considerável bagagem de noções e de ideias. Gostava de história, aprendia francês, inglês e latim, como gostava de desenhar. Lia atentamente o Self-help de Samuel Smiles, um dos best sellers do século I8. Compilava, anotava

36 Direito à legítima defesa: "É lícito reprimir a força com a força.” 
e, naturalmente, tentava e conseguia pôr preto no branco tudo que pensava e imaginava poder interessar aos demais: um vício que nunca perdi. Como primeiro resultado, moço ingenuamente ambicioso que era, tentei estrelar mandando um manuscrito à editora Avanti!

Tinha descoberto no tumulto da minha ânsia de procurar encontros, o Utilitarismo de Geremia Bentham, a ética transformada numa ciência positiva da conduta humana, exata como a matemática, o que será a posteriori o aspecto fundamental do Positivismo. (Na minha transferência encontrei esta doutrina epicuriana que identifica o bem com o útil, adorada no Brasil dos Oitocentos.)

O trabalhinho se referia aos negócios absurdos das naçóes para conquistar e desfrutar das colônias. Depois de alguns meses minha liliputiana obra-prima foi publicada. Fiquei sabendo disso ao abrir um pacote vindo de Miláo, ao retomar de uma partida de futebol, em que minha equipe venceu de goleada, seis a um. (Fui um bom center-half.)

Isto foi antes de partir para a guerra. Naquela horrenda carnificínia, certas noites, quando qualquer ruído provocava alarma, aprisionado num ambiente dantesco, muito refleti a respeito do Utilitarismo, como hoje estou meditando páginas escritas por Erich Fromm, no To Have or to $B e$, em que o autor examina o homem como capacho de um progresso ilusório, náo conseguindo se integrar na natureza e propiciar a paz social, subjugado na engrenagem do possuir, do egoísmo, da violência. Voltei do inferno. Imbuído das acusaçóes de Barbusse, ${ }^{37}$ (numa recente

37 Henri Barbusse, (I873-1935) foi escritor, membro do partido comunista da França e líder de um movimento que buscava combater a guerra e o imperialismo através de uma literatura pacifista que tornou-se cada vez mais pacifista, depois de ter servido à França contra a Alemanha por dezessete meses, na primeira guerra. $\mathrm{O}$ movimento fundou a revista Clarté, que inspirou a criação de revsitas homônimas na América Latina, como Claridad, pesquisa para meu último livro dedicado ao Modernismo no Brasil, descobri que também aqui Barbusse interessou a Affonso Schmidt, que o divulgou, lá pelos anos vinte, na revista Claridade) passei por outros transtornos: patrulhar, em defesa da ordem governamental, contra os agitadores que empunhavam bandeiras vermelhas e nos apedrejavam, a nós inocentes soldados. Fui ferido pelos próprios compatriotas, os quais, afinal, também eram utilitaristas, reclamando contra quem tinha demais sem distribuir aos que nada, ou quase nada, possuíam. Andavam aprendendo a presença imperiosa da política.

Liberado das estrelinhas de cinco pontas, entregue minha espada de "caporal-major," (nem mesmo sargento) recebendo como prêmio um corte de tecido cinza-verde, sapatos novos devidamente ferrados, a folha de serviços prestados e a medalha correspondente, reentrei na vida chamada civil. Não retornei à baía de La Spezia, (assombrada pelas figuras de Shelley e de Byron, então meus poetas preferidos) já que meus pais estavam desaparecidos; fiquei na cidade sede do meu regimento, a ilustre Bergamo. Iniciei-me no jornalismo local, de cunho genuinamente provinciano, porém com bom espaço destinado ao setor cultural. Editei o semanário humorístico Il Fischietto. Admitido como redator do cotidiano Il Giornale di Bergamo, foi então que consegui experiência, defrontando-me com um caso que vale a pena ser lembrado.

\section{Início incerto nas lutas políticas}

Para dizer a verdade, a politização era na Itália assunto por demais abstrato. (Como instrutor dos soldados da minha bateria, fiquei sabendo que ninguém se dava conta do que era o Parlamento ou mesmo o Senado. Eram recrutas da Toscana. Não sabiam o que fosse Monarquia e muito menos quem era Garibaldi; porém contavam detalhadamente toda a história do conterrâneo Davide Lazzaretti, um Cristo socialista e profeta das comunidades jurisdavídicas, e repetiam o que o agitador

em Buenos Aires, Clarté, no Rio de Janeiro - e é a essa última, de iniciativa de Afonso Schmidt, que Bardi se refere logo a seguir. 
gritava aos carabinieri que o trucidaram durante sua última procissáo: Io vado avanti in nome di Cristo Duce; se volete il mio sangue ecco il mio petto; uma tragédia que antecipou de uns vinte anos a do Conselheiro em Canudos.) A ignorância política era generalizada, apesar de ter a Itália razoável número de personagens habilitados a governar e desempenhar o controle da oposição, estes últimos notáveis no romântico partido socialista.

Depois da guerra, as confrontaçóes se destinavam a vencer a copa do governo nas semifinais, reduzidas a dois times, o bolchevista e o fascista. (Confusóes ideológicas inenarráveis: na minha qualidade de patrulheiro tinha visto Mussolini discursar aplaudindo as ocupaçóes de fábricas por parte dos trabalhadores. Um Mussolini ainda socialista que se dispunha a uma nova ação: a de acabar com o poder real e contestar o papado, para logo depois se compor com Vitório Emanuel III e com Pio XI.)

Chegou-se à marcha sobre Roma. O diretor e o redator-chefe do meu jornal, dias antes, tinham sido punidos com copiosos goles de óleo de rícino e trancafiados nos banheiros. Não eram exatamente contra Mussolini. Paladinos democratas-liberais, condenavam porém a violência do manganello. O dia da marcha (a Itália acomodatícia atrás do vencedor) me colocou inopinadamente diante de um caso singular: na falta dos chefes, eu mesmo assumi a direção do vespertino. Nesta investidura ocasional, recebi uma ostensiva visita dos novos mandachuvas políticos devidamente armados, os quais, arrogantemente, me incumbiram da tarefa de redigir substancioso editorial laudatório para exaltar o evento.

Desde menino jamais acatei ordens de prepotentes. Assim, o jornal ao invés de sair com o panegírico imposto, em seu lugar aparecia o primeiro capítulo do Promessi Sposi, de Manzoni e, com crônica política, trechos da vida de Santo Eustáquio, a brincadeira combinada com a poesia infantil Vispa Teresa, páginas dedicadas à música etc. - numa palavra: um protesto-caricatural. Como resultado sofri dura agressão, ferida na cabeça, hospital e a responsabilidade pelo fim do jornal. (Os tipógrafos comunistas, que me ajudaram no exploit, depois me acusaram de terem perdido o emprego por minha causa.) Como sobreveniência ativa, passei a desfrutar de uma certa consideração entre os declinantes cultores do frangar non flectar.

Aos vinte e poucos anos, renomado jornalista graças àquela spirito saggine e, também, por ter produzido alguns furos de repercussão internacional, me vi até disputado pelos grandes jornais de Miláo. Passei a ser redador do Il Secolo e, depois, do Corrirre della Sera. Deixei esta meca do carreirismo para me dedicar a um outro vício mais preferido, o de mexer com as coisas de arte. (Revelo estas historietas jornalísticas por terem elas exercido uma espécie de reflexo em minha temporada brasileira: quando o caro amigo Chateaubriand descobriu minhas antigas andanças no campo do papel impresso fez questão de que o recém-chegado de um país derrotado na guerra tivesse uma participação verde-amarela, investindo-o nada mais nada menos na condição de diretor-geral dos Diários Associados. Durante certo tempo a exerci muito a contragosto e sem brilho: mas como o Capitão mandara.)

Livre por não dever mais pensar em liberdade ou censura de imprensa, (responder a processos por ter, por exemplo, criticado uma estátua cívica, ou ter de entrevistar uma nulidade) mudei quase totalmente de vida. Abri, frente à Academia de Brera, sacrário de arte e do ensino da mesma, a Galleria Bardi. Injetava polêmica e novidade de vanguarda na São Paulo italiana encabulada, como a tropical, em produzir e acumular dinheiro, migalhas dele mal empregadas no setor da arte, um lazer de ricos em que os clássicos eram transados a peso de ouro, deixando para os talentos que realmente valiam uns mixurucos cobrinhos. A ação de sacudir uma burguesia atrasada como a daqui, (lá nem tivemos uma Semana de Arte Moderna) a sustentei através do periódico editado pela galeria, o Belvedere. (Vejam como as coisas acabam se repetindo: o mesmo que me aconteceu em São Paulo há trinta anos, se deu na Miláo dos anos 20: contribuir para o pessoal conhecer Cézanne, Modigliani, Picasso, Matisse, Gropius, Mies van der Rohe, e assim por diante.) 
Tempos aziagos aqueles para a arte não oficializada. Uma exposição e um meu livro dedicado aos futuristas Carrà e Soffici (dois mestres cujas pinturas eram vendidas quase por tostôes, hoje adquiridas mediante cheques polpudos onde os zeros à direita não são poucos) uma descabida tentativa dos alunos da academia, insuflada pelos professores, para empastelar o novel "centro de subversão artística,” e uma passeata de protesto suscitaram a curiosidade de Mussolini. (Tinha certa simpatia por ele quando estava na guerra; aliás, tenho cartas do Duce falando da sua mutilação e sabia da historieta contrafascista de Bérgamo.) Vi-me nomeado diretor da "Galleria d'Arte de Roma.” Aceitei o cargo, porém sem vencimentos, (como igualmente se deu com a combinação que fiz com Chateaubriand e que até hoje permanece) a oportunidade de desencadear na capital uma polêmica da qual o "coelhismo" nacional precisava com urgência: a renovação da arquitetura, então nas mãos férreas dos costumeiros reelaboradores dos estilos históricos. Ao mesmo tempo a possibilidade de afirmar alguns pintores novos e inaugurar o sistema de ampliar o interesse pelo problema arte, envolvendo-o com outros setores (o mesmo que procurei e procuro realizar no Masp.)

Ouço do venteuno as mais constantes reprimendas, como mandam o modismo e o gosto pelo boato. São geralmente pronunciadas pelos vira-casacas, dando a entender que toda a Itália era antifacista. Curioso: eu que lá vivi, conhecendo os poucos românticos contestadores (encaixando-me no grupo) sempre pensei numa península mal ajeitada para a defesa, território geograficamente infeliz, disposto a se acomodar com as pequenas ou possantes ditaduras, padecendo as invasóes dos bárbaros, apesar da presença central da Santa Sé.

A Itália do fascio (símbolo que procede dos etruscos com ranços hauridos na Revolução Francesa) foi como as outras Itálias: acomodada, naturalmente alinhando seus mártires. (Alguns gloriosos como Gramsci.)

Uma polêmica para renovar a arquitetura

Vejo agora, quase meio século depois, que os historiadores me atribuem a iniciativa de ter chefiado a polêmica que lancei numa exposição dedicada à nova arquitetura italiana, apresentando projetos e documentos de algumas construçóes não ortodoxas, especialmente de engenharia.

Inaugurador, o próprio Mussolini. A ele apresentei o Tavolo degli Orrori, ampla fotomontagem onde as incongruências dos benjamins construtores-pega-tudo do regime fascista eram postos em decisivo ridículo, o mesmo jeito por mim combinado no Giornale de Bergamo ao tempo da marcha. Previsão: um escândalo. Todavia, tudo correu perfeitamente. Mussolini, apesar de não ser prático em problemas de estética, nos deu razão e até apoio, a ponto de mandar publicar o manifesto desmancha-festa por mim redigido em termos inusitados em tempos de adormecimento nacional. Resultado: a Itália começou a sair lentamente do impasse do estilo romano imperiale modernizzato. $\mathrm{O}$ Duce, entre um erro e outros acertos de sua política autoritária, sabia que deixar um respiradouro para haurir um pouco de ar ajudava a conduzir a nau peninsular. Como todos os ditadores, adorava arcos, colunas, tímpanos e retórica. Talvez tenha calculado que as novidades propostas com gotas d'água no mar da situação. Ingenuamente, nossa intenção era inserir as propostas no contexto assim dito revolucionário.

Meus ataques, quase sempre virulentos, contra os mestres da arquitetura oficializados com o fardão da Academia Real, ataques veiculados no cotidiano L'Ambrosiano; uma viagem, como correspondente italiano da revista Architecture d'Ajourd'hui, que fiz à Rússia; os comentários referentes a uma tela do pintor Arnaldo Carpanetti deificando o chefe e seus quadrúnviros, cortejados por uma multidão de camice nere e precedidos de squadristas chicoteando Benedetto Croce e (com que honra) P.M. Bardi; fofocas e denúncias, tudo isso determinou as prescritas intervençóes policiais, comuns nos regimes apoiados não na justiça e bom senso, mas na força. A revista Quadrante por mim dirigida juntamente com um dos grandes escritores italianos, Massimo Bontempelli, contando como colaboradores nomes da envergadura de Le Corbusier, Pirandello, de Jouvenel, Léger, Ezra Pound e quantos outros valentes, foi proibida. O motivo? 
Naquele tempo o onipotente do PNF, Achille Starace, tinha inaugurado a escola política-cabide-de-emprego destinada à formação de gaulaiterzinhos, sendo a principal disciplina a ginástica. E o vestibular, como prova de base, pular dentro de um circulo de fogo, e outros gags. Achei aquilo idiota. Escrevi textualmente, assinando: "Nós estimamos muito os jovens, menos aqueles que estudam para ser secretários federais." Foi uma das raras discordâncias na opinião pública sob a égide do totalitarismo. Como recalcitrantes por já ter censurado o passo dell'oca, que o infeliz acordo com Hitler tinha imposto ao soldado italiano, eu protestando por chamá-lo passo romano, tive o prazer de ser liquidado. Uma única consolação: continuar admirador de Capaneo da Divina Comédia. Na nova condição de ovelha negra, consegui sobreviver comodamente marginalizado, me dedicando a estruturar o Studio d'Arte Palma, que se constituiu em importante centro de concentração de exame e ação de problemas das artes plásticas: conservação, restauração, comércio, estudos, galeria e tudo quando se refere à arte. Desembarcados os americano em Roma, restabelecidas as relaçóes diplomáticas, meu Studio começou a ativar intenso intercâmbio com as naçóes estrangeiras. Uma das Primeiras foi o Brasil, cujo embaixador em Roma, Pedro de Moraes Barros, e os da missão, tornaram-se hóspedes habituais. (Ainda privo da amizade de um deles, o embaixador Landulfo Borges da Fonseca.)

Os diplomatas brasileiros então andavam me falando de um Senhor diretor e dono de uma cadeia de jornais e rádio, que tencionava criar no pais um museu, mais especificamente, no Rio de Janeiro. O embaixador [Pedro de] Moraes Barros pensava que o Studio d'Arte Palma podia ser proposto para organizá-lo. ${ }^{38} \mathrm{O}$

38 Tentori menciona esse prévio conhecimento que Bardi possuía de Chateaubriand antes de sua chegada ao Brasil, intermediados pelo diplomata brasileiro. Conta que "é provavelmente no cenário da primeira exposição ["Exposição de pintura italiana antiga," no Ministério de Educação e Saúde, RJ, em 1946] que vem a conhecer (...)
Brasil não me era desconhecido, pois aqui estivera de passagem. ${ }^{39} \mathrm{~A}$ única instituição que me lembrava, e assim mesmo muito vagamente, era o Museu Nacional de Belas Artes. Curioso em relação às possibilidades acenadas, pensei numa travessia do Atlântico. Meu amigo, professor Deoclécio Redig de Campos, dos Museus Vaticanos, muito me ajudou, dando-me um bosquejo da arte brasileira; emprestou-me livros e, para lê-los, aprendi português. (Deoclécio lembrou a coisa, quando foi entrevistado em Aparecida do Norte para assumir a responsabilidade de restaurar no Masp a imagem de Nossa Senhora reduzida a I6o fragmentos.)

Descobri o Brasil a meu modo. Privava bastante com pracinhas expedicionários que estacionavam em Roma, muitos deles filhos de emigrantes italianos, e com os quais exercitava o português.

Em 46 preparei minha viagem que apelidei de Et in Brasilia ego.

O caro embaixador conseguiu uma cabina para mim e minha mulher Lina, no Almirante Jaceguay, que retomava as rotas da Itália.

Tinha pensado, com preocupaçóes, nos resultados da viagem. Quase sem perceber, tinha disposto uma transferência, pois levava grande parte de minha coleção de arte. As previsóes eram de que se eventualmente combinasse um museu com o sr. Chateaubriand, devia começar ativando um pouco de ensino e, assim, acabei recolhendo obras representativas de todos os tempos e continentes e, mais,

o jornalista Assis Chateaubriand," dado que Bardi desmentiria vária vezes a afirmação que fizera em Sodalício com Assis Chateaubriand, de que haviam se encontrado em Roma. \{Tentori, 2000, p.I72\}

39 Bardi a bordo do Oceania, em I933, fez escala em Recife, Salvador, Rio de Janeiro, Santos, Porto Alegre e Montevideo, quando estava a caminho de Buenos Aires levando consigo o material para a exposição do Movimento Italiano pela Arquitetura RacionalMIAR. \{Tentori, 200o, p.72\} 
carreguei parte da minha biblioteca de história da arte. (Todas estas coisas doei alguns anos atrás, juntamente com as instalaçóes da lanchonete que serve aos frequentadores, ao museu.)

Sem saber, estava me transferindo mesmo da Itália para o Brasil. Amava, como amo, o meu pais natal. Devo dizer que pensava, como todos, (inclusive Churchill e Roosevelt, admiradores da ordem italiana pré-bélica) Mussolini ter merecimentos singulares. Depois da hecatombe é fácil arengar. O pajé mandava e os indígenas consumidores de panem et circense obedeciam. Esta buona gente matou barbaramente, depois, o condottiere para enterrar um passado confuso e incerto do qual todos fomos cúmplices, inclusive os ingleses e os franceses que não deram mão forte à Itália, quando esta tentou impedir a anexação da Áustria.

No que se refere à última roda do carro, isto é, ao retratado da capa deste $S V$ : especialmente desgostoso com a inflaçáo dos vira-casacas preferi então abandonar meus lares. (O mais penoso foi assistir à candidatura do meu colega Bontempelli, acadêmico d'Itália, como senador comunista.) Embarquei para o Brasil. O generoso Chateaubriand me acolheu com cordialidade caseira, inesquecível. É por respeito a esta monumental figura de patriota que continuo a operar para que o museu seja sempre mais digno de sua singular iniciativa, rasgando caminho, ensinando e obrigando os ricos a contribuírem para o aprimoramento da cultura (Infelizmente desaparecido o "fiscal," os contribuintes do museu colocaram mais uma fechadura em suas próprias "burras.")

Contei sucintamente algumas peripécias de minha vida, antes de demandar o trópico, apenas para evidenciar quanto prezo a independência. Afirmo que dentro de uma independência e de uma liberdade que cultivo, nunca me foi difícil ganhar a vida, sem mercadejar amadoristicamente com a bagatela arte. (Pode ser por isso que me apelidam de professor.) Sei julgar suas produçóes, pois me preparei seriamente para avaliar com consciência e competência. Adquiri as pinturas do amigo Giorgio Morandi numa época em que ninguém as queria nem de graça. Nunca comprei terrenos, paredes, muros, bônus e bilhetes de loteria; só comprei obras de arte. Descobri-as e continuo descobrindo-as. Fui perito de conspícuos acervos entre os quais o de Pellerano, em Buenos Aires, lá pelos anos 30, época em que tive oportunidade de conhecer como turista o Brasil. Publiquei razoável número de livros, vários dos quais traduzidos até em cinco idiomas, sendo os mais elaborados The Arts in Brazil, 1956, e Profile of the New Brazilian Art, 1964, monografias que penso sejam essenciais para que o estrangeiro conheça o que se passou aqui como atividade das artes. O Profile foi editado contemporaneamente em Amsterdã, Londres e Nova York.

Considero-me um simples e competente operário da caneta e praticante assíduo da arte, vícios cultivados juntamente com outros menores, como o de ir dormir no horário das galinhas para acordar com o alarido dos galos.

\section{Sinto-me muito brasileiro}

Penso que possa interessar meu desembarque nesta terra. Num livro, que espero publicar brevemente, registrarei o seguinte: náo sei bem se aproei no Rio de Janeiro em I546 ou em 1946. Sinto-me táo brasileiro como se aqui tivesse nascido. Pertenço a esta varonil raça de saborosa mistura humana onde são caldeados harmoniosamente índios, africanos, arianos, árabes, orientais etceterone, como dizia São Thomas. Proclamo-me personagem, menor, naturalmente, perfeitamente integrado na história fascinante do continente descoberto por meus conterrâneos Colombo, Vespuccio, Verazzano. Ambiciosamente: um registrador, como Pigafetta.

Mas foi em 46 que passei pelo crivo da alfândega: o conferente examinou número inédito de lift-vans repletas de obras de arte. A estátua grega Diana, do século 5 a.C., que Winckelmann ilustra no seu famoso tratado, restaurada por Cavaceppnos Setecentos foi a única peça da minha coleção que não podia ser liberada, já que era vetada a entrada no pais de "mármore trabalhado." (O caso foi resolvido, porém, por Chateaubriand.) Aprendendo que no Brasil tudo se resolve, integrei-me nesta nova pátria onde tudo estava (agora muito foi feito) por ser 
encaminhado, terra nova, venturosa, em perfeita sintonia com o meu caráter. Levei alguma vantagem por trabalhar com um companheiro caputmagister aventureiro que tudo fazia, inventando dia a dia novidades e golpes, eu como seu Sancho Pança pronto a empenhar a lança do ingenioso hidalgo.

Vendo as estampilhas do passaporte, fora da imaginação, constato ter chegado ao Brasil ao tempo do presidente Dutra. Pena, pois gostaria tremendamente de ter sido um pioneiro. Os quatro séculos, de qualquer jeito, os sobrevoei e deles tomei conhecimento nas aterrissagens, valendo-me de um outro vício, a impenitente curiosidade de mexer com a história. Uma das consequências foi a ambição de escrever um livro dedicado à arte brasileira, homenagem aos artífices que criaram as obras, como engenhos de cana-de-açúcar, rodas d'água, alambiques, teares, teares de boi, capelas, igrejas, pelourinhos e mais coisas que os reis ou os vice-reis tinham em conta, além daquilo que meus colegas ocidentais consideram arte pura, conseguindo eles repartir o cabelo em dois, verticalmente, uma operação que não sei fazer. Onde bato os olhos vejo arte. Escandalizei professores habilitados e habilidosos, ao comparar Rafael a José Antônio da Silva. Prezo-me de ser um desmistificador da arte. Na última Bienal arrumei uma sala, o "Pacote de Mitos e Magias," que um crítico local definiu como "piada." (Acontece que os críticos se encontram quase sempre num momento crítico, quando são obrigados a julgar.) Penso que se um cidadão não conhece a história do país onde paga os impostos, (a verdadeira pátria, como diz Brecht) falta-lhe algum mérito. Hobby ou não, gosto da história brasileira. Saturado de Grécia, de Roma, e especialmente de Renascenças, quase quase dou razáo a Oswald de Andrade que, no Manifesto de Antropofagia, xinga todos os ilustres. Porém, não consigo entender por que incluiu Goethe.

Exagero, sei. O exemplar que possuo dos Colóquios de Eckermann com Goethe está repleto de anotaçóes; gosto muito daquela conversação única. $\mathrm{O}$ mesmo se dá com Os Sertóes, de Euclides, um clássico que, quando tentei publicá-lo em edição italiana, o editor Alves me disse que o autor lhe tinha passado todos os direitos menos o de traduzi-lo para o italiano. Lembretes apenas para dizer que adoro os gênios como os geniais, mestres como os operários, Piero della Francesca como Tarsila.

Não gosto de chutadores. (A última vez que fui convocado para formar banca universitária e para sacramentar um postulante a uma cátedra, este convidado por mim para citar o nome de um dos participantes da Semana de 22, respondeu-me: Heitor dos Prazeres.) Sei que os bem-pensantes me carimbam de herético. (Num dos últimos Istoé, de "rigoroso.") De fato, sempre me coloquei atrás do porta-estandarte balizando os Inconformados. Algumas vezes, pelo cansaço do abre-alas, empunhei a bandeirola.

Quando em Copacabana, combinei com Chateaubriand a fundação do museu. ele queria apelidá-lo de "Arte Antiga e Moderna.” Minha proposta foi a de superar a fórmula corrente, titulando-o simplesmente de "Arte," deixando para a macacada xeroar os modelos rotineiros. Criamos um fato novo, mundialmente falando, como proposta museográfica, tão novidade que ao apresentar o plano no I Congresso da Unesco, no México, todo aquele colegiado de conservadores nada compreendeu. O Brasil tinha dado, sem o saber, procuração a um italianinho para fazer notar que o subdesenvolvimento é pretensão e conveniência dos que se proclamam desenvolvidos.

Armando o balancete do que obrei ao longo de uma vida que já vai extensa, cuido de não ser impertinente ao declarar ter inserido no Brasil o negócio mais substancioso do que cérebro + matéria cinzenta + casualidade + ocasião (nos termos de Pascal) + empresa (nos termos de Maquiavel) + (porque não) sorte, podem oferecer a um inquilino da repartição dos Agitados. Dei à álgebra do dia-a-dia museográfico nova proporção.

Tentativas de contribuir para criar um ambiente favorável ao trânsito das artes foram numerosas. Alguém lembra da revista Habitat, sem dúvida fato essencial para discutir problemas, dirigida por Lina Bardi, o arquiteto que se incumbiu de todas as construçôes do Masp e responsável 
pela restauração do Solar do Unhão, em Salvador, bem assim pela fundaçáo do MAM da Bahia. Habitat proporcionou vivazes intervençóes não por seu conteúdo, mas porque, em termos linguísticos, foi acusado de ter criado a " 3 a língua" pelo eminente Paulo Duarte e outros numerosos puristas, náo sabendo todos que o responsável do trato da língua era outro eminente purista.

Chefiar a instituição emergente suscitou o imprevisto das invejas. Eu sorria, defendendo-me dos boatos, das cartas anônimas, e até mesmo de alguns elementos invejosos e ambiciosos do próprio staff; não foi nada fácil. O livro 30 anos do Masp, publicado no ano passado, é crônica resumida do ativo.

Aguentei, sabe Deus como, desenvolver este hercúleo trabalho que para mim se tornou um hobby. Às vezes, ao ler depois de tanta água passada embaixo da ponte, certas coluninhas redigidas por alguns orgulhosos inscritos na Associação dos Críticos de Arte, relativas ao que vamos realizando, ou sabendo das pueris conjuras do silêncio oriundas dos calos nos cotovelos, penso que Chateaubriand alimentava a mesma convicção de Sousandrade: operar com cinquenta anos de antecedência.

O progresso se baseia naqueles que se antecipam aos fatos, pois caso contrário estaríamos ainda no paleolítico. Os contraditores que não se enquadram na situação devem suportar a censura, quase sempre mafiosa, dos preguiçosos e das nulidades. Trinta e dois anos entre os brancos, na rotina, foi-me possível aguentar com fúria e paciência, como aliás convém àqueles que pretendem acompanhar o estandarte acima lembrado, sem fazer caso dos poltróes.

\section{Legenda}

p.78-79 Bardi com Thomas Mann, em Düsseldorf, 1954 P.M. Bardi em I929: retrato de Ruggero Ruggeri 9 Inauguração do Masp, em I947, com Assis Chateaubriand $A$ mesa dos horrores (da arquitetura oficial do fascismo) apresentada a Mussolini, na Galeria de Arte de Roma pelo seu diretor P.M. Bardi, I93I p.8o-8I Um ensaio dedicado a Bentham, I9I7 A primavera, de Botticelli, I945 Um ensaio dedicado a Le Corbusier, I95I The Arts in Brazil and Masp, 1956

Burle Marx, monografia, I964

p.82 The New Brasilian Art, 1970 g

O Museu de Arte de São Paulo, 1976

g O Modernismo Brasileiro, 1979

p.84 Bardi com Le Corbusier no congresso de Atenas

Dez perguntas provocativas

Senhor Vogue queria saber umas tantas coisas. E foi perguntando.

SV Não são poucos os boatos espalhados a seu respeito. Qual o que mais o irritou? PMB Nunca me irritei por causa de boatos, nem mesmo o mais recente em que assoalharam que vou deixar a direção do Masp, face à recente contratação do amigo Emmanuel Massarani para ajudar-me como conservador da instituição

SV Num livro recentemente publicado sob os auspícios da Olivetti e dedicado aos índios Yanomami, prefaciado e traduzido para o italiano, você se refere àqueles silvícolas com muito carinho. Por quê? PMB No Catrimani navega um grande barco batizado com meu nome e que mandei construir para em seguida doar àquelas tribos. Sempre fiz o que estava ao meu alcance, visando ao bem-estar daquelas criaturas, numa evidente demonstração de que ainda existem brasileiros que gostam deles.

SV Você conta que o brasão de armas de sua família ostenta o lema Io son gentil benché di spada armato. Contudo, as crônicas às vezes registraram que, olvidada a gentileza, você quebrou a cara de alguém. PMB Defesa. Não suporto os maleducados. Eles, sim, irritam e fatalmente provocam a reação do contrário. São casos de temperamento.

SV Dizem que você recusa convites coquetelescos e que jamais pôs os pés numa boate. Detesta a sociedade?

PMB Mentira. Não gosto de perder tempo. Confesso: recolho-me às 2I horas e me levanto às $4 \mathrm{da}$ matina. Como vê, trata-se de um horário que não coincide com o daqueles que entram e saem das festas. 
SV Parece que você está sempre de ponta com dois cronistas sociais da haute carioca. PMB É verdade, mas isto se deve a eles se servirem demais do dito de Beaumarchais: Calomnier, calomnier, quelque chose en restera. ${ }^{\circ}$

SV Dizem que você, pelo seu caráter autoritário, chega a ser drástico demais e sacode o saco de gatos dos seus colaboradores.

PMB Mentira: os gatos e as gatas de lá não dão problemas. Naturalmente, quando o saco se mexe demais abro-o e solto os inoportunos.

40 "Calúnia, difamação, sempre haverá alguma coisa.” (tradução nossa)
SV Na edição n ${ }^{\circ} 6$ que encerrou o casamento de Arte Vogue com Casa Vogue, você atacou durante a repartição do Patrimônio Histórico e Artístico Nacional. Por que foi táo severo?

PMB Disse só um quinto daquilo que deveria dizer.

SV Na seção de arte que Senhor Vogue lhe confiou vai continuar sendo polêmico?

PMB Você por acaso não sabe que a raposa pode perder o pêlo mas jamais o vício?

SV Quantas condecoraçóes você já recebeu? PMB Perdi a conta.

SV Quais os artistas contemporâneos que mais admira?

PMB Francis Bacon e Saul Steimberg.

Dar Crédito aOS Valores reais. Motivar os QUe PODEM E DeVem aJUdÁ-Los. Pensar BRASIL. p.85

Ter em Senhor Vogue um amplo recanto onde são divulgados e discutidos assuntos relacionados com a cultura e, dentro dos seus quadros, as artes, é fato novo na imprensa brasileira. Até agora, após numerosas tentativas, raramente se conseguiu publicar no país revistas dedicadas a essa área. É que faltam, entre nós, ambiente e estruturas que alimentam tão respeitável propósito. Seria leviano alguém me inscrever no rol dos pessimistas. Ledo engano. Sou otimista e tanto isto é certo que continuo a resistir nas minhas posiçôes, convencido de que o Brasil vai atuando e queimando etapas também, neste campo.

Seria, porém, faltar com a verdade se afirmássemos que tudo vai de vento em popa. Nas seis ediçóes de Arte Vogue, por exemplo, várias matérias demonstraram que se no setor alguma coisa foi realizada, (Conselho Federal de Cultura, Funarte, Embrafilm etc.) falta muito ainda para que possamos contar com uma organizaçáo técnica, mas de acordo com os tempos correntes.

Problemas políticos e de censura, desorientação no considerar o que realmente seja de utilidade, construção de pirâmides de cultura começando da cúspide e não da base, empreendimentos de cunho internacional deixados cair na rotina empregatícia, verbas mal aplicadas, ambiçóes de Mecenas à busca de status, que recorrem não aos seus bolsos mas aos cofres públicos para brilharem, escândalos estourados em fundaçóes - e quantas outras crônicas conhecidas encheram esse maltratado barco chamado Cultura. De qualquer jeito, é bom frisar honestamente: apesar dos erros e dos obstáculos, as coisas das artes estão indo para a frente, aliás como todas as coisas no jovem Brasil.

Trata-se de ajudar a melhorá-las, revendo as situaçôes, redimensionando as instituiçôes, dando crédito aos valores reais, animando e incentivando, esperando que as classes produtoras além de adotar atletas pensem também em adotar intelectuais, o governo equiparando os artistas aos futebolistas, e assim por diante, configurando com eloquência o dito de Juvenal: "Mens sana in corpore sano."

A gente que trabalha no teatro, TV, cinema, os músicos, os escritores, os artistas plásticos, os arqueólogos, os pesquisadores, os colecionadores, os artesãos, toda uma ampla comunidade de responsáveis pela cultura nacional, não goza ainda da posição que lhe corresponde. Sem pretensóes, procurando vencer as barreiras ou, melhor dizendo, as panelas que ainda prosperam no campo, este caderno de Senhor Vogue procurará informar e discutir problemas de âmbito nacional, pois para nós, saindo do eixo Rio-Sáo Paulo, o Recife que hoje congrega bons grupos de artistas ou Santa 
Catarina que mostrou suas atividades na última Bienal, tudo isso é sempre Brasil.

UMA HISTÓRIA DA ARTE CONTADA UM MODO DIFERENTE, p.86-87

A vida cotidiana é o fio condutor de uma exposição pioneira do Masp. Que conta Brasil,

As exposiçóes dedicadas ao produto Arte concentram-se, quase que exclusivamente, na mercadoria Pintura, complementação e ornamento da parede, integrada pelos ingredientes moldura e assinatura. $\mathrm{O}$ que vale é, também, a temática, prevalecendo a natureza-morta (para a sala de jantar), paisagem ou algo abstrato (para o living), o sacro (para o dormitório), as gravuras (para os corredores). Admitidos: os retratos da família ou de hipotéticos antepassados. A escultura é rara, pois dizem, não se sabe onde colocá-la. A Arquitetura, como apresentação em mostras, se vê somente nos galpóes que as construtoras implantam quando lançam um prédio.

As artes ditas plásticas apresentam um consumo genérico e rotineiro. Seus problemas não são discutidos e nem propostos, desenvolvendo-se a rotina: penduração de telas, expedição de convites, coquetel de inauguração, press-release e catálogo indicando o nome do banco que financia a compra, telefonemas do galerista aos possíveis fregueses...

Se a exposição for um clube, museu, instituto cultural ou escola, a convenção convocatória de possíveis adquirentes é a mesma. Multiplicou-se o número de exposiçóes de pintura.

São Paulo e Rio de Janeiro devem possuir, cada uma, cerca de uma centena de galerias comerciais. Há uns trinta anos existia somente uma ou duas: sinal de que o progresso está em marcha, porém não em benefício da Estética que resulta a bagunçada, sem caráter, sem rumo. Considerando o que se passa com as produçôes do passado a situação difere, pois existem cultores do Antigo, os assim chamados colecionadores, os beneméritos da conservação do patrimônio que a História vem ajuntando no tempo.

Trata-se de uma categoria restrita, que descobre objetos, estuda-os, conserva-os desempenhando singular serviço para que não se perca a memória do Brasil, evitando que ela se apague.
A premissa é para anotar que na situação do interesse reservado às Artes, de vez em quando se organizam manifestaçóes diferentes das habituais, tentativas de propor discussão de problemas. Por exemplo: a Bienal da Magia de dos Mitos foi um pretexto para diversificar o costumeiro vieu-jeux das exposiçóes correntes. Se não deu certo, ou pelo menos o que se esperava que fosse, foi por falta de infra-estrutura técnica, não contando a entidade com pessoal capacitados, pois no Brasil, a situação ainda está na base do tudo por se fazer neste campo.

\section{A distinção entre arte culta e aplicada, arte maior e menor, não tem mais sentido.}

Agora o Masp, sem dúvida o pioneiro no setor, propóe uma exposição de novo tipo: a da história da arte brasileira vista subespécie da vida cotidiana. Tem, sim, os Frei Agostinho, o Aleijadinho, Vitor Meirelles e Portinari, porém é arte também a dos carpinteiros nordestinos que produziram as obras-primas que são os engenhos de açúcar ou a dos caldeireiros que fabricavam alambiques de cobre.

É curioso notar que depois de tanto se falar em torno da Pop-art ou da Arte-pobre, o objeto de uso náo tenha tido adequada valorização estética, continuando, imperturbável, o império idealístico da fórmula “arte pela arte." Pensamos no mestre dos Profetas de Congonhas do Campo como num artífice que, sem dúvida, forjava seus próprios instrumentos para esculpir com a mesma naturalidade com que desenhava uma igreja para a sua vila. A distinção oitocentesca das artes em cultas e aplicadas, superiores e menores, não tem mais sentido hoje, quando o design é considerado a arte mais expressiva do tempo. Tendo em conta tudo isso, o Masp, pela primeira vez na historiografia dos museus, desmontou a pinacoteca (aproveitando o fato de que cinquenta de suas telas estão, atualmente, numa série de apresentaçóes no Japão) para ajeitar a exposição dedicada à "Arte no Brasil: uma história de cinco séculos." 
Trata-se de uma comunicação didática que, como outras similares já apresentadas, como a "Mão do Povo," suscita o interesse não dos adeptos do requinte decorativo, mas do vasto público indiferenciado, hoje freguês assíduo do Masp e que conta, em sua maioria absoluta, jovens desejosos de saber das coisas.

A técnica é a de considerar a criatividade nas expressóes populares do cotidiano e nas expressóes-sintese do ambiente, certos de que a teoria de Taine é correta: a arte é produto do milieu. Os vários momentos da História, que são de guerra, trabalho, pensamento, economia etc. são comunicados em síntese através de objetos, criaçóes ambientais e de obras de invenção individual.

Um fato novo é a intercalação de obras de artistas contemporâneos interligadas à compreensão de acontecimentos históricos.

Uma participação curiosa é a de alguns pintores aos quais se encomendaram grandes telas de interpretação de fatos como a Primeira Missa, o Grito da Independência e Tiradentes, a cargo respectivamente de M.H. Chartuni, Carlos Alberto Araujo, Wesley Duke Lee. De um pintor popular, Agostinho Baptista de Freitas, é uma ampla historieta em quadrinhos evocando doze episódios do Império e da República.

O conceito é encarar a produção num quadrante de amplitude tal que concilie o resultado, seja do artista como do artífice, e até do simples operário. Sei, por experiência, que este modo de pensar é, ainda, mal aceito. Quando, há uns vinte e cinco anos, apresentei na Europa o meu livro The Arts in Brazil: A New Museum at São Paulo, a perplexidade por se ver ao lado de uma paisagem de Cézanne uma floresta amazônica (era para informar que pela primeira vez, o mestre da Aix-en-Provence visitava o Brasil), ou uma belíssima mãe e menino preto ao lado da Nossa Senhora e Jesus Menino, de Giambellino, a perplexidade chegou ao auge. Censurou-se este meu modo de mesclar tempos, seres, coisas.

A gente tem o hábito de ver figuras isoladas e, quando acopladas com outras não análogas, o raciocínio é confuso.
Assim, mesmo para meus assistentes aceitarem, por exemplo, na seçáo dedicada aos índios, a intercalação de uma pintura romântica do Oitocentos, ou de uma fotografia, foi necessária uma explicação frontalmente baseada na filosofia de Bergson.

A discussão se complicou cada vez mais. $\mathrm{Eu}$, gentilmente, fiquei encabulado com a proposta de que, para sair da cronologia e do ver com tapa-olhos, é preciso inventar, considerando a História como um reinado de casualidades a serem combinadas e recompostas ao bel-prazer, através de conexôes de incidência, a fantasia servindo para apresentar, interpretar, propor as infinidades de correntes da vida vivida. Neste caso, a vida vivida no Brasil nos seus séculos de formação, confluindo nela um infinito de possibilidades existenciais e, portanto, de criatividade.

Os casos e as casualidades são muitos: trata-se, aliás, tratou-se, de juntá-los como proposta interpretativa de nossa história da arte, contada de modo diferente.

O que foi útil ontem é arte hoje. Ou será que foi sempre? Foi sempre.

A exposição foge aos cânones tradicionais, isto é, o contexto cronológico e a divisão por setores. Pode até ser julgada como produto de confusão. Apesar de ser o assemblage uma das conquistas da estética contemporânea, ainda há considerável maioria de visitantes que náo compreende as propostas que diferem dos seus hábitos de perceber e entender.

Nunca vi lembradas nos textos de história da arte ocidental as façanhas de Robinson Crusoé. Para mim se trata do protótipo do artista. Dou muito valor ao dito popular: quem não tem cão caça com gato. Existe uma arte brasileira justamente desenvolvida caçando com gato. O próprio Aleijadinho, notabilíssimo artista, caçou com gato. $\mathrm{O}$ interessante da arte brasileira é este ajustar espontâneo, o superar dificuldades de técnica, o refazer modos importados, o "deixa comigo e fique sossegado" que o artífice diz ao comitente, certo de conseguir bom trabalho.

Se os anjos de uma talha apareciam demasiadamente gordos, eram considerados bonitos; e se o índio ou o africano 
incumbido de entalhar o símbolo da uva, ignorando do que se tratava, entalhavam uns abacaxis, tanto melhor: tudo aprovado, pois afinal levantar uma capela era negócio caseiro, não coisa de Bernini ou de Borromini da Roma barroca.

Quando d. João vi teve a infeliz ideia de convidara Missão Francesa de I8I6 para reformar o que no Brasil se continuava a fazer, pensando melhorar a situação da arte, raciocinava da mesma maneira que os historiadores europeus que chegam ao Brasil: vêem em Minas ou no Recife as igrejas, as capelas douradas, os retábulos pintados nas tábuas encostadas, torcem o nariz e setenciam: arte provinciana.

É lógico que nem Miguelângelo nem Rafael passaram por aqui.

\section{Legenda}

p.86-87 Maria Helena Chartuni, Alegoria da Primeira Missa, 1979, tríptico, óleo sobre tela, 200 x $436 \mathrm{~cm}$

p.88 Teodoro Braga, Anhanguera, óleo sobre tela. Acervo Museu Paulista

p.89 Contador, jacarandá, Pernambuco, fins do século i8. Col. Benjamin Steiner g Carranca de barco do rio São Francisco, início do século 20. col. João Marino

p.90-9I A exposição é rica de comparaçóes: apresenta, intercalados nos vários períodos históricos, exemplos de arte europeia, para demonstrar além da dependência dos modos, a reinterpretação e, às vezes, a singular autonomia das produçóes brasileiras. Ao mesmo tempo, compara interpretaçôes diversas de artistas brasileiros de épocas diferentes. $\mathrm{O}$ mesmo tema em visões comparadas: à direita $A$ libertação dos escravos, na visão do mestre Pedro Américo, I895. À esquerda, o pintor primitivo Agostinho Baptista de Freitas.

p.92-93 São Francisco de Paula, Minas Gerais, século I8. Col. M.J. Arena Berço, Minas Gerais, século I8. Col. Particular Lamparinas de lata de fabricação popular, Minas Gerais. Col. Paulo Vasconcellos. 9 Mesa de ourives e banco, Minas Gerais, século I8; sobre a mesa: caixa de pesos para ouro. Col. B. e M. Pimenta Camargo.

p.94-95 Alegorias. Por que não? Aqui o assunto é a independência. Vista por dois artistas de hoje. Valor dos contrastes. Uma das particularidades desta exposição é a comparação, a integração e a interpretação dos acontecimentos históricos por parte dos artistas contemporâneos. Destaca-se na pinacoteca uma obra singular de Wesley Duke Lee, a quem foi sugerido apresentar o mito de Tiradentes. Tendo presente a esquecida pintura de Pedro Américo que está no Museu Procópio de Juiz de Fora, MG - o mártir esquartejado depois do enforcamento - Wesley compôs o impressionante episódio da epopeia nacional, confiando a figura à dramaticidade da tragédia ao mesmo tempo à grandiosidade da mensagem liberdade conquistada através não do palavreado dos políticos, mas do sacrifício e da fraternidade. Obra destinada a provocar discussão a respeito de Wesley, espírito pronto a assumir as posiçóes mais controvertidas e antecipadoras, como esta da participação do artista numa alegoria a Tiradentes. À direita, Carlos Alberto Araújo, na mesmo Alegoria da Independência, I979, tríptico, óleo sobre painel, $200 \times 436 \mathrm{~cm}$

OSCILAÇÕES DO MERCADO DE ARTE, P.96-97

O sistema da aquisição de obras de arte obedece a um ritual simples: o objeto deve ser antes de tudo de um autor consagrado, dos períodos melhores, de qualidade e de temática geralmente correntes (Di Cavalcanti: mulatas; Pancetti: marinhas; Portinari: espantalho; e assim por diante), valor monetário corrente no mercado. Quem compra pensa, naturalmente, além do prazer de participar do raro grupinho dos assim chamados "amadores de arte", em investimento, com os mesmos cálculos e consideraçóes dos investimentos em Bolsa, no imóvel, no ouro e nas pedras preciosas. Trata-se de operação, como tantas, de risco. Não que o valor monetário colocado numa obra de arte renda determinado plus em determinado intervalo. No mercado do objeto de arte o rendimento é imprevisível. É um risco e, portanto, pode-se ganhar ou perder. Nenhum comerciante sério, ao vender uma obra de arte, pode avançar e afiançar possibilidades futuras. Muito colecionista deixa-se levar em conversa 
por galeristas ou leiloeiros espertos em iludir, oferecendo informaçóes mirabolantes. Tudo depende da honestidade e do bom senso do vendedor e do comprador.

Como se verifica com qualquer outro bem, todos sabem que uma obra de arte adquirida a preços correntes, um valor que é consequência da lei da oferta e da procura, posteriormente pode vir a representar um valor inferior, fator que se dá em qualquer bem de consumo. Seu valor geralmente aumenta com o tempo, um tempo que ninguém em sã consciência pode prever.

A diferença em relação a outros tipos de investimento é que a obra de arte deve ser adquirida com ponderação, tranquilamente, eivada de boa informação e um certo faro para assim contar com a garantia de um plus-valor capaz de surpreender e mesmo superar aplicaçóes em outros setores. Sua vantagem está também no fato de que uma obra de arte náo paga imposto e supera crises econômicas.

Jacqueline Grapin num lúcido artigo estampado em Le Monde (23-3-73) e intitulado Le Jeu de L'art et du Hasard, examinando o que aconteceu no último decênio anotou que "a taxa de desvalorização da moeda nos países desenvolvidos foi mais alta, cerca de $38 \%$ em 73 enquanto não foi média durante os anos do período I969-72 e de 79\% mais forte nos países subdesenvolvidos. A fuga, em consequência da desvalorização da moeda, explica assim largamente a recusa e a especulaçáo dos objetos de arte. Entre 66 e 70 o valor dos mesmos aumentou numa média entre $5 \mathrm{e}$ $8 \%$ ao ano. De 70 a 72 , um percentual de I $2 \%$. De janeiro de 73 a junho de 74 , de 30 a 40\%. Japoneses, europeus, americanos, estabeleciam concorrência na vendagem de obras de arte. Do início de 74 a junho de 75 se constatava um reajustamento para menor da ordem de 15 e $20 \%$."

O ensaio de Grapin cita um estudo da Banque Industrielle et Mobilière Privé (Les placements en objets d'art et de collections, 1974) em que dá conta dos aumentos de valor de algumas categorias de pintores: partindo de uma base Ioo em 5I, autores como Rembrandt, Rubens, Gainsborough alcançaram coeficiente de 800 em vinte anos, ao passo que os Impressionistas passaram a quota 2000, e pintores como Bonard, Chagall, Van Dongen, Kisling, Matisse e Picasso 3000; as gravuras chegaram a 4000, chegando a aumentos da ordem de $400 \%$ no espaço de dois anos.

É natural que estes números deveriam passar por um exame mais técnico e assim nos dar conta das obras que realmente serviram de base para estabelecer-se deduçôes, mas em geral a valorização em termos incomuns foi patente.

Foi justamente nos tempos anteriormente alinhados no estudo em questáo, que no Brasil ocorreu o caso da mosca branca chamada Chateaubriand, o qual em 47 tomou a iniciativa de constituir a pinacoteca do Masp. Temos seguros elementos que confirmam em parte os casos citados. Corriam os anos em que era possível adquirir a coleção das 73 estátuas de Degas por US\$ 45.000,00, a mesma coleção que foi emprestada a um grupo de museus japoneses mediante um seguro da ordem de US\$6.000.000,00. Quem comprou logo após a guerra boas obras de arte certamente fez excelente investimento. Como reflexo, mutatis mutandis, o fenômeno da valorização das obras de arte verificou-se também no Brasil. As três pinturas da série Retirantes, de Portinari, foi por mim adquirida para o Masp por US\$3.000,00 em 48, quantia paga em parcelas durante um ano; estas telas valeriam no mercado um milhão de dólares, bem entendo no mercado nacional e assim mesmo por se tratar das obras mais importantes do mestre.

Estas anotações são publicadas para inteligência dos economistas, entre os muitos que temos e donos de elevado preparo, os quais examinariam tecnicamente $o$ desenvolvimento do mercado de arte no Brasil, fato econômico já enraizado e merecedor de estudos. A sugestão vem da leitura de um interessante livro (L'Economia dell'Arte, Mercato e Piano) de Andrea Villani, docente do Instituto de Ciências Econômicas da Universidade de Milão. 


\section{Arte Societária}

O presidente do Sesc em São Paulo, José Papa Júnior, tomou uma nova decisão em prosseguimento ao seu saudável programa de difusão da cultura em favor dos usuários dos centros de lazer da instituição. Além de organizar periodicamente exposiçóes de arte, vai formar uma pinacoteca de obras intimamente ligadas à vida dos seus associados: ilustraçóes e comentários do cotidiano, menos os superados divisionismos abstratos e conceituais. Mais uma contribuição por uma arte onde a genialidade de nossos artistas vai se manifestar para que seja aceita e apreciada por parte do povo: uma arte societária.

\section{[II Mostra Internacional de Cinema em São Paulo]}

O filme mais discutido na II Mostra Internacional de Cinema em São Paulo foi Alicia en la España de las Maravillas, de Jordi Feliu, nova proposta para saber mais de uma personagem que perturbou a consciência vitoriana e, agora, as consciências da Europa inteira e das Américas. No Brasil, pelo menos os 40.000 espectadores que lotavam o auditório do Masp receberam a mensagem de Alicia com reservas, visto parecer por demais contrastante com a figurinha da menina bem comportada e ingênua, encantadora, apresentada por seu autor, um pastor e matemático, recentemente descoberto como fotógrafo de crianças que despia diligentemente. Jordi Feliu desmistificou o passaporte de Alicia, a corpulenta Mireia Ros, amarrando-a com sua fita nacional.

\section{[Lex]}

Esta pintura, Lex, provocou multa curiosidade na pauliceia. Doada há alguns anos ao MAM local, foi encontrada recentemente num depósito do dito estabelecimento do Ibirapuera, assim julgada indigna de fazer parte do mesmo, e restituída não ao doador, mas sim ao próprio autor, Tito de Alencastro, acompanhada de uma carta semi-insolente. Será mostrada numa exposição individual em seu novo atelier que é ao mesmo tempo um antiquariato de fino gosto, mas não para freguesia de fino gosto. Tamanha desconsideração a uma obra de arte e ao seu autor não foi entendida por ninguém e motivou franco repúdio à comissão de arte mamesca.

\section{[Millôr]}

Em primeira mão anunciamos que Millôr Fernandes vai expor em São Paulo. Será uma retrospectiva de sua obra para lançar a monografia que a ele está dedicando a editora Praxis. Nesta foto, de uns vinte anos atrás, eis Millôr quando fazia promessa de um dia expor no Masp. Adiando, adiando, mas exposiçáo e monografia vão ser agora uma realidade.

\section{[Rockfeller, cultura-capitalismo]}

Nelson Rockefeller que a morte surpreendeu quando estava revisando as provas tipográficas do catálogo da sua desconhecida coleção de arte, envolvido no mais estranho plano cultural-capitalístico, isto é, o das reproduçóes, era amigo do Brasil, pois também nesta terra tinha ramificaçóes de negócios. Visitou-nos várias vezes, cumprindo modestos gestos mercenários, como o de adquirir pinturas de Portinari que, ao tempo recente do boom do mercado nacional, revendeu a brasileiros, obtendo substancial lucro. A visita lembrada foi a de I950, convidado de Assis Chateaubriand para a inauguração de novas salas do Masp, calculando o anfitriāo receber do seu convidado uma condigna doação destinada à nova pinacoteca: Nelson distribuiu somente congratulaçóes e sorrisos ao pessoal do Terceiro.

Senhor Vogue \#I2, março de 1979 p.83-97 (Senhor e as artes)

Arte Vogue, p.83

Alexander Calder, o inventor da escultura dos mobils gostaria, certamente, de seguir as vicendas movediças da iniciativa do Luis Carta. (Oferecer ao consumidor de revistas, uma dedicada alfa-ômega ao folguedo, às vezes consolo genericamente apelidado Arte.) 
Foi divertido curiosar os galhos balouçantes de Arte Vogue no turbilhar das correntes alísias, tão próprias da nossa atmosfera tropical, inspiradora também da cultural, galhos se comportando como pagine al vento.

O editor tinha decidido publicar um Arte Vogue desenvolvido, de I2O páginas, para sacudir o panorama adormecido do adagio das artes; porém, o sonho não combinou com a realidade, e assim Arte Vogue mudou de status e se tornou inquilina de Casa Vogue, trimestralmente. O mobil não se imobilizou, pois as lembradas correntes alísias sopraram forte e perturbaram a galharia que deveria penetrar pelas janelas das casas, aliás dos palacetes, propiciando sugerir pingos de atenção, não estritamente concentrados no bibelot e na leitura dos solenes eventos das crônicas sociais.

Pois nem esta segunda façanha deu certo, o paciente editor, preocupado com problemas de estética, transferiu o meu mobil para Senhor Vogue, uma sede mais conveniente. Prometemos, nas dezesseis páginas confiadas, a consideração, sem caturrismo, de fatos e problemas (pensamos) merecedores de sinalização, e especialmente de discussão.

Março é, tradicionalmente, o mês da abertura da estação das artes, no mundo inteiro e, consequentemente, no Brasil, que pontualmente aplica o calendário gregoriano, o da ONU, ou até dos que inventam dias especiais para incentivar o consumismo. (Importamos demasiadas propostas do comércio internacional: agora é o tempo do contra-Cooper, como no ano passado foi o do Cooper, vendo-se cidadãos flanando fardados de macacão azul e brancos calçados.) Então, conforme a prescrição de Paris e de Nova York, este mês começam as atividades da arte, coincidindo por acaso com a política envolta com uma tal de abertura.
Abre aqui, abre acolá, algumas novidades sem dúvida váo aparecer nas crônicas. No que se refere ao setor das artes, as sibilas ainda não compilaram as previsóes, mas é de se supor que estejam tratando dos assuntos acomodados na panela costumeira para decidir de antemão qual será a musiquinha ou a exposiçãozinha a ser premiada em 1979.

Para o ano que ora desponta, a quase duas décadas da alvorada do novo milênio, o que se prenuncia como o fato mais notável deveria ser o início da construçáo de uma nova cap do Estado de Sáo Paulo, aliás dos planos sociais, políticos e de urbanística e arquitetura. Futurólogos de valor já foram convocados pelo novel Juscelino e, ao que parece, os Péricles estão pensando seriamente no empreendimento.

Os erros cometidos em Brasília deveriam se constituir em advertência, convindo ser da máxima utilidade para que seja feito um estudo mais adequado, não só das reais necessidades funcionais de uma cidade administrativa, mas precipuamente quanto ao existencialismo humano. Brasília ensina: construída às pressas para ser inaugurada com finalidades eleitoreiras, como funciona depois de poucos anos de vida? O faraônico e o favelístico mal se combinam, pois a moda tecnologística não levou em conta que afinal uma cidade é habitada por gente. $\mathrm{O}$ ponto ainda obscuro da Paulália nos parece o da dificuldade de um ajeitamento social. Não deveria ser um caldeirão de barnabés, isolado, abandonado ao banho-maria da melancolia praxis da burocracia. Veja-se Brasília: uma grande cidade fria, onde até o estádio para a prática de esportes ainda se encontra em dificuldades, onde tem um autódromo, para quê? E não tem, naturalmente, uma biblioteca náo tanto quanto como a de Washington, mas pelo menos digna de uma capital de um país emergente.

Pier Luigi Nervi: O Mestre do Concreto, p84-85

A arquitetura contemporânea muito deve à descoberta do concreto armado, as possibilidades que vão modificando sua aparência formal e sua substância funcional. A contribuiçáo para este avanço extraordinário náo foi devida aos arquitetos, mas sim aos engenheiros, à técnica e não à estética. Os arquitetos beneficiaram-se do invento e passaram a ser dependentes da colaboração dos engenheiros: o esteta precisando do serviço de quem se responsabiliza pela estática de uma estrutura. 
Quando na Europa fervilhavam as polêmicas para renovar a arte por Vitrúvio definida como a "princesa" entre as outras, a arte decaída no formulário da híbrida reelaboração dos estilos do passado, herança de um século caracterizado pelos progressos mais promissores, tive ocasião de examinar de perto as posiçóes das duas categorias, (arquiteto e engenheiro) inconformando-me com a curiosa situação de alguém que desenha um edifício e outro profissional que providencia sua segurança. Constatava então que as grandes obras públicas, como pontes, barragens, hidrelétricas, fábricas e até casas populares, sendo de autoria de engenheiros, não eram consideradas como arquiteturas.

Contrastando o espírito partidário dos jovens arquitetos com os quais eu estava promovendo a polêmica na Itália, parti em busca de obras geralmente desconsideradas como "arte," a não ser a "arte muraria," descobrindo na Sardenha uma barragem de arcos múltiplos no rio Tirso, uma ponte em Roma com ampla arcada e, finalmente, um estádio de futebol em Florença. Tratava-se, em minha opinião, de arquitetura.

O estádio apresentava uma cobertura das escadarias lançadas ao ar, teve como uma pluma, sem sustentação alguma. Achei a soluçáo inédita e surpreendente. Fotografei-a, consegui do mestre de obra o desenho do corte da estrutura e, então, soube do nome do engenheiro responsável: Pier Luigi Nervi.

Procurei-o em Florença sem contudo encontrá-lo, já que morava em Roma. Ansioso por revelar minha descoberta, fui no mesmo dia para Miláo onde era editado o cotidiano L'Ambrosiano do qual era redator de arte. Escrevi a crônica, convenci o diretor de publicá-la na primeira página, pois era uma matéria importante, única mesmo. Única sempre em minha opinião, pois a dos outros, em sua maioria, era diferente, tanto assim que aquela página provocou protestos de leitores. Um assinante do jornal reclamou veementemente, pois era arquiteto, afirmando que a cobertura era simples "produto de cálculo" e não de "inspiração artística."

O elogio que fazia à construção também se estendia ao comitente. (Disse mais tarde, Nervi: "Raramente encontrei, em minha longa vida de construtor e de projetista, comitentes à altura, capazes de compreender claramente um problema, escolher projetistas e projeto, e dispostos a assumir as responsabilidades inerentes a soluçóes técnicas e esteticamente audaciosas.")

Mas eis um fato curioso: do mesmo parecer "resultado de cálculo" era o autor. Procurou-me: nervosíssimo, quase me investindo, reprovou a publicação, pois ele "não era um arquiteto, mas um engenheiro." Alinhou uma série de razóes entre as quais uma de ordem fiscal face à publicidade dada a sua firma "Nervi e Nebbiosi" etc. Como resultado da controvérsia, o reclamante deu esta definição lapidar: "L'architetto è um muratore che sa il latino." Levei o homem na conversa, à maneira do rapaz do conto de Saroyan que vai ao empório onde a família teve sua conta fechada por não honrar seus compromissos e, falando, falando, conseguiu obter mais um pequeno crédito. Nervi acalmou-se. Descobrimos que na mocidade tínhamos tido um encontro ao jogarmos futebol no mesmo campo, em Savona. Conversa vai, conversa vem, ficamos em paz um com o outro após longas horas de troca de ideias, ponto de partida para uma amizade que começada depois de 1930 só agora termina com seu desaparecimento.

Lembro Nervi nestas páginas não somente pelo fato de ter sido ele uma das máximas figuras da arquitetura do século, mas também porque, quando iniciei o museu, consegui que ele viesse ao Brasil para ministrar um curso dedicado aos problemas do concreto armado.

Uma centena de engenheiros e estudantes de engenharia assistiram as suas aulas: comunicação simples, não teóricas, fruto de experiências de trabalho. Apresentava e explicava obras realizadas e alguns projetos suscitando incomum interesse. A declaração que mais surpreendeu foi a do reconhecimento do nosso "Código de Obras" como mais avançado por ele conhecido, e o elogio de nossa técnica construtiva por ele examinada em diversos canteiros paulistas. Particular admiração Nervi teve por Joaquim Cardozo, o engenheiro que possibilitou a construção das formas 
projetadas por Oscar Niemeyer. Vinte anos depois Nervi viu o projeto do edifício do Masp. Muito o agradou, pois obedecia aos critérios por ele seguidos, gostando das soluçôes estáticas permitida para a construção do vão projetado por Lina e possibilitado pelo nosso grande engenheiro José Carlos de Figueiredo Ferraz, com a aplicação de sua patente do protendido.

O ensejo da estada do construtor, determinou o sr. Assis Chateaubriand a estudar um projeto para edificação de um prédio de pluriuso para abrigar a sede dos Diários, Rádio e TV Associados, pretendendo incluir dois auditórios. $\mathrm{O}$ terreno localizava-se ao lado do Viaduto Major Quedinho; arquiteto Lina Bo, projeto da estrutura a cargo de Nervi.

Deste trabalho restam somente os desenhos com o nome de "Taba Guaianazes." No projeto colaborou também um dos filhos de Nervi, Antonio, arquiteto recém-formado. Conta Lina: "Tínhamos o costume de náo cotar rigorosamente os desenhos, falha grave e verdadeira dos arquitetos frente aos engenheiros. Quando o mestre a descobriu imprecou uma reprimenda duríssima, em plena mesa, e eu e Antonio acabamos chorando.” Nervi era muito rigoroso em questão de trabalho.

Nasceu num vale dos Prealpes, porém se formou na Ligúria, uma região onde a gente é de poucas palavras, encabulada no trabalhar, parcimoniosa, perseverante, predisposta a correr riscos nas aventuras. Estas qualidades contribuíram para que o jovem engenheiro se distinguisse na profissão. Reservado a ponto de parecer fechado, escondia no fundo uma gentileza extraordinária. Sua convicção a respeito da técnica do concreto armado à qual se dedicou era o propósito de conseguir estruturas com o menor emprego de materiais.

A intuição das possibilidades da resistência da forma buscava na observação dos eloquentes exemplos oferecidos pelas formas das folhas lanceoladas, canas, cascas de ovo, conchas, para-lamas de automóveis. Partindo destas observaçôes, Nervi andou descobrindo as novidades estruturais que fizeram dele um inventor.

Penso que do movimento do Racionalismo dos mestres da nova arquitetura na Europa, na primeira linha Le Corbusier, lhe surgiu a ideia fundamental que tinha chegado a hora da "engenharia." O mesmo se verificou nos Estados Unidos, quando os irmãos Greene, célebres arquitetos adeptos do Arts and Crafts morrisiano declararam desprezar a "engenharia:" estava vencendo a tendência que clamava a arquitetura da simplicidade, das paredes lisas, condenando o desperdício decorativo, a arquitetura que os inconformados apelidavam hospitalar.

Encontrava-o em seu escritório de Lungotevere: ou desenhava ou experimentava no laboratório de provas. Meticuloso, ficava descontente quando o que fazia não o agradava cem por cento. Pouco conversava. Quando combinamos participar de um concurso para a construção do Museu da Civilização Italiana, o edifício principal da Exposição Universal de 1942, (é minha a sigla $\mathrm{E}_{42}$, como registram os dicionários) criou-se entre nós um convívio que me possibilitou melhor conhecer o caro amigo. Ele acalmava meus ímpetos, cortava os voos da fantasia, reconduzia os termos do trabalho aos trilhos da realidade mais rigorosa. Quando dizia non si può fare, era uma sentença. Foram meses de aprendizado para mim. Como se vê na planta aqui reproduzida, minha ideia de reformar a burocrática não-vivência da museugrafia começava a se manifestar: queria um visitante que visse o que aconteceu em vinte séculos, cronologicamente percorrendo os círculos dedicados às várias artes, e também, século por século percorrendo as salas pelos raios convergentes do centro, num jardim ornado de vinte esculturas, uma de cada século.

Nervi tinha aprovado o plano, por ser "didático e prático," devia desenhar a estrutura, uma cobertura sem colunas. Tomou o lápis, riscou e disse: "È questo che si può fare."

Calculava desenhando, passava depois para seus assistentes os desenhos para serem calculados. Me diz Lina: "Antecipava o que o Ocidente está descobrindo hoje: a impossível substituição do Computer pelo homem. Um dos maiores engenheiros do século não acreditava nos cálculos de mesa, mas na experiência real; seu credo era a intuição estrutural sentida como fato "físico-existencial: o intuito das estruturas, rigorosamente verificadas em seguida.” 
Sou testemunha das desconfianças do profissionalismo italiano contra Nervi. Quando ele ganhou a concorrência para construir os hangares da aviação militar de Orvieto, em 1936, corria o boato de que iam desmoronar. Nunca vi Nervi preocupado. No dia anterior ao primeiro descimbramento, perguntou-me se o acompanharia para assistir à fase final. Convidei outro famoso engenheiro, que estava na ocasião em Roma, Gaetano Ciocca, construtor da fábrica de rolamentos de Moscou, autor do livro Giudizio sul Bolscevismo, por um prefaciado.

Nós três, ao longo da viagem, quase não trocamos palavras. Chegamos, nos colocamos conversando nos pontos mais visados da última fase do descimbramento. Em torno do hangar estava a comissão fiscalizadora do Ministério, confiante, como nós, no bom comportamento da construção. Afinal: o hangar estava em ordem. Então contei outro episódio parecido: quando, em Roma, se verificou a resistência do arco da Ponte del Risorgimento, os bombeiros molhando os sacos de areia para aumentar o peso, no ponto central da arcada, o engenheiro responsável pela construção realizada mediante a patente Freyssinet, Mosca, acompanhado de toda a família, se colocou embaixo, nas águas do Tevere, para com isto demonstrar que a ponte era sólida e náo caía. (Para esta ponte os teóricos alemães mostravam-se alarmadíssimos, preconizando seu desmoronamento, pois as solicitaçôes unitárias dos materiais, calculadas segundo as fórmulas da "teoria elástica” superavam os limites de segurança e, em certas zonas, os limites de ruptura.)

Voltando de Orvieto, Nervi nos disse: grazie.

A fama de Nervi está ligada principalmente às grandes estruturas pré-moldadas. Sua grande felicidade: quando os alemães, na Segunda Guerra Mundial, dinamitaram as seis vigas-pilares de sustentação da grande estrutura de Orvieto, a cobertura caiu num só bloco, sem uma falha. Demonstração positiva de uma pesquisa que previa o pré-moldado como excelente solução para a arquitetura do futuro. (O cimento geralmente usado para formas e modos resistentes próprios do ferro não foi ainda considerado nas inumeráveis possibilidades oferecidas pelas suas específicas características para solucionar problemas de estática.)

O corresponder através do oceano dava mais certo quando era atravessado pelos navios a vapor do que agora, com os telefones diretos. Assim, de há muito que não tinha notícias do Nervi, a não ser os relatos estampados nas revistas de arquitetura europeias e norte-americanas. Todavia sabia: o dominador do material típico da era que permite barrar o rio Paraná ou o Volga, continuava mantendo sua característica modéstia, sempre disposto a ajudar alguém, severo somente com os que atrapalhavam. Disseram-me: respeitado pelos alunos, porém julgado como de uma mentalidade por demais "oitocentista."

De fato sua formação tinha muito do pensar, experimentar e da disciplina própria do século que não foi o "stupide" de Daudet: o gosto pela ordem, a atenção ao detalhe, o sondar com circunspecção, a gratidão para com os mestres. Disse certa vez a Nervi que observava a forma de um para-lama: Você é um enciclopedista. Comentou: De fato considero muito d'Alembert. Um iluminista iluminado.

\section{Legenda}

p.84 Uma visão do Palácio da

Civilização da Itália, projeto de P.L. Nervi e P.M. Bardi.

UMA OBRA DE ARTE QUE VOCÊ SÓ VÊ PELA TV, p.86-87

Uma rotina: obras como Itaipu ficam escondidas dos olhos do público

Como funciona o serviço de public relations de Itaipu e a informação em geral do maior empreendimento de barragem do mundo? Desviar o curso do rio Paraná, construir aquele colosso hidrelétrico, afundar territórios, implicaçóes ecológicas, discutir problemas com o partner paraguaio e com outro usuário das águas, a Argentina, e tantos outros fatos, (entre eles o trabalho de dezenas de milhares de trabalhadores) pensa o redator que isto tudo merece o funcionamento de um ativíssimo centro de informaçóes, pela singularidade da obra e para dar satisfação a quem, no final das contas, deve se orgulhar de pagar pela realização do empreendimento. 
Um dos sistemas mais correntes na rotina das obras públicas é o de tê-la, geralmente, se não escondidas, pelo menos resguardadas do conhecimento público. É o caso de Itaipu. Salvo as comunicaçóes difundidas quando há uma festa, circunscrita ao vídeo (com a retórica própria da propaganda que desenha a geografia do Brasilestrela, felizmente agora sem a proverbial insistência do slogan do país que vai para a frente) o que se divulga daquela grandiosa obra é, verdadeiramente, pouca coisa.

Por outro lado, também a Central Atômica de Angra dos Reis náo goza de adequada divulgação, a não ser a negativa, em consequência dos relevos relativos ao atraso e às divulgadas deficiências dos trabalhos suscitando perplexidade na opinião pública. O mesmo, isto é, pouca, quase avarenta informação que se dá com outras obras das quais o cidadão comum sabe vagamente da necessidade e do desenvolvimento.

Voltando a Itaipu, informamos que não foram poucas as vezes que o Museu de Arte de São Paulo se dirigiu aos seus representantes visando a promover, em sua Pinacoteca, uma comunicação a respeito, dirigida ao público que frequenta o maior e mais visitado centro cultural do pais. Projetava-se apresentar o que é e o que representa Itaipu como técnica, estética, economia, futuro, todos ingredientes do desenvolvimento. O Masp estava certo de despertar algum interesse entre seus visitantes, ainda mais que a intenção do proponente era o de levar a exposição a Brasília e a outras cidades para finalmente estabelecê-la em Itaipu para ser vista pelos turistas.

Todas as tentativas para discutir o problema foram em vão. Não que os responsáveis

\section{[ObSERVADOR] p.88}

\section{A Musa publicidade}

Das Musas, apesar de colocadas numa espécie de sala de espera hermeticamente fechada, como aqueles mecanismos tão comuns aos cofres blindados dos bancos, de vez em quando algum romântico fala, mas são casos pertinentes ao oficio das patronesses das artes. Hoje estas atividades se desenvolvem e são reguladas pelo comando do absolument modern

naquela confusão entre elas. De fato tenham respondido que a proposta (proposta ate publicada em Arte Vogue \#3, para ser conhecida) não despertou interesse. Simplesmente os dirigentes do complexo não deram nenhuma resposta e muito menos qualquer evidência de boa educação, quando, na verdade, os maiores beneficiários seriam eles.

Vamos juntar ao triste episódio mais um item? Em janeiro, o Masp, na exposição "Arte no Brasil: uma História de cinco séculos," queria representar o vigor progressista nacional, lembrando que estamos construindo a memorável barragem. Afinal, diante da insistência que tanto caracteriza os pacientes colaboradores do Masp, eles receberam como resposta ao pedido (sem qualquer ônus para Itaipu,) que deveríamos escrever uma carta destinada ao presidente do complexo, general Costa Cavalcanti.

Agora é ao ilustre e operoso general que dirigimos, publicamente, esta notificação para lembrar que os serviços de informaçáo de Itaipu poderiam melhorar e divulgar Itaipu até como um ato de dever nacional. Por isso é que divulgamos nas páginas seguintes matéria pertinente àquele empreendimento.

\section{Legenda}

p.86-87 Canteiro de obras no começo das atividades 9 Canteiro depois de um ano de trabalho Escavação do canal e uma das barragens a serem explodidas Lado paraguaio: escavaçóes e início das ensecadeiras Produção de pedra britada e areia artificial 9 Torres de cabo aéreo para as concretagens Concretagem no vão unindo Brasil e Paraguai

a qual Musa atribuir um múltiplo, um vídeoarte, um happening, um conceitualismo e assim por diante?

Pierre Restany, recentemente propôs eleger-se uma décima Musa: a Publicidade. Posta de lado a iniciativa de abrir o cofre blindado e lá encerrar uma Musa, a Publicidade é, sem discussão, a reguladora do agitar das Artes: as congloba e as dispóe integradas num novo fazer que vai sempre mais prepotentemente 
assumindo o comando da comunicação e do provimento do seu consumo, não mais reserva de poucos, mas domínio de todos.

\section{Caro sr. Soeiro}

O sr. Renato Soeiro, diretor-geral do IPHAN, a respeito das observaçóes contidas no artigo Um Caso de Banaustia (Arte Vogue \#6) nos envia uma longa carta cujo teor é o de confirmar que o acervo do Masp foi tombado mediante uma simples carta datada de 7.II.68 a pedido da sra. Yolanda Penteado, e confirmado pelo então presidente da entidade, senador Alexandre Marcondes Filho, em I7.8.69.

Tudo isto se sabia, e é tão verdade que quando o sr. Soeiro (baseado em uma das tantas calúnias lançadas por um coitado cronista social do Jornal do Brasil) enviou ao diretor-técnico do Masp um telegrama para lamentar (risum tenetis) que o mesmo tivesse vendido uma tela de Renoir, imediatamente telegrafou-se em resposta para informar que já que o acervo estava tombado, naturalmente a tela continuava no seu lugar, não tendo assim fundamento a "barriga" do escriba carioca.

O que na nota Banausia se dizia, amigavelmente, era de que "não nos considerem simples banausianos, mas amigos do IPHAN. Afinal, se trabalhamos nas 'artes mecânicas’ e vocês no alto do poder, todos devemos permanecer unidos para participar da emergência nacional.”

O que objetivávamos era postular, isto é, combinar um mais cordial relacionamento entre o principal museu do Brasil e o Patrimônio.

Como o sr. Soeiro em sua carta não acena qual a técnica utilizada para o tombamento do acervo do Masp, tomamos a liberdade de preparar o dossiê técnico, incluindo as obras entradas depois de 1969 (especialmente as doadas por Lina e P.M. Bardi) para que o tombamento seja atualizado e técnica e juridicamente ad-hoc.

Não nos move nenhum sentimento hostil para com o sr. Soeiro. Ao contrário, o estimamos a ponto de no primeiro número de Arte Vogue mandarmos entrevistá-lo, pois entendemos ser dever precípuo da imprensa e de todos os cidadãos, colaborar com o Patrimônio.

Nossa nota banausiana tinha este espírito, apesar de saber que no Brasil não se cultiva o hábito por todos os títulos salutar e democrático de discutir.

\section{Finis panelarum}

Quando mudam os governos, os assim ditos cargos de confiança, são colocados à disposição. As panelas são postas de lado para deixar limpa a mesa, aguardando os novos dirigentes. Queimadas, amassadas, craqueletadas, as alças partidas, às vezes o mofo aparecendo, as panelas emergirão para a cena no dia que o chefão cessante, arrogantemente convocará o pessoal para os tradicionais abracinhos de despedidas, e para ouvir os laudatórios discursos pronunciados pelos que receberam melhores atençôes.

Tais tipos de eventos foram batizados por emérito latinista prático de burocracia: finis panelarum. Panela, todo mundo sabe o que significa: é aquele recipiente onde se cozinham as marmeladas, dicção que outros latinistas, aliás grecistas, apelidaram de ekklesinha, assembleia de congregados conjurantes que opera em favor dos interesses dos inscritos.

Não é a questão semântica que interessa, mas a arrumação das mesas, particularmente aquelas onde irá se comer o bolo das artes, bolo pontualmente não considerado como nós de outra repartição gostaríamos que fosse.

Será que para a mesa irão em março panelas mais capazes do que aquelas que se eclipsam no esquecimento? Dizem os entendidos que no enrolar dos tempos, as panelas pioram em termos de qualidade, furando-se facilmente. (É o costumeiro detestável pessimismo.)

\section{Briga de gravuristas}

Também os gravadores lutam pela vida e, como as coisas nem sempre são amenas, $\mathrm{o}$ resultado é que alguma briga acontece. A última é entre pessoal do mercado e os produtores. Grupo maciço de gravadores criou uma cooperativa para vender diretamente ao consumidor, acusando três 
galerias especializadas (Gabinete de Artes Gráficas, Graphus e Bric-a-B’arte) de não se dedicarem 100\% aos interesses dos artistas. Em reação, as três acusadas ofereceram no mercado (mixuruco) gravuras dos reclamantes que guardavam no acervo, pela metade dos preços fixados pelos neo-cooperativistas, anunciando a decisão através de vistosos anúncios pagos em jornais.

O mercado de arte é pobre. Para empobrecê-lo mais, eis agora as brigas entre produtores e vendedores.

\section{Niemeyer em Pátria}

Ninguém quer vetar a imprensa de se interessar por assuntos pertinente à arte. Só que, geralmente, quando as folhas o fazem, utilizam caneta que pousam em tinteiros com tinta fortes de escândalo, com denúncias e mexericos. O último mexerico (por sinal malévolo) é em relação a Oscar Niemeyer. Veio de Paris para boatizar no Caderno B do Jornal do Brasil. Noticiaram que os funcionários do Centro Georges Pompidou, onde está sendo apresentada a grande exposição da obra do arquiteto de Brasília, picharam a manifestação, provocando a costumeira e desagradável fofoca. O redator, ao invés de informar o que Paris está apreciando e discutindo, isto é, a arte de Niemeyer, desentocou barnabés sem gabarito sem responsabilidade que sopraram no ouvido do condigno jornalista umas besteirinhas sem sabor. É sempre assim: a dor de cotovelo tem agora outra titulação, ou seja, calo de cotovelo.

60 milhões

No orçamento federal para o ano em curso, estáo previstos recursos da ordem de sessenta milhôes de cruzeiros destinados à formação musical da juventude. $\mathrm{O}$ governo federal tem especial interesse no fomento da música executada por leigos, e onde as possibilidades de formação, no momento, ainda não são suficientes. ( $\mathrm{O}$ governo federal é o da Alemanha Ocidental.)

"A DIFERENÇA ENTRE UM BOM ARQUITETO E UM MAU ARQUITETO É QUE ESTE CEDE A TODAS AS TENTAÇÓ́ES E O OUTRO RESISTE." - Ludwig Wittgenstein, p.89

(Uma revisáo da arquitetura pós-Brasília a partir da página a seguir)

UMA ARQUITETURA MAIS RUDE, p.90-9I

Os arquitetos, como de resto os demais profissionais, (menos os advogados) em geral não são muito dados à discussão dos problemas a eles inerentes. Lê-se na introdução de uma série de depoimentos e debates: (Arquitetura Brasileira Após Brasília, vol.3, IAB; Departamento do Rio de Janeiro, Comissão de Estudos) "Desde o início - quando a unidade era fundamental para a implantaçáo do movimento da arquitetura moderna - a crítica tem sido um verdadeiro tabu." Tabu também é "o desnudamento de seus possíveis conflitos.” Corajosamente se afirma: “... nossa estrutura de profissão é débil; nossa contribuição político-social discutível." A autocrítica vai mais longe: “...nossa responsabilidade de arquitetos em um país subdesenvolvido não pode aceitar o comodismo a que temos nos acostumado."

\section{Le Corbusier e o Racionalismo}

Senhor Vogue recebeu a grata visita do presidente dos arquitetos do Brasil, seção do Rio de Janeiro, cargo que vem ocupando ao longo de cinco anos, o arq. Luiz Paulo Conde, bem conhecido pela sua ação em favor de uma arquitetura voltada para a realidade social brasileira.

Conde tem suas próprias ideias sobre esta realidade e sempre demonstrou a respeito uma posição exemplar. Arquitetura, aliás urbanística, sua contendora, sempre dependeu do poder. É o poder político e, em consequência, econômico, através suas estruturas, que condiciona o construir. No Quinhentos, Filarete era de parecer que a arte edil era filha do comitente e do arquiteto. Após tantos séculos a situação não mudou. $\mathrm{O}$ arquiteto continua fazendo as contas com quem lhe encomenda uma obra.

Conde é de parecer de que foi ao tempo do mando de Getúlio, quando foram dados os primeiros passos de uma arquitetura desvinculada do Culturalismo inoperante. Foi quando Capanema resolveu convidar Le Corbusier para fazer o risco do Ministério da Educação e Saúde, confiando a construção do edifício ao grupo que 
depois liderou a renovação, no Rio de Janeiro, continuando durante muito tempo aí centralizado, como bem observa Conde. "Não que tenha sido negativo, mas no Rio é que se estabeleciam as regras do que se poderia chamar de qualidade em termos de expressão artística brasileira, numa linha muito oficial, muito programada. Eu acho que isso se deu até a década de 60 , e Brasília, digamos, foi o ponto culminante dessa fase cultural. Já no início da década de 50, o Brasil começa a se modificar. Com a expectativa da mudança da capital para Brasília, o Rio começa a perder a característica de centro difusor da cultura. São Paulo cresce, prospera, cria museus, faz a Bienal, e as escolas de arquitetura assumem também uma certa importância, independentes do Rio de Janeiro, caracterizando uma profunda modificação."

Conde é de opinião de que o Brasil importou o Racionalismo, numa época em que andou se desenvolvendo a tentativa anacrônica de um estilo neocolonial, recuperação de certos valores fachadísticos pescados no Ecletismo oitocentesco. Aquele estilo representou a arquitetura na Semana de Arte Moderna de 22.

Conde tem suas dúvidas a respeito da escolha do Racionalismo como contribuição para a postura de uma cultura arquitetônica nacional. De qualquer jeito, apesar das contestaçóes de Villanova Artigas, mais atraído pela tendência orgânica de Frank Lloyd Wright, chegou-se até a construção de Brasília. Conde lembra que "se formaram correntes na Faculdade de Arquitetura do Rio: os orgânicos e os não-orgânicos, isto é, os racionalistas. Discutia-se muito o formalismo da arquitetura brasileira, havia um embrião de discussão das tendências e também uma certa intuição, por parte dos estudantes, de que não seria possível continuar naquele caminho. Nós achávamos aquele repertório esgotado.”

\section{Brasília docet?}

Foi Brasília que afinal recordou aos jovens que a arquitetura é um elemento e se integra na urbanística. Não se sabia com exatidão o que era um plano urbano.
Sendo que parte da conversação com Conde se deu viajando de carro pela periferia de São Paulo, (que ainda cresce sem um desejável plano diretor) postergados os jardins e os arranha-céus, ao longo de ruas, cortando vilas clandestinas e improvisaçóes de favelas, natural o assunto desembocar no plano da posição do profissional face à realidade social. O hóspede volta a evocar mais um pouco de história, lembrando o ponto de partida da urbanística, que foi o Seminário de Reforma Urbana de 63. Entre as conclusóes se afirmou que o arquiteto, além do desenho, deveria participar da consideração de outros mecanismos: situá-lo na tarefa de "mestre de vida," implicando necessariamente nos números os fatora determinantes do fato cidade.

Perfeito; porém: o poder? Deve-se ter presente que muitos e diversos são os Brasil, considerando clima, sociedade, migraçóes e, agora, instalaçóes de barragens e empreendimentos mineralógicos e industriais. Infelizmente a moradia popular, na maioria dos casos, é a que sabemos. Observa Conde: "O loteamento popular sem serviços ou serviços precários é consequência do poder aquisitivo das famílias.” Mais uma vez o trabalho do arquiteto se defronta com a realidade econômica. Boa pontualização de Conde: "Nossa arquitetura deverá ser mais rude, menos preciosa no detalhe, pois sendo nossa tarefa muito grande, temos que minimizar certos comportamentos. Não podemos aceitar o padrão de comportamento americano ou o europeu frente ao fato arquitetônico. Nessa última viagem que fiz à Europa compreendi isso muito bem. Lina Bo Bardi comenta que o arquiteto europeu está dividindo o fio de cabelo em quatro partes na vertical, quer dizer: uma preciosidade difícil de ser conseguida aqui no Brasil. Não devemos achar ruim que seja impossível essa preciosidade, devemos encarar isso e tentar nos expressar com mais força, mais no geral do que no particular."

Nosso comentário diante desta declaração: são os postulados iniciais do Racionalismo, cuja polêmica se concretizou no combate ao "desperdício arquitetônico," procurando seguir as recomendaçóes do Sócrates da arquitetura, o padre Carlos Lodoli que, chateado com o excesso decorativo do 
barroco, no Setecentos, pregava a simplicidade e organicidade da arquitetura. Lembramo-nos de Lodoli, pois Conde afirma: "No Brasil, a preciosidade teria um custo absurdo, improdutivo, pois não há mão-de-obra para se chegar a uma proposta desse tipo, nem a indústria vai responder a isso. Temos que acertar muito no conceito, no essencial do projeto, no partido correto, no dimensionamento, na escala, no relacionamento com a cidade, com o local. Esses fatores são mais importantes de que a preciosidade e resultarão numa expressão que vai caracterizar a nossa arquitetura. Alguns poderiam dizer que isso é uma arquitetura até certo ponto subdesenvolvida. Eu não acho. Acho que ela poderá ter contingentes de força. $\mathrm{O}$ cinema novo, por exemplo, demonstrou isso. Às vezes, a técnica não era tão preciosa, tão precisa, não era tão perfeita, mas havia uma força contida dentro do trabalho, e essa força estava mais nas ideias, no conceito. Não que o arquiteto não deva seguir o seu projeto, ir até o fim, mas cair na ouriversaria náo é o nosso caso, tem que ser uma atitude mais direta."

\section{História e seu ensino}

A conversa continua. Vêm-nos aos lábios as contradiçôes brasileiras que não podem ser resolvidas à l'instant. Conde sempre se reporta à História. Lembra que na Bauhaus o ensino da História não existia, e por isso pensa justamente que a História deve ser conhecida pelo menos a recente. Diz que "se faz em cinquenta anos, não se faz mais em trezentos anos:” o que aconteceu no Brasil de 30 até 60 é História, e como tal tem que ser conhecida e discutida.

Bauhaus, como escola, levou-nos a uma troca de ideias sobre o problema de base no ensino da arquitetura. Basta constatar que só no Rio se formam uns mil arquitetos por ano. Conde acha que o ensino da arquitetura no Brasil podia ser melhor, especialmente no que se refere à História. De fato, este ensino é bastante eivado de lero-lero, esquecendo-se, por exemplo, o trato do período que vai desde o início da arquitetura industrial até hoje, pois até uma obra apenas inaugurada é História e matéria de conhecimento.
A respeito da missão dos diplomados no ensino da arquitetura, Conde disse: "Me pergunto: qual o caminho que eles deverão seguir, e acabo achando que o caminho seria propor certos parâmetros, em nível de clima, da economia, da construção, para que esses arquitetos se sentissem responsáveis pelo que fizessem em relação a um programa, a um relacionamento ético com a construção, que se preocupassem basicamente em saber se a construção está correta, bem implantada, bem relacionada com os elementos à sua volta.”

Parece-nos muito importante divulgar as opinióes e as preocupaçóes dos arquitetos. Eles governam os timóes dos barcos de uma arte que é o cartão de visita de uma nação. O plural depende da heterogeneidade deste cartão de visita: varia, variada, volúvel, regionalista, contraditória, modista, mais propensa à elaboração do que se imita, apesar de Gilberto Freyre afirmar que os brasileiros sempre absorveram as influências francesas e inglesas, as digeriram bem, quer dizer, não cuspiram e, ao digerir, geraram outro produto mais brasileiro.

Conde conhece bem o Brasil. Viaja continuamente e assim fica em condiçóes de anotar como a tradução em paredes do desenho arquitetônico ainda náo representa unidade, marcadamente no que se refere a planos urbanísticos.

Voltando à implicação social, à situação do fruidor de moradias, qual o gosto das classes que lutam para conquistar um status satisfatório de vida incluindo um "quanto basta" de estética?

Conde trabalhou no Departamento de Habitação Popular do Rio, dirigido pelo saudoso arq. Afonso Eduardo Reidy, onde se projetavam casas com desenhos completos e a planta legalizada era vendida por cinco cruzeiros. Os projetos eram com telhas, considerada a melhor solução. Diz o arquiteto que geralmente os proprietários em vez do telhado, faziam uma laje colocando um telhado-borboleta por cima: sociologicamente explica-se que as classes menos favorecidas aspiram a uma expressão estética semelhante à das classes mais altas.

Posta a conversação (baseada nos debates a que nos reportamos) em termos em que se apresenta o panorama da arquitetura 
brasileira após Brasília, depois da saída de Niemeyer, o estilo cobiçado é o "colonial," pelo menos é o que se observa no loteamento do lago Paranoá. Perguntamo-nos: para onde vai a arquitetura colonial?

Parece que continua a prevalecer a confusão: um novo Culturalismo, desta feita não de estilos históricos, mas de propostas que surgem na Europa e nos Estados Unidos que vão estruturando o Culturalismo de passado recentemente iniciado no Brasil, isto é, nos tempos de Warchavchik e levado à fama internacional por Niemeyer. A respeito do mestre, Conde sentencia: "É uma das figuras mais importantes da arquitetura brasileira e em certos aspectos nos dá uma lição. Vejo parte da obra dele sob esse ângulo; a possibilidade de construir com mais simplicidade, e de não complicar certas propostas, talvez seja uma das razóes pela qual a obra do Oscar é a mais construída entre os arquitetos brasileiros."

Nossa impressão: será que do Novo Culturalismo deste fim de século afinal emergirá no Brasil uma arquitetura pelo menos aurea mediocritas?

\section{Legenda}

Três exemplos da arquitetura de Luiz Paulo Conde: Escola do Premen Vila Velha (com Flávio M. Rego); Universidade do Rio e residência (com Carlos A. Bittar)

Documento, AVIDA Num ÁlbUM DE FAMÍlia, p.92

Texto de Dulce Soares, cf. Anexo B, p.636

Quando se fala de memória do Brasil não é porque os nostálgicos queiram conservar tudo. Eles compreendem que o decorrer dos tempos, do progresso, dos imperativos do existência, arquiteturas parece que ao se falar em abatê- las oara em suas áreas construir novas edificaçôes, o alarido vai se tornando constante. Porém é justo conservar conjutnos ou exemplos. mudam o panorama. No que se refere às

UM PRÉdio PARA SER VISTO, p.93-95 [SOBRE O EDIfício SHARP, NA PAUlista]

A arquitetura que satisfaz, nas metrópoles, só é descoberta com alguma dificuldade, pois quase sempre está sacrificada (é o termo) em ruas e também em avenidas não muito espaçosas. Leonardo da Vinci prescreve que se veja uma pintura à distância de seis vezes sua altura; a que distância é - que se poderá contemplar um edifício?

A nova sede paulista da Sharp é um dos poucos edifícios que podem ser visualizados, pois o arquiteto, arquiteto, autor do projeto, ao erguê-lo entre duas ruas, conseguiu notáveis áreas fronteiriças.

Dentro do espírito de racionalismo, não do racionalismo dos tempos do seu lançamento, ainda muito dependente da função por razóes polêmicas, Juliano resolveu perfeitamente o problema do organismo em combinaçáo com a estrutura formada de quatro paredes-cortinas (calculadas por Mario Franco) que permite e propicia conveniente utilização do espaço.

$\mathrm{O}$ arquiteto cuidou de ajeitar no prédio um tipo de brise-soleil que, de certo modo, representa a proposta de se servir do sistema lecorbusiano, através de diafragmas bem combinados, uma das tantas propostas que revisionam a função e a estética do elemento fachada, desvinculando-a do esquema secular da janela. O que se constata no prédio é um funcionamento que agrada ao visitante e aos que lá mourejam diuturnamente.

Depoimento: Miguel Juliano, p.93

Texto de Miguel Juliano; cf. Anexo B, p.636

\section{Legenda}

p.64-65 Edifício Sharp ao lado da alemeda Rio Claro; o auditório. Na foto maior outra visão do lado que dá para a rua Pamplona; outra vista do lado da alameda Rio Claro; hall de entrada do edifício. No gráfico: a planta do edifício.

Salvar o Artesanato: na Europa ele está desaparecendo. No Brasil, resiste, p.96

Pesquisas levadas a efeito recentemente na Europa informam que o artesanato está desaparecendo. A era industrial liquida o operário prático de técnicas 
seculares. Felizmente no Brasil o artesão resiste, especialmente no interior, mas alguns sintomas não são lá muito animadores, pois a máquina vai tomando conta de inumeráveis operações desempenhadas pela mão e pela cuca.

O caso da marcenaria, por exemplo: até há uns dez anos, nas grandes cidades brasileiras, os pintores contavam com artesãos que fabricavam chassi segundo especificaçóes técnicas tradicionais; hoje os chassi são fabricados industrialmente, rígidos, sem cunhas, sem cruzetas ou travessas, armados com telas por sua vez mal preparadas para receber a pintura.

E os restauradores de móveis antigos, molduras, marquetadores e quantos outros produtos feitos com madeira trabalhada? Existe um ou outro especialista, mas em comparação, com a demanda, a pobreza é quase absoluta. $\mathrm{O}$ mesmo se passa com ferreiros, serralheiros, mecânicos, os que sabem mexer com relógios e autômatos antigos. Que falar da ausência de gente capacitada para restaurar cerâmicas, bronzes, tecidos, tapeçarias, tapetes? É verdade que estes objetos não são tão numerosos no Brasil, porém existem e, quando procuramos profissionais capazes, é difícil encontrá-los e quando são encontrados se apresentam com a aura de serem os últimos, pois nas mais das vezes são anciāos que sempre dizem não encontrar continuadores do seu ofício.

No que se refere ao artesanato criativo, no Nordeste as coisas andam um pouco melhor; mas já a produção das cerâmicas, pela ganância dos comerciantes sulinos, está perdendo sua espontaneidade, como no caso dos objetos dos índios comissionados pelo comércio das lojas de Manaus, carentes da graça dos tempos quando o branco ainda não especulava por lá.

Quando se trata de artesãos, o caso implica num problema de extrema complexidade. $\mathrm{Na}$ França existe um comissariado que cuida destes profissionais em categorias que são nada menos que em número de 360 , consideradas apenas aquelas que trabalham em especialidades existentes antes do advento do industrialismo. É o mundo que está mudando; e, por outro lado, uma advertência sobre a necessidade de considerar o artesão um elemento indispensável no tempo em que a tecnocracia tende a nos transformar em mecanismos sempre menos pensantes.

É confortador que no programa da Funarte o problema do artesanato vem sendo considerado juntamente com os da assim dita "arte culta." Será arte do artesanato um dos assuntos que Senhor Vogue vai tratar proximamente nesta seção.

\section{EXAME RADIOGRÁFICO DE PINTURA, p.96}

Hoje quando os problemas da conservação e dos estudos interessantes sobre as obras de arte vão se profissionalizando, o emprego do raios-X começa a ser praticado, e com utilidade, especialmente para verificar a autenticidade das pinturas. Para chegar-se a interpretar uma radiografia é preciso capacidade técnica e experiência, pois os casos se apresentam sempre diversos, notadamente quando se trata de possíveis dúvidas quanto à autenticidade.

Recentemente tivemos ocasiáo de ver um trabalho experimental do amigo dr. José Nemirowsky, que se diplomou recentemente no Art and Antique Appraisal Program de Nova York, dedicado ao famoso quadro de Tarsila do Amaral, "Carnaval em Madureira," obtendo um resultado inédito ao descobrir a textura da criatividade da grande pintora. Eis o resultado da pesquisa do José. Comparando com a fotografia do quadro: a figura da negra bem alta embaixo e à direita, localizada olhando a ponta do primeiro patamar, tem os braços lisos, mas a radiografia mostra pequenas áreas brancas. Evidentemente a artista pensou em modular a cor dos braços, colocando tinta branca (branco carbonato de chumbo, que é muito opaco no raio-X) em algumas áreas e, sobre estas, a cor escura que ficaria mais clara sobre o branco. Contudo, mudou de opinião e carregou o terra- escuro, ficando os braços lisos à inspeção visual.

Outro ponto curioso é o referente às inserçóes medianas das duas janelas, logo à direita da figura anterior, que originariamente desciam até o mesmo nível: isso pode ser visto na radiografia, (fig. 2) porém a observação normal mostra 
um capuz sobre a cabeça da primeira criança à direita da negra alta, impedindo a inserção das janelas no mesmo plano. Esse acréscimo, "pentimento," dá mais inquietação à base das janelas.

Também a porta escura, à esquerda da mesma figura, foi rebaixada e o raios-X mostra a porta mais alta chegando ao nível superior da testa. Essa análise parcial já nos dá ideia do cuidado com que o quadro foi elaborado. Além disso, o raios-X elimina qualquer possibilidade de falsificação. E isso de forma definitiva.

Cartas EXTRAVIADAS

As cartas são imaginárias, mas os problemas da arte bem reais, $p .97$

\section{Grilos e coruja}

Querido: sempre acreditei na intuição dos valentes filósofos da Escola de Wittensbaden, convencidos de que temos no cérebro grilos e uma coruja. Esta, biologicamente é símbolo da linearidade da vida e tem o ofício de engolir os grilos quando eles perdem a compostura, atrapalhando o bom funcionamento do mecanismo mental. O meu psicanalista me informou sigilosamente que tenho na cabeça bastantes grilos, que se reproduzem até por ortogenese, tanto que a coruja comeu-os provocando forte indigestão que a levou à morte. Assim os grilos agora mandam, jogando-me num descontrole inimaginável. Você sabe: sou crítico de arte. (Pelo menos assim o atesta minha caderneta do Sindicato.) Antes da coruja desaparecer, eu gostava dos acadêmicos e agora os odeio.

De um ano para outro me vejo embaraçado nestes mares agitados do hermetismo. Até lá eu podia julgar apreciando figuras, enquanto agora estou metido em julgar nos negócios de minhocas, quadros pintados como se pintam paredes, envelopes com carimbos e assim por diante. Você que é do zoológico poderia me dar uma coruja? Tenho um neurologista que vai enfiá-la em minha cabeça para matar os grilos e, com tal chefia, voltarei a raciocinar. Abraço, João.

\section{Mulheres na arte}

Inesquecível amigo: Se existe um feminista este sou eu. E disso você sabe muito bem. Aguento a mulher até quando ela quebra as panelas na minha cabeça. Com esta premissa quero confirmar que quanto lhe escrevo hoje é para repetir que continuo feminista; repito: sou profundo apreciador das fêmeas, pois Deus as consignou a nós para continuar este negócio no Mundo. E aqui estou para lhe dizer: você viu quantas mulheres poluem o setor chamado arte? Antigamente, nos séculos passados, você encontrava apenas uma ou duas mulheres pintoras. Nâo sou historiador nem crítico de arte, porém sei que no Quinhentos, na Itália, Sofonisba Anguissola ${ }^{41}$ foi a única personalidade que fazia sensação. Hoje, meu caro, só no Brasil falam que existem mais de duas mil pintoras de cavalete. Sei que os tempos mudaram. Existem até executivas, médicas, engenheiras, e por que não deveriam existir artistas? Tudo justo e tudo justificado. Mas lhe escrevo para me queixar náo das mulheres produtoras de arte, porém delas quando se aproveitam do status dependente do sexo para atrapalhar a vida de nós artistas profissionais. Existem demasiados pintores, especialmente pintoras, em geral amadoras que interferem. Garatujam e já pensam que são Picasso. Arranjam curriculum, invadem os salóes, corrompem os críticos, vão aos jornais encantar os redatores, em suma, uma política pouco correta contra nós que vivemos momentos difíceis. Você, que é membro do júri do próximo Saláo, seja severo com a concorrência feminina. Sei que uma moça, de nome Z.Z., vai mandar para o Saláo o único quadro que pintou na vida. Atenção: é uma chutadora, pois chegou a declarar, numa roda apreciada

4I Sofonisba Anguissola (I532/I538-I625) estudou no ateliê de Bernardino Campi e, juntamente com sua irmã Lucia, começou a praticar a pintura restrita à temas que abordavam o ambiente caseiro e familiar, por ser mulher. Atualmente as obras das irmãs Anguissola têm sido alvo de estudos e com dificuldades, já que é difícil a atribuição correta dos trabalhos, muito similares. $\{$ Hargrave, 20IO, p.2II 
pelo José, que se for aceita no Salão continuará pintando. Mais uma. Veja bem: nada tenho contra ela. Aliás, é mais bonita e mais simpática que a plus-vocativa Bruna Lombardi. De qualquer jeito esteja atento: é um perigo: Abraço, Teodósio.

\section{Noticiário do Recife}

Caro professor: as últimas notícias que lhe dou do Recife são as seguintes: minha exposição no Museu foi o que já esperava: muito bem montada, visitada, e pouco interesse da diretoria que ocupa o cargo politicamente sem a menor responsabilidade. Aqui o sol é muito forte e as praias estão repletas. Mania de vestibular e pintores preferidos: Lula, ${ }^{42}$ Brennand, ${ }^{43}$ Teruz, ${ }^{44}$ Cícero ${ }^{45}$ e alguns mais impostos pelas galerias que são três: a "Picasso," a "Ranulpho" e agora a "Artespaço," separada dos móveis e decoraçóes. Abraços, Crisaldo.

\section{Programa cultural}

Caro confrade: como telegrafei, consegui finalmente encontrar o presidente eleito, aliás designado pela turminha que faz e desfaz os conselhos diretores do nosso clube. Fui informado de que existe na gaveta um programa cultural de amplíssima envergadura e capaz de suscitar o máximo de entusiasmo entre os associados. Além de um espetacular torneio de bridge e um de canastra que será registrado nos anais da história das diversóes, ele convidará famoso trio bandolinístico

\begin{tabular}{ll}
\hline 42 & $\begin{array}{l}\text { Luiz Gonzaga Cardoso } \\
\text { Ayres. (I9IO-I987) }\end{array}$ \\
43 & $\begin{array}{l}\text { Francisco de Paula Coimbra de } \\
\text { Almeida Brennand. (1927-) }\end{array}$ \\
44 & $\begin{array}{l}\text { Provavelmente Orlando } \\
\text { Teruz. (1902-I984) }\end{array}$ \\
45 & Cicero Dias. (1907-2003)
\end{tabular}

do qual ainda não é possível revelar o nome. Você me pergunta da biblioteca. Sobre o assunto o presidente não quis se pronunciar; me confiou, porém, que vai fazer novas assinaturas de revistas, entre as quais o Sei Tudo. Abraço do Francisco.

\section{Problemas de inveja}

Caríssimo: atendendo ao seu pedido eis a minha opinião a respeito do problema “inveja." Antes de tudo não é um caso tão sério. Não se deve dar bola aos invejosos. Os coitados é que merecem piedade. É verdade que aquela fulana da qual você fala se manifesta com preocupantes sintomas psicopáticos, razão pela qual é preciso considerá-la uma doente. Seria uma boa ação encaminhá-la a um psicanalista, ou melhor, a um psiquiatra, pois as últimas manifestaçôes repercutiram gravemente nos dois cotovelos. Deve a coroa cuidar dos seus afazeres sem dar-lhe a mais microscópica bola. A invejosa é ávida por bolas. Assim sendo, seja cristão: perdoe-a, e Deus registrará sua generosidade. Cordialmente, Felipe Tiradentes.

\section{Recomendação}

Sr. decorador: agora lhe digo como quero que fique o living que, como sala de estar, deve concentrar o melhor arranjo, e de modo a demonstrar aos recepcionados, nossa condição de gente ultra-abonada e, por que náo dizer, um pouco por cima, e tal de suscitar consideração e inveja. Nas paredes, que serão de damasco vermelho, o senhor deve escolher quadros dos pintores mais badalados nas crônicas sociais e, caso algum destes cronistas tiver esposa pintora, compre dela. E preste atenção para que todas as telas sejam vistosamente assinadas e a moldura etiquetada, com o nome bem grande. Saiba que gosto de abstrato. Atenciosamente, Fulana.

SENHOR E AS ARTES p.98

\section{Uma nova fase da Arte Global}

Mudanças de vulto ocorem na Rede Globo, particularmente no setor da divulgação das artes plásticas. Até aqui o popular Canal 5 esteve presente em São Paulo ao longo de cinco anos com as exposiçóes que eram pontualmente anunciadas na TV e menos vistas na galeria Arte Global. ${ }^{6}{ }^{6}$ Quem

46 A Galeria Arte Global (1973-I983), instalada na alameda Santos, de propriedade da Rede Globo de Televisão, "tem como finalidade 
encerrou as mostras na Arte Global foi o fotógrafo Olney Krüse, ${ }^{47}$ aqui caricaturado por Sandra Abdalla. Os artistas apresentados foram em número de uma centena, escolhidos quase sempre entre os experimentadores geralmente indigestos ao grande público. Agora a Arte Global deixa de ser uma galeria de artes plásticas. Em seu lugar passa a existir uma entidade que vai apoiar as atividades culturais mais significativas, promovidas pelos principais museus, sociedades culturais, secretarias de Cultura. Uma boa iniciativa que irá conciliar o grande público (desejoso de entender cultura não hermética) com o nosso maior canal de tv.

\section{A morte do "marchand"}

Quase centenário morreu em janeiro deste ano o marchand dos Fauves, Picasso,

promover a arte contemporânea brasileira, divulgando artistas consagrados e jovens talentos. Utilizando-se de seu alcance nacional, a Rede Globo informa sobre as exposiçôes em horário nobre, - antes da novela das oito - com isso busca despertar o interesse do público e da crítica.” \{Enciclopédia Itaú Cultural\}

47 Oswaldo Olney Krüse. (São Paulo I939-SP 2006)
Braque, Vam Dongen e de quase todos os outros mestres da Escola de Paris: DanielHenry Kahnweiler. alemão naturalizado francês. Desconhecido no Brasil, a única vez que teve ocasião de saber que aqui existia alguma coisa de arte foi quando expertizou um desenho de Picasso que uma senhora-marchand vendeu a um marchand, por dois mil cruzeiros, sendo que os dois moveram-se mutuamente um processo judicial, onde o perito que justamente tinha se dirigido a Kahnweiler, disse, no pretório paulista, que os dois primários deveriam ser condenados por ingenuidade, uma vez que a peça valia na época quinze mil dólares.

\section{Antigo delírio para Harrison}

A vinda e a rápida estada de George Harrison no Rio, apesar de já serem os Beatles pré-história, causou os mesmos delírios das mocinhas, e até as hoje coroas dos anos 6o, proteção de patrulha de guardas armados, entrevista concedida a 64 jornalistas, ruas interrompidas e quanto mais se pode depreender do estampado nas páginas dos jornais que dedicaram acontecimento da Presença de um dos reis fabricados pela propaganda. (Bach ou Vivaldi, Ravel ou Strawinsky, nos seus tempos, benjamins de uns quatro gatos pingados. $\mathrm{E}$ depois, dizem que os tempos mudaram.)

\section{Casa Vogue \#7, julho-agosto-setembro de 1979, p.IIO-II3} Seara do COlecionador: uma Coleçấo de Modernos, de Enrica Profili

Infinitos são os jeitos de decorar uma casa, particularmente quando seu fruidor se dedica ao negócio; são limitados quando ele contrata o decorador, o qual, fatalmente, tende a aplicar sua concepção rotineira e, por mais que se esforce em diversificar, sempre acaba evidenciando um resultado genérico. Isto se dá também com a moda: quem se veste prêt-à-porter ou mesmo quem compra nos costureiros momentaneamente na crista, fatalmente participam daquilo que acima dissemos, do genérico.

Então? Somos de parecer que a ambientação ou, como dizem, decoração de uma casa, deve ser determinada por quem vai habitá-la, superando o complexo de confiar a outrem a solução de um problema marcadamente pessoal, aliás íntimo. Trata-se de complexo quando se ouve dizer: não entendo de arte, náo sei como resolver etc. Aí telefona ao tal para que este venha arrumar os móveis, quadros, bibelôs e quantas coisas mais amealhadas pelo orçamento disponível e... pronto. Assim, a família se adapta no estandardizado.

Conselho: desiniba-se e arrume você mesmo o ambiente, decorando-o a seu gosto. Faça como Enrica Profili, que realizou com medidas oportunas e soluçóes pessoais seu novo apartamento em São Paulo e cuja característica é a de ressaltar as inúmeras obras de arte colecionadas ao longo de anos, através de escolhas que denotam um gosto particular tão falto nesta metrópole onde muitos pensam que só existe a pintura dos clássicos nacionais, 
ignorando-se o que se produz no mundo e também o que se produziu nos séculos.

As paredes revelam a personalidade de Enrica, onde despontam obras de artistas da vanguarda latino-americana, como o grande Cuevas, as dos Primitivos da Iugoslávia adquiridos quando ainda não eram procurados; e que dizer dos mestres italianos do Novecentos e dos brasileiros dentre os quais se destaca Manabu Mabe? Falando-se em Mabe, bom será informar que Enrica detém o maior conjunto de telas do famoso período dos anos 60.

As ilustrações dispensam as descrições nesta seara do colecionador; desejamos pura e simplesmente mas com o maior prazer registrar esta descoberta quando vemos uma senhora inteligente que habita uma morada que bem espelha uma vivaz personalidade, magnífica apreciadora da arte, numa escala que infelizmente tem poucos imitadores.

\section{Legenda}

p.IIo-III I. "Cabeça de Menina," de Bruno Giorgi; litografia de Carrà; guache de
Pignon e guache de Castillo 2 . Sobre uma escrivaninho italiana do século $\mathrm{I} 7$, um raro vaso da Companhia das Índias; ao lado, uma cerâmica pré-lncaica "Cuchimilco;" ao fundo, vaso etrusco do século 3 a.C.; na parede dois óleos de Manabu Mabe e um de Fillppo de Pisis. 9 3. A mais rica coleção de objetos que configuram o caracol existente em São Paulo. 9 4. Guache de Georges Mathieu; óleos de Szyslo; de Tsutaka; pinicos de prata espanhola do século I7; antigo lustre de cristal.

p.II2-II3 5. Pencas de prata baiana do século I9; cerâmica deCândido Flore; óleos de Ivan Rabuzin, de Gerson de Souza; guache de Mathieu. 96. Um óleo de Juan Moray guache de Pons; duas esculturas de Marino Marin e Giuliano Vangi. Na parede rara carta geográfica da Âfrica, editada em i970. 9 7. Óleos de Manabu Mabe. Di, Guignard, Antônio Bandeira, Pancetti e Rosai; cerâmica de Picasso. 9 8. Tecido pré-incaico óleos de Capogrossi e desenhos de José Luis Cuevas.

Senhor Vogue \#I3, abril de I979, p.IIO-I2I (Senhor e as Artes)

DESIGN, p.IIO

Dedicamos esta seção do Caderno das Artes de Senhor Vogue ao Design, uma das atividades que mais incidem no cotidiano, já que existe uma marcante relação entre gente e objeto. Expressão e síntese da arte determinante Arquitetura, o Design envolve forma, cor e utilidade, sendo sua presença fator de vida e de contentamento estético.

Uma vez que a Revolução Industrial propôs e impôs o múltiplo, e o standard com a universalização dos produtos, o Design assumiu o papel irreversível da representação mais certa da Arte. Deve ser também registrado o fato dos contínuos intercâmbios internacionais de Design, que tendem necessariamente para o alcance de um denominador comum de preferência prática e de gosto.

Um eletrodoméstico, um móvel, um avião, uma simples ferramenta tomam a posição de objeto de arte. Considera-se, justamente, o Concorde como obra-prima do século que vai se exaurindo. Admitimos que nem todas se bitolam com esta atribuição, a começar por Jean
Dubuffet, um dos mestres das agora antigas vanguardas que pensa o Ocidente ter de aprender boas aulas dos selvagens: em vários campos, soluçóes e pontos de vista dos mesmos, que nos pareceram erradamente simplórios, e que pelo contrário são mais próprios dos nossos. $\mathrm{O}$ réfinement, $o$ cerebral, a profundeza, pertence a eles, selvagens, e não a nós. (A anotação é para indicar a coluna "Fiat e Dubuffet.")

Design e comunicação de massa, sem mexer com o labor dos artistas isolados que têm sua indispensabilidade e seu destino, vigoram como os propulsores do relacionamento homem-vida, conforme, naturalmente, a cultura de cada país. Como estamos no Brasil, o que a nós interessa é o Design e a comunicação de massa já em atividade.

Enganchados às insistências, às vezes desnecessárias do progresso tecnológico, está fora de discussão que uma vez entrados no baile deve-se dançar. Os inícios de nossa participação com o propósito de progredir não foram nada fáceis, mesmo 
porque os problemas de estética se subordinaram por demais aos da produção. (Seria exagero definir a situação como pré-histórica, continuando a contar que as fábricas de sapatos mandaram comprar na Europa as novidades para aqui copiá-las, o mesmo se dando com todos os maquinários, objetos, gráfica etc.; uma resenha do Design brasileiro ainda está para ser feita, porém, na exposição "Tempo dos Modernistas," realizada no Masp, o público se surpreendeu ao observar peças que poderiam ser incluídas, como resultado estético, numa história ocidental.)

É no após última Guerra que se verificou a atenção para com o Design, e se viram os primeiros galhos e frutos, sendo possível hoje constatar a presença de certos status, não exaltantes, porém de um padrão generalizado com alguns toques de originalidade.

Se entramos num supermercado (alguns ostentando ainda fachadinhas decorativas contrastantes com a racionalidade e atualidade de uma geladeira ali em venda) o conjunto dos objetos, (menos o desagradável setor do mobiliário, luminárias, tapeçaria e outros objetos produzidos segundo formas já superadas) a disposição, as embalagens, a gráfica manifestam algum interesse de apresentação de um certo nível.

Fácil avançar reservas e críticas por esta ou aquela série de etiquetas, por rótulos que poderiam ser compostos por um designer e náo por um praticante, reservas até pela linha de vestuário dos que trabalham. Uma unidade estética não é fácil de ser ajeitada, por outro lado, produto de uma quantidade de fatores culturais que começam pela educação.

Estamos no começo do Design. Ainda não foram dados os primeiros passos para uma organizaçáo industrial coordenada com o espírito nacional, aberta às consideraçôes de função, ação e finalidade comunitária. Estamos ainda longe de um planejamento governamental distributivo dos bens contemplando todos, e não somente classes.

Se os gêneros alimentícios sobem, as donas de casa vão para as ruas assinar manifestos, iniciativa desesperada com ranços de caos. Até circularem no Brasil revistas essenciais nos moldes do "Consumer Report," ou publicaçóes como "The Updated Last Whole Earth Catalog," as águas do Amazonas deveráo rolar por baixo da insegura ponte planejamento nacional.

O Design é uma consequência disto tudo, satélite menor da Cultura, este satélite principal do sistema ainda náo descoberto pelos nossos astrônomos.

Nas páginas seguintes foram, propositadamente, os colaboradores deixados em liberdade para se pronunciarem. Os fatos são estes para que os leitores tirem suas próprias conclusóes.

\section{Legenda}

O rigor do Design no Quarto da Senhora Blavatskij, desenhado em Dresden, em I927, por Piet Mondrian e reconstruído na ultima Bienal em Veneza

As opçôes culturais do design, p.IIo-III

Texto de Lina Bo Bardi; cf. Anexo B, p.637

DESIGN ITALIANO, EXEMPLO PARA O BRASIL, p.II2

O Design está alcançando as metas do sofisticado, beirando a um alto requinte. Isso na Europa, tendo como centro irradiador a Itália, considerada a meca, pela qualidade da produção. $\mathrm{O}$ mundo inteiro despacha para a Península todos aqueles que pensam se integrar na grande novidade, de um viver entre coisas bonitas em contínua renovação de formas e de cores, e daqueles portos aéreos e marítimos a exportação é fato que influi na balança comercial de modo apreciável, como outro tanto é o turismo.
Quem acompanha a movimentação do Design italiano, através de visitas e da ampla ilustração estampada nas revistas especializadas, o mínimo que pode fazer é perguntar: Para onde vamos?

Há muito que pensar no destino de tanta sofisticação, no objeto que se torna elemento não mais apenas de uso, ou de uso complicado, mas de adorno: certas poltronas que incutem timidez ou que, como certa noite Jô Soares mostrou no Planeta dos Homens, não permitem com que os que estão sentados se levantem com 
certo conforto; determinados serviços de mesas dáo, às vezes, o complexo de não tocá-los; tudo suntuoso a ponto de quando se pensar em limpeza, conservação constante, ficar-se preocupado; enfim, um objeto derivante da fórmula "repartir o cabelo em dois, verticalmente."

Será possível dar, com o tempo, uma estruturação ao Design brasileiro? Há trinta anos que se discute o problema. Arte Vogue, em sua edição n ${ }^{\circ}$ I, examinou com certa amplitude a Situação, ainda, a nosso ver, necessitando ser aclarada. Lógico que um país, no curso da sua
Revolução Industrial, deve assumir e escolher posiçóes estéticas estrangeiras.

Porém, nós existimos, também, no campo em que o Design está no palco. Não faltaram no passado, desde os tempos pioneiros do Instituto de Arte Contemporânea do Masp, os apelos à indústria nacional e multinacional. (Esta transferida para cá com seus próprios padrôes.) Os resultados foram até agora esporádicos.

\section{Legenda}

O Design é pouco aplicado no Brasil. E copiamos propostas de fora.
TAMBÉM NA MECA DO DESIGN, p.II2

O pouco interesse da indústria para com o "Design" não é somente um caso brasileiro, pois na atual meca daquela atividade, a Itália, Paolo Fossati (Il Design in Itália: 1945-I972, Einaudi Ed.) conta o seguinte: “...pode-se afirmar, com boa aproximação, que ao longo de um arco de tempo de quarenta anos, a grande indústria nunca se pôs no problema; a média indústria combinou raras relações com o mundo do 'Design;' a pequena, às vezes interessando estruturas econômico-produtivas artesanais, foi com exceçóes e particularidades o único terreno dos nossos 'designers.' Nos anos 6o, se houve uma certa mudança, com intervençôes maiores da grande indústria e uma mais ágil intervenção das outras duas, porém, se deve também dizer que neste ponto estamos no centro de uma crise, ideológica, cultural e formal do nosso 'Design'...”

O homem é o fim, p.II2

Texto de Sônia Levy; cf. Anexo B, p.639

Prático, leve e lavável, p.II3

Em Porto Alegre foi lançado um novo conceito de Design, circunscrito aos móveis: adaptado para a vida de todo dia, prático, leve, lavável como blue-jeans. Além da função óbvia, (por exemplo, sentar) outras funçôes adquirem prioridade, qual a necessidade de ser barato, ter qualidade, leveza, transportável. Um móvel precisa ser lavado, combinar, mudar de lugar. Náo se necessita de um novo móvel apenas pela novidade. Precisa-se de móveis racionais, práticos, bonitos por si próprios, porém, moderados e preocupados com o consumo de materiais e processos de fabricação.

A indústria de mobiliário deve economizar os minguados recursos da terra. Foram os suecos os criadores do conceito innovator: Jan Dranger e John Huldt. Não querem ser os únicos preocupados com a criação de um móvel bem projetado, que concilie o atendimento de uma função específica com o menor consumo de material. Eles gostariam de receber dos desenhistas industriais, arquitetos criadores brasileiros, desenhos que depois de selecionados e testados na Suécia, seriam distribuídos pelo mundo inteiro. Senhor Vogue poderá oferecer dados complementares.

Os interessados devem ter presente o conceito fundamental de que o desenho industrial não é um fim em si mesmo, mas um trabalho que busca conciliar o atendimento de uma função específica com o menor consumo de material. As necessidades básicas devem ter prioridade. Os produtos precisam ser projetados para passar rapidamente através de todas as fases de fabricação e terminar atingindo com êxito grande número de consumidores. Pagar pelo espaço é um desperdício. Desmontar as estruturas é a solução. 


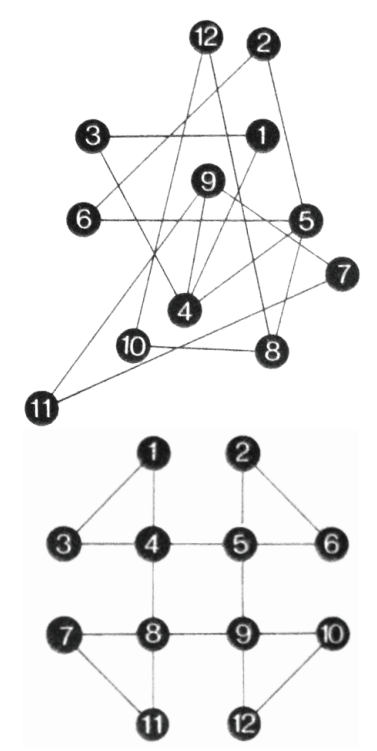

(1) (2)

\section{[REARRANJO], p.II3}

O complicado padrão do gráfico [acima] pode ser transformado no padráo simples [abaixo] por um rearranjo dos nós. Isto é análogo para a "mudança de posição" que possibilita a alguém resolver um problema anteriormente insolúvel. É a síntese de uma operação Design: pôr em ordem, simplificar, resolver. É o que se apreende em Christopher Jones.
DisCIPLINA EM VIAS DE EXPANSÃO, p.II3

Existem disciplinas que se pensavam, ou se pensam, delimitadas em áreas circunscritas nas finalidades tradicionais, mas que, ao contrário, procuram desbordar em outras, até interferindo e procurando conquistar novos espaços. O Design é uma destas disciplinas em via de expansão, tanto que as definiçóes comuns vão sendo superadas.

Christopher Jones, em Design MeWhods, (J. Wiley \& Son ed, New York) apresentando o óbvio do Design até em falar em congestão de tráfego, poluição etc., diz:

FEIRA NÁO MOTIVOU INDUSTRIAIS, p.II3

Caio de Alcântara Machado é o responsável pelo grandioso empreendimento que é o Anhembi, na verdade a meca nacional do Design pela tradição e continuidade das feiras que lá se realizam. Perguntamos a ele o que pensava, depois das primeiras manifestações, ainda no Ibirapuera, e se o Design no Brasil havia melhorado. Respondeu a Senhor Vogue:

— Eu acho que não, ou para melhor especificar, acho que não evoluiu no mesmo ritmo em que se desenvolveu a indústria brasileira nestes últimos dez anos de inauguração do Anhembi. Da nossa parte, fizemos o possível desde o Prêmio Roberto Simonsen até o Prêmio Lúcio Meira. Não fomos felizes para motivar os industriais brasileiros neste setor. Há uns sete anos fiz com Severo Gomes várias
"Estes não devem ser vistos como acidentes da natureza ou como atos de Deus, para serem aceitos passivamente: eles devem, ao invés, ser pensados como falhas humanas no Design por condiçóes causadas pelos produtos do desenho. Muitos reagirão a este ponto de vista porque ele coloca demasiada responsabilidade nos designers e muito pouca nas demais pessoas. Se este for o caso, então já é tempo para que todos os que sáo afetados pelas omissóes e limitaçóes dos designers interfiram no ato de desenhar."

Embalagem, um mudo, p.II4

Texto de José Luiz de Paula Paiva, da ABRE; cf. Anexo B, p.639

A POUCA VALIA DOS CONCURSOS, p.II4

De vez em quando anunciam um ou outro concurso visando a solucionar problemas de Design, de gráfica e de criação de nomes. Somos de opinião que este sistema pseudamente democrático a nada serve. Aborrece muito mais as comissóes julgadoras, que devem descartar quantidade de materiais absolutamente reuniôes, juntamente com a diretoria do Museu de Arte Moderna, para desenvolvermos juntos planos neste setor em que todos éramos grandes idealistas. Foi tempo perdido. O próprio Severo, que teve o Ministério da Indústria e Comércio nas máos, durante três anos, também nada fez - pelo menos que eu tenha conhecimento. Na última UD, realizada em maio de 1978 , retomamos o assunto com um grupo de arquitetos e idealistas e fizemos um recanto em que tivemos oportunidade de apresentar os desenhos de móveis.

Foram grandes planos, grandes projetos... e fogo de palha. Estamos outra vez na estaca zero. Mas não perdi a esperança. Acho que mais dia, menos dia, encontraremos o mapa da mina. 
O TÍMIDO RESPEITO AO DI, pIIS

Há um ano nascia o Núcleo de Desenho Industrial, iniciativa da Federação das Indústrias de São Paulo, sugestão de José Mindlin, Luiz Villares e Dilson Funaro. Responsável pela direção a artista Iole de Freitas, que deu exaustiva e cansativa entrevista à Folha de S.Paulo. O ponto de partida, a origem do empreendimento, foi descoberta da falada exposição de DI, há uns dez anos, no mam de Nova York.

Parece que parte desta mostra vai ser apresentada no $13^{\circ}$ andar do prédio do Viaduto Dona Paulina, sede da Fiesp, numa área relativamente pequena, de $800 \mathrm{~m}^{2}$, que incluiria também as atividades do NDI, programadas com empenho profissional e riqueza de proposiçóes como a de demolir a torre ebúrnea dos donos do vapor industrial, os quais continuam velejando, aliás, remando, nos mares do não levar a sério o problema.
A ação do Núcleo pode dar contribuição notável para um futuro que todos esperam lisonjeiro. Nossas reservas, sem contestar, aliás, aplaudindo a decisão, se baseiam na clandestinidade do fazer, problema do Design não é assunto de uns poucos iniciados ou aspirantes a tais, mas ação que implica ampla participação não somente de fabricantes, comerciantes e publicitários. Náo tivemos como alcançar o $13^{\circ}$ andar de um edifício de burocratas, que fatalmente será governado por burocratas.

De qualquer maneira a estatura dos promotores e a força financeira da Fiesp muito prometem. O que muitos profissionais não compreendem é por que a Fiesp, ao invés de conceder o espaço no $13^{\circ}$ andar, não construiu um pavilhão adequado à façanha. O Design é filho da Arquitetura, e deveria ser uma arquitetura a hospedá-lo.

Tecnologia vai ao povo. Através de um museu, p.II5

Texto de Frederico de Paula Machado de Campos; cf. Anexo B, p.64o

Entre a Arte e o Design, p.ir6

A novidade internacional na participação "arte" por iniciativa da indústria foi, nestes últimos tempos, o convite da Fiat a um dos pintores mais discutidos da velha vanguarda, Jean Dubuffet. Dele Giovanni Agnelli exibiu uma retrospectiva total em Turim, encenando autêntica façanha, daquelas que provocam náo tanto a discussão, mas o escândalo. A famosa indústria que, como todas as colegas italianas, até então interligava o fato arte-indústria em moldes puramente circunscritos às aplicaçóes publicitárias, num passe de mágica armou um espetáculo-chamariz, empenhando o prestígio da Fiat não mais uma entre muitas tantas propostas de Design, porém, uma evidente participação em termos de estética.

Dubuffet todo o mundo (ou parte dele, aqueles que se interessam por pintura) sabe que é um artista de dificílima compreensão, por sua arte balanceada entre grafias primordiais e delírio dadá. Quando o Masp organizou uma sua exposição, juntamente com trabalhos de Giacometti, De Koonig e Bacon, o público reagiu pensando mais em brincadeiras do que na realidade de arte através de quatro mestres.

O que interessa, agora, é o raporto arte-indústria, pois a seção é dedicada ao Design; e, como estamos no Brasil, pensar em eventuais iniciativas da nossa indústria no setor que interessa.

A Revolução Industrial, desde o começo do século, está sacudindo a tradiçấo que emana das premissas artesanais nas artes. $\mathrm{O}$ Futurismo tentou exaltar a máquina como símbolo de nossa civilização e Duchamp descobriu, com o ready-made, que o produto estético consequente era o objeto fabricado e multiplicado pela indústria, não mais a obra-prima, mas a obra-para-todos. A indústria, então, produz as coisas e nós as consumiremos. As produz práticas, bonitas e baratas e nós as requisitaremos e apreciaremos. Isto parece ser a função da indústria. No caso da Fiat, ela produz bons carros, (como de fato é o Fiat I42) aviôes, maquinários de aspecto agradável, edita cartazes e anúncios para a TV à altura, obedecendo a uma normalidade quase secular. 
Entretanto, o presidente da Fiat mandada explodir uma bomba estética: absolutismo dogmático, indecifrável para milhôes, de Dubuffet. E para encarar a surpresa, de Dubuffet se apresenta também o famoso ballet Coucou Bazar. (Representado antes somente no Museu Guggenheim, de Nova York, e no Petit Palais, de Paris.) Nos elementos teatrais são usados materiais da indústria, como o poliestireno expandido, as tintas vinílicas, resinas, produtos luminiscentes.

Os riscos de um design ausente, p.II6

Texto de Francisco Augusto Sememaro Júnior; cf. Anexo B, p.64I

Forma, material e cor, p.II7

Texto de Carlos Chitl, presidente da diretoria das Indústrias Romi S.A., cf. Anexo B, p.642
Seus robôs-fantoches, sua art brut, cavernística, enigma, ambígua, é o contraste inexorável da Revolução Industrial, o anti-status, sua acusação, sua caricatura.

Por outro lado, se a Fiat chamou a Turim Jean Dubuffet não o será por acaso. Pode ser que a descoberta das vanguardas da arte por parte da indústria tenha um significado: influenciar o Design e a Gráfica que marcam o passo na plataforma do geometrismo e do limpo-limpo, da fantasia mas non troppo, ausente de brilho e subversão?

\section{[MOBILIÁRIO ESCOLAR] p.II7}

Estamos no ano da criança. Concentra-se, através uma extraordinária campanha de comunicaçóes de iniciativa da TV-Globo, a atenção sobre um mundo ainda não contemplado, ou pelo menos não considerado em seu potencial consumístico, na escala merecida. Não se tem notícia, no

Além do belo, o funcional é o design, p.II7

Texto de José Olavo de Azevedo, diretor da Pereira Lopes-Ibesa, cf. Anexo B, p.642

Não TEMOS DESIGN. E DE QUEM É A CULPA?

Há muitas dificuldades na definição de um design

brasileiro, segundo Alexandre Wollner, p.II8-II9

Buscamos uma palavra de Alexandre Wollner sobre o momentoso assunto do Design no Brasil. Com ele estabelecemos o seguinte diálogo:

Senhor Vogue Você, Alexandre, é designer que se preocupa com a escassa importância que se dá a esta profissão. Posso testemunhar que desde sua frequência no Instituto de Arte Contemporânea no Masp, nos anos 50, você se distinguiu no setor conseguindo ir se aperfeiçoar na Escola de Max Bill, em Ulm. Diga-me antes de entrar no âmago da entrevista, qual foi sua experiência naquela escola?

Alexandre Wollner A necessidade de reconstruir as cidades alemãs após a Segunda Guerra provocou uma situação de mutirão na Alemanha, deixando de existir classes sociais e profissionais, com todos atuando para um objetivo comum, com um sentido coletivo. Esse comportamento na escola de Ulm, desde a escolha
Brasil de uma atividade realmente empenhada no preparo de ambientes escolares satisfatórios, tais para alegrar e ensinar a criança. Na ilustração: os famosos móveis em plástico desmontáveis da Kartell, que se tornaram populares na Europa. da primeira turma (trinta alunos com experiência semiprofissional, seis jovens professores com experiência profissional) ajeitou o sistema de mutirão, produzindo e instalando os equipamentos além de dar o acabamento final nos edifícios da própria escola, resultando uma equipe de funções e responsabilidade equivalentes. Esse mesmo espírito prosseguiu durante os quatro anos acadêmicos, também para a definição da filosofia que iria orientar a escola. Tudo isso me marcou profundamente e ainda mais, a proposição de resolver os problemas da reconstrução da Alemanha, racionalizando os meios produtivos de construção em todos os níveis onde o Design atuava. (Arquitetura industrial, Design, comunicação visual e informação.) Daí a preocupação de Ulm em atualizar esses setores utilizando os recursos tecnológicos e o estágio de conhecimento cultural e científico da época, 
criando uma metodologia adequada àquela realidade, com a finalidade de pesquisar como o homem podia viver melhor tendo em vista os equipamentos habitacionais, de uso e de informação. Ulm previu que a adoção dos mesmos métodos desenvolvidos nas pesquisas científicas (levantamento, tratamento, análise de dados relativos a comportamentos humanos, materiais para construção, técnicas, sistema de montagem etc.) facilitaria a programação de estruturas industrializáveis exigidas pelo surgimento da nova era industrial em que se colocava.

SV Você trouxe para o Brasil um know-how que foi logo considerado "suíço." Diga-me como encontrou a situação quando do seu retomo da Europa e quais as dificuldades? AW Participando da experiência de resolver os problemas reais da Ale manha, compreendi que os conhecimentos técnicos e culturais de caráter mais universal precisam ser adequados às condiçóes regionais. Percebi que nada adiantaria fazer no Brasil igual ao que se fazia na Alemanha, simplesmente porque a Alemanha é a Alemanha, e o Brasil é o Brasil, da mesma forma como perceberam também seus colegas japoneses, americanos, suíços, néo-zelandeses ao voltarem para seus respectivos países. Mas no Brasil não houve a experiência da guerra e até hoje não foi incorporada nos indivíduos a vontade de atendei às reais necessidades coletivas, considerando o real estágio tecnológico nacional. Isso significa que ainda não foi entendido o processo de coletividade, nem pelo povo nem pelo sistema político econômico. Até hoje, isto é, há quinhentos anos, ainda não se estabeleceu ou não se identificou um way of life brasileiro, principalmente nos grandes centros, que são os difusores de costumes para o resto do país. Assim, como se vê, os políticos e empresários não querem, e a coletividade não está conscientizada desta situação, e então você pode imaginar quantas dificuldades a gente tem para dar características brasileiras aos nossos projetos. Daí também se explica por que imperam no Brasil obras faraônicas e a proliferaçáo de produtos supérfluos. Também é preciso considerar que a interação coletiva gera preocupação de identidade nacional, preciosa para as pessoas, altamente cultivada pela própria comunidade e difundida para o exterior através da exportação de produtos culturais e de bens de consumo. Por isso reconhecemos uma identidade alemã, uma identidade japonesa, americana, suíça, italiana, e até mexicana. Em contraposição ao espírito de Ulm, a minha formação no Brasil me condicionava a uma atuação individualista. Esta situação é em parte consequência de um vicio do sistema educacional local, o que pode ser percebido curriculum, por exemplo, das faculdades de arquitetura, urbanismo, desenho industrial e comunicação visual. Isso condiciona que o profissional assim formado se considere suficiente para se envolver, por exemplo, num projeto complexo que abranja estas quatro áreas e às vezes ainda mais outras áreas, decidindo com autonomia sobre cada uma delas. Esse especialista polivalente é a antítese de uma equipe de profissionais. Então, tendo eu vivido a experiência alemã em Ulm e tendo sentido a verdade e a eficiência dela, minha posição ao voltar ao Brasil foi de expectativa quanto à possibilidade, não de transportar os conhecimentos aprendidos em Ulm, mas de criar entre nós uma consciência de atuação coletiva e de responsabilidade para com a coletividade, em termos de unir profissionais em equipe, cada um respondendo por sua área específica, e trabalhando em projetos para a comunidade. Hoje sinto que a minha vontade impetuosa de propor uma atuação de tal nível não foi compreendida na época, - e acredito até hoje - mas que acabou sendo tomada como uma posição radical, em que as pessoas achavam que eu pretendia impor uma visão individualista importada de Ulm.

SV Um dos fatos mais curioso o de que São Paulo não conseguiu uma escola de Design, enquanto o de Janeiro teve a sua. Você, aliás, foi um dos primeiros professores da escola carioca e continua lá ministrando suas aulas. Como vê o ensino da matéria no Brasil?

AW O Rio sempre esteve mais interessado no aspecto humano de suas atividades e obras. São Paulo, como cidade industrial da América Latina, peocupou-se mais em equipar seu parque industrial, sendo que o elemento humano para acioná-lo preparado quase que empiricamente, mantendo a tradição nacional da improvisação, um dos nossos orgulhos. A ESDI é atualmente 
a escola de Design com o melhor know-how de ensino. O simples acidente de estar situada fora do contexto industrial brasileiro não dificulta o seu contacto, principalmente sendo os nossos meios de comunicação e de locomoção eficientes e rápidos. A escola de Ulm também estava fora do contexto industrial alemáo. Por vícios criados nos anos 70 com a proliferação de escolas de arquitetura que contêm em seu curriculum o Design gráfico e industrial, os estudantes de arquitetura são incentivados ainda no primeiro semestre, a desenvolver projetos de Design. Você poderá sentir como são realizados esses trabalhos, para "bolação," sem aprofundamento e com um pouco de apresentação temos aí, em campo, mais um profissional que vai quebrar alguns "galhos" como "bico" enquanto não se formar e não pintar "aquele" trabalho que vai revolucionar a arquitetura, ou enquanto alguma Secretaria Estadual ou Municipal não precisar de "pesquisadores" ou funcionários para desenvolver problemas urbanos da capital. Isto vai ser agravado, pois essas escolas atualmente estáo opinando ao MEC como deve ser o curriculum de Design e, principalmente, permitir oficialmente a função profissional dos arquitetos neste campo em detrimento das escolas de Design.

SV Evidentemente falta atenção, sem se falar de popularidade, para com o Design, mas o que deveria ser esta realidade? AW As preocupaçôes na área do Design são essencialmente elitistas. Fazemos Design de móveis para alta burguesia, produzimos equipamentos eletrodomésticos com formas e funçóes inadequadas, puramente imitativos e dirigidos para uma classe sofisticada onde deveráo ser operados por empregadas domésticas, quando os projetos originais destes eletrodomésticos são criados nos países desenvolvidos onde esta classe profissional já está extinta. Usamos uma linguagem visual divorciada da heterogeneidade cultural de nosso povo, enfim nosso Design é mais dirigido ao consumo do supérfluo, antifuncional, antieconômico. É mais fácil imitar.

SV Deve existir indústrias que se preocupam com o Design. É certo? AW Algumas, muito poucas, em se considerando o potencial brasileiro. $\mathrm{Na}$ verdade podemos dizer que a preocupação maior é o lucro direto, uma atitude normal capitalista, mas sem sentido prático em termos de uma política sócio-econômica, técnica e cultural, haja vista que pagamos royalties e não temos reais condiçóes de competitividade no mercado internacional.

SV Na sua opinião existe possibilidade de contar-se com um Design nacional, ou você pensa que vamos continuar sendo importadores de Design de fora, como tudo indica que acontece?

AW O governo como o maior cliente interessado em desenvolver uma tecnologia nacional, principalmente na área agrícola, deveria se esforçar por criar oportunidade de criação de um Design voltado às nossas necessidades reais, e condicionar possibilidades de desenvolvimento de equipamentos para melhorar nossa produção; aí sim vou acreditar no aproveitamento de nossa criatividade através de um know-how que poderemos inclusive exportar, conquistando mercados na África, China, América Latina e mesmo na Rússia... Mas se quisermos competir com os Estados Unidos, Alemanha e Japão, bom, vamos entrar pelo cano.

SV Sei que você não é profissional que contorna as coisas. Diga francamente o que pensa da situação?

AW Acho que já me estendi bastante pelo assunto. Em todo o caso acredito ser primordial desenvolver a educação do profissional, náo maciçamente, porém lenta, gradual e qualitativamente. Acho também que seria muito bom se os amigos do Design, museus e outras instituiçôes culturais, se livrassem do complexo de "arte," pois acabam atuando como se estivessem criando status de colecionadores e apreciadores. Digo, "apreciadores” e não promotores efetivos de um desenvolvimento industrial. Quero estender minha crítica ao amadorismo em geral, bastante responsabilidade das butiques. Outra coisa: uma ideia que pretendo desenvolver quando tiver a chance da atençáo dos órgáos governamentais e que acho fundamental para o Design no Brasil é a organização de uma escola de Design em termos de pós-graduação, de caráter internacional, abrangendo principalmente a América Latina. Uma escola centralizada em São Paulo, por exemplo, 
com alunos graduados na América do Sul, inteiramente voltada para os problemas sul-americanos, em convênio com a Unesco através da Unido e dos governos latinos, trazendo professores internacionais e já com experiência em países subdesenvolvidos.

Legenda

Desenhando o novo sinal da Ultragás,

Alexandre Wollner considerou as características das figuras representativas. Um dado para o seu redesenho foi a análise da evoluçáo do pictograma, onde o homem aparece em movimento, desde o desenho nas cavernas do homem primitivo, a representação japonesa até os pictogramas usados nas Olimpíadas de Munique. Pranchas da análise morfológica do comportamento do sinal. A foto de publicidade da Ultragás nos bondes é de Albert Lauw-Photography Year Book 1969/Foutain Press Ltda.

Todas as intenções do envelope, p.I2O

Texto de Fred Jordan; cf. Anexo B, p.643

E NENHUMA ESCOLA DE DESIGN, P.I2O

São Paulo é o maior parque industrial da América do Sul. Curioso o fato de não possuir uma Escola de Design à altura. (Não se aceitam queixas das escolas genéricas de artes plásticas, estas em número por demais exagerado.) Fala-se de escolas de Design especialmente dedicadas ao desenho industrial, naturalmente criativo e náo o técnico importado e aqui, às vezes, arranjado para o produto que passa por nacional.
Lógico que estamos dependendo do conclamado knowhow de fora, porém, o que se faz para preparar o nosso? Sem dúvida, alguma coisa já foi feita e de vez em quando algum fato surpreende pela vivência; mas o que é preciso fazer é muita coisa.

$\mathrm{E}$ as coisas devem ser iniciadas, conduzidas e realizadas. Parece-nos que tudo deveria começar com uma escola.

Presença do design na bienal, p.I20

Texto de Lais Moura; cf. Anexo B, p.643

Tipografia, Design NASCENTE, p.I2I

A exposição do Masp, "História da Tipografia no Brasil," documentada por um catálogo contendo centenas de ilustraçóes que vão desde o primeiro folheto saído das prensas da Imprensa Régia, em I808, ano inaugural da tipografia nacional, até as produçóes de agora, fornece um

Gente E EVEnTOS, p.I2I

\section{Funarte: Perspectivas}

Odylo Costa, filho foi designado para ser o novo presidente da Funarte. Reconfirmou no cargo de diretor-geral Roberto Parreira, bem como os chefes de departamentos, Alcídio Mafra de Souza, no INAP, e Marlos Nobre, no Instituto Nacional de Música, que têm a seu crédito várias iniciativas louváveis em seus respectivos cargos. Este fato deve ser inscrito em lápide com carvão branco, pois é de praxe a tradicional tábua rasa, tão inconveniente na rotina administrativa.

A Funarte, que até aqui teve intensa atividades como reconhecimento das entidades panorama completo da evoluçáo da gráfica, da composição dos anúncios e do trabalho dos ilustradores dos tempos do Império e da República. Sobre o ponto de vista do Design a exposição pode fornecer material precioso para pesquisar e realizar uma história da gráfica nacional culturais, e ação em todos os Estados, não só continuará com seu programa mas, segundo se informa, revigorará sua organização. Uma das iniciativas poderia marcar o estreitamento de ligaçóes com um órgão que deveria nela estar integrado: o Instituto do Patrimônio Histórico e Artístico Nacional. Se a Funarte cuida da Arte brasileira, bom será lembrar que não existe Arte sem História e que finalmente não há Arte sem Memória.

\section{Investimentos}

$\mathrm{Na}$ falta de publicaçóes de arte, as galerias começam a veicular folhas de informações. Até agora a melhor é Arte e Cultura, 
da antiquária Raquel Brito. No primeiro número um depoimento de José Papa Júnior, presidente da Federação e Centro do Comércio e dos conselhos regionais do Sesc e Senac de São Paulo. Diz Papa: "Pediram-me que opinasse sobre a arte plástica como investimento. Não parece haver dúvida de que se trata de um bom investimento e, como prova, temos a acentuada valorização de numerosas coleçóes que se encontram escondidas, em mãos de particulares, longe de olhos não privilegiados. Considerando a obra de arte como um fator de aprimoramento cultural, creio que a mesma deve chegar ao grande público. Sendo o resultado de uma expressão elitista, minoritária em sua elaboração, creio que, por isso mesmo, deve ser apresentada a grandes plateias, para assim atuar vigorosamente como fator de aprimoramento cultural do povo.”

\section{[Casa Grassmann]}

São Simão, SP, tem agora a Casa Grassmann, homenagem ao nosso mais destacado gravador. O imóvel foi doado pela família Grassmann ao governo do Estado para nele realizar um ativo centro cultural, num "gesto-exemplo de cooperação com o poder público e de responsável maturidade cultural para com a comunidade," como afirma o secretário Max Feffer, no prefácio de uma publicação comemorativa do evento, onde se lê um ensaio de Jacob Klintowitz dedicado ao mestre.

Senhor \#I4, maio de I979, p.94-IO7 (Senhor e as Artes)

Pintura, p94

No recanto que Senhor Vogue dedica aos problemas das artes desta feita é o relacionado com a pintura que vai ser apontado. Como nas ediçóes precedentes: não panaceias, mas simplesmente visando a indicar alguns casos de possível apreciação e discussão.

Quando se trata de pintura, logo o elemento símbolo torna-se o produto quadro, e como consequência imediata o seu habitual posto de apresentação, a parede. Uma vez que as luzes de uma pinacoteca, galeria, casa ou depósito se apagam e na escuridão a pintura encravada na sua moldura reflete a respeito dos adjetivos de admiração, reserva e condenação, que foi gratificado durante a iluminaçáo. A soma das exclamaçóes dá conta do interesse e da contribuição social para com o labor do artista. Somem os pareceres atribuídos às obras e, em consequência, aqueles que as pintam, e estará construída a Torre de Babel do linguajar que aquele setor da arte provoca.

Dos trabalhos paroleiros quem não participa? Você conhece um fulano que, diante de uma tela de Velazques ou de Max Ernst não manifeste sua opinião? Que pensar daqueles júris de artistas e críticos que não admitiram no Saláo de I876 o L'Artiste, de Manet, ou a constante xingação da obra de Van Gogh, ou, para pisar no gramado de casa, a indiferença em relação a Ismael Nery? Se penso na crônica deste não compreender e no condenar manifestações válidas de mestres e, por outro lado, o favor e a exaltaçáo que a gente reserva aos medíocres, ocorre-nos pensar na situação pouco propícia daquele participar na formação da cultura nacional.

$\mathrm{Na}$ Torre de Babel, pelo menos nos andares reservados à arte pintura, o que se sente é hilariante. O desenvolvimento demográfico dos que pretendem não só ser pintores, mas inventar universos, e dos suportes é tal que não se entende mais nada. Não que sejamos contra as manifestaçôes numericamente exageradas; nos perturba a petulância, as convicçóes arrogantes,

O chutar, o se servir do publicismo e dos meios escusos para aparecer e impor. Gostamos da premissa levantada na entrevista dada ao $O$ Estado pela cantora Isaurinha Garcia: "Há artistas que se tornam conhecidos como produto de escândalo. Outros, via influência de poderosos. Outros ainda, como ocorre com frequência cada vez maior, como resultado final de campanhas publicitárias de largo âmbito, cuidadosamente planejadas e executadas. E raríssimos são os que ganham reconhecimento e renome exclusivamente por seus próprios méritos."

Eis o impraticável: distinguir, encontrar o que vale, reconhecer o merecimento. Será que nós mesmos somos inquilinos da Torre 
sem que saibamos que as academias têm razão, os realistas, os hiper-realistas, os surrealistas, os concretos, os geometristas, os optistas, os abstracionistas e todos os outros praticantes de ismos na enorme caixa de ressonância, isto é o Brasil cultural, na definição de Alceu de Amoroso Lima?
Na Torre de Babel da Arte Nacional, visto que náo conta com porteiros severos, também o Bardi teve a audácia de entrar. Foi para incentivar a crítica, aliás o cronista social que cuida do meu curriculum negativo.

Dilema, p.94

Continua o dilema: produzir objetos ditos de arte executados com ofício, originalidade, utilidade, gozando até das permissôes formais próprias da evolução da estética; ou deixar de lado a produção do objeto e se dedicar à melhoria da vida num sentido sensorial?

O artista deve continuar, na tradiçáo, sendo o solitário que manipula pinturas, esculturas, edifícios, e até design, modelos de múltiplos e tantas outras coisas que ele oferece, impóe, vende? Ou o artista, este ser distinto que se autoproclama um ser apontado por Deus para distribuir felicidade aos outros, não seria, pelo contrário, chamado a participar numa meditação e bolar não mais objetos enfeitativos, mas beneficiar a gente com ideias, gestos, conselhos que possam melhorar o comportamento?
O dilema existe, e seria por demais simplório o subavaliar ou desprezar aqueles elementos convencidos de que a tarefa do artista é hoje a renúncia em elaborar o objeto de destinaçáo burguesa, para concentrar a própria engenhosidade na elaboração de axiomas de utilidade coletiva, pois não se deve perder tempo no preparo do objeto quase sempre escondido entre quatro paredes, egoisticamente usufruído por poucos, e venerado náo tanto porque emana arte, mas porque conserva um valor venal.

Aqui, para solução do dilema, apresenta-se peremptória madame Economia, sem as tranças com as quais não é lícito pôr no tapete problema de arte.

\section{WESLEY \\ Gráfico e pintor extravagante, cada vez que o artista deseja marcar \\ sua presença ele o faz com uma surpresa, p.95-98}

Cada vez que Wesley Duke Lee decide marcar presença, usando seus jeitos para valer, o faz de maneira surpreendente, numa alternativa de cunho sempre diverso, intercomunicantes, porém com sua extraordinária vivacidade no dominar a expressão própria de sua extrovertida personalidade.

Gráfico, gostando de euritmia, pintor extravagante de cavalete, com a mesma desenvoltura passa a construir conjuntos plásticos e sonoros; agita-se para manifestar e tumultuar um happening; em seguida volta à prancheta para desenhar de maneira sutil caçando o caprichoso enigmático; deixa decantar as páginas em que as ligas de mulheres estão em cena num cancan estático e envolvente; compóe semblantes de senhoras, alegrados com símbolos renovatórios do repertório nattieriano; deixa, a certa altura, tudo de lado e levanta o atelier de Santo Amaro, mais repleto ainda da multidão de lembranças que estavam penduradas e colocadas em seu famoso Barnum da rua Augusta; vai a Tóquio ganha prêmio numa Bienal de lá e saboreia o fascínio do Oriente; desembarca para expor em Miláo; discute Veneza em Veneza; cria ironicamente o helicóptero sedentário circundado de horizonte, pois do contrário não teria graça: o inquieto não tem paz e não a concede ao seu cronista. Este quando registra uma façanha ou uma trouvaille, logo deve interromper o serviço, pois seu recomendado vai até a Califórnia para combinar um engenho que deve contar um caso de proveta biônica. Bom ator teatral, abraçador, dono de generosa cordialidade Wesley é, como se costuma dizer, um Número.

Os mestres da Renascença operaram em todas as artes ou quase, das circunscritas às liberais; agora, que se está passando uma esponja naquele labor (até por iniciativa de meninotes-artistas que não sabem nem 
ler o quadrante do relógio) produzir arte é bambolear com a ciência sua concorrente, futricar com a esfinge tecnológica, com ninharias e espirituais, tendo em conta que o materialismo está firme ainda. Justamente o mexer do Wesley, o que fez e faz; porém (atenção) vade retro quem ousa desconsiderar a história.

É a história o mais recente brinquedo do inventor do Trapézio, a câmara cúbica habitada por senhores bem maneirosos, que numa Bienal de Veneza na década de 60 foi notada pelos raríssimos críticos (não ornados com tapa-olhos e que levam na sacola a tabela de Roger de Piles, ou o prontuário da última teoria 'Autre') como proposta realmente viva. Ele não se aproximou (mas não foi agora, pois gosta de meditar laboriosamente para, na hora certa, realizar com flama, conforme o conselho de Winckelmann) de assuntos históricos como o fizeram domesticamente Pedro Américo, Vitor Meirelles ou Cândido Portinari; náo se intrigou nada menos com o mais emaranhado labirinto de todos os tempos, o fabuloso da Mitologia.

Sabia, há anos, deste interesse de Wesley: ao longo do convívio, várias vezes ele retirou da minha biblioteca volumes do Prampolini ou do Nicolini para verificaçôes de circunstâncias, pensava, inerentes a Vênus ou a Júpiter. Porém, São Paulo, a par de todos os fatos extraordinários tem seu ciclo: corsi e ricorsi vichianos, épocas em que a gente aparece e desaparece no vaivém (como vai? vai bem!) encontrando-se e desencontrando-se, palidíssimo acontecer daquilo que dizem acontecer, no ciclo do mundo. A uma certa hora perdi de vista não o Wesley, mas as maquinaçóes de uma de suas surpresas.

Existe pelo menos uma preocupação, entre as inúmeras do homem sapiens ou mais simplificadamente pensante, que é mesmo a bagatela do ciclo do mundo. Os Estoicos, tendo Nemésio como porta-voz, advertiam: "Uma vez que os astros, ao modo deles, voltam ao mesmo ponto de latitude e longitude em que cada um era ao princípio, o mesmo acontece com o ciclo dos tempos, uma conflagraçáo e destruição total; depois novamente se volta para o princípio, na mesma ordem cósmica e novamente os astros se inovem, cada acontecimento verificado no precedente ciclo se repete sem qualquer diferença. Encontraremos assim de novo Sócrates, de novo Platão e novamente cada um dos homens com os mesmos amigos e conterrâneos; as mesmas coisas em que se acredita e os mesmos assuntos discutidos; de cada vila e cidade e campanha, tudo voltará igualmente. Este retorno universal se verificará não uma, mas muitas vezes atingindo as raias do infinito.

Compreendida esta advertência, com seriedade perplexa, Wesley se aproximou dos intrincados problemas que a eterna descontente filosofia vem acumulando, para apresentar uma sua interpretação, se não do ciclo do mundo, do ciclo da humanidade, subespécie das suas vicissitudes individuais. Incursionou como curioso, depois de ter intensamente refletido sobre as novidades dos tempos que foram, nos meandros da bagatela que chamam de antigo, acreditando na convenção de que do passado nós somos a consequência. Saiu então ao encontro, além de Sócrates e de Platão, de amigos desconhecidos, de mitos, de nascimentos e casamentos de divindades, de quedas, de certezas, de destruiçóes efêmeras, de amor e de justiça, às vezes triunfando: o afã dos seres engatilhados neste riquíssimo negócio que é a vida.

Desta sua viagem ao além, no mapa de um território modesto no espaço, sem fim no espiritual, com a intenção de deduzir possíveis créditos de experiências agora utilizáveis, Wesley nos dá agora o relato na sua declaração e nestes desenhos a serem inscritos não sei bem em que categoria de produção. (Penso nos impulsos que animaram William Blake.)

Um coloquiar com os numerosos marcadores de princípios discutíveis porém inamomíveis, não seria melhor considerá-lo como atitude de ironia? Naturalmente no sentido filosófico: a verdade exaltada ou diminuída, o exagero da vanglória, a timidez dos incertos. Um dos figuróes da Academia dos Sapientes, indicador de um caminho sem atalho, também reverenciado pelos que palmilham o primeiro desvio errado, é no passeio weslyano, Sócrates. Certa vez, discutindo a respeito da Justiça, isto é, da ordem máxima das relaçôes humanas, ele disse: "Eu penso 
que o acertar está além de nossas possibilidades e vocês que são batutas devem ter piedade de nós, ao invés de se enfadar conosco." Ao que Trisímaco comenta: "Eis a costumeira ironia de Sócrates."

Wesley, imbuído deste áureo conceito possibilístico, ajeitou-se na descoberta das mirabilias de todo aquele fora de série e, para não deixar de ser original, alugou para facilitar as pousadas e achar caminhos mais convenientes. $\mathrm{O}$ problemático helicóptero de Leonardo da Vinci. Assim no novel e novecentesco Et in Arcadia ego o piloto, deixando seu atelier de subúrbio, empunhando o cetro do poeta e também a ampulheta do filósofo, romanticamente (ir à Lua é mais romântico que o luar) persuadido de desfrutar de liberdade absoluta no desvelar qualquer mistério mitológico, (esqueci de informar que colocou no porta-mala da aeronave o fetiche da autonomia existencial, o cogito salvo-conduto que permite atravessar qualquer fronteira) assim equipado embarcou, acenando com um adeus para sua motocicleta favorita: vê-se nos desenhos a barulhenta, a Saudade do tempo dos pés na terra.

Wesley sobrevoa a Grécia cobiçada, atrevido porém reflexivo, assumindo posiçóes de prestígio, do seu prestígio de descobridor e explorador de tudo que é explorável. Ajeita seu placet e opina do alto das asas, contemplando as coisas que seus colegas artistas, metidos ao longo dos séculos nos afazeres de esculpir mármores, acumularam para ele se sentir dono daquilo que os sacerdotes os incumbiram de representar: o divino retalhado em tantas parcelas propiciatórias.

É uma ideia, não certamente de cada dia, revisar os significados da estatuária grega, para reatribuir a ela sugestóes e às vezes contrariá-las atribuindo funções não canônicas. A imaginação é também sensação: opinião; e o que os demais fizeram: lícito interpretá-lo pela via da nossa intuição, deduzindo outro e diverso ideário. Não é por acaso que o Ícaro desenhista enxerga os monumentos do alto da máquina leonardesca, alusão às coisas vãs e hipótese à espera de ser experimentada.

Não teria aceitado a incumbência de escrever estas notas se também eu não tivesse lá desembarcado; não pelo ar, mas por via marítima. Confesso: desci no Pireu confuso, (lembrava-me do meu preceptor eruditíssimo no capítulo Roma, o qual me declarava nunca ter tido a coragem de ir à Eterna, uma vez que estava certo que desmaiaria diante de tanta história; e o Bardi, impertinente, a caricaturá-lo num jornal humorístico; o que se passou aos tempos do art-déco) o medo de nada entender ou de entender sem brilho, remoendo a dúvida de não saber deduzir e levitar o encanto.

Foi, deitando fogo num feixe de arbustos secos para iluminar o Sepulcro de Agamenon, então abandonado, que me lembrei de Sócrates. Estava com Le Corbusier e Fernando Léger. Ficamos os três mudos, aquelas pedras nos contemplando. Léger, saindo, disse somente: quels testicules! Todos os adjetivos foram riscados de nossas conversas. Desde o pisar no chão daquela relíquia até Epidauro, pedibus iter facere, nenhum comentário. (Contam que Schliemann, quando desenterrava os tesouros de Micenas, proibia as exclamaçôes.) Voltávamos de cada visita sem nada dizer. (Em Cabo Sounion, porém, falou-se bastante, para evocar Lord Byron, que tinha esculpido seu nome numa coluna do templo dedicado a Poseidon.) A Grécia nos convidava ao silêncio, aliás uma atitude mística assaz apropriada aos que pensam diante da obra de arte.

Também eu, ingenuamente, relatei minha crônica sobre a Helade (depois de ter dado uma vista d'olhos na Iliade, na verdade pouco entendendo, de qualquer feito, um pouco mais que os professores de grego propiciam aos adolescentes matéria que deveria ser reservada aos pré-anciáos.) Nunca, ao longo de quarenta e tantos anos, tive a coragem de relê-la, pois aquelas histórias fazem parte de uma intimidade que já se foi e das quais gostamos em sonhos. Por isso, quando Wesley mostrou-me os desenhos, agora aqui esplendidamente reunidos, considerei mais a impressão da arte que o significado encabulatório, para mim quase um manifesto complexo de inferioridade. Parei, como sempre, diante do signo carinhoso do pintor da série das Ligas, táctil, alegórico, grandioso no minucioso, a cor pontilhando discretamente para iluminar o conceito. 
Passaram-se alguns anos. Nem sabia da decisão do amigo Regastein Rocha de publicar através sua Praxis o conto deste planar na seara proibida reservada ao duelar de Dionísio e de Apoio, onde Platão e Aristóteles se escondem na fortaleza de Tirinto, sem responder aos alôs. (Eu também sou ligeiramente irônico.) As dúvidas que grudam na verdade me sugerem indecisão no opinar, o hesitar no afirmar ou negar: mexer no labirinto proteja do pelo Parthenon, sempre a considerei empresa para heróis; e uma vez que herói é um semideus nascido de um deus que transa com mulher mortal, ou mesmo de um homem mortal enamorado de uma deusa, o leitor deve ter aprendido quão complicado é julgar o heroismo do Wesley.

Logo, recapitularei sumariamente os vários pontos do espírito do pintor. Moço, calambourou no João Sebastião Bar, batizou de Rex uma bem organizada bagunça happinística, enfrentou as paradas mais polêmica que outros colegas deixaram de lado, se fechando no banheiro. A obra singular de Wesley é a sua vida privada de artista, o colchão em que mediata para bolar a representação, o pensar calmo em períodos quase letárgicos preparatórios das surpresas.
O reboliço da transposição, às vezes a rebours, da mitologia em termos próprios $\mathrm{e}$ particulares é uma prepotente tomada de posição do Wesley: o apoderamento de um universo para nela se acomodar justamente como um herói. Deve ser gostoso abraçar uma destas peladas que escondem segredos misteriosos, ou combinar braço de ferro com o simulacro de um dos temidos personagens agora habitantes de museus para turista não entender; é também gostoso se jogar numa batalha (por ironia homérica) ou mais prudentemente supervisionar manobrando um helicóptero, jogando afinal a coroa ao capitão vitorioso. Espirituoso, menefreguista, convencido de que tudo vai e tudo vem e que nada é certo, que cada ideia é válida como seu contrário, Wesley sobrevoa os Mistérios de Eleusis ou aterra no trono de um Deus sem fiéis Para cumprimentá-lo cordialmente; e conversa com o Hermafrodita sobre os problemas que agora o filósofo da moda Michel Foucault está resolvendo ao determinar que o sem sexo é símbolo da união dos contrários na história da cultura.

Admiro esta notável viagem de Wesley, fruto de anos e anos de aproximaçóes com o mundo de Péricles, Ictino, Fídias \& Cia. e sua geórgica da alma.

Um pintor inédito: Rosário Bernaudo, p.99-IOO

Texto de Edimar Soares, cf. Anexo B, p.644

[Pintura: Homenagem ao Mestre], p.ioI

No Brasil não se tem notícia de uma temática que na Europa é bastante comum, qual a do pintor que copia, ou homenageia um mestre.

Uma dessas últimas iniciativas foi a de Picasso, que se dedicou a refazer, a seu modo, obras de Velazques. Na França se inspirar na obra de colegas é comum. Ainda náo se pensou numa grande exposição que poderia intitular, "A la Manière de" saindo de Manet para finalizar com o iniciador do Cubismo. Do Brasil, um colecionador poderia emprestar o bem famoso, "Homenagem a Gauguin" de Paul Elie Ranson (I862-I909).
A premissa é para apresentar uma série de trabalhos de Ubirajara Ribeiro, que evoca para uma série de telas de Jules Bissier, (I893-I965) o criador das composiçóes dos pequenos e aparentemente insignificantes recortes, elevados nos seus folhetos à condição de grandiosas representaçóes de realismo mágico. Ubirajara conseguiu, amorosamente, nos oferecer um Bissier pictórico, ampliando e dando sentido singular às invençóes do mestre europeu. (A série de Ubirajara foi exposta no Centro Campestre do Sesc, em São Paulo, numa coletiva que reuniu Carlos Alberto Araújo, Paulo Penna, Tito de Alencastro e Bramante Buffoni.)

\section{MERCADO, p.IO2-IO5}

$\mathrm{Na}$ Itália, uma instrutiva polêmica (pode muito bem ser útil ao Brasil) está sendo travada. Discute-se os retrocessos do mercado de arte, depois do milagre 
econômico responsável na Península pelas numerosas mudanças de costume político e existencial. Hoje aquele mercado passa por uma crise: Le cafard après la fête dos anos 70, os anos das vacas gordas que advieram após a repentina descoberta do negócio Arte, multiplicando-se as galerias comerciais não só nas grandes cidades, mas também nas pequenas, determinando autêntica psicose: o possuir objetos de arte. A convergência do interesse não representava nenhum coup-de-foudre em madame Estética, pois tratava-se de uma envolvente e frenética participação no boom do dinheiro fácil e de sobra, o mesmo reservado ao jogo da Bolsa. Mais intenção de especulação monetária do que acordar em termos culturais. (O mesmo fenômeno, naturalmente in minimis, ocorrido paralelamente no Brasil, circunscrito a Sáo Paulo e ao Rio de Janeiro, quando o bom andamento do cruzeiro suscitou entre os abastados particular atenção por uma mercadoria até então desconsiderada.)

Multiplicaram-se os mercadores e, consequentemente, os produtores; o mesmo se deu em relação ao aspecto galerístico, que dada à insuficiência de abastecimento nacional, não tiveram dúvidas em recorrer à importação, ativando intenso fluxo de obras transalpinas. Os italianos foram picados pelo boom no intercâmbio internacional, que resultou num confuso e pouco satisfatório fato, que Flávio Caroli no Corriere delia Sera andou denunciando como um provincialismo de uma subcultura exportadora de artistas magliari. Magliaro, na Itália, é uma espécie de sujeito que vai girando pelo mundo inteiro, vendendo tecidos de péssima qualidade e conseguindo tapear os incautos compradores, por via de conversas e de truques pitorescos. (No Brasil o tal se farda de marinheiro e conta histórias fantásticas; o mesmo fato ocorre com certos árabes vendedores de tapetes persas fabricados à máquina.)

Entre inumeráveis denúncias, o redator apontava o fato de, no delírio mercantil, a estrutura museugráfica italiana continuar na tradicional vegetatividade, sem dar o menor apoio ao conhecimento e à difusão da arte contemporânea. Em termos culturais, o intercambiar com
O estrangeiro resultou negativo, justamente por estarem em cena os espertalhôes ao invés de artistas idôneos que deveriam criar uma boa imagem da vivência italiana. A preocupação era mais pelo negócio, do que com a Cultura.

A polêmica peninsular pode sugerir algumas reflexóes na Terra. Como se disse, também em nossas metrópoles tivemos um surto de mercado da arte, provocado por acaso por um magliaro italiano ao qual, nolente volente, se deve a descoberta por parte de especuladores e de razoável grupo de nóveis apreciadores, da mercadoria chamada pintura. $\mathrm{O}$ surto foi limitado; elementos nacionais e assim mesmo a uns quantos picos produtores, certamente aqueles que passaram a inquinados de clássicos, conseguindo-se criar um certo mecanismo comercial que explodiu numa rocambole falência. A megalomania do magliaro chegou a abusar até da ingenuidade de alguns bancos.

O que nos interessa náo é propriamente o acontecimento interno. Interessa-nos tão somente tirar da lição italiana a consideração de que, in minimis, se verifica no Brasil no que se refere ao intercâmbio com o estrangeiro, e particularmente à imagem que nossas atividade exportatórias determinam. Parece que também nós enveredamos pelo mesmo caminho.

Quem está acompanhando o caso, descobre que mos levando a arte para fora eivada de qualidade dúbia e que acaba dando uma falsa ideia da realidade nacional, mormente quando as apresentaçóes são organizadas em galerias dependentes de embaixadas, consulados gerais, ou têm a chancela oficial.

Em geral trata-se de artistas, quase sempre pintores, cujo valor é modesto, porém cuja capacidade contar histórias e historietas é proverbial. A maior parte das exposiçóes de nacionais nas capitais europeias e americanas são a consequência de golpinhos de sabidos, aplicados em ingênuos do poder incompetente, boa gente à qual náo passa pela cabeça que o apadrinhar fato cultural é uma responsabilidade nacional. Se existe um país que precisa zelar para que tenha uma boa imagem cultural no estrangeiro este é justamente o Brasil. 
Outro fato análogo, sempre in minimis, entre a política artística italiana e a brasileira é que as duas contam respectivamente com a Bienal de Veneza e a Bienal de São Paulo, esta imitação pedissequa da lagunar. Na polêmica aqui comentada, Emílio Isgrò intervém no Il Giorno para reagir contra o sistema de mencionar os nomes dos magliari que se serviram da Bienal para trampolinar no estrangeiro.

Eis um outro caso a ser anotado: também nós temos os espertos que se servem da Bienal local para suas transas ultramarinas. Mas isto faz parte do jogo e seria ingênuo lamentá-lo. O que se lamenta é o comprometimento dos departamentos governamentais nas trampolinagens, a falta de uma política cultural: não ocasional, não omissa, não acomodatícia, mas não, (sempre in minimis) da pseudocrítica maglieristica nacional.

O desenho como instrumento é uma comunicação organizada pela Coooperativa de Artistas Plásticos de São Paulo. Vai reunir 52 artistas na Pinacoteca do Estado. Fato inédito por vários aspectos: são desenhos e anotaçóes de estúdio que eles usam na criação ou para o desenvolvimento de trabalhos, croquis preparatórios para pintura, desenhos de construção para escultura, frases e lembretes para si próprios, estudos e reflexôes pessoais.
Os expositores vão mostrar o preparatório, não o definitivo e o comercial.

É sintomático que a preocupação da Cooperativa se volte para trazer a público o lado de dentro do processo criativo.

$\mathrm{O}$ visitante vai ver um conjunto de desenhos íntimos, sem preocupação de mercado (os trabalhos não estarão à venda). A Cooperativa desenvolveu outra ideia original: editará paralelamente uma caixa/ quadro de formato grande, contendo fac-similes dos painéis da exposição, contendo uma coleção de 52 obras intercambiáveis, sempre representando aspectos até então não conhecidos do trabalho de cada artista. O livro/quadro está sendo produzido com a colaboração das firmas Lastri e Young \& Rubicam e, sendo vendido praticamente sem lucro, terá um preço acessível. Outras empresas estão manifestando seu apoio adquirindo lotes de caixas, e firmas como a Eucatex e a Vidrobrás forneceram material para a montagem da exposição.

\section{Cooperativa}

O significado deste substantivo é o seguinte: "Sociedade ou empresa constituída por membros de determinado grupo econômico ou social, e que objetiva desempenhar, em benefício comum, determinada atividade econômica.” (Aurélio)
Gente E EVEnTOS, p.IO6-IO7

$\mathrm{Na}$ avenida em certo tempo a mais elegante de São Paulo - a Paulista - o município está intervindo mais uma vez para melhorar sua aparência.

Como se sabe, ao tempo do alargamento da avenida, uma panela de arquitetos (uma das quais convencida de ser paisagista) andou por lá.

As calçadas foram embelezadas com as costumeiras inutilidades decorativas que custaram fortunas aos cofres públicos: guarda-chuvinhas amarelos, banquinhos de plástico amarelo e até um quiosque amarelo para abrigar florista (que nunca funcionou).

Mas todas estas ideias são até grandiosas se comparadas à trouvaille da paisagista de prontidão, sra. Rosa Kliass, que inventou os "penicos de elefante" jogados nas faixas de verde - agora tornados depósitos de lixo. Finalmente há alguma ordem, pois o município está recolhendo os penicos, para doá-los aos circos equestres que têm elefantes.

Caulos veio do Rio para São Paulo para o lançamento do seu esplêndido cartaz da Sharp. E para rever esta antiga aquarela em coleção particular.

No panorama da pintura brasileira é impossível esquecer-se dos assim chamados "primitivos" - que não são hoje mais aqueles tranquilos enamorados das 
ideias simples, quando punham tintas nas telas, nos domingos e nos feriados.

Hoje eles são autênticos profissionais, dando tempo integral à sua arte, montando exposiçóes nas metrópoles e no exterior, e registrando seus nomes em monografias e estudos internacionais. Crisaldo Moraes, autor desta composição, desfruta de sucesso lá fora. Tanto assim, que tem programado - convidado que foi por universidades dos Listados Unidos - diversas conferências. Dele: o óleo Trapezistas, Ioo por $80 \mathrm{~cm}$.

\section{Aposentadoria}

Uma comissão de artistas irá mais uma vez ao presidente Figueiredo para que seja concedida à classe aposentadoria aos 25 anos de serviço. Tal como aconteceu com os jogadores de futebol.

\section{Unicamp}

É como se imitassem o vereador de Campinas, Hélio Rosolen, que gritou em plenário:

"Não me interessam Wagner, Beethoven ou Verdi," ao negar a Orquestra Sinfônica da Unicamp. Pois quase todos os membros das diretorias dos museus do Rio e de São Paulo não gritam, porém pensam em gritar!

"Não me interessam Cézanne, Picasso ou Portinari" (o que lhes interessa é o anúncio fúnebre dos jornais lembrando que eram, também, membros de entidades culturais.) Dizem em Campinas que os negador Só em Campinas?

O Brasil conta com um grupo de desenhistas aos quais se pode adjetivar de excepcional.

São jovens sem nenhum currículo, mas que desenham por instinto, numa palavra: autodidatas, fantasiosos, analíticos, pondo em preto e branco lendas, poética, coisas e maravilhas do turbilhar da espontaneidade das religióes secretas, como se vê neste estupendo desenho do nortista Ubirajara Monteiro.

\section{Pergunta}

Competências específicas, habilidades particulares, capacidade no uso e aproveitamento dos meios materiais ou conceituais contribuem para o progresso individual na sociedade, tornando-se a própria sociedade, todavia não constituem o essencial para a formação de uma cultura equilibrada e harmônica de participação ampla, incluindo no processo não as elites, mas a sociedade.

No Brasil, em via de completar seu embasamento industrial e econômico, o problema da concentração cultural, nas várias especialidades, irá atingir um ponto capaz de conciliar as exigências do desenvolvimento científico e industrial com as de uma formação humanística mais difusa.

Senhor \#15, junho de 1979, p.94-I06 (Senhor e as Artes)

Nosso Tempo Livre, p.94-95

O lazer e seus negócios encarados como uma obra de arte

Nossa seara na presente edição de Senhor Vogue é dedicada ao tempo livre, ao lazer e à comunicação de massa, temas que d'amblé podem parecer fora do tradicional conceito que rotineiramente se continua dando às artes, as elitistas do consumidor burguês ou aburguesado, circunscritas aos limites do conjunto arquitetura, pintura e escultura e artes menores e das demais como o espetáculo, a música etc.

É permitido insistir numa velha novidade? Hoje a atividade arte vai sempre mais se entrosando com a vida e seu comportamento, resultado de mil e uma ideias, coisas, gestos etc., representando o objeto de uso papel preponderante na estética em desenvolvimento. A fórmula arte pela arte é sempre mais distanciada num mundo em vias de transformaçōes, de fim de época. Assim também o lazer e negócios relativos podem ser considerados perfeitamente interligados à dita atividade, por si mesmos, e pelas implicaçóes e dependências que mantém com ela, de modo marcante na sua relação com tudo quanto é reservado $\mathrm{e}$, às vezes, produzido pela massa, ou por ela praticado nos desempenhos da indústria cultural, esportista e modista.

Os pontos de vista e as consequências desta relação são os mais díspares, positivos 
e até conflitantes, incluídas, aliás, em parte decisiva, as motivaçóes políticas que dizem ter origem no panem et circense, evoluídas para os sistemas e organizações que propóem, ou pretendem disciplinar o tempo livre, naturalmente o das massa pois os que mais podem porfiam por conta própria no gozo do folgar incluindo como salutar a corridinha do Cooper.

O assim chamado tempo livre é um problema emergente da humanidade e, de modo particular, dos tempos hodiernos, pois o progresso tecnológico está cada vez mais minguando as horas empregadas no trabalho, sem contar estar próxima a fixação da jornada de quatro dias; e mais: o encurtamento dos anos de serviço com vistas à aposentadoria. Vão se multiplicando as aspiraçóes do lazer, o turismo, novel folguedo, se espraiando, a caça às pontes no calendário é sôfrega, com os dias celebrativos de dezenas e dezenas de acontecimentos e homenagens a figuras representativas da hierarquia familiar, política, científica e assim por diante: afinal um combinar de artifícios para fugir do trabalho e fruir das perigosas experiências do relax. (Curiosos cultores de paradoxos dizem que Deus dispóe das guerras para manter o homem ocupado, a fim de que ele não morra de inanição e não se acostume ao ócio.)

Os rumos da organização social devem se ajustar sempre mais a crescente necessidade do balanceamento entre a produção e a distribuição riqueza de um lado, e a utilização tempo livre de outro. Volta-se mais uma vez a dialogar com o marxismo e com outras filosofias sócio-econômicas, porquanto o alcançar soluçóes não oferece a impressão de se concretizarem satisfatoriamente. Delas vai depender o futuro da conciliação trabalho-lazer. Nos dois pólos opostos (naçóes de regime socialista e nações de regime capitalista) o problema do tempo livre e o consequente tratamento e supervisão da cultura de massa, isto é, o fator determinante do seu condicionamento, tornaram-se objeto de intensa atenção e discussão.

As mudanças provocadas pelo advento da industrialização, a alfabetização, a intensa difusão dos meios de comunicação marcam a passagem da cultura popular oitoentesca para a cultura agora denominada de massa. No século estruturado pelo romantismo, Gustave Flaubert caricaturava as preferências que o leitor popular reservava às patéticas, (“...amores, amantes, damas perseguidas que desapareceram em pavilhôes solitários, postilhóes mortos em cada estação de troca de parelhas de cavalos, ... lágrimas e beijos, barcos ao luar, rouxinóis no mato") e assim por diante, todo o combinatório empolgante de emoçóes de um sir Walter Scott, o benjamim a quem nossos antepassados juntavam os romances de Alexandre Dumas. Faltando o futebol e as diversôes de hoje, a cultura do povo fera sistematizada na prática religiosa, nos circos, nas comoçóes daquela literatura. $\mathrm{O}$ que se dava no Ocidente todo, não excluído o Brasil onde, já em I862, isto é, em tempo recorde, tinha sido traduzido, no Maranhão, Les Miserables, de Victor Hugo.

Conspícua parcela do arsenal cultural o novecentos recebeu em herança e andou cultivando. Não são muitos os decênios que os cotidianos deixaram de apresentar os feuilletons de George Ohnet ou de Ponson du Terrail, (que escrevia: "Tinha as máos frias como as de uma serpente") à espera da moda dos romances policiais e dos rosas com abertura à pornografia.

A indústria editorial, a difusão dos rotocalcos, o rádio, depois a televisão, a proliferação poluidora da música popular, o futebol, as corridas de cavalos, as loterias e quantos outros expedientes preenchedores do tempo livre, na opiniáo de alguns sociólogos apelidados de ópio para uso das classes inferiores, andaram formando as cruzes e as delícias do mundo descobridor dos mais secretos mistérios do universo, e inventor de como mais cruelmente acertar as carnificínias humanas. Também esta atividade não se apelidou Arte da Guerra?

Aculturar o povo? Prover para que o povo tenha um lazer que náo seja o que se define de degradação ou caricatura, o condenável domínio do poder sobre os medíocres, as manipulaçôes das elites, um tudo enfeixado nas mãos aproveitadoras da incapacidade das massas em subir degraus, a náo ser as propositadamente ministradas pelo sistema, seja ele da condição capitalística ou socialística? 
Não se trata de problema simples, justamente considerado pelos futurólogos com muita perplexidade: a aculturação das massas que já estão desfrutando de boas parcelas de tempo fora daquelas dedicadas ao trabalho e, vencendo a progressão impressionante da automação, irão dispor de mais possibilidades de usufruí-lo, a fim de cultivar os próprios interesses espirituais e materiais. (A situação dos adultos deve ser alinhada à das crianças que estão se aculturando geralmente na TV.) Milhões de pessoas, e não somente as das classes menos abonadas, e até as não abonadas (as favelas cobertas de nuvens de antenas) religiosamente assistem ao desfilar de telenovelas, não mais sir Walter Scott ou Dumas, mas por aí afora; milhôes leem visualmente historietas em quadrinhos; dias e noites inteiras centenas de rádios transmitem musiquinhas geralmente banais; em dias de matchs, as avenidas que levam aos estádios mudam de mão de direção, para dar passagem às caudais de aficionados que desfraldam as gloriosas bandeiras dos clubes: tudo cultura de massa, fruição do tempo livre, lazer, as novas acomodaçôes da civilização.

O sociólogo Luciano Gallino disse justamente: "Para precisar o significado de cultura de massa como tipo específico de cultura, ou como conteúdo, quaisquer que sejam os meios de comunicaçáo de massa, ou ainda, como tipo de audiência (o público) se deve esperar uma resposta rigorosa e exauriente às interrogaçóes que nem as pesquisas nem as especulaçóes até hoje não souberam fornecer." As interrogações são numerosas, entre as quais estas: nas bancas começa-se a ver, ao lado dos contos policiais, obras-primas de escritores que se pensava lidos somente por possuidores de um certo gosto e cultura; nas TVs, mescladas com futilidades que encontram o favor dos simplórios, de vez em quando são apresentadas peças musicais de nível (por exemplo: no Brasil a rádio Eldorado transmite excelente música clássica, e na TV Globo são transmitidos concertos de valor internacional) e reproduçôes de bons romances; pinturas famosas de museus estão tendo reproduçóes com grandes tiragens (por exemplo: a Menina com Espigas, de Renoir, do Masp;) nos supermercados o design, a embalagem, a composição das estantes, vão contribuindo para a difusão de um gosto mais apurado, e nos departamentos do mobiliário as produçôes racionais estão eliminando o colonial; o prêt-à-porter vence e está liquidando o sofisticado dos costureiros barrocos; no cinema, além das pornochanchadas, o povo vê filmes que dão o que pensar; e assim por diante, dando resposta às interrogaçóes. Como responder se, ano após ano, estamos participando de um evoluir, poderia se dizer do desabrochar de uma homogeneização cultural pela qual todos somos responsáveis?

É evidente que as atividades ditas das artes representam os fatores determinantes da cultura de massa, porém, qual o resultado, qual a situação, qual o futuro?

O patrimônio intelectual e material que denominamos genericamente cultura é heterogêneo, em certos grupos étnicos integrados, e também antagônico e sujeito a transformaçôes que se manifestam através de mudanças das mais variadas procedências. No que se refere ao Brasil, pela vastidão de seu território e pela composição demográfica, a definição cultura é complexa e se devem levar em conta inúmeros componentes histórico-demográficos. Assim a cultura de massa não é, e não pode ser, unitária, por se dirigir a camadas de diferente educação, às vezes antagônicas e não integradas. Eis um problema a ser colocado. Senhor Vogue julga oportuno chamar atenção a respeito.

É preciso que o povo tenha um lazer que não seja uma caricatura
DOIS HOMENS DO LAZER, p.96

José Papa Jr.

SV Que significa para o Senhor liderar uma instituiçãa que se ocupa do lazer?

JPJ Como homem dedicado às atividades empresariais, sempre busquei conhecer o sentido prático dos trabalhos sociais. Muitas vezes me indagava se eles tinham, na realidade, os efeitos esperados. Parecia-me algo muito fluido e complexo. Como me achasse distanciado, não sabia 
exatamente avaliar a sua real significação. As coisas mudaram radicalmente a partir do momento em que passei a conviver no dia-a-dia com o trabalho desenvolvido pelo Sesc e pelo Senac. Foi ao tomar contato com a dimensão democrática e sócio-educativa da ação dessas entidades é que pude perceber o alto alcance de suas propostas para o trabalhador brasileiro. Ficou patente para mim, também, a responsabilidade social dos empresários perante seu meio. Foi exatamente imbuído deste sentido, de

\section{Renato Requixa}

Autor de inúmeros estudos dedicados à teoria e prática do lazer, (o primeiro foi a conferência de abertura do primeiro Seminário sobre Lazer: Perspectivas para uma cidade que trabalha, São Paulo, 1969) Renato Requixa é também homem de ação: foi o principal assessor de José Papa Júnior na transformação do Sesc em instituição de vanguarda na promoção do lazer, na defesa da cultura popular e do patrimônio cultural.

Donde as Feiras Nacionais de Cultura Popular, os Circuitos Estaduais de Música Popular e Erudita, de Cinema, de Exposiçôes de Artes Plásticas, o Teatro Pixinguinha, a Orquestra de Cordas do Sesc, a Pesquisa de Brinquedos Tradicionais no Brasil (em realização,) o Centro Campestre, a restauração da Fábrica da contribuição positiva à expansão da democracia cultural em nossa sociedade, que venho me dedicando com afinco à criação de novos equipamentos de lazer para os comerciários no Sesc. Há os que acham serem eles luxuosos. Em ambos os casos noto indisfarçáveis preconceitos elitistas, além do ceticismo e do pseudomoralismo daqueles que se escandalizam ao ver, na prática, um empreendimento que valoriza o ser humano e facilita o acesso, a muitos, àquilo que antes era privilégio de poucos.

Pompeia, as demarches para aquisição da Vila Itororó. Seu nome ganhou dimensão internacional. Em 76, no II Congresso Mundial de Lazer apresentou trabalho sobre o lazer no Brasil, recebido como uma das mais importantes contribuiçôes. Em 1978, no Congresso Internacional de Sociologia, realizado em Ipsala, na Suécia, foi eleito membro diretor do Comitê de Sociologia do Lazer, da Associação Internacional de Sociologia. Em abril deste ano, em Bruxelas, apresentou novo trabalho no in Congresso Mundial de Lazer e em Paris assume suas funçóes no Comitê, onde é o representante dos países do chamado terceiro mundo. Ainda este ano deverá visitar o Japão, a convite da Associação Japonesa para o Desenvolvimento da Cultura e do Lazer, onde proferirá uma série de palestras.

Defendendo uma política nacional do lazer, p.97-99

Texto de Renato Requixa; cf. Anexo B, p.645

\section{Legenda}

p.IIo-III Tempo livre no Brasil, pelo litoral quilomético, é sinônimo de praia, onde o lazer é praticado desde o fim do século, aqui lembrado numa esplêndida marinha do pintor português F.Gil que a intitulou Praia de Banhos: Figueira da Foz, I896

\section{[Catálogo de Objetos Impossíveis de AChaR] p.IO2}

O lazer e um dos assuntos que mais interessaram o humorista Carelmann, autor de um, "Catálogo de Objetos Impossíveis de achar" publicado em Paris pelas ediçóes Balland e agora traduzido para o italiano pelo editor Mazzotta, de Miláo. Aqui reproduzimos alguns desenhos das coisas indispensáveis para quem queira usá-lo à "rebours," certos de que mais de um leitor estará interessado em conhecer o singular e divertidíssimo volume.

\section{Legenda}

Luta de boxe anatômica, fuzil para caçar pássaros que voam em bando, revólver-estilingue, cachimbo para a semana, globo xadrez e botas para pesca subaquática.

VIAJANDO EM CASA, p.IO3

O tempo livre que o cidadão vai caçando com ardor e sabedoria, abençoando

a automação, e à espera do robô 
para colocá-lo ao seu serviço, oferece uma diversão atraente: o trailer.

Nestes últimos decênios os arquitetos não projetaram somente arranha-céus, mansóes e aquelas colmeias para beeneagaista morar, (deixando aos pobres a tarefa de se tornarem arquitetos de casebres e de favelas) mas se preocuparam também com os mínitetos e com tetos móveis e provisórios.

A moda do campismo (os algarismos semi-oficiais informam que no ano passado a indústria brasileira vendeu 250 mil barracas, e as fábricas de trailers produziram algumas centenas de unidades por mês e por preços que variaram entre 25 e 200 mil) vai de vento em popa, significando a necessidade de o metropolitano sair, de vez em quando, das angústias proporcionadas pelo cárcere do concreto, do trânsito, da poluiçáa etc.

Sem dúvida, preponderando o nível econômico, a indústria automobilística irá promover o estudo do carro-trailer, como ocorre na Europa e nos Estados Unidos, onde a fuga para um weekend é comum e espetacular (no Velho Mundo a ordem é de dois milhôes e meio de trailers e 45 milhóes de tendas, enquanto nos Estados Unidos e no Canadá esses números alcançam, respectivamente, 3 milhóes e 27 milhóes.)
Na Itália dois arquitetos, Francisco e Tereza Ginoulhiac, construíram dois protótipos de casa-móvel e recentemente divulgados pela revista Arquitetura, de Roma. Em síntese, trata-se da adaptação de um apartamento, aliás, de um sobradinho num automóvel, capaz de transportar uma família que não sofra de claustrofobia e composta de até nove pessoas, o que nos leva a crer tratar-se de mais uma lata de sardinha do que de uma moradia.

Todavia, os realizadores do projeto asseguram que o conforto se não é total, pelo menos é suportável. A distribuição do espaço desta autocasa é inteligente. Num chassi Fiat (comprimento $360 \mathrm{~cm}$ ) motor Diesel de 8I,5 cv, 3 lugares na cabina, IOO $\mathrm{km} / \mathrm{h}$, os arquitetos construíram uma carroçaria em vidro resina, cubagem de $30 \mathrm{~m}^{3}$, portas de correr, janelas de alumínio com cristal temperado atérmico divisão de ambientes com cortinas. Os móveis são de fibra transparente; os colchões de espuma de $12 \mathrm{~cm}$; aquecimento a gás; aeração mecânica; sanitário igual ao dos aviōes; reservatório de água; fogão, geladeira e quantas outras tralhas necessárias a uma casa foram bem resolvidas, tendo em conta a economia do espaço.

e os poucos casos náo contam com a presença de uma simples biblioteca.

Todos estão cientes de que falta uma decisão neste setor prioritário. Sem cultura difundida e incentivada não se constrói uma nação. O país que emerge no esporte rico de atores atléticos, que facilita a adoção de elementos para os espetáculos esportivos alimentados pelas indústrias, sempre ausentes nas iniciativas da mens, este país deve afinal enfrentar o problema se não das Casas da Cultura, pelo menos deve começar a organizar alguma coisa a serviço de um tempo livre que náo atenda somente ao corpore, equilibrando a absoluta verdade social da mens sana in corpore sano.

Quem conhece os nossos municípios está a par da carência de cultura, mas a verdade é que, aqui como lá, raras são as atividades, para não dizer inexistentes,

A pobre relação entre lazer e leitura, p.IO3

Texto de Cláudia Marino Semeraro, cf. Anexo B, p.650

USUÁRIOS FALANDO DO SESC, p.IO6

O que pensam os usuários do

Centro Campestre do Sesc?
Marly de S. Rodrigo, 2I anos, trabalha na Contabilidade Fiscal, 
mora em Nova Socorro, considera o lazer um descanso. À pergunta: o que você acha que existe de mais importante aqui?, respondeu: "O sossego. Dá para você desenvolver o corpo, fazendo exercícios, mas o principal é a tranquilidade.”

Samuel Pinto Ribeira Neto, I7 anos, balconista, mora em Pedreira:

"Para mim é um lugar sossegado, onde você se descontrai mais. Você encontra amizades e não preocupação, movimentação, nervosismo. Aqui você se sente mais livre, limpa um pouco a cuca. Gosto de ouvir música.”

José Antônio Russo, I8 anos, balconista, mora no bairro São Jorge: "Saindo de casa, vou trabalhar, e quando venho para cá, eu descanso, tanto o corpo como a mente."

Waldir Cunha, 2I anos, trabalha em auditoria, mora no Jabaquara:

"A gente pode enquadrar lazer em termos econômicos e em termos de diversão. Em termos econômicos, a gente não gasta muito dinheiro. Qualquer lugar que você vai, tem que pagar, preços aí que realmente não compensam, entendeu, e nem sempre você sai satisfeito. Aqui é uma opção que você tem. Do lado da diversáo, você como vive numa cidade dessas como Sáo Paulo, em que a neurose predomina, certo? Você pega aí de manhã o metrô, faz qualquer coisa, você sabe que de manhã você tem que se virar para bater o cartão, numa cidade onde você náo tem nenhum companheiro, nenhum amigo, onde todo o mundo quer passar por cima; você vive nessa agitação a semana toda e se no fim de semana você náo tem nada para aliviar a cuca, para relaxar, você entra nessa aí, em pouco tempo você acaba ficando neurótico."

Jurandir Pereira, 22 anos, trabalha no Páo de Açúcar, estuda na FMU, mora no Jabaquara: "Olha, para mim é o meu horário de descanso, porque eu levo uma vida bem conturbada, muito serviço, uma correria; do serviço eu vou para a escola, quer dizer, fim de semana é para descansar e eu acho o Sesc um bom lugar pra descançar, porque aqui a gente pode fazer de tudo, pode se divertir, se quiser ler um livro, lê; qualquer tipo de diversão aqui tem. Acho muito bom.”

Izildete Costa, I7 anos, trabalha numa fábrica de roupas, mora no Jabaquara: "Gosto da piscina. Ah, porque aqui a gente encontra bastante gente. Sempre quando eu venho faço novas amizades."

Elizabeth do Vale, I5 anos, recepcionista, mora no Brooklin: O que significa para você estes momentos na piscina? "Uma tranquilidade, né? Afinal de contas a gente passa a semana inteira trabalhando, a gente tem um desgaste físico e aqui é muito bom. Mais importante, pra mim] são as quadras, porque eu gosto muito de jogar e praticar esportes. Então pra mim jogar vôlei, basquete, handball, é gostoso."

Maria Luísa da Silveira, 24 anos, recepcionista, mora em Santo Amaro: "Lazer tem tanto significado que, sei lá, não sei bem como explicar. Sei lá, é uma paz, a gente se sente diferente, né? A gente busca um ar diferente, uma vida diferente. Eu me sinto bem nesta busca."

Ângela Maria dos Santos Siqueira, senhora de prendas domésticas, mora em Interlagos: "O lazer é aquilo que a gente não pode fazer dentro de casa, porque não tem espaço bastante para a criança brincar, acho I que lazer é isso; a gente ter bastante espaço para as crianças brincarem.”

Marina Curota, 17 anos, secretária, mora no Jabaquara: "É bonito, gostoso porque aqui eu posso jogar, almoçar, descansar, entrar na piscina, tomar sol, bastante coisa."

Maria Aparecida, 26 anos, preparadora de dados, mora na Liberdade: "O lazer para mim significa poder jogar, nadar, ler, conversar, bater papo, fazer amizades, acho que tudo isso é lazer.”

O CONFLITO NO LAZER, p.IO6

Seria imitar a avestruz que, ingenuamente, esconde a cabeça na areia certa de que não será vista, se nos lembrarmos de coisas relacionadas com o tempo livre e ao escrevermos esqueçamos o fato principal: o conflito social, característica intrínseca de todos os povos, o contraste entre grupos e massas que parece, de século em século, ser o pensamento político insolúvel, o confiar a liberdade do indivíduo ao Estado 
que, conforme a moral de sua estrutura, sirva a uma ou a outra parte, procurando conciliaçóes e não de todo impossíveis, pelo menos de dificílima composição.

O tempo livre é condicionado pela subordinação ao poder. As duas tendências competitivas hoje válidas, a "conflitualista" própria do marxismo e a "integracionista” formada por outras tendências dependem do status quo capitalístico, que propóe ajeitar aqueles espaços de tempo na maneira mais conveniente para manter a ordem social que lhe interessa. Num caso, como no outro, propondo e, mais, organizando o lazer, integrando-o no sistema.

De qualquer jeito o conflito continua, pois alcançar o contentamento náo é próprio da natureza humana, e as delongas nascem e se apagam através as mudanças do tempo. O tempo livre é utilizado também para pensar.
UMA EXPOSIÇÃO: TEMPO LIVRE, p.IO6

Há dois decênios a Trienal Internacional das Artes de Milão dedicou uma manifestação inteira ao tempo livre, onde cada nação participante apresentou os modos usuais do preenchimento. (Causou muito interesse a presença do Brasil na manifestação, que em sua sala mostrou uma série de redes em cujo bojo continha um violão; o autor do arranjo foi o arquiteto Lúcio Costa.)
Uma exposição deste teor, realizada hoje, seria bem diversa daquela, pois o problema do tempo livre nestes últimos anos recebeu várias e notáveis contribuiçóes e ajeitamentos, suscitando o interesse de numerosos governos. Eis então uma proposta de exposiçáo: o tempo livre, a qual daria a possibilidade de uma pesquisa que nunca foi feita, qual a do lazer dos brasileiros e a revelação de quanto foi possível fazer e, principalmente, do que ainda (muito) se deve fazer.

Senhor Vogue \#I6, julho de I979, p.98-III (Senhor e as Artes)

A ARTE DE COLECIONAR ARTE

Artes se dedica hoje ao colecionismo. Todos sabem de alguém que cultive o hábito de reunir obras de arte (ou coisas náo propriamente tidas como tais) satisfazendo um prazer estético, ou mesmo profissional, em alguns casos com intençóes especulativas ou razôes de prestígio social.

Quem adquire obras de arte ou as encomenda participa do fator essencial da realidade das artes. É o consumidor, e depende de sua cultura e do seu interesse, das suas decisóes - e por que náo dizer dos seus caprichos - o rumo da produção, a conservação, a valorização e tudo quanto implica no setor.

Satisfazer um hobby juntando coisas é colecionar. Tudo pode ser recolhido. Sabem-se de colecionadores de botóes antigos, automóveis, relógios, posters, vidros.

E mobiliário, caixas de charutos, figurinhas de chumbo.
No setor das artes ditas plásticas, o colecionismo se interessa mais especialmente por pintura. E esta é a preferência dos grupos - felizmente hoje bem numerosos - que se formaram nos últimos vinte anos em várias partes do território nacional.

Antes eram poucos os colecionadores. Mas já existiam as famílias que adquiriam quadros com a simples intenção de decorar. Em geral, o gosto tendia mais para os bons e honestos operários do academismo. $\mathrm{O}$ colecionador de então (reunia obras dos chamados "clássicos," pagas hoje pelo colecionador retardatário por preços mil vezes acima do preço inicial) nem tinha visão.

Pois para colecionar arte se faz mister participar, prever as trajetórias do gosto, ter um certo faro, náo seguir os rastros dos charlatães e não buscar a opiniáo do senhor decorador.
O exemplo da Sul América, p.99-IOI

Quem redige estas notas confessa-se uma das testemunhas e, ao mesmo tempo, um pouco protagonista do nascimento do colecionismo de arte no Brasil, o que 
se deu logo depois da última Guerra, quando Assis Chateaubriand tomou a iniciativa de fundar o Museu de Arte de São Paulo. Inaugurado em outubro de I947, o incentivador de tantas atividades culturais, técnicas e filantrópicas lançou a ideia, realizando com impulso espetacular, em favor de uma participação positiva do poder econômico com vistas à formação de um acervo bem significativo e pleno de valor internacional.

A ação despertou outras e variadas iniciativas, imitativas, como a inauguração de pequenos e novos museus, bem assim incentivos a entidades financeiras visando a contribuir no desenvolvimento das artes. Adquirir obras e colecionar na época foi novidade. Recordou Leonídio Ribeiro Filho, presidente da Sul América Seguros - que deve ser considerado o autêntico pioneiro do movimento, pois nele aplicou e continua imprimindo invejável e incomum espírito humanístico: "Incorporamos ao acervo da Sul América obras de jovens que depois se tornariam famosos. É evidente que o valor do nosso acervo constitui um patrimônio da empresa em constante valorização. A preocupação de apoiar e prestigiar a arte vem desde o início de nossas atividades empresariais. Já em I949, quando da inauguração da sede na rua do Rosário, a Sul América, em colaboração com o Museu de Arte de São Paulo e de colecionadores particulares promoveu uma das mais importantes exposiçóes já realizadas no Rio, mostrando obras de grandes artistas nacionais e estrangeiros."

Naquela época se comentou uma exposição bem inédita: ao lado de Renoir, Kandinsky e Picasso, se alinharam Portinari, Di Cavalcanti, Teruz, Djanira, Milton da Costa. Eram tempos em que o problema arte se endereçava com vistas à mais ampla consideração em termos de abertura. Léon Degan pronunciava conferências demonstrando a arte abstrata ser o máximo. $\mathrm{O}$ Masp - depois de uma memorável exposiçáo de Le Corbusier - convidava Max Bill, Steinberg e outros elementos das vanguardas. As bienais de São Paulo faziam conhecer os mestres do século. Abriam-se escolas como se ministravam cursos.

A Sul América de Seguros deu um exemplo ao formar, metodicamente e sem correr atrás do modismo, um dos acervos nacionais mais interessantes do período que abrange estas últimas décadas, juntando obras de Di Cavalcanti, Portinari, Manabu Mabe, Raimundo de Oliveira, Reynaldo Fonseca, Carlos Scliar, Maria Polo, José de Dome, Paulo Roberto Leal, Heitor dos Prazeres, Newton Rezende, Farnese de Andrade, Zaluar, Rosina Becker do Vale, Wakabayashi, Fukushima, Inimá de Paula e quantos outros.

A benemerência do singular colecionador reside basicamente no elevado propósito de proporcionar a um vasto público a contemplação das obras. Assim, quanto antes a coleção da Sul América for apresentada a São Paulo, na sua sede da avenida Paulista, 2000, tanto melhor. Mais tarde será apresentada em Florianópolis, Porto Alegre, Brasília e Fortaleza, Continua válido o tema orientador da iniciativa que é: "Quadros não devem ser obras-primas conhecidas por poucos."

O empenho cultural da Sul América náo se limita à pintura ou à escultura, (recentemente a empresa doou ao Parque da Catacumba, no Rio, uma bela peça de Stockinger) mas se estende à literatura, à ciência, à música, atuando nesse setor através dos Circuitos Sul América de Música Erudita, que ao final deste ano. o terceiro da programaçáo, completará 127 representações em todo o país, dando vida a uma experiência inovadora considerada como uma das mais edificantes. No III Circuito, João Carlos Martins, Roberto Szidon, Jacques Klein, Turíbio Santos, duo Assad e Paulo Bosísio e Lilian Barretto levarão o melhor da música erudita a 37 cidades do Brasil.

Comenta o entusiasmado Leonídio:

"Acreditamos que, acima de tudo, cabe, também à empresa privada a missão de promover atividades que elevem o padrão cultural de uma nação. Pela própria função social de sua atividade principal, a filosofia empresarial de nosso grupo identifica-se com a preocupação de disseminar conhecimentos e expressões artísticas nacionais, seja incentivando o trabalho profissional do artista brasileiro, seja promovendo mostras periódicas do seu acervo. Tudo isso, visando, também a incentivar, em particular, a classe empresarial a prestigiar 
e apoiar a arte brasileira como expressão da cultura de um povo, levando o nosso exemplo a encontrar ressonância nas outras grandes empresas do país.”

Aliás, o seu exemplo já deu resultados, e hoje em dia vemos bancos, empresas industriais, companhias aéreas e redes de televisão abrir galerias e encomendar a artistas livros e ilustração de calendários ou relatórios administrativos. Estamos indo para a frente, Senhor Vogue irá registrando.

PorCElana CHINESA, EMOÇÃo PARA UNS POUCOS, p.IO2-IO3

O requinte branco e azul, de Ming e Ching

Em termos de colecionismo, São Paulo é metrópole carente de ilustração, especialmente quando se trata de objetos cujo interesse e consideração técnica e histórica implicam reflexão saber, além do gosto e naturalmente de meios.

Na São Paulo que foi invadida há alguns anos pela arte oriental (geralmente importada de Hong Kong, suscitando a costumeira e passageira moda decoracionística) existem algumas coleçôes de arte chinesa às quais é justo dar-lhes o adjetivo de excepcionais.

Uma destas coleçóes é a do casal Michel C. Etlin, ela brasileira e ele de tradicional família francesa. O casal tem o hobby do colecionismo, tanto assim que em sua casa podem ser vistas pinturas de Di Cavalcanti, Wesley Duke Lee, Volpi, Bonadei, Tomoshigue, Gregório, entre outros, ao lado de antigas imagens da estatuária colonial, móveis de vários estilos, raridades bibliográficas, prataria, tapetes (um gostoso heterogêneo disposto com simplicidade, criando ambientes de agradável convívio.) O que nos interessou, com surpresa, foi a coleção de porcelana branca e azul do período Ming (Hsuan-Tê, I426-I435) e do princípio do período Ching (Kang-Hsi, I662-I722). É bom saber que a dinastia Ming terminou em I644, seguida pela dinastia Ching, e o período entre 1630 e I680 é chamado de Transição, devido à mudança no estilo de desenho.

Disposta em grupos de períodos em estantes e sobre móveis, a coleção, pela sua singularidade e o excepcional valor museugráfico, faz lembrar as similares existentes em museus europeus, norteamericanos e naturalmente da China, ou conjuntos admirados nas exposiçôes internacionais, organizadas pela "Oriental Ceramic Society," sendo as últimas a de Veneza, em 1954, e de Londres, em I97I.
Nestas manifestaçôes algumas das peças dos Etlin foram incluídas, como a "Caneca," que reproduzimos aqui. Nestas e em outras peças dignas de encanto é a harmonia que combinam o "orno" e o "ordo," em ritmadas modulaçóes, andamentos do branco e do azul, cada peça de uma originalidade entusiasmante, convidando à contemplação. Estamos diante de um dos pontos altos da arte chinesa, num período a ser denominado clássico, pois representa o melhor e o máximo de um labor.

As peças dos Etlin alcançam a casa dos sessenta e dão uma ideia precisa da história do período de ouro do "branco-azul" da porcelana, cujo início é no século I6. (A datação mais recuada de uma destas cerâmicas é o grande "Vaso de Templo,"na Fundação Sir Parcival David, de Londres: I35I, um dos anos mais repletos de batalhas travadas por Chu Yüan-chang que de filho de camponeses conseguiu, conquistadas as províncias e afinal Pequim, se proclamar imperador, dando-se o cognome de "Luminoso," fundando a dinastia Ming.)

O vaso é uma simples taça em que se acumulam a história, manipulada no isolamento das oficinas que ativaram o esplendor desta arte, bem representativa, e a sobreposição da cor fusível, através do cozimento em fogo brando. Um objeto que tem o poder de nos levar a considerar tempos tão longínquos e absorver os prazeres que a cultura favorece. $\mathrm{O}$ colecionismo, sem este prazer e as possibilidades de divagaçóes, nada vale.

Quando os Etlin escolhem uma porcelana para nos mostrar eles a descrevem, anotando detalhes, insistindo no tom do azul, ou num símbolo do budismo, ou como o pintor sintetizou um fênix. Conversar com eles significa ir ao mundo mágico da China, num tempo fascinante para os ocidentais, face aos mistérios 
desvelados apenas nos relatos dos missionários jesuítas. Examinar um antigo objeto é participar de mil e um acontecimentos espirituais e de conteúdo cultural.

Sempre se aprende do colecionador inteligente. Em I368 a dinastia Ming iniciou seu reino liberando a China da invasão mongol, e aconteceu uma novidade em relação à produção da porcelana branca e azul: a importaçáo de cobalto vinda da Pérsia pela estrada da Seda. Ao mesmo tempo o comércio entre o Oriente Médio e a China se desenvolvia, sendo os persas fanáticos por porcelana chinesa (resultado disto são hoje as maiores coleçóes de branco e azul, exceção do Museu Nacional de Taiwan, que se encontram no Museu Ardebil, de Teerã, e no Museu Topkapi, em Istambul). Por outro lado, como sempre acontece nestas simpatias, os persas transmitiram aos chineses algumas influências desenhativas. Trata-se de simbiose que deu origem a coleçôes de arte muito requintadas, como o interesse pela arte cerâmica Gnathia, produzida na homônima cidade da Apulia, com alguma relação com a cerâmica italiota (séculos 4 e 3 a.C.) de fundo preto e onde aparecem pintadas cenas dionisíacas, ou, para citar outro caso, colecionadores de arte Gandhara, o conúbio greco-indu (séculos I e 2 a.C.).

O gosto tem seus andamentos particulares, capacidade de entender antes de tudo, saborear, apreciar. No caso da porcelana chinesa existem colecionadores que se dedicam exclusivamente aos estilos sucessivos aos apontados, como os que florescem ao longo da dinastia Ts'ing, no Seiscentos, que deu muita importância à porcelana, continuando sua produção na admirável pureza da matéria, esmalte e nos modos da decoração, a gama dos vários estilos "verde," "preto" e "rosa." Sem tirar nada da originalidade destas porcelanas, para nosso gosto por demais ricas de decoraçáo, e somente repetitiva e recomposta sem um objetivo "ordo," a diversidade e o contraste do branco e azul se ajustam com a sensibilidade mais própria do nosso tempo, que visa a formas e resultados mais próximos ao geométrico que ao "historiado," continuando válida a definição do setecentista Burko a respeito do gosto: “...em sua genérica acepção, não é uma simples ideia, mas produto primeiramente da percepção dos prazeres do senso e depois dos prazeres da imaginação, além das conclusóes da razão, à qual considera as relaçóes destes prazeres, as paixôes do homem, seus usos e suas ações."

Quem vive em companhia do objeto de arte original sente isso tudo. Usa-se $o$ adjetivo original para determinar a assim chamada autenticidade que, numa coleção, é sua base, especialmente no setor da porcelana chinesa, pois no século I9, no eco da apreciação para o fascínio que data de Marco Polo para o fabuloso da arte oriental, China e Japão invadiram a Europa e as Américas com colossal quantidade de mercadorias artesanais, em parte cópias de originais.

Aqui o colecionador precisa de ajuda para aclarar a situação. Náo sei quantos objetos Ming e Ching os antiquários espalhados pelo mundo inteiro veem a cada momento: famílias herdeiras de bibelôs que comparam a similares aparecidos nos catálogos da Christie's e da Sotheby's, ou em monografias, dão a ilusão de possuir fortuna, pois leem que um vaso realmente produzido durante uma das dinastias vale umas setenta mil libras esterlinas (quando aparecem peças excepcionais alcançam importâncias bem mais altas, como foi o caso da venda recente pela firma Spink \& Sons, de Londres, de uma "Moon Flask" Ming, do início do século I5, anteriormente pertencente à coleção Alfred Clark, por I60.00o libras esterlinas.) É sempre difícil desfazer as ilusóes, particularmente em centros onde náo existe um mercado de antiguidades qualificado. Spink, oportunamente, dando notícia da venda da "Moon Flask," aconselhava advertindo: "Antes de adquirir procure um técnico no assunto."

Os Etlin, também nesta circunstância, demonstraram ser prudentes: boa parte das peças da sua coleção procede da Spink \& Sons, três pertenceram à coleção Clark, uma vem do mais conhecido antiquário de arte oriental de Paris, C. T. Loo; outras de Joseph M. Morpurgo, e de Aalderink de Amsterdã. A maioria tem um certificado do sr. H. Hancock, o septuagenário considerado como o maior perito em porcelana branca e azul em Londres. Na monografia 
The Book of Family Rose, de George C. Wilhamson lê-se: "As a general expert there is no better man than Mr. H. Hancock."

O fato da autenticidade das obras de arte é indispensável para todos que póem valores neste lazer, pois é justo que se assegure sob o ponto de vista de investimento. Nestas notas dedicadas a dois colecionadores foi oportuno frisar também aquele aspecto, chamando a atençáo de quantos no comércio antiquário pensam que lebre e coelho sejam a mesma coisa.

O BRILHO SAGRADO DA PRATA, p.IO4-IOS

Os artifices, motivados pelo culto, produziram muitas obras-primas

Confirmando as observaçóes feitas ao colecionismo, temos notícia de uma iniciativa do Banco Sudameris de São Paulo. Uma nova publicação, inserida na série Arte e Cultura, que enfocará o colecionismo da prata através de um resumo das surpreendentes criaçóes da lavra e da arte daquele metal no Brasil, nos tempos coloniais.

Eis um colecionismo que data dos tempos mais remotos, pois de prata são os objetos de culto. Nossos antigos mosteiros e igrejas ainda são ricos de autênticos tesouros que os artífices portugueses antes, e depois os nativos, produziram. Foram notáveis também os aparelhos de mesa das casas grandes, os ornamentos pessoais e os ajaezamentos dos animais, sem contar o uso da moeda de prata.

Ao longo dos séculos, parte dos materiais saíram dos lugares sagrados, muitos dos quais foram refundidos para modernizar segundo o talento de alguns, seguindo o perpassar das várias propriedades, interessando o mercado e. consequentemente, incentivando o colecionismo. Hoje no Brasil numerosos são os que reúnem e estudam a história da prata. Nestas páginas são mostradas algumas peças escolhidas pela diretoria do Banco Sudameris para ilustrar o Relatório Administrativo, numa edição preparada por Promonei.

Todas as peças aqui publicadas pertencem a colecionadores de Sáo Paulo, em parte apresentadas nas duas grandes exposiçóes realizadas pelo Masp: "Artistas e Artífices do Brasil, séculos I6-I8" e "Arte no Brasil, uma história de cinco séculos." Na ocasião do lançamento do volume dedicado à "História da Prata no Brasil," que será editado pelo Banco Sudameris, o Masp vai organizar uma mostra dedicada ao tema.

As FRENÉTICAS CORRIDAS PARA SE ACOMPANHAR A MODA, p.IO6-IO9

Paris e Nova York nos dizem, antes, o que é bom

Nos anos 40 foi proposta a um mecenas que procurasse resolver o problema museugráfico em São Paulo. Chegou-se mesmo a ponto de se tentar a compra de uma casa art-nouveau que estava em vias de ser demolida para ali ser construído mais um arranha-céu. A proposta foi rejeitada, pois não atinava com a ideia de alojar um museu num prédio apelidado de mau-gosto. Quem foi chamado para resolver dito problema, persuadido de que a novidade ensejaria o aparecimento de algum seguidor, adquiria (por uma ninharia) num antiquário bric- à-brac na rua Barão de Itapetininga, dois belíssimos vasos, pensando que tais peças seriam um ótimo começo da coleçáo in pectore. Naturalmente a ideia do visionário não deu em nada: a casa foi demolida, o art-nouveau continuou sendo condenado pelo gosto da emergente classe dos decoradores. Foi na abertura do Mirante das
Artes, em 1966, que se inaugurava uma vitrina com peças excepcionais de art-nouveau. Uns quantos gatos pingados, duvidando, apenas olharam o conjunto.

Fluem os decênios, lapso de tempo útil para a revisão das artes do passado, e Paris descobre náo só o art-nouveau, mas o art- déco e, consequentemente, Sáo Paulo e Rio de Janeiro descobrem os dois movimentos de fim do século e da Exposição das Artes Decorativas de Paris. Tímida no começo, frenética logo depois, a corrida iniciada para vasculhar os poróes empoeirados onde tudo era atirado às traças. E a moda pega.

Hoje temos em São Paulo antiquários que se interessam por objetos daqueles dois estilos, como Benjamin Stein e Lídia de Carvalho, com sua loja Melindre. 
ESTRANHO, ESQUISITO, INDESEJÁVEL (antes de ser colecionado) p.IIO-III

Tudo se coleciona. De vez em quando nos surpreendemos ao admirarmos grupos de objetos que náo se pensava merecedores de qualquer atenção. Recentemente no SESC de São Paulo foi apresentada uma exposição de arreios e pertences da agropecuária, colecionados ao longo de uns vinte anos. No Masp, recentemente foi realizada bela exposição do cartaz inglês que alguém pacientemente agrupou, quando aquelas folhas no mais das vezes eram destinadas ao esquecimento. Em São Paulo já existe apreciável número de colecionadores de desenhos, atividade muito comum na Europa e nos Estados Unidos. (Recolher documentos da ideação criativa do artista, antes ou no ato de realizar uma imagem gráfica, é um prazer para o colecionador que não pensa em parede, mas na intimidade das pastas o desenho faz parte da primeira concepção do artista no que diz respeito ao processo estrutural e como expressiva prova para a finalização da obra, e às vezes no desenho a obra já está definida.) $\mathrm{O}$ coletar as coisas de que se gosta depende da sensibilidade ou da inteligência de cada um. Em São Paulo existe uma famosa coleção de autômatos e instrumentos de astronomia reunida ao longo de anos pelo arquiteto Ludovico Martino e, no Rio, existe uma coleção de bengalas que cobre todos os tempos e inumeráveis países, representando agradável surpresa.

Mudando de tema, existem colecionadores de carteiras de cigarros; (no Oitocentos as impressoras produziram, especialmente no Rio de Janeiro, carteiras com belíssimas figuras) rótulos de garrafas de pinga; etiquetas de livreiros (apresentadas no Masp durante a exposição dedicada à História da Tipografia no Brasil) e quantas outras curiosidades que nem se pensavam existir. E que dizer de peças arqueológicas, um tema bem interessante e carente de estudos para elucidação de suas origens?

Numa palavra, colecionar e conservar tudo que o homem andou fazendo representa o autêntico lazer, e ao mesmo tempo uma participação visando à preservação da memória, já que somos expressão e síntese do passado. $\mathrm{O}$ antigo somos nós.

\section{Legenda}

São José de Botas, Minas Gerais, século XIX

g Tripé e máquina fotográfica, c.I890

Senhor Vogue \#17, agosto de 1979, p.IO3-II3 (Senhor e as Artes)

SENHOR E AS ARTES ERÓTICAS

Pietro Maria Bardi tira o erotismo de seus envelopes plásticos

Numa seção dedicada às artes, seu redator procura principalmente interessar o leitor, diversificando os assuntos, circunavegando a rotina da crônica que pela verdade não se apresenta lá muito animada no Brasil. Quando Masp desmonta sua Pinacoteca para apresentar a exposição "Brasil: Cinco Séculos da Arte Nacional," (considerando os engenhos de açúcar, os alambiques, os carros de bois, as serras, os martelos, as rodas d'água dos moinhos e quantas outras coisas) o pessoal da situação normalmente estética protesta, e se náo protesta vendo uma sala do museu repleta de apetrechos usados para maquilagem, ou expostos materiais que documentam a história da tipografia no Brasil, reclama que quer ver pinturas.

Antonio Tari, um esteta napolitano do século I9, não muito conhecido em nosso meio, proponente da Pirâmide das Artes, colocava na cúspide a Pintura, como manifestação mais comunicativa e mais próxima de Deus. Oe fato a Pintura é o benjamin da gente, desde as imagens sagradas até as historietas em quadrinhos. E vira e volta é com esta arte que se deve contar quando precisamos fazer conhecido um caso ou um pensamento. Os analfabetos da Idade Média não sabiam ler a Bíblia, porém conheciam vendo os afrescos. Hoje, nesta seção, o caso e o pensamento em foco é a Pintura e o Desenho que são apelidados de eróticos, tema escolhido pela "Arte Aplicada" para armar mais uma das exposiçóes que conferem àquela galeria paulistana uma posição bem distinta entre as inúmeras que, em geral, convocam o mestres, semimestres, aspirantes a mestres da pintura propriamente dita.

A temática escolhida, normalmente, é considerada "interna," assunto fechado, 
a ponto das revistas dedicadas a tais passatempos serem postas no mercado fechadas em envelopes de plástico. Antigamente (uma época de passado bem recente e numerosamente ainda atual por conta dos morigerados) o negócio era tabu. Quem conhece a história da arte sabe quais os inventos botânicos para vedar ao contemplador de uma estátua nua as partes reputadas escandalosas, aquelas absurdamente inquinadas como instrumentos do pecado original.

Tivemos no começo do século pintores processados (depois anistiados) por maridos que num retrato da esposa descobriram que o autor não tinha observado as regras combinadas: a saia cobrindo rigorosamente os pés. (O pandemônio mais famoso foi aquele armado quando Giovanni Boldini colocou, na Bienal de Veneza, o retrato de uma adolescente mostrando as pernas ostentando meias pretas.)

Os pintores dedicados, com insistência ou por acaso ao paraíso-inferno erótico, tiveram de lutar contra o ambiente, e superar a conjura perseverante dos moralistas. Pensemos nas peripécias por que passou Toulouse-Lautrec que pintava casas-fechadas, ou do nosso grande Henrique Alvin Correa. E por analogia à série de denúncias e condenaçóes que a Justiça pronunciou contra escritores "prosa aberta," inclusive Gustave Flaubert. E ainda por analogia, o trabalho dos censores de todos os países ocidentais. (Somente há poucos anos foi que a censura da Inglaterra liberou o Dacameron, de Boccaccio, hoje apenas páginas eivadas de água de colônia, se se considerar as andanças da juventude hodierna.)

Dona Sabina abre, com esta exposição, uma espécie de aplicação do artista plástico às motivaçôes que, aos tempos dos gregos, Eros e Afrodite eram consideradas divindades do amor, sendo também e oportunamente venerado e como, Himeros, personificação do desejo de amor. (Historiadores garfadores de episódios atribuem às poucas representaçôes de Eros confundindo-o com Cupido, na escultura helênica, evidenciando a dificuldade de esculpi-lo com seus atributos, além das asas abertas para alçar voo, os mais substanciosos.)
Seja como for, o erótico se constituiu sempre em objeto de atençáo, sem se falar do interesse e reprimendas que a igreja Católica e também a Protestante dispensaram, em nome de Jesus Cristo e, por procuraçáo, de Deus. Mas somente a constatação de que aquela atividade sobreviveu, é sinal que tem quem gosta de Arthur Miller ou de Pablo Picasso mergulhado nos amores não precisamente platônicos, encontros proibidos aos que fazem questão de se conservar puros para se apresentar no Juízo Final com chances de absolvição.

Geralmente os limites que separam o Eros e a pornografia nunca foram definidos. Tudo depende dos encarregados de estabelecê-los. Existe o pessoal que considera pornografia as representaçóes do amor da Índia e os rótulos didáticos dos chineses e dos japoneses. É questão de espirituosidade, inteligência. Famosa, entre os estudiosos de história da arte, a queima de todas as obras eróticas recolhidas por Samuel Bing, o lançador do art nouveau, por iniciativa da sobrinha, a qual não era uma solteirosa qualquer, mas uma historiadora da arte, secretária do grande exegeta da Renascença, Warburg, cujo nome juntamente com o de Curtland intitula o centro de estudos da Universidade de Londres.

É questão de mentalidade. A senhorita Bing podia vender ou ceder os preciosos materiais recolhidos; não, pois os considerou uma ofensa, sem saber que para os orientais não se trata de pornografia, mas sim de prática de vida, como igualmente se dava com as civilizaçóes mexicanas e andinas.

O Museu de Arte de São Paulo deverá apresentar no próximo ano uma exposição preparada pelo Playboy, o ponto alto calibrado em termos pacíficos e documentativos do problema em tela. Parece não haver impedimentos, pois muita água já rolou por baixo da ponte neste após-guerra, provocador de lamentaçóes por parte dos que procedem em decênios em que o gostoso Can-Can era espetáculo reservado aos excêntricos.

O calendário muda. Eis em São Paulo uma exposição não-canônica. Pelos tempos que correm, pode ser considerado um fato perbene. 
O MARQUÊS NÃO É MAIS UM SÁdICO, p.IO8

Curioso que mais ou menos antes da última guerra, o Marquês de Sade era escritor posto no índice da Moral, com total proibição de ser nomeado. Decorridos alguns anos o Marquês vem à tona e elevado à condição de Divino. Não é mais um sádico. Literatos de peso o julgam "Grande eversor," "grande moralista," um "santo às avessas," um "libertador do desejo."

Para os da mass-média (cinema, historieta em quadrinhos, foto-romance e teatro), Sade continua a ser o perverso, canalha e assim por diante. As últimas definiçóes negativas atribuem ao autor das Cartas de Vinciennes e da Bastilha o uniforme da polícia de Hitler.

A distinção entre perversidade e normalidade é difícil de ser determinada nos tempos que correm. Curiosa a tendência de considerar Sade como o campeão dos assaltos à ordem constituída que obstacula o advento de uma sociedade afinal realmente livre de uma moral falsa. Pretexto também para desabafos intelectualísticos e políticos (suficiente lembrar o filme Saló-Sade, de Pasolini.) O Marquês, última encarnação, serve até para compilar uma história fantástica em quadrinhos, De Sade, que na Itália, país que abriga a sede papal, registrou um sucesso estrondoso: I5O fascículos já publicados. Sade, um dia o outro, irá aparecer entre nós? Contas a ajustar com a censura. É de se esperar que a inteligência

Na sala de espera de Franz, p.Io9

Franz Von Bayros foi desvelado e revelado recentemente. Agora todos o conhecem, pois hoje em dia não mais se fecham as portas dos quartos onde estáo em cena as alunas de Ninon de Lenclos.

Nos tempos do ilustre Von Bayros o intercâmbio amaroso era, aos olhos da Moral corrente, bem complicado.

Franz iconoclasta, desenhista das peladas, caçava o prazer indiscriminado, que considerava único bem possível e fundamento de outra faceta da Moral. Folheando o volume Die Purpurschnecke Erotische Zeichnungen (Gala Verag Hamburg,) recentemente dedicado a Von Bayros, os encontros desconcertantes eram assustadores, pois e, mais especialmente o bom gosto, tratem convenientemente o monstro ideológico, se tal é considerado, evitando a pornografia barata própria dos textos de Justine.

O culto fálico existe desde a aurora dos tempos. Considerado o órgão genital como uma autêntica divindade, todas as civilizaçóes por ele se interessam, desde a Babilônia até as das Nova Guiné, inclusive as da América.

Mágico instrumento propiciador do procriar e do fecundar, cada povo e cada religião criou relativas lendas e superstições.

O altar bramânico na família era últimas considerado de sesso feminino, o fogo do sacrifício, o elemento viril assim como o sacrifício se torna um real e místico acoplamento do altar e do fogo.

Para os gregos a falofonia foi elemento essencial do culto, sendo Dionísio muito popular. Mas o povo que mais se preocupou com o falicismo foi o romano: homens e mulheres se ornavam de amuletos personificantes do deus Fascinus, ao qual tributavam honras às sacerdotisas em templos particulares.

Destes amuletos se descobriu uma coleção em São Paulo, pertencentes a um diletante de arqueologia. E coleção rara e demonstra quais as representaçóes dos artistas produtores deste ornamento religioso, tanto masculino quanto feminino.

a inventiva está na sala de espera daquele divertimento que o austero Catão, o Censor, teria apelidado de pornografia. Franz, sem se salvar do inferno, orquestra com dignidade os comportamentos condenados terrenamente; ambienta-os com requinte, divertindo-se nos subentendidos e na alusão mais que no prosaico: uma arte franca no contar delícias, até envolvida de um certo ascetismo. A neurose não deixa de dominar as cenas. Franz desenhava para os que conseguiam arrancar do arabesco das linhas motivo para saber melhor, e pôr as novidades na batedeira da fantasia.

Naturalmente se fala dos que têm à cabeceira os Ragionamenti, de Messer Aretino, julgando o Decameron, manual 
romanceado, por demais reticente. Trata-se de degustadores de apetites sensíveis, sensualísticos com pingos de luxúria: uma categoria que não mais é a maçonaria acima indicada, pois a comercialização do erotismo tornou-se inflacionária, alcançando níveis de perversidade vulgar, generalizando atividades demais que, sem a reserva e o gosto do proibido, acabam por tornarem-se monstruosas.

Os desenhos de Von Bayros não são mais propriedades das elites apreciadoras de Lucrecio e de Safo, desprezadores horrorizados das ruas noturnas de Amsterdã e dos catálogos da senhora alemã que industrializou os objetos de consumo para pobres diabos encabulados na ars de Eva.
O sexo na televisão, p.ıı2

Até agora, no Brasil, a censura se mantém bastante vigilante em relação à $\mathrm{TV}$, no sentido de torná-la bem comportada e obediente às regras do jogo de uma comunicação que náo agrida a moral aceita e mantida por nossa gente. Quando se trata de censura os opositores protestam, pois o desejo seria que a liberdade governasse soberanamente, dizem, como acontece nos Estados Unidos. Por exemplo, em termos de transmissóes televisivas?

Lá no setentrião as coisas chegaram a um ponto francamente lamentável.

Existem transmissóes que em certos casos podem ser definidas como vetriolescas. Por exemplo: no "Cable TV," strip-tease e total, de uma porno-star (duzentos quilos) que acaba numa verdadeira orgia; aulas de técnicas masturbatórias, apresentadas pela pintora Betty Dodson, autora de telas de arranha-céus fálicos.

Recentemente a revista TV Cuide realizou uma pesquisa entre telespectadores. Os resultados: vamos acabar com os heróis policiais, cirurgióes, advogados etc. Queremos a enfermeira, porém que dispa suas roupas. Soube-se que setenta por cento das pessoas estáo cansadas de assistir a filmes de violência, e que os do sexo, contrariamente ao que se pensa, de acordo com a "moral pública," são mais aceitos. A Opinion Research Corporation, de Princeton, em conclusão a uma pesquisa efetuada, precisa que a porcentagem de telespectadores a favor programas de sexo é exatamente o dobro dos que são a favor da violência, inclusive mulheres.
Picasso para adolescentes, p.II2

O máximo dos máximos teóricos da Renascença, Leon Battista Alberti, no que se refere à moral que os pintores e os escultores devem rigorosamente observar é explícito: 'Tem-se que configurar alguém nu... sempre fique atento à vergonha e ao pudor. As partes feias a serem vistas do corpo e outra similar de pouca graça, se cubram com pano, com alguma folha ou com a mão.” A Contrareforma foi ainda mais severa com os pintores, e seriam denunciados mestres como Watteau, Boucher, Fragonard, Greuze, Dégas, Toulouse-Lautrec, Millet,
Deveria, Beardsíey, Fuseli, Rowlandson, Daumier, Courbet, Gauguin e quantos outros, sem contar Baltus e Picasso, para citar alguns da "Liga dos Erotistas," para arreglar as contas com a Inquisição.

Em tempos de quase absoluta liberdade vigiada, o editor paulista Massao Ohno publica um livro ilustrado com os impiedosos desenhos do excessivo mestre do Cubismo, não-pornográficos, pois o censor os considera tabu, manifestação de arte. De qualquer jeito: café pequeno para adolescente descobrir.
Neurose no começo do SÉculo, p.II2

A recente publicação das cartas que James Joyce endereçou a sua esposa Nora, motivaram discussóes e polêmicas entre os estudiosos. Certamente que ler tais cartas, como a seguinte, vai surpreender o leitor. Ei-la: "Me escreva uma longa carta, amor, cheia daquelas coisas e outras parecidas, porém falando de você. Você sabe como me excitar. (No original a expressão é mais vulgar.) Me descreva as coisas mais minuciosas sobre você, mas que sejam obscenas, secretas e sujas. Não me escreva 
de outra coisa, mas somente frases repletas de palavras e sons sujos e impudicos. São todos muito doces de ouvir e ver no papel, mas os mais belos são aqueles mais sujos. Gostaria de ouvi-las, sim, aquelas palavras sujas táo excitantes e ver a boca que produz aqueles sons, sentir teu corpo que se agita embaixo do meu, e cheirar as ventosidades porcalhonas de menina que saem do teu c... nu, e copular copular a tua louca b... para sempre, sempre.”

Joyce, no Utysses, no monólogo de Molly Bloom, ironiza as expressóes da carta: "Oh, quanto barulho se o mal que estamos fazendo neste vale de lágrimas e de sofrimentos, o sabe Deus que não é tanto o que todos fazem, só que não se deixam ver: penso etc. (Uma página nauseabunda, que é mais próprio, para os que não sofrem de náuseas, ler no original.)

Os tempos no erotismo tiveram seu auge no começo do século com vistosos personagens, agora evocados nestes anos de revival em que se vasculham situaçóes secretas. Uma das últimas: as proesas da milionária Romaine Brooks, cantante, pintora e lésbica, amante da dançarina Ida Rubistein, famosa pelo coup-de-foudre que a levou aos pés de Gabriele d'Annunzio. Carta de Monte Carlo ao poeta em I6 de agosto de I9II: "Gabrielino, devo ser sua namorada ao lhe escrever sem maior razão. Mas que importa. Se neste momento eu puder tê-lo para mim, somente por uma noite. Vejo-te completamente nu na cama, num atelier. Você se dá conta como eu ficaria estática diante da tua nudez? Isto parece incrível para uma mulher que sempre professou o máximo desgosto para com o amor físico entre os sexos..."

De fato, para Romaine, este foi um caso passageiro, pois seus amores, inúmeros foram sempre lésbicos. Já envelhecida se uniu a uma boêmia parisiense, dançarina-poetisa fiel à pintora até o fim da vida, quase centenária, esquecida, talvez feliz por ouvir poemas como este: (à Vênus chorona) "Reencontrar o equilíbrio| triste por não se sentir livre| e longe das tuas crueldades| riqueza ou miséria| de ser mais somente minha?"

Hoje se define o que contamos como "romantismo decadente de começo de século," em que no final do mesmo ciclo porém, o pastiche eteros sexual mudou?

Senhor Vogue \#I8, setembro de I979, p.99-IIO (Senhor e as Artes)

Arte da AmÉrica Latina, AlÉm das Bienais E do EXOTISMO, p.99

$A$ arte do Continente é caudalosa, e nem sempre as promoçóes

oficiais revelam sua dimensão mais profunda

De vez em quando se organiza uma exposição de arte latino-americana. A intenção é de oferecer um panorama útil para que se tenha uma ideia da atividade desenvolvida ao setor mais significativo do Continente. Porém, os certames nunca satisfazem as expectativas, pois náo se consegue reunir todos os países, e os países não mostram o que têm (e sabemos que têm) de realmente válido.

Bastará lembrar a última Bienal LatinoAmericana em São Paulo: apesar da boa vontade, o visitante de uma cultura não superficial esperava admirar os mestres, mas acabou encontrando o genérico de uma produção ocasional, resultado dos compromissos combinatórios comuns nas burocracias oficiais, quando não consquência das mafiazinhas dispostas a lançar penetras aprendizes das novidades europeias e interamericanas.
O mesmo se deu na Colômbia, quando se organizou uma Bienal em Medellin, patrocinada por uma grande indústria. A única vantagem desta bienal foi a de não premiar (Sheila Leirner no O Estado diz justamente a respeito da paulista: "Hoje, felizmente, já temos tempo suficiente para constatar que o indiscutível valor das partes internacionais da manifestação nunca foi medido pelas premiaçóes. É que muito ao contrário, a sua maioria foi composta por mediocridades oficiais e pelo fruto de simples relaçóes de amizade ou de troca.")

Dividida em quatro grupos (Arte figurativa, não figurativa, tecnológica e científica, e conceitual) em Medellin foram reunidas as mais conflitantes expressóes, sendo a fatia maior do bolo oferecida aos argentinos componentes do grupo denominado Cayc e que, tendo à disposição finanças à vontade, tornou-se o 
mais representativo do Continente, não faltando em nenhuma manifestação internacional, aliás, criando-as nos centros europeus e norte-americanos.

O que é ótimo para a Argentina não serve para determinar uma imagem da arte latino-americana, tanto mais que o sistema convívio buenoairense, genericamente modernoso, náo exprime o labor daquela nação. Como acontece somente na América Latina, os que fazem o bom tempo no jardim das musas são magnatas que declaram abertamente nada entender do assunto, mas que o promovem para benefício autopromocional (conta o espirituoso Aldemir Martins, o qual, por não usar gravata, foi encaminhado para $o$ elevador de serviço numa recepção granfina, a respeito das nossas bienais: "A tônica das matérias social, ninguém questionava o papel da bienal na sociedade. As manchetes de jornais e revistas eram bem ufanistas; algumas chegavam ao exagero: "São Paulo tem um encontro com o mundo," manchete de um jornal de São Paulo, ou então "Nosso país é a sede, no momento, da mais importante exposição de arte viva do mundo," anunciava uma revista. Em cada matéria publicada, sessenta por cento eram dedicados ao casal Yolanda e Francisco Matarazzo, considerado pela imprensa o casal típico de São Paulo.”)

A situação das artes plásticas é bem diferente da literatura. Os latino-americanos tiveram boa afirmação no estrangeiro. Não é mais verdadeiro o aforisma de Russel Baker, humorista do New York Times: "Os americanos são capazes de fazer qualquer coisa pela América Latina, menos ler sobre ela." Há mais de vinte anos que a literatura produzida na parte baixa da América explodiu: prêmios Nobel a Astúrias e a Neruda, traduçôes contínuas de Borges, Amado, Garcia Márquez, Cortazar, Octavio Paz, Nicanor Parra, Guimarães Rosa, para lembrar alguns. (Borges, por demais angustiado por sua perda de visão, disse a Álvaro Alves de Faria, numa entrevista publicada nas Folhas, que despreza os escritores latino-americanos: "Não pretendo falar nenhum nome porque eles, na verdade, não existem, não existe nada na América Latina. É como se todo o Continente fosse um romance mal escrito.”)

Não se deve levar em conta os ditos do anciáo genus irritable vatum. Existe e vive, conquistando sempre mais leitores, uma literatura o continente fosse um romance mal vivência, uma terra motivada por uma única força, a despeito das suas diversas e não integradas naçóes, vários mundos, como escreve a historiadora paraguaia Annick Sanjurjo de Casciero.

Aos escritores que contribuem para a formação da imagem da América Latina correspondem a personalidade de artistas plásticos de valor análogo? Fácil responder afirmativamente, uma vez que são pronunciados nomes como Matta Batera, Cuevas, Lam, Piza, Le Pare, Merida, Tamayo, Obregon, Marisoll, Soto, e quantos outros mais, à parte as distinçóes iconográficas, sem se falar daqueles que os precederam.

Mas a literatura tem a prerrogativa de não se mostrar nas bienais. A seleção é normal, ao passo que para os pintores e os escultores e, agora, os que pegam um tubo de esgoto e o expóem à admiraçáo (inexistente) do público, tudo vale, vigendo a multiplicação dos proponentes do conceito em proliferação cada vez mais alarmante daqueles que, antigamente, compunham sonetos convencidos de serem realmente poetas. Ao lado da literatura deve-se lembrar o cinema: nos festivais seletivos assiste-se a filmes produzidos na América Latina que podem ser inscritos entre os mais representativos do tempo.

De qualquer jeito, do que mais se fala é das artes ditas plásticas. É este campo que mais tem cartaz, pois as visuais, de fato, constituem a comunicação mais difusa. Nesta comunicação a América Latina não está representada como deveria. Existe uma arte continental. Tudo se passa de modo a não ser conhecida e apreciada como seria oportuno e acertado.

JOAQUín TORRES GARCÍA, O MERGUlHO NA ALMA LATINO-AMERICANA, p.IOO-IO3 Um complexo artista plástico, de raizes peculiares, atinge o universal

A história de quase todos os artistas latino-americanos registra como crônica normal uma estada no Velho Mundo, concentrando-se mais habitualmente 
em Paris: desde os mexicanos até os argentinos (contam-se inúmeros brasileiros como, entre outros, Pedro Américo, Vitor Meirelles, Belmiro, Visconti, Portinari, Tarsila, Vicente do Rego Monteiro, Ismael Nery, Brecheret) que lá aprendem e se formam.

Quando voltam ao país vão ao encontro das motivaçóes e do desempenho do próprio fazer, e se afirmam superando as reservas do ambiente, geralmente hostil às novidades que importam.

Entre os mestres de maior relevância destaca-se Joaquín Torres García, itinerante na Espanha, Nova York, Itália París. Vai de Montevidéu a Barcelona ainda adolescente, participa das experiências mais mirabolantes nos trilhos-surpresa dos movimentos de vanguardas e, depois de quarenta e três anos, retorna à terra natal, ajustando suas ideias, meditando quanto às andanças e às peripécias vividas, dando finalmente consistência e afirmação a uma das propostas mais originais a serem registradas na tumultuada arte do novecentos: o Construtivismo Universal. Escreveu muito, batalhou, ensinou. É, sem dúvida, a personalidade mais singular da arte latino-americana. Apesar de alinhar ampla bibliografia, ainda não é uma figura bem definida, certamente não por falta de biógrafos ou críticos, mas por causa da imensa atividade que desenvolveu e pela complexidade do pensamento, da vitalidade e da obra.

O caso de JTG guarda alguma analogia com o nosso grande poeta Sousândrade, já que ambos foram antecipadores do tempo, incompreendidos mesmo. (O brasileiro: "Ouvi dizer por duas vezes que $O$ Gueza Errante será lido cinquenta anos depois: entristeci - decepção de quem esteve cinquenta anos antes;" o uruguaio: o artista sempre encuentra gente con tal pobreza de espiritu que le admira, y eso le hincha como un pavo. Y por eso habla con autoridad, y si conviene grita. Acaso no tiene él derechos adquiridos? Muchas revistas se han ocupado de él, y alli le han dicho que és un 'valor de los más destacados de nues- tros plásticos, y luego que ha tenido recompensas y encargos oficiales etc.)

\section{Do Uruguai à Espanha}

Pouco depois de I89o a família Torres García (ele catalão, sua mulher filha de um caucasiano e de uma crioula, Joaquín com I6 anos e mais dois irmáos) deixa Montevidéu onde os negócios de empório e de carpintaria náo correm como o imigrante imaginava. Voltam, então, para Barcelona. O rapaz estuda numa escola de artes e ofícios e, em seguida, em academias, desejando ser pintor.

A capital da Catalunha é um arsenal de atividade e se orgulha de contar com uma juventude que se diz modernista, e quem se opóe à guinada é o resistente e impermeável academismo. JTG, ao mesmo tempo em que pratica pintura, estuda, adquirindo invejável cultura. Cauteloso, mergulha no ambiente. Tem suas próprias convicçóes, observa as polêmicas pululantes como um espetáculo, sem nelas se mesclar.

O Modernismo catalão é um cadinho de sensibilidades tentaculares, ingredientes heterogêneos, prevalecendo o sentimentalismo próprio do fim-de-século, em que se abraçam os propulsores $\mathrm{da}$ renovação moral da Europa, desde os do Impressionismo e do Realismo até o Japoncsismo, e Ruskin, Maeterlink, Morris e os pré-rafaelitas, Auguste Com te, Zola, Wagner, os russos, Ibsen, e tutto quanto. Barcelona tem contato com o mundo, inclusive com os Estados Unidos, sendo Poe, Whitman e Emerson quase de casa. Não faltam as apresentaçóes dos mestres do art nouveau. JTG se impressiona com de Mucha, Toulouse-Lautrec e Steinlen.

$\mathrm{Na}$ frondosa árvore das tentaçóes, o jovem dá sua preferência ao Simbolismo, admira a serenidade sentimental de Puvis de Chavanne, menos Boecklin e Hodler. Simpatiza com o revival Mediterrâneo, do qual participa como alma platônica, no dizer do lançador do movimento, o futuro historiador do barroco Eugênio d'Ors.

É atraído pelo asceta Antoni Gaudí, que o convida para colaborar na reforma e restauro da Catedral de Maiorca. Forma grupo com Picasso, Isidro Nonell, Joaquín Mir, Gargallo, José Pijoan e outros. Decora o Salón de San Jorge, na Mancomunidad de Cataluna. Depois se desentende com os comitentes, pois pinta no mural operários, 
locomotiva, avião, chaminé de fábricas. É o desejo de viver o próprio tempo.

JTG, convencido do cansaço do classicismo incrustado de academia, também da academia modernista, se dispóe a encontrar um mito mais coerente. Opta pela paisagem e o dinamismo urbano. Descobre a cidade: "Por cada calle, miles de agujeros, vivienda de esos millares de individuos. Nuestra ciudad acabo de descubrirla. iQue bella! Encuentro a un poeta. 'Por dónde andrá la poesid, me dice."

Pensa em ambientes que se distinguem por outras liberdades. Barcelona depois das brigas e intrigas lembradas, lhe parece inabitável. Decide se estabelecer em Paris, pensando contar com a amizade de Picasso, lá em posição aureolada de prestígio. Quando encontra o amigo numa viagem explorativa, compreende que alguma coisa não está certa naquela amizade. Decide então tentar a sorte em Nova York. Sabe que é difícil viver de pintura. Lembra-se de ter alcançado sucesso na Galeria Delmau, em Barcelona, expondo e vendendo curiosos brinquedos de madeira pintados. Quer repetir a experiência em Nova York, até montando uma pequena fábrica. (Tinha aprendido a trabalhar a madeira desde menino, na marcenaria do pai, ali construindo suas estatuetas-brinquedos, figuras com partes móveis, já pensando em arte cinética e em Construtivismo.)

Manhattan causa no artista estrondoso impacto: descobre o tumulto da metrópole, ilustra o Canto da Vida Pública, de Whitman. Procura trabalho, conseguindo encomencomendas que não lhe interessam, em teatros e no e no desenho de publicidade, pinta retratos rejeitados pelos clientes. Vende algumas pinturas à Société Anonyme fundada por Maitd Duchamp e Katerine Dreier. Resiste ante as dificuldades.

Desesperado, porém mantendo sua calma, JTG do transtorno americano vai pousar em Gênova, depois na paz de; Fiesole nas colinas de Florença, e se desloca até Livorno, sempre para fazer e vender seus brinquedos; mas na Itália se defronta com a crise provocada por Mussolini, o que o leva a se transferir para Villefranchesur-Mer, perto de Nice, e ali recomeça a fazer brinquedos. Deve sobreviver.

\section{A experiência de Paris}

Da Costa Azul o próximo destino, seguindo conselho de Vicente Blasco Ibánez, é Paris: "Alli tiene usted un campo digno de su ambición."

A primeira pousada da família é em Montmartre, em 26. Começam as decepçóes, a ambientação é fatigante. Os tempos são de revisão, a Escola de Paris vive de lembranças, repetiçóes e relançamento de tantos ismos, etiquetas que os artistas escolhem para alegorizar suas preferências técnicas ou sentimentais. $\mathrm{O}$ artista vindo da longíqua América Latina, isolada e pobre de motos propulsores de discussão, progresso e agitar de ideologias, vai se interessando agora pelas tendências que reduzem a representação às sínteses geométricas e figurativas, evitando os termos da anedota sociológica. Não é rápida e muito menos fácil a escolha das preferências de uma ou de outra poética.

JTG faz, então, amadurecer uma proposta sua, participando do clima centrifugador da batedeira parisiense pleno de ideias e aventuras, a contraproposta sendo lei de improviso manifesta uma sua formulação teorética realista não faltando nelas evidentes sintomas de certo gosto popularesco tão próprio do encanto americano, um sabor de primitivismo, certa independência que os mais conceituados artistas do Novo Mundo demonstram no operar, desde Rivera até a Action Painting.

Da pintura do uruguaio emana um senso de América: tem estruturas que parecem sugeridas pelas muralhas ciclópicas de Cuzco e pelas esteias astecas. Pode-se descobrir signos africanos e dos aborígenes da Austrália. (Este pensar sobre as origens do Continente ocorre tam- bem com os brasileiros mais vivos: Oswald de Andrade, como reaçáo ao bem penteado europeismo, volta e lança o manifesto do Antropofagismo; Tarsila do Amaral, depois da aprendizagem na escola de Léger, pinta o festivo e pacato que intitula Pau Brasil, participando também da iconoclastia de Oswald; Vicente do Rego Monteiro se serve das experiências parisienses para acionar seu plano indianista e caboclista.)

Chega, finalmente, o momento de JTG: funda, com Michel Seuphor a revista e 
movimento Cercle \& Carré, que origina uma exposição programática, da qual participam com ele, Arp, Baumeister, Léger, Le Corbusier, Kandinski. Mondriani, Ozenfant, Russolo, Pevsner, Prampolini, Sartoris, Huszar, Schwitters, Sophia Taeuber, Gorin, Vantongerloo.

JTG pensa agora na nova etapa: Madri. Passa lá um período de transitoriedade sem resultados. Um ano depois muda de cidade. Deveria se dirigir ao México onde lhe oferecem uma cátedra. Fica indeciso. Nosso caro itinerante retorna a Montevidéu de onde se afastara por vários decênios, Saudade? Desembarcando na terra natal, acha a superfície de Montevidéu bem envernizada, porém atrás da situação o recém-chegado vê "si, un enorme, espantoso desaliento." Descobre que o público ri diante de obras respeitáveis: "Rie su própria ignorancia.” Apesar do ambiente, JTG ventila mais uma ideia, qual a de uma possível unificação americana através da arte.

Trata-se, evidente, de um pensamento generosamente idealista e característico dos utopistas. Acreditava ou sonhava: "De toda America hoy surge un gran deseo de unificación. Y si algunos pueden interpretarlo en un sentido politico estrecho. nosotros. sin perder de vista lo primor-dial, debemos contribuir en eso sentido, desentendiéndonos del otro. debemos ir a lo profundo, despreciando lo material y que no debe entrar en nuestra cuenta." Acrescenta: "No es, esto que promonemos, um 'panamericanismo', sino union espiritual, por vinculación en lo profundo..."

JTG, ingênuo e apostólico, mais parece um romancista de ficção. Funda uma Asociaciôn de Arte Constructivo. Ignora a melíflua indiferença e a preguiça do ambiente.

Alguém o avisa: "Usted va a fracasar, usted no conoce el ambiente de aqui y se hace ilusiones; esto, amigo, no es Europa." JTG não acredita. Vai ao encontro do que julga vulgaridade desesperante. Às vezes desconsertado, mas vigorosamente reanimado, enfrenta com firmeza a incomprensão. Sua disposição de operar, imaginar, estar presente, se adaptar e dominar é sumamente admirável.

\section{O Construtivismo Universal}

No itinerar pelos dois mundos, JTG andou revigorando sua ânsia de inovaçóes. Sabe muito bem que a originalidade pode ser um dom natural, mas é também uma laboriosa conquista em que a paciência, gozo da liberdade, sensível, gosto pela discussão, servem para alcançar resultado desejado. Para JTG o ciclo de sua arte é positiva de eventos: evoca a participação amestradora da experiência classicista; a descoberta da poética da cidade, o aglomerado, confusão e estética dos elementos que compóem; a descoberta do geometrismo e a seção áurea; e o encanto dos símbolos-coisas. Agora ordena sua visão, resume, sintetiza, propóe o definitivo. Os anos do retorno são profícuos, repletos de iniciativas.

As fases para modular o Construtivismo Universal são JTG passa gradativamente do figurativo ideal, sugerindo uma lei que apelida de "frontalidad: ritmo, proporción, equilibrio, ordenamiento: unidad." A natureza no sentido paisagístico tradicional, como reprodução figural pouco lhe interessou. Interessou-lhe mais o fantasmagórico do cotidiano.

Compóe num conjunto de quadrados e retângulos, dispondo-os conforme uma inter-relação substanciosa e condicionada em concretas dimensóes espaciais, os compóe numa euritmia geométrica, dando-lhes unidade e, ao mesmo tempo, variando suas dimensôes, reduzindo as figuraçôes à Uma medida igualitária, as estruturando num sistema geométrico-gaiola: proposta de uma outra lógica, o als ob, de Kant, as coisas representadas como deveriam ser, a sua "real realidade."

JTG apelida sua teoria de Construtivismo Universal. Por universal entendia uma arte aceita, válida e grata a todos, a antiga proposta setecentesca de David Hume e similar da lembrada de Doesburg: chegar a uma regra do gosto através da qual concordar os sentimentos dos homens: realidade impossível de ser alcançada, e que deve ser colocada na cornucópia das generosas utopias.

O desejo do universal é a sua regra moral, o antiindividualismo, a subordinação do indivíduo ou da comunidade. Despreza o hedonismo. Em La Ciudad 
Sin Nombre, que poderia ser o testamento espiritual, o poeta-filósofo-pintor, entra numa comunidade onde os personagens são simples números, sem realidade humana, participantes do drama do mundo atual: "Entre los valores ideales del espiritu, universales y eternos, y los interesses materiales, individuales o coletivos..."

Quando JTG volta de outro Continente, reencontrando e redescobrindo a terra que o viu adolescente, quase para compensar o esquecimento de tantos decênios, amadurece o princípio do americanismo. Depois de ter "recogido las ultimas vibraciones tocantes al arte en Europa," reflete e insiste na vinculação com a tradição arcaica da América, afirmando-se tratar-se de um "critério que creemos haber fijado nosotros por primera vez..."

Depois das experiências ocidentais, JTG sonha o revival da "perfecta y asombrosa cultura" indo-americana. (No Brasil tivemos os mesmos casos, além dos já citados o de Theodoro Braga, enamorado do indigeanismo da ilha do Marajó.) O visionário quer o retorno da "tradidón autóctona de este hemisfério," necessitado de se identificar com as culturas indo-americanas.
Em sua juventude, quando JTG está fascinado pelo esplendor da arte do Mediterrâneo, pensa no tempo que vive: "Busquemos lo eterno en lo nuestro, como hicieron los griegos..." Em outra oportunidade escreve no livro El Descubrimiento de sí Mismo: "Para qué vivir en el passado? Observamos con calma el actual"; e mais: "Fuésemos. pues, como fueramos, puros y compostos, con sangre o no indigena, por el hecho de haber nacido aqui, nuestra consigna debiera ser, y fuésemos de Chile o de Mexico, del Plata o del Brasil: 'buscar a América: profundizar en la viva entrana de la tierra; arraigar definitivamente en ella; crecer, existir para este suelo; y ya sin mas veleidades europeas. Construir. Formarnos. Crear."

Percorrer as ilusóes, os acertos, as sondagens do impossível de ser revelado, o perlustrar e o curiosar nas volutas das fantasias, o gosto do real posto logo em questão pelo irreal: um prazer, e mais um modo para entender a manifestação de JTG, o queridíssimo indio sul-americano descrito por Michel Seuphor: "Effigie patinée par les siècles et en même temps creusée, ravinée comme ces hautes terres arides sur lesquelles les humeurs du ciel s'exercent sans pitié."

America Latina, ser ou não ser: este mundo existe além do geográfico? p.IO4-IO5

Texto de Felipe Herrera, presidente do Conselho Administrativo do Fundo internacional de Promoção da Cultura do México; cf. Anexo B, p.65I

A ARTE PROTESTANDO, p.IO4

$\mathrm{O}$ artista chileno Roberto Matta, nesta sua obra (A Traição dos Roses, c. I953, óleo sobre tela, 87 x II $2 \mathrm{~cm}$ ) carregada de dramaticidade evocou o caso de Ethel e Julius Rosemberg, justiçados na prisão de SingSing sob a acusação de terem transmitido aos russos segredos da bomba atômica. $\mathrm{Na}$ última carta de Ethel, aos filhos, afirmava que um dia a história vai fazer justiça.
Dois anos atrás o caso Rosemberg voltou à tona, e uma comissão luta por reabrir o processo feito no tempo da caça às bruxas, como um caso que toca a consciência de uma nação. A tela de Matta é a generosa participação de um artista num dos fatos da convulsão política americana. Durante a Guerra Civil da Espanha, Picasso pintou Guernica. Coleção particular, São Paulo.

\section{BUROCRACIA NACIONAL E ARTE LATINO-AMERICANA. UM ENCONTRO INFELIZ.. p.IO6}

Em 1966 o Museu de Arte de São Paulo apresentou à Organização dos Estados Americanos um detalhado projeto com vistas à organização e publicação de um Dicionário das Artes Latino-Americanas. Após a aprovação do ambicioso projeto seria constituído um centro de pesquisas a fim de que equipes de vários países do Continente redigissem o dito dicionário.
O projeto previa uma indagação metódica de toda a história partindo desde as grandes civilizaçóes até as manifestaçôes contemporâneas: um levantamento geral das artes, a ser feito também na Europa. Elaborado o projeto, este foi submetido à apreciação da OEA, que o considerou do maior interesse, particularmente sob 
o ponto de vista da coesão dos países participantes. Mas a malfadada burocracia brasileira entrou em cena opondo entraves que não foram superados, e assim o projeto acabou no Ministério da Educação e Cultura, sendo que seu titular, Tarso Dutra, numa longa entrevista radiofônica o ilustrou demoradamente. Depois da fala ministerial nunca mais se falou no assunto, sendo vãos os esforços do Masp visando a tornar realidade um fato da maior importância para a cultura.

Felizmente o problema de uma investigação sistemática da arte latino-americana está prestes a ser encaminhado para uma solução, desta feita sem interferências burocráticas, pelo menos brasileiras, pois sua sede será em New Haven, Connecticut, Estados Unidos.

Trata-se do Center for Planning Latin American Handbook of Art, uma instituição fundada pelo National Endowment for the Humanities e que reúne um grupo de estudiosos americanos e latino-americanos. Seu objetivo é publicar um Manual de Arte Latino-Americana, isto é, o Dicionário anteriormente proposto à OEA.

Diversas entidades do Continente colaboração nas pesquisas, que serão coordenadas pela prof. Joyce W. Bai- ley. Os países são divididos por seçóes, correspondentes em parte às divisóes geográficas: Seção I - México, América Central, Sudoeste dos Estados Unidos (provavelmente área de influência hispânica) e Caribe; Seção II - Zona dos Andes: Venezuela, Colôm-bia, Equador, Peru, Bolívia; Seção III - Brasil, Guianas e Suriname; Seção IV - Cone Sul: Chile, Argentina, Paraguai e Uruguai.

Os organizadores se propóem a abordar os mais variados aspectos do desenvolvimento das artes e da cultura latino-americanas, objetivando dar uma visão global. O único fato para nós que soa estranho é que as línguas escolhidas são o inglês e o espanhol, ficando o português de fora. No projeto do Masp três seriam as línguas: português, espanhol e inglês.

Lamentamos apenas que nossas autoridades tenham permitido que a magna iniciativa parta dos americanos e não dos brasileiros.

Direita, ESQUerda. A ARTE SUblima A POlítica, p.io6

Há alguns anos que as atençóes estão voltadas para a pintura dos mestres latino-americanos, determinando assim uma revisão crítica não só a respeito do seu valor criativo, mas também quanto à influência que exerceu em outras áreas, notadamente a norte-americana. Notável um ensaio de Leslie Judd Ahlander publicado no último número de Américas: Os Muralistas Mexicanos e a Escola de Nova York.

Anota a antiga organizadora do programa Artes Visuais da Organizaçáo dos Estados Americanos que "é corrente a ideia de que a influência tende a ser derivativa e eclética, curvando-se às influências de Barcelona, Paris e Nova York. Artistas latino-americanos, cujos nomes adquiriram importância internacional, são muitas vezes referidos como membros da escola de Paris ou da escola de Nova York, ignorando-se, sem mais nem menos, o seu berço.

Dessa forma, Roberto Matta, Jesus Soto e Wifredo Lam são considerados membros da escola de Paris, enquanto que artistas como Marisol, Maurício
Lazansky, Antonio Frasconi, entre outros, são tidos como pertencentes aos Estados Unidos. Poucos indivíduos versados em arte em Nova York saberiam informar que Marisol é venezuelana, Matta chileno, Lam cubano, Lazansky argentino, Frasconi uruguaio, apesar de estes artistas usarem temas especificamente indígenas em sua obra. Presume-se que aprenderam tudo que precisavam saber em Paris e Nova York."

Realmente, logo depois da crise que abalou os Estados Unidos em 1929, o público se voltou para outras alternativas filosóficas e o esquerdismo político passou a ser aceito. O movimen- to se propagou pelas universidades e pelo mundo artístico. A época era propícia à aceitação de uma arte do povo, pública e de cunho propagandista e a escola muralista mexicana empolgou a imaginação de intelectuais por toda parte.

Entre os que sofreram a influência o crítico aponta Jackson Pollock, Philip Guston e James Brooks, sem contar o episódio do jovem Ben Shan que, impressionado com a posterior destruição do 
mural de Rivera no Rockefeller Center, se ofereceu como aprendiz do mexicano. Diz Ahlander que não era possível naquela época ser artista nos Estados Unidos sem levar em conta os pintores mexicanos.
De qualquer maneira, os muralistas centro-americanos, pela marcante posição política contrastante com o liberalismo estadunidense, acabaram voltando à pátria. Porém, resta uma dívida em relação a eles, hoje em vias de reavaliaçáo.

Cuba libre. Mas a SUA PRODUÇÁo De ARTE um tANTO PRISIONEIRA, p.IO6

Quem se interessa pela cultura latino-americana. num sentido total, isto é sem preconceitos nacionalísticos ou ideológicos, considera o que a República de Cuba está realizando, uma atividade que não encontra paralelo em nenhum outro país do Continente. (Sem contar o Brasil que neste campo é um deserto habitado por uns quatro gatos pingados que se agitam sem despertar a menor atenção.)

O que a ilha do Caribe combina no registrar e incentivar a cultura que apelida de Nuestra America, naturalmente puxando o carro para os horizontes políticos socialistas, é singular, e deve ser considerado pelo vigor que se dá ao desenvolvimento cultural em todos os campos. (Uma avalancha de fatos em comparação ao nosso Brasil, à espera do advento de uma política despojada de burocracia não tanto cunho latino-americano, mas certamente te de cultura brasileira mesmo.)

Cuba, logo depois da independência estabelecida por Fidel, conta com a Casa de las Américas, oficina de ajustamento do que se produz no Continente nos setores da literatura, musica, teatro, artes plásticas, e "en todo lo que oferezca possibilidades y la iniciacione para el conocimento y la profundización del Hombre de Nuestra América y en el ahondamiento de su conciência politica y cultural."

TV E COMUNICAÇÃO, p.IO7

A Fundación Cultural Televisiva do México se distingue das outras estaçóes similares por se interessar mais pelas manifestaçóes de arte. Além de transmitir programas dedicados à história e especialmente à arqueologia, forma grandes coleçôes de video-tapes que divulga em outros países. Eis uma iniciativa que a Organização dos Estados Americanos poderia tomar, animando um intercâmbio destas comunicaçóes hoje em dia fáceis de circular pela América Latina. Da parte brasileira o ponto de partida seria o programa "Arte do Brasil' que a TV Cultura, Canal 2, preparou, dirigido por Pedro Manuel Gismondi.

Cultura, ReCursos, p.IO7

"Se houver uma área que transcenda as consideraçóes políticas, esta terá de ser a da Cultura. Por outro lado, se houver uma área em que as necessidades e oportunidades são gigantescas e o apoio financeiro frequentemente escasso, terá de ser também a da Cultura. É imperativo, portanto, que os promotores e paladinos do desenvolvimento cultural redobrem os esforços conjuntos e tirem o máximo proveito dos recursos disponíveis:" é a filosofia da Unesco e da OEA, que vai de vento em popa nos Estados Unidos; menos na América Latina.
DAS RAÍZESS PARA O UNIVERSAL, p.IO8-IIO

Como descobrir hoje a origem de uma obra de arte? Quando é figurativa, ainda é possível, por parte naturalmente dos que entedem e têm uma experiência. Porém, quando a obra é a-figurativa ou abstrata, ou pop, ou conceituai, a identificação é sem solução, a menos que uma etiqueta advirta que se trata de autor de tal país.
No que se refere aos artistas latino-americanos que mergulham nas tendências universalizantes, a decifração das origens determina o mesmo problema que se dá nos outros países, como se viu agora em Roma, na exposição que o Instituto ÍtaloLatino-Americano organizou da gravura do Continente. Desta mostra exibimos ilustraçóes que revelam o conflito das tendências: na da esquerda, de cima para baixo, da 
esquerda para a direita: Carlo Colombino, do Paraguai; Ines Blumencweig, da Argentina; Peter Mussfeldt, do Equador; Antonio Diaz Cortez, do México; Ugo Demarco, da Argentina; Mareia Rothstein, do Brasil e Bencan, de El Salvador.
Na página à direita: José Luís Cuevas, do México; O. Mendoza Nunez, de Honduras; Antonio Joseph, do Haiti; Carlo Bernarconi, do Peru; Fremer, de Cuba e Isa Aderne, do Brasil. É evidente que as artes, geograficamente, deixam de ser as terras onde se produzem.

O ARTISTA MENDIGO, p.IIO

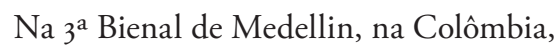
o argentino Carlos Ginzburg, ao invés de expor obras, vestiu-se como os ambulantes que propagam nas ruas, portando cartazes. Ele autodefiniu-se como O Artista Mendigo. Dizia o cartaz que carregava: "Um artista não é, como opinam os pedantes, ou os funcionários do Estado ou o público em geral, um cavaleiro desembaraçado que, em sua louca alegria, lança, de quando em quando no mundo, suas obras de arte. Na maioria dos casos, é um pobre infeliz que, afogado numa riqueza inútil, há que desprender-se de algo seu. O mito do artista feliz nada mais é que tagarelice de profanos. Ninguém sabe o porquê de tudo isso. Um artista sério e que se respeite, deve ser desditoso na vida. Cada vez que tem fome e abre a geladeira, encontra ideias em lugar de alimentos."

Casa Vogue \#8, outubro-novembro-dezembro de I979, p.II3

ANTIQUA, SIMBIOSE DE DOIS MOMENTOS

Um novo centro dedicado ao movimento do antiquariato é oferecido aos que gostam da memória do Brasil e, naturalmente, dos outros países. Iniciativa de Vera Andraus e Isaac Catap, animadores de Antiqua, na rua da Consolação, nº 3115 .

O idealizador da apresentação-decor foi Ugo di Pace que, tendo experiência nas coisas que se foram e ao mesmo tempo, das vivências do presente, desenhou um ambiente no qual se interligam os séculos, com a simplicidade criativa que lhe é própria.

A Antiqua é a simbiose de dois momentos: se ascende, passado numa grande sala onde móveis, pinturas, esculturas, objetos formam um conjunto raro de se ver, escolhidos com gosto e olho técnico, para depois subir a um recinto obtido num mezanino: um espaço destinado a exposiçóes de artistas da linha avançada. A primeira manifestação foi a mostra dos desenhos de Zaragoza, o manipulador excêntrico de formas inusitadas, emergentes pelo encanto de seu bem conhecido capricho. Antiqua entáo: um mesmo ambiente que acolhe o moderno, o qual, afinal, é a síntese do que se passou no tempo, e o antigo, que sempre preside e estima. Eis um antiquariato-galeria que, sem dúvida, terá imitadores: a fórmula do Ugo, o qual concebe a decoração como integração de tempos, pois a arte não é nem antiga nem moderna, mas arte, sem limites de espaço, época, território.

Senhor Vogue \#20, novembro de I979, p.IO4-II5 (Senhor e as Artes) I $5^{\text {a }}$ BIENAL

É mais que sabido que a Bienal sempre foi prenhe de defeitos, acumulados desde a primeira manifestação, porém, não inferior à dos tempos em que o ordinarismo andou em conúbio com a desinformaçáo. O esforço foi correto, mas certamente poderia ter sido melhor. O que foi oferecido é, como se diz na gíria, sempre vinho da mesma pipa. Ou então que cada um dá o que têm. A impressão geral é que a arte está passando por uma fase de revisão e de reformulação no mundo inteiro, já que a pintura e a escultura são mostradas como uma manifestação em si, mas até mesmo posta em cheque em face da avalancha conceitualista que cogumela no Velho e no Novo Mundo.

Não é o caso de maratonizar esta bienal recém-inaugurada. Vai-se constatando, de dois em dois anos, aliás de ano em ano, para não dizermos abertamente de mês em mês, que tais desfiles de pinturas 
acabaram cansando os mais voluntariosos, os distinguidos com o apelido de amadores.

Seguir, talvez não aprofundadamente o que se passa no mundo da atividade que se vangloria de conglobar nos amplos limites das artes plásticas, é empresa na verdade para profissionais. $\mathrm{O}$ mesmo acontece com as demais artes, tais como a música, o teatro e a própria literatura. (Só cientistas de alta cultura sabem que num instituto berlinense, que cuida do registro de doenças, tem uma lista computorizada de trezentas mil enfermidades; isto só para ficarmos na área da ciência.)

Agora impingir a um visitante milhares de telas ou painéis dispostos ao longo dos famosos sete quilômetros, conforme o antigo slogan bienalesco, é francamente demais.

Estas são observaçóes feitas e repetidas ao longo de trinta anos, recomendando que não se deve correr atrás de delegaçóes de dezenas de países convidados, que pensam ser as salas da bienal um encher linguiça. Nesta edição bienalesca existem salas que, se reduzidas à metade, ou melhor, a um quarto, seriam mais legíveis, inclusive a de seiscentos metros quadrados dedicada (e muito justamente dedicada) a Oscar Niemeyer.

Mais uma vez é preciso que se diga que o sistema da exposiçáo deve obedecer a uma inteligente síntese, e não a simples enchimento. (Todos estáo lembrados da I $4^{\text {a }}$ Bienal quando foi oferecida uma visão quase total da obra de Rufino Tamayo, que resultou num autêntico desastre sob o ponto de vista da formaçáo de uma ideia da personalidade do mestre mexicano.)

Sem contar a topografia do edifício ibirapuerano, que foi concebido não para funcionar como local de exposiçóes de arte; fica-se a pensar que os fatores favoráveis a uma reformulação da Fundação (à qual seu patrocinador surpreendentemente não deixou um único centavo, pois preferiu deixar centavos e barôes aos sobrinhos queridos, os quais, por sinal, já tinham e têm tantos) são numerosos, sendo o principal o de uma sede mais apropriada. (É penoso ver os escritórios divididos com tabiques que convertem o santuário bienalesco em autênticos tugúrios.)
Passada a festa de inauguração, um pretexto de muitos que certamente nem sabem o que é uma bienal, mas que para lá correram para ver o presidente, (que não compareceu) é de se esperar que mais uma vez náo se verifique o caso do assento que Napoleão mandou pintar, postando ao seu lado um gendarme para que ninguém nele se sentasse, deixando-o secar; e por não ter o vencedor de Austerlitz dado ordem para que, depois de seco, o guarda fosse retirado, $\mathrm{o}$ assento continuou devidamente vigiado.

Será que o presidente da Fundação Bienal que, apesar de ter descascado vários abacaxis, fez o máximo para realizar esta bienal, bastante rica e bem apresentável, não conseguirá ligar seu nome ao imprimir uma renovação técnica, administrativa e estética ao já veterano evento?

Tem muita gente querendo que isto ocorra.

$$
\sim
$$

Um despretensioso cultivador de abacaxi (não local) chegou a propor aos organizadores da bienal que não ignorassem um fato, talvez o principal, qual a da produção do passatempo chamado arte.

O que se andou ignorando foi o Mercado. É verdade que os artistas, com os pés descalços pisando tapetinhos de pele de leopardo de tenra idade, com a cabeça na estratosfera da fantasia, a inspiração sagrada perlustrando no atelier; os artistas despachando as telas e objetos silentes; é verdade que não pensam em produzir uma mercadoria, pois produzem arte por mandato divino e, se náo divino, pelo menos por sugestão de alguém de alguma entidade espiritual mirim.

De acordo. Ainda não foram cumpridos os tempos da arte pela arte, nutriçáo do espirito, cartão de visita das civilizaçóes. De qualquer jeito, prosaicamente, o artista precisa se sustentar e, se possível, dar-se ao luxo de possuir um carrinho e outras tantas regalias.

Para satisfazer suas necessidades, ele deve encontrar quem lhe compre o que faz. (É verdade que, agora, quem vai cuidar da tarefa de comercializar a produção artística é uma cooperativa, fundada por artistas que operam na Athenas do Brasil.) 
Para vender, o produtor encontra vários elementos e entidades para escoamento da produçáo; bienais, salóes, amadores, feirantes, mascates; (se alguém os conhece, será favor dar um telefonema discando I85-4899, entender-se com d. Ermenegilda) e aí aparece o marchand, o acusado como atravessador, o tal que suga o sangue do coitado do pintor ou do escultor. (Telefonar para o número acima para saber se existe alguém capaz de fazer um retrato.)

Noventa por cento dos artistas na Europa e nos Estados Unidos aspiram contratar um marchand. Os mais hábeis conseguem-no, e fazem carreira. Temos, hoje, para dar um exemplo, marchands que representam nada menos que uma centena de bons elementos de circulação mundial. Se um artista como Bacon conta com um marchand é evidente que o negócio lhe serve.

Para sermos francos: também aqui na Athenas cabocla existem galerias que procuram sobreviver, vendendo a mercadoria pintura ou escultura; naturalmente coisas vendáveis; mas fiquem certos de que se a moda é de bandeirinhas, de galos, de Vênus Infladas, naturezas petrificadas e mais quejandos, os senhores fabricantes as produzem às pampas, sem descansar, como manda o Senhor até mesmo no domingo, pois têm como lema: "Produzir para vender." O artista, desde o advento do Romantismo, é condicionado pelo mercado, isto é. tendo em vista o gosto dos que compram, e a manipulação do gosto é exercitada pelo personagem denominado marchand. Naturalmente não a Fulaninha que, depois de ter despetalado a margarida (butique, galeria, botequim etc.) abre (com coquetel) sua própria loja. Fala-se, para entrar no assunto, de galerias comerciais de arte, como, por exemplo: Malhorough, Knodler, Castelli etc.

São estas potentes organizaçóes que propagam o belo ou não belo e, ao mesmo tempo, através também de influentes relaçôes com a assim chamada crítica, no setor da própria estética, que tornam os produtos conhecidos do público consumidor. (Quando Rosenberg deixou de vender a Metafísica de De Chirico, sugeriu que o mestre passasse a pintar cavalinhos com fundo de templos gregos, e a crítica tentou justificar a decisão: era para vender, tanto no atacado como no varejo.)

A proposta a ser feita à bienal é a de que ela convide os bigs do mercado mundial para que exponham seus poulains e os novilhos, para que o público fique ao corrente do internacional show, e saiba como funciona o mecanismo mercantil do setor. Sem dúvida a performance alcançaria sucesso e poria a descoberto um lado da vivência das artes do século que esta declinando.

A pergunta (qual o futuro da bienal ) é formulada pelos práticos desta antiga novidade do amostrar arte. Após numerosas ediçóes do tradicional certame, esta indagação, tem sua razão de ser.

Contudo, as respostas são sempre vagas e incertas. Más não podia ser diferente. Bastante acertadas as que, tendo presente a evolução dos tempos, afirma a oportunidade de - no caso da mesma continuar - bisturizar e bolar uma daquelas reformulaçóes dignas do adjetivo "histórica." O dilema - continuar ou fazer ponto, final - não é de fácil solução, pois em geral a bienal é como os salóes que são detestados e muitos gritam para acabar; no entretanto, de ano em ano são inauguradas de novo.

Liquidar a bienal; mas como? Com todo aquele volume de verbas disponível seria uma pena perdê-la e sepultar um mecanismo montado com ingentes esforços. Salvo melhor juízo, o que deveria acabar é a burocracia bienalesca a fim de rejuvenescê-la, remaquilá-la, injetando-lhe generosas doses de adrenalina, face a um corpo já combalido.

Tempos atrás estas observaçóes foram escritas por Jacob Klintowitz na revista Istoé, ${ }^{48}$ ocasiáo em que elencou os que ocuparam cargos de relevo nos escritórios do Ibirapuera, em uma escala de fazer inveja a um catálogo telefônico, num vaivém que nos recorda um teleférico.

Será que não aparece um êmulo do prof. Zerbini, capaz e prático na antiga

48 Jacob Klintowitz. "XV Bienal de São Paulo." Istoé \#I42, I2 set 1979, p.65, Artes: Grande Vexame; cf. Anexo B, p.65I. 
novidade de amostrar arte e afins, com vistas a um transplante de mentalidade?

Os laureados nas bienais, em três décadas, foram, em media, uns vinte por edição, constituindo-se assim num verdadeiro festival de prêmios outorgados a mestres da tradição e da vanguarda, que ocuparam os 32.600 metros quadrados do infeliz pavilhão do Ibirapuera. As enchedoras de curriculuns foram, no passado, as comissôes dos críticos convidados, elementos às vezes à altura, enquanto outros eram manipulados pela esperteza dos representantes nacionais, conseguindo desviar a água revigorante para os próprios moinhos, premiando nada menos que 43 artistas locais: um número gigantesco, internacionalmente falando. Sobre o sistema ridículo de prêmios, só tolerados nas corridas de cavalos inútil opinar. Premiar Moore, Léger Morandi etc., era o mesmo que levai vasos à Samos. Mas, felizmente, a premiação foi cancelada pela atual presidência da bienal, o que significa um passo à frente no difícil caminho que a entidade tem de percorrer.

Os conceitualista s. aqueles que propóem como produto arte um qualquer fato da vida, como, por exemplo, um tal subir numa cadeira e lá permanecer imóvel como se tora uma estátua; os conceitualistas, nesta bienal, encontram mais colegas, não inscritos na mostra, porém nela exibidos. Foram, estes participantes. as autoridades presentes e chefiados pelo jovem e valente governador de Sáo Paulo.

Depois da enxurrada de discursos, (festa sem discurso é como orquestra sem trombones) as autoridades passaram a desfilar diante dos estandes. correndo à velocidade de um foguete.

O costumeiro cronometrista registrou que cada uma das duas mil obras expostas recebeu, exatamente, por parte das autoridades inaugurantes, uma atenção de segundos 0,0105, pois a inspeção durou exatamente trinta minutos.

Como diz o apresentador do jornal da TV canal I3: "Estas as notícias, a conclusão é sua."
Com todo o respeito que votamos às autoridades, eleitas pela via direta ou indireta, chamadas para presenciar a uma cerimônia de abertura de uma exposição internacional, seja ela de arte ou de bovinos, somos de opiniáo que tanto as pinturas como as vacas, pelo simples fato de estarem sendo exibidas merecem um pouco mais de consideração.

Por outro lado, bem sabendo que as autoridades não estão interessadas nem em artes e muito menos em pecuária, nossa conclusão é que, afinal, esta comédia inauguradora deveria ser abolida por decreto. Ela, a inauguraçáo, faz parte de um sistema mundanístico superado, sem graça, repleta de chefôes que têm seus olhos voltados para o relógio, pois náo vêm a hora de embarcar no carro oficial e retornar aos seus pagos.

Repetimos: festa sem discursos e sem autoridades é festa?

O que chama atenção nesta $\mathrm{I}^{\mathrm{a}}$ Bienal é a ordem. Salas bem distribuídas estrategicamente para que a exposição seja vista por inteiro, sem aquele confinamento de participaçôes de menor porte e geralmente despachadas para o terceiro andar, muito acertadamente inquinada de deserta.

Em nossa opinião uma exposição de arte deveria ser por si mesma um fato integrados com aquilo que se apresenta. Mostrar é espetáculo, é fazer saber e compreender; numa palavra; teatro. Organizadores capazes de inaugurar uma ruptura na rotina poderiam introduzir, no espetáculo de uma bienal, uma série de motivos corroborantes para melhor entendimento do que é exposto, dando e afirmando um significado orientador e geral, uma explicação para que o visitante receba um impacto global. Principalmente quando se trata de comunicar-se com um público, senão despreparado, pelo menos náo preparado para ver.

Por outro lado, numa exposição por sim mesma cansativa, (para ver seriamente ou mini-seriamente duas mil obras são necessárias pelo menos umas trinta horas) seria recomendável boa distribuiçáo de bancos ou cadeiras, apresentação de audiovisuais, cortinas musicais: outras complementaçôes. 


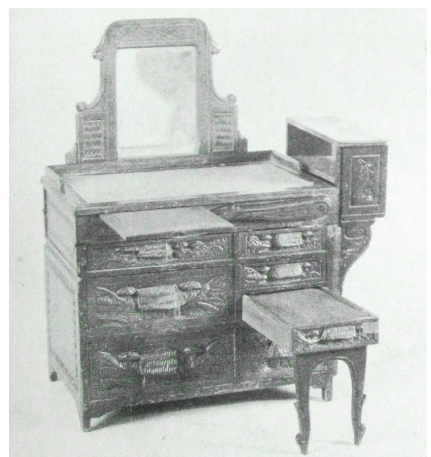

O móvel polivalente
Somos de opinião que uma parte das polpudas verbas destinadas às bienais deveria ser gasta justamente na melhoria da comunicação, ou melhor dizendo, da didática. De fato, o fruidor destas manifestaçóes em geral (a começar pelas autoridades que as inauguram e das dondocas que acorrem para mostrar suas toilettes que correspondem ao último grito da moda) náo está preparado para compreender os problemas da arte contemporânea, difíceis de serem assumidas até por aqueles que se interessam profissionalmente.

Concluindo, será que no futuro os que vão às bienais (sem nenhuma exclusão) saberão alguma coisa mais e assim entender um pouco melhor o que o pessoal pretende lhes comunicar?

A última novidade como técnica expositiva é a dos documentários filmados que substituem as obras originais. Assim o foi para apresentar Henry Moore e Bárbara Hepworth, os dois ingleses premiados na $2^{\mathrm{a}}$ e na $5^{\mathrm{a}}$ bienais respectivamente.

Os visitantes que pensavam se extasiar com as obras originais dos dois monstros sagrados tiveram que se contentar em vê-los na tela: coisa para brasileiro ver.

Um crítico local muito conceituado disse que o sistema é bom, pois sentados muito comodamente poderão ver arte, pois com o atual calor senegalesco não é possível plantar-se bipedemente.

Depois de uma bem orquestrada campanha dos eternos do contra para crucificar a bienal, autêntica decisão de Maramaldo, já que o guerreiro estava lamentavelmente ferido (todos ou quase todos conhecem a história de Ferrucio Ferrucci) as coisas continuam como antes e o novo ministro Bulhóes nada pode reformar para erradicar a burocracia. A bienal cansada e, como dissemos, ferida, continua com ares de quem náo pensa em ser desativada, pois quando está em jogo o magnífico cabidão de empregos tudo se concentra no jogo da tolerância, do deixa como está para ver como fica.

O sistema é errado, pois é consular ou itamaratinesco, está superado, se bem que alguém já tenha afirmado que as bienais de Veneza (mãe da paulistana e de todas as outras filhotas) sofrem do mesmo mal. Quando surgiu esta bienal as composiçóes ferroviárias marchavam a quarenta quilômetros por hora.

Mas: pois é, pois é: como renunciar a um dos raros lazeres ibirapueranos? Os frequentadores do parque têm seus direitos de tempo livre, e as senhoras da gloriosa sociedade do Tavares de Miranda precisam de mais uma passarela, mesmo que seja por breves períodos.

Senhor \#22, janeiro de 1980, p.94-97 (Senhor e as Artes)

A DESCOBERTA DO MÓVEL POLIVALENTE

Cômoda, toucador, escrivaninha, estante e cama

Um incrivel móvel polivalente, que de escrivaninha chega até a virar cama.

Não é todo ano que um antiquário (atividade da qual nunca me ausentei e que sempre me deu gratas satisfações ao longo da minha já não tão breve vida) descobre um objeto como este que ilustra estas páginas, e que eu reputo como sem precedentes.

Trata-se de um móvel construído para desempenha as funçóes de todo o mobiliário necessário a uma casa, sintetizando o indispensável, compacto para ocupar um espaço mínimo e, no que se refere à sua estética, decorado pelo seu autor com uma série de entalhes em alto relevo de finíssima feitura.

É obra de Pedro Antônio da Silva, nascido na cidade de Amparo, em I862, e falecido em São Paulo em i92I. Sua família é ilustre já que seus pais eram filhos dos Ramos Pimentel, fundadores do município de Bragança Paulista.

Formando-se como professor, Pedro Antônio preferiu dedicar-se à agricultura situando-se na região de Ribeirão Preto. Temperamento vivaz, intrépido abolicionista e patriota ardente, alistou-se nas forças que propugnavam pela implantação do 
pais do regime republicano, fazendo-o sob a bandeira do marechal Floriano Peixoto.

Serve nas fortalezas de São João e do Lage, no Rio de Janeiro, participando das campanhas emergidas no Sul, sob o comando do tenente-coronel Salustiano Quintanilha, de quem obteve a patente de tenente.

Por ocasião dos movimentos militares demonstrou ser dono de conhecimentos logísticos: Pimentel desenhou e construiu uma cama portátil, que surpreendeu por sua leveza e múltipla praticidade. Voltando aos seus afazeres, póe-se a estudar e desenhar um móvel capaz de servir às mais variadas utilidades. Preparou um modelinho, e depois um marceneiro realizou o exemplar sob sua direção. A peça $(97 \mathrm{~cm}$ de comprimento, $57 \mathrm{~cm}$ de largura, $80,7 \mathrm{~cm}$ de altura, números que misteriosamente terminam 7) constitui o primeiro exemplo conhecido de um móvel de campo ou como outros pensam, para uso em viatura de circo equestre. Seja como for, o móvel é engenhoso e serve perfeitamente. A um tempo se apresenta como uma cômoda, com sete gavetas espaçosas para conter vestuário e roupa de cama e banho de uma pessoa; da frente, pode-se puxar um assento que se apoia em pés bem ornamentados, em correspondência com uma mesa útil para comer ou escrever; na parede direita, levante-se uma caixa para por objetos de toalete ou qualquer outro uso: atrás, do lado oposto da frente, pode-se levantar um espelho, levantando-se a parte superior e apoiada em duas pernas, uma das quais antes servindo como cabide estende-se uma cama cujo colchão, lençol e colcha estão guardados; e mais: a cama tem sua cabeceira que se ergue quando tudo está pronto.

A descoberta do móvel, depois de um contato com a família do autor, resultou em mais notícias sobre o "curioso móvel-cômoda," como o apelidou os jornais quando foi exposto na Exposição Industrial de Sáo Paulo, em I917, no Palácio das Indústrias. O júri da famosa manifestação premiou Pimentel com medalha de ouro, assim descrevendo-o na relação: "Móvel, na primeira posição é uma commoda; na segunda uma toalete com o respectivo espelho; na terceira, uma escrivaninha e sua cadeira; na quarta uma estante para livros, com ou sem escrivaninha e cadeira; e, finalmente, na quinta, cama e criado- mudo."

Um dia conversava a respeito da descoberta com Vera Andraus, lá em seu novo campo de ação, o antiquariato. (Mas de novo e oportuno tipo, direi misto, pois ao lado dos objetos do passado tem uma sala para apresentar periodicamente obras de artistas contemporâneos, fórmula oportuna para favorecer o convívio da história com os produtos que no devido tempo irão se tornar história, inteligente combate àquela insensatez dos decoradores que pensam erradamente no conflito entre as duas realidades.)

Conversando com Vera fazia uma segunda descoberta: o interesse curiosíssimo para com o móvel que descrevia. Combinamos vê-lo no Mirante das Artes, onde o ajeitamos em todas as serventias, provocando entusiasmo da jovem senhora. Seus olhos, conhecidos pela singularidade e penetrabilidade, iluminaram-se como a demonstrar encanto pela novidade.

A cara colega anotava e comentava o design original da peça, enquanto eu ia imaginando como ela mesma, disfarçada numa figura de circo, naturalmente acrobata, diante da esbelteza do corpo e os reflexos ágeis e garboso. A fantasia na rapidez de seus lances, às vezes, foge aos freios do controle, e sugere propostas impertinentes.

Interrompi: "Vera, devo apresentar este móvel no Vogue; a senhora poderia me sugerir um modelo para realizar a reportagem? A resposta, de uma naturalidade rica de candor e desprendimento bem feminino (as últimas damas da assim chamada aristocracia criticam duramente): "Não poderia ser eu mesma?"

Decidido. Aqui, nas fotos do meu aluno Rômulo Fialdini, apresento o resultado da reportagem feita na Antigua, de Vera Andraus, na rua da Consolação, 31I5.

A antiquaria Vera Andraus transforma-se em modelo para apresentar as várias fases do móvel desenhado por Pedro Antonio da Silva. 
Senhor \#23, fevereiro de 1980, p.94-95 (Senhor e as Artes)

A COMUNICAÇÃO EM SEUS NOVOS CAMINHOS E PROPOSTAS

A rapidez que marca o viver diuturno está desgastando os sistemas de comunicação. Quem mete as mãos na rotina das exposiçôes, volumosas ou pequenas, dedicadas às produçóes da arte, pendurando monotonamente telas nas paredes ou ajustando esculturas nas bases deve ser considerado o herói continuador da tradição que os Salóes napoleônicos transmitiram a este século. Tudo, nesta rotina do mostrar, deve ser julgado fora e como antítese em relação ao tempo, cegueira diante das mudanças do dia-a-dia.

As modificaçóes ocorrem em todas as atividades. Vale a pena registrar, por exemplo, o que se deu na última Feira do Livro, em Frankfurt. Um fenômeno que andou crescendo é o da imagem que vai tomando conta da comunicação, em prejuízo da palavra. Parece que a gente lê menos e quer saber através das imagens. $\mathrm{O}$ protagonista torna-se cada vez mais o desenhista, e menos o escritor. Valem os livros ilustrados, sem dizer-se das historietas em quadrinhos e os manuais didáticos. (A Pendulum, de Nova York, apresentou na Feira uma programação escolar completa, desenhada, com explicaçóes para os professores aprenderem a ensinar; começa-se por Homero, Ilíada e Odisseia e vai-se até Einstein e Madame Curie.) O desenhista faz-se acompanhar do fotógrafo. Hoje a fotografia informa mais que a escrita.

$\mathrm{Na}$ comunicação de assuntos históricos ou contemporâneos, quando dedicados a um grande público, deve ser levada em conta a mudança, pensando nas possibilidades que o progresso impóe. Afinal estamos em tempos de TV e de satélites.

Vamos voltar às comunicaçóes de arte-arte. As galerias ditas de arte, como também as bienais e a pletora de salóes estaduais, municipais, de bairro, se burocratizam dentro do antiquíssimo sistema. Também quando se trata de apresentar algumas novidades que fazem, ou contestam os esquemas tradicionais, a mise-en-page é acorrentada a antiquada rotina. (Os organizadores ainda não descobriram o gosto dos vitrinistas.)
Raro ser convidado pelas galerias para assistir a manifestaçốes que os jornais trombeteiam, e observar comunicação abrilhantada por uma certa distinção, uma ideia que signifique e se destaque por alguma singularidade.

Galerias e, infelizmente, museus governados mais por elementos cabidescos do que por fulanos da profissão, parecem umas tantas lojas normais e normalizadas. Têm em comum os adendos indispensáveis ao processo: fileira de quadros, catálogos com curriculuns, etiquetas, convite prometendo generosos coquetéis etc.

Eu mesmo, no Masp, devo, de vez em quando, engolir situaçóes parecidas, pois convencer alguém a que renuncie a uma inauguração é, certamente, comprar uma briga. (E, como todo mundo sabe, sem uma certa dose de diplomacia nada se conduz no Brasil, nem mesmo uma bicicleta.) Existem artistas, na maioria, que vivem para mostrar o trabalho na noite da inauguração, certos de estarem convocando a cidade inteira, na expectativa de abundantes colunas de crítica nos jornais. É a moda, aliás a rotina, e contra este fato nada se pode fazer, como é certo que quando chove, ou se abre o guarda-chuva ou se molha. ( $\mathrm{O}$ curioso do acontecimento é o seguinte: você convida para uma mostra que em Paris motivaria dezenas de milhares de pessoas, como seria o caso de uma de Paul Klee, ou de Bonnard, ou de Torres García, e aqui aparecem apenas uns quatro gatos pingados, lamentando que o evento não tenha coquetel. Perguntamos: é uma sociedade amante das artes?)

No Masp, quando a rainha Elizabeth II inaugurou o prédio da avenida Paulista, compareceu, naturalmente, gente. (Mais para ver a soberana do que contemplar Ticiano, Velazquez e Van Gogh.) O escândalo foi não ver as telas diligente e rigidamente dispostas nas paredes (possivelmente revestidas de tecido adamascado na cor vermelha ou verde) e vê-las colocadas em placas de cristal, obedecendo ao conceito que uma pintura nasce num cavalete, no ar, e volta para a presumível posição de origem. Apriti o 
Cielo: desilusão e crítica. (Especialmente dos que entendem bolhufas.)

Inovar comporta contrastes. Não nos perdoaram, os protestos continuaram, o que me induziu a não por o nome dos autores embaixo das obras, obrigando o visitante a ler do que se trata (nome, notícias, posição de tempo etc.) atrás da placa transparente. A iniciativa objetivava despertar um interesse real para com determinada obra, ler um pouco mais, saber e aprender.

Fomos criticados, logo depois, quando começamos a revisar o sistema das exposiçóes periódicas. Deixando adormecer a fórmula superada da arte pela arte, consideramos a arte como fato sociológico, abordando problemas, optando por uma comunicação que exclui o sublime para investigar também na vida.

Confissão: não é tarefa simples dirigir um museu que não leva a sério o sistema do Louvre. (Em Paris, todavia, sentiu-se a imperiosa necessidade de criar o Beaubourg, oferecendo um exemplo no pôr a comunicaçáo das artes em dia.) E quando os estetas reclamam por que o prédio do Masp não tem uma fachada como o Museu do Ipiranga?

A situação do gosto local não propicia aceitar desvios radicais. Porém, devo dizer que pelo contato cotidiano com a juventude (o Masp é frequentado em sua quase total maioria por estudantes) nota-se uma franca adesão às ideias de renovação do sistema. Exposiçóes como a "Mão do Povo," a "História das Historietas em Quadrinhos," a "Tecelagem do Triângulo Mineiro," realizada por Lina Bo Bardi, sem contar a comemoração da "Semana de Arte Moderna de 22," a "Grande São Paulo” e quantas outras que um soberbo calendário exibe aos visitantes durante o ano todo, se encontraram as críticas dos posapianos, foram muito bem visitadas e compreendidas pelos jovens.

Tudo deixa entrever que através do consumo dos calendários, no setor da comunicação das exposiçóes teremos a aceitação das novas propostas. No que se refere ao Masp estão em estudos para I980 três exposiçóes que deveráo acentuar e contribuir para uma virada no setor: "A Bola do Tri;" (história da "alegria do povo," sob um ponto de vista sociológico, contando com a indispensável colaboração de Pelé, lamentando-se apenas que o almirante Nunes da ex-CBD não quis emprestar a Taça Jules Rimet, preferindo guardá-la num cofre, escamoteando-a da contemplação das torcidas, estas sim autênticas donas do precioso troféu) "Brasil-Itália;" (história, desde Cristóvão Colombo até nossos dias: as relaçôes entre os dois países, pontualizando naturalmente o fenômeno da imigração; uma preciosa manifestação a ser levada a efeito com a colaboração da Fondazione Giovanni Agnelli, que se incumbe das pesquisas na Itália, anunciando uma montanha de inéditos também no campo das artes, como esta "Alegoria da América do Sul," de Nicolò Frangipane, (I537-I597) e as raridades do italianist Dom Pedro II) "O Objetivo Esquecido.” (Apresentação comentada de uma centena de máquinas, aparelhos e de coisas em desuso, da coleção do sr. Raful, importantíssimo e inteligentíssimo acervo à espera de ser colocado num museu dedicado à técnica: protótipos de automóveis, rádios, fonógrafos, geladeiras, caixas de música, máquinas de escrever, de costurar, de fazer cigarros etc.)

Como se vê arte é um pretexto, mas arte é atividade implícita em todas as atividades passadas e presentes da vida. Um dos conceitos em que, no Masp, se insiste, é a necessidade de desmistificar a crença de que a arte é quase e táo somente a pintura. (Infelizmente, por circunstâncias ambientais, seu organizador náo pôde ajeitar o acervo como tão bem queria, diplomaticamente contentando o gosto de seu amigo dr. Assis Chateaubriand, concentrado na pintura dos nomes clarinados pelos sustentadores do Impressionismo. Justifico: perdemos o lift que, no Canadá, continha todos os cenários e costumes dos Ballets Russos de Diaghilev, a coleção das antiguidades chinesas de um senhor desembarcado no Brasil, a famosa coleção das gravuras do príncipe de Lichestein e quantas outras raridades que no após Guerra era possível comprar-se com os dólares gastos em uma parte de uma tela de Renoir.)

De qualquer jeito, desde a fundação, percorrendo caminhos nem sempre planos, optou-se pela interligação das 
manifestaçóes das artes, nenhuma

excluída, inclusive a ecologia.

Senhor \#24, março o de 1980, p.94-95 (Senhor e as Artes)

A ARTE E CORPO

Parece que o corpo é, agora, o ponto convergente das novidades teológicas, depois que o Papa João Paulo II, expliciter serbis, deu a entender que Adão e Eva, aliás Eva e Adão (a mulher tem sempre precedência) representam algumas coisas. Citando o gaudium et spes, as palavras do máximo da grei católica deu a entender que, cumpridas as penitências medievais que ainda perseguem as gentes, a existência do corpo não pode mais ser ofendida com censuras moralistas.

Superados os obstáculos dos constantes prejuízos que andaram humilhando, o fato mais natural e sustentador da vida, um modo novo que nos enveredando em determinado caminho a fim de gozar de liberdade de há muito aspiradas, e pelas quais uma ampla e irrestrita vontade, se náo propriamente coletiva, pelo menos por vontade doa responsáveis pelas vanguardas, estava ativamente operando.

No Brasil, alegrado ainda por grupos indígenas que não precisam de ordenanças papais para se olharem no espelho e ver que sua nudez é natural, continente rico de moçoilas que nas praias póem em prática o achado do topless (os delegados do bom costume deixando-as em paz,) é de lembrar que quando Julian Beck tentou nos deliciar, ou cacetear, com seu Living Theatre, a polícia interveio e despachou o visitante para fora do pais onde, até anos atrás não se entrava no cinema tem gravata. Julian predicava: "O corpo é o mecanismo da vida, a fonte da vida. Se nosso corpo é sujeitado a modelos repressivos de comportamento, deve-se reagir, e libertá-lo.” Para chegar lá, Julian pensava que a sociedade procurava matar o corpo com o trabalho, com a frustração sexual e física, num leito de Procuste incômodo e irracional.

Teatralmente falando, o fautor de espetáculos em que o nudismo é praxe, observava que o amor e castigado, a gente perde o prazer da vida, e que censurar o amor é provocar o ódio, pensando no normal da animalidade. E mais: o operário e o camponês sabem que o gingar o corpo como fazia Carlitos e em Tempos Modernos, acaba se aviltando a liberdade, e assim por diante; mas a polícia nacional não gostou.

Agora que o papa abriu as portas, e também porque a literatura estava sem assuntos, iniciou-se uma corrida visando à recuperação do corpo. Naturalmente, pois a pintura depende hoje da literatura, eis a reavaliação de uma tendência que fez um certo sucesso, a body art.

Um livro de uma feminista que se chama Lea Vergine, Dall'Informale Alta Body-Art, na Itália, vem sendo sucessivamente relançado esta bela italiana acaba de apresentar, no Palazzo Reale de Miláo, a exposição "A outra metade da vanguarda," convidando uma centena de mulheres: é autora também de um outro livro muito discutido: Il Corpo Come Linguaggio. Interessa-se somente pelo corpo, que para mostrar que está desgostosa diz: "Mi si sfilano le calze." Um jornalista foi entrevistá-la recentemente para Tutto Libri. Disse e mostrou uma infinidade de particularidades e respeito da sua ciência: cenas produzidas por artistas, como corpos pintados, travestidas, maquilados, até os detalhes do corpo, como uma orelha ensanguentada ao lado de uma lâmina, e assim por diante. A fotografia, lógico, é a técnica mais adaptável a tais tipos de festivais.

O mais interessante são as declarações de Virgem: "Aqui os artistas não fazem cenas da história de uma personagem. Eles procuram o homem-humano, não castrado da sociedade." O homem que se subtrai ao conceito de propósito, um estado em que a cultura não serve para mais nada. Não faltou, na conversa, um acenar relativo à angustia que deveria ser praticada normalmente para ter o corpo em ordem. Porém, para Lea, a ginástica, e sem dúvida o Cooper que de manhã alegra as ruas dos bairros dos executivos, é "prática contra a natureza."

Substancialmente o que os fautores da Body art apreciam é o corpo em todas suas atitudes, manipulaçóes e aventuras. Não o verismo, coxas as coxas, seio ao seio, nem 
o de Michelangelo que o bolou na Sistina, sem folha de parreira. (Um brasileiro, o prof. Deoclécio Redig de Campos, diretor dos Museus do Vaticano, encontrando o afresco com as "partes vergonhosas recobertas," mandou que as coisas voltassem como anteriormente.) Não o verismo à antiga, mas tudo que um corpo pode e deve conseguir ser. Corpo como múmia, corpo açoitado, amputado, castrado, esquartejado. Cada leitor deve acrescentar o que bem lhe aprouver, até pornografia, para totalizar os temas da body art.

Os bens pensante ou, pelo menos, os que opinam sobre Eva e Adão, normalmente, devem gostar mais da placidez de Giorgione e de Cranach, de corpo distendido. Talvez gostem do $\mathrm{Nu}$ que sir Kennet Clark em seu famoso texto dedicado à body art do passado, reputa ser o último clássico, o de Renoir, que este escriba, há trinta anos, conseguiu trazer para o Museu de Arte de Sáo Paulo.

A lembrança serve para contar um episódio e que bem pode contribuir para explicar como os tempos estáo mudando, isto no tocante ao corpo e suas representaçôes. Quando perdemos o nosso caputmagister Assis Cnateaubriand, foi improvisada uma câmara-ardente no hall dos Diarios Associados. Participei do triste evento, tomando a iniciativa de compor, na parede do fundo, uma lembrança de arte a quem tanto tinha dado ao Brasil, o único acervo de arte que ainda hoje possui, incluindo cinco Frans Post, os quais foram pagos na base de dois mil dólares cada um, peças que agora os nouveaux-riches pagam 400.000 dólares, pois da status ter o petit-maltre nas paredes mansonianas.

Fui até a Pinacoteca, escolhi cinco pinturas de porte: a representando o Conde Duque de Olivares, (souvenir da tomada da Bahia, da qual Assis me ensinava os mínimos detalhes) de Velazquez; a do Cardeal Cristoforo Madruzzo, (organizador do Concílio de Trento, fato importante da religião no Brasil) de Ticiano; a de Dom Llorente, (o último secretário da Inquisição espanhola, morto no exílio, como o pintor do seu retrato) de Goya; Lord Hastig, (pela atitude de comando e de que era do tado Assis) de Gainsborough; e, finalmente, para não esquecer-se que o desaparecido tinha um justo e exemplar penchant para com as mulheres: o $N u$, de Renoir.

Quando acabei de ordenar a parede, Renoir no meio, fui literalmente assaltado por alguns diretores dos Diários, classificando de imoral a presença daquele belíssimo exemplar de nudez. Os carolas me obrigaram a renunciar à minha homenagem feminina para alguém que se levantava quando uma senhora se levantava, o charmoso que, viajando a Paris, comprava montanhas de coisas para oferecer às suas amigas.

Pois é: assim andavam as coisas nos idos de 6o. Felizmente, agora, João Paulo II, homem não certamente dirigida cultura-vaticano-não-ecumênico, indica que vamos recuperando autenticidade de vida, depois do défilé em parábola descendente de inúmeros tabus.

Senhor \#25, abril de I980, p.I7, IIO-III (Senhor e as Artes)

BRASIL 2I, p.I7

Uma revista voltada para ofuturo dá 500 mil por seu logotipo

A exposiçáo dos projetos que participaram do concurso lançado pela Editora Três para escolha da capa da revista Brasil Século 2I, composta no Museu de Arte de São Paulo, é um fato positivo da gráfica nacional, como profissão, técnica e inventiva.

O prêmio ao projeto vencedor, o maior de que se tem notícia, no valor de quinhentos mil cruzeiros, atraiu elevado número de participantes. $\mathrm{O}$ julgamento, tanto pela qualidade dos trabalhos, como pela originalidade das propostas, não foi fácil.
Tratava-se de escolher um logotipo de comunicação imediata Para um público indiferenciado, o das bancas de jornais e revistas, surpreendendo curiosidade do leitor: Uma revista sui generis, eivada de um certo senso de futurologia, que prevê acontecimentos, pois seus textos serão dedicados a um Brasil que ingressa no século 2I, daqui a uns vinte anos, uma geração de preparadores de estruturas econômicas, culturais; .morais e, mais especialmente, políticas. 
Vamos ver o que reserva à Terra por Deus insistentemente tido como brasileiro nato, além de observar a validade do slogan de um Brasil "grande potência." (A respeito será interessante lembrar que um escritor positivista italiano, Giuseppe Compagnoni, em sua Storia dell'America, reserva ao Brasil o papel de se tornar o mais importante Estado do mundo, balanceando com os Estados Unidos, "mas com mais vantagens," profecia esta publicada em I820)

Os gráficos participantes do concurso para a nova revista (de não fácil redação, pois não se trata de registrar, mas de astrologar, conjeturar, adivinhar) encabularam-se naturalmente na colocaçáo do número, entrosando-o com as letras Brasil, às vezes introduzindo no título a palavra século, dando origem a uma série de logotipos curiosos e ao mesmo tempo persuasivos, alguns, como o leitor de Senhor pode ver nestas páginas, realmente engenhosos.

A exposição na grande sala do Masp, onde a cada participante era reservada uma prancha de fundo preto, representou por sua parte um aos fatos de gráfica comunicativa do melhor padrão. (Trabalho de Dan Fialdini, o gráfico do Museu.) A limpeza dos projetos, a boa distribuição e paginação, a variedade e a harmônica disposiçáo da mostra devem ser consideradas um dos resultados auspiciosos do nível alcançado pelos nossos artistas no setor, formado nestes últimos trinta anos, datando seu início quando da abertura do Instituto de Arte Contemporânea do Masp e da exposição de Max Bill, iniciativas que chamaram a atenção para os problemas, até entấo náo considerados, do design.

Se futurologia é polemizar, trabalhar para preparar o amanhã, superar os limites da situação, parece- me que a nova revista, além de cuidar de futuro deverá reservar uma seçấo para os bâtisseurs d'avenir.

No que se refere à locução Brasil 2I, (o logotipo premiado valeu-se de algarismos arábicos e não os tradicionais romanos, o que pode representar uma inovação; de qualquer jeito uma proposta válida, antitradiçáo) sendo de se sublinhar que alguém se serviu inteligentemente da letra $S$ e do número 2, conseguindo ótima solução gráfica. Mas e o leitor de Senhor quem vai ver e julgar.

Nós, aqui mesmo, queremos esperar pelo século 2I, com a antevisão a ser oferecida por uma revista dedicada à gráfica, outra dedicada ao design, além de uma que tenha por objetivo o enfoque dos problemas da nova estética. (Até hoje quem mais se interessou pela gráfica brasileira foi a revista suíça Graphis.) O futuro e eventualmente a potência de uma nação devem ser operados através da cultura, e não na base de tanques e de olimpíadas. Discursos, mesas redondas, agitação jornalística, congressos, etecétera que Brasil Século 2I deve incentivar, para nos direcionar, enveredar, aliás avenidezar, com confiança e bom humor no século que está às nossas portas.

\section{Legenda}

Algarismos arábicos, no lugar de romanos, premiaram Sidney Pinto Ribeiro

Made in England, p.IOI-III

Em São Paulo, o lirismo de um estadista cáustico e a crítica de um pintor lírico

Depois do recente desaparecimento de Sutherland foram dadas a conhecer algumas particularidades de uma famosa história, quase única na história da arte, de um pintor que viu queimada uma sua obra, justamente aquela que lhe deu maior renome, pois o retratado não gostou da mesma.

Para homenagear Winston Churchill, a Câmara dos Comuns pensou em pendurar no seu saláo de honra um retrato do grande estadista do século, decidindo confiar a feitura ao pintor número um da Inglaterra. Porém, o vencedor da
Segunda Guerra Mundial não gostou, a crítica mergulhou em acirradas discussôes, convencendo a maioria dos responsáveis da homenagem a um vade retro clamoroso. A tela voltou para o atelier do autor. Contam que Churchill vendo sua figura com ar agressivo e bem atarracada, ironicamente declarou que se tratava de "notável exemplo de arte moderna."

O ex-primeiro-ministro era pintor nas horas de lazer e consequentemente possível conhecedor de problemas de estética e até de prática educacional nas relaçóes com os colegas. 
Pedindo vênia aos admiradores do grande cultor da língua inglesa, e portanto minucioso historiador da sua vida agitada, diremos que ele é um modesto reprodutor em tela de vistas de marinhas e interiores; e que Graham, ao contrário, é um dos raros mestres ingleses do século com direito a registro não nas crônicas, mas na história.

Questôes e brigas de "gosto-não-gosto" não são fáceis de resolver. Depende dos que pronunciam as duas locuçóes. E aqui uma primeira lembrança pessoal. Nos anos 50 o sr. Assis Chateaubriand, nos momentos cruciais das aquisiçóes para formar a pinacoteca do Museu, tomou avião para desembarcar em Londres, e participar de um leiláo beneficente em que a peça-chamariz era a Sala Azul em Trent Park, de sir Winston.

Tratava-se da única pintura do amador a sair de sua casa, suscitando estrondosa curiosidade na Christie's. Um dos pretendentes e empenhados na disputa era o ator norte-americano de cinema, Montgomery. O brasileiro e o americano, levantando o braço um após outro, numa cerrada disputa, lançaram seus valores, até que o dr. Assis, aplaudido, arrebatou a obra e a trouxe para o Brasil.

Lembro-me bem do ingresso no Museu e de minha cortês observaçáo ao receber a obra: "É mais objeto de propaganda que de pinacoteca." O chefe replicou: "Todo o mundo, ao saber que temos um Churchill, correrá ao Museu.” Minha tréplica: "Dr. Assis, quando o senhor voltar à Inglaterra, de lá me traga um Sutherland."

Expliquei quem era Sutherland. Meses depois o magnífico peregrino de Umbuzeiro, voltava de Londres com uma tela do mestre: Formas Articuladas, obtida graças à doação do sr. H. p.Juda. A nota que escrevi no catálogo era esta: "Após uma breve e notável experiência de retratista, Sutherland empreendeu a arquitetura de um mundo imaginoso, como representação simbólica das coisas da natureza; autor também de obras de caráter religioso."

Apreendendo que o artista inglês era retratista, Chateaubriand falou-me de seu desejo de encomendar a ele um retrato. Adivinhem de quem? Do almirante
Nelson. Acrescentando: "Ganhou as batalhas de Aboukir e de Trafalgar..."

Não compreendi bem o que tinha a ver com a arte e com o Brasil. De qualquer jeito era bom ter mais uma pintura de Sutherland. Encomendei. Encabulado o pintor, grave mas espirituoso, deu sua versão nelsiana: retratou-o à la Bertillon. Ficha fotográfica de polícia, de frente e de perfil, tratando-o mais como um matador do que como um almirante.

Ninguém gostou do quadro. Eu gostei imensamente e inseri na Seção dos Ingleses o Churchill entre os dois Sutherland. Depois de comprarmos outros dois Sutherland para aquela aventura sem cabeça e nem cauda dos museus regionais fantasmas, destinando um para Porto Alegre e o outro para Feira de Santana, na Bahia. (Não sei onde andam estas peças, e se algum leitor souber do paradeiro, favor me escrever.)

Agora, saber que o retrato de Churchill foi queimado enche-me de tristeza e me obriga a enviar aos seus autores toda classe de anátemas. Parece que a iniciativa partiu do próprio pintor. Sua mágoa devia ser pesada, pois os que sabem ver pensam que no retrato churchilliano Sutherland destemperou sua arte de maneira mais viva.

Infelizmente tratava-se de sujeito metido a pintor amador. Sabemos quais os caprichos, a incompetência, a vaidade do amador. Senta-se numa cátedra e pensa seriamente que Picasso náo sabe pintar, ou "pinta como seu netinho."

Amador é um desastre, se bem que gente boa. O vencedor da Segunda Guerra era pessoa excelente, duro com os inimigos e ao mesmo tempo paciente e gentil com os amigos. Quando o sr. Chateaubriand foi condecorá-lo com a Ordem do Cangaceiro, humildemente o grande estadista deixou que o Velho Capitão o armasse cavaleiro, não com uma espada, mas com um punhal a tocar-lhe os ombros. (Sei de que se tratava, pois também já tinha recebido idêntica e parcimoniosa láurea.) Mas tudo correu bem. Falou-se de pintura, naturalmente da do homenageado, orgulhoso de saber que sua obra estava na pinacoteca paulista, ao lado de Cézane, Manet, Renoir e companhia bela. 
De qualquer modo o apreço do amador se inclinava mais por Ingres e pelos pintores da Royal Academy do Oitocentos.
Legenda

Grahan Sutherland, Formas

Articuladas, 1953

Senhor \#26, maio de I980, p.IIO-III (Senhor e as Artes)

UM MUSEU NÃO PODE ABRIGAR SÓ PINTURAS E ESCULTURAS

O sucesso da Feira de Trocas do Masp, em São Paulo,

com sua exposiçâo de quinquilharias e antiguidades

O Museu de Arte de São Paulo, do ponto de vista da documentação da cultura, necessita sempre de injeçóes para seu revigoramento. Já se passaram 26 anos sem que a pinacoteca recebesse uma obra de arte de um certo brilho, a não ser peças de secundário valor. Única exceção é a série de doaçôes feitas pelo casal Bardi, que ainda recentemente entregou ao Masp um obra de autoria de Joaquín Torres García, o celebrado pintor uruguaio. A coleção, no tocante a escolas e autores, é desigual, mais concentrada na pintura, valendo igual observaçáo no tocante à escultura, pouco destaque havendo em relação à gráfica.

Mas um museu de arte que ignora outros setores, como o mobiliário, artes aplicadas, sem se falar de objetos em que a arte é determinante, como o design de todos os tempos e marcadamente deste século, esse é certamente um museu parcial. Seria concebível uma organizaçáo como a do Masp, se na cidade existissem outros museus que se interessassem, de maneira geral, em recolher e conservar materiais complementares às artes plásticas de maior significação.

Em São Paulo não faltam alguns museus específicos, como o do Folclore e Artes Populares, o da Aeronáutica, o de História, do Ipiranga, e outros dedicados a problemas particulares. Porém, se pensarmos no Metropolitam Museum of Art, de Nova York, seria mais fácil entender qual deve ser o conceito de um museu de caráter geral, no qual o visitante pode encontrar tudo aquilo decorrente da produção de todos os tempos e de quase todos os países.

Naturalmente, não se pretende dotar São Paulo de um Metropolitan, pela óbvia falta de meios. Já é tarde demais para começar. Inexiste uma vontade suficiente para empreender táo grande empresa face, entre outros empecilhos, às leis que regulam a importação e que são inteiramente desfavoráveis à cultura. E, por último, falta mentalidade para um coordenado desenvolvimento cultural. O governo lança pálidas campanhas destinadas a incentivar a Memória do Brasil. Porém, tudo fica olvidado, segue-se a premissa preguiçosa de deixar como está para ver como fica. E adeus sonhos de ter-se uma cultura realmente ativa, valendo-se de boas bibliotecas, museus e institutos.

Derramada a costumeira geremíada, volto a tratar do curioso caso de concentrarem-se na pintura todas as atençôes, esquecendo-se as pessoas de que ela é uma parte bem representativa das artes, mas apenas parte delas. Apontadas as musas tradicionais, veremos que é uma entre outras. Deve-se notar que às musas que determinaram ó conceito "belas artes," hoje, clamam por outros colegas, pois nasceram outras donzelas: fotografia, cinema, rádio, televisão e no setor de artes plásticas também o design.

No Masp, como todos sabem, desde a fundação, tentamos não deixar de lado nenhuma das artes, procurando entre elas uma interligação, suscitando um interesse geral para todas, intervindo em atividades não pertinentes a um museu - como, por exemplo, a moda, a propaganda, a ecologia e assim por diante.

Uma das iniciativas que em seu tempo suscitaram interesse, mais curiosidade que interesse, não sem comentários hostis, foi a de termos posto na pinacoteca a Vitrina das formas, em que eram periodicamente mostrados objetos como machados da Idade da Pedra e até uma máquina de escrever - objeto este que surgiu aos espirituosos dizerem que o diretor do Masp tinha esquecido na pinacoteca tal instrumento de trabalho.

A Vitrina das formas reunia objetos de arte e de uso de todos os tempos, desde a Babilônia até este século já em declínio. Servia para lembrar ao admirador de 
Rembrandt e de Picasso que a história da arte era composta também de objetos de uso cotidiano e náo somente de contemplação, dignos da mesma consideração e de contemplação.

Transcorridos os tempos em que a fórmula "Arte pela Arte" parecia granítica, vai tomando conta da produtividade a fórmula "Arte pela Vida," incluindo uma série de manifestaçôes não elitistas, mas consequência da espontaneidade e genialidade com que a vida marca certo labor: desde um fósforo até o Concorde, todos objetos de arte. A tecnologia e o design representam fatos da vida em que o homem pôs talento, jeito, cultura, tenacidade, arte.

Todas estas consideraçóes desfilaram pela minha cabeça durante uma conversação, num domingo veraneico, no belvedere do museu, tendo como interlocutores Mário Chamie, secretário de Cultura do município, e os antiquários Benjamin Steiner e Francisco da Natal. Era um domingo em que a Feira de Antiguidades, com suas cento e tantas barracas, dava ideia de um formigueiro. Disse a certa altura: "Este é o museu; o de cima é complemento deste aqui."

Perplexidade, natural, como comporta qualquer paradoxo. Destarte, como viver sem paradoxos? Eu voltava a lembrar que temos necessidade de acolher num museu uma variedade de objetos, os mais díspares. Sugeria que devêssemos escolher entre aqueles que se encontram cada domingo no belvedere, alguns dignos de serem preservados, função típica da museulogia. Materiais que vão se perdendo e que os antiquários mal guardam e que colecionadores e amantes do que se chama de bugigangas apenas salvam e valorizam.

Pela primeira vez, em São Paulo, o público mais que heterogêneo teve acesso a um museu, museu de rua, para tomar conhecimento da existência de coisas que nos confortam no dia-a-dia, como deve ser em qualquer casa de ricos ou de pobres, até mesmo em favela - porque não? - onde certa vez, e ao longo de uma pesquisa, encontrei folhinhas, oleografias, vasos de flores, santas ceias de Leonardo, numa palavra, artes como quaisquer outras, às quais seria pueril não atribuir valor, pois se trata de estética popular.

De barraca em barraca, no belve-

dere, podem-se encontrar objetos que surpreendem. Tem de tudo, numa variedade que puxa para o infinito das formas, reunindo operosidades, inventos, capacidades técnicas, fantasias, novas propostas. Passam-se horas a descobrir, e o vendedor paciente vai explicando aos curiosos de que se trata, quando um objeto não é de fácil compreensão. Há até os especializados: um belíssimo conjunto de armas antigas, o que implica na necessidade de competência para serem apreciadas; cerâmicas orientais táo do agrado do veterano estudioso Eldino da Fonseca Brancante que, às vezes, lá é encontrado: art-nouveau e art- déco, últimos revivals com suas legióes de apaixonados; livros raros, autógrafos, até documentos da Roma papal. E mais peças de numismática, de filatelia, e pinturas antigas e contemporâneas e até gravura de Picasso, Pollock, e outros mestres.

Os mesmos objetos que se encontram no Marche aux Pouces, de Paris, ou na Porta Portese, de Roma, porém bem melhor apresentados, não abagunçados como lá: uma ordem quase militar, de se pensar num castrum romano. Exemplarmente criada e conduzida pelo amigo Francisco da Natal, um antiquário aberto a todos os problemas do seu oficio.

Um dos problemas em pauta é uma manifestação sui generis: a convocação dos colegas para participarem de seminários, tratando de casos pertinentes à profissão, visando a fortalecer a Associação de classe da qual Francisco é o presidente.

Também está sendo objeto de cogitação a realização de um congresso internacional de antiquários, sendo que várias de marches já foram feitas. Longe dos mercados de arte, como Londres, Nova York, Munique e Paris, os antiquários do mundo inteiro debateriam seus pensamentos, numa metrópole quase nova, que apenas ensaia seus primeiros passos. A iniciativa à qual foram prometidas várias solicitações de ordem turística e alfandegária, e a sede, o Masp, serão fatores auspiciosos para um definitivo passo na senda de uma ação cultural de primeira ordem. 
A Feira de Antiguidades no belvedere do museu, deve, então, ser considerada como uma realização positiva: um museu dominical que não deixará de produzir dividendos para a cultura.

Senhor \#27, junho de I980, p.22 (Senhor e as Artes)

DeIXA COMIGO QUE EU VOU MOSTRAR UMA NOVIDADE

A magia de Wesley, do tufáo da Rex ao mapa-mundi de agora

Hoje, mais precisamente neste século já em ocaso, náo é como ontem, tempo em que o pintor se adaptava e portanto se obrigava a se manifestar dentro das regras prescritas do cânone tradicional, admitidas apenas algumas pequenas liberdades. Náo que os revoltados não aparecessem. Apareciam, sim, para confirmar que as andanças eram normais, e a Musa Pintura era respeitada e até homenageada. Arcimboldi, por exemplo, considerado um louco: idem Monsú Desiderio, idem Blake e assim por diante. Hoje, os loucos constituem legióes imensas, e parecem tomar conta do campo. A pintura está de mudança e seu carro não se move mais, como ontem, nos trilhos aprovados e consagrados.

Há no mínimo dois decénios que estou observando nosso herói do deixa-comigo-que-vou-te-mostrar-uma-novidade: Wesley Duke Lee. Descobri Wesley quando, num local da antiga avenida Iguatemi, desencadeou a performance pop denominada Rex. Foi uma noite de bagunça, um tufấo varrendo a metrópole inteira que, inteira, gostava somente do quadrinho-paisagem-romantizada-pelo-luar, o alvo de Marinetti: "Uccidiamo il chiaro di luna nostalgico-sentimentale."

A assistência, parece, andou se acostumando um pouco perplexa diante das novidades. Digo acostumando, porém sem deslumbramentos, pois nosso ambiente é pacato, quietinho e pobrezinho em relação à apreciação da Pintura: amoroso com os clássicos caboclos e, como limite de licença, não ultrapassando a ousadia das mulatas do Di e as bandeirinhas do Volpi.

As contrapropostas de Wesley, de qualquer jeito, vão ganhando apreciadores. Se existem nas cidades de dez milhôes de habitantes, onze milhóes que apostam na loteca, na verdade também há uns quatro gatos pingados dispostos a constituir um círculo defensivo para o cultivo das liberdades reservadas ás artes. Sendo um detentor das chaves desse bunker, peço licença ao senhor de Senhor, para convidá-lo a tomar conhecimento das duas paredes que o novo mestre armou na Galeria de Luisa Strina, em Sáo Paulo.

Figuras cortadas. Trata- se, desta vez, de dois mapas do globo: um geográfico, e outro formado de 48 pranchas que denunciam aquilo que o homem, na opinião e arte do Wesley, combinou e está combinando no território. $\mathrm{O}$ autor se serve da pintura, ou melhor, do desenho, para se expressar, intercalado de uma multidão de figuras cortadas das biblias pauperum contemporâneas, isto é, as revistas.

Não colagem, não montagem, francamente não sei como definir: mas é uma história do comportamento Ocidente-Oriente, apontando os focos da discórdia pública, as guerras, a impossibilidade da paz, riquíssima de subentendidos, advertências.

O singular é que as figuras recortadas são aquelas que cada dia vemos nas publicaçóes e na TV. Também Rimbaud tinha captado seu mundo das figurinhas dos mais corriqueiros manuais, porém ajeitados numa arte metafísica não sem esfumaturas herméticas e complicadas. Nesta tentativa de Wesley, de explicar a situação do mundo hodierno, cada uma das pranchas desenhadas num mapa do ar, carimbada com dois motivos (a serpente que não consegue engolir a cauda, conseguindo o símbolo do Eterno, e a águia do estema estadunidense agarrando a cartilha, argutamente, invocando a paz) as interpretaçôes são de indivíduo a indivíduo.

É como resolver palavras cruzadas. Só que para averiguar cada combinação de figuras, encostamentos alusivos, colocação de palavras, demarcaçóes divisórias por via de uma linha ziguezagueada, tudo fazendo parte de uma linguagem para iniciados. É o mundo fantástico de um pintor não solitário que às excentricidades, une o controle dos fatos, sindicalizando até as minúcias. 
Wesley se propóe a conduzir sua freguesia a um labirinto de notícias, chamando a atenção sobre problema existencial. Não imitador e reprodutor da natureza, mas indicador de situaçóes inconvenientes: figuraçóes missionárias num certo sentido apocalípticas de alguém, não decorador, preocupado participante, ativista da cruzada para resolver o insolúvel da harmonia humana. Generosa oferenda de um elemento que, antes de tudo quer transitar tempo como homem.

Senhor \#28, julho de I980, p.II2 (Senhor e as Artes)

O ERotismo de Zaragoza

E o texto lúcido e lógico de Jacob Klintowitz

Não sei bem por que, mas folheando as páginas do frisante volume de José Zaragoza dedicado ao erotismo, pensava num episódio ocorrido no fim do século e que sempre me fez pensar neste essencial problema derivado do chamado pecado original: o que é íntimo e o que é público, no quadro geral da moral. O episódio é o seguinte, e eu conto mais para que seja conhecido por maior número de lei tores: em I895, na Bienal de Veneza, um pintor de Turim, famoso pela compostura de suas telas, tão cara à burguesia, expôs um grande quadro intitulado O Supremo Convênio, mostrando cinco atraentes moças com aquela provocante nudez que os acadêmicos sabiam ajeitar concupiscentemente, as stupidelas dançando e jogando flores no cadafalso logo identificado pelos visitantes por conter os restos de Don Juan. Uma oferenda de sabor clássico como a de Poussin que os leitores podem admirar no Museu de Arte de Sáo Paulo.

Só que, no quadro de Poussin, as moças estão vestidas, enquanto na pintura de Giacomo Grosso estão peladas. Assim: escândalo. E, para enfrentar tal abertura, o Patriarca de Veneza lançou um protesto dos mais veementes, $\mathrm{da}$ mesma forma como o teria feito um pároco medieval. O escândalo foi dos mais apetitosos, pois um grande escritor peninsular, católico, Antônio Fogazzaro, tomou a defesa do artista.

Aproveitando-se do barulho, um empresário adquiriu a tela para levá-la em tournée pelas Américas que, ao que parece, estavam curiosas para admirar as cinco moças. Um incêndio, não se sabe se provocado, acabou com a obra pouco antes de ser embarcada.

Na Itália foi um rebuliço. A Itália é especialista em censura antierótica. Há alguns anos foi censurado, na
Cidade Eterna, um cartaz turístico que reproduzia um nu de Botticelli.

Pensava nestas andanças focalizando as harmoniosas páginas em que Zaragoza anotou uma população de moços e moças se exercitando no amor, entre umas e outras, entre eles, sozinhos sonhando, durante uma reunião de amigos e amigas em casa do pintor.

Todos olhavam e perscrutavam em silêncio, sem pensar em moralismos, sem subentender e alegorizar. Nenhum alarde, nenhum sorriso. Quando as figuraçóes provêm de mãos de um artista não induzem ao perverso, e ajudam a contemplar e a levitar pensamentos corretos, também quando as combinaçóes implícitas no ato amoroso incluem momentos geralmente vetados ao descobrimento.

Zaragoza é dotado do signo franco, direto, espontâneo, signo nervoso e sem arrependimentos, uma escritura incisiva, corrente, sem pontualização que espelha o caráter do desenhista, abrangendo boutades e imensa cordialidade.

Sua iconografia do amor não platônico parece a visualização do acontecimento de base que perturba a vida, o mais comum e o mais escondido, só recentemente falado, e falado, foto e cinegrafado, desenhado e cantado, e porquanto se vê, se lê e se escuta: cacete e banal.

Cacete e banal pois o erótico e suas consequências vão caindo nas mãos dos intrusos, dos malandros aproveitadores da ignorância e da estupidez, ajudados pelo gosto do proibido, do censurado e do escandalístico. Existem hoje muitos especuladores pornôs, prontos a imitar o empresário teatral que pretendia levar em turnê o Supremo Convênio. 
O convite desta Bíblia amantorum

é para tratar de moral, pois Eros é coisa inerente, mas disto se encarrega Jacob Klintowitz, no ensaio intercalado entre uma série de fotografias de Moacir Lugato, dedicada ao pintor.

Jacob é escritor, lúcido e lógico. Suas páginas valem os desenhos, os contornam e justificam. Suas definiçôes e alusões são incisivas: um percurso pamilhado lado a lado das figuraçóes, integrando o que zaragoza quer fazer ver. Jacob complementa num explícito fazer saber, adicionando os comportamentos de Eros como deus da união, e também solidão quando o ser anela à união. Páginas esplêndidas de escritura ritmada, exata na definiçáo dos variados e complicados momentos de Eros.

Outra singularidade do volume: a composição, a disposição dos desenhos numa eurritmia surpreendente, realização tipográfica de Raízes. À qual: palmas.

Senhor \#29, agosto de 1980, p.IO4-IO5 (Senhor e as Artes)

As Quermesses DE ARTE. ArTE?

As festinhas cheias de medalhas inúteis, e os leilóes regados a whisky e champagne

Outro dia se apresentou no Masp uma senhora muito bonita e que, portando nos dedos um festival de anéis, levou-me a situá-la numa das duas classes sociais, Ai e A2, isto é, aquelas possuidoras de condiçóes capazes de alegrar não poucas favelas. A senhora em questão mandou a criada que a acompanhava - uma próspera mulata de extrema simpatia a quem, naturalmente, apertei a mão, apesar da micagem patronal - desembrulhar um pacote que continha um quadrinho.

Declarando-se pintora, por sinal premiada com pequena medalha de bronze num dos Salóes que cogumelam por este imenso país, a visitante, visivelmente contrariada pela proibição que lhe fiz de não fumar no local, quando enfiou logo a mão na sacola para tirar os armamentos dos viciados, (cigarreira, piteira e isqueiro) queria que eu, logo incensado como "entendido de arte," expressasse um parecer a respeito de sua arte e, se favorável, esperava expô-la no Museu.

A posição de um diretor de museu no Brasil obriga-o a se disfarçar de diplomata, tendo que conversar cordialmente, cozinhando em banho-maria os postulantes à glória de terem suas obras expostas, lado a lado, juntamente com os grandes mestres, como ainda ter, de explicar-lhes que hoje em dia os salóes se constituem em organismos superados, já que calcam suas diretrizes no conceito da premiação. Longe de nós dar risadas em face do que em tais salóes se outorgam: medalha de ouro grande, média e pequena; de prata grande, média e pequena; de bronze grande, média e pequena; e, como prêmios de consolaçáo, imenso caudal de mençóes honrosas. Mas não é o caso de achar graça em tudo isso?

Hoje o sistema está superado. Não mais existe o método De Piles para avaliar e julgar artista, pois estes senhores, senhoras e senhoritas se manifestam fora das regras acadêmicas que, bem ou mal, permitiam estabelecer se um pintor sabia desenhar, ou pintar, sombrear melhor uma figura, compondo melhor que seu concorrente.

Mas o sistema medalhístico serve para encher a linguiça dos currículos e torrar a paciência das tipografias que imprimem os vistosos, mas nem sempre de bom gosto, catálogos distribuídos nas exposiçóes. Os currículos servem também para a compilação de dicionário de artistas, em cujas páginas aparecem os tais como ganhadores de competiçóes que mais parecem corridas das nobres raças cavalares, ou mesmo de fitipaldianas fórmulas 30.

Explicando bem o assunto à citada senhora, teci consideraçôes, bonariamente, de interesse pela sua arte, lembrando-a que também minha avó fora distinguida com uma medalha, numa exposição realizada no Círculo de Diversão dos Salesianos de La Spezia, onde apresentara uma aquarela representando um buquê de margaridinhas. Juntei que minha avó era tão modesta que chegou a proclamar que a distinção de que fora alvo era produto de marmelada, pois na comissão julgadora figurava uma sua parenta.

Porém, a pintora não se convencia, ainda que gentilmente, de não pensar mais nas suas pretensóes de ser artista consagrada. Sua acompanhante me 
olhava como se quisesse dizer: "O senhor seja paciente com esta vaidosa."

Felizmente tudo se concluiu quando lhe disse que tivesse fagueiras esperanças quanto ao seu futuro.

$\mathrm{O}$ caso, um entre muitos em que, às vezes, sou parte, leva-me a querer falar de quermesses. Sociologicamente, hoje em dia, as quermesses da arte são divididas em duas grandes categorias: Salóes e Leilóes.

Os Salóes vêm de longe, duros de morrer, após dois séculos de vida. Surgiram em Paris, para mostrar as produçóes dos mestres da Academia. Pioraram quando a arte se democratizou e se desvinculou do oficialismo governamental. Como os governos se intrometem também nos problemas da arte, os salóes se estruturaram nos moldes ainda hoje vigentes: manipulados por uma comissão organizadora, uma de seleçáo, uma de julga mento, e finalmente uma de premiação. Atualmente, os salóes murcharam nas metrópoles, ou estão mais discretos. Passaram a vigorar nas cidades interioranas, onde, canhestramente, se repetem, à moda oitocentesca, às premiaçóes.

Aqueles que recebiam triunfalmente a coroa de louros não eram nem Monet nem Van Gogh mas os Messonier. (Na pinacoteca do Museu de Arte existe o Retrato de Desbulin, de Manet, obra-prima recusada no Saláo de Paris em I875, juntamente com uma outra sua, Le Linge, o que nos dá muito bem a medida do que valem tais comissóes.)

Não tenho a menor dúvida de que as comissóes sempre aceitarão e premiarão as palhaçadas. Os salóes servem somente para distribuir generosos cachês aos convidados a festival quermesses.

Recentemente fui convidado, juntamente com Paulo Chaves e Maria Helena Chartuni, para julgar os concorrentes ao Saláo de Universitários de São Carlos. Devo dizer que nunca fui membro de júri, porém não poderia recusar o convite, para não desagradar amigos que até intitularam um prêmio com meu nome. Primeiro procedimento: que todos os participantes fossem aceitos. Depois: indicação de um grupo que me parecia mais original, sem julgar primeiro, segundo, terceiro etc...
Salóes continuam em moda. Vejo o catálogo de um realizado em Presidente Prudente com algumas benesses: I. De Honra com quatro figuras; 2 . De Organização com quinze membros; 3 . De Seleção, com cinco elementos; 4. de Premiação com outros cinco elementos, encabeçado pela professora Aracy Amaral, a salsa que está presente em todas; 5. Comissão de colabora cão.

Os artistas selecionados eram militarmente divididos em repartiçóes de produto: I. Pinturas; 2. Aquarela; 3. Desenhos; 4. Gravuras; 5 . Técnica experimental; 6. Escultura. A maioria dos aceitos inscritos no anágrafe da Atenas do Brasil, quase todos amadores. Por motivo de economia, as medalhas: (as costumeiras de ouro, prata e bronze) primeira, segunda terceira, como numa corrida ciclística.

Não seria hora de se acabar com esta, sem sentido, história de premiacão substituindo-a por um sorteio?

Um sorteio pode ser proposto também para um outro tipo de happening, isto é, o do Leilão. Antigamente, no apogeu da glória efêmera do Panettone, um italiano trapaceiro, de nome legal Paolo Businco, aqui atuando rocambolescamente com o falso de José Paulo Domingues, os leilóes eram absolutamente nada sérios, com poluição de vícios, dos quais os mais graves eram os lances frios e algumas obras de duvidosa autenticidade, fatos esses passíveis de serem penalizados pela lei inexistente. Depois, as coisas tomaram outro rumo, e o Panettone reformulou o sistema de leilóes: I. Introduziu o sistema de um speaker-trombeta que se encarregava de explicar aos jejunos do negócio Arte se o valor correspondia a um preço justo, usando linguagem monetária, abundando em adjetivos mesmo quando a peça oferecida não era legítima; 2. Numerosas e atraentes ninfetas em provocantes mínissaias e generosamente decotadas se encarregavam de receber das cortes de apostadores os lances, mesmo quando as peças licitadas eram dos próprios interessados e proprietários; 3. Garçom portando refulgentes bandejas e oferecendo generosas doses de whisky de boa marca e idades longevas, escoltadas por saborosos e ricos canapés; 4 . O empresário, de preto, passeando inflado de orgulho no 
salão regorgitante: um Napoleãozinho que, ao invés de se fazer notar pelos milênios das Pirâmides, se fazia pela crème burguesa.

Como os salóes, a moda do leilão pegou. Ainda hoje se desenvolve com sucesso. A assistência aumentou vertiginosamente, como cresceu o número de casas, escritórios, repúblicas, terraços, patrulhas e mascates que se dedicam a uma tarefa que de veria ser exercitada com mais decência e maior pudor.

Um amigo me fez um cálculo do interessante e aproximativo, computando dados oficiais de um dos últimos leilóes havidos nesta pauliceia às vezes um tanto desvairada: presentes, três noites de ofertas e recreio social-mundano, nada menos que 4500 pessoas; oferecidos sessenta lotes por noite o que nos dá um total de I80 lotes nas três noitadas e que dá uma média de pouco mais de $2 \%$ presentes abiscoitando as maravilhas oferecidas.

E como certamente nem tudo foi vendido, e ainda pelo fato de um comprador ter adquirido mais de um lote, chega-se à triste conclusão de que o sucesso não foi assim tão grande como alardearam seus organizadores. E isso nos leva a uma outra conclusão, por sinal melancólica: da multidão de 4500 pessoas presentes ao evento, apenas uns quatro gatos pingados se aventuraram a abrir a bolsa para comprar coisas que, em outras circunstâncias e locais, não se cifrariam tão altamente.

No que se refere aos preços alcançados, repetimos, nos leilóes, nunca se sabe se são verdadeiros, já que não se tem acesso à economia interna dos seus organizadores. Em muitos casos, Londres docet, são colocadas em leiláo obras que, através de lances combinados, servem par a valorizar autores. Os compradores com a cabeça fria e que não se deixam levar pelos cantos de sereias, e que portanto náo fazem aquisiçóes por preços artificiais, como aquele pessoal que, ao sabor e calor de whisky trava ardentes duelos competitivos, visando, quase sempre, a demonstrar poder e posse, exibindo em público a cor do seu dinheiro. Alguns, os tidos como ladinos,esperam o dia seguinte ao último leilão para adquirir obras por preços vantajosos, diremos, de autêntica liquidação.

Nos leilóes, o pessoal que frequenta está dividido em quatro categorias: I. Os proprietários das peças, que incentivam os lances, parando-os quando têm alcançado o desejado valor; 2 . Os que, para enganar o tempo, para encontrar amigos, para degustar whisky e canapés de caviar e salmão, vão assistir ao espetáculo; 3 . Os que querem mesmo comprar; 4. Os ingênuos, geralmente jejunos do problema Arte, que se deslumbram com uma conversa vivaz e sonora, e que acabam comprando, por vultosas importâncias, objetos bem montados. Esta categoria, na gíria engloba os denominados de "patos."

Num dos últimos leilóes vimos que um desses "patos" pagou mais de um milhão de cruzeiros por um quadro que vale, no mercado, menos de um quinto.

Senhor \#30, setembro de 1980, p.II2 (Senhor e as Artes)

A DESCOBERTA DOS SIMBOLISTAS

Um elo esquecido mas importante na longa corrente da história da arte

O historiador do futuro, aliás, as equipes de historiadores do futuro, terão um trabalho nada mole pára decifrar e descobrir os valores do século em seu último quartel, pois as tendências e as personalidades deste são numerosas, para não se dizer inúmeras. Se ainda hoje há quem registra artistas do passado e a cada momento são descobertos muitos esquecidos e ignorados, ou marginalizados, imagine-se agora qual a pletora dos que poluem a republica das artes. $\mathrm{O}$ historiador do futuro, de qualquer jeito, será favorecido por nós, cronistas, que vamos documentando as operosidades, valendo a fotografia como testemunho eloquente, possibilitando assim o conhecimento até dos menorzinhos e dos amadores. Peneirando e separando, o trabalho será facilitado aos julgadores, tudo dependendo, naturalmente, do sistema, do código preferido, da estética, aliás das estéticas acertadas ou chutadas, vigorando os saltos de fortuna e de recuperação dos modos, as mudanças e as oscilaçóes do gosto.

Não resta a dúvida que ao nos reportarmos aos tempos em que a publicidade 
excercerá sempre mais influências determinantes, fabrico de ídolos, imposiçóes, participando das decisóes, além dos atrelados à estética, dos manipuladores do valor venal da bagatela arte. O que se está assistindo na mercantilidade do produto artístico, faz prever que daqui há pouco o valor de um artista será estabelecido pelo barômetro das bolsas. Até que o poder dos poucos não passe para o poder dos muitos, até a queda da nova Bizáncio, teremos a vitória do amadorismo e das suas meladas que influem deleteriamente no julgar as situaçóes.

Sem recorrer ao que aconteceu neste século, na Europa, no que se refere às injustiças e nos esquecimentos de mestres, vamos registrar alguns dos mais inexplicáveis casos brasileiros: o tardio descobrimento do valor de alguns artistas que não têm capacidade de fazer propaganda, (hoje comum até em mocinhas que aos vinte anos exibem curriculum quilométrico) o lento e tardio descobrimento de Tarsila, Vicente do Rego Monteiro, Domingos Viegas de Toledo Piza, para citar alguns.

Parece que o contemporâneo não sabe julgar, fruidor como é do bombardeio publicitário e do nome repetido às pampas nas crônicas sociais. Bastará lembrar o caso de Ismael Nery cuja obra, escondida ao longo de quarenta anos, emergiu tímida e desconsiderada, para depois a comercialização levá-la aos píncaros dos valores pagos em termos de autores nacionais.

Mas, como se disse, o fenômeno não é brasileiro. Depois de um decênio a presença dos Simbolistas não provoca e nem é motivo de risos. Para confirmar: só agora se descobre o Art Nouveau e o Art déco, e então vemos o pessoal correndo atrás dos Gallés e dos Majorei, famélico e ansioso, naturalmente sem nada entender, somente inebriado por causa dos generosos preços que alcançam.

Agora é a vez dos olvidados Simbolistas. Notava argutamente Mário Praz, dedicando um seu ensaio a Jean Delville, (1867-I953) que deste pintor não se tem notícia em nenhuma das muitas enciclopédias das artes, e muito menos nos tratados dedicados ao século I9 e nas publicações dedicadas ás ciências ocultas, apesar de ser ele um notável estudioso neste setor. Nem se encontra seu nome no exaustivo Art and the Occult, de Paul Waldo Schwartz.

A redescoberta do Simbolismo coincide com o desempoeiramento do surto do teosofísmo, a aproximação às religióes orientais, à Rosa-Cruz, ao espiritismo e quantas outras misteriosóficas práticas espirituais. Certas lojas de objetos litúrgicos de candomblé devem ser consideradas de marca simbolista.

Recentemente, obra famosa de um simbolista italiano, Giovanni Constantini, (I872-1947) deu não poucas voltas no mercado local sem encontrar apreciadores para finalmente acabar, como sempre; em Mirante das Artes, a galeria que há quinze anos inaugurou-se com uma exposição de Art Nouveau, suscitando a mais desoladora das indiferenças e apodos como coleção de mau gosto. (O mesmo não aconteceu quando comprei em 1947 dois magníficos vasos figurados Art-Nouveau para o Masp, espalhando-se meia voz que teria organizado uma pinacoteca de caracóis?)

O que queria dizer é o seguinte: o público que tem no bolso a varinha de condão para se apropriar do objeto de arte, com a filantrópica intenção de fazer bons negócios, procura se informar, possivelmente estudando o problema arte, participando da vivência implícita no problema, tendo em mente que os artistas que valem são antecipadores, que o tempo sempre produz arte, o mesmo ocorrendo quando o público, em sua maioria, se acostuma ás coisas correntes, ao normal, ao bonitinho aceito, à moda.

Pela prática que tenho no assunto, penso que daqui há pouco assistiremos a uma galopada em busca de obras de simbolistas, pois, por enquanto, estão digerindo o romantismo e o esoterismo nelas inseridos. Autores como Helios Seelinger ou Rosário Bernaudo terão reconhecimento e consideração, mutatis mutandis o que aconteceu na Europa com os pré-rafaelitas. Na verdade, é justo dizer que se devem aos interessados no mercado da arte as descobertas, apontando como antecipador o famoso J.B.P. Le Brun, marido da pintora Elisabeth Vigée-Le Brun, entendido e comerciante. Ele, em I783, escrevia: "Devemos aos marchands a regeneração, se me permitem 
tal definição, de um grande número de quadros profanados pela mão ignorante."
A história da arte é uma corrente a qual se juntam elos: este do Simbolismo é um deles, ainda desconhecido dos senhores que descobrem a arte é dinheiro em caixa.

Senhor \#3I, outubro de I980, p.IIO-II3 (Senhor e as Artes)

Os ITALIANOS NO BRASIL

No Museu de Arte de São Paulo, uma comovedora exposição sobre a vida, a arte e a cultura dos imigrantes que ajudaram a fazer o Brasil

O redator destas notas, que procuram ilustrar a exposição "Brasil-Itália” do Masp, pede vênia aos superiores e aos visitantes para agradecer aos que colaboraram na realização da manifestação. Muito especialmente à Fundação Giovanni Agnelli, de Turim, que táo generosamente se dispôs a patrocinar a mostra, bem como aqueles que emprestaram documentos, fotografias e objetos e a quantos, de uma ou de outra maneira, se tornaram credores de um comovido muito obrigado. Mas deseja agradecer, sobretudo, ao Brasil. Parafraseando o famoso Et in Arcadia ego, o redator, que há mais de três décadas deixou a Itália onde tinha crescido no culto de Atenas e de Roma, veio para o Brasil da mesma maneira como anteriormente fizeram milhóes de compatrícios, com o propósito de viver uma experiência sob muitos títulos desafiantes. Nesta sua seção de Senhor, quer contar por que e como desenvolveu o trabalho proposto.

Pode ser que aos emigrados seja natural um certo senso de nacionalidade, talvez um nacionalismo: nunca esquecendo a língua materna, os costumes, o modo de pensar. A saudade é um fator que acompanha aqueles que se transferem de uma terra para outra, mesmo que seja por curto período. Provoca inúmeros e imperceptíveis atos comparativos entre o que foi deixado para traz e o que encontrou pela frente. Pedidos nem sempre realizados, recordaçôes marcantes, desalentos que levam invariavelmente á saudade.

Minha preocupação, com vistas à realização da exposição, foi justamente a de náo esquecer este fato, coletando em casas de descendentes dos imigrados alguns objetos apropriados para matar a saudade das lembranças d'além mar: símbolos, que se chamam de ricordini, desde a miniatura de uma carreta siciliana até a gôndola, a Torre de Pisa, o
Vesúvio, São Pedro descalço para que os pés sejam beijados, e assim por diante.

Ao longo das minhas peregrinaçóes pelo Rio Grande do Sul e Santa Catarina onde, por ocasiáo do centenário da vinda do elemento peninsular, foram criados atraentes museus de imigração, pude saborear o verdadeiro encanto de descobrir os objetos, classificá-los, idealizando a respeito da serventia ou do proprietário. Nos museus de Caxias do Sul, Bento Gonçalves, Orleans, Urussanga e Criciúma, passei horas perguntando, rebuscando em recintos nos quais um antigo e humilde baú era uma testemunha eloquente da micro-história dos pioneiros do campo. Os museógrafos daqueles Estados são elementos que dão justamente valor a tudo que descobrem e, às vezes, conseguem recolher esplêndidas peças carregadas de memória.

\section{Jornais e publicações}

Também a pesquisa bibliográfica ensejou resultados inesperados. É riquíssima, especialmente nos anos Oitocentos, a partir das coleçóes dos jornais italianos que atingem, entre os encontrados, o número de I6o, constituindo-se em autênticas minas de informaçóes a respeito da vida, lutas, decepçóes e vitórias dos imigrados. Livros de viajantes, exploradores, missionários, relatos burocráticos de governos, publicaçôes de divulgaçóes mandadas a Europa com vistas ao engajamento de mão-de-obra. E que dizer de inexplicáveis volumes como, por exemplo, um curioso de Carlo Fabbricatore, que descreve, na sua língua, tudo que aconteceu no Rio no dia I5 de novembro de I889, volume editado pela Imprensa Nacional, evidentemente um documento de caráter diplomático? Durante as pesquisas surgiu outro caso, por acaso relatado em jornais norte-americanos: publicaram que o Brasil seria, 
brevemente, uma das maiores potências mundiais. Curioso que um escritor italiano, Compagnoni, publicou nos primeiros decênios dos Oitocentos uma história do Brasil em que prevê que este país seria uma potência mais forte que os Estados Unidos.

As safras fotográficas surgiram em número bastante elevado. Fomos neste setor, muito bem servidos, pois numerosas famílias conservaram seus álbuns, cartas e quantos outros comoventes documentos: os passaportes, os normais e os vermelhos que, ao longo de um certo tempo, se destinavam aos imigrantes, então considerados vergonhas dos governos fim de século. E os certificados de serviço militar, numerosos relativos ao cumprimento do dever de cidadão participando da guerra - pois tinha gente que a saudade levou de volta à pátria para combater no conflito libertador de Trento e Trieste.

Procurou-se ver friamente o panorama: cada papel, cada objeto, uma simples colcha, bandeiras das Società de Mutuo Socorso, trombones, folhetos, cartolas e borsalinos, máquinas, etiquetas de vinho, condecoraçóes, armas, jornais e quantas outras comuns e estranhas coisas recordativas, levantaram cada vez mais em mim e nos meus assistentes, Ana, Eugênia, Christiane, Carla, Leila, Fernanda, indagaçóes prenhes de curiosidade, diria de amoroso tributo a este milhão de Italianos (justo escrever, neste momento, com I maiúsculo) que vieram à Terra de Santa Cruz confraternizar-se, trazer valiosa contribuição, construir, a maioria ignota, muitos se destacando pela capacidade de trabalho.

\section{Homenagem à massa}

A exposição ora oferecida à consideração do público quer, antes de tudo, prestar homenagem à massa e, com ela, a todos os que conseguiram afirmaçôes de conotação emergente. Quantos são? Não é possível elencar, desde os liberais atingidos pelas perseguiçôes políticas, despontando um campeão o médico Libero Badaró, o herói de dois mundos Giuseppe Garibaldi, esposo de Anita, e os idealizadores da Colônia Cecília do Paraná, precursores utópicos de uma sociedade comunitária de complicada realização. A Itália, na confusão do êxodo para as Américas, despachou, favorecidos pela inexperiência dos agentes encarregados de selecionar o pessoal e também pelo jogo da furbicia, despachou também livres pensadores, profissionais e de poucas letras bakumnianas. Eles se meteram em agitaçôes políticas e foram os primeiros a mexer nos nascentes sindicatos. Serviram-se de teatrinhos para propagação de ideias proibidas. Seu poeta era o anarquista Pietro Gori que, com Lorenzo Stecchetti, era o preferido dos operários paulistas. A exposição se inspira na figura da Misericórdia: todos, confraternizados, sob o manto que tem por nome Itália.

Se o leitor de Senhor visitar o Museu de Arte de Sáo Paulo na oportunidade, penso que conhecerá várias páginas pontilhadas de novidades, extraídas de arquivos e relaçóes escondidas nos textos geralmente só conhecidos por alguns especialistas. A história das relaçôes Brasil-Itália, bom será lembrar, começou com Colombo e Vespucci e, bem interessante, com o armamento de uma das caravelas de Cabral por parte de Bartolomeo Marchioni, um dos representantes dos banqueiros florentinos em Lisboa, provavelmente pensando que o navegador se dirigia direto para as índias.

No primeiro século, o Brasil, ao lado dos portugueses, já apresentava italianos de valor. Bastará lembrar os pertencentes á família genovesa dos Adorno. Vieram na nau de Martim Afonso de Souza, pioneiros na regiáo de São Vicente, onde foram os primeiros a plantar cana-de-açúcar e a construir engenhos, enquanto que Sebastiano Caboto descobria terras no Sul e às quais dava o nome de Santa Catarina.

Italianos, como é fácil imaginar, chegaram como missionários sob a tutela de várias ordens. A exposição do Masp dá noticia de alguns que náo só participam da catequese, mas também da estruturação da Colônia, bastando citar o caso do Inchese Giovanni Antonio Andreoni que, sob o pseudônimo de André João Antonil, escreveu o famoso tratado Cultura e Opulência do Brasil.

\section{Sucesso nas artes}

No Brasil os italianos se distinguiam também nas artes, notadamente em arquitetura militar. Para citar alguns: 
o bolonhês Antonio Landi, que leva ao trópico as primeiras novidades do Neoclassicismo. Vindo ao Pará com outros companheiros, construiu as igrejas e palácios mais importantes de Belém. Sempre nos Setecentos, eis outros arquitetos e engenheiros: Primoli, construtor da grande igreja das Missóes no Rio Grande do Sul; Antonio Galluzzi, desenhista da fortaleza de Macapá; Francesco G. Roscio, responsável pela fortificação de Porto Alegre e da Ilha de Santa Catarina e ainda encarregado de reconhecer as divisas meridionais do Brasil. O padre Capassi, jesuíta, nomeado matemático real, continuou a tradição dos cartógrafos peninsulares que elaboraram mapas do Brasil desde sua descoberta.

Nos Oitocentos os laços Brasil-Itália mais se estreitaram, logo após o início do Reinado, e posteriormente ao longo dos Impérios: desembarcou a irmã do rei de Nápoles, Tereza Cristina que veio se casar com Dom Pedro iI. O erudito soberano estreitou muitas e cordiais relaçóes com a cultura italiana, ao corresponder-se com seus expoentes. Trocou cartas com Cesare Cantú e Nicoló Tommaseo. Assistiu as aulas de Carducri, gostava de Rossini. Sua admiração dedicou-se a Alessandro Manzoni, a quem visitou e com o qual se correspondeu por mais de dois decênios.

Proclamada a República, a crise de mão-de-obra, consequência da libertação dos escravos, encontrou a solução para ativar a lavoura através da imigração maciça. A contribuição da Itália foi essencial e determinante no campo também da indústria.

Em algumas regióes, como o Paraná, Santa Catarina, Rio Grande do Sul, Espírito Santo, o governo ofereceu ao imigrante lotes de terra e condiçóes favoráveis. $\mathrm{O}$ projeto era povoar as regióes desertas então ocupadas pelos índios, desmatar e criar pólos de desenvolvimento. Os emissários brasileiros correram Europa a fim de convidar e engajar camponeses do Veneto e do Sul da Itália. Surgia o mito da América, a terra prometida. No último decênio dos Oitocentos e no primeiro dos Novecentos, desembarcaram no Brasil centenas e centenas de milhares de italianos: assalariados nas fazendas de café conheceram a dura lei imposta pelos fazendeiros, muitos dos quais ainda não acostumados ao trato com o trabalhador livre.

Apesar dos inevitáveis contrastes de ordem social, no tocante aos salários, a integração progrediu. Muitos italianos, pouco a pouco, se tornaram proprietários de pequenas glebas, conseguindo, com operosidade, talento e integridade, realizar obras de acentuado vulto - como foram os conhecidos casos dessas figuras admiráveis chamadas Geremia Lunardelli, o rei do café, Morgantú, Ometto, Carbonari, Biagi, para apenas citar alguns.

Outros peninsulares, deixando o campo ou entáo chegando com recursos e capacidade técnica, além de visão a respeito do futuro do país, como ainda dando vida a pequenos laboratórios, muito contribuíram para dar base à indústria nacional, distinguindo-se como autênticos capitães, sendo o mais famoso, entre eles, o conde Francisco Matarazzo.

Demonstrando capacidade e espírito inventivo, conseguiram iniciar a fabricaçáo de produtos que, antes, o Brasil comprava fora. Basta lembrar o caso de Matarazzo que, para superar a importação de banha aos Estados Unidos, inventou o sistema de produzi-la em Sorocaba, enlatando o produto.

Raro, enfim, foi o setor em que o peninsular não esteve presente. Agricultura, indústria, comércio, artes, profissóes liberais, notadamente na engenharia, arquitetura, pintura, escultura e artesanato de alto nível.

Entre os engenheiros: Giuseppe Giorgi, que construiu a Estrada de Ferro Sorocabana; Giuseppe Chiapori e Giulio Micheli, que trabalharam nas estruturas do Viaduto Santa Ifigênia; e o versátil Giuseppe Martinelli, que ergueu, nada menos, o primeiro arranha-céu que leva seu nome no Anhangabaú; Domiziano e Cláudio Rossi, construtores do Teatro Municipal de São Paulo, projetado por Ramos de Azevedo; Antonio Januzzi, no Rio de Janeiro, o construtor de mais renome nas décadas de I880 até I9Io. Destaque mereciam inúmeros personagens da edilidade, arquitetos de valor como Tommazo Gaudenzio Bezzi, autor do palácio onde hoje se encontra insulado o Museu do Ipiranga, fronteiriço 
ao Monumento da Independência, obra do romano Ettore Ximenes. E os mestres de obra? Os que construíram o Brás e o Bexiga? Ainda há uns trinta anos se viam por lá casas de fachadas ricas de decoraçóes.

O primeiro pintor italiano do qual se tem registro é João Francisco Muzi, no século i8.

Os Oitocentos são ricos de nomes italianos: os irmãos Bernardelli, chegados do México, e Eliseu d'Angelo Visconti, Giambattista Castagneto, Gustavo Dall'Ara. Sempre para citar alguns: os irmãos Angelo e João Simeone, Fúlvio Pennacchi, Alfredo Volpi, Mário Zanini, Paulo Cláudio Rossi Osir, Torquato Bassi, Hercules Barsotti, Inocêncio Borghese.

E a escultura? Foi a Francesco Benaglia, da Academia de São Lucas de Roma, a quem se encomendou o momento a Dom Pedro I para a Biblioteca Imperial. Da Itália vieram quase todos os escultores do Brasil. Em São Paulo formou-se uma verdadeira escola onde despontaram Amedeo Zani, João Badsta Ferri, Antelo Del Debbio, Eugênio Prati, Nicola e Adolfo Rocco, Alfredo Oliani, Ricardo Cipicchia, Bartolomeo Cozzo, Lelio Coluccini, A. Zago e mestre Victor Brecheret que veio ainda criança de Farnese, do Lazio para Sáo Paulo.

Os italianos tomaram-se os protagonistas daquela instituição que, ao tempo da formação urbana, era considerada em São Paulo a meca do bom gosto, o Liceu de Artes e Ofícios, ao lado da Pinacoteca do Estado e da Academia de Belas Artes, no grande edifício de Ramos de Azevedo. A chefia do melhor período foi a de Luiz Scattolin. Berço de artesáos de reconhecida capacidade, o Liceu atendeu a todos os ramos das artes aplicadas. Ao lado do Liceu, deve-se lembrar a atuação muito importante do Colégio Dante Alighieri, fundado em ryı e ainda hoje considerado uma das escolas altamente qualificadas para a formação de nossa juventude.

A exposição indica também personalidades brasileiras que se distinguiram na Itália. Não são numerosas, porém lá deixaram lembrança notável. Além de Carlos Gomes que Miláo considerou com alto respeito e admiração, o pintor Pedro Américo se estabeleceu e morreu em Florença, onde teve oportunidade de executar grande parte da sua obra, a partir da Batalha do Avai, que levou ao seu atelier para visitaçáo além de Dom Pedro II, mais de cem mil populares.

Neste século, o poeta Murilo Mendes e Deoclécio Redig de Campos, como historiador de arte e diretor dos Museus do Vaticano, representaram a cultura nacional em Roma muita consideração.

\section{Legenda}

p.II2 A tabela dos fundadores da Pátria e Lavoro (SP) A providência e Cabral, por Eliseu Visconti Lembrança das núpcias de Pedro II e Tereza Cristina Garibaldi, num modelo da cerâmica popular 9 Mostruário de letras para toalhas e lençóis p.II3 Imigrantes italianos, por Antonio Rocco Máquina primiriva de fazer macarrão Um bibelô siciliano, bom gosto e singeleza

Senhor \#32, novembro de 1980, p.96-97 (Senhor e as Artes)

O ANTIGO E NÓs

Os problemas do tempo na cultura e as fórmulas que usamos para solucioná-los

A arte, por nós entendida como todo ato de exaltação do espírito, assemelha-se a uma curva balística que, em seus vários ciclos de espaço e tempo, em sentido circunscrito e em sentido absoluto, volta sempre ao seu ponto de partida: uma curva originada numa determinada razão que a segue e a governa, substanciando-a novamente em si. Algumas curvas, projetadas por um homem, por um povo ou mesmo por um século, deixaram mais profundamente seu marco no éter, enquanto outras apenas foram percebidas, o que não significa, aliás, que milhares, e por que não dizer milhões de curvas, foram tentadas sob várias formas desde o princípio da criação até nossos dias, mesmo quando lançadas por pessoas iludidas ou inadequadas, e que náo concorreram para determinar uma curva maior, isto é, uma súmula dos pensamentos mais próximos da grandeza de Deus.

O tempo estabeleceu um pacto mútuo e inexorável com a arte. E por outro lado ofereceu oportunidade para novas atividades, a defesa das mesmas, a salvação consciente, silenciosa e contínua. O tempo 
salva o que efetivamente vale, predispóe uma sequência de iniciativas, aproxima e amalgama a formação do espírito, resguarda dia a dia o patrimônio da curva diretora da arte que, como palavra comum, mas, significativa, chamamos de Antigo.

O Antigo e o passado, aquelas coisas dignas que nossos antecedentes acumularam, selecionados pela fatalidade, a fim de preparar o alimento normal do espírito do homem vivo.

O desenvolvimento da civilização consiste justamente naquele ato de tirar do berço do Antigo as ideias que pretendemos aperfeiçoar; reunir a vida a seus antecedentes, almejando certezas que a experiência nos proporciona. Sendo que civilização, em última análise, significa arte, acreditamos que a arte de todo tempo e de toda escola deve ser subentendida como o princípio que homenageia o Antigo.

$\mathrm{N}$ áo nos compreendam mal: perante o Antigo deve-se manter o inusitado da vida, sem renúncias, sem medo, sem arrependimentos, em relação aos nossos trabalhos de audaz pesquisa e de nobre sondagem nos escaninhos da fantasia. Quem honra o Antigo é uma pessoa corajosa que traça na calma da normalidade uma curva absurda, e náo o ruminante que recompóe algo encontrado no álbum dos séculos. Os artistas conscientes sabem que o patrimônio que possuem é o resultado de anseios, de buscas, a fim de atuar de maneira diferente, para corrigir, para reagir, para superar e ajustar algo do passado; esse progresso pressupóe um apreço, aliás, um conhecimento do Antigo.

A obra de De Chirico, de Morandi, de Matisse, de Tarsila (só para citar alguns) é a prova do que estamos falando. Para os homens de talento, o Antigo é uma "energia vital," como bem sublinhava Taddeu Zielinski ao falar de filologia. Por outro lado estudar o nosso passado significa conhecer nós mesmos, já que somos seu resultado.

Deve-se ver e honrar no Antigo as coisas de outras épocas, longínquas ou próximas, testemunhas eloquentes da extraordinária efervescência criadora do homem. O estilo de um casa não é consequência da radical observância de cânones divulgados por contemporâneos, com a rigidez de neófitos, mas de interpretaçáo livre e generosa da beleza que é regida por uma única lei e que impossibilita a derrogação do bom gosto.

O fetichismo do moderno é tão ridículo quanto o olvidamento do mesmo. Assistimos, de há muito uma luta surda e estranha entre "modernistas" e“tradicionalistas," isto é, entre aqueles que acreditam estar concordes com a estética, usando para tanto uma cadeira feita de tubos cromados ou olhando para a reproduçáo de uma tela de Picasso; o mesmo se pode dizer daqueles que pensam possuir a pedra filosofal quando assentam-se numa cadeira Luiz XV ou tendo em sua frente uma copia de Aurora, de Guido Reni. Os primeiros reformaram seu apartamento liquidando talvez uma valiosa mobília dom João vi, enquanto outros fizeram loucuras incríveis que o marceneiro da esquina lhes fabricou móveis estilo manuelino do século I6.

Acima dessas multidóes, agitando, em boa fé ou incidindo em erro, está a gente culta, serena, educada que raciocina. É àquela nos dirigimos: sabemos que onde $o$ arquiteto prescreve a exclusão de objetos antigos, ela coloca - digamos - ao lado de uma mesa de cristal e base de aço escovado, uma tapeçaria chinesa do século is ou uma têmpera antiga. Harmonizar não significa concordar, mas sim desenvolver seu próprio gosto em aprazível intimidade.

Excluir o antigo do ambiente moderno é um vício originado pela ignorância de muitos decoradores; por outro lado a hostilidade ao moderno é uma tomada de posição, teimosa mesmo, do oponente; a resistência ao belo-novo é responsável pelo carunchamento das imitaçóes, na verdade um cancro da vida contemporânea. É claro que não estamos apregoando o conúbio entre o Antigo e o Moderno como sistema que deve ser seguido ao pé da letra; mas é certo que nossas referências ao Antigo não se relacionam a uma determinada época: o passado é uma antologia em que todos podem colher uma flor, onde todos podem, às vezes, encontrar junto uma erva daninha.

Cada época, aliás, os curtos momentos que a formam, compreendem o florescer e a declinar da moda, que é o oxigênio 
respirado pelo estilo; a moda é imperceptível, emergida às vezes de um esconderijo que traz em si o sentido da hora que passa. El Greco e Magnasco, esquecidos durante séculos, foram apresentados de novo por mestres influentes da moda. Da mesma forma como agora os antiquários desvendam, de dentro da neblina, o estilo Luiz Felipe, abandonado até há pouco tempo a comiseração hilariante quer do filo-futurista, quer de aspirantes a castelos ornados de ameias. São esses os ciclos do gosto que se sucedem segundo as próprias leis de Vico. Cada século tem suas preferências, e é lógico que com o passar dos tempos as coisas preferidas aumentam numa progressão geométrica. Hoje podemos escolher num jardim infinito; é justamente no momento da escolha que mostramos um sentimento.
Mencionamos, linhas atrás, os futuristas. $\mathrm{E}$ não o fizemos por mero acaso. A já antiga iniciativa de Marinetti é considerada como fato determinante do gosto moderno: lamentamos que o autor do manifesto tenha partido da ideia de destruir o passado para criar o futuro. Foi uma rebeliāo e seus propósitos deviam ser tomados ao pé da letra somente por cinco minutos. Alguém devia ver na Vitória de Samotrácia uma locomotiva, já que outro via numa locomotiva a vitória de Samotrácia.

São esses os "problemas do tempo" e cada um inventa sua própria fórmula para solucioná-los.

\section{Legenda}

Rosário Bernaudo, Odalisca 9 Eduardo

Torassa, A vida g R. Hauer, A vaidade

g Anônimo do século I9, $O$ paraíso 9

Giovanni Constantini, Adeus a Roma

Senhor \#33, dezembro de 1980, p.65 (Senhor e as Artes)

Bienal, TRIENAL, QUAdRIENAL...

A cada dois anos é inaugurada em São Paulo uma Bienal, sequencia de muitas que vêm desde os anos 50, época em que seu idealizador conseguiu de um prefeito amigo destruir o Trianon, então um belvedere das maravilhas idílicas que andavam crescendo e castigando o Anhangabaú; lá construiu um barracão sob cujo teto implantou a primeira edição.

Depois sua articulação, o Brasil se meteu a realizar algumas coisas no setor, recorrendo aos moldes de fora e, como os interessados os elegem sempre mal, a Bienal internacional-paulista sabendo que o farol deste tipo de manifestação projeta seu facho de luz na distante Laguna do Adriático, não teve dúvidas em recorrer aos matizes venezianos.

Os neófitos foram peregrinar por aquelas mecas quando adquiriram um Regulamento e lastrearam seus passos inspirados no evangelho que o prof. Fradeletto obrou em I893, por sua vez calcado nos sistemas do já rançoso internacionalismo das exposiçóes industriais de Londres e de Paris e que náo passavam de eventos para verificar como cada país produzia seus bens de consumo e de diversão. Mais uma vez a Atenas do Brasil acabava distribuindo uns bombons já mastigados, na própria pátria de fabricação para quermesse de importância turística, tão do agrado da classe hoteleira.

No barracão plantado diante do Parque Siqueira Campos, Regulamento veneziano à mão, os costumeiros Péricles que tudo sabem começaram a convidar as naçôes. Quais? Todas, convocadas por intermédio dos então poucos cônsules de carreira e daquela multidãozinha de honorários, sempre presentes nas festas cívicas e mundanas, devidamente encartolados. Pegaram a lista telefônica, anunciaram o festival.

Nasciam assim gloriosamente as Bienais internacionais para gáudio da cidade aspirante ao foro de metrópole. No burgo existia então uma única galeria de arte moderna, a Domus, uma iniciativa do casal italiano Fiocca, logo fechada por falta de cultores.

A Atenas, enfim de um dia para outro, se lançava na apreciação da arte internacional, incorporando nas salas centenas e centenas de artistas locais que, descobrindo o Abstracionismo então na moda, manufaturaram o produto. $\mathrm{O}$ que aconteceu depois todos sabem, e as últimas notícias que se tem do nababesco evento é a seguinte: este ano nada de Bienal, que 
cederá lugar a uma Quadrienal que assim terá condiçóes de, burocraticamente, informar aos quatro ventos cada quatro anos aquilo que mensalmente se sabe a respeito aos movimentos espraiados nos campos da pintura e da escultura.

Bienal... Trienal... Quadrienal ou Decenal. Todas não passam de novidades com barba já branca e bem mandarinesca.

Os dirigentes da Fundação Bienal (um parêntese: não dispóem em caixa de um único cruzeiro como capital, vivendo de angustiantes verbas) convocaram os críticos de arte das Américas Central e Meridional para que, num longo passeio por estes pagos, oferecessem sábias soluçóes com vistas à edição de um certame dedicado ao cone, a mesma ideia e realizaçáo do antigo presidente da Bienal, dr. Rodrigues Alves, que nos permitiu, pela primeira vez, apreciar bons artistas sul-americanos.

Cerca de quarenta pensadores pontificaram, sendo que um deles chegou a propor exposições de caráter histórico: Pré-colombiano, Barroco, Oitocentos, numa evidente competição ao que já fazem os museus.

Agora, caro amigo Luizinho Villares, presidente em exercício da Bienal, (à qual seu fundador e magna pars não deixou nem estrutura técnica e muito menos estrutura financeira) visto que Hegel fantasiou mal, pois o fazer arte jamais vai morrer, o que se precisa não é escutar, democraticamente, quarenta Licurgos, mas operar a tabula rasa de um passado não edificante; enfrentar o cacarejar das galinhas e os gritos dos galetos; fechar o poleiro; se ne fregare dos palpiteiros; náo elocubrar em "maior do mundo;" convencer-se de que as grandes iniciativas nascem de uma simples ideia; raciocinar em termos de Brasil e não de Beaubourg ou MoMA, pensando que as verbas vêm do povo; e assim por diante.

Não desprezemos o adjetivo caseiro. Se o Brasil é elemento no concerto internacional, não queremos dizer que devemos continuar a recorrer às modas de fora, como fez meu caro amigo Cicillo.

O Brasil tem de encarar sua própria realidade. Parece-me, digo-o sem exagero, que o último Saláo Paulista, com aquelas premiaçóes, é um marcante exemplo de subdesenvolvimento. Quatro gatos pingados irradiando contentamento não representam a realidade do fazer-arte neste país. A arte não é o que promana de um Cardin ou Saint Laurent, como meia dúzia de tributárias caboclas da alta costura acreditam; mas uma realidade que faz parte da cultura de um povo, deixando de lado tudo que é sofisticado-importação.

Caro presidente Luizinho: devo dizer-lhe que, hoje, o Brasil precisa mais de "arte socialista" (entenda-se como fato de utilidade social) que de arte prêt-a-porter ditada pelas desmoronantes vanguardas. Vanguardas que sequer conseguem agradar os poderozinhos da elite, pois este pessoal nada entende de estética. E tanto isto é verdade que continuam comprando Mulatas de Cavalcanti e Marinhas de Pancetti, tendo presente que compram mais para investir o dinheiro ocioso, do que para se inebriar espiritualmente.

Nestes tempos bizantinos, a arte dos prêt-a-porter de chancela parisiense é divorciada do público, pois o que oferecem é ininteligível. Será que uma tela rica ou pobre de retângulos de cores chapadas suscita emoção a alguém? E será que um arco de flecha pintado de branco colocado numa parede chama atenção? Será? Não desconsidero seus fabricantes, porém me parece que as determinaçôes Tristan Tzara e dos madeistas entraram na História como curiosidades. De qualquer jeito melhor ser fautor de uma reconsideração da arte em termos tradicionais, valendo o bloco das liberdades abertas. Um único veto: o chute modístico.

Parece-me que a Bienal (se continuar) deveria se conceituar de que a arte não é divertissement para grupinhos.

Senhor \#34, janeiro de I98I, p.72 (Senhor e as Artes)

ACADEMIE-VANGARDE

Ou, como descambar rapidamente para o ocaso

Em recente programa de televisão, o Vox-Populi da TV Cultura de São Paulo,

tive ocasião de definir a situação contemporânea das artes, qual a de um evidente 
caos. Respondendo a alguém, não tive dúvidas em incluir no caos a participaçáo dos penetras, aqueles elementos que apropriadamente apelidei de provisórios, uma parafernália de voluntários que pretendem superar a tradição milenar do comunicar, o figurai, apresentando enigmas objetivados nas propostas derivadas do Dadá ou do Pop, o celebrar coisas e utilidades do dia-a-dia, gags de fácil achado, quase a descoberta do óbvio, às vezes sem perceber que o produto é uma simples contrafação, caricatura, paródia do já visto e manjado.

Dizia no Vox-Populi que, observando pinturas compostas de uma única demão de tinta, por exemplo, Klein, ou uma exposição oferecendo quatro cubos distanciados uns dos outros e colocados no chão, me parecia que o figurativo ainda tem sua presença firme e inamomível. Paradoxalmente, quando vejo estas frescuras esnobísticas, mais adoro o pintor camponês primitivo e as pinturas a serviço do socialismo.

Não que as tentativas de fuga e de abertura no considerar e representar a forma mereçam ser severamente desconsideradas. Absolutamente. Devem ser consideradas, porém usando o grano-salis, peneirando as novidades, procurando a originalidade.

Ao longo das emergentes polêmicas focalizando o Contenutismo, se aprendeu que a pintura e a escultura, diremos, passadistas, postas nas casas, acabam sendo ornamentos decorativos.

Então: um Bosch ou um Cézanne ou mesmo um Picasso, devidamente emoldurados, seriam decoração, ao passo que seriam perdoados da classificação Decoraçáo, produçóes, diremos, conceituais, como o amontoar e prensar uma massa destinada â forragem, ou uma invenção plástico-colorista de arte-pobre. Arte é interdependente de Decoração, nada tendo a ver com os que cancelam a tradição quando opinam que a Arte, como se continua ou se deveria confirmar a entender, morreu, passando o ofício aos contestadores ou reformadores.

As discussóes fazem parte do caos que está envolvendo a Arte. Para quem tem sensibilidade com alguma ponta de ironia, não passa de um panorama divertido. Admitidos no teatro quaisquer espécies de participantes penetras e provisórios, deixada de lado a corrente finalidade estética ou bem intencionados no operar em favor de uma estética outre, assiste-se às mais variadas negações, ostracismos, divisóes que incluem até as modas do Séculos, desde os tempos do Cubismo até os do Surrealismo.

A atenção da assim chamada crítica que se preocupa mais em patrocinar os conceitualistas, para fugir da definição de academista; me faz pensar em advogados que aceitam acusar ou defender, invariável e indistintamente. A crítica em geral é advogatesca. Para quem observa as confusóes que o caos alimenta, é gostoso ler frases apodíticas para exaltar campeóes da última trouvaille ou saber que comissóes oficiais de peso outorgam prêmios a alguém que empacota pequenamente o que Cristo embalou volumosamente. É verdade que se deve levar em conta a existência da burguesia continuadora do colecionismo interesseiro que defende, com unhas e dentes, agitando os boletins da bolsa de valores, melancólica situação da estética acadêmica e post-acadêmica: outro contribuinte alimentador do caos, encabulado no vestimento, confundindo os acertos dos valores pecuniários, em lugar dos do talento. Contestar é o último grito com foro de palavra de ordem, segundo os que se arvoram em advogados.

As vezes, revirando o caos, descobrem-se fatos que enunciam tempestades, fatos os mais curiosos, sendo o último, para citar apenas um exemplo, o do pintor Rafael Maia Rosa. Ele era apontado, entre os jovens, como elemento promissor, distinguindo-se pelo talento e pelo entusiasmo. Apresentei uma sua exposição bem convincente, no Masp. Passados alguns anos, o jovem mudou repentinamente de tendência, expondo na galeria da Cooperativa, na rua Joaquim Floriano, um grupo de pinturas de difícil compreensão. Francamente, rejeitando as prováveis acusaçóes de passadista, parece-me difícil entender o conteúdo. Penso que o Rafael, voltando ao figural, pode dar mais. Afinal os tempos da academie-vangarde estáo descambando para o ocaso. 


\section{Legenda}

Este articulista pediu ao seu velho amigo Saul Steinberg (do qual o Museu de Arte de São Paulo armou uma grande exposição nos anos 50) permissão para reproduzir dois dos seus desenhos publicados no famoso volume Der Inspektor, comentário insuperável do caos apontado.

Senhor \#35, fevereiro de 198I, p.80 (Senhor e as Artes)

AsSUNTO: CARICATURA

Ou, o sucesso de um desenhista brasileiro numa grande exposição em paises de além Cortina de Ferro

A caricatura, no amplo setor das artes do desenho, continua sendo um parente pobre. Geralmente os mestres, que se dedicaram ao setor, não são lembrados nas histórias: para eles, a colocação se dá mesmo nas próprias histórias da caricatura, o que representa uma das falhas dessa literatura. Tem-se a impressão que Hogarth, Goya, Daumier são julgados repartidamente, pintura e desenho, mas nunca numa única posição. O desenho é considerado um acessório, a caricatura apenas uma curiosidade.

Temos salóes de caricatura, (no Brasil o notável de Piracicaba, SP) publicaçóes que recolhem expressóes de humor, sendo raro, senão impossível, ver algo caricatural de um pintor intercalado numa exposição, quase a desconsideração, como iniciativa $a$ latere, menor, se não transcendental. Apesar da praxe, a manifestação da caricatura está ganhando sempre um maior interesse. Penso que aqui, em Senhor, as páginas humorísticas são bem apreciadas, dando aos respectivos autores o correspondente valor. Por isso dedico esta seção a um volume que recebo de longe, da Bulgária, onde um brasileiro se faz presente, o jovem Nicoliello, que reputo entre os mais singulares no panorama nacional.

Nos países de influência soviética, a manifestação humorística parece ser um desabafo tolerado, contando-se bons artistas que o usam com jeito de crítica social. Às vezes existem charges contendo saborosos relevos de situaçóes, que valem um texto ou um discurso, evidenciando constataçóes com todos os visos de censura.

O caricaturista não deixa de ser, um pouco, algo de juiz, manifestando-se através do desenho, bonariamente, não certo à maneira de Grosz, mas apontando fatos a serem considerados como necessitantes de intervenção, até política.
O castigai ridendo mores neste volume búlgaro é rico de achados e de "falar à nora para sogra entender," rico também de utilização de circunstâncias do dia-a-dia, quando as linhas náo escondem uma veia que tem todo o timbre de uma revolta contra o normal por demais formalístico.

Na Bulgária, em Gabrovo, existe a "Casa do Humor e da Sátira." Organiza exposiçôes que são mostradas também em cidades de outros países. A de 1980 foi em Varsóvia, Cracóvia, Lublin, estando agora em Viena para em seguida ser mostrada em Praga. O título da exposição é "Io6 Cartunistas Contemporâneos."

No catálogo, Athanas Stoikov resume a história da caricatura na segunda metade do século 19, além de seu irresistível desenvolvimento no presente, como consequência do advento do jornalismo e da TV que andou formando e multiplicando os adeptos, favorecendo a popularização deste modo de expressão crítica: "Hoje, a armada dos caricaturistas é bem numerosa e multinacional, abarcando grande variedade de temas e tratando de problemas interessantes de todos os países. Efetivamente, esta arte indica a sensibilidade, o humor, o conceito do mundo, das tradiçóes, dos usos e costumes e da herança artística de cada povo.”

O prefaciador nota como a ideia satírica participa como crítica dos alarmantes acontecimentos que o progresso tecnológico impóe, preconizando "novas perspectivas para a caricatura contemporânea no mundo.” 
Senhor \#36, março de 198I, p.72-73 (Senhor e as Artes)

O MERCADO ASSINATURAL

Comprar para estocar. Essa é a tese do chamado colecionador. Quer

dizer, do comerciante. Mas isso náo ofende a arte?

Sendo este reportei o tal que dá informaçôes sobre as atividades do Museu de Arte de São Paulo, toca-lhe, também, a missão de receber colegas que vêm buscar notícias das exposiçóes ou das aventuras culturais que naquele recinto se desenvolvem. Tratando-se de colegas, nada mais natural que lhes seja oferecida uma acolhida cordial ao redor de uma mesa rica de cafezinhos.

O hóspede, naturalmente, quer saber, formula perguntas, anota e, finalmente, sapeca: "Quanto vale o acervo do Masp, qual o quadro mais valioso, qual o montante do seguro, se a reavaliação é feita de acordo com a inflação," e assim por diante. Inútil explicar que a conversa virando em torno do problema arte, o financeiro é secundário e, portanto, não interessante. Se falamos de Van Gogh ou de Ismael Nerv, o que vale é a arte deles e não o cheque posto na mesa para adquirir uma tela. Mas não há jeito, pois é preciso avançar uma cifra cheia de zeros para aplacar o anseio do colega e ainda assim ele insiste: "É isso que o público quer saber."

De fato o jornalista tem razão. Pois, hoje, arte tornou-se mais objeto de valor pecuniário do que um acontecimento de ordem espiritual. Há algum tempo, um redator do Jornal da Tarde me procurou para saber sobre "investimento" em obras de arte, propondo-me duas perguntas precisas: um milhão ou cinco milhôes a serem aplicados compram o quê, hoje, e em que espaço de tempo pode-se obter um generoso lucro?

Pela pergunta pode-se aferir que mais uma vez a arte passa a ter uma conotacào em dinheiro: e desta feita desafiando os operadores de uma hipotética bolsa de valores que não existe oficialmente embora seja mais que lógico pensar se na sua próxima instituição Sugerimos que não acreditem naqueles que sustentam serem os leilóes uma espécie de bolsa. Bem ou mal uma bolsa existe, dominando: o boato.

Geralmente os que descobriram, além das açóes petroelétricas ou indústrio-químicas, dos imóveis, do ouro e diamantes, dos selos etecetera etecetera, que existe também a bagatela arte, em que são cidadãos que pouco ou nada entendem do negócio, autênticos usuários dos boatos. Ouvem dizer que tal pintor tem oitenta anos, que é um clássico, que vende por não muito dinheiro, considerado bom investimento e que, depois do funeral, explode em termos de valores, um boom espetacular: entáo, por que náo correr e comprar para estocar? Corvejam, como urubus implumes, o artista e sua obra.

São conhecidos nas principais praças artísticas do país uns senhores que se arvoram em desprendidos, mas que já coletaram dezenas e dezenas de "valores" obrados pelos coitados que sofreram a vida toda por falta de "investidores." O espetacular é que a estes distintos financistas se dá o pomposo título de "colecionador" e, mais triste, arvoram-se eles, afamadamente, em oráculos, cassandras que tudo sabem, ditando leis até estéticas, distribuindo conselhos, catequisando como vestais do mercado, trombeteando astutos e marotos boatos favoráveis, sempre, ao próprio arsenal e espinafrando os arsenais concorrentes.

Porque os grupos são vários: disfarçados em colecionadores, cumprimentam-se de frente e, ao virarem o traseiro, biliarmente se manifestam hostis. É extraordinariamente satisfatório, para os raros gozadores do humor, observar esta fauna que, ao invés de enquadrar numa definição um quadro de Di ou de Dó, avança: 500 mil, 700 mil, à vista. Nunca eles póem o pé numa Bolsa de Valores, mas sua linguagem é idêntica à dos operadores: o corretor se exprime em números, sem nada saber do título que apregoa aos gritos naquele mercado de ilusóes.

O mundo vai vivendo em tempos sempre mais interessados na produção arte, prática que na verdade tem o seu lado positivo, qual o da progressiva consideração em relação ao que de mais importante sabe o homem criar, o que resta e o que realmente vale. Porém, é de se observar que nestes últimos anos criou-se uma 
verdadeira psicose não da arte, mas do valor da arte. É normal que o objeto de arte tenha o seu valor, deve ter. Não se deve ficar maravilhado pelo fato de a Benci, de Leonardo da Vinci, custar 5 a 6 milhôes de dólares, preço equivalente a um trambolho espacial que mata gente.

O que me parece anormal é o alto e preocupante grau de psicose reinante e a manifesta ignorância do problema, sem se falar no artificialismo das contrataçóes em que se veem obras despidas de qualquer característica estética ou decorativa trocadas por valores astronômicos. $\mathrm{O}$ tal que se mete no negócio acaba comprando assinaturas, chancelas, e não obras, não porque gosta mas porque constitui investimento.

Diante de uma obra de arte, em vez de usarem a cabeça para participar de uma mensagem espiritual, o que fazem é pôr em movimento o computador mercanto-assinatural. Não é ofensa à arte? É. E para aliviarmos nossos humores, fiquemos com um pintor das décadas de 30 e 40 ainda não convenientemente descoberto: Carlos da Silva Prado, autor de Maternidade, 1946, óleos sobre cartão, coleção particular, São Paulo.

Senhor \#37, abril de I98I, p.I28 (Senhor e as Artes)

Siron, NARdin, CaCiporé E (POR QUE NãO?) BARdi

Dentre os premiados pela Associação Paulista dos Criticos de Arte, versão-8I, o escriba que assina esta seção: justa homenagem a três artistas solitários, inquietos, contestadores. E ao velho professor, que diz: "grazie"

Recentemente a Associação dos Críticos de Arte, exercitando uma prática anual, deliberou premiar os que em 1980 mais se destacaram no cenário das artes. Os contemplados foram, além do repórter desta página, mais Siron Franco, como pintor, Ermelindo Nardin como desenhista e Caciporé Torres, como escultor.

Apesar de suspeito, já que sou um dos laureados, devo dizer que a distinção foi justa, demonstrando a atenção que aquele Colegiado pôs na escolha, valendo a independência com que agiu, na verdade pleno de autoridade. ${ }^{49}$ Outorga de prêmios sempre dá galhos, pois existem aspirantes armados de grossos pistolóes e que passam metade do seu tempo trabalhando arduamente para esticar seu curriculum.

Passando à crônica, eis Siron Franco, um jovem que ninguém notou quando expôs há alguns anos na galeria Cosme Velho, e recentemente revelado em individual realizada no Masp. É goiano, vive lá num sitio, isolado mas acompanhado dos estranhos personagens que imagina e que transporta para suas telas, coloquiando com elas. Admitidas e agraciadas, participam do seu fechado clube pictórico.

49 Sobre este prêmio, cf. Anexo C, p.663, "Nos museus, os verdadeiros tesouros," de Jacob Klintowitz.
Cordialmente irônico, incapaz de sarcasmos, Siron indaga argutamente caracteres, analisa expressôes morais, preferindo as da não-normalidade, apontando ângulos de interesse curioso. Insere, para melhor fixá-las, acessórios complementares, às vezes reduzindo o parceiro a simples papéis alegóricos.

Um manipulador de seres anti-graciosos, porém náo desfigurados, mas causa e condição de uma escolha amadurecida, acentuando um pingo de mágico esotérico, um traço de oculto que substancia intençôes e motivos a serem percebidos através uma íntima consideração.

De Nardim o Colegiado evidentemente tinha descoberto a exposição que mais um, entre muitos isolados, apresentou na Arte Aplicada, a tenda da ativíssima Sabina. Era um conjunto de desenhos que afirmava a personalidade do autor piracicabano.

Formas diversas, curiosa multiplicidade de composiçóes, um fugural sensivel que me convidou a percorrer as searas do desenho dos antigos, lembrando que no Il libro dall'Arte, mestre Cennino Cennini define: "...un'arte che si chiama dipingere, che conviene avere fantasia e operazione di mano, di trovare cose non vedute, cacciando si sotto ombra di naturali e fermarle con la mano, dando a dimostrare quello che non $\dot{e}$, sia?"

Nardin provém de uma série disciplina acadêmica que, no abagunçamento dos 
fatores abstracionísticos, me parece indispensável para se comunicar. Não engajado nas passageiras definiçóes da arte, Nardin se vale de um signo irrequieto, temperamental, mesclado de uma certa dramaticidade, provocando interrogaçóes por parte de quem observa e obtém respostas enigmáticas.

O terceiro premiado é Caciporé Torres, outro solitário operador que, apesar de com ele manter amizade raramente o encontro pois suas andanças são mesmo a de um solitário. Pertence à raça daqueles que primam pela ausência.
Temos no Masp uma sua escultura que nos emprestou para uma exposição realizada, há anos, em Budapest, e que até hoje não veio buscar. Certamente deve estar prisioneiro do trabalho. Sua obra é conhecida: contesta a própria escultura, serve-se do metal para alcançar uma expressividade não de ordem estética, propondo frequentemente soluçóes plásticas dimensionadas em espaços particulares, aflorando ideias sem se preocupar que outrem entenda ou não.

Concluindo, é de se oferecer congratulaçóes ao pessoal votante da Associação de Críticos de Arte, e um particular grazie do repórter de Senhor.

Senhor \#38, maio de 198I, p.96-97 (Senhor e as Artes)

A IMPORTÂNCIA DA MEMÓRIA NACIONAL

No Masp, mais uma exposição fundamental: os arquivos de São Paulo, enfim livres dos ataques do descaso, do pó e dos cupins

No momento, como acontece em todos os setores da vida nacional o das artes também sofre as consequências da inflação. A produção é enorme e nem sempre o volume de negócios acompanha a dimensão da oferta. Na verdade o galardáo é para a música popular, porém, a pintura vem vindo aí.

Este repórter vem de tempos quase antigos. E um produto formado em cidades italianas, onde as artes eram exercitadas e cultivadas de maneira mais ou menos equilibrada. Cidades como Miláo e Roma eram praças em que os pintores, escultores e alguns arquitetos se encontravam quase diuturnamente nos cafés, se conheciam e se frequentavam. Enfim, vindo daquela convivência amável, já que as possíveis divergências giravam mais no terreno das ideias, hoje, aqui em São Paulo, fico aturdido com a bagunça inflacionária que é cada dia mais galopante.

Recebo diariamente de dois a três artistas que me pedem uma exposição no Masp. Todos são cordialmente, recebidos, porém, o leitor deve imaginar que dose de diplomacia sou obrigado a utilizar para contornar os casos.

Tentei várias vezes inventar e mesmo ensaiar, preparar alguém para me ajudar na direção técnica do Masp sem lograr qualquer êxito. Para dirigir uma destas instituiçôes é preciso ser bastante milagreiro, já que é obrigado a inventar, detectar e buscar meios econômicos, arranjar acontecimentos, realizá-los, fiscalizar para que haja boa ordem, disciplina, limpeza, funcionalidade, redigir e veicular notícias para alimentar os comunicadores, escrever prefácios, enfim, fazer mais movimentos que um macaco pulando de galho em galho. E por falar em galho, quantos tenho que quebrar cada dia...

O duro é praticar um outro ofício certamente dos mais complicados: atender visitantes que de tanto ouvirem falar em arte e dos valores que representa desembarcam no Masp para avaliar objetos que descobrem nas paredes e nos poróes das casas.

Confesso ser esta a tarefa mais divertida dentro da conjuntura inflacionária, e faz parte do trabalho que se mescla com os outros. Diariamente, portadores de cacarecos tidos como artísticos formam fila, desfilando histórias e historietas sobre as origens dos tesouros. Trata-se, geralmente, de coisas de passado recente e que são examinadas cordialmente, mas com imensa dose de paciência e de diplomacia. Trata-se de um serviço que nenhum museu de arte deve propiciar, procurando manter a imagem da instituição que dizem ser o Olimpo. (Tanto isto é verdade que a Associação dos Críticos atribuiu este ano ao diretor do Masp o grande prêmio das artes.) 
Nestes últimos tempos procurei encontrar ou formar um sucessor, pois acho mais do que justo, depois de quase 35 anos de lutas indormidas, ser-me lícito pensar nisto. Talentos, por autodefinição, não faltam. Numerosos, para não dizer legióes, são os elementos existentes que se julgam altamente capacitados para táo ingente tarefa.

Se morre um pároco logo outro assume. Francamente, a vinda de um coadjutor seria um imenso alívio para mim, pois confesso que antes de ir para o Inferno gostaria de acabar de escrever um livro dedicado ao Santo dos museus de arte, o inolvidável Assis Chateaubriand, ao mesmo tempo que muito me agradaria realizar um filme dedicado a este raro brasileiro de visão. (Penso que o único ator capaz de interpretá-lo seria o filósofo Chacrinha, dono de inesgotável dose de ironia, qualidade implícita no caráter do fundador do Masp.) Sei de cineastas interessados, mas sabe-se como é o negócio: poluem a atmosfera com substanciosa verborragia oratória, para no final das contas nada realizarem. (Insisto: se encontrarem um vice-pároco, fiquem certos de que preparo um banquete espetacular, igual ou melhor que os arrumados pela classe política no solene Teatro Municipal, com a plateia aplaudindo os discursos, envolto em um delicioso cheiro de churrasco.)

Uma vez convidei o amigo professor Lionello Venturi a visitar o Brasil. O mestre respondeu-me negativamente, alegando: "Sono troppo vecchio." Penso, às vezes, nesta resposta. Mas quando me encontro com vários e variados jovens, ambiciosamente adio a oportunidade de escrever sobre a frase do bom e famoso historiador, por sinal o autor do catálogo geral da obra de Cezanne e revelador da correspondência dos Impressionistas.

Às vezes me sinto um personagem do tipo do astronauta, aquela figura tão bem imaginada pelo escritor Italiano Gaetano Mosca e que constantemente contava aos netinhos: tinha ido à Lua. Mas esta balela merecia meninos este lamento: "O avô conta sempre a mesma história...” Isto posto, vale a pena contar o que combinou na vida, mesmo que a história já seja rançosa e bem fora de moda?
Naturalmente, procuro reagir. Tanto assim que, com os amigos diretores dos Arquivos do Estado e do Município e graças à pronta e inteligente deliberação do deputado Cunha Bueno e do secretário Mário Chamie, estou preparando no Masp uma exposição dedicada àquelas papeladas seculares antigamente banqueteadas pelos cupins. Quando informo sobre o evento, o pessoal acomodado e bitolado me olha de soslaio e não compreende. Interrogam: um diretor de museu de arte se interessando por esta sepultada burocracia? Explico a amplitude do problema arte. Difícil ser entendido por iluminados de última hora que restringem a arte ao trinômio Portinari-Di CavalcantiPancetti e que voam para casa para não perder um único detalhe do capítulo da novela da super Janete.

$\mathrm{Na}$ exposição dos Arquivos o objetivo é dar incentivo à memória. Os não bitolados vão encontrar na apresentação também arte, pois arte é tudo que nos circunda. Por isso, o Masp armou e montou exposiçóes "estranhas:" "História da maquilagem," "ItáliaBrasil," "A mão do povo brasileiro" e assim por diante. Meu quebra-quebra rotineiro irá culminar ao apresentar a manifestação. "O objeto esquecido" no Centro de Lazer que o Sesc está implantando numa antiga fábrica no bairro de Vila Pompeia, em São Paulo: uma arquitetura de "arqueologia industrial," importante recuperação e adaptação de uma construção do começo do século, obra a cargo de Lina Bardi.

Peregrinamente, beneditinamente, há anos, vasculho os bric-a-bracs e ferro-velhos, os depósitos de museus tentando descobrir e dar utilidade viva às muitas coisas atiradas às traças e ao esquecimento. $\mathrm{O}$ que me interessa das artes são mais os anônimos que os consagrados. Meu próximo livro, o quarto das edições Sudameris, é carinhosamente dedicado aos oficiais mecânicos da Colônia. Por que falar sempre de Mem de Sá e não dos carpinteiros navais, ferreiros, alfaiates, tanoeiros, cozinheiros, carroceiros, curtidores, e assim por diante?

Chega. Diferente o Bardi se confessa prolixo derivando para proeza, não-proezas; mas na verdade simples trabalho de um operário de museu. 


\section{Legenda}

Publicidade da "Casa Fuchs" na revista industrial para a exposição de Paris, 1900. Acervo do Museu Paulista da Universidade de São Paulo $g$ Maquete do frontspício da igreja de São Benedito, no município de São Roque, I867. Arquivo da Cúria Metropolitana Representação dos moradores de São Paulo com inúmeras assinaturas para o restabelecimento da Casa da Fundição em Sáo Paulo, I766. Acervo da Divisão de Arquivo do Estado de São Paulo 9 Plano de viação de rodagem do Estado de São Paulo, 1930. Arquivo particular de Aureo de Almeida Camargo.

Senhor \#39, junho de I98I, p.96 (Senhor e as Artes)

E OS LEILÓES, CHEGAR AO FIM?

Se não chegarem, que o comprador inexperiente se acautele.

Mas o "boom" deve entrar em baixa fatal

Os leiloes de arte foram muito bem definidos por Christian Herschenröder, em seu recente volume dedicado aos mercadores da arte, como o "falso paraíso do comprador inexperto." Chegados os dias da necessidade de diversificar as rendas, o dinheiro campeando fácil, os salóes alugados e arranjados elegantemente com um serviço; de bufê principesco, correndo solto o uisque datado, sorrisos abertos de orelha a orelha, moças generosamente decotadas, tudo isto mobilizado para convocar os descobridores de um novo caminho do investimento monetário, os leilóes tornaram-se numerosos e múltiplos.

O fato ensejou o aparecimento de um pseudocolecionismo que, pela esperteza comercial dos organizadores, recrutou buona gente que, sem ler os regulamentos de venda, andou confiando e comprando. No regulamento, um dos artigos repetia o que na Europa os colegas afirmaram: "A Casa é exonerada de qualquer garantia sob o perfil legal e material."

Os inventores dos leilóes de arte, a Casa Christies, de Londres, insere em seus catálogos o seguinte: "Age exclusivamente como comissionária... e nem a Casa, nem o vendedor são responsáveis por algum eventual defeito ou má qualidade dos objetos ou da correçáo das indicaçôes relativas à paternidade, origem, data, idade, atribuição, autenticidade, procedência ou condição dos objetos."

Traduzidos os dizeres, cá na Terra, para brasileiro ver, os leilóes de arte, por empolgante iniciativa de um tal Businco, esperto no cálculo da psicologia dos tais aspirantes a status, tornou-se mais um fato social, presentes parcela razoável do que Herschenröder apelida de "comprador inexperto." Viu-se gente, nutrida patrulha de bobocas, comprando por comprar, somente para olimpicamente competir, agitando no ar polpudos cheques para encher de raiva o concorrente derrotado nos lances, promovendo na verdade hilariante espetáculo. Uma comicidade bem observada por raros presentes.

Seja como for, os leilóes murcharam. Hoje estão murchos, tudo indicando que os tempos desvairados ficaram para trás, a euforia desapareceu e agora pessoas lamentam que sua vontade de dobrar o valor pago na quermesse náo alcançou o desejado. Murcharam também as inúmeras e sofisticadas convocaçôes, não somente porque tudo que era disponível foi leiloado e releiloado, mas também porque os afidalgados são inconstantes em relação às novidades, mudando suas preferências ao sabor dos ventos e dos acenos dos espertalhóes.

Mas houve a intervenção de um outro fator para que os leilóes decaíssem: a ultima novidade decretada pelo Congresso Nacional que, de repente, lançou na praça a lei da mais-valia, gravando a venda das obras de arte, pensando erroneamente os legisladores que uma pintura ou uma escultura automaticamente sempre aumenta de preço no mercado. O Congresso esqueceu-se de que qualquer um é dono de um objeto legitimamente comprado, sendo o mecanismo da mais-valia de complicadíssima averiguação, pois não se conhecem, ou são moscas brancas, os cidadãos capazes de estudar com a devida minúcia como escapar do pagamento, por menor que seja, dos impostos. E mais: quando um objeto de arte, ao invés de subir de preço é vendido abaixo do custo, quem paga a diferença ao possuidor? 
Outra pergunta: como estabelecer as mudanças do valor monetário histórico? Nem pensar que as vendas e compras passassem a ser registradas em tabelionatos.

É neste ponto que desejamos chegar. No falso paraíso do comprador inexperto, aparece agora a lei que manda dar $20 \%$ ao autor aos seus herdeiros, percentual esse estabelecido entre o preço de compra e o preço de venda efetivamente havido.

Somente nos leilóes existirá a possibilidade do cumprimento dessa lei que foi decretada, sem audiência de muitas partes diretamente interessadas. Dizemos que somente os leilóes têm condiçóes de cumprimento pelo fato de o homem do martelo, como um quase oficial público, ser obrigado a registrar na Junta Comercial do Estado as atas dos leilóes apregoados, tornando-se, assim, pública a transaçáo. Como há inúmeros ricos de imaginação - e de truques - não será difícil assistir-se a uma gama de comicidades e, naturalmente, saberemos da abertura de muitos processos por parte de viúvas ou desquitadas, ou atormentadoras da vida de artistas, contra o incauto comprador de uma tela do marido, surgindo, então, advogados que circunspectamente fabricarão uma jurisprudência.

É de prever-se que os leilóes diminuirão de número e intensidade, reduzindo a zero o apregoamento das obras, já que estarão sob a mira dos arcabuzes empunhados pelos felizardos herdeiros amparados por uma lei certamente parcial. O boom altista começa a experimentar limitaçóes.

Senhor \#40, julho de 198I, p.64-65 (Senhor e as Artes)

As AQUARElas-MEMória DE MiguelzinHO

Nestas aquarelas, um pouco da história de S. Paulo, esquecidas como

Miguelzinho, seu autor, num canto deste pais sem memória

Temos, agora, a burocracia da Memória. Em pleno funcionamento e tendo como epicentro a Capital. Visa a melhorar e chamar atenção com o propósito de regenerar a história brasileira. Todos devem fazer força para aquele departamento alcançar o máximo de eficiência.

Insistimos nisso, pois o descuido na preservação da Memória, apesar das constantes recomendaçôes, continua. E pode-se afirmar que em cada canto são descobertas memórias. Na edição anterior de Senhor tratamos da preocupação que se deve ter com a conservação dos Arquivos. Para passar à ação, organizamos a exposição São Paulo, onde está sua história, no Masp.

Para demonstrar quantas operaçóes são necessárias à recuperação de documentos, queremos aqui registrar um fato curioso relativo ao pouco caso que envolveu um artista da Itu, Interior de São Paulo, por sinal uma personalidade notável, poliédrico, a um tempo músico, pintor, ourives, escultor, arquiteto, construtor de órgãos, sendo também cidadão da mais alta posição social: Miguel Arcanjo de Assunção Dutra, nascido em I8Io e desaparecido em 1875, em Piracicaba, dando origem à família de pintores Dutra, entre os quais se destaca Arquimedes, o qual obteve a cátedra de História da Arte defendendo uma tese na Escola Superior de Agricultura Luís de Queiroz.

Depois de I875; salvo um ou outro artigo estampado na imprensa, ninguém se preocupou em estudar o caso do artista ituano e muito menos os acontecimentos a ele relacionados. Decorrido mais de um século, I07 anos para sermos mais precisos, quando o redator destas notas soube da existência no Museu Paulista de uma série de aquarelas de Miguelzinho, documentos bastante sugestivos para que melhor se conheça fatos e personagens do Estado de Sáo Paulo daquele tempo já recuado.

Descoberto o material, e contando com o consentimento do atual diretor do Museu Paulista, prof. Setembrino Petri, pensei logo em uma publicação. Um pessoal metido na Memória, sabendo da minha iniciativa, agitou-se e desencadeou a proverbial campanha do contra.

Acostumado aos assaltos de intelectuais nem sempre merecedores de tal apelido, imperturbavelmente atirei-me ao trabalho e, sem pedir as habituais verbas que sempre estão mais na base do interesse memorial, consegui concluir um livro dedicado ao mestre, e que será lançado 
brevemente. Ofereço aos leitores de Senhor a primeira notícia de alguns inéditos.

Abro a lembrança do personagem reportando-me aos versos de Osório de Souza: "Viver sonhando foi a tua sorte,| morrer sorrindo foi a tua morte!| Se morte pode haver a quem na vida,| primaveras semeou de luz e de Arte,| estas eternamente irão levárte| a palheta de auroras guarnecidas."

A. E. Zaluar, na Peregrinação pela Província de São Paulo (I860-I86I) escreveu naquele longínquo tempo: "As honras e as condecoraçóes, reparte-as o governo pelos que prestam serviços eleitorais e são também aquinhoados pelos cofres públicos: este há de morrer obscuro.” Tratava-se de Miguelzinho.

Mais tarde, em I896, O Piracicabano define o caráter do artista: "Está ainda na memória de todos o que foi Miguelzinho, e os relevantes serviços que durante 30 anos prestou a esta terra. Ativo, inteligente, trabalhador, era versado em quase tudo: bom ourives, pintor, escultor, arquiteto, bom musico, excelente organista; bom latinista, versado em Teologia, reunindo a todos estes dotes a mais fina educação. $\mathrm{O}$ seu culto, porém, mais fervoroso, o seu fanatismo, era a caridade. Que o digam os pobres, cujas lágrimas vivia a enxugar! Como político liberal extremado, era a imagem veneranda da virtude cívica! Ninguém como ele provou maior isenção, maior hombridade de princípios, maior elevação de caráter. Por isso, sem ódios e sem ambiçóes, austero, mas magnânimo, logrou o grandioso intento de passar, como passou, íntegro e ileso, e o que é mais, adorado e respeitado por entre corrilhos dos pobres partidos desta naçáo! A morte prostrou-o quando ele ia talvez a meio da sua gigantesca obra de sacrifícios e de sagrado entusiasmo - a sua querida Igreja da Boa Morte, hoje abandonada pela descrença dos homens, alertando o olvido do repúdio...”

O mais significativo da obra pictórica de Miguel são as aquarelas que enfocam os aspectos da vila ituana. Espontâneas e penetrantes acertos iconográficos, valendo sua compreensão e seu jeito popularesco.

Fácil imaginar como o artista era rodeado, por não ser comum a presença em praça pública de um pintor. A iniciativa de
Miguelzinho nos permite formar uma ideia da Itu dos tempos em que o burgo atinge a condição de município, gozando a lavoura canavieira e, consequentemente, a indústria açucareira, seu auge.

Por ocasião do bicentenário da Matriz de N. S. da Candelária, o historiador Ernani da Silva Bruno, a quem sempre se recorre como fonte preciosa dos fastos da história paulista, há algum tempo lembrou um fato curioso: "...o ituano chegou a ganhar o apelido de mel de tanque, porque se deliciava (segundo a observaçáo de um viajante sueco, em I8I3) com o melado de seus engenhos, e que tinha o hábito de mascar com frequência pedaços de cana ou rapadura. Viajando pelos arredores de Itu, esse cronista observou que era impossível não notar que toda a gente da classe humilde tinha os dentes incisivos perdidos pelo uso constante da cana." Notou ainda o cronista: "Quer em casa, quer fora dela, não a largam e é possível que esta seja a causa de haver aqui mais gente gorda do que em outros lugares." Também "os próprios bois e burros participa da mesma inclinação e encontram-se eles, tais quais seus condutores, mastigando cana."

Dos usuários do mel de tanque, o anotador Miguel nos deixou uma antologia abundante, talvez sem similar no Brasil, para nós muito mais documentativa do que a dos pintores estrangeiros que cruzaram os trópicos, preocupando-se mais com o inédito do pitoresco do que com a realidade.

Deve-se levar em conta que o ilustre historiador Affonso d'Escragnolle Taunay, em I92I, avança, quando se referiu ao épico episódio do Ipiranga, por ocasião da visita de D. Pedro iı a São Paulo, em I846: "Vivia nesta época na província de São Paulo, um artista modesto, a quem se deve a iconografia paulista assinalados serviços: o ituano Miguel Arcanjo Benício d'Assunçáo Dutra, homem que deve ter tido singular intuiçáo artística para resistir à ação asfixiadora do meio tão atrasado do Brasil contemporâneo, sobremodo avesso ainda à arte. Pintava graças aos dotes naturais e seus desenhos e aquarelas ingênuas e primitivas têm hoje um valor documental. Foi quem desenhou a série de vistas que orna a planta de I84I de Rufino Belisário 
e Costa, os mais antigos documentos iconográficos conhecidos na capital paulista."

Deve-se insistir na posição limitadamente profissional destes pintores que desempenharam o ofício, aliás os vários ofícios, muito procurados quando da celebração de festejos cívicos e religiosos, para decorar e ajeitar alegorias, arcos comemorativos, ereçáo de colunatas simbólicas e, conforme o caso, tocar música, como acontecia com Miguelzinho.

Definiria as aquarelas de Miguelzinho como expressóes de um primitivo, a adjetivação precisando de uma melhor e oportuna digressáo. $\mathrm{Na}$ escala dos valores determinada pelo gosto que está prevalecendo, no que se refere àquilo que neste momento se verifica no Brasil, enfocando primórdios históricos, se atribui a definição de primitivo a elementos geralmente desprovidos de capacidade propriamente criativa, prevalecendo, como observamos, a preocupação pela novidade-novidade.

\section{Legenda}

Vista do Quartel General, I846 e Sítio do Capitão José Manuel

Senhor \#4I, IO setembro de I98I, p.70 (Senhor e as Artes)

Museus, um CABIDÁO DE EMPREgOS?

No lançamento da correspondência de dois pioneiros da abertura

cultural, um alerta para o abandono de nossos museus

Fico pensando, às vezes, na saga dos diretores de museus espalhados pelo território nacional, quais pilotos, brevetados ou não, comandantes de empresas atuantes mas ainda confusamente marginalizadas, desconhecidas, à espera de resoluçóes governamentais, sejam elas federais, estaduais ou municipais.

Burocraticamente os museus (em número, eu diria, até demais) vegetam, cumprindo mais funçóes empregatícias do que realmente prestando algum serviço público. Há alguns anos, lembro-me, o então secretário de Estado da Educação, José Bonifácio Coutinho Nogueira, defrontou-se com um problema muito sério nos quadros de sua Secretaria, que foi o de constatar a presença de dezenas e dezenas de professores nomeados através de favores políticos e que, oficialmente, exerciam a direção do Museu local na hinterlândia paulista.

Por acaso conheci um desses inventados, e portanto desqualificados diretores, por sinal além de educador também advogado e que muito circunspectamente dirigia um arsenalzinho de ferros velhos pomposamente denominado museu, função que lhe permitia retirar, mensalmente, um belo ordenado de professor lotado em escola onde nunca colocou os pés.

Como ele, mais de sessenta desfrutavam das benesses que a política lhes dera em troca de favores eleitoreiros, e o secretário Nogueira Coutinho, severamente, mandou que eles voltassem às aulas, o que provocou uma revolta dos aproveitadores. Estou certo de que a maioria dos museus está clamando por uma intervenção saneadora, não de fiscalização acomodada e complacente, mas de eliminação pura e simples.

Há pouco, discursando no Masp por ocasião do lançamento de um livro que reúne a correspondência trocada entre Mário de Andrade e Rodrigo Mello Franco de Andrade, o secretário de Cultura do Ministério de Educação anunciou que vai intervir visando uma melhor coordenação dos trabalhos dos museus federais, a fim de que eles participem com mais empenho em favor da Cultura, a qual, (aqui entre nós) está passando por um dos seus piores períodos no contexto da história nacional.

Evidentemente, Aloísio Magalhães se refere aos museus federais. Mas como coordenar e animar os dependentes dos Estados, dos Municípios e mesmo os das universidades? Parece-me que em sua maioria estes estabelecimentos são os mais carentes de coordenação e animação, melhor, precisando ser devassados, lancetados se preciso for, a fim de que seja estirpada esta chaga curtida por muitos que é a de "deixar como está para ver como fica."

Em sua maioria tais prepostos de curadores de museus pertencem àquela categoria dos pendurados no imenso cabidão de emprego, esta praga inexterminável que gera acomodação, rotina, preguiça, comprometendo assim esta nova atração que se chama museologia. 
Observei, quando da reuniáo Promovida para o lançamento do livro publicado pela Memória do MEC, a ausência de muitos interessados no caso inclusive os da Escola de museologia local. Tratava-se, no entretanto, da lembrança para dois pioneiros que promoveram a abertura cultural tempos heroicos de criação do SPHAN.

Como empresário de um Museu, recorro ao Mala tempora currunt..$^{\circ}$ (Para a cultura nacional.)

5o Expressão de Cícero, Mala tempora
currunt sed peiora parantur em

\section{Legenda}

Retrato de Mario de Andrade, desenho a lápis de Lasar Segall 9 Mario de Andrade: Cartas de trabalho divulga a correspondência entre o autor de Macunaíma e Rodrigo Mello Franco de Andrade

tradução literal: "Os tempos maus se aproximam, mas [tempos] piores se preparam" ou, em tradução livre: "As coisas vão mal, mas prepare-se para o pior."

Senhor \#42, 24 de setembro de 198I, p.70 (Senhor e as Artes)

MiChelangelO, SÉC. XX

Sérgio Ferro recaia um mestre, descobrindo novas interpretaçôes, numa proposta singular epolêmica

Os pintores nos propóem hoje, ininterruptamente, leques de tendências, as mais desconcertantes, e quase todas devotadas ao massacre do Figurativo. Apesar da cruzada, há os que resistem no gramado, declarando-se fiéis à tradição, reagindo aos assaltos e à generalização do Informal.

As artes comportam um total de conceitos, todos derivantes ou próximos uns dos outros: ideias, jeitos, sugestóes, imitaçóes, renúncias, contradiçóes, tudo participando da inspiração e da execução.

Mil e uma as consequências e os resultados. Os que julgam procuram descobrir origens, entrosamentos, espírito, originalidade.

Pensa-se neste constante processo, sempre aparente em presença de uma obra. No caso incomum, a ponto de parecer estranho e até inclassificável no contexto da assim chamada arte moderna, em certo sentido polêmica, está a mais recente atividade de Sérgio Ferro, exposta no Museu de Arte.

Encontrei-o há uns vinte anos, o pintor preso ao momento das generosas exaltaçóes das vanguardas, e o notava, prevendo suas atuaçóes certas e operosas. Reencontro-o agora, vindo da França, onde ensina na Universidade de Grenoble, como um discípulo, ou melhor, um ajudante de bottega, devotado ao drama violento do seu mestre Michelângelo.

Abrindo-se um parêntese, é de se lembrar que também Picasso, às vezes, se transferia idealmente ao atelier de Velazquez para refazer, num modo atual, as Meninas.

Sérgio foi se aventurar num inexaurível labirinto, complicadíssimo pela infinidade de itinerários sem saída, num universo titânico e misterioso governado com imensa potência pelo poeta da palavra, da forma, do espírito.

Perscrutá-lo, indagando e desvelando, é empresa se não audaciosa, arrojada, depois de séculos ao longo dos quais mais se questiona, mais renascem motivos e enigmas, como ocorre com Ésquilo e Dante, sendo notório a todos os competentes que, conjungamente aos hinos, a obra de Michelângelo provocou invectivas, protestos, injúrias: é sempre assim quando o artista manda brasa.

Sérgio, para compreender e firmar em absoluto a expressão do gênio, valeu-se do procedimento usado por inúmeros mestres: identificar-se com a arte, interpretá-la, antes de tudo copiando-a.

A definição cópia implica em alguns equívocos, especialmente por parte dos que pouco entendem do problema da história e da crítica de arte. Não se dá muita importância a obras que reproduzem as de um outro autor e pensa-se que pode se tratar de um exercido, quando, pelo contrário, em todos os tempos, foi espontâneo o copiar os mestres.

Bastara ver nos catálogos de Rubens, Rembrandt, Velazquez, Goltrius, dos 
Carracci, quantas as cópias por eles executadas. A tradição continuou no Oitocentos quando, além dos acadêmicos, foram os próprios Impressionistas a copiarem colegas da Renascença, sendo Manet e Degas os mais ativos. Também nosso Eliseu Visconti copiava, conseguindo interpretações extraordinárias dos Velazquez do Prado.

Eram homenagens a grandes espíritos, possibilidades de descobrir modos de expressão, captar sentimentos.

Há artistas que observam e estudam a natureza. Sérgio escolheu a natureza de Michelângelo, como, escrevendo a ele, descobria Pietro Aretino: “... nele man Vostre vive occulta l'idea di una nuova natura..."

A proposta é singular e, como disse, polêmica, porque chamada a uma ordem figurativa que, antes ou depois do desequilíbrio da situação histórica, deveria voltar, os signos servindo para comunicar imagens, compreendidos por todos e não passatempo esnobe.

Não é que se aproveite do reviver que Sérgio nos apresenta, através de suas interpretaçôes de Michelângelo, para intervir sobre o que hoje se produz, de formal ou de informal. O tempo é o que é e o que dá, e seria ingênuo reclamar em nome do gosto-náo-gosto.

De qualquer modo, esta exposição de Sérgio me parece indicativa de um despontante momento, caracterizado por um crescente desejo de voltar a tradição do servir-se da figura para manifestar fatos e sentimentos.

Legenda

São João Batista, a valorização da figura São Bartolomen e Hamá, em busca de novas expressóes

Senhor \#43, 8 de outubro de 198I, p.72 (Senhor e as Artes)

BRASIL, UM GRANDE EXPORTADOR DE PINCÉIS

$O$ filho de um madeireiro se propôs um dia a fabricar pincéis. Seu sonho é hoje uma realidade

Os problemas da arte parecem não pertinentes a uma revista como Senhor, dedicada à vida industrial e econômica. Pensava isso percorrendo, departamento por departamento, a fábrica de pincéis Tigre na Via Anhanguera, aprendendo extraordinários fatos, não só industriais mas interligados à arte da pintura.

O pincel, na Antiguidade, como as cores, os vernizes, os painéis, as molduras e tudo quanto servia para o preparo e a execuçáo da pintura era produzido nos ateliês de cada mestre. Os aprendizes, antes de passar a pintar, deviam operar artesanalmente no oficio. O progresso industrial, no Oitocentos, andou modificando a situação, começaram a surgir laboratórios de tudo o que servia aos pintores, no princípio em pequena escala e depois, neste século, em fabricas como esta em visita, que produz cinquenta mil pincéis por dia. Chegou a este grau de expansão saindo, como tantas indústrias brasileiras, da iniciativa individual de um homem de visão, filho de um madeireiro do Paraná: Nicolau Jacob Filho.

Ele se propôs a produzir pincéis em grande escala. Foi à Alemanha para estudar o problema industrial, complexo mas promissor, de uma solução para o Brasil, aliás para a América Latina que, entáo, tudo importava da Europa. Tratava-se de conhecer, experimentar e produzir objetos que se compunham de variados elementos, implicando a utilização de fibras vegetais, pelos animais, madeira, partes metálicas, corantes.

Em 1929, Nicolau volta ao Brasil, dono de uma prática que lhe permitiu implantar um laboratório de utensílios para pintura, não só em escala artística mas também industrial, denominando seu produto Tigre. Bem-equipado, a par de todos os achados da tecnologia, aplicando-os, procurando adaptá-los às circunstâncias brasileiras, aperfeiçoando os processos, em dez anos o empreendedor industrial conseguiu se impor no mercado, começando até a efetuar as primeiras exportaçóes e pouco a pouco, ampliando-as. Além da fábrica em São Paulo, a Tigre tem, para a madeira, outra fábrica, no Paraná. A preocupação de Nicolau era o emprego da matéria-prima nacional, mas uma indústria de pincéis depende dos pêlos predominantemente de animais de climas temperados. Assim, nos armazéns de matérias-primas 
veem-se caixas vindas da China e da Europa: são os pêlos de porco e de marta.

Pesquisas feitas pela indústria conseguiram obter, no Nordeste, matérias-primas para substituir as de fora, em determinados tipos de utensílios, como na fabricação de broxas para a caiação servindo-se da fibra de casca do coco-da-Bahia.

A visita à fábrica da Via Anhanguera, onde trabalham setecentos elementos foi motivada por uma constante preocupaçáo dos filhos do Fundador: pediram ao Museu de Arte de São Paulo para reunir um grupo de pintores a fim de se discutir problemas ao aperfeiçoamento do pincel. Lá estivemos, com Ermelindo Nardin, Maria Helena Chartuni, Dan Fialdini e Paulo de Andrade, examinando a produçáo com os técnicos, fazendo sugestôes, cada um dos presentes dando suas próprias opinióes.
Foi curioso para os diretores saberem que, ignorando que fabricava-se pincéis no Brasil, Maria Helena contou que, procurando esse produto no comércio de artigos de artes plásticas, em Roma, ofereceram-lhe os da marca brasileira Tigre.

O Brasil é hoje grande exportador de pincéis. Mais um setor em que nossa indústria está atuando firmemente, e um campo no qual, percorrendo a fábrica, nos damos conta da capacidade industrial. Surpresa para nós, leigos, que pudemos ver maquinários complicadíssimos que produzem um objeto tão simples, como é um pincel.

\section{Legenda}

Panorâmica de um dos departamentos da fabrica Nicolau Jacob Filho, fundador da fabrica de pinceis Tigre

Senhor \#44, 22 de outubro de 198I, p.72 (Senhor e as Artes)

Os PARAQUEDISTAS DA ARTE

Eles existem aos montes, expóem em qualquer lugar, promovendo uma confusâo dos diabos com seu amadorismo

As declaraçóes feitas à imprensa por Ariano Suassuna, informando que vai abandonar o exercício da literatura e, ato contínuo, eremiticamente retirar-se para levar uma vida de solitário, provocaram uma certa curiosidade, ou melhor, aquela curiosidade de sempre: passageira e superficial, à qual já estamos acostumados, sem deixar rastros, simplesmente à espera de uma outra qualquer e rotineira notícia, para voltar à ribalta.

Por uma certa simpatia para com o valente escritor pernambucano, pensei, no momento, em imitá-lo, abandonando o exercício de focalizar os problemas da Arte e, em seguida, refugiar-me num sítio que tenho lá no Acre, para dedicar-me ao cultivo do abacaxi e esquecer-me de tudo e de todos ao ponto de náo enviar nem mesmo um cartão-postal aos poucos amigos.

Por que a decisão?

Simplesmente porque diante de tantas peripécias, encontros e desencontros, ilusôes e desilusôes contínuas na seara, o mais paciente dos pacientes a ponto de provocar inveja num santo, à certa altura, fica saturado de tanta cacetice. Aguentar o cidadão que produzindo, ou sem produzir, aproveita desta cruz e delícia, apelidada Arte, afinal cansa.

Antigamente era mais divertido, pois os patenteados num determinado oficio eram uns poucos gatos pingados, os relacionamentos não eram tão fatigantes, aflorando, ás vezes, algumas polêmicas. Mas, de qualquer forma, um fato normal. Éramos numericamente uns poucos e, no final, acabava-se em perfeito entendimento. Agora a poluição, de suportável, acabou se tomando perniciosa. Mesmo esforçando-se para considerá-la calamidade corrente, ajustada aos próprios desejos, engolir algumas pílulas amargas não dá, pois intermitentemente desponta uma nova trapalhada para contrariar.

Difícil estar-se no campo, livres para pensar e agir sem que náo surjam desgostos. A certa altura, o saco está tão cheio que ali nada mais cabe, o que talvez seja o caso de Suassuna, ao ponto de levá-lo a sentenciar: basta.

Como as coisas andam, certamente chegará o dia em que terei o mesmo procedimento. A indormida participaçáo no cotidiano vai gerando insuportável carga de aborrecimentos, especialmente por me 
encontrar no vértice de uma instituição cultural, hoje que a Cultura tirou férias.

Houve tempo em que um museu era como uma biblioteca, pois bastava mandar tirar a poeira dos livros; mas inventamos os museus dinâmicos que acabaram por se tomar arenas concorridíssimas, pelo menos em relação ao Masp, gerando um trabalho estafante, já que se deve receber gente, escutá-la, ser gentil, defender, acomodar, contentar gregos e troianos, fazer milagres às vezes.

Apresentam-se diariamente dois, três ou mais artistas inflados e donos de uma reputação carecedora da máxima atenção, invocam um lastro de participantes de nada menos que trinta salóes, como destarte, nos impóem que tomemos conhecimento de quilométricos currículos. A falsa popularização da Arte, as facilidades vigentes para sua produção, a multiplicação das galerias, salóes, bancos, restaurantes, butiques que organizam exposiçóes incontáveis, suscitou a moda da Arte, o fazer por fazer, gerando tremenda confusão. Aliás, é como ocorreu nos anos da descoberta do jogo de boliches: cada rua de São Paulo contava com um, dois ou mais salóes para acolher a jovem e a velha guarda atraídas pela nova moda. O leitor deve se lembrar também da moda dos tobogãs, e agora a dos multicubinhos herméticos para os que querem perder tempo. O enorme e desvairado interesse para com a Arte deixa a impressão de mais um jogo de boliches. Por quanto tempo?
Não é que se note o incremento para condená-lo, mas o que preocupa é a superficialidade, a pouca substância cultural, o amadorismo sem bases. É verdade que se voltarmos para outros setores, acabamos descobrindo os mesmos casos, como, por exemplo, o do ensino.

A respeito do ensino, existe o da arte e da sua história. Antigamente existiam as Academias de Belas Artes que formavam grupos restritos de profissionais. Hoje existe a incomensurável Academia do Informal: centenas e centenas de Cabrais desembarcam nos Territórios das Artes: compram uma chapa de ferro, dobram-na e, num passe de mágica, o objeto é exposto numa das tantas casas de arte espalhadas nas cidades. Já se vê estas chapas usadas como elemento embelezador de jardins, sem se falar na inflação da Praça da Sé, digno complemento do goticozinho da Catedral.

Seria negar a continuidade da Estética, reação contra as novas propostas, às quais a Forma deve se adaptar. O pluralismo das Tendências é fato normal. O que não se aceita é o chutar, os ignorantes se metendo no assunto, o macaquear, o dar a entender, o aproveitar da confusão própria de uma sociedade ainda imatura sob o ponto de vista da Estética.

\section{Legenda}

Suassuna, dando exemplo ao saturados

Senhor \#45, 5 de novembro de I98I, p.70 (Senhor e as Artes)

Pelas TRILHAS DE MINAS

Os caminhos da Arte mineira estão no Masp. Lá perfilam-se os

figurativos, os românticos, futuristas e até os tradicionalistas

A Rede Globo movimenta a comunicação em várias direçóes, visando precipuamente levar ao recesso das casas os mais variados espetáculos, bem como informar, discutir as mais diversas atividades.

Às vezes, quando realizamos no Masp uma manifestação merecedora de um maior interesse por parte do público, apela-se para a Globo que, através de chamadas e dos comentários de Jacob Kiintowitz, informa a respeito, triplicando o número de visitantes.

A Cultura brasileira precisa da TV. Os entendimentos entre as instituições culturais e as emissoras contribuem para uma maior informação sobre os eventos. E já que estamos no assunto, não queremos esquecer o trabalho que também a TV Cultura, canal 2, vem realizando.

No momento, está sendo exposto no Museu de Arte de São Paulo o viı Salão Global de Inverno de Minas Gerais, patrocinado pelo Etapas Vestibulares com o apoio da Globo, evento que nos possibilita saber qual a situação da arte atual nas Alterosas.

A iniciativa de uma ação modernista em Belo Horizonte partiu de Alberto da Veiga 
Guignard, coincidindo com a arrancada encetada por Juscelino Kubitschek, quando prefeito, dando à cidade eventos da mais alta importância. Ao pintor convidado foi confiado um Curso de Desenho e Pintura, logo seguido por numerosos jovens. Lembro-me de tê-lo visitado em 1947, quando mal tinha começado os trabalhos de estruturação do Masp. Tratava-se de uma escola que funcionava ao ar livre com o entusiasmo muito próprio dos novos descobridores da arte. Guignard, sob a égide da Liberdade com disciplina, obteve logo resultados extraordinário. Deixava a cada aluno a liberdade de manifestar-se segundo sua vocação, o mestre cuidando do ensino técnico, com cordialidade, num ambiente aberto a discussóes, ao intercâmbio com outros Estados, afirmando o conceito de moderno. O duro foi superar os preconceitos que, de resto em todo o Brasil, pairavam no imperante academismo.

Os êmulos de Guignard passaram a ser apelidados de futuristas. Mas tudo, como sempre, deu certo pela perseverança do mestre, numa época em que Oscar Niemeyer andava criando o conjunto da Pampulha. O mesmo aconteceu em São Paulo aos tempos em que Monteiro Lobato atacava Anita Malfatti chamando-a de paranoia, diante do que ela apresentava como consequência dos ensinamentos hauridos com seu mestre Lovis Corinth, em Berlim. Sem contar o que se verificava no Rio de
Janeiro, onde a refugiada de Portugal Vieira da Silva vivia pintando quadrinhos para serem vendidos em livrarias.

As consequências da ação de Guignard podem ser vistas no Saláo Global, ainda valendo o tema Liberdade com disciplina: cada participante segue seu próprio caminho, os jovens-veteranos e os jovens-jovens em ação.

Exposição bem documentária da operosidade dos artistas das Minas Gerais. Os figurativos estão em maioria, dentre eles, Álvaro Apocalypse com sua constante sátira, Chanina, Carlos Bracher, paisagista de emoçóes românticas, Chico Ferreira, Iniiná de Paula, cujas impressóes evocam a maneira dos Fauves franceses, Márcio Sampaio, que se diverte representando este redator seriamente preocupados em severos ambientes. É de se lembrar também Petrônio Box. Artistas tradicionais são a imaginosa Sara Ávila e Yara Tupinambá, esta combinadora de fantasias exuberantes de estupor.

$\mathrm{Na}$ mostra figuram vários desenhistas seguidores da tradição, como Arlindo Daibert, e um dos destruidores da tradição, o original Amilcar de Castro, autor de Formas Monumentais, como lembra Ferreira Gullar no catálogo, e numerosas outras promessas do Informal.

\section{Legenda}

Tocadores de flauta, o figuritivo satírico de Álvaro Apocalypse.

Senhor \#46, I9 de novembro de i98I, p.70 (Senhor e as Artes)

QUANDO A ARQUITETURA ESQUECE SUA FUNÇÃO

É normal surgirem projetos arquitetônicos revolucionários, mas que se esquecem de sua função primeira: servir de abrigo às pessoas

É divertidíssimo ouvir conversar os arquitetos que vão, ou dizem que vão, para a frente, decididos a mudar o rumo da arte na qual academicamente se formaram. Visto que Dada decretou o fim da arte, propondo um novo balbuciar, razoável grupo de ingênuos em cada parte do mundo pensa que algumas coisas precisam fazer para que a arquitetura não seja mais a de sempre, a da tradição, até da tradição dos mestres do século, válidas suas variantes e extravagâncias.

Não sei se é propriamente o arquiteto a operar para a nova estética ou uma quantidade de náo-adidos aos trabalhos que penetraram no campo: literatos, designers, publicitários, gente de marketing, magnatas e assim por diante.

A penetração ocorreu até nas escolas. Numa, italiana, chegou-se a ver professor emérito que, numa profusão de curso, quebrou o lápis para informar oficialmente que o arquiteto não precisava mais desenhar. Paradoxos não faltaram, nem posiçóes curiosas, sendo a última a que vamos contar. 
Todo o mundo da profissão conhece e respeita Philip Johnson. A ele é confiado, pela firma Marshall Field \& Co. de Houston, no Texas, um volumoso edifício para conter um Store. O arquiteto o projeta com a diligência que lhe é própria. Sabe que a firma pretende uma fachada-impacto, assim pensa em recorrer a um artista. Escolhe Claus Oldenburg, personagem da moda e consequentemente de renome.

Os dois começam a trabalhar juntos. Trata-se de oferecer a Houston um vulto arquitetônico memorável, do qual se falará, procurando o empreendedor de negócios mirabolantes consequentes lucros. O caso é produzir um conjunto publicitário, num certo senso o antigo problema da arte: numa arquitetura o que vale é o aspecto exterior da fachada.

Será que a arquitetura, depois de sofrer pelo fachadismo, ao longo de milênios, vai continuar na mesma, sem ter em conta a função? O arquiteto insistindo nas historietas do espaço, do volume, da representação e companhia, descuidando de que, afinal, o construir serve para morar? Num certo sentido, a dupla Johnson-Oldenburg estava no caminho certo, pois tratava-se de chamar a atenção. Porém, quando se sabe que o arquiteto sacrificou na famosa fachada janelas indispensáveis para se ter luz e ar, e no seu lugar pôs as largas manchas do pintor decorador, surge espontaneamente a dúvida de que o arquiteto se deixou convencer pelo decorador.
O episódio, que teve por conclusão a náo-aceitação do projeto por parte do comitente, serve para algumas consideraçôes. Depois de certo tempo, agitam-se grupos sempre mais numerosos de projetistas anômalos. São os ilustradores da fantaciência. A extravagância, às vezes, é necessária para resolver um problema de espaço, e faz parte da elaboração de um plano; porém, quantas vezes ela é fruto de deliberado propósito de dar singularidade a um edifício, a nota chamariz para distingui-lo dos demais, outra vezes, autêntico produto para mostrar e se mostrar inovadores. Por exemplo, aquele prédio do Tribunal de Contas da Prefeitura, em São Paulo, erigido sobre quatro colunas para o céu, complicando a vida daquela administração por falta de espaço. Pode ser que a arquitetura, alguém a julgue bonita, mas, mais uma vez, a pergunta é a mesma: a racionalidade não tem as suas exigências. Num tempo brasileiro em que as contas devem ser ajustadas a uma realidade carregada de incógnitas, parece aconselhável que os arquitetos não desperdicem o talento em tentativas fora de um contexto normal, pensando também que faz-se sempre mais urgente a consideração do destino geral da construção nos últimos decênios, por demais displicente com relação aos problemas da habitação popular.

\section{Legenda}

As novas tendências da Arquitetura

Pós-Moderna: Casa-Sapato dos arquitetos Hänsel e Gretel, no Parque Nehru, em Bombaim.

Senhor \#47, 3 de dezembro de I98I, p.72 (Senhor e as Artes)

As MEMÓRIAS DA CIDADE

"Paulista não é homem muito dado a diversóes... um homem mais dado à luta que um bom viveur, accomodado às facilidades da terra e da boa fortuna."

Depois da descoberta do fato Memória, pode-se perfeitamente registrar que já existem sinais de que as coisas estão mudando, a ponto de verificarmos que as contribuições já são bem numerosas. Certamente uma série de iniciativas e açôes levadas a efeito pela Secretaria de Cultura do Município de São Paulo é bem importante, numa magnífica abertura visando despertar o adormecido tran-tran tão característico de recentes transcursos secretariais, ao longo dos quais assistimos ao exercício de um funcionalismo ortodoxo. O merecimento por tais transformaçóes deve ser creditado por inteiro ao titular da pasta, Mário Chamie.

Cada um de nós, confessamos, carentes de títulos como o de historiador, quando nos metemos neste delicioso campo que é o de contar coisas do passado, recorremos continuamente aos mestres preferidos para saber e confirmar os fatos. Quando queremos adentrar na história de São Paulo, nos valemos preferencialmente de um texto, História e Tradiçóes da Cidade 
de São Paulo, de Emani Silva Bruno, editado pela Livraria José Olympio em 1953. Em seus três volumes sempre encontramos o que procuramos, ali inseridos com precisão e clareza, a certeza imparcial, o complemento da fonte.

Ernani Silva Bruno frequentemente nos dá novas e últimas notícias da sua São Paulo. As últimas aparecem em um novo livro editado pela Secretaria Municipal de Cultura e inserido na série Registros: Depoimentos de Moradores e Visitantes da Cidade entre 1553 e 1958. Trata-se de uma antologia de opinióes as mais diversas e emanadas de participantes da estruturação do burgo piratiningano.

Acompanhamos a evolução com curiosidade desde o "colégio fixo, porque já tem casas e igreja e cerca," como escreveu o Padre Nóbrega em I556, até a beleza do cimento, notada por Roger Bastide, e imóveis pomposos e fora de moda e outras selvagerias descritas por Lévi Strauss.

A respeito de opiniōes sobre megalópole paulistana: num outro volume da Secretaria Municipal de Cultura e dedicado ao Teatro Municipal, encontramos o perfil do cidadão do começo do século. Redigido por um jornalista que escreve em antiga coluna denominada "Onde Sáo Paulo se diverte, os nossos theatros e jardins, as nossas praças de sport," textualmente: "Paulista náo é homem muito dado a diversôes. Pelo contrário. A faina de trabalho em que andamos é que, dia a dia, com as necessidades cada vez maiores da vida contemporânea, mais aumenta, accendendo em todos os animos a febre da labuta pela conquista do habitat, fes do paulista, desde os tempos de Fernão Dias, um homem mais dado à luta, que um bom viveur, acomodado às facilidades da terra e da boa fortuna."

Recuamos trinta anos, àqueles tempos em que o Museu abriu o Instituto de Arte Contemporânea, uma escola dirigida por Lina Bardi e que objetivava pôr em linha o então incógnito Design.

Pensávamos chamar atenção para uma atividade que na própria Europa, depois da extraordinária empresa que foi a Bauhaus de Gropius e de Mies van der Rohe, andava se impondo. Para explicar a iniciativa Design, convidamos para uma grande exposição Max Bill, que teve um modesto sucesso em comparação com sua personalidade.

Foram alunos do IAC, entre outros, Alexandre Wollner, Antonio Maluf, Irene Ruchti, Luís Sadaki Hossaka, Emilie Chamie. Cada um destes pioneiros se afirmou num ou em outros campos. Particularmente Emilie na gráfica, para a qual tinha singular vocação. Dela nos recordamos, pois foi quem cuidou do volume ao Teatro Municipal. Já tinha produzido ediçôes de alto interesse, o mesmo que conseguiu quando se dedicou e se dedica a problemas de produção teatral.

A gráfica de Emilie espelha bem o seu caráter: a ordem e a delicadeza, regulando em uma página a harmonia de elementos, marca pelo equilíbrio compositivo.

\section{Legenda}

Teatro Municipal, 1926 àquela época, palco das inovaçôes culturais

Senhor \#48, I7 de dezembro de I98I, p.72 (Senhor e as Artes)

O manifesto de Piracicaba

Os salóes de Arte estão-se tornando frequentes no Brasil e refletindo o mundo cheio de labirintos de nosso tempo, inventor de poéticas imprevistas

De há muito desejava comentar que, enquanto na França os Salóes de Arte são centenários, aqui no Brasil somente agora é que se nota algum progresso no setor. Constato que as reunióes agrupando pintores e escultores vêm sendo organizadas em número crescente não apenas nas capitais mas também em numerosas cidades do Interior, sejam elas de porte médio ou pequenas.
Num destes fins de semana fui ver o Salão de Arte Contemporânea de Piracicaba, visita que me levou a algumas reflexôes, notadamente a respeito das novas e vivazes atividades da juventude militante, neste fascinante campo em que é hoje possível semear e colher frutos dos mais variados matizes e sabores.

Recorde-se que neste fim de século, o salão é reservado aos acadêmicos, intransigentes 
mantenedores da tradição, porém o batalhai das vanguardas conseguiu, tanto a nível nacional quanto estadual, dividir salomonicamente a produção das artes em dois aglomerados: a dos fiéis às regras de Polieleto e a dos contestadores deste costume, como bem disse Ortega y Gasset, desumanizadores da arte, incentivadores $\mathrm{da}$ revolta antifigurativa, ou remanipuladores dela através de reformulaçóes e até arremedos, os genericamente tidos como informais, conceitualistas, e assim por diante.

Graças a decisóes dos Salomóes federais, estaduais e municipais, para julgar o andamento das produçôes, basta correr aos dois templos-salóes, para que neles se descubra quem são os ídolos preferidos e, consequentemente, os adoradores.

No recinto de Piracicaba ouvimos os discursos do prefeito João Hermann Neto e do coordenador da ação cultural José Antônio Carlos David Chagas, na oportunidade da inauguração e da premiação. Fiquei impressionado ao saber que o assim dito modernismo hoje desfruta de algum prestígio e fama e com o bafejo oficial. Soube que, estando ainda em vigor a lei de Salomão, prefeito e coordenador se predispóem a alojar também os tradicionalistas, os quais, em Piracicaba, se concentram em tomo de Arquimedes Dutra, descendente do famoso Miguel (I8IO-I875), mestre glorioso da arte paulista e paraninfo de tudo quanto de tradicional ali se faz, tanto assim que a sede das façanhas artísticas locais é a ele, justamente, dedicada.

O salão atual homenageia duas personalidades, consagrando-as: o escultor Caciporé Torres e o pintor Ermelindo Nardin, o primeiro introdutor do Informal na Pauliceia, modelador de fantasias plásticas originais; o outro considerado o agitador da pintura antitradicionalista na sua terra e, em nosso parecer, um dos artistas que dão significado à arte nacional.

As premiaçóes neste $14^{\circ}$ Salão de Piracicaba superaram a praxe do sistema de atribuir medalhas e mençóes aos portadores de curriculuns. Em vez de medalhas deram-se aquisições a recrutas merecedores de distinção. Pela crônica: Gastão Magalhães, estruturador de ambientes imaginários; Graziela Rodrigues Davoli, dedicada à Divina Comédia; ao surrealista Pablo Martinez Freyssier; Renato Consentino, redutor de aspectos humanos à simbologia animalesca; Angela Leite, gravadora de surpreendente meticulosidade; ao carioca André Scarlazzari, e a José Carlos Martins, decompositor do figurativismo.

Prevalência dos desenhistas e dos interessados em técnica mista e fotografia, sinal de que a pintura vai perdendo a atualidade, mas para isso os acadêmicos se encarregam de prover.

As conclusóes oferecidas pela manifestaçáo piracicabana, singular pelo decoro versus Arte, são as seguintes: a presença de elementos de bom nível; a tendência do profissionalismo que vai descartando o amadorismo, petulante imitador de esquemas em moda; a riqueza das ideias temáticas, prevalecendo as sugestóes literárias; enfim, o mundo labiríntico característico destes tempos, inventor de poética imprevistas.

\section{Legenda}

Composição de Ermelindo Nardin, o agitador da pintura antitradicionalista 9 Ruptura 8I, de Caciporé Torres, o primeiro introdutor do informal na Pauliceia

Senhor \#49, 3I de dezembro de I98I, p.72 (Senhor e as Artes)

UM NORDESTE MENOS AUTÊNTICO

A qualidade da cerâmica popular começou a cair com o consumismo.

Hoje, há exaustão de fontes anteriormente ativas e originais

Quem viaja pelas pequenas cidades do Nordeste, sempre encontra arte popular, principalmente nas feiras, e, por tradição, muita cerâmica.

Num certo período, o intercâmbio era feito entre gente simples, nas feiras, troca e venda por alguns centavos. Depois a situação mudou: agora a produção é acelerada, feita por fazer, não mais objeto de serventia ou brinquedo, mas bibelô de adorno em casas burguesas.

Nestes últimos anos, temos assistido, no Sul, a uma difusão impressionante da cerâmica nordestina, a ponto de se pensar que a 
mesma seja fruto de produção industrial. $\mathrm{O}$ consumismo recrutou uma nova categoria de comerciantes, os do folclore. Em Sáo Paulo, há uns vinte anos, viu-se nascer e logo desaparecer, por falta de interesse, uma única loja de arte popular, a "Antigonovo," iniciativa de uma culta pesquisadora. Os fregueses eram quatro gatos pingados. Hoje é fácil encontrar atacadistas, retalhistas e vendedores daqueles materiais em número desconcertante, e tudo indica que meio mundo agora ama uma quinquilharia em que o sabor nativo vai deixando de existir.

A moda do ornamento de gosto popular pegou de tal maneira que a produção caiu fatalmente de qualidade, prevendo-se, em consequência, uma exaustáo das fontes anteriormente ativas e originais.

No Nordeste, a tradição é vigorosa, de vez em quando leem-se nos jornais amplas crônicas sobre esta ou aquela atividade, reportagens que, justamente, lembram os artífices. Sabe-se assim que em Tracunhaém, em Pernambuco, operam a septuagenária Antônia, produtora de belíssimos anjos; Maria do Nuca, autora de espetaculares maciços de sabor estroso; Severina Batista, figurativa, e o jovem Carlos Roberto, continuadores da tradiçáo local.

No entanto, o artista mais falado foi, e continua sendo, como um mito, Vitalino Pereira dos Santos. Sua arte genuinamente espontânea, característica da cultura popular, foi sintética e lapidarmente definida por Rachel de Queiroz: “.... deliciosa ingenuidade, a pureza genuína e inimitável, porque absolutamente autêntica." Os temas das figuras são os dos fatos comuns, cotidianos, naturalísticos, observaçáo do pequeno mundo de Caruaru.

Em Vitalino é singular a cor, sempre vivaz e berrante, tradicional I dos africanos, que faz pensar num maracatu ou numa passeata de carnaval, no pitoresco das tintas fantasmagóricas. Foram os africanos que transformaram até as festas religiosas em alegria e em pirotecnia de cores: quanto mais perto do Equador, mais alegria e cores dominam as cenas populares, e Vitalino assimilou este senso. Uma característica de sua cerâmica é o otimismo da vida patriarcal. O barulho, o anormal, o diabo não tem vez naquele seu manufaturar. É raro encontrar entre milhares de imagens a configuração do demônio. Tudo indica que o popular é mais propenso a personificar o bem. Sua representação mais elevada é Nossa Senhora, e também a devoção aos ídolos das práticas espíritas, exus e pombas-giras, que estão ocupando destacado lugar nos altarezinhos dos umbandistas.

Ainda existe a casa de Vitalino. Dela a família retirou tudo, depois de um roubo ocorrido anos atrás. A moradia hoje é um museu para conservar sua memória. Mostra os pífanos, o chapéu, a faca do fumo cama acolchoada de capim, o baú, o guarda-louças, os retratos das visitas. $\mathrm{O}$ casaco não está mais lá, foi roubado.

Agora, os filhos e netos continuam a tradição, circunstância comum nas famílias de ceramistas. Os preços das estatuetas subiram, pela inflação e pela demanda dos turistas, tornando-se centro de produção maciça.

\section{Legenda}

Cerâmica típica de Caruaru: a beleza que falta à arte de consumo

Senhor \#50, I5 de janeiro de I982, p.72 (Senhor e as Artes)

UMA PESQUISA DIFÍ́CIL

Enquanto a pintura provoca delírios, a escultura continua quase esquecida, reservada apenas aos monumentos públicos e às recordaçóes funerárias

A escultura clássica teve recentemente um momento de extraordinária atenção, através das reportagens, na imprensa e na televisão, por ocasião da descoberta, no Mar Jônio, dos esplêndidos bronzes gregos representando dois guerreiros.

Em geral, a atenção é dada sempre para a pintura, arte presente nos leilóes que, pela importância alcançada, empolgam as pessoas, provocando discussóes sem fim, isto sem falar nos centenários dos Mestres, como foi o caso de Picasso, suscitando até delírios.

A escultura parece continuar sendo uma arte reservada aos monumentos públicos e as recordaçóes funerárias. Enquanto 
existem inúmeros colecionadores de pintura, náo se conhecem colecionadores de esculturas. Em São Paulo temos uma centena de galerias que tratam da arte dos pincéis e somente uma que se dedica exclusivamente à arte do formão e da fundição.

Faz muitos anos que o Museu de Arte de Sáo Paulo tenta provocar interesse pela escultura, mas só agora foi possível realizar o objetivo. Refletindo sobre a situação com Jacob Klintowitz, pensamos numa exposição dos escultores que operaram nestes últimos cem anos no País, justamente desde os tempos de Rodolfo Bernardelli até Caciporé Torres. Isto é, o período da Plástica Figurativa e depois da mudança para o Informal. Para realizar a manifestação, o Masp conseguiu o generoso apoio da Phillip Morris que possibilitará a publicação de um volume a respeito.

Dividimos a organização da mostra, que se realizará nos meses de março e abril: o redator desta nota tratará do Figurativo e Jacob do Informal. O primeiro grupo é formado especialmente pelos mestres do Oitocentos e do começo do século e pelos que ainda hoje se expressam na tradição, como é o caso de Oxana Narozniak, Vasco Prado, Abelardo da Hora e muitos outros. Ao Lado deles estarão os que não acreditam mais na reprodução do humano e se manifestam em ajeitamento de formas abstratas.

Esta comunicação é feita para informar que as pesquisas têm sido extremamente difíceis: há falta de documentação e de bibliografia, dificuldade de encontrar obras, principalmente no caso de escultores figurativos, ou informaçóes, onde é possível procurá-las. Se algum leitor puder colaborar com o Masp, desde já, aqui vai um “obrigado."

A manifestação terá um preâmbulo histórico. Será lembrado que o Aleijadinho desaparece num decênio de grandes alteraçôes políticas, sociais e também estéticas. O Brasil se envolve na “civilização," sendo João vi seu portador na Terra que tanto ouro tinha garimpado para Portugal.

A arte da Escultura de feitura não religiosa surgia no Brasil, transitando por dificuldades diversas. A Pintura se ajeita melhor à nova situação de transplante europeu, apesar de se improvisar em composiçóes de temas como 'O Gênio da América' caminhando para o triunfo da Humanidade, ao mesmo tempo que o Sol gira do "Oriente para Ocidente," ou "Restabelecimento da saúde de Dom Pedro II em I823." Devia-se encontrar e combinar alegorias de nova e inédita retórica.

Para obter o mesmo resultado no mármore ou no bronze, a incumbência era complicada. E o plástico Marc Ferrez, da Missão Francesa, com seu companheiro Francisco Pedro do Amaral, tentaram algumas cenas parecidas, em baixo-relevo, nas decoraçóes em estuque na mansáo da Marquesa de Santos, porém de modestos resultados.

Esculpir era também problema para os alunos da Academia, envolvida em fabulosas lutas internas entre franceses e portugueses, instituição que o ministro José Ignácio Borges, em I836, quis fechar por "despesa de luxo," declarando que a arte se podia comprar mais barata nos botequins ou lojinhas da rua do Ouvidor. Os alunos, por exemplo, os do professor João Joaquim Allão Ferreira, apresentavam nas exposiçóes trabalhos assim denominados: Cabeça de hun menino copiada dos gessos da galleria d'Aula, Mão de homem, Pé esquerdo de Laocoonte em ponto mais grande. A Missão liquidava o último suspiro do Barroco e do caçar com gato, golpeando a espontaneidade dos artífices.

Os tempos eram de ingênua aproximação não às Artes, mas as Belas-Artes assim descritas: “...reunida ao pé do Throno, recebendo das máos da Minerva Brasileira os prêmios destinados pelo Governo Imperial. À esquerda do quadro se observão differentes produções de artes, que testimunhão sua estabilidade e permanência no Brasil Fama abrindo as promotas asas, vai promulgar a data do Dia fortunado para as Bellas-Artes."

Penso que estamos preparando uma exposição interessante e divertida.

\section{Legenda}

$N u$ (1924) de Victor Brecheret: uma obra para a exposição do Masp 
Senhor \#5I, 28 de janeiro de 1982, p.72 (Senhor e as Artes)

AudÁCIAS DE UM PASQUIM DO IMPÉRIO

$A$ reedição de um jornal pioneiro na sátira política e dos

costumes, que sacudiu a São Paulo provinciana de 1876

Um esplêndido volume dedicado ao antigo jornal $O$ Polichinello vem a confirmar o interesse sempre crescente por um setor particular da história nacional.

Foi o Museu de Arte de São Paulo que, em I979, apresentou uma exposição dedicada à Tipografia Brasileira, documentando-a num volume que reproduzia centenas de frontispícios e de páginas de folhetos e livros, publicados entre o princípio do oitocentos e a afirmação da técnica de comunicação, infelizmente sempre vetada e perseguida no tempo da colônia quando alguém tentava usá-la.

Foi a primeira vez que se operou a pesquisa, que esteve a cargo de Claudia Marino, a qual na introdução do livro apresentava este trecho dedicado ao pioneiro da imprensa brasileira: "Em I798, Hipólito da Costa recebe a tarefa do ministro d. Rodrigo de Souza Coutinho, de examinar os progressos agrícolas e industriais dos Estados Unidos e México; naturalmente toma contato com os novos princípios da democracia americana, chegando a se filiar a uma loja maçônica da Filadélfía. Em I802, novamente parte em missão do governo português, com o intuito de adquirir material gráfico e livros para a Real Biblioteca, uma vez que, desde i8or, é editor literário na Junta que administra a Impressão Régia portuguesa. Ao retomar de Londres é preso sob a suspeita de filiação com alguma loja maçônica, encontrando-se entre seus pertences cartas-patentes e documentos comprometedores. Ficando dois anos e meio preso e sendo interrogado pela Inquisição em I80s consegue fugir da prisão, refugiando-se na Inglaterra."

No volume, reconstrói-se o desenvolvimento da tipografia, dando-se conta do jornalismo. Agora, no volume editado em convênio entre a Imprensa Oficial do Estado e a Divisão de Arquivo do Estado de São Paulo, com pormenorizada introdução de Ana Maria de Almeida Camargo, o público pode ver como o original periódico foi se impondo na São Paulo dos 30 mil habitantes de 1876. O Polichinello foi uma das primeiras iniciativas jornalísticas que intervieram na comunicação com comentários caricaturais. O gênero não era, naturalmente, bem aceito pelos figurôes, mas grato ao público, suscitando os imagináveis galhos, e os contemplados pela folha reclamavam inquietos. Pouco a pouco, a situação envolveu o sistema. Reclamava um "assinante devedor:" "O principal redactor e proprietário do 'Polichinello' é um homem honrado, que distingue-se pelo respeito que tributa aos outros. Admira-se que me atirasse tão ofensiva alusão e com tanta injustiça."

Numerosas eram as revoltas. Hoje a manifestação da crítica humorística continua, (ma num troppo) pois está passando de moda. De qualquer jeito, $O$ Polichinello ficou como um precursor nesse campo. Sua reediçáo é muito significativa para se observar os primeiros passos do sacudir irônico, baseado nas lutas políticas dos tempos do Império.

Na apresentação do volume, o prof. José Sebastiáo Witter, que superintende ao Arquivo, convida à reflexão do documento: O Polichinello, conforme se verá, é algo assim, que se escondia nas estantes do Arquivo e era procurado por pesquisadores pertinazes e intelectuais interessados no período em que ele circulou. $\mathrm{O}$ manuseio constante o estava ameaçando de extermínio, pois o mais cuidadoso dos consulentes não pode evitar o contato físico com a obra a ser compulsada e neste compulsar o agente de deterioração.

Várias foram as "audácias" de O Polichinello. No número 4, publicava-se duas personagens da política real, literalmente desnudadas. A sensaçáo deu lugar a acusaçóes de atentado ao pudor. Comentava a Tribuna Liberal: "O p.esta elle de tal nudez que náo podemos dizer a verdade nua e crua." O Correio Paulistano anotava que as figuras estavam "despidas demais..." Cada página do periódico é um informe de extraordinário valor para os historiadores, especialmente sob o ponto de vista iconográfico e também sob o enfoque das 
artes pois aparecem composiçóes surrealistas e tantas outras invençôes plásticas.

Os "segredos de Polichinello" eram revelados através de argutos desenhos de Nicolau Huascar de Vergara e textos de Luís Gama, que dizia: "O que estou vendo, vou escrevendo."

\section{Legenda}

O Polichinello foi reeditado para escapar da destruição

Senhor \#52, II de fevereiro de I982, p.II (Senhor e as Artes)

O "POSTER" JAPONÊS CONTEMPORÂNEO

Vendo de perto a arte japonesa, os críticos podem analisar sua

influência na formaçấo da escola nipo-brasileira

Parece-me que já chegou o tempo de se pensar em estabelecer quais as influências exercidas pela arte japonesa na arte brasileira, e determinar como andou se formando uma escola nipo-brasileira em São Paulo, surgida espontaneamente, sem programaçôes e nem manifestos.

Quem está seguindo o desenvolver das atividades dos japoneses emigrados para o Brasil, - e os nisseis sabem mais do que ninguém sobre suas origens - atribui a Yoshiya Takaoka a iniciativa de se dedicar à pintura em modos ocidentais, porém sem se esquecer da tradiçáa pátria. Conheci-o nos anos 40. Artista simples, modesto e talentoso. Mais tarde chegou Manabu Mabe vindo de Lins, interior de São Paulo, para se estabelecer na capital, apresentando uma série de paisagens, espetaculares pela novidade de ver o Trópico numa interpretação e grandiosidade inéditas: não mais a reprodução fiel, comovida da realidade, mas uma fantástica síntese de cores violentas, agressivas, gritantes. Depois, Mabe passou a produzir telas abstratas, participando da nova comunicação com a originalidade que foi premiada nas Bienais de São Paulo e de Paris, reconhecimentos que o lançaram no campo internacional.

Ao mesmo tempo, Tomie Ohtake participava da afirmação dos japoneses, com estilizações de formas e cores de um brilho extraordinário. Muitos outros artistas também engrossaram este núcleo como Wakabayashi, Fukushima, Kusuno, Koshikoku, Lydia Okumura, Tomoo Handa, Yuji Tamaki, Teiichi Suzuki, Jorge Mori, Kogure, Bin Kondo, Masao Aki, Masato Okinaka e muitos outros, todos contribuindo para a formação do que logo se batizou de Escola Japonesa do Brasil. Os elementos não são somente os citados, há muitos outros. A cada ano se afirmam novos recrutas, e sempre constitui uma surpresa encontrar outros pintores como, recentemente, foi o caso do jovem Celso Suetake, um desenhista que, sem medo de ser desmentido, classifico como um mestre de excepcional capacidade, pelo domínio que tem da linha e da composição. De qualquer jeito, deixo aos críticos a missão de reunir e estudar os artistas japoneses, e seus descendentes, a fim de prepararem um ensaio a esse respeito.

Agora, uma novidade: o Masp expóe, de 29 de janeiro a I4 de fevereiro, os cartazes contemporâneos japoneses. Uma seleção do melhor que se produziu no Japão na área dos posters, nos últimos anos. Os nomes são pouco ou nada familiares ao grande público, porém dos especialistas, como os colegas brasileiros da comunicação, esses artistas são bem conhecidos. Trata-se de uma mostra promovida pelo Masp com a cooperação do Consulado Geral do Japão em São Paulo, Fundação Japão e Aliança Cultural Brasil-Japão. O cartão de apresentação dessa mostra é o próprio cartaz que a anuncia, produzido pelo jovem sansei Nelson Okumura e pelo artista japonês, aqui radicado, Toshiake Oe.

Bastará apreciá-lo para se constatar a sua originalidade. Não é nada simples desenhar um cartaz deste tipo. Achei-o uma ideia singular no seu lay out e, ao mesmo tempo, delineia a personalidade de cada contribuidor, resumindo a expressáo dos conjugados. Cada um deles tem seu caráter, seu gosto, seu sistema de fazer, porém o grupo dá logo a confirmaçáo de que se trata de uma maneira que toma o apelido de Escola. A exposição vai evidenciar esta Escola e como, no Japão, homens de negócio e instituiçóes públicas veem o poster com uma nova luz. A obra de Yusaku Kamekura, em 1964, denominada Trilogia, desenhada especialmente para as Olimpíadas de Tóquio, recebeu uma entusiástica recepção 
geral. Shiseido, uma empresa de cosméticos, confiou aos artistas Makoto Nakamura e Eiko Yoshioka os desenhos e a organização da campanha de posters para anunciar seus produtos. Outras empresas também começaram a utilizar este veículo para engrandecer as imagens institucionais, obtendo sucesso considerável. Os próprios artistas gráficos sentiram que as formas e cores do poster deram a eles uma nova e riquíssima liberdade de expressão de suas próprias ideias e experiências. Parece-me interessante concluir esta nota com uma observação do designer japonês Kazumasa Nagai:
"O cartaz japonês expressa bem a história do Japão, como um país relativamente isolado e racialmente homogêneo, cujo povo se inclina para responder mais fortemente aos apelos para a sensibilidade do para a lógica. A trídimensionalidade da arte europeia, por exemplo se origina na teoria lógica da perspectiva, enquanto a arte japonesa é bidimensional, buscando mais a emoção do que a profundidade da ilustração.”

\section{Legenda}

Manabu Mabe: uma visão inédita do Trópico

Senhor \#53, 25 de fevereiro de 1982, p.68 (Senhor e as Artes)

PinTURA PARA PINTURA

O prazer dos críticos é descobrir a possivel vocação, a intimidade, a

emoção, o secreto intransmissivel da arte de pintar

Existem alguns pintores que preferem trabalhar em telas de grandes dimensóes onde espraiam temas repletos de figuras ou labirínticos rabiscos; outros, ao contrário, preferem pequenas superfícies para se manifestarem abordando temas mais simples e modestos. A este respeito dizia Fernand Léger: "Um pintor não deveria procurar reproduzir uma bela coisa, mas fazer de tal maneira que sua pintura resulte numa bela coisa, pois para mim a figura humana, os corpos, não têm maior importância que um prego ou uma bicicleta: não passam de objetos de valor plástico que utilizo como melhor me parecer."

Doutro lado temos a obra de Giorgio Morandi que representa somente objetos domésticos, os mais humilaes, compostos e recompostos em pequenas telas. Seu pretexto era a "natureza silente," na definição de Giorgio de Chirico.

Num tempo, como o presente, em que a Pintura andou servindo para as mais curiosas aventuras plásticas, sendo uma das últimas a "arte postal," próxima uma da outra trouvaille, a, "arte telegráfica” sem contar que também o xerox, o mata-borrão e os livros dos contadores tornaram-se objeto de interesse; hoje os pintores que reduzem a expressão à contemplação, por exemplo, de uma simples coisa, passam por excêntricos passadistas, acadêmicos, cartâo-postal etc.

O mesclar cores, ajeitá-las na infinita variedade das possibilidades inventivas, harmonizá-las numa superfície, constitui o maior prazer do pintor independentemente daquilo que depois vai representar. Num quadro de mestre o conhecedor vê, antes de tudo, o modo técnico, o jeito do extrelaçar as tintas, o mesmo que, por trás das palavras, vai- se descobrindo num poema, e também numa prosa, a que os críticos designam de "prosa d'arte."

Descobrir a possível vocação, a intimidade, a emoção, o secreto instransmissível do pintar é o prazer dos que entendem do assunto. As descobertas podem se manifestar nas obras dos gênios, desde o maravilhoso artífice Giotto até o misterioso Velazquez, como na lendária companhia dos seguidores de Turner que desfaziam e recompunham o espectro solar. Não se excluem do prazer de compreender as obras dos assim ditos primitivos, inexpertos em maneiras pictóricas, porém plasmadores de expressóes encantadoras.

Valendo-se da audácia que às vezes vem em socorro dos que se apaixonam pela Pintura, tentarei dizer que desta arte entendo não o bastante, pois tal é impossível, mas um pouco. Recebo no Masp em média de três a cinco fulanos por dia que pintam. Semanalmente levam o detestável curriculum, fotos, algumas telas ou desenhos. A conversa mantida é essencialmente cordial. Sem deitar cátedra, sem pedantismo, se discute, se aconselha, se recomenda independência, perseverança etc. Às vezes resulta em combinar-se exposiçóes. 
Lembro-me que no ano passado apresentou-se uma senhora, Linda Kohen, portando alguns pequenos quadros. Logo me lembrei do meu caro amigo Morandi, pela escolha dos motivos, pela parcimoniosa justeza do pincelar, ingênuo, quase surpresa de pintar. É quando a curiosidade toma conta de nós que pretendemos entender. É gratificante imaginar o que pensam os que se metem neste trabalho-não-trabalho para satisfazer quem sabe algum desejo. No caso da referida senhora, apenas diversão. Mas sou de opinião que todo o produzir arte é diversão, menos para os enganadores.

Todos sabem que na história da arte as pintoras são em número pequeno, contando-se nos dedos das mãos. Foram considerados casos e tudo indica que os talentos femininos não foram relevantes, ao passo que depois da "libertação" despontaram em escala apreciável pintoras que conquistaram as mesmas posiçóes dos rivais. Aliás, de passagem, deve-se dizer que o número das artistas aumenta bastante.
Em certa época elas, as mulheres, empregavam seu tempo disponível exercitando os bordados, fazendo serigrafia ou aquarelas, sendo o copiar flores o tema mais frequente; hoje pintam e esculpem profissionalmente, fixam-se naquelas novas tendências mais carentes de ideias do que suor na fronte, a arte favorecendo o fácil e o curioso.

Fato diverso, para não dizer contrastante dos ainda fiéis a tão ameaçada, "imitação da natureza" isto é a tradição dos milênios. Não que seja preciso eliminar do contexto da Pintura tudo que é novidade, extravagância, boutade. $\mathrm{O}$ sol nasce para todos. Porém, talvez pelo longo exercício e convivência com pintores-pintores, as telas de Linda me interessam pois representam o gosto de quem com candor incursiona nesta seara maravilhosa que é a Pintura.

\section{Legenda}

Taça, de Linda Kohen: quase a surpresa de pintar.

\section{Casa Vogue \#2, março-abril de I982, p.84-89}

UM CONTATO COM ARTES EXÓTICAS: na casa de uma designer

Aqui, na casa de Orietta del Sole, numa harmoniosa ordem absolutamente pessoal, reúne-se um vasto assemblage de formas, desde a mais extravagante até a mais comum.

A cidade de São Paulo agrupa notável número de casas ricas em coleçôes de obras de arte, cada uma obedecendo ao gosto e às predileçóes dos donos. Geralmente o colecionismo se compendia mais nas pinturas, acadêmicas para os filiados à Sociarte, modernista para os que pensam na Semana de 22 como a liberaçáo dos produtos "belas-artes." Várias casas têm conjuntos de móveis e esculturas antigas, nacionais, dos séculos em que o barroco era o estilo preferido, ambientes, às vezes, de algum interesse museugráfico.

Bem menos numerosos os que recolheram objetos de arte europeia, sendo raros os brasileiros a isso dedicados, pois quem possui coisas de outros países são geralmente estrangeiros aqui radicados, isolados do ponto de vista da convivência estética, pois o fator tangencia mais para o nacional.
Eu mesmo, tendo trazido da Itália mobiliário, pinturas e esculturas da Renascença, vejo, quando recebo a visita de amigos brasileiros, que minhas obras não lhes causam qualquer impressão, apesar de serem peças pelo menos curiosas, como, por exemplo, uma mesa de artesáo romano executaria para um casamento entre membros das famílias Barberini e Della Rovere, peça esculpida e com uma rica e maravilhosa decoração dourada, aplicada às armas dos príncipes.

Isto posto, fica evidente que arte é fato nacional, direi municipal. Cada um gosta do próprio ambiente e tradição. Difícil renunciar ao que nos acompanhou desde a infância: mas difícil ainda é ter um gosto para tudo que seja expressáo de outros povos, até mesmo de continentes, sem se falar do Oriente.

Visito periodicamente a casa de uma artista onde gosto de apreciar um conjunto de obras de arte das mais variadas. Gosto da casa náo só para ter um contato com artes exóticas, mas também para saber como a coleção foi formada. Através das ilustraçôes será fácil o leitor compreender do que 
se trata, as amplas legendas indicando as mais díspares origens. Orietta del Sole é a artífice de joias das quais Vogue falou no ano passado, por mim apresentada aos feitores, comentando seu gosto na elaboração de uma ourivesaria distinta por um design original. Parece-me consequência, um pouco, das coisas que reuniu, $\mathrm{o}$ vasto assemblage de formas, desde a mais extravagante até a mais comum.

Orietta acolheu na própria sensibilidade propostas estéticas tấo heterogêneas, que constituem atos complexos que pressupóem um esforço de compreensão, jogando com a cultura e a simpatia.

Acostumamo-nos a tudo que é neo-alguma-coisa, especialmente o que é nos oferecido destacando-se a intenção do gosto. É preciso que se lembre que no passado, o gosto era ajustado ao enfeite dos movimentos estéticos das épocas, deixando nos objetos desproporçóes e inutilidades decorativas. Por isso mesmo, a aceitação torna-se um fato de cultura e de simpatia.

As longas viagens empreendidas pela artista lhe permitiram encontrar, notadamente no Oriente, aventuras formais de diferentes requintes, às vezes não facilmente aceitas, porém sua compreensão em relação a tudo se anima de singularidade perfeitamente aceita.

Sua casa está repleta disto tudo, numa harmoniosa ordem absolutamente pessoal, oferecendo aos hóspedes, como aqui é mostrado, um museu particular, para ela, de formas amigas.

\section{Legenda}

p.84 Acima, na entrada, duas estátuas venezianas de madeira policromada, da metade do século I9, onde estâo pendurados objetos orientais e brasileiros. Biombo formado de gravuras populares dedicadas a Napoleão.

À direita, no living, uma arca gótica pintada com o tema Sant'Ubaldo, da escola napolitana do século 17 . Sobre ela, uma coleção de chimarrôes e queimadores de incenso. À esquerda, pintura persa e um retrato de Giacomo Favreto, datado de I875, além de outras pinturas. Mais à direita, uma vitrine contendo uma coleção de caixinhas antigas.

p. 87 Num outro lado do living, papeleira estilo Maria Thereza. coleção de gravuras antigas japonesas, cadeira de ebanista romano de 1820 , relógio Biedermeier e bureau cilindrado estilo Luiz XvI com signos maçônicos marchetados. p. 89 À direita, no dormitório, cômoda estiloimpério italiano e um grande espelho holandês do século. Sobre a cômoda, um espelho, também império, de toilette, antigos recipientes de vidro e alguns colares de tribos indígenas brasileiras. À esquerda na sala de jantar, coleção de cerâmica e vidros da Ásia, Europa e África. Sobre a mesa de jogo, coleção de pequenas formas de peltro para doces. Os pratos foram desenhados pelo pintor argentino. Castagnino. As cadeiras laqueadas são procedentes de um convento em Montevidéu.

Senhor \#54, II de março de I982, p.68 (Senhor e as Artes)

Os ARTISTAS SÃO PITONISAS?

O pintor Francisco de Mello une homens e máquinas, com um desenho escrupuloso

Entre os pintores que se manifestam informalmente, rabiscando e até mesmo passando para a tela uma única e solitária mão de tinta, obedecendo aos imperativos da moda corrente entre nós, como de resto em quaisquer outras paragens, despontam de vez em quando os da resistência, aqueles que se refugiam na tradição figurativa. São os independentes que não aderem às últimas novidades informais, continuando os caminhos de sempre, rejeitando o apelido de "moderno."
Tivemos nestes últimos anos enorme safra de abstratistas, concretistas etc., sem se falar da última descoberta, envelope selado que representa uma outra faceta da estética: a "arte postal." Na confusão, em grande parte incentivada pelas decrépitas Bienais, de vez em quando são descobertos elementos isolados, despertando algum interesse.

É o caso de um jovem alagoano que já há cinco anos vive em Paris, onde é apreciado. Trata-se de um moderno, desde que se dê a este adjetivo o senso 
justo: alguém que compreendeu a realidade dos tempos, sua poética, seus símbolos, a eles dedicando o trabalho.

Não conhecia Francisco de Mello, o qual chegou certo dia ao Masp para mostrar a tela que ilustra estas notas, pedindo ao leitor para observá-la atentamente.

Logo pensei na cibernética, ou mais precisamente, em computadores. Não naqueles sistemas em que são obtidos desenhos através de uma máquina, sugestão de precisão, de cálculo, de auxílio. O pintor pensou em integrar a figura humana inserindo-a no labirinto dos maquinários: uma e outros definidos, nas suas anatomias, com paciente perfeição. Tem-se a ideia da volta a um desenhar escrupuloso, miniaturístico, o perseguir o detalhe, como se vê nas obras dos antigos mestres.

Não se trata de impressão, mas de um mecanismo através do qual transparece o extraordinário significado deste fim de século e milênio, em que é impossível acompanhar a marcha do progresso, sem que por outro lado se possa conceber como é possível um robot construir automóveis ou um foguete correr teleguiado.

Francisco de Assis Amorim de Mello procurou curiosar no recinto mágico das máquinas. Os Futuristas intuíram a chamada, porém se manifestaram superficialmente, tendo os temas interessado a inúmeros pintores, que também foram levados a considerar o efeito decorativo de uma máquina, isto é, interessando-se pelos aspectos exteriores.

O caso do alagoano leva-nos a crer que o que lhe interessa é a intimidade da máquina, sua redução a peças-símbolo, por outro lado entrosada à figura, procurando estabelecer uma simbiose, espiritualizando-a, igualizando valor face às duas entidades. Máquina dentro do homem, este engrenado à máquina, numa síntese própria da época.
Na pintura deste artista que, de Alagoas veio estudar em Sáo Paulo e aqui náo encontrado ambiente propicio demandou a Paris, se reúnem várias e variadas ideias aproximadas de certos mitos que estâo circulando, resumíveis no prepotente interesse por tudo que seja relacionado com a sondagem aos mistérios.

$\mathrm{Na}$ era da informática surgem novas conquistas como também novas interrogaçôes. As máquinas poderosas e automatizantes produzem em tal escala que reduzem o trabalho do homem. Benefícios e insídias planaram aqui. Parece-me normal que os artistas tentem fixar o momento em que o "mecanismo" deixa de ser a coisa que "tem um senso de baixo, de viláo, de pouco digno de uma pessoa honesta" como registra um dicionário de 1680 , quando ainda o conceito de trabalho e técnica não tinha alcançado sua afirmação.

Lembrava recentemente um filósofo dedicado aos problemas da ciência, Paolo Rossi, como Bacone, Cartesio, Galilei, Leibniz e Diderot, os quais consideravam a literatura das máquinas, cultura em progresso e, portanto, conquista humana, dignidade a ser relacionada a cultura. A seu modo, Francisco de Mello participa da arrancada maquinística e ajeita a afirmação desta civilização ainda não completamente aceita, pois não faltam os que negam sua presença, não só por palavras como por fatos. É intensa a destruição aparelhos informáticos, considerados pelas esquerdas mais ortodoxas como inimigos da classe operária e por estarem a serviço das deliberaçóes do poder.

O pintor alagoano parece saber de mil e uma coisas a respeito, amalgamando homens e máquinas, seres vivos mas desajeitados. Tal imagem leva-nos a esta pergunta: os artistas são pitonisas?

\section{Legenda}

"Cibernética," óleo sobre tela de Francisco de Mello.

Senhor \#55, 25 de março de I982, p.72 (Senhor e as Artes)

CONSElHOS AO COLECIONADOR

Num documento sobre a arte russa de vanguarda, um "expert" publica as suas regras para se formar um acervo

George Costakis é conhecido como o maior colecionador de arte russa de vanguarda.
Uma parte do seu imenso conjunto está sendo exposta no Guggenhein Museum 
de Nova York. O editor Abrams publicou todo o acervo, ("Russian Avant-Garde Art," The George Costakis, Collection, Nova York, 198I) agrupando sessenta e cinco artistas, entre eles Chagall, Jawlensky, Kandinsky, Larianov, Malevich, Poliakoff, Popova, Puni, Tatin.

$\mathrm{O}$ volume contém reproduçôes de mais de mil obras. E não é toda a coleção, pois o sr. Costakis separou algumas obras para doá-las à Galeria Tretiakov de Moscou. Trata-se de um documento de alta importância que, entre outras facetas, permite saber o quanto a Rússia contribuiu na arrancada da arte contemporânea, fato muito bem delineado nos textos confiados a Frederick Starr e a Angelica Zander Rudenstine, completados por uma cronologia dos eventos culturais russos entre I894 e I934.

O interesse que nos despertou esta esplêndida publicação foi um assunto já tratado nestas páginas. $\mathrm{O}$ sr. Costakis, a fim de tomar seu hobby algo bem mais produtivo e sua vida um tanto tranquila, dá alguns conselhos ao colecionador. Ele pensa que se deveria observar alguns métodos simples e práticos, os mesmos que ele, Costakis, considerou úteis quando tormou sua coleção. Os preceitos que recomenda certamente não podem se constituir em panaceia para tudo, especialmente aqueles cujos caracteres pessoais não podem ser mudados. Por exemplo: que nenhum homem ganancioso pode ser bondoso, nenhum calculista pode se tomar generoso, e que a desonra nunca deve ser transformada em honra. Todavia, com vistas à meta a que se propóe, o colecionador poderia seguir sistemas que, de certo modo, contradigam seus instintos. Escreve o sr. George: "À primeira vista, podem parecer estranhos, mas eu atribuo muito de meu sucesso ao fato de tê-los seguido.”

Os preceitos são os seguintes: I. Um verdadeiro colecionador deve sentir-se como um milionário; mesmo quando estiver sem dinheiro, deve agir como se o dinheiro lhe saísse pelas orelhas. Se ele compreende e ama uma obra, não deve temer comprá-la. Um trabalho de alta qualidade artística literalmente não tem preço para o colecionador, valendo vinte vezes mais que qualquer forma de dinheiro eventualmente mencionado. Para um trabalho assim, ele sempre achará que pagou menos do que vale; o passar dos anos mostrará que o valor subiu não apenas vinte vezes mais, mas uma centena, cinco centenas de vezes, ou mais. Isto eu afirmo por minha experiência pessoal, sem exageros. (O que eu digo refere-se a pessoas que colecionam examinando trabalhos pessoalmente, e não por ouvir dizer.)

\section{Racionalização é a maior} inimiga do colecionador

O verdadeiro colecionador está pronto a desistir de tudo que tem por uma obra que ele deseja. É mais fácil para ele suportar necessidades materiais do que perder seu novo achado. As vezes, isto pode significar um mês de salário ou talvez economias reservadas para as férias, ou ainda renunciar a uma casa nova ou a um carro. Ninguém morre deste tipo de abnegação. A casa esperará e um caminho não dilemático sempre aparece. Certamente que uma obra de arte perdura. Portanto, quando o sucesso depende do próprio colecionador, ele deveria se mobilizar decisivamente e seguir minhas regras.

Um colecionador não deve pechinchar. É mais vantajoso para ele pagar muito mais do que não pagar o suficiente. Esta regra de ouro tem sido testada repetidamente por muitos anos. Se o colecionador tenta pechinchar o preço, ele pode perder a obra para outra pessoa, mas e ainda pior se o vendedor ceder sob pressão. Algum tempo mais tarde, depois que tiver gasto o dinheiro, o vendedor irá lamentar pelo que perdeu, podendo nunca mais oferecer coisa alguma ao colecionador. E a pior consequência de tudo e que o vendedor insatisfeito pode avisar aos outros das táticas do colecionador. O dinheiro economizado pode, portanto, voltar-se contra o colecionador.

Um dos preceitos mais importantes para o colecionador é que ele deve precisamente, mesmo desapiedadamente, definir os limites de sua coleção, e deve resolutamente lembrar-se que particularmente neste aspecto - seu escopo não deveria jamais exceder suas posses. 


\section{Legenda}

Mulher, aquarela sobre papel

de Alexej Von Jawelensky

Senhor \#56, 8 de abril de 1982, p.73 (Senhor e as Artes)

UM APELO PARA MANTER A OBRA DE CHATEAUBRIAND

Aos 35 anos, o Masp deve continuar recebendo o apoio das classes

produtoras, como acontece desde a sua fundaçáo

Conheço um bom número de capitães de indústria, comércio, agricultura, finanças, enfim, aqueles que tornam as chamadas classes produtoras e que detêm os meios para distribuí-los entre vários campos da filantropia, cultura, esporte e uma infinidade de outras manifestaçôes; portanto, é natural que os que porfiam acabem algebrizando para finalmente formar fortunas.

O mecanismo utilizado para obtenção de ajudas com vistas à consecução de iniciativas de utilidade pública já é do meu domínio, pois para tanto aprendi com um mestre e senhor de singularíssima estatura, Assis Chateaubriand, aquele que foi a um só tempo empresário e homem de visão.

Sei que vários daqueles amigos que participaram financeiramente para o bom êxito de suas campanhas nacionais andaram, ou se vivos, continuam acumulando reservas a respeito dos métodos por ele usados a fim de amontoar tudo quanto servia para suas distribuiçóes. Posso dizer, e vou demonstrá-la num dos meus próximos livros e que intitularei A.C., o Inimitável, que ele era tido como o aplicador de um sistema muito pessoal para sacar tanto dos corres particulares quanto dos públicos, quantias que eram aplicadas na respública.

Chateaubriand sabia muito bem o que Colombo queria dizer quando descobriu a América: "O ouro é coisa excelentíssima," já que é a base do tesouro que lastreia os mais variados poderes como aquele de desenraizar almas do Purgatório.

Foi graças ao desenraizamento de contribuiçóes arrancadas dos que podiam, que A.C. pôde dar aos Aéreos Clubes do Brasil mil avióes de treinamento, centenas de postos de puericultura espalhados pelo Interior e, entre as muitas outras prodigalidades, constituir este marco da cultura brasileira que é o Museu de Arte de São Paulo, que leva muito honrosamente seu nome.
Sem sair do assunto da minha página nesta revista que procura espelhar as atividades das classes produtoras, começando as comemoraçóes de registro dos 35 anos de atividades do Museu que funciona ininterruptamente, vive e, na medida do possível, rejuvenesce diuturnamente, quero lembrar que sua existência é devida justamente aos forjadores da riqueza nacional, de fábricas, de bancos, do campo, aos milagrosos elementos das bolsas, a empreendedores amigos da audácia. Tive sempre o cuidado de colocar os nomes dos doadores de obras nas legendas de cada uma delas, menos naquelas em que os mecenas pediam anonimato, mas espero que na próxima publicação do catálogo geral do Museu, (estou buscando um generoso patrocínio à altura de tal empreendimento editorial) vou relacionar todos os brasileiros e os estrangeiros que permitiram a São Paulo ter o maior acervo de arte ocidental da América Latina. Trata-se de um acervo que, falando-se em termos de dinheiro, vale hoje centenas de milhóes de dólares, consagrado nas exposiçóes que apresentamos entre 1953 e 1956 na Orangerie do Louvre, Palais de Beaux-Arts de Bruxelles, Centraal Museum de Utrecht, Kunstmuseum de Berna, Kunsthalle de Dusseldorff, Tate Gallery de Londres, Palazzo Reale de Miláo, Metropolitan Museum de New York, e nem me lembro mais de quantos museus do Japáo, país para onde daqui a poucos meses enviaremos mais uma coleção para a inauguração do Mie Prefectural Art Museum e Gunma Prefectural Museum of Modem Art, cidade gêmea de São Paulo.

O Masp, graças à mágica de A.C., aos prefeitos Adhemar de Barros, que lhe destinou oportunamente o terreno do Trianon, Prestes Maia, que iniciou a construção do complexo mediante o projeto de Lina Bo, Faria Lima, que o concluiu fazendo a inauguração em 7 de novembro de 1968 e contando com a presença de S.M. a rainha Elizabeth II, da 
Inglaterra; graças aos amigos do fundador, está hoje entrando em nova fase de atividades. Por isto o diretor, através das páginas de Senhor clama em alto e bom som a fim de provocar algum interesse por parte das classes produtoras para que o Masp, sociedade civil sem fins lucrativos, reconhecida de utilidade pública e como entidade filantrópica, continue haurindo benesses, como nestes últimos anos foi possível verificar, aqui devendo ser lembrado o Banco Sudameris, a Fiat, a Philips Morris, a Fundação Giovanni Agnelli, e incontáveis iniciativas que temos recebido do governo Paulo Maluf.

\section{Legenda}

Retrato de Assis Chateaubriand,

(I953) de August Zamoyskui

Senhor \#57, 2I de abril de I982, p.77-78 (Senhor e as Artes)

\section{QuANTO VALE O PASSADO?}

Como o leitor deve estar informado, o Governo Federal criou, dentro dos quadros do Ministério da Educação e Cultura, a Secretaria da Cultura cuja direção foi confiada a Aloísio Magalhães, o designer das nossas notas monetárias. A novel Secretaria ainda se encontra em formação e certamente vai enfrentar notórios problemas com a conservação e defesa do patrimônio, literariamente agora chamadas de Memória. Assunto de manuseio pouco fácil quando pensamos no que acontece, por exemplo, na Itália.

As últimas notícias chegadas de Roma são alarmantes, a começar pela constatação de que o balancete para atender à conservação do mais vasto patrimônio artístico do mundo, é bem inferior ao que gasta o Metropolitan Museum de Nova York. A Itália deve defender monumentos e preservar objetos contra a ação destruidora do tempo, da poluição e, mais especialmente, dos roubos. Nos últimos cinco anos desapareceram cerca de 40.000 peças e ... 17.000 pinturas. Os custódios lotados no serviço do Patrimônio são 9.000 , porém os efetivamente em atividade chegam somente a 7.000.

A burocracia também campeia nas BelasArtes, e não atende às necessidades para um bom funcionamento administrativo. Há alguns anos o Parlamento instituiu o Ministério dos Bens Culturais, mas até o momento as coisas pouco mudaram.

Este Ministério absorve 0,28 por cento da despesa complexiva do Estado. Como sói acontecer nesta atividade, o corpo de funcionários, com raras e honrosas exceçóes, preocupa-se mais em mamar no, "Eldorado das Belas-Artes" onde infelizmente os cabides de emprego são numerosíssimos. Um funcionário, responsável pela direção da Galleria d'Arte Moderna de Roma, o prof. Bruno Mantura, esteve em Sáo Paulo a fim de preparar a participação italiana na última Bienal, oportunidade em que declarou ao redator de La Stampa, para um inquérito relativo ao "Ministério dos Bens Culturais:" "Ganho um terço do que percebe um colega francês."

Um dos numerosos problemas existentes é o da falta de catalogaçáo que determinaria acertadamente o que o Estado possui. Na referida reportagem fica a denúncia de que as Galerias Corsini, Palácio Baroerini, Brera, Mantova, Urbino e Capodimonte nem têm catálogos.

Como se vê é desoladora a situação do patrimônio da nação mais rica de História e de monumentos, riqueza que gera inusitada atividade dos traficantes, talvez a mais expressiva da Europa. Recentemente em Paris, em um leilão, as autoridades italianas descobriram que estava sendo licitado um importante tríptico de Mariotto di Nardo, pintor do século xiv. Esta obra estava em Florença e, não tendo sido exportada regularmente, infere-se a existência de uma fraude.

Na Península a exportação clandestina é prática comum. Apesar da existência de um órgão policial destinado a enfrentar o tráfego ilegal de obras de arte, a atividade criminosa é ativíssima. Doutro lado, quando uma maroteira é descoberta, torna-se difícil a recuperação das obras, devido a complexidade das práticas judiciais em termos internacionais. $\mathrm{O}$ desaparecimento das peças coincide com a esperteza dos colecionadores, e também dos diretores de museus estrangeiros que 
nem sempre se preocupam em indagar a origem daquilo que o mercado lhes oferece.

Quem acompanha, por motivos profissionais, esta migração constante de obras de arte de um país para outro, sabe de histórias rocambolescas, em que as experiências das tapeadoras dos exportadores clandestinos rivalizam com a malandragem dos combinadores de uma infinidade de crimes que os meios de comunicação nos contam a cada dia.

Situemos o problema em termos brasileiros. É verdade que o patrimônio não é tão imenso, porém trata-se de um acervo de alta importância para o País, e que deve ser protegido. Também nós, em escala menor, temos as mesmas atrapalhadas da Península: falta de meios para a conservação, deterioração, roubos, falta de catalogação e assim por diante.

Quase semanalmente tem-se notícia de que esta ou aquela igreja foi despojada de uma imagem, ou de algum elemento de culto. Aliás, recentemente em Santos, estava à venda um lavabo de pedra-sabão com a indicaçáo de tratar-se de uma peça do Aleijadinho, procedente de uma igreja, porém não roubada, mas simplesmente vendida, num tempo em que esta prática era fato comum. Tão normal o episódio que ninguém faz caso. E, num parêntese, deve-se dizer que, felizmente, existem colecionadores que se empenham bravamente em salvar muita coisa. Dizemos salvar, porque achamos ser esta a palavra certa, o que é móvel do Patrimônio.
Quem acompanha atentamente a situação da Memória nacional fica extremamente preocupado, pois sabe das dificuldades, antes de tudo de "produzir" funcionários competentes e animados não em desenvolver uma carreira empregatícia, mas uma carreira de interesse realmente nacional.

Há alguns anos aconteceu-me ter de discutir, como perito de arte, com um eminente diretor do antigo SPHAN, a respeito de uma papeleira austríaca do século XviıI que "não podia entrar livremente no País porque a mesma não tinha mais de cem anos, conforme a lei." Eu sustentava a antiguidade da peça, e o meu oponente contraditava afirmando ser a peça nova. Perguntei-lhe se já tinha visto alguma papeleira europeia do Setecento. Respondeu-me: náo. Trata-se de um episódio que bem retrata como o pessoal do Patrimônio deveria cursar continuamente, reciclando-se e se dedicando não por acaso ou dando uma de bicáo, a uma função que é entre muitas a mais delicada e da mais alta responsabilidade.

A importação de obras de arte do estrangeiro está relegada a um segundo plano. A lei que possibilitava a entrada de obras de arte com mais de cem anos náo existe mais; e que dizer das manobras dos conferentes de Alfândega quase sempre jejunos de Cultura?

Os problemas existem aos montes; alimentamos a esperança de que a Secretaria da Cultura os encare com seriedade e agilidade. Porque só assim se construirá uma base sólida para consolidação da cultura nacional.

Senhor \#58, 28 de abril de 1982, p.67 (Senhor e as Artes)

ADHEMAR E O MASP: SEM INGRATIDÁO

Recordo-me, depois de mais de três lustros, que entre as variadas excentricidades que envolveram a organização do Museu de Arte de São Paulo, uma sempre me encabulou: era a prática de promover comemoraçóes em honra de personagens que, no final das contas, nada tinham a ver com os problemas da estética. Rotineiramente a ideia era a de fixar na parede o retrato de uma personalidade marcante no campo social, político e cultural.
Quem sugeria esta forma de homenagem, no Masp, era o sr. Assis Chateaubriand. A primeira, em I948, foi dedicada à dona Veridiana Prado, personalidade marcante, exaltada em conferências proferidas por Gilberto Freyre, Yan de Almeida Prado, Roberto Moreira e outros historiadores, complemento da mostra que recordava aquela dama paulista.

No Masp continuamos especialistas em lembranças de cidadãos que muito fizeram pelo País. Recentemente foram rendidas 
homenagens a homens do estofo de um Edgard de Cerqueira Falcáo, médico e historiador que publicou monumentais livros como, "Relíquias da Terra do Ouro" "Relíquias da Bahia" e outros mais; o beneditino dom Clemente Maria da Silva - Nigra, historiador e fundador do Museu de Arte Sacra de Salvador; o prof. Almeida Santos, infatigável divulgador da arte colonial brasileira. Estamos preparando, agora, evento recordativo da figura do marechal Cândido Mariano da Silva Rondon, isto por ocasiáo da exposição do projeto que leva seu nome, e uma outra dedicada a Euclides da Cunha, pela passagem dos oitenta anos da publicação de "Os Sertôes."

Neste mês o Masp promove um ato para reverenciar a figura de Adhemar Pereira de Barros. Graças a este estadista desaparecido é que São Paulo tem hoje uma sede cultural que, sem modéstia, pode-se definir como uma das mais importantes não só do Brasil como mesmo em relação a outros países que, por tradição, meios financeiros e forte turismo, conseguem criar conjuntos espetaculares, como é o caso do Beaubourg de Paris.

São Paulo, como posição geográfica e cultural, não desfruta de grandiosidade parecida, porém o organismo fincado no local do antigo Trianon pode ser considerado uma gratificante antecipação do espírito e da prática ao Centro Pompidou: precursores em 1947, sem alimentar o propósito de sugeridores e muito menos não querendo repetir modelos já apresentados, queríamos simplesmente um centro de difusão cultural, ativando as várias artes, desde a música até o design, abrindo escolas de vários interesses como a fotografia, ecologia, teatro, música, modas etc.

A complexa instituição foi inicialmente instalada na sede dos Diários Associados na rua Sete de Abril, tudo funcionando bem e crescendo sempre, e de tal maneira que em I960 chegou-se à conclusão de que o local já não era conveniente. $\mathrm{O}$ prefeito da cidade era Adhemar de Barros, bom amigo do sr. Assis, nosso fundador e patrono.

Recordo-me que certo dia, enquanto aguardava o inicio de uma viagem com destino ao Rio de Janeiro, no Aeroporto de Congonhas, as duas personalidades conversavam animadamente a respeito das atividades e do êxito consolidado do Masp. Este redator perguntou ao prefeito: "Que tal a ideia de se construir um edifício para sede do Masp, lá no Trianon?" Adhemar apanhava as ideias no ar, bátisseur d'avenir reconhecido, não replicou no momento. Mas Chateaubriand, outro manipulador de progresso, indômito e intimorato rompedor de barreiras, achou muito boa a ideia. Tudo acabou, como sempre, na mesa de Edmundo Monteiro, diretor dos Associados, o qual, dias depois, foi parlamentar com o alcaide paulistano dele obtendo a aprovaçáo para a construçáo da nova sede do Masp.

Existia um projeto de autoria de Lina Bardi e que foi devidamente aprovado pelo engenheiro José Carlos Figueiredo Ferraz, então secretário de Obras da Prefeitura de São Paulo. As coisas marchavam, mesmo levando-se em conta outros projetos para aquele local do espigão da avenida Paulista, como o destinado às sedes do Automóvel Club e do Museu de Arte Moderna, este de autoria de Afonso Eduardo Reidy. Lina tinha estudado muito bem o problema, e sabendo que o terreno era doado com a expressa condição de que o local deveria continuar sendo um Belvedere, teve a ideia de levantar um edifício apoiado sobre quatro colunas, utilizando o subsolo para auditórios e salas destinadas aos mais variados eventos.

Adhemar de Barros convocou a imprensa, circunscrita principalmente aos vários órgãos dos Associados, em especial à TV Tupi, e comunicou que em breve São Paulo contaria com um novo edifício, desta feita dedicado à cultura, a nova sede do Masp.

Em 1968 deu-se a inauguração da nova sede, honrosamente presidida por S.M. Elizabeth II, da Inglaterra, quando visitou o Brasil.

Há quem afirme que a ingratidão é a marca dos povos fortes, mas aqui desejo opor um firme desmentido. Nós do Masp desejamos registrar nosso preito de gratidão a Adhemar de Barros, na oportunidade da passagem do $80^{\circ}$ aniversário que o estadista desaparecido comemoraria se ainda estivesse entre nós. 
Legenda

Adhemar, segundo o escultor Ricardo

Cipicchia: padrinho de uma boa ideia

Casa Vogue \#3, maio-junho de I982, p.I2O-I2I (Arte)

VISITA A UM ANTIQUARIO

Dois decênios depois começaram a surgir não mais os clássicos bric-à-brac, mas lojas de antiquários.

São Paulo é agora pólo de atração por parte dos bigs do mercado internacional.

Quando cheguei ao Brasil imediatamente acionei uma antiga mania que mantenho até hoje, qual a de visitar antiquários. $\mathrm{O}$ primeiro encontro, sem poder conversar muito com ele, foi com o senhor Henrique Liberal, decorador das moradias dos magnatas. Fiquei um tanto desiludido com as poucas peças em exposição e pela fria acolhida dispensada ao visitante.

Em São Paulo, então, as coisas andavam bem menos animadoras: não existiam antiquários aos quais se podia atribuir qualquer qualificativo de profissional. $\mathrm{O}$ único, simpático, cordial, inteligente, o José Florestano Felice, leiloeiro também, apresentando um vasto armazém na rua da Consolação, repleto de um pouco de tudo, desde boa estatuária até mobiliário de vários estilos, nacionais e estrangeiros. Os outros colegas operavam nas próprias casas, alguns com bons conhecimentos, como o Saul.

Notando a ausência de um ambiente de algum valor, eu, Lina e o arquiteto Gian Carlo Palanti, tivemos a errada ideia de abrir aqui na pauliceia uma filial do meu Studio d'Arte Palma que, enquanto se instalava o Masp, mantinha funcionando em Roma. Náo deu certo e decorridos dois anos acabamos fechando, à espera de tempos mais propícios e alimentando a esperança do aparecimento de mais interessados na história das artes.

Dois decênios depois começaram a surgir não mais os clássicos bric-à-brac, mas lojas de antiquários. Hoje São Paulo agrupa comerciantes que sabem e que contribuem seriamente para o fortalecimento do colecionismo, o qual, por sua vez e salvo casos raros do passado, praticamente não existia.
São Paulo agora é polo de atração por parte dos bigs do mercado internacional. Cada ano a cidade é visitada por gente da Sotheby e da Christie's, bem como por mercadores que vêm em busca de objetos, visitando lojas e mesmo algumas residências.

Recém-chegados e já com atuação marcante, são Ariane Elkins e Edoardo Giuliani que abriram a mais rica loja do setor na rua Pe. João Manuel, II56. Lá o visitante pode ver móveis, esculturas, tapeçarias, vidros e porcelanas de alto interesse, e como característica, uma coleção de peças orientais de extraordinário significado. É também possível descobrir pinturas de jovens artistas brasileiros.

Edoardo e Ariane, sua mulher, são também decoradores e designers de mobiliário bem original. Produzem ambientes que recebem muitos aplausos pela singeleza e ao mesmo tempo por implantar uma nova maneira de simplificar e valorizar obras de arte, distanciando-se do amontoar que sempre foi a tônica da decoração local.

\section{Legenda}

I.Biombo francês Régence, começo do século i8; Aubusson e moldura dourada da época Console italiano (Roma) da metade do século I8 Bronze de Antonio Canova, fim do século I8

2. Par de aparadores italianos em mogno de meados do século 19, Retour d'Egipt; Painel policromado, madeira maciça, indu, século I8, representando a deusa Vismi. Dois pequenos espelhos dourados, venezianos, metade do século I8; Mesa moderna com tampo de mármore branco

3. Sofá Regence francês século I8; Tapeçaria do começo do século I7; Duas peanhas douradas, italianas, começo do século I8, servindo como suporte para duas esculturas em madeira policromada do século I8, italianas

4. Recanto com um sofá-cama francês do século I8, estilo Luiz XVI, forração com 
couro; na parede, uma série de papier peint italianos, c. I830; sobre uma mesa baixa em ferro pintado de preto com tampo de cristal, um Buda tailandês do século I8, dourado; ao lado uma bergére italiana estilo Luiz XVI, século I8

Senhor \#59, 5 de maio de 1982, p.67 (Senhor e as Artes)

A ESCULTURA, SEM HISTERIA

A Escultura está experimentando um momento de mudanças as mais díspares possíveis. Por exemplo: os temas figurativos raramente são abordados, enquanto o informal é praticado sem limites e regras, motivo pelo qual toma-se difícil estabelecer valores. Trata-se de uma novidade órfã de pai e mãe, adaptada aos fantásticos progressos dos quais somos mais espectadores do que participantes.

Para registrar qual o passo, eis a famosa definição de A. F. Doni, lá pelos idos de 1549: "Os escultores entendem como verdadeira arte da Escultura todos os corpos compostos e formados com qualquer tipo de matéria, escavado ou relevo, ou mesmo redondo... Deve ser entendido por Esculturas todas as figuras que se formam nas matérias e que são inumeráveis."

Também hoje as matérias são inúmeras, porém nem sempre representam figuras e muitos nem se aventuram nos "tondos" e nos, "relevos" mas se dedicam a objetos livres nas formas.

Para nós que somos da velha guarda e que ainda pensamos na "mão que obedece ao intelecto," lembrando um verso contido num soneto de Michelangelo, torna-se complicado averiguar, entre os escultores do informal, os mestres, sub mestres, amadores, chutadores etc. E por isso que ordenando a exposição, "Um século de escultura no Brasil" aprendemos um útil abc das tendências em curso, já bem consideradas e prometedoras.

Afirma Jacob Klintowitz que, depois da Exposição de Max Bill no Museu de Arte de São Paulo, assistimos no Brasil a "uma arte quase oficial, o concretismo, aprovada pela crítica e pelos artistas, premiada em salóes, frequentando museus e galerias." Foram os tempos desfilados paralelamente ao Abstracionismo em termos de pintura, na verdade uma renovação ao ponto de levar Vitor Brecheret, Felicia Leirner e Bruno Giorgi a abandonar o figural para se expressarem no informal.
Vieram, depois, as legióes de convertidos e também as dos improvisados. Tudo correu em certo diapasão até esta Exposição que resume o labor escultórico nacional nestes últimos cem anos.

A impressão deixada pelo evento é que a tendência tradicional do figurativo é agora mais manifesta, resultando inclusive na "descoberta" de numerosos escultores até então desconhecidos e dos quais os dicionários registram dados incompletos e cheios de interrogaçóes. A finalidade do empreendimento que ocupa largos espaços da sede do Masp é chamar atenção, principalmente, daqueles que sejam capazes de redigir um estudo dedicado ao desenvolvimento da escultura depois do Reinado, recolhendo documentaçóes. Aliás, o Masp coloca à disposição dos eventuais estudiosos os materiais que conseguiu recolher bem como indicaçôes de entidades e historiadores espalhados pelos vários Estados interessados no problema.

O problema foi posto, cumprindo solucioná-lo, sem histerismos como sói acontecer com certos cronistas, alguns dos quais chegaram a declarar ser a atual mostra do Masp algo, "lamentável” pela ausência de alguns benjamins certamente cupinchas dos bem-aventurados exegetas. As faltas em empreendimentos de certo porte são normais, pois ninguém e onipresente. Doutro lado para reconstituir a história da arte no Brasil náo é possível elaborá-la com histerismos, particularmente quando se trata de moças que não se sabe de onde vêm e para onde querem ir, ou entáo calcadas em prosinhas dos bombeiros da repartição de água.

\section{Legenda}

Despertar, de Nélide Casaccia Bertolucci 
Senhor \#60, I2 de maio de 1982, p.67 (P.M. Bardi)

No Campo movediço da Cultura

A notícia ${ }^{\mathrm{o}}$ I referente à cultura, recentemente divulgada, é a da inauguração do Centro Cultural construído na rua Vergueiro pela administração Reynaldo de Barros. Trata-se de um empreendimento de vasta importância que deverá, certamente, influenciar bastante no lazer-cultura da Grande São Paulo. O novo espaço cultural foi ambiciosamente projetado em termos de dimensóes e de programaçóes nos moldes do Centro Pompidou de Paris, hoje farol das artes da França e atração turística da Europa.

O Beaubourg local já ofereceu e comprovou as costumeiras discussóes. Cada vez que se tentam iniciativas, os legionários do Contra logo se eriçam e passam a criticar, inspirados mais por motivos estranhos, na maioria das vezes nem interligados ao fato.

Não que o Centro da Vergueiro não possa ser examinado e discutido. Muito pelo contrário, pois se trata de coisa pública, à custa e a serviço dos contribuintes; porém deve ser julgado quando estiver funcionando. Por enquanto deve-se formular os melhores votos para que consiga tornar-se um exemplo no campo movediço e particularmente complexo da Cultura. Esta na antiga Athenas do Brasil, precisa de ação ponderada e de paciente dedicaçáo. $\mathrm{E}$ diria mais, de reformulação, de um plano realmente bem pensado, endereçado ao povo e não as elites que, por sinal, ainda se encontram em fase de formação.

Como se vê, a discussão vem à tona. Fatal. Mas é digno de louvor o fato da prefeitura instalar um Centro visando abranger as diversas áreas culturais, a partir da biblioteca, agrupando teatro, artes plásticas e tantos outros ramos, dando unidade às mais diversas manifestaçóes.

O redator desta página está alegre, pois se recorda de que em 1947, na metrópole de entáo, deu o seu recado, abrindo o Museu de Arte de São Paulo, uma instituição inovadora, criando as primeiras escolas de arte não acadêmica, incluindo matérias endereçadas ao futuro, como as referentes à ecologia, design, cinema, fotografia, propaganda e até comportamento.
Tudo, inclusive a Pinacoteca que continua sendo a mais rica da América do Sul, foi concentrado em quatro andares do edifício dos Diários Associados, até que o então prefeito Adhemar de Barros, num gesto de visão e apreço pela cultura, ofereceu ao "beaubourguesinho" antecipador a construção da sua atual sede à avenida Paulista.

Lembrando as discussóes travadas naqueles tempos com os legionários do Contra, clamando e reclamando pululantemente, a agitação dos falsos mecenas, dos usuários dos bares de museuzinhos querendo compartilhar de espaços do Trianon etceterone como dizia São Tomás, penso naquela parafernália, agora ressuscitada em vista da novidade de Reynaldo de Barros e de Mário Chamie, seu secretário de Cultura. Manifesta-se uma certa analogia entre casos dos anos 40 e 50 e os de 1982. De qualquer forma deve-se aplaudir o surgimento do grandioso Centro, aconselhando-se a discutir, não o fato em si, mas aquilo que ele irá produzir.

Sei muito bem, por experiência quase quarentenal, o que significa realizar empresa parecida, dar-lhe continuidade cotidiana, fazendo e apanhando de todos os lados, e ao mesmo tempo defendê-la, pois caído um legionário do Contra, logo o filho toma seu lugar.

Será divertido acompanhar o desempenho do novel diretor, ao qual, desde já, ofereço cordialmente minha solidariedade.

Dirigir uma instituição cultural não é fácil, porém, não é difícil se o responsável usa a mão de ferro e possui um aparelho indispensabilíssimo: o obturador de orelhas para deixar blaterar os palpiteiros, outra legião de próspera vivência, ainda mais petulante que a do Contra.

Legenda

O Centro Cultural da rua Vergueiro; provocando os "legionários do Contra" 
Senhor \#6I, I9 de maio de 1982, p.65 (P.M. Bardi)

Os Nervos ABALAdos DA CRÍTICA

Li, sorrindo de gosto, em $O$ Estado de S.Paulo, sob o titulo, "Comportamento Incompatível" na coluna Dos Leitores, esta carta: "Sr. A Associação Brasileira de Críticos de Arte, Seção de São Paulo, reunida na Seção (Sessão, parece-me, é a palavra correta) Ordinária do mês de abril, repudia a atitude tomada pelo Masp em relação à crítica de Sheila Leirner, "O resultado lamentável de uma ambiciosa exposição," publicada no O Estado de S.Paulo, por ferir a ética profissional e por se tratar de um comportamento incompatível com o espaço do Museu.

Pedro Manuel, presidente."

A origem da lamentável reação foi o ferimento de uma ética que a Associação encara a seu modo, aliás, com sua filosofia: a invulnerabilidade dos pareceres ou elocubraçóes do senhor Crítico. Este, conforme seu talento, seu bom ou mau humor, sente-se ipse-dixit, não permitindo que os por ele linchados reajam. O que me lembra o espirituoso e grande Ferravilla (vejam nos dicionários teatrais de quem se trata) quando duelava no palco com um adversário, lamentando que o outro se defendesse e atacasse, gritava: Come faccio a ucciderlo, se si muove! Isto é, referindo-se ao caso: a pretensão de maltratar, sem que seja permitido ao maltratado responder à altura. Isto é realmente lamentável e já que estamos respirando a atmosfera da abertura, não é democrático.

Organizei no Masp a exposição "Um século de escultura no Brasil," fato que perturbou e deixou nervosa a senhora Sheila Leirner que apelidou a mostra de, "ambiciosa" condenando-a não em si, com critério e possivelmente com uma pontinha de erudição como ideia e realização, mas somente porque entre os convidados náo figuravam artistas de sua roda. E mais, (o que, francamente, me parece inédito) sem nem ter visto a mostra. A falta de três dos seus benjamins na manifestação, determinou molto rumore per nulla, nem se dignando a dar um pulo no que o crítico-pintor Pedro Manuel define de "espaço."

Minha decisão, sempre sorrindo, foi a de afixar a melancólica ejaculatória da Crítica, pondo ao lado a embalagem de uma caixinha de Camomila. Significava: lo divulgar a prosa; $2^{\circ}$ não levar a sério; $3^{\circ}$ reagir brincando. Nem de longe imaginava que uma simples, aliás legítima, cortês e jocosa réplica, permeada de recomendaçóes de calma, provocasse a arregimentação dos prezados Críticos paulistas a fim de condenar o "espaço do Masp." Caro Pedro Manuel, o Masp não é um "espaço.” Sem modéstia, ensinou todos vocês a verem, pela primeira vez, as obras de arte antigas e modernas, bem como contribuiu para que Sáo Paulo desvestisse a capa da indiferença que a própria Semana de Arte Moderna não conseguira lhe tirar. Se cometemos alguns erros, em contrapartida combinamos muitas atividades que nos conferem o direito de acalmar burlescamente uma associada da entidade máxima da Crítica de arte local, de quem não conhecemos ainda a posição pois, quando assina os alvarás é quase sempre dando o contra, sem cordialidade, como no citado episódio da Escultura, evento do qual falou sem visitar. Fato realmente lamentável e portanto, merecedor da Camomila prescrita. Fico apenas, e no momento, com a Camomila. Outros remédios guardo para a próxima ocasião.

\section{Legenda}

Caricatura de P.M. Bardi dedicada a Ugo Ojetti, diretor da revista Pegaso

Senhor \#62, 26 de maio de 1982, p.69 (P.M. Bardi)

As CONFusốE DO "EsPAÇO"

Ao se falar de linguagem é curioso assinalar como o prazer de macaquear vai superando as mais lisonjeiras previsóes. Senão vejamos: inventa-se ou se redescobre uma nova palavra e logo em seguida alguém a faz circular em grande escala a ponto de tocar às raias da obsessão.
A última palavra em curso e que vem tendo ampla divulgação é Espaço. Dela me ocupei em crônica anterior em Senhor, quando comentei a algaravia da Associação dos Críticos de Arte que apelidou o Masp de "espaço." Procurei saber daqueles colegas a motivação, sem 
obter qualquer resultado. Abrem-se restaurantes, bares, lojas de decoração, empórios, com a denominação de Espaço. Penso que quem começou a série foi o "Spazio Pirandello." E conto: certa feita fui atraído àquele espaço, ocasião em que verifiquei tratar-se de uma casa de pasto.

Lembrei-me, então, ter lido uma definição de Albert Einstein: "O espaço não tem uma existência separada a respeito do que enche o espaço... os objetos físicos não estão no espaço mas espacialmente lá estendidos; então o conceito de espaço vazio perde seu significado." Os objetos físicos, lá, eram bocconcini alla caseira e vinhos do Rio Grande do Sul.

Entro num local de "objetos físicos," decorativos, intitulado com o apelido da moda e fico pensando em Einstein: são “espacialmente estendidos.” Um dos meus guias, abrindo a boca diante de um console, me explica: "Observe como este móvel ocupa satisfatoriamente o espaço."

Fico um tanto encabulado enquanto o conceito fica labirintando na cabeça; então descubro que o problema Espaço preocupa realmente os artistas e, por extensão, os críticos. Um pintor, para dar maior relevo ás suas telas foi mais longe ao se socorrer de uma citação de Leibniz: "Considero o Espaço como alguma coisa puramente relativa, assim como o Tempo... é uma ordem das consistências, ao par do Tempo que é uma ordem de sucessóes... Não estou com isto dizendo que Espaço e Matéria sejam a mesma coisa, absolutamente, mas digo somente que não existe Espaço onde não há matéria, e que o espaço em si mesmo não é uma realidade absoluta."

Registro a circunstância apenas para irisar como a produção das artes vai se distanciando cada vez mais dos princípios tradicionais, depois do funeral das "Belas Artes."
O mesmo pintor, num Diálogo, explicou a razão de ser do uso da cor branca ou mesmo de qualquer outra cor tormentada: "Sim, o branco é a cor da pureza e do ascetismo, enquanto o tormentado tem grande significado, pois representa a base, o substrato da consciência que não emana, que fique bem claro, da essência de qualquer coisa, mas de inumeráveis pequenas percepçóes que a compóem e as animam, esperando a ocasião de se manifestar.

Estas pequenas percepçóes são justamente aquelas milhares de pequenas saliências e asperezas que constituem o fundo.”

Entre tantas declaraçôes, esta: "Hoje campeia o vício de se falar demasiadamente sobre a obra em si, mas no recôndito percebe-se a ambiguidade e o despreparo que altera a obra." E mais, a respeito do trabalho: "Deixo aos outros, pelo menos inicialmente, o prazer de deduzir e de operar a passagem desde a eventual aforia até a euforia, para não deixar de lado o momento espiritual e a necessidade quase religiosa que nos aproxima ao coração da criação..."

Longe de mim a ideia de subestimar declaraçôes deste jaez, cuja difícil inteligibilidade confirma as radicais mudanças que se vão afirmando na linguagem, sempre mais complicada e misteriosamente inacessível, conceitos para iniciados nas nebulosas em que a arte se enreda.

Trata-se de um outro Espaço que já desponta por aí, não mais vazio, mas já recheado de confusóes.

\section{Legenda}

Exemplos de Espaço livra e Espaço ocupado em pinturas contemporâneos: Day One, da Barnett Newman a Sem Título, de K.R.H. Sonderborg.

Senhor \#63, 6 de junho de 1982, p.64 (P.M. Bardi)

Só O FUTEBOL É QUE MERECE VIAJAR?

Para não tratar nesta página apenas de assuntos locais, é interessante focalizar de vez em quando novidades acontecidas no estrangeiro. Por exemplo: estou lendo no jornal do PCI um título bastante curioso: "Il 'Paese della Cultura' rischiera di precipitare nel sottosviluppo,” abrindo o texto com estas palavras: "A crônica dos danos sofridos pelo patrimônio histórico-artístico é quase um boletim de guerra: um afresco de Pier della Francesca que está desaparecendo, pedaços de arquiteturas do centro histórico caindo sobre os transeuntes em Roma, belezas 
ambientais que lutam contra as coisas de cimento. Para combater a guerra as armas estão gastas e enferrujadas..."

Diz um provérbio italiano: "Tutto il mondo é paese." Com isto quer-se afirmar que quando se lamenta algo de um país, igualmente outros estão passando pelo mesmo. Parece que as verbas destinadas às entidades culturais da Península vão diminuindo, e parlamentares comunistas estão propondo leis sobre o assunto, uma delas sobre a reforma dos bens culturais e a outra sobre o incremento da produção artística contemporânea. A primeira visa um "relançamento da cultura para que não caia até níveis de subdesenvolvimento."

$\mathrm{O}$ que nos interessa de maneira especial é a projetada transformação da Galeria Nacional de Arte Moderna de Roma numa instituição capaz de organizar exposiçóes e intercâmbio com outros países, bem como documentação da produção artística. É evidente que o exemplo vem da prática dos museus americanos, isto e, dar vida aos museus, ativando para ficar fora da burocracia circunscrita à simples conservação.

Outra proposta na qual estamos interessados é a da instituição, em Nápoles, de um organismo nacional destinado a cuidar e documentar as relaçóes entre a cultura europeia e a do chamado Terceiro Mundo.

E justamente este o motivo principal destas notas: a dificuldade para um bom relacionamento cultural entre a Europa e esta longínqua América. Sendo raro algum interesse por parte do Velho Mundo para com a América Latina, e muito particularmente em relação ao Brasil, aqui cabe lembrar como nossos tuteladores de governo pouco interesse dispensam à difusão cultural fora dos nossos limites geográficos. Longe de mim criticar o trabalho dos adidos culturais nas embaixadas, porém me parece que o Itamaraty ainda não descobriu que uma das afirmaçóes do Brasil no estrangeiro é justamente contribuir para maior divulgação da nossa cultura que, a meu ver, não pode ser tida como de Terceiro Mundo, desde que seja escolhida criteriosamente.

Vejo no setor das artes, o que mais pratico, como são desenvolvidas as manifestaçôes: nas várias galerias Debret de nossas embaixadas são expostos trabalhos de elementos que conseguem tais espaços mais armados de grossos pistolóes do que por reais merecimentos, até mesmo senhoras esposas de potentados tupiniquins.

Não deve ser complicado estabelecer um calendário de manifestaçóes sobre arte brasileira a serem apresentadas nas grandes capitais. Seria interessante, antes de tudo, pensar numa exposiçã́o demonstrativa do Modernismo, completamente ignorado no Exterior, com a possibilidade de fazer conhecer um grupo de personalidades notáveis e ligadas a Paris, o centro ativo daqueles tempos. Penso que uma comunicação dedicada ao Modernismo seria bem acolhida no Beaubourg, principalmente se organizada com critérios não cívicos, isto é, marmeladecos. Uma mostra da Semana de 22 mais as consequências entre aquele ano e 35, incluindo um panorama social e justificativas políticas, teria um bom público e provocaria repercussão. Naturalmente deveria ser acompanhada de um catálogo-livro à altura. Seria uma despesa mais justa, e mínima, em comparação aos milhôes jogados nas competiçóes de futebol.

Espera-se, finalmente, atenção para a cultura, além da oferecida ao esporte. É um problema a ser resolvido. Como se vê acima, também uma nação como a Itália se propóe a um "relançamento da cultura para não cair até níveis de subdesenvolvimento.” E nós precisamos nos desenvolver.

\section{Legenda}

Eis uma exposição a se lançar no Exterior. Capa do volume, em segunda edição, publicada em 1978 pelo Banco Sudameris.

Senhor \#64, 9 de junho de 1982, p.65 (P.M. Bardi)

A PINTURA MURAL

Os muros paulistanos, depois do petulante pichamento com a frase, "Cáo Fila Km 26” vão sendo sofregamente cobertos de inscriçóes e figuras, desabafos, mensagens amorosas, conselhos para se votar na chapa II, rabiscos e injúrias gratuitas nas mais das vezes endereçadas ao pessoal governativo. Um espetáculo canhestro e muito pouco edificante. 
Agora o que se vê é um pintor, numa delirante promoçáo, escrever nos muros e nos bancos de ruas e praças públicas, um convite ao transeunte: ir escutar uma banda de música, por ele batutada.

A comunicação estradeira vai-se alastrando e firmando cada vez mais, fenômeno de vanguardas anônimas ou estritamente personalísticas, que os talentosos chefes das Bienais irão descobrir somente quando o caso ficar envelhecido, como aconteceu com a "arte postal" e a "arte brut" rebatizada "arte incomum," o etcetera das novidade de curta duração. É o frenesi que agita o pot-pourri das extravagâncias do nosso tempo.

A respeito de "arte incomum" não sei se os especialistas desta categoria, que inclui loucos, crianças e chutadores já se deram conta da figura do pichador.

Os muros, alguns decênios atrás estavam reservados para os pintores. Tivemos os últimos afrescos nas paredes do interior da igreja de Nossa Senhora da Paz, na várzea do Glicério, pela máo de Fúlvio Pennacchi. Hoje não existe artista que conheça aquela técnica.

Os muros agora pertencem aos pichadores. Não se trata de uma novidade já que este labor vem de longe. Para não recuar até alguns milênios, bastará que se observe embaixo dos afrescos de Giotto na Capela Superior de Assis, na Itália, onde se desenvolve uma torrente de lembrancinhas de antigos visitantes. Sempre existiu esta mania de se comunicar com o público. No Brasil teremos, sem dúvida, neste ano eleitoral, manifestação extraordinária.
O que não se compreende é a não participação dos artistas na iluminação dos muros das vias públicas. O pintor está ausente das competiçốes sociais, a não ser dos decrépitos salóes. $\mathrm{O}$ se dedicar ao muro ensejaria o desenvolvimento de uma atividade sempre mais emergente, qual a do figurativo praticado por dedicados elementos, bem como a do abstrato não comprometedor.

Até agora o registro da manifestação partidária de artistas circunscreveu-se à classe teatral: três atores se inscreveram, com conveniente comunicação jornalística, no РмDв. Os plásticos ainda não deram sinais de adesão às lutas post-abertura.

Imagine-se qual o aporto de propaganda caso pintores de renome saltassem nas calçadas e pichassem muros, manifestando credos partidários, valendo desenhos e, por que náo, pinturas. Naturalmente nos referimos a artistas de valor, aos possíveis inexistentes Daumier.

Os pintores de hoje se acomodaram na profissão produtora não mais de prazeres hedonisticos, engajada nos caprichos do bom burguês que nela encontrou novo caminho para investir dinheiro...

Quando se sabe da massa de capitais acumulada pelo marxista Picasso, somos levados a pensar que os artistas não vão descer às ruas para pichar mensagens em favor do próprio credo político.

\section{Legenda}

Pichação em São Paulo: um espaço que deveria ser ocupado pelos artistas

Senhor \#65, I6 de junho de 1982, p.69 (P.M. Bardi)

AS LEIS DO MERCADO DE ARTE

Nunca conversei com economistas profissionais para deles receber rudimentos de leis que regulam o mercado das artes plásticas. Acredito existirem tais leis.

O fenômeno deste mercado é novo, mas nem tanto, pois a produção da arte teve sempre um valor controlado. Antigamente era mais fácil segui-lo, pois os potentados recorriam aos mestres, os quais sabiam como tirar vantagem do próprio trabalho. No Oitocentos, a situação mudou, o gosto se generalizou, os artistas serviam à burguesia então pouco treinada e um tanto volúvel, em grande parte compradora mas sem intençóes de investimento, sem se fixar objetivamente nas avaliaçóes.

Ainda no Oitocentos existiam previsores de afirmaçôes de artistas. Relendo as cartas de Van Gogh fiquei ciente de que o mesmo pouco ou nada tinha de futurólogo, isto em termos comerciais. O holandês foi redescoberto, mas em virtude de que princípios? 
Recordando o caso de Van Gogh é fácil prever que enquanto hodiernamente alguns artistas produzem obras que pouco valem, certamente em futuro próximo elas subirão de valor. Lembro-me que quando, nos anos 20, eu acreditava em Morandi e Sironi, empenhei muito do meu dinheiro para montar a Galleria Bardi de Miláo e sua abertura foi marcada com uma exposição dedicada a Carrà e a Soffici, lançando na ocasião um volumoso e bem-cuidado catálogo. A Itália, naquele tempo, não tributava aos dois mestres maiores consideraçôes, e tanto isto é verdade que somente duas obras, uma de cada expositor, foram vendidas e assim mesmo por intermédio de Lionello Venturi e destinadas ao rei da seda artificial, Riccardo Gualino, que naquele tempo formava sua pinacoteca, comprando Modigliani, colocado ao lado dos grandes mestres do Século XIII.

A Sotheby's, em 54, vendeu por 7000 libras à Tate Gallery, a Cabeça de Paul Derain, de Matisse; um Soutine por 44Io libras, um Picasso por 2940 libras, um Braque por 1260 e a mesma quantia por um Juan Gris. Quanto valem agora estas obras?

I954 foi o ano em que o Museu de Arte de São Paulo encerrou seus esforços para a compra de obras de arte. Apesar de sermos novatos no mercado, pelo que conseguimos importar, pagando não preços de banana, mas certamente baratos, fica evidente que fizemos bons negócios. Se uma obra, a meu ver, não entre as excelentes de Picasso, foi paga em leiláo mais de quatro milhóes de dólares, penso que a Mademoiselle Bloch do Masp deverá valer mais, como o Atleta do mesmo mestre, que compramos em 50.

Mas como estabelecer valores neste momento em que a cotação da produção pictórica sofre as vertigens das grandes alturas?

Dias atrás me perguntaram quais os autores novos para comprar com visos de investimento. Difícil responder a perguntas desta ordem. Aconselha-se a considerar com muita atenção as obras, e mais especialmente o caráter do autor, servindo-se dos olhos e não dos ouvidos, pois nas orelhas se aninham sempre sentenças soltas e muito do agrado dos interessados.

Foi Georges Bemier, um dos tantos a afirmar que cotar a arte é uma ciência. Em suas conferências contava casos que confirmam a necessidade da informação para estabelecer valores. Também as anedotas devem ser contadas como esta, referente a uma tela de Gauguin. O mestre, quando morava na Bretanha, após sua primeira viagem ao Pacífico, pintou uma natureza morta que acabou dando de presente a uma certa condessa de Nimal a fim de que a aristocrata o recomendasse a um determinado ministro. A tal, que provavelmente não gostava da arte de Gauguin, e tanto isto é verdade que nada falou ao ministro, logo se desfez da tela, que depois de várias passagens, em I960, aparece na Sotheby's e obtém nada menos que 45 mil libras. Outra natureza morta, também foi objeto de épica luta entre dois armadores gregos e, um deles, o sr. Basil Goulandris, saiu vitorioso comprando-a por I04 milhóes de francos franceses.

Façam os cálculos e imediatamente estabeleçam uma ciência das cotaçóes. É evidente que as pesquisas deveriam ser desenvolvidas antes de tudo no society descobrindo a mentalidade dos poderosos em condiçóes de comprar, os casos de esnobismos, os casos de ignorância e de ambição, a sutil propaganda dos proprietários metidos nos negócios a fim de, a qualquer momento, efetuarem suas transaçóes, no mesmo estilo das operaçóes de Bolsa, como Senhor registra periodicamente em suas páginas.

\section{Legenda}

Mademoiselle Bloch, de Picasso, e $O$ atleta: quantos milhóes de dólares?

Senhor \#66, 26 de junho de 1982, p.65 (P.M. Bardi)

VANTAGENS DO MECENATO

O novo secretário de Cultura do Estado de São Paulo, João Carlos Martins, está lançando uma açáo para convencer as classes do poder a contribuir para a difusão das iniciativas culturais, em suma, pede a colaboração de entidades bancárias, industriais e comerciais.

A Cultura, nos seus vários setores, no Estado de São Paulo, apresenta um conjunto de atividades merecedoras de 
revisões e de incentivos que deveriam convergir para um plano definido, levando em conta as funçóes realmente úteis dos vários campos e estabelecimentos. Isto não é novidade, pois o problema se apresenta desde o século passado aos governos que se sucedem, cada qual sem conseguir afirmar princípios, quase sempre deixando-se envolver pelos mecanismos contaminados da política, do hábito, dos favores pessoais na hora da aplicação das verbas que, por sua vez, nunca foram adequadas às situaçóes.

Devo, necessariamente, lembrar um precursor da campanha que João Carlos está empenhado em realizar: o dr. Assis Chateaubriand que conseguiu criar o Museu de Arte de São Paulo com a contribuição de entidades bancárias, industriais e comerciais. Ele o fez a seu modo, promovendo-se fiscal e exator aos meios. Digo a seu modo, metade ortodoxo e metade não, mas oferecendo ferreamente ao Brasil uma Pinacoteca de valor internacional, hoje bastante conhecida nos círculos da arte, e, ao mesmo tempo, uma instituição atuante, sem os altos e baixos que balanceiam outros museus.

Desaparecido o dr. Chateaubriand, o Masp pode continuar e incrementar sua atividade de difusor de Cultura,(com exposições periódicas, cursos, espetáculos musicais e teatrais, cinema) contando, além das verbas estaduais e municipais, com a generosas participaçóes da classe abastada. Entre os mais recentes, deve-se lembrar o Banco Sudameris que nos proporciona, há cinco anos, a publicação de volumes de grande tiragem, dedicados à história das artes nacionais; a Phillip Morris que nos possibilitou a exposição "Um século de escultura no Brasil" e o Banco Francês e Brasileiro que garante os Concertos do Meio-Dia, nas quartas-feiras, organizados pelo Mozarteum Brasileiro.
Tivemos este ano sensíveis contribuições: a doação, pelo príncipe Roman Sanguszko, de famosa tapeçaria da sua ilustre família, na Polônia, datada do século XVII, além dos donativos da Digirede Indústria e Comércio de Equipamentos Eletrônicos, Levi-Strauss do Brasil, Guerissi e Contoli Publicidade e Produçóes, Staroup S.A., Philips do Brasil, DPZ e Vulcan Material Plástico, sem contar as pessoas físicas como Carla Milano Benclowicz, Armando Vasone Filho e José C.S. Salles Filho.

A estas doaçôes juntaremos, daqui a poucos meses, a ingente contribuiçáo de um grupo de cinco museus japoneses para onde levaremos duas mostras, uma de obras do acervo do Masp e outra de 23 artistas brasileiros e de ascendência japonesa. Todas estas contribuiçoes confirmam que o espírito de colaboração à Cultura existe e, sem dúvida, irá se desenvolvendo.

Há, naturalmente, banqueiros, industriais e comerciantes que ainda não descobriram o sistema de socorrer a Cultura. Estamos bem longe do espírito factível dos norte-americanos, o que é justificado, de resto, pelo andamento da nossa economia, porém, é bom registrar como, nestes últimos tempos, as doaçôes e os patrocínios de manifestaçóes culturais tomaram rumo promissor no País, prevendo-se um bom futuro.

Por isto, como prático nestes tipos de ajuda à Cultura, estou certo de que a campanha do secretário João Carlos Martins vai dar bons frutos. De qualquer modo, será indispensável estabelecer um plano de aplicaçóes para que os meios sejam aplicados em utilidades culturais específicas, e não se destinem à burocracia oficial. Até mesmo a Secretaria seria passível de um plano de reforma.

\section{Legenda}

Tapeçaria flamenga, século XVII, do acervo do Masp, doada pelo príncipe Roman Sanguszko

Senhor \#67, 30 de junho de i982, p.69 (P.M. Bardi)

O PREÇO DA VANGUARDA

Corriqueiro constatar-se, sendo até mesmo ingênuo repetir o slogan, que os tempos mudaram. O mesmo se poderá dizer daquilo que nesta seara é abordado com frequência, isto é, o lazer-negócio "arte" cada vez mais encalhado no rochedo do Indeterminado. Quem nele mexe está sujeito a defrontar-se com muitas surpresas e, assim sendo, deve se adaptar à poluiçãa das novidades excêntricas que vão 
relegando a Tradição ao banco dos castigos, os conservacionistas convidados a fazer boa cara diante de um jogo que não vai, procurando conciliar e justificar. Se os tempos são estes que fazer? Seria idiotice não manipular o computador ou não ver televisão.

É preciso que cada dia se reflita, julgando e tirando consideraçóes a respeito da marcha dos tempos, aproveitando que as constituições ainda não proíbem esta faculdade. Segui, desde jovem, a revolução estética acionada pelos grupos do Cubismo e do Futurismo, virando de cabeça para baixo as propostas timidamente antiacadêmicas do Impressionismo. Os Cubistas quiseram ver e representar uma figura por meio de fatias, os Futuristas procurando idolatrar a máquina, alargando a praça para acolher as tendências que todos sabem. Lembro-me das polêmicas travadas nos anos que precederam a Primeira Guerra: a impopularidade dos novos lançamentos que chegava as raias da agressividade. $\mathrm{O}$ generoso F. T. Marinetti se fazia presente nos teatros para explicar que os tempos não eram mais os mesmos de 1845 e, como resposta, era literalmente bombardeado com uma saraivada de ovos podres, tomates e projéteis de couve-flor.

Os preguiçosos situacionistas, os temerosos, conjuravam contra Cubistas e Futuristas, atitude frequentemente repetida cada vez que um artista se destaca da rotina convencional, aceita sem maiores consideraçóes. Fato hoje bem normal: afirmada uma tendência, decorrido algum tempo para a devida consagração, o assunto toma-se moda e o pessoal acaba engolindo o novo pitéu.

Deixando de lado acontecimentos desenrolados na Europa, em nosso Brasil onde as atividades da arte se engataram à locomotiva internacional, quando as Bienais indicaram que o último modismo era o Abstracionismo, nossos pintores se engajaram no mais recente sistema. E tudo correu normalmente até uns poucos anos atrás; depois o Abstracionismo murchou e deixou de ser algo de bom para as paredes, configurando-se assim uma das tantas mudanças que o avançar dos tempos registram.
Estas minhas anotaçóes são para dizer que se assiste agora à celebraçáo de um pintor autenticamente inovador, Jackson Pollock, um norte-americano desaparecido em 1956 e que se tomou um mito, pois lançados da janela paleta e pincéis, executava suas pinturas jogando as cores a seu talante, o “dripping." Tem muito de Dadá, o movimento irracional que abolia tudo, cultura, tradição, para descobrir uma "realidade autêntica” baseada no não-senso: explosão de cansaço e protesto contra o deflagrar da Guerra. Não há dúvidas de que Pollock era seguidor do Dadaismo, à volta para o Nada. Os Estadunidenses, finalmente, apontando esta maneira extravagante, rompiam seus liames com a Europa, inaugurando o futuro da pintura estritamente nacional, sem nada dever a quem quer que fosse.

Levou tempo, mas hoje, como se disse, a celebração culminada com uma retrospectiva de Pollock no Beaubourg de Paris, deu certo. Críticos inteligentes descobriram que Pollock, lançando ao acaso a tinta na tela, expressava uma intenção íntima, em "imagens universais" fora da prisáo do Figurativo, do fazer saber a todos, intrigando o observador com ambiguidades e mistérios.

Tudo certo. Cada artista procura transmitir o que sente. Deve-se respeitar a criatividade. Infelizmente acontece o que ocorreu com os Cubistas e a quantos outros inventores de tendências lançadas neste Século: o mercado se apodera das produçóes, articula a ascensão dos valores, reconstrói romances de biografias acidentadas como a de Pollock, afirma a moda e o assunto Arte vira assunto de Negócio. É o destino dos que criam.

Anotando isto, me parece justo assinalar que na Itália foram editados dois ricos volumes para lembrar o mito de Giorgione: mudam os tempos e no entretanto ainda tem gente que pensa em Tradição. As crônicas devem se concertar com a História.

\section{Legenda}

Giorgine, A Tempestade (detalhe) 9

Jackson Pollock, $O E c o$, I95I 
Senhor \#68, 7 de julho de 1982, p.6I (P.M. Bardi)

A Memória E O Egoísmo

O último assunto histórico-estético-nacional em circulação é o da Memória. Descoberto o fato de que o Brasil não dava muita importância à sua História como devia, em tempo propício surgiu um grupo de jovens que passou a lutar visando a instituição do Serviço do Patrimônio, incentivados e protegidos pelo ilustre ministro Gustavo Capanema. O arauto foi Rodrigo de Melo Franco Andrade.

O Patrimônio, baseado numa lei de salvaguarda da conservaçáo dos monumentos históricos andou desenvolvendo uma atividade de primeira ordem, através da Lei do Tombamento. Tombado um edifício de caráter histórico, aos proprietários era imposta a responsabilidade de conservá-lo, não alterá-lo, não fazer qualquer modificação sem aprovação prévia do Serviço do Patrimônio. Os trabalhos, chefiados por Rodrigo em todo o País, foram precisos e sempre oportunos.

O Patrimônio recentemente foi aperfeiçoado: agregado e passando a integrar os quadros da nova Secretaria da Cultura no Ministério da Educação e Cultura. Seu organizador foi o benemérito Aloísio Magalhães, recente e repentinamente desaparecido, quando a açáo da Memória se andava popularizando e se impondo, com resultados de extraordinária significação, interessando a todos os Estados da União.

Entre os Estados, o de São Paulo, onde o órgão titular é o Condephaat, dependente da Secretaria de Cultura, é seu presidente o ativíssimo arquiteto Ruy Ohtake. Sob sua direção, em São Paulo, começou-se a encarar o problema com muita e inteligente atenção, com bom senso e energia.

Foi justamente a energia que proporcionou à crônica um material surpreendentemente escandaloso. O Condephaat já vinha considerando tudo que está ocorrendo na avenida Paulista: o antigo boulevard paulistano surgiu ao tempo da animação derivada do amplo cultivo do café, os felizardos cafeicultores alinhando lá as mansôes que Levi-Strauss muito bem lembrou em Tristes Tropiques, formando uma rua que lembrava uma via de estação de águas daquelas tão comuns na Europa, para finalmente descambar para toda sorte de benefícios e cacetices interligados à especulação territorial. Cada proprietário, descobrindo de um ano para outro, que o metro quadrado localizado na avenida Paulista aumentava vertiginosamente de valor, destacando-se os Bancos que ambicionavam lá armar suas sedes centrais ou marcar presença com suas agendas, mergulhava em verdadeiras orgias especulativas. Hoje na grande artéria o custo do terreno é simplesmente monstruoso, mesmo quando comparado com o do coração de Wall Street.

A suntuosa Wall Street local tinha um grupinho de mansóes do Oitocentos e do início do Novecentos, curiosas expressóes $\mathrm{da}$ arquitetura culturalista daqueles tempos, arremedos de uma época sem estilo.

Tâo logo alguns proprietários perceberam a ameaça que pairava sobre seus próprios interesses pecuniários, na calada da noite de um domingo da Copa do Mundo, contrataram uma firma demolidora que com suas possantes escavadeiras mecânicas deitaram por terra os casaróes para assim evitar o tombamento de marcos da história da cidade. Agiram ao arrepio da lei, isto é, sem os competentes alvarás da Prefeitura, exercendo a um tempo o direito de posse mas em contrapartida oferecendo triste espetáculo.

O que concluir? Nossa conclusão é de ordem estética com visos de moral: a Memória deve persistir e inserir sua filosofia na consciência nacional. O espetáculo paulistano é índice bem eloquente de que ainda estamos bem longe no considerar a propriedade como um fato absolutamente egoístico. Doutro lado ainda falta uma lei mais rigorosa que coloque o interesse da Memória acima do particular.

Isto posto, com o exemplo das derrubadas clandestinas, os donos de edifícios passam a ser visados pela Memória, antes que os argentários mobilizem os serviços das firmas demolidoras.

\section{Legenda}

Fim dos casarôes, resultado da orgia especulativa 
Senhor \#69, I4 de julho de I982, p.69 (P.M. Bardi)

\section{A BienAl DA IMITAÇấO}

Voltou à crônica a Bienal Internacional de Arte de Sáo Paulo. Lançou o regulamento da próxima: uma crônica triste pela perda coincidente de Aloísio Magalhães, secretário de Cultura do MEC, quando estava presidindo o Conselho de colaboração entre a América Latina e a Europa, na sede inventora das pululantes Bienais, Veneza. Aloísio fora até a Laguna para prestigiar a participação brasileira que, até o último minuto, como sempre, destinava-se a ser um fiasco, pois o Itamaraty não dispunha da verba necessária para enviar à Itália as obras dos dois artistas brasileiros participantes, Sérgio Camargo e Tunga. (Teria sido suficiente a verba de um dos inúmeros componentes da Legião Seleção para satisfazer à microscópica torcida das artes brasileiras. Mas, pois é...)

A respeito da Bienal de Veneza, para uma antiga participação brasileira, o Itamaraty dirigiu-se a este redator para indicar nomes. Escolhi Sérgio Camargo e Arthur Luiz Piza, como expoentes das correntes abstratas internacionais, e elementos da assim batizada; "arte espontânea" o pintor José Antônio da Silva, o Utrillo de São Paulo Agostinho B. de Freitas, e o ilustrador da Amazônia, Francisco Domingos da Silva, conhecido como Chico da Silva. Surgiram as criticas locais das elites, pois confundia o Sagrado internacionalista com o Profano genuíno de casa.

Estavam em Veneza os representantes do assim dito Terceiro Mundo, justamente para discutir. Aloísio presidia. Abriu a sessão com uma declaração do seu habitual bom senso: "Antes de mais nada, é preciso deixar bem claro que tipo de cooperação o Brasil, um país que ainda enfrenta problemas graves na área da educação, pode manter com países europeus.”

Imitador inveterado do que lá se produz, o Brasil teve também a pouco feliz ideia de resolver seu problema da arte dita moderna, instituindo a sua Bienal. Foi o costumeiro carro adiante dos bois, numa São Paulo sem milênios, sem os Gardini, sem San Marco, sem ambiente. Digamos a verdade: o carro era o da ambição autopromotora do seu idealizador, e os bois já estavam no matadouro. Naquele tempo, na antiga Atenas do Brasil, encontrava-se um grupinho de artistas que mal, para não dizer muito mal, remediavam a existência. A história das Bienais paulistas tornou-se a rotina do banco que Napoleão mandou pintar, deixando de guarda um soldado que, após o exílio do Ditador, ainda continuava a posto, pois esqueceram-se de chamá-lo de volta.

As artes, hoje, não se submetem mais ao mecanismo sete-oitocentesco dos Salóes. Tenta-se de tudo ara descobrir novidades. Na I8 a Bienal paulista, diz o artigo 3: dois são os "núcleos." O primeiro: "confrontar aspectos importantes da arte na pluralidade dos Media e linguagens que a caracterizam no presente."

Não sei qual é o número dos leitores que podem entender esta elástica definiçáo. A menos que o regulamento seja dirigido aos iniciados nas altas modulaçóes da crítica, de resto característica evidente do atual momento de uma estética sempre mais confusa nas elites-superelites internacionais.

Lê-se na crônica da inauguração da $4 \mathrm{O}^{\mathrm{a}}$ Bienal de Veneza que lá foram afixados vários cartazes, um dos quais dizia: "Abaixo a elite cultural. " Como se vê, o exagero em reduzir a manifestação artística a rebus e enigmas, soutises e piadas, já está enchendo.

Ninguém é contra o elitismo. O tempo dá o que pode. E para voltar ao assunto: será que o público paulistano já está ansioso por ver as elucubrações práticas do anunciado Núcleo $n^{\circ}$ I da próxima Bienal? Será que a ordem e complicar de tal maneira as ideias para que ninguém possivelmente entenda mais nada, e eclipsar este belo contentamento que sempre foi para a Humanidade, a Arte?

\section{Legenda \\ Sem titulo de Sérgio Camargo \\ - Vale do Anhangabaú, de \\ Agostinho Batista de Freitas}


Senhor \#70, 2I de julho de 1982, p.69 (P.M. Bardi)

Agora que a fotografia penetrou no recinto das Artes Plásticas, com insistente presença, deve-se dedicar a ela atenção especial. É ocasião de se falar de um elemento que, depois de alguns decênios, está conseguindo posição de destaque: David Zingg.

Opera no difícil setor da retratística, onde conquistou bom sucesso. Tive ocasião recentemente de posar no seu ainda romântico atelier da rua Frei Caneca. Logo me lembrei daqueles pintores concentrados no trabalho de reproduzir fisionomias, evocando toda uma história que começa, praticamente, na Renascença e que no Oitocentos era ainda normal, à espera de que a objetiva a eliminasse pouco a pouco.

O episódio da repulsa ao retrato de Winston Churcnill pelo Parlamento e a classe abastada inglesa, no fim a tela sendo queimada, demonstra muitas facetas da mentalidade contemporânea. Foi um fato que, em certo sentido, deve-se atribuir à invasão da arte fotográfica. Retrato é, hoje, operação mecânica, uma vez que somente um artista do pincel ou do buril, em minha opinião, pode interpretar uma cara. Mas é difícil saber de pintores e escultores que ainda se dedicam ao retrato, como de resto poucas são as pessoas que procuram os artistas para a dita tarefa.

Curioso: nos anos depois da última guerra, quando fui incumbido de reunir as obras da Pinacoteca do Museu de Arte de São Paulo, advertia-se no mercado uma espécie de idiossincrasia pelo gênero retrato. Aproveitei a novidade e assegurei ao Masp uma esplêndida coleção de retratos. Compraram-se a preço quase de banana, também de mestres como Ticiano, Velazquez, Goya, Gainsborough, Reynolds e Lawrence, e até de Manet e de Van Gogh, o retrato pintado náo era moda, um dos contra-sensos destas fileiras de montanhas que formam a história da arte.

Os substitutos dos retratistas foram e são os fotógrafos. Já no Oitocentos surgiram mestres aos quais devemos o conhecimento direto dos personagens do século: retratos que, às vezes, superam os dos pintores, pois os que manipularam a objetiva eram artistas.

Para fixar as lembranças de alguns, nada mais adequado do que a infalível objetiva. Naturalmente se trata de escolher e provocar momentos em que o sujeito se manifesta. E mais vale o caracterizar, localização, posição, vestimenta, expressão, atitude, espírito.

Esta prerrogativa é uma das do David, rápido e inteligente empreendedor. Ele tem uma ampla e vivida experiência profissional. Pratica, como poucos, o que é mais difícil, o humor, determina ambiente e comportamento. Fotografou muita gente.

Conheço-o desde seus inícios no Brasil, seu percorrer caminhos, então proibidos à sua profissão: desejo irresistível de documentar, paciência no estudar atitudes, ajeitando o acessório. Zingg, reputo, é um mestre do retrato.

\section{Legenda}

Dois trabalhos de Zingg (num auto-retrato, ele é o caubói)

Senhor \#7I, 28 de julho de I982, p.69 (P.M. Bardi)

PELA JANELA DO MUNDO

Parece que o presidente Figueiredo, em sua visita aos Estados Unidos, contou ao seu colega americano que o Brasil pertence ao Terceiro Mundo. Ouvi nacionalistas reclamarem, pois é melhor a fórmula "País em desenvolvimento.” No Brasil, sem dúvida lançado para a frente, à espera das reformas sociais que cada governo promete implantar sem porém realizá-las, continua o costumeiro status-quo. Ditaduras ou democracias imperantes ou mini-imperantes, ainda indecisas no providenciar, esquecem que o Brasil finalmente merece uma solução social. Maduros os tempos, não faltam os corajosos com reformas estudadas, prontas para entrar em ação. Mas.

Nesta situação de sala-de-espera, o observador da bagatela Arte, a respeito de Terceiro Mundo, deve notar quanto pouco, para náo dizer nada, se opera a respeito de fazer saber lá fora o quanto de desenvolvido o Brasil está em condiçóes de mostrar. 
Os tempos são de comunicação. Pelo que se vê na imprensa do Exterior e nos reflexos aqui do Interior, o que de Brasil se fala é mais para as mulatas do Sargentelli e para as originais boates do Ricardo Amaral do que para fatos não de Terceiros, mas de Segundo Mundo.

$\mathrm{E}$ verdade que não temos empreendedores de manifestaçóes de vulto no Brasil. A onda corre mais para as futilidades e pouco para os mergulhos nos mares da ciência, técnica, literatura e arte. Já conheço o relevo: aqui não se produz grandes coisas naqueles mares. Porém, o pouco que de bom se faz fica sendo prata da casa e não se tem possibilidade de comunicá-lo lá fora. Nos próximos meses, o Museu de Arte de São Paulo enviará ao Japão, através de um convênio com a Província de Mie, Estado-gêmeo do nosso, uma coleção de obras- primas de seu acervo e uma exposição que pretende mostrar o Modernismo aqui desenvolvido.

Parece evidente que se trata de uma iniciativa que não apenas honra a cultura brasileira, mas também contribui para corrigir conceitos errados de Terceiro Mundo. Corrigir in minimis, naturalmente, e por parte de entidades privadas, sem interferência do Itamaraty que, bem ou mal, deveria se encarregar de promover o País através do que tem de culturalmente exportável.

O fato piramidal é que para nós do Masp ativarmos estas comunicaçóes culturais, perdemos tempos incríveis com a burocracia para obtenção de permissão de exportação. E temos que preparar tudo sozinhos, no mais completo silêncio, inclusive da parte dos órgãos que deveriam nos incentivar.

Seja como for, armados com uma couraça de samurai, vamos fazer saber a cinco cidades do amigo Japão o que de ocidental e nacional o Brasil têm em matéria de arte, lá deixando cinco pinturas de artistas brasileiros que uma "avis-rara" anonimamente doou ao novo Museu de Mie-ken. Trata-se de um colecionador particular que náo quer seu nome divulgado mas que todos podem imaginar quem seja.

Acho muito importante o intercâmbio com os países estrangeiros. O Brasil tem hoje um grupo de artistas que podem acertadamente demonstrar suas próprias atividades, como de resto temos elementos que se afirmam lá fora, como Arthur Luiz Piza e Roland Cabot em Paris, sem falar de Oscar Niemeyer. Penso em intercâmbios de obras para afirmar que o Brasil tem ambiente e características próprias no setor.

Foi o que tentamos na exposição a ser apresentada no Japão, procurando compor um conjunto de certo interesse. Deve-se continuar, estabelecendo um plano que não deve ser consequência de ocasióes mas algo preparado tecnicamente.

\section{Legenda}

Arthur Luiz Piza, gravura

Roland Cabot, escultura

Senhor \#72, 4 de agosto de 1982, p.69 (P.M. Bardi)

Os LEILÓES MELANCÓLICOS

Livrar-se dos preconceitos é um bom início para quem quer

modificar a rotina artística em Sáo Paulo

Cada época sempre registrou as preferências dos compradores de obras de arte, tendências essas mais inclinadas para as coisas próprias, isto é, nacionais. Assim, objetos brasileiros que por acaso são oferecidos à licitação em leilóes internacionais passam quase completamente despercebidos, e, quando são objetos de algum interesse, seus valores são sempre pequenos.

Há algum tempo a Sotheby vem manifestando um certo interesse pela arte latino-americana a ponto de organizar, em Nova York, leilóes bastante ricos, especialmente de pinturas mexicanas e de artistas da Venezuela e da Colômbia, elementos que vêm alcançando boa aceitação internacional.

Se existe um continente pobre de objetos de arte este é a América Latina. Aos tempos do trigo abundante, do cobre, do café e das outras fortunas vegetais e minerais, os potentados andaram comprando coisas de arte, em geral mais destinados à decoração do que pelo espírito colecionístico. Exceção deve ser creditada a Buenos Aires que sempre contou com coleçôes realmente esplêndidas, como 
a dos Santamarina. Numa palavra: em outras capitais o colecionismo em moldes internacionais nunca existiu.

Nos leilóes da Sotheby aparecem, de vez em quando, algumas pinturas de brasileiros como Di Cavalcanti, Mabe, Portinari, Cícero Dias, Voipi, Segall. Os preços conseguidos não são indicativos e pouco correspondem ao real, pois os leilóes sofrem o crivo das combinaçóes do marketing. Os proprietários póem as, "reservas de preço" abaixo dos quais não pode ser vendido. Marchants, colecionadores, pseudocolecionadores sempre se transformam em especuladores. É por isto que os leiloes, hoje, marcam o passo, com os valores correntes ao mercado, salvo quando ingênuos e coitadinhos pagam preços astronômicos por coisas de pouca valia, bem influenciados astutamente pelos espertos.

Foram-se os tempos dos leilóes livres quando os lotes obedeciam aos rigores da oferta real, como se deu no caso de uma recente venda no Hotel Drouot de Paris, onde foi vendida uma famosa coleção de arte japonesa, deixada em herança ao Instituto Pasteur: venda totalmente sem, "reservas" atraindo compradores de muitas naçóes, especialmente japoneses. Os preços não foram aqueles que alcançariam um século antes na Paris em que foi liquidada a coleção oriental dos Gouncourt, no próprio Hotel Drouot. Aquela arte estava na moda e, como se disse acima, cada época estabelece suas leis em termos de gosto e conveniências.
Tratando de arte oriental: qual sua situação em termos de mercado brasileiro? Para quem o estuda, não através dos leilóes que constantemente apresentam as mesmas mercadorias, tanto pinturas quanto gravuras, especialmente em São Paulo, (Bonadei, Rebolo, Pennacchi, elementos do Grupo Santa Helena e que são frequentadores das quermesses leiloísticas etc.) o mercado é monótono, despojado de iniciativas mais generosas, sem variedades, melancólicos.

São Paulo é uma metrópole rica que deve, qualquer dia, contar com colecionadores e não com investidores, pois a arte e a história, agora que está na moda o slogan da Memória, oferecem boa contribuição para a formação de uma cultura, a qual se baseia também no enriquecimento dos museus, ao recolher memória e coisas.

No caso da arte oriental não temos ainda manifestaçôes importantes. Em São Paulo existe um único antiquariato especializado digno de apreço, o Objects d'Art. É confortador saber que estão aparecendo colecionadores de objetos asiáticos, uma mudança na rotina que está reduzindo o mercado de arte de São Paulo a um solilóquio provinciano.

\section{Legenda}

Bodas Misticas de Shiva e Parventi: para os colecionadores emergentes Deusa, arte tailandesa do século I8

Senhor \#73, II de agosto de I982, p.69 (P.M. Bardi)

Os antIACADÊMICOS DO RIO

Nos anos 20, São Paulo começava a dar sinais de reação contra o assim chamado Academismo, explodindo (mas "non troppo") com a Semana de Arte Moderna. Depois da agitação para lançar o Modernismo, as coisas se ajeitaram e pararam no Grupo do Santa Helena, maneira postimpressionística de adaptação local, sem muito brilho. Entre 30 e o fim da guerra, em São Paulo, salvo a atividade dos elementos da Semana, não se registraram notáveis acontecimentos no campo da Pintura.

É muito mais rico o grupo de artistas devotados à modernidade no Rio de Janeiro. A prova disto está agora documentada numa monografia de Frederico Morais sobre o Núcleo Bernardelli, que se definiu "movimento de belas-artes." Apesar da dição B-A e a escolha do nome do paraninfo, o sodalício contou com pintores que se afirmaram nacionalmente, como José Pancetti, Manoel Santiago, Aldo Malagoli, Quririno Campofiorito, Bustamante Sá, Eugênio Sigaud, Milton Dacosta, Edson Motta, Yoshya Takaoka, Yoji Tamaki, João José Rescale, Expedito Camargo Freire, Joaquim Tenreiro, José Gomes Correia, Borges da Costa e Brandão Poiava. 
Deve-se destacar entre eles um artista que, inexplicavelmente, náo teve a consideração que merecia: Bruno Lechowski, polonês que, depois de ter estudado em Kiev e São Petersburgo, se transferiu para o Brasil.

Os componentes do Núcleo demonstraram um afastamento, ou melhor, uma espécie de vade retro às novidades que na Europa, e logo depois nos Estados Unidos, irromperam, abrindo os caminhos mais livres e desconcertantes para as tendências. Globalmente se constatou que o pessoal não deu passos audaciosos, rompendo a tradição já cansada do Impressionismo. Tarsila do Amaral também, depois das fases felicíssimas do Pau Brasil e da Antropofagia, voltando da viagem na Rússia, praticou a ordinária administração da pintura populista.

O Núcleo não levou a sério Cubismo, Futurismo, Expressionismo e outros "ismos" amontoados em Paris. Uma demonstração de independência, prevalecendo a continuação, sem extravagâncias, da tradição? Apesar desta realidade, o grupo carioca visto agora em conjunto, aparece formado de pintores autênticos, no exercício não tanto da arte quanto da profissão. A temática não choca com a mentalidade estética do ambiente. Produzem paisagens, nus, retratos, naturezas mortas. Sigaud é, como temática, o mais original. Vemos Pancetti, pintor de extraordinária valentia, se dedicar de contínuo às praias.

Do Núcleo não faziam parte alguns artistas que tiveram naquele tempo carioca presença importante, antes da afirmação de Portinari, inaugurando lá um modernismo promissor de novidades. Penso em Seelinger que foi estudar em Munique com Franz von Stuck. Muito mais interessantes os desenhistas de charges humorísticas.

A monografia é muito interessante e confirma que a editoria brasileira agora conta com casas de primeira ordem. A "Pinakothekè" produziu um bom livro, e é de se esperar que continue a editar outras documentaçóes da arte brasileira, como esta de Frederico Morais que sempre nos oferece textos sobriamente redigidos, com informaçóes derivadas de pesquisas conduzidas com perspicácia e saber. Como já ocorrera em seu primeiro livro dedicado ao design.

\section{Legenda}

Dacosta, Paisagem Urbana (1938)

- O Núcleo Bernardelli traba-

lhando, segundo Luís Sá (I93I)

Senhor \#74, I8 de agosto de 1982, p.68 (P.M. Bardi)

\section{SuperMERCADO DE ARTE}

Antepassados dos atuais gigantescos super e hipermercados eram a vendinha e os empórios que comerciavam e ainda vendem de tudo. Os empreendimentos se ampliaram e hoje, com tantas novidades, os grandes centros comerciais estão desenvolvendo técnicas de propaganda e marketing absolutamente inéditas.

Em 1950 dei vida, no Masp, a uma Escola de propaganda que passou a se chamar, seguindo a evolução dos novos tempos, "Escola Superior de Propaganda e Marketing” e que está comemorando seu $30^{\circ}$ aniversário. Os formandos deste ano me escolheram para ser seu paraninfo quando da colação de grau. Recorde-se que antigamente o fazer conhecer um produto, isto se vinculava à venda, ao contrário de agora em que as duas atividades se integram como uma única. Quando vejo ou escuto a pergunta um pouco cacete e, por que não dizer discriminatória, se alguém tem ou não tem cheque especial Banespa, volto meus pensamentos para os primeiros passos dados pela Escola, inaugurada para provocar uma autonomia face ao hábito de copiar, quase servilmente, os sistemas norte-americanos. A generosa proposta deu seus frutos, pois ao longo destas três décadas, não mais veredas cobertas de galharias frondosas, mas uma larga estrada dotada de todos os confortos.

Lógico que um supermercado se vale de todos os meios para incentivar as atividades comerciais. Nos primeiros anos de ação do Masp consegui convencer a alta direção do Mappin quão importante era colaborar conosco para o lançamento (pura ingenuidade) da moda brasileira que criamos e apresentamos na Pinacoteca: as vitrinas do Mappin que davam para a Praça Ramos de Azevedo, em São Paulo, 
mostraram as produçóes. Naturalmente a generosa ideia náo logrou sucesso, pois a importação da moda continuou como dantes. De qualquer jeito estava lançada a semente arte na técnica do mercado.

Desfilaram os decênios. Certo dia do ano passado os dirigentes do Supermercado Eldorado me procuraram a fim de pedir a apresentação de uma exposição de arte em seu recinto, na suposição de que tal evento chamaria bastante atenção. Uma surpresa para mim tal o inusitado da proposta. Após ter examinado o local, sugeri apresentar uma mostra de moda feminina antiga. Não recebi até hoje uma resposta para concretização da proposta. Mas agora vejo que o grande Center Shop de São Bernardo do Campo expóe nada menos que um conjunto de objetos antigos da coleção de Gilbert C. Asmar. Ao mesmo tempo o Morumbi Shopping pede ao Masp que arme uma exposição de arte. Os tempos da cultura, e neste caso o marketings estão em plena e promissora uniáo e evolução.

Já tinha notado como o supermercado do Morumbi procurou se diferenciar dos demais, recorrendo a espetáculos de excepcional interesse para despertar atençáo e ampliar seus negócios; vitrina teatralmente animada com manequins vivos; pista de gelo, e presença de inovaçóes que nos levam a pensar como o campo da comunicaçáo vai tomando direçóes coerentes com a nova mentalidade e vigorosa senda do progresso.

O Masp aceita cooperar com o entusiasmo daqueles que buscam inovaçóes. No mais moderno supermercado agora o usuário, e sem dúvida os que se interessam pelo fato arte, podem ver uma exposiçáo de arte italiana desde o século XVI até o século XIX, alinhando peças raríssimas relacionadas com a descoberta e história da América: uma alegoria de Niccolò Frangipani e outra de Francesco De Mura. Exposiçóes de arte em supermercados são um fato importante, pois constituem mais um elemento para melhor difusão da cultura. Certamente será imitada, como sempre acontece entre nós.

\section{Legenda}

Alegoria à América, de Francesco De Mura (Nápoles, I696-I782) em exposição no Morumbi Shopping.

Senhor \#75, 25 de agosto de 1982, p.63 (P.M. Bardi)

CoISAS DA INDÚSTRIA ANTIGA E MODERNA

Em diversas oportunidades os leitores de Senhor leram informaçōes sobre a "Fábrica" da Pompeia, o novo centro de lazer e cultura realizado por iniciativa do Sesc e que foi oficialmente inaugurado pelo presidente João Figueiredo no dia I8 de agosto.

A título experimental o Centro já vem funcionando há algum tempo, o que possibilitará ao primeiro mandatário brasileiro saber da eficiência com que vem operando. Trata-se de fato absolutamente novo dentro da rotina do assim denominado lazer, geralmente circunscrito ao esporte e aos piqueniques. O Centro foi criado para oferecer aos seus frequentadores biblioteca, atelier para aprender e se exercitar em fotografia, cerâmica, tipografia, gravura, tapeçaria e múltiplas atividades de interesse geral.

Certo domingo tive oportunidade de visitar a antiga Fábrica de tambores, esplêndida arquitetura funcional, projeto evidentemente importado de Londres ou de Paris naqueles tempos em que a economia industrial brasileira ainda dependia das experiências estrangeiras. Sem alterar sua estrutura, Lina Bo Bardi distribuiu nas amplas áreas as seçôes propostas no programa, como artesanato, salas de reunióes, espaço reservado à criança, restaurante, choperia, cafeteria, teatro de arena. Na tarde da minha visita, tive oportunidade de assistir aos ensaios de um grupo de pessoas que formava um ballet-jazz vindo do Rio de Janeiro.

Uma antiga e estreita colaboração existente entre o Sesc e o Masp está bem manifesta na atual apresentação do Centro: "O design no Brasil: história e realidade." Oportuno porque o design tem sua história bem singular, como bem o demonstra a construção da máquina do engenho de açúcar, que passou de horizontal a vertical através de várias e inteligentíssimas correçôes. O jesuíta Andreoni, autor de um livro que o obscurantismo dos portugueses mandou queimar, definiu muito bem o instrumento: "Quem chamou as oficinas, em que se fabrica o açúcar, engenhos, acertou verdadeiramente 
no nome... um dos principais portos, e invençóes do engenho humano, o qual com pequena porção do Divino, sempre se mostra no seu modo de atuar, admirável."

$\mathrm{Na}$ exposição, entre muitas máquinas de beneficiamento agrícola, estão centenas de industriosos objetos produzidos ao tempo da Colônia, numa eloquente confirmação de quanto o emergente povo brasileiro operou com vistas à construção da nova Naçáo. Ao lado do conjunto do histórico passado está uma amostra do design contemporâneo, apresentado pelo Núcleo de Desenho Industrial da Federação das Indústrias do Estado de São Paulo, núcleo presidido por José E. Mindlin, e que trabalha com vistas ao incentivo de produçóes em modos decorrentes de ideias e gostos nacionais.

A sede da exposição, graças à ambientação, tem sido muito visitada, e quem conhece o assunto, nota que o design brasileiro contemporâneo deve ainda trabalhar bastante para desvencilhar-se da inventiva estrangeira. É bem verdade, como disse com exatidão Lúcio Costa referindo-se à arquitetura, que a nossa está atrelada à locomotiva da arquitetura internacional, chegando os tempos em que tutto il mondo é paese.

Mas é uma felicidade poder-se constatar que a cada momento o Brasil vai para a frente, acima de inflação de três dígitos e poluição nos campos cultural e educacional. E exemplo esplêndido disso é esta "Fábrica" onde o povo vai descansar e aprender, amigavelmente, pensando em paz.

O difícil, como aliás se dá com todas as instituiçôes de cultura, será manter a "Fábrica," para que uma obra tão singular não caia na rotina.

\section{Legenda}

Vista de um dos ambientes da Fábrica da Pompeia, o novo centro de lazer e culturado Sesc

Senhor \#76, I de setembro de i982, p.65 (P.M. Bardi)

A TRÉGUA CHEGA AOS MUSEUS

Este cronista é portador de uma novidade, talvez promissora para as andanças da arte na Metrópole antigamente ornada pelo título de "Athenas do Brasil." Dois museus, o grande Masp e o MAM, depois de uns trinta anos, acabam chegando a um modus-vivendi para combinar manifestações em conjunto, iniciando um espírito de cordialidade que, até agora, não era dos mais exemplares.

As divergências vinham de longe. Quando fundamos o Masp, em 1947, a instituição, desde o dia da inauguração, interessou-se naturalmente pela arte dita "moderna" ou "contemporânea," tanto que a sala da Pinacoteca em formação alinhava obras de Picasso, Léger, Morandi, Severini, além de uma exposição de esculturas, pinturas e desenhos de Ernesto de Fiori.

Apesar da explicita demonstração de "modernismo," o que aconteceu? Um grupinho do contra, sempre de prontidão para atacar quem se aproxima seriamente dos problemas da cultura, funda um Museu de Arte Moderna. Até aí nada de extraordinário, pois a Constituição nada impede. Mas o caput, o saudoso sr. Cicillo Matarazzo, despacha sua senhora até o sr. Assis Chateaubriand, fundador do Masp, obtendo uma sede para o MAM no próprio edifício dos Diários Associados onde estávamos alojados.

Cria-se uma piramidal confusão: São Paulo passa a ter dois museus funcionando no mesmo prédio, um devidamente munido de bar, o outro náo. Como a intelectualidade recrutada gostava mais de uísque do que de arte, os dois institutos em fralda foram denominados o "museu do Bar" e o "museu do Bardi."

Seja como for, tudo andou crescendo, dando origem, infelizmente, a desgostosos incidentes entre os quais um que resultou em batalha corporal. A petulância provinciana dos adeptos pseudomodernistas contra o "Museu de arte antiga" continuou. No entanto o Masp formava a única pinacoteca da América Latina, possibilitando ao público ver a arte dos Impressionistas, Max Ernst, Miro, Wolls, Grotti, Kitaj etc.

O maм, ao invés, estourou. Morto, alguns voluntariosos o ressuscitaram, recomeçando a estúpida inimizade. 
Quando o Masp se transferiu para a avenida Paulista, os ressuscitadores fizeram misérias para obter um local no mesmo edifício. Conseguido depois um espaço no Ibirapuera, quando a rainha Elizabeth da Inglaterra inaugurou a sede do Masp, o MAM também inaugurou a sua: no mesmo dia e hora, convidando as mesmas autoridades.

Ao lado do mam estava o Museu de Arte Contemporânea da USP, ao qual o fundador do MAM, extinguindo-o, doara arbitrariamente o acervo, galardeando-se com uma formatura honoris-causa. A partir daí: processos, brigas, polêmicas, sendo afinal reaberto o bar.

Seria longo contar as histórias, ricas em comicidades. Para concluir: a enésima diretoria do Museu de Arte Moderna de São
Paulo, acalmadas hoje as disputas sucessórias, presidida autorizadamente por Paulo Egydio Martins, achou conveniente pôr um fim às controvérsias entre os museus, propôs um armistício e uma colaboração, bem aceitos, e que deveria ser estendido também ao Museu de Arte Contemporânea, pois darâo frutos em beneficio do público que se interessa pela bagatela Arte.

Minha primeira proposta: organizar, em conjunto, o primeiro "Panorama da Arte Contemporânea Brasileira” superando o que até agora foi malfeito, não passando de puro amadorismo com tintas mundanas.

\section{Legenda}

Bryca Canyon Transiation, de Max Ernst (do Masp)

Senhor \#77, 8 de setembro de 1982, p.65 (P.M. Bardi)

NOS JARDINS DA MEMÓRIA

Um dos mecanismos que a nova e oportuna instituição da Memória deveria considerar e pôr em ação é o de não esquecer, alem dos monumentos, da gente que operou com vistas à estruturação da cultura nacional. Passada a festa, neste caso os festejos do funeral, tudo é cancelado ou, no máximo, lembrado na burocracia toponomástica de rua, hoje nem mesmo uma lapidinha de pedra mas de simples lata.

É mais para recordar personagens, nem sempre do circuito das artes, no qual estamos inscritos pela pedantesca mania de classificação dos trabalhos, que no Masp costumamos homenagear alguns personagens não precisamente de nossa área, como ora o fazemos em relaçáo a um botânico. A iniciativa náo foi propriamente do Masp mas de Roberto Maluf, da Eucatex, o qual dedicou seu Relatório de 1982 a Frederico Carlos Hoehne, figura extraordinária e merecedora do título de príncipe dos botânicos.

Vale a pena recordá-lo por dois motivos: pela sua figura, naturalmente, e por ver-se consagrado num documento industrial, a novidade de um texto cultural, quebrando a praxe dos números e dos gráficos estatísticos.

Frederico Carlos Hoehne foi um singular botânico, de abundante e exemplar atividade. Nasceu em $1882 \mathrm{em}$ Juiz de Fora, Minas Gerais, e faleceu em São Paulo, em 59.

Tenho em meus arquivos grande parte $\mathrm{da}$ vasta obra científíca do Mineiro, leitura somente acessível aos naturalistas, menos portanto para quem quer se inteirar dos problemas da vegetação. São prosas que confirmam a vocação profissional e mostram um espírito rico de curiosidade, quando registra casos passíveis de maravilha: "Encontramos restos de 'Eichhornias' e outras plantas aquáticas quase mortas que jaziam semi-sepultadas, esperando, naturalmente, que as janelas dos céus se abrissem para lhes fornecer o elemento pelo qual ressuscitariam para continuar a reprodução da espécie.”

Estou transcrevendo de um dos, "Relatórios dos Trabalhos de Botânica e viagens executados durante os anos de 1908 a 1909 da Comissão de Linhas Telegraphicas Estratégicas de Matto-Grosso ao Amazonas" Hoehne a serviço, como ajudante botânico do tenente-coronel de engenharia Cândido Mariano da Silva Rondon.

Hoehne, naqueles tempos, trabalhava como “jardineiro-chefe” no Museu Nacional do Rio de Janeiro. O implantador dos telégrafos ao partir para sua patriótica missão requisitou Hoehne, escolha mais 
que oportuna pois a prática e o saber do jovem se casavam perfeitamente com sua compleição física, capaz de resistir às asperezas da selva. De fato a prova de resistência foi chamada quando, saindo de São Luis de Cáceres, ele nos conta que "caminhamos 306 quilometros por água, 384 a cavalo e 336 a pé, perfazendo assim um total de 1026 kilometros percorridos."

Minucioso, Hoehne recolhia plantas, as catalogava, não as numerando por espécie mas por exemplar "pois só desta forma, podemos evitar repetiçóes... podemos entretanto, garantir, que temos mais de trezentos e cinquenta espécies de diversas de plantas macroscópicas, que são representadas por mil e vinte e três specimes.”

O botânico, sequioso de indagação científica, curioso constante, anotava tudo que observava, o detalhe aparentemente secundário era descrito com precisão, particularizava tudo que se referia ao ambiente, como bem se vê em seus volumes. No "Album de Orchidaceas brasiliensis" e nos exames dos Herbarios, são exaustivas as fontes de especificaçóes, constando em cada ficha anotações do habitat como floração sobre ninhos de uma pequena formiga, a qual indaga para classificá-la no grupo das Aztecas.
Nas expediçôes Rondon, o botânico sempre aproveitou para recolher materiais desconhecidos, apontando contribuições para determinação da flora do Brasil, publicando uma centena de trabalhos e monografias científicas, além de quase quinhentos títulos em jornais.

Fundou a Associação dos Amigos da Flora Brasileira, dava cursos, proferia conferências, criou um museu, entendendo a botânica como "sciencia fundamental da agricultura e da pecuária e base angular de grande numero de indústrias." Ao mesmo tempo atendia a seus estudos, editando incessantemente, tanto que sua obra é considerada, no seu campo, a mais extensa em língua portuguesa.

Se um título deve ser conferido ao mestre este é o de apóstolo. Sabia das dificuldades para afirmar as ideias, porém nunca desistiu. Depois de decênios de operosidade na divulgação de suas conclusôes, ainda perguntava se sua ação instrutiva e indicativa dava resultado; respondia "como reformadora de hábitos e costumes do povo, será talvez difficil descobrirmos factos que nos autorizem a dizer que existem provas do mesmo."

\section{Legenda}

Do Album da Orchidaceas, de Hoehne

Senhor \#78, I5 de setembro de 1982, p.69 (P.M. Bardi)

COISAS DO PATRIMÔNIO

Quando, no princípio do século, proliferavam os modos neogótico, pseudo-renascentista ou de inspiraçáo colonial, Carlos Eckmann construía uma residência para o conde Álvares Penteado, na rua Maranhão, em São Paulo, hoje abrigando um departamento da Faculdade de Arquitetura e Urbanismo da USP, não mais como foi desenhada face a várias alteraçôes. Este prédio foi uma das primeiras novidades do Art-Nouveau, mais calcada nas artes aplicadas do que na Arquitetura, especialmente pela decisão do diretor do Liceu de Artes e Ofícios, Luigi Scattolin.

Eram tempos em que se usava o tratado de Urbain Vitry, que oferecia, "modelos de habitação de qualquer gênero arquitetônico, pois também o egípcio, o chinês e o gótico têm as próprias belezas" um prontuário rico de sugestóes às mais variadas e características pela terminologia curiosa, como por exemplo: templo de volupcia para indicar o banheiro. Surgiram um tanto timidamente alguns palacetes com sabor de Secessão vienense e, finalmente, o racionalismo, trazido ao Brasil por Gregori Warchavchik, difundindo as razóes práticas do funcionalismo e do bom senso, eliminando o habitual enfeite da decoração.

A história da arquitetura dita moderna no Brasil é compreendida neste trecho. Alinharam nas ruas o mostruário do que nos tempos do Culturalismo se produziu na Europa, arquitetura mais curiosa do que merecedora de atençáo diria histórica, no sentido da Memória.

Recentemente, como já tivemos ocasião de lembrar, ocorreu um rebuliço na avenida Paulista face à atitude de alguns proprietários de imóveis que, na calada da 
noite, numa autêntica Noite da Estupidez e amedrontados por um possível tombamento, destruíram alguns registros de uma época de São Paulo. Realmente um espetáculo de má educação, onde o civismo cedeu lugar à ganância financeira.

Apesar do triste episódio ocorrido na urbe paulistana, o que leva à reflexão é a posição dos responsáveis pelo patrimônio, os tombadores, definição que deveria ser mudada, pois encerra um certo sabor tumular. Na Itália o processo tem o nome de catalogaçáo, o que nos parece mais apropriado. Na Península o Patrimônio se interessa mais por monumentos históricos.

Nada mais justo do que catalogar vestígios do assado colonial, mas para os edifícios 'modernos' seria bom que se estudasse isoladamente os problemas de cada imóvel, possivelmente levando em conta o que é curiosidade e o que é de real interesse arquitetônico. Quanto à curiosidade, seria suficiente a documentação fotográfica. Quando em 37 o ministro Gustavo Capanema criou o Serviço do Patrimônio Histórico e Artístico Nacional, configurou-se a forma legal de proteção.
Muito acertado andou o deputado Cunha Bueno, antigo secretário da Cultura do Estado de São Paulo, quando em projeto apresentado ao Congresso Nacional consagra o dia 30 de novembro como o Dia da Memória Nacional. Afirmou: "A história é dinâmica e o compromisso de nossa geração é também com o futuro. Assim acreditamos ser conceitualmente fundamental que o tombamento abranja, igualmente, as obras contemporâneas."

Parece-nos que o catalogar edifícios contemporâneos seja mais importante do que o preservar curiosidades. Cunha Bueno cita, por exemplo, como meritórios, os edifícios da igreja de São Francisco, em Salvador, o mosteiro de São Bento, no Rio, o Palácio do Governador, em Ouro Preto e o Museu de Arte Sacra, em São Paulo. Agora: é pacífico dar a mesma importância a um palacete onde viveu um dos baróes do café, de estilo árabe ou renascentista?

\section{Legenda}

Casa modernista de Warchavchik, na rua Itápolis e casarão mourisco da Paulista: barão ou sultão?

Senhor \#79, 22 de setembro de 1982, p.69 (P.M. Bardi) HISTÓRIAS DE FALSÁRIOS

Muito instrutiva a conclusão de um processo que a Justiça francesa acaba de encerrar, depois de doze anos, contra o famoso Fernand Legros, responsável pela venda de um lote de pinturas falsas ao texano Medow. Este, pouco contente com a pena condenatória imposta ao réu na sua pátria, quis também tê-lo nas barras dos tribunais da nação da qual era oriundo. Por quê? Disse textualmente: "Para salvar meus interesses pecuniários... e porque os certificados de autenticidade eram de franceses...”

De fato, treze experts dos mais competentes declararam as obras como autênticas; ao longo do processo dezesseis negaram a autografia. A falsificação de manuscritos é comum como a das pinturas e outros objetos de arte.

O curioso é que o sr. Medow e seus herdeiros, quando ele desapareceu, continuaram a ter as pinturas em discussão nas paredes do próprio, "museu" o que póe em discussão o papel ao expert $\mathrm{e}$ ao mesmo tempo o caso da evolução dos costumes colecionísticos.

Quando o Tribunal sentenciou mandando que as obras fossem destruídas, o Instituto de Pictorologia de Paris que tem por objetivo "... a conduta simultânea e a coordenação do conjunto de meios e de métodos que permitem o conhecimento e o reconhecimento da pintura, sem pretensão de julgar e nem de prescrever" interveio para que as pinturas não fossem destruías, afirmando: "A Justiça pensa em queimar os documentos do processo? Por que então pulverizar as obras que dão aos documentos seu senso?"

Poder-se-ia escrever um volume de mil páginas relatando as controvérsias e longo seria o capítulo dedicado a Giorgio de Chirico que instaurou inúmeros processos contra museus, colecionadores, marchands acusando-os de possuírem telas que não eram de sua autoria, na maioria dos casos, na verdade, de sua esplêndida autoria. 
A autenticidade de uma pintura é, às vezes, objeto de controvérsia, dependendo de numerosas circunstâncias, sempre em estreita ligação com seu valor venal. A maioria dos assim ditos amadores que compram pintura subespécie monetária não entende bulhufas de problemas técnico-estéticos: na maioria das vezes amontoam as obras e ficam esperando a alta dos preços. A mensagem das Mulatas, das Praias, das Bandeirinhas e tantas outras temáticas que o "esprit d'imitation" manda poluir é entendida por poucos. Náo creio que os possuidores de trinta, quarenta ou mais telas de Volpi sejam mesmo amantes da arte.

O caso do Texas e a condenação do falsário, mais uma vez, póe na mesa das discussôes como a arte vai representando sempre mais seu peso monetário. A última confirmação vem da Itália e a notícia me parece de uma importância notável: o Erário foi autorizado a receber, em pagamento de impostos devidos, obras de arte. A consequência desta nova sistemática será a de enriquecer os museus.

As transações ensejarão evidentes dificuldades, justamente no tocante ao problema da autenticidade. Também na Itália, após o escândalo das esculturas de Arturo Martini, declaradas originais por Giulio Carlo Argan, um dos mais prestigiosos nomes da história de arte, depois que o caso foi parar na Justiça foram dadas como falsas; também lá o problema da autenticidade é sério.

E como estamos no Brasil, é o caso de se perguntar como vão as coisas em terras tupiniquins.

Os materiais são ainda de pouca monta, circunscrevendo-se aos artistas nacionais. O país ainda não se fez notar no setor do colecionismo como se dá na Europa e nos Estados Unidos. A atenção limita-se às pinturas dos expoentes do modernismo, e até agora não foram notados casos clamorosos de falsificação, mas simplesmente de atribuiçóes erradas.

O pintor brasileiro que, guardadas as devidas proporçóes, poderia ser comparado a De Chirico, foi Emiliano Di Cavalcanti, o qual era capaz de negar autoria de telas que os documentos davam como suas, sem se falar de manipulaçóes de adidos ao trabalho de falsificar, porém com resultados passíveis de fácil averiguação.

\section{Legenda}

Bandeirinhas de Volpi? O pintor jura que é falsificação

Senhor \#80, 29 de setembro de 1982, p.64-65 (P.M. Bardi)

MaIS UMA VIAGEM DO MASP

No próximo dia 25 de setembro, duas mostras de arte enviadas pelo Brasil irão inaugurar o Museu de Arte da Provinda de Mie, no Japão. Uma das exposiçóes compõe-se de sessenta pinturas do acervo do Masp e a outra, de 23 obras de autoria de artistas brasileiros, japoneses radicados no Brasil e descendentes de japoneses, entre eles Tomie Ohtake, Takaoka, Jorge Mori, Tarsila do Amaral, Cândido Portinari. O governador Ryozou Tagawa veio a Sáo Paulo, em I98I, especialmente para formular o convite para inaugurar, com as obras do Masp, o museu de sua província. Mie, por protocolo de irmandade, é Estado-irmão do Estado de São Paulo. O catálogo da exposição traz as mensagens do ministro Ramiro Saraiva Guerreiro, das Relaçóes Exteriores, e do governador de São Paulo, José Maria Marin, além de um longo prefácio deste cronista em que se frisa a importância que tiveram e ainda têm os japoneses no contexto das novas tendências da arte brasileira.

O Masp já realizou outras mostras no Japão. A primeira ocorreu em I973, no grande magazine japonês Matsuzakaya, patrocinado por aquela empresa e pelo jornal Mainichi, quando nossas obras foram vistas por meio milhão de visitantes. Em I978, em comemoração aos setenta anos da imigração japonesa para o Brasil, novamente nossas obras foram ao Japão com o patrocínio do Mainichi e no ano seguinte nossa coleção completa dos bronzes de Degas foram àquele país junto com uma mostra da gravura contemporânea brasileira. Todas essas iniciativas ativaram um intercâmbio cultural bastante profícuo do Brasil com o Japão. Tanto que, em todas as oportunidades, o Masp recebeu conspícuas doaçóes das entidades japonesas 
promotoras dos eventos, o que, nesta revista que se interessa por economia e exportação, torna-se merecedor de consideração.

O fato é que hoje a arte possui um valor intrínseco, estabelecendo na economia uma presença sempre mais marcante. Constata-se, num país como o Japão, qual o interesse pelas grandes exposiçóes, empreendimentos de cultura e de diversão que, por sua vez, geram receitas bastante consideráveis. Considere-se aqui o fato de que as mostras do Masp naquele país são realizadas sem ônus para nosso museu pois as despesas correrão totalmente por conta dos museus japoneses que, além disso, doarão uma importante soma ao Masp para aplicação em nosso programa cultural. É uma grata notícia para um país tão carente na área artística como o Brasil, esta possibilidade de exportar cultura. Além de Mie-ken, a exposição brasileira visitará os museus oficiais de Gunma-ken, Yamaguchi-ken Fukuoka-ken e Oita-ken.

É importante participar destes intercâmbios pois permitem mostrar o quanto e como se desenvolve, no setor da arte, a cultura nacional. Lamenta-se somente que as manifestaçôes no Exterior sejam não só raras mas, na maioria das vezes, iniciativas de elementos mais em busca de repercussão individual do que de afirmação de valores. Esta é uma das causas da dificuldade de se fornecer uma informação concreta sobre a atividade brasileira no campo da arte, o que nós estamos tentando realizar agora, com estas exposiçóes no Japão.

\section{A recepção}

Estou prevendo, pelos cálculos dos diretores dos cinco museus que vão exibir essas duas exposiçóes, uma visitação de meio milhão. Seria o caso de lamentar o minúsculo interesse que o Brasil dedica para fazer saber que, bem ou mal, temos uma cultura que pode ser exportada? E no caso atual a pedido de uma naçáo que, de cultura, tem o quanto quiser.

A primeira provinda que visitei, nesta minha atual estada no Japáo foi Gunma-Ken. O governador enviou um representante a Tóquio para acompanhar a comitiva do Museu de Arte de São Paulo (sr. Key Kimura, Luiz Hossaka, Jacob
Klintowitz e eu). Assim que chegamos fomos recebidos pelo governador estando presente o secretário de Educação e seu staff cultural. Deu-nos as boas-vindas e tudo quanto foi possível por parte de políticos de excepcional bravura e cortesia.

Tendo conhecimento de que o Masp está organizando para a Fábrica da Pompeia do Sesc a mostra "Mil brinquedos para a criança," fomos convidados a visitar uma fábrica de brinquedos, espetacular pela criatividade e feitura. No dia seguinte fomos visitar os museus daquela província sobre os quais é impossível descrever pois faltam os adjetivos.

Surgem num vasto parque de mata tratada e também de plantas em estado natural, um dos museus dedicado à arte e o outro dedicado à história da província. No de arte recolhem-se pinturas antigas e contemporâneas. Por acaso, lá assistimos ao julgamento do salão anual. Aqui se aprende sempre alguma coisa: os jurados sentados, os pintores apresentando as obras. Calma absoluta, sim ou não educados e ponderados. Lembrava-me da famosa fotografia de um julgamento de Saláo em Paris, nos fins do século passado, vendo-se o numeroso júri de pé, levantando as bengalas para manifestar-se a favor. Manet, naturalmente, fora reprovado.

O Museu de Arte e um dos que agora vai receber parte do acervo do Masp. O boletim já anuncia a manifestação, publicando nosso edifício e obras de Van Gogh e Portinari. As mostras serão montadas numa grande sala, do tamanho da nossa Pinacoteca: uma satisfação para quem operou a façanha trinta anos atrás, não imaginando que um dia o resultado chegaria até aqui.

O Museu de História é de uma exemplaridade didática única. Não tem similares: desde a pré-história até nossos dias, cronologicamente todos os tempos são mostrados através de peças originais, dioramas, videoteipes. Sob o ponto de vista da técnica de museus, a maneira é perfeita. Foi um prazer ver a criança se interessar por cavernas reconstruídas, por objetos de pedras cerâmicas, têxteis, esculturas e maquinários. Refletindo: 
como são pobres os museus brasileiros, marcadamente no que se refere à didática.

É verdade que o redator desta nota levou trinta anos para convencer os secretários da Educação a permitirem que os escolares visitem o Masp, mas como há sempre tempo de se tomar iniciativas é de se perguntar se não seria, finalmente, hora de se instituir museus didáticos de História no Brasil. Surgem, não uma mas ideias em multidáo visitando-se o quanto se faz no Japão. Gunma-Ken é uma província com um milhão e trezentos mil habitantes. Sua cultura, pelo que se concentra nos dois museus visitados, é a contribuição extraordinária de sua constante participação na vida japonesa. $\mathrm{O}$ governador nos recebeu, tremulando na mesa de reunióes as duas bandeiras, a japonesa e a brasileira. Falou-se muito do Brasil e também da nossa cultura.

Eu propus uma grande exposição do Japão no Masp. Será que os responsáveis não oferecem a Gunma-Ken uma grande exposição do Brasil? Seria o maior êxito desta manifestação que estamos para inaugurar no Japáo.

\section{Legenda}

A Feira, de Tarsila do Amaral, vai para o Japão 9 Van Gogh, outra obra da mostra

Senhor \#8I, 6 de outubro de I982, p.73 (P.M. Bardi)

\section{UMA DUPLA MUITO AGITADA}

Seja-me permitido fazer uma comunicação de ordem pessoal. Ao longo de um tempo que já me parece um tanto exagerado, na condição de empreendedor de múltiplos e incontáveis eventos, dirijo o Museu de Arte de São Paulo que em outubro próximo completa 35 anos de ininterrupto funcionamento. Para registrar a efeméride vou abrir a exposição "Masp 35 anos."

Não tanto para contar por que e como as coisas andaram se amontoando, mas para lembrar um amigo, o "deus ex máquina” que teve a feliz ideia de fundar este, "serviço público" como tão bem o definia, por meio de "vacas" isto é, as doaçôes indispensáveis à constituição da única Pinacoteca da América Latina reunindo arte do Ocidente.

Em 1947, na São Paulo de então, o reboar das clarinadas da Semana de 22 já não se fazia mais ouvir, a arte marcando passo, perdido seu animador Mário de Andrade, um vivificador do Modernismo, com Oswald não mais agitador, escultores e pintores dispersos, uma pasmaceira, mas enfim, todos à espera do despertar da metrópole. Foi em tal atmosfera que o sr. Assis Chateaubriand decidiu abrir o Masp e resolveu confiar-me sua organização e direção.

O nascituro despertou a cidade e contribuiu para a retomada da empreitada ao se tomar um centro de ação que recolheu forças juvenis e encorajou indecisos ou acomodados. Deu seus primeiros passos pelas veredas não muito aplainadas. Todavia, conseguiu avançar em direçáo ao seu radioso futuro, formando um acervo que, poucos anos depois, era apreciado desde o Orangerie até o Metropolitan Museum de Nova York e apresentando-se também em museus japoneses.

Superando os ensinos ministrados na entâo corrente museográfica, o Masp tangenciou-se mais para a didática: abriu escolas de artes plásticas e de música, dança, fotografia, cinema, propaganda, design, jardinagem e tantas outras atividades, chegando até a lançar a ideia de uma moda brasileira, desenhando, tecendo, costurando e desfilando uma inteira coleção.

O Masp representou ao longo de seus 35 anos um calendário rico de ação e informação, crítica e polêmica, tutto quanti se arquitetou de original no setor arte em São Paulo, provocando, fatalmente, a imitação de outros e bem-vindos organismos que assim como nasceram não conseguiram sobreviver; outros renasceram, felizmente, para incentivar a cultura e as ambiçóes locais, pois tornou-se moda ser diretor-presidente ou simplesmente diretor-adjunto, para figurar nas crônicas do Tavares de Miranda.

A exposição inaugural documentará como foi possível pela primeira vez depois da construção do edifício da praça da Luz - que hospedou o Acadêmico, a Pinacoteca do Estado e o Liceu de Artes e Oficios - a um museu instalado num prédio da 
avenida Paulista dar vida cultural febricitante à cidade, antecipando o grande Centro que este ano foi inaugurado pelo município lá na rua Vergueiro.

Deve-se convir que, sem a iniciativa do senhor Chateaubriand que tão bem soube buscar recursos, normais e anormais, para realizar o Masp, sem ele e a sua força de choque Diários e Emissoras Associadas, São Paulo e o Brasil não teriam tão soberbo patrimônio que silencia os portadores de mentalidade provinciana que relega a cultura aos inacessíveis pantanais onde é difícil transitar.

A exposição "Masp 35 anos" recorda um homem de visão que dotou o Brasil, através de oportunas campanhas e ações, dos avióes de treinamento indispensáveis à formação de uma elite aeronáutica, hoje um orgulho de toda a Nação, de postos de puericultura nas regióes mais carentes; da mudança da mentalidade dos nossos agricultores com vistas à melhoria das produçôes do algodão e do café; e de numerosos outros instrumentos econômicos e culturais.

Professor universitário, jornalista, escritor, acadêmico, diplomata, Chateaubriand deve ser recordado como um dos pró-homens da vida brasileira na primeira metade deste século, como os visitantes poderáo ver na exposição do Masp e como se lê no livro que publiquei e intitulado Sodalício com A.C., para registrar um encontro que tudo indica que deu certo: uma dupla talvez um tanto agitada e muito pouco ortodoxa.

\section{Legenda}

Outubro de 47: Chateaubriand fala, Bardi (na mesa, segundo à esquerda) ouve

Senhor \#82, I3 de outubro de 1982, p.69 (P.M. Bardi)

O VERDADEIRO MILAGRE DA VIRGEM

Uma festa em Aparecida do Norte e algumas reflexóes sobre a permanência da Arte

Aquele sujeito apelidado de, "crítico de arte” como a locução afirma, vive da crítica e certamente também de momentos críticos, de arte também, pois é esta bagatela que substancia seu labor. Às vezes o escriba é convocado para se manifestar sobre produçôes de pintores, escultores e arquitetos oficialmente inscritos na congregação intitulada, "A Arte já Era" elementos ricos em boa fé ou em chutes que tentam cancelar a tradição, surpreendendo, virando de cabeça para baixo os termos que traduzem alguma inteligibilidade.

Semanas atrás, estava na sala de espera da Varig, no aeroporto do Rio de Janeiro, pousando os olhos sobre numerosas telas em que rabiscos, um pouco de geometria e placas coloridas, apesar de representarem joguinhos decorativos - por que não? - agradáveis, nada francamente comunicavam. É quando o degustador de arte se encabula e pensa, pode ser, que não entende, que é atrasado e que a Arte acabou.

Estava reevocando as citadas reflexóes na manhã de domingo passado, em Aparecida do Norte, ali presente por ter sido o reconstrutor da Imagem de Nossa Senhora, quase destruída pelo gesto de um louco, operação levada a bom termo no laboratório de restauro do Masp, pela habilidade profissional de Maria Helena Chartuni.

Na manhá brumosa daquele domingo a venerada imagem era transferida da antiga basílica para $\mathrm{O}$ arcebispo que presidia o tocante ato fez questáo de que participássemos da cerimônia, permanecendo no altar improvisado em frente da nova basílica. Levada numa viatura de bombeiro, a relíquia foi acolhida fervorosamente por uma massa oceânica de fiéis, em seguida participando da Santa Missa, rezando, aplaudindo quando dom Geraldo Penido contava um rosário de milagrosos episódios que ao longo de quase três séculos asseguraram a popularidade da simples terracota em todos os rincóes do Brasil.

Pensava então este cronista de coisas interligadas ao assunto arte, nos milhóes de populares comovidos, vindos dos mais longínquos sertôes a fim de contemplar a imagem. Há milênios que os símbolos das religiôes são figurativos. $\mathrm{Na}$ peregrinação que tive ocasiāo de fazer para conhecer os antigos templos do Japão, pude observar a imensa variedade de esculturas e pinturas dedicadas a Buda. Por analogia as comparava ao infinito da Arte inspirada na vida de Jesus Cristo. 
De um amontoado de ideias e lembranças passa-se a arquitetar outros, acertando e duvidando. As consideraçóes sobre o passado levam a indagar o futuro. Pode ser que as andanças da manifestação Arte acabem encontrando novas fronteiras, que incontáveis estímulos envolvam a criatividade, as artes despontadas ao longo de milênios acabem julgadas sem interesses específicos.
Penso nas elites, nos quatro pingados fautores da, "Arte já Era" lembrando de uma multidão que medita sobre a representação plástica de Nossa Senhora. Evidentemente: Arte.

\section{Legenda}

A Virgem de Aparecida, em I6o pedaços, e após a restauraçáo no Masp

Senhor \#83, 20 de outubro de 1982, p.68 (P.M. Bardi)

\section{A ARTE DA FALSIFICAÇÃO}

Acertar a autografia de uma obra de arte é fato muito importante, mesmo quando se tem em conta de que são inúmeras as obras que levam uma assinatura ou então quando são atribuídas a um determinado mestre, mas que na verdade foram executadas por outros. No passado era comum um artista receber uma encomenda e passá-la a outro colega e, para dar um exemplo, a riquadratura da "Adoração dos Reis Magos” (Galeria dos Uffizi) de Lourenço Monaco, paga a Baldovinetti, foi na verdade executado por Cosimo Rosselli.

Estes casos de participação de alunos, ajudantes, colaboradores, eram comuns na Renascença. É a história dos Bottegas. Assumiam um trabalho e o executavam normalmente e nada tinha de escandaloso o contratado mandar outro executar o trabalho. Se averiguarmos o que aconteceu com a Stanze de Rafael chegaremos à conclusão tratar-se de uma crônica de romance atribudonístico: Rafael idealizava e os ajudantes executavam. Quantas figuras não pertencem à mão de Júlio Romano? Rafael manda a Dürer, como um bom exemplo do seu modo de pintar, um estudo de mão de Júlio Romano, evidentemente satisfeito por bem representar sua arte.

Os tempos mudaram. A pintura virou individual. Quando se quer aferir uma assinatura, vai-se ao tabelião para autenticá-la. Apesar de tudo, o tráfego clandestino dos imitadores, copistas, falsificadores continua, em grande ou pequena escala, provocando dores de cabeça, especialmente aos que se interessam pela obra de arte que representa um bom valor e não como obra de arte mesmo.

Em São Paulo, neste segundo semestre em curso, foram descarregadas quantidades não modestas de pinturas de Picasso, Matisse, Klee e vários outros nomes na crista. $\mathrm{Na}$ verdade pinturas, aquarelas e desenhos de uma mestria convincente, o que fez refletir como os signos e os modos pictóricos dos modernos são imitáveis. Por outro lado também as pinturas da Renascença eram imitadas ao ponto de confundir um correto julgamento e se constituindo num problema de autografia controvertida.

A hodierna safra que inundou e continua inundando São Paulo sugere duas constataçôes: a primeira é a ingenuidade dos eventuais compradores que se mostram convencidos de terem feito um alto negócio, pagando um preço modesto por peças que valem no mercado cem vezes mais; a segunda constatação é a pouca habilidade dos que comerciam as falsificaçóes, o número excessivo da mercadoria, a simploriedade das conversas que contam para justificar o valor pecnincheiro: um Senhor de preferência argentino, arruinado, que deve atender um problema de saúde ou então resgatar um, "papagaio" etc.

Mas não são somente Picasso $\&$ Companhia que constituem o objeto da ilícita especulação. Diante do frenesi para com a arte brasileira, acadêmica, neoacadêmica, mais-ou-menos acadêmica, os que se dedicam à falsificação tendem a aumentar a produçáo dos nossos mestres, entre os quais, para dar um exemplo, Bonadei, que de pintor de segunda categoria, foi promovido à figura de exceção nos quadros da pintura local.

Vi alguns Bonadei belíssimos mas não são de sua autoria, falsificaçóes constatadas através de exames de laboratório, que vale a pena ser apreciado e até mesmo 
comprado, desde que se tenha em mente apenas o fato arte e não o número dos milhôes, ordinariamente pagos.

\section{Legenda}

O torso de gesso, de Matisse, da coleção do Masp

Senhor \#84, 27 de outubro de I982, p.65 (P.M. Bardi)

O CRIME DAS CINCO LETRAS

Na semana passada me tornei conhecido como valente pichador de muros. Não como colega dos que, a mando dos políticos em disputa eleitoral, são recrutados para inscrever os nomes, números e partido protetor, mas como pichador de um único palavrão.

Foi assim: cansado de apagar escritos nos muros do Masp e constatando, na manhã do dia I3 de outubro, vergonhoso emporcalhamento em todos os espaços externos livres do edifício, resolvi mandar comprar um balde de tinta vermelha e um grosso pincel. Com esses instrumentos e com uma palavra que começa com $M$ e acaba com $a$, precisando para inteligibilidade de e, erre e dê, cobri as mais recentes e, infelizmente, exageradas palavras de não sei qual candidato.

O zeloso moralista em guarda, notando o escândalo, telefonou à polícia que, imediatamente, despachou numerosas viaturas ao Museu. Tudo acabou no $4^{\circ}$ Distrito, onde o novel pichador e mais um dos seus auxiliares foram indiciados como contraventores do artigo 234 do Código Penal, passíveis de detenção por dois anos e multa de quatro mil cruzeiros.

Bardi por Fortuna, na Folha de S.Paulo do último dia io

Submetido a interrogatório por um delegado muito gentil, declarei ser o autor do crime, como cidadáo que tem horror de pichaçóes, e, como diretor do Masp, por ter obrigação de manter a casa limpa, casa também tombada pelo Patrimônio como monumento de interesse histórico e artístico.

Redigido o documento de ocorrência, fui transferido para um setor do Distrito para estampar mãos e dedos em dezenas de módulos. Aproveitei para contar aos policiais, como prático de História, que aquele sistema foi invenção de Louis Adolphe Bertillon.
Liberado, o criminoso foi abordado por jornalistas, radialistas e redatores de televisóes. $O$ fato teve as consequências que todos sabem, uma revolta náo só dos órgãos de comunicação, mas de incalculável número de cidadãos. A solidariedade para com o momentâneo pichador registrou-se em centenas de telegramas, flores, telefonemas vindos desde o Rio Grande do Sul até do Amazonas, chegando até pacotes de doces.

Os jornais colocaram a questão semântica: o palavrão é realmente obsceno? É de uso comum no cinema, teatro e na linguagem do dia-a-dia; ilustres escritores e acadêmicos de Letras se manifestaram, declarando que é ridículo considerar as corriqueiras cinco letras como ofensa à moral.

Em minha página de Senhor quero especificar que minha revolta foi romântica, desabafo contra a estupidez eleitoreira perturbadora do decoro cívico, demonstração de imaturidade política e de tantas outras agravantes.

Quero ainda acrescentar: em São Paulo e no Estado são milhares os pichadores recrutados que operam ao longo de horas e horas, às vezes caprichando quando a retribuição é mais generosa por parte dos partidos e dos excelentíssimos candidatos. Não se sabe de um, um só pichador qualquer, que tenha sido denunciado, apesar de contrariar a lei que proíbe o serviço a que se dedica.

Lamento que o único sujeito que a Polícia pegou seja o tal que queria, justamente provocar a intervenção dos tutores $\mathrm{da}$ ordem para acabar com o exagerado desperdício de tinta e de pincéis. E dos bilhóes de cruzeiros que isto custa.

\section{Legenda}

Bardi por Fortuna, na Folha de

S.Paulo do último dia Io 
Senhor \#85, 3 de novembro de 1982 , p.69 (P.M. Bardi)

Manchas E Rabiscos: Wallinho Simonsen, a revelaçáo de uma maturidade

A cada dia se encontram agregados neste caminhar do operariado das Artes, agora ainda mais, pois este labor tornou-se emprego comum. Se conversa, se vê, se discute, se manda ao diabo quando é evidente o desvio, mas também de vez em quando se descobre alguém que vai mesmo para sua aventura certa.

O constatar um valor ocorre num instante ou nunca mais. A aproximação é imediata; se não for assim não vale, o contato torna-se penoso e ilusório.

Os julgadores acreditados no burocratizar da profissão podem enganar-se. Ninguém nasce campeão, porém estou convencido do que disse: o valor de um artista se descobre logo.

O preambulinho é apenas para lembrar, e o pintor objeto de atenção nesta página de crônica me recordou, que em tempos antigos, conhecendo Wallinho Simonsen, então jovem rabiscador sem pretensões artísticas, titubeante até em mostrar seus desenhos, compreendi que seu temperamento era o de alguém que devia prosseguir o caminho.

Depois de alguns decênios reencontro-o no Centro de Arte intitulado em memória do saudosíssimo leiloeiro Irineu Ângulo, (avenida Iv Centenário, 713) galeria instalada num espaço senhorial. Voltando a São Paulo depois de uma longa moradia no Rio de Janeiro, Wallinho se apresenta, pela primeira vez, com uma exposição de suas obras. É rica de humor, veias cheias de evidentes ironias, padrão expressivo total como raramente se nota.
Serve-se de aguadas para marcar ideia, senso e sentimento nas folhas, num ímpeto que diria paroxístico, de vai ou racha, momentos de conclusão daquilo que lhe vem à cabeça, o absolutamente normal nos que se distinguem da normalidade hipócrita da mediocridade.

O pintor intitulou a manifestação, 'Es| só| qui| frenia' para se inscrever na categoria dos livres pensadores, os perseguidos pelos, "médicos-chefes dos asilos de loucos" aos quais, no catálogo, reportando a um ensaio publicado na revista, 'La Revólution Surrealiste’ em 25, se lamenta que "as leis, os costumes, concedem-lhes o direito de medir o espírito."

O catálogo e polêmico, contra os bem-pensantes usuários das obras- não-arte maravilha para investidores, contra os habitantes das boates, hípicas, reuniōes sociais, ambientes que num tempo o Wallinho frequentou. Agora os repudia para se dedicar livre e seriamente as suas manchas reveladoras de um espírito autenticamente mensageiro deste caminhar da Arte. Wallinho chama sua pintura de manchas, e de lato há anotaçóes abreviadas e, ao mesmo tempo, jogadas no espaço, em soluçôes rápidas. Sáo justamente as de quem adere às maneiras expressivas destes tempos abertos e favoráveis de tentar e afirmar rumos novos. São manchas não improvisadas, mas pensadas que, naturalmente, deverão encontrar os que sabem entendê-las.

\section{Legenda}

Retrato: a normalidade hipócrita

Wallinho Simonsen, Situação:

as veias da ironia

Senhor \#86, Io de novembro de 1982, p.65 (P.M. Bardi)

\section{A SOLIDARIEDADE URBANA}

Tratando, recentemente, de lembranças do Masp, tive ocasião de contar que os primeiros jovens que me assistiram na tarefa de implantar o empreendimento, partindo do zero, tornaram-se personagens da vida paulista e brasileira : catedráticos da USP, atrizes de renome, chefes de comunicaçáo, arquitetos e urbanistas de atividade emergente.
Hoje, transcorridos mais de três decênios, interesso-me por um deles que sempre segui com paterno interesse, Jorge Wilheim, na época estudante de arquitetura no Mackenzie, depois profissional destacado, autor de planos urbanísticos, lançador de ideias e projetos de marca nova.

Foi, mais tarde, secretário de Planejamento do governo Paulo Egídio Martins, e agora os jornais o apontam, no caso de vitória 
da chapa do senador Franco Montoro, como possível candidato a prefeito de São Paulo. Há poucas semanas convidei-o para lançar, no Masp, seu livro Projeto São Paulo, propostas para a melhoria da vida urbana (editora Paz e Terra.)

A aspiração de quem gosta de comentar os fatos da sua vida inclui manifestar-se sobre encontros singulares e mudanças determinantes de moradia. No meu caso, sair de Roma para viver em São Paulo, deixando a sujeição da história imperial para me encaminhar na ação da crônica. Uma crônica rica, aliás riquíssima em novidades, aventuras e convites para percorrer caminhos ladeados pelas prósperas árvores da polêmica.

Inserido na movimentaçáo paulista, pude acompanhar o indefinível desenvolvimento, bem colocado na "Proposta" de Wilheim, produzida como consequência de uma longa série de reunióes com dezenas e dezenas de intelectuais versados nos ramos interdisciplinares do fenômeno "cidade." Discutiram, cada qual com seu ponto de vista e experiência pessoal, os problemas interligados, para confluir no geral. Que é político: eliminação dos egoísmos, conciliação das disparidades sociais, educação, numa palavra, advento de uma solidariedade humana.

Combinar vivências numa cidade é difícil, mesmo quando os habitantes são de uma aldeia; mas, e nas grandes, nas metrópoles? O poder pode ajustar, facilitar, ajeitar mas não está em condições de aculturar.

O conglomerado demográfico é na sua preponderante maioria constituído de famílias em luta permanente com o morar mal, nutrir-se mal, mover-se mal.

Vejo, citada no livro, uma consideração de Antonio Candido, descrevendo o caipira sujeito à pressão da miséria: "Para sobreviver a esta condição aviltante, ele se desloca no espaço," solução que o brasileiro resolve adotar para descobrir possibilidades de vida, determinando o aparecimento, nas cidades, das favelas e dos cortiços.
Por este migrar, a São Paulo de trinta mil seres do Oitocentos, tem agora dez milhóes, a indústria se espraiando, junto com os conflitos econômicos e sociais, a violência e a mendicância, as greves e até passeatas de operários coletores de recursos, pois a fábrica fechou.

A viabilidade. Refletia sobre os problemas urbanísticos de São Paulo, há pouco tempo, durante minha estada em Tóquio, um amontoado orgânico de minhocóes, um sobre o outro, facilitando o trânsito numa ordem perfeita, ajudada pela participação de pedestres e motorizados. O problema paulista está na educação do usuário do tráfego. As leis são insuficientes e o concurso cívico pobre.

Eis um dos tantos fatos a serem resolvidos. Jorge, oportunamente, ilustrou a "Proposta" e, ao lado do capítulo sobre o tráfego, colocou a foto de uma subida, na verdade quase um assalto, de passageiros a um ônibus, documento que convida a sublinhar a necessidade de educar, como ponto de partida para operar em favor da cidade harmoniosa.

Como um caso leva a outro: proponho que cada canal de TV furte o espaço de uma das inúmeras e banais novelas para dedicá-lo a um problema central, a educação, a instrução, a cultura, o lazer, beneficiador não só do corpo, mas também da mente.

Impossível numa nota informar sobre este livro, ao mesmo tempo técnico e político. É de se ler para conhecer, antes de tudo, quais as circunstâncias do cotidiano paulista e quais os remédios propostos, com clareza e esperança, e, mais especialmente, com competência específica, uma vez que o autor tem experiência nesta ciência urbanística, agrupando funcionalidade e estética, civismo, sociabilidade e política: uma ciência ainda, infelizmente, ensaiando os primeiros passos.

\section{Legenda}

A São Paulo que Wilheim quer mudar

Senhor \#87, I7 de novembro de 1982, p.73 (P.M. Bardi) O CANSAÇO DO FIGURATIVO

$\mathrm{O}$ adjetivo figurai vai desaparecendo nas crônicas de arte, substituído por outros: a-figurativo, informal, geométrico, assemblado, brut, pop, até por 
“realismo fantástico" e tantos outros termos que os escultores, contemporaneamente aos pintores, andaram e vão lançando aos ventos para etiquetar o que produzem, e para se diferenciarem.

Ouve-se afirmar que o figurativo não contém mais, "energia moral" que não historia nossa época, caracterizada por um "dinamismo plástico" e mais definiçôes que devem ser consideradas, independentemente das preferências estéticas, como elementos válidos na oscilação constante do gosto, a qual, depois da última Guerra, apresenta tensôes tão rápidas que tomam difícil um registro.

Não são de hoje os sintomas indicando um certo cansaço do Figurativo. Courbet disse certa feita, por descontentamento ou por complexo, considerar ser o Realismo, porquanto prático, bastante obsessivo de verismo: "Estou vendo demais claro, seria bom que meu olho se machucasse."

Por outro lado Duchamp referindo-se ao lançador do apodítico il faut être absolument moderne ser ele um pintor, "demais retínico" coincidência por demais curiosa já Que baseada no "demais" e tendendo a sublinhar que os excessos perturbam a comunicação pintada. Um "demais" é aplicável também a Duchamp ou a qualquer outro mestre, pois a criatividade consiste em juntar algumas coisas a mais ao que já temos, consequência das junçóes e dos "demais" que se andaram seguindo e acumulando nos tempos e nas searas. É por isso que para ver e apreciar é indispensável saber ver estando implícito também saber no sentido da informação e relativa dedução cultural.

Quem gosta do cartáo postal, serve-se de símbolo comparativo para julgar pintura, mas jamais estará em condiçôes de compreender os opostos Courbet ou Duchamp. E para ficarmos em termos locais: Pedro Américo ou Tarsila do Amaral.

Evolução não quer dizer destruir ou sonegar as formas e os pensamentos do passado, para dar vida a novidades absolutas; evoluir significa adaptar o que no passado se produziu. No Oitocentos, Berlioz era considerado um megalômano, pois exigia 360 músicos para tocar suas sinfonias, introduzindo na instrumentação sinos e tiros de canhão. Megalômano então era Russolo que, no tempo dos futuristas, compunha música com o intonarumori, utilizando qualquer espécie de ruído.

O que aconteceu na música pode ser comparado ao que ocorreu na pintura: o maltrato da figura começado pelos cubistas e continuado com a difusão sucessória dos outros ismos, até chegar à sua anulação. São todas aventuras bem próprias do labor dos artistas, a inquietude do renovar, de ajeitar novas vivências e sondagens de futuro. Por isso é preciso ter o cuidado de considerar as tendências, mesmo aquelas de difícil compreensão e, ás vezes, indigeríveis. Quando se pensa que a Paris do Oitocentos náo digeria Monet, Manet e alguns outros impressionistas, e Cézanne, é bem aconselhável julgar com prudência os novos.

Julgar é assunto complicado. Antes de tudo é preciso estabelecer se uma produção historia realmente nossa época.

Quando se julga o Oitocentos encontra-se uma massa enorme de pinturas, esculturas e mesmo de músicas para as quais torna-se difícil dar um posto representativo no século. É o academismo de rotina, o genérico, o que foi executado sem juntar o lembrado demais.

Este ajuntamento constitui hoje o problema de base da produção, pois invés de ser união é anulação, redução da forma ao incompreensível. Todavia, como se disse, deve-se considerar, procurar entender e, portanto, distinguir entre criatividade e imitação, entre espírito e chute, numa palavra, pôr de lado o novo academismo.

O novo academismo também faz história, pois aí é possível isolar manifestaçóes válidas, pelo menos coerentes com fatos extravagantes relacionados com ã vida contemporânea. $\mathrm{O}$ difícil mesmo é estabelecer esta coerência, enquadrá-la nos seus limites, prever a história.

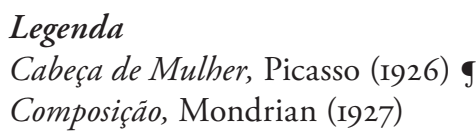


Senhor \#88, 24 de novembro de 1982, p.76 (P.M. Bardi)

UMA NOVA POLÍTICA CULTURAL

No auge das disputas eleitorais, no aceso dos discursos e no proliferar da panfletagem, as atençóes dos assim chamados intelectuais estavam voltadas mais para a descoberta de eventuais, não diria programaçóes, mas acenos e até mesmo alusóes à Cultura.

Ledo engano, pois o que se verificou é que as cartas postas na mesa foram, e continuam sendo, estritamente políticas, acrescidas de anexos econômico-sociais em função da economia, inflação etc. Sem dúvida, é daquelas cartas na mesa que deveriam sair as esquecidas cartas da Cultura, para muitos uma complementação secundária, simples acessório, nem sempre registrada. Quase uma atividade independente nas intençóes de todos os que por lá se metem, livres as iniciativas das expressóes, desde que náo incomodem a censura ou o código penal, este mesmo código que me foi aplicado por ter escrito um palavrão sobre as insuportáveis pichaçóes candidatoriais nas paredes do Masp.

O governo, agnóstico em Cultura, não interveio para acalmar o assalto à compostura das cidades, inclusive igrejas, monumentos e natureza viva, e por relevante motivo quase foi posto na cadeia o único pichador que protestava contra o emporcalhamento.

O problema Cultura é considerado mais como uma prática burocrática que se desenvolve no competente Ministério e nas proliferadas Secretarias Estaduais e Municipais de Cultura, Esporte e Turismo, pela aplicação de generosas verbas para uma e outra empresas, voltadas para soluçóes locais, fragmentárias, quando não personalísticas, sem obedecer a uma determinada unidade nacional.

Quem se interessa pelo caso encontra as mais disparatadas e inúteis iniciativas conflitantes entre si: bilhóes para futebol e minguados cruzeiros para institutos científicos, ou férreos apoios a irrelevantes museus de arte, quando todos sabem como vive o Goeldi de Belém, ou o Masp, responsável pela conservação do maior patrimônio de pintura da América do Sul, travando luta permanente para obter um novo aparelhamento de ar condicionado.

$\mathrm{Na}$ Alemanha, durante o ano passado, em muitas cidades, deu-se uma pichação não eleitoral, mas de protesto contra o relacionamento político-social-cultural. Num jogo inteligente de palavras, (Fehlstaat/Fehlstart) isto e, "Estado falho/partida malograda," foi criticada certa ordem estatal considerada deficiente, resultando no malogro de chances para possibilitar convenientes arranjos culturais em função do futuro.

No Frankfurter Rundschau, o comentário relativo à decorosa pichação foi feito por um anúncio de imprensa alternativa e assim redigido: 'Tendo em vista a carência de participação, renunciamos ao futuro.”

É natural que o assunto Cultura seja demandado ao futuro. Mesmo em relação ao novo Brasil, pois os passos de agora servem para direcionar os de amanhá.

O importante é enfrentar o problema

Cultura em termos nacionais, estabelecendo-se o que vale e o que representa superestrutura dispensável, definir, concentrar as cabeças e buscar os meios necessários. Necessário, antes de tudo, planejar, superando as manias elitistas circunscritas a grupos privilegiados, e não para todos, harmonizando no caldeirão aspiraçóes totalitárias, tradição, realidades e conveniências.

Gente ligada às ciências e às técnicas, às letras, às artes, à música, enfim, todos contribuindo para confeccionar o "pacote."

No tocante às artes plásticas, setor onde sou mais versado sem contudo bancar o especialista, posso afirmar que tudo está para ser feito, ou melhor, à recombinar, nacionalmente.

Náo me refiro à criatividade que deve ser livre apesar desta provocante frase de Samuel Beckett: "Talvez tenha chegado o tempo de fazermos a espantosa constatação de que a arte nada tem a ver com a clareza, de que ela náo se movimenta no claro e muito menos nas trevas." Mas isto faz parte do tempo.

Um sistema de Cultura que deveria interessar é o apoio, uma fórmula que 
já é apresentada nas TVs, (aqui seria o capítulo mais complexo a ser discutido num plano nacional de Cultura) os meios necessários a espetáculos e performances. Apoio à implícita e fatal concessão de verbas. Sendo esta procedente dos cidadãos através de impostos, taxas etc., eis o imperativo de distribuí-las criteriosamente.

Desemboca-se assim no movediço ponto crucial: a destinação ponderada, no complexo campo em que os postulantes estão armados de cartaz político e não cultural, empenhados em resolver o próprio desejo de prestígio. As limitaçóes são sempre locais, ad personam. Raros os que pensam em termos nacionais.

Ocorreu-me, há dois meses, levar para o Japáo, convidado a inaugurar o novo Museu de Mie-ken, duas exposiçóes, uma de sessenta obras-primas da Pinacoteca do Masp e uma de pintores nacionais do século xx. Naturalmente foram exposições feitas para uma maior afirmação do Brasil em terras estrangeiras. Apesar de o convite ter sido formulado pelo governador de Mie-ken e, mais modestamente a mim, nosso embaixador naquele país amigo não presenciou o corte da fita que eu mesmo, em nome do Brasil, realizei, com luvas brancas e tesoura dourada.

Voltando ao ponto de partida destas notas que, presumo, deveriam provocar depoimentos incontáveis, concluirei que é urgente ponderar-se sobre o problema Cultura nacional, tendo em conta as interferências educativas, econômicas e sociais, através de um sério exame da situação, de propostas efetivamente úteis. Insiste-se: nacionalmente, com a severidade que preside, quando está em jogo o fazer saber, como um país se comporta na sua mais significativa atividade, a Cultura.

Senhor \#89, I de dezembro de I982, p.76 (P.M. Bardi)

\section{UMA ARQUITETURA TROPICAL}

Não são tão numerosas as cartas que recebemos tratando de assuntos de arte, exceção apenas para aquelas que indagam do valor de uma tela ou de um bronze, conforme o sistema hoje corrente em que o fato arte é visto num prisma puramente econômico.

Porém, numa exceção, temos em mãos uma missiva que fala de arquitetura. Assim sendo, penso valer a pena divulgá-la.

Diz a carta: "Prezado redator: Meu marido cultivou na cabeça (e ninguém lhe tira fora) a maluca ideia de erguer uma moradia na praia. A disparatada ideia náo toca ás raias de uma mansão situada em uma praia, mas sim uma casa em que o estilo escolhido depois de consultar mais de uma dúzia de arquitetos - é o Luiz XVI. Eu aprendi nas aulas de uma dessas fulanas-professoras que ministram História da Arte que Luiz XVI (caso não esteja equivocada) foi um rei francês, que mandou no século (se não estou errada) XviıI e morreu guilhotinado. Apesar da discordância destes números, (xVI e XVIII) eu me pergunto, como indago ao distinto jornalista, pessoa formada em Filosofia: se nós estamos (se não estou errada) no séc. xx, e até no fim, então por que recorrer ao XVI ou XVIII?"
"Prolongadas discussóes foram travadas entre primos e primas cultíssimos, mas sem nenhum resultado prático. Ninguém tira da cabeça do tal esta mania de Luiz XVI. Até seu pai, ironicamente, gritou: - Filho, naqueles tempos não se praticavam banhos de mar, digo mais, nem de banheira e, hoje, vai-se à praia de calcinha, biquini e topless; assim sendo, como você pode pensar em Luiz XVI ou XVIII, que é a mesma coisa? Meu marido é um daqueles executivos mandóes, não gosta e rejeita contrapropostas e nos apelida de palpiteiros, ele que dá palpite até sobre o molho da salada. Isto posto, caro redator, me diga se estou certa. Cordialmente etc. etc."

Em edições precedentes de Senhor, falou-se de kitsch. O que se nota no setor arquitetura é a presença desta anomalia. Fácil ainda constatar, na metrópole, a aplicaçáo de estilos do passado remanejados, sem que se saiba por que e como.

Não se trata do caso formulado pela senhora que pretende uma mansão neoclássica. Este estilo é o preferido dos capitães do dinheiro, pois um grupinho de colunas, com ou sem capitéis, confere uma certa imponência à fachada, especialmente se pintadas de branco, destacando-se contra 
as paredes pintadas na cor tijolo. Às vezes, o retorno à magnificência do Parthenon é decisão de um tal que mexe o dia todo com produtos elétricos, sendo então difícil estabelecer sintonia entre os tempos e os gostos, bem como descobrir as motivaçóes de uma escolha de ordem estética.

A arquitetura é, sem dúvida, a arte da distinção. Nunca consegui descobrir os verdadeiros motivos que nortearam a construção, em estilo goticizante, da Catedral de São Paulo. Gótico no trópico? Doutro lado, um passeio ao longo da avenida Paulista nos dá a possibilidade de lembrar como os baróes do café dos anos 30 julgavam a arquitetura, produzindo uma rua de estação de águas purgativas, como escreveu Levi-Strauss.

As agora acesas polêmicas para que se tombem, ou não, palacetes dispersos na avenida onde um metro quadrado de terreno anda pela casa de um milhão de cruzeiros provocaram atenção sobre a Memória e a Arquitetura. A oficial é que é. Basta ver Brasília, mas a produção burguesa ainda está por demais interligada às disputas domésticas, como se depreende da carta em tela, isto é, no núcleo da ignorância.

\section{Legenda}

Museu do Índio em Brasília, projeto de Oscar Niemeyer: arte oficial?

Senhor \#90, 8 de dezembro de 1982, p.69 (P.M. Bardi)

Os SALÓES DO FIM DO SÉCULO

Recebo de Oostende o catálogo da exposição dedicada ao "Prêmio da Europa" I982, evento que reuniu 570 pintores. A manifestação, que teve inicio em 1962 com a participação de 283 elementos, é uma iniciativa do Stedelijk Museum e pode perfeitamente ser comparada a um dos mais concorridos salóes nascidos na França há mais de um século e, com o costumeiro retardamento, imitados em inúmeras naçôes, no Brasil inclusive.

Salôes de Belas-Artes sempre foram a minha diferença, não tanto pelo gênero do empreendimento, (e infelizmente vejo que, apesar das tantas águas passadas embaixo da ponte, de ano em ano se constata que um ou outro município brasileiro abre um destes estabelecimentos) nem pela organização das festinhas, mas pelo sistema das prescritas premiaçóes, o comportamento dos juízes incompetentes que decretam as distinçóes, marmeladamente ajeitadas nesta estúpida, aliás estupidíssima, graduação: I. medalha grande de ouro; 2. média; 3. pequena; 4 . medalha de prata grande; 5. média; 6 . pequena; 7. medalha de bronze grande; 8 . média; 9. pequena.

Da classificação 9, passa-se às, "mençôes honrosas"aos "prêmios de consolação," etc. A mania de premiar é antiga e os tempos assim classificados de progresso não conseguiram e muito menos pensam em eliminá-la.
Bem. Voltando a Oostende - uma espécie de Guarujá da Bélgica - no tocante ao seu "Prêmio da Europa" constata-se que ali também o vício de medalhar é uma constante. Aboliram a medalha das medalhas e em seu lugar outorgam simplesmente uma peça de ouro, algumas de prata e um verdadeiro festival de bronzes; distribuídas ainda algumas coroas do Casino-Kursaal e uma das Províncias. Bom será dizer que as medalhas de bronze distribuídas foram nada menos que 32 e aí se tem uma boa ideia da bondade do júri.

Os participantes são quase todos da Bélgica, Irlanda, Dinamarca e dentre os de outras nacionalidades aparece uma brasileira a quem deram o galardão de prata. Trata-se de Ana Maria Pacheco e, pelo que se depreende do catálogo, vive na Inglaterra. Sua pintura se intitula "All is Vanity" e alude à antiga temática de "Suzana e os Velhos." Examinando as ilustraçóes, em sua maioria de tendência non-sense, a tela da brasileira merecia a medalha de ouro que, no entretanto, foi decretada para obelga Van Gestel Fik.

A premiação oferece a ocasião para que se note a situação da produção de pintura a qual vai se alternando entre figurativo e não-figurativo, entre inteligível e ininteligível: aventuras dos tempos que se encaminham para o fim do milênio. 
Legenda

A obra All is Vanity, de Ana Maria

Pacheco (esq.) merecia o primeiro lugar em Oostende. Mas a medalha de ouro foi para Aanval, de Van Gestel.

Senhor \#9I, I5 de dezembro de I982, p.72 (P.M. Bardi)

A ARTE MAIOR DE UMA OURIVES

Uma das classificações atinentes às artes que nunca foi devidamente aceita é a da sua divisão em dois grupos: a arte propriamente dita e a "arte menor." Esta hierarquia vem da Renascença e se acentuou no Oitocentos, face ao advento industrial.

No grupo das menores foram incluídas as, "aplicadas" as, "complementares" a "popular" e assim por diante, uma distinção entre arte feita por artistas dotados e "menores" produzidas por artesão. Quando Rafael pintava, ou mandava executar, as "rafaelescas” decorativas, era pintor menor? As ourivesarias de Benvenuto Cellini inserem-se no campo da arte menor?

Os manuais de história da arte dizem que em cada século são registrados o "maior" e o "menor." Assim, uma cadeira de Thonet, de Le Corbusier ou de Eams, para lembrar alguns mestres, faz parte da arte dita menor. Se um inexperto rabisca algumas linhas numa tela é registrado nas mais conceituadas revistas da crítica como produtor de arte, sem o objetivo de menor ou de tapeador.

E quando falam de música? Ou é clássica, erudita etc., ou é popular. Em arquitetura ainda pior: uma pequena casa executada por um mestre de obras é uma construção qualquer, mesmo que se trate de uma esplêndida arquitetura; em contrapartida, um genérico arranha-céu international style é sempre arquitetura. E assim por diante.

Estas distinçóes ocorreram-me vendo uma exposição de ourivesaria, requintada e vistosa, que um catedrático empolgado nas prescriçóes dos manuais relegaria à categoria das "artes menores." Infelizmente as medidas têm suas tradicionais exigências. As gravuras de Rembrandt são de pequeno formato, e lembro-me de um caso para recordar que existem até catedráticos que relegam a gravura à condição de "arte menor."

Seja como for, os objetos que Orietta del Sole expóe na Galeria Rastro (rua Augusta, 2.223, São Paulo) devem ser considerados como arte. O local da exposição é um centro onde as produçóes artísticas são numerosas, sem distinçôes classificatórias, e sem consideraçôes preconceituosas.

O conjunto de joias na mostra participa das atividades que nos interessa, a arte, aliás a Arte.

Orietta dedica-se, com curiosidade persistente e meticulosa, à descoberta de mil e uma coisas. Sua casa chancela um infinito de interesses estéticos: o que para o leigo pouco significa, para ela é magia. Vai à feira dominical da praça da República, e volta com brinquedos- arte, volteia pelo Oriente e de lá retoma com pedras, joias, metais, amuletos, papéis de singular novidade,às vezes novidades arqueológicas. Tudo é precioso sob os olhos de quem sabe ver e, imediatamente, fantasticar.

Daqui, deste gosto amplo, onde tudo tem valor, nasceram e despontam suas joias: recomposiçóes, reelaboraçóes, criaçóes de uma atualidade que chamaria de senso extempore, de amor ao passado e de um amor com visos ao universal. Os espaços reservados aos dignos frequentadores de recintos da Arte se alegram, ao contemplar estas vitrinas. E mais: pedem o consenso dos visitantes.

A exposição destaca-se da rotina galerística que em Sáo Paulo se tornou parafernália de pintura. Mostra um setor que, na metrópole, tangencia para a generalidade do ornamento feminino melancolicamente interligado a ordinários valores monetários, posta de castigo a inventividade, a novidade, a originalidade. Orietta opera nesta distinta categoria.

\section{Legenda}

Dois colares do Orietta del Sole: ao lado, peça feita com turquesas, espinha de cobra e escaravelho egípcio; acima, além das turquesas, um antigo relicário do Tibete em prata. 
Senhor \#92, 22 de dezembro de 1982, p.68 (P.M. Bardi)

ARTE NA HORA DO CHÁ

Convidaram-me recentemente para, numa casa de novel colecionador, conhecer algumas obras de arte. Quando de lá saí veio-me à mente a figura do autor dos Gulliver's Traveils, o qual manifestava uma certa antipatia a propósito de um jornal. Numa carta datada de I7II, e endereçada a um amigo, afirmava: "Ler os números do Spetactor? Eu nunca."

Pensava: visitar coleçôes recolhidas assim, jamais, como nunca deveria aceitar este tipo de convite.

Swift abominava o jornal de Joseph Addison, um escritor pedante que no seu Account of the Greatest English Poets não incluiu Shakespeare, já que votava uma certa idolatria por Milton. Swift dizia na carta que aquela folha era "vagamente escrita" e, como consequência, sua aceitação na sociedade burguesa era "um dos acessórios do chá da manhã," como bem definiu Mário Praz, o maior e saudoso crítico italiano da literatura inglesa.

Dizia Swift: "Recomendaria particularmente estas minhas reflexôes a todas as famílias ordenadas, que dedicam uma hora cada manhã ao chá e ao pão com manteiga, e calorosamente aconselharia, para o bem delas, dispor que aquele jornal seja recapitulado com pontualidade e considerado como parte do serviço do chá."

As "famílias ordenadas" dependiam do esnobismo, do cultivo das virtudes caseiras e nacionais numa Inglaterra puritana, Addison declarando que, "levei a filosofia para fora dos ambientes das bibliotecas, das escolas e dos colégios a fim de introduzi-la nas conversações e nos cafés" passatempo daquelas famílias.

Ainda hoje a burguesia, mesmo no Brasil, de manhã, gosta de ler as páginas de jornais que não se confunde com a própria mentalidade? Nem por sonho. Ela quer saborear os comentários convenientes, que espelhem as ideias morais, sociais, políticas, econômicas etc., a começar pelas crônicas do status ao qual pertencem.

Assim, refleti que, ao ensejo da visita que fiz para conhecer a coleção mencionada, não devia absolutamente aparecer como campeão do desmancha-prazeres, disfarçado e mergulhado em incômodos silêncios, mutismo encabulador, dando assim desgosto aos presentes, sonegando respostas face às exclamaçóes barulhentas ou hosanas a esta ou àquela tela.

Fui educado. Não me servi do clássico vade-retro de Picasso: tableaux imbecils, preferindo não acatar o humor esplêndido de Swift: "Refrescar a memória (da burguesia) de cada dia, até que eu não consiga resgatá-la daquela desesperada condição de vício e de folia na qual está decaído o tempo.”

É difícil, neste circuito aberto por todos os lados, discutir tendo por tema a estética. Cada um tem a sua, como existem os que sabem pensar e não sabem ver. Retomando ao Masp matutei muito em relação a colegas que veem obras com a ótica dos turistas, que dedicam ao Louvre uns 35 minutos, pois o ônibus não pode esperar.

No burburinho se alternavam as computaçóes do colecionador: "Vale dez milhôes," "Vale duzentos mil," etc., transformando uma tela em cheque. O que me levou a compreender que a estética andava se entrosando com a caderneta bancária.

Ninguém é tão simplório a ponto de negar o valor monetário da arte, porém não deve chegar às raias da obsessão, numa proclamação peremptória. Longe de mim censurar o colecionador, sempre por educação e pelo fato da arte ter- se tornado um bom negócio. Mas o que não digeria, como não digiro mesmo, é um certo tipo de colecionismo exercitado conforme a obtusidade dos medíocres que não se destacam do, "chá, pão com manteiga" a receita de Addison para uma vida sem sobressaltos, praticando uma vida sem desvios, equacionando perfeitamente entre normalidade e economia.

Naqueles parnasos domésticos, as obras dos artistas jovens não têm acesso. É, geralmente, isto que desperta mau humor, ao se constatar que inúmeros bons elementos, que o Brasil hoje alinha, não têm apreço.

Mas foi o que aconteceu com os jovens Di Cavalcanti, Anita Malfatti, V. Rego Monteiro, Ismael Neri etc. etc. 
Legenda

Anita Malfatti um dia foi jovem

Senhor \#93, 29 de dezembro de 1982, p.72 (P.M. Bardi)

CONSERVAR, PARA SOBREVIVER

$\mathrm{O}$ artista produz uma obra, esta circula, seus itinerários são imprevisíveis, sua integridade é problemática e o valor depende de inúmeras contrataçóes. Se a obra acaba em um museu, seu caminhar termina por ali, porém acontece que o museu pode desfazer-se dela, trocá-la, vendê-la, relegá-la a um depósito.

As peregrinaçôes das pinturas, esculturas e objetos permitem romancear, ocorrendo os fatos mais curiosos, pois quem se envolve com obras de arte é cidadão normalmente anormal: apaixonado, interesseiro, sonhador, impulsivo, negocista e assim por diante, misto de qualidades positivas e negativas, entre elas as de futurólogo e de possível acertador lotérico.

Eu sei bem disto, pois me joguei nesta aventura de mexer com coisas de arte, plástica naturalmente, incluindo a Arquitetura, a cinderela, pois pouco, para não dizer quase nada, recebe de atenção, a não ser das imobiliárias.

Devo fazer um parêntese para a exceçáo das obras sem itinerário, as irremovíveis. Para dar um exemplo, a mais famosa, a Santa Ceia, de Leonardo da Vinci no refeitório da Igreja de Santa Maria das Graças, em Milão, que sugere uma lembrança para registrar que tem um itinerário complicado de atentados e intervençóes, causas do estado lastimável em que se encontra.

Foi o Duque de Milão quem fez a encomenda. Leonardo, entre I495-98-99, pintou o afresco, infelizmente usando e experimentando sistemas técnicos impróprios, conjurando para sua progressiva destruição, sem oferecer possibilidades de conservação. Às más condiçóes do mural, como queijo no macarrão, os próprios padres dominicanos acrescentaram uma porta na parede, amputando as pernas do Cristo e as dos discípulos que lhe estavam perto. Dulcis in fundo: quando o exército aliado ocupou Milão, no fim da última Guerra, o local da Santa Ceia tomou-se depósito de materiais militares.
Agora o afresco, depois de numerosas restauraçóes, uma mais falha do que a outra, está sendo limpo aos cuidados de uma técnica especialista, Giuseppina Branbilla Barcilon, usando um microscópio ótico que lhe permite descobrir e remover poeira, sujeiras, antigos retoques, na tentativa de recuperar o quanto foi feito pela máo do engenheiro militar, inventor, pintor, arquiteto, engenheiro hidráulico, organizador de festejos e revistas militares, figurinista e até provedor do aquecimento do castelo: o gênio Leonardo.

Considerando então, se o assunto é conservação de obras de arte, visto como foi tratado Leonardo, deve refletir-se o quanto o problema é preocupante, especialmente para nós do Brasil, que também temos que proteger a memória. Existem órgãos federais e estaduais de tutela do patrimônio histórico e artístico, mas, francamente, seria de reconsiderar o sistema para lhe designar tarefas mais adequadas, sem contar a necessidade de uma organização técnica mais consistente e responsável.

Pela experiência pessoal na função mais específica das repartiçóes, o tombamento de bens arquitetônicos, paisagísticos e de produçôes artísticas, parece-me que ainda não se chegou a resultados satisfatórios. A definição do valor histórico ou artístico é relativa e ainda não está bem definida, especialmente no que se refere aos patrimônios existentes nos Estados. Quanto aos patrimônios móveis, os tombamentos junto aos colecionadores não foram nem considerados.

Depois de ter constatado como acabou a Santa Ceia de Leonardo, pareceu-me urgente pensar mais carinhosamente em nossos bens culturais. Alguns dias depois leio no Jornal da Tarde o inquérito sobre o Pantanal do Mato Grosso. É de estarrecer. Um redator, tranquilamente, fotografa autênticas devastaçôes de uma espetacular paisagem, mal protegida pelos poderes públicos. 
Leva a pensar em quantas destruiçóes estão-se somando nos Estados, no setor da arte propriamente dita. $\mathrm{O}$ problema se coloca a cada momento e a soluçâo é sempre e sempre adiada.

\section{Legenda}

Nem a Santa Ceia, de Leonardo da

Vinci, escapou do vandalismo

Senhor \#94, 5 de janeiro de I983, p.64 (P.M. Bardi)

\section{A ESCUltura AVANÇA}

No quadrante das artes plásticas a escultura é, certamente, a que menos atenção e consideração recebe. Serve para monumentos, medalhas, quase sempre ingrediente de celebraçóes, raro o emprego na arquitetura, ainda não aceita pelos senhores colecionistas, adeptos em geral somente da pintura.

Temos centenas de galerias comerciais que apresentam a arte pictórica e somente uma que, em São Paulo, se dedica exclusivamente à escultura; pioneirismo entre o audacioso e o sacrificado, iniciativa de um grupo de três senhoras: Raquelita Calabrone, infelizmente desaparecida, Clara Pascowitch e Sarah Taub Teperman. Fundaram, há alguns anos, a "Skultura," reanimando um setor desconsiderado, recolhendo um grupo significativo de jovens de todo o Brasil e, ao mesmo tempo, dando reconhecimento aos anciãos. Publicam até uma revista séria e operam para a verdadeira ressurreição da escultura, que começa a encontrar seus admiradores e compradores.

As exposiçôes periódicas da "Skultura" participam do gosto que está acampando também no Brasil, o informal que, me lembro, começou a interessar nosso máximo mestre Victor Brecheret nos anos 50, alternando no seu figurativo fantasioso formas globais; o mesmo se observando na obra de outro mestre, Bruno Giorgi, e de outros artistas, inaugurando a fase de transição entre a tradição e as novidades do presente.

O século xx andou afirmando idiossincrasia para com a figura humana; ou melhor, os artistas decidiram representá-la sem graça, recompô-la desvirtuando-a. Começaram os Expressionistas e mais os Cubistas, seguidos por pintores e escultores, comunicadores audaciosamente decididos à anulação.
A gente continua, fisicamente que sempre foi. Os artistas, na maioria, se esqueceram da Vênus de Milo, transferida para os debates dos concursos de beleza e páginas de revistas, paliativos insuportáveis rotina pedante, pela lei dos contrários justificadora do "ponto e basta" que se adverte no salão da estética. É rotina o insistir banal da fórmula, "nu pelo nu" pensando na outra, "arte pela arte" no cansaço do academismo enchedor e provocador de reaçóes, desbotadas fatalmente, como continuamente se dá, nos exageros, e até no esquecer ou cancelar a História. Lembro-me que uma das numerosas e ilustres "críticas de arte" locais, na exposição, "Um século de escultura" declarou-se horrorizada pelos figurativos, pois no seu elucubrar, "não estavam mais em moda" o que me levou a recordar a famosa definição de um inovador custe-o-que-custe: "Miquelângelo não interessa ao Brasil."

Não é fácil julgar as produçóes da escultura, como de resto as da pintura, nesta contemporaneidade rica de penetraçôes e excentricidade. Tanto para os que ainda se manifestam recorrendo à figura, como para os que propóem o informal. É difícil descobrir símbolos e singularidades.

Recentemente se apresentou, no Masp, a exposição de uma escultora figurativa, Oxana, e foi observado um interesse bastante acentuado do público. Estamos ainda num período de transição. A escultura de Oxana não é para ver, mas para entender, com a simplicidade instintiva e o amor que ela pôs no criá-la.

Faz parte da bagagem, um dia de volta, do Romantismo. Não tenho receio em dizer que, sem se comover, náo adianta ver. Sei que é um caso em vias de extinção nestes decênios de corrida para o positivismo hedonístico do materialismo. 
Os que contemplam Arte, a famosa e a menos famosa, através dos séculos, sempre constituíram patrulhas, não legióes. Estava, nos anos 30, em frente ao Parthenon, com Léger e Le Corbusier, decepcionados pela sua destruição. - "É o tempo que faz assim" - disse Le Corbusier, talvez pensando no futuro de sua arquitetura.

\section{Legenda}

Obras de Oxana Narozniak: para

abrir o apetite dos colecionadores

Senhor \#95, I2 de janeiro de 1983, p.64-65 (P.M. Bardi)

VÊNUS NA CASA DE MASSAGEM

Um distinto publicitário me procurou para que eu o ajudasse na solução de um problema relativo à elaboraçáo de um anúncio que, em sua opinião, deveria marcar época. Tratava-se do lançamento de um laboratório de massagistas (não sabia se for men ou se for women) e como figuração a escolha recaíra sobre uma Vênus.

Prático dos gostos dos comunicadores e para não perder tempo aconselhei-o a recorrer à Vênus de Milo. O moço foi logo me dizendo não gostar desse mármore, que aliás só conhecia através de um cartão postal, mas que na verdade "já encheu demais."

Aprendo, então, que existem algumas Vênus que "enchem." A uma pergunta, responde-me que aquela monumental escultura é "estátua fria:" queria uma, "vivaz e quente" um símbolo feminino que provocasse atenção. Indiquei a coleção do Play-Boy, onde certamente encontraria algo que seria um "estouro." Objetou-me: não, o cliente quer, "Vênus no duro já que o mito é que deve aparecer. Revela-me confidencialmente que o nu será envolvido por uma multidáo de máos para alegorizar a massagem, portanto seu colega arte-finalista precisava de um corpo sadio e macio.

Deixei de lado os mármores e passei em seguida à pintura. Comecei a mostrar-lhe algumas Vênus da Renascença. Esquecendo-me do negócio das mãos que deveriam apalpar os músculos da escolhida, recorri a outra Vênus em pé. Não: ela deve ser deitada. Abro uma monografia de Giorgione e, em seguida, uma de Tiziano.

Meu freguês se anima um pouco mais. Porém quando alguém é jejuno como o Burro de Buridano (para aqueles que, felizmente, ignoram a história da Filosofia, devo dizer que se trata da figura proposta por João $B$, no séc. XIX, em que o burro faminto é posto entre dois montes de feno e fica indeciso quanto ao primeiro monte que deve abocanhar e ... acaba morrendo de fome) quer ver outras Vênus. De passagem aparecem, (para mim as mais fantásticas) as de Cranach o Velho, consideradas com este comentário do rapaz: "Esta é boa, mas ela deveria estar deitada em vez que massagem se faz em posição horizontal."

Não serve a famosa, não bem Vênus, porém facilmente promovível a tanto, de Boucher: deitada e, por felicidade, numa cama, de costas; mas não está estendida numa postura apropriada a um gabinete de massagem, que está sendo laçado por uma comunicação publicitária, já que as pernas estáo levemente abertas.

- E se passarmos da História para a Crônica?

Meu Burrinho de Buridano, uma vez explicada à diferença entre tautologia $\mathrm{e}$ reportagem, aceita considerar uma Vênus dos nossos dias. Fica indeciso. Volta atrás: afinal lhe encomendaram encontrar a figurinha mítica da própria considerada, domesticamente, aquela que fez virar a cabeça de Marte, nada menos, um militar também ele, no duro. Rejeita a proposta de uma bela nudez impressionista de Renoir; não quer Coubert por demais realista; nem a coleção de Iracemas que nossos acadêmicos pintaram tendo como modelo algumas bem-dotadas mulatinhas.

$\mathrm{O}$ pretensioso torce o nariz à vista de uma volumosa Vênus de Milton Dacosta, a qual, em minha opinião, serviria muito bem aos propósitos das mãos dos massagistas, constituindo novidade e adequado golpe publicitário.

Voltamos a considerar a arte do passado, sem contudo achar a preferida. Gostei de ver a repulsa do rapaz por certas Evas dos períodos Romântico e Gótico, julgadas por demais vulgares, sem perfumes de alcova primitivas e primárias, sem graça, numa palavra não entendia o nu tratado sem 
savair faire. Voltei a Botticelli, a Bronzino, aos mestres das Fêtes Galantes, aos acadêmicos da Europa inteira que pintavam Vênus sem dar-lhes este nome, porém na intenção de exaltar o chuchu. Sem sucesso.

O impassível supervisor de minha fototeca nâo conseguia encontrar a sujeira destinada ao anúncio, e cheguei a pensar em enquadrá-lo na lei de segurança contra a categoria dos pernósticos (como devia ser o animal de Buridano.) Tudo isto (para mim muito divertido) levou-me a pensar a respeito dos encontros e das escolhas das Vênus, no caso reduzidas ao denominado nu de uma jovem em flor ou por aí, as candidatas vitoriosas e derrotadas dos Concursos de Beleza que, apesar de ter a Beleza tomado outros rumos no pincel do pintor, representam o ponto alto da importância da fauna feminina.

Difícil hoje determinar um conceito razoável de perfeição sensível do ser e na aparência da mulher. Nós que, por profissão, nos interessamos pelos problemas, vemos como a representação da mulher varia com o tempo, mas de qualquer forma como perene símbolo da Beleza que desde Platão ("o privilégio de ser a mais evidente e a mais amável de todas as substâncias perfeitas") vai mudando, mudando, até virar caricatura, como dizia antigamente Monteiro Lobato ao censurar a audaciosa moça Anita Malfatti, rejeitada por pintar caras amarelas ou verdes, certamente não Vênus, obedecendo às novas tendências dos Expressionistas.

Curioso conhecer-se o pensamento dos leigos, a perplexidade e o raciocínio desinformado daquele que me procurou para um servicinho de rotina. Interessou-me bastante, oferecendo-me a possibilidade de chegar à conclusão que, no tocante à Estética, vivemos num mundo em transição. Tanto assim que dias atrás um executivo me convidou para sua mansão a fim de mostrar (entusiasmado) uma tela de Picasso, uma figura com três olhos e dois narizes. Durante a conversa contei o caso do publicitário.

Assistia-nos a esposa do meu anfitrião, por sinal uma autêntica Vênus, mas naturalmente revestida de sua condição de senhora da sociedade.

\section{Legenda}

Vênus de Urbino, de Tiziano:

desprezada pela publicidade

Senhor \#96, I9 de janeiro de 1983, p.69 (P.M. Bardi)

Os ESCULTORES-ARQUITETOS

Um dos mestres da escultura italiana contemporânea, Arturo Martini, escrevia em 42, de Carrara, onde eslava "massacrando mármore sobre mármore.”

"Trabalho em silêncio e escondido, para ver se afinal vai sair das minhas mãos a forma eterna do costume moderno, e espero, mas até agora nada ..." Martini era figurativo, como os outros dois grandes: Marino Marini e Giacomo Manzú. Foi com estes amigos que me instrui no amar a arte da Escultura, fautor da tradição, como de resto continuo a ser, vigiado e, pode ser, pressionado por ela. Aliás, quando o editor Abrams, de Nova York, dedicou uma monografia a Marini, eu mesmo fui escolhido para escrever o texto.

Passaram os decênios e, vindo ao Brasil, encontrei bons escultores, realmente de meu interesse. Assisti ao repensamento de Vítor Brecheret, o qual, além de figurativo, começou a raciocinar no Informal.
Abri, no Museu de Arte de São Paulo, a exposição, "Um Século de Escultura no Brasil" em colaboração com Jacob Klintowitz, reservando a ele o grupo do Informal e a mim o do Figurativo. Combinamos uma seção particular para dar conta da passagem de uma a outra manifestação de Brecheret, Bruno Giorgi, Felícia Leirner e outros que ajeitaram sua arte nas novas expressóes. Neste período de transição, sinto-me um dos inúmeros cidadãos que ainda se devem atualizar, como Giulio Carlo Argan disse certa vez, quase num verbete de Enciclopédia, o qual traduzo, pois é fundamental para nos aproximarmos dos afigurativos: "Náo se trata de uma escolha livre; é a condição de necessidade em que a arte, considerada através de toda uma tradição cultural como forma, vem a se encontrar numa sociedade que desvaloriza a forma ou não reconhece mais na linguagem o modo essencial da comunicação entre os homens ... O artista 
existe e existe porque faz: não diz o que deve ou quer fazer no e para o mundo, cabe ao mundo dar um senso ao que ele faz."

O Informal é, afinal, forma. Tem sua presença no cotidiano. Para nós, que manuseamos objetos nos recintos maldefinidos de museus, cabe-nos algumas responsabilidades na definição da arte. A advertência de Argan é sugestão correta: somos nós todos que devemos dar um "senso" ao que o artista faz. Cada um é participante. Devo lembrar que no Masp, em 50, quando inauguramos a Vitrina das formas, coloquei, num sintético panorama histórico que ia desde as pedras do Neolítico até as produçóes do Oitocentos, uma máquina de escrever para representar nosso século. Objeto de arte? O "mundo" não gostou, achou excêntrica e ofensiva a iniciativa, sem contar as condenaçóes pelo "mau gosto."

Estava no ar a lenta reconsideração e aceitação das propostas das vanguardas, que atribuíam valor de arte ao objeto, ativadas pelos Futuristas, que exaltavam a máquina e o novo dinamismo, descarga tremenda contra a Tradição, abertura para o infinito das possibilidades. Fídias, Antelami, Donatel, Bernini. Rodin, postos de castigo.

Às vezes, indisponho-me com preocupaçóes e até contrariedades a respeito do Informal. Náo com os produtores categorizados, mas com os da Academia que, como se deu com o Abstrato na pintura, aquartelou imensas falanges de penetras, os quais, "sem arte nem parte,” empastelaram a situação.

A Pinacoteca hospeda hoje um profissional. O que me dá prazer constatar, na arte de Emanoel Araújo, é a simbiose entre arquitetura e escultura. Estas artes são íntimas uma com a outra, desde a Antiguidade: o escultor contribuindo no preparo da aparência exterior ou no modelar os elementos. A coluna, a base e o capitel são obras de escultor, obedecendo às prescriçóes estéticas. O Partenon é grandiosa obra de escultura, sem contar o que lhe está próximo, o Erectêion. E a autêntica fábula plástica da arquitetura da índia?

Nos anos 20, quando Le Corbusier lança o jejum da machine-à-habiter, a decoraçáo, os acabamentos de fachada vão desaparecendo. É o tempo da arquitetura dita hospitalar: paredes lisas, rigidamente imaculadas, portas sem relevos, tudo calculado para não "embelezar" nada. Também para o mestre franco-suíço o jejum não durou por longo tempo: a Capela de Ronchamp é mais um bloco escultórico do que propriamente uma arquitetura.

Menciono sucintamente estas notícias pois me parece que Emanoel é um arquiteto, num certo sentido, voltado à construção. Suas peças metálicas são obras moduladas com talento formal e destacam-se quando servem à arquitetura, ao nela se instalarem, dando relevo, integração e animação à parede.

Tudo isto pode criar uma maneira de considerar o binônimo arquitetura-escultura. Quero somente aproximar-me ao modo emanoelino, deixando para o visitante dar "senso" ao que vê, como advertia Argan.

\section{Legenda}

Obra do Emanoel Araújo: um artista voltado para a construção

\section{Senhor \#97, 26 de janeiro de 1983, p.69 (P.M. Bardi)}

O TALENTO EM POLIEDRO

Convocada pelo Canal 4 do Sílvio Santos, uma multidão de amigos de Maurício de Souza reuniu-se no último dia ro para lhe dar um abraço, caseiramente, como se faz nos aniversários. A única diferença era que Maurício estava entronizado numa cadeira Savonarola e o cenário mostrava, ao lado, duas grandiosas fileiras de colunas, com a função de representar a Grécia como símbolo da Cultura.

A fila foi espetacular: antigos colaboradores do criador da Mônica, jornalistas, admiradores, colegas e, dulcis in fundo, os familiares: uma centenária senhora avó, a esposa, filhas e parentes, cada um devidamente apresentado pelo simpático J. Silvestre, combinador de elogios e ajeitador de currículos.

Só faltaram as velinhas para serem apagadas, substituídas pelos holofotes, além da confusão de praxe nas festinhas caseiras. No entanto: orquestra animada e, no final, um gostoso balé de máscaras, alusivo aos personagens do desenhista. 
Por que o diretor de um museu, apelido este que lembra poeira e cupins, estava presente? O redator de Senhor recebeu o convite por ter apresentado há alguns anos, na Casa onde são hóspedes Rafael, Ticiano, Velazquez, Cézanne e Van Gogh, um jovem e fino rabiscador de figurinhas.

Atualmente está aberta no Masp uma ampla resenha de ilustradores de revistas e jornais, um setor pontualmente desconsiderado nas pomposas bienais e nos salóes envolvidos em pensar a arte de elite, com os patróes desses antediluvianos estabelecimentos murmurando ainda, "arte pela arte" ignorantes cultivadores do prescrito nos manuais que espartilham a arte em maior e menor, estando os ilustradores a meio caminho entre elas.

Ninguém nega a singularidade dos excelentes, dos inventores, dos mestres; mas as separaçóes, o classificar, distinguir e premiar são fatos superados. Uma das denominaçóes mais estúpidas é a de embrulhar o trabalho popular das artes no pacote do "folclore."

Seja como for, festejamos Mônica e seu pai. O caso do Maurício é, no Brasil, único: alguém que se comunica com milhóes de pessoas, em vez do restrito agrupamento elitista. A arte para camadas da burguesia em ascensão representa status, ornamento do poder e da riqueza adquirida, senso de distinção, fachada; arte que geralmente não tem uma função especifica, que não serve para reforçar a cultura, as emoçóes, a moral, tendendo mais a satisfazer pretensôes sofisticadas.

Porém numa civilização que vai ao encontro da evolução da cultura popular, deve ser considerada também como atividade essencial a dos artistas que se dedicam à massa. Náo resta a menor dúvida de que a arte de origem romântica ou idealista, sob a influência das teorias positivistas e marxistas, andou desembocando no mais amplo domínio da sociologia da cultura.

O produto de grande consumo deve ser encarado como o reflexo mais característico da vida contemporânea, em suas contrastantes estruturas existenciais. É difícil, senão impossível, peneirar o que é arte representativa em nossos tempos, ainda à espera de definiçốes. Parece não muito certa a definição de Adler, no biblesco Kunstzoàologie: "Em cada tempo o que vem admirado, discutido e adquirido de um público como arte é arte para aquele público daquele tempo. O que prevê vários grupos de público: a massa, a burguesia, as elites, os fautores das ideologias socialistas e tantas outras preferências."

$\mathrm{Na}$ produção para as massas existem elementos prático-in-telectuais que contribuem para a educação popular. Pode ser lembrado o que na Idade Média se pintava nos afrescos das igrejas, ou nos palácios (com a finalidade de instruir o povo através das parábolas espirituais, ou do "bom governo" político.)

Existe uma correspondência entre artistas e consumidor, determinando o elemento decisivo do espírito de uma sociedade. Se juntarmos as produçóes do Maurício àquelas que em outros centros de divulgação, na Europa e nos Estados Unidos, são lançadas periodicamente no mercado, apreende-se a dimensão de um acontecimento da arte seguindo caminhos tipicamente antitradicionais. Arte, em certo sentido industrializada, participante das mudanças que a tecnologia vai impondo nas transformaçôes próprias do desenvolver das estratificaçóes sociais.

Maurício de Souza, neste setor, é hoje um dos elementos internacionalmente mais expressivos. Tem a particularidade de cumprir uma função pedagógico-educativa através da vida que dá aos seus personagens que dialogam com bom humor. Ele anima uma comunicação universalizante, aceita por fruidores de outras tradiçóes, línguas e costumes, numa evidente prova da validade da proposta. Trata-se de uma centena de personagens, dos quais os mais conhecidos são Mônica e Cebolinha, e depois Cascão, Bidu, Magali, Horácio, Tina, Chico Bento, Pelezinho, Os Sousa, Astronauta, Anjinho, Jotalhão e outros mais.

O talento de Maurício é poliédrico, de facetas espelhadas nos mais diversos campos da psicologia e da ação, todas por sua vez, refletidas na personagem que forma número em massas bem conhecidas e às quais o artista vai ao encontro 
periodicamente apresentando amigos. Maurício cria esses amigos, desenhando-os, confiando-os depois à colmeia obreira de dezenas e dezenas de assessores que os batizam, limpa, vestem e ambientam, como se deu com uma de suas crias: o comunicador máximo do Brasil pediu emprestado a Shakespeare o teatro e a música do "Romeu e Julieta" para remanipular os dois namorados como Mônica e Cebolinha, obtendo o sucesso de sempre.

Senhor \#98, 2 de fevereiro de 1983, p.69 (P.M. Bardi)

A veZ DE BRAsília

A contínua expansão e estruturação da capital do País, inclui naturalmente o setor cultura. Além dos grandes órgãos da administração governamental que a propóem e a difundem no País, existem iniciativas cívicas que visam ao desenvolvimento cotidiano do indispensável e essencial ao bem público em termos de lazer.

Se pensarmos o quanto os norte- americanos se preocuparam em instituir a soberania da cultura em Washington só então é que nos daremos conta dos passos que ainda precisam ser dados para que nossa nova e esplêndida Brasília também tenha a sua.

Conhece-se muito bem as andanças da cultura: ela marcha a passos de tartaruga, lenta e circunspecta no avançar, diria meditativa. Bom será lembrar-se disso em tempos de happenings. A cultura é resultado de um labor bem-planejado, paciente, não ocasional, sem exclusão das arrancadas. Pela minha experiência pessoal, eu diria arrancada mais de singularidades que de repartiçôes. Valem os polêmicos, os ambiciosos, os visionários. Se o Brasil pode hoje mostrar um museu de âmbito internacional, o Masp, isto se deve ao bâtisseur d'avenir Assis Chateaubriand o qual, volente nolente, por meios considerados escandalosos, numa São Paulo que só se interessava por assuntos econômicos, criou e impôs. E já lá vão 35 anos.

Fico imaginando alguém que um dia, espero próximo, resolve dar a Brasília uma sua National Gallery ou uma Smithsonian Foundation. Estou certo de que lá chegaremos, pois confio na cultura e no Brasil.

Deixando de lado o futurologismo, eis que acabo de visitar em Brasília uma instituição da qual pouco, para não se dizer nada, se sabe, proposta e realizada pela Caixa Econômica Federal. Cuidando da memória da tradicional instituição, fundada por Dom Pedro II em I86I como Monte de Socorro, foram coletados e reunidos antigos pertences de trabalho, como cofres, móveis, balancinhas para pesar pedras preciosas, moedas, livros contábeis, máquinas, desde às destinadas à extração de loterias até os computadores, e máquinas de escrever, gráfica e tudo quanto representou sempre a atividade bancária, até mesmo um oitocentesco escritório da Caixa descoberto em Mato Grosso.

Um curioso poderá observar uma extraordinária quantidade de peças bem ilustrativa da vida brasileira, como cadernetas pertencentes a proprietários de escravos e mesmo de escravos que com suas economias compravam a liberdade.

Todo este material está agora disposto na sede em Brasília formando um atraente museu. É parte do Conjunto Cultural da Caixa que compreende uma frequentada biblioteca e uma galeria de arte. Nesta última estão alinhadas obras de artistas contemporâneos brasileiros adquiridas nestes últimos anos, em parte encomendadas atendendo a celebraçóes de eventos, para ilustrar bilhetes lotéricos com temas dedicados a São João, Independência, Natal etc.

Dá-nos algum prazer constatar o empenho dos autores da iniciativa que, saindo do específico da memória da Caixa, procuram ampliar o interesse cultural, utilizando também um excelente auditório para representaçóes de eventos na atual Brasília, ainda pouco rica em diversóes e, portanto, propiciar algum lazer aos que ali moram ou estáo de passagem.

O Centro desenvolve uma atividade cultural digna de nota. Poderia ser ainda mais apreciada atualizando sua atividade com exposiçôes periódicas recorrendo ao 
acervo próprio do depósito ou estabelecendo intercâmbios, ganhando, assim, mais visitantes. De qualquer jeito, a direção da Caixa está animada e pretende realizar novos e proveitosos empreendimentos.

\section{Legenda}

O conjunto cultural de Caixa: investimento na memória

Senhor \#99, 9 de fevereiro de 1983, p.69 (P.M. Bardi)

Quando Ambroise Vollard, um dos marchands dos impressionistas, teve a coragem de organizar uma exposição de Cézanne, contou em seu livro de memórias: (por que um editor brasileiro não o manda traduzir?) "Devia-se notar em primeiro lugar a indignação de certos artistas que não se limitavam a gostar de escândalos, mas, na convicção de que aquela pintura pudesse encontrar adquirentes, se consideravam lesados nos seus interesses, e não menos ofendidos em sua dignidade. Lembro ainda o juízo de um crítico de arte do Journal des Artistes que denunciava a 'dolorosa visão daquelas atrocidades ao óleo'...” Ao longo de um século as coisas pouco mudaram. A evolução da arte não é, e não foi, acompanhada de uma compreensão geral. Numerosas são as causas, inclusive as referentes ao comportamento dos críticos de arte. (Deles noto um caso singular: alguns, para que saibam que são os tais, assinam seus textos como "membro da Associação Internacional dos Críticos de Arte," visando, com isto, exibir um prestígio capaz de impressionar os matutos.)

O caso de Cézanne, penso, é sempre possível, em face da operosidade de pintores que vivem isolados; por outro lado, é preciso que os Ambroise Vollard sejam numerosos. De vez em quando, descobrem-se obras de artistas dos quais nada ou muito pouco se sabe, não só entre os viventes, mas também entre os que operaram no século passado, aqueles que a turminha da Sociarte apelida de "acadêmicos."

Nos últimos decênios, várias e surpreendentes foram as reconsideraçôes de elementos de valor que foram guindados a uma justa posição. Lembremo-nos de uma: Ismael Nery, autêntico mestre, inexplicavelmente esquecido; e o que dizer de Domingos de Toledo Piza, outra personalidade de extraordinário vigor?

Em tempos de consumismo, o que influi é o circular de nomes de produtos, a publicidade que se impóe e acaba vencendo. $\mathrm{O}$ sistema também é válido para os artistas, dentre os quais os mais expertos náo deixam de cultivá-lo. Com isto, elementos bem medíocres, mais ou menos, freneticamente se lançam na própria promoção, conseguindo sempre estar na crista, usando de todos os meios para aparecer e, a seu modo, vencer, exibindo a cada momento o cheque especial Banespa.

Cèzanne não pertencia à turma. Messonier sim. Quando o pintor de Aix-en-Provence finalmente conseguiu expor em Paris, lá chegou modestamente com suas telas enroladas, como conta seu marchand, provocando até ciúmes e protestos.

Em nossa praça desembarcam, às vezes, bons pintores, vindos de outros Estados, inexperientes e tímidos, sem alcançar qualquer sucesso, fechando as exposiçóes individuais sem vender seus trabalhos, isto por que lhes falta divulgação, o palavrório da crítica, e por não terem acesso aos presumíveis colecionadores.

Estas notas são escritas para registrar justamente a falta de interessados na arte contemporânea, salvo a dos arranjadores de presença e grupos de pressão. Assistem-se a exposiçóes de seguro interesse até mesmo em museus, sem qualquer resposta. Isto numa metrópole altamente abonada.

Os que se propóem a juntar pinturas (da escultura nem é bom falar) se arregimentam no pelotão dos assim ditos investidores que só pensam em potencialidade, descobridores que acham que arte é só negócio e que portanto se fixam em assinaturas constantes nos boletins mercantis. 
$$
\sim
$$

Sempre foi difícil explicar à respeitável camada que tem a chave das burras e convencê-las de que arte não é apenas cifrão, mas também um fato de cultura; lembramos à dita camada que mesmo $\mathrm{cm}$ termos de investimento devem efetuar aquisiçóes de boa perspectiva financeira, como as obras de artistas que começam, logicamente os de talento. Tudo está em se interessar pelo problema arte, prevendo as futuras posiçóes. Mas quantos são
\end{abstract}

os assim denominados amadores que, diante de uma tela, se entusiasmam pelo encontro de um prazer estético e não pensam na historieta do bom negócio?

Os que compraram obras de Cèzanne em 1906, na Galeria de Vollard, acertaram: "aquelas atrocidades ao óleo" entraram na História e hoje alcançam milhōes de dólares na Sotheby.

\section{Legenda}

Domingos Piza, Paisagem: justiça 9

Cèzanne, Paisagem, atrocidade

Senhor \#IOO-IOI, I6 e 23 de fevereiro de I983, p.8I (P.M. Bardi)

FALANDO DE PRIVILÉGIOS

Os manuais que tratam de artes plásticas as dividem em Arquitetura, Escultura e Pintura. De Arquitetura, nossos críticos, pouco, para não dizer quase nunca, escrevem, o mesmo ocorrendo com a Escultura, sendo reservado à Pintura o melhor da prosa.

A Pintura, que se manifesta em numerosas seçóes, é citada quando é Pintura a óleo. Raramente se leem artigos dedicados a artistas ilustradores, chargistas, caricaturistas.

Este último recinto, apesar de ter presença cotidiana nos jornais e revistas, não goza da consideração que, a meu ver, mereceria, pois do ponto de vista social e moral representa uma atividade incrivelmente artística. Lembro-me que quando organizei, no Masp, uma grande exposição de Saul Steinberg, a curiosidade do público foi notada, porém as críticas não apareceram, como, aliás, já se esperava. Maior relevo foi dado à mostra internacional de historietas em quadrinhos, todavia náo com o interesse que se reserva em geral à Pintura a óleo.

É de se pensar: óleo, pastel, aquarela, lápis, nanquim, fotomontagens etc., são técnicas da Pintura. Mas é a tela que goza de popularidade entre os críticos e seus leitores.

Há semanas lembrou-se, nesta página, o criador da Mônica, Maurício de Souza, por ter recebido, na SBT, uma justa homenagem da qual participaram eminentes personalidades. Para confirmar o que digo acima, não se leram artigos de crítica nos jornais.
Colaborando com minha tese, Márcia Vicaren, leitora de Senhor, me envia o recorte de um artigo de Warren Hoge, de 24 de dezembro passado, especial para o The New York Times sob o título "In Brazil at Christmas, the Red Noses are Probably Sunburn." A página traz este comentário: "É verdade que Papai Noel é Santa Claus?" grita um desiludido garoto ao pai que lê uma manchete de jornal sobre a terrível dívida externa brasileira, em cartoon publicado esta semana. Cabisbaixo, o garoto se retira dizendo: "Que vexame! Até o Papai Noel é emprestado!" A ilustração é a charge de Fortuna, da Folha de S.Paulo, que aqui se reproduz.

Trata-se de um esplêndido desenho de um dos nossos mais espirituosos pintores que se exprimem no setor assim definido Caricatura. Não se trata da arte dita, "menor" se o próprio Leonardo da Vinci já se exercitava nestas expressóes grotescas.

O senso polêmico e satírico de Fortuna é natural, de um jeito absolutamente pessoal, sempre centrado em situaçóes de crônica que denunciam inconveniências necessitadas de intervençóes punitivas. Nisto Fortuna é mestre e se exprime com bonomia, porém incisivo, direto e persuasivo. Trazendo a esta página o problema Caricatura, aproveito a ocasiáo para informar que o Masp está programando uma exposiçáo dedicada à matéria em questão, recolhendo tudo que de singular se produziu no Brasil, desde um desenho humorístico que, se acredita, inaugurou aqui o sistema que, na Europa, se costuma atribuir a Gian 
Lorenzo Bernini que, se encontrando em Paris, mandou pedir a Luís XIV que deixasse caricaturar, de maneira "laid et ridicule" certos personagens da Corte.

\section{Legenda}

Fortuna, charge. Folha de S.Paulo. dez. 82: uma "arte menor?"

Senhor \#IO2, 2 de março de I983, p.69 (P.M. Bardi)

AMOR À TIPOGRAFIA

Quem transa com a imprensa é natural que se sinta em casa entre cavaletes de tipos, maquinário tradicional ou sofisticado e papel empilhado, enfim, um conjunto de elementos que tradicionalmente denominamos tipografia.

Nós, veteranos, tivemos as primeiras experiências nas topografias mesmo, vendo os oficiais compondo à mão, juntando tipos, letra por letra para formar palavras. Ficávamos deslumbrados ao ver como manuseavam as linhas, uma a uma para, findo o trabalho, amarrá-las com barbante formando um bloco para tirar as primeiras provas a fim de serem corrigidas. Em seguida era o processo de paginação que, uma vez concluído, era repassado à máquina de impressão.

Es primeiras aproximaçóes representavam um encanto, um verdadeiro milagre que vinha dos fins do Quatrocentos. Mais tarde, apareceram as linotipos. Mas já não era a mesma coisa. O linotipista nâo mais o tipógrafo, já que dele nos ficava a impressão de um datilógrafo. Ensaiava-se uma revolução, e hoje típógrafo e linotipista, máquinas Marinoni, tudo foi abocanhado pelo off-set. Os que porfiam neste último sistema nem sabem como foi o passado de sua Profissão.

Encontro entre meus antigos livros o campionário da tipografia de minha cidade natal, La Spezia. Posso este livro desde minha mocidade, mas foi editado em I887 por uma empresa fundada em i844. Era uma loja de porta aberta, onde passavam horas para ver sair o seminário local dos conservadores.

Depois, apareceu outra tipografia, mas esta era de um fulano que ostentava a gravata preta solta, típica dos anarquistas, os verdadeiros, chefiados por Malatesta. Naquela gráfica se publicava Il Libertário, um órgão francamente incendiário. Raros eram seus leitores na cidade, enquanto grande número de exemplares era exportado para os italianos emigrados e de tendências extremistas.

Sem me interessar muito pelas tintas políticas, interessava-me pela produção, pelo contraste entre as duas tipografias, a antiga burguesa dos herdeiros Argiroffo e a nova do agitador Binazzi. Da primeira, obtive o campionário que agora reabro, recuando no tempo, com saudade dos elzevires e dos bastoni, os ornatos para emoldurar as páginas. E mais: os tipos de madeira que eram feitos nas próprias oficinas, com o maior capricho.

Hoje não existem mais entalhadores para produzir letras ou letreiros. Os tipos são de metal ou então a chamada letra-set ou fotoletra. De vez em quando se descobre um antigo cartaz tipográfico, verdadeira relíquia, como o é qualquer catálogo do qual falo.

Na exposição "O objeto esquecido" que estou preparando, pretendo incluir uma seção dedicada à tipografia da qual ninguém se lembra mais, em homenagem ao artífice que compôs os textos das antigas leituras.

Fico pensando no Machado de Assis tipógrafo, a quem se deve render comovida homenagem. Será lembrada ainda à máquina cuja ilustração aparece na capa da "História da Tipografia" que publicamos quando da realizaçáo da mostra dedicada à Imprensa no Brasil, no Masp.

As figuras que reproduzimos são bem familiares a Machado, pois a tipografia do tempo do autor de Dom Casmurro era do mesmo estilo existente no mundo inteiro, praticada por artesãos que se consideravam evoluídos e até determinadores das lutas de classe. Sobre Machado de Assis: ele era ao mesmo tempo um homem de letras e das letras.

\section{Legenda}

Duas preciosidade da tipografia nacional: I82I e I900 
Senhor \#IO3, 9 de março de 1983, p.67 (P.M. Bardi)

ARTE PARA ENCHER OS OLHOS

A. R. Mengs, um dos mais pedantes controladores da arte neoclássica, o mais severo observador do prescrito uso das regras acadêmicas para produzir Beleza em termos rafaelescos, corajoso censor de Michelangelo, apelidava 'estilo viciado' a arte executada mais para os olhos do que para a razão. A razão deveria considerar mecanicamente a harmonia das linhas, o colorido suave, as sombras calculadas na base das tabelas e a composição bem proporcionada. Numa palavra, para o Teórico, famoso como pintor frio e sem élan, a pintura e a escultura derivavam de um conjunto de computaçóes fixas, rigidamente aplicadas, sem participação do temperamento do artista. O fruidor devia julgá-la, mirando o resultado. O artista 'viciado' era então aquele que não seguia ao pé da letra os ensinos acadêmicos.

Passados dois séculos, aquela definição de arte produzida para olhos e arte feita para a inteligência, depois de tantas aventuras formais, parece que vai merecendo melhor consideração. Os termos do julgamento? Deve-se ter presente que Mengs dizia que os "estilos viciados soam agradavelmente aos que não têm tato delicado capaz de fazê-los distinguir a verdadeira excelência dos homens grandes." Esta definição possibilita estabelecer, no panorama da arte contemporânea, posiçóes análogas, tendo-se em conta que os rumos estéticos mudaram radicalmente.

Existem, e são tantos, os que na produção artística se interessam mais pelas obras destinadas ao visual do que ao calcado na razáo. Pense-se na moda do Abstracionismo, ponto de partida de Kandinsky e Mondrian, para apenas lembrar duas tendências que irradiaram inumeráveis satélites: a pintura e a escultura, objetos para os olhos, convite à meditação para de certo modo refletir a caça aos símbolos para provocar emoçóes.

Isto posto, infere-se que o Abstracionismo representou uma reaçáo ao maneirismo figurativo, reduzido ao foro de anedota.

Neste século já em seu ocaso, o espraiar de manifestos e a cascata de novidades correndo solta criaram a confusão em curso.
As aceleradas iniciativas são de difícil apreciação e raramente encontramos aqueles que Mengs chama de 'homens grandes,' uma vez acabada a festa, para colocá-los no pedestal. De qualquer jeito, algumas consideraçóes devem ser feitas. A primeira é relativa ao Abstracionismo, uma manifestação mais para os olhos do que endereçada à razáo. Convenientemente propagada no após-guerra, aquela tendência, sem se preocupar com a comunicaçáo, tornou-se epidemia. Lembro-me do que aconteceu em nossas praças quando as Bienais paulistas descobriram os primeiros vírus. Pintores de um certo talento, que até então produziam naturezas mortas de um verismo irritante, passaram a se dedicar ao rabisco das manchas e, para melhor encontrar as misteriosas vias do inconsciente, pintavam de olhos fechados.

Foi um festival fora de série, feérico. As Bienais se encheram de surpreendentes telas, provocando contentamento por parte de todos aqueles que aspiravam à condição de estetas. Estava de volta a decoração na pintura, as "rafaelescas." Os quadros, que para serem vistos não necessitam de raciocínio, agradavam visualmente, juntamente com a cor ou o desenho do estofado de uma poltrona.

Certo dia, na casa de um poderoso, vi forrando as paredes enorme quantidade de telas abstratas e, pasmem, de um único pintor. Fiquei atônito, não tanto pelo espetáculo, quanto pela satisfação do proprietário, que, aos borbotóes, fazia correr razoável massa de adjetivos, infelizmente colocados no superlativo. Interrompi a alegria do tal ao perguntar-lhe se me faria o favor de reservar algum espaço para Francis Bacon e outros figurativos.

Confessou-me que não conhecia nenhum Bacon.

Sic transit gloriam dos que compram pinturas devidamente assinadas na parte direita, melhor ainda se datadas. Porque, bom que se diga, existe uma turma de compradores que assim raciocina, pensando mais em valores. Leem atentamente o boletim da Bolsa da Pintura, (a Escultura ainda não tem preços compensadores, 
ficando assim na sala de espera) telefonam aos escritórios dos corretores para saber como vai o mercado e correm, sôfregos, aos coquetéis dos leilóes. $\mathrm{O}$ restante já se sabe.

Nos leilóes as pinturas abstratas desapareceram. No momento a moda é a dos figurativos. $\mathrm{O}$ colecionador, não que tenha sido descoberta a inconsistência da pintura que não diz nada, verificou que agora está na moda o quadro que conta uma história qualquer, mas compreensível.
Como acontecia no tempo do abstracionista, o colecionador continua comprando os autores já afirmados, com curriculum escrito em letras de ouro, seu custo denunciando a valia. E só lembrar o fenômeno Frans Post.

Legenda

Angélica Acorrentada, de Ingres:

para delírio dos acadêmicos

Senhor \#IO4, I6 de março de I983, p.8I (P.M. Bardi)

O vírus do KITSCH

O Kitsch é fenômeno bastante generalizado, não se circunscrevendo somente a manifestaçóes bibelotescas, mas a qualquer outra, não excluída a política.

Quando ocorrem pleitos eleitorais, (diretos ou indiretos) os candidatos a salvadores da Pátria, os comitês que se encarregam de promover e veicular as afirmaçóes, produzem safras generosas de Kitsch: cartazes, bilhetinhos, chapeuzinhos, legendas, faixas de ruas, slogans, discursos laudatórios, promessas de bicos e cabides, sem contar as fotografias dos postulantes aos vários cargos, em que aparecem maquiladamente bonitos, engravatados, sorrisos giocondescos ou esparramados, certos de que representar o povo implica firmeza, austeridade, alto espírito público e consciência cívica, enfim, todas aquelas virtudes próprias do jogo eleitoral.

Existem políticos que conseguiram a cátedra, ou a perderam, como recordistas de Kitsch: arranjaram as mais estranhas (naturalmente no juízo de quem pensa em Política-Coisa-Séria) novidades comunicatórias para fazer saber ao coitado do possuidor de título eleitoral sua 'plataforma.'

Falando-se de Kitsch há que lembrar outro fato que deixou Sáo Paulo curioso: o kitschismo especulativo de proprietários de terra que vale Cr\$ I milhão o metro quadrado, os quais decidiram demolir casaróes da avenida Paulista, destruindo a Memória da qual tanto se fala (fala-se demais e pouco se faz para salvá-la.) $\mathrm{O}$ espetáculo oferecido por certos argentários paulistanos foi Kitsch, pois, como se disse linhas acima, o atributo estilístico não se circunscreve somente ao bibelô que consideramos de mau gosto. $\mathrm{O}$ fenômeno é generalizado, e nunca houve tempo (alegre) como o deste fim de século em que se está kitschiando.

Bastará refletir sobre os campeonatos de futebol para se formar uma ideia da corrida às atitudes e atividades mais imprevistas e o fora do comum descontrolado, a torcida exagerada, o ver nas coisas os lados de moda: kitschianos que viajam de carro ornamentado com bandeiras e vidros cheios de inscriçóes prenunciadoras de vitórias; gente até séria dando entrevistas assegurando 3 a I, 6 a 2 etc.; jornais seríssimos que abrem espaços na primeira página com grandes manchetes, dando a sensacional notícia de que um craque teve uma distensão muscular; seguem-se anomalias, piadas sérias, diversóes e tudo que satisfaça aos aficionados.

Esta nota poderia ser extensa com visos de uma enciclopédia a fim de anunciar uma exposiçáo no Masp dedicada ao Kitsch. Recebemos, em doação do Olney Kruse, uma riquíssima coleção de objetos expressivos do fenômeno típico do começo do século, coleção que completaremos com alguns Kitsch de nossa aquisição.

O discreto mas famoso sociólogo Kurt Kurtmann, estudioso do Kitsch, chegou à conclusão de que o mesmo outra coisa não é senão um vírus ainda não devidamente estudado e portanto sem condiçôes de ser combatido. Comparou-o ao vírus que provoca esta coisa banal mas cacete que é o resfriado mas que às vezes perdura a ponto de tornar-se crônico. De fato existem artistas que parecem mesmo 
ser inoculados com aqueles vírus, pois produzem invariavelmente um achadinho temático, sem nunca sair dos limites, pedantes, obstinados, cacetes.

Ignorando a bela carta de Gauguin, em que afirma ser dever dos pintores produzir somente para os amigos e náo para quem compra quadros, repetem o achadinho temático até o mesmo kitschiar. Um exemplo: o bravo Pedro Alexandrino que pintava sofregamente aqueles tachos de cobre polidos com bombril. Aconteceu que, num dado momento, o vírus KK se ausentou ou saiu de férias e o bom artista pintou um suculento bolo, talvez de noiva, obra mais tarde indo parar na galeria de um marchand. A 'natureza morta' ficou na parede ao longo de anos. Perguntado ao dono o motivo da invendabilidade, explicou que sua freguesia, apesar da ilustre assinatura e absoluta autenticidade do quadro, preferia pintura com tachos de cobre como Alexandrino habitualmente fazia, rejeitando qualquer outra composição do mestre.

O que nos leva a considerar o fato de que o vírus KK se insere também no assim dito, 'consumidor de arte' podendo ele ser o responsável pelo Kitsch pictórico que campeia. por aí afora.

\section{Legenda}

Do escritório ou do futebol, direto para os museus de arte

Senhor \#IO5, 23 de março de I983, p.82 (P.M. Bardi)

O VAlOR DA "ArTE MENOR"

Várias vezes, nesta página, os assuntos escorregam por caminhos que não correspondem ao rigor de um enquadramento na manifestação Arte. Os novos conceitos pertinentes ao labirinto desta imensa atividade, de qualquer modo, não vencem o dito rigor que herdamos e consolidamos academicamente. Agora se admite no recinto, ao lado das produçóes elitistas, inúmeras outras de complemento ou, como opinam os críticos, marginais.

Assim, eis a descoberta de um setor a que se deve atribuir importância de arte como criatividade, técnica e significado. Me ocorreu de participar, nada menos que como protagonista, de um comercial de trinta segundos de TV, para o lançamento do carro Alfa-Romeu 83, apreendendo o extraordinário trabalho que comporta uma comunicação desse gênero por parte de uma equipe, diria de artistas, composta de idealizadores, redatores, gráficos, cenógrafos, fotógrafos, cinegrafistas, iluminadores, gravadores de som, pintores, maquiladores, costureiros, operários. Cada um prático em sua arte, o grupo harmonizado numa disciplina com a insígnia da cordialidade.

Comandava o diretor Carlos Roberto de Barros, da Sol Criação e Tradução Cinema Publicitário: ordens curadas, rápido, provas e novas provas de fotografias e de dizeres na base da aprovação de obter o 'melhor' e, finalmente, o 'mais perfeito.' Eu mesmo operando como apresentador do design do carro, vi transcorrer horas. A equipe devia conseguir o máximo, produzindo uma 'arte-final' de consumo para milhares de telespectadores, combinar psicologia e estética, alcançar um resultado extremamente perceptível. Fizemos uma pausa na metade da operação: chegaram marmitas em que cada um pescou seu bocado. Depois da siesta, retomada do trabalho.

Pensava na arte da fotografia, no espetáculo de teatro, na imagem pictórica e, acima das circunstâncias singulares, numa nova realidade e, numa mais ampla função das artes o de se transferir do individual para o coletivo. Arte a serviço da massa e a maneira de servir. Pensava também nos artistas absolutamente anônimos, merecedores de aplauso que em geral é reservado para um simples pintor que ganha colunas num jornal para o registro de uma simples exposição.

A assim denominada crítica de arte, como se disse no começo, não se interessa pelos fatos de arte aparentemente marginais, descuido evidente por uma produção bem representativada contemporaneidade.

Esta nota pode significar um reparo a um hábito por demais atrasado e incrustado nas velhas delimitaçóes das artes, o desconsiderar os novos e já afirmados avanços que modificaram e modificam costumes superados no encarar os problemas da atualidade através da presença da Arte. 
Finalmente devemos inserir na Arte, depois do mais ou menos tolerado ingresso da fotografia e do cinema, uma infinidade de expressóes interessadas na formação da estética deste fim de século. Me parece oportuno nos dedicarmos também a este labor dos que atendem à produção dos filmes publicitários para TV, produçóes nas quais se somam engenhosidade, invenção e técnica, ou seja, Arte.

\section{Legenda}

Por trás de um simples anúncio, a invenção e a técnica de artistas ainda não reconhecidos

Senhor \#I06, 30 de março de I983, p.68 (P.M. Bardi)

UMA FEIRA PRECIPITADA

A Secretaria de Cultura do Estado encerrou seus trabalhos apresentando uma manifestação singular: reuniu em São Paulo artistas de todos os Estados, organizando uma série de eventos que se desenvolveram em quase todos os museus e centros culturais.

A finalidade foi ambiciosa: mostrar qual o ritmo das atividades dedicadas às artes, não exatamente um panorama, mas uma espécie de lembrete em dimensão nacional, uma proposta válida que intitularam caseiramente de Feira. De fato teve o sabor de feira.

Inaugurada num dos andares do prédio da Bienal com uma declaração do pianista João Carlos Martins, cada Estado mostrou, em stands, as produçóes mais variadas, particularmente objetos de folclore, acentuando mais o gosto popular do que o elitista. Em algumas seçôes observou-se individuais de pintores primitivos. O Acre, por exemplo, era representado por um único artista, Hélio Holanda Melo, especialista em paisagens de sua regiáo. A pintura prevaleceu, pois os organizadores deixaram livre a participação da amostragem, vendo-se entre bons mestres também a indispensável presença dos amadores. O espírito,repito, foi mesmo de feira. Ouviu-se a orquestra de Tatuí tocando 'Aquarela do Brasil' e composiçóes de Villa-Lobos.

Os leitores que se interessam pelos problemas da Cultura estão a par das discussóes e das polêmicas que envolveram a manifestação, prevalecendo as opinióes negativas.

Parece-me que a Feira não teve a repercussão devida. Afinal, concentravam-se na Locomotiva que conduz o Brasil, isto é, em São Paulo, secretarias de Cultura e personalidades do País inteiro. $\mathrm{Na}$ hora da inauguração não se encontrou nem o governador, nem o prefeito, nem o secretário de Cultura do município, nem artistas locais e nem mesmo o público que, bem ou mal, a reuniáo merecia.

Sei perfeitamente, e de longa data, que os certames de arte convocam o pessoal das grandes ocasióes quando o badalo jornalístico promove o espetáculo devidamente coquetelizado. De qualquer modo, parece-me que a ausência de autoridades e de ilustres decorados foi uma desatenção, para não dizer falta de educação.

Os convidados, pelo que conseguimos saber, voltaram aos seus Estados um pouco desiludidos com cordialidade paulista. Pode ser que a organização não tenha correspondido totalmente, porém a desculpa dos prepostos foi de que se tratava de Feira, desprendida de oficialidade, requinte, crônica social etc.

Como feira o sucesso foi atingido pois o público simples, o que náo paga ingresso para ver os esoterismos das Bienais, o público que gosta de apreciar o que sabe ver e entender, este não deixou de visitar a Feira de Cultura.

É preciso ter uma opinião sobre a Feira. A nossa é esta: outra vez que se organizar uma manifestação semelhante será necessário um pouco mais de tempo para o preparo. A Secretaria decidiu um pouco precipitadamente. Deveria ter despachado para cada Estado um emissário para aconselhar a respeito das participaçóes procurando escolher o que de mais singular se cria. De outro lado, nas exposiçóes o que mais interessa é a mise-en-scêne, dando atrativo à arquitetura ambiental, intercalando a improvisaçáo de eventos emergentes, a técnica dos macacos velhos que não faltam na praça. Apesar das eventuais falhas, deve-se reconhecer que a administração cultural do Estado, que entregou à nossa governança a papelada 
do futuro, não poupou esforços para montar uma Feira que, espera-se, tome a ser realizada nos próximos anos.

\section{Legenda}

Dança na Feira da Cultura, para alegria

do público que não paga ingresso

Senhor \#I07, 6 abril de 1983, p.64 (P.M. Bardi)

SURPRESAS NAS EDIÇÓES DE ARTE

Verifica-se, hoje, no Brasil, um notável desenvolvimento da editoria dedicada às artes. Rara a semana que náo registre o aparecimento de publicaçóes de grande interesse, ás vezes surpreendendo pelos temas tratados e, mais especialmente, pela singularidade das ediçóes.

Acabo de receber duas belíssimas obras: Pintores da Paisagem Paranaense e As Tanagras, a primeira editada pela Secretaria de Estado da Cultura do Paraná, enquanto a outra pela senhora Eva Klabin Rappaport.

A paisagem paranaense aparece pintada por artistas que passaram pela terra dos pinheirais, tanto no litoral como no interior, mostrando mar e araucárias, oferecendo-nos um conjunto de pitorescos panoramas, a começar por um dos mestres da Missão Artística Francesa, Jean- Baptiste Debret, observador verista, dono de um espírito elegante no traçar cordial, um pouco caseiro e penetrante.

Fazem companhia a Debret: João Leão Palliére, William Lloyd, William Michaud, enamorado ora da poética da floresta ora da pacata arquitetura da vida popular. Outros: Alfred Andersen, Lange de Morretes, Estanislau Traple, Theodoro de Bona e mais alguns modernos. É um caminhar pelo Paraná, onde se encontra além da paisagem também gente, sendo um dos mais próximos no tempo, Guido Viarc.

Na introdução do livro, Newton Carneiro, o bem-conhecido historiador, propóe uma repartição de fases, concentrando nos 'itinerantes' os estrangeiros dos quais relata o comportamento graças ás anotaçôes em que são registradas uma gama de eventos a ser inscrita no romantismo tradicional. $\mathrm{O}$ livro nos lembra alguns dos pintores documentadores de um período dos mais ricos pela movimentaçáo dos aspectos ecológicos e vitais da região. É um palmilhar por sertôes e um navegar em rios plácidos e encachoeirados, saber de queimadas, descobrir a Curitiba oitocentesca, pôr-do-sol deslumbrante, tropeiros e lavoura, em síntese: um apanhado esplêndido.

Os raros cultores de arte grega podem ver no Masp exemplos de estatuária do século v a.C., como também uma vitrina abrigando objetos da Antiguidade. $\mathrm{O}$ conjunto do Masp náo é mais um caso isolado, pois está no Brasil uma extraordinária coleção de Tanagras, recolhida no Rio de Janeiro por d.Eva Klabin Rappaport, inaugurando assim no colecionismo nacional um caso todo particular : na corrida aloucada para caçar pinturas dos nossos mestres, eis uma inteligente senhora que reuniu uma importante coleção de cerâmica da Grécia.

São excelentemente reproduzida, em um álbum-catálogo. D. Eva desde os I5 anos coleciona obras de arte, reunindo peças de um certo interesse, seguindo uma tradição familiar; sua irmã, d. Ema, em São Paulo, conseguiu juntar também notável e variado acervo de peças antigas.

D. Eva se propóe editar o catálogo da sua coleção. Este é o primeiro, por ela mesma compilado com a colaboração da conservadora Fernanda de Camargo e Almeida Moro e Lourdes Rego Novaes, conhecidas museólogas cariocas. $\mathrm{O}$ álbum fornece muitas informaçôes de ordem geral sobre a Tanagra, ídolo de devoção surgido na Beócia, objeto de culto iniciado na Grécia, produzido em extensa variedade de formas, sendo natural comparar-se à multiplicação das imagens em uso no Brasil no tempo da Colônia: o ex-voto oferecida a Nossa Senhora.

As Tanagras têm extensa variedade de feitura calcada na mitologia, fatos da vida quotidiana, especialmente teatrais. No catálogo Klabin temos um resumo do assunto, devendo-se contudo considerar que a coleção é bem selecionada, esplêndida contribuição, diria sugestão, aos colecionadores de arte para uma maior abertura em termos de história da arte. Uma espécie de nacionalismo, de feitura provinciana, limita o interesse pelas artes 
em tempos de aproximação e abertura sempre mais amplos e promissores para as esperadas vitórias do universalismo.

Vamos, ou pelo menos se espera operar num mundo confraternizado. Uma simples iniciativa, como pode à primeira vista parecer a de d. Eva, pode levar-nos a novos horizontes e alterar a visão daqueles que ainda pensam em termos de arte como fato municipal.

\section{Legenda}

Uma Tanagra representando Ícaro

Marinha, da Alfred E. Andersen

Senhor \#I08, I3 abril de I983, p.65 (P.M. Bardi)

A ARTE DO TROPEÇO

Já tive ocasiāo de lembrar aos leitores que as artes andaram perdendo um pouco daquele elitismo herdado da tradiçáo europeia, sendo sempre mais colocados nos pedestais os protagonistas badalados, saindo da acrópole os inúmeros artífices que operam nos vários setores erradamente definidos como 'complementares' da vivência das artes.

Em comentários anteriores falou-se de elementos que trabalham no campo da propaganda, seja escrita, falada ou televisionada Hoje, ao receber o belíssimo volume Anuário do Clube de Criação de Sáo Paulo, defronto-me com a oportunidade de recordar os participantes da estruturação cultural e estética do Brasil.

O Anuário condensa o resultado de uma matéria escolhida em 1982 e aprovada por um júri formado de 35 profissionais eleitos pelo voto direto; representa o melhor da produçáo do ano passado. Foram julgados, pelos mais conceituados profissionais da comunicação, nada menos que 1.648 itens, ao longo de quatro dias. Os trabalhos foram divididos por setores: $\mathrm{TV}$, rádio, imprensa, fotografia, ilustração, promoção e editorial.

A finalidade do Anuário, precipuamente, documentar e confirmar, até certo ponto polêmico, o conceito 'se não vende não é criativo.' No prefácio se lê: “Uma peça de comunicação não é clara, objetiva, não é persuasiva, não é atraente, não é nada. Ao julgar-se uma peca, se deve ou não entrar neste Anuário, o primeiro critério que um profissional usa é a eficiência. Se a peça comunica, se cumpre o seu objetivo de informação, se chacoalha a indiferença do consumidor, se consegue destaque da massa de informação.”

É claro que ao compor um anúncio dirigido a um consumidor indiferenciado ou de determinada categoria ou segmento social, deve- se ter o hard-sell, a finalidade da destinação. Assim o jeito é ser inventivo, marcar uma participação psicológica, o mise-en-page tornar-se empresa de singular percepção e responsabilidade: deve dar resultado.

Sem entrar no julgamento dos singulares trabalhos, realizado sempre por equipes, é de maravilhar como o Brasil conseguiu afirmar-se, mundialmente, nesta atividade que faz, como argutamente se lê no prefácio 'o consumidor tropeçar' em um anúncio impresso ou nos fugazes segundos da TV.

A estas equipes, que apelidaria de artistas, é atribuída a estética de massa, o design e a imaginação do dia-a-dia: a criação é "ingrediente que se coloca na receita da mensagem para que ela fique mais gostosa." Diga-se que "daquilo que é mais gostoso, a gente quer mais."

Eis uma afirmação que interessa ao protoplasma da arte.

Folheando o volume, encontramos boa quantidade de originais criaçóes: a fantasia e a finalidade do resultado entrelaçadas através de inventivas e trouvailles singulares, aquelas que vemos mais presentes na TV.

Trata-se de um ramo da arte todo especial, onde o saber e a intuição substanciam a mensagem, consequência e síntese do entendimento entre várias individualidades. Participar de uma destas produçóes de criatividade da propaganda, como já me ocorreu, significa constatar quanto e como este exercício tem conta das atuais tendências da arte que definimos 'culta.'

\section{Legenda}

Mostra de cinema Cartaz do Anuário 
Senhor \#I09, 20 abril de 1983, p.88 (P.M. Bardi)

A REVOLUÇÁO DOS BRINQUEDOS

Também para o brinquedo, o objeto de arte tão do agrado das crianças, chegam os tempos de mudanças ou da adaptação às novidades não mais mecânicas mas eletrônicas que estão tomando conta do cotidiano nas mais díspares regiôes do mundo.

Na recente Feira de Nuremberg o boom dos computadores e dos videojogos foi notado como promissor na produção dos brinquedos. Lemos no Die Welt, num artigo de Peter Schmalz, que "a profusão de novidades sugere que muito breve os lares alemães serão inundados por uma onda de ruídos extraterrenos. $\mathrm{O}$ computador pede passagem. A exemplo do jogo, 'Halma' transferido já no ano passado do tabuleiro para o sistema minichip, os técnicos e inventores trabalham com afinco na recriação eletrônica de jogos tradicionais."

Repetem-se os tempos em que a aparição do ídolo da Máquina marcou determinante influência no brinquedo destinado aos meninos, pouco variando o das meninas, que continuaram preferindo as bonecas. Está aberta na 'Fábrica' da Pompeia - o exemplar e dinâmico posto de lazer do Sesc na Capital paulista - uma grande exposição de brinquedos que confirma a evolução dos tempos, a mecânica tomando conta, enquanto a boneca continua em sua tradicional característica e preferência. Naturalmente não faltaram as 'modernizaçôes' da boneca. Viu-se na Feira uma, em tamanho natural, que anda, bastando mexer os braços para tirar a chupeta da boca, berrando até que a recebe de volta.

Mas a sensação é a eletrônica enxertada no brinquedo, o que leva o usuário a ingressar na era que distingue a civilização. No Japão e nos Estados Unidos a presença do brinquedo eletrônico já está em escala avançada, mais precisamente na ordem de $40 \%$ das vendas. Um fato consumado a sempre crescente aceitaçáo da novidade. Na Alemanha a porcentagem não chega a $6 \%$, notando-se uma certa resistência por parte dos fabricantes de brinquedos a jogar-se na aventura.

Aventura?

Pode ser, pois na Alemanha foi desencadeada forte reação contra a apariçáo do último grito, valendo o slogan 'Apertar botôes não desenvolve a inteligência.' Mas será que náo é a mesma coisa dar corda num brinquedo para que este se mova? $\mathrm{O}$ Nümberger Nachrichten comentou: "Uma coisa é certa: as empresas do ramo terão de habituar-se com esta onda eletrônica que invade os quartos das crianças. Mais depressa e melhor do que os adultos, os jovens acostumaram-se com ela. E também parece inevitável que, em escala ainda crescente, brincar significará apertar um botão e nada mais. Para remediar, só a dedicação dos pais e a imaginação fértil dos fabricantes de brinquedos. Negar-se a entrar na dança sem dúvida náo é soluçáo.”

E o Brasil?

Eis um problema de ordem industrial e, ao mesmo tempo, educativo que deveria provocar ampla discussáo para, entre outros motivos, ter-se a possibilidade de conhecer potencialidade e tendências dos novos fabricantes de brinquedos que, ao que tudo indica, na citada exposição da 'Fábrica' da Pompeia são numerosos e ativos.

\section{Legenda}

Exposição no Sesc Pompeia: uma reflexão sobra o potencial do mercado

Senhor \#IIO, 27 abril de I983, p.85 (P.M. Bardi)

Os HEROICOS MUSEUS DO INTERIOR

Esperanças para uma atividade maldita

A política que foi anunciada pelo secretário de Cultura do governo Montoro, João Pacheco Chaves, é a de intensificar a ação no Interior. Mais que oportuna a decisão, pois até hoje tudo se concentra nas capitais e pouco, para não dizer muito pouco, se destina aos outros centros.
Quando se abriu o Museu de Arte de São Paulo, seu fundador, Assis Chateaubriand, se preocupou com este problema. Foram tomadas várias iniciativas nos anos 50 , na tentativa de constituir um museu em Marília e outro em Pinhal, porém sem resultados. De fato, os tempos não eram 
propícios. Nos anos 60 o sr. Chateaubriand dedicou-se à criação de museus regionais, filiados ao Masp. Conseguiu-se alguma coisa em Campina Grande, na Paraíba, em Feira de Santana, na Bahia, em Porto Alegre e em outras cidades.

Hoje, o funcionamento dos museus de arte é mais promissor, existindo novas entidades no Estado de São Paulo, com atividades notáveis. Temos, por exemplo, boas notícias de Mococa e de Assis.

O Museu de Mococa, abrigado em belo prédio, foi fundado em 1972 por iniciativa do saudoso pintor Quirino da Silva. Sua esposa dona Cilda Dias, é de Mococa, motivo do interesse de Quirino, que conseguiu uma série de doaçóes por parte de pintores, escultores e gravadores, formando hoje um conjunto de obras que constituem um importante acervo, a começar por um grande bronze de Bruno Giorgi, também nascido em Mococa, e de obras de Tarsila do Amaral, Flávio de Carvalho, Ângelo Simeone, Walter Levy, Darel Valença, Gruber, Rebolo, Wesley Duke Lee, Lívio Abramo, Gino Bruno, Carlos Palatini.

O Museu de Mococa, agora dedicado ao seu iniciador Quirino da Silva, continua desempenhando seu programa que é, conforme a decisão do próprio Quirino, essencialmente didático com exposiçóes periódicas, seminários e cursos.

Outra entidade a ser citada no interior do Estado de São Paulo é o Museu de Pintura Primitiva de Assis, inaugurado em janeiro último pela Prefeitura local, formado basicamente com obras doadas pelo pesquisador de arte ingênua, José Nazareno Mimessi, daquela cidade. $\mathrm{O}$ abnegado doador, responsável também pela divulgação do museu em outros centros, abriu mão de mais de 200 peças e do rico arquivo que possuía para dar vida à instituição, colocando as peças à disposição do público e de pesquisadores. Fazem parte do acervo quadros de José Antônio da Silva, Agostinho Batista de Freitas, Chico da Silva, Crisaldo Morais, Eli Heil, Maria Auxiliadora e muitos outros. Além disso, o museu apresenta uma sala especial dedicada ao artista Ranchinho, natural de Assis, que pintou cenas da cidade e da região.

As iniciativas de Assis e de Mococa são exemplares e gratificamos para os que lidam com a arte e a cultura.

\section{Legenda}

Bronze, de Bruno Giorgi, orgulho do acervo da cidade de Mococa 9 Tela de José Antônio da Silva, um pintor presente em Assis

Senhor \#III, 4 de maio de I983, p.73 (P.M. Bardi)

Cinquenta Retratos do Brasil

Mês a mês, para não dizer dia a dia, o observador dá de cara com fatos empolgantes no avanço firme e decisivo desta atividade bem representativa que apelidamos de arte. Várias as tendências, nascentes os valores individuais, ricas as iniciativas e as contribuiçóes originais.

Já se disse que este redator acompanha o futurama das artes nacionais há quase quatro decênios, isto é, desde os tempos em que as coisas se desenvolviam sim, porém num ritmo não tão acelerado, ao qual pouco tinha acrescentado a Semana de Arte Moderna de 22, resultando um Modernismo restrito e bastante sonolento. É neste último decênio que tudo andou se abrindo em conquistas e realizaçóes realmente notáveis.

As novidades aparecem uma após a outra, e uma das últimas, pela singularidade do projeto, deve ser comentada nesta página: a pintora Gretta Sarfaty se apresenta numa exposição no Masp com um Autorretrato do Brasil e a Arte Aplicada publica um livro documentativo que se compóe de cinquenta retratos e depoimentos dos personagens. Um substancioso volume prefaciado por Sabina de Libman que conta que Gretta "trabalhou realmente de maneira excepcional, dedicando-se exclusivamente e tenazmente somente a este projeto, não mais aceitando outros convites de exposiçóes, passando todo o seu tempo nos encontros com os 'personagens' de todas as partes do Brasil, falando com eles, conhecendo-os, entrevistando-os, fotografando-os e fazendo-os colaborar ativamente com seus textos-depoimentos."

Por sua vez, no livro em três idiomas, Gretta nos dá o seu auto-retrato escrito: 
"Anos de trabalho, especulação profunda, autofotografando o meu corpo, minhas expressóes, meu rosto e depois destruindo, beatificando, erotizando, ironizando, violentando, mistificando, condicionando, exaltando estas minhas imagens."

Foi justamente este o motivo da dedicação a interpretar as lembranças dos 50 elementos escolhidos, dando a cada um o timbre do caráter, carimbadora a desenhista, acertando quase sempre. Para ela tudo correto. Para os retratados, naturalmente, algumas reservas, pois esta é a consequência da relaçáo entre os dois combinadores de um retrato. Cada um se vê e se sente outro nestes casos, porém quem está certo é, quase sempre, o que interpreta, o descobridor do espírito do 'sentenciado.' Veio nas figuras: Oscar Niemeyer, Pelé, Perissinoto, Raquel de Queiroz, Sílvio Santos e Alfredo Volpi bem como são.

Também os depoimentos ajudam a fixar os tipos. Volpi não escreveu, desenhou; o mesmo fez Menotti del Picchia; Pitanguy acerta seu conceito a respeito de beleza e faz um aceno sobre cirurgia; Henry Maksoud encabeça uma bem sociológica declaração com um; 'Somos todos extraordinários’ e assim por diante: um autêntico documento dos imersos e emergentes brasileiros que atuam no momento.

Tudo converge numa manifestação de padrão bem distinto, daqueles que se discutem.

Reduzindo o número de participantes a 50 náo significa que o propósito de Gretta seja excluir outros 500, pois as personagens brasileiras do momento atingem no mínimo este número.

Mas os não-beatificados neste altar fiquem sossegados pois a desenhista se propóe a continuar o trabalho.

\section{Legenda}

Menotti del Picchia, Pitanguy e Niemeyer, segundo Gretta Sarfaty

Senhor \#II2, II de maio de I983, p.73 (P.M. Bardi)

UM PINTOR DA AVENTURA HUMANA

Quem presta atenção aos problemas que se vão multiplicando na Pintura, através das propostas de grupos antigamente ditos de vanguarda, está a par das tendências que rasgam e remendam um exercido, até o começo do Século, comunicação de normal percepção.

Senão fácil, pelo menos não embaraçoso era opinar. O registro, depois, se complicou pois inúmeros devotados ao oficio se manifestaram por meio de novidades desconcertantes, dando impulso e agitação a uma fascinante Torre de Babel.

$\mathrm{Na}$ Torre, cada um de nós mantém suas preferências. Estão emergindo aceitaçóes para os que recusam qualquer elemento naturalista, exibindo outra realidade, a abstrata. Todavia continuam presentes os adeptos do figurai. Para quem tem o hábito de mexer mais com a história do que com a crônica do dia-a-dia, o julgar não se refere à temática, mas à consideração da mestria, do modo ou maneira de se expressar, o inventar, à engenhosidade, ao jeito de fundir, numa tela, ideias, sentimentos, originalidade e tantos outros lances de singular vivência e, naturalmente, de correção ou ruptura com a tradição. Quando apareceram Klee, Kandinsky, Miró e Companhia, os alôs eram entusiásticos, os mesmos reservados aos mestres do Expressionismo, do Surrealismo e até do Hiper-realismo. Neste Século de alucinante efervescência tudo vale.

Escrevi mais ou menos o que disse acima anos atrás, por ocasião da primeira exposição, no Masp, de Mino Carta, que hoje volta às nossas salas. Sua pintura continua a de sempre, porém a temática é outra. Antes era dedicada à paisagem, agora é de composiçáo, o gênero que o clássico abade Luigi Lanzi classificava como manifestaçáo prevalente, sendo os "compositores de histórias" diferenciados dos dedicados à, 'pintura inferior' isto é, os paisagistas, animalistas, floristas, marinistas, artífices de perspectivas e de bambochatas.

O ingresso de Mino no recinto do social me parece um fato natural, por ser ele ativo participante do cotidiano, presente a casos que favorecem a observação direta de comportamentos, atitudes, extravagâncias e sacrifícios. Por ser este redator curioso por crônicas antigas, narradas por 
fileiras de mestres, possibilitando conhecer fatos, aventuras e mitos humanos, talvez sua preferência, é satisfatório apresentar nesta Pinacoteca, ainda carente de pintores realistas, alguém que, acima do corrente bagatelar abstrato, pratica assuntos de vida.

A exposição se prestaria a uma discussão das mais vivas neste período labiríntico, também do ponto de vista dos precedentes no representar a realidade, desde Caravaggio e pintores espanhóis e flamengos do Seiscentos até Courbet O recorrer à realidade sempre constitui na Pintura motivo de surpresa e de reação, atitude talvez polêmica, pois se situava em contraposição a uma situação de maneiras cansadas.

Quando Roberto Longhi apresentou em 53 a mostra dos pintores da realidade na Lombardia, (Moroni, Moretto, Ceresa, Frà Galgario, Cifrondi, Ceruti) notou que a definição certa era 'pintura da realidade' e não, 'realismo' palavra, 'pesada e decisiva' como era certo usar 'maneira' em vez de 'maneirismo.'

Mino, em meio ao andamento de uma produção genérica bastante a serviço da decoração, insere uma chamada a outra poética, a relação direta com a ordem moral, o interesse pelos problemas existenciais, um meio de convencer, a intervenção na formação da sociedade, o participar da vida em lugar do se refugiar nos cômodos divertissements do Informal. É o mesmo caso, mutatis mutandis, de quando Courbet e seus seguidores agiram contra a corrente neogrega então ainda em moda, uma das inúmeras alternativas que marcam o desenvolvimento da arte.

Mino Carta póe na praça uma advertência, o convite a se interessar por uma arte que investe no problema da sociabilidade, o não fugir da realidade. $\mathrm{O}$ visitante observe, pense e julgue.

Legenda

América Latina ou a brava iuta

do peru, de Mino Carta

Senhor \#II3, I8 de maio de I983, p.7I (P.M. Bardi) UMA VISÃO CIENTÍ́FICA DA ARTE

O exame e definição de uma obra de arte é operação de laborioso saber. Numa certa época, bastavam os olhos e a experiência para acertar a autoria, técnica, época, valor, ofício dos assim chamados conhecedores. Mudaram os tempos também para nós: impôs-se o uso de raios X, a lâmpada de Wood, o uso da química e muitos outros sistemas, até os recentes empregos dos raios laser.

Cada um de nós que lida neste setor de responsabilidade tão perturbadora se dispóe à aceitação da colaboração científica, sempre útil. Mas ás vezes também constatamos que trabalhos feitos para acertar que determinada peça seja de tal pintor (nós usamos o termo autografa) são inúteis pois a evidência é total.

Meses atrás ocorreu sermos procurados no Masp por um químico envolvido na decifraçáo de um problema de lana caprina; se a assinatura de uma paisagem juridicamente contestada era coeva ou náo da pintura. Não lhe adiantou ensinar a ver o craquelê que estava rachando homogeneamente toda a tela, inclusive a assinatura.
Ele quis, através da retirada de vários pontos da obra, demonstrar a náo-legitimidade da firma, náo sendo o vermelho de uma casinha o mesmo do vermelho das letras. De nada lhe valeu demonstrar que os pigmentos do vermelho poderiam ser de duas procedências diferentes.

Relato um dos tantos fatos que ocorrem para que se saiba como todos, conhecedores e técnicos pesquisadores, podem divergir nos laudos, geralmente páginas que acabam nas mesas da Justiça.

E quantas vezes a própria Justiça não sabe o que decidir. Os problemas não são fáceis para os que opinam. Quando foi contestada a autoria de um quadro, Argonautas, de Giorgio de Chirico, ação promovida pelo próprio artista (infelizmente um mestre que, por inveja, farol, excentricidade enfim, tinha o hábito de negar as autografias) as testemunhas e peritagens demonstraram o contrário. Diante porém da negação do autor, para não destruir a tela, foi determinado que se 'cancelasse' a assinatura. 
Aqueles Argonautas gritavam serem filhos de De Chirico. O caso fez a crítica censurar o pintor que, contudo, continuou inexplicavelmente com seu modo de agir.

Qual então a solução? Devemos aceitar, além do parecer do conhecedor, o dos peritos colaboradores. Sem dúvida a ciência permite hoje indagaçóes que o resultado visivo não alcança.

Por este motivo estamos tentando constituir, no Masp, uma seção de exame e identificação de obras de arte, por sugestão do amigo José Nemirovsky que nos doou alguns aparelhos muito úteis e rica bibliografia norte-americana, animados por abrir o campo a jovens interessados na tarefa. Aliás, o Masp está implantando um setor de restauração e recuperação de imagens fotográficas a fim de se preservar toda documentação fotográfica esparsa pelas bibliotecas, coleçôes, escolas e universidades, além dos museus.

Essa ideia surgiu quando da organização da exposição dedicada aos oitenta anos de lançamento de Os Sertóes, de Euclides da Cunha. O arquiteto Joáo Sócrates de Oliveira, que se especializou em fotografia, executou magnífico trabalho de recuperação das imagens fotográficas de Flávio de Barros, o fotógrafo expedicionário que chegou a Canudos com a $4^{\text {a }}$ Expedição e documentou as tropas ali estacionadas. Esse álbum pertence à coleção do Museu Histórico Nacional do Rio de Janeiro e sua leitura está-se tornando, cada dia que passa, mais difícil devido à ação deteriorativa sobre os agentes químicos da emulsão fotográfica. Sem interferir nos originais, nem mecânica e nem quimicamente, João Sócrates de Oliveira trouxe à luz todos os pormenores das personagens fotografadas.

Por falar em equipar tecnicamente um museu para atender às exigências dos serviços de restauração e conservação de obras de arte, o dr. Gerardo Brito Raposo da Câmara está implantando no Museu Histórico Nacional, sob sua direção, um projeto que, ao seu término, será exemplar náo só aos museus brasileiros como também aos estrangeiros. Será um centro da maior importância para os jovens estudiosos e pesquisadores desenvolverem-se na prática da preservação dos documentos e de obras de arte da cultura brasileira.

\section{Legenda}

Antônio Conselheiro, foto de Flávio de Barros recuperada por João Sócrates

Senhor \#II4, 25 de maio de I983, p.69 (P.M. Bardi)

A OUTRA FARSA DE HitLER

A farsa do diário de Hitler faz

lembrar as falsificaçóes que atra-

palham o campo das artes.

Náo é novidade recente, pois os laboriosos metidos no negócio, a começar pelos falsificadores de papel-moeda, formam uma legião. Recentemente morreu F. Legros, destacado especialista em mandar fabricar pinturas de mestres que alcançam bom dinheiro nas praças onde operam especuladores que, salvo exceçôes, se apelidam de colecionadores.

Um parêntese: quem lida com a mercadoria pintura, infelizmente, salvo, repito, as raras exceçôes, mede nas telas um conveniente número de notas quando investe, calculando qual o número de notas a mais que vai encaixar na hora da revenda. A arte se tomou artigo de comércio. Assim como se falsifica uísque, falsifica-se arte e, agora, como se viu, até manuscritos íntimos.
Para os que se interessam por objetos de arte, nada de novo, e nada de sensacional tanto na ingenuidade dos diretores da $\mathrm{O}$ editor da popular revista alemá, (também ele especulando na presumível descoberta e levando na conversa outros colegas simplórios, europeus e americanos) aceitou a determinação do ministro do Interior, decidindo-se por esperar os 'últimos esclarecimentos.'

Incrível pensar em primários nas duas categorias: os que estão certos de tapear e os que estấo certos de náo ser ludibriados.

Além disso, um manuscrito, distribuído em nada menos que 60 cadernos, forma uma série de objetos em que texto, escrita, papel, tinta, cola, umidade etc., constituem possíveis realidades de pensamento, prática, indústria e marca de tempo. 
Quando se soube que até mesmo trechos das inventadas elucubraçóes do Endemoninhado foram colhidas, às vezes literalmente, de um livro publicado em '64, dá vontade de pegar um avião para conhecer de perto este colega Henry Hannen e sua infinita ingenuidade.

À parte as piadas fáceis, o mundo está repleto destes Hannen. Frequentam também a arte da pintura. A cada semana se escutam as conversas de elementos que caíram ou estavam por cair no conto-do- vigário, o que permite registrar que os adeptos do falsificar são membros de uma vasta máfia de fácil descoberta. Hoje não é mais como há cinquenta anos, quando o expertise se baseava no saber e no ver. Vieram em socorro os raios $\mathrm{X}$, os exames químicos, as provas mecânicas e tantas outras possibilidades que a ciência e as experiências favorecem.

Um caso que pode ser comparado ao da fraude em questão, neste século, foi o das falsas pinturas de Vermeer, na Holanda, nos anos 1953-54. A repercussão foi extraordinária, a corrida à procura de experts foi notável. Afinal, o cronista que escreve esta página, talvez por ter um certo currículo como conhecedor, fez parte da tríade que, por conta do Museu Boymans-van Beuningen, de Roterdã, deveria estabelecer a verdade a respeito de duas obras do mestre holandês.

Lembro-me exatamente, e não estou dizendo isto para contar vantagem, da impressão imediata: como foi possível ao diretor do Boymans aceitar como autógrafos de Vermeer as duas pinturas executadas pelo coitado do modesto van Megeren? O veredicto faz parte da história das falsificaçóes, e o adjetivo usado foi 'grosseiras.'

Vejo agora o termo usado na farsa hitleriana, para não deixar dúvidas e possibilidades de reexames.

O que surpreende é a excessiva boa fé dos editores de uma das mais conceituadas revistas europeias. E fácil perguntar: por que as indagaçóes sobre a autenticidade não foram desenvolvidas antes da edição, uma vez que o diretor do Arquivo Federal da Alemanha, Hans Booms, declarou que "o falsário parece ter inteligência limitada" e que a falsificaçáo era táo óbvia que os peritos do Arquivo precisaram de apenas 48 horas para chegar a essa conclusão?

É o que acontece sempre nestes casos: o estábulo se fecha quando já fugiram o animais.

\section{Legenda}

O falso Canaletto, vendido em São Paulo em 45, denunciado pelo Masp em 47

Senhor \#II5, I de junho de I983, p.93 (P.M. Bardi)

\section{ARQUiTETURA: UM PASSO ATRÁS}

Todo o mundo sabe o que significa Post-Modemismo em Arquitetura. É uma trouvaille que pretende suceder ao Racionalismo dos mestres do século, desde Gropius e Mies van der Rohe até Le Corbusier e, para ficar em casa, o Oscar Niemeyer de quando era seguidor do Missionário que veio ao Rio de Janeiro em 1936 para riscar o edifício do Ministério da Educação e Saúde. Depois dos últimos Congressos do Ciam, as doutrinas racionalistas andaram desperdiçando-se, aqui e ali, resultando um quase carnaval de um modo de construir representativo do século que se encaminha para o ano 2000, puluído por invençôes as mais surpreendentes e, para a maioria das pessoas, incompreensíveis.
Ao que parece, os sintomas de cansaço à estética da linearidade, funcionalismo, antienfeite etc. estáo sendo notados, atribuindo-se ao arquiteto ex-racionalista Philip Johnson o primeiro grito de revolta: coroou um arranha-céu em Nova York com uma espécie de tímpano monumental para frisar que a doutrina modernista acabou, dando espaço para o retomo do enfeite de fachada. No interior: precisão utilitária até requintada, a sofisticaçáo do racional; na fachada, um símbolo do Classicismo- modemizado.

O repórter desta página é macaco-velho da polêmica para a renovação da Arquitetura. Está para publicar um volume dedicado a Lè Corbusier, de quem foi íntimo, dando a conhecer todos os desejos inéditos 
executados no Brasil pelo Mestre. O macaco continua propenso a considerar que os tempos são favoráveis à machine-àhabiter, à simplificação, ao passo na medida da perna, enfim a tudo que se leu na entrevista que o ministro Hélio Beltrão deu no último número de IstoÉ, ("A simplicidade consiste exatamente em evitar as soluçóes sofisticadas e prestar atenção no que existe ao nosso redor ... O Brasil é um grande país de pequenos ... A solução para o nosso desenvolvimento passa pelo atendimento às necessidades básicas da população ... Não se pode ser apenas Don Quixote, é preciso também ser Sancho Pança... As obras de infra-estrutura voltadas para a saúde e para o saneamento ... assim como à habitação popular, à produção de alimentos, ao subsídio à agricultura...") declaraçóes que, se espera, sejam plataforma dos candidatos à Presidência da Nação.

Voltando à Arquitetura, no mesmo número da entrevista, a revista publica a seção 'Imóveis - estilo inglês no morro.' Anuncia-se o lançamento de um 'projeto conservador' em, 'rígido estilo inglês' parto da senhora Elza W. Wolthers, nada menos um 'Hampeton Court' de dez andares, $p u b$ privado e quadra de squash. Diz a parturiente: "É projeto de alto luxo para pessoas de bom gosto."

E a volta ao Culturalismo, a abertura para nos refugiarmos atrás das fachadas inglesas, alemãs, italianas, francesas, de todo e qualquer século.

No meu livro sobre Le Corbusier, falando sobre a arquitetura do começo do século, lamentava: "O auge do Ecletismo ou, como dizem alguns historiadores encontrando sua antecipação na aparição do Neogótico, o Pré-ecletismo, resultou no Posto da Fazenda da Ilha Fiscal na Guanabara, famoso, pois, ali, uma semana antes da Proclamação da República, celebrou-se o último baile da monarquia. A mudança de regime náo alterou o setor da estética, incrementando-se, aliás, ainda mais, a variedade estilística da Arquitetura, imitada dos álbuns históricos. Continuava, favorecida pela formação da sociedade burguesa, então desaparecendo o patriarcalismo agrário, lançando-se as bases do progresso industrial, o gosto pela singularidade das construçóes unifamiliares, e depois os prédios de apartamentos, competição de status, alinhando mostruários curiosos, como a avenida Central no Rio de Janeiro e a avenida Paulista em São Paulo.”

O Post-modernismo progride, agora, em São Paulo, e o último grito é o passo para trás da senhora Wolthers.

\section{Legenda}

Le Corbusier: desenhos inéditos

Corremos o risco de voltar ao passado?

Senhor \#II6, 8 de junho de 1983, p.73 (P.M. Bardi)

A OBRA QUE SURPREENDEU A RAINHA

Cinco séculos de Rafael, um pintor sem mistérios

A 'beleza familiar' que um culto americano, Nathaniel Hawthorne, anotou para a Madona delia Seggiola, por ele admirada em I858 no Palácio Pitti, em Florença, permite usar uma dicção bem apropriada na consideração obrigatória das obras de Rafael, por ocasião do quinto centenário do nascimento do Mestre, um pintor sem mistérios, sereno comunicador de história e de gente: sentimento, fantasia, alegoria, cativador de emoçóes profundas sugerindo reflexôes.

Com relação aos festejos, no dia 25 de maio, foi lançado no Masp o selo comemorativo em homenagem ao Mestre, reproduzindo o seu painel Ressurreição de Cristo, do acervo do Museu, a melhor maneira que encontramos para, junto com a Empresa Brasileira de Correios e Telégrafos, comemorar a data. Também Senhor se une às universais celebraçóes.

E, para não repetir o muito que se dirá a respeito do Rafael, parece-me, aliás, estou certo (pedindo desculpas aos eminentes colegas locais que somente viram as obras do jovem de Urbino em cartóes-postais) de ter assegurado um quadro do gênio para a Pinacoteca à qual dediquei o meu saber e a minha paixáo.

As certezas pertencem sempre a quem as proclama e as gratuidades das reservas e das contrariedades a quem destas fazem profissão. Assim, o raciocínio que se difundiu foi: "Impossível um Rafael no Brasil," e o boato andou acarretando 
as costumeiras cargas negativas, locais naturalmente, enquanto que lá fora a Ressurreição era finalmente inscrita no catálogo das autografas do Mestre.

O curioso, no que se refere a Rafael, é que, nos anos da boataria, um decorador, de prontidão para mais diligentemente embelezar o apartamento que, no Palácio dos Bandeirantes, se arranjou para hospedar a rainha Elizabeth, da Inglaterra, teve a luminosíssima ideia de reduzir uma reprodução vagabunda do tondo da Madona della Seggiola em formato retangular, para adaptá-la a uma moldura qualquer.

Quando a rainha inaugurou o edifício do Masp, na Paulista, naturalmente parou diante do nosso Rafael, e ficou surpresa ao saber que a obra viera do seu país.

A história (autêntica, como a pintura) é a seguinte: descobre-se em Rossy Priority o painel e quem o compra pensa logo ser uma obra-prima digna da National Gallery, de Londres. Naquela Meca: entusiasmo, porém quem dá a certidão de nascimento é o papa da Renascença, Bernard Berenson. Este famoso historiador, pontificando no seu vaticano de Florença, despacha que o autor é um tal de Ser Austério de Perugia. A National Gallery entáo não a adquire e o vozerio desclassifica a peça que passa a vogar no mercado. Até que o diretorzinho de um museu sul-americano a encontra em Nova York e, sem saber ler nem escrever, a compra na manhã de um dia de Páscoa de 1954. O negócio se articulou cheio de mistérios: num dia que os americanos festejam, numa galeria aberta contra o uso habitual, não existindo nenhum documento, bibliografia, currículo, somente a necessidade de uma decisão positiva ou negativa.

Presente no local o sr. Assis Chateaubriand, Walter Moreira Salles e o Bardi. Mutismo absoluto, ar de arapuca. Eu deveria decidir-me antes de sair. Devo declarar que nunca julguei obras de arte lendo papeladas ou escutando conversas interesseiras: uma obra deve investir, convencer, enamorar, encantar de imediato. Sem fazer blague, desde a entrada eu já havia decidido. Talvez eu nem soubesse por que mas disse sim, convencido de estar adquirindo uma das mais surpreendentes pinturas de Rafael.

O resto se sabe: descobri no Museu de Oxford os desenhos de duas figuras da Ressurreição, além de uma antiga referência de Wilhem Bode sobre a obra que Roberto Longhi publicou num ensaio em Paragone etc. etc. Até hoje, qualquer monografia dedicada a Rafael reproduz o quadro como obra juvenil. Quando o papa da Renascença soube da molecagem de um simples clérigo, que justamente o tinha contradito, ficou furioso.

Parece-me excelente que, comemorando o quinto centenário de Rafael Sanzio, São Paulo também participe com o Museu de Arte indicado como dono, não de um Ser Austério nem de um Pinturicchio nem de um Perugino, (como se deu na época da aquisição) mas de uma esplêndida obra do Mestre.

\section{Legenda}

A Ressurreição: um Rafael no Masp

Senhor \#II7, I5 de junho de I983, p.73 (P.M. Bardi)

Aventuras de Manet em Sáo Paulo

Por ocasião do centenário da morte de Édouard Manet, os jornais noticiaram as relaçóes entre o pintor e o Brasil, assinalando sua passagem pelo Rio de Janeiro, aos 18 anos, como tripulante de um veleiro. Mas no que se refere às ditas relaçóes, o cronista de arte de Senhor quer juntar alguns outros fatos.

Quando corriam os tempos do Império e nosso bom Dom Pedro II mandava distribuir bolsas de estudo aos pintores que tinham cursado com honra as Academias, o destino era quase sempre para o chamariz da Ville Lumière, sendo Roma, Florença e até Munich descartadas, pois desde a vinda da missão francesa, o farol da cultura flamejava em Paris. Lá estava-se afirmando o Impressionismo e as possibilidades para os outros 'ismos' superadores do Romantismo. De qualquer jeito, os bolsistas verde-amarelos se entrosavam com os colegas acadêmicos retornando mais armados da maneira lá predisposta para o gosto da burguesia.

Os inovadores tinham vida difícil. Para dar ao leitor uma demonstração, eis o 
estupendo Retrato do Artista, de Manet, que, apresentado no Saláo de I875, foi recusado, juntamente com Le Linge. $\mathrm{O}$ pintor o apresentou ao público em seu atelier, convidando os visitantes a escrever os pareceres num caderno. O reconhecimento do valor da tela veio somente em I900, quando apareceu e foi notado pela crítica na Exposição Universal de Paris.

Este retrato pertence, há trinta anos, ao Museu de Arte de Sáo Paulo, com outras três obras de Manet da mesma importância: Caçador de leóes, A amazona e As banhistas.

Agora, para as comemoraçóes do centenário da morte do Mestre, os quadros $O$ artista e o $O$ caçador de leóes foram escolhidos para figurar nas grandes exposiçóes no Grand Palais de Paris e no Metropolitan Museum de Nova York. Não é a primeira vez que os Manets do Masp viajam, pois várias vezes foram emprestados a museus da Europa, dos Estados Unidos e do Japão.

Lembrei os tempos do imperador, mas devem ser lembrados também os tempos da formação da Pinacoteca do Masp: o desinteresse, a indiferença e até o boato permanente de que a coleção era formada de 'obras falsas.'

A cultura histórico-artística era então em Sáo Paulo, bastante mesquinha, sendo ultramodestas as próprias atividades de poucos e generosos artistas. Quando começamos a estruturar o Masp havia uma única galeria de arte, a do sr. Beneteau, dedicada à pintura acadêmica; pouco tempo depois o casal italiano Fiocca abriu a, 'Domus' na rua Álvaro de Carvalho: uma singularidade. Raras, para não dizer inexistentes, as escolas particulares de arte, a Academia de Belas Artes, concentrando a pouca freguesia disposta a se dedicar à Pintura e, em menor número, à Escultura.

Não mais os tempos de Dom Pedro II, do general Dutra. Vieram os da abertura: o exercício das artes não é mais o duro dos cinco anos de academia. Lê-se no depliant de uma das inúmeras escolas agora existentes que é "possível se tomar um artista plástico profissional e em pouco tempo, além de aprender bem e ter plena consciência de um desenho preciso e inteligente, facilitando o ato de criar, gravar e pintar." E, enquanto há tempo: "Somente quatro grupos de oito alunos, possibilitando um acompanhamento individual. Uma vez por semana de 4 horas/aula."

Estamos assistindo a um milagre. A moda das artes está tomando conta, esplendidamente. As exposiçóes não são somente as mixurucas e habituais dos Salóes da Galeria Prestes Maia: museus, galerias comerciais, também bancos e instituições como o Sesc, os supermercados, os centros de lazer, os restaurantes e os clubes. Uma fileira contínua de mostras de pintura parece dar a São Paulo uma primazia a mais entre as numerosas que já possui. Está-se criando uma espécie de acrópole da arte, justificando afinal o título divulgado quando ainda pintava Almeida Júnior de Athenas do Brasil. Não falta o auxílio publicitário em jornais, rádios e televisôes.

E São Paulo está até descobrindo que o Masp despacha obras-primas de Manet para o mundo.

\section{Legenda}

$O$ artista e Pertuiset, o caçador de leóes, ambos do acervo do Masp

Senhor \#II8, 22 de junho de I983, p.73 (P.M. Bardi)

UM FARO INFALÍVEL

\section{Histórias do maior editor da Itália}

Recentemente a Editora Mondadori, de Milão, publicou uma história da arte brasileira, em co-edição com a Abril Cultural, pediram-me para redigir um amplo prefacio, para que o público italiano tivesse uma síntese da trajetória que, saindo das produçóes aos Índios, passando pelo Barroco, Aleijadinho, Missóes Jesuísticas, Franceses de I8I6 e o Academismo, apresentasse a atualidade da Semana de 22 até Portinari e Niemeyer, o arquiteto convidado para construir a nova sede da Casa, em Segrate, perto de Milão.

Reencontrava a singular figura de Arnoldo Mondadori, o criador da maior editora italiana, em memória de quem, nesta semana, o Masp está dedicando uma exposiçáo que evoca a abnegaçáo e a constância do protagonista, que se resumem no slogan "de ano em ano, de livro em 
livro." Conheci este editor e acompanhei sua afirmação, que na Itália se definia, lembrando o título de um volume popular: Volere é Potere, de Michele Lessona, conjunto de biografias de arrancadores.

Arnoldo, filho de camponeses da pequena cidade de Ostiglia, de poucos estudos, depois de vários empregos como contínuo e vendedor ambulante, vai trabalhar numa tipografia, torna-se artesão, sócio e dono, e dá início à sua vocaçáo de lançar livros. Escolhe os dedicados à criança, atingindo o mercado nacional. Transfere-se para Verona, onde implanta uma grandiosa poligráfica e, depois, para Miláo. Reúne e edita obras dos mais eminentes escritores italianos: Pirandello, Gozzano, Ferdinando Martini, A. G. Borghese, Virgilio Brocchi, Pastonchi e, finalmente, audacioso, convence Gabriele d'Annunzio a lhe confiar a edição de sua Opera Omnia.

Conheci bem Arnoldo, pois era interessado no cotidiano Il Secolo, do qual este cronista era um dos redatores da cúpula. A lembrança é nítida: visão, convicção internacionalista da cultura, volitivo, vendo e superando qualquer obstáculo, otimista e humano, sua casa crescendo metodicamente.

Lembro que escutava as propostas para depois falar, "ora dico la mia" afirmando soluções que reuniam bom senso, inteligência e certeza, não sem, às vezes, uma franca e ribombante risada.

Um faro infalível e imediato, decisóes à l'instant, "um livro depois de um livro," desde os escolares, impondo novos critérios, principalmente na ilustração, até os volumes de mestres do mundo inteiro, incluindo agora brasileiros. A Mondadori publica: A Escrava Isaura, de Bernardo Guimarães; Não Verás País Nenhum, de Ignácio de Loyola Brandão; e, Galvez, $o$ Imperador do Acre, de Márcio Souza.

Como se vê, as escolhas da Mondadori são persuasivas, de abertura para os novos. Uma vez em que foi oferecida uma homenagem a Arnoldo, ele disse: "Eu, afinal, procurei ser o colaborador fiel de muitos homens de letras, é a eles que se deve a honra com que vocês me distinguem."

De qualquer modo, a presença da Mondadori é extraordinária também no campo dos periódicos e é contínua, abrangendo, além da informação, a ciência e a arte. Bastará saber que a editora publica por ano uma média de 15 milhôes de volumes.

A exposição apresenta a potencialidade de uma casa editorial hoje de envergadura internacional, exemplar no divulgar e integrar cultura, trabalhando com resultados altamente eficientes. Registrando no Masp o empreendimento italiano, produto de um único homem, me sugere a ideia de, um dia, em nosso centro cultural, (não exatamente museu) mostrar dois análogos acontecimentos editoriais brasileiros: o da Abril e o da Manchete, exploits de Victor Civita e Adolfo Bloch.

Legenda

Arnoldo Mondadori: "Ora dico la mia..."

Senhor \#II9, 29 de junho de I983, p.92 (P.M. Bardi)

O DIREITO HISTÓRICO DA ARTE

No Brasil, um problema idêntico ao dos mármores da Acrópole

Os gregos, como se sabe, no v século a.C., construíram a Acrópole. No desfilar dos tempos, o Parthenon passou por vicissitudes as mais desrespeitosas: a um tempo transformado em igreja cristã pelos bizantinos, doutra feita em mesquita pelos turcos, bombardeado no seiscentos pelos venezianos, até que Lord Elgin, em I8oI, comovido pelo desaparecimento do que restava do monumento, conseguiu um alvará do governo junto ao qual representava, como embaixador, a Grä-Bretanha. Isto posto, desmontou os mármores do frontão, e os despachou para Londres, conservados no British Museum.

Recentemente esteve lá em visita a ministra da Cultura grega, a ex-atriz Melina Mercouri que, na oportunidade, transmitiu à direção do dito museu, um pedido: nada menos que a devolução, a Atenas, dos mármores. Com tal solicitação verificou-se o levantamento de uma questão, aliás uma série de questóes bem novas e complexas, já que envolvem questóes de direito internacional e diplomacia. 
Por que trato de um assunto grego-inglês? Simplesmente porque caso análogo, naturalmente bem, bem menor, temos à mão: Brasil-França, fato que deu muito o que falar lá pelos idos dos anos 50.

Quando o Museu de Arte de São Paulo foi convidado para expor na Orangerie do Louvre a sua improvisada, mas rica coleção, incluiu, no lote de cem pinturas, cinco telas francesas do século XVII: os quatro retratos Senhoras da França, nada menos que as filhas de Luiz Xv, de Jean-Marc Nattier, alusivas ao caráter das representadas, e o retrato dos meninos que futuramente seriam o desventurado Luiz Xvi Luiz XvıII, de François-Hubert Drouais Filho.

Estas pinturas tinham proveniência famosa, o Castelo de Versalhes. Os Nattiers estavam sobre as portas do gabinete do Delfin. Depois da revolução, as telas, compradas ou roubadas quando o Castelo foi invadido, apareceram no mercado de antiguidades e, mais ou menos um século depois, eu as encontrei junto ao Drouais em Nova York. Não tive dúvidas em comprá-las para o Masp.

Voltando ditas obras a Paris para serem expostas, o leitor pode imaginar o tamanho da repercussão. Náo foram poucas as propostas e pressóes para que lá ficassem as relíquias. Do ponto de vista legal, nossa propriedade é legítima, toda documentaçáo está em ordem. Do ponto de vista relaçóes Brasil-França as discussôes correram em todos os matizes.
As senhoras Melinas, isto é, os ministros franceses da Cultura reclamantes à possível restituição, num gesto histórico-amigável, continuavam, depois da exposição, a insistir.

O sr. Chateaubriand, a única pessoa que podia decidir, empolgado pelo fato da inauguração da mostra ter sido presidida pelo presidente da República e a senhora Vincent Auriol, insistia para eu aceitar uma troca proposta pelo diretor do Louvre, no caso um Rubens, que descartei por não estar convencido da autografia. Chateaubriand, para acalmar o pessoal, fez vultosa doação em francos para a restauração de Versalhes.

Seja como for, os franceses continuaram ao longo dos anos pedindo os quadros, numa verdadeira ofensiva. A última investida foi de André Malraux, quando exercia, no governo De Gaulle, cargo igual ao da sra. Mercouri.

Que fazer?

Uma troca seria possível, mas com obras realmente importantes para a história brasileira. Mas na Europa, como vimos no recente leilão de Zurique, só há xicrinhas e bengalas do tempo de D. Pedro II.

Então?

Legenda

$\mathrm{O}$ que as Senhoras da França têm em comum com Melina Mercouri?

Senhor \#I2O, 6 de julho de I983, p.73 (P.M. Bardi)

OS CAPRICHOS DA ARQUITETURA

Uma arte que dificilmente chega ao consenso

Como já se observou, a Arquitetura é uma arte, hoje, caprichosa. Cansada da última passada do Racionaismo, dos Le Corbuseir, Gropius, Mies van der Rohe (e por que náo associar a eles o nosso pioneiro Gregori Warchavchik?) esta enfrentando o estilo sucessivo, o PósModemo, complicadíssimo labor, pois cada construtor quer mostrar a sua.

Um dos últimos exemplos provocadores de consenso eu fui ver em Poços de Caldas: o novo edifício que substitui o da antiga Casa Bancária Moreira Salles \& Cia, que deu origem ao Unibanco, prédio de autoria de Aurélio Martinez Flores, da Inter Design Arquitetura, de São Paulo.

Numa publicação-lembrança do Unibanco, uma nota crítica de minha autoria é intitulada 'um monumento.' De fato, a arquitetura é, ao mesmo tempo, sede bancária e lembrança do fundador, João Moreira Salles, que seu filho, Walther, na nota de abertura, relembra com a parcimônia de palavras que lhe é própria: "Já vai longe aquele dia de fevereiro de 1924 quando foi fundada a Casa Bancária Moreira Salles \& Cia. Tudo que fizemos foi adaptar a ideia aos novos tempos e circunstâncias 
e assim continuaremos, com a graça de Deus. A maior homenagem que podemos prestar aos fundadores é constatar o quanto estavam certos em suas convicçóes e em sua fé nos destinos do Brasil. O meu reconhecimento a Poços de Caldas, à sua gente, aos dirigentes e colaboradores do Unibanco e também aos milhares de nossos acionistas, jamais poderá ser expresso por palavras.”

Eram mineiros os iniciadores, herdeiros do maravilhoso operar, lutar, vencer, os silenciários que constituem as grandes empresas nacionais.

Eis uma nova arquitetura na bela cidade, que vejo apelidada num antigo jornal de 'capital em miniatura,' e constato que ainda é possível desfrutar de ruas tranquilas, numa ordem que tem por fundamento o normal, a cordialidade, atraindo simpatias.

A tendência da arquitetura atual é a de superar a característica da terra em que surge, tendendo a uma espécie de linguagem esperanto, valendo um modo de geometrizaçâo inseparável do que no Novecentos se pretende mais: a função reduzida aos termos de utilidade. O que impóe ao arquiteto renunciar aos desperdícios individualistas, ao chamar a atenção para o formalismo.

Assim: uma conquista da estética, ao enfrentar com ideias puras uma proposta de construção. No caso em apreço, a ocasião foi mais que propícia para que se visse um edifício de proporçôes limitadas e portanto bem convidativo para concentração de elementaridades.

Quando se julga uma arquitetura, os que raciocinam, não esquecendo que o presente vem de longe, lembram-se de motivos e opiniôes emanados de mestres. Ocorreu-me naturalmente, visitando a obra, pensar no Filarete, que afirmava no seu 'Tratado' ser uma arquitetura a consequência do encontro de dois elementos: o comitente e o executor, isto é, de quem determina o trabalho e de quem o desenha e o leva a bom termo. A situação se verificou, neste edifício, de um jeito concorde, diria sentimental. A ocasião ensejou conciliar duas circunstâncias: cultivar a memória de quem iniciou a empresa comercial, como símbolo da atividade ao longo de anos desenvolvida, e a perpetuaçáo da operosidade posterior.

$\mathrm{O}$ arquiteto foi incumbido de prover e combinar dois espaços: o do normal funcionamento de um estabelecimento bancário e o da lembrança. Este último deveria recompor o ambiente de um lar, isolando-o e atribuindo-lhe indispensável privacidade. Alguns objetos, móveis, retratos de família dão o registro do tempo.

A composiçáo do edifício foi idealizada e desenhada com rigorosa atenção para o funcional. Por fora, vê-se uma arquitetura derivada de plantas, de massas ajustadas harmonicamente, novidades de paredes intersecadas formando um conjunto movimentado, bloco em contraste com as construçóes existentes nas redondezas. Delineia-se um edifício convincente e original, novidade para Poços de Caldas, lembrança de um cidadão pioneiro, um desses pró-homens que unem à ação a persistência e a visão do futuro.

Esse projeto cria um traçado arquitetônico que chamarei de puro, já que descarta a preocupação de surpreender com sensacionalismos modulares, tão em moda no Brasil, e deixa que o resultado do externo seja o da solução orgânica.

\section{Legenda}

Sede do Unibanco em Poços de Caldas

Senhor \#I2I, I3 de julho de I983, p.65 (P.M. Bardi)

O BOOM DO TEMPO LIVRE

Criatividade artística agora é moda na sociedade de massas

Nesta era de incertezas, inquietudes e angústias que tanto afligem esta pobre Humanidade, da qual fazemos parte, (ameaças de guerra atômica, impossibilidade de melhor distribuição de bens e riquezas às diversas classes sociais, solução dos sistemas econômicos entre países ricos e os chamados de Terceiro Mundo’ etc.) entre os problemas relativos ao marasmo-esperança, eis que surge um novo elemento dentro do já avançado mundo tecnológico e que certamente agravará ainda mais o já sério problema social dos povos: o robô. 
Sim, porque o robô vai aumentar a produtividade e consequentemente reduzir a mão-de-obra humana.

Como resultado haverá menos trabalho e mais gente desempregada, um problema seríssimo e explosivo a desafiar a boa vontade e a capacidade dos governantes.

Alguns futurólogos preveem que estamos caminhando para novos tempos, neste planeta superpovoado o 'tempo livre’ será uma constante na vida de cada um, surgindo uma, 'sociedade criativa e esportiva' generalizada, de participação sempre mais coletiva.

Quando criança, este redator praticava o gioco dei caldo, nos jardins públicos, com uma bolinha de bolso, passando depois a futebolizar no Campo de Marte de sua cidade, improvisando as marcas do gol com pedras, os mais velhos formando uma modesta esquadra representativa da cidade para participar do então nascente campeonato.

Amadorismo puro. Táo puro que um nosso companheiro, suspeito de ter recebido algum favor de um clube inglês que estreava na Capital da província, foi duramente agredido e tachado de 'traidor.'

Surgia na Itália, como em toda a Europa, o profissionalismo. Hoje o ex-flamenguista Zico é arrancado do Brasil por quatro milhôes de dólares. A repercussão no Brasil e Exterior foi imensa, já que se constituiu em assunto bem mais extraordinário que o mundial, galvanizando a opinião de um bilhão de seres que vivem nos países ricos e dos três bilhões que lutam para sobreviver, espalhados em países pobres.
Num sábado e num domingo estive na Fábrica-Sesc, no bairro paulistano de Vila Pompeia, para observar o lazer: somente aqueles que pela idade seguiram a evolução dos tempos é que podem descobrir as profundas mudanças ocorridas e as plenas e prepotentes conquistas.

A Fábrica vai inaugurar o maior edifício da metrópole dedicado aos esportes de salão, recrutando ginastas que se juntarão ás massas frequentadoras do Centro, confirmando com isto que o 'tempo livre' está-se afirmando como motivação de vida.

Também no que se refere à, 'criatividade' alguma coisa está sendo feito. E o que se dizer da criança que é favorecida com diversóes as mais variadas, além dos ateliês de cerâmica, gravura, marcenaria, tipografia? A frequência é enorme e o teatro sempre apresentando novidades, idem com a música, especialmente a popular.

A 'criatividade' tomou, nestes últimos anos, grande impulso, aliás, tornou-se moda. A pintura e a escultura, há três décadas praticada por poucos profissionais, são, hoje, 'cavalos de batalha' de milhares e milhares de amadores. Postas de lado escolas e noviciato, a dedicação às artes plásticas é torrencial: centenas de galerias, bancos, indústrias, clubes, shoppings, lojas, todas febricitantemente apresentando arte e não-arte.

É o boom, sintoma de que as portas estáo abertas à sociedade futura para que apresentem novas propostas. A arte deixou de ser prerrogativa de elites para ser apanágio de todos que queiram participar da vida incrementada que vamos vivendo.

\section{Legenda}

Brinquedos na Fábrica da Pompeia: a arte dos amadores ao alcance de todos

Senhor \#I22, 20 de julho de 1983, p.73 (P.M. Bardi)

VESTIR COM LIBERDADE

Da tragédia do colarinho à democracia dos jeans

Uma revista interessada na moda, Jeons \& Sportswear, em edição especial dedicada aos trajes para esportes e lazer, dedicou-me duas páginas para homenagear um personagem envolvido em assuntos da moda e que teve a ideia, há 30 anos, de lançar uma moda tipicamente brasileira, iniciativa sobre a qual tive oportunidade de escrever recentemente na revista Vogue. Trata- se de episódio que me leva a recordar algumas interferências com aquele fenômeno do comportamento no qual estamos, volente ou nolente, todos interessados, observando prescriçôes passiva ou ativamente.

Nas famílias burguesas dos Jardins ou das longínquas periferias, a moda representa o status. Antigamente, isto é, nos 
meus tempos de criança, o vestir bem era importante como fachada, um tributo que se devia à opiniáo dos outros. Através do hábito envergado é que se julgava as pessoas. As coitadas das crianças deviam também contribuir para que a aparência resultasse apropriada, limpa e admirada.

No começo do século, a moda prescrevia que o rapazola saísse de casa munido de um detestável colarinho, dito à carluccio, circundado por um gravatão azul, calçando os pés com sapatinhos reluzentes e com as pontas bem afuniladas, um suplício que fazia lembrar a pedologia dos chineses. Colarinhos e sapatinhos constituíam meu desgosto e motivos de protesto e rebeldia.

As famílias, aos domingos, faziam seus passeios, o footing das nossas cidades interioranas, ocasiấo em que as vestimentas eram observadas e propiciavam julgamentos nas discussóes de casa, na hora do lanche. A moda, então, principal fato mundano e social, culminava com a eleição das mais elegantes...

Tudo corria normalmente, mas certo dia a cidade foi agitada por uma alegre dama e que por muito pouco náo acabou em tragédia. A origem foi um caso modístico: a mulher do dentista local saiu à rua exibindo uma jupe-coulotte, uma espécie de calça masculina.

Depois de um primeiro espanto e passada a curiosidade, ouviu-se uma torrente de gritos e imprecaçóes, gente protestando contra a atrevida, sapecando-lhe bofetóes e pontapés, num começo de linchamento só sustado graças à intervenção dos carabinieri. A coitada foi levada para casa seguida de uma multidão que entoava palavrôes de corar um frade, por pouco náo se atirando também contra os agentes da lei.

Hoje, todas, velhas e moças, vestem os apertados jeans, (porque não abrasileirar a palavra, pronunciando simplesmente gins?) numa evidente abertura para a descontração e simplificação, ensejando um comportamento mais coerente com as liberdades conseguidas pela sociedade. Há decênios que se fabrica milhôes de saias e agora chegou a vez dos gins que são usados até na África. A mentalidade, as superstições, foram superadas.

Outra, impensada estética, emergiu. Relação com as Artes? Não. Mas sim com a tecnologia. Até há pouco tempo notava-se uma certa interligaçáo, a moda como elemento expressivo do artista, um combinar de modos determinantes e bem característicos. Bastará pensar no trato que pintores e escultores deram ao andamento da civilização figurativa, reflexo do gosto, da época, compêndio de uma morfologia ideográfica, documento marcante da linguagem plástica.

Leonardo prescrevia que, "os trajes que vestem as figuras devem mostrar que foram talhadas para as ditas figuras... indicar atitude e movimento, dando conta de mil e uma realidades do vestir. Depois começou-se a desvestir as Vênus.

Agora contemplamos o advento vitorioso dos gins, tudo que se refere a roupas, os planejamentos, as sutilezas das sobras, enfeites, costuras e outros componentes vinculados ao vestuário, eis a liquidação de um costume milenar. Os gins aderem ao corpo, o delineiam, o revelam tal qual, nada escondem, melhorando até as feiçốes corporais.

$\mathrm{Na}$ verdade, os gins fizeram uma verdadeira revolução na maneira de vestir ao ponto de prever-se futuras e até drásticas inovaçóes. Vamos esperar.

\section{Legenda}

Delírio de Dali para o ano 2050

Senhor \#I23, 27 de julho de I983, p.89 (P.M. Bardi)

As MANIAS DO PÚBLICO

Quais são os critérios artísticos dos visitantes dos museus?

A National Gallery de Londres inaugurou uma exposição original sob o título The Neglected National Gallery. É uma insólita e irônica manifestação composta de 25 pinturas normalmente negligenciadas pelos visitantes, resultado evidente de uma pesquisa, à primeira vista, de não fácil execução.

Problemas de cultura, de gosto, de manias? $\mathrm{O}$ visitante tem liberdade para, nos museus, ver o que quiser, valendo as suas próprias 
opiniōes. Os museógrafos nem sempre se interessam pelo público. A sua tarefa é mais a de catalogar as obras: nome e prenome do autor, data do nascimento e morte, título da produção. Pesquisas, descrições, pareceres são objetos da escrivaninha.

No Masp se reagiu a este sistema simplista colocando as pinturas, ao invés de nas paredes, sobre placas de cristal embutidas em blocos de concreto tendo na parte de trás uma biografia resumida do artista, notas a respeito do quadro, reproduçóes de outras obras do mesmo autor, tudo possibilitando uma informação.

O modo de comunicar é, então, didático e, no que se pode constatar, de extrema utilidade, pois é normal se ver estudantes principalmente que anotam ou copiam as prosas sem contar os que aparecem pedindo esclarecimentos e indicação de bibliografia.

A cada visitante o Masp oferece um folheto que reproduz um certo número de obras da Pinacoteca, isto graças a uma inteligente iniciativa da Embratur, Empresa Brasileira de Turismo.

No que se refere à exposição da National Gallery, penso que deve tratar-se de uma constatação cultural dos conservadores (também eles, naturalmente, podem ter suas preferências) desgostosos por saberem que certos mestres são "negligenciados" pelos visitantes.

É uma questão de opinião. Eu mesmo, como diretor do Masp, sempre registrei que as apreciaçóes do visitante são pessoais, às vezes estranhas. A maioria dos frequentadores contempla mais os três Picassos do Museu do que a Madona, de Bellini. Os impressionistas atraem mais do que Ticiano, Velazquez, Van Dyck e Murillo.
Sei que ainda mais do que sobre os Picasso, Matisse, Max Ernst e Soutine, os olhos pousam com maior admiração nas telas de Anita Malfatti, Di Cavalcanti, Segall, Portinari, Rego Monteiro e outros mestres brasileiros.

Qual é a razão? As artes são acontecimentos nacionais, diria quase municipais, a atualidade sendo mais considerada do que a história, as coisas de casa apaixonam mais do que as de fora. Sem entrar na explicação de problemas de psicologia, parece-me que náo é dado a todos entrar num museu e acomodar a mente à tradição, até mesmo no passado próximo, fantasiar por épocas remotas superficialmente conhecidas, vendo-se, ao contrário, os visitantes ao seu bel-prazer observando o labor mais falado e atraente.

Às vezes acompanho pessoas de uma certa cultura na visita à Pinacoteca do Masp e, por exemplo, diante do esplêndido Vuillard, Retratos de Sacha, Guitry e de Ivonne Printemps, observo o desinteresse dos hóspedes. É evidente que o náo nada saber das aventuras teatrais dos dois personagens não provoca curiosidade pela tela.

Mas, chegando à Moema, de Vector Meirelles, o entusiasmo se revela, pois lembram a lenda, o autor José de Alencar, o Romantismo e até mesmo quanto foi pago pela tela (em I948, custou mais do que os seis Modiglianis juntos, mais do que os Gainsborough, Constable, Turner juntos etc.) Por quê? Mistério.

Que fazer e que dizer? Deixamos o visitante livre para gostar. De qualquer modo, acho que vou fazer um inquérito para saber quais são as obras do Masp preferidas pelos visitantes. E informarei sobre isto.

Senhor \#I24, 3 de agosto de 1983, p.65 (P.M. Bardi)

UMA ARTE QUASE SECRETA

Quando o Museu de Arte de São Paulo, em I953, iniciou uma série de exposiçóes de parte do seu acervo adquirido nos três anos precedentes, a primeira deu-se em Paris, a convite do governo francês, na Orangerie do Louvre. A novidade perturbou nossa Embaixada, que recusou meu pedido de convidar, para a inauguração, o presidente da República francesa, deferência que, finalmente, tomou-se possível graças a alguns amigos meus daquele país. M. Auriol, acompanhado da primeira dama, no dia 3 de outubro, veio de Ramboulet e abriu a manifestação deflagradora de repercussão absolutamente inédita.

O acontecimento acordou nossos diplomatas, ausentes de Paris, mas que tomaram conta do fato de um museu de sua pátria merecer tanta atenção, notadamente com 
as ediçóes que se seguiram em Bruxelas, Utrecht, Dusseldorf, Berna, Miláo, Londres e depois em Nova York, quando nos apresentamos no Metropolitan Museum.

Estas exposiçóes iniciaram intercâmbios culturais de alto nível entre o Brasil e países europeus e Estados Unidos. Esforço apenas de nossa parte, pois de lá, por enquanto, não recebemos a recíproca em termos de mostras importantes, mas apenas algumas circunstanciais e assim mesmo de arte contemporânea. E o Masp as promoveu convidando Le Corbusier, Max Bill, Saul Steinberg, Georg Goerg, até que combinamos com o Museu de Arte Moderna de Nova York algumas exposiçôes, sendo a última de De Chirico, Mirò, Max Ernst e Magritte; em contrapartida, até agora não consegui realizar lá fora nenhuma exposição de artistas nacionais.

A única exceção deu-se quando Jenny Segall levou para museus europeus as obras cie Lasar, depois que o Masp as mostrou na Bienal de Veneza, o mesmo acontecendo com as de Ernesto de Fiori, independentemente do intercâmbio entre aquela Bienal e a paulista.

No tocante à arte antiga, São Paulo obteve, por intermédio do sr. Francisco Matarazzo Sobrinho, uma discreta exposição de pintura italiana do Seiscentos, e no Masp tivemos a exposiçáo "Do Renascimento ao Neoclassicismo," em 1952, de coleção particular francesa.
Evidentemente, é muito pouco para ativar contatos com vistas à melhor difusão da arte do passado.

Sei, por experiência, quais as dificuldades de realizar este tipo de intercâmbio. A América do Sul é um continente ainda não devidamente considerado sob o ponto de vista cultural.

Penso muito numa eventual exposição tendo por tema, "A Arte no Brasil, do Séc. XVI ao Xx" que seria organizada por historiadores de arte, com muito cuidado, e que seria levada ás capitais da Europa é a várias cidades aos Estados Unidos. O agrupamento de tais obras seria possível com a cooperação dos museus e de colecionadores, iniciativa do Itamaraty, que através de embaixadas deveria contatar os museus para reservar salas e acertar condiçóes.

De qualquer modo, deixando de lado as possibilidades oficiais, de onde é sempre oportuno esperar atuaçóes, informamos nossos leitores, em primeira mão, sobre a realização de uma grande exposição de arte brasileira solicitada ao Masp pelo prefeito de Roma. Será dedicada ao Modernismo, desde a Semana de Arte Moderna de '22 até a fundação do Museu de Arte de São Paulo, em 1947. Trata-se de uma manifestação que, pela primeira vez, mostrará à Itália a repercussão de um período nosso, rico em personalidades e eventos.

Legenda

O Modernismo em Roma: o Masp abre caminho para a Europa conhecer todo um período excepcional da arte brasileira

Senhor \#I25, IO de agosto de I983, p.7I (P.M. Bardi)

UM PAISAgista EM Curitiba

Paul Garfunkel reafirma, em nosso século, uma tradição artística que vem desde Maurício de Nassau e que se tomou, com o tempo, num importante patrimônio da História do Brasil

O Brasil, como de resto todos os países sul-americanos, atraiu pintores que documentaram a natureza, gente e eventos. Deve-se aos holandeses, por iniciativa de Maurício de Nassau, a mais prestigiosa companhia de artistas reunida em Pernambuco para reproduzir a paisagem, preparar cartóes utilizáveis para a Série de Tapeçarias ditas das Índias, como fez Frans Post, a ser considerado o ilustrador que mais representou e comunicou para os europeus as novidades do formando e fervoroso Brasil dos Seiscentos.

Mais tarde continuaram a se manifestar numerosos paisagistas, desembarcados ao longo da costa, até que a chamada da Missão Francesa de I8I6 provocou, em coincidência com o incremento das imigraçóes, a extraordinária presença de mestres e desenhistas. É a eles que devemos a imponente quantidade de obras que visualmente mostram nossa História. 
De vez em quando arquivos e museus expóem os materiais a que se alude, surpreendendo a revelação de alguns inéditos.

Um dos casos mais recentes está agora exposto no Museu de Arte de Sáo Paulo. É a obra de autoria de Paul Garfunkel, um artista nascido em Fontainebleau, em 1900, e desaparecido há dois anos em Curitiba. Havia-se formado na École Polytecnique e, depois de exercer sua profissão em Paris, veio em 28 para o Paraná para dirigir uma empresa francesa, cargo que, por desentendimentos políticos, deixou em 32, transferindo-se para Santos.

Garfunkel, desde moço, se dedicou ao desenho, fixando de imediato o que considerava de interesse. No Brasil, foi preenchendo seus álbuns, passando depois a praticar a pintura.

As crônicas populares, as atividades de porto, de fábricas, o lazer, a natureza, inspiraram o artista francês a fazer um conjunto de trabalhos a ser definido um patrimônio sem precedentes de anotaçóes em que se notam, além da bravura excepcional do traço, a compreensão e o amor com que conseguiu representar. Em reconhecimento por seus trabalhos, Garfunkel foi nomeado cidadão honorário do Paraná, Estado em que se radicou após deixar Santos.
Quando nosso pintor marca atentamente a vida brasileira, atraído pelo que se passa no campo e na costa oceânica, procura animar a representação através da comunicação-confissão. Eis seu adeus ao navio que o trouxe ao Brasil: "Nossas ilusôes se desvaneceram... O Brasil nos acolheu e nos arrebatou - estranho país irritante e envolvente como insuportável amante," porém quanto amor transparece no vagar pela inquieta imensidão da Terra, colhendo na natureza e entre os muros o pitoresco de um baile popular, de um curral de gado, um carregamento de café, saída de navios, festas, passeios depois da missa, e tantos outros episódios.

A versão original do Brasil de Garfunkel pode ser vista na Pinacoteca do Masp: uma iconografia abreviada, palpitante, em movimentados esboços que revelam um desenhista de espírito, alguém que sabe passar para o papel a impressão recebida, a ponto de se pensar nos álbuns dos mestres que transferiram a pintura, da consideração verista e parada, à impressão individual.

\section{Legenda}

Duas obras de Paul Garfunkel:

Praça Tiradentes, em Curitiba, e

Cruz Machado, de I94I

Senhor \#I26, I7 de agosto de I983, p.69 (P.M. Bardi)

\section{O terno combate de Segall}

$\mathrm{Na}$ recente discussão entre diretores de museus e entidades culturais atuantes em São Paulo, promovida pela Secretaria Municipal de Cultura, sob a presidência do secretário Fábio Magalhães, permiti-me notar que, pela experiência, podia afirmar o seguinte: às soluçóes correntes, no assim chamado círculo de associaçóes, lamentavelmente, salvo raras exceções, faltam a cordialidade e a colaboraçáo. Permiti- me lançar um apelo à mudança de sistema, à melhoria de relaçóes, superando eventuais dissabores, colaboraçáo para contornar as divergências e especialmente malentendidos. Em síntese: ver de se combinar a tarefa dos museógrafos (diplomados e não diplomados, amadores e emprecabidados) numa cordial família, promovendo encontros e fazendo planos.
Descoberta evidente: os tempos mudam. Ocorre-me, lembrando os anos em que Sáo Paulo ignorava os grupinhos de pintores, quase todos operantes no edifício Santa Helena, na praça da Sé, e por outro lado me pareceu então São Paulo ignorar também os artistas inovadores, os recalcitrantes às prescriçóes acadêmicas, os apelidados de vanguarda, quando não de 'futuristas.'

Hoje é bem diferente: calcula-se que a metrópole seja cidade, senão das artes, pelo menos de seus praticantes. Registram-se mais de mil pintores, escultores, gravadores etc. Pode ser que o número seja restrito, pois, através dos convites de exposiçóes que se recebem por parte das cento e tantas galerias ativas, no centro e nos bairros, constata-se que as artes invadem a maximetrópole. 
Aqui, além dos simpáticos do Santa

Helena, notavam-se os artistas da elite, isolados, embora amigos: Tarsila do Amaral, Flávio de Carvalho, Anita Malfatti, Lasar Segall, consagrados, porém não populares, salvo Flávio de Carvalho, produtor de brilhantes excentricidades.

É de Segall que desejo lembrar, por causa de um surpreendente acontecimento relacionado com o primeiro parágrafo: a doação, por parte do Museu Lasar Segall, da monumental pintura Guerra ao Museu de Arte de Sáo Paulo. Fato inédito no setor, provavelmente originado pelo antigo sodalício entre este redator e o Mestre

Já nos anos 30 conhecia a obra de Lasar. Ele esteve na Itália, realizando duas exposiçóes: uma em Milão e outra em Roma, e lhe dediquei duas páginas em minha revista Quadrante.

Ao me transferir para o Brasil a primeira coisa que fiz foi encontrá-lo, dando início a uma amizade bem viva e, para mim, bastante rica e proveitosa. Posso afirmar que Lasar e dona Jenny foram os meus introdutores no deserto da arte paulista.

O Masp vai colocar a Guerra em sua Pinacoteca, em lugar de destaque, como ela merece, homenagem mais do que justa ao singular criador e humanista de altíssima sensibilidade.

A sua arte sempre foi dedicada às manifestaçóes de empenho moral e social, aos casos da dor, da pobreza e das revoltas contra as injustiças sociais. Quando da eclosão da Segunda Guerra Mundial, Lasar Segall caiu num profundo desgosto e, mesmo invadido pela tristeza provocada pela irracionalidade dos homens, operou e denunciou através de sua paleta esse crime contra a humanidade.

Lembro que, ao me mostrar em 47 a tela hoje dada ao Masp, o Mestre manifestava seu veemente pronunciamento contra os provocadores da carnificina, uma explosão de aversão que mostrava a espontaneidade e o sentimento do humanista.

\section{Legenda}

A Guerra, de Lasar Segall, agora no Masp: o humano e o desumano

Senhor \#127, 24 de agosto de I983, p.85 (P.M. Bardi)

VANGUARDA: O BRASIL NA TRINCHEIRA

Uma infiltração de jovens artistas em Nova York

$E$ Esempre bom registrar quanto os artistas nacionais da extrema vanguarda, caso esta definição ainda tenha alguma significação, produzem no Exterior, através de afirmaçóes singulares veiculadas em círculos restritos a grupos que procuram romper de forma decisiva e surpreendente, para acabar não só com a tradição, mas com todas as tendências aparecidas depois do Futurismo, Cubismo e do próprio Dadaísmo.

As inovações, os exageros, o gosto pelo malbaratar, maltratar e confundir as ideias dos conservadores ainda apegados às antigas maravilhas de Picasso, Klee, Kandinsky etc. são - nas programaçóes dos superadores do que foi oferecido não apenas até o ano passado, mas até ontem - insistentes no proclamar que a arte, ou parecido exercício, é causa e efeito do cotidiano.

As surpresas partidas dos capatazes das escolas acima citadas, para lembrar apenas algumas surgidas ao longo do Novecentos, foram veementes e nem sempre passíveis de aceitação; as de hoje precisam de paciente atenção e cordial compreensão, de um esforço não facilmente possível. Nem os habituais apreciadores do brinquedo Arte, os geralmente familiarizados com as inventivas normais, as dos figurativistas até muito além do real, não conseguem compreender.

De fato, veem-se formas, signos, alusóes de difícil definição que nos levam a pensar que na história das artes plásticas isto é coisa frequente: ainda hoje não conjeturamos sobre o sólido à esquerda do Melancolia I e sobre o Quadrado Mágico, à direita, na gravura de Dürer?

Para nós mesmos, recebendo agora a publicação Flue, editada pelo Franklin Furnace Archive, como se vê na reprodução na capa, com as Américas de cabeça para baixo, digo nós mesmos para assim indicar raposas prontas a receberem até carimbadas que podem quebrar a cabeça, o divertido fascículo interessou por ter podido constatar 
como a América Latina das artes ingressou em Nova York, alinhando operadores brasileiros por sinal representativos de novidades.

Aliás, quem introduz os colegas do continente, agrupados desde a Venezuela até a Argentina, na seção De Primeira Linha, é Regina Vater e, na seção de Múltiplos, Fátima Bercht. Regina, carioca, é elemento da mult-media, atualmente participante de tendências em que ela considera metafísica, antropologia e mitologia, porém sob consideraçóes de futurama; Fátima, historiadora de arte contemporânea, reside em Nova York e seu ensaio sobre o dito assunto é bastante claro, como de resto o catálogo que nos revela os brasileiros e estrangeiros que aqui vivem, presentes na exposição do Franklin: A. A. Barrio, Vera Chaves Barcellos, Paulo Bruscky, Daniel Santiago, Augusto de Campos, Lígia Clark, Júlio Plaza, Leon Ferrari, Yole de Freitas, A. B. Geiger, Ivaldo Granato, Carmela Gross, Rute Gusmão, M. Ishikawa, Artur Matuck, Cildo Meirelles, Roberto Evangelista, Maria Luísa Saddi, Regina Silveira e a própria Regina Vater.
Os brasileiros foram, ao mesmo tempo, os apresentadores e notavelmente participantes da reuniáo, oferecendo destacada contribuição no setor do Conceitualismo, das Performances, e de uma infinidade de voleios no vácuo, no móvel, no sem-fim do novo se expressar.

Leu-se em recente crônica sul-americana que as embalagens que o grego Christo faz de coisas, edifícios, montanhas, valem, no Tribunal da Estética, tanto quanto o Moisés de Michelangelo, e as telas de Ives Klein, que, como se sabe, recebem uma única camada de tinta, têm o mesmo valor da Escola de Athenas de Rafael.

O redator desta página é incompetente para julgar as comparaçóes, pois não frequentou respeitados cursos de futurologia. De qualquer jeito, é sintomático notar que nada impede que na ordem inacabada do amanhã também generosos jovens brasileiros estarão na trincheira.

\section{Legenda}

Flue: ume revista pare iniciados

Obra do venezuelano Carlos Zerpa

Senhor \#I28, 3I de agosto de I983, p.89 (P.M. Bardi)

A Histeria NACIONALISTA

Redutos conservadores arrepiam-se com a "morte" da identidade cultural

De vez em quando (felizmente casos raros, incluindo os de histeria) se ouvem divagaçóes a respeito dos perigos que a 'identidade nacional da cultura' estaria correndo.

Parece-me que aquela categoria de conservadores tradicionalistas, não se sabe bem de qual cultura realmente enraizada no Brasil, se reduz a poucos elementos, sem um séquito apreciável. Todavia, seria leviano não registrar o fato, pois o contra-senso de um nacionalismo exacerbado é atividade que campeia também em naçóes da Europa.

Recentemente, num congresso da, 'União Democrática Cristã’ em Colônia, na Alemanha, o problema da 'identidade cultural' foi discutido. Ali aprendeu-se que na Alemanha estão presentes 'muitos turcos' e houve quem propusesse até mesmo limitaçôes da imigração de "estrangeiros oriundos de círculos culturais estranhos." Uma das reaçóes mais vivas foi a de Werner Strodthoff no jornal Kolner Stadt Anziger: "Quem pensa sobre o que são os fenômenos, as relações, as frutificaçóes culturais, não tardará a relegar ao reino irreal ao wishful thinking cultural- chauvinista das sólidas 'categorias' da identidade. A antítese artificial e pretensiosa - cá a, 'identidade cultural' lá o 'círculo cultural estrangeiro' - não se aplica tanto à cultura alemã quanto à de outros países europeus ou náo. A abertura sempre demonstrou ser capaz de produzir as melhores realizações culturais. Por outro lado, o protecionismo e a delimitaçáo - ambos expressão de fraqueza - levam ao isolamento, ao incesto e, finalmente, à esterilidade." Numa grande nação como a Alemanha, depois do desastre hitlerista, conclui-se que a abertura para outras culturas é frutífera.

Esta é uma consequência que registramos no Brasil e continuamos a registrar, pois somos um povo formado por várias intervençôes, contribuidores todos da nossa 'identidade cultural.'

Lembro isto porque soube que na exposição "Artesanato contemporâneo dos países francofônicos," apresentada no Sesc 
Pompeia, uma das legendas indicativas de peças de arte africanas causou discussão. O texto afirmava: "Que esta coleçáo de objetos de arte africana seja encarada como lembrança de um continente que muito participou na formação demográfica do Brasil, ao mesmo tempo em que contribuiu marcadamente na renovação da arte europeia deste século na Escola de Paris. Assim, o visitante considere a mostra uma homenagem à África e ao seu original gênio nas artes, modesta mas cordial iniciativa de fraternidade entre duas Terras."

Quem se opôs, naturalmente, vive fora de qualquer recinto de intercâmbio, base, hoje, do progresso que o mundo há tempos está desenvolvendo, mas também se mantém em recintos bem fechados, manobrando atrás de uma porta onde se lê a palavra 'nacionalismo.'

Lógico que é justo amar, avançar, fazer respeitar a nação da qual somos inquilinos, mas, no que se refere às aquisiçóes e evoluçóes culturais, parece-me que aquela palavra escrita acima da porta pode, e deve, ser cancelada.

\section{Legenda}

Peças do artesanato africano: uma originalidade que ajudou a renovar a arte europeia deste século

Casa Vogue \#5, setembro-outubro de I983, p.I44-I47

COLEÇÁO ARTE BRASILEIRA

...um senhor que tem dedicado seu lazer em descobrir, estudar, classificar

obras de arte referentes aos periodos da Colônia e do Império, imprimindo rara atenção e demonstrando apaixonado interesse...

Colecionar arte é exercício de antiga tradição. No Brasil é fato recente. Depois do desembarque de dom João vi, ao longo do Oitocentos o juntar obras andou se desenvolvendo porém ocasionalmente, mas de qualquer maneira numa escala bem lisonjeira em termos nacionais. Era apenas uma novidade, na verdade um fato quase excêntrico guardar memórias, sendo oportuno aqui mencionar-se o senhor Jonathas Abbot, o qual, na Bahia, pode ser lembrado como um eminente e inteligente colecionador ao reunir materiais que José do Prado Valadares, um dos mais sérios museólogos, catalogou num palacete em Salvador. Já neste século temos algumas notícias de acervos conservados e estudados por particulares, enquanto que alguns estabelecimentos dedicados à conservaçáo da Memória articulam algumas aquisiçôes. Em todo caso foram sempre os interessados na Memória nacional que se tornaram colecionadores.

Uma extraordinária demonstração neste sentido acaba de acontecer com a edição de um volume que João Marino, seu autor, intitulou de Coleção de Arte brasileira. Trata-se de um pouco da história nacional desfilada e denota o gosto de um senhor que tem dedicado seu lazer em descobrir, estudar, classificar obras de arte referentes aos períodos da Colônia e do Império, imprimindo rara atençáo e demonstrando apaixonado interesse científico, como demonstram as descriçóes e as ilustraçóes estampadas no livro.

A monografia torna-se um autêntico manual, notadamente no que se refere à imaginária e ao mobiliário, setores que tiveram no passado historiadores de reconhecido preparo. Marino, além da consideração estética, se preocupou em estabelecer as regióes de origem e as indicaçóes técnicas das madeiras, para tanto buscando a colaboração do Instituto de Pesquisas Tecnológicas da Universidade de São Paulo.

A coleção apresenta imagens de rara composiçáo e demonstra numerosas personalidades, escultores de talento que diversificam, no livre exercício da singular maneira do amplo espírito barroco.

Também a prata, a cerâmica, objetos decorativos completam a coleção, notando-se o rigor e, às vezes, o justo conceito do colecionador que sabe apreciar tudo quanto encontra independentemente do valor venal e das volubilidades da moda, mas sim quanto representa como tempo, documento e estética. Precisa conhecer, ter experiência, paciência, viajar, visitar antiquários, atender a qualquer chamado.

Tive ocasião de me interessar com João Marino por problemas da história nacional, fato que me proporcionou 
ricos conhecimentos. A prática, o manusear e naturalmente o amor muito ajudam a compreender. Isto pode ser observado folheando o novo livro, agora que uma simples 'paulistinha' recebe as honras da divulgação.

Coleção de Arte Brasileira enfeixa esplêndidas fotografias da bela casa do colecionador, cujas paredes mostram também obras de pintores brasileiros contemporâneos.

O livro é apresentado pelo embaixador João Hermes Pereira de Araújo e nos proporciona uma visão do colecionismo no Brasil. Lembra do caso do "Arcebispo vice-rei da Nova Granada Antonio Caballero y Gongora que trouxe a Bogotá inúmeros quadros flamengos e espanhóis, importantes coleçóes de medalhas, esculturas e objetos de prata, acervo cujo inventário fez recordar o de um príncipe do Renascimento," Sob a ótica da espacialidade geográfica que o embaixador Araújo dá ao colecionismo, me parece que seria justo lembrar um "príncipe" brasileiro: Assis Chateaubriand. E ao lado de Chateaubriand lembraria também o conde Fancisco Matarazzo cuja coleção de obras de arte tem sido, pelo tempo, de suma importância.

Deve-se lembrar que o boom do colecionismo começou com a inauguração do primeiro museu de arte digno deste nome, e levado a efeito com a colaboração deste cronista: o Masp. Desde 47 até hoje foi possível reunir um acervo que sem maiores ufanismo pode e deve ser qualificado de espetacular.

Voltando a Coleção Marino, devemos repetir mais uma vez que ela representa um conjunto dos mais singulares, digna de ser vista, na verdade um acervo bem escolhido e bem considerado.

Oxalá muitos imitem o esforço e o bom gosto do Marino.

\section{Legenda}

p.I44-I45 I. Residência do autor: sala de jantar. 9 2. Frei Agostinho de Jesus, Nossa Senhora dos Prazeres, primeira metade do século I7, Santana do Parnaíba SP, barro cozido e policromado, altura $102 \mathrm{~cm}$. 3. Carranca configurando cabeça de leão, segunda fase (I90I-I940). Madeira cedro,altura $100 \mathrm{~cm}$. 4 . Arcaz de capela, segunda metade do século I7, Olinda PE, madeira, vinhático, molduras de jacarandá, puxadores de ferro, comprimento I24 $\mathrm{cm}$; profundidade $86 \mathrm{~cm}$; altura $85 \mathrm{~cm}$.

p. I47 5. Mesa, final do século I7, Sorocaba SP, madeira, amoreira , ou taíuva, comprimento I28 cm; largura $105 \mathrm{~cm}$, altura $83 \mathrm{~cm}$. g 6. Naveta tipo galera, primeira metade do século 17, Salvador BA, Prata fundida, repuxada e cinzelada, comprimento $23 \mathrm{~cm}$; altura $17 \mathrm{~cm}$; peso 630 gramas 7 . Escada de acesso ao nível superior 9 . Sala de estar

Senhor \#I29, 7 de setembro de I983, p.69 (P.M. Bardi)

O VALE-TUDO DOS ESTILOS

Indefiniçóes da arquitetura numa época fechada para as reformas estéticas

Há algumas semanas, nesta seção, falamos de Arquitetura, a cinderela que vai como pode, genericamente pensada e genericamente construída. O Brasil, através de uma proposta do arquiteto Sérgio piado, autor de uma fantástica torre que pretende elevar no final da avenida Paulista, tomou conhecimento de um fato que vai passando despercebido: o moderno acabou e agora emerge o postmoderno, 'estilo' este também já superado.

Trata-se de um caso simples e que deve ser explicado: os estilos ou os modos, depois de imperarem ao longo de um certo período, mudam. O Gótico deixou o caminho aberto para a Renascença e esta, refeitas as formas segundo o modelo clássico da Grécia, acabou abocanhada pelo Barroco, e este pelo Neoclássico. Esta remastigada propiciou finalmente o surgimento de uma maneira que chamamos de Culturalismo, com isto indicando o minestrone manipulado com ingredientes de todas as proveniências históricas e resultando num pseudo-estilo sem pé nem cabeça.

De tão dispare situação surgiu a reação dos que não toleravam o minestrone, afirmando-se já nos primeiros decênios do século os arquitetos da polêmica novecentista. Os princípios gerais se concentravam tentativa de persuadir as pessoas quanto à inutilidade e inconveniência, num tempo 
de fantásticos progressos científicos, do desperdício decorativo das fachadas, da aplicação de figuras nas paredes, emoldurando-as, carregando-as de ornamentos.

Os arquitetos, propondo tais cancelamentos, clamando por uma revisão do conceito de moradia, apontando para a essencialidade da máquina, lançando a fórmula machine-à-habiter, clamando pela simplicidade do viver e assim por diante, se constituíram em vanguardas bem ativas. Os nomes são conhecidos: Le Corbusier, o lançador da fórmula, Gropius, Mies van der Rohe, Frank Lloyd Wright e tantos outros.

O novo modo de arquitetar teve a denominação de Racionalismo. Como sempre acontece, com a difusão das novidades, em cada nação surgiram os seguidores que as andaram espalhando. O caráter do Racionalismo poderia ser reconstruído evocando a Carta de Athenas de 1933.

Posso escrever na primeira pessoa, pois eu mesmo fui um dos participantes da delegação italiana, sem dúvida a mais polêmica, pois, três anos antes do conclave, eu tinha exposto, na Galleria d'Arte de Roma, por mim então dirigida, a Mesa dos Horrores, recolhendo fotos do monumentalismo retórico ideado pelos excelentíssimos senhores acadêmicos d'Itália, etiquetado de estilo "Romano modernizado," autêntica caricatura estética da Urbe imperial, e, para caricaturá-lo, misturei os exemplos com invólucros de chocolates e piadescas inscriçôes.

A publicidade deflagrada para anunciar uma exposiçáo dedicada aos jovens arquitetos foi presenciada, sem prévio aviso, por Mussolini, o qual se inteirou oportunamente do problema, divulgando na imprensa oficial meu manifesto.
A partir daquele ano, a Itália passou a pensar em uma arquitetura funcional, racionalista e outras denominaçóes que se seguiram. Convidei Le Corbusier para proferir conferências em Roma.

Meio século depois esta aventura foi descoberta pelo citado arquiteto Sérgio Prado, o qual, como disse, é o propugnador de virulenta campanha contra o Racionalismo, ou Moderno e até mesmo Post-Moderno. Como em toda e qualquer polêmica tudo serve, vi-me envolvido, num certo sentido, como peça histórica, pro domus sua.

Difícil oferecer uma opinião a respeito da atualidade da Arquitetura no Brasil, bem como antever quais os caminhos que irá palmilhar. Vejo que ainda existem construtores enfeitando as fachadas com colunas e tímpanos, herança grega do século 5 a.C., outros que se refrescam em casas esféricas tal qual Ledoux no Setecentos, enquanto outros náo se livram do Barroco, um certo pot-pourri labiríntico de complicada instrumentaçáo.

Estamos ainda longe de uma definição estilística no Novecentos. De qualquer modo, Brasília é um fato concreto. Niemeyer, saindo dos ensinamentos de Le Corbusier, conseguiu oferecer inovações urbanísticas e arquitetônicas. Mas não quero fazer digressóes, apesar de que é sempre bom discutir, mesmo sabendo de antemão que não estamos vivendo tempos propícios a reformas estéticas. O Ecletismo continua impávido sua trajetória sem a menor dor de cabeça.

\section{Legenda}

Uma torre na avenida Paulista, projeto do arquiteto Sérgio Prado $\mathbf{g}$ Torre de Houston, em forma de míssil

Senhor \#I30, I4 de setembro de I983, p.93 (P.M. Bardi)

UMA NOVA CORRESPONDÊNCIA

Nas cartas a Oneyda Alvarenga, as ideias de Mário de Andrade sobre as artes plásticas

Reunidas em livro, Cartas Mário de Andrade: Oneyda Alvarenga, (São Paulo, Livraria Duas Cidades, I983) uma mina para saber-se não digo mais, mas quase tudo, sobre um período da cultura paulista, o Modernismo, permitindo-nos penetrar no sodalício de dois eminentes protagonistas post-Semana: uma correspondência que delineia o labor não somente dos missivistas, como o afloramento de um conjunto de fatos que documentam vivências e comportamentos, diria o severo e ao mesmo tempo cordial humanismo de Mário, e do outro lado a devoção compreensiva e a colaboração com ele da ativa Oneyda.

Nas Cartas são desvelados adendos indispensáveis ao conhecimento das duas 
biografias, episódios que bem caracterizam os protagonistas até na intimidade, como quando Oneyda fala de um médico operador: "Além do mais tem a garantia (enorme para quem não tem crença, como eu...) de trazer Deus na ponta do bisturi...;" ou Mário: “...estou torcendo com toda a força radioativa que um feiticeiro indiano descobriu em mim.” Foi um convívio exemplar, francos e extremosos um com o outro, evocaçáo de coisas de Minas Gerais e especialmente paulistas, através das prosas de Mário, um misto de poesia e de sentimentos de profunda emoção; e também de Oneyda, que propicia ao Mestre atençóes deste teor: "Guarde a amizade imensa e a saudade ...," "o Senhor é mesmo um anjo. (Desculpe a confiança.)”

Naturalmente, a correspondência, depois do encontro no Conservatório dirigida pelo professor Mário e a aluna Oneyda que vem de Varginha, é permeada de didatismo, manifesta anos depois nos trabalhos do Departamento de Cultura, uma operosidade que muito contribuiu para a formação da cultura musical e folclórica dos tempos. Sempre, na contínua troca de cartas, afloram opinióes e desabafos. Nosso, "bardo mestiço" a 25 de maio de '35, escreve: "Mas, Oneyda, sou obrigado a lhe confessar que já estou completamente enfartado e amargurado dos homens. Só a perspectiva de que eu seria o Diretor do Departamento despertou a sabujice indígena, com uma virulência de enjoar. Fora a quantidade vasta de pedidos de emprego que já recebi, vindos de todas as partes do globo terrestre e das diferentes espécies de relaçóes entre seres humanos, o que me repugna mais são os que me detestavam, os que me tinham por detestável por qualquer razão, os que sempre viveram desprezivamente afastados de mim, e que agora váo-se chegando, ou chegam semvergonhadamente duma vez, com o rabinho entre as pernas, se estendendo como capachos pra eu passar, é horrível. E si [sic] eu lhe contar que já houve até um amigo, sim uma pessoa que tenho por minha amiga há quase vinte anos, que já sacou sobre o dinheiro que provavelmente eu ia futuramente ganhar! ... É horrível, Oneyda, dá uma desilusão dos homens que custa aceitar."

Superando a constante de tais pronunciamentos, da ainda ingrata mas possível produçáo no campo cultural, o que é interessante para esta página é o pensamento de Mário de Andrade no tocante ao setor das artes plásticas.

Oneyda, em fins dos '40, tinha-lhe pedido para esclarecer qual seu conceito sobre obra-de-arte. Na longa resposta, rica também de notícias biográficas, dizia que "...trabalhando como professor, logo veio a Semana de Arte Moderna, em que perdi todos os meus alunos..." "levo sempre pelo menos três quartos de hora me barbeando... ;" "vivo um perene mundo de descobrimento;" "o 'conhecimento' não me atrapalha nunca, porque ignoro" etc. Numerosos são os pareceres sobre pintores e escultores, demonstraçóes do modo de julgar de Mário.

Por exemplo: “... Si [sic] eu gosto sublimemente de um quadro de Brueghel e muitíssimo menos de outro de Segall é porque eu compreendo mais Brueghel que Segall... Brueghel sendo genial e Segall não sendo." Curiosas as comparaçóes do Mestre, como entre André Lhote e Paulo Rossi Osir, e curiosas também algumas afirmaçóes um pouco precipitadas, a mais estranha dedicada a Pinturicchio, com tal desprezo que grafava com $p$ minúsculo: “...qualquer pinturriquio ignorantíssimo do que seja uma abstraçáo...” A correspondência revelada neste livro é bastante rica e, sem dúvida, será comentada pelos cultores do Modernismo. De minha parte vai a recomendação de ler para saber.

\section{Legenda}

Mário de Andrade, segundo Portinari

Senhor \#I3I, 2I de setembro de I983, p.69 (P.M. Bardi)

UM MUSEU RECÉM-NASCIDO

A Propaganda não pode ser vista como uma arte "menor"

Esta semana nossa página talvez tenha mais leitores, pois o assunto, em última análise, é o marketing, antiquíssima prática, hoje no auge da consideração, 
pois somos inquilinos da era do consumismo imperante. Estou-me referindo à nova exposição aberta no Museu de Arte de São Paulo e dedicada à publicidade brasileira: Anúncios de Ontem. Grandes Marcas de Hoje. As maiores empresas estão cooperando com interessantes materiais conservados em seus arquivos, entre elas: General Motors, Ford, Artex, Antarctica, Gessy Lever, Souza Cruz, Alpargatas, Philips e muitas outras. A apresentação de rótulos, cartazes, displays, dépliants, velhos anúncios, permitirá ao público acompanhar o extraordinário desenvolvimento alcançado na comunicação publicitária. Trata-se de uma iniciativa que representa uma contribuição valiosa para a história recente da nossa publicidade, com seu ativo na formaçáo da estética nacional.

Foi no começo de I950, quando o sr. Assis Chateaubriand me chamou para organizar o Museu de Arte de Sáo Paulo, que, sem saber que um dia o pessoal do Beaubourg poderia vir a ter a mesma ideia, atribuí à nova instituição tarefas completa e audaciosamente meditas. Uma delas era a Propaganda.

Era a época em que meus "colegas" do presumível concorrente MAM, para dar a São Paulo a última novidade, copiaram o regulamento de 1893 da Bienal de Veneza e, como, "símias imitatórias" inauguraram uma manifestação já em decadência na Laguna do Adriático.

Uma das práticas normalmente atribuídas a um museu é a conservação de acervos reunidos para estabelecer a Memória, materiais esses que compreendem desde a Antropologia e Arqueologia até aquilo que é produzido nos mais variados setores. Particular importância é dada a arquivos e bibliotecas. As artes, mais representativas em termos de história, evidentemente recebem atenção particular, sendo a Arquitetura, a Escultura e a Pintura as preferidas. Menor atenção é dada às artes erroneamente classificadas de, "menores" como os objetos de uso e ornamentação, ou melhor, o mobiliário, tecidos, prataria, ourivesaria etc.

Todavia, a Memória não abrange apenas as artes, pois é sabido que depois do
Setecentos, com o aparecimento da indústria, houve notáveis mudanças. $\mathrm{O}$ setor provocou o surgimento dos museus da técnica e, de iniciativa em iniciativa, apareceram instituiçôes dedicadas aos mais singulares ramos, visando conservar maquinário e produçôes.

A Memória continua gozando de um melhor e salutar favor. Tanto assim que surge agora um novo centro interessado na conservação de um dos materiais mais representativos e relacionado com as atividades artísticas e técnicas: a Propaganda, que traz no seu bojo a imagem, o televisivo, as mensagens escritas, uma complexa e dinâmica operosidade a ser apreciada como contribuição essencial à estética, criação de uma categoria náo de complementação, "menor" mas participante ativa nos propósitos de formação do gosto.

Disso eu mesmo tive plena consciência quando, entre outros departamentos de ensino, como Música, Dança, Fotografia, Paisagismo, Desenho Industrial etc., abri, nos anos 50, no Masp, a Escola de Propaganda, ainda em plena atividade, evoluindo de acordo com os tempos, sob o título Escola Superior de Propaganda e Marketing.

A Escola, recentemente, voltou ao Masp, pois combinamos estabelecer em São Paulo um Museu da Propaganda. A antiga matriz ofereceu, para iniciar a formação do acervo da nova instituição e enquanto se procura uma sede, uma sala no prédio da avenida Paulista. Inaugurada há pouco, durante uma reuniáo de publicitários, presente o secretário de Cultura do município, Fábio Magalhães, o diretor do Museu da Imagem e do Som, Ivan Negro Ísola, e representantes das classes produtoras. Discutiu-se o programa já alinhavado e foi feita uma demonstração de como os materiais e documentos serão arquivados e classificados.

A exposição, que dá uma primeira ideia das manifestaçóes que se seguirão, pode, aliás, deve provocar o interesse das indústrias e casas comerciais para que o Museu da Propaganda possa completar suas coleçóes. Os materiais existem mas, 
na maioria dos casos, caminham fatalmente para a destruição. Apelo então a todos os que puderem que ajudem o recém-nascido Museu da Propaganda.

\section{Legenda}

Anúncio antigo em exposiçáo: ajudando a formar uma estética nacional

Senhor \#132, 28 de setembro de I983, p.97 (P.M. Bardi)

A DEMOCRATIZAÇÃo DA ARTE

Perguntas da Sociologia para um mercado que se fortalece

As atençóes que São Paulo está dedicando a este ofício que apelidamos Arte mereceriam uma indagação sociológica, para estabelecer seu quase repentino desenvolvimento verificado neste século, um fato que surpreende alguém que teve oportunidade de acompanhar, ano a ano, depois da última guerra, a contínua e prepotente afirmação.

Seria o caso de enquadrar o acontecimento na Sociologia: averiguar como ensina os mestres dessa ciência, os fenômenos determinantes, as relações distinguíveis entre os conteúdos e as formas dos diferentes gêneros e tipos de atividades, as interpretaçôes, os modos de fruição por parte do público, a posição do artista de um lado e, do outro, a estratificaçáo social, a estrutura de classes, os meios de domínio, a realidade política, os fenômenos das mudanças e as ideologias das classes dominantes e dominadas, as relações de dependência que provocam os efeitos.

A esses acertos deveriam juntar-se os do mercado, a participação dos assim denominados, 'galeristas' a categoria de contato entre o produtor e o público, base da funçáo comercial e da estética.

Quando abrimos o Masp, em '47, não existiam na futura metrópole estabelecimentos comerciais de arte, a náo ser o do sr. Beneteau, na Barão de Itapetininga. Anos depois surgiu a Galeria Domus, de breve duração. Será nos anos '6o que a situação irá melhorar pouco a pouco, até chegar aos dias de hoje, quando Sáo Paulo conta com mais de $\mathrm{I} 50$ galerias, sem contar a multiplicação dos museus, demonstrando que a produção e colocaçáo das produçóes da pintura, escultura e das artes ditas decorativas tiveram um impressionante surto. $\mathrm{O}$ mercado andou-se fortalecendo, popularizou as produçóes dos artistas por uma série de iniciativas, valorizando uma já esquecida mercadoria que se tornou até mesmo bem aceita, envolvendo aplicaçóes de investimentos econômicos. As galerias atendem aos mais disparatados gostos.

Vendem-se objetos de arte de alto preço e também peças de adorno que possibilitam as compras das pessoas mais interessadas na satisfação estética do que em negócio: são as obras produzidas em série, as gravuras e, agora, a novidade que se vai tomando o acontecimento do dia no setor: os múltiplos. A difusão das serigrafias, litografias, esculturas assinadas e numeradas, os múltiplos, deve ser colocada em relaçáo ao sempre maior interesse que, num estudo sociológico, deveria ser apontado como uma democratização, a possibilidade de acesso à obra de arte por uma menor quantia.

Faço essas observaçóes ao visitar a exposição de múltiplos na Arte Aplicada, uma galeria antecipadora do vanguardismo: obras singulares de Becheroni, Calabrone e Franklin, na escultura, e, na gravura, Gretta e Massuo Nakakubo.

\section{Legenda}

Obras de Becheroni e Calabrone: múltiplos na Arte Aplicada, uma galeria antecipadora do vanguardismo

Senhor \#133, 5 de outubro de 1983 , p.69 (P.M. Bardi)

ITÁLIA DE TODOS OS MUNDOS

No Masp, plano geral de um pais de descobridores

No grande auditório do Museu de Arte de Sáo Paulo, estamos evidenciando um tipo que, por ser eu um entre tantos, conheço, como se da em nossa terra, a menadito: é o italiano, dalle molte vite, ilustrado uma multivisão composta e divulgada pela Fondazione Giovanni Agrelli, de Turim, e patrocinada pela Fiat do Brasil e Alitalia. 
A multivisão é intitulada Itália, um pais modelado pelo homem. Essa proposta é destinada às Américas e usa "melhorar as relaçôes culturais entre a Itália e os principais países americanos, bem como instaurar e intensificar as relaçóes com cidadãos americanos de origem italiana... o slogan do programa poderia, portanto, ser: conhecer-nos melhor para melhor colaborar."

Existe muito pouco para melhorar, pois as relaçóes entre nós e a Itália nunca foram perturbadas, salvo o intermezzo da última guerra, episódio bélico que não ocasionou problemas mais sérios, pois a maioria das pessoas vogliamoci bene para aqui emigradas já possui hoje a caderneta de brasileiro naturalizado.

Os italianos sempre se aventuraram pelo mundo, aceitando bem viver nos países que os acolheram. Nada estranharam nesta terra, onde árabes, japoneses, europeus de todas as raças e quadrantes se entendem e dão valiosas parcelas para estruturação da nação brasileira, portadora de problemas como acontece em tantas outras comunidades, mas que vamos resolver bafejados por um sadio otimismo, depois de o regente ter descoberto o trópico, o que muito contribuiu para o avanço na senda do progresso.

Lógico que em cada neobrasileiro exista uma viva recordação das origens etnográficas. Porém a realidade é que a família verde-amarela, sem dúvida uma das mais acolhedoras, para não dizer exemplar, está hoje estruturada de forma granítica, emergindo seu caráter de base, num espaço de terra e de tempo, única língua, história que formou uma consciência comunitária e calcada em elevado espírito afetivo, integração, sentimento e independência.

Assim é mais que bem-vinda qualquer contribuição cultural, sem preferência, como notamos linhas atrás, todavia felizes por reencontrar a cara Itália que extraordinariamente participou com braços e alguns cérebros no progresso nacional.

A manifestação da Fundação Agnelli deve ser vista sob o prisma evocativo da península da qual saíram, ao longo dos séculos, os descobridores de outros mundos, os que nas cançóes contavam que iam fazer a América, os braccianti espalhados pelos campos, os ragionieri que edificaram indústrias, os construtores de monumentos, os pintores, os nascidos da "Mãe das artes e alunos da poesia."

Assistindo às provas da multivisão, brotou espontaneamente em minha mente que da Itália vieram tantos mestres, ou seus genitores, um grupo que abrilhantou as artes nacionais, como Castagneto, Parlagreco, Anita Malfatti, Di Cavalcanti, Pancetti, Girardenghi, Portinari, Bonadei, Zanini, Pennacchi, Visconti, Brecheret, Prati, Coluccini, Bruno Giorgi, Volpi, Hugo Adami, Mino Carta, Rosário Bemaudo, Barboso, Francisco Cuoco, Novelli, uma extensa lista difícil de ser relacionada.

\section{Legenda}

Uma foto da amostra: o porto de Messina antes do terremoto de 1908

Senhor \#134, I2 de outubro de I983, p.84 (P.M. Bardi)

EMOÇÓES DE UM COLECIONADOR

Uma arte contra muitos preconceitos, à procura das obras esquecidas dos brasileiros anônimos do passado

Quem lida neste serviço indicado como Arte, de vez em quando dá de cara com um senhor que recebe o título de colecionador. É alguém que decidiu adquirir obras para sua satisfação, por hobby, ou mania, ou intenção especulativa ou outra decisão não definível. Encontrei, ao longo de minha já longa carreira, sujeitos carimbados de colecionador, desde recolhedores de figurinhas de caixinhas de chocolate até magnatas norte-americanos que deram vida a fundaçóes e museus. $\mathrm{O}$ reunir objetos tem sempre uma finalidade: mecenato, lucro, passatempo, promoção, um certo prazer íntimo. Cada colecionador pode relatar sua vocação e experiência; o escolhido para esta página deve ser apontado como um dos que mais merecem distinção. Trata-se do paulista João Marino. 
Sua zona de ação: a história da arte do Brasil, o que aqui produziram mestres e artesãos, e interesse por tudo que de mais válido foi feito para tomar um altar ou particularizar uma arquitetura, resultado dos empreendimentos de uma elite que soube, desde suas primeiras formaçóes sociais, dar intimidade e originalidade à estética colonial, depois nacional.

O volume que documenta a Coleção Marino, distribuído nas livrarias por estes dias, oferece um panorama da arte plástica brasileira. Os historiadores de moldes superados, como Bernard Berenson, a definiriam como 'periférica' ou 'provinciana,' ou ainda marginal pela transferência dos modos portugueses. Nada disto: o Brasil se distingue por sua expressão, contribuiçáo autônoma do Barroco.

Aventurar-se pelas veredas que levam idealmente às oficinas dos adeptos às artes exige cordial familiaridade com o passado, além da sensibilidade e capacidade, João Marino, com o que apresenta, demonstra ser um atento conhecedor, um dos raros personagens que sabem atribuir uma obra, definindo procedências, individuando autores operosos em regióes às vezes isoladas. Sei, por experiência, o que significa descobrir, se não certas, pelo menos possíveis origens. É preciso evitar falsos raciocínios, não se deixar entusiasmar, ter frieza e logicamente, saber e gostar.

São todas qualidades que se reconhecem no colecionador João Marino, constantemente procurado para obter opinióes positivas a respeito de antiquariato brasileiro, campo que necessita de especializaçáo e, particularmente, de compreensão para uma infinidade de operários anônimos que compóem um Barroco coletivo e espontâneo, emergindo talentos de exceçáo como o Aleijadinho, que desaparece quando nosso dom Joáo vi teve a banal ideia de modernizar País chamando a Missão Francesa de i8ı6.

Já que o tema é o colecionismo suscitou surpresa o impedimento feito ao leiloeiro Fernando Soares de vender uma coleção de documentos brasileiros no Hotel Maksoud, há duas semanas. $\mathrm{O}$ evento divulgado através de uma campanha publicitária pela imprensa guarnecido por um coquetel classificado pelos especialistas como um dos maiores do século,com todo ávidos em voltar para as mansóes com uma assinatura do Feijó, ou um antigo carimbo do Itamaraty foi interrompido quando o representante do Sphan interviu, proibindo a venda, baseado numa lei de 1937.

De nada valeram os protestos de colecionador-marchand - o leiloeiro reempacotou o martelo enquanto o uísque continuava consumido. É o caso de se perguntar: por que vetar a um cidadáo o direito de vender objetos de sua propriedade? Seria justo o Sphan tombar os documentos estritamente de interesse para a Memória Nacional. Mas proibir a venda de uma carta de Tarsila do Amaral me parece infantilidade.

\section{Legenda}

Mesa do século I7, de Sorocaba e sino de 1778 , de Minas Gerais

Senhor \#I35, I9 de outubro de I983, p.72 (P.M. Bardi)

MudAnÇAS NO ENSINO DAS ARTES

Aprender com liberdade, uma opçấo capaz de romper com o pedantismo

O ensino das artes, em nosso país, como bem constatamos em recente mostra realizada na Faculdade de Comunicação da Universidade Mackenzie, teve e terá mudanças, o que leva a pensar na desatualização com que a disciplina era ministrada até recentemente: $\mathrm{o}$ academismo pedante, espelho da mentalidade calcada no salonismo. Quando o tradicional Saláo de Belas Artes se desdobrou em duas propostas, uma acadêmica e outra moderna, a novidade ensejou muita discussão, como em 1922, quando São Paulo foi surpreendida com as audaciosas propostas da Semana de Arte Moderna.

Agora, observando os trabalhos dos alunos daquela Faculdade na mostra intitulada, 'Elementos de comunicação visual sensível' nos convencemos das diretrizes coordenadas pelos docentes e das possibilidades expressivas deixadas livres para cada um dos discentes operar sem prescriçóes restritivas. 
O resultado é excelente. Cada aluno desenvolve aquilo que prefere no amplo leque do Design, aplicando disposiçáo, fantasia, economia em projetos e objetos ricos de atualidade, oferecendo boa contribuição, neste fluir de fim de século, em que as Ciências determinam as novidades mais inesperadas.

Professores e alunos, cordialmente integrados, realizam uma Escola de Comunicação exemplar, como diz o diretor do departamento de Arte, Itajahy Martins:

" $\mathrm{Na}$ complexa rede em que vive o homem da era eletrônica, da cibernética e da automação, não poderia ser outra a diretriz da Faculdade de Comunicação e Artes, que na sua postura consciente, procura revelar através da valorização de suas atividades o papel que lhe cabe na formação da juventude universitária. E isso é um bom começo."

O começo está certo. Não resta a menor dúvida de que da Escola vão emergir jovens que, profissionalizando-se, vão participar da produção brasileira do setor, já com extraordinário valor e reconhecimento internacional, seja na área do desenho industrial como no desenho da propaganda. É um fato muito gratificante para o redator desta página de Senhor, pois foi sua a ideia de abrir no Museu de Arte de Sáo Paulo, há mais de três decênios, duas Escolas, a de Design e a de Propaganda, a primeira dirigida pela arquiteta Lina Bo, e a outra por Rodolfo Lima Martensen. Saíram da pioneira do Design atuais professores do Mackenzie, como Alexandre Wollner, que do Masp, passou a se aperfeiçoar na Escola de Ulm, na Alemanha, tendo por mestre Max Bill, de renome internacional.

Estas lembranças servem para confirmar que o Brasil, tanto em campos complementares como nos básicos, nesta arrancada internacional do inelutável progresso, vai conquistando posiçáo e, apesar de gestóes complicadas, (que poderiam ser bem melhores) inflação etc., o Brasil vai para a frente.

$\mathrm{Na}$ inauguração da Mostra, no contacto com centenas de jovens, em sua maioria moças, cordialmente reunidos com o presidente do Mackenzie, rev. Boanerges Ribeiro, o reitor Felix Savério Majorana e todos os administradores e professores, o ambiente era de sadio otimismo.

Parece-me, então, ser muito acertado o registro de um fato universitário que é, ao mesmo tempo, um grato acontecimento de arte e de confiança na geração que desponta e que certamente irá vencer.

\section{Legenda}

Obras dos alunos Fábio Alves Abbud (acima, à esquerda), Nazareth

Pacheco e Silva (acima, à direita) e

Maria Cristina Álvares (embaixo)

Senhor \#I36, 26 de outubro de I983, p.II8 (P.M. Bardi)

UM CONVITE À INDIGESTÃO

A Bienal de São Paulo não imita mais Veneza. Imita a Alemanha

Leio no antigo 'Cozinheiro Nacional' certos menus incríveis, de trinta, quarenta pratos, imaginando a indigestão e o vômito dos devoradores. Por reação histórico-higiênica, hoje comerei somente um sanduíche. Leio também que no Ibirapuera vai ser inaugurada uma exposição de arte, a maior do mundo, alinhando mais de mil obras de duzentos e tantos artistas de 43 países, não se podendo apreciar o que se faz em cada nação separadamente, pois as produçóes estarão misturadas e apresentadas por tendências.

Penso no cansaço dos olhos, pés, cérebros e nervos dos degustadores se, ao invés de correr, vão observar, dedicando a cada uma das peças, no mínimo, cinco minutos, conforme as prescriçóes do psicanalista Osvaldo de Philip: total de milhares de horas, injeções de cafeína para resistir, ambulâncias, clínicas etc.

Teremos então, no ano 1983 da Era Eletrônica, uma volta a I893, Era do Academismo; último grito: os Salóes.

Mas é assim mesmo. Esta das Bienais é uma macaquice de "país em formação." Em 47 nascia o Masp, cuja sala principal era dedicada a uma explicação do problema 
Arte, abriram-se escolas, apresentavam-se exposiçóes periódicas. Grupinhos de estetas abrem logo depois, no mesmo prédio dos Diários Associados, um maspinho e, para proclamar que São Paulo era a Atenas da América do Sul, caputmagister o sr. Cicillo Matarazzo, fabricaram um carro antes dos bois: uma Bienal Internacional.

Cicillo atravessa o Oceano, desembarca em Veneza, descobre o regulamento daquela Bienal, novidade de I893, transfere-a para a Pauliceia, e a macaquice tem início.

Tudo corre bem e mal. Agora a Bienal é autre, pois seguindo as imitaçôes, o novo diretor prof. Walter Zanini, descobre a Quadrienal de Kassel. Veneza já era, as luzes vêm da Alemanha, propondo novas problemáticas do não-figurativo, indefiníveis, pelo menos para os "obscurantistas," isto é, os tapados que não entendem, os que não sabem que numa simples pincelada ou num corte de faca na tela ou num tubo está "a emoção da vida no mistério do seu desenvolver para identificar na arte de hoje o espírito humano" - é o que se lê em um dos inúmeros manifestos que, francamente, nós, obscurantistas, não sabemos interpretar. Para nós é mais conveniente ver e decifrar sozinhos o Informal do que nos deixarmos guiar pelos apologistas e pelos funcionários das Bienais.

O obscurantista, "aquele que ainda não possui uma óptica desenvolvida e discernimento para estabelecer comparaçóes estéticas," como sentencia a presidenta do Supremo Tribunal da Crítica; o obscurantista não pode compreender.

Seria lícito perguntar: quantos são os não obscurecidos, capazes de compreender grande parte dos rabiscos, quando rabiscos, que são expostos?

Seria infantil negar a liberdade de escavar no imenso das possibilidades da comunicação, não deixar negar a tradição, procurar, inventar, propor, virar de cabeça para baixo, admitir até mesmo simplórios e primários, penetras e chutadores no exercido que ainda se apelida de Arte. Todavia, de acordo com o fato que tudo pode valer e tudo pode servir, parece-me burocrático continuar, no Brasil, colocando o carro adiante dos bois.

\section{Legenda}

No espaço do Trianon: a $\mathrm{I}^{\mathrm{a}}$ Bienal em I95I (regulamento de i893) e mais tarde a sede do Masp (regulamento de 1947)

Senhor \#137, 2 de novembro de I983, p.7I (P.M. Bardi)

\section{UMA PROFISSÃO SEM DIPLOMA}

Paulo Francis, escrevendo na Folha de S.Paulo a respeito da profissão de jornalista, teve oportunidade de traçar o perfil de um colega que lhe endereçou uma carta, onde às tantas diz: “(...) Fiquei comovido. Ainda há realmente quem faça fé na imprensa escrita no Brasil ou de qualquer outro país. Luiz Costa diz que 'infelizmente' passou pela faculdade de jornalismo. Primeira explicação: acho tolice a exigência de curso universitário porque atrasa a vida das pessoas, nada lhes acrescenta (excetuando um ou outro professor) e porque, em verdade, qualquer jovem de talento como Luiz Costa pode aprender em três meses de redação o que não (sic) aprenderá numa faculdade. Há quem ache que essas escolas dignificam a profissão. É a velha ideologia do bacharelismo no Brasil (...)"
De fato, o ensino superior caiu verticalmente. De popular e gratuito passou, nas mais das vezes, para improvisados especuladores. Ninguém mais se lembra de Anísio Teixeira, nem mesmo da grande escola, Carneiro Ribeiro, em Salvador, fechada em '64.

Paulo Francis levanta um problema que vai muito além da profissão de jornalista, como certamente acontecerá com a mais nova, a de museólogo.

Quem abraça a profissão pensando em trabalhar num museu, certamente não precisa de diplominha. Como afirma o Francis, para ser profissional, basta um estágio de três meses numa redação para se habilitar ao exercício da mesma.

Sei que os autores de leis para fixar a profissão, vão alegar que eu mesmo abri, $a b$ antiquo, para jovens aspirantes que 
desejavam servir no Masp, um curso com todos os visos de caseirismo, ministrado em três meses, devendo-se explicar aos possíveis escolhidos fatos bem elementares: Rafael, elemento do Século I6, Van Gogh do Século 20, o Aleijadinho do Século I8, que a pintura se faz a óleo, com tinta acrílica, a aguada etc.; que a base $\mathrm{da}$ função reside no respeito às obras e aos visitantes, devendo-se observar a prescrição de não fumar no recinto, não gritar, não tocar nas obras expostas e quantas outras normas de comportamento.

Evidentemente, o diretor de um Museu de Arqueologia, ou de História Natural, ou de Zoologia, de Técnica e de quantas outras especialidades, pretenderá uma formação universitária dos praticantes, para náo ter de explicar que os bois têm quatro pernas ou uma árvore é formada por troncos, galhos e folhas.

No caseiro curso do Masp estudaram e dali saíram elementos que depois encontrei exercendo funçôes como redatores de tevê, fotógrafos, designers, pintores, os quais exerciam outras atividades que não a de museólogos. Talvez os participantes náo tenham gostado da profissão escolhida ou então pelo fato dos ordenados não serem convidativos, os horários pouco serem convenientes e outros fatores pertinentes ao empreguismo.

Nos museus, como em qualquer instituição cultural, existem os moscas-brancas, os quais, em vez de chegar ao serviço às nove horas, chegam is minutos antes, os que trabalham aos sábados, que renunciam às férias, e outras tantas e pouco comuns loucuras. $\mathrm{O}$ certo é que a quase totalidade dos assim ditos museólogos pertencem à categoria do funcionalismo burocrático, como acontece em outros setores.

Como tive oportunidade de explicar aos autores da lei que visa profissionalizar os elementos que trabalham ou aspiram a uma função em museus, pela prática que tenho no setor, sou de opiniáo que mais vale a vocação, tal qual se dá com os jornalistas. Penso que quando Paulo Francis apresentou- se pela primeira vez num jornal para publicar um artigo náo desconfiava que o progresso acabaria por envolver a profissáo de escrever para o público. Eu mesmo, quando tive a audácia de publicar meu primeiro artigo, focalizando um pintor lá pelos idos de 1917, pouco me dava conta da profissáo de jornalista.

É bem verdade que em um artigo da discutida Lei, para a gente que de há muito já labora em museu, será conferido um diplominha de consolação honoris-causa. Para mim será de pouca valia, talvez até mesmo para meus assistentes, como o Luís Hossaka que está no Masp há mais de trinta anos.

\section{Legenda}

Museu é como jornalismo: precisa mais de vocaçáo do que de curso superior

Senhor \#138, 9 de novembro de I983, p.76 (P.M. Bardi)

\section{Cresce o MERCADO DE ARTE}

Senhor é uma revista que enfoca os mais diversos assuntos e atividades que vão desde os de caráter político, econômico e social até os relativos às artes, objeto desta página, dando, assim, significado e interesse ao valor das produçóes que representam uma realidade no setor dos bens.

Nunca será demais recordar que no Brasil o mercado de obras de arte vem desenvolvendo-se satisfatoriamente. A mais recente realização, foi a Feira de Antiguidades, no Masp, evento que, se tiver continuidade, será uma valiosa contribuição ao setor. $\mathrm{O}$ mercado está reagindo, depois de mais ou menos um decênio, melancolicamente reduzido a leilóes que mostram apenas "artistas nacionais" ou então aqueles "catalogados no Benezith." Na citada feira, além das produçóes do pincel, foi possível admirar-se um conjunto de coisas do antiquariato, desde objetos do Egito e da arqueologia peruana até o Art Nouveau e Art déco. Constatou-se ainda um certo interesse pelo fato cultura, manifesto em objetos adquiridos não mais em termos apenas de telas dos chamados "clássicos nacionais."

O mercado ainda ensaia os primeiros passos na senda de um futuro que almejamos promissor mas que deve ser exercido por comerciantes com bom preparo técnico, especializados em setores que precisam 
de competência, dispostos a promover a importaçáo daquilo que possa ser bom para os apreciadores do colecionismo, como é o caso de Paulo Vasconcellos, em cujo stand se mostrou alguns instrumentos de trabalho em madeira, como, por exemplo, um tomo em pleno funcionamento, além de serras, martelos etc. e de Annamaria Barni, com preciosas peças de armaria, além de centenas de outras petas de interesse como mobiliário da década de ' 20 que foram apresentados pelos vários expositores.

Devo dizer que não é só falar sobre a feira o objetivo desta nota, mas sim para frisar uma determinante do interesse em relação ao mercado do antiquariato que, depois de dois séculos vigentes na Europa, e de um século nos Estados Unidos, representa o empenho de grandes empresas bem como a participação de porçôes consideráveis de gente, entre elas se destacando os beneméritos capitalistas que doaram bens e capitais a museus e a instituições públicas. Recebo de Londres os últimos catálogos da Sotheby's, os quais anunciam vendas de extraordinários patrimônios que vão desde prédios históricos até marfins, bronzes, pratas, móveis, joias, relógios, manuscritos, livros, cerâmicas, porcelanas, tecidos, tapetes e tapeçarias, bonecas, maquinário e inumeráveis lotes. Noto em um dos catálogos entre 397 objetos de prata, alguns da época vitoriana de I879, ostentando, ao lado das armas reais inglesas, as imperiais brasileiras e de um dos nossos nobres náo identificados.

No mundo inteiro as vendas cifram-se em bilhóes e ocorrem com impressionante frequência, o que vem demonstrar que o objeto de arte passou a ser efetivamente moeda.
Há alguns anos recebi a visita do presidente da Sotheby's que veio ao Brasil para uma inspeção, isto é, para sondar as possibilidades mercantis do nosso país. Conversamos exaustivamente mas sem lograr qualquer resultado positivo. E ainda recentemente, como acontece todos os anos, recebi emissários da Sotheby's de Nova York que aqui desembarcam para recolher peças para os leilóes que dedicam à arte da América Latina. Repeti a eles o que dissera ao presidente: enquanto não for decidida a organização de um leilão em moldes internacionais, nada se deve esperar. Fui mais longe ao oferecer o auditório do Masp, pois acho que o mercado tem interesse em uma ampla difusão cultural.

Mas... e as leis alfandegárias?

Esta é uma pergunta muito importante, pois nunca me esqueço como foi difícil, para não dizer complicadíssimo, (apesar do jeitinho brasileiro) a importação de obras que hoje formam o esplêndido acervo do Masp, notadamente uma estátua grega do século 5 a.C., obra que dormitou na alfândega ao longo de quatro anos.

Penso que já é hora de o Brasil participar também do marketing do antiquariato e da arte. A confirmação surge desde o nascimento do Masp, graças ao futurólogo Assis Chateaubriand, que assegurou ao País o patrimônio que todos conhecem, adquirido por alguns milhóes de dólares, os quais, hoje, cifram-se em mais de quatrocentos milhóes.

\section{Legenda}

Consolo de pedra-sabão da regiẫo de Congonhas do Campo (Minas. séc. I8)

Senhor \#139, I6 de novembro de 1983, p.93 (P.M. Bardi)

Nos LABIRINTOS DA ESTÉTICA

A difícil missão de escrever sobre arte numa época confusa

No Reino das Artes os ministérios são numerosos e, felizmente, não são eles dependentes do monarca e muito menos regidos por um estatuto. Produtores, marketingadores, historiadores, colecionadores, especuladores, penetras, amadores, prima-donas, segundos homens etc. etc., todos operam com total independência ou, quando é preciso, juntos, porém não sem antes jurar com a mão pousada num código qualquer.

Pelo visto, deixei de incluir na turma acima citada os críticos, uma categoria que desejo enfocar nesta página. $\mathrm{O}$ motivo é que vários amigos e inimigos (cada ministério é prenhe de antagonismos) pensam que este redator é um "crítico." 
Pelo amor de Deus, longe de mim ostentar tal título. Não foram poucas as vezes em que me declarei ser um simples cronista, um modesto registrador de fatos possivelmente interessantes, algumas vezes cordialmente duvidosos quanto a certos fatos, mas em última análise, bonzinho, sem parti-pris, pois no Reino a maioria dos participantes merece confiança. Lógico que, às vezes, existem casos em que um possuidor ou possuidora de calos nos cotovelos exagera e, então, reage-se além dos limites. Mas isto faz parte do comportamento normal inclusive dos "bundas-moles."

A crítica relativa às artes não deveria ser tendenciosa e nem bajuladora de qualquer produção, tendo por símbolo o vogliamoci bene, aceitando tudo e de tudo, sem pisar em cima do tal. A crítica partidária, para dar um exemplo histórico, era a do iluminista Francesco Milizia, fautor do nascente Neoclássico, o qual descarregava contra os barrocos Borromini e Bernini duras invectivas, a mais cordial sendo que os dois mestres produziam a, "peste do gosto" arruinando todos os seus seguidores. Tais disparates aconteciam e ainda acontecem quando a paixão, a inimizade, a inveja, o ciúme, dominam ou turbam a serenidade. Se do Setecentos passarmos ao Oitocentos (aqui um parêntese para lembrar um campeão: "A crítica d'arte deve ser parcial, apaixonada, politica; isto é, deve ser feita de um ponto de vista exclusivo, para abrir os mais amplos horizontes." Baudelaire) e, mais, aos tempos contemporâneos, arrasadores do tipo Milizia, encontraremos às pampas: os dispara-fuzis formavam uma patrulha intransigente, sem dúvida animada por suas razóes polêmicas contra o academismo, a mesma atitude do Milizia, opositor intransigente do barroco.

O crítico deve, então, ver, examinar e se convencer de que nas propostas emerge ou se esconde alguma originalidade, tendo em conta que o serviço obedece a um senso de capacidade, seriedade, virtudes e tudo quanto tenha validez. Porém, descobrir tudo isso não é tão simples, pois as correlaçóes, os plágios, as cópias, póem um Salomão no tortuoso itinerário da recente devassa das vanguardas, não mais dez, vinte, cem, mas centenas de tendências, variantes a não mais acabar, notadamente os dependentes da moda do Informal, do Concreto ou do Livre, enfim, gostos que melhor se classificam genericamente quando são criados nesta época de crise da Estética, canceladora de definiçóes universalmente válidas, determinadora do labirinto em que vagamos.

O crítico deve aventurar-se na selva com os pés chumbados para não acabar como um colega exaltador de um determinado artista, o qual, para castigá-lo, vingou-se mostrando-lhe, como sendo de sua autoria, pinturas copiadas de um abstracionista norte-americano, convidando o crítico a constatar o plágio na monografia do mestre, e aconselhando-o a mudar de profissão.

Contaram-me este mexerico, e ficaram maravilhados por eu ter justificado o coitado, observando: vocês se referem a um crítico de arte contemporânea perdido no labirinto; se vocês transferirem o exercício para o campo da história da arte, onde as afinidades entre artistas constituem casos muito comuns, verão, então, quanto é complexo julgar as autorias das obras. Eu mesmo adquiri para o Masp um retrato de Ticiano em que todas as evidências e modos eram do mestre e, no entretanto, alguns anos depois convenci-me de que se tratava de obra de Páris Bordon.

Quero dizer que julgar autores de obras de arte é tarefa complicada, e algumas vezes pode-se errar.

Até alguns anos atrás, o operar dos adidos à produção das artes era classificado em termos de maneiras e escolas.

As produçóes não são mais de grupos ou comunhão de tendências, mas individuais, cada mestre ou aspirante a tal julgando-se o número um. Esta é a sua primeira atitude, mesmo quando tem todos os visos de um primário. Assim é tão perigoso exercer a carreira de crítico que quando me dão este título imediatamente replico: sou apenas um cronista, aliás o "escrivão público de arte” trabalhando nesta praça.

\section{Legenda}

Tela de Páris Bordon atribuída, por engano, a Ticiano 
Senhor \#I4O, 23 de novembro de I983, p.75 (P.M. Bardi)

Reflexos da informática

Uma revolução que está isolando os "obscurantistas"

Pode parecer óbvio descobrir, em 1983, que os tempos estão mudando em todos os setores do viver, inclusive no recinto das artes que, como sempre se soube, constituem o seu reflexo.

Recebo agora três publicaçôes: Notícias do Canadá, que informa sobre a "mais importante exposição de alta tecnologia de todos os tempos:" Visual Arts 82, da Bienal de Veneza, capa ilustrada por nove leóes alados, símbolo dos antigos chefôes, segurando numa das patas algumas manchas coloridas; e, finalmente, o catálogo da mostra de pinturas e desenhos de Mário Donizetti, realizada na Pinacoteca Ambrosiana, ou seja, o sagrado Musaum do Cardeal Federico Borromeo.

As três publicaçóes sugerem ao cronista tecer algumas consideraçóes a respeito da situação das artes, admitindo, antes de tudo, que a informática influenciou não só a tradição daquelas atividades, mas está também impondo viradas de cabeça para baixo, isolando aqueles que os críticos à la page apelidam de "obscurantistas."

De fato, é obscuro, para mim, saber a que corresponde um "terminal... à semelhança de um seletor de canais de controle remoto, utilizando uma radiação infravermelha para chamar o computador pelo teclado..."

E complicado também, por outro lado, assimilar o que quer dizer através de sua peça, aqui reproduzida, o brasileiro Tunga, o convidado da Bienal veneziana do ano passado. Ele, como escreve o apresentador Ronaldo Brito, deve ser da tendência da transvanguarda: "Estas peças são, visivelmente, o resultado de operaçôes concretas em etapas sucessivas."

Não sei exatamente se se trata de um problema de conteúdo ou de "vai-à-puta-tradição:" porém, para ser tranco, chuto a opinião: por se tratar mais de literatura do que de plástica, seriam úteis explicações didáticas para nós, obscurantistas. Saiba-se também que nossa categoria não é tão idiota a ponto de não concordar com Radha Abramo, a qual, na Folha de S.Paulo, percorrendo "os caminhos e descaminhos" da bilionária (em cruzeiros) Bienal paulista, afirmou: "A obra é o discurso plástico do artista."

Se não se entende, o problema é do degustador.

Eis agora o catálogo de Donizetti: trata-se de um verista de talento, um artífice de indiscutível capacidade, daqueles que os superficiais apelidam erroneamente de acadêmicos, em certo tempo substanciosa freguesia da Bienal de Veneza inaugurada em I897 e levianamente macaqueada pelo Cicillo na São Paulo de I95I. O verista é hóspede de honra nada menos que da "Ambrosiana." O diretor da famosa Pinacoteca evoca Federico Borromeo, e para justificar a tendência do convidado lembra que o cardeal, em I6I8, doou uma pintura representando um grande vaso em que são pintados com extrema graça flores de vários tipos, e no fundo, uma joia, obra de Giovanni Breughel.

Como precisou Borromeo: “...Um diamante que me fez compreender... que as pinturas têm o valor das pedras preciosas," relevo que já o próprio holandês tinha feito: "As pinturas podem superar o ouro e as s."

Nesta passagem de tempo, com os computadores tomando conta de nós (não sou muito obscurantista, pois este ano armei no Masp uma grande exposiçáo dedicada ao vídeo) as artes encaminham-se para zonas onde é complicado se aventurar, sendo porém normal procurar compreender os artífices que espelham o dia-a-dia: os que mexem na tecnologia, os do futurama e os que persistem no verismo.

\section{Legenda}

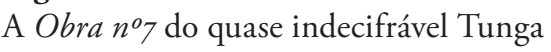
e Solitudine (1969) de Mário Donizetti: níveis idênticos de atualidade 
Senhor \#I4I, 30 de novembro de 1983, p.95 (P.M. Bardi)

Os JOVENS E A PINTURA

Surpresa: nenhuma obra da transvanguarda no Prêmio Pirelli

Se as nossas maiores indústrias tomassem iniciativas como a que acabo de registrar, esplendidamente realizada pela Pirelli S.A., chego a pensar que os problemas das artes se encaminhariam para algumas soluções, sendo uma das mais notáveis a necessidade de auxiliar os jovens que abraçam a dificultosa carreira da pintura.

O empreendimento desta grande indústria surgida na Itália no Oitocentos, e hoje ativa em numerosos países, se substancia no lançamento de um prêmio, organizado em colaboração com o Museu de Arte de São Paulo. O prêmio é destinado a jovens artistas, entre os vinte e os trinta anos. Todos os Estados do Brasil participaram do certame, tendo sido julgados por uma comissão composta por Jacob Klintowitz, Armindo Trevisan, Flávio de Aquino, Emanoel Araújo e P.M. Bardi.

Devo dizer que o nível dos concorrentes resultou bem satisfatório, notando-se elementos entre os quais é possível prever futuras afirmaçóes. Seguidores de várias tendências, aparecendo preferências pelas temáticas mais diversas, às vezes bastante originais, porém nunca fora das linhas de comunicação consideradas tradicionais.

O interessante foi constatar, além do número dos participantes, a atenção e a disposição com que se atende a arte da pintura, por parte dos jovens.

Não foram encontrados trabalhos do assim chamado transvanguardismo, hoje uma das manifestaçóes em moda. Teve-se a impressão de que este espírito da não meditada superação da modernidade ainda não convenceu a juventude. Ao que parece, o objetivo da jovem pintura é uma comunicação a ser possivelmente compreendida por parte do público.

Muito convincentes foram os desenhos, de uma qualidade realmente extraordinária, determinando à comissão prover amplas escolhas.
Pois é sempre difícil e, às vezes, errado o antiquado sistema de premiação: primeiro lugar, segundo, e assim por diante; na manifestação foram escolhidos trabalhos considerados entre os mais merecedores, atribuindo a cada um prêmios de igual valor.

$\mathrm{O}$ apreciador da arte da pintura pode ver a exposição que reúne cem obras na Pinacoteca do Masp, de 25 de novembro a II de dezembro, observando assim um panorama da nova geração que hoje opera em todo o Brasil.

Sei que um outro panorama está sendo apresentado no ressuscitado Museu de Arte Moderna, no Ibirapuera, com os elementos preferidos pela apreciação, simpatia e até pela ajeitadinha típica dos que se atarefam nos probleminhas da arte adjetivada.

De qualquer maneira, o momento, na Athenas brasileira, é único no que se refere ao conhecimento de como vão as coisas na arte: Prêmio Pirelli, no Masp; Panorama, no MAM; Últimas Mudas, na Bienal e uma centena de individuais nas galerias comerciais. As artes plásticas vistas, finalmente, como um novo lazer.

Até mesmo a imprensa notou o antes nunca verificado interesse dos paulistas pelas grandes exposiçóes, como a de Tomie Ohtake, a do Expressionismo Alemão, ambas no Masp e as acima citadas. Se a estas juntarmos os leilóes de arte, como o que a TV Globo organizou em beneficio das vítimas da seca do Nordeste, que teve ampla participaçáo dos doadores, pode-se constatar a popularidade das artes, hoje um fato característico da metrópole paulista.

\section{Legenda}

Obras de Carlos Otávio F. de Oliveira, do Ceará, e César Otacillio Gomes, de Santa Catarina: dois ganhadores do Prémio Pirelli 
Senhor \#I42, 7 de dezembro de 1983, p.77 (P.M. Bardi)

Chega De Adular a CUltura

A tecnologia brasileira é que está precisando de um museu

Lê-se que um grupo de artistas plásticos, reunidos em Porto Alegre pediram ao governo a bagatela da criação de um ministério exclusivamente dedicado à cultura, isto é, à cultura, isto é, à Cinderela nacional.

Dias atrás, no conselho diretor do projetado Museu da Tecnologia, do qual faço parte, em reunião para decidir, finalmente, quando se deverá abrir a instituição, tomei a liberdade de ser franco, talvez até por demais franco, pois os adjetivos que utilizei para a situação cultural paulista foram encarados como uma espécie de exagerada afronta ao típico princípio local de contornar, esperar, vai-se resolver, paciência, confiança e tudo o mais que carrega o caminhão da chapa "Deixa como está para ver como fica.” Desculpei-me, porém insisti. Especialmente por ter aplicado a etiqueta "palhaçada" para denunciar fatos os mais absurdos verificados e que ainda estão ocorrendo.

Um dos primeiros: enquanto se multiplicam os museus de arte, poluição provocada após o surgimento do Masp, em I947, na entấo São Paulo-Sahara, após mais de um decênio, continua-se a não se obter os meios para abrir o Museu da Tecnologia na metrópole que cresceu e vive da mesma. $\mathrm{O}$ estranho é isto: as classes econômicas, de cofre, se náo cheio, pelo menos regurgitante, e os poderes públicos deram Cr\$ I,2 bilhão para mais um festival bienalesco, desta vez não mais regulamentado na coirmã de Veneza de 1893 , mas na alemã de 1950.

Seria "obscurantismo" negar aos quatro gatos pingados que descobriram as novidades de Marinetti de 1908 ou do já antigo Mondrian; todavia, parece-me que a São Paulo-culturalmente-desvairada, deveria encontrar os meios para abrir, na Cidade Universitária, o Museu da Tecnologia, onde já existe a área e o prédio ainda não terminado, para abrigar o acervo pacientemente reunido pelo engenheiro Francisco de Paula Machado de Campos, animador e presidente da entidade que está à espera de vista pelo público.
Prático e praticante destes edifícios etiquetados, "museus" estou certo de que o da Tecnologia é fato cultural indispensável para São Paulo. É lógico que o MT não terá o milhão de visitantes que passam anualmente pelo famoso confrade de Washington, uma das 300 instituiçóes do gênero existentes nos Estados Unidos, que permitem conhecer a tecnologia em constante evoluçáo.

É evidente também que se não se começa, não se cria o que se quer. Nossa história (começaria por montar um engenho de açúcar) e a aparição e consolidação de nossa indústria devem ser mostradas através do pioneirismo que, do nada, foi criada, dia a dia. Reproduzo aqui, do catálogo da Exposiçáo Internacional de I85I, no Christal Palace, em Londres, a fraca participação do Brasil imperial: "Somente quatro expositores mostram produtos da indústria brasileira. Estes consistem de um bonito buquê de flores feito de penas, um modelo de embarcação indígena, um par de rédeas de cavalos e alguns objetos ornamentais feitos de casca de besouro."

Voltando às "lamentaçóes:" durante a citada reuniấo, soube que, anos atrás, a Fiesp incumbiu uma empresa de encaixotar a famosa biblioteca de Roberto Simonsen: duzentos mil volumes em caixas que continuam guardadas num depósito por falta de um local para ser organizada.

Curioso: o modismo das artes produz até mesmo sociedade de senhoras, leigas no assunto mas amigas dos museus(o redator teve contato com elas quando, em abril deste ano, numa "boitada" no Regine's, arrecadaram alguns milhóes em beneficio do Masp, até hoje nunca recebidos.) As artes, como se vê, estáo em pleno auge e a tecnologia, na arrancada da informática, passa mal, museograficamente falando.

\section{Legenda}

Descaroçador de algodão e engenhoca de cana-de-açúcar (século I9): quem se interessa? 
Senhor \#I43, I4 de dezembro de I983, p.79 (P.M. Bardi)

A DECADÊNCIA DO PLÁGIO

Esforços a favor da criatividade da propaganda no Brasil

Noites atrás, o distinto público que assistiu ao ato de entrega dos prêmios conferidos pela $I^{\text {a }}$ Bienal Internacional de Arte Fotográfica, promoção da Escola Panamericana de Arte de S. Paulo, e prestigiada pela sempre benemérita Kodak, estranhou ao ver o redator desta página entregar ao suíço Christian Lichtenberg o troféu de vencedor. A oportunidade ensejou-me verificar que os diretores da Escola Panamericana se lembraram dos primeiros avanços da arte na Sáo Paulo dos anos 40.

Vinte e cinco anos depois do memorável evento da, "Semana" muito longe no tempo mas sempre próximo como grata lembrança do entáo novíssimo Museu de Arte de Sáo Paulo, aberto por Assis Chateaubriand, entre outras coisas, pensei em criar uma série de escolas, uma delas dedicada à Propaganda, a qual vingou ao longo do tempo e hoje presta inestimáveis serviços sob o título de Escola Superior de Propaganda e Marketing.

Mencionando a Escola de Propaganda, desejo prazerosamente evocar nesta crônica a figura de Rodolfo Lima Martensen, o qual acaba de publicar um interessante livro sob o título O Desafio de Quatro Santos. (L R Editores Ltda., São Paulo)

Com Rodolfo e Napoleão de Carvalho montamos o Io Salão dedicado à Propaganda.

A proposta produziu uma certa surpresa: um museu iria encarar a propaganda como arte e abrir uma escola destinada à nova disciplina. Mas as coisas não ficaram por aí: o Masp inaugurou outros cursos, como o do design industrial, fotografia, pintura, escultura, paisagismo et cetera, como atividades dependentes da arte. Organizou, ainda, desfiles de Christian Dior na Pinacoteca, e deflagrou a tentativa de se criar uma moda genuinamente brasileira, isto é, desenhada, cortada, costurada e apresentada aqui, uma autêntica novidade no País.

O memorialista Rodolfo, em seu livro, lembra o que lhe declarou, na época, este cronista: "Enquanto os meus Rembrandt, Velazquez, Goya, Picasso, Renoir, ficam às moscas, esperando uns poucos visitantes no Museu, vocês da propaganda entulham os olhos do povo com toda sorte de porcaria. Você, Rodolfo, náo gostaria de organizar um curso de arte publicitária para ajudar o Museu a melhorar o nível artístico da publicidade deste país?" O candidato pediu um prazo de nove meses para estudar o caso: profissional de absoluta competência, informado do que se passava internacionalmente, foi à Europa, comunicou-se com universidades, agências e elementos do ramo e, regressando ao Brasil, apresentou-me um anteprojeto exemplar. A proposta definia as matérias e o sistema de ensino a ser adotado. Em seguida, apresentamos o negócio ao sr. Assis Chateaubriand, o qual, de pronto, mostrou-se entusiasmado.

O sucesso da Escola de Propaganda foi imediato, graças ao apoio de professores de primeira ordem como o caro amigo Renato Castelo Branco, vice-diretor da Escola, Geraldo Santos, Oswaldo Sangiorgi, Linneu Schützer, Geraldo Wilda, da "Lintas" e tantos outros veteranos táo bem lembrados no livro do Rodolfo.

A comunicação publicitária, penso, beneficiou-se da pioneira iniciativa e passou a considerar a necessidade de uma criatividade que superasse a rotina geralmente tributária das atividades norteamericanas. Lembro-me de ter visto nos arquivos de uma das maiores agências paulistas algumas ilustraçóes publicitárias do New York Times, que serviam para elaboração de anúncios, desde o layout até mesmo a arte-final. A nova escola propiciou o surgimento de desenhistas, como também provocou mais inventividade e originalidade; numa palavra, um sensível progresso da comunicação e um rápido e extraordinário desenvolvimento da nossa arte publicitária, hoje reconhecida internacionalmente como exemplar.

Basta folhear as páginas reservadas à propaganda industrial nas grandes revistas brasileiras para que se tenha confirmada a 
originalidade bem diversificada, demonstração eloquente de que os fatores arte e inventividade estão felizmente presentes.

\section{Legenda}

Masp, I950: publicidade é arte

Cartaz da I ${ }^{\mathrm{a}}$ mostra: invençóes

Senhor \#I44, 2I de dezembro de I983, p.79 (P.M. Bardi)

MEMÓRIAS DO "REI DOS VENTOS"

As aventuras dos trens brasileiros e sua galeria de heróis

Eis o sexto volume da coleção Arte e Cultura que, a cada ano, é publicada pelo Banco Sudameris Brasil, como lembrança para seus clientes e como contribuição à cultura nacional. Depois dos ensaios dedicados ao Modernismo, Prata, Cerâmica, Mestres e Artífices, Madeira, em 1983 o tema é a ferrovia, com o título Lembrança do Trem de Ferro, que o autor tirou de um verso de Castro Alves sobre o invento que "Acorda o Tigre no cerro| E espanta os caboclos nus| Fazei deste rei dos ventos| Ginete dos pensamentos| Arauto de Grande Luz!"

Devo resumir um livro que, penso, talvez tenha interesse como lembrança da operosidade de bandeirantes do progresso, engenheiros, pessoal técnico e operários participantes de uma história em que a bravura e o duro trabalho braçal, às vezes heroico, deram provas de extraordinário senso humano. Bastaria o desafio da, "Ferrovia do Diabo" no Amazonas, quando se enfrentou a Madeira-Mamoré, comparável às façanhas de Raposo Tavares, para se reverenciar a massa de brasileiros que vitoriosamente penetrou naquelas florestas.

Foi este um dos mais audaciosos projetos de estradas de ferro, como se vê na antiga documentação fotográfica das operaçóes de abate do impenetrável mato e as primeiras arrancadas, desastres, duros combates, hospitalizaçóes e dizimaçóes de operários, vitimados pela malária.

A exuberância da natureza venceu os empreendedores no Amazonas, mas cedeu, a partir de I852, quando, após trinta anos de discussóes parlamentares, finalmente Dom Pedro II inaugura os trilhos sobre os quais transita o primeiro trem.

O realizador da primeira estrada de ferro é Irineu Evangelista de Souza, o sulino que resolve o problema refletindo: quem manda é o Imperador, e ele passa as férias em Petrópolis; sem dúvida, o trem é mais cômodo do que a carruagem. Idealizada a Mauá-Petrópolis, o futuro Barão de Mauá descobre o engenheiro que pode dirigi-la. Não é bem um engenheiro, é um professor de Matemática na Escola Naval, militar de rígida disciplina, polêmico desejoso de um Brasil progressista, que repetia a cada momento: "Com a dedicação que professo ao futuro de meu País." Seu nome: Christiano Benedicto Ottoni. irmão de Teófilo. Receberá o apelido de "pai das ferrovias brasileiras."

A excursão pela senda do trem, na segunda metade do Oitocentos, torna-se, em cada província, motivo de encontro de singulares personagens que defendem a novidade, pois nem todos estavam de acordo, havendo interferência de interesses de grupos econômicos e até mesmo de fazendeiros do café. Discutia-se se o novo sistema não prejudicaria os tropeiros que, da zona de Campinas, levavam o rico produto até o porto de Santos. É o Barão que novamente entra em açáo e, depois de um intenso vaivém a Londres, consegue libras e técnica. A Serra do Mar é enfrentada.

Formam-se companhias, os ingleses antecedem, como sempre, o negócio, o Brasil povoa-se de estaçóes, o mais próspero meio de comunicação se impóe e vence. Os tempos ficam à espera das rodovias e do automóvel. Hoje, as ferrovias estão passando pelas dificuldades causadas pelo acerto técnico-econômico. O livro dá conta do admirável incremento da indústria nacional, exemplar produtora de tudo que é necessário para a estrada de ferro. São várias as interrogaçóes, as previsões incertas, mas existem também os interessados na reconsideração do sistema ferroviário.

Meu livro é uma lembrança, não uma tratação técnica. Parece-me simpático evocar os ferroviários, tanto os do pioneirismo como os que ainda andam nos nossos trilhos, quase peças de museu, agora que tudo é eletrônica. 


\section{Legenda}

Composição de carga na Santos-Jundiaí:

fora de moda na era eletrônica

Senhor \#I45, 28 de dezembro de I983, p.IOo (P.M. Bardi)

Os CRÍTICOS DOS TRÓPICOS

Arte na imprensa, um setor aberto à xingação e ao ataque pessoal

Sob o título de, "Zona tórrida" talvez para advertir o leitor de que não se trata de simples lero-lero, o Jornal de Letras, Artes e Ideias, de Lisboa, publica uma entrevista de Irineu Garcia, correspondente de Isto É em Washington, feita com Paulo Francis, escritor que a revista chama de "layout de aristocrata britânico que esconde um carioca apaixonado.”

Considerando a personalidade do antigo redator de Senhor, um dos diretores do Pasquim e do jornalista muito lido da Folha de S.Paulo, penso ser oportuna a divulgação de algumas de suas opinióes flechadas no alvo Cultura.

À pergunta: "Por que no Brasil o debate intelectual, sobretudo quando envolve o trabalho da crítica das artes, degenera quase sempre em xingaçâo, em ataque pessoal?," Francis responde: "Existe essa tendência, de fato, mas com uma pequena ressalva. Eu acho que a tendência geral é ao contrário, é bom-mocismo, é a gentileza, e talvez por causa disso, quando a coisa degenera, em vez de haver uma crítica equilibrada, cai em porrada. Vai-se de oito a oitenta. Há uma série de fatores que talvez expliquem isso. O que é um crítico? Você deve ver se a pessoa tem a devida instrução intelectual para poder comentar um livro, uma pintura, uma música.”

O dedo foi colocado na ferida, pois Francis, categórico, afirma que, em primeiro lugar, "...no Brasil, existe muito pouca gente que tenha esse preparo; em segundo lugar, as poucas pessoas preparadas têm muito poucas oportunidades de manifestar sua competência...” Especifica as causas, lembrando os casos da profissão, com exatidão, ao pontar: "O fato é que nenhuma das artes no Brasil tem a cobertura jornalística que deveria ter. À exceção de uma das coisas menos importantes, que é a música popular, porque as pessoas são taradas por música popular e televisão.”
A esperança, depois dos percalços originados pelo movimento de I964, é reposta na nova geração.

Trata-se, então, de saber se a loteca de amanhã vai aquinhoar os valentes.

Não tenho competência para tratar de problemas relacionados com a literatura e a música; dominar um pouco os fatos relativos à arquitetura, escultura e pintura. Nestes setores, é verdade a crítica não oferece provas de alta capacidade. De qualquer jeito, penso que operam no Brasil, se não elementos portadores de diplomas de crítico de artes plásticas, pelo menos alguns que porfiam nas resenhas, sejam ou não jornalísticas, de certo modo dotados de algum interesse.

Confesso que eu mesmo sou um destes resenhistas de fatos e problemas de história e interpretaçáo contemporânea, que tenho publicado livros, até com editores estrangeiros de importância, no setor das artes, como Abrams e Praeger Publisher, de Nova York, Union Verlag, de Stuttgart, Collin, de Glasgow, Rizzoli e Mondadori, da Itália etc. etc., numa evidente demonstraçáo de que não estamos totalmente desamparados. No entanto, não apareço no volume Criticos $x$ Artistas, editado recentemente pela "Arte Aplicada;" os autores são Alberto Beuttenmüller e Aldir Mendes de Souza.

Acompanho o setor no Brasil desde quando iniciei a instalação do Masp, e já se vão quase quatro décadas. Concordo que não se realizaram maravilhas, mas deve-se convir que o passo foi notável, mesmo levando-se em conta que as atividades plásticas estão envolvidas nas estéticas.

Reconheço não ser um crítico de arte, mas simplesmente um praticante e aprendiz atento aos problemas mas interligados à arte. Ao invés de esperar, como Paulo Francis, que a geração jovem vença, parece-me ser oportuno dizer que no Brasil já 
temos elementos sem cabelos brancos que estâo dando provas mais que satisfatórias.

Pescaria na entrevista do autêntico crítico que é Francis, esta sua constatação: “...o meio cultural é extremamente pobre.” Que fazer? Enriquecê-lo. Mas isto depende de fatores históricos e de contingências.

\section{Legenda}

Paulo Francis: "O excesso de gentileza degenera em porrada."

Senhor \#I46, 4 de janeiro de I984, p.64 (P.M. Bardi)

UMA ÁRVORE NA HORTA

O mercado de arte no Brasil precisa de uma publicaçáo especializada de interesse público

Por ocasião da publicação do livro que dediquei ao Trem de ferro, rei dos ventos, vários jornais e revistas, ao informarem sobre minha biografia, incorreram num lapso, afirmando que o cronista desta página foi, antigamente, diretor do Corriere della Sera. Esclareço que pertenci ao big milanês simplesmente como redator, aliás repórter.

Aproveito esta correção para desmentir outra informação que não corresponde à verdade, isto é, ser o Bardi um "crítico de arte." Considero-me um cronista das artes e, como tal, dirigi revistas, penso eu, não de pouca valia, também no Brasil, como Habitat, Mirante das Artes e Vogue-Arte.

Mexer no setor publicações de assuntos de arte sempre foi empresa complicadíssima, pois relatar e comentar o trabalho de arquitetos, pintores, escultores, e tantos outros adeptos às artes, até não sei bem quando, era considerado um exercício não digo marginal, porém, não muito digno de ampla atenção: eram poucos, para não dizer raros, tanto os produtores como os apreciadores. Quando o presidente Dutra inaugurou o Museu de Arte de Sáo Paulo, em I947, a cidade era órfã de galerias, havendo uma única, do francês sr. Beneteau, num corredor próximo à Barão de Itapetininga; as lojas dos aprendizes do antiquariato eram em seus próprios apartamentos. Nos leilóes do pioneiro José Felice Florestano, quase sem público, arrematavam-se obras importantes por ninharias.

A ultra-ativa cidade, apelidada sem saber por que, de, "Athenas do Brasil" nestes últimos decênios mudou, e o esplêndido lazer das artes não é mais como uma Cinderela, mas obtém distinção excepcional. Os jornais cotidianos dão páginas e páginas às artes, (em '47, a inauguração do Masp não recebeu menção do maior jornal paulista, registrando somente a vinda do presidente Dutra sem acenar ao motivo da visita) e hoje, os leilóes tornaram-se praga, o mercado é vivo, a produção pictórica e escultórica supera em volume a música popular, e assim por diante.

A Metrópole é até sede de uma Bienal que recebe $\mathrm{Cr}$ \$ I bilháo para mostrar aos leigos as últimas provas da transvanguarda, exaltada pelos, "críticos" que tacham os simples cronistas de obscurantistas, por ocasiáo da festa bilionária (com mais alguns quebrados, em milhóes).

A premissa serve para anotar que, apesar do boom realmente notável, o que é que falta? Uma publicação periódica especializada.

Quando nós, cronistas, precisamos verificar eventos do final do Oitocentos, e começo do Novecentos, procuramos as extremamente raras coleçóes da Ilustração até o agitador Klaxon. Lembro-me que, expondo o caso acima a um colega, o Luís, da família Carta, este concordou e decidiu uma ação, colocando nas bancas a Vogue-Arte.

Com Luís Carta, editor e, ao mesmo tempo, realizador, no Brasil, de uma revista de importância internacional como Vogue, nos empenhamos numa publicação que representou um fato singular. Edição de uma organização reconhecida como das maiores, continha ensaios de história e crônicas dos movimentos ilustrados como devem ser, além de consideração por cada problema, não apenas circunscritos às "lanas caprinas," mas de amplo interesse; em suma, uma publicação de interesse público. Felizmente, Vogue Arte deu vida à Casa Vogue, dirigida por Andrea Carta, a mais interessante revista de arquitetura que temos e que completa agora oito anos. Finalmente uma publicação prestigiosa e bem considerada. 
Num dos últimos números de Senhor havia uma página publicitária propondo um periódico que teria, no futuro, a máxima aceitação nas exuberantes florestas da economia e do PIB. Pensei na horta da Cultura, onde não há alma viva que plante, entre tantas hortaliças, uma árvore e como a que se sugere nesta página.

\section{Legenda}

Três bons exemplos: ilustração, edição brasileira, I885; Klaxon, I922, e Habitat, I950

Senhor \#I47, II de janeiro de I984, p.65 (P.M. Bardi)

RuMO À MAXIMETRÓPOLE

São Paulo tenta imaginar como vai ser sua cultura, no fim do século

Entre as numerosas exposiçôes que estão em preparo no Masp, começa a ter particular atençáo e, devo candidamente confessar, me dá preocupação e até medo, o tema é ultracomplicado. Trata-se de mexer no Futuro: "São Paulo do ano 2000," um projeto que decidimos realizar como complementação à promoção, "SP 2000," da TV Globo, e com a colaboração daquela emissora. Estamos apelando a todos os elementos que quiserem colaborar: economistas, técnicos, poetas, artistas, futurólogos e mesmo os formados na universidade das ruas. Numa palavra: apelando a todos.

Implícito será alinhar como estarão no fim do século os problemas dos instrumentos monetários dependendo da política, a robotização e a informática, a escrita dos fantasiosos e os riscos ou o hiper-realismo dos pintores, a arquitetura, o urbanismo, o metrô etc. etc.

Nada de comparável ao, "Baile Excelsior" do pacato,, se bem que inquieto, I900.0 Baile será um, "Jazz Atômico" já se sabe.

Como cada um, diplomado ou não, operoso, contando vantagens ou chutando, estará presente, como acontece agora no panorama paulista, penso no setor em que me meti, esta antiquíssima novidade denominada museu.

Tendo o currículo, contestado ou não, de três decênios e meio neste serviço, permito-me não a futurejar, mas a dar uma olhada no status quo da museografia local, não a histórica ou a científica, mas a das artes denominadas plásticas: um sistema que é de chorar.

Basta saber que o Masp, o único centro cultural a possuir, na América Latina, uma Pinacoteca de arte ocidental comparável às europeias, precisou desmontá-la por não ter os meios para consertar, depois de três anos, o aparelhamento de ar condicionado, num edifício de propriedade do município, distribuidor de verbas colossais para manter um vultoso funcionalismo "artístico."

São Paulo, nos primeiros anos do Século 2I, será a maximetrópole prevista. Espera-se que a Cultura seja fato mais ativo, adaptado a um humanismo mais interessado no idealismo do que nas lotecas, turfes, bolas, baús etc., uma vez resolvido o problema social, solução imprescindível.

No que se refere aos museus de arte, é inútil adiantar previsóes se não se decretar um agir seduta stante, isto é, fortalecer as atividades úteis já existentes, cancelar as atividades anacrônicas baseadas nas ambiçóes impertinentes, numa palavra, em resumo, definir e estruturar um sistema.

Fábio Magalhães, secretário de Cultura do município, nos reuniu, diretores de museus de arte, para discutir nossos assuntos. Eu fui. Tratou-se quase exclusivamente de verbas, empregos, diplomas e fatos secundários. Ninguém relevou a miséria museográfica da Metrópole, a necessidade de possuir acervos, interessar aos que podem para ter o que é indispensável mostrar, criar o espírito de contribuir, de participar e de ver grande, análogo ao vigoroso avanço de Sáo Paulo para o ano 2000.

Temos vários museus de arte: os dedicados à história mereceriam maior impulso. Antes de tudo, seria preciso enfrentar o problema do Museu Paulista, rico em materiais, mas com poucos meios. O mesmo ocorre com um museu que parece, nos dias de hoje, indispensável a uma metrópole: o da Tecnologia, depois de sempre, fechado ao público. 
Masp, 1983: 1500 visitantes por dia (em I947, eram só 50) 9 Magalhães: o que fazer dos museus?

Senhor \#I48, I8 de janeiro de 1984, p.67 (P.M. Bardi)

\section{PATRIMÔNIO E INICIATIVA}

De vez em quando, a crônica deve interessar-se por controvérsias que agitam as artes às quais não se dá a atenção reservada, por exemplo, à música popular ou ao transvanguardismo pictórico: a arquitetura.

Não vou repetir o que já se sabe a respeito da casa de Vila Mariana, construída, em '27, pelo arquiteto russo Gregory Warchavchik, "escândalo” rico em episódios até de empurróes a colegas jornalistas e, pelo que se continua noticiando, o assunto agora está na mesa do presidente do Serviço de Proteção do Patrimônio Artístico e Cultural.

O cronista desta página, deixando aos Sólons da conservação as decisões supremas, quer somente lembrar dois brasileiros com os quais a amizade e estima favoreceram um relacionamento de intimidade e afinidade de ideais: Rodrigo Mello Franco de Andrade e Gregory.

Um conhecido, da turma que dá mais importância ao desfrutar de uma área urbana do que a um caso de história, me acusou de ser mais intransigente que Rodrigo, pois me pronunciei a favor de se dar um jeito para que o palacete não seja demolido, mas sim respeitado no conjunto residencial projetado.

Parece-me oportuno, então, lembrar o criador do Patrimônio, em tempos difíceis e complicados da política republo-ditatorial, no fatal momento em que um estadista de visão como Gustavo Capanema teve a excepcional coragem de pagar um prêmio ao vencedor do concurso para o edifício do Ministério de Educação e Saúde, projeto de Arquimedes Memória, o qual, para superar até o estilo, "neocolonial” então na crista, propôs servir-se do estilo, "marajoara" pensando: se de Brasil se deve absolutamente tratar, superamos a lembrança dos séculos coloniais para se buscar decoraçáo na civilizaçáo que Cabral encontrou em I500.
Rodrigo foi um dos solidários a

Capanema, como Manuel Bandeira, Carlos Drummond de Andrade e Lúcio Costa, renovador do ensino na Academia Nacional de Belas Artes. Breve: convocou-se Le Corbusier para o "risco" do edifício.

Ao mesmo tempo em que o Brasil inaugurava esplendidamente sua nova arquitetura, Rodrigo, com espírito de acertada sensibilidade, incentivava e impunha o respeito e a valorização da história. Este cronista lhe dedicou, no Masp, a exposiçáo A Mão do Povo Brasileiro, na justificativa afirmando: "A ele se deve o trabalho de toda uma existência, que nos encaminhou não só para a definição de uma cultura, mas de uma civilização. Que seu exemplo seja seguido pelos que o sucederem..."

A Semana de ' 22 foi o estopim da assim dita Modernidade. No que se refere à arquitetura, indecisão, falta absoluta de ideias de contemporaneidade, e até o arquiteto espanhol Antonio Mova, cultor do mourisco, foi convidado a fazer parte do protesto.

Gregory, vindo de Roma no ano precedente, ainda não era da roda. E a ele, todavia, que se deve atribuir a primeira contrastadíssima posição para a renovação da arquitetura: em ' 25 publica um manifesto teórico, em ' 27 constrói a casa em discussão. Em ' 65 , tempo em que o Brasil era considerado no estrangeiro como contribuidor avançado da arquitetura, este cronista lhe dedica uma exposição individual no Masp e o livro de Geraldo Ferraz Warchavchik e a Introdução da Nova Arquitetura no Brasil: 1922-40.

Foi iniciativa de justa lembrança a um pioneiro. Se um dos tantos Rodrigos pôde abrir a boca, até concordando com a denúncia que a Visão fez, ("Tombamentos: muita demagogia") que, pelo menos, náo se destrua a primeira casa modernista da América do Sul. 


\section{Legenda}

Duas fotos da casa do arq. Warchavchik

de 1927: a fachada e uma sala com obras

de Tarsila do Amaral e Lasar Segall

Senhor \#I49, 25 de janeiro de I984, p.9I (P.M. Bardi)

\section{Sáo Paulo, arte E futuro}

Um assunto que está bem na ordem do dia e contando com ampla divulgação é a proposta "São Paulo 200o:" ampla discussão, previsões, antevisóes, múltiplos conselhos e até soluçóes para que esta megalópole encerre o Século feliz da vida e adentre no próximo milênio caminhando de forma ordenada e sem maiores problemas, superando e deixando para a história os dilemas e agruras até agora registrados.

Geralmente, as visóes cultivadas são caseiras e com enfoques nitidamente municipais, sem colocar o negócio no quadrante universal, já que nós, como entidade, não passamos de uma entre muitas partículas dispersas pelo Globo, valendo no futuro a densidade demográfica, a produção de alimentos, o desenvolvimento industrial, a utilização de bens naturais, a situação da poluição, sem contar o que as ditas "grandes potências" podem combinar acionando os terríveis mísseis que serấo os responsáveis por um amontoado de problemas, mais de terror do que de paz.

Há uns dez anos, o alarme foi dado pelo Instituto Tecnológico de Massachusetts, que concluiu ser necessário limitar o desenvolvimento deste Mundo ainda com ranços medievais, dominado pelo espírito de conquista, acúmulo de riquezas, sendo a um só tempo símbolo e ídolo, os desacordos humanos evidenciados nos mais distantes confins, microscópicas ilhas determinando expediçôes militares, um ridículo moral, político e territorial, de se pensar náo em Idade Média, mas em tribos primitivas.

Dentro de tão pouco lisonjeiro quadro, eis São Paulo, lançada ao Futuro, levando seus problemas em andamento, o político que volta e meia atrela todos os demais.

A anotação é mais uma premissa para responder a uma carta que o repórter recebeu e cujo missivista quer saber como serão as artes em São Paulo no 2000.
Diz: “... Nas previsóes sempre se avançam propostas de política, economia, produção, religião, e nunca a respeito das artes ...”

Boa pergunta. Também no lembrado relatório do MIT, o System Dinamic Group se interessou por "matemática do crescimento exponencial," de "bens naturais não-renováveis," de "hipóteses quantitativas” etc. Afirmaram: “... A Humanidade náo pode continuar a proliferar em ritmo tão acelerado, considerando o desenvolvimento material como finalidade principal, sem cruzar-se com os limites naturais do processo, em frente dos quais ela pode escolher: aviar-se por novas estradas que lhe permitam padronizar o futuro, ou aceitar as consequências inevitavelmente mais cruéis de um desenvolvimento incontrolado.”

Deve-se refletir quanto e como os dedicados às artes poderiam contribuir no projeto. Porém, parece que os operadores participam do caos para com isto, confundir ainda mais a passeata para o absurdo do incontrolável, emergindo a bizarra e incompreensível pintura que nada revela, as brincadeiras plásticas de um sapato numa mesa, o enigma e o refúgio de trouvailles banais para uma freguesia pseudo-excêntrica.

Os artistas do 2000 continuarão a não considerar as comunicações legíveis, isto é, figurativas tendentes à participação, difusão e discussão dos problemas da Humanidade em busca de uma estiada mais acertada?

Ninguém nega o interesse de alguns mestres que pensam no momento científico do Século, a partir do Futurismo; parece também lógico esperar dos operadores do instrumento Arte algumas sugestôes que seriam valiosa contribuição para uma maior difusão de princípios úteis à sociedade de consumo com todos os seus excessos. 
Não se trata de retomar à pintura tradicional, com vistas a uma nova propagação do Cristianismo ou para celebrar históricos acontecimentos, mas esperar por uma arte empenhada, contribuidora da vida, para todos e não reservada aos pseudo-excêntricos.

\section{Legenda}

As fases do tempo, em poucos anos, por um mestre como Pablo Picasso: Busto de Mulher, (Suzanne Bloch) 1904; Toalete, I906; Atleta, 1909. Acervo do Masp, São Paulo

Senhor \#I5O, I de fevereiro de I984, p.83 (P.M. Bardi)

A ARTE ANTES DE CABRAL

Antes do desembarque de Cabral, o Brasil vivia sem os problemas que os brancos sempre deixam caminho das conquistas. Os invasores, naquele 1500 , consideravam o Índio um selvagem que devia ser escravizado, com tendência a desaparecer. $\mathrm{O}$ resto, no que se refere aos antigos donos da Terra, não entra, ou começa a aparecer nas páginas da história nacional repleta de portugueses e seus opositores holandeses e franceses, de capitanias, reinados e impérios, repúblicas, eleiçôes etc.

Assim,foi surpresa receber o esplêndido volume, "Herança" editado pelas Empresas Dow, que trata da, "expressão visual do brasileiro antes da influência do europeu" e que, num dos primeiros capítulos, resume o espírito da iniciativa: "O futuro do nosso passado." Não se trata de um trabalho científico, mas de aproximaçáo a um setor histórico da máxima importância.

É mais uma iniciativa que testemunha qual a civilização desta parte do globo organizada e distinta, prosperando de modo primitivo com base na agricultura, caça e, na simplicidade do próprio fazer, produtora de uma arte genuína. A ciência arqueológica, geralmente reservada aos fastos da Grécia e da Roma clássica, finalmente se tomou assunto também brasileiro e, apesar das dificuldades que não lhe tornam o trabalho fácil, vai documentando, através de escavaçóes e pesquisas, um material de extraordinário valor, em parte custodiado em museus, no Amazonas, no "Goeldi" de Belém, no Piauí, Mato Grosso, Goiás e em outros Estados, inclusive o de São Paulo, onde o "Paulista" conseguiu formar notável acervo.

Os arqueólogos, os poetas e os que mexem fantasiosamente nos primórdios da Humanidade nos póem a par de, "continentes perdidos" de oceanos engolidores de ilhas, eldorados, o Brasil terra de especulaçóes temporárias, de século em século meta de curiosos, o último sendo o coronel Fawcett desaparecido no Amazonas. As lendas, fantasias e projetos são as páginas de Renato Castelo Branco, lembrando escavadores, cientistas e visionários, um pessoal realmente em primeiro plano, exceção da quantidade de descobridores de minas de ouro ou de plantadores de café e algodão.

Esta premissa dá conta de 170 séculos de manifestaçóes a serem consideradas como fatos espirituais dos índios: hieróglifos e sinais secretos esculpidos na rocha, às vezes coloridos, todo um ciclo plástico que se assemelha aos transvanguardismos pictóricos e metálicos, hoje em moda. Algumas figuras de gente e de animais em movimento, como as do Piauí, mostram sabor futurista, notando-se inscrições rupestres que, examinadas através do, "carbono I4" possivelmente são datáveis de 17.000 anos atrás.

Os textos do livro, formando uma espécie de antologia dos arqueólogos, marcam os traços da nossa antes-pré-história, rica de uma ideografia ainda não definida, pois as interpretaçóes mágicas da vida indígena permanecem ainda nos mistérios.

O volume dá a sequência das épocas, uma evolução lenta que se afirma em formas plásticas nas urnas funerárias, nos vasos e nas representaçóes de cariátides de várias posturas, comportamentos, adornos, numa variedade, estruturas e cores de excelente gabarito.

A criatividade, como a que se encontrou no Marajó, é encantadora com senso do bizarro, procurando no inexaurível sertão dos modos a originalidade que 
lembro concebida por um dos primeiros futuristas, Ardengo Soffici: "A originalidade náo é tanto uma qualidade natural quanto uma laboriosa e dura conquista. Nasce-se geniais, para se tomar originais."

Voltando ao que se disse no começo da nota, penso que nas escolas o ensino da história nacional se deveria iniciar neste rico conjunto arqueológico que contribuiu para estruturar o homem brasileiro, consequência de inúmeras migraçóes, notável a preta, todavia nas origens não devem ser deixados de lado os primeiros amores entre conquistadores e carinhosas selvagens.

$\mathrm{Na}$ última Bienal, o interesse compensador da bagunça modística dos produtores atuais foi para a seção dedicada à arte plumária. Sugere-se para a próxima Bienal levar em conta nossa arqueologia, como atividade da modernidade, "o futuro do nosso passado."

\section{Legenda}

Restauração de pinturas rupestres pré-cabralinas (do livro Herança)

Senhor \#I5I, 8 de fevereiro de I984, p.67 (P.M. Bardi)

UM ARQUITETO DE VANGUARDA

A Arquitetura, como as outras artes no século 20, transita ao longo de praças, avenidas e veredas quais é impossível definir o roceiro e encontrar um guia. $\mathrm{O}$ avanço tecnológico, o empenho em superar tudo o quanto se considera fora dos limites convencionais, o gosto por esturdiar acumulam um inédito de afanosa e contínua criatividade. Nas faculdades italianas de Arquitetura, logo que o aluno recebe o abc, sabe que o mestre dos mestres, isto é, Andrea Palladio, sentenciava: "Antes de iniciar uma construção, deve-se estudar atentamente cada parte do plano e da estrutura do edifício que se deve construir." Isto no século I6. Nos fins do 20 , além disso, o projetista deve imaginar o espetáculo da novidade.

Nas primeiras filas de arquitetos destruidores de todas as também recentes tradiçôes, aliás na sua vanguarda, está o italiano Renzo Piano, ao qual se consagra uma exposição no Museu de Arte de São Paulo. Trata-se de uma personalidade singular, do padrão de Le Corbusier, o criativo que se autodefinia "viajante da terra e da vida," presente a cada momento em todos os continentes. Piano aprendeu com sua própria família de construtores a erguer muros como um pedreiro, dando a máxima atenção aos artesãos. "Penso," diz ele, "que esta foi uma oportunidade, pois a profissão de arquiteto precisa de competências específicas e de armas eficazes; desarmados, cai-se muito facilmente, presas de todo um sistema que efetivamente tende a marginalizar o arquiteto, a lhe atribuir uma função mais ou menos evanescente na sociedade de hoje."

Quando, nos anos 70, se decidiu construir em Paris um "utensílio diferente para produzir cultura e informação," o Centro Georges Pompidou, Piano e sua equipe ganharam a parada. Sua fama, porquanto jovem, era já consagrada pela singularidade de mexer em construçôes mais no positivo do laboratório do que no executivo da fantasia. Valeu sua posição contra a monumentalização do conceito de museu, realizada futuristicamente em Houston, EuA. O "Beaubourg" devia ser o fato liquidador de todo o sistema antigo, um centro difusor do saber, extensão das mudanças totais do século 20.

Todos consideram aquele conjunto chamariz como uma consequência estética da tecnologia. Todavia, na opinião do seu planejador, se não é absolutamente oposta, pelo menos pede que seja corrigida. Numa declaração, Renzo Piano afirma: "Atenção, não é assim! Efetivamente este é um edifício profundamente artesanal, feito praticamente a mão, pedaço por pedaço. É artesanal no sentido de cada protótipo. As técnicas e os processos pertencem, obviamente, à cultura de hoje. Nada no 'Beaubourg' é casual, tudo foi desenhado com meticulosa aproximação à projeção.” O espírito inovador se caracterizou, então, por soluçóes de função como a distribuição e a sensibilidade do ar e tantas outras providências de conforto para favorecer amplas concentraçóes de frequentadores. 
O Centro é visitado em média por 20 a 25 mil pessoas/dia, 30 mil aos domingos. É, portanto, um "mecanismo urbano" que, para atender a tal massa de consumidores, deve corresponder através de serviços em constante renovação e perfeito funcionamento. Uma nova definiçẫo da cultura que conclui as previsóes pioneiras de Le Corbusier, a poética da machine-à-habite. Neste caso, à-utilizer. O conceito já é história, mas é justo lembrá-lo, mesmo porque Piano também declara: "O que existe é uma disciplina importantíssima, é um modo de partir." Não é verdade que para ser criativo precisa-se ser livre: este é um critério que vem sendo continuamente utilizado como desculpa para justificar a incapacidade de se fazer as coisas.

A exposição permite ver, estudar o surpreendente no que se refere ao "Beaubourg," universalmente conhecido, e oferece a possibilidade de se perceber que Paris é, mais uma vez, indicadora de futuro. E o que mais interessa é o extraordinário conjunto de seçóes para atender a um público exigente que inclui desde o especializado nos vários campos culturais até o aprendiz. $\mathrm{O}$ esplêndido é a coordenação, o ambiente agradável e o atender a qualquer pedido utilizando os últimos e até discutidos mecanismos da informática.

$\mathrm{O}$ arquiteto italiano consegue realizar suas obras com a colaboraçáo de maciços grupos de arquitetos e, especialmente, de engenheiros especializados nas mais diversas tecnologias.

A Arquitetura não mais como resultado de um artista, mas como produção de uma empresa, a industrialização a engolindo.

\section{Legenda}

Detalhes de estruturas metálicas do arquiteto Renzo Piano

Senhor \#I52, I5 de fevereiro de I984, p.67 (P.M. Bardi)

UMA CHANCE PARA DOIS ESTILOS

Quem se interessa por enfeites decorativos antigos?

A última notícia, inédita, das artes, é um assalto, não a banco, mas, a uma loja exclusivamente dedicada ao Art-Nouveau, com roubo de uma quantidade bastante significativa de objetos naquele estilo, entre os quais alguns Gallé. O estilo floreal entra assim na crônica negra, ocasião para uma recordaçáo brasileira de um período bem interessante.

Não vi nascer o Art-Nouveau, porém lembro-me muito bem do seu primeiro aparecimento numa cidade de província italiana. Seus avanços nas casas de famílias de um certo cultivo das artes foram difíceis, o mesmo que aconteceu em São Paulo, Denso eu, quando apareceram, alem dos primeiros bibelôs de Gallé, dois arquitetos contrastando o post-classicismo de Ramos de Azevedo: Carlos Ekman e Victor Dubugras.

Naturalmente, duas andorinhas não fazem o verão. $\mathrm{O}$ movimento na Arquitetura não teve saída, mas, pouco a pouco, os novos enfeites decorativos ganharam sua trajetória. Esta diminui, como na Europa e nos Estados Unidos, após a Primeira Guerra, para dar lugar a moda do Art-Déco, o qual também teve no Brasil acolhidas não muito entusiásticas.

De qualquer modo, a São Paulo que andava se agigantando com arranha-céus e fábricas, desenvolvendo todos seus setores, tendo como ponto de partida a inesquecível Semana de Arte Moderna de 22, meta de imigraçóes, de mão- de-obra e de modos estéticos, nos anos em que o sr. Assis Chateaubriand inaugurava a novidade do Museu de Arte de Sáo Paulo, não falava mais das produçôes dos dois recordados estilos. Foi fácil para o redator desta nota juntar uma coleção, quase um acervo particular, do qual aqui se reproduzem alguns exemplares.

Mas se deve dizer: como sempre, acontece, a história da arte procede através de revivals. Assim, alguns anos atrás, a São Paulo dos estetas curiosos andou descobrindo os mestres franceses do Art- Nouveau, e, mais tarde, deixado o floreal, soou a hora do geométrico, liquidador do precedente borboletear. Não foi pouco o quanto se encontrou e quanto foi comercializado e, em parte custodiado por prevenidos 
colecionadores. Ao que parece, o interesse pelas significativas esculturas e objetos decorativos expressão do Século não teve a sequência que merecia. Isto é fato normal no colecionismo da arte, no Brasil ainda dando seus primeiros passos, a não ser as corridas para possuir os assim ditos, "clássicos brasileiros" clássicos para indicar os pintores e muito menos os escultores nacionais destes últimos 150 anos.

\section{$\sim$}

Pode ser que a notícia do roubo possa despertar interesse pelos dois estilos aos quais, na Europa e nos Estados Unidos, já foram dedicados tratados históricos da maior importância.

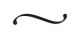

Nestas crônicas procuramos dar notícias do singular desenvolvimento e, às vezes, de rupturas imprevistas da recente tradição, acontecimentos característicos de um final de século cheio de novidades atordoantes. Assim, verificar que, no prevalecer da tendência informal, erroneamente considerada derivada da informática, há um pessoal que se encanta com as novidades do final do Oitocentos, confirma, como disse na página dá semana passada, que as artes transitam hoje por praças, avenidas e veredas para as quais é impossível definir o roteiro e encontrar um guia.

Há cerca de uma semana observei, no saláo de estar do mais inteligente colecionador de Sáo Paulo, abaixo da parede onde estava pendurado um esplêndido Fautrier, um vaso, também esplêndido, de Daum, mestre do floreal. Cada período tem, realmente, seus representantes.

\section{Legenda}

Art Nouveau e Art-Déco: exemplos de um acervo mal recebido no Brasil

Senhor \#153, 22 de fevereiro de 1984, p.84 (P.M. Bardi)

A SAFRA DA ARTE RELIGIOSA

Maravilhas do catálogo do Museu de Arte Sacra

A editora dedicada as artes esta tomando consistência e participando finalmente do novo desenvolvimento cultural. Promotores deste passo decisivo são as indústrias e os bancos, patrocinadores de monografias de mestres da pintura e da escultura, de acervos de museus, discussóes de problemas e tudo o mais que se relaciona com a Cultura.

No final do ano passado, foram publicados vários e interessantes volumes, entre os quais um de singular importância: o catálogo geral do acervo do Museu de Arte Sacra de Sáo Paulo, edição do Banco Safra, lançado há algumas semanas numa reunião de personalidades em que esteve presente também Sua Eminência o cardeal dom Paulo Evaristo Arns.

Deve-se observar que a atenção que no Brasil se tributa à história das artes nunca foi das mais responsáveis por parte do governo e das próprias autoridades eclesiásticas. Patrimônios de alto valor acabaram deixando igrejas, capelas e conventos aparecendo no mercado antiquário felizmente recolhidos por colecionadores, como é o caso do engo João Marino, exemplar coletor de objetos religiosos como aqui mesmo em Senhor foi comentado quando do lançamento de seu livro.

Como sempre há os que devotam à Memória iniciativas exemplares. Assim, tratando-se do Museu de Arte Sacra (MAS), vem logo à lembrança seu diretor, o padre Antônio Godinho, que se dedica de corpo e alma à coleta desses materiais e à difusão de seu conhecimento para um vasto público.

A publicaçáo do acervo do MAS paulista dá conta do extraordinário conjunto de obras lá reunidas e custodiadas.

Dá prazer, muito prazer mesmo, folhear o livro, dedicado a um dos mais notáveis de nossos museus e estritamente ligado à memória nacional, editado por um banco, o que demonstra que os grandes construtores de nossa economia estão presentes também na área cultural.

A edição, como a anterior, dedicada ao Masp, é esplêndida e praticamente mostra o Museu de Arte Sacra visto sala por sala, apresentando uma série de obras-primas de pinturas, esculturas e objetos nos quais se reflete o labor dos artistas 
que, ao longo dos séculos de nossa história, celebraram a espiritualidade do povo.

Através de vicissitudes, reformas e mudanças das igrejas católicas, muitos objetos religiosos foram recolhidos ao museu, ambiente de conservação e estudo: são inúmeras estátuas, altares, pinturas que testemunham o caminho das preferências estéticas e a capacidade do artista que as interpretou. Admiram-se obras de singular prestígio, também como execução, mostrando a existência de importantes ateliers em Sáo Paulo.

Junto ao esplêndido volume, o Banco Safra este ano tomou outra iniciativa, realmente notável: Brasil Histórico, uma série de fascículos com resumos históricos e atuais de cada Estado ilustrados por fotos. Escreve-se na apresentação da coleção: "No mundo inteiro o Brasil é hoje reconhecido como um país de grande potencialidade em todos os sentidos. Porém, uma boa parte dos brasileiros ainda náo tem o conhecimento da beleza e da extensão territorial que é este Brasil. A cultura, costumes, folclore, os pontos turísticos, a arquitetura que varia de região para região, são apenas alguns exemplos que estão aí para ser conferidos, conhecidos e explorados por todos nós. Através desta coletânea o Banco Safra está convidando você a sentir ainda mais orgulho de estar vivendo aqui e a conhecer um pouco da história de tudo aquilo que é seu. Ou melhor, o que é nosso: o Brasil."

\section{Legenda}

Óleo s/madeira do século I8, do convento de Santa Clara de Taubaté 9 Cruz relicário (antiga Sé de S. Paulo)

Senhor \#154, 29 de fe vereiro de 1984 , p.96 (P.M. Bardi)

TAMBORES INTERNACIONAIS

Os milagres do Masp, uma sociedade sem fins lucrativos cercada de incompreensão e atacada pelos que justificam gastos públicos exagerados em promoçóes de pequena repercussáo cultural

Se há alguma instituição de artes plásticas no Brasil possível de ser aproximada dos acontecimentos internacionais, declaro-o, sem a mínima modéstia, esta é o Museu de Arte de Sáo Paulo. Exibimos a Pinacoteca do Masp, a convite de governos ou de grandes museus do Exterior; a cada ano emprestamos obras para as mais importantes exposiçôes comemorativas de escolas ou de artistas. Nossos Ticiano, Manet, Ingres, Monet, Dégas, Van Gogh, Cézanne e Portinari circulam em várias capitais; e assim por diante.

De qualquer jeito, a cada dois ou três anos o que se alardeia como de âmbito internacional é a Bienal paulista, precisando de verbas astronômicas, naturalmente públicas, como se sabe. A última temporada custou mais de Cr\$ I bilhão. Não conseguindo muitos visitantes, encheram as ruas de faixas convidando o público.

Na semana passada, em O Estado de S.Paulo, refazendo vidas, milagres e futuro da Bienal, Leonor Amarante, citando um regimento de penetras no gramado da Arte, lembrou em duas linhas o Masp, contando que este museuzinho "tem aproveitado o intercâmbio com custo zero, mediante apoios empresariais e o de instituiçóes no estrangeiro."

De fato: nós somos uma sociedade civil sem fins lucrativos, reconhecida como entidade filantrópica, e, em 37 anos de, ao que parece, bom trabalho, conseguimos um público constante, editamos livros, produzimos concertos até ao meio- dia, teatro, festival internacional de cinema, uma exposição periódica por semana etc. etc.

E o internacional?

O leitor, nesta temporada, vai ver uma excepcional celebração de São Francisco de Assis que vem da Itália, o acervo do Museu do Ouro da Colômbia, a Arqueologia do México e outras.

Isto para explicar aos metidos, recrutas e generais sem tropas, que seria bom passar pelo gabinete especializado e deixar cortar os calos pendurados nos cotovelos.

A Bienal, naturalmente, é mais uma manifestação a ser, e que deve ser, prestigiada. Seu nascimento foi amadorístico: copiaram, linha por linha, o regulamento vetusto da Bienal de Veneza, a invenção turística do Oitocentos; depois, quando na Laguna 
perderam os remos da barca, nossos iluminados caboclos imitaram a trama transvanguardistica da Bienal de Kassel.

Agora, constatada a crise de comando e a rotineira imitação do que se produz lá fora, apesar dos tambores falarem em, "sucessos sem precedentes" a Fundação reelege os novos Pitanguis que deverão modelar a beleza na cara do Casarão do Ibirapuera. Nomearam para o comando até mesmo este cronista, o participante das artes locais e internacionais. Tenho na sacola algumas panaceias que, já sei, serão banidas, pois, em vez de incrementar o amadorismo cocktailesco, proporia a consideração de iniciativas não para as elitezinhas, mas para amplas camadas sociais.
Mais um "de qualquer jeito:" vejo nos conselhos bienalescos, que tomaram posse segunda-feira passada, gente do poder cultural e do econômico. É, sem dúvida, um pessoal para valer e, pelo que se ventilou na reuniāo, pronto a sistematizar uma manifestação que ao lado de registros de repetição de tendências modísticas, não apresentou as novidades realmente interessantes para o consumidor brasileiro de estética.

\section{Legenda}

Um exemplo da penetraçáo do Masp, um museu requisitado no Exterior 9 Uma obra no outro lado do mundo Casa Vogue \#2, março-abril de 1984, p.68 (P.M. Bardi)

[INÍCIO DA SEÇÃo P.M. BARDI]

O diretor de Casa Vogue me homenageia com uma página para, de agora em diante, conversar a respeito de algumas coisas: comunicar, discutindo, formal ou informalmente, a aventura do cotidiano.

Curiosa coincidência: neste fim de século, para mim calendariando os últimos decênios do mexer na vida, me veio à mente trabalhar num novo livro da coleção "Arte e Cultura" editado há seis anos pelo Banco Sudameris, um livro que terá por título A Comunicação no Brasil.

$\mathrm{O}$ aventureiro ingressa assim num labirinto esperando no fim encontrar a saída. De fato, não imaginava que esta intrincada casa fosse táo complicada no que se refere às primeiras comunicaçóes da Terra. Fui ver, para estar a par e por respeito à história, o que tinha ocorrido antes que Cabral navegasse o Atlântico Sul. Descobrindo que os portugueses desembarcaram para "holocaustear" a ordem, lembrei da opinião do barão do Rio Branco de que duas coisas são sagradas no Brasil: a desordem e o carnaval. De qualquer jeito preocupei-me em ver se a desordem já estava por lá. Pela mania de buscar as origens das origens dos antigos donos, um eminente mitólogo me comunicou que os índios acreditavam que o Sol era perseguido pela Noite até que um dia a Noite se enfia na casca de uma abóbora, custodiada depois por uma serpente; passa-se algum tempo, celebra-se um casamento e alguém abre o fruto para se banquetear e o Sol volta a resplandecer.

Pesquisando seriamente junto a credenciados etnógrafos vim a saber que o responsável pela criação dos nossos indígenas é Monan, um manda-chuva que, ao que parece, não satisfeito com o comportamento do pessoal, jogou sobre eles milhares de cobras em flancos. Porém, seu rival, o mago Irin Mage, comovido, sustou na última hora a carnificina, pois também era manda-chuva, e tudo voltou à normalidade, salvo as cinzas dos já acabados.

Saindo desta história vou escrevendo o relato que vai até os dias de hoje. Amigos meus que estão estudando um computador que funcionará integrando silício e proteínas vivas para conseguir, finalmente, um instrumento de inteligência, não a artificial, mas a humana, os ditos amigos vão me auxiliar na pesquisa das origens da Terra pois, parece certo, a nova maravilha da informática será capaz de registrar a história.

As artes plásticas brasileiras produzidas na década de trinta ainda não foram ampla e devidamente estudadas. Salva-se, em tal período, apenas a arquitetura e assim mesmo devido a Le Corbusier 
cuja presença entre nós ensejou algumas consequências no modorrento ambiente de então. Racionalismo ou Funcionalismo aceito como substituto do neocolonialismo e face o desaparecimento do persistente Ecletismo oitocentesco.

Naquele tempo a escultura revela algumas personalidades como Celso Antônio e Vitor Brecheret cujas manifestaçóes se destacam dentro do contexto ainda acadêmico exercitado por numerosos artífices, especialmente os italianos engajados e insistindo na continuidade do academismo tradicional.

Antônio Gomide, um entre outros mestres, se manifestou com autonomia em raras obras. Este extraordinário elemento, quando um dia for devidamente estudado, mostrará a força da sua obra escultórica.

No tocante à pintura, a bem da verdade, sabemos de significativas contribuiçóes de personalidades que combatem mesmo o gosto tradicional, porém sem conseguir popularidade, já que o reconhecimento fica circunscrito a limitados ambientes genericamente inscritos no círculo do Modernismo. Será somente nos anos 40 que pintores de excepcional valor merecerão alguma atenção, destacando-se Tarsila do Amaral, Anita Malfatti, Emiliano Di Cavalcanti, Portinari e uns tantos outros.

Bastará que se diga que um pintor da estatura de Vicente do Rego Monteiro, ainda nos anos 60 , quando organizei no Museu de Arte de São Paulo sua primeira exposição individual, não alcançou maior repercussão. Caso análogo ocorreu com o autêntico e original Ismael Neri, o mesmo se dando com outros veteranos do calibre de um Reis Júnior, Toledo Piza, Ângelo Simeone, para lembrar apenas alguns. Foram eles que romperam com a fixação escolar-BeauxArts, o academismo rico de valores, mas todavia refratários às tentativas de renovar a representaçáo, apesar dos conhecimentos das novas tendências e recentes propostas parisienses, apenas reservadas a poucos.

Não é bem da sorte e da trajetória dos artistas que aqui desejamos tratar, mas particularmente da temática. Em São Paulo e no Rio de Janeiro os pintores se adaptam à nova ordem, isto é, à figuração, com predileção para a paisagem, pintando florestas, fazendas, praias e marinhas, as preferências dos adquirentes. Por exemplo: um pintor-pintor como Pancetti se refugia nas marinhas, uma tendência e vocação da qual jamais se liberta.

Obviamente que temos algumas exceçóes, como Lasar Segall, um autonômo com forte vocação para o social, bastando lembrar ser ele o autor de "O Navio dos Imigrantes.” Registre-se o caso de alguns artistas que partiram para outros tipos de composiçóes, destacando-se entre eles John Graz, pintor que após seu casamento com Regina Gomide Graz (irmã de Antônio Gomide), veio da Suíça e aqui passou a executar encomendas de artes decorativas como a execução de painéis alegóricos destinados a grandes residências, em tudo mostrando uma cultura e uma capacidade profissional singulares.

O gosto dos comitentes e dos que perlustravam pelos salóes naqueles tempos ainda divididos em "arte acadêmica" e “arte moderna” era incerto. Visitando as poucas mansóes que ostentavam em suas paredes pinturas dos decênios em questão, a paisagem era a que prevalecia. Era a temática mais apreciada e, assim sendo, a mais constante.

\section{Senhor \#I55-I56, 7-I4 de março de I984, p.89 (P.M. Bardi)}

InÉDITOS DE MODIGLIANI

O centenário de um mestre descobridor dos segredos plásticos, que, na sua época e em sua própria terra, sofreu também a injustiça do esquecimento e da incompreensão

Transcorre este ano o centenário do nascimento de um pintor particularmente bem representado no Brasil: Amedeo Modigliani, livornês mas considerado da escola francesa. Morreu em Paris em 20, nas condiçôes mais tristes, para não dizer trágicas, o que confirma que também na capital das artes ditas modernas ou de vanguarda e, agora, de transvanguarda, um mestre podia desaparecer sem suscitar o interesse do ambiente. 
É o que ocorre quando se opera fora dos padróes. Giuseppe Ungaretti dizia que o ato da poesia exige, por causa da singularidade do sentimento, que se seja diferente dos outros, apartado, como os danados, e que se esteja abaixo do peso de uma especial responsabilidade, a de descobrir um segredo e de revelá-lo aos outros.

Modigliani era um descobridor de segredos plásticos, e como tal devia sofrer as consequências.

Estou relendo a nota que lhe dediquei no catálogo do Masp: "Completa na pátria os seus primeiros estudos junto de Micheli, um epígono dos Macchiaioli, frequentando depois a Academia de Florença. Passando por Paris em 1906 e ligando-se ao ambiente dá vanguarda, aproxima-se da pintura de Cézanne e da escultura negra, experiências decisivas para a sua formação artística. A breve, mas rica atividade de Modigliani, culminante nos retratos e nos nus executados entre 1905 e I919, caracteriza- se pela sensibilidade, natural à origem toscana do artista, pelo arabesco linear fluidamente melodioso e todavia capaz de articular a imagem no espaço e também pela lírica intensidade da cor. Pela excepcional pureza de sua arte, Modigliani está entre os maiores e originais mestres da moderna pintura europeia.”

Quando teve início o Masp, nos anos '40 e '5o, este cronista adquiriu no mercado europeu que, às vezes, abre os olhos com atraso, não a costumeira única pintura para, como acontece, encher um vazio, mas bem meia dúzia de obras de Modigliani. Foi e talvez seja este um fato que distingue o Masp como o museu que possui o maior número de telas do italiano.

Revelo o motivo da jogada: de acordo com o senhor Assis Chateaubriand, o único mecenas das artes autêntico do Brasil, o plano era adquirir tudo o que tinha possibilidade de valorizar no futuro para depois fazer-se trocas e até mesmo vender, conseguindo assim sistematizar a Pinacoteca do museu. É por este motivo que temos I3 Renoir, dezenas e dezenas de Degas, dezenas de Portinari e assim por diante.

Tudo corria à perfeição quando nosso Lourenço de Medieis local adoeceu, incumbindo-me, todavia, de negociar as trocas. Reuni entáo o Conselho do museu, composto por leigos que não entendem do problema. Colocada em movimento a maquininha do contra pelo amigo-da-onça, democraticamente as coisas ficaram como estavam. E os seis Modiglianis continuaram seis.

Mais uma curiosidade modiglianesca: há uns vinte anos, descubro em Santo André uma família que possuía um esplêndido desenho do mestre, doaçáo dele a uma colega de estudo da Academia de Florença, a qual retratou o companheiro atrás do mesmo desenho.

Senhor nesta edição publica os dois inéditos, comemorando o centenário de um esplêndido artista.

Legenda

Retrato de Modigliani, de L. d'Andrea

g "Desenho" do mestre, de i9io

Senhor \#I57, 2I de marços de I984, p.79 (P.M. Bardi)

A ARQUITETURA DO ÍNDIO

Ainda recentemente, nesta mesma página, tivemos oportunidade de recomendar uma visita à exposiçáo mostrando trabalhos do arquiteto Renzo Piano, autor do edifício mais discutido neste século, o Beaubourg de Paris, determinador de discussóes que em tempos passados foram travadas em relação a Torre Eiffel e, em termos locais, sobre a Casa Modernista de I925, projetada e construída por Gregori Warchavchik.
A arquitetura, por indicação dos mestres inovadores, articuladores da revolução eletrônica, caminha na senda das mais imprevistas novidades, não mais arte mas ciência; ou melhor, uma coisa e outra simultaneamente, uma máquina como previu Le Corbusier, com prevalência da função, o enfeitar e o ornamental desaparecendo, a estética clamando por novas propostas. 
Nestes tempos de "superamentos," de indefinições num certo senso, os problemas da arquitetura do fim do século são bastante complicados face à necessidade de se considerar os fatos sociais, (permito-me saudar o prefeito de São Paulo, engenheiro Mário Covas, que destilou uma grande área municipal a favelados, para que cada família construa sua casa) este cronista recebe o volume Habitaçôes Indigenas, publicado pela Nobel e pela editora da Universidade de São Paulo, enfeixando um esplêndido grupo de ensaios de estudiosas brasileiras, as quais analisam o espaço doméstico criado e usado pelos índios. A autoria se identifica com uma coincidência: "Que não deve ser desconsiderada - já que a casa é, predominantemente, de domínio feminino - todos os artigos foram escritos por mulheres e, à exceção de uma arquiteta, todas as demais são antropólogas." A saber: Sylvia Caiuby Novaes, supervisora, Maria Elisa Ladeira, Aracy Lopes da Silva, Lux Boelitz Vidal, Dominique Gallois, Lucia Hussak van Velthem, e arquiteta Cristina Sá.

A arte do construir começou lá, pelas mãos e cabeça dos que se costuma apelidar de selvagens, propulsores constantes das descobertas visando a tudo que pudesse abrigá-los, utilizando materiais, através do invento dos instrumentos para adaptá-los ao desejado. O aperfeiçoamento e a defesa face às contrariedades, o ganhar dia a dia as possibilidades do viver, dão muito que pensar, maravilhando-nos mesmo. Que dizer do trabalho dos africanos que, ao chegarem ao Brasil, também tiveram que fabricar suas habitaçóes?

A Humanidade vencia ao longo da avenida denominada Progresso. Os da civilização sul-americana avançaram de maneira singular, diria autônoma, marcada mais pelas intuiçôes, a pureza do sentimento, um sentido próprio de estética. $\mathrm{Na}$ arquitetura, desde a cabana até a grandiosidade dos templos mexicanos: uma originalidade que visava testemunhar uma participação na vitória da Humanidade.

O volume das antropólogas leva-nos imediatamente a pensar em Le Corbusier, na teoria do Racionalismo que o mestre afirmava ser justamente emanada dos primitivos. De fato, se se admira o Parthenon como o maior exemplo do Racionalismo, observando quanto de inteligência, solução prática, imaginação poética, intimidade, o senso social, o diferenciar planta e cobertura, a presença do verde, vê-se que as habitaçóes dos índios não se circunscrevem à arquitetura, mas vão mais além, pois envolvem gente, vivência, usos, religião. A contribuição finalmente supera a antropologia, quase sempre mais dedicada aos índios do que à sua habitação.

A arquiteta Cristina Sá se interessa pela construção e estética presentes em três tribos: Yawalapiti, Karajá e Xavante, incluindo a posiçáo das aldeias, ilustrando as técnicas de construção e ideação das estruturas que resultam numa espetacular simplificação: formas racionais de absoluta solidez. É notada também a história, o intercâmbio com os caboclos das regióes circundantes até os últimos contatos, os compromissos do dar e do viver.

\section{Legenda}

Criatividade na arquitetura indígena: a montagem de uma casa; escada para um plano superior; e a casa concluída

Senhor \#I58, 28 de março de I984, p.89 (P.M. Bardi)

NosSA MEMÓRIA PEDE SOCORRO

De vez em quando, se lamenta que as providências tomadas para as atividades de conservação da Memória se mostram um capítulo sem importância. Pela lei dos contrários, sabe-se que os capítulos importantes são os mais considerados, especialmente se tratam de política. E à Memória se dedicam meios marginais, cantos de páginas e não o que seria oportuno e justo.
Este ano o Banco Safra vai editar o terceiro volume de uma esplêndida coleção dedicada aos museus nacionais. O primeiro foi sobre o Masp, o segundo sobre o Museu de Arte Sacra de São Paulo e o terceiro será sobre o Museu do Ipiranga. Uma vez que o cronista participa desta novidade 
museográfica, tive ocasião de constatar, numa visita, como o edifício que custodia boa parte da história da metrópole mereceria maior atenção. Pertencente a USP, que este ano comemora seu cinquentenário, o Museu Paulista é dirigido pelo ilustre ex-reitor do nosso maior estabelecimento cultural, o benemérito professor Orlando Marques de Paiva.

Denunciou Antônio Gonçalves Filho, na Folha de S.Paulo: "Faltam condições técnicas para conservar materiais, e o jeito é improvisar ... Não por outra razão, valiosos quadros que retratam figuras do Primeiro e Segundo Império foram colocados fora do alcance de visitantes, após constatados alguns atos de vandalismo em outras peças do museu. Outras foram sumariamente escondidas," e assim por diante. Lamentável?

A competição, no que se refere à História, se manifesta entre os assim definidos obscurantistas, isto é, os devotados ao respeito da Memória, e os atualistas, isto é, os intransigentes adoradores das transvanguardas, descobridores das conquistas estéticas e morais do acelerado momento técnico-espiritual.

Vive-se do hoje, sem cancelar o ontem. Tenho observado a massa de jovens que vai descobrindo os desenhos de Leonardo da Vinci no Masp, nas reproduçóes fac-similares dos originais que se conservam em várias instituiçôes europeias.

O Gênio, lembrado por ocasiáo do cinquentenário da USP, serve para reconfirmar o tema da página: antigo-moderno.
Foi o passado que construiu o que usufruímos agora. O caminho das artes como símbolo da Humanidade percorreu a trajetória desde o Bizantino até o Moderno, do qual o autor da "Gioconda" é mestre. Cronologicamente é possível continuar as etapas: Barroco, Romantismo e por aí até o Picasso cubista. É preciso compreender, avaliar, saber que muito se fez antes para que a gente pudesse, hoje, trocar dinheiro por meio de um computador e também saber que a desvairada sociedade atual, isto é, nós, do século dos mísseis, somos consequência do que fizeram nossos avós e as precedentes geraçóes.

Volta-se à Memória e, por precisão, ao caso do Museu Paulista, sabendo que se trata de uma minúcia no universal. Porém, para nós brasileiros, acima da discussão se pertencemos biologicamente a um "povo-testemunha," "povo-novo ou "povo-transplantado" de cultura brancaíndia-negra, que seja, para nós deveria valer o fato de considerar a lendária São Paulo com o respeito e, possivelmente, o delírio que nos estádios se celebra um dos inúmeros gols dos campeonatos.

Fica a sugestão ao emérito reitor da USP, prof. Antônio Hélio Guerra Vieira, de uma possível combinação com o governo que conseguiu mais de Cr\$ I bilhão para a última inútil Bienal, para agir em favor da salvação da casa da Memória Paulista.

\section{Legenda}

O Museu do Ipiranga precisa das verbas públicas para sobreviver 9 Reitor Guerra Vieira (USP): um apelo

Senhor \#159, 4 de abril de I984, p.89 (P.M. Bardi)

UMA QUESTÃO DE PRESTÍGIO

As viagens internacionais do acervo do Masp

Quando, em 47, o raro entre os inexistentes raros magnatas que pensavam em criar um museu de arte, superando o lero-lero para passar à ação e conjugar o verbo realizar no presente e náo no futuro, o sr. Assis Chateaubriand confiou- me a tarefa de lançar o Masp, disse-me: "Pense também na história do Brasil; em suas andanças pela Europa compre tudo que se refere à Terra."

Confesso: meus conhecimentos a respeito eram primários; porém, lendo e pesquisando tudo que de europeu podia interessar ao Brasil, logo descobri algumas coisas e também não faltaram oportunidades em que meu saber melhorou. Uma das primeiras investidas foi dedicada à pintura de Frans Post. Era um tempo em que as obras do ilustrador paisagístico da aventura do príncipe de Nassau se adquiriam por ninharias. Comprei cinco telas do holandês. 
E mais: consegui trazer para São Paulo também a série das tapeçarias ditas, 'das índias' confeccionadas pela Manufatura dos Gobelins, baseadas nos desenhos de Albert Eckout, outro holandês que aqui esteve com Nassau. Os desenhos faziam parte de uma doação, provavelmente com fins políticos, feita por Nassau ao rei Luís XIv, da França, sendo possível que o próprio príncipe holandês tenha sugerido a adaptação dos desenhos para as tapeçarias que, depois de prontas, figuraram na decoração do Palácio de Versalhes.

A invasão dos holandeses me envolveu também na Reforma e na Contra-Reforma: desembarquei em Trento, sede do Concílio, tendo lido que lá, no Castelo do Buon Consiglio, se conservava o retrato do cardeal Cristóforo Madruzzo, um dos artífices daquela reunião católica. A tela tinha desaparecido no começo do século.

Assumindo as funçóes de detetive e pesquisador, ambicioso por descobrir o paradeiro da obra, vasculhei em várias cidades, sabendo afinal que o Cardeal Príncipe Arcebispo estava no Metropolitan Museum de Nova York. Fui para lá. Tratava-se de um empréstimo a ser devolvido em 1936. Per li rami, como dizem os italianos, encontro a pintura tempos depois no depósito do antiquário Knoedler. Consigo ler a inscrição: Anno Dmi atatis sue XXXIII Tician... fecit. Adquiro, naturalmente.

Neste momento o retrato está, como empréstimo do Masp, na Royal Academy of Arts de Londres, na exposição "The Genius of Venice," um dos eventos culturais mais importantes do ano.

O leitor que chegou até aqui por certo se pergunta: é simples notícia ou o fato propicia um comentário?

Realmente: o Masp, possuindo uma Pinacoteca composta de obras de uma certa importância empresta, a cada ano, parte de seu acervo a outros museus, como é o caso citado, além de dois Manet, agora voltando um do Metropolitan de Nova York e outro do Grand Palais de Paris, tendo participado do centenário de morte do mestre. Três Ingres do Masp estão no JB Speed Museum de Louisville, Estados Unidos.

Cito a participação nas grandes exposições internacionais para mostrar $\mathrm{o}$ prestígio cultural do Brasil, este ano ainda com maior movimento pois nos pediram em empréstimo três obras de Cézanne para Madrid, um Matisse para o Kimbell Art Museum dos Estados Unidos, O Escolar, de Van Gogh, que irá para o Metropolitan em Nova York e cinco obras de Renoir, o impressionista que será tema de uma grande exposição em Paris, Londres e Boston.

\section{Legenda}

O Retrato do Cardeal Cristóforo Madruzzo, de Ticiano, em Londres O Escolar vai para Nova York

Senhor \#160, II de abril de I984, p.73 (P.M. Bardi)

A ARTE É PARA POUCOS?

Os eternos grupinhos, do informal ao abstracionismo

Na alvorada deste Século, as artes plásticas passaram a contar com uma novidade, a do Informal, uma expressão que revelou seus primeiros mestres e, como sempre acontece, ensejou o aparecimento e a multiplicação de pintores e escultores do assim definido Abstracionismo.

Os simplórios passaram a opinar que se Kandinsky pintava aquelas linhas que se entrelaçavam e que, em última análise, pouco diziam para a gente, no entanto imensamente apreciadas e valorizadas pela patrulha dos historiadores e críticos, por que não provarmos também nós? Não fazemos um esforço imenso para promover muitos campeóes no campo das artes?

Hoje os artistas praticantes do Abstracionismo são inúmeros: fogem da realidade romântica em busca de variantes, cujos itinerários podem perfeitamente desembocar em qualquer hermética função, significados e símbolos de rica inventiva que se espalham pela Terra.

A epidemia se propagou nos mais cultos ou acaboclados países, a moda espraiando-se, superando qualquer limite, deglutida e normalizada. Condenados à morte $\mathrm{o}$ 
desenho, temas, alusóes, virtuosismos, mensagens e tudo que de passadista degradava as manifestaçóes espirituais, desembuchou-se para condenar qualquer lembrança da tradição, cancelando-a mesmo, pois a nova proposta era a de refazer, "tudo para a frente." A corrida encetada visava estabelecer uma espécie de nova ordem, uma espécie de virada que alguém acreditou ser possível como consequência da moderna tecnologia.

$$
\sim
$$

Seja como for, o Abstracionismo, como um dos setores das artes plásticas, marca hoje uma marcante presença. Os tempos mudam a ponto de náo ser mais preciso cursar uma escola para aprender um ofício. Seria idiotice negar alguns resultados positivos, notadamente quando alguns que operam têm vocação. Todavia são raros os que no afigurativo se impóem, muitas vezes fazendo esforços para conseguir algum destaque, apelando mesmo, a ponto de sintetizarem seu pensamento numa tela pintando uma única camada de tinta, o catálogo mais parecendo um mostruário de fábrica de tintas.

E que dizer dos penetras na seara da pintura que procuram igualar-se aos mestres do Abstracionismo?
Certamente que a arte é destinada ao consumidor, tal como hoje é considerada e julgada, pois seu destino final é sempre a parede de uma casa ou uma praça pública. Todavia, o Informal vai, lentamente, chamando a atenção da gente. Parece-me um tanto exagerado, e até mesmo impulsivo, o que Jean Fautrier, um aos primeiros mestres do Informal, falava da arte e do público: "O público pode ir para o inferno... A pintura hoje está reservada a um grupinho de entendedores; para o grande público existem as fotografias, o cinema, que é bem melhor do que David e Delacroix: ao público precisa-se dizer que náo perturbe, que nós desejamos estar tranquilos ...”

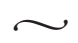

Uma observação: a arte não terá futuro se o destinatário for um dos componentes do mencionado, "grupinho de entendedores" pois a função do alegrar, confortar e até mesmo indicar caminhos morais e sociais é demandada aos que têm o dom de antever, aos generosos em condição de convencer o consumidor, admitidos eventualmente alguns inscritos nos anacronísticos "grupinhos."

\section{Legenda \\ Composiçâo Abstrata (1930) de Vassily Kandinsky 9 Atleta (1909), de Pablo Picasso}

Senhor \#I6I, I8 de abril de I984, p.69 (P.M. Bardi)

\section{MARKETING: ARTE E AGILIDADE}

Em Senhor mais uma vez, o cronista quer interessar o leitor sobre problema que parece o mais importante na produção das artes plásticas: seu mercado, neste momento determinante em que tudo para ele conflui, com o marketing tornando-se problema de estrita atualidade.

Quem trata do assunto nesta página é alguém que, desde tempos quase pré-históricos, pratica, no setor, conseguindo apreciável experiência antes e mesmo depois que o sr. Assis Chateaubriand o convocou para compor a hoje preciosa pinacoteca do Masp.

Não são todos que conhecem qual foi o resultado obtido, mas justo será dizer que tudo se passou sob o signo do marketing, na verdade, um surpreendente negócio, aproveitando-se ao máximo e agilmente uma situação propiciada pelo pós-guerra, como também arriscando-se bastante, tendo em vista o comportamento de um futuro próximo favorável à produção de pintura, escultura e as artes estupidamente ditas "menores;" insisto em dizer que tal negócio foi o único realmente rentável realizado no Brasil.

Os Sólons da Economia afirmam que tudo isto foi muito natural; do meu lado posso declarar que somente anos depois de concluir as aquisiçóes é que me convenci de que náo errei em trazer para o Brasil obras de Bellini, Rafael, Ticiano, Velazquez, El Greco, Goya, Ingres, Turner, Cézanne, Manet, Renoir, Dégas e até os 
contemporâneos Picasso, Matisse, Max Ernst, além de recolher nossos Portinari, Di Cavalcanti, Anita, Rego Monteiro etc. Devo declarar que somente depois é que me tranquilizei, deixando os Sólons bestejar.

\section{$\sim$}

Linhas atrás fiz alusão às "artes menores." Penso ser possível medir a altura de um cavalo ou um daqueles pintorzinhos frequentadores das crônicas sociais que visam antes de mais nada o marketing para suas produçóes e não a arte, notadamente em presença da ourivesaria, cerâmica, prataria e assim por diante. No que se refere a valores definíveis através do "dragão-dinheiro" tão bem definido pelo amigo economista Benedito Ferri de Barros, posso oferecer uma notícia aos Solons: em '50, adquiri em Londres toda a coleção Imbert de cerâmicas italianas dos séculos is e i6, compreendendo algumas centenas de peças, conjunto já exposto no Museu do Louvre, com um catálogo, em I9I3. Aproveitei, sabido ou não, do fato de se tratar de, "arte menor" pechinchando para obter um bom preço, o qual, diga-se de passagem, foi de banana, não das mais saborosas, mas daquelas menos apreciadas. Vendendo hoje cinco dessas peças, naturalmente escolhendo pratos figurados, certamente alcançaria um valor para adquirir o conjunto inteiro.
Tais fatos confirmam que, neste fim de século, os objetos de arte adquirem uma substanciosa posição monetária que causa espanto aos próprios mestres da economia, quando se lê que num leilão em Londres ou em Nova York uma pintura famosa ou de fama haurida no fato marketing, foi vendida por milhóes de dólares, ou então que nos Estados Unidos existem fundaçóes e museus que dispóem de centenas de milhóes do mesmo quilate para aplicar em obras-primas obtidas num mercado vertiginosamente ativo.

Há alguns anos, o presidente da Sotheby's esteve em São Paulo e, em conversa com este cronista, perguntou se por acaso o registro dos recolhedores de arte se tinha povoado de elementos náo-provincianos. Expliquei-lhe que no Brasil talvez existissem raridades, mas que, no entanto, os sothebyanos locais só sabiam bater o martelo para miniespeculadores disfarçados de colecionadores.

O magnata inglês perguntou-me sobre a figura do criador da pinacoteca do Masp. Confirmei que, infelizmente, só tivemos um único Assis Chateaubriand.

\section{Legenda}

El Greco no Masp: estratégia correta

g Portinari: negócio surpreendente

Senhor \#162, 25 de abril de 1984, p.93 (P.M. Bardi)

\section{A MEDALHA INESPERADA}

O Centro Cultural Francisco Matarazzo Sobrinho deliberou, no ano passado, me outorgar o troféu 1983 pelo trabalho que o cronista de Senhor tem desenvolvido.

A medalha inesperada, naturalmente, me surpreendeu e devo considerá-la uma espécie de conciliação com um Benemérito das artes ao qual se deve a criação do Museu de Arte Contemporânea e da Bienal Internacional. Digo conciliação, enumerando, de minha parte, algumas divergências de opinião, cordiais, porém firmes, não influindo todavia nas relaçóes pessoais.

Em '46, o sr. Assis Chateaubriand me confiava a organização de um, 'museu de arte antiga e moderna' a ser aberto em São Paulo, tendo como mediador do empreendimento o embaixador do Brasil em Roma, Pedro Moraes de Barros. Abrimos a instituição e eu consegui convencer o dono dos Diários Associados a simplificar a insígnia, pois nunca me agradou juntar adjetivos à arte.

O que o Masp inaugurou e o que; em 37 anos realizou e continua realizando os leitores sabem. O que o Cicillo fez também é notório. Pode ser que a ele tenham faltado colaboradores, visto que as coisas não andaram bem; aliás, se atrapalharam, pois há alguns anos fechou o MAM, doando o acervo à USP para formar o atual MAC. O procedimento provocou vários problemas de ordem pessoal e soluçóes de remendo. Como acontece em todas as instituiçóes culturais, veem-se chefóes que conseguem utilizá-las 
para se promover escandalosamente, ao passo que autênticas personalidades são ignoradas e até desconsideradas. Para confirmar: de um lado, os manipuladores; do outro, para lembrar um caso apenas: Lasar Segall, que nunca foi convidado para representar o Brasil no pavilhão que a Bienal Paulista tinha na de Veneza. Segall teve sua individual naquela Bienal por exclusiva iniciativa deste cronista, e isto ocorreu depois da morte do mestre.

Mas, como digo, estes são lamentáveis acontecimentos normais nas organizaçôes culturais e não deveriam, pro bano pacis, ter registro. São lembrados para confirmar divergências opinativas e também para fazer saber que no campo do desenvolvimento das artes plásticas, em São Paulo, vale antes, repito bem, antes de todas, a inauguração do Masp em '47, a ser creditada ao sr. Assis Chateaubriand: implantar no deserto em que a única base era a Pinacoteca do Estado, um movimento de difusão e interesse pelas artes, começando pela formação de um acervo. Impossível ser fã de Picasso e não compreender bulhufas de Giotto.
O que passou, passou. Os assim apelidados museus proliferaram, a Bienal, infelizmente órfá da quase secular de Veneza e até da caçula de Kassel, continua no partian partian do coro da ópera Nabuco, à espera de uma virada. E continua em São Paulo uma política cultural para as artes plásticas, à espera de decisóes capazes de juntar as fragmentaçóes, pelo menos numa programação concorde de discussóes e eventos.

É normal que cada instituição produza independentemente, porém numa intenção mais unitária, dirigida ao beneficio da comunidade.

Recebendo a distinção da Fundação, que leva o nome do generoso Cicillo, o cronista, na qualidade de antigo navegador das águas agitadas do mar das artes, despacha para ele uma saudação, postulando um futuro de ordem e progresso, como ensina nossa Bandeira.

\section{Legenda}

Cicillo Matarazzo, pouco antes de morrer (numa foto de Olney Krüse): patriarca de uma entidade cultural que também cometeu alguns deslizes e provocou soluçóes de remendo

Casa Vogue \#3, maio-junho de 1984, p.62 (P.M. Bardi)

\section{COMUNICAÇÃo No Brasil}

Estou preparando um livro dos meus, que não são exatamente livros, mas colchas de retalhos dedicados a temas que considero de um certo interesse, o de agora é a Comunicação no Brasil. Joguei-me nesta selva tentando estabelecer como se entendeu a turma de Cabral com os indígenas de Porto Seguro a 22 de abril de 1500 , continuando por etapas até tentar dar uma ideia da Informática.

Há seis anos produzo estes livros, editados pelo Banco Sudameris na série "Arte e Cultura.” Uma parte do último será dedicada à Publicidade. E é realmente disto que vou tratar neste rascunho.

A publicidade no Brasil é de um padrão excelente. Fui, se não um profissional, pelo menos alguém que se interessou muito por técnica da propaganda.

Em minhas lembranças de jornalista, em tempos bem recuados na Itália anterior a Mussolini, a distinção entre matéria de redação e matéria de publicidade era regra absoluta. Era até proibido dar o nome de algum restaurante onde acontecera um banquete ou mesmo um crime: usava-se a circunlocução "num restaurante da rua tal."

Em tempos mais esclarecidos, nos anos 30, quando realizei para o cotidiano $I l$ Messaggero, de Roma, uma série de reportagens dedicadas ao "Ardita," novo carro da Fiat, que depois se transformaram no livro La Strada e Il Volante, o diretor, Francesco Malgeri, recomendou-me ser um pouco discreto na publicidade, para não incomodar a administração, a qual, no entanto, se entendeu com a fábrica de Turim.

Lembro o caso pois analisei-o numa aula da Escola de Propaganda. Esta escola, bastante conhecida, agora com a incorporaçáo dos adjetivos de "Superior e de Marketing," foi por mim fundada no grupo de escolas que criei no Museu de Arte de São Paulo, cuja organização o Hearst do Brasil, Assis Chateaubriand, me 
confiou. E foram os colegas dos Diários Associados e o sr. Rodolfo Lima Martensen que muito me encorajaram e contribuíram para dar a São Paulo aquela Escola.

Desde 1950 muita água passou por debaixo das pontes. Hoje a Propaganda é, no Brasil, esplêndida realidade, promotora de progresso industrial e também de estética. Repito: estética, pois a engenhosidade ao mesmo tempo literária e artística com que se produz uma página de publicidade,é representativa do gosto deste final de século.

Acabei de apresentar, no Masp, a exposição dedicada ao Kitsch, a definição que condena o mau-gosto do fim do Oitocentos e principio do Novecentos. O material foi recolhido pelo jornalista Olney Krüse, neste caso improvisado historiador e crítico. $\mathrm{Na}$ primeira função se registra, na segunda, julga-se. Todos os quinhentos objetos reunidos foram classificados e colocados no inferninho estético do gosto vade retro.

Ao organizar a manifestação, alguém me propôs dedicar-me ao Kitsch na publicidade, naturalmente não a publicidade de agora, pois o julgamento das atividades refere-se sempre ao passado.

Fui verificar então, em velhas revistas e jornais, inserçôes publicitárias, naturalmente as ilustradas, e consegui arranjar algumas pranchas, chegando à conclusão de que não se trata bem de Kitsch, mas do resultado do tempo. A comparação entre aqueles anos e os de hoje náo pode ser realmente feita, mas significa que cada época tem sua maneira de se expressar.

Mesmo na arte de anunciar, de mostrar as novidades, está presente o Kitsch.

\section{Casa Vogue \#3, maio-junho de I984, p.80-86}

Em meio ao verde: A CASA DO MORUMBI

Batizada de "casa de vidro," a primeira residência do bairro, projeto da arquiteta Lina Bo

Os desgostosos episódios de ver antigas casas da avenida Paulista serem demolidas, contra a lei, à noite, por medo de um possível tombamento pelo Patrimônio, por pertencerem à memória da tradicional artéria que Claude Levi-Strauss, quando lecionando na USP, gostava de comparar a uma rua das estaçóes de água da Europa, demonstram uma faceta da situação: os ricos não se preocupam com a memória mas sim com as polpudas contas bancárias. Um imigrante que, nos fins dos anos 40 escolheu uma grande área no então recém-lançado Jardim Morumbi, antiga fazenda de chá, e construiu sua habitação, é de opinião completamente oposta à dos amigos da especulação: neste caso o Patrimônio quer tomar, que tombe e, desde já, muito obrigado.

Sabia que Gregory Warchavchik estava restaurando, numa mata virgem cheia de pássaros e bichos que beirava São Paulo, uma casa-grande, futura sede de um clube. Era o Jardim Morumbi, com o qual se pretendia preservar uma mata ao lado da capital, com todas as suas histórias de índios e jesuítas e de caipiras colhedores de chá da antiga fazenda Müller-Carioba. A Prefeitura estava disposta a conceder um código rigoroso: nada de muros, só cercas verdes, casas com afastamento de vinte metros das ruas, abrigos afastado para carros, e, sobretudo, muito respeito pela vegetação natural.

Poucos anos depois a primeira casa do Morumbi estava pronta e, por suas características de utilização de aço e cristal, foi logo batizada de "Casa de Vidro."

Foi a primeira residência do bairro, projeto de Lina Bo, a mesma arquiteta que desenhou o prédio do Museu de Arte de São Paulo na avenida Paulista e que transformou a Fábrica da Pompeia em Centro Cultural etc.

A casa do Morumbi teve como calculista da estrutura o meu caro amigo Pier Luigi Nervi.

A casa não-mansão do Morumbi, se me é permitido avançar um parecer, tem idade e singularidade para ser tombada, pois representa, naquele bairro, uma arquitetura que revistas internacionais já apontaram como expressiva, sendo notada a novidade dos seis pilotis mistos de ferro e de concreto, além da ideia do envidraçamento parietal completo. Como ambientação, ao invés do verde penteadinho habitual, circundada pela vegetação da floresta nativa. De 
fato, nunca se tocou numa só árvore nem foram mortas as preguiças e as cobras.

Concluída esta apresentação, o subscrito quer dizer que o conteúdo em obras de arte da casa parece ser caso único no Brasil. Boa parte do acervo que eu trouxe para o Brasil foi doado ao Masp, como também minha biblioteca composta durante mais de meio século, e o restante lá está.

Então, a casa em objeto, declaro que irei doar a uma entidade pública.

É o inverso dos demolidores da Paulista e de outros temerosos proprietários. Não por espírito de contradição, mas para dar um exemplo. Talvez ingênuo mas não imbecil.s.

\section{Legenda}

p.80-8I I, 2 e 3. Primeiras fotos da casa pronta em espaços limpos 4. A "Casa de vidro," circundada por densa mata virgem, constituiu-se em caso único de

5I Esse desejo pelo tombamento da residência era antigo no casal. Em carta datada de 23 de junho de I98I, dirigida ao Dr. Modesto Carvalhosa, entáo presidente do Condephaat, Lina afirma que "queria muito, muito que a casa fosse tombada. E o foi, por unanimidade do Conselho do Condephaat, em 1986. O casal criou, em I990, uma entidade pública, o Instituto Quadrante, rebatizado de Instituto Lina Bo e Pietro Maria Bardi e, para abrigo de sua sede, em 1995 , Bardi doa a casa. Em 2007, também por unanimidade, a casa é tombada pelo Conselho do IPHAN. \{Iphan, 2007\} moradores despreocupados e que podem muno bem ser inquinados de ingênuos observadores de cláusulas contratuais, pois o código que determinava restriçóes e regalias acabou, como sempre acontece, em letra morta e devidamente sepultada.

p.82-83 5. Diana, escultura grega do século 5, publicada no setecentos por J.J. Wickelmann e restaurada por Cavaceppi no setecentos, originariamente no castelo de Lowther, onde, em 1947 foi adquirida por Bardi. Ao lado, cadeira do século 17. $\mathrm{Na}$ parede, pinturas de autores italianos do século I7. No fundo, à direita: parte da biblioteca e uma pintura de mestre italiano do seiscentos 6 . Ao redor de um móvel florentino do século i6: pinturas de italianos do século I7; árabe do século I2; obras de Giorgio Morandi e Pablo Picasso 7. Na parede: Retrato de dom Sebastiáo de Orleans e Bragança, neto de dom João vi, obra de Francisco Goya; ao lado, pinturas de Cranach, Lazzaro Tavarones, Bernardo Strozzi e outros pintores italianos do seiscentos.

p.84-85 8. Vista geral do living 9. Em cima da lareira: terracota de Ernesto de Fiori; Voltaire, de Joseph Rosset; Gladiador, terracota pintada de Giorgio de Chirico e outras esculturas Io. Sala de jantar. $\mathrm{Na}$ parede: José Maria dos Reis Júnior, Baia da Guanabara, 1923; Roberto Matta, $O$ caso dos Rosenberg; Domingos Viegas de Toledo Piza, Entrada na Floresta; Pedro Figari, Composição; Joaquín Torres García, Composição; Ermelindo Nardin, Composição, aquarela; Miguel dos Santos, Retrato. Bernardo Strozzi e outros pintores italianos do seiscentos.

Senhor \#163, 2 de maio de I984, p.72 (P.M. Bardi)

A DESCOBERTA DE NOVOS MUNDOS

Cristóvão Colombo escrevia, quando da descoberta: "Não creio que haja no mundo homens melhores, assim como não terras melhores," porém, quando, em I5O3, naufraga na Jamaica, escreve que se viu "assaltado por um milhão de selvagens cheios de crueldade, e que nos são hostis." Fantasias numéricas, impressôes fantásticas, juízos superficiais, o falar de "plantas, animais e gentes" como elementos semelhantes são próprias de alguém continuamente surpreso, nada menos o
Almirante que, como diz a inscrição da lápide na sua suposta casa em Congoleto (traduzo do latim): "O mundo era um só; ele disse: não, somos dois, e dois foram.”

O Novo Mundo continua a ser objeto de verificaçóes históricas sempre mais interessadas no estabelecer as origens e o destino das conquistas incrivelmente desumanas que vão levantando, a posterior, questóes morais, como se lê num importante livro agora publicado de Tzevetan Todorov, $A$ 
conquista da América, a questão do outro. (Tradução de Beatriz Perrone Moisés, Martins Fontes Editora, São Paulo.) O autor declara ter escrito o livro "para tentar fazer com que não se esqueça esta história, e mil outras semelhantes. Para responder à questão: como se comportar em relação aos outros?, o único meio que encontrei foi contar uma história como exemplo, a história da descoberta e da conquista da América. Ao mesmo tempo uma pesquisa ética e uma reflexão sobre os signos, a interpretação e a comunicação, pois o semiótico náo pode ser pensado fora da relação com o outro.”

$\sim$

Coincidência: no Masp, estamos esperando uma grande exposição dedicada a São Francisco de Assis, que vem da Itália. Logo que tivemos o oferecimento da mostra, rica em documentos e obras, propus integrá-la com uma exposição sobre, "São Francisco no Brasil" pois foi a Ordem do Santo que exerceu na terra dos, "outros" a América, uma ação realmente digna. Basta dizer que são os franciscanos os primeiros a aprender as línguas dos "selvagens" para se comunicar, ainda no Quinhentos, tempo mais de espadas do que de cruz. Numa carta inacabada ao Papa, em 1579, Las Casas lamenta: "Certas pessoas indignas se apresentam diante de Vossa Beatitude e depreciam os bispos que aprendem a língua de suas ovelhas."

Ler o documento Todorov para ter um panorama dos séculos americanos leva a pensar num problemão também brasileiro: o Indianismo, e, refletir sobre sua origem, "questão do outro" e refletir sobre solução de situaçóes náo-satisfatórias diante dos restos de uma povoação que ainda está sujeita ao poder.

$\sim$
Eis então mais um livro relevando um dos restos da raça "vencida:" Índios no Estado de São Paulo: resistência e transfiguração, uma antologia de ensaios de Silvia H. Simóes Borelli, Mara Manzoni Luz, John Monteiro, Lúcia Helena Rangel, Maria Inês Ladeira e M. A. Barbosa. (Coedição de Yankatu Editora e Comissão Pró-Índio de São Paulo.) Declara-se na introdução que o objetivo principal é mostrar que "ainda, e apesar de tudo, existem populaçóes indígenas em nosso Estado. Resistindo ao processo de colonização, à escravização, à usurpação e à diminuição de suas terras, esses índios chegaram à década de '8o transfigurados, aculturados e retirados de seus territórios ancestrais."

É outro documento a ser considerado, dando conta das "naçóes" em extinção que vivem nas aldeias do Morro da Saudade, M’Boi Mirim, Silveira, Boa Vista, Rio Branco, Itariri, Jaraguá, Crucutu, e nos postos indígenas de Peruíbe, Araribá, Vanuíre e Icatu.

A história das migraçôes dos autóctones e das ocupações gradativas nas várias regióes do território paulista, a ganância de certos fazendeiros e até tentativas de salvação, depois a intervenção do governo, afinal, as lutas para preservar a identidade cultural e tantas outras questóes inerentes são exaustivamente tratadas pelos autores, chegando-se às mesmas conclusóes de Todorov: "Na síntese dos vários elementos que compóem os universos contraditórios e conflitantes do mundo tribal e do mundo capitalista, síntese esta que deve ser buscada pela valorização da diferença: o 'eu' deve sentir-se diferente do 'outro' e se afirmar como tal."

É o caso de pensar em Indianismo?

\section{Legenda}

Crianças Guarani da aldeia

Morro da Saudade, SP, I98I

Senhor \#164, 9 de maio de 1984, p.69 (P.M. Bardi)

UM ARTISTA SEM RÓTULOS

Os centenários de nascimento ou desaparecimento das personalidades importantes da história das artes são numerosos este ano, sendo obrigação dedicar-lhes a devida lembrança.

Neste final de século, no Brasil, é indispensável recordar os 150 anos de
Edgar-Hilaire-Germain Degas (I834I9I7) pois, talvez por acaso, no acervo do Museu de Arte de São Paulo, conserva-se um dos grandes patrimônios do pintor-escultor. Pode ser que a empresa de adquirir obras de Degas tenha derivado do agir contrário ao gosto do pós-guerra, 
quando se faziam previsóes erradas a respeito dos "valores" da arte Degas, nem impressionista nem acadêmico, era artista, simplesmente, a se compreender.

Degas observava a realidade calculando-a matematicamente na forma e no movimento, conseguindo fixar numa bailarina um gotos naturais. $\mathrm{O}$ mesmo ele fazia quando o tema era os hipódromos. Amava o espetáculo, queria dar conta dos protagonistas e, fato curioso, trabalhava para si mesmo, sem se preocupar em expor para colocar suas esculturas.

No Degas escultor, gostamos de considerar suas representaçóes de dança e de corridas de cavalos, imaginando seu ateliê de Montmartre, solitário, um pouco misógino, dando vida a figuras vistas e mecanicamente fotografadas na sua prodigiosa memória. Tão prodigiosa que lhe permitiu plasmar, até mesmo quando ficou cego, ocasiāo em que teve de deixar o trabalho de cavalete, mas mesmo assim continuou fazendo esculturas.

Degas nasceu e morreu em Paris, mas pertencia a uma rica família de banqueiros napolitanos que operavam no Oriente Médio. Desenhava para representar a figura, usando a precisáo de um renascentista italiano, com absoluto rigor verista, o que no seu tempo se dizia acadêmico.

Quando, em Paris, seu quartel- general foi visitado por Paul Valéry, a definição deste foi: "O mais sensível observador da figura humana, o mais obstinado amante das linhas e das posiçôes do corpo feminino, um profundo conhecedor das belezas dos mais nobres cavalos, o mais clarividente, avisado, exigente, inabalável de todos os desenhistas do mundo.”

Figura singular na agitação do Impressionismo e mais, das liberdades então conhecidas na Belle Époque, Degas considerava-se um independente, não exatamente um inovador.
Poucos anos antes da Grande Guerra, quando a obra de Degas foi vista na "Orangerie" do Louvre, foi considerada própria do caráter e da mentalidade burguesa de I880, a qual se deliciava com a solidez do desenho no sentido mais tradicional, de um certo resíduo de mau gosto, quase de bombeiro, como então se começava a definir os conservadores do neoclassicismo.

Só após as revisóes começou-se a notar a poesia de sua arte, o vigor, o irrequieto procurar de formas. A crítica atribuía ao mestre a continuação de um espírito classicista, considerando-o sua força e também seu defeito, pelo mudar das tendências. Filippo de Pisis, comentando a já lembrada exposição no jornal que, naquele tempo, este cronista dirigia, o Meridiano di Roma, evocava que Degas, um dia, diante de uma pintura de Bernard, proferiu uma boutade arguta e cruel: "C'est un pompier qui a pris feu!"

Estou revendo a coleção completa das esculturas de Degas que adquiri há já trinta anos para o Museu de Arte de São Paulo, agora colocada na grande vitrina que divide a lanchonete de uma das grandes salas de exposiçóes periódicas: são bailarinas e cavalos em bronze. Quem se diverte penetrando nas personalidades dos artistas pensa logo na maneira de viver do pintor-escultor: maníaco, com alguns momentos trágicos na vida, um vieux-garçon bastante neurótico, emplastro de esquisita gentileza e, como notou De Pisis, de bousqueries sauvages num período parisiense tão rico em motivaçóes sociais.

Em breve, mais uma vez, a coleção das esculturas de Degas do Masp irá ao Japão. A primeira exposição destas peças naquele mundo de cultura foi em 1979.

\section{Legenda}

Duas obras de Degas: Mulher Enxugando a Perna Esquerda (pastel/ papel) e Bailarina de I4 anos (bronze)

Senhor \#165, I6 de maio de I984, p.68 (P.M. Bardi)

UM COLECIONADOR AUTÊNTICO

Eis em São Paulo, hoje meca da moda das exposiçóes, uma de particular importância, pois em vez de apresentar um artista, mostra uma coleção completa, isto é, obras adquiridas obedecendo ao propósito de formar um panorama do operar brasileiro. A iniciativa, pelo gosto, pela abertura ás tendências, pelo número, 
pode ser considerada única neste setor onde os amadores de arte visam mais o elitismo, às vezes, infelizmente monetário, do que um cordial e generoso senso de compreensão e participação cultural. $\mathrm{O}$ colecionador convidado pelo maм é o sr. Gilberto Chateaubriand. Apelidaram-no de "colecionador profissional," alguém que se distingue por ter reunido obras, sabendo valorizá-las como singulares de cada artista, prevendo a durabilidade como representativas de uma época, a do século em conclusão. Ao mesmo tempo, a amplitude da iniciativa repara um costume do passado, a desconsideraçáo, por parte dos assim chamados amadores da arte, para com os nossos artistas. Numerosos deles tiveram consagração somente depois de desaparecerem.

Lamento que a exposição não seja realizada no Masp, recebendo uma consideração toda particular pela unicidade do acervo e também pelo nome do colecionador, filho do fundador da instituiçáo que se orgulha de ter o nome do excepcional capitão dos Diários e Emissoras Associados, antigo sinônimo de empresas emergentes no Brasil moderno.

O cronista de Senhor se permite observar, como de resto muitos amigos já o fizeram, que Gilberto, infelizmente, não destinou a manifestação à sede mais apropriada para consagrar seu esplêndido empreendimento de arte e mais, reunido bem no espírito e inteligência de seu Pai.

Espera-se que antigas divergências, por outro lado comuns nas famílias, sejam esquecidas. O velho diretor do Masp, campeão de brigas à maneira do Assis, sabe Gilberto conhece o quanto de positivo seu Pai realizou e lançou, aliás criou, do quase zero da vida das artes no Brasil. Por coincidência, o mesmo empreendeu o filho, hoje dono de um autêntico museu, aliás de acervos tâo ricos que poderiam formar um museu de pintura contemporânea nacional.

Seja como for, o colecionador, agora hóspede do MAM, demonstra como se reúne um conjunto de obras que testemunham a realidade da arrancada iniciada pela Semana de Arte Moderna de 22, distinguida por eminentes personalidades. $\mathrm{O}$ conjunto é consistente e, sem dúvida, será analisado pelos nossos críticos.

É o que não se faz nesta página, onde se dá preferência aos problemas, em vez de se preocupar com as resenhas. O que nos convém é assinalar um autêntico colecionador da arte contemporânea: um exemplo.

\section{Legenda}

Auto-retrato, de Ismael Nery...

I...Les Nageuses, de Rego Monteiro

I...e Eles e Elas, de Ivan Serpa: obras

do acervo de Gilberto Chateaubriand, em exposição no Mam de São Paulo

Senhor \#166, 23 de maio de 1984, p.73 (P.M. Bardi)

RAROS TESOUROS BRASILEIROS

As produçôes móveis das artes plásticas, como se sabe, representam cada vez mais valores pecuniários em constante consideração, refugio de capitais e meios de negócios. Às vezes, uma pintura ou uma estátua atinge a importância de milhóes de dólares. A meca deste mercado é a América do Norte, para onde confluem patrimônios artísticos de todos os continentes, em menor número da América Latina, pois aqui as produçóes foram modestas, como também as importaçóes. No Oitocentos, foi registrada uma modesta importação de obras de arte que, nestes últimos anos, tem voltado para o estrangeiro.
Todavia, lentamente, um mercado vai afirmando-se também no Brasil, concentrado especialmente na assim dita arte barroca e na arte pictórica do Oito e Novecentos. As peças antigas são as mais cobiçadas, quase sempre de arte sacra e procedem das Igrejas. Como? Difícil dizer. Também na Europa, o êxodo de objetos de culto sempre ocorreu.

Venda direta do clero, atuação de malandros etc. É dos malandros metidos no setor que falo agora, pois li uma notícia em $O$ Globo sobre os que operam na Itália.

$\mathrm{Na}$ Península, nos últimos quatro anos, os roubos nas igrejas foram nada menos que 2177; nas coleçóes particulares, I587; e nos museus, 23I. Um terço dos dez mil objetos de arte roubados na Itália no ano 
passado foi retirado de igrejas, por vezes com violência, como há alguns meses na Catedral de Crotonc, na Calábria, onde os ladróes derrubaram a porta a machadadas.

Para debelar as quadrilhas, a Itália organizou uma seção na polícia, especializada no combate a estes crimes, conseguindo até prender uma delas, de italianos, na Grécia, que tinha extraído sete quadros de vultoso valor do Museu de Budapeste, desmantelando assim uma rede que traficava em toda a Europa. A polícia, usando o mesmo sistema de organização contra o comércio da cocaína, isto é, a infiltração, através de cursos para, "agentes-artistas" ministrados em Florença, com um coronel no comando, está conseguindo resultados excepcionais.

As pilhagens nas igrejas brasileiras são contínuas. Os jornais noticiam, mas é raro saber a descoberta dos responsáveis. São Paulo e Rio de Janeiro são as praças em que essas peças de arte têm possibilidade de serem comercializadas, contando-se numerosas e notáveis coleçôes nestas cidades. Pela experiência que se tem, o aparecimento, principalmente de esculturas de tamanho médio, foi constante nestes últimos tempos e, como se disse, parece que os guardiães da ordem não conseguiram descobrir os receptadores.

Por outro lado, vale uma informação que pode parecer não muito canônica: no final, não chega a ser um dano a passagem de uma propriedade a outros pois, nas mãos dos colecionadores, em geral pessoas que dão importância aos objetos, estes têm a vantagem do restauro e da conservação garantidas.

Não sei se esta página tem leitores dedicados à conservação das artes nacionais mais antigas; de qualquer modo, informo que a próxima Bienal será dedicada a um panorama da arte brasileira, lá veremos o quanto e como os colecionadores conseguiram conservar o nosso patrimônio. E ninguém se perguntará como este fugiu das igrejas.

\section{Legenda}

Grande arcaz de sacristia, arte mineiro-goiana do séc. I8. Origem: Igreja-matriz Jaraguá, GO (Col. Mirante das Artes, Sáo Paulo) Cristo de procissão, arte mineira, séc. I8, em madeira policromada (Col. Mirante das Artes São Paulo)

Senhor \#167, 30 de maio de I984, p.97 (P.M. Bardi)

Molecagem COM O Belo

Se existe um lazer ou manifestação que desperte algum interesse e tenha muitos fấs, não há dúvida de que é a Arte. Ela recruta curiosos para qualquer acontecimento além de defensores de modos, tendências, extravagâncias e tantas outras derivaçóes do tradicional normal, deglutido e praticado pelos cultores canônicos de um ingrediente denominado Belo.

Sua contrapartida é o Feio, e quem julga uma ou outra dessas facetas é um consumidor constante. Há os que gostam a um só tempo da Primavera, de Botticelli, e do cartáo-postal romântico dos namorados que se beijam; do outro lado, estão os excêntricos, que detestam as duas figuraçôes, mas que ficam de joelhos quando observam uma pintura indecifrável do Abstracionismo, ou uma daquelas informalidades escultóricas que as Bienais premiam como obras-primas.
Difícil, aliás impossível, conciliar os contendores, especialmente quando se trata não de simplórios, mas de elementos oficialmente inscritos na Corporação da Crítica.

Os que se propóem seguidores da independência existente entre Beleza e não-Beleza, os acomodados do viver e do deixar viver, responsáveis que dão importância a Gregos e Troianos, estes primam por não ser partidários do sistema centrista, náo se alinhando nem à esquerda e muito menos à direita.

O cronista de Senhor é sempre um conciliador; todavia, neste mês, na qualidade de responsável por exposiçôes periódicas do Museu de Arte de São Paulo, decidiu realizar algo que os críticos irão considerar uma molecagem: o Masp acaba de abrir uma mostra do Kitsch. O termo é alemão e, em linguagem corrente, significa objeto de mau gosto. A Galeria Arte Aplicada, 
da sempre atuante Sabina Libman, colabora com o Museu em mais este evento.

Volta-se, ao que parece, ao não- Belo, na sua pior e detestável combinação da coisa indigna de ser considerada, tendo, portanto, um destino: a lata de lixo.

O Kitsch é passível de defesa, podendo-se advocatescamente aventurar em cavilosidades e suposiçóes, a fim de se justificar que o recolhedor das peças deu-se ao trabalho de reuni-las, uma razão mais que probante de existir, tanto mais que se trata da coleção pacientemente organizada nada menos que por um dos críticos de arte do Jornal da Tarde, o bem conhecido e estimado Olney Kruse. Gostaria de juntar um outro adjetivo: generoso, pois a coleção agora exposta foi doada pelo Olney ao Museu de Arte de Sáo Paulo. Livres são os murmuradores de maledicências para atribuir ao cronista mais uma patente negativa, isto é, a de não entender de problemas de estética.
O colega italiano Gillo Dorfles julga o Kitsch "uma espécie de desvio, degeneraçáo do que, querendo ou não querendo, deve ser considerado como a norma da atitude ética e estética do homem" isto é, o "mau gosto," considerado o cansativo Belo.

Todavia, como estabelecer uma hierarquia dos valores estéticos? Hoje, viajamos numa múltipla galáxia de propostas artísticas, literárias, musicais, cinematográficas, da tevê, da moda e de tantas outras atividades, incluindo as do viver, tanto familiar quanto público.

No que se refere ao tal que se condena por náo entender o significado da arte, golpeando na ocasiáo o turista que segue sua caminhada, surgiu o apelido de Homem-Kitsch.

De qualquer maneira, estáo convidados os aficionados da Arte, para que julguem esta interessante e inédita exposição no Masp.

\section{Legenda}

Bibelô em gesso imitando marfim 9 Mulher espelho: outro Kitsch do Masp 9

A câmara-automóvel: Kitsch alemão 9

Isqueiro em forma de granada

Senhor \#168, 6 de junho de 1984, p.72 (P.M. Bardi)

Simbolismo, UMA ESCOLA QUE SAI DO ESQUECIMENTO

Acusada por algum tempo de ser uma cópia malfeita da Renascença, ela só recentemente foi ressuscitada pela crítica e pelo interesse do público

Há alguns anos percorreu a Europa, a América Setentrional e o Japão (como sempre excluída a América Latina, a eterna viúva das manifestações de porte) uma exposição dedicada à pintura do Simbolismo e que suscitou vivo interesse. Uma mostra parecida, realizada entre as duas Guerras, não teria provocado tamanha atenção; aliás, teria provocado reação negativa, pois aquela tendência não só estava esquecida como era considerada superada e sem sentido.

De fato, o julgamento do Simbolismo nunca resultou em consensos, tomado mais como fenômeno retardado do Romantismo de ciclo sentimentalizante, entre o superado gosto pelo mitológico e a personificação de seres lendários. Superando o produzir acadêmico da evocação da história, outro ingrediente romântico, os devotados às cenas místicas enfrentavam sua crítica desfavorável, porém conquistando um público seleto e até conseguindo refrescar vastas paredes, como se deu com Puvis de Chavannes, o simbolista mais prestigioso de fins do século, no tempo em que começaram a se articular os ismos um após outro.

Entre o plein-air e o decorar com figuras gregas, o contraste foi sério. Os próprios alunos do simbolista Gustave Moreau se distanciaram da maneira do mestre. Basta pensar em Marquet, Matisse e Rouault, De qualquer jeito, o Simbolismo inspirado em Beaudelaire, Mallarmé Rimbaud e Verlaine, e rapidamente difundido em vários setores, criou um clima cultural em contraposição ao Naturalismo e ao Impressionismo, superando os contrastes que se debateram no Oitocentos, o século empenhado em chegar a uma síntese de "arte-ciência-verdade-beleza," confluindo depois para o Decadentismo, outro interessante fenômeno de sonhos e de aventuras estéticas. 
Nasceu a arte Fauve, o Cubismo, o Dadaísmo, o Surrealismo; o Simbolismo foi esquecido, considerado um empecilho face a evolução combinatória dos novos modos lançados na pintura. Viraram pintores esquecidos: Arnold Boeklin, Frans von Stuck, Ferdinand Hodler, Fernand Khnopff e outros artistas dos quais, depois da Guerra, se procuraram avidamente as obras, pois o Simbolismo tomou-se inopinadamente a última moda, convergindo também para um interesse imprevisto em relação aos mestres ingleses do pré-rafaelismo, inauguradores marginalizados de um Simbolismo esotérico.

Hoje, o que era Kitsch virou não-Kitsch. $\mathrm{O}$ mesmo se deu em relação ao Art-Nouveau e ao Art-Déco: objetos e pinturas amontoados nos quartos de despejo e hoje afanosamente reabilitados e (nunca faltando o fator monetário) procurados.

Para os que estudaram nos textos de dois manda-chuvas da crítica, Elie Faure e Pierre Francastel, os que, em vez de pensar com a própria cabeça, pensam com a do professor, os pré-rafaelitas eram uns coitados que refaziam mal os mestres da Renascença, e os simbolistas idem.

Reavaliados, os protagonistas dos dois movimentos, incluindo o da Secessão de Viena, que ensejou o aparecimento de um dos grandes mestres do século, Gustav Klimt, a apreciação é geral. Quer dizer o seguinte: os artistas operam quem julga a posteriori.

Legenda

Criação do Homem, óleo sobre tela do espanhol Daniel Sabater

Senhor \#169, I3 de junho de 1984, p.65 (P.M. Bardi)

E COMO SOBREMESA, UMA BíbLIA DO MASSACRE

No álbum de cartuns de Hugo Corrêa, o julgamento do gosto humano pela criminalidade guerreira implica uma condenação carregada de ironia

Os eventuais leitores desta página, justamente relegada aos fundos de Senhor, sabem que o redator participou e participa de uma destas aventuras que tentam dar vida a um negocinho definido por Celso Furtado, no recente congresso-movimento de Ouro Preto, como simples "sobremesa," ou seja, a cultura.

No dito congresso o bicho cultura, foi naturalmente, acariciado no élan das maiores atençôes, e até indicado como solucionador de inúmeros problemas, exaltado e até proclamado como o único em condições de encaminhar o Brasil nas diretrizes vitoriosas da vida internacional.

Por ser solidário com os revoltosos, de vez em quando alguns artistas me procuram para conversar, propondo solidariedade para com enunciados não muito colocáveis no sacrário das genéricas aceitações locais. Um certo tempo apelidavam a decisão de "vanguarda:" açôes não-canônicas, onde havia os tímidos e os inflamados. No tempo dos recalcadores do Impressionismo, eram os Futuristas que exageravam na tendência. Depois das escaramuças do começo do Novecentos, a ação vanguardista degenerou para uma manipulação que é inútil recordar, pois todos sabem do comportamento.

Continuam entấo as simpatias pelos que exageram, que sacodem esta manifestação Arte e a agitam, participando de açóes de maior élan para renovar a própria mentalidade social e política deste fim de Século, esplêndido nas conquistas técnicas e não encabulado na vida moral. É por isso que, acima de tantos esteticismos, apreciam-se os que póem a mão nas denúncias da acomodação do deixa como está para ver como é que fica. Falo dos artistas que participam das denúncias morais, os que detestam especialmente a assim denominada atividade armamentista e, como o jovem cartunista Hugo Corrêa, enfrentam o problema da paz.

Eis uma das bíblias contemporâneas: Um Certo Animal; um álbum de cartuns que aponta a mais idiota anomalia do século, ou seja, o homem continuador do se massacrar. Estas duas ilustraçóes esclarecem a inspiração e o valor do desenhista, seu insurgir aberto contra o gosto da criminalidade guerreira. $\mathrm{O}$ signo 
de Hugo, logo que o ajeita para rascunhar a ideia até o final para colocar a assinatura, é meditado num lance sensorial que parece o sentenciar de um juiz de decisóes justas, contra as quais não existe apelo.

Decreta a sentença bondosamente, na ideia, no gesto, em cena ingredientes-símbolos, combinaçóes, acertando o alvo do cartum: ironia castigada, inofensiva quase absolvição para os implicados.

No desfile transita também o condenado a penas mais severas, pois tem-se o direito de perder a paciência quando a estupidez não para em nenhuma fronteira.

De qualquer jeito, o espírito do Corregedor é de pacata compreensão, o deixa viver, passando a limpo atitudes, encontros e desencontros cotidianos dos usuários da boa-vida. Suas advertências são circunscritas a um contemplar o homem, o animal, notas musicais, brinquedos, instrumentos de beleza envolvidos com as desatençôes e pretensóes, proporcionando-nos um singular modo de ver.

Inventividade e obediência a uma figuração curiosa combinam a arte de Hugo, que conclui o desfile dos indicados numa procissão de gente-lápis que carrega num baldaquim o seu ídolo, um apontador de suas pontas: uma página de esplêndido sabor.

\section{Legenda}

Dois desenhos de Hugo Corrêa: uma denúncia original da atividade armamentista feita com bom humor

Senhor \#I70, 20 de junho de 1984, p.72 (P.M. Bardi)

\section{A POÉTICA DA EMBALAGEM}

$\mathrm{Na}$ primeira vez que estive no Japão, uma das muitas novidades que me surpreenderam foi, ao adquirir um objeto numa loja, ver como este vem embalado, desde um doce até um utensílio, sempre diferenciando materiais e design.

A surpresa me sugeriu observar com atenção aquele fato, e, tendo a oportunidade de conhecer o sr. Suzusaburo Ito, então presidente do imenso magazine "Matsuzakaia," de Tóquio, pude inteirar-me sobre o assunto.

Aprendi uma saborosa lição. Tinha levado para o Japão um grupo de obras do Masp para serem expostas em vários museus japoneses, observando com cuidado a colocação de cada obra nas caixas, usando o sistema tradicional praticado na Europa, isto é, eliminar as consequências de possíveis sacudidelas e trepidaçóes. Gentilmente, os amigos japoneses incumbidos da tarefa de transportar a exposição para outras cidades se interessaram pelo problema e me convenceram a deixar refazer caixa por caixa, o que foi feito com absoluto benefício para o acervo, e eu aprendendo qual é o cuidado que se deve ter com uma embalagem.

Sempre pensei em apresentar no Museu uma exposição dedicada ao problema. Apresentamos a proposta à benemérita Fundação Japão, cujo presidente, Shoji
Sato, concordou, e agora a mostra está aberta no Masp, a partir de i8 de junho.

Escreve o presidente da Fundação Japão no catálogo: "O costume de embalar objetos com delicadeza existe desde antigamente, arraigado na vida cotidiana dos japoneses e deu origem à tradição das embalagens. Utilizando-se de madeira, bambu, palha e papel, produtos naturais que existiam desde o passado, no Japão, eram confeccionadas a partir de uma técnica artesanal com finalidades práticas. Estas embalagens fundamentam-se na inventividade do cotidiano, cultivado por longos anos de experiências e cuja natureza difere um pouco do espírito racional do Ocidente.”

A essência da arte, aliás autêntica, da embalagem é estudada pelo sr. Hideyuki Oka, num ensaio muito instrutivo. Ele lamenta que, nos últimos 20 anos, devido ao consumismo, as embalagens tenham sofrido um processo de revisáo, o mesmo aconteceu na Europa: em I9I5 surgiu, na Inglaterra, a Design and Industries Association para integrar o trabalho artesanal às novas exigências dos processos industriais, como se verificou de resto no Deutscher Werbund, precursor do Bauhaus de Gropius. Assim, a embalagem se adaptou a novos critérios.

$\mathrm{Na}$ modernização do Japão foi notado o continuar de uma poética tradicional: a confecção do mais simples pacote é de 
um cuidado e de um design apropriado à função e à estética. Os materiais escolhidos são os mais singulares: cascas de madeira, palha e suas várias aplicaçóes, bambu, folhas, pano, papel e tantos outros derivados são adaptados com prática.

Parece um rito, um operar artesanal-industrial combinado com sensibilidade. A exposiçáo demonstra o esplendor de uma estética utilitária.
Desde o início do Masp, os problemas de estética nos interessaram nas mais variadas formas. E uma das que primeiro nos envolveu foi a do design. Assim, apresentar agora uma exposição dedicada à embalagem é consequência da programação de uma entidade fora dos padróes elitistas da arte-pela-arte.

\section{Legenda}

Uma tradição japonesa: recipiente para peixe marinho, cesta de ovos e uma doceira

Senhor \#I7I, 27 de junho de 1984, p.IO6 (P.M. Bardi)

A HOLANDA NORDESTINA

Aprendem-se sempre mais notícias sobre a história do Brasil no Seiscentos, um dos séculos mais estudados, marcadamente a respeito de um assunto de particular interesse para os cultores da iconografia e do tempo da ocupação holandesa.

Ainda não foi revelado tudo o que realizaram os 46 artistas, cartógrafos, médicos e naturalistas que desembarcaram no séquito de Johan Mauritz de Nassau-Siegen, o jovem coronel e príncipe humanista incumbido da aventura colonial na Terra que definiu como "não tendo similar sob o céu."

Quando este cronista foi designado para formar a coleção do Masp, ao percorrer a Europa para adquirir obras, já sabia há tempo da importância dos holandeses como pintores da paisagem e da vida nordestina, não deixando de lado nenhum esforço para assegurar ao Brasil obras de Frans Post, na época o mais celebrado daqueles artistas.

Um parêntese: o Masp possui cinco paisagens de Post e também tapeçarias Gobelin que consegui comprar em Londres, na casa Abingdon, em 1949.

Naquele período pós-guerra, estes souvenirs coloniais compravam-se por quantias de cinco cifras em dólares, começando pelo i ou pelo 2. Mais tarde, como sempre acontece, os tardios descobridores nacionais daquelas antigas novidades adquiriram algumas peças por importâncias enormes.

Por que me envolvo na performance de Nassau? Para dar notícia aos meus leitores de descobertas de extraordinário e inédito valor: o prof. P.J.P. Whitehead, do Departamento de História da Zoologia do British Museum, sob o título Redescoberta do Brasil, acaba de publicar um exauriente ensaio na revista italiana Kos, de Franco Maria Ricci, dando conta das suas pesquisas sobre iconografia brasileira. O estudo faz parte do volume em fase de impressão do mesmo autor e de M. Boeseman, A Portrail of I7th Century Brasil, Animal, Plants and People by the Artists of Johan Mauritz.

A pesquisa demonstra a excepcional personalidade do estudioso: considerando o quanto a vasta bibliografia já revelou, conseguiu, através de uma persistente indagação, conhecer uma grande quantidade de documentos esquecidos em bibliotecas, conventos e coleçóes particulares europeias. $\mathrm{O}$ trabalho teve origem num caso singular: o professor se propôs a encontrar uma ilustração de um peixe que Marcgraf descrevia como "piquitinga" para determinar se se tratava de um arenque ou de uma sardinha, para fixar sua distribuição ao longo das costas sul-americanas. Começou a indagar dez anos atrás, Era indispensável saber quem tinha sido o desenhista dos quatrocentos animais e plantas xilografados na História: o próprio Marcgraf ou um artista? E ao mesmo tempo encontrar o álbum de desenhos dos pintores que reproduziam cada elemento realisticamente. De biblioteca em biblioteca, levando em conta as distinções e transferências devidas à última guerra, Whitehead chegou à Polônia, mais exatamente ao Convento dos Beneditinos de Krzeszow. Lá soube que haviam sido exportadas numa caixa de documentos, e, por contato com os frades, soube ainda que, 
em vez de memórias brasileiras, as caixas continham nada menos que quase metade dos manuscritos musicais da biblioteca estatal alemã, com a Sétima, Oitava e Nona Sinfonias de Beethoven, peças de Mozart, Bach, Brahms, Schubert e Haydn. Confessa o cientista: "Evidentemente estava procurando muito mais do que um simples desenho de 'piquitinga."'

No papel de detetive, mobilizando todos os ajudantes possíveis, consegue descobrir as caixas, indo de Grüssan à Cracóvia, na Biblioteca Jagiellon. Só então foi possível resolver o que Whitehead define como "uma ocasião histórica," sendo o problema estabelecido numa belíssima pintura. Tratava-se de um arenque.

$\mathrm{Na}$ relação constam cerca de oitocentas aquarelas, guaches, óleos e desenhos executados no Brasil e no livro será contada a operosidade de Post, Eckhout e do não devidamente apreciado Wagener, autor de um mercado de escravos no Recife, definido como "obra-prima da arte de protesto," além de outras cenas ligadas à vida nordestina. Tudo isto vem mostrar que ainda são inúmeras as pesquisas a serem feitas no setor. E leva a pensar na possibilidade de que algum de nossos editores publique uma Enciclopédia da Figuração do Seiscentos, hoje que a contribuição do mestre inglês abre um cantinho.

\section{Legenda}

Duas obras do século I7, uma coruja e um arenque, pesquisadas pelo professor P.J.P. Whitehead do Departamento da História da Zoologia do Museu Britânico, que publicou recentemente o ensaio Redescoberta do Brasil

\section{Casa Vogue \#4, julho-agosto de 1984, p.5o (P.M. Bardi)}

\section{[SP 2000]}

O cronista desta página participa das reuniōes do projeto "SP 200o," em franco desenvolvimento da Rede Globo. $\mathrm{Na}$ última, foi instrutivo escutar o depoimento do engenheiro José Carlos de Figueiredo Ferraz, nosso ex-prefeito, que opinou a respeito do inadiável problema de habitação popular. Baseou-se numa fórmula a um só tempo apropriada ao momento político e à prática humana: o direito de morar.

Cada brasileiro sabe como vivem milhóes de famílias, especialmente nas grandes metrópoles, consequência de desconcertantes anomalias de uma nação que ainda náo estabeleceu um planejamento condizente com suas necessidades demográficas e econômicas.

Parece que a época é ainda a aventureira do pós-colonialismo, a habitação uma incógnita, pois para grandes multidóes a casa decente é mais um sonho do que um complemento lógico da operosidade.

Por outro lado, quando o governo decide prover, o que aparece é o BNH. Não é o caso de refazer aqui a história da entidade, porém se sabe que sua atuação não deu e não dará certo. $\mathrm{O}$ primeiro erro foi aglomerar apartamentinhos "cara-a-cara," usando um sistema que lembra as casas populares do Oitocentos na Europa: esquálidos tetos impróprios sob os quais os inquilinos são relegados a uma sobrevivência vegetativa. $\mathrm{Na}$ discussão, Figueiredo Ferraz propôs formar desde já um "Conselho SP 2000 Ecumênico," para que não se percam no tempo as sugestóes apresentadas em todos os seminários e para que se tenha um constante acompanhamento das medidas efetivadas e uma cobrança daquelas carentes de realização. Isto é, recolher os elementos, discutir e procurar traduzir as propostas em providências para dar à Grande São Paulo, onde o déficit comprovado de habitaçóes é de setecentas mil moradias aumentando de cem mil a cada ano, melhores condiçóes.

Quando se fala em déficits é fácil verificar que se não se provê a tempo vai-se para a bancarrota. $O$ contínuo erguer de arranha-céus, palacetes e tudo o mais que surge no desvairado da especulação edil, contrasta demais com o penoso aglomerado das favelas. Ferraz justamente bateu na fórmula "direito de morar," indicando uma série de providências administrativas e políticas ditadas por sua reconhecida experiência: recomendaçóes que não devem, em absoluto, seguir o caminho do verbavolant. Tratou-se, no debate, de 
"cartas de recomendação," e disse muito bem a escritora Lygia Fagundes Telles que notou o que é indispensável: a Globo, com sua penetração imensa pode, aliás deve, criar a consciência do "direito de morar," e eu acrescento: dignamente.

Quando se constata que um terço da população da capital paulista tem seus abrigos em favelas e cortiços é fácil prever um futuro desastre social. Então: nem curto, nem médio, nem longo prazo, nem estudos de fundos e receitas, nem distinçóes conjunturais, reajustes e tudo o os burocratas colocam nas mesas de discussão; nada disso. A solução deve ser "já!"

Senhor \#I72, 4 de julho de I984, p.72 (P.M. Bardi)

Milagres DA ARTE POPUlaR

O Masp faz uma exposição de pintores primitivos, apesar da má vontade de certos especialistas

O pintor popular imagina, não reflete, a expressão lhe vem espontânea, sem procurar, indo direto ao assunto que está na sua poética, aliás, na ignorância do conceito do praticar arte. $\mathrm{O}$ versificador de cordel está na mesma posição: o desabafo vem como vem, sabe já o que vai dizer. Às vezes quando declamam seus versos trocam rimas.

Por outro lado, os Românticos não definiram como popular, e alguns até popularesco, o poema de Homero? O autor da Ilíada é considerado por muitos como "primitivo" por sua poesia sem inflorações que vai direto à comunicação de todos, fato absolutamente individual, porém de interpretação e gosto coletivos.

Há naturalmente alguns colegas, os apegados à arte como reserva particular dos "espíritos cultivados," agarrados à acolhedora torre de marfim da aristocracia, sujeitos que olham para uma pintura popular com expressáo de dúvida, definindo-as como de manualidade etnográfica. Aliás, um dos frequentadores desta citada torre, Bernard Berenson, classificava o quadrinho popular como elaboração detestável das "mudas e obtusas massas." A vida nos leva ao encontro dos fatos mais curiosos. Sabe-se que, além de elitista, Berenson era o papa da Renascença e, quando a pintura Ressurreição de Cristo, de Rafael, atualmente no Masp, deveria entrar para a National Gallery de Londres, ele não deu sua indispensável bênção para uma obra daquele autor ingressar em tão importante templo. O papa Berenson classificou-a apenas como de um pintor popular, talvez de Mariano di Ser Austerio, artista praticamente desconhecido. Mais tarde, o cronista desta página, na qualidade de noviço no sacerdócio, adquiriu a pintura para o Masp, a qual foi depois consagrada como de Rafael por todos os historiadores que a observaram.

A lembrança serve para, às vezes, se desconfiar dos expertises. E, no caso da implicância de Berenson com os pintores primitivos, não se importar.

Seja como for, quando se acolheu no Masp a manifestação vinda de Assis, Itália, dedicada à universalidade de São Francisco, foi natural para mim propor a convocação dos pintores populares do Brasil que se inspiraram no Santo da Paz, recebendo a imediata adesão do padre Antônio Godinho, diretor do Museu de Arte Sacra, também participante da mostra.

Se o leitor me der licença, estou pensando num mestre comparável ao já lembrado Homero: refiro-me a Giotto. Não quero fazer confusão mas permitam-me apelidar o afrescador da famosa capela de "primitivo." Emerge-se num pensamento mágico-cultural, uma abstração do seu tempo interpretativa de uma explosão espiritual parecida com autonomia das áreas culturais totêmicas.

Hoje, a pintura não tem mais a tarefa de comunicar aos simples observadores a vivência de um Santo com a indispensável utilização do tradicional modo figurativo. Mesmo assim o Masp recorreu a vários primitivos que o retrataram Poverello e que compóem o acervo do Museu de São Francisco, de Penápolis, SP, para colocá-los junto a mostra italiana. Entre esses estão Euridice Bressane, Osvaldo, Ana Maria Dias, Inácio da Nega e L. Alves. 
Legenda

Ana Maria Dias: visão de S. Francisco

g Obra de L. Alves: entre italianos

Senhor \#I73, II de julho de I984, p.72 (P.M. Bardi)

No CORAÇÃo DO PASSADO

Como se sabe, Claude Lévi-Strauss, no tempo em que, devido à última Guerra, ficou bloqueado em Nova York, ligou-se aos surrealistas, tornando-se bom amigo, entre outros, de Breton e de Max Ernst. Declarou recentemente, em entrevista dada a Le Nouvel Observateur, reproduzida no Jornal das Letras, de Lisboa: "É verdade que os surrealistas e eu próprio temos as mesmas fontes, as mesmas origens e que nos agarramos ao século I9. Não era por acaso que Breton tinha uma paixão por Gustave Moreau, por todo esse período do Simbolismo e do Neo-Simbolismo.

Os surrealistas estavam atentos a tudo o que aparecia como irracional e tentavam explorá-lo do ponto de vista estético. É esse o mesmo material de que me sirvo, mas, em vez de investigar com fins estéticos, procuro reduzir esse irracional à razão.”

Deve-se dizer que o autor de Tristes Tropiques é, no campo das artes plásticas, elemento portador de ideias e participaçóes nos mais díspares caminhos da contemporaneidade de tendências avançadas. Todavia, ao entrevistador que lhe observou ser a sua filosofia pessoal profundamente ancorada no passado, como se lê no Le Regard Eloigné, que condena as artes modernas, a pintura, a pedagogia, o etnólogo manifestou alguns pontos que me parecem interessantes, como o referente ao momento que está emergindo da polêmica em contínua discussão: o vanguardismo anulador da estética do passado.

$\mathrm{O}$ antigo professor da usp que aí lecionou em seus primórdios contou que, como muita gente, foi ver a exposição de Manet no Grand-Palais, da qual o Masp participou com a pintura do seu acervo Pertuiset, o caçador de leóes. Disse: "Fui tocado pelo que me surgiu como uma mistura de gênio e de impotência e pelo sentimento de que, se Manet tivesse seguido o seu lado genial, no fundo, ele ter-se-ia voltado para o passado."

Vejam de onde vinha isto de lembrar o passado, isto é, estar entre dois fogos: no
Grand-Palais havia uma outra exposição minguadamente visitada, ao passo que a do impressionista atraía imensa massa de visitantes. A mostra marginalizada era dedicada à pintura napolitana do século I8. Nestas salas solitárias, Lévi-Strauss descobre uma pintora da qual nada sabia. Tratava-se nada menos que de Artemisia Gentileschi, ${ }^{52}$ encantando-se também com outros mestres participantes que o levaram a pensar na "dimensão lírica" de Proust. Assim afirmou peremptório ao seu entrevistador: "Como é que você quer que eu não esteja virado para o passado?"

Tirando algumas conclusôes: é recomendável evitar o fanatismo na apreciação da arte e normalizar o critério da fórmula “antigo-moderno," já proposta por Vasari, porém num sentido cronológico.

Um número infelizmente inflacionário de colecionadores embrulhados pela propaganda com vistas ao consumismo das últimas novidades (novidades de imitadores das já digeridas maneiras das vanguardas históricas) considera o passado como “já era," com isto contribuindo para a circulaçáo de uma ignorância por demais difundida.

\section{Legenda}

Judite, de Artemisia Gentileschi g Pertuiset, o caçador de leóes, de Edouard Manet
52 Artemisia Gentileschi (1593-I652/53) foi a primeira mulher a entrar na Academia de Arte de Florença. 
Senhor \#I74, I8 de julho de I984, p.72 (P.M. Bardi)

TENDÊNCIAS DA PANELINHA

Qualquer elemento investido na tarefa de fazer funcionar ou desfuncionar uma entidade cultural, se náo estiver em boas graças com o Diabo, o qual tudo dispóe e manda, curte suas penas justamente no Inferno. O caso náo se dá apenas com os acomodados, os que registram tradicionalmente a rotina normal, retirando no fim do mês seu ordenadozinho, gozando as férias regulamentares, sábado inglês e feriados e com o pensamento voltado para as "pontes" etc.

Os alinhados com o Diabo, ao contrário, se esforçam no querer fazer, aliás, exagerar no trabalho, procurando melhorar as atividades, quando necessário até polemizando, não dormindo nem sonhando.

Lendo recentes declaraçóes, de Sheila Leirner, crítica de arte de $O$ Estado de S.Paulo, sob o título "Determinaçáo fanática: inaptidão ou pretexto?”, pensei: eis alguém que deve procurar imediatamente um Satanás para vencer na tarefa que assumiu de "coordenadora" da próxima $18^{a}$ Bienal Internacional de Arte, aqui em São Paulo.

A colega, atacada com uma certa petulância pela sociedade dos artistas plásticos locais, nada menos que deflagrando o solene emblema da Democracia, querendo que a Bienal não abrigue na seção nacional uma panelinha de astros, - aliás um pouco como sempre foi - ou um Saláo de Belas Artes, como também se notou em certas antigas ediçóes, Sheila, atacada, ilustrou as exigências comunicativas que, hoje em dia, parece que internacionalmente, se consideram válidas, isto é, dar lugar à nata, batida no contexto das artes deste fim de século, efetivamente inflacionadas por tendências, (de mestres e de não se sabe quantas turmas famélicas de amadores, guerreadores para democraticamente vencer) nota Sheila: "Participação com tudo aquilo, é claro, em que ela implica, ou seja, prestígio, currículo, divulgação, fama e dinheiro."

Trata-se, segundo a coordenadora, de colocar no próximo certame ibirapuerano um mostruário de pinturas e esculturas que demonstrem qual o significado da arte contemporânea brasileira. Não parece simples separar para coroá-los como louros. Fatalmente, Sheila deverá acantonar os figurativos, mexer na complicadíssima poluição do abstrato geométrico, informal, conceitualismo extravagante etc., e até mesmo conta as contrapropostas anuladoras de qualquer princípio a um tempo apelidado de estética.

Os associados da ala democrática insistem: nada de panelinhas, mas panelona para todos, indistintamente, deixando o visitante livre para apreciar ou detestar. Escreve Sheila: “...Em suma, os artistas plásticos exigiram dos responsáveis pela manifestação - numa espécie agressiva de determinação fanática - a transformação da Bienal num amplo e indiscriminado panorama da obra, pensamento e trabalho do artista brasileiro."

Todos sabem: o amigo Cicillo Matarazzo, pondo o carro antes da bois na Sáo Paulo provinciana das artes, apesar de alguém tê-ia apelidado impropriamente de "Athenas do Brasil," abriu as Bienais. Simplisticamente recopiando, letra por letra, o regulamento da única Bienal então existente, a de Veneza trouvaille turística de I893. É como tudo se engolia e se continua a engolir, o fato é que a primeira modesta desta edição aqui realizada, e que ensejou a destruição do antigo Trianon, foi seguida de algumas curiosas edições e, mais tarde, como sempre acontece, surgiu a rotina, transando do inútil para o mais inútil, de uma facção a outras, com a constante troca de coordenadores tudo se desenvolvendo de anormal. Assim choveram os pedidos e denúncias de remodelação. $\mathrm{O}$ último destes dias, para dar nova vida à Bienal, gastou-se melhor as riquíssimas verbas, numa tentativa de salvar a por demais envelhecida manifestação, depois de anos de superação em termos de ideias e de açáo pela coirmá de Kassel e de não sei quantas outras similares.

Não seria justo revisar sistema bienalesco? E aconselhar os responsáveis a darem vida a uma iniciativa original, até terceiro-mundista, caso sirva, mais simpática aos Diabos do que aos cultores de deixa como está. 


\section{Legenda}

Bienal paulista: qual o signifi-

cado da arte contemporânea?

Senhor \#I75, 25 de julho de I984, p.IIO (P.M. Bardi)

A ARQUITETURA DA TERRA

Inspiraçóes do caboclo à disposição da curiosidade urbana

$\mathrm{Na}$ antiga fábrica da Pompeia, que o

Sesc adquiriu e transformou num centro de lazer para seus associados e para o público em geral, sempre se assiste a manifestaçóes de caráter popular com visitação maciça. Os eventos tendem a lembrar o Brasil da estruturação, com evidentes sinais de polêmica social.

Naquele local, as festas juninas foram recordadas de maneira genuinamente caipira, com uma dás áreas evocando um poético vilarejo. Reconstruiu-se algumas moradias e também recintos para animais, poleiros, botequins, fornos e até mesmo um velho alambique produzindo pinga: o pitoresco ambiente alegrado por música, orquestra, danças infantis, loteria, cantos, afinal, tudo o que exige a estética da gente do campo, e que se define erradamente como "folclore."

Vamos abrir, no Masp, daqui a alguns dias, uma demonstração da "Arquitetura de terra," elaborada no centro Georges Pompidou, o popular "Beaubourg," de Paris.

$\mathrm{Na}$ Pompeia, os interessados podem ver a realidade desta técnica de construir em pau-a-pique, inventiva e aperfeiçoamento da sapiência do caboclo, que por hábito caça com gato quanto náo tem cachorro. Quem viu a obra do apelidado Capitão, a um só tempo arquiteto - plasmador de terras e galhos - caiador-enfeitador, ficou encantado; e o mesmo se deu, de resto, com o manipulador do antigo alambique. É um prazer encontrar um boi na entrada, ovelhas, galinhas, uma selva de paus-de-sebo, simbolizando modernamente a floresta, na parede lateral pintada abstratamente por Leone Miroglio, o cheiro dos fogóes a lenha, os visitantes confraternizando, todos cumprimentando o presidente do Sesc, Abram Szajman, incentivador de um lazer que não perde de vista a cultura, conciliada com o espírito popular e, naturalmente, ajeitada nas conquistas do progresso.
Disse acima que a manifestação tinha até mesmo um ar de anotaçáo de tempos em mudança: para os preocupados com a última palavra do parágrafo anterior, esta festa junina tem um significado social bastante acentuado. Vendo os casebres reconstruídos, a simplicidade reduzida ao mínimo das exigências vitais, é lógico pensar na realidade e, por coincidência, no debate que a TV Globo convocou recentemente dedicado ao problema habitacional em São Paulo, aproveitando para algumas deduçóes e opinióes. Por analogia, como não pensar nas favelas que, cada vez mais, circundam a metrópole? Algumas têm aparelhos de rádio e de tevê, modismo da tecnologia, porém falta tudo o que é básico e indispensável.

Um assunto se interliga a outro: neste caso, ao nacional, focalizado exatamente pela Globo, sendo mediador do debate o nosso antigo prefeito José Carlos de Figueiredo Ferraz, ${ }^{54}$ que, lapidariamente, afirmou: "É necessária uma reestruturaçáo no processo de desenvolvimento do País, para que ele cresça da forma mais equilibrada, evitando que apenas alguns pólos se desenvolvam desmesuradamente ensejem uma acumulação de população que é muito violenta, como é o caso de São Paulo. Numa cidade que recebe quinhentas mil pessoas a cada ano não há solução que equacione definitivamente nenhum problema. Não só de habitação, como de transportes, educação, saneamento etc." O pitoresco da exposição da Pompeia, justo tributo aos heróis com caráter, (que me desculpe Mário de Andrade) não é um chamariz para problemas que sei complicados, porém solucionáveis, na própria São Paulo "maior que a crise"?

54 Bardi escreve sobre esse evento em Casa Vogue, jul-ago I984, p.5o. Cf. p.402 deste Anexo. 


\section{Legenda}

Um ninho de galinha de Conceição

dos Ouros (MG): uma arte surpreen-

dente Boca de Pito: exposto no Sesc

Senhor \#I76, I de agosto de I984, p.80 (P.M. Bardi)

A veZ DAS ENCICLOPÉDIAS

Onde está o nosso Giovanni Treccani?

Recebo a mais original revista da Europa, a F.M.R., - título que corresponde ao nome do editor: Franco Maria Ricci - publicação esplêndida com colaboraçôes internacionais abrangendo ciência, história e estética, textos ilustrados, documentaçóes inéditas, como ocorreu recentemente num ensaio dedicado ao Brasil, ao qual já me referi nesta página.

No último número, o editor informa que reedita em fac-símile os dezoito volumes da Enciclopedie de Diderot e d'Alembert, Paris, I75I-I772, ilustrada, como se sabe, com mais de três mil desenhos. Ricci acrescentou um volume de estudo e ensaio dedicado ao Século das Luzes, notas biográficas e índices, completado por uma copiosa iconografia.

Num outro semanário, de Lisboa, Jornal de Letras, Artes e Idéias, aprendo, através de um anúncio, que se está traduzindo para o português a Enciclopédia, do editor italiano Einaudi, obra que logo, sem dúvida, será exportada para o Brasil.

E sempre a respeito de enciclopédias, recebo de um editor de Roma, Gherardo Casini, a notícia de que está para publicar uma grande enciclopédia, para a qual me pede colaboraçáo no setor da arte Brasileira.

Lógico então pensar no Brasil, e justamente na ideia de finalmente fazer um ponto a favor da cultura, dedicando-nos ao preparo da Enciclopédia Brasileira.

Temos algumas ediçôes diligentemente compiladas; todavia, o que se propóe é uma obra de porte, como por exemplo, a Enciclopédia Italiana, que representou há meio século um fato muito importante, isto é, a reunião de cientistas, escritores, artistas, profissionais eminentes, participantes de uma comunicação que documentou o saber daquele país.

O realizador foi o senador Giovanni Treccani, um facultoso industrial têxtil, apoiado, naturalmente, pelo governo, valendo o prestigioso talento de um industrial tipográfico, Angelo Rizzoli, que realizou esplêndida edição.

Quando tento lançar a ideia de se pensar realmente na $E . B$., recebo, especialmente por parte de editores, consideraçóes negativas, aliás, sobre a absoluta impossibilidade de se tentar até a imprensa. Lógico que estou a par do vultoso capital necessário para iniciar os trabalhos de redação, a formação das direçóes de seçóes, dos contribuintes, dos materiais ilustrativos, revisôes etc. Todavia, continuo sendo da opinião de que hoje seja possível convocar os realizadores, tanto no que se refere à editoria quanto à redação. Sem dúvida, daqui a alguns anos, quando do lançamento das subscriçóes para assinantes, será recuperado o capital empregado.

Veja o número da Enciclopédia Italiana que assinei no começo dos anos '30: é 23.515. Eu penso que a $E . B$. teria certamente várias dezenas de milhares de assinantes: universidades, institutos culturais, indústrias, público, todos desejosos de ter na biblioteca um instrumento indispensável de trabalho.

Trata-se de avaliar o empreendimento. Por experiência, dou um exemplo: foi possível criar do zero o Museu de Arte de Sáo Paulo. Deixo de lado sistema, peripécia, vicissitudes por todos demais conhecidas. Seja como for, a entidade existe e funciona.

O Brasil não é mais um país em desenvolvimento. Parece-me essencial sair deste impasse e se empenhar, desde já, em pensar na E.B. Nunca é tarde para começar a estudar uma empresa deste porte: elas se estruturam, então, na vontade de vencer.

Será, com tantos capitães de indústrias, personalidades da Academia, manipuladores do dragáo-dinheiro, que não temos um Giovanni Treccani? 


\section{Legenda}

D’Alembert e Dederot: I8 volumes

de uma enciclopédia que é um

exemplo para o Brasil

Senhor \#177, 8 de agosto 1984, p.77-79 (Negócios)

EU NÃO ENTENDO MAIS NADA

O maior conhecedor de arte do Brasil entrevista a si mesmo e

declara-se perplexo com a evolução do mundo das artes

$O$ mercado das produçóes das artes em geral está hoje muito ativo. Há poucos dias, os jornais noticiaram que foi vendida pela Sotheby's, de Londres, uma Marinha de Joseph William Mallord Turner pela espetacular importância de quase US\$IO milhóes; também a casa londrina Christie's, no mesmo periodo, vendeu um desenho de Rafael por US\$4,2 milhóes; no mês de junho, último, foi vendida em São Paulo a tela Abaporu, de Tarsila do Amaral, pela disparatada quantia de Cr\$30o milhóes. Por outro lado, se sabe que, hoje, a pinacoteca do Museu de Arte de São Paulo está avaliada em mais de US\$ 0,5 bilhão. Tais fatos denotam como as finanças no mundo continuam a se concentrar nas obras de arte, pois os valores a elas atribuidos alcançam altas cotaçóes.

Como os leitores de Senhor sabem, nosso colaborador semanal P.M. Bardi, cofundador do Masp, já em 1947 era considerado um técnico de renome internacional não só na historiografia, mas pessoa dona de amplo conhecimento do mercado de arte face sua intensa atuação no setor. Com tais credenciais, pensamos em entrevistá- lo sobre a situação, particularmente no que se refere ao campo brasileiro.

Mas Bardi fez melhor. Entrevistou-se a si mesmo. Com vocês, o maior connoisseur de arte do Brasil, em perguntas e respostas implacáveis:

\section{P Que pensa do colecionismo nacional?}

R Nunca pensei muito a respeito de uma prática táo comum, dependendo do gosto e das possibilidades monetárias dos que se decidem a entrar em tal negócio...

\section{P Por que negócio?}

R Espero que você não seja tão ingênuo a ponto de considerar o assim chamado colecionador um tal que adquire obras de arte só para pendurá-las nas paredes e passar noras e horas admirando-as. Estes tais sempre existiram, no passado muito mais. Hoje, é muito comum lermos anúncios publicitários assim redigidos: "Arte: o melhor investimento... você encontra antiguidades e objetos de arte para fazer a melhor aplicação de seu dinheiro. Investir em arte não significa apenas bom gosto, significa também bom senso..." Parece-me que você mesmo procura minhas luzes, bruxuleantes, vá lá, para saber de problemas de mercado, marcadamente no tocante à aquisição de pinturas e esculturas como investimento e não como deleite estético.

P Por que disse "luzes bruxuleantes"?

R Porque, se as luzes servem para iluminar, não vejo muito claramente o mercado de arte. Nos meus tempos de Europa, o caso se processava com mais luzes, às claras, era mais compreensível, em proporções menores. Hoje, não é suficiente uma iluminação normal, mas os faróis devem ter lâmpadas com não sei quantos watts, pois deve-se considerar uma série de circunstâncias para que se averigue, indague, até se chegar a um consenso de sistema, alguns até bem curiosos. O mundo das artes, desde sua produção até a comercialização, tem passado por constantes evoluçóes que eu mesmo, confesso, não entendo mais nada.

P Curioso escutar isto do responsável pelas compras singulares, diria singularissimas, das obras que formam hoje o preciosos acervo da pinacoteca do Masp.

R Eu o fui com a ajuda de um autêntico Diabo, o sr. Assis Chateaubriand. Tendo carta branca, usei-a para aplicar o slogan: "Não quero conselho, pois sei errar sozinho;" dólares na mão, foi-me possível concluir bons negócios. Devo-lhe dizer, e é inédito: convenci o dr. Assis a comprar, além das obras do acervo, 
muitas peças para posterior revenda, a fim de diversificar o nascente acervo.

P Então, especulação.

R Sim, mas saiba que sempre me interessei pelo mercado de arte. Com isto estou habilitado a dizer que existem, hoje, autores não tão considerados, mas que amanhã alcançarão valores surpreendentes; há quem sabe prever ou adivinhar quem será quem; contudo alguns podem ser descobertos e, quando promovidos, mostrarão suas potencialidades. Assim pensei e adquiri um lote de obras para venda ou trocas. Acumulei coisas de futura mercadologia.

P Tratava-se, então, de acreditar e ficar à espera de nova consideraçáo e consequente reavaliação mercantil...

R Exatamente. Por acaso não existem os que especulam até com mantimentos? Compram produçóes que, por uma razáo ou outra, um dia podem aumentar de preço e, chegado o momento, soltam pela melhor oferta. Isto é comum, hoje. Como estamos no Brasil, lembro-me muito bem do que disse Lévi-Strauss: "Os colecionadores desprezaram as coisas que não lhes interessavam, aquelas que hoje justificam o interesse pela etnologia," o mesmo, mutatis mutandis, se dá, pode-se dizer, no setor da arte. De fato, a maioria dos compradores de obras de arte vai na onda dos celebrados e despreza o que não alcança o desejado valor. Somos nós, etnólogos da arte, que temos condiçóes, portanto, de dizer que o mercado de arte tem suas singularidades.

P Será que, às vezes, não se dáo inverso no dito mercado de arte?

R Naturalmente, pois há os que sabem e os que se metem em um ginepraio, como dizem os italianos, num matagal onde podem ser colhidas flores e espinhos para se ferir. Por isto lhe falei de luzes. É preciso que se dê atenção à quantidade de gente de todos os matizes para se ver claramente em cada transaçáo como origem, passagens, valores de uma obra de arte que percorre caminhos complicadíssimos.

$\mathbf{P}$ Por exemplo? Conte-nos algumas curiosidades.

R O Brasil nem sempre foi uma nação de tradição artística, excluídas as produções coloniais, como pouca é a pintura do Oitocentos; finalmente, hoje é reconhecida a produção dos Modernistas, mas mesmo assim o que existe pouco dá para alimentar um mercado de arte.

\section{P Mas temos um mercado.}

R Sim, restrito às coisas brasileiras, e devendo-se observar que em bases um tanto prósperas, especialmente quando se recorre aos leilóes. Quando cheguei ao Brasil, em 46, os leilóes de objetos de arte eram raros, tanto que adquiri, no Rio, os dois grandes retratos em tamanho natural de Dom Pedro II e da Imperatriz, ambos de autoria de Victor Meirelles, a preço de banana; em São Paulo ocorria o mesmo, operando o saudoso Florestano. Agora nos leilóes é encontrada sempre a mesma mercadoria, às vezes modesta demais; todavia, para os que sabem escolher as ocasióes, existe um jogo de mercado. Os conhecedores de valores têm a possibilidade de negociar.

P As obras de arte não são vendidas apenas em leiloes. Sabe-se de contrataçóes que alcançaram importâncias vertiginosas, cifradas em centenas e centenas de milhóes de cruzeiros. Por exemplo, pinturas de Tarsila do Amaral.

R Simples: como já disse, o colecionador compra mais para especular do que para conservar. Pode ser que exista algum fanático e, na verdade, tem; de qualquer jeito, sei que logo que o tal passa para o Paraíso, ou para o Inferno, ou para o Purgatório, seus herdeiros transformam em moeda o que os velhos deixaram. Fique certo de que arte e valor, mercado e tudo quanto isso comporta.

P O Bardi está sendo um pouco cínico nesta conversa...

R Não se trata de cinismo. Mas adotarei um positivismo para melhor me orientar.

$\mathbf{P}$ Acha trezentos milhóes de cruzeiros um valor certo para uma tela de Tarsila?

R Se amanhã o comprador vender a mesma tela por 350 milhóes cruzeiros, o preço está certo. Difícil estabelecer. Para falar de experiências pessoais, eu lá pelos anos 20 comprava "naturezas-mortas" de Giorgio Morandi por cinquenta liras italianas, isto é, o que aqui se diz a preço de Coca-Cola; em Miláo, no mesmo tempo, se pagava 
trinta mil liras por paisagens de Angelo dall'Oco Bianca; o primeiro, um artista desconsiderado, e o outro, badaladíssimo. Hoje, dá-se uma inversão total de valores. Morandi procuradíssimo, enquanto o outro está totalmente esquecido. Devo juntar: me honro de ter, em 46, doado uma pintura de Morandi à Tate Gallery, de Londres, justamente para chamar a atenção sobre o artista bolonhês. Fui bom amigo dele e negociei muitas de suas telas. Mas estas são as vicendas do traficar as produçóes dos artistas.

P O sr. deve ter comprado milhóes e milhóes de dólares, em obras...

R Acho que sim, pois não dormi no ponto. Todos sabem que o acervo do Mirante das Artes é meu. Aliás, as duas telas da Tarsila, Antropofagia e Abaporu, esta última vendida recentemente por trezentos milhóes de cruzeiros, foram adquiridas pelo Mirante diretamente da grande pintora, ambas sendo comercializadas mais tarde. Trata-se de um exemplo eloquente de quando se acredita num artista. Comprei quando Tarsila não conseguiu vendê-las, notadamente a preços ultranormais. O mesmo caso se deu, desde tempos bem recuados: quando comprei a inteira exposição de José Antônio da Silva na primeira galeria que São Paulo teve, a do casal Fiocca, na rua Álvaro de Carvalho. Quantas vezes comprei uma exposição inteira de pintores, que nem eram quentes ou gelados perante a crítica...

\section{P Por exemplo?}

R Vicente do Rego Monteiro. Hoje, é célebre e objeto de mercado; em 60, quando organizei a primeira exposição de suas obras, não se vendeu nada. Assim, adquiri a mostra inteira. Mas isto é rotina na profissão. Esperamos que, neste fim de século, finalmente o Brasil participe de tão fascinante mercado num sentido mais amplo, possivelmente eliminando, dos dépliants dos leilóes, aquela ridícula divisão: pintores nacionais e pintores catalogados no Benezith.

P Dizem que o sr. fez uma proposta à Sotheby's para promover um leilão internacional em São Paulo.
R Justamente: falei certa vez, com o presidente da Sotheby's a respeito do assunto. O Brasil é, hoje, uma nação vitoriosa em todos os setores empresariais e com alto trânsito internacional, praticando um desenvolvimento altamente espetacular, partícipe desejado de todas as iniciativas voltadas para o futuro. Por que, entáo, não pode aplicar, digamos, a palavra especular também no mercado da arte em sentido internacional? $\mathrm{O}$ amigo Colasuonno, da Embratur, as companhias de aviação, os bancos etc. etc., enfim, os que ganham fortunas comerciando nossos mestres, devem aproveitar até como turismo e suas evidentes consequencias mercantis. Tudo é questão de decidir. Não há nada em que o Brasil não possa participar. É preciso aposentar os preguiçosos os medrosos, os não- audaciosos, os acomodados...

P ...o sr. Assis...

R Ele me antecipou. Se hoje o Brasil se dá ao luxo de emprestar obras-primas aos maiores museus de Londres, Nova York, Paris, Tóquio etc., é porque o Masp rompeu a geleira e teve a coragem de participar do mercado de arte. Não foi fácil, foi difícil mesmo para um país novo, ativo - desculpe-me por memorizar Mário de Andrade quando falou de caráter do brasileiro e que nunca digeri : herói, sim; sem caráter, não.

P Mas o sr. ...

$\mathbf{R}$ Peço-lhe que acabe com este solene senhor: os que trabalham devem tratar-se por você.

$\mathbf{P}$ Bom, você imaginou o ingresso do Brasil no mercado internacional da arte.

R Deve saber que está na cabeça, a minha naturalmente, um plano que já sei que os "bem pensantes" vão dizer: o Bardi, como sempre, é um moleque aloucado, continua o mesmo de sempre, aquele que em protesto pichou o muro do Masp durante as últimas eleições com um palavrão...

$\mathbf{P}$ Me dá licença de lhe dizer que você é, às vezes, exagerado.

$\mathbf{R}$ A respeito, conto-lhe a última, se bem que datada de 53: quando apresentei o fruto do meu trabalho do Masp, sob o título de Ioo obras do Masp em Paris, a convite 
da direção dos museus da França, este entrevistado que você chama de exagerado correu à embaixada do Brasil a fim de pleitear que fosse o presidente da República o inaugurador da façanha. Me disseram, talvez diplomaticamente certo, porém errado para nós, moleques, que eu era um exagerado. Virei as costas. Alguns amigos meus, franceses, que tinham boas relaçôes com M. Vicent Auriol, conseguiram que o estadista francês, acompanhado de Mme. Auriol, inaugurasse a mostra, permanecendo no local por várias horas, admirando o feito de alguns brasileiros.

P ...E quem fez as honras da casa a fim de receber em nome do Brasil tão ilustres convidados?

R O recém-naturalizado P.M. Bardi.
P Mas náo se esqueça de me dizer como lançaria um fato internacional de mercado de arte em Sáo Paulo

R Proporia aos dirigentes da Sotheby's um grande leiláo, que seria realizado no auditório do Masp, naturalmente depois de obter as devidas permissóes expressas em leis, decretos, portarias, simples regulamentos etc. etc. etc.

P Pensa que daria certo?

$\mathbf{R}$ Por que náo deve dar certo? Tudo dá certo no Brasil. E, depois, não precisamos trazer dólares para pagar a Fregatura Monetária Internacional?

Legenda

p.Bardi sob o acervo do Masp: querendo abrigar um leiláo da Sotheby's

Senhor \#I77, 8 de agosto I984, p.93 (P.M. Bardi)

A CONQUISTA DO SUPÉRFLUO

Difícil dar uma definição da colagem, uma das comunicaçóes mais prósperas neste Século, rica de soluções notadas em vários países, incluindo o Brasil, onde, quase de improviso, edita-se até um volume bastante singular redigido por Sérgio Cláudio de Franceschi Lima.

Trata-se de uma monografia original intitulada Collage em Nova Superfície, (Ed. Massao Ohno e Editora Parma Ltda. Associados, 1984) dividida em três partes: sua história, reproduçóes I919-1979 e desenvolvimento da técnica. Justifica o empreendimento uma afirmação de Gaston Bachelard: "A conquista do supérfluo provoca uma excitação espiritual maior que a conquista do necessário. $\mathrm{O}$ homem é uma criação do desejo, não uma criação do necessário.” E Sérgio calca:

"Há outros meios de responder à riqueza das imagens que não os da razão ou da lógica. As limitaçôes que pesam sobre todas as formas de expressão podem ser abolidas, como acreditam e professam os surrealistas, por exemplo. Essas limitaçóes, dizemos, podem e devem ser abolidas, através do próprio trabalhar a imagem, da visão ativa da imagem, do image-work como rosácea do conhecimento."

$\mathrm{O}$ volume passa em resenha uma quantidade significativa de imagens, e o autor propóe ao leitor se dedicar ao serviço: uma espécie de noviciado numa das técnicas do Modernismo, motivada por digressóes de ordem crítica que confirmam o quanto o autor aprofundou sua pesquisa em todos os setores: uma autêntica antologia de escritos dos que se interessaram pela colagem como arte-novidade.

O uso que popularizou a "colagem" ou o papier-colé foi lançado pelos pintores cubistas, dando-se primazia a Pablo Picasso que, em I9I2, se serviu da técnica na sua Nature Morte à la Chaise Canné. Depois, cubistas, dadaístas, futuristas, surrealistas, com finalidades e intençôes diversas se valeram dos meios os mais originais, até o da "descolagem," o oposto da "colagem," que consistia em arrancar pedaços de cartazes publicitários, tendendo a documentar uma espécie de efêmero das paredes urbanas.

Colagem, às vezes, faz pensar no desempenho de mestres que se expressaram na caricatura como, para dar um exemplo, William Hogarth e Gian Lorenzo Bernini, com desenhos em que associavam dezenas e dezenas de rostos, o que lembra as composiçóes dos contemporâneos dedicados à colagem utilizando rostos de fotografias. Os modos de manifestaçôes sempre têm precedentes. Por outro lado, Bernini e Hogarth justamente na 
caricatura não apresentam como precedente as caricaturas de Leonardo da Vinci?

A seção mais curiosa é das reproduçóes que podem - aliás, devem - ser recortadas e coladas nos espaços correspondentes indicados no livro, conforme as instruçóes, numa escolha curiosa de obras de artistas contemporâneos, em preto e branco e em cores.

Entre as colagens dos primeiros tempos, isto é, dos anos 30, é reproduzida também uma que eu mesmo compus na Itália, dedicada à polêmica que desencadeei para que Mussolini parasse de destinar as obras públicas aos arquitetos do "estilo romano imperial modernizado," uma autêntica palhaçada. Tratou-se de uma colagem de denúncia política e estética, ridicularizando a situação da arquitetura oficial: recortes de fotografias de edifícios mescladas com enfeites, cabeçalhos de revistas e jornais corriqueiros e tantas outras figurinhas negativas.

Daqui é fácil argumentar que a colagem se presta a náo importa qual destino, desde o estético até o polêmico.

\section{Legenda}

Tavolo degli orrori, de P. M. Bardi: uma denúncia contra Mussolini Bachelard: uma excitação espiritual

Senhor \#I78, I5 de agosto de I984, p.75 (P.M. Bardi)

Como SAlvar os MUSEUS?

Uma atividade que sofre tanto quanto os acervos

Tenta-se aqui movimentar as mesinhas de discussão de problemas mais variados, possivelmente os assuntos interligados ou aproximados à grande aventura que etiquetaram de Beleza.

Eis um assunto ligado à Memória: nossos legisladores descobriram que aqueles que se propóem a conservar e, possivelmente, difundir os significados e utilidades culturais dos museus devem ser profissionais diplomados em "escolas de graduação e pós-graduação oficiais ou oficialmente reconhecidas."

Transcrevo do projeto de lei $n^{\circ} 4858$-A, apresentado na Câmara dos Deputados, em I98I, esta justificativa: “...Lugar onde são guardadas velharias à espera de intelectuais ou alguns raros curiosos." Definição um tanto indefinida da ação dos museus, invocada para mexer com nosso "imenso patrimônio cultural...” Quanto ao museólogo, este só "...tem conhecimento para a realização ... de um processo educacional e cultural do povo em forma dinâmica ..." Continua a propositura: "A atuação de pessoal não habilitado na área específica do museólogo acarreta prejuízos imensuráveis à Memória Nacional ... expóe os objetos ... a constantes e crescentes riscos" etc.

Justificativa, com exceção à locução "velharias," digna de aplausos. Acho muito lógico que se prepare o futuro, como espero também que a salvação de tudo quanto tenha sido conservado até a promulgação da lei não venha a se converter na deletéria praga do "cabide de emprego," aquela gente ansiosa por bicos, carreirismo, aposentadoria e tudo mais que qualquer funcionário desejar.

Permito-me (no meu papel de improvisado metido em assuntos de museu) agradecer vivamente ao proponente da lei, por legislar que podem ter o título aqueles que atendem em museus há mais de cinco anos. Com esta prerrogativa, eu, que não sou diplomado, com uns trinta anos a mais do que os já prescritos, não deixarei de sentenciar que náo são as escolas, superiores ou inferiores, que irão formar os tais que, conforme a lei, farão o "planejamento, organização e direção dos museus." Porque, antes de tudo, se a entidade for, vamos imaginar, de informática, logicamente, alguém especializado em ciências está mais capacitado que um genericamente diplomado por escolas recentemente desenformadas.

As especializações são bem diversificadas. Por exemplo: no ano passado, a Escola Superior de Propaganda e Marketing (a que eu mesmo inaugurei em 50, juntamente com Rodolfo Lima Martensen e Napoleão de Carvalho) deliberou criar o Museu da Propaganda, visando, além das 'velharias', classificar e conservar os materiais contemporâneos. Penso que somente os práticos e militantes na propaganda é que devem 
operar. Se amanhã alguém pensar em instituir um museu de armamentos, o portador de diplominha saberá por acaso manipular espadas, flechas, canhóes, mísseis?

Quando se trata de problemas museográficos que contemplam a Beleza, isto é, a Arte, os candidatos a se meter na tarefa provêm dos setores os mais diversos, muitas vezes com consequências pouco entusiasmantes.

Cito um caso que fui constatar: o do Museu de Arte, naturalmente Moderna, de Belo Horizonte. Fui chamado para opinar a respeito da situação do acervo, o qual não é grande coisa, mas, de qualquer jeito, representativo do que se produziu nestes últimos dois decênios no País. $\mathrm{O}$ museu está instalado no Cassino da Pampulha, às margens do lago: umidade, raios solares que esquentam as grandes vidraças, morcegos e tantos outros elementos contrários à conservação.

Me pergunto: um museu instalado num edifício próprio para as impróprias roletas? Minas, que acaba de construir o estupendo Aeroporto Internacional, por que náo transfere o seu MAM para outro local, para conservar a Memória da avalanche pictórica e escultórica deste fim de Século?

\section{Legenda}

Um museu no Cassino da Pampulha: exposto à umidade e ao sol

Senhor \#I79, 22 de agosto de I984, p.77 (P.M. Bardi)

BALANÇO DE UM VALENTE

Alice Brill, uma pintora e também excelente fotógrafa que conheci nos tempos em que o Masp tentava estabelecer algumas novidades de museografia antecipadora na difusão cultural, publica agora um livro na vivíssima coleção Debates, da Editora Perspectiva, dedicado ao artista Mário Zanini, reevocando fatos e gente da Sáo Paulo historicamente tâo mal registrada.

São decênios nos quais se verificam não sei quantos episódios curiosos de se contar, vários também de se esconder na história desta nossa então chamada "Athenas do Brasil," a arquitetura do Teatro Municipal no lugar do Parthenon. Seja como for, São Paulo, que teve o privilégio de impor a "Semana de Arte Moderna de 1922," depois caiu em sonolência, até quase esquecendo a performance, apesar da generosa insistência e operosidade dos poucos modernistas, na frente Mário de Andrade.

Em 47, quando o sr. Assis Chateaubriand quis mudar a situação fundando o Masp, São Paulo quase não tinha ainda galerias de arte. Uma das primeiras exposiçôes feitas foi na Galeria Domus, em 48, apresentando Volpi, Rebolo e Zanini. Sobre este último, Menotti del Picchia escreveu em A Gazeta: “...Está em plena marcha ... constrói com vigor e equilibra com segura maestria os volumes, sendo suas telas repousantes pela justa localizaçáo de todos os valores. Desenho seguro, largo, cores livres, sem obediência a uma convenção cromática..." Já em 39, Paulo Mendes de Almeida, no Diário da Noite, notava Zanini por ocasiáo do Segundo Salão da Família Artística Paulista, como um dos artistas em franco progresso. Mas o tempo se encarregou de esquecer o valente: raras as críticas, quase nulas as vendas, raras as informaçóes sobre o desenvolvimento da pintura europeia, sendo cada assim dito vanguardista um autodidata. Mário era um dos elementos do Grupo Santa Helena com Volpi, Rossi, Nóbrega, Rebolo, Graciano, Martins e Rosa, atendendo ao que Sérgio Milliet definia: “...Arte honesta, sincera, feita de sangue e carne...”

Vanguarda é modo de dizer: os jovens de então procuravam náo ser adicionados aos da escola acadêmica; Geraldo Ferraz, todavia, um crítico mais ao par do que se passava lá fora, os considerava "tradicionalistas ... defensores do carcamanismo artístico da Pauliceia, a morrer de amores pelos processos de Giotto e Cimabue.”

Apesar das confusóes, o Grupo Santa Helena representou o que se tentava na renovação. Mário Zanini, fazendo-se uma escolha na obra que deixou, pode ser apontado, especialmente na temática da paisagem, como um sucessor dos movimentos antiacadêmicos. Deixando de lado o que Alice, às vezes, no justo entusiasmo para valorizá-lo, afirma: "Como 
Cézanne, Zanini procura conciliar a harmonia das cores com nova elaboração plástica do espaço, a emotividade com a construtividade," parece-me que o paulista se revela mais original quando, na maturidade, se orienta para o Expressionismo e as correntes do Cubismo, divulgadas nas exposiçóes didáticas do Masp como a "História das ideias abstratas," e também as individuais de mestres como Arp, Le Corbusier e Max Bill.

De qualquer jeito, a recuperação zaniniana dá a possibilidade ao leitor de acompanhar a evolução e, diria, a afirmação da pintura paulista juntamente à arrancada que, bem ou mal, apesar dos inúmeros carros antes dos bois, conseguiu transformar a "Athenas" na "Paris" da América do Sul.
A respeito da realidade de então e sua consequência, diria "parisiense" ou "nova-iorquina,” no livro dá-se relevo a uma justa observação de Marta Traba: “... Por mais esforços que faça o artista para equiparar-se ao homem comum e por mais declaraçóes que emita manifestando sua repugnância por toda condição elitista, a própria natureza do seu trabalho separa-o do corpo social, e seu maior esforço deve ser, justamente, voltar a inserir-se nele através de sua obra. A exigência socialista de que os artistas saiam do povo em lugar de provir de uma classe média desprezível e elitista não é mais que vã retórica, que não tem possibilidade de concreção real..."

\section{Legenda}

Figuras, de Mário Zanini: um esforço antiacadêmico

Senhor \#I80, 29 de agosto de I984, p.IO9 (P.M. Bardi)

A CIVIlizaçÃo DO FUTURO

$A$ arte do ano 2000 deverá contribuir para a difusáo de princípios

úteis a uma sociedade contaminada pelo consumo

Fala-se muito no assunto: "São Paulo 2000:" discute-se, faz-se previsóes, dá-se conselhos e até soluçóes para que a metrópole encerre o século feliz da vida, e comece a percorrer o novo com todos os inúmeros problemas resolvidos, num impulso superador e recondicionador dos percalços até agora registrados.

Geralmente as visões são caseiras, os argumentos se restringem à esfera municipal, sem colocar o fato no quadrante universal, pois, como entidade, não passamos de um dos inúmeros itens do mundo, valendo no futuro a densidade demográfica, a produção de alimentos, o desenvolvimento industrial, a utilização dos recursos naturais, o nível da poluição, sem contar b que as chamadas "grandes potências" podem ainda provocar remanejando seus mísseis. Vai-se delineando um amontoado de problemas, provocadores mais de terror do que de paz.

O alarma foi dado há uns de anos pelo Massachusetts Institute of TechnologyMIT, que concluiu sei necessário limitar o desenvolvimento deste mundo ainda medieval, dominado pelo espírito de conquista, o acúmulo de riquezas- símbolo, o desacordo humano evidente até entre os confins das menores naçóes, ilhas microscópicas determinando expedições militares, um ridículo moral, político e territorial de se pensar não em Idade Média, mas em tribos das mais primitivas.

No marasmo eis então nossa São Paulo lançada no futuro levando seus problemas adiante, inclusive o político, que continua puxando todos os outros.

A anotação é uma premissa para responder a uma carta que recebo. Alguém quer saber nada menos do que como seráo as artes na Sáo Paulo do 2000. Diz o missivista "... Nas previsóes sempre se avançam propostas de política, economia, produção, religião, e nunca a respeito das artes..."

É verdade. Também no lembrado relatório do MIT, o "System Dynamic Group" se interessou por, "matemática do crescimento exponencial" "bens naturais não-renováveis," "hipóteses quantitativas" etc. Afirmaram: "... A humanidade não pode continuar a proliferar em ritmo acelerado, considerando o desenvolvimento material como finalidade principal, sem cruzar os limites naturais do processo, diante dos quais ela pode escolher por desembocar 
em novas estradas, que lhe permitam padronizar o futuro, ou aceitar as consequências inevitavelmente mais cruéis de um desenvolvimento incontrolado.”

O fato leva a refletir sobre quanto e como os dedicados às artes poderiam contribuir no projeto. Porém, parece que os operadores participam do caos para confundir mais a passagem para o absurdo do incontrolável, emergindo a bizarria, o incompreensível das pinturas que não revelam nada, as brincadeiras plásticas de um sapato numa mesa, o enigma e o esconderijo de trouvailles banais para uma freguesia de pseudoexcêntricos.

Os artistas do 2000 continuarão a não considerar as comunicaçóes legíveis, isto é, as figurativas tendentes à participação, difusão e discussão dos problemas da humanidade, sem auxiliar na busca de um caminho certo?
Ninguém nega o interesse de alguns mestres em refletir o momento científico do século, a partir do Futurismo; porém, parece lógico esperar também dos operadores do instrumento Arte sugestóes que contribuam para a difusão de princípios úteis à sociedade dos consumos e do jogar fora.

Não se trata de retomar à pintura tradicional, que servia para propagar o Cristianismo ou celebrar acontecimentos históricos, mas esperar uma arte empenhada, contribuidora da vida, para todos e náo reservada a poucos, como já disse, pseudoexcêntricos.

\section{Legenda}

Deixando de lado o Abstracionismo: há um século, exageravam na beleza (Renoir, Menina com Espigas); hoje, exageram na feiura (De Kooning, $A$ mulher \#I)

\section{Casa Vogue \#5, setembro-outubro de 1984, p.92 (P.M. Bardi)}

\section{CuIDAdo AO DESTRUIR}

Há algumas semanas, no Museu de Arte de São Paulo, durante uma reuniáo em que se falava de problemas da cidade moderna, refletiu-se a respeito da Memória, isto é, do respeito que se deve a arquiteturas representativas de épocas passadas.

Os jornais são sempre muito ricos em denúncias por parte dos classificados "nostálgicos" desta ou daquela construção destruída clandestinamente, em contravenção às leis que regulam a urbanística. É fácil ler o título "Mais Uma Vez..." informando sobre os crimes: demoliçóes realizadas sem o alvará de autorização da Prefeitura.

Existe o órgão controlador da Memória, o Conselho de Defesa do Patrimônio Histórico e Artístico, muito ativo, pronto a intervir, infelizmente quando os contraventores já agiram. Quem segue as crônicas das demoliçóes ilegais sabe que a avenida Paulista é o palco preferido dos atentados contra a Memória. Assiste-se aos casos mais curiosos. Um deles é o de um antigo casarão no número 283 , na esquina da rua Teixeira da Silva. Tempos atrás o transeunte constatou que durante a noite os demolidores tinham arrasado a frente do casarão, as colunas e o tímpano da fachada em estilo neoclássico, e um montículo de escombros testemunhava o esplêndido espírito cívico do proprietário.

Passaram dois anos, o Condephaat interveio, processou-se a papelada da contravenção, protestou-se na imprensa, convocou-se o diabo. Mais uma vez, como sempre, tudo acabou sendo esquecido no paraíso dos safados, e uma máquina pesada de terraplanagem arrebentou o que ainda restava da primeira destruição, inclusive uma parede na qual um meu colega pichador, em solene tinta vermelha, havia escrito estes memoráveisversos de Caetano Veloso: "Da força da grana que e rguee destrói coisas belas.”

A advertência do popular cantor me faz lembrar Petrônio Árbitro que sentencia: "Quid faciant leges, urbi sola pecúnia regnat?” Na tradução: O que podem fazer as leis onde só o dinheiro impera?

A história é sempre a mesma: os ricaços não se assustam, a sua tarefa é de apenas multiplicar o que acumulam no cofre sabendo que vão vencer a parada custe o que custar, (naturalmente em 
dinheiro) pois o reinado da especulação é o governador do que vai por ai.
Ninguém é contra a renovação da cidade, porém o imperativo da Memória deve ter a sua consideração.

Senhor \#I8I, 5 de setembro de I984, p.80 (P.M. Bardi)

AMBIGUIDADES DA CRÍTICA

Há algum tempo que na Europa se trava uma discussáo bastante interessante: qual a posição do artista e qual a do crítico. O primeiro produz, enquanto o último explica, comenta e julga, resultando serem duas atividades afins e, ao que parece, integradas. Nem todos os que observam a obra de arte têm a capacidade de julgar a personagem denominada, "crítico" o aproxima- dor, diria um cronista, cuja posição é ambígua, tendo em conta as ultimíssimas discussóes que, na Itália, chegaram até a estabelecer convênios.

Não se trata de um paradoxo, mas vai-se estabelecendo que a crítica é comparável à obra, as duas manifestaçôes consideradas de igual validade estética, invocando um novo julgamento. O que, caso tenha algum valor, dará margem a outros, outros e mais outros, numa continuidade carente de verificação.

A dialética dos que defendem e afirmam estas últimas novidades, de fora ou atacando a linguagem da tradição estética, dá como normal o manifestar de inúmeros elementos que interpretariam o momento confuso pelo qual as artes estão passando, o que faz lembrar um relevo de Sartre, de que o silêncio também é uma maneira de exprimir-se.

Quase sempre no decorrer das discussões fica evidenciado o binômio arte-crítica. Leio uma definiçáo do pintor italiano Agostino Bonalumi: "Ao passo que a palavra é imagem, a imagem não pode descartar-se da palavra e, então, a arte é também crítica de arte. Os artistas perguntam até quando deverão esperar o crítico uma vez que depois de séculos ainda suportam o ônus da formação científica e também da profissional." Observação bastante sintomática face a uma situação que não pode passar despercebida.

Desde o advento das novas hipóteses culturais advindas do Cubismo, as tendências andaram encaminhando-se para as mais díspares direçóes, compreensíveis ou não, reencontrando-se num labirinto de difícil entendimento diante da diversidade das linguagens.

As proposiçôes teóricas, as discussóes, de um lado as propostas dos inovadores extremistas e, do outro lado, o exercício dos críticos, as intervençôes sociológicas, políticas e, às vezes, filosóficas, as atividades mercantis que devem ser incluídas no labirinto, produziram e ainda continuamente produzem um estado de perplexidade, provocando em certos casos uma dúvida de difícil definição, pois não é fácil pensar que um discreto número de metidos na seara não acredita seriamente no próprio trabalho.

A tendência que parece emergir leva ao massacre daquilo que se produziu ao longo de milênios, ou pelo menos o considera superado, insistindo que vale muito bem retornar às origens primitivas, fascínio que evoca os elementos que substanciam a vida, como a água, o fogo, o ar e a terra.

Vejo que existem pintores que se valem do verismo para indicar este retomo à maravilha da verdade-verdade, o que me faz lembrar, por analogia, de Jean-Marc Nattier. (Do qual o Museu de Arte de Sáo Paulo tem em seu acervo quatro pinturas representando as filhas de Luís xv, indicadas cada uma com o próprio símbolo: terra, fogo, ar, água, com precisão absoluta, diria fotográfica.)

A divagação é pertinente, pois, no Brasil, as novas poéticas vão afirmando-se, assistindo-se nestes tempos de transição à presença de operadores que abandonaram os modos de expressão tradicional do figurai para se dedicar ao informal, ou às sublegendas deste modo.

Uma das poéticas da transição foi, no setor da Pintura, o Abstracionismo, observando-se, na sequência das primeiras Bienais, este modo assumido entre os jovens como uma tendência do tempo, num certo sentido para acompanhar a moda e, para alguns, um convite à renovação consciente. Longe das novidades e após as iniciativas de Kandinsky, Mondrian e outros. 
Legenda

O Sonho do Rei, de Manabu Mabe

Senhor \#182, I2 de setembro de 1984, p.76 (P.M. Bardi)

A Semana QUASE FUTURISTA

Antropofagias brasileira do mito Marinetti, a partir do evento de 1922 e dos calafrios que o idolo provocou quatro anos depois, numa visita que trocou o Páo de Açúcar pela favela

Quando tentamos reconstruir numa exposição no Masp, em 72, o espírito, mais do que a ação da Semana de Arte Moderna, por ocasião dos seus 50 anos, a preocupação deste cronista foi responder a uma pergunta relacionada com a iniciativa revolucionária: por que "modernista" e não "futurista?"

Em 22, na Europa, a invenção do futurismo, "já era" sendo considerada como conotação superada e decadente, pois tendências ainda mais inovadoras tinham conquistado as praças.

Marinetti, participante da Guerra, para ele, "única higiene do Mundo" em igr4I9I9, tomou-se personagem da política de Mussolini, sendo logo nomeado membro da Academia Real e vivia na Itália. Encontrei-o várias vezes, sempre notando seu jeito dinâmico; como, porém, ele estava aposentado, era impossível levar a conversa para o seu Manifesto de I909.

Passou a Segunda Guerra, o acaso me transferiu para o Brasil, e foi lógica uma investida na historia da, "Semana" para mim um fato da maior importância, pois, naquele tempo, na Itália, apesar da presença marinettiana, não tivemos nada de parecido, isto é, uma discussão da situação ainda passadista das artes locais.

A curiosidade era saber por que a "Semana" não recebeu o adjetivo de futurista uma vez que, pelas primeiras pesquisas, viu-se que as luzes de Paris iluminaram as letras e o produzir dos artistas plásticos renovadores, quase todos frequentadores assíduos daquela capital. Mas, como já disse, Marinetti naquela época já tinha encerrado sua ação de ruptura.

Sabe-se que os conjurados de 22 ficaram em dúvida entre a denominação "futurista" ou, "modernista" preferindo a segunda, pois soava bem mais compreensível como oposição ao passado e à tradição. Futurismo era um termo ainda não divulgado como conotação e, por outro lado, na área da linguística nacional, como observa Luciana Stegagno Picchio, da Universidade de Roma, em seu ensaio Pessoa Marinetti e il Futurismo Mondiale, o substantivo "futuro" no Quinhentos significava essencialmente; "póstero" Camóes, por exemplo, escrevia que construía sua obra como um "somptuoso" templo "nada deixando já para os futuros." Assim, a denominação da "Semana" obedeceu a uma comunicação de mais fácil aceitação.

Lembrei Luciana, a mestra da historiografia literária portuguesa brasileira, que me deu ocasião de revisitar Marinetti através de seu ensaio publicado em Il Poeta e la Finzione, Saggi su Fernando Pessoa, coordenação de Antônio Tabucchi. (Gênova, Tilgher, 1984)

Marinetti veio ao Brasil somente em 26, convidado por Graça Aranha, que continuava padrinho dos inovadores. As boutades são prerrogativas nossas e logo Mário de Andrade apelida o hóspede de, “demais Francesca Bertini" aludindo a uma vedete cansada de teatro, e o irreverente Oswald de Andrade, anos depois, dirá ter importado por engano, da Europa, o Manifesto, de Marinetti, em vez de o de Kart Marx. Oswald tem sua dívida para com Marinetti pela imensa liberdade de suas palavras, como se lê em $O$ santeiro do Mangue na versão que publiquei na revista Mirante das Artes, encontrada por Mário Chamie nas cartas inéditas do poeta: um, "mistério gozoso à moda de ópera" ironicamente dedicado a Goethe, Paul Claudel, Murilo Mendes e Jorge de Lima, "aos michês em geral," às senhoras católicas, sendo protagonistas também "o estudante marxista.” Tudo bem mannettiano.

Será naquela visita do lançador do Futurismo a São Paulo e ao Rio de Janeiro que Graça Aranha publicará, "Futurismo, Manifesto Marinetti e seus companheiros" com o convidado tornando-se motivo de reportagem, e um dos jornalistas, aliás, rei da atualidade e admirador do 
Futurismo, Assis Chateaubriand, levou Marinetti não a admirar o Pão de Açúcar, mas a uma favela carioca, como mostra esta fotografia, que ele mesmo, para apagar minha curiosidade, me doou.

\section{Legenda}

Merinetti (seta da esq.) visita uma favela do Rio, levado por Assis Chateaubriand. (seta da direita) A foto é de 1926.

Senhor \#183, I9 de setembro de I984, p.72 (P.M. Bardi)

O NOVO ACADEMISMO

Um debate sobre as energias e o cansaço do Figurativo

$\mathrm{O}$ adjetivo figural vai desaparecendo das crônicas de arte, substituído por outros: afigurativo, informal, geométrico, assemblado, brut, pop, até mesmo por, "realismo fantástico," e tantos outros termos que os escultores, simultaneamente aos pintores, lançaram e continuam lançando para etiquetar o que produzem e se diferenciar.

Ouve-se afirmar que o figurativo não contém mais, "energia moral" que não documenta nossa época, caracterizada por um "dinamismo plástico" e mais definiçóes que devem ser consideradas, independentemente das preferências estéticas, como elementos válidos na oscilação constante do gosto, a qual, depois da última Guerra, apresenta uma tensão rápida, sendo difícil o registro.

Não são de hoje os sintomas do cansaço do Figurativo. Courbet disse certa vez, descontente ou por complexo, considerar seu realismo, porquanto prático, bastante obsessivo de verismo:"Estou vendo claro demais, sena bom que meu olho se machucasse."

Por outro lado, Duchamp disse do lançador do apodítico il faut être absolument moderne ser ele um pintor, "demais retínico" coincidência curiosa baseada no, "demais" para sublinhar que os excessos perturbam a comunicação pintada. Um "demais" é aplicável também a Duchamp, e a qualquer mestre, pois a criatividade consiste em juntar algumas coisas a mais ao que já temos, consequência das junçóes e dos demais que andaram seguindo-se e acumulando no tempo e nos territórios.

É por isso que para ver e apreciar é indispensável saber ver, estando implícito também saber no sentido da informação e relativa dedução cultural. Quem gosta do cartáo-postal, serve-se de símbolo comparativo para julgar pintura, mas jamais estará em condiçóes de compreender os opostos Courbet ou Duchamp. Para ficarmos em termos locais: Pedro Américo ou Tarsila do Amaral.

Evolução não quer dizer destruir ou sonegar as formas e os pensamentos do passado para dar vida a novidades absolutas; evoluir significa adaptar o que no passado se produziu. No Oitocentos, Berlioz era considerado um megalômano, pois exigia 360 músicos para tocar suas sinfonias, introduzindo na instrumentação sinos e tiros de canhão. Megalómano então era Russolo que, no tempo dos Futuristas, compunha música com o intonarumori, utilizando qualquer espécie de ruído.

O que aconteceu na música pode ser comparado ao que aconteceu na pintura: os maus-tratos à figura começados pelos Cubistas continuam com a difusão sucessiva dos outros ismos, até chegar à sua anulação. São todas aventuras próprias do labor dos artistas, a inquietude de renovar, de ajeitar novas vivências e sondagens de futuro. Por isso é preciso ter o cuidado de considerar as tendências, mesmo se de difícil compreensão e, às vezes, indigeríveis. Quando se pensa que a Paris do Oitocentos não digeria Monet, Manet ou outros impressionistas além de Cézanne, é aconselhável julgar com prudência os novos.

Julgar é assunto complicado. Antes de tudo, é preciso estabelecer se uma produçáo documenta realmente nossa época. Quando se julga o Oitocentos encontra-se uma quantidade enorme de pinturas, esculturas e músicas, às quais não é possível dar um posto representativo no Século. É o academismo de rotina, o genérico, o que foi executado sem juntar o lembrado "demais." Esta junção constitui hoje o problema de base da produção, pois, em vez de ser, juntar é anular, reduzir a forma ao incompreensível. Todavia, como 
foi dito, deve-se considerar e procurar entender, distinguir entre criatividade e imitação, entre espírito e chute, numa só palavra: pôr de lado o novo academismo.

O que faz história é também este novo academismo, pois aqui e possível isolar manifestaçóes válidas, pelo menos coerentes com fatos extravagantes da vida contemporânea. O difícil é estabelecer esta coerência, enquadrá-la nos seus limites, prever história.

\section{Legenda}

Obra significativa de Hélio Oiticica, Relevo Espacial, 1959, exposta no MAM, Rio de Janeiro, na mostra Arte Neoconcreta, naquele ano. Coleçáo Carlos Vergara. Está atualmente em exposição na Galeria de Arte Baneri (RJ)

Senhor \#184, 26 de setembro de 1984, p.I06 (P.M. Bardi)

Cultura NÃO É SOBREMESA

A importância do intercâmbio artístico para o desenvolvimento

das relaçóes entre o Brasil e o Japão

Uma das naçóes do Oriente mais interessadas nas artes ocidentais é o Japão. Posso afirmar isso por experiência, pois faz mais de dez anos que tive ocasiáo de iniciar um intercâmbio cultural entre aquele pais e o Museu de Arte de São Paulo.

Iniciou-se exatamente em 73 , quando nos convidaram a levar para Tóquio uma parte do acervo de pintura que conservamos, obras que compreendem desde o século I5 até o século 20 , em mostra realizada no Magazine Matsuzakaya e depois apresentada nas cidades de Osaka, Nagoya, Shizuoka e Kiushu.

A visitação foi impressionante, pois filas enormes se formavam diariamente para ver a mostra, com uma divulgação extraordinária; em resumo, como disse a um repórter, a manifestação atraiu, em numero, um público que não conseguimos ao longo de um ano no Brasil. Curioso: quando organizamos na antiga sede, no prédio dos Diários Associados, uma exposição de arte japonesa, somente os nipônicos de São Paulo foram vê-la. Em Tóquio, o conhecimento da arte ocidental determina, ao contrário, uma intensa visitação às mostras. Constatei isto novamente em outras exposiçóes do Masp que para lá levei, como a da coleção completa dos bronzes de Degas, em 1979, em comemoração aos 70 anos da imigraçáo japonesa no Brasil, e mais recentemente a do maior conjunto de pinturas da coleçáo europeia do Masp, em 1982, juntamente com a apresentação da arte brasileira, e que teve lugar na inauguração do grande Museu da Província de Mie.

Foi este, sem dúvida, o ponto alto do intercâmbio, pois despertou interesse também pelos nossos Portinari, Di
Cavalcanti, Anita Malfatti, Tarsila do Amaral, Lasar Segai e artistas japoneses aqui radicados, como Tomie Ohtake, Manabu Mabe, Yoshiya Takaoka, Masao Okinaka, e também para jovens brasileiros, como Celso Suetake e Jorge Mori.

Pessoalmente, fiquei tão surpreso que doei àquela pinacoteca cinco obras brasileiras dos artistas Maria Helena Chartuni, Ermelindo Nardin, Evandro Carlos Jardim Glauco Pinto de Moraes e José Antônio van Acker.

É justamente Mie que me motiva a escrever esta nota: os senhores Hiroshi Kimura e Miki Natsuaki, da alta administração da Província de Mie, vieram ao Brasil para fortalecer ainda mais o intercâmbio cultural. Acompanhados do amigo Kei Kimura, que sempre colabora neste intercâmbio, tivemos há dias uma reuniáo no Masp, ocasião em que se planejou novas manifestaçóes envolvendo obras do acervo do Masp e de artistas brasileiros, no Japão.

No mês de julho foi aberta no Museu de Mie uma importante individual de Celso Suetake, um singular pintor natural de Piracicaba e cuja família é originária daquela provinda. Eu mesmo o apresento no catálogo: "No Brasil, considera mos Celso Suetake um artista de exceção, ao mesmo tempo pintor e, mais, desenhista de uma capacidade sem muitos iguais. Penso francamente que ele representa um caso bem raro. É espontâneo compará-lo aos mestres de maior projeção, especialmente os flamengos e os holandeses. O signo é, para ele, uma expressão inata por significado, gosto e precisáo, de uma exatidão absoluta que obedece a uma poética em magia e também em misteriosos 
enigmas. Seu operar é singular, estou certo de que o visitante desta exposiçáo vai se surpreender, como aconteceu comigo ao ver os primeiros ensaios do jovem, que, expostos no Museu de Arte de São Paulo, determinaram o mais vivo sucesso."

A iniciativa é fruto do intercâmbio BrasilJapão no setor das artes ao qual queremos dar o máximo de atenção, considerando-o determinante para o desenvolvimento das relaçóes entre as duas naçóes, a cultura não sendo simples sobremesa, mas, sim, indispensável fator de amizade e estima.

\section{Legenda}

Desenhos de Celso Suetake: comparável dos mestres flamengos e holandeses

Senhor \#185, 3 de outubro de 1984 , p.90 (P.M. Bardi)

Ossos E Nervos DO COPA

A pesquisa fotográfica de Olney Krüse nas salas e corredores de um edificio-

símbolo do Rio antigo ajuda a desmascarar a moda da poluição visual

$\mathrm{Na}$ expansão, quase poluição, das exposiçôes de pintura em São Paulo, que alguém já comparou a Cubatão de tão intensa, de vez em quando se registram manifestaçóes de comunicaçóes não-pinceladas, mas produzidas pela objetiva. Para entrar no assunto: mostras de fotografia e, também nesse setor, aos gritos de, "somos todos fotógrafos" outra poluição.

Nas duas áreas, naturalmente, se notam os valentes, isto é, os que não chateiam, mexendo nos academismos da moda, os que valem e se devem considerar, sem dar importância às consagraçóes oficiais da imprensa, a qual, geralmente, também entra na onda da moda. A respeito da moda: é imposta através de artifícios da propaganda e tanto é verdade que os artistas em evidência contam até com agentes publicitários. Mas isto faz parte do marketing atual.

Eis agora um caso singular: na Galeria Bonfiglioli, o jornalista Olney Krüse apresenta, à sua maneira, uma performance sem precedentes. (Não esqueço que, graças a ele, o Masp pode, em maio passado, exibir o documento do gosto burguês brasileiro, o Kitsch, colecionado por Olney, que, no papel de Mecenas, doou-o ao museu.)

O redator do Jornal da Tarde fotografou, no Rio de Janeiro, o "Copacabana Palace" por dentro, penetrando em todos os ambientes, desde a cozinha até a suíte onde mora dona Mariazinha, viúva de Octávio Guinle, fundador do monumental prédio planejado pelo arquiteto francês J. Gire, após 60 anos um dos edifícios-símbolo da antiga Capital.

O savoir-faire do anatomista do

Copa conseguiu evidenciar, descobrir, particularizar tudo, das paredes ao teto: cérebro, ossos, nervos sangue do famoso hotel, curriculum afinal, de vida, história e milagre usando seu talento de pesquisador! Vê-se na reportagem fotográfica, ao lado da foto da dona da empresa acomodada na sua suíte, a de dois jovens serviçais, tendo na parede o retrato de Getúlio, a advertência: "Desperdício de alimentos é crime!” e, acima, a marcação das horas.

Olney é repórter de sutil intuição. Após o Kitsch, eis este inquérito do Copacabana. Qual será seu próximo registro do Brasil?

De Olney tudo se pode esperar. No press-release da exposição promovida por dona Neyde Rosa, lê-se: "Inovando o vernissage nas galerias de São Paulo que não mudam a mesmice e só talam em crise, foi convidada Madalena de Paula, que cantará, ao vivo, durante uma hora, ao piano. Seu repertório, old fashioned e jazzístico, será cantado em seis idiomas..."

\section{Legenda}

Dona Mariazinha Guinle na suíte presidencial e o lanche de dois trabalhadores: marcas de uma sutil intuição 
Senhor \#186, Io de outubro de I984, p.76 (P.M. Bardi)

O RELÂMPAGO DOS PINCÉIS

A convivência com uma fábrica que fornece a matéria-prima da pintura na

era industrial provoca algumas reminiscências do tempo dos mestres

Dias atrás, numa grande fábrica, se festejou um aniversário de trabalho. Reuniram-se donos, técnicos, operários, vendedores e, caso que me acontece pela primeira vez, um grupinho convidado do pessoal do Masp. O convite foi originado pela consideraçáo pelo museu de um estabelecimento que fabrica pincéis : o instrumento tradicional dos que utilizam as tintas e, consequentemente, dos artistas. A pintura, quando vale, acaba, depois de inumeráveis aventuras, sendo conservada nos museus, templos antigamente sacrários das Musas e agora centros irradiadores de cultura, superando a denúncia que Marinetti gritou no Manifesto do Futurismo, em 1909: "Nós queremos destruir os museus, cemitérios ... Dormitórios públicos onde se repousa para sempre..."

Assim, o diretor do Masp e colegas participaram da festa dos 55 anos dos Pincéis Tigre, empresa dirigida por Nicolau Jacob Neto, filho do fundador. Durante a festa, eu refletia sobre uma cornucópia de fatos envolvendo as artes, desde o instrumento ao qual nós, metidos no setor, atribuímos, além da função puramente técnica, a maneira, a evidência do modo de se expressar, a maestria, o senso, a doçura e até o fulminar de uma pincelada.

Observando os convidados da cordial churrascada, deslocava-me pela Veneza do Quinhentos, imaginando o atelier de Tintoretto, o qual, no parecer barroco do seiscentista Carlos Ridolfi: "Era seu pincel um raio, assim para dizer, que espantava com seu relâmpago.” Todavia, na reunião, apreciando as cebolas assadas e a cerveja, conversando até sobre as trovoadas políticas com esta maravilhosa gente operária, pensava na função social e econômica da indústria, exportadora das suas produçôes até mesmo para os Estados Unidos, como explicou dona Margarida Bresciani, também filha do fundador. E eu imaginava os pincéis brasileiros nas mãos dos artistas de outros países, minha fantasia divagando na operosidade do pintor desde a dos amanuenses até os mestres.

Via, imaginando, os usuários das cores, "simples e compostas" lembrando Leonardo, e, pulando os séculos, o combine-painting de Rauschemberg, e, desviando, pensava na paciência da pincelada tímida, levíssima, delicada do miniaturista.

Vendo minha absorção, uma colega me perguntava se gostava mais das costeletas ou das fatias de carne. Reagi: penso que estamos aqui pra homenagear o pincel, diluidor do infinito das cores, agitador de fusóes, nuances floridas, austeras, naturais ou artificiais.

Reconduzido à realidade, conversei com os donos da indústria, principalmente sobre exportaçáo, considerando que o Brasil avança também numa produção especializada, como a do pincel.

\section{Legenda}

Pincéis Tigre: vista noturna... 9

... de um trabalho fundamental

para a arte contemporânea

Senhor \#187, I7 de outubro de 1984, p.77 (P.M. Bardi)

ASTÚCIAS DA ARTE NUM TEMPO DE POLÍTICA

Uma reunião acadêmica na Universidade Mackenzie, com vaias, aplausos, uma medalha e consideraçóes múltiplas sobre a capacidade da cultura de abrir todas as portas

Esta Senhora que todo o mundo conhece genérica e superficialmente como Arte, matrona de requintados costumes, mas também, às vezes, dada a surpresas de comportamento, ora legislando no trono da História ora envolvida nos joguinhos mais banais, esta Senhora Arte, é aparentada com meio mundo.
Eu mesmo, que há muito tempo me meti a cortejá-la, conseguindo, na verdade, que me permitisse armar um negócio superador do interesse nacional, alcançando renome internacional, eu mesmo constato que esta Senhora goza de extraordinária popularidade. Eis que um simples diretor de Museu, talvez mais conhecido na crônica como pichador de palavrão nas 
paredes do edifício onde são conservados famosos filhos desta Senhora, por ela batizados Rafael, Ticiano, Bosch, El Greco, Velazquez, Goya, Cézanne, Picasso, Matisse, além dos locais como Portinari, Di Cavalcanti e Flávio de Carvalho, pois este diretor constatou, noites atrás, ser a Madame Arte realmente uma astuta, aliciadora, insinuante e carinhosa fulana capaz de abrir qualquer porta.

Convocado para presenciar o quinto Fórum de Debates Brasil 1984, na Faculdade de Ciências Econômicas, Contábeis e Administrativas da Universidade Mackenzie, nos primeiros contatos, em vez de ouvir falar a respeito de economia, crise, quem sucederá Delfim, superávits e companhia, a conversa se voltou para a Senhora, parente próxima do Dinheiro: as ultimas relaçôes entre ambos. (Os US\$ IO milhóes pagos por uma paisagem de Turner, os quatro pousados sobre um desenho de Rafael, Cr\$ 300 milhóes vertidos para o Abapuru, de Tarsila do Amaral etc.)

Este assunto podia ser um diversivo, uma saída para aquele momento, porém quando, nos sentamos à mesa diante da plateia repleta de jovens universitários, o presidente incumbiu este cronista de entregar a medalha "Eugênio Gudin" ao Conselho Internacional do Comércio e Produção na pessoa de seu presidente, Carlos Eduardo Calfat Salem, em vista do apoio e incentivo que a instituição desenvolveu no campo da educação e da cultura.

$\mathrm{O}$ dr. Salem, além de economista, tem atuado extraordinariamente na difusão cultural e, nós do Masp, conhecemos sua generosidade. Incompetente para entender os hieróglifos pelos quais viaja a Economia, hoje pontilhados de signos informáticos, sagrado mistério mantido por seus adeptos, ao longo da relaçáo do dr. Salem eu me aventurava em consideraçóes pertinentes ao meu ramo, naturalmente aparentadas com a árvore que tudo alimenta, a árvore que no Auditório florescia em, discussôes, interrupçôes, aplausos e até vaias.

Vaias em reuniões acadêmicas? A Economia tem parentesco estreito com a Política. Assim, foi curioso para um contemplador da Senhora Arte saber que a esplêndida juventude do Mackenzie se anima em vocaçôes políticas neste momento pré-eleitoral. As vaias eram dirigidas a um diretor favorável ao candidato a presidente da República considerado de direita. As atitudes da juventude hoje são as mais diversas e notou-se com prazer esta liberdade de manifestação.

Voltando para casa, depois do debate, fantasiava ainda à custa da Senhora Arte que envolve não sei quantas atividades. Inclusive as que registro nesta revista Senhor, que, vejam a coincidência, é dirigida por Mino Carta, um pintor ao qual acabo de dedicar um prefacio no catálogo da exposição que abriu há dias, na Galeria São Paulo.

\section{Legenda}

$\mathrm{O}$ professor Bardi entrega a medalha "Eugênio Gudin" a Carlos Eduardo Calfat Salem

Senhor \#I88, 24 de outubro de I984, p.80 (P.M. Bardi

LEMBranÇA DE LE Corbusier

Como surgiu uma estética anti-sensual de um olhar fascinado?

O cronista desta página está corrigindo as provas de seu livro dedicado à Lembrança de Le Corbusier: Atenas, Roma, Brasil, que será editado em dezembro pela Nobel, editora que aos poucos se vai especializando no setor da Arquitetura.

O motivo desta anotação me é oferecido pelo exaustivo livro de Eduardo Subirats, Da Vanguarda ao Pós-Moderno, publicado agora também pela Nobel. No primeiro capítulo se trata, evocando outros mestres, do inventor da, "casa-máquina" que conheci em 1930 no Congresso que determinou a Carta de Atenas e, depois, como divulgador de sua polêmica na Itália e, finalmente, como organizador da primeira exposição retrospectiva que teve no Brasil, no Museu de Arte de São Paulo, em i950. Vou revelar, ouso afirmar, um riquíssimo material inédito de cartas e desenhos em meu próximo livro, inclusive os das conferências de 1936 no Rio 
de Janeiro, e até com alguns fatos não muito exemplares do caráter do Valente.

Seja como for a novidade, eis que me interessa transcrever do ensaio de Subirats uma observação correta: Le Corbusier, em sua passagem pelo Brasil e, pode-se dizer, por alguns países da América do Sul "com olhar fascinado e melancólico, se extasia de emoçáo ante o inesperado espetáculo dos ondulados movimentos das sambistas cariocas, e se surpreende intimamente quando observa a proporção interior e a harmonia com a natureza das velhas casas... Isto não impede... o dictat de uma estética anti-sensualista e agressivamente cartesiana, uma concepção de arquitetura radicalmente separada da natureza e o sacrifício da história em nome da hegemonia universal da técnica."

Um adendo a este parecer pode ser uma discussão que me ocorreu com o Inovador em 1934. Tinha-o convidado à Itália, superando seriíssima oposição da polícia italiana, pois era erroneamente fichado como comunista. Obtive o ingresso diretamente de Mussolini, e como hóspede pretendia convencer o Ditador a deixá-lo mexer nas cidades do Agro-Pontino, em construção ao meu convite de ir examinar a zona ao redor de Roma, a recusa foi instantânea: não lhe interessava a natureza, sendo suas soluçôes úteis para qualquer terreno.

Permito-me afirmar, como escreve o professor Subirats, que não "se pretende de modo algum diminuir a perspectiva histórica ou artística do arquiteto. Sua visão era provavelmente muito mais ampla que a de seus colegas provincianos, do mesmo modo que o verdugo sempre sabe mais do que a vítima se tem coragem de mirá-la nos olhos, reconhecer sua dor e compreender que, de todos os modos, não há salvação para ela.”

É evidente que o Racionalismo e a arquitetura-máquina explicam exatamente a realidade atual e, talvez, o futuro de construir. Explica-se o, "talvez" pois as reaçóes ao genericamente indicado como Moderno vão afirmando-se.

Indicaria que os primeiros a não concordarem com Corbu, apesar de reconhecerem a sua indispensável imposição, se manifestaram no Brasil: veja a nova Capital. São índices de experimentaçóes de formas, não certamente indicando uma vontade e muito menos o concretizar de um estilo. Fácil estabelecer um tempo de incertezas para determinar a arquitetura deste fim de século.

Por outro lado, para o leitor entender o conceito, basta comparar a Ville Savoye com a Igreja de Ronchamp. Nota-se um Reformador, disposto, de vez em quando, a levar em conta revisóes, ajustamentos, adaptaçóes a necessidades de vida, aspiraçôes normais, chegando ate ao compromisso. Na polêmica novecentesca o post-moderno deve ser considerado, à parte os exageros e certos princípios destes exageros, como a superação do Culturalismo, assunto excelentemente enfrentado no livro do espanhol Subirats, que lecionou em várias universidades neste momento, é hóspede do Brasil.

\section{Legenda}

Le Corbusier: o sacrifício da história em nome da hegemonia universal da técnica. 9 Uma homenagem em Zurique ao arquiteto

Senhor \#I89, 3I de outuro de I984, p.I40 (P.M. Bardi)

O ENCANTO DAS PEQUENAS OBRAS

Um dos capítulos menos considerados no ensino da história, no Oitocentos, era o intitulado das "artes menores." A importância era dada ás maiores, (as “excelentíssimas": arquitetura, escultura e pintura) produtos da inteligência, sendo as artesanais produtos complementares. Hoje, isto está geralmente superado. Procura-se descobrir um jeito espiritual em qualquer manifestação, intuição, invenção e tantas outras capacidades originais, tudo isto somado na Estética.
Anos atrás, este cronista publicou um volume dedicado à Arte da Prata no Brasil. Teve um crítico que classificou a prataria de "arte menor;" outro de, "aplicada" lembrando até o Liceu de Artes e Ofícios, de acadêmica memória. Todavia, as lamentaçóes máximas recebi quando, pela primeira vez, no recinto da Pinacoteca do Masp, apresentei um desfile de modas de Christian Dior para lembrar que moda é arte. 
Parêntese: era, naturalmente, uma novidade, aliás, um choque. Não foram poucas as recriminaçóes. Outros museus europeus, decênios e decênios depois, hospedaram desfiles de moda. Mas que aprendo nestes dias? Recebo o convite que transcrevo: "A Associação de Alta Moda Brasileira - através de seus membros: Amalfi, Clodovil Hernandes, José Nunes, Lenzi, Roberto Issa, Rui e Sérgio Blain - convida para seu primeiro desfile no Palácio Campos Elíseos.” Significa que a moda, alta ou baixa que seja, pode desfilar nas sedes historicamente mais reservadas. Único pedágio: “Traje passeio escuro."

No meu desfile de 1950, ocorreu-me encomendar um vestido a Salvador Dali, para carimbar, através do nome de um mestre, a moda de "arte maior." Se eu soubesse da iniciativa da Aambra, teria renunciado a uma excepcional exposição, há pouco apresentada no Masp, aconselhando-a como complemento do desfile do Palácio.

No Masp, admiramos os objetos-adorno de dois jovens mestres que operam no Rio: Romuald, vindo de Recife, e Jacque, francês, mas completamente integrado no Brasil. Produzem joias: um encanto de formas, imaginação, descoberta, ressuscitar de materiais, finura execução, precisão ultramilimétrica em suma: uma cornucópia de jeitos, amor, singularidades incríveis.

Esta exposição, passando os olhos de vitrina em vitrina, convidou a refletir sobre um assunto realmente pouco discutido: uma denominação para o que este recanto das artes produz atualmente.

É simples, para dar um exemplo, incorporar no Art-Nouveau qualquer objeto inspirado nas linhas singulares das flores, tanto que, na Itália, o estilo é justamente apelidado de floreal. É também possível acertar o modo do Art-Déco, geométrico e cubista. Mas quais os modos sucessivos destes dois estilos?

As contribuições são inúmeras. A unidade estilística demonstrada pelos dois brasileiros sugere ideias: juntam e sintetizam a simplicidade que o Racionalismo impôs em arquitetura, em linhas medidas procuram composiçóes sóbrias, uma feitura diversa.

Não como artífices, mas como artistas, propóem formas ornamentais apropriadas, uma afirmaçáo, concreta que nos dá a impressão de um estilo que se vai inserir no tempo.

\section{Legenda}

Uma roupa criada por Salvador

Dali e dois colares de Romuald e

Jacque: a arte do ornamento

\section{Casa Vogue \#6, novembro-dezembro de 1984, p.98 (P.M. Bardi)}

\section{SEM MAIS PROBLEMAS}

Intercalo nestas páginas dedicadas à propaganda de não sei quantos móveis e objetos de decoração, uma lembrança, num certo sentido auto-propaganda, pois se trata de um tal que há mais de três decênios, aliás, já se aproximando dos quatro, se adiantava, em uniấo a dona Una. para dar impulso a que então ainda se definia "decoração."

Foi em 1946, quando se planejava oferecer a Sáo Paulo um museu de arte, sendo o promotor do fato e inesquecível Assis Chateaubriand. Projetado um auditório, o principal problema era adquirir uma centena de cadeiras. Selecionados os possíveis fornecedores, constatou-se a impossibilidade de negociar, pois se exigia um modelo dobrável, já que o local atenderia a várias finalidades. A solução foi desenhar a cadeira e encontrar quem a produzisse. Foi contratado um tapeceiro, recém-chegado, e no dia da inauguração do Masp os convidados depararam com a novidade.

Hoje, São Paulo não tem mais esse tipo de problema: uma indústria poderosa $\mathrm{e}$ designers de extraordinário valor atendem a qualquer pedido. É só escolher, não só um assento, como qualquer outro móvel. Temos até firmas especializadas que representam fabricaçóes estrangeiras comercializando os originais dos excelentes mestres europeus e estadunidenses. Por ocasiáo da exposição que dediquei a Le Corbusier, no Masp, em I95I, a Probjeto forneceu-me um conjunto desenhado pelo racionalista e por Charlotte 
Perriand, sua discípula, obtendo-se a mais curiosa atenção e apreciação.

Se dos móveis nos transferirmos para a decoração, cada número de Casa Vogue mostra-nos, realmente, um riquísimo catálogo de materiais, demonstração de que nestes últimos tempos o Brasil está a par do desenvolvimento estético mundial, contribuindo notavelmente em criatividade.

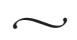

Penso num caso bem estranho do começo do século: o conde Armando Álvares Penteado, retornando de Paris, mandou construir sua mansão na rua Maranhão, escolhendo o art nouveau para estar à la page, no estilo que então fazia furor na Europa, porém, quando se tratou de decorar, um momento de perplexidade: qual o estilo decorativo? A solução foi recorrer a um dos tantos Luíses franceses, naqueles tempos ainda preferência da burguesia, juntamente com as outras sugestóes do Culturalismo, que ditavam lei. Para dar um exemplo, o recorrer ao gótico para construir a Catedral da Sé ou ao neoclássico para o Palacete dos Campos Elísios, e assim por diante.

O progresso arquitetônico foi promovido em São Paulo pelos mestres de ruptura como Gregory Warchavchik, Rino Levi e tantos outros anunciadores do futuro. $\mathrm{O}$ puxão foi dado pelas visitas de Le Corbusier ao Brasil. A ele este cronista vai dedicar o livro Lembrança de Le Corbusier: Athenas, Roma, Brasil, editora Nobel, São Paulo.

A intercalação desta página significa a exultação de alguém que, pode ser, participou com convicção da renovação da estética nacional, em companhia, naturalmente, de toda uma turma empenhada na batalha. Digo batalha, pois tratou-se de combater nos anos 50 uma mentalidade ainda devotada a um espírito conservador.

Encontro então ocasião para lembrar os produtores de móveis, tecidos. luminárias, tapetes, bibelôs e tudo que serviu para estabelecer um gosto certo.

Senhor \#190, 7 de novembro de I984, p.88 (P.M. Bardi)

O PACIFISMO E OS ENCANTOS DA MOCIDADE

Uma homenagem em meio à Autobiografia, de Bertrand Russell:

para meditar sobre a crise e renovar o otimismo

Notícia em primeira mão: estamos organizando, no Museu de Arte de São Paulo, numa exceção entre as habituais exposiçôes aparentadas com as Artes, uma mostra bastante singular, dedicada à Paz. Será realizada em conjunto com o Movimento Pacifista Brasileiro, cujo presidente, o professor Alberto Castiel, já a anunciou, na recente Convenção de Perugia.

Será mais uma das variadas iniciativas que este centro cultural paulista oferecerá aos visitantes, ocasionando-lhes uma reflexão sobre problemas de ordem humanitária.

Ao programar a mostra, uma das decisóes foi reservar uma lembrança aos pioneiros do Pacifismo, e logo o nome de Bertrand Russell brilhou.

Coincidência: estava relendo a Autobiografia, do filósofo, quando fui convocado a uma grandiosa festa no campus da Universidade Mackenzie para receber nada menos que uma homenagem, a medalha "George W. Chamberlain" fundador da escola.

Surpreso e, francamente, encabulado, remexia então na cabeça um trecho de Russell em que alude às vantagens de ser velho e às desvantagens de ser jovem. $\mathrm{E}$ me veio à mente parafrasear um juízo de São Gregório Magno: Non Angli sed Angeli, o obstinado defensor da Paz, um anjo.

O espetáculo esplêndido de centenas e centenas de alunas praticando ginástica rítmica no campus, a música, os gritos alegres, tudo resultava numa alegoria de concórdia.

$\mathrm{Na}$ minha avançadíssima idade, em presença da massa juvenil, refletia no texto russelliano: "Poder voltar para o passado e rever um longo caminho percorrido que da peso e substância à experiência... Num plano mais pessoal, vê-se que é natural para quem é enérgico e animado pelo espírito de aventura de provar na juventude um desejo inquieto e muito vivo de fazer alguma 
coisa de importante, a sorte ajudando, sem ter uma visão clara do que se vai fazer. Velhos, tem-se o senso do que fizemos, ou não fizemos ..." Mais adiante: "Minha velhice, como a estou vivendo, poderia ser um período de felicidade completa se eu conseguisse esquecer a situação do mundo.”

Então, este cronista, encantado com a festa da belíssima mocidade, refletia sobre a exposição dedicada à Paz, o evangelista inglês, este nosso Brasil, permitindo-me comentar com meus dois vizinhos no palanque, Caio Pompeu de Toledo e Itajany Martins: "Vamos parar de falar em crise? Vejam o futuro nesta página de vida..."

Quando me entregaram a medalha, convidado a falar ao microfone, encontrei somente estas palavras: "Viva o Brasil!"

\section{Legenda}

O professor Bardi recebe a medalha George Chamberlain durante o espetáculo de ginástica rítmica no campus da Universidade Mackenzie

Senhor \#I9I, I4 de novembro de I984, p.92 (P.M. Bardi)

UM ESTÍMULO À CRIAÇÃO

$A$ arte do design nos pequenos objetos

Cada produção, artesanal ou industrial, tem sua origem num desenho, desde o mais simples até o mais complexo, este por sua vez, determinado por centenas e até milhares de outros desenhos. Geralmente, na denominação industrial design, inclui-se estética e técnica do objeto em série: é o que notamos diariamente como consumidores de tudo que se precisa, a começar pelo café da manhá.

Uma cafeteira, uma xícara, uma colher, um açucareiro nos propiciam um encontro com o design, motivo eventual de não sei quantas especulações de ordem crítica, se a consideração implica um julgamento.

Esta reflexão me ocorre por ter recebido, da Itália, duas publicaçôes dedicadas a modernas cafeteiras, escritas por Aldo Rossi: La Cônica e Altre Caffetiere e Officina Alessi, uma fábrica de Crusinallo especializada em objetos de mesa em metal, produzidos com tecnologia industrial.

$\mathrm{O}$ arquiteto Rossi, designer ilustre, professor em várias universidades dos Estados Unidos, dá à cafeteira a importância de uma "construção," atribuindo ao cone uma posição ideal como recipiente. Sob o ponto de vista do uso e do tempo, eis uma observaçáo curiosa: "Creio que o comércio dos objetos em muitos casos seja misterioso; às vezes, observo os objetos como o material argiloso exposto nos museus, um material para um mundo que parece invocar somente o uso e, ao mesmo tempo, sua destruição: as duas maneiras pelas quais consideramos as coisas."
Como o leitor percebe, saindo de uma simples anotação sobre café que, por boas razóes, consideramos de casa, (o autor diz que "se gosta da cafeteira por si mesma e também por sua história, tradição e hábito”) as consideraçóes vâo ao infinito, e o designer nos fornece as suas preferências numa extraordinária série de soluçóes.

O mesmo se vê na outra publicação da Alessi: os resultados das formas e das funçóes são variados, os designers lançando propostas: valem a linha curva ou a reta, as duas combinadas à procura de uma originalidade e até a lembrança do bule tradicional. O empenho dos que criam novidades é o mesmo dos artistas: conseguir uma atenção, convencer, surpreender, à espera que o tempo depois consagre ou esqueça, às vezes reconsiderando, redescobrindo, conseguindo aplausos; então, entram em ação os museus.

O design participa da história das artes maiores; todavia, deve dizer-se que o castigo reservado às "menores" é um contra-senso. Um objeto em série vale tanto quanto uma produçáo individual. As duas publicaçóes de que falamos confirmam a excelência ao design italiano e, no caso dedicado ao café, penso no estímulo para nossas indústrias.

Em I950, este cronista inaugurou, no Museu de Arte de São Paulo, a primeira Escola de Design, com aulas nada menos que de Max Bill: surgiram alguns elementos, porém, não tantos quanto se esperava. A respeito do famoso designer suíço, lembro-me de ter publicado nas irreverentes páginas da revista Habitat, 
em 1950: "A andorinha que não faz verão é nosso amigo Geraldo Ferraz, que escreveu um artigo sobre a exposição de Max Bill no Museu de Arte de Sáo Paulo. Os críticos paulistas não falaram - como se soube mais tarde - por não saberem o que dizer, ou por terem recebido a ordem superior de náo falar."
De qualquer modo, o design brasileiro está desenvolvendo-se. As notícias desta página servem para estimular iniciativas: o que falta.

\section{Legenda}

Cafeteira em aço inox, de Aldo Rossi 9

Serviço de chá e café, de

Kasumasa Yamashita

Senhor \#192, 2I de novembro de 1984, p.84-85 (P.M. Bardi)

A ARTE DA MESQUINHARIA

O cronista reage a "mentiras" e "maledicências" e esclarece uma

história que envolve Tarsila, o Masp e o Abaporu

$\mathrm{O}$ cronista desta pagina, dizem as boas línguas, é conhecido como brigalhão. Justifica-se: reage somente quando é molestado, como é o caso de hoje.

Recebo um livro-catálogo dedicado à exposição de Ismael Nery no MAC, mais um justo reconhecimento do valor deste mestre. A exposição é uma remastigação manifestação que o Masp realizou há cerca de dez anos, cujo catálogo aparece ultraminimizado na bibliografia do livro em pauta.

O Masp se interessa $a b$ antiquo por Nery. Aliás, na grande mostra "Image du Brésil,” que eu organizei e apresentei em Bruxelas, em 1975, figuravam numerosas obras de Ismael.

Outro aliás: uma delas, Seis Aquarelas, aqui reproduzida, fazia parte do acervo. Estas aquarelas, naturalmente, não foram aceitas na exposição do MAC, juntamente com as outras trinta peças do nortista, pois pertencem a Bardi.

Não reclamo: cada diretor de museu tem seus direitos também de produzir mesquinharias. Queixo me por causa de uma mentira inserida no texto da senhora Aracy, assunto que nada tem a ver com Ismael. A impenitente bisbilhoteira em vez de se dedicar a contabilizar os proventos do seu emprego, consome o que lhe sobra do seu mal de fígado para escrever maledicências fazendo falar até uma defunta. Motivo: desmoralizar este cronista. A velhinha escreveu no prefácio do livro: “Tarsila (do Amaral) ainda tinha em sua casa, à rua Albuquerque Lins, uma grande parte de sua pintura, inclusive o Abaporu e Antropofagia adquiridas então por P.M. Bardi e em seguida vendidos aos colecionadores Erico Stickel e José Nemirovsky, respectivamente, embora a artista tivesse tido a esperança de vê-los destinados ao acervo do Masp.”

Seria como dizer que o Bardi se aproveitou ou tapeou Tarsila para realizar um negócio.

Agora, como recomenda Tácito, (para a professora analfabeta em história romana, Tácito não é o famoso cozinheiro da feijoada do MAC, mas o Publius Cornelius, o moralista estoico) sine ira et studio, a verdade é a seguinte: sempre bem recebido por Tarsila, um dia disse-me que estava interessada em vender alguns de seus quadros, uma mesa déco, um gongo de arame e outros objetos. Disse-me quanto queria, aceitei e no dia seguinte mandei pagar e retirar os objetos.

Nunca se falou em acervo do Masp, pois o museu havia parado de fazer aquisiçóes em 1953. É bom saber: em I946, quando o sr. Assis Chateaubriand me confiou a formação da Pinacoteca do Masp, sabia perfeitamente que eu era interessado no mercado de arte, tanto é verdade que na praça Dom José Gaspar abria a filial do meu Studio d'Arte Palma, de Roma.

A própria inventora de historietas falsas publicou, em 1967, no número $3 \mathrm{da}$ revista Mirante das Artes, o Abaporu, num seu artigo, (pago) obra reproduzida como de propriedade da casa que levava o nome da revista. Passaram-se anos e anos, e os quadros foram comercializados até por colecionadores.

Desfeita a insinuação da responsável pelo MAC, sendo a instituição pertencente à Universidade de São Paulo, permito-me assinalar o caso ao reitor, prof. Antônio Hélio Guerra Vieira, denunciando o carcamanismo e a leviandade da funcionária, a qual, para desabafar 
ciúmes e invejas pessoais, se vale nada menos do que da proteção da USP.

\section{Legenda}

Seis aquarelas de Nery, numa moldura: bom para Bruxelas

Senhor \#193, 28 de novembro de 1984, p.II5 (P.M. Bardi)

A FÁBRICA DE VALORES

Cada época tem o Sócrates que merece

Quando um professor tem a seus cuidados alunas esforçadas que se destacam numa classe, eis a ocasião para que ele apreenda o que não sabe. Há alguns anos, numa conversa em que enfocava as novas tendências da arquitetura, eu insistia em que a manifestação da arte experimenta constante evolução, em consonância com o pensamento dos filósofos do começo do Oitocentos. Não sei se por um lapso ou mesmo por não saber exatamente a citação, lembro-me que uma moça me interrompeu para sentenciar: "Foi Hegel, e não Kant, quem previu que, com o progresso da razáo, a fantasia acabaria e, consequentemente, a arte também.”

$$
\sim
$$

Tive, então, ocasião de demonstrar minha quase competência quanto ao assunto, inserindo na conversa a figura de Cesare Lombroso, o estudioso do cretinismo na Itália que sentenciava, em Nuova Sorgenti della Estética, que cada época cria novas fontes, novas formas, pressentindo a reação dos Futuristas, com páginas merecedoras de uma tese de doutoramento, tendo em conta a difusão que o pensamento lombrosiano teve na América Meridional.

Seja como for, as artes em cada época se ajustam aos mais variados caminhos ricos em novidades, notadamente iniciativas partidas das vanguardas.

Tendo levado à aula fatos relacionados ao enfocado pela aluna com relação à dupla Hegel-Kant, disse: "Finalmente, aparece alguém que diz que o que vale é a Modernidade." A moça interrompeu: "Pois os dois gênios e o senhor Lombroso já eram; professor, diga alguma coisa sobre o Informal!”

Como se sabe, as aulas não decorrem como aquelas ministradas no passado, quando a fala do mestre era ouvida com atenção, a ponto de se ouvir o zumbir dos mosquitos; hoje, é mais um bate-papo cordial, de sobremesa, com algumas batidinhas nos ombros. Assim, se passou do cretinismo do começo do Século à genialidade dos mestres ativos na senda das reformas estéticas. Conversa vai, besteirinhas vêm, chegou-se a estabelecer quais os mestres da arte brasileira em evidência

Constatação: o Ibope deu que os números eram aqueles badalados na imprensa, os tais que se apoiavam em eficiente marketing, com presença constante no noticiário dos meios de comunicação, figuras obrigatórias em coquetéis, batizados, exéquias e quantas outras solenidades mundanas.

Fez carga ainda a aluna da dupla HegelKant que estes também recebem badalos por parte da crítica devidamente registrada em associaçóes profissionais.

Permiti-me, então, explicar que todos, eu mesmo incluído, (sem ser crítico de arte, belas ou feias) expressamos nossos pareceres obedecendo às circunstâncias, como de resto se dá nas principais praças. Às vezes, deve-se esquecer que o tal pintor deriva, sem ser um copiador, digamos, de Kandinsky, Rotko, ou de um dos dez expressionistas alemães, porque tudo é lícito, a tudo serve.

Não é possível se aventurar pelos caminhos do sutil. Doutro lado, hoje a pelouse está cheia de gente que estabelece valores obsoletos. Só é possível estabelecer valores, no futebol, nas figuras de Pelé, Sócrates e Zico.

\section{Legenda}

Osmar Reyez, pintura concreta, Galeria Ena Beçak, S.P.; e Nigel Waymouth, pintura realista, Galeria Lefévre, Londres 
Senhor \#194, 5 de dezembro de 1984, p.76 (P.M. Bardi)

UM PULO INTERNACIONAL

Ecos da Escola de Paris, na exposição do Masp

Duas exposiçôes no Masp confirmam os princípios que governam, desde sempre, o trabalho que comecei em 46, quando um autêntico empreendedor brasileiro me incumbiu de dotar, não digo São Paulo, mas o Brasil, de um museu de arte em condiçôes de participar da realidade estética internacional. As duas exposiçóes abertas como conclusão do calendário I984 são a de Henri Cartier-Bresson, sem dúvida o mestre dos mestres da arte da fotografia, e a apresentação da pintura francesa do Século 20, praticamente a Escola de Paris, que obtivemos do Musée d'Art Moderne de la Ville, de Paris

Estas manifestaçóes foram possíveis graças ao patrocínio de empresas. A de CartierBresson, com o apoio da American Express, e a da Escola de Paris, pela Associação dos Amigos dos Museus, uma entidade que deveria diminuir a finalidade da promoçáo social, que nada tem a ver com os problemas da arte. Trata-se, praticamente, de um caso de reciprocidade: o Masp, em 53, tinha apresentado na Orangerie do Louvre, a convite da direção dos Museus da França, a exposição "Cent Chefsd'Ouvre du Musée d'Art de São Paulo,” inaugurada pelo presidente da República Francesa, Vincent Auriol e Senhora, dando origem a um dos casos mais piramidais que, ao longo da minha já longa carreira, me aconteceram: ser eu, um recém-naturalizado brasileiro, a receber o casal em nome do Brasil, pois a embaixada não tomou conhecimento de nosso primeiro fato cultural de repercussão internacional. E, doutro lado, nem o senhor Assis Chateaubriand esteve presente a façanha.

Seja como for, passaram-se três decênios e o Masp recebe agora esta mostra. Nosso público poderá ver, por exemplo, mais um Modigliani (no Masp temos seis) e tantas outras obras-primas (sem esquecer que também no Masp guardamos quase todos os mestres da Escola de Paris, juntamente com a safra mais recente, pois a escolha de Madame Marie Odile Briot, conservadora do museu amigo, incluiu até os elementos atuantes nesta década.
Nesta página não se publicam críticas, mas somente comentários circunstanciais. O cronista aproveita a ocasião para recordar que, agora que as trocas de exposiçóes com a Europa, Estados Unidos e Japão são fatos normais, seria chegada a hora de se organizar mostras da arte brasileira para o estrangeiro, superando, finalmente, repito, finalmente, toda uma série de manifestaçóezinhas que não têm, francamente, nem pé nem cabeça.

Ninguém pretende tomar o lugar dos ansiosos que aproveitam qualquer ocasião para dar pulinhos apresentando o que combinam os hábeis manipuladores de revelaçôes estéticas nacionais.

Todavia, se, pela experiência que tenho, estou aprovado para da conselhos, sugeriria ao Itamaraty e ao Ministério da Educação e Cultura que organizem uma representação da produção das Artes Brasileiras deste Século, diria da Semana de 22 até Brasília. Seria uma resenha pensada tecnicamente, apresentada num catálogo conveniente etc. O Brasil seria mostrado na sua posição, num resumo de tudo que se fez no período. Repito: as artes, todas naturalmente, compondo um espírito nacional, fora das subordinaçôes ao espírito aproveitador que sempre prevalece, infelizmente.

Citamos acima: Itamaraty e Ministério de Educação e Cultura. Todavia, pensa-se agora até num responsável único a ser nomeado pelos dois ministérios, em lugar da costumeiríssima comissão.

No dia 27 de novembro, terça-feira, no grande auditório do Museu de Arte de São Paulo, às 2rh, foi realizado o leiláo de obras de arte doadas em prol da reconstruçáo do Tuca, o teatro da Pontifícia Universidade Católica destruído por um incêndio no dia 22 de setembro passado. Organizado pela PUC com a colaboração de Renato Magalhães Gouvêa, sendo o leiloeiro Fernando Soares, o evento apresentou uma centena de pinturas e esculturas oferecidas por colecionadores e artistas. A primeira obra doada para a campanha foi uma tela de Anita 
Malfatti, O Zoológico, de São Paulo, I935, doação feita pelo redator desta página.
Legenda

Femme a L'evantail, de Modigliani

I Zoológico, de Anita Malfatti,

doado para o Tuca

Senhor \#195, I2 de dezembro de 1984, p.92 (P.M. Bardi)

Notas MERIDIONAIS

Sobre um artista em dois mundos

Conheci Jorge Luis Borges este ano quando esteve no Masp para um debate promovido pela Folha de S.Paulo: cada resposta sua tem o dom da clareza e de um espírito poético encantador.

Recebi, há pouco, da Itália, um livro prefaciado por Borges, dedicado a um escultor ítalo-latino-americano. Começa com esta definição: "A arte não é a menos misteriosa entre as paixóes dos homens. Desde o princípio, desde o princípio conjectural do primeiro capítulo da Bíblia, criou e continua a criar universos paralelos aos que nos dão os dias e as noites. Os materiais que a arte usa são cores, formas, as outras percepçóes, a memória, a imaginação e o olvido." O livro apresenta o argentino Santiago Cogorno num texto do escritor Alfredo Galardi: publicaçáo de requinte, numerada, que recebi por ser citado na biografia do homenageado.

$$
\sim
$$

Eis uma ocasião para falar de artistas da América ao Sul. Na Europa, isto é casual, e Santiago é contemplado com o livro por sua longa permanência na Itália, onde eu o conheci em tempos que recuam, no mínimo, meio século. O que me permite lembrar que na Galleria di Arte de Roma, então por mim dirigida, apresentei pela primeira vez uma exposição de argentinos, como intercâmbio de uma mostra da nova arquitetura italiana por mim organizada no Museo de Bellas Artes de Buenos Aires, inaugurada pelo presidente daquela República, Agustín P. Justo.

Santiago era de casa, na Itália, conhecido como um escultor de talento, distinguia-se pelo gosto do classicismo mediterrâneo, sem excluir os influxos do Egito e por um certo modelar dos artífices pré-colombianos dos quais, na verdade, não estávamos muito a par.

Sobre a arte atual da América Latina, diz Galardi: "Área cultural não unitária, mas conjunto de várias culturas bem diferenciadas, raras as influências recíprocas apesar de as raízes serem de uma matriz hispano-lusitana comum e primeira." O território rio-platense sentiu mais a cultura espanhola e, em parte, a italiana no Oitocentos, pelas imigrações maciças e, no que se refere à arte, pela transferência para Buenos Aires de artistas que ensinaram à maneira acadêmica.

O figurativo de Santiago revela as origens, todavia, essas vêm expressas através de um indigenismo que distingue a operosidade dos artistas sul-americanos, para anotar os mais conhecidos na Europa e nas diversas tendências: Rivera, Botero, Figari e Portinari. É o que ocorre: a disposição dos que começam a produzir arte numa variedade sem limite de modos nada tem a ver com as escolas, como acontecia numa certa época. Os elementos mais em evidência do nosso Continente tiveram um período de ensino nos centros europeus, deixando transparecer seu próprio exotismo do qual, de resto, se beneficiou o ambiente, se pensarmos no próprio Picasso em seu tributo à arte negra. Santiago, em vez de Paris, preferiu deslocar-se para a Itália, talvez, pela popularidade que os artífices, do mármore tiveram nas repúblicas americanas, (é surpreendente o quanto fizeram no Brasil os escultores italianos, como veremos numa próxima publicação planejada por Anna Carboncini, do Masp) assumindo, da tradição greco-romana, a vocação de um plasticismo anatômico sensual.

A lembrança do argentino, que se manifesta também na pintura e na gráfica, permite tratar de um fato que precisa de atenção e de consideração: a arte contemporânea dos sul-americanos ainda à espera de uma afirmação dos seus reais valores. Infelizmente, para ficar nos Trópicos, observe-se o que o Brasil, nas várias iniciativas tipo 
Galeria Debret, apresenta no Exterior São mostrados até os, "mestres locais da arte abstrata” aventura organizadas ingenuamente por pessoas não ligadas à área.

\section{Legenda}

Universos paralelos 9 [Augustín P.]

Justo: patrono do intercâmbio

Senhor \#196, I9 de dezembro de 1984, p.92 (P.M. Bardi)

As LUZES DE PARIS

Um debate com o presidente do Centro Georges Pompidou

Todos sabem que o caput-Paris das artes é o Centro Georges Pompidou, o imenso Beaubourg que recolhe e administra as atividades mais atraentes que se pode imaginar no ambiente artístico. Seu presidente, Jean Maheu, esteve em São Paulo por ocasiāo da exposição apresentada no Masp, dedicada à Escola de Paris, procedente do Museu de Arte Moderna daquela cidade.

O sr. Maheu participou de um seminário, no auditório da Folha de S.Paulo, ao longo do qual foram debatidos problemas museológicos, sendo o principal a maneira de se fornecer cultura ao povo. Um dos debatedores, descobrindo o guarda-chuva, afirmou que construir um museu é tão importante quanto construir uma barragem, o panem et circensis de Giovenal.

Este cronista foi ouvir as declarações e, a seu modo, participou do palavreado, lembrando que uma personagem daquelas que operam com decisão generosa, Assis Chateaubriand, em 46 fundou o "beaubourguesinho" local, inteligente e espirituosamente definido pela curadora MAM parisiense, Marie Odile Briot como un petit Louvre, e, em minha opinião, a Meca local da cultura das artes. E foi organizada, diga-se, sem querer dar muita importância ao fato, como novidade, imitada depois por várias "filiais," inclusive no Exterior.

Tratava-se de implantar tudo que faltava, e como faltava tudo, providenciou-se até a abertura de escolas, desde música para formar orquestra juvenil até design, convidado Max Bill para lecionar propaganda, (a atual Escola Superior de Propaganda e Marketing eu fundei em 50) maquetes de arquitetura, restauro, biblioteca etc.
O Beaubourg funciona com recursos espetaculares: US\$ 40 milhôes anuais, tem centenas de funcionários e agora está para ser ampliado, conforme noticiou seu presidente. Enquanto o sr. Maheus explicava, o diretor do Masp refletia sobre a realidade de seu quase quarentão empreendimento: dez mil metros quadrados de espaço; pinacoteca; pesquisa; restauro; quatro a cinco exposiçôes por mês; cinema e música todas as noites em dois auditórios; até mesmo concertos sinfônicos duas vezes por mês, ao meio-dia; cursos; publicações; presença do Masp por empréstimo de obras em museus europeus, japoneses, norte-americanos; biblioteca aberta ao público. Uma série de fatos que fizeram Cláudio Abramo escrever na Folha quando visitou a exposição (estupenda) de CartierBresson: "O Masp: que me parece ser o único verdadeiro museu de São Paulo.” Sem dúvida: o que é possível se faz.

Declaro o número de funcionários: (assistentes, contínuos, guardadas) 4I. Poderia ser um recorde se aqui, na própria Capital, o Museu Lasar Segall, de proporçóes diminutas, não tivesse 6I empregados, mantidos por aquela repartição do MEC denominada Pró-Memória a qual, se espera, um dia descubra também o Masp que, se este cronista náo tivesse tido a iniciativa de emprestar obras da coleção a entidades e até grandes magazines japoneses, recebendo notáveis ajudas financeiras, não sei se ainda sobreviveria.

\section{Legenda}

Uma exposição sem rupturas $\mathrm{O}$

Beaubourg: uma lição cultural com múltiplas atividades

Senhor \#I97-I98, 26 de dezembro de I984, p.Ioo (P.M. Bardi)

As aulas de Le Corbusier

Uma evocação dos mestres da arquitetura

Lancei no Masp, na semana passada, do Brasil, (sem a contribuição das em festa promovida pela Du Pont indústrias e dos bancos, não existiria 
editoria de arte no Brasil) meu livro Lembrança de Le Corbusier: Atenas, Itália, Brasil, editado pela Nobel.

Conheci o Batalhador ab antiquo: o primeiro encontro deu-se no navio Patris II, que em I93I levava para a Grécia parte dos congressistas para assinar a chamada Carta de Atenas. Este cronista chefiava então a modesta delegaçáo italiana, com uma participação não-oficial, pois, na terra de Vitrúvio, o vulto estético se ajoelhava para o "estilo romano modernizado," caro a Mussolini a quem, mais tarde, eu mesmo, como se pode constatar nas papeladas registradas neste novo livro, tive oportunidade de explicar a besteira daquela arquitetura e de convencê-lo a mudar de opiniáo.

Depois de Atenas, convidei Le Corbusier a palestrar em Roma, superando o veto da polícia que o tinha fichado como nada menos que comunista, por ter projetado um edifício em Leningrado. Aliás, num capítulo, revelo as tentativas do Ativista para servir ao Fascismo: fatos inéditos e curiosos, úteis, penso eu, para um currículo.

A lembrança leva em conta o Brasil. O delineador do risco do Ministério de Educação e Saúde apareceu aqui, pela primeira vez, em 1929. Quem o convidou foi um mecenas de primeira hora, Paulo Prado, 5 do qual no livro consegui publicar parte das cartas de Corbú.

55 O único projeto de Le Corbusier em São Paulo foi para a construção de um anexo-biblioteca na residência de Paulo Prado, conforme mostrou o prof. Dr. Rodrigo Queiroz em pesquisa recente. $\mathrm{O}$ projeto seria acompanhado in loco pelo escritório de Warchavichik
O convite de 1936 se deve ao mestre a quem dedico o volume com estas palavras: "A Lúcio Costa, Mestre orientador e propulsor da nova Arquitetura no Brasil.” Foi ele que convenceu o ministro Gustavo Capanema a chamar Le Corbusier. Na entáo Capital, o Inventor da "máquina-para-morar" pronunciou seis conferências. Por mais que possa parecer estranho, todos os grandes desenhos de parede que ele então realizou para ilustrar as conferências são de minha propriedade pois, em 1950, quando organizei sua exposição individual no Masp, sabendo que tinha levado os desenhos para Paris, o contatei e comprei os mesmos.

Le Corbusier sabia administrar as suas contas e no livro revelo alguns episódios justamente para fazer seu perfil, sem a preocupaçáo costumeira do panegírico. Preocupei-me em dar realce à sua obra espetacular, a página mais viva da arquitetura deste Século, da qual também o Brasil se beneficiou: Brasília docet.

O que o autor da Lembrança pode contar aos leitores? Quando se resume o que aconteceu no passado, tenta-se dar importância a alguns episódios que se considera indispensáveis. Mas esta é a convicção de quem redige, com o agravante, no meu caso, de ser maníaco por historiografia. Todavia, é bom saber que evoquei Le Corbusier também pelo gosto, diria, retrospectivo, talvez um pouco chateado por constatar, de vez em quando, que, de campeóes como ele e, acrescentaria, Gropius, Wright, Mies van der Rohe e até Alvar Aalto, com o qual tivemos em Atenas inesquecíveis discussóes, para mim, aulas, como dizia, enfim, de todos eles, é raro hoje se falar.

\section{Legenda}

Lúcio Costa: homenagem a um mestre

I Le Corbusier, Bardi e o arquiteto

Gino Pollini, no navio Patris II

\section{Casa Vogue \#I, janeiro-fevereiro de I985, p.54 (P.M. Bardi)}

\section{Gentoteca: uma SOLUÇÃo?}

Leu-se em Istoé um noticiário intitulado "Maratona de ideias," relativo a um seminário realizado na Fábrica da Pompeia cujo tema era os problemas da cultura: "O capitalismo selvagem é inculto. Nossa burguesia é inculta. O Estado tem então de assumir esta responsabilidade," isto é, fundar a primeira "gentoteca brasilis." Em resumo: um grupo de cabeças pensantes para bombardear a letargia que vem acometendo o mundo das artes. Os conceitos são do secretário da Cultura do 
Estado de São Paulo, Jorge Cunha Lima, e tendo ele o controle do que se desenvolve no setor, evidente ficarmos preocupados.

Mas não será por demais pessimista o nosso secretário?

É fato que a situação da cultura que Darcy Ribeiro define com "sobremesa" não têm o brilho merecido: é, em miúdos, cultivada da maneira provinciana de sempre, mais produto do andamento burocrático do que deesplêndidas conquistas. Todavia, parece que o secretário, se são realmente suas as declarações, foi um pouco precipitado no julgar.

Como promover a cultura sem o capitalismo? Selvagem ou civilizado, é o que serve para produzir cultura, também para a "burguesia inculta" a qual, bem ou mal, nos dá os elementos que estruturam o saber e tudo o mais que dele deriva.

Sendo mesmo como o secretário afirma, a "gentoteca" resolveria, através de bombardeios, a letargia que envolve as artes?

E verdade que "um grupo de cabeças pensantes" é mais eficiente que os inúmeros grupos de cabeças não pensantes que andam por aí. Mas oproblema é descobrir as cabeças invocadas, instrui-las na polêmica confiar-lhes as bombas, a munição, depois de lhes ter explicado paracombater até a última gota de pensa mento, consequência de boa matéria cerebral.

Caro Cunha Lima, você é prático em cultura, experiente com as pessoas e conhece os problemas dos intelectuais perfeitamente, de modo que, se opinou, sabe o que quer. Assim, quando desencadear a ofensiva, favor me dar um telefonema pois quero assistir para redigir uma reportagem sobre a movimentação da "gentoteca."

O repórter tem prática em "gentoteca." Está a par das complicada: mas dificuldades de convencer pessoas não burguesas a participar de açôes decisivas, contra-a-corrente expor-se e, talvez, fracassar com honra. Encontrei mais burocratas do que elementos de ruptura, bombardeios sim, porém sem armas. Tive sempre a impressão de que a aspiração da "gentoteca" era o emprego remunerado, o contrato de trabalho, férias, sábado inglês.

Senhor \#199, 9 de janeiro de 1985, p.73 (P.M. Bardi)

UMA SÍNTESE DA GRAVURA:

O gesto criador de uma arte múltipla

Insere-se na Gráfica todas as manifestaçóes do desenho é também as reproduçóes, artesanais ou mecânicas, em exemplares obtidos através das técnicas mais diversas como xilogravura, litografia, serigrafia, água-forte e várias outras, geralmente editadas em folhas numeradas pelo artista. O ponto de partida para a inscrição é o desenho, consequência da "conversa mental” na qual já pensava Leonardo, delineando com perfeição analítica suas indagaçóes sobre natureza e figura.

Eis, dedicado à Gráfica, um esplêndido Álbum de Jacob Klintowitz, publicado pela Volkswagen do Brasil, o terceiro que aquela grande indústria edita, sendo os anteriores A Cor na Arte Brasileira e Mestres do Desenho Brasileiro.

Diz Jacob no prefácio: "Estamos convictos de que a iniciativa privada, além de criar riquezas materiais, deve contribuir para o estímulo e a divulgação das atividades cultural e artística." É um fato que, efetivamente, honra as classes produtoras e também os bancos. Sem estas contribuiçôes, a editora dedicada às artes teria continuado modesta. $\mathrm{O}$ cronista desta página publica, em beneficio do Masp, o sétimo livro da coleção Arte e Cultura, lançada pelo Banco Sudameris: Comunicação: de Cabral à Informática. Também meu último livro, Lembrança de Le Corbusier, foi publicado graças ao patrocínio da Du Pont do Brasil S.A.

O álbum do Jacob se abre com uma sintética notícia historiográfica: a "primeira gravação, a impressão, o sinal, a linguagem, a ousadia da criação," investigando ao mesmo tempo o anônimo que incidiu nas pedras até o pintor de hoje, que divulga seu adiado se servindo dos 
atuais meios de comunicação, atendem "ao desejo de poder repetir, obedecendo ao mesmo rito, o gesto criador."

Destes brasileiros ativos na gravação, escolhidos com rigor antológico, temos agora um primeiro repertório. Sua composição, no que se refere aos artistas, bem como às obras de cada um deles, é consequência de um rigoroso exame.

Parece-me que a iniciativa poderia, no futuro, provocar uma tomada de decisão: a catalogação da Gráfica brasileira, um álbum para cada produtor.

O de Jacob revela, é a palavra, alguns elementos dos quais pouco ou nada se sabia como interessados na Gráfica, como por exemplo: os pioneiros no setor Carlos Oswald e seu filho Henrique; o original Oswaldo Goeldi; Lívio Abramo, de quem recentemente se admirou em São Paulo uma significativa exposição; Lasar Segall, um dos emigrados que afirmaram o modernismo; todos mestres de alto valor. As páginas a eles dedicadas permitem considerar a sua importância e fornecer a ideia de como se registrou a arrancada da geração, aliás, das gerações que se seguiram. São notados até os mais recentes gravadores, os dedicados às novas correntes, desde o geometrismo dos que se inspiram nas formas mandálicas até o abstracionismo, em cujo campo se destaca Maria Bonomi, a revelação que todos admiram, devendo lembrar que ela, juntamente com Lívio Abramo, há um quarto de século, criou em São Paulo o Estúdio Gravura. ${ }^{56}$

Eis também as gravuras em relevo de Artur Luiz Piza, o brasileiro que, em Paris, é considerado como inovador pela sua técnica expressiva baseada no ajustar forma e cor.

$\mathrm{Na}$ escolha do crítico de arte do Jornal da Tarde, encontram-se elementos particularmente populares, como Evandro Carlos Jardim e o surpreendente Aldemir Martins, além de outros figurativos ainda influenciados pelo realismo e pelo expressionismo.

Para concluir: um Álbum de segura contribuição para a difusão das artes do País.

Legenda

Jacob Klintowitz: pesquisa rigorosa 9 Ars Mobile, uma obra de Lívio Abramo

56 Fundado em i96o.

Senhor \#200, I6 de janeiro de 1985, p.88 (P.M. Bardi)

O LABIRINTO DA COMUNICAÇÃO

Um balanço de Pero Vaz de Caminha à informática

Informei os leitores desta página que, em dezembro passado, tive ocasião de lançar o livro dedicado ao meu velho amigo Le Corbusier, obtendo uma certa repercussão na imprensa, não só nacional como também internacional. Informo agora que no fim do ano também publiquei um outro: Comunicação, Notícias de Cabral à Informática, o sétimo livro que compilei, um cada ano, dentro da série Arte e Cultura, editada pelo Banco Sudameris, coletânea na qual já foram publicados $\mathrm{O}$ Modernismo no Brasil; Arte da prata no Brasil; Arte da cerâmica no Brasil; Mestres, artifices, oficiais e aprendizes no Brasil; $A$ madeira: desde o pau-brasil até a celulose; $\mathrm{e}$ Lembrança do Trem de Ferro, todas publicaçóes realizadas no Museu de Arte de São Paulo, cuja biblioteca especializada em assuntos brasileiros está em condiçóes de oferecer amplo material histórico.

Desta vez, como também no passado, o tema foi tratado para satisfazer a vasta freguesia do Banco Sudameris, pois o livro se torna o brinde de fim de ano deste banco. Pensei em abordar a comunicação no Brasil, nos seus variados aspectos, partindo das primeiras manifestaçóes dos descobridores ao rei de Portugal. $A$ Carta de Caminha é o documento inaugurador do momento, sendo os últimos os que não precisam mais de papel, tinta e pena, pois hoje é a eletrônica que abrevia espaço e tempo, numa época em que nem sabemos que fim vai levar a Humanidade.

$\mathrm{Na}$ excursáo, procurou-se mais do que redigir uma história, um pouco também como ocorreu com o Trem, encontrar fatos, descobertas, vaticínios, tentativas e vitórias emergentes do progredir da vida brasileira.

Normal, então, como base do comunicar, dar conta do avanço das estradas. Quando se sabe dos milhares e milhares de quilômetros de asfalto que hoje tomam o Brasil em grande parte conhecível, pensa-se 
qual foi a maravilhosa, para não dizer heroica, capacidade dos pioneiros e de todo um povo integrado, isto é, conseguindo comunicar-se e entender-se, educar, operar, comercializar, construir: todas as vivências que têm no comunicar a razão de ser.

Como disse, não se tentou historiar, mas, sim, alternar uma notícia à outra, às vezes curiosando, num pesquisar só aparentemente fora do tema, o totalismo da comunicação. Setores como as artes e, naturalmente, o rádio, televisão, vídeo etc., tiveram de ser lembrados, como expressóes da civilização. Tudo vale na comunicação, desde o que lemos no jornal até as leis que divulgam comportamentos. É um labirinto onde é possível nos perdermos, atingindo à vontade o que interessa, até descobrindo fatos sui generis, às vezes aventuras famosas, como, por exemplo, o trabalho do general Rondon, que implanta as novas linhas de comunicação desbravando o Sertão, ou Santos Dumont, que encanta Paris com seu dirigível voando em torno da Torre Eiffel.
Vai-se de uma notícia a outra, vagando e divagando, descobrindo e pondo de lado, naturalmente registrando o que o professor de comunicação Celso Kelly sentencia a respeito de sua matéria, considerando-a como uma das inúmeras artes, certamente, "criadora de interesses," quando dá "a dimensão do tempo ao efêmero, e valoriza o vulgar, extraindo do banal a essência humana, com o que penetra em planos superiores."

E, para ficar no campo do ensino, vejam na ilustração um diploma do século in $\mathrm{da}$ Academia de Ciências Sociais e Jurídicas: de um simples certificado é possível dar espaço e interesse à comunicação, adicionando e multiplicando fatos, açóes e não sei quantos outros episódios da vida humana.

\section{Legenda}

Rondon: aventura pioneira

Diploma do século in da Academia

da Ciências Sociais a Jurídicas

Senhor \#20I, 23 de janeiro de I985, p.84 (P.M. Bardi)

O PAPEL HISTÓRICO DA NOSSA VANGUARDA

Um balanço do trabalho dos pioneiros que colocaram a arte brasileira no rumo da modernidade

I922 é o ano da polêmica (diria futurista) da inteligência brasileira - a "Semana," que Cassiano Ricardo definiu dessa maneira: "O carão que assobiou demoniacamente desencadeou tempestades de uivos e guinchos, em frente à gambiarra onde currupira ria, sarcástico, desafiando a assuada. E quando o carão imaginou ter assassinado publicamente o currupira este, azougado, imortal, reaparece vitorioso, operando o milagre de criar, para o Brasil, uma consciência nova." Cassiano, antes de escrever o quase indecifrável que se reporta, precisou que a "Semana" no Teatro Municipal tinha o "currupira" no palco e o "carão" nas frisas e nos camarotes.

Complicadas as imagens, todavia bem próprias do evento que dá o sinal de partida ao movimento determinador dos subsequentes, entre os quais os Salóes de Maio, através dos quais se pode considerar os resultados tangíveis da ação da modernidade.

Entre as publicações-brinde que no final do ano passado foram oferecidas por entidades bancárias e industriais, esplêndida contribuição à cultura nacional foi a da Metal Leve. Editou um fac-símile da Rasm, a Revista Anual do Salão de Maio, de 39: um documento da mais alta importância para reconstruir a apaixonante história da nossa vanguarda, à qual se deve a singular posição inovadora, mais tarde registrada. É muito interessante o conhecimento, aliás a avaliação desta revista-catálogo, especialmente para se ter mais informaçóes a respeito do seu animador, personagem única no tempo: Flávio de Carvalho.

Conheci-o quando, em 46, o sr.

Chateaubriand resolveu criar o Masp. Foi um dos primeiros amigos e incentivadores. Lembro-me que ainda não tinha desistido do seu antigo plano dos "seis anos" que me recomendava, doando ao Museu uma das suas telas.

Francamente, era para mim (recém-chegado) difícil entender. Agora compreendo melhor: para Flávio tudo era engenharia, números, método, tempo, prazo... Tinha dividido o caso em meia dúzia de anos no seu modo de fantasiar: 
um "período arqueológico" que recolhe as "peripécias e modalidades das diversas erupçóes... De revolta... Na construção do mundo plástico, literário e político dê hoje;" o consequente, "período dialético" acomodador de "cumes de raiva e ódio, explosôes anárquicas e todas as belezas inerentes à luta anímica e mental do homem;" e, finalmente, o "período visionário:" "Construtivo e poético ao mesmo tempo e o seu mentalismo aliado a sua poesia..."

Por este complicado manifesto se estabelece quais os fermentos que agitavam os renovadores da cultura nacional, na ação de uma produtiva elite formada por Lasar Segall, Oswald de Andrade, Anita Malfatti, Victor Brecheret, Antônio Gomide, Tarsila do Amaral, Gregory Warchavchik, Chinita Ullman, Paulo Rossi Osir, Ugo Adami, Luís Martins, Rino Levi, Guilherme de Almeida, Ciro Monteiro Brisola, Villa-Lobos, Sangirardi Júnior, Alberto
Cavalcânti, Jacob Ruchti, Paulo Mendes de Almeida, Oswald de Andrade Filho, Carminha de Almeida e muitos outros.

Parece-me que a edição desta Rams deveria ocasionar, entre nossos estudiosos, a decisão de aprofundar o conhecimento e a divulgação da extraordinária arrancada que os pioneiros conseguiram para encaminhar nossa cultura no setor das artes. Espera-se que a "novidade" que nos proporcionou José Mindlin, o caro e tão apreciado cultor da história brasileira e, ao mesmo tempo, vigoroso industrial, suscite um vivaz interesse em nossos historiadores. Ainda há muito a documentar e mostrar.

\section{Legenda}

Flávio de Carvalho. Nu feminino

deitado, óleo/tela. Coleção Masp.

Senhor \#202, 30 de janeiro de 1985, p.IOo (P.M. Bardi)

A ARTE NAS MÁQUINAS

A construçâo de Cumbica: arte e engenharia andando juntas

Eis uma oportuna ocasiāo para recordar-se da Arquitetura: a inauguração do Aeroporto Internacional de São Paulo-Guarulhos.

Foi após a primeira Guerra que, na Europa e nos Estados Unidos, se começou uma ampla discussão, aliás uma intensa polêmica, sobre a situação culturalista da Arquitetura, até então assunto obrigatoriamente inserido e restrito ao embelezamento das estruturas, com o enfeite de cada cantinho. As obras de autêntica arquitetura eram as da engenharia, pura consequência de cálculo e de técnica: fábricas, pontes, hangares, navios, aviōes, máquinas. Os engenheiros: profissionais que não tinham nada a ver com problemas de estética, a maravilha da Torre Eiffel sendo admirada como resultado avenirístico da técnica de um novo sistema construtivo.

Mas, lembrando as ideias do "racionalismo" e do "funcionalismo" afloradas sem maiores consequências, na segunda metade do Setecentos, pelo abade Carlo Lodoli, é nos tempos recentes que se entende a arquitetura em relação á razão, subtraindo-a da extravagância dos enfeites decorativos: Le Corbusier, Walter Gropius e Frank Lloyd Wright devem ser indicados como os responsáveis pela ação que acreditou nas novas tendências.

Ocorre-me acenar a tudo isto pelo fato de, no último domingo, a crônica diária ter intercalado, ao lado de exaltaçóes às proezas do rock e dos preparativos do carnaval, um fato emergente: o novo aeroporto internacional de São Paulo, uma arquitetura como está no projeto: um organismo destinado a funcionar, diria como um conjunto de máquinas, ausência de ornamentos na estrutura, no exterior e nos ambientes.

É uma obra que dá ao Brasil mais um ponto na marcante contribuição à Arquitetura do final do Século. Pode-se afirmar que, depois de Brasília, a nova construção representa um dos eventos singulares no panorama mundial. E um conspícuo exemplo de arquitetura integrada à engenharia e às sempre mais surpreendentes inovaçôes da ciência eletrônica. Mostra a operosidade de milhares de trabalhadores e técnicos, ativos em grandes conjuntos da construção como a Camargo Corrêa e outras 
indústrias participantes do espetacular resultado que vimos ao lado da Capital.

Para que nosso público compreenda e comente o evento, o Masp decidiu apresentar uma exposiçáo dedicada ao novo Aeroporto, síntese da dinâmica nacional, pontuada sim de problemas que, por conta e felicidade da Nação, o presidente Tancredo irá cancelar.

Procuraremos ilustrar a obra completa: origens, decisóes, justificativas, custos, fases do empreendimento, previsóes e organização, pois comporta um conjunto onde passaráo, a cada ano, três dezenas de milhóes de usuários.

Junto com o arquiteto Jorge Michirefe, que chefia a equipe da projetação, veremos como simplificar a documentação, especialmente para que a juventude que compóe a maioria dos visitantes do Masp, possa entender, com já foi feito em exposiçóes anteriores dedicadas a arte do construir.

É indispensável que se conheça e se aprecie um evento tão significativo da conquista do espaço, para a qual os pioneiros brasileiros Bartolomeu de
Gusmão,,$^{57}$ Ribeiro de Souza,$^{58}$ Albuquerque Maranhão ${ }^{59}$ e Santos Dumont deram provas de efetiva participação.

57 Bartolomeu Lourenço de Gusmão (Santos I685-Toledo I724) fez diversas experiências com balóes de ar aquecido, bem-sucedidas a partir de 1709, inclusive na presença de dom João $\mathrm{V}$ e corte.

58 Julio Cezar Ribeiro de Souza (Pará I843-I887) foi o primeiro a patentear, I882, no Brasil e na França, uma estrutura de navegaçáo que viria a ser copiada, três anos mais tarde, pelos capitães Franceses Charles Renard e Arthur Krebs, sem mencioná-lo na autoria. O plágio aconteceu enquanto Julio Cezar se desdobrava, no Brasil, para conseguir verba e realizar seus experimentos em dimensóes suficientes para carregar pessoas.

59 Augusto Severo de Albuquerque Maranhão (Macaíba I864-Paris I9O2) construiu um dirigível baseando-se nas ideias de Ribeiro de Souza, com modificaçóes técnicas que permitiram mais equilíbrio e controle de voo. Também sofreu com a falta de investimentos, tendo ele mesmo custeado os gastos de boa parte de seus experimentos.

Senhor \#203, 6 de fevereiro de 1985, p.76 (P.M. Bardi)

UMA NOVA PEDRA

Uma resposta a cartas apócrifas cheias de acusaçōes. E uma advertência

Quem viu crescer os cabelos brancos, aliás quem perdeu os mesmos trabalhando na imprensa, sabe qual é o destino da sua jornada: encontros, tratos, contrastes, lutas, e de vez em quando segura-se um punhado de moscas, outras vezes passa-se por momentos incertos, mesmo dramáticos e, sem exagero, trágicos. Estou-me divertindo nesta página por um caso geralmente habitual na carreira: não levar a sério um episódio.

Escreve-se, dá-se notícias, exprime-se pareceres, às vezes é preciso também se defender. Para entrar no assunto: o leitor desta página sabe de uma respostinha que dediquei a uma eminentíssima colega, a professora Aracy Amaral, diretora geral do Museu de Arte Contemporânea, a qual, num seu livro dedicado a Ismael Nery, me acusava de não ter dado ao Masp duas pinturas de Tarsilla do Amaral, por mim mesmo adquiridas juntamente com um móvel e um gongo, daquela artista, em 1969. A denúncia não era explícita, mas alusiva, servindo-se de uma frase ambígua Repliquei em Senhor nos moldes que a velhinha merecia. Tudo parecia esclarecido quando aconteceu que um cupincha da colega vergastou uma carta à revista para reforçar não só a acusação de minha imaginária trapaça, mas atribuindo-me outra, não só imaginária, mas impudentemente inventada, como se diz em minha pátria de origem, de sana pianta: a mentira-mentira-mentira.

A carta provocaria um processo penal, porém pensando tratar-se de um 
débil mental, correspondente apócrifo, prefiro levar a missiva em gozação, ocasionando uma consideração sobre o andamento do costume social.

O tal, repito, tão primário para não dizer irresponsável, já que não percebeu que poderia incorrer numa punição legal, não é exemplar a ser repertoriado em manual de zoologia: é frequente esbarrar-se neste tipo de lançador de pedra que esconde o braço. Isto aconteceu a este cronista, desde tempos bastante remotos, por sua posição de envolvido na novidade dos museus.

Defender e acalmar a inveja que provocou o afortunado desenvolvimento do Masp, vencer provas e conseguir algumas vitórias é um empecilho que ocorre desde a sua inauguração. As provocações, os boatos, as denúncias infundadas foram constantes, explodindo até mesmo no próprio auditório do museu, causando reação por parte deste diretor, o que teve como consequência a ida para o hospital do desenvolto propalador das mal-arrumadas inconveniências.
A singularidade do episódio foi que aquele adversário teve a coragem, talvez consequência de bebedeira, de se pronunciar de viva voz. É o que se desejaria de quem redigiu a citada carta cupinchista: apresentar para conversar. Talvez seja ele a vítima do equívoco. Seria informado cordialmente sobre os assuntos que expóe na missiva, porque não se exclui que possa ser até em boa fé, por imbecilidade. No caso de se tratar de sujeitinho de comprovada má fé, irão registrar-se as devidas consequências.

\section{Legenda}

Os miseráveis, que espalhem boatos, são conhecidos do cronista desde e constituição do Masp. O primeiro que surgiu foi o de que encerrávamos "quadros falsos." Aborrecido, sabendo pelo dr. Assis Chateeubriend que processar é perda de tempo, tive e ideia de apresentar o acervo do Museu em vários museus europeus e americanos, desde e Orangerie do Louvre até o Metropolitan Museum de Nova York. Na volta os boatos continuaram, pois o vício é mesmo uma $\mathrm{m}$. (Aqui o cartaz de uma das mostras: no Museu de Düsseldorf, Alemanha)

Senhor \#204, I3 de fevereiro de 1985, p.73 (P.M. Bardi)

\section{O ARREPIO CONTEMPORÂNEO \\ O que é o novo e o que é o bom? A arte percorre estranhos caminhos antes de impregnar a sociedade}

O problema do "gosto-não-gosto" na arte de todos os séculos e de todos os países tem seu ponto alto no Oitocentos e, mais especialmente, na França. Quando o Neoclassicismo começa seu ocaso, aparecem os Românticos, depois os Impressionistas e, superada esta novidade, surgem as mais desconcertantes para os consumidores de Arte: o Cubismo, a gritaria de Marinetti, e tantos outros manifestos destruidores de antigas maneiras estéticas. Incrementam-se não bem as épocas da transiçáo mas seus relâmpagos, sendo inúmeros os caçadores de surpresas.

Afirmou Francis Haskell no NY Review of Books, traduzido no Suplemento Cultural de $O$ Estado de S.Paulo: "De qualquer modo, para o historiador da 'ideia da arte moderna,' Manet é, certamente, muito mais significativo por um quadro muito mais fraco que Olympia, pois foi com seu levemente cômico retrato M. Pertuiset, o caçador de leóes que, em i88I, ele ganhou sua medalha de segundo lugar no Salon; poucos meses mais tarde, através da intervenção de seu amigo Antonin Proust, do Ministério das Artes, ele recebeu a Légion d'Honneur - um casamento religioso e civil, por assim dizer, pois neste mesmo ano houve a total separaçáo entre a Academia e o Estado.”

E parece curioso que a fama do Mestre, inimigo de tudo que ainda permanecia da Academia, começa com esta pintura, hoje no acervo do Masp: homenageado, condecorado, reverenciado.

Os premiadores e os denegridores, estes que ridicularizavam Manet, antecipavam as disputas entre tradicionalistas e vanguardistas, de resto as mesmas que tivemos e continuamos a registrar agora. Descobrir quem se dispóe a oferecer a novidade, o artista que se desgosta e que 
até nega os valores tradicionais é decisão de raros apreciadores, às vezes, simples sustentadores, por motivos até mesmo estranhos ao juízo rigorosamente crítico.

Émile Zola, para negar o valor do pintor Bastien-Lepage, assim se manifestava: "Todos os grandes criadores encontraram, no início de suas carreiras, forte resistência: esta é uma regra absoluta, para a qual não há exceçóes. Mas ele é aplaudido. É um mau sinal."

$\mathrm{O}$ que mostra, se ainda for preciso documentar as divergências do "gosto-não-gosto," como o apreço dos valores é decisão mais de adivinhação do que dum juízo ordinário. Trata-se de situar uma personalidade nos tempos que viráo.

Em escala muito menor tivemos o mesmo no Brasil. Bastará lembrar como um literato do valor e da credibilidade estética de um Monteiro Lobato pôde descarregar uma inconcebível ira sem precedentes contra Anita Malfatti, a pintora que, vindo da Alemanha operava mais com o espírito dos expressionistas do que com as quinquilharias do academismo tão acadêmico local.

São Paulo não era, então, Paris, porém se penso nas não-acolhidas burguesas à Semana de Arte Moderna de 22, confirma-se que, de certo modo, o destacar-se ou infrigir as regras da tradição foi motivo audaz, pois o conformismo pedante e conservador ditava suas exigências.
Para passar a épocas mais recentes: quando eu mesmo apresentei no Masp, em 67 a exposição de Vicente do Rego Monteiro cujas telas enroladas foram postas em chassi e emolduradas no museu, a recriminação, salvo o consenso explícito de Mino Carta, então diretor do Jornal da Tarde, foi total. Isto para dizer que julgar produçóes de arte não é tarefa para todos.

Paia concluir: será que envolver- se no dilema, "gosto-não-gosto" "vale para o futuro-não vale," e tantas outras informaçóes que passam na cabeça de quem julga, será que o decidir é fato que se ensina?

Dias atrás fui ver uma coleção, no Rio de Janeiro, composta inteiramente de pinturas abstratas, de todas as tendências, naturalmente sugerida pelas novidades de fora: dezenas, aliás uma centena de telas que me levaram, mais uma vez, ás consideraçóes apontadas pelo crítico norte-americano, segundo o qual há uma hostilidade instintiva contra a arte contemporânea, que se deve superar: "As consequências dessa hostilidade, seu repudio e sua recriação ainda estão entre nós. Sob campos aparentemente pacíficos, armas náo detonadas espreitam perigosamente."

\section{Legenda}

Manet chega à glória: M. Pertuiset caça o leão das formas tradicionais e consagra um inimigo da academia

\section{Senhor \#205, 20 de fevereiro de 1985, p.73 (P.M. Bardi)}

A PINTURA COMO DENÚNCIA

A importância da obra de Cândido Portinari

Para nós maníacos, é bom confessar, por aquele negocinho que apelidamos Arte, é reconfortante saber que, $a b$ antiquo, assuntos como a Pintura não só representavam fatos de governo mas também decisóes de supremo atendimento. Sempre me impressionou uma carta que o senhor De Noyers, logo que o rei Louis XıII o nomeou "superintendente dos seus bens," escreveu, a I4 de janeiro de I639, a Nicolas Poussin, naquele tempo transferindo-se para a Itália: “...quero colocar em ordem as artes e as ciências, pois tenho um amor particular pela pintura... quero o Mestre de volta a Paris, e até importar... alguns outros excelentes pintores italianos..." O superintendente oferece a Poussin: patentes reais, escudos a não se acabar, permanência na "residência do rei," isto é, no Palácio do Louvre ou no Castelo de Fontainebleau, à sua escolha, mobiliados a gosto do hóspede, contrato de cinco anos, prevendo que "logo que o artista respirar o ar da pátria dificilmente deixará o paraíso.”

E para reforço do convite, o próprio rei escreveu, no dia seguinte, longa carta ao "caro e bem-amado" declarando-lhe saber qual a estima que o circunda na Itália. Em substância: volte para "ornar e decorar as casas reais," recomendando a Deus que cuide da sua saúde etc. Inútil recontar aqui todas as vicissitudes do convite, que surpreende 
Poussin, assoberbado de empenhos na Península, sua mulher obstinada a não viajar e os problemas familiares inerentes.

Não sei se hoje ainda existem reis ou presidentes de repúblicas que façam questão de ter no palácio um artista. A lembrança me ocorreu, ao devolver ao arquivo a papelada que me serviu para compilar meu livro Lembrança de Le Corbusier: Atenas, Itália, Brasil, (Editora Nobel, São Paulo) em que dou conta de um dos raros casos, nos tempos modernos, do interesse de um governo por um Poussin nacional: no caso um ministro, Gustavo Capanema, que faz questão de confiar a Cândido Portinari o brilho da Casa da Cultura que mandou construir na Capital. É uma história que mereceria uma tese universitária.

Sem me dar a importância da qual gozava o Sieur de Noyers, me aconteceu, em 1946, de encontrar um esplêndido rei da imprensa brasileira, o sr. Assis Chateaubriand, o qual me investiu na superintendência da criação de um (desculpe o leitor) Castelo, apelidado Masp. Antes de encontrar o rei, desembarcando no Rio de Janeiro, a primeira visita foi ao ateliê do Candinho, para externar minha simpatia e adquirir uma pintura dele que doei à Galleria d'Arte Moderna de Milão. (Junto a telas de Emiliano Di Cavalcanti e de Lasar Segall. $)^{60}$

60 Sobre este episódio, Bardi conta amargurado: "doei em 48 três obras de Lasar Segall, Emiliano Di Cavalcanti e Cândido Portinari à
O Chatô era um senhor-rei. Apreciador de Portinari, seu mecenas, eu mesmo um modesto Sieur de Noyers, aproveitei para reunir no novo Museu várias obras do Poussin local através de aquisiçóes, retiradas dos oito painéis de "Série Bíblica" do auditório da Tupi e até recuperação de pinturas de Candinho já doadas a amigos.

De Portinari admirava seu senso popular, seu coração, sua fraternidade, seu representar os que precisamos socorrer. Devo lembrar que fui criticado por ter comprado o tríptico dos Retirantes e tê-lo exposto na nossa Pinacoteca em lugar de honra, pois documentava a miséria, e os costumeiros do contra proclamaram que o Masp mostrava a pobreza do Brasil.

$$
\sim
$$

Veja-se assim a que discussôes a arte pode levar. Não eram mais os tempos do Sieur de Noyers, quando as fadigas do pintor estavam a serviço do "vai tudo bem." Candinho denunciava que também no Brasil havia fatos que não eram agradáveis.

\section{Legenda}

A Ira das Mãos, de Cândido Portinari, um dos quadros da Série Bíblica, adquirido por Assis Chateaubriand e hoje no acervo do Masp

Galeria de Arte Moderna de Milão, para que soubessem que no Terceiro Mundo existem bons pintores; aquela galeria nem ao menos responde quando escrevo pedindo fotografias dos quadros.” \{BARDI, Vogue Brasil \#II5, fev. I985; cf. Anexo C, p.678\}

Senhor \#206, 27 de fevereiro de 1985, p.8I (P.M. Bardi)

UMA CHUVA DE HOMENAGENS

Agradecimentos de um paulista assumido no mês do seu aniversário

Eis um aguaceiro. Se está à mão, abre-se o guarda-chuva. Porém, como se proteger de uma chuva de reconhecimentos honoríficos?

Alguém, no caso o próprio redator desta página, aproa num onomástico de numeração por demais exagerada, procura disfarçar os enjoos da velhice, se esconde para não ser notado. Em vez disso, por gentil punição, eis os cumprimentos, as medalhas, as cruzes, os diplomas e dulcis in fundo: o evidenciado recoberto nada menos que pela capa de Cavalheiro de São
Paulo. Desta iniciativa me orgulho pois me declaro paulista, se não nato, pelo menos vivo de amor pela metrópole onde recebi amizade e permissão para organizar o Masp.

É fatal então na meditação lembrar Sartre que recusa o Prêmio Nobel: blague ou gesto publicitário, polêmica ou consequência de uma convicção social?

Reflito na sentença: Honores mutant mores: sed raro in meliores, as honrarias enchem a cabeça mas não propiciam o melhor. 
É preciso considerar os reconhecimentos atribuídos ao próprio trabalho, lembrando quem o favoreceu. Por isto, surpreso pela concessão de uma placa do Ministério da Educação e Cultura, recebida das mãos da própria e eminente ministra Esther de Figueiredo Ferraz, coloquei em cena a estátua de Assis Chateaubriand como o determinador do Masp, declarando que aceitava a homenagem em nome dele. Grato momento: escutar o elogio de Edmundo Monteiro, presidente e, posso dizer, contribuidor sine qua non do Masp, de Marcos Vinicios Vilaça, o fecundíssimo animador da Fundação Pró-Memória, ladeado pelo nosso inesquecível ex-governador Laudo Natel, pelo secretário de Estado da Cultura Jorge Cunha Lima e por Gianfrancesco Guarnieri, secretário municipal da Cultura.

O complicado é cunhar frases genéricas para replicar às congratulaçóes que te dirigem. Os manuais de boas maneiras prescrevem que nos escondamos, minimizando-nos na modéstia, afirmando que não merecemos e quantas outras declaraçóes fujonas, culminando a conversa numa censura aos sistemas das homenagens.

Mas isto vai contra a normalidade do dia-a-dia, pois parece que se vive para ganhar medalhas. (Devo confessar que me arrependi por ter dito em Vogue ${ }^{61} \mathrm{de}$ fevereiro, a mim dedicado, na legenda da foto que mostra o grupo de minhas honoreficências, que uma premiação de que me orgulhava era a medalha de ouro ganha numa corrida de bicicletas em 1923 ,

6I Vogue Brasil \#II5, fev I985.

Edição comemorativa de dez anos, especial sobre Pietro Maria Bardi. Cf. Anexo C, p.664 a "Milão-Miradolo." Era francamente uma boutade, pois o reconhecimento de um trabalho, no caso de alguém que vai a pé, por suas próprias pernas, não embarcando nos chamados trens da alegria, é condição de vida. Pode ser que as premiaçóes tenham-se tomado rotineiras, medalhas demais e distribuidores idem, todavia vale esta espécie de controle dos merecimentos na corrida aos obstáculos da vida.)

Curioso, e isto me ocorre ao falar em obstáculos: foi-me oferecido um cordial almoço por parte da Academia Paulista de Jornalistas e na esplêndida oraçáo de seu presidente, deputado federal Israel Dias Novaes, ele refez a história da minha passagem por cotidianos famosos na Itália e por não sei quantas revistas de cultura por mim fundadas. E lembrou mais, que o amigo Assis me incumbiu até da direção-geral dos Diários Associados.

Se esta página tem leitores posso assegurar-lhes que não perdi o antigo vício de driblar, se for o caso empurrar, procurar jogar isolado, mexer com farinha do próprio saco, escutar a todos, até os latidos dos cachorros e os piu-pius das galinhas, porém, como disseram no Il Corriere: o B. fica a cavalo nas testardaggine. ${ }^{62}$

E por falar nesta pelouse da imprensa, peço à Senhor que me deixe ilustrar este rabisco com a capa de Vogue. Aos 85 compreendi que a vanitas dá prazer. Assim abraço a todos os amigos, personalidades, companheiros de trabalho que assistiram ou imaginaram o meu sopro nas velinhas do bolo de mais um aniversário.

Legenda

"Aos 85 anos compreendi que a vaidade dá prazer"

62 Teimosia.

\section{Casa Vogue \#2, março-abril de 1985, p.76 (P.M. Bardi)}

\section{ARQUiTETURA E ARTE}

Todos - menos os mais obstinados seguidores das regras canônicas que definem a arte em repartiçóes manualescas - sabem que a arquitetura, para ser realmente considerada, deve representar um estilo, um dos inúmeros que a história registra no setor, particularmente o embelezamento das fachadas.

Os historiadores acabaram por encontrar um termo para indicar aquela bagunça pseudo-estilística oitocentesca de cópia ou imitação banal dos estilos do passado, 
cunhando a palavra "culturalismo." Entra nesta definição tanto o gótico arruinado da Catedral da Sé quanto o Teatro Municipal de Ramos de Azevedo, ou seja, grande parte da arquitetura.

Não é para me dar o ar de um descobridor de inconveniências, porém, nos anos 30, tendo a possibilidade de manifestar uma opinião, organizei uma "Mesa dos Horrores:” fotografias de edifícios do "culturalismo," especialmente do estilo "romano-imperial-modernizado," caricaturadas com figurinhas e escritas de áspera censura. Isto se deu na Galleria d'Arte de Roma, que naquele decênio eu dirigia e, sem contar para ninguém, convidei para inaugurá-la nada menos que o ditador Mussolini. Este compreendeu muito bem que era chegada a hora de acabar com o carnaval culturalista, decretando a possibilidade de os jovens arquitetos operarem no estilo racional ou funcional, então proposto na Europa. Contei isto, agora, num volume que se intitula Le Corbusier: Atenas, Itália e Brasil (Editora Nobel, São Paulo) no qual lembro minha intimidade com o mestre da machine-à-habiter.

Porém não é dele, nem do "culturalismo" que quero tratar nesta nota. Descubro no boletim do Sphan, o órgão do Ministério da Educação é Cultura que defende e incentiva a memória, o tombamento não exatamente, conforme o uso e costume, de uma igreja, de um palacete ou de um capricho também culturalista, mas de um açude e de uma fábrica de vinho de caju. Trata-se do açude do Cedro, em Quixadá, Ceará, e da fábrica de vinho de caju Tito Silva, em João Pessoa, na
Paraíba. Outro tombamento: a caixa d'água de Pelotas no Rio Grande do Sul.

O açude é uma obra de técnica pioneira construído entre I877 e I879. Servia para resolver uma função social: irrigar terrenos áridos. Além da importância histórica, a obra apresenta uma singularidade como arquitetura, arte em consequência da função técnica. Pretende-se restaurar as antigas oficinas.

A fábrica de vinho de caju, fundada em 1982, preserva um estabelecimento raro do pioneirismo tecnológico e um patrimônio, desta vez pode-se dizer, arquitetônico.

Finalmente a arte, no caso a arquitetura, envolvendo obras não bem de autoria de profissionais daquela disciplina, mas de engenheiros que as realizaram sem se propor a produzir arte. E hoje a memória as reverencia não só como história mas também como documento artístico.

Em um dos meus próximos ensaios cujo título provisório é Arquitetura e Engenharia, proponho-me a examinara interdependência entre as duas "ciências," tentando estabelecer o quanto a engenharia depois do oitocentos na arquitetura até mesmo definindo-a através do advento do funcionalismo, numa nova maneira.

Não há dúvida nenhuma de Torre Eiffel possui um significado renovador na arquitetura. Não foi pensada como arte mas como função. A partir daí, quantas construçóes de ferro, a novidade do cimento Portland, o uso das ligas metálicas e quantos outros materiais não contribuíram para modificar a arquitetura?

Senhor \#207, 6 de março de 1985, p.65 (P.M. Bardi)

UMA AVENTURA INDISPENSÁVEL

A história de um empréstimo em Nova York

Numa longa reportagem dedicada a este cronista e publicada há alguns dias, $O$ Globo relata um pouco de minha vida no Masp com o título "Aventuras indispensáveis de quem ama e protege as artes." ${ }^{63}$ Naturalmente, contei algumas aventuras. Agora, para completar o

63 "Aventuras indispensáveis de quem ama e protege as artes: Pietro Maria Bardi." O Globo. I3 fev 1985, Segundo Caderno, p.3. curriculum das marotagens, conto mais uma, daquelas que os Italianos pedem que sejam escritas com carvão branco. Tem, por acaso, uma coincidência de crônica.

Os cotidianos contaram sobre a visita de David Rockefeller ao Masp, acompanhado de diretores do Chase Manhattan Bank e seus representantes no Brasil, quando doaram uma obra ao nosso acervo. Infelizmente, devido a um vírus que contraí, não pude receber o ilustre visitante. Teria 
lhe lembrado que foi ele, em um dos nossos difíceis anos Cinquenta, que ajudou a solucionar a formação da Pinacoteca do Masp.

O negócio se deu assim: eu estava importunando o dr. Chateaubriand para adquirir parte substancial de obras em vista do crescente aumento dos preços. Aconselhei o chefão a fazer um empréstimo. Sua resposta: "Aqui ninguém nos confia um cruzeiro.”

Foi quando, lembrando a presença de Nelson Rockefeller numa das festinhas no Museu, de imediato o Miraculoso repicou: "Amanhã nós vamos a Nova York."

Deixo de precisar o pitoresco de um complicadíssimo caso financeiro, de títulos vencidos, aquisiçóes comprometidas, todos estes fatos resolvíveis culminando num outro que nunca se consegue resolver: o boato, que investia contra os Diários Associados e este não inocente cronista então motivo do escândalo como maníaco por grandezas etc.

Os dois obstinados desembarcam em Nova York. O Assis, falando seu inglês, contata diretores do Chase, propóe, demonstra a importância de um empréstimo norte-americano para erigir o primeiro museu de arte ocidental da América Latina etc. Fala e convence. Em resumo, para o leitor saber: assina-se um papagaio de US\$ 4 milhôes, David Rockefeller autorizando. ${ }^{64}$ Faço graça da solenidade da assinatura da papelada. O Generoso, o esplêndido brasileiro de sempre, difícil e irrequieto, eu sei, mas realizador, naquela noite, depois de um dia cansativo, ao assinar

64 Bardi, na versão dessa história em Masp 40 anos (1987) menciona que o banco é o Morgan e a quantia US\$ 5 milhôes. Já Kirst e Simôes, em Masp 60 anos (2009, p.54-55) registram a quantia vencida ser de mais de US\$ 2 milhóes emprestados da Galeria Wildenstein, além de uma declaraçáo do presidente da galeria (p.59) sobre a dívida somar US\$ 3 milhóes. O banco intereveniente da operação de quitação da dívida, segundo Kirst e Simóes, foi o Guaranty Trust Company of New York. É invariável em qualquer versão a figura de Rockefller. a ata, escrita a palavra Chateaubriand, baixou a cabeça e roncou, para susto dos presentes. Eu os acalmei, explicando ser fato corriqueiro. Daí a pouco ele voltou da dormidinha e completou a assinatura com o Bandeira de Mello. Saiba-se que ele deu, em garantia, todos os seus bens.

A última exigência para consumar o convênio era uma outra assinatura, a do fiador. Não sabia que o Amigo me tinha escolhido como tal.

Cara cronista de $O$ Globo, esta é uma das "aventuras indispensáveis" que colecionei, e deu certo, pois o Diretor dos Associados, quando deixamos o Banco, me passou a mão pelos ombros e anunciou: "Eu não sou tão louco a ponto de pagar estes quatro milhóes de dólares.” Então eu, fiador, pagaria!

- Tenho um plano.

$$
\sim
$$

O diretor do Masp foi então incumbido de redigir imediatamente um catálogo do acervo existente em casa, do ainda não pago e do in mente Deis, escrevendo relaçôes e perícias. Com isto, Chateaubriand conseguiu que a Caixa Econômica Federal de São Paulo pagasse o Chase. A dívida, assim, tornava-se nacional. Passa-se um ano, dois, dez, até que um dia o ministro da Educação e Cultura, Jarbas Passarinho, visita o Masp, e pergunta como estavam indo as coisas. Expliquei a novela do caso nova-iorquino, com dívida ainda aberta, sem correção monetária, reduzida a Cr\$ 350 mil, me parece. O ministro disse: - Bardi! Me dirija um ofício.

Redijo-o e meu assessor, Luiz Sadaki Hossaka, que embarca para o Rio de Janeiro. Passam-se poucos dias e ele retoma com a quitação dos antigos US $\$ 4$ milhóes, pagos com parte do dinheiro arrecadado com a Loteca. Obrigado, ministro Passarinho!

Foi uma "aventura indispensável” na qual me orgulho de ter tido alguma cumplicidade. ${ }^{65}$

65 A versão publicada em Masp 60 anos, uma história em 3 tempos, ao contrário desta, deixa transparecer o momento 
de grande tensão quando o acervo em si, dado como garantia pelo empréstimo da Galeria Wildenstein, passou em exposição por Nova York. Os credores locais, percebendo o valor das obras, quiseram saldar a dívida naquele momento - ou as obras não sairiam daquele país. $\mathrm{O}$

\section{Legenda}

Têmpera, quadro a óleo de Christian Haub (Flórida, 1952) doado ao Masp por David Rockefeller um incentivador do Masp

episódio foi resolvido recorrendo-se ao Governo Federal. Chateaubrinad foi, por isso, obrigado a se afastar do Masp. $\{$ Kirst e Simóes, 2009, p.54-59\}

Senhor \#208, I3 de março de 1985, p.73 (P.M. Bardi)

Os ESPECIALISTAS INÚteIS

A difícil caçada das obras-primas internacionais

Nos ambientes artísticos internacionais, onde o problema de juntar um acervo para criar ou fortalecer uma pinacoteca é maior do que entre nós, as recentes confissóes de Thomas Hoving, o antigo diretor do Metropolitan de Nova York, produziram surpresas e curiosidades por ter posto a nu situaçóes quase incríveis da política museográfica do país que mais reuniu arte neste século.

Entre 59 e 77, Hoving foi responsável pela aquisição de 25 mil peças num valor de US\$ 250 milhóes, lamentando porém uma quantidade de obras que não pôde assegurar ao seu museu devido a casos de ingenuidade, confiança mal depositada, falta de meios etc. Ele conta um fato ocorrido em 40, com um grupo marmóreo de Gianbolonha, vindo da Casa Medici, passando pela corte de Felipe IV da Espanha, depois para Carlos I da Inglaterra e para George III.

O Metropolitan estava à caça do conjunto pois fora passado a uma família que o colocou à venda: discussão, encontro dos meios, obsessão de Hoving, quando no final o presidente do Metropolitan declara, pouco inteligentemente: "Se todos procuraram se desfazer do mármore, por que nós o queremos?” E a caçada terminou.

Numerosas obras-primas escaparam do Metropolitan, segundo relata o ex-diretor, por "imbecilidade" das juntas deliberadoras. Em contrapartida, o museu adquiriu, em 70, o Juan de Pareja (I606-I670) pagando por ele, num leilão Christie's, US\$ 5,5 milhóes. A partir daí se desencadeia a frenética concorrência entre museus norte-americanos para conseguirem obras de exceção. Bastaria lembrar a disputa entre a Galeria de Ottawa, no Canadá, e o magnata Paul Mellon para possuírem a Ginevra Benci, de Leonardo, para saber do valor atribuído à Arte, hoje, no mundo inteiro, autêntica novela.

As recordaçôes de Hoving servem para conhecer o trabalho de um autêntico connoisseur. Conta seu primeiro encontro como assistente: um americano, casado com uma grega, abre uma caixa de papelão e surge uma cabeça tardo-antiga do IV Século. "Quase cai no chão, aturdido pela beleza da obra: a intensidade do olhar foi hipnótica..." conta ele. Porém, os superiores não compraram: "As grandes obras de arte não fogem somente dos museus; cada marchand e cada colecionador têm seus casos de dor," declara o confessor e recomenda que não se dê ouvidos a nenhum expert.

Como se sabe, estou expondo no Masp parte da minha coleçãozinha pessoal, complementaçáo do lançamento do Vogue de fevereiro. Revendo pinturas por mim adquiridas há meio século, teria vontade de relatar, ao modo do colega Hoving, como fez um dos últimos connoisseurs, não sei quantos casos de decisóes que tomei por mim mesmo d'amblé, sem ouvir conselhos. Posso afirmar que, se o Masp possui um acervo suficientemente preciosos em arqueologia, telas, mármores de prestigioso valor, isto se deve à inexistência, no museu, de comitês de compras. Nós, aliás eu, me aventurei, refletindo, às vezes, cabeçudo, diziam todos, despótico. Pode ser que tenha dado certo. Ou melhor, deu certo.

\section{Legenda}

Maestà, de Maestro del Bigallo

Retrato do infante dom Sebastian

de Bourbon e Bragança 
Senhor \#209, 20 de março de 1985, p.88 (P.M. Bardi)

O SONO DAS ARTES PLÁSTICAS

Um setor que pouco se envolveu com a denúncia social no Brasil

Uma publicação dedicada aos problemas nacionais de mais urgente cultivo é Retrato do Brasil, da editora Política. São postas não a nu, mas ao esqueleto, situaçóes sociais que deveriam provocar, além do arrepio, o propósito de solucioná-las.

É fácil, naturalmente, apontá-las, documentá-las e oferecer receitas na atual encruzilhada política, a partir da herança deste março de complicado porém esperançoso amanhã. No número 26 da revista, Gilberto Freyre dá uma "visão geral” do momento: "O Brasil precisa de uma liderança política que concentre uma visão geral da situação dos seus problemas, que são complexos. Para que haja então um ajustamento econômico, haja um ajustamento social, haja um ajustamento cultural."

Dois outros depoimentos que parecem o ab antiquo da realidade atual documentam a apologia do poder e são uma síntese de quanto a literatura e o teatro representaram, desde os romances de José de Alencar até os escritores vivos, na definição do nosso desenvolvimento. Um ensaio de Flávio Aguiar analisa autor por autor: um espelho do pensamento dos convocados a registrar a vida brasileira.

Tudo é bem relatado e cada romancista, teatrólogo e poeta tem sua recensão (que prazer reler, no artigo de Ricardo Maranhão, o "Samba do Crioulo Doido" de Stanislaw Ponte Preta: Foi em Diamantina $\mid$ Onde nasceu JK| Que a Princesa Leopoldina| arresolveu se casar $\mid$ Mas Xica da Silva| Tinha outros pretendentes $\mid E$ obrigou a Princesa| a se casar com Tiradentes.

Permito-me perguntar: qual a contribuição das artes plásticas nos mesmos períodos?

Enquanto Arquitetura: inaugura-se nestes dias, após o restauro, o Paço Imperial do Rio de Janeiro, onde dom Pedro II foi coroado e onde a princesa Isabel assinou a Lei Áurea; mas a arte do construir não é complemento de posiçóes sociais e políticas que, em vez, têm mais reflexos na Pintura e na Escultura.
Mármores e bronzes sempre serviram para celebrar episódios do poder, ou representar imagens da religião. A Pintura, depois da chegada da Missáo Francesa, ao longo do Oitocentos, seguiu as andanças da Escultura e, no começo do Novecentos, não se afastou da tradição celebratória ou reprodutiva do que as elites pediam para eventual embelezamento das paredes palacianas, os ricos ignorando ou desfrutando dos pobres e de seu estado de vida.

Qual, então, a participação dos pintores? Estou certo de que a ruptura do burocrático desenfornar de paisagens, reproduzir belezinhas, amontoar naturezas-mortas, exaltar generais e presidentes etc. deve ser atribuída a Cândido Portinari, do qual pode ser interessante lembrar um caso que envolveu este cronista.

Quando, em 47, comecei a formar a Pinacoteca do Masp, fui ao Rio visitar Candinho, tencionando adquirir algumas obras. Por acaso, vi o Triptico dos Retirantes. Estupendo. $\mathrm{O}$ autor me obrigou a refletir se seria oportuno expor num museu uma obra "denunciadora" da miséria nacional.

Novato, aliás nada sabendo do Brasil, apreciava a pintura posta nas telas num tumulto de emoção. Em suma: comprei. Vinte contos, pagando cinco cada mês. Quando abrimos o Masp, começaram as geremíadas: o italianinho denegridor, e até me tacharam de comunista, com a recomendação e até ordem de eliminar aquela "fome e suor.” As três pinturas ainda estão ali.

Voltando ao assunto da página: enquanto nas manifestaçóes escritas os Euclides da Cunha e os Jorge Amados, para citar alguns, pensavam no povo, os pintores dormiam?

Legenda

Enterro na Rede, Os Retirantes e Menino Morto, de Portinari: exceçóes que provocaram polêmica 
Senhor \#210, 27 de março de 1985, p.IO4 (P.M. Bardi)

A ARquitetura EM Cumbica

Algumas soluçôes criativas expostas no Masp

Abrimos no Masp (gosto de falar deste centro cultural porque, se fosse esperar que os colegas escrevessem a respeito do que aqui se passa, acabaria desistindo) uma exposição dedicada ao recém-inaugurado aeroporto de Cumbica, como informação ao público de um fato importante não só de vida, como de arquitetura.

Arquitetura bem representativa deste século devido ao tráfego aéreo que vai se impondo e já tem sua história, para mim que segui as primeiras corridas das máquinas se levantando no Campo de Marte, os espectadores surpresos e delirantes, de decênio em decênio, nós cada vez mais integrados, aliás, usuários dos avióes, nem dando importância aos foguetes que vão à Lua, pois viver no espaço é coisa do dia-a-dia.

Admiradores de Santos Dumont, não só pioneiro, mas ídolo: vejo-o lembrando num antigo livro italiano sobre aviação: "Chegamos assim, seguindo um período de atividades sempre crescente, a outubro de 1906, quando Santos Dumont, o apaixonado e intrépido sportman, faz na França os primeiros duzentos metros de voo com um aeroplano a motor." A data assinala o início de uma nova era em que começavam a surgir máquinas voadoras de todo tipo. Entre elas o Demoiselle, do brasileiro, exposto na primeira mostra da aviação italiana em Milâo, em 1909. Naquele tempo, para a meninada, havia os poemas a se recitar. Cantava Giovanni Bertacchi: “... Vejo a vida se desenvolver em movimento| leve, fluente mais perto do sonho| e na amplidão do envolvente vazio| se aplacar a ânsia e o místico desejo| do infinito..." Admirávamos o poeta Gabriele d'Annunzio no avião ao lado do intrépido Curtiss. Pode ser que evocar a história seja superado, porém quando fui convidado a ver a construção de Cumbica, as lembranças se amontoaram na cabeça, prepotentes. Lá estive para colaborar com o arquiteto Jorge Michirefe no anexar à grandiosa construção algumas obras de arte, sinal de estética, para o viajante se distrair ou gostar de algum elemento em contraste com o ambiente, produto da tecnologia. Minha primeira ideia foi colocar no grande hall de entrada uma escultura representando Pégaso, porém com as asas móveis, para dar ao mito o senso da atualidade. O escultor por mim escolhido era Alberto Frioli.

Por razóes independentes do acordo, nada se concretizou, mas julguei interessante mostrar no Masp a arquitetura do Aeroporto, anotando para o visitante várias características realmente de feliz solução. Uma delas é o paisagismo, encarado de maneira técnica e funcional e não apenas decorativa. $\mathrm{O}$ viveiro de plantas já produziu até hoje mais de um milhão de mudas, obtidas a partir de sementes e cerca de trezentas mil já estão plantadas. Estão previstos bosques nos limites das cabeceiras de pistas que funcionarão como barreiras vegetais contra $\mathrm{O}$ ruído. A gramagem de toda a área também apresenta qualidades de absorção acústica, assim como facilita a manutenção das obras de terraplenagem, drenagem e redes embutidas no solo.

Uma das singularidades marcantes é o terminal de passageiros que tem, basicamente, três pavimentos visualmente integrados através de halls com pé direito duplo ou triplo, sendo possível, para uma pessoa que esteja em um dos pavimentos, observar o que se passa nos outros. Esta integração de ambientes facilita o conhecimento do prédio por parte do usuário, simplificando o sistema de sinalização.

Outra característica é o esquema das cores: uma gama extensa de meios-tons que evitam a monotonia, tomando os ambientes internos coloridos. $\mathrm{Na}$ exposição do Masp está também exposta a documentação dedicada ao mobiliário, pois foi criada uma série de módulos combináveis entre si.

\section{Legenda}

A integração de ambientes é uma das boas ideias no aeroporto de Cumbica 
Senhor \#2II, 3 de abril de 1985, p.68 (P.M. Bardi)

SÁo Jerônimo LIBERADO

A restauração de uma obra com cinco séculos de idade

A imprensa confecciona uma infinidade de colunas para os artistas jovens, aplicando-lhes os mais exaltadores adjetivos. Permito-me nesta página, geralmente um tanto polêmica, apresentar uma obra-prima do Renascimento: o quadro Sáo Jerônimo no Deserto, de Andrea Mantegna, que acabamos de liberar, no departamento de restauro do Masp, de fatais alteraçóes, consequência de intervençóes de conservação ou não, açóes procedentes de insetos, e tudo que se acumula num painel cuja ancianidade é de mais ou menos cinco séculos.

Mantegna é um dos titulares da Renascença. Opera no Quatrocentos, severo anotador de episódios sacros. Situou nosso Santo numa paisagem de natureza árida, à sombra de uma imensa rocha, valendo-se de um realismo idealizado espiritualmente. Ao seu tempo abandona o Gótico, deixa a briga para seu mestre Squarcione, torna-se da família Beillini, promove-se no stil nuovo e vai, aliás é chamado para trabalhar nas cortes dos príncipes italianos.

Suas figuraçôes, mais que pictóricas, parecem esculpidas, estátuas marmóreas, como as considerou Bernard Berenson. O São Jerônimo o confirma. Para o historiador, este painel representa esplendidamente a novidade "mantegnesca."

O Masp pôde adquirir a obra em I950, graças à doação do Município de Sáo Paulo, por deliberação da Câmara. Tinha pertencido ao príncipe Paulo da Iugoslávia, e ainda tem, no verso, um lacre azul com as iniciais P.P., além de várias etiquetas que registram as numerosas passagens de propriedade.

Durante o ciclo de exposições das "Cem Obras-Primas do Masp," que se iniciou na Orangerie do Louvre, em I953, a convite do governo francês, seguindo depois para importantes museus de Londres, Bruxelas, Utrecht, Dusseldorf, Berna para o Metropolitan de Nova York a mostra foi apresentada no Palácio Real de Milão, e o São Jerônimo foi escolhido para ilustrar, em cores capa do catálogo.

$\mathrm{Na}$ Itália, a obra, considerada pelo mestre dos mestres do Renascimento, o professor Roberto Longhi, como um Mantegna do período tardio, provocou ampla bibliografia, sem contar a surpresa de se constatar que o Masp tinha tomado a iniciativa de formar uma Pinacoteca realmente de peso, colocando o Terceiro Mundo às portas do Primeiro.

Seja como for, tomei a decisão de limpar o painel no mês passado, confiando-o a Maria Helena Chartuni, a pintora dedicada ao restauro, que se tomou conhecida por ter recomposto a imagem em cerâmica de Nossa Senhora Aparecida, em 1978, que um desequilibrado jogara ao chão, reduzindo-a a I65 pedaços.

O São Jerônimo recebeu um tratamento de limpeza total, permitindo até a descoberta de detalhes desaparecidos pelas intervençóes pictóricas precedentes. Antes de começarmos a retirada dos velhos vernizes, foram aplicadas várias camadas de resina Mowilith 35/73 na parte posterior do painel para recondicionar a madeira anteriormente atacada por cupins. Iniciamos a limpeza verificando que a parte da pintura que se soltava era apenas os restauros antigos, os quais eliminamos, substituindo-os por outros, mais apropriados. Terminada a limpeza que devolveu à obra seu esplendor original, procedemos ao restauro pictórico científico. Já que estamos no assunto história: votos de vitória ao novo ministro da Cultura, José Aparecido de Oliveira, e recomendações de que continue a política de desenvolvimento e operosidade do Sphan, pois a Cultura é, antes de tudo, respeito e amor ao Passado. Lê-se que o ministro declarou: "Não sou novidadeiro nem vanguardeiro," ótimo!

Legenda

Sáo Jerônimo no Deserto, um

quadro de Andrea Mantegna 
Senhor \#212, Io de abril de 1985, p.75 (P.M. Bardi)

UM BALANÇO DA VANGUARDA

O Chase Manhattan Bank e a renovação das artes plásticas

Comentar numa simples página o monumental volume que o Chase Manhattan Bank publicou para documentar sua heterogênea coleção de obras de arte é, confesso, uma espécie de sacrilégio, pois se trata de uma das coleçóes mais famosas dos Estados Unidos, um dos mais significativos registros de quanto se produziu nas vanguardas do mundo inteiro.

Não aparece o “já-era” das vanguardas históricas, das post-vanguardas dos decênios que apontavam Picasso como o concluidor do Modernismo.

A escolha se ateve aos exercícios dos renovadores das artes plásticas, os criadores da nova estilística estritamente aparentada, não digo como o café pequeno do progresso, mas da tecnologia computadorizada e que nos surpreende na proposta da Expo'85 de Tsukuba no Japão: as mil e uma noites do futuro.

Recebi o volume com uma cordial dedicatória de David Rockefeller, por ocasião da visita que fez ao Masp no mês passado. É ele o articulador da coleção do Chase. Conliou-a a profissionais favoráveis às tendências sem preocupação de agradar nem a críticos nem a troianos nem aos consumidores da arte de ocasiáo. As fotomontagens flagram os funcionários e os usuários do banco em suas atividades normais, na companhia de esculturas, pinturas e objetos da nova decoração, oscilando entre brincadeira e peça de exceção. Numa sala que tem o aspecto de ser destinada aos diretores está pendurado um amplo mobile de Alexander Calder. (Um parentesis: este cronista convidou para vir a São Paulo o mestre quebrador do ar com formas metálicas em 1948, expondo sua esplêndida obra no Masp; porém, naquele tempo, ninguém se impressionou. Mesmo assim eu garanti um móbile para o Museu.)
Em outras salas se admiram os fabricantes de novidades emaranhados no pot-pourri do geometrismo, cubismo, abstracionismo, empacotadores, caricaturas, animalística, naturismo, gags a não se acabar, até trouvailles futuristas, ironias, evocaçōes de modas femininas e também o realismo, não digo nem acadêmico, mas academicíssimo.

Afinal, servindo-me do latim: de gustibus non est disputandum. Às vezes, eu mesmo me pergunto: será que alguém que escreve uma página sobre Andrea Mantegna não passa de um superado? Alguém que tem um pé na história para não cancelar a tradição e o outro, com o que ainda lhe resta na cabeça, envolvido em negócios estéticos por demais inatingíveis, e talvez gratuitos, dos criadores de futilidades?

Disse, não sei bem se Kant ou outro filósofo, que as artes servem para o lazer das pessoas. Pode ser que um outro Kant diga o contrário, ou talvez diga até que servem para preocupar as pessoas. De qualquer modo, o volume Art at Work é um documento de grande importância sobre o quanto se desenvolve no setor.

É justo observar que toda esta mudança jogou a atividade até ontem dita Arte num marasmo de complicada definiçáo. Arte era sinônimo de Beleza... Ainda agora, mexendo com o passatempo, escuto o adjetivo "belo" para julgar obras produzidas numa das inúmeras tendências que povoam o acervo do Chase Manhattan. Acho lícito refletir que chegou a hora de cunhar definiçóes mais apropriadas para manifestar uma convicção estética favorável.

\section{Legenda}

Chase: uma homenagem aos

criadores de novos estilos

Senhor \#2I3, I7 de abril de I985, p.73 (P.M. Bardi)

A OBRA DOS PENETRAS

Uma visão otimista sobre a inflação de talentos nas artes

Vai-se desenvolvendo e, feliz ou infelizmente, tomando conta da pelouse das artes, razoável número de penetras que se intitulam pintores ou escultores. Constatando 
que a liberdade de manifestação não é proibida e dando uma olhada nas últimas ou penúltimas novidades celebradas nas revistas internacionais, os novatos póem-se ao trabalho. Logo que reúnem algumas dezenas de quadros ou de gessos, correm à procura de uma bienal, galeria, filial de banco, sala de clube, restaurante ou qualquer outro espaço e, obtendo-o, mandam imprimir um convite, amolam familiares, amigos, jornalistas, agitam para alcançar o primeiro sucesso e dali partem para compilar mais uma linha do currículo.

A cada dia recebe-se dezenas e dezenas de convites. Nestes últimos, tempos, multiplicando-se as galerias e locais de exposição, tem-se a impressão de que a pelouse está agora sendo invadida por multidóes de produtores de artes plásticas, ao lado dos Maracanãs da música popular, dos estádios teatrais, cinematográficos e tantos outros conclaves. É a moda das artes.

Há os "bem-pensantes" que discutem o que resumimos acima e se queixam, ironizam, lamentam até que se construa um Sambódromo, condenando qualquer vantagem para a alegria da arte que hoje realmente é moda.

Este pessoal retrógrado evidentemente está errado, pois ainda não descobriu que no fim do nosso século as inflações, os exageros e até os carros colocados antes dos bois são costumes a serem suportados e até mesmo incentivados. Esta presença, às vezes carregada de anomalias e de incongruências, faz parte do progresso, as artes ganhando popularidade após um estagnado abandono, quando estiveram relegadas a uma função de sobremesa que provocou a reação dos generosos da Semana de Arte Moderna de 22, um fato tão singular que explodiu porém sem as merecidas consequências.

A São Paulo séria, grave, provinciana, não aceitou a recomendaçáo da Semana e, tanto é verdade que, quatro anos depois, apesar do ativismo dos Andrade, Mário e Oswald, Menotti del Picchia, Tarsila, Anita e tantos outros que participaram para afirmar a poesia e as artes das novas correntes no Brasil, apesar desta ação, a vinda de F.T. Marinetti, em 1926, para conferenciar sobre o Futurismo, foi assim registrada: "Recebeu tremenda vaia plateia que foi ouvi-lo pregar a sua revolução estética... Foi uma noite memorável, que se escreveu com batatas e ovos podres e muito assovio num dos principais auditórios da cidade." Isto em São Paulo; no Rio foi ainda pior.

A capital paulista, cidade do futuro, foi hostil ao Futurismo. Menotti del Picchia tentou, já em 2I, esclarecer, no Correio Paulistano: "Falam-se por ai coisas tremebundas e fulminantes contra o Futurismo, como se em São Paulo estivesse por estourar um antraz literário dessa ordem. Os que assim gritam, num pudor anacrônico, ignoram que o Futurismo, inaugurado na Itália, há muitos anos, já não existe, ou melhor, já produziu à sociedade todos os seus benéficos efeitos."

Por outro lado, nos mesmos anos 20, os Gregori Warchavichik, Rino Levi, Flávio de Carvalho não passavam por baixo das "forcas caudinas" para afirmar a arquitetura moderna?

Não faltam os combatentes. A Respeito da repercussão do manifesto de Marinetti, deve-se lembrar o que foi transcrito e traduzido por Almáquio Dinis, na Bahia, como se lê na História Concisa da Literatura Brasileira, de Alfredo Bosi.

Assim sendo, vamos encarar a atual inflação das atividades no setor das artes como uma moda, consequência lógica da ação dos pioneiros, ocasionando uma lembrança para os mesmos.

\section{Legenda}

Menotti del Picchia: gritos antigos

g Desenho de Paim Vieira: considerado "futurista" no século passado

Senhor \#2I4, 24 de abril de I985, p.IO4 (P.M. Bardi)

A CENTRAL DE BOATOS

Problemas com um código herdado da Colônia

A página encabeçada pelo nome de quem a redige de vez em quando serve para desfazer boatos fabricados pela maldade

dos costumeiros filhos e filhas de buona donna para retorcer malignidades. 
Boatos, no labirinto cultural, são praxe. Para náo divagar, conto um, bastante velhaco, fabricado para liquidar $a b$ antiquo o cronista. Estava compondo o acervo do Masp, solidário ao mais "boatizado" dos brasileiros, Assis Chateaubriand, quando a praça intelectual murmura que as obras selecionadas são falsificaçóes baratas, recolhidas por um carcamano italiano.

Apesar de ter desferido um soco na cara do crítico de arte do maior matutino local, porta-voz da lenda, durante uma conferência de Flávio de Carvalho no auditório do próprio Masp, apesar, repito, desta normal reação, os difamadores continuaram.

Dirigi-me a Chateaubriand pedindo que os Diários Associados interviessem. O chefe me explicou que os recém-chegados têm obrigação de se adaptar, socialmente, ao código herdado da Colônia, e concluiu: "Bardi, não lhe faltam meios para desmentir. Você é livre para agir!"

E me veio uma ideia: escolhi cem pinturas da Pinacoteca, embalei-as coloquei-as num lift, comuniquei-me com Germain Bazin, diretor do Museu do Louvre, desembarquei em Le Havre e fui até Paris, onde obtive o convite do governo francês para apresentar o conjunto na Orangerie do Louvre.

Ingênuo, corro à embaixada do Brasil, postulando convidar o presidente da República para inaugurar a exposiçáo. Julgaram o italianinho um atrevido. Resumo: consegui, através de amigos parisienses, que o presidente Vincent Auriol e senhora inaugurassem a novidade brasileira, o que se deu sem a presença sequer dos contínuos da nossa embaixada. E o mais incrível: nem o dr. Assis esteve presente, conjecturando sobre a minha possível loucura. De Paris a mostra passou à Tate Galery de Londres e foi acolhida nos grandes museus da Europa, culminando finalmente no Metropolitan de Nova York.

Volto triunfante, mas os manipuladores do boato dos "quadros falsos" reforçam sua consistência: o Bardi vendeu os originais e trouxe de volta as cópias...

Relato o caso fazendo saber que ao longo de decênios consegui estabelecer a verdade, acostumando-me aos boatos; porém, quando as insinuaçóes aparecem na imprensa, a reaçáo volta.

Já publiquei nesta página o que penso da velhinha enroladora que dirige o MAC, em réplica a estúpidas insinuaçóes.

Agora é a vez de outro, registrado na lista dos mexeriqueiros de profissão, que responde pelo apelativo de Zunzunidor.

O tradicional delator (a serviço, não sei se retribuído ou não, de inconformados inimigos do Masp) declarou textualmente no Jornal do Brasil: "Há suspeitas de que na esteira do negócio (do Bardi) esteja sendo tramada a venda de algumas obras que compóem o acervo do Masp, formado por raridades dignas de figurar na coleçáo de qualquer grande museu."

Traço acima do nome Zózimo ${ }^{66}$ o mesmo $M$ que pichei num muro para reprovar a última pichação eleitoral, tendo sido depois levado para uma delegacia, acusado de atentado ao pudor.

\section{Legenda}

O Masp no Orangerie do Louvre: obras verdadeiras contra falsas noticias

66 Bardi relacionará, mais tarde, Zózimo a Gilberto Chateaubriand

\section{Casa Vogue \#3, maio-junho de 1985, p.78 (P.M. Bardi)}

\section{COMO DESENHAR UMA CADEIRA?}

Esteve na Faculdade de Arquitetura e Urbanismo da USP para pronunciar uma conferência um dos mais renomados designers italianos, Mario Bellini. Leio sempre seus ensaios na revista Ottagono, de Milão, e um dos mais recentes surpreendeu-me e até propiciou-me lembrá-lo no texto de meu próximo livro Arquitetura e Engenharia na Construção, que será o oitavo da coleçáo Arte e Cultura, iniciativa do Banco Sudameris, que publico a cada ano.

No seu escrito o designer proclamava e demonstrava que desenhar uma cadeira é táo complicado quanto desenhar um computador.

Eis que o problema da cadeira me traz à mente uma infinidade de fatos que 
me ocorreram ao longo do interesse que dedico à arquitetura. Estou escolhendo um, brasileiro, ocorrido em 1946. Vamos então para o começo dos quase quarenta anos de direção do Museu de Arte de São Paulo. As soluçóes para sua implantação foram as mais inéditas: tratava-se então de isolar na estrutura de concreto que o arquiteto Jacques Pilon estava acabando, na rua Sete de Abril, para a nova sede dos Diários e Emissoras Associados, um local para o museu.

A arquiteta Lina Bo projetou o primeiro andar, já idealizado para hospedar o museu planejado pelo senhor Assis Chateaubriand, eliminando a fonte decorativa com esguicho de água então prevista, infelizmente, no projeto, e reformulando a divisão dos mil metros quadrados existentes conforme o plano por mim disposto: uma sala para a pinacoteca em formação, duas para as exposiçóes periódicas e finalmente uma para conter a auditório.

O caso das cadeiras deu-se justamente no auditório: este deveria servir para conferências, concertos musicas e espetáculos de dança, sendo indispensável a possibilidade de retirar as cadeiras em algumas ocasiōes. Em consequência eram necessárias cadeiras dobráveis paraeventualmente serem empilhadas. Foram convocadas as indústrias paulistas para prover $\mathrm{o}$ fornecimento. As propostas foram inaceitáveis, pois a mentalidade da decoração da época ainda era baseada no estilo do Culturalismo. Foi assim necessário estudar uma cadeira dobrável. Lina desenhou-a, dirigindo-se aos possíveis fabricantes, porém nenhum quis assumir o trabalho.
Na última hora conheceu-se um tapeceiro, recém-chegado da Itália, Cesare Sarracchi, que aceitou a encomenda e o problema foi resolvido. São Paulo contou então com um dosprimeiros designers na renovação arquitetônica, como se vê na foto da cadeira, ${ }^{67}$ por vários motivos histórica, e aqui publicada.

Tendo assistido à sua gestação, fabricação, escolha da madeira e do couro pode-se confirmar o que diz o arquiteto Bellini de que a tarefa é tão difícil quanto desenhar o mais sofisticado computador.

A propósito, nestes últimos tempos, o Masp recebeu uma esplêndida doação de Léo Seincman, da Probjeto: reforma da sala da direção, com cadeiras e poltronas de autoria de Le Corbusier, que os curiosos podem ver no meu recente livro Lembrança de Le Corbusier: Atenas, Itália, Brasil, edição da Nobel, Sáo Paulo.

Penso neste meu velho amigo e mestre Le Corbusier e também em Charlotte Perriand, sua colaboradora na idealização e construção do mobiliário. Mais ou menos tinha ouvido do arquiteto autor do risco do edifício Ministério de Educação e Saúde, a mesma afirmação de Bellini sobre as dificuldades de se desenhar uma cadeira. Quero acrescentar que tudo é difícil quando se procura a perfeição, ou pelo menos, quando se tenta chegar perto.
67 O que aparece ilustrando o texto de Bardi é um desenho aqua- relado da cadeira de Lina.

Senhor \#215, I de maio de 1985, p.79 (P.M. Bardi)

A Cultura de Alagoas

Alguns perfis do Brasil imperial e republicano iluminam a leitura de um aprendiz de História

Aprende-se a história-história, que relata os acontecimentos decisivos, determinadores do avanço da Nação; para os curiosos de minúcias, é preciso complementá-la com uma infinidade de fatos a serem classificados entre o supérfluo e o inútil, todavia contribuidores da história. Por exemplo: a vida particular de um e de outro participante em cargos ou no dia-a-dia. Foi para o cronista muito divertido passar o fim de semana lendo dez opúsculos dedicados a alagoanos eminentes, de alguns sabendo-se bem pouco, salvo o pintor Rosalvo Ribeiro, naturalmente lembrando Floriano Peixoto e Deodoro da Fonseca.

Foram publicados pelo Departamento de Assuntos Culturais de Maceió, lembrando expressivas inteligências do Brasil imperial e republicano, nos campos literário, musical, militar e científico. Além de Rosalvo, sabe-se da vida de Guimarães Passos, Sabino Romariz, Jayme de Altavila, Heckel Tavares, Aloysio Branco, Arthur Ramos, Carlos Pausilios e Breno 
Accioly. A lembrança é publicada“...Não só com o fim de fazer-lhes justiça no tempo, mas com a ideia principal de trazer aos contemporâneos a ligação com o passado e o orgulho da nossa cultura."

Quando se recebem publicaçóes dedicadas à história dos outros Estados, ficamos sempre confusos, vindo à tona a imensidade da cultura do nosso Brasil, humilhados ao constatar o grau da nossa ignorância.

Para um aprendiz da história da formação nacional, é comovente a descoberta nas antigas fotografias, como uma do poeta Guimarães Passos, "de bigodes ponteagudos e gravata branca” posando num grupo em que está presente Machado de Assis: o alagoano é descrito como um "belo mancebo tropical: alto, elegante, biceps gigante... Quando ria um riso jovial entre a ironia satisfeita e a ingenuidade irônica." De cada um dos evocados, surge uma primeira providência: a descrição física.

Se aprendem curiosas e inéditas novidades também da vida de Rosalvo: o pai, fazendeiro arruinado pela libertaçáo dos escravos, consegue fazer estudar o filho na Escola Imperial de B.A., obtendo a bolsa para Paris, onde, para viver, se defende como vendedor ambulante nos subúrbios, casa-se com uma francesa, volta a Maceió, onde vive ensinando francês, com os conterrâneos considerando-o estrangeiro, a rapaziada caçoando dele como sendo galego.

Uma das figuras que alcançaram reputação nacional, aliás internacional, é Arthur Ramos, por seus estudos, de maneira particular a Introdução à Antropologia Brasileira. Seus pais estimularam no filho uma vocação literária e musical que cultivou exercendo, todavia, a medicina e a ciência, não ligando a quem o acusava de narcisista e temperamental. Sua dedicação: estudava de noite, servindo-se de um cafezinho que chamava de "bonde;" única divagação: no sábado ia ao cinema.

As biografias, quase sempre, não revelam as pequenas informaçóes. Nós, cronistas viciosos do que é segredo, gostamos do detalhe. Assim, como náo contar ao leitor, voltando ao Oitocentos, que Sabino Romariz foge do seminário às vésperas da ordenação, o avô lhe corta a mesada e o futuro poeta romântico dá para beber, "desregradamente" veste fraque e se embriaga com vagabundos nos arredores do rio São Francisco? Versejava: "Nasci pobrezinho qual ave de bosque| Mas tenho uma estrela...| Um cetro...| E nem por império esta estrela não dou.” Parece-me certo, nesta ocasião, lembrar a cultura alagoana.

\section{Legenda \\ Noticias desagradáveis, obra do pintor alagoano Rosalvo Ribeiro, pintada em Paris em I896}

Senhor \#216, 8 de maio de 1985, p.76 (P.M. Bardi)

O PÂNICO DO FUTURO

Enquanto os artistas se afundam na abstração, os cientistas preparam o Apocalipse

Somos, dizem frequentemente, os chamados videntes, inquilinos de uma cultura que algum dia será fatalmente destruída por qualquer bárbaro cataclismo atômico. Os historiadores avançam com palavras de que o desaparecimento das civilizaçóes é fato normal, pois assim como emergem acabam sempre engolidas para, em seguida, qual nova fênix, ressurgir das próprias cinzas.

Em todas as épocas as naçôes vencem e perdem, os impérios surgem para depois desaparecerem.

Lembro que, durante um seminário especializado no discutir iconoclastia cultural, os "Diálogos de Römerberg," em
Frankfurt, o tema proposto foi tratado. A discussão propunha dar "uma visão correta da história para mostrar que todo avanço humano também é a suspensão, a supressão, a transformação, a rejeição e, finalmente, a destruição ao velho. Por positivista que fosse, convicto do incessante avanço da humanidade, (com o que em nada se diferenciava dos iluministas) Hegel constatava, e com razão, os retrocessos no decurso da história, quando ruíram culturas que foram grandes e ricas. E para voltarem aos degraus já antes ocupados, as geraçóes subsequentes teriam de galgar as escadas num esforço penoso e infinito.”

Posto em apreciação o "progresso cultural,” o cientista iugoslavo Ivan 
Ivanjí negou a assertiva: quem se desenvolve é o homem e não a cultura, pois o desenvolvimento nem sempre é um avanço, a cultura transformando-se e se adaptando à situação existencial.

Notou Sigurd Baecker no Vorwärts que, para Ivanjí, "a arte e a cultura são aspectos que embelezam e enriquecem a existência humana, mas não a determinam.”

Lendo o que resulta, em parte catastrófico, dos "Diálogos de Römerberg," somos levados a refletir sobre o destino deste produzir arte e cultura, do pânico com que nos defrontamos em relação ao futuro, com essa contínua corrida armamentista e o possível desaparecimento de tudo que foi construído de bom. O planeta Terra torna-se cada vez mais pobre, inquinado mas os instrumentos armazenados nos arsenais bélicos são cada vez mais mortíferos e destruidores fantasma da guerra rondando ameaçadoramente.

É curioso constatar como prática das artes e da cultura, nossa geração se mostra insensível. Os comunicadores estáo cada vez mais interessados em esquivar-se de temas que abordem crises universais, os referentes aos tremendos problemas sociais, os religiosos superados, artistas que embalam montanhas arquiteturas, detendo-se em formalismos abstratos, o obtuso e o incompreensível ganhando sempre mais créditos.

Parece que a antevisão de tempos de terror não suscita preocupaçôes, ao passo que outra elite, a dos cientistas, vai ganhando corpo, aperfeiçoando os sofisticados instrumentos destinados a realizar o "tábula rasa" da civilização, desta feita não apenas a do Ocidente, mas se espraiando em todos os continentes.

Continua raro o relevo dado às tentativas de recordar-se outros, "diálogos" que incidem mais na realidade voltada para a cultura, como por exemplo o evidenciado em fevereiro deste ano em que três mil delegados, de 42 países, se reuniram em Monte Abu para, no final, aprovar uma Declaração Universal da Paz e cujo primeiro artigo recomenda: "Verei todas as coisas materiais como transitórias e irei usá-las como meio e não meta de vida, e não considerarei seu valor, maior que valores morais. Ao contrário, verei o desenvolvimento moral como sendo de importância fundamental para meu próprio bem e beneficio público e para uma sociedade de paz. Serei honesto, justo e sincero em meu trabalho e não adotarei meios injustos para atingir posiçóes mais elevadas ou riqueza e nem usarei minha posição para um motivo que prejudique alguém.”

Esta mensagem mais parece um sonho.

\section{Legenda}

A Guerra, de Lasar Segall: uma preocupação cada vez mais rara

Senhor \#217, I5 de maio de 1985, p.72 (P.M. Bardi)

ARTES DE UM ESCRIVÃO PÚBLICO

Agradar a artistas e criticos tem sido um dos muitos fardos de um diretor de museu. Mas o importante é saber o momento adequado para investir numa obra pouco conhecida

O cronista, em sua remota juventude, ainda conseguiu ver de perto os scrivani publici, indivíduos que, sentados numa mesa, compilavam, mediante pagamento, cartas para analfabetos. Curiosíssimas as exigências dos postulantes, ansiosos por serem bem compreendidos, aprovando ou desaprovando quando o amanuense lia o que escrevera.

Há dias, disse a um pintor que me pediu para escrever a apresentação para sua exposição, especificando quantas e quais as finezas elogiativas da sua arte: "Você pensa que eu sou um escrivão público?"

Como ele não entendeu, expliquei-lhe aquela função. Todavia, mais tarde, refletindo, considerei-me como um que desempenha a tarefa acima descrita.

De fato: os postulantes não são poucos e, por outro lado, é mais demorado recusar do que segurar a caneta e caligrafar. Uma das incumbências de um diretor de museu é também esta das apresentações, sendo complicado ajeitar os adjetivos, 
parafrasear uma recomendação pouco genérica que, ao mesmo tempo, agrade e não comprometa. Em outras palavras, uscire dal rotto della cuffia, como dizem os italianos, usando uma prosa que, caindo sob os olhos dos críticos, não desencadeia a tradicional reprovação.

Este escrivão público de arte, todavia, no passado, escreveu algumas páginas que agora, na Itália, são lembradas até em livros, seja no setor da arquitetura seja no da pintura e da escultura, especialmente dedicadas a artistas ainda no começo da carreira. Parece-me correto este ato de simpatia para os novatos.

Entre minhas recordações gratas está a de Giorgio Morandi, o qual, no festejo dos seus 70 anos quando a Galleria del Milione de Milão, querendo prestar-lhe uma homenagem através de um livro pediu ao Mestre que escolhesse um crítico para o prefacio e ele respondeu: "Bardi."

De fato, eu preparei o livro, indo especialmente à Itália para isso. Um dos motivos da escolha de Morandi se devia ao fato de que eu comprava suas obras quando quatro gatos pingados se interessavam por ele. É justamente este o tema a que queria chegar nesta página: quando o assim chamado colecionador deve adquirir uma obra.

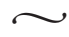

Nas últimas semanas têm aparecido no Masp numerosos jornalistas para comentar as recentes compras de duas pinturas, cada uma totalizando uma dezena de milhóes de dólares: um Mantegna e um Van Gogh. Como os repórteres descobriram que o Museu de Arte de São Paulo possui em seu acervo um famoso painel de Mantegna e bem cinco telas do Holandês, nada mais jornalístico do que interrogar o Bardi.

A uma redatora contei o caso do Morandi para explicar que os momentos dos negócios com obras de arte dependem do acreditar na sua importância e decidir a aquisiçáo imediatamente.

Acrescentei ainda que o Masp conseguiu reunir o Mantegna, os Van Gogh e outras obras, como Raphael, Velazquez, cinco Modigliani etc., explicando que compra de arte a preços convenientes é aventura que, "já era" como se diz, reevocando ainda a ousadia do senhor Chateaubriand e, modestamente, deste cronista, que, com um capital de hoje se dar risada, reunimos o mais importante museu de arte europeia da América Latina.

Para os capitalistas, o argumento é bastante interessante: cheio de surpresas, trapaças, felicidade. No que se refere ao Masp, orgulho-me de dizer: agimos bem, obtendo um bom resultado.

\section{Legenda}

Natureza Morta, da Giorgio Morandi: reconhecimento na hora certa

Senhor \#2I8, 22 de maio de 1985, p.76 (P.M. Bardi)

INTERVENÇÃO NA ARQUITETURA

Um exemplo de recuperação artística e histórica em Gênova

O Palácio Ducal de Gênova é uma das monumentais obras de potentados que, de geração em geraçáo, conseguem dominar um território. Os "patróes” de Gênova governaram durante séculos príncipes de um conjunto arquitetônico do qual, agora, o Museu de Arte de São Paulo documenta, desde o dia I4, particularmente no que se refere aos recentes restauros, realizados com a finalidade de restituir à obra a possível fisionomia que o tempo andou alterando, através de estragos e transformaçóes. $\mathrm{O}$ Palácio funcionou como sede dos duques, depois como República, departamento de Justiça e, finalmente, como Palácio da Cultura, sua atual atribuição.

A história do Palácio é a história de Gênova, inclusive sofrendo incêndios, conjuras e guerras, como o bombardeamento da frota de Luís xiv, com treze mil bombas, no dia I3 de maio de i684. Dois séculos e meio depois, em 1942, outro descarregamento de bombas, desta vez vindas do céu, foi lançado por uma esquadrilha da RAP.

A exposição promovida pelo Instituto Italiano de Cultura é de grande interesse, 
pois oferece uma informação precisa de como se realizou o restauro arquitetônico, instrutivo para nossos mestres dedicados, às vezes, a recompor edifícios históricos. Eis a ocasião para elogiar os que reintegraram, recentemente, o Paço Imperial do Rio de Janeiro, de maneira exemplar: uma sede que, como a genovesa, será destinada à Cultura. (A lembrança é oportuna, pois o Paço, em época e situação política totalmente diversas, passou pelas mesmas vicissitudes ao edifício genovês, no começo do Oitocentos, funcionando, inclusive e incrivelmente, como sede dos Correios. O que vale para insistir sobre a responsabilidade própria do Serviço do Patrimônio: conservar tudo o que é história do Brasil.

A metodologia que de certo nos Palazzo Ducale foi bem elaborada, levando em conta sua história. Eis as diretrizes do método, nas palavras da doutora Ida Maria Botto: "O restauro de conservação deve ser ligado a uma metodologia unitária, conduzida de maneira a que o restauro arquitetônico e o restauro estético se completem e atinjam uma unidade ideológica dada a importância do conjunto do edifício dentro do tecido urbano e da história da cidade. Na primeira intervenção procedeu-se à consolidaçáo de todas as paredes, estuques incluídos, à extração dos sais, à limpeza, à reparaçấo das zonas onde faltavam os estuques, à preparação $\mathrm{e}$ douradura dos estuques, ao restauro pictórico de cada elemento ao verniz e à patina."
Operando de uma maneira propícia a restabelecer o conjunto como ambiente dando-lhe nova função, constituído um laboratório interdisciplinar para definir os trabalhos, cuidando de uma infinidade de projetos, evitando o convencional, enfrentando os pareceres contrários, como é praxe em todos os restauros de monumentos.

A intervenção no Palácio se relacionou com a solução de reconstruir o contexto do quarteirão tradicional, como expressão da Gênova dos tempos da República. Baseados em pesquisas de arquivo, nas sondagens de terreno e valendo-se de leitura histórico-crítica dos espaços, procurou-se realizar a antiga cittadella, conjunto de comando e, na eventualidade, de defesa.

Observando a sequência dos restauros e remodelaçôes da famosa arquitetura, cada seculo adaptando-lhe os estilos em voga, verdadeiros assaltos estéticos, é possível julgar como foram resolvidos os problemas das estruturas. Outro resultado a observar é a solução de criar um espaço histórico atribuindo-lhe funçóes de atualidade, pondo em prática a lembrança cívica da Memória e, ao mesmo tempo, o lugar de convívio destinado à Cultura, que será denominado, "Centro Regional dos Bens Culturais" rico, como é possível imaginar, também, em aparelhamentos de informática.

\section{Legenda}

Palazzo Ducale: novas funçóes

para um velho monumento

Senhor \#219, 29 de maio de 1985, p.92 (P.M. Bardi)

A IMPORTÂNCIA DO CÁLCULO

Uma visão "excêntrica:" a arte da matemática na arquitetura

Foi realizada, na algum tempo, uma passeata de engenheiros na avenida Paulista, que culminou com a colocação de três grandes ovos no Belvedere do Masp para chamar a atençáo para os problemas da classe no setor da consultoria, que envolve várias categorias profissionais como: arquitetos, agrônomos, geólogos, economistas, técnicos e desenhistas, situação que havia sido discutida num animado seminário nacional realizado no Anhembi.

A passeata não provocou na imprensa as reaçóes esperadas.
A engenharia incide hoje na vida brasileira, como aliás na de todas as naçóes, de maneira básica, pois, desde a construção civil até a informática, a presença daqueles que Le Corbusier apelidava “profissionais do cálculo" é indispensável.

Tive ocasião de me interessar pelas relaçóes Arquitetura-Engenharia, justamente no caso da posição do articulador do Racionalismo, chegando à conclusão de que o projetista de uma construção acaba pontualmente confiando o plano técnico a quem é responsável pelo cálculo estático. Escreveu Le Corbusier que se deve admitir 
que, para o criador da forma, as observaçóes do engenheiro podem até provocar emoções, pois "nos dão a medida de uma ordem que sentimos em consonância com a ordem... da lei do universo.” Em outra definição do arquiteto se aprende: "Estética do engenheiro e arquitetura são duas coisas solidárias, consecutivas, uma em pleno florescimento, a outra em penosa regressão."

O motivo é sempre o mesmo: a evidência para quem desenha a fachada, e o desconhecimento do cálculo da estrutura.

Este cronista sempre se preocupou em associar o idealizador de um edifício com quem faz o cálculo do mesmo, o que parece mais correto, apesar de náo ocorrer normalmente. (E considero aqui tanto as esplêndidas criaçóes de Niemeyer para a nova capital, calculadas pelo engenheiro e poeta Joaquim Cardozo, como o palácio do agora Museu Paulista, no Ipiranga, dando ao arquiteto Tommaso Gaudenzio Bezzi e ao construtor Luigi Pucci a mesma importância.) E, já que se lembram os museus, cito ainda o Masp, desenhado por Lina Bo estruturado esplendidamente pelo cálculo de José Carlos de Figueiredo Ferraz.

Para voltar a Le Corbusier na placa que lembra o "risco" do então Ministério da Educação e Saúde, no Rio, em I936, atribuindo-lhe a arquitetura, na lista do grupo de arquitetos colaboradores, falta o nome do engenheiro.

O autor de Vers une Architecture, naturalmente em consequência da sua definição da casa como machine-à-habiter, por desgraça recebeu acusaçóes de ter-se comportado como engenheiro em vez de arquiteto, relatando: "Pessoas refinadas, habituadas aos salóes, (em Paris ou nos
EUA) qualificam-me hoje de arquiteto 'barroco.' É a mais atroz designação que me possa ser conferida. Tratado de ‘engenheiro sujo' em I920, (eu o aceitava) eis-me aqui no outro lado dos infernos - nos extremos...! Talvez seja uma felicidade ainda ser xingado aos 70 anos!!!"

Os avanços do Modernismo na arquitetura também no Brasil teve os seus opositores. Citaria como o mais aguerrido José Mariano, que atacava o responsável pelo "risco" como um "destruidor da cultura," dizendo: "As ideias pessoais do arquiteto sobre os problemas da arquitetura moderna, ideias conhecidas e surradas que ele repete inexoravelmente no curso de suas tournées remuneradas com o caráter de novidade originalíssima, foram a tábua de salvação de todos os náufragos da profissão arquitetônica... discípulos fanáticos."

Curioso: nunca foram ouvidas reprovaçôes para os engenheiros, e para concluir: nem reconhecimento. Mas isto é comum. $\mathrm{O}$ nome de um arquiteto que projeta um palacete é decantado; o do engenheiro que possibilitou sua estrutura, nada, assunto reservado.

Quando, nos meus tempos, a polêmica para uma nova arquitetura constituía escândalo, considerar arquitetura um estádio, ${ }^{68}$ um hangar, uma barragem hidrelétrica, às vezes, esplêndidas obras de autêntica arquitetura, era também visto como julgamento excêntrico.

\section{Legenda}

O Masp: projeto de Lina Bo e cálculo de José Carlos de Figueiredo Ferraz

68 Bardi sofreu críticas por ter considerado obra-prima o estádio projetado por Nervi em Florença. Cf. p.I74 deste Anexo.

Senhor \#220, 5 de junho de 1985 , p.76 (P.M. Bardi)

A PRONTIDÁO DOS PENETRAS

Como enfrentar a astúcia aos vendedores de obras falsas

Nas Dissertazioni Sopra le Antichità Italiche se lê: "Até nos tempos antigos, vivente o próprio Santo Agostinho, não faltaram falsários e impostores os quais, por amizade, distribuíam às pessoas muito crédulas relíquias adulteradas de Santos e, o que é pior, vendiam-nas conduzindo um mau mercado, lucrando com tais astúcias... O fato de serem tão ávidos os Cristãos por tais tesouros fazia-os receber tudo o que tinha aparência sob o nome de algum Santo, sem perceberem se o perigo era o de se enganar ou serem 
enganados, nem se verdadeiros ou falsos eram os milagres gabados pelos espertos..."

Cada vez que um ou outro aproveitador me procura para submeter ao "professor" (repito que eu náo sou professor de nenhuma matéria, a não ser a de saber defender-me do pessoal Speculum cerretanorum) obras ou pastiches de arte, o trecho da prosa de Ludovico Antonio Muratori - que transcrevo do terceiro volume do citado livro, publicado em Nápoles em 1783 (se houver leitor curioso, a página é I22) como dizia, o ditado me volta à memória. Aliás, é por tê-lo mastigado bastante ao longo da carreira que o repito agora.

$\mathrm{O}$ mais simplório dos tais que me procuram conta logo uma história, mimetizando origens, currículo, singularidade do produto apresentado, quase sempre pintura. Se o presumido autor da peça figura no Benezith, as apreciaçôes explodem; se, por acaso, o autor resulta na bíblia dos valores, isto é, em alguns Mayer: apriti o cielo.

Minha tática é deixá-los exaltar o quanto querem, lembrando, ao perceber que a pintura é uma falsificação, ou não, da máo do decantado mestre, volto ao meu Muratori, na página em que conta: “...Aos bons Casinenses foi aplicada uma solene burla por parte daqueles vagabundos monges, quer dizer que, em vez de uma relíquia, foi dada uma partícula de tela...” isto é, uma tapeação por parte dos malandros travestidos de padres.

Conto essas histórias para anotar que, nestes últimos anos, o comércio da mercadoria arte em São Paulo, capital de todos os comércios, tornou-se um favorável campo de ação, talvez consequência das peripécias da economia, com os ricos descobrindo que “arte é investimento." Não de prazer espiritual mas por cobiça do ouro, como ocorria nos tempos da Colônia com as minas ou com os campos de cana-de-açúcar. Hoje os amantes da moeda descobriram a pintura.

Li no Folhetim da Folha de S.Paulo um ensaio do professor Flavio R. Kothe, assim encabeçado: "O único modo de entender as vanguardas é não entendê-las como elas se entendem: afinal, elas mesmas não se entendem, mesmo sendo extremamente espertas em termos de mercado."

Então até as vanguardas participam do negócio? Afinal, é o momento da descoberta da arte como matéria de Bolsa.

Não estou tão fora do assunto para não pensar em comércio de arte. Se hoje o Masp possui uma Pinacoteca que vale mais de US\$ 700 milhóes foi o Bardi que arranjou, gastando o equivalente ao primeiro algarismo daquela soma. Todavia, hoje náo entendo quase mais nada do mercado de arte. Como acontece no desenvolver da moda, os "penetras" estão de prontidão, e entre eles os que sabem contar vantagens. Nos tempos evocados por Muratori, os aproveitadores não viviam o castigo da inflação.'

Seja como for, bem ou mal, acabaram os anos em que era impossível concentrar a atenção, no Brasil, sobre obras de mestres. Adquiri, em 47, o famoso tríptico Retirantes, de Cândido Portinari, por quantia irrisória, até parcelada. Hoje tem gente que pagaria mais de Cr\$ 2 bilhóes por essa obra.

Já vi pinturas do generoso de Brodósqui falsificadas. Naturalmente, pensei no meu socorrista de tópicos jornalísticos, bibliotecário da Ambrosiana de Miláo, emérito fundador da crítica histórica.

Senhor \#22I, I2 de junho de I985, p.73 (P.M. Bardi)

DESIGN: O VOO DOS PIONEIROS

Uma conferência no Instituto Tecnológico da Aeronáutica desencadeia reflexóes

sobre a arte de projetar avióes. Ideias que vão render uma exposição no Masp

O leitor (se houver) já compreendeu que os tópicos desta página são ocasionados por encontros e miniaventuras do dia-a-dia do redator. Às vezes se relembram crônicas do passado próximo e personagens, para sublinhar uma ou outra empresa considerada de um certo interesse.
Como é o caso de agora. Motivo: convidado a conferenciar sobre arte no Instituto Tecnológico da Aeronáutica-ITA, me achei envolvido em problemas nada menos que aviatórios, surgindo a lembrança do meu encontro com um idealista que só imaginava e criava fatos novos com grandiosidade, o senhor Assis Chateaubriand. 
Dele, desembarcando da Itália, sabia somente ser o dono de dezenas e dezenas de jornais e de dezenas e dezenas de emissoras de rádio, um discutido propulsor de açôes para o Brasil ao futuro.

O Visionário positivista d'amblé me confiava a tarefa de organizar um museu de, "arte antiga e moderna" tarefa à qual estou ainda me dedicando. Em 46, a dita empresa, numa capital quase esquecida da Semana de 22, podia ser registrada como aérea, isto é, a se perder no ar. Sem lembrar que o Masp, hoje, é uma entidade que honra internacionalmente a Nação, eis que no auditório do ITA tive ocasiāo de evocar a Campanha Nacional da Aviação, da qual o proprietário dos Associados foi o esplêndido animador.

A campanha, iniciada no governo de Getúlio, estava em pleno desenvolvimento. Chateaubriand me enfiou no seu aviãozinho particular, aterrissamos não me lembro em qual aeroclube, e me convidou a batizar um paulistinha registrado sob o nome de "Giuseppe Garibaldi."

Foi um acontecimento singular como a conferência no ITA. Revirava-me a cabeça falando de Rafael, Goya, Picasso e Cândido Portinari, de radiografias de pintura, de obras falsas e autênticas. Depois, quando Maria Helena Chartuni tratou de casos de restauro, e da recomposição no Masp da cerâmica de Nossa Senhora Aparecida, destruída por um pobre enlouquecido, tive mais possibilidade de refletir sobre o fato de estar em São José dos Campos, no internacionalmente famoso ITA.

A reflexão verteu justamente na participação do meu caro dr. Assis empreendedor e, interligado a personagens de exceção, eis também que penso em Santos Dumont contornando a Torre Eiffel, o engenheiro Carlos Euler que em 1903 publica a monografia Consideraçóes sobre o voo mecânico, o maranhense João Auto de Magalhães ideador do dirigível alongado Ornictóide e tantos outros pioneiros, até o comitê de três membros (Paulo de Frontim, Coelho Neto e o marechal Bernardino Bormann) instituído pelo comendador Garcia Seabra para criar a primeira fábrica brasileira de aviôes: todos eles parte da história da indústria aeronáutica brasileira, aprendida na bem documentada monografia de Roberto Pereira de Andrade. Para concluir: devo fazer saber que, nos anos 30, tempo em que dirigia a Galleria d'Arte de Roma, apresentei uma exposição dedicada a já ativa aviação italiana, animada por Balbo.

Vou propor-me a organizar uma mostra do design brasileiro da náutica. Afinal, no Masp, continuamente apresentamos resenhas assuntos interligados à tecnologia.

\section{Legenda}

Desenho do primeiro monoplano brasileiros experimentado em igro (SP) Santos Dumont, por Theo, em igro (Paris)

Senhor \#222, I9 de junho de 1985 , p.76 (P.M. Bardi)

UM PASSEIO PELO BRASIL

Fotos tiradas antes de 1900 revelam um país desconhecido

A Fundação Nacional de Arte e a

Pró-Memória publicam, em conjunto, um importante volume que dá conta da arte da fotografia no Brasil no período I840-1900, distribuído em Sáo Paulo pela Editora Ex-Libris e realizado sob os cuidados de uma equipe coordenada por Pedro Vasquez, João de Souza Leite, Solange Garcia de Zuniga e Vera Bernardes.

Trata-se de um espetacular passeio pelo Brasil oitocentesco, edição refeita e ampliada da primeira pesquisa sobre fotografia que, em 47, o decano ciestes estudos, Gilberto Ferrez, publicou na Revista do Patrimônio Histórico e Artístico Nacional. $O$ acréscimo à citada publicação constitui um conjunto de fotografias, um quíntuplo dos precedentes itens, que apresentam a atividade desenvolvida naquele período: material precioso, ilustrador da vida nacional.

A pesquisa foi muito laboriosa, pois a consideraçáo do material fotográfico é de interesse recente, porém o que foi encontrado compóe um panorama geográfico e sociológico de alto valor, fornecendo uma documentação do cotidiano, desde as primeiras tentativas fotográficas no Brasil.

Neste volume poderia ficar mais esclarecida a participação de Hércules Florence. Em 77, tomei a iniciativa de publicar, nas ediçôes do Museu de Arte de São Paulo, a Viagem 
fluvial do Tietê ao Amazonas, realizada entre I825 e I827, onde se lê, na parte biográfica, que foi em I832 que Hércules Florence intuiu a possibilidade de fixar imagens em câmera-escura, por meio de um elemento que mude de cor, por ação da luz, e, com a colaboração de boticário Joaquim Corrêa de Mello, pensa em formar, sendo francês, a palavra photographie, confeccionando uma câmera-escura numa pequena caixa. Escreve em seu Diário: "Queira Deus que se possa imprimir com a luz e se obtenham exemplares coloridos."

Após seu invento, a máquina apareceu também no Brasil. Profissionais e anônimos produziam chapas e mais chapas, crescendo o número de adeptos.

Quem tem um destaque singular na história da fotografia é Marc Ferrez, ao qual se deve o mais completo trabalho a respeito, uma excepcional documentação.

Desde que abrimos o Masp, em 47, uma das escolas inauguradas foi a de fotografia, sob os cuidados de Thomas Farkas, hoje da Fotoptica.

E nestes últimos decênios a arte fotográfica tem brilhado, recrutando elementos de valor, reconhecidos também no estrangeiro.

No livro em foco, temos uma esplêndida iconografia das cidades em formação, as tradições que se formavam e um significativo retrato da realidade humana. Tudo bem fixado no papel, a começar pela antiga capital, o Rio. São vistos históricos edifícios, cenas de mercados, dom Pedro II e a Imperatriz posando e vários personagens. Vemos portos, ruas, praças, estaçóes e até uma fotografia utilizada num anúncio publicitário por Ângelo Agostini na sua revista $A$ Vida Fluminense, em i870, curiosidade dos primórdios da propaganda, naquele tempo relegada à gráfica de tipografia.

Se do Rio de Janeiro, onde a coleção de fotografias é logicamente mais rica, passarmos para São Paulo, a mudança é para uma cidade, ainda não-metrópole: nossas estradas de dimensão modesta, sabor de província, poucas as igrejas, o viaduto da Grota Funda na Serra de Cubatão, numa esplêndida, antecipadora e modernista chapa de Marc Ferrez. Ele é o mestre: enquadra visóes com perspectivas das mais animadas; fixando a vida, escolhendo pontos de vista originais, panorâmicas singulares. O título de mestre lhe compete.

Também os outros Estados, sempre sob a objetiva de Ferrez, aparecem documentando sua vivência, como por exemplo o Paraná. Em Santa Catarina, distingue-se J. Otto Niemeyer. No resto do País, outros profissionais e anônimos ilustram o Brasil da época.

O livro termina justamente com uma lembrança de Marc Ferrez, o pioneiro que em I865 abre seu laboratório no Rio de Janeiro à rua São José, oferecendo a "especialidade de vistas do Brasil."

\section{Legenda}

Casa no interior do Paraná, fotógrafo anônimo do fim do Oitocentos

Senhor \#223, 26 de junho de I985, p.IOI (P.M. Bardi)

O MANSO LEÁO DAS ARTES

O Imposto de Renda e a participação cívica dos empresários na cultura nacional

Todos sabem: o presidente José Sarney, acadêmico de Letras, logo depois da posse, preocupou-se com um dos numerosos, aliás, numerosíssimos problemas aflorados em Brasília pela implantação da Nova República. Uma das preocupaçôes foi a instituição do Ministério da Cultura, através do desdobramento do MEc. Nomeado José Aparecido, o aplauso dos intelectuais foi unânime. Depois foi atribuído ao ministro, numa misturada política, o cargo de governador da Capital. Conhecem-se as consequências: convite a Fernanda Montenegro, a qual, valendo-se de seu bom senso, não aceita o ministério para desteatralizá-lo, produzindo-se assim a costumeira corrida para ocupar o mandato. Os impasses se resolveram e, agora, o ministro é o prof. Aluísio Pimenta.

Pelo que se soube, uma das primeiras providências foi atender à permanente questão baseada no pedir mais verba. Ao que parece, o presidente, justamente, vai socorrer a Pasta, pois, como se disse, uma das preocupaçóes do governo é que, finalmente, funcione a cultura. (Muitos cidadãos insistem: funcione a educação, 
atribuindo às massas populares do Novo Brasil os meios para que se solucionem de uma vez por todas o analfabetismo e o caso da instrução primária, a começar pela remodelaçáo dos ordenados dos professores. De fato, é um escândalo saber quais são seus honorários num país onde mordomos, marajás e paxás conseguem vistosas prebendas.)

Voltando à ação do presidente: uma lei por ele proposta em março passado está transitando no Congresso para dar à cultura, um dos incentivos, talvez o mais prático, esperado e já objeto de favoráveis apreciaçôes.

O Artigo Io legisla: "A presente lei dispóe sobre benefícios fiscais na área do imposto sobre a renda atribuídos a operaçóes consideradas de caráter cultural ou artístico. Parágrafo único - Os benefícios previstos nesta lei não excluem nem reduzem outros benefícios ou abatimentos, nem afetam a dedutibilidade de despesas operacionais ou de publicidade ou propaganda, assim regulados pela legislação vigente, integrando cumulativamente o limite máximo de 50\% de deduçóes permitidas em lei.”

Em outras palavras: aquele que tem a ver com fatos culturais, em qualquer área, é beneficiado no Imposto de Renda, encontrando não bem um leão, mas um bípede compreensivo, lembrando a justificativa do senador Sarney: permite "às empresas deduzirem até $20 \%$ do imposto de renda devido para aplicação nas atividades culturais, e coloca-se apenas, ao seu alcance, a possibilidade de, intervindo no processo, acelerarem o crescimento cultural do País e o estabelecimento de estruturas mais sólidas e permanentes para esse crescimento."

A justificativa do presidente deve ser considerada, pelo conceito de valor que se dá à Cultura, um autêntico manifesto inaugurador das possibilidades de um futuro real para a participação cívica na estruturação da cultura nacional. Não em termos burocráticos e, como às vezes sublinha Joelmir Beting, com seu, "mini-sterio," mas factivamente, num impulso nacional. Quero dizer: naturalmente sem decretos que, para dar vida à Cultura, pouco servem. Serve a lei proposta que todos esperam ver sancionada,o mais cedo possível.

\section{Legenda}

O Masp foi construído através de doaçôes de entidades e particulares. Agora, sancionada a Lei Sarney, pode-se repetir um destes casos?

\section{Casa Vogue \#4, julho-agosto de 1985, p.76 (P.M. Bardi)}

ENGENHARIA, ARQUITETURA E ARTE

Estou preparando mais um livro da coleção Arte e Cultura, editada pelo Banco Sudameris, desta vez dedicado a um tema que me parece de um certo interesse: Engenharia e Arquitetura na Construção. Será o oitavo volume que publico naquela coleção. Irá tratar da história das duas profissóes, relaçóes, solidariedade, encargos e o quanto é possível contar com simplicidade, sem descobrir nada de extraordinário. Será uma escolha de notícias da construção no Brasil, a começar pela atividade dos engenheiros militares, idealizadores e fabricadores das poderosas fortalezas, os canhóes contra as flechas dos nativos, depois reservadas também aos invasores que tentavam expulsar os portugueses. São fortalezas que ainda existem no Norte e Nordeste e se constata, pelo que restou, se tratar de grandes arquiteturas do estilo convencional usado no Quinhentos pelos ibéricos.
Arquiteturas? É justamente a classificação que me intrigou na lembrança, o estabelecer o quanto de estética é possível descobrir nas construçóes da danada utilidade das armas. Por consequência também nas obras viárias, portuárias, industriais e, hoje em dia, nos monumentos hidrelétricos, nas centrais atômicas, e até nos próprios implantes para o lançamento dos mísseis, isto é, atividades atribuídas aos engenheiros, não só da construção mas dos mais variados ramos. Todavia eles também dependem dos arquitetos. Uma barragem é uma obra de engenharia e, ao mesmo tempo, é uma arquitetura. A atribuição da arquitetura, como se sabe, é geralmente reservada as obras religiosas, aos palácios e palacetes, as moradias. No meu livro trato também dos refúgios populares, até das favelas, dado que as primeiras ilustraçóes se referem às cabanas dos americanos. 
Foi interessante acompanhar o impulso dos centros mais populosos, especialmente o operoso trabalho dos construtores de igrejas e conventos, esplêndido manuseio do estilo barroco no Seiscentos e Setecentos, consequência da capacidade, aliás, do valor de arquitetos e mestres-de-obras vindos de Lisboa e de elementos que aqui se improvisaram e se formaram.

Nos dois séculos o incremento edílico foi realmente extraordinário: aldeias tornaram-se cidades, os edis erguem as conhecidas "Câmaras e Cadeias," abrem-se muitas estradas. Os construtores são chamados aos latifúndios para criar casas- grandes e senzalas. Será no campo que aparecem os capacitados a implantar o engenho para triturar a cana-de-açúcar.

Engenheiro? Evidentemente o título lhe pertence. De fato o fazendeiro que mexe com açúcar é chamado de "engenheiro." No campo desenvolvem-se histórias singulares: colonizadores, bandeirantes, simples trabalhadores, caçadores de minas, especuladores e tantos outros sujeitos representam uma estirpe heterogênea sim, mas de qualquer jeito são os estruturadores do Brasil. Engenheiros construtores de pontes, aperfeiçoadores de maquinários, arquitetos projetistas de capelas, templos, catedrais, palácios: todos merecedores de lembrança nos tempos do barroco. Depois que Napoleão provoca a fuga de João vi, o Oitocentos reserva às duas profissóes as incumbências que na Europa já eram fixadas na frequência das escolas. Será o século da vivência do industrialismo e, através do aparecimento do concreto armado, arquitetos e engenheiros reúnem-se em combinaçóes.

Estabelecer as tarefas do arquiteto e do engenheiro, diria, do esteta e do calculador das construçôes, foi se aventurar num assunto de difícil consideração. De qualquer jeito enfrentei-o, encontrando ilustraçóes curiosas. E os leitores irão julgar.

Anúncio divulgando a abertura no Museu de Arte de São Paulo da exposição "Queijo e Vinho" escandalizou aquela camada de elitistas da Arte que veem, através do próprio binóculo, somente as elucubraçôes dos devotados artífices das manifestaçôes da Beleza, (vi numa revista este respeitado substantivo com a apêndice: "sem ela tudo está perdido”) descartando qualquer possível parentesco desta sagrada com as vulgares atividades cotidianas.

Este cronista é réu em numerosos atentados à Beleza, pois numa vitrina do Masp já coloquei antigas ferramentas de marcenaria, e por outro lado, viu-se, no passado, mostras ilustrando fatos não exatamente enquadráveis, aliás incompatíveis com o funcionar de um museu, ficando o Masp muito afastado do Culto do moderno, aliás do extramoderno.

Será excêntrico apresentar uma mostra de embalagens japonesa ou computadores e robôs que desenham arquiteturas, ou ikebana etc.? Fui duas vezes ver uma exposição realmente a mais entusiasmante deste 85: o "Exotiquarium" composto de uma série de 34 aquários no Morumbi Shopping. Arte? Ver peixes, animais, natureza, pôr-do-sol, chuva, neve etc. é sair do ponto de partida para apreciar Arte. Não me acusem de respeito ao verismo e desrespeito ao abstrato.

Assinalo uma outra exposição muito singular que está entusiasmando crianças, no Centro de Lazer da Fabrica da Pompeia. Escreve no catálogo o presidente do Sesc, Abraam Szajman: "A vida urbana vai distanciando cada vez mais a criança doa bichos. Acabam por conhecer somente os cachorros e os gatos, os passarinhos presos nas gaiolas que assim mesmo cantam, náo se entende porquê. Ou os insetos, pequenos e grandes, vítimas de uma guerra sem tréguas de uma infinidade de produtos, ameaçadores como canhóes, que são anunciados por toda parte e que enchem as prateleiras dá todos os supermercados."

Estão em cena, neste "entreato para a criança” os insetos. Causou surpresa ver no cartaz da exposiçáo uma borboleta ao lado de uma barata. Este bicho é considerado indesejável mas, observa muito justamente o senhor Szajamn: "Mesmo os chamados 'nocivos' têm o seu papel no táo falado, tão mal-compreendido e tão pouco preservado equilíbrio ecológico. Até nos bichos perigosos - a cobra! - é possível descobrir uma, beleza, quem sabe uma poesia que ajuda a desenvolver a sensibilidade, a curiosidade, 
a vontade de saber, ainda que de longe, com cuidado para evitar uma mordida..."

A manifestaçáo é muito visitada e a

Fábrica da Pompeia tornou-se um invejável centro de lazer popular, consequência do interesse que reserva às apresentaçóes de agrado para acriança bem como para a criança adulta: considerar o restrito da arte nas suas interferências com a vida.

Senhor \#224, 3 de julho de 1985, p.73 (P.M. Bardi)

Algumas PISTAS PARA CERCAR O TRABALHO DE RENOIR

As cinco obras do mestre, expostas no Masp, são indispensáveis para qualquer

retrospectiva internacional. A opinião é de experts de Paris e Londres

Esta página se vai tomando um relatório de fatos penso que curiosos para os interessados no andamento das artes, no qual o redator se mesclou. Esta semana está em cena Renoir e, naturalmente, o Masp.

Finalmente a imprensa, quase que de improviso, descobriu que o museu paulista goza da prerrogativa de continuar em condiçôes de participar com obras do próprio acervo nas maiores exposiçóes internacionais, como é o caso da retrospectiva de Pierre-Auguste Renoir, inaugurada pelo Arts Council of Great Britain em Londres, transferida agora para Paris no Grand Palais, para depois se concluir no Museum of Fine Arts de Boston.

O curioso para o diretor do Masp foi constatar a maravilhosa surpresa de possuirmos cinco obras do pintor de Limoges, telas famosas que afirmam a singularidade da arte do impressionista, e que nos foram pedidas pelos organizadores como "indispensáveis" para a celebração do mestre. Neste último meio século ele não gozava das preferências daqueles personagens que com suas canetas, podem liquidai ou colocar no trono um talento e no caso do desfecho, até um pintorzinho hábil no marketing publicitário.

Renoir teve suas sangraduras. Angélica de Morais lembra na Afinal uma que não conhecia, de Louis Leroy, os impressionistas como alvo: "Selvagens obstinados, por preguiça ou incapacidade, não querem terminar seus quadros."

Porém, não é sobre crítica que quero conversar, mas sobre o caso inédito da compra dos Renoir. Não adquiri, nos anos da formação da Pinacoteca, só cinco obras do mestre, mas exageradamente 13 . Motivo: o combinado com o fundador Assis Chateaubriand era que eu estava livre para comprar, para juntar peças que, no mercado internacional, se encontravam a bons preços, em minha opinião passíveis de possível valorização. Assim, julgando conveniente reunir obras de autores "com futuro," (gíria que nós, marchands, ultilizamos) adquiri mais de uma dúzia de Renoir, quase uma dúzia de ToulouseLautrec, meia dúzia de Modigliani e mais de seis dúzias de Degas, para mais tarde remodelar, a meu modo, a Pinacoteca.

Infelizmente o Patrono adoeceu, depois morreu, e, no momento certo de remodelar a Pinacoteca, o pessoal do Conselho Consultivo do Masp proibiu as trocas que andava propondo. Talvez por medo de o Bardi vir a fazer negócios. Seja como for, na minha qualidade de maior doador de obras à Pinacoteca e também como um dos mais generosos em doar dinheiro, reputo-me compensado pelo amor que tangivelmente dediquei ao Masp, homenageando mais uma vez a memória do seu animador, dr. Chateaubriand, na ocasião do esplêndido sucesso dos nossos Renoir na Europa.

\section{Legenda}

Entre as treze obras de Renoir pertencentes à Pinacoteca do Masp está a escultura Vênus Vitoriosa. De cada bronze o Mestre costumava mandar tirar três cópias. A do Masp é a de número 2. A número I está no Petit Palais de Paris; a número 3, no Museu Boymans de Rotterdam. Há outros museus que apresentam a mesma escultura em ediçôes não numeradas.

Senhor \#225, IO de julho de 1985, p.72 (P.M. Bardi)

UM ASSALTO ESTÉTICO

As chances do design brasileiro no mercado internacional

Lê-se no Il Giomale dell'Arte, de Turim, uma entrevista que deveria provocar um debate bastante animado, pois as declaraçôes do arquiteto José Duarte 
de Aguiar, a respeito do design brasileiro, convidam a uma discussão. Ele afirma que o design italiano, depois de um certo apogeu, está no ocaso, e que o brasileiro dança num jardim florido.

É a primeira vez que na imprensa da península onde, há alguns anos, este cronista nasceu se lê uma prosa que interessa o setor das artes dos dois países. Afirma José que o Brasil, hoje em tempos de democracia, levou à direção ao arquipélago dos Estados brasileiros "personagens mais inteligentes e preparados que, certamente, irão favorecer um desenvolvimento autóctone também no setor das artes." E acrescenta: "Já existem muitos arquitetos que estão desenvolvendo pesquisas novíssimas e vocês vấo ver nos próximos anos que o design será seguramente o brasileiro, com primazia mundial."

Temos muita estima pelo declarante para duvidar deste grito de guerra. Que o design peninsular esteja, num certo sentido, não digo estacionado, mas repetidor de conquistas anteriores, parece-me justo. Todavia, pelo que de novidade se observa na revista Ottagono e outras, parece-me que a Itália ainda goza de uma posição e, especialmente, de uma quantidade de operadores no setor industrial determinadores de uma situação que não será fácil atacar.

Todavia, o que vale - e num certo sentido me maravilha e me convence na entrevista de José Duarte - é o propósito de lançar o Brasil num assalto estético internacional. Nada de estranho, pois quem escreve teve ocasião, mais de três decênios atrás, de formar um museu num estilo novo, criando até mesmo escolas, e uma das primeiras foi exatamente a de design. Sendo esta matéria totalmente inédita na Pátria, apelou-se ao arquiteto Max Bill, então um dos mestres do ramo.

A Escola teve pouca duração pois o momento náo estava voltado para a estética. Em contrapartida, a Escola de Propaganda, aberta no mesmo período, foi um sucesso tanto que ainda hoje continua sob o título de Escola Superior de Propaganda e Marketing.

As artes, quando lancei o Masp, estavam, modernamente falando, nos primeiros passos. Devo lembrar que, tendo necessidade de uma cadeira para o auditório do Masp, a não foi possível adquirir um modelo prático e elegante, tendo a arquiteta Lina Bo de desenhar um (aqui reproduzido) e a construção do conjunto ficou a cargo de um tapeceiro italiano recém-chegado.

Hoje tudo mudou. São Paulo possui indústrias que produzem mobiliário de linhas contemporâneas e também o que genericamente apelidamos de decoração, realidade que pode ser comparada à de naçóes mais desenvolvidas.

Voltando a figura de José Duarte, - que considero um designer de capacidade inovadora e que recentemente abriu filial do seu Estúdio em Roma - convidei-o a organizar uma exposição sobre a história do design nacional no Masp. Penso que uma manifestação deste tipo permitirá avaliar a posição exata da operosidade nacional no setor. E servirá também para comparaçóes com o que se cria fora do Brasil, ou seja, será a resolução opinativa do grito do arquiteto brasileiro.

\section{Legenda}

Residência em Uberaba, de José

Duarte Cadeira dobrável do

Masp em 1947, de Lina Bo

Senhor \#226, I7 de julho de 1985, p.85(P.M. Bardi)

O DINHEIRO DA ARTE

O mecenato e a formação do patrimônio do Masp

Nestas ultimas semanas a imprensa se interessou bastante por este cronista que, bem ou mal, (conforme as raras amizades e as muitas invejas) foi o responsável pela formação da coleção do Masp, hoje um acervo que vale cerca de US\$ 700 milhóes e, como noticiou $O$ Estado, foi comprado por US\$ Io milhôes.
O escândalo é que o Bardi sempre se interessou pelo marketing das artes, e ainda se interessa, vendendo atualmente, na galeria do arquiteto José Duarte de Aguiar, em São Paulo, um grupo de pinturas sob as quais está escrito: "Venda em beneficio do Museu de Arte de São Paulo.” 
Fato controlável: este cronista é um dos maiores doadores (obras, biblioteca, dinheiro) do Masp.

Tudo ocorria e corre no silêncio, porém um fulaninho do qual faz até mal dizer o nome protestou porque $\mathrm{O}$ patrimônio do Masp não está tombado. Todos sabem que está, desde dezembro de 1969. O "tal" conta ainda outras bobagens que se baseiam na descoberta de que arte representa dinheiro.

Este desvario pelo mercado de arte, depois das sensacionais altas verificadas nos leilóes pelas pinturas de Mantegna, Van Gogh e Turner, tornou-se assunto do momento. Vejo no Il Giomale dell'Arte de Turim um grito de alarma intitulado: "Uma Cassandra americana: o apocalipse do mercado de arte está fixado para 1990.” O título foi provocado por um artigo do Time que profetiza um crack, consequência do exagerado e, até agora incontrolável, significado econômico da obra de arte após 1960.

O dinheiro faz mais bem do que mal ao artista. A ideia de que dinheiro, mecenatismo e comércio corrompem as fontes de inspiração deve ser descartada. É o que afirmou recentemente Robert Hughes, crítico do Time, no artigo "On art and money," publicado no The New York Review of Books: " ...Meu principal terreno de indagação náo se refere à relação entre dinheiro e arte na influência para com o artista, mas como reflexo no público, que, necessariamente, inclui os artistas e os outros profissionais da arte num conjunto que, nos últimos 25 anos, assumiu dimensôes enormes."

Existe uma relação entre arte e dinheiro que os americanos difundiram e definiram no contínuo sistema de apresentar as obras nos museus com as respectivas somas pagas por elas, exibindo-as a um público hoje condicionado pelo modismo. Corre-se para ver o Velazquez que custou US \$ Io milhóes: maior importância à quantia paga do que à pintura. Uma obra é prima quando é tesouro? Hughes escreve que o museu, em grande parte, hoje substitui a Igreja como ponto de atração da metrópole, tomando-se um mass media em pleno direito.

É de se observar, por exemplo, que o Metropolitan Museum, em I983, teve um público de quatro milhóes e meio de pessoas. No que se refere à metrópole paulista, apesar de também termos no Masp Rafael, Mantegna, Van Gogh etc., estamos náo digo longe, mas acantonados em números bem mais modestos. Isto se deve em parte à escassa divulgação que a imprensa dedica aos fatos realizados. $\mathrm{O}$ empréstimo de cinco Renoir do Masp à grande retrospectiva do mestre em Londres, Paris e Boston não provocou o tantã esperado. O Masp, do ponto de vista de valores, não impressiona. É evidente que estamos a espera de melhores tempos.

E nosso comércio de arte, então, este está na mesma: a descoberta de que Portinari, Di Cavalcanti e Rego Monteiro são autores de valor continua; e Frans Post vale meio milhão de dólares... o Bardi comprou cinco, entre 1947 e I950, por US\$ I mil cada um.

\section{Legenda}

Aspecto da Roma Antiga, do Gianpaolo Panini (I69I-I764), à venda em beneficio do Masp no Studio José Duarte de Aguiar

Senhor \#227, 24 de julho de 1985, p.82 (P.M. Bardi)

O OFÍCIO DA CRÍTICA

O exemplo das mostras didáticas no Exterior

Será montada na bastante ativa Galeria Municipal de Arte Moderna de Bolonha e nas galerias de Rimini, Ravena e Ímola uma série de exposiçóes internacionais que vâo focalizar o quadro das tendências e das linhas de pesquisa e "interpretaçóes parciais” deste decênio. A finalidade é pôr ordem no "clima faccioso e polêmico que se estabelece no círculo da crítica militante na Itália," e ao mesmo tempo individuar os fenômenos gerais, possivelmente definíveis, procurando estabelecer até mesmo as "formaçôes históricas" dos vários grupos de artistas reunidos ao redor de um programa ou de uma poética.

No convite se relaciona uma "trilha esquemática das tendências de caráter geral." Considero de interesse evidente esta classificação: Presença do passado, recuperação dos estereótipos (post-modernos, anacronistas, neoclassicistas francesas, 
arquitetura desenhada etc.); Post-abstração (neo-informal, post-minimalismo, californiano etc.); Expressionismo, espírito selvagem e neoprimitivo; (transvanguarda italiana, Neo-expressionismo alemão, artistas de Berlim, Hamburgo, Colônia, Neo-expressionismos americano, francês, suíço e austríaco); O Lugar Mágico (nova escultura inglesa, new image, new painting etc.); Decoração, "pintura veloz," espírito lúdico (pattern painting, grafismo, novo futurismo, design neomoderno, histórias em quadrinhos etc.)

Observação do cronista: deveria ser reservada uma premiação ao calibrador das tendências e subtendências, obrigando-o a revelar o que entende no aceno aos etc. Outro relevo: a habitual consideração do que se realiza no continente europeu e na América do Norte. A América Latina continua sendo Terceiro Mundo e, como tal, não é admitida na mesa dos poderosos.

Não sou versado no minestrone das tendências da assim adjetivada "arte moderna," que, no que se refere ao Brasil, está provida só em São Paulo de bem dois museus, onde, de resto é possível observar o quanto nossos pintores e escultores procuram novidades, às vezes, originais, infelizmente, sabe-se, também, confundidos com a quantidade repetitiva dos esquemas em moda lá fora.
A resenha que será apresentada na Emília-Romagna terá um certo interesse para quem exerce hoje o complicado ofício da crítica da arte facilitando-lhe as definiçóes dos modos em moda.

Às vezes, leem-se caprichadas prosas entulhadas de numerosos new, difíceis de entender até para navegantes do mar da Atualidade, também dito Moderno. (Aliás: esta indicação valia no tempo da Semana de 22; hoje, já era.)

As mostras na Itália serão didáticas. Curioso será constatar qual a real autonomia dos pintores contemporâneos que sempre oferecem motivos de perplexidade, quando se tenta uma classificação.

É tão difícil julgar. Sem falar dos próprios artistas vestidos de presidentes do Supremo. Por exemplo: Manet sentenciou a Monet, que lhe mostrava uma pintura de Renoir: "Este rapaz não tem o menor talento; diga-lhe que não pinte mais!” E me vem à mente também a prosa de Monteiro Lobato contra Anita Malfatti.

Parabéns ao "comitê científico" de Bolonha para não prendere delle cantonate.

\section{Legenda}

Claude Monet, A canoa sobre o Epte, e Auguste Renoir, Menina com as espigas: a vantagem de não escutar certos conselhos

Senhor \#228, 3I de julho de I985, p.I08 (P.M. Bardi)

A AVEnTuRA DA TECNOLOGIA

Memórias de uma atividade que não pode prescindir do estimulo do governo

e das empresas privadas. E que desperta muita curiosidade no público

Quando ouço a palavra "tecnologia," o pensar logo se aventura e se perde nos trilhos da última notícia sensacional, recentemente atrás do trenzinho aéreo que se vai encontrar com o Cometa de Halley, já no espaço, viajando não se sabe bem a quantos milhóes de quilômetros. Contam os astrônomos que está equipado para fotografar o cometa e descobrir todo o mistério.

A tecnologia é, naturalmente, aplicada a simples novidades mecânicas, como o robô. No Masp estava sendo ministrado um curso, pelo professor Bernardo Rubinstein, onde um destes aparelhos, recebidos os impulsos de um computador, desenhava no papel planos de arquitetura. É francamente complicado para o cronista compreender esta novidade. Comecei a me espantar, ainda menino, ao assistir ser implantada em minha casa a iluminação elétrica, em substituição aos lampiốes e às velas.

Refiz, a meu modo, a história das descobertas deste século arrancador, uma dessas manhãs, enquanto que, na minha qualidade de membro da diretoria, se aguardava pelo governador Franco Montoro no Museu da Tecnologia, na Cidade Universitária. $\mathrm{Na}$ noite anterior havia sonhado com os andares do edifício (considero-o um espaço convenientíssimo para a tarefa) repletos de objetos, mecanismos, surpresas e até música.

Em vez disso, por mais incrível que possa parecer, o grupo da diretoria, mais uma vez, encontrava-se num espaço vazio: 
estava meditando sobre o que pedir ao governo. Naturalmente verba, para finalmente oferecer ao contribuinte, depois de anos e anos, o lazer da tecnologia, como acontece em todas as grandes capitais: museus visitados por milhóes de curiosos. O governador chegou, viu o deserto do Museu, o engenheiro Francisco de Paula Machado de Campos, deus ex maquina do organismo sem órgãos, pronunciou um justo apelo. Montoro replicou afirmando que, entre as cinco metas do governo PMDB, a terceira é (lupus in fabula) a de "apoio à tecnologia nacional, em substituição a tecnologias e produto importados," expondo amplamente o quanto já realizou e vai realizando nos setores dependentes da técnica e, lógico, das arrecadações. Então?

Minha ideia, como prático em realização de museu, sabendo que o Masp nasceu num edifício em construção na rua 7 de Abril, em 47, e que agora náo vive mais de press-releases, mas tem uma vida ultra-próspera na avenida Paulista, como prático, disse e repito: São Paulo é a cidade da tecnologia, isto é, da indústria e, consequentemente, dos bancos, da criatividade - então, sejam os que manejam o dinheiro a dar os meios para acabar com o maior escândalo da Terra que é não abrir o Museu da Tecnologia, e passar do êxtase para o dinamismo, organizando uma grande Feira da Tecnologia.

Há muitos anos, no Masp, inaugurei uma exposição dedicada a máquinas e instrumentos do Brasil antigo, conseguindo apresentar até um esplêndido engenho de açúcar: um sucesso sem igual.

Vamos então romper o gelo e inaugurar o Museu da Tecnologia com uma feira

\section{Legenda}

O abandonado Museu da Tecnologia na

USP: um escândalo incompreensível

Senhor \#229, 7 de agosto de 1985, p.8I (P.M. Bardi)

UMA SAÍDA CRIATIVA

O trabalho cultural aos publicitários

Atribui-se ao nosso século a singularidade da tecnologia, porém se deveria também dar evidência à propaganda, pois este sistema o caracteriza tanto quanto o outro.

Sem dúvida, a propaganda exerce uma contribuição indispensável na vida contemporânea, não excluída sua participação no andamento das artes. Logo que inauguramos o Masp foram instituídas escolas, sendo uma das primeiras a de propaganda, a qual, mais tarde, destacada dos geradores, promoveu-se como Superior e de Marketing, hoje de nível universitário, fato normal devido à importância da profissão.

A decisão de criar a escola provinha do gosto que este cronista sempre teve pela propaganda. Devo dizer que nos (parece que bem longe) anos 30, produzi até o livro La Strada e il Volante para o lançamento de um carro da Fiat.

De I950, ano das primeiras aulas da escola, até hoje, o desenvolvimento das agências, sua esplêndida eficiência e inventiva, o credito de que gozam, é tudo extraordinário. $\mathrm{O}$ progresso do exercício da propaganda em todos os setores pode ser incluído no avanço constante do Brasil. Curioso: a simbiose propaganda-arte é consequência do interesse que numerosos elementos das artes plásticas demonstraram formando agências, e da criatividade que evidenciou a comunicaçáo publicitária, especialmente no setor televisivo, nas assim ditas publicaçóes de brinde, no muralismo e em tantos outros modos de operar.

Queria notar mais um caso de interesse do pessoal da arte de evidenciar produtos, ideias e até atividades governamentais: o de cuidar de organismos culturais. Temos agora na chefia da Bienal de São Paulo o publicitário Roberto Muylaert. Recentemente foi nomeado presidente do Museu da Casa Brasileira o publicitário Roberto Duailibi. Apesar dos breves períodos de gestão, já se prevê para as duas entidades um resultado significativo. Mais ainda para aquele tradicional certame internacional, que nas últimas performances deu sinais de deficiência, característica habitual e própria deste tipo de manifestação, como também dos salóes que acabam caindo na burocratização e no envelhecimento precoce.

É natural que, para elementos com prática na propaganda, e capazes de liderar uma agência em que o pessoal tem parentesco 
com a arte, a função de dirigir uma Bienal ou um museu represente tarefa comum. Um dirigente de propaganda é, geralmente, um psicólogo, além de um consumado conhecedor de processos administrativos e políticos, é um político que sabe dar un colpo al cerchio e uno alla botte, servindo-me de um provérbio italiano.

O que preocupa os tais que, bem ou mal, se mesclam nesta antiga novidade que é a arte é justamente acertar funções de comando e conseguir meios para a sobrevivência das instituiçóes culturais.

No que se refere a personagens da publicidade, estou certo de que Washington Olivetto, da DPZ, seria um esplêndido diretor do Masp: precisa-se mais de ativistas da novidade do que corriqueiros e corriqueiras funcionárias.

\section{Legenda}

Reuniāo dos professores da Escola de Propaganda do Masp, em 1953: o reconhecimento de uma atividade artística

Senhor \#230, I4 de agosto de 1985, p.80 (P.M. Bardi)

A POSSÍvEL VIAGEM

Novos rumos para o mercado de arte no Brasil

De vez em quando se trata nesta página de um assunto que em Senhor é habitual: o dos complicados problemas da economia, no aspecto em que esta tem parentesco com as artes, mais particularmente com a pintura e a escultura. Há alguns anos, o comércio da arte tem recebido uma certa atenção.

Já se notou um interesse reservado, sob o ponto de vista monetário, pelos mestres nacionais e pelos aspirantes a tais, determinando polpudas cotaçóes, consequência do modismo.

Seja como for, deve-se constatar que a obra de arte se tomou um bem de investimento, ativando nesta metrópole um mercado de consideráveis proporçôes e, sem dúvida, de um consistente futuro: o mesmo que se verificou na Europa e, mais, nos Estados Unidos.

Há dez anos, os leilóes tinham dimensões modestas; hoje, já têm uma certa importância, surgiram dezenas e dezenas de galerias, multiplicaram-se os antiquários, tem-se uma feira semanal deles no Belvedere do Masp, tudo isto confirmando que o Brasil está ajustando seu mercado de arte. Observa-se: existem, então, mercadorias suficientes para comerciar? Existem. Numa destas manhãs tive ocasiáo de dar uma volta no setor. Visitei lojas, mas o que mais impressionou foi a organização mais reputada de São Paulo, a fundada pelo dr. Renato Magalhães Gouvêa: um centro de mercado, exposiçóes, leilóes, restauro, estudo, planejado nos moldes mais apropriados, não deixando nada a desejar frente aos similares estrangeiros.
Nos seus depósitos se encontra um acervo de alto nível em objetos antigos e do século em curso. Para mim, velho prático no setor, um acervo de notável valor, notando-se aí a possibilidade de se iniciar um mercado no sentido internacional, Além de esplêndidos exemplos do Barroco brasileiro, encontram-se muitos objetos preciosos importados, desde mobiliários até pinturas, esculturas, cerâmicas, tapetes, joias, prataria de numerosos centros europeus.

Todo leitor sabe que na Inglaterra funcionam, há dois séculos, casas como a Christie's e a Sotheby's, os magnatas do comércio de objetos de arte, que comerciam até edifícios de arquitetura singular. (A respeito de leilóes: são simplesmente tentativas de novatos a se servirem dos realizados em Nova York para justificar artificialmente os incríveis valores dos pintores da terra. Precisamos de profissionais no mercado, não de improvisados.)

Pergunto-me: na metrópole protagonista de uma imensidade de iniciativas vitoriosas, não é possível prever que proximamente o mercado de arte tome grandes rumos?

Não sou prático nos mistérios da economia; todavia, é possível imaginar o Brasil participando do mercado de arte internacional, sem dúvida conseguindo uma afirmação através de acordos com casas estrangeiras. Até mesmo o turismo se beneficiaria.

Afinal, quando em 47 fundamos o Masp, a decisão pareceu paradoxal. Quarenta anos depois, se nosso capitalismo ainda não descobriu o "negócio," deve-se realmente pensar em cegueira. 


\section{Legenda}

Nossos leilóes e acervos como o de

Renato Magalhães Gouvêa definem

um negócio de nível internacional

Senhor \#23I, 2I de agosto de 1985, p.92 (P.M. Bardi)

A PÁTRIA DOS ESTRANGEIROS

Um país sem revanchismos antropológicos não pode recriar

velhos preconceitos contra os imigrantes

Não entendo de problemas políticos e é impossível acompanhar os atuais pois se mostram bastante complicados para quem não é do galho. Não sendo oriundo, não estou a par das tradiçóes, sendo incapaz até mesmo de decifrar as linguagens, por exemplo, dos candidatos à prefeitura local. De qualquer modo, num palavrear de político, nada menos que do ministro Aureliano Chaves, aprendi um desaforo francamente despropositado em que ele investe contra milhóes de brasileiros, os tais cidadãos que, em vez de se vangloriarem por serem naturais da Terra, deram os primeiros vagidos além do oceano.

$\mathrm{O}$ aposentado vice-presidente da República, furioso, batizou pessoas de bem que para cá imigraram no pós-guerra como "imigrantes cretinos e ordinários que ninguém sabe de onde vieram."

Francamente, possuidor de uma ambiciosa carteira de naturalizado, pensava que o preconceito idiota tivesse sido arquivado desde os confusos tempos oitocentescos da arrancada do País, a qual se verificou justamente graças ao labor da gente desembarcada de navios vindos de inúmeras nações.

Não sei como aqui se traduz a locução italiana perdere le staffe: não é bem o ato de reagir. O cavalheiro se agita, quase cai do animal, grita, se embanana, é cinematografado em situação ridícula e desesperada: o inverso do que ocorre quando um político coloca os pés nos estribos e desfila solene, respeitado e aplaudido por seus eleitores.
Jejuno dos comportamentos, próprios do pessoal que, uma vez proclamado representante do povo circula pelas bancadas do Congresso e do Senado, ocupa mesas de ministérios e, quando pode, até se senta no trono democrático; jejuno, repito, como permaneço, permito-me protestar contra a perda das estribeiras do ministro. Soube do seu encapelamento lendo um artigo em Veja, por acaso, quando estava preparando alguns rascunhos que servirão para uma comunicação, num seminário, a ser promovido pela Fondazione Giovanni Agnelli, em outubro, na Universidade de São Paulo, quando se discutirá a influência dos italianos nas artes brasileiras.

Lembro este encontro para anotar como no Brasil existe cordialidade, sem revanchismos antropológicos e ideológicos. A intenção e a vontade são de se continuar a estruturar o que existe, esquecendo os eventuais - na verdade raros - desaforos (que pena!) do ministro contra imigrados capazes de ação que deram à Pátria contribuiçóes culturais, sociais e econômicas importantes e não cretinas nem ordinárias, que se sabe de onde vieram.

Senhor ministro, saiba que Seneca diz: Patria mea totus hic mundus est.

\section{Legenda}

A saida dos imigrantes, de Angiolo

Tomasi (Galeria de Arte Moderna.

Roma): um fluxo que deu certo

Senhor \#232, 28 de agosto de I985, p.IOo (P.M. Bardi)

UM TERREMOTO ARTÍSTICO

Memórias da Trienal Internacional de Milão

Eis duas interessantes exposiçóes no Masp, apresentadas pelo benemérito Instituto Italiano de Cultura. Uma delas informa sobre a História da Trienal Internacional de Miláo, a outra sobre a obra do arquiteto Alberto Sartoris.
São duas manifestações que relembram ao diretor do Masp tempos singulares da renovação, nos anos 30, da estética italiana, objeto de vivazes polêmicas. Foi o período do desaparecimento, ou quase, do culturalismo, com consequências 
positivas, fatos que se deram lambem no Brasil. Aqui o propulsor foi o russo Gregori Warchavchik, construtor de duas famosas “casas modernistas." Na Itália, isto se deu através de um outro tipo de espetáculo.

Lá, o protagonista foi este cronista, que, sendo diretor da Galleria d'Arte di Roma, organismo oficial, teve a ideia de apresentar os jovens arquitetos da vanguarda anticulturalista numa reunião onde aparecia um manifesto, náo de palavras, mas um tavolo degli orrori: uma colagem de reproduçóes de obras dos arquitetos remastigadores do estilo do passado, entre estes o chamado: "romano imperial modernizado" uma caricatura pontilhada de brincadeiras e de ironia.

Foi convidado para a inauguração nada menos do que o ditador. Veio, surpreso pelo espírito polêmico da manifestação, constatando que, entre as arquiteturas ridicularizadas, estavam algumas de edifícios do regime e calmamente escutou nossos protestos. Foi possível discutir o absurdo de a Itália continuar usando na construção o modo híbrido de recompor os estilos do passado, e ainda mais anacrônico tentar dar popularidade à retórica imperial de Roma.

A Trienal construía então sua sede: um imponente edifício, infelizmente inspirado num pseudo-neoclassicismo. Todavia, foi nesta sede que se deu vida à renovação da estética italiana e, pode-se dizer, da europeia, pela larga e sempre atualizada participação estrangeira. Aliás, em 1930, houve uma exposição organizada pelo Liceu de Artes e Ofícios de São Paulo, chefiada pelo arquiteto Tomaso Buzzi.

Foi uma época de muita operosidade, e um dos participantes mais em evidência, pela açáo polêmica e pelas atividades, foi o profissional que agora mostra sua obra pioneira no Masp: Alberto Sartoris.

Ele deve ser considerado um intransigente no manifestar sua capacidade de arquiteto nos mesmos princípios que foram os de Le Corbusier, Gropius e Frank Lloyd Wright. Deve-se lembrar que, nos tempos da citada polêmica, com a Itália em obstinada mania nacionalista, o que se apelidava de "esterofilia" representava sacrilégio.

Mesmo assim, a Península, favorecida pela atividade da Trienal, conseguiu marcar sua presença na arquitetura moderna. E as duas exposiçóes do Masp registram, então, como se deram os fatos.

\section{Legenda}

Projeto de edifício (Sartoris,1930) g A XVII Trienal é dedicada às cidades I932: Mussolini inspeciona a sede de um evento que renovou a estética italiana Casa Vogue \#5, setembro-outubro de 1985, p.64 (P.M. Bardi)

\section{...E, POR QUE NÁO? Os TRONOS}

Aconteceu-me na longa, dizem até longa demais, andança em busca de objetos de arte para comerciar ou para guardar de lembrança em minha casa.

Um dia, visitando um velho pintor paulista, de retour de Paris, aconteceu-me de descobrir uma das poltronas desenhadas por Le Corbusier bem antigamente, antes ainda dos tempos do congresso de Atenas, em 1933.

A descoberta me levou a recordar tempos de minha juventude, juventude já adulta mas que ainda suportava o bom humor e um certo espírito de pensar a modo mio. Aí me lembrei de Le Corbusier e de algumas brincadeiras organizadas em sua companhia, e da minha tentativa de saber coisas proibidas sobre ele. Entre estas, qual teria sido sua colaboração com
Charlotte Perriand, justamente quando projetava, no seu setor, peças de mobiliário.

Naturalmente, junto com os quadros do pintor, adquiri a poltrona, um cimélio de um tempo ainda em desenvolvimento se meu amigo Leo Seincman continua produzindo aquela peça. Não sei porque, sempre pensei que o desenho fosse, todo ou mesmo em parte, de Charlotte, pois no jeito de abrigar o usuário, tem bastante de feminino: o agradável da comodidade, o prazer da conversa.

E eis que tratando destes assuntos, me ocorre dar notícia de uma outra peça: a cadeira do auditório do Masp, mas do Masp do pré-histórico, que ficava na rua Sete de Abril, quando tivemos a audácia de inaugurar a novidade museogrática, não simples pinacoteca, mas 
verdadeiro centro cultural, num andar isolado do prédio dos Diários Associados.

Passaram, ou vão passando, quatro densos decênios. O sr. Assis Chateaubriand, um magister em açóes audaciosas que não podem nem ser escritas ou, se o forem, será preciso usar carvão branco, deu ordem para que no mês de outubro de 1947 se inaugurasse o Museu, com a solene cerimônia já prevista: o presidente Eurico Gaspar Dutra, ministros, banqueiros, industriais, artistas etc., presentes. Era preciso reuni-los num auditório, sendo indispensáveis as cadeiras para o público.

A mesa para o palco, eu mesmo providenciei: uma solene obra no final do quinhentos italiano, toda entalhada, com tampo de mármore. Mas e as cadeiras? Deveriam ser dobráveis, pois o espaço da sala deveria servir também para exposiçôes. Corremos então por não sei quantas fábricas em busca de uma possibilidade, Nada. Ofereciam modelos que não combinavam nem de longe com aspecto que se deu ao ambiente. Que fazer? Por acaso vem ao Masp, por curiosidade, um tapeceiro italiano recém-chegado, o senhor Saracchi. Sabendo do caso se prontificou a fabricar ele mesmo uma série de cadeiras utilizando o desenho que minha mulher, Lina, havia preparado. Nesta página se reproduz a cadeira, supérstite de uma série de duzentas que, agora, um produtor de móveis quer ressuscitar pois, pelo seu jeito construtivo, representa conveniência, praticidade e economia.
Cadeira. Sentar numa cadeira: o problema é antiquíssimo. Não sei se algum historiador já compilou um álbum para mostrar sua evolução, incluindo, naturalmente, as poltronas, os sofás e, por que não?, os tronos. Eis uma sugestão para os nossos pesquisadores brasileiros: a história do assento no Brasil. Devem resultar trechos de crônica pouco monótonos. Nos tempos modernos, então nem se fala: basta olhar as revistas de arquitetura e decoraçáo com as ótimas novidadesas propostas para sentar convenientemente. Às vezes há autênticas trouvailles e com assinaturas de mestres, ostentando até controle de biólogos.

Vejo nas Notícias Internas Cassina o anuncio de um concurso no Canadá . $\mathrm{Na}$ Universisade de Quebec está aberta uma exposição chamada "A cadeira, um objeto de design ou de arquitetura?" Cassina está presente com um modelo desenhado por Le Corbusier (com Pierre Jeanneret e Charlotte Perriand:) a pequena poltrona modelo LC-7.

Sentar numa cadeira não é uma ação simples. Deve-se dar a importância que o tato merece. O possível pesquisador da história da cadeira poderia revelar, mesmo limitando-se ao Brasil e às importaçôes da Europa, que houve aqui uma extraordinária contribuição, até mesmo de interesse sociológico.

Senhor \#233, 4 de setembro de 1985, p.76 (P.M. Bardi)

Pimenta no VATAPÁ

Um novo espaço para o debate cultural

Recebo um novo periódico: o carioca Espaço Cultural, comunicação inteligente sobre problemas discutidos com franqueza, à maneira bossa-nova dos que têm os pés em dois sapatos e não em vários, como convém aos conservadores.

Visto que a cultura é o leitmotif da folha, é natural um assalto ao ministério que deveria valorizá-la. O título das duas páginas centrais: "Pimenta no vatapá,” síntese das numerosas denúncias à declaração de Flávio Rangel: "O Ministério da Cultura da Nova República é igualzinho à lei de obrigatoriedade do cinto de segurança: não pegou."

Deixando de lado esta velha novidade, o que interessa é uma página dedicada à "Moda do marketing cultural," de Celso Japiassu, distinguido com as atribuiçóes de "poeta, e publicitário." No seu segundo papel, admite que os conceitos da nossa publicidade se baseiam em hard selling, positioning, new wave, gross rating point e o mais recente de marketing cultural. Confessa o poeta: "O leitor vai perdoar a enxurrada de termos em inglês, mas é que 
a profissão é importada e o seu vocabulário instrumental é em inglês mesmo."

Pode ser que o Celso não saiba que, em 50, no Museu de Arte de Sáo Paulo, tentei instituir uma Escola de Propaganda, excluindo o palavreado americano, procurando discutir os assuntos em termos, possivelmente, locais. A tentativa foi feita junto com um personagem que o articulista lembra como czar das comunicaçôes: "...Atendia pelo nome de Assis Chateaubriand. Quem queria ler revistas tinha $O$ Cruzeiro e quem queria ouvir rádio tinha a Rádio Nacional. Ambos cobriam do Oiapoque ao Chui e todos os consumidores estavam ligados em um ou nos dois."

Os tempos mudaram: minha Escola de Propaganda passou a se denominar Superior e de Marketing e a última formada de publicitários realizou sua festa de formatura numa cerimônia alegre e simpática no grande auditório do Masp.

Para programar, as agências contam, só em revistas, com 650 títulos, e a aceitação social mudou: valeu a participação de uma espécie de mecenato, com o patrocínio de eventos culturais. Diz Celso: "Da mesma forma como os bicheiros patrocinam as escolas de samba (desculpem a comparaçáo) para serem respeitados. terem a gratidão do morro, usufruírem a admiração, expandirem sua vaidade. Foi a fase em que Assis Chateaubriand pôde formar o acervo do Masp com doaçóes de empresas, os balés patrocinados, os prêmios literários beletristas."

Eram ainda os anos do Brasil agrícola, (Assis, quando decidiu onde abrir o Museu, disse-me: "São Paulo, lá está o café") a sociedade de consumo estava em sua pré-história, com veículos de propaganda "simples, ingênuos, sem ambição, despretensiosos e pobres. A única diferença para os dias de hoje é que somos complexos, maliciosos, pretensiosos e continuamos pobres."

Vale a pena ler o ensaio no jornal (de astuta propaganda) Espaço Cultural. Permito-me declarar-me solidário com o espírito de um outro ensaio do diretor do Museu do Reinado, Ferdy Carneiro, (designer e jornalista) o qual, lamentando a realidade da nossa museologia, afirma: "Que o carnaval, a antropofagia, a tropicalidade e a mestiçagem da cultura brasileira invadam o espaço até entáo olímpico dos museus."

O colega não está a par do que sempre ocorreu no Masp

\section{Legenda}

Celso Japiassu: um balanço sobre

o marketing cultural no Brasil Aluísio Pimenta tempero forte

Senhor \#234, II de setembro de I985, p.82 (P.M. Bardi)

O SONHO DA CIDADE IDEAL

Os tumultos do progresso criaram a necessidade de reformas totais no espaço urbano. Mas como adequar desejos e aspiraçôes a uma realidade cada vez mais negativa?

Tive ocasião de constatar como e o quanto a corrida do progresso tumultuou vários campos, inclusive um que parecia resistente às inovaçóes: as cidades, e mais, as metrópoles. Todos sabem como é complicado fazer intervençóes no conglomerado urbano, decidir reformas para propiciar uma vida menos congestionada e mais salubre para todos. Desde o tráfego até as moradias, as causas negativas vão impossibilitando os desejos e as aspiraçóes, ficando sempre mais evanescente a "cidade ideal" imaginada pela fantasia dos renascentistas. Um deles, A.F. Doni, preconizava "uma grande cidade... Fabricada num tondo perfeitíssimo como uma estrela."

A ocasião para medir esta corrida se deu no Congresso das Cidades do Futuro realizado em agosto, em São Paulo, quando eminentes urbanistas vindos da China, Europa, Estados Unidos e Japão discutiram o problema. Aliás, quem promoveu a reuniáo foi a fábrica de motocicletas Honda, aproveitando para lançar um concurso dedicado à realidade das motos, visando possibilitar a livre criatividade dos participantes, "tendo em vista o veículo motorizado de duas rodas inserido no contexto urbano das cidades do futuro... Não visando o design deste veículo, mas sim como será seu desempenho sob os mais diversos aspectos da vida urbana, procurando harmonizar o homem e o seu entorno."

Escutando os conferencistas, me diverti lembrando o que se tratou no Congresso 
de Atenas em 1933, para definir e propor inovaçóes na arte da arquitetura e na ciência do urbanismo. Recomendava-se a descoberta de um ovo de Colombo: construir casas em série, com luz, ar e sol como único remédio para reordenar a cidade com bases sóciofuncionais. $\mathrm{O}$ redator desta página integrava então a delegação italiana. Como relatei em meu livro Lembrança de Le Corbusier: Atenas, Itália, Brasil, o patrão foi o lançador da machine-à-habiter. Autor também da Ville Contemporaxru, ele propunha a repulsa radical à estrutura urbana corrente, com bairros e formas de habitação do sistema antigo, pregando reformas totais.

O convidado italiano, arquiteto Marco Cavallotti, secretário-geral da Trienal Internacional das Artes de Milão, contribuiu para as discussóes do congresso paulista distribuindo o volume editado pela Electa e pela Triennale com o título La Ricostruzione della Città, que ilustra a exposição dedicada a Berlim, bastante interessante, oferecendo um panorama das pesquisas arquitetônicas e urbanísticas de requalificação das cidades contemporâneas.
Os interessados, através das publicações especializadas, poderão conhecer as conclusóes ao congresso, e saber que um dos iluminados foi Kenzo Tange, que participou do conclave chefiando uma dezena de seus assistentes. Entre as várias afirmaçóes do Mestre, destaco a seguinte: "Deve-se prever o que vai ser a cidade do futuro, assunto de poetas e de visionários."

Lembro-me perfeitamente que, na antiga reuniáo de Atenas, (éramos quatro gatos pingados e não os 3500 concentrados no Palácio das Convençóes do Anhembi) aquela afirmação foi várias vezes proferida. Sem futurejar, o que se espera destas reuniōes são as diretrizes de um urbanismo de difícil previsão neste final de século em que o progresso chega a jato. Espera-se que, em 1986, a vida do cidadão não seja mais tâo complicada como a deste 1985 .

\section{Legenda}

Kenzo Tange: iluminaçóes de mestre numa conferência do congresso

"Cidades do Futuro," ilustrado por

desenhos de Kisho Kurosawa

Senhor \#235, I8 de setembro de I985, p.88 (P.M. Bardi)

AS TRAPAÇAS DA ARTE

Perdas e danos de um negócio cheio de armadilhas

Vejo na imprensa italiana dedicada à vida das artes, aliás, aos problemas monetários das artes plásticas, crônicas relatando brigas e processos nos tribunais, por crimes e casos de "perdas e danos." Em cena, sujeitos de todas as categorias: falsários, galeristas, corretores, colecionadores e outros metidos nos negócios da mercadoria arte.

Viúvas, filhos e herdeiros de mestres denunciam falsários, às vezes associados a poderosas quadrilhas, um processo depois do outro, sendo atores advogados, peritos, tabeliôes e delegados de polida, além, naturalmente, dos juízes para proferirem sentenças tão modestas que são quase um convite a continuar as trapaças.

Um dos últimos eventos envolveu 50 telas de Giorgio de Chirico, sequestradas de um fulano que foi uma espécie de factótum do mestre. Pois ficaram evidenciadas dúvidas sobre a autoria das obras, seguido de espetaculares avalanchas de apócrifos, produtor e vendedor tinham combinado autenticar as telas num tabelionato colocando a declaração escrita e autenticada atrás das obras. Que fazia o espertalhão? Fixava atrás de uma pintura original uma tela nova que recebia a autenticação. E o falso virava autêntico.

É instrutivo aprender o que inventam os malandros e mais, o trabalho dos assim nomeados peritos, seja os das partes como os indicados pelos tribunais, na Itália hoje penalizados, pois recentemente os mais ilustres caíram numa armadilha: consideraram autênticas algumas esculturas pescadas no rio que banha Livorno, como sendo de Amedeo Modigliani, obras até banais de tão falsas.

Infelizmente, o mercado se baseia, por questôes de investimento, na compra de assinaturas e não da pintura ou da escultura pelo prazer, gosto, penchant por um autor, o qual, para valer, deve estar já no túmulo ou não muito longe do funeral. 
Seja como for, no Brasil começou-se a ver Portinaris, Dis, Tarsilas etc. de máos ainda vivente e com capacidade enganadora bastante fértil. É o mesmo que acontece além-mar: estava lendo nas crônicas italianas que foram descobertas dezenas e dezenas de obras falsificadas de Mario Sironi. Um dos herdeiros disse: "Se olharmos os quadros declarados falsos, eis infinitas vezes as mesmas montanhas incertas, as arvorezinhas amarrotadas, as casinhas isoladas sobre fundos cinzentos, porém sem nenhum valor volumétrico e espacial."

O trecho serve para constatar que a falsificação dos pintores do Novecento é feita pela facilidade imitativa. O que nos remete para outro tópico: qual o destino de uma peça falsificada? A solução, deixando de lado o valor venal, o mais importante, é de curiosa decisão. E saindo do tempo presente, eis que a historiadora mineira Myrian Andrade Ribeiro de Oliveira publica agora em seu livro, Passos e Profetas, que o Aleijadinho operava ajudado por numerosos auxiliares, injustamente esquecidos.

Autêntica, de colaboração, copiada, imitada, falsa a tal estátua? Deixemos aos peritos meticulosos a tarefa de promulgar as árduas sentenças. Quanto trabalho dáo as artes, especialmente aos que, em vez de colecionar obras, juntam letras que não trocam porque manipuladas por trapaceiros.

\section{Legenda}

Praças da Itália, de Giorgio de Chirico

- Coleção Bergamini, Miláo: um

autor exposto a muitas espertezas

Senhor \#236, 25 de setembro de 1985, p.I24 (P.M. Bardi)

UM CONVITE À AVENTURA

Relato de uma viagem ao purgatório tropical

Renato Castelo Branco escreve do mesmo modo como se conversa, tentando não levar o leitor ao labirinto das zonas de difícil trânsito. Em meu recente livro dedicado a Le Corbusier, declarei francamente estar relatando um encontro jornalisticamente. Renato, neste Romance de Sáo Paulo, consegue dar conta de fatos e personagens da história através, sim, de maneira canônica que é por documentos, porém imaginando jeitos e comportamentos dos protagonistas. É meticuloso, demais, aponto de pedir desculpa por usar a data da bandeira de Brás Cubas de 1563 , e não a real, de I560, "por conveniência narrativa."

$\mathrm{O}$ roteiro geral de algumas partes do romance se baseia na Viagem ao Brasil, de Hans Staden, intrépido turista, cronista e divulgador da empresa do primeiro século, protagonista de reais e imagináveis aventuras, e Renato junta a seu prazer uma e outra de modo romanceado que serve para biografar intimamente o alemão.

Prosa das mais convincentes é o encontro de Vasco da Cunha com o alemão. Está em uso o gravador da imaginação: Vasco embaraçado e hesitante, medroso; Hans, “... um homem novo, robusto, de cabelos louros. Sua tez era rosada, os olhos claros e inquisitivos, a barba rala e encaracolada... não saberia dizer se ele sugeria doçura ou agressividade... Sai a conversa, a intimidade, as aventuras no mar, as lutas. Definição de Staden: o Brasil é o Jardim do Éden e o Inferno de Satá, depende de encontrar ou não o caminho certo. Para João Ramalho, o Purgatório: casou-se sem bênçãos, atarefados em produzir oriundos.

Renato, de página em página, revela panorâmicas do paraíso da terra e de seus inigmáticos habitantes, motins, naufrágios, abrigos em portos, ilhas, e gente, sempre gente entre as quais afloravam os protagonistas: histórias que divertem e ao mesmo tempo instruem o leitor.

De vez em quando se intercalam odes de Paulo Bomfim, o pontilhar poético evocando o "convite à aventura."

Mas, para um imigrado, como este cronista, que teve a audácia de penetrar na história de cinco séculos, o interesse da leitura dirigiu-se para o engenho. A definição do autor: "O engenho constava de um grande eixo de madeira, cilíndrico, erguido em vertical, e encaixado, na parte inferior, em uma roda dentada, a bolandeira. Esta, por sua vez era acoplada a outra roda, postada verticalmente, que, através de duas rodas dentadas menores, cada una fixada a um eixo cilíndrico pequeno, fazia-os girar paralelos, um de encontro ao outro, esmagando 
e moendo a cana." Uma descrição exata da máquina da riqueza colonial.

Diante do engenho ouve-se a conversa de Vasco e Hans. O leitor é levado às praias e ao Planalto, a espera do metrô e da disputa para prefeito, com invejável espírito.

Certa vez, pesquisando nas antiguidades brasileiras, tive a sorte de encontrar um destes esplêndidos instrumentos e pude usá-lo numa corajosa iniciativa expondo-o na Pinacoteca do Masp, já na avenida Paulista, na exposição "A mão do povo brasileiro."

Um engenho de açúcar num museu de arte? Esta pergunta circulou bastante e um jornal me atribuiu o título de "excêntrico.” É sempre assim: quando se sai da rotina, isto é, da repetição corriqueira das coisas que se presume que sejam arte é preciso se justificar. Encontrar arte na vida náo é bem o papel de cada diretor de museu de arte. Todavia, penso que repetiria novidade. Aliás, estou estudando como encarar o cotidiano Jornal da Tarde como fato de arte por ocasião da próxima comemoração de seus 20 anos de vida.

\section{Legenda}

Engenho de açúcar do séc. I9: a arte "excêntrica" do povo

Senhor \#237, 2 de outubro de I985, p.80 (P.M. Bardi)

UMA ARQUITETURA EXEMPLAR

Bons exemplos de design num supermercado de São Paulo

Nesta página, de vez em quando, os temas não são estritamente dedicados às artes, como deveria ocorrer pela posição do signatário. Transgride-se, às vezes, abordando assuntos relativos ou próximos a problemas da estética, talvez até de um jeito que pode ser considerado arbitrário. Todos sabem o que ocorre normalmente nesta área, ou seja, "arte-arte," e se sabe também o que se passa ao redor desta definição; as artes que, no Oitocentos, foram batizadas de menores, ditas também decorativas, complementares e acessórias.

Quando eu abri, no Masp, em I950, a Escola de Design, a imprensa confundiu design com decoração. Aliás, recentemente me indicaram a existência de um novo supermercado na cidade, surgindo na conversa as palavras arquitetura, design, decoração.

Fui lá ver: é o Supermercado Especial Páo de Açúcar, na avenida Santo Amaro. Esplêndida construção, funcionalismo perfeito e racionalismo combinados numa arquitetura exemplar. A distribuição dos componentes comerciais é calculada e, sob o ponto de vista da arte, trata-se de um espetáculo de ordem agilizado pela distribuição dos setores, composição das mercadorias colocadas em espaços livres e alinhadas nas vitrinas refrigeradas, valendo como design e cores o que é apresentado nas embalagens.
Devo declarar que se trata de um conjunto a ser indicado como resultado das tentativas de uma definição estética da contemporaneidade. $\mathrm{O}$ empreendimento oferece o espelho desta função, aludindo a uma conquista de ordem, singularidade, limpeza e, deve-se acrescentar, expressão civil sem precedentes.

Disse civil também por considerar como o visitante, guiando seus carrinhos ou carregando suas cestinhas metálicas, se comporta: andando, mexendo, observando tudo o que compra, vendo surpreso a banca dos pescados ou dos frios, seções jeitosamente compostas. Cada elemento é acondicionado num visual agradável.

Os detalhes inseridos no conjunto, os conjuntos harmonizados no todo, e este distinguido numa atmosfera que parece dirigida por um computador. Esta última palavra está presente hoje no dia-a-dia. Aqui a uso para que se tenha uma ideia que tudo obedece a um cálculo, a previsões de função, com economia de esforço, apresentação de bom gosto e, o que é mais importante, um espírito apropriado para satisfazer desejos em sincronia entre a paz e a arte, neste caso, a arte do viver.

É esta a meta. De acordo, vamos nos encantar, se o prazer e o gosto contribuem. O prazer é o mesmo que um aficionado sente ao ver um afresco de Michelangelo ou um desenho de Picasso ou até, para os que mexem nas vicissitudes do Abstracionismo, 
num quebra-cabeças de Klee. Todavia, seja permitido a um antigo cronista de arte anotar que apreciou o muito, ou melhor, o imenso de arte que se realizou neste século, incluindo esta que, sem dúvida, terá os críticos de prontidão. Parabéns então ao senhor Abílio Diniz, por ter alegrado São Paulo com este supermercado-modelo. Penso nele, mutatis mutandis, como num dos príncipes de Florença que embelezaram a cidade com uma das arquiteturas que admiramos. Os monumentos surgem pela vocação de quem decide. São os beneméritos das artes. Então: bravo, senhor Diniz.

\section{Legenda}

Abílio Diniz: uma vocação decisiva para a arte nas suas atividades empresariais

Senhor \#238, 9 de outubro de I985, p.84 (P.M. Bardi)

RoteIRO DE UMA OUSADIA

Onde está a história da arte brasileira deste século?

Levou anos, aliás, decênios, - para não dizer quase uma metade de século - para que a arte denominada moderna ou contemporânea fosse considerada, ou melhor, respeitada. Foi discutida, sim, mas forçada a um ostracismo como se registrou, por exemplo, na época da Semana de 22: seus atualizadores convencidos de estarem no rumo certo, os inimigos de prontidão, condenando.

Foi uma semana apaixonada, aparição extravagante mais do que convicção de rompimento com a granítica rotina acadêmica, um monumentalismo que parecia indestrutível.

Os brasileiros ligados aos progressos, que também se interessam por arte, costumam denunciar o escritor Monteiro Lobato por ter publicado o artigo castigador de Anita Malfatti. Para confirmar que os denegridores das artes fora aos trilhos da tradição eram numerosos também na Europa, e não só nos anos 20, mas até nos anos 30, eis como concluía, numa História da Arte Italiana, dedicada aos liceus, o professor Aldo Foratti, da Universidade de Bolonha, no trecho dedicado ao período do Novecentos: "Em I895, um prefeito engenhoso e um conferencista bem aceito abriram em Veneza a primeira mostra internacional de arte, que continua a reabrir em anos alternados. Deu para reconhecer as mais discordantes tendências da vanguarda: os mais originais e os mais estranhos trabalhos; muitos dos nossos artistas, velhos e jovens, alucinados pelas coloraçóes pelas extravagâncias de Paris, da Espanha e do Norte, contrafizeram e deformaram os modelos.
"A imitação e a falsificação eliminaram os caracteres substanciais das escolas florescentes nas várias regióes da Itália, e a arte passou por dificuldades. Na vigília da Grande Guerra, a arrogância do Cubismo do Futurismo proclamam inútil a lógica da evidencia e as relação com a realidade sensível; e depois da vitória veio o Novecentismo que abriu um ciclo de experiências mais ou menos plásticas que os pósteros vão avaliar com ânimo mais sereno."

Como em parte protagonista, posso dizer que a situação das artes fora do circuito acadêmico na Itália era ainda pior do que no Brasil. Na Bienal de Veneza, de dois em dois anos, se apresentavam obras dos impressionistas e da Escola de Paris: a indiferença liquidava esta última novidade, os mestres do mais válido momento do final do Oitocentos não eram considerados. $\mathrm{O}$ próprio Marinetti, apesar de estar engajado no fascismo, passava por momentos dos mais difíceis. Lembro-me de ter viajado, já nos anos 40, com ele, num trem MilãoFerrara: sua verve rebaixada, ou melhor, oficializada a serviço de uma empresa política. Seja como for, quando tentei reconstruir no cinquentenário da Semana a história desta, numa exposição no Masp e mais tarde, numa publicação, tive a impressáo de que a vanguarda de Sáo Paulo foi mais para a frente do que o Novecentos italiano. Talvez com menos mestres, porém, o ímpeto e, sobretudo, a criaçáo de uma interdependência das artes representou um dos fatos mais singulares da ação para dar ao $20^{\circ}$ século uma fisionomia de exceçáo.

Tudo o que escrevo me vem à mente enquanto leio um esplendido texto de 
Mário de Andrade dedicado ao pintor Hugo Adami, um artista paulista que, logo após Primeira Guerra, se distinguiu na Itália participando da reação novecentesca e expondo nas primeiras mostras do grupo ao qual se deve a reação contra o academismo.
O esquecimento que noto obra de

Adami me sugere uma outra observação: quem se vai dedicar a uma história da arte brasileira deste século?

\section{Legenda}

San Gemignano, (1927) de Hugo Adami: no roteiro de Mário de Andrade

Senhor \#239, I6 de outubro de 1985, p.IOo (P.M. Bardi)

A ANTIGUIDADE DA VANGUARDA

Excessos e conveniências da Bienal paulistana

Foi aberta mais uma edição da Bienal paulistana. Desta vez náo mais nas maneiras oitocentescas repetidas provincianamente nas ediçôes anteriores, mas nas do último grito, e já velhinhas, copiando a manifestação de Kassel, na Alemanha. ${ }^{69}$

Que o transvanguardista não me jogue na penitenciária dos superados. Ele, ou ela, ainda não eram nascidos quando no Masp eu já apresentava a exposição de Alexander Calder: indiferença total de público. $\mathrm{O}$ cronista não é do contra ao saber dos acontecimentos de Kassel e de outros centros europeus. Simplesmente não gosta da cópia incontrolável das novidades típicas de outros ambientes culturais. É do contra quando vê que se póe o carro na frente dos animais encarregados de conduzi-lo.

Foi isto que disse ao benemérito Francisco Matarazzo Sobrinho quando copiou o antiquado estatuto da Bienal de Veneza, pois havia outras iniciativas bem mais úteis para a cultura nacional.

Cada um de nós tem suas idiossincrasias. Tendo alguma prática no sistematizar exposiçóes de arte, quase sempre me desinteressei das que amontoam números excessivos de obras. Nesta Bienal, mais de 2400. Atribuo preferência às apresentaçóes restritas, de possível e tranquila apreciação. O mesmo se dá com os museus: prefiro

69 Xviı Bienal, sob curadoria de Sheila Leirner, que polemizou ao criar "a grande tela:” projeto expográfico onde todas as telas foram expostas a trinta centímetros de distância umas das outras, em três corredores de cem metros cada, distribuídas sem critérios geográficos, temáticos, cronológicos ou estilísticos. visitá-los não nos dias festivos - o tempo destinado a determinadas escolas, às vezes a um punhado de pinturas ou de esculturas.

Gostar de uma produção é tarefa repleta de interrogaçôes, dúvida surpresas: por isto me permito descartar o lado visionário das feiras por demais colossais.

Não nego a conveniência de realizá-las, podem ser até de utilidade; todavia, bastante metido neste tipo de evento, prefiro recolher-me a ambientes de menores proporçóes.

Já escrevi numa página anterior de Senhor que as artes, dos profissionais e dos candidatos a tal, inclusive os bravos primitivos e os petulantes amadores, dependem hoje do battage jornal-rádio-tevê. Estou tâo certo disto que pensava em transmitir a direção do Masp a um elemento daquele setor, para conseguir mais público, naturalmente sem considerar as artes como uma corrida de automóveis, ou um jogo de futebol ou uma eleiçáo para prefeito.

Uma confirmação do que afirmo é a concentração publicitária que andou criando evidente chamariz para a $8^{\mathrm{a}}$ Bienal, antes de sua abertura. Para exemplificar: na mesma semana em que se premiava Bruno Giorgi e Oscar Niemeyer com o maior prêmio nacional, o do Moinho Santista, poucos jornais deram pequenas notícias, ao passo que o anúncio bienalesco há tempos lotava páginas e páginas: Sáo Paulo inundada de cartazes, (não de designer) folhetos, cartóes-portais, coquetéis e até distintivos de lapela.

Propagandisticamente, que seja permitido ao fundador da Escola de Propaganda, em I950, congratular-se com o ativíssimo presidente da Fundação Bienal, Roberto Muylaert. 
Que fique bem claro que minha constatação é mais de caráter social do que propriamente relacionada com a arte. Estou a par de que, no seu proceder, o comportamento é outro, a linguagem refugiada nos silêncios da informática, valendo a caça precipitada às surpresas, cancelado o estereotipado do modo figurativo. $\mathrm{O}$ inteligível parece dirigido ao apreciador da notícia de que, no Ibirapuera, está montada uma escultura de borracha de dezessete toneladas. Bestinhas nós que ainda estamos encantados com os mestres que não usam nem tambores e nem trombones.

\section{Legenda}

Claes Oldenburg, em 1966, carregando sua obra pelas ruas de Londres

Senhor \#240, 25 de outubro de 1985, p.80 (P.M. Bardi)

O NÓ DA TRADIÇÃO

A contribuição do artesanato à cultura brasileira

Várias vezes já se escreveu que a cultura nacional deve parte do seu recente e extraordinário desenvolvimento às grandes empresas e indústrias que patrocinam publicaçóes dedicadas especialmente à nossa história e às atividades contemporâneas. Entre estas deve ser evidenciada a Rhodia, que, desde a década de 30, envolveu-se na cultura brasileira através de personalidades como Mário de Andrade, Menotti del Picchia e Guilherme de Almeida e, mais tarde, convidando para desenhar padronagens para seus tecidos os artistas Manabu Mabe, Alfredo Volpi, Caribé, Maria Bonomi e vários outros, além de ter editado úteis monografias. O décimo volume foi publicado este ano: Trançado Brasileiro, de autoria de Jacob Klintowitz, livro lançado no Masp no dia I7 de outubro.

Finalmente a revelação de uma das tradicionais experiências populares e a anotação da singularidade de um artesanato presente, de região em região, renovador das inusitadas expressóes de desenho e de aprimorada técnica. A produção é manual, herança que tem seus iniciadores nos primórdios da humanidade: os inventores do entrelaçar fios vegetais. Impossível imaginar o tempo passado em desilusóes, provas, reprovas, vislumbres de satisfação até atingir a criação de uma corda, uma cesta, um pano.

Quando Cabral aqui desembarcou, já encontrou alguns capacitados naquela atividade. Em nosso encontrar com a história, o que os índios, escravos, portugueses e emigrados produziram de precioso se sabe, valendo também as significações totêmicas e mágicas, além dos símbolos religiosos.

No trançado, as maravilhas não paravam. Foi uma ideia certa do Jacob ir ao encontro, aliás, à descoberta, de quanto ainda se realiza neste setor popular, e documentar um completo estudo crítico uma atividade que reúne a criatividade espontânea de autênticos artesãos. Escondidos, autônomos, surpresos de que algumas visitas fotografem suas obras. São pessoas que vivem longe, sem tomar conhecimento do industrialismo, num constante acerto individual.

"No trançado o nó é funda mento da ligação; o nó é um ato e um fato. Ele revela a intençáo e demonstra uma realidade. $\mathrm{O}$ nó representa a ligação com o divino. É por esta razão que o atar e desatar é tão importante para todos os povos... O nó é o símbolo de acordo entre o terreno e o transcendente...," adverte o crítico. Reproduzo este trecho para ressaltar a prosa do ensaio, a um tempo documento e interpretação humana do trabalho.

Ocorre-me pensar nas tradicionais produçóes do povo da Paraíba, usando o sisal para confeccionar tapetes, cordas, mantas grossas, redes, laços para segurar os animais, e na ornamentação, esplêndidos bordados, rendas, fitas.

O descrever de Klintowitz todos conhecem através das colunas que publico no Jornal da Tarde. ${ }^{70}$ Às vezes, eu mesmo me reporto a alguns de seus juízos pela singularidade no definir casos, precisando ao mesmo tempo de indagação sutil e de anotação superadora, como leio num livro do venezuelano Roberto Guevara, de infinitas circunstâncias: "Qualquer

70 Aqui, um outro levantamento a ser feito: Bardi, cronista em jornal. Vale observar que o Jornal da Tarde teve Mino Carta envolvido em sua elaboração. 
atividade crítica é ingrata. A que tem por finalidade aí artes plásticas é ingrata mais especialmente porque, pela abundância das exposiçôes, manifestações e presenças, condena o trabalho crítico..."

Desta vez, não há a complicação de se referir ao que apresentam nas inúmeras e improvisadas galerias, mas a descoberta de elementos possuidores de uma sabedoria de alta qualidade, naturais desenhistas na trança de quantidades infinitas de motivos geometrizastes.
A edição do Trançado Brasileiro é esplêndida e permite o conhecimento de uma produção à qual raras vezes se deu atenção por parte de um crítico de arte. Jacob anota os modos dos executores que podem ser inscritos na categoria dos perseverantes da tradição neste momento de alucinação.

\section{Legenda}

Cesto de pesca em tala de arumá.

Tribo Tukano, Amazonas

\section{Casa Vogue \#6, novembro-dezembro de 1985, p.36 (P.M. Bardi)}

\section{NO BAILE DAS ARTES}

Reputo-me com prática suficiente em jornalismo para saber que, hoje, os leitores que gostam realmente da crítica de arte são cada vez menos numerosos, pois evitam ser impingidos dos mais indecifráveis pareceres. Doutro lado, apesar deste redator passadista ter publicado catalogaçóes de mestres, como a última dedicada a Velazquez, com prefácio nada menos que do prêmio Nobel Miguel Angel Asturias, o que mais me convém é falar um pouco dos casos nos quais me envolvi pulando no baile das artes.

$$
\sim
$$

Pode ser que eu seja vítima de um ditado que meus pais e meus avós repetiam para amestrar as crianças quando começavam a se barbear: saia com os melhores que você e pague-lhes a bebida. ${ }^{11}$

Então, na minha inexperiência e, talvez, natural senso de inferioridade, considerava qualquer um, até o mais simplório, mais batuta, mais esperto, mais tudo. $\mathrm{O}$ complexo tomou conta do meu andar na vida e, também quando descobri que não era contra a lei julgar, me esforçava em usar respeito, benevolência, dando crédito a fulanos que de imediato se compreendia serem pobrezinhos de mente e de coração. Valia, sobretudo, a cultura religiosa com a caridade, a bondade, o altruísmo.

Um pensamento constante opinando sobre pobrezinhos: e se, por acaso, são melhores do que eu? Consequentemente lhes oferecia a prescrita bebida, para não transgredir as ordens familiares. Levou

\footnotetext{
7I Provérbio italiano: Va con chi è meglio di te e pagagli le spese.
}

muito tempo para distinguir gente de bem e gente malandra. Tendo-me apoderado quando rapazola servia como escriturário num escritório de advocacia - de algumas noçôes jurídicas, entre as poucas: se não tem provas não se pode julgar e condenar, nunca me decidia a evitar os poco di buono que envolvem os ingênuos. Comecei, entáo, a colecionar fregaturas.

Devo confessar que ainda hoje, viajando no ônibus da minha tenra idade, de vez em quando, para náo dizer a cada dia, encontro sujeitos e sujeitas que erroneamente estimo como a quinta-essência da perfeita moral: trafego com o pessoal, me abandono em amizade, socorro, fecho um olho para ver menos novidades das quais não gosto, suporto, fiel ao parecer que posso me enganar; e pronto, a certa altura da relaçáo tenho a prova da boa esfrega.

Às vezes compilo a conta dos gunk (me intrigou muito estas gíria manhattanense, e finalmente, no The American Heritage Dictionary, pude decifrar: serve também para definir este tipo de cidadão que se dedica em passar continhos do vigário, disfarçando, puxando o saco, enganando com sistemas profissionais, paroleiro, vagabundeando na praça autêntico ator.)

Uma médium me fez saber que, no meu antiguíssimo passado extraterreno, desconsiderava os atores, pois pensava que um ser náo pode se dispor a agir como uma quantidade de personagens. Por herança nunca fui a um teatro. Pode ser porque, os atores, os encontro cotidianamente.

Pela posição que ocupo não estou a elencar o número de "melhores de mim" que me 
procuram exclusivamente para receber favores neste campo aberto a qualquer um que entra na dança da arte. Por vício de origem não consigo dizer à Senhora de Tal: "Experimente cozinhar, pois sua pintura é gunk." Converso, não me incomodo, me faço gentil. Mas logo essa reação: "Então por que o senhor náo me dedica uma exposição no Masp?" Digo que o calendário de exposiçóes está completo, desconverso. A Senhora de Tal agride astutamente. Defendo-me. Resultado: mais uma inimiga ou, se é do sexo masculino, um inimigo, os boatos enriquecidos de novas calúnias.

Às vezes, mas é raro, vem somente quando vale a pena, o desabafo explode pela lei dos contrários, e provoca as repulsas dos interesseiros. Para contar uma: tendo pichado anos atrás, um muro do Masp com uma palavra parente estreita ao gunk, fui condenado náo pelo delegado que mandou me prender, mas pela senhora Pitangui da Estética por ter revelado ser um superado pois pichar paredes e pavimentos é um dos últimos gritos.

De fato, na abagunçada Bienal vemos consagrada a novidade. Somente lamento que o mais famoso pichador paulista náo tenha sido convidado para aquela performance, copiada da Quadrienal de Kassel, definida pelo diretor daquela mostra como heterogênea.

Senhor \#24I, 30 de outubro de 1985, p.II6 (P.M. Bardi)

O APRENDIZADO DO URSINHO

As memórias de um jornalista intimo dos homens que mandaram no Brasil nas últimas décadas

Anuncia-se um livro que, sem dúvida, vai contar um arsenal de fatos emergentes nestes últimos decênios da vida brasileira: será Memórias, de Samuel Wainer, nas ediçôes Record, coordenadas pelo jornalista Augusto Nunes.

Sem dúvida, as páginas vão revelar andanças, paradas, retomadas da política, nudez de personagens, artimanhas e quantos outros casos anotados por aquele mestre de jornalismo, renovador de sistemas no exercido desta profissão, que, ainda nos anos 50, contemporizava no "deixa como está para ver como fica."

Posso afirmar que o descobridor do talento e, diria, da natural jactância de Samuel, foi Assis Chateaubriand. Vejo, numa antecipação das Memórias, esta lembrança: "Chateaubriand passou a levar-me aos lugares que frequentava e a exibir-me como um ursinho, um animal de estimação. Admito que aquilo me envaidecia. Ele me aproximou da plutocracia, dos seus amigos aristocratas, dos donos do poder." Muitas vezes em companhia do amestrador, timidamente, mexia sua cauda um outro ursinho, este cronista, então apresentado como o organizador de um dos inúmeros empreendimentos do criador dos Diários Associados. Eu, bastante calado para não me pronunciar em mau português, Samuel falante, inteligentemente emitindo pareceres políticos para mim indecifráveis, às vezes discordando de seu chefe.

O qual comigo discursava em italiano, e me confiava ser impossível revolver a floresta para se apoderar de outro mascote daqueles para seus cotidianos. De fato, sem desmerecer tantos colegas, não é que nos Associados brilhassem exceçóes do calibre de Samuel. Privando dele, era fácil compreender sua capacidade, seu espírito novo e sua aspiração de independência, de conseguir ter o patráo de um jornal, para dar a uma folha um fôlego mais amplo, e sacudir o more solito.

Estou curioso para ler como tarão Samuel memorializar os Associados. Uma digressão: seria do máximo interesse algum estudioso mexer nos papéis do Assis. Este cronista poderia colaborar, pois teve a possibilidade de guardar não só a documentação relativa a quarenta anos de Masp, como também cartas dos D.A., pois afinal, por pouco tempo eu tive o cargo de seu diretor-geral, vindo a conhecer até segredos, que não revelei no meu livro Sodalício com Assis Chateaubriand.

Na minha qualidade de "ursinho," espero as Memórias com particular curiosidade, pois colaborei nos jornais de Warner, o qual, às vezes, para testemunhar a verdade de certos acontecimentos provocados por medalhóes no setor das artes, dava-me 
páginas inteiras. Confirmava seu espírito de homem público atento a qualquer problema, o político como protagonista ou parte, às vezes determinante, de arranjos entre manda-chuvas. Era empreendedor jeitoso no escrever; aliás, foi este seu autêntico trunfo: seus editoriais eram marcados com sua verdade, numa linguagem à la Seneca filósofo: Veritatis simplex oratio est. Escrevia de modo simples e cordial o "ursinho" que rapidamente se tomou até o reconciliador de duas feras: Getúlio e Assis. A Folha antecipou o texto de Samuel: “...Tirou o chapéu e aproximou-se do presidente eleito, que prontamente tratou de amenizar o clima: 'Dr. Assis, que prazer revê-lo', exclamou."

\section{Legenda}

Warner póstumo: nudez da

história recente do País

\section{Status \#136, novembro de 1985 , p.78-79, 84}

\section{CoOper MAL FeITO}

Já tive ocasião de anotar numa página de Senhor que uma das minhas modestas idiossincrasias é a de me encontrar, a contragosto, numa exposição de arte e enxergar obras demais. Penso. Aliás, estou certo de que para apreciar pintura, escultura e algum artificio aproximado ou aparentado a elas, ou até, coisa comum, suas caricaturas, deve-se dispor de tempo, pois interrogaçóes, reflexóes, compreensões nos tumultuam a cabeça. Apesar da preferência absenteísta, eis o Bardi pisando na Bienal paulistana, incumbido de redigir uma crônica para a revista Status, sede, como escreveu um dos seus diretores, "de assuntos que levantam polêmicas.” (Pão para meus dentes)

Proponho-me a observar com paciência: bem ou mal, deve-se ter interesse por uma manifestação a qual, bem ou mal, tem seu passado e, bem ou mal, dá uma ideia de como, mais ou menos, hoje se desenvolvem estas operações até anteontem etiquetadas Beleza; sintomas de uma estética jogada às urtigas.

Fique claro: não sou inscrito em nenhuma associação de críticos de arte. Deste lazer entendo um pouco, versado mais nas oblaçôes inteligíveis do que nas indecifráveis. Confesso: outra idiossincrasia é não saber compreender, apesar de esforços alentadores das minhas capacidades com injeção de uma gota de condescendência, certas obras não bem de arte, não sei por que assim apelidadas, batizadas não por clérigos sem doutrinas mas por bispos e cardeais cuja infalibilidade, na opinião de grupinhos, ás vezes mafiosinhos, é de interessados interesseiros, sendo até proclamadas obras-primas.
Passando os olhos por este aglomerado de mercadorias bienalescas, naturalmente tiramos o chapéu, por deferência, a certos talentos das vanguardas históricas, provocadores de inovaçóes, generosos proponentes de acertos e modos de expressão: é evidente que a Ingres sucedeu Courbert que náo podia pintar um Anjo, pois não o via; os

Impressionistas, Picasso e companhia até Francis Bacon e, para não esquecer os informais Kandinsky, Klee e outros e, por que não, Ives Klein, Oldenburg e o meu caro amigo Lúcio Fontana? Mas este pessoal estava presente na minha fantasia.

Foi num destes dias de outubro, a chuva cancelando meu cooper no Parque do Ibirapuera, que acabei por cumpri-lo na Bienal. Trajado de visitante, dez mil cruzeiros de pedágio, me aventurei pelo labirinto da Arte, estrelado ao som de tambores e trombones pela imprensa local e, como li num semanário, "o apoio do Comind foi essencial:” os bancos descobrem o painting marketing.

Estava em mostra a quintessência do que, náo a província, mas o mundo à espera do cometão já pintado por Giotto, está armazenando em arte, empenho de aguerridos exércitos de amanuenses.

Em minha condição de responsável pela brincadeira Masp, a penetração foi tímida, pois a Dona ao Vapor tinha declarado, apertis verbis, que teria dado à luz uma performance "antigaleria e antimuseu." Não se sabe por que não acrescentou antibienais pois, afinal, estes receptáculos estão situados entre galerias e museus. Declarou mais: "A I8a Bisp é deliberadamente não consagradora... a 
minha orientação crítica foi exatamente evitar que o 'retrômodemismo' pudesse ser defendido como causa estética.” Kassel, aliás a Quadrienal de Kassel docet; antes o cansado verbo vinha de Veneza, agora é da Alemanha que vem a batuta.

Subida a primeira rampa, meditando sobre a scientia cognitionis sensitive, refletindo a respeito do meu escasso saber crítico, propus encostar-me, novato aprendiz, à nova filosofia, quase convencido de que, se a sapiência dos prepostos à nossa Cultura confiaram o certame à Loira, (turibuíam os incensadores: "Deu uma lição de profissionalismo") deveria concentrar-me aqui e averiguar os novos cânones a serem deglutidos. Eu, cabeçudo, não consegui engoli-los.

Maníaco por crônica, ocorreu-me lembrar o surgimento destes espetáculos bienalescos. A deliberação partiu do senhor Francisco Matarazzo Sobrinho, o qual tornando-se improvisado fautor da modernidade na Pauliceia, para emular o paraibano Assis Chateaubriand que acabara de fundar o Masp, abriu um museuzinho m. (- Senhor Assis, o Cicillo comprou um Modigliani; - Bardi, compre meia dúzia! Assim era a competição.) Para atrapalhar, o Concorrente fez saber ao mundo que São Paulo era uma capital das artes implantando uma bienal internacional. Embarcou num navio e saltou em Veneza. Quis ver como se regulamentava uma empresa então ainda tu- risticamente famosa, imaginando: se lá ajudava o passear de gôndola na Laguna, aqui podia servir o Tietê.

Lembro-me de ter dito ao Cicillo: pelo amor de Deus, não ponha o carro adiante dos animais, não imite a Cidade dos Doges. Aquilo é um negócio do Oitocentos, um salão superado. De dois em dois anos as artes não mudam. Os próprios italianos agora organizam trienais, quadrienais. Não senhor. E no belvedere, (adjetivo de verbo per modo di dire) destruído o Clube do Trianon, em barrancos improvisados inaugurou-se a Primeira. Agora estou caminhando nos 33 mil metros quadrado: da I $^{\text {a }}$. Tinha lido no porta-voz do Salão do Ibirapuera, O Estado de S. Paulo, as linhas de uma senhora crítica: "Mesmo lixo, na Bienal, é obra de arte." Na nota os palpites dos visitantes: "Não. Absolutamente não. Chega de pintura;" "Náo entendo nada de arte, mas não importa, estou curtindo muito." (Insiste-se: é uma arrumação para o leigo que se deve aculturar.)

Classifiquei de salão. Não fui o único. Leio no "Vejo em São Paulo," de J.C. Galvão: "Manifestaçóes como a Bienal foram criadas para combater os grandes saloons que imperavam no fim do século passado. Quase no fim do nosso, verifica-se que, excetuando-se a abolição dos prêmios, a Bienal é exatamente a mesma coisa."

Honestamente, na qualidade de cronista, mesmo que do contra, começava a pesar os pareceres. Náo me cheirava a gênio a comprovação entre arte e aquilo que a vassoura é prescrita para limpar. Todavia, enfrentando uma parede pichada como se detesta ver nas ruas, exercício de emporcalhadores de escassa educação, borrado não só o muro mas também o chão; o desgosto me assaltou.

Lembro-me: quando, cansado das pichaçóes eleitorais nos muros do Masp, escrevi a palavra merda, fui preso, levado à Delegacia, deixei marcadas as impressóes digitais e fui libertado como menino irresponsável. E lembro que a Descoordenadora da Bienal me confinou, em prosa do "Estadão," ao hospício dos que não entendiam que qualquer ato de pichar é arte. A Severa acumulou desaforos para mim. Pichação de muros e de chão é arte?

Se a já citada reporteressa fosse mais própria, em vez de lixo deveria dizer brincadeira. Teria sido mais apropriadodo como característica deste Salâo, não de B.A., mas como intitula num dos seus clássicos issues no Time Magazine, Robert Hughes: "Bad Art," sublinhando: "Why is American painting so popular these days, when it s so invencibly dumb?”

O causticissimo Hughes anota, a propósito de uma outra Bienal, a do Whiteney Museum of American Art de Nova York, o blablablaesco que quer determinar o gosto, não mais de qualidade, tomando-se fato normal um vazio cultural expresso por um produzir órfao de qualquer bom senso: desabafos vendedorizados por avalanchas de improvisados mamarrachos. Revelou 
o escritor: trata-se de certa "gunk" (na gíria nova-iorquina "meleca") que nem é "Kitsch," pois espalhou um andamento estético incentivado por despachantes de pintura "quente," provocador de um ensino enrolado vertiginosamente: em '82 formaram-se 45 mil, em Manhattan trabalham 90 mil "artistas." (Curioso: é um tipo de inflação que, mutatis mutandis, começa a se notar em São Paulo, como mostrou o último Prêmio Pirelli de Pintura Jovem outorgando a medalha P.M.B.)

Naquele dia o antigo ranchão era um Saara: transitava um ou outro, entre o surpreso e o abstraído. Eu, perseguidopela objetiva da fotógrafa Cristina, buon viso a cattivo gioco, meio avacalhado, me distraia evocando a multidão festeira da inauguração para ver o presidente Sarney, obrigado a gostar. (Propenso a se felicitar, pelo que se compreendeu, mais com o forte senador Cardoso do que com as chefias organizadoras?)

Repensava: um dos handicaps da comunicação sobre o desempenho das artes é, hoje, a reportagem: jornalistas demais, sem saber bulhufas daquele operar tratam certos elementos à maneira dos craques, como membros de uma torcida que se exalta porque o tal marcou o gol. Assim, como teria dito Gian Lorenzo Bernini, no Seiscentos (veja-se no Masp sua Diana): "Chi non sa stupir, vada alla striglia." Isto é, a quem não sabe maravilhar, uma almofaça, como a um burro.

Mas o curioso é que também a senhora Pitanguy da Estética deveria receber uma passada de almofaça, naturalmente carinhosa porque, se um dote ela tem, é o de ser bonita.

A Filha de Mamãe, em vez de correr á procura de mestres realmente válidos, recrutou penetras aspirantes a craques, convencida de que um tal cozinhador de um frango assado é digno de láurea. (Impressionante a ausência de nossos bons artistas. Uma pergunta: que tem a ver o itinerário turístico do Mário, fotografado pela Maureen, a qual conseguiu se encher de colunas, "honorárias" como se deu com Trajano, não de mármore mas de papel jornalístico: um autêntico excesso se comparado à insignificância folclórica das chapas.)

Procuro adaptar-me neste autêntico playcenter. O que aborrece é o espetáculo cenográfico. A Comandante, circundada de uma corte de práticos em agências de propaganda e de faço-tudo-eu em montagens, tendo sabido nos anúncios econômicos de uma "Zeitung" do oferecimento de um milagroso elemento na profissão de ambientar feiras artísticas, o bravo alemão Jurgen Harten, contratou-o, custe o que custar (quem paga é o Pantaleão de plantão) e com ele se dispôs à tarefa. No serviço constatou a sensatez do teutônico, contrário a abranger assuntos demais. A Importadora, furiosa, não escutou conselhos e, venter caret auribus (a barriga não escuta prescriçóes) como teria sentenciado Catão, o Censor, o despediu. Houve ainda brigas, naturais, entre mandóes e artistas. Se sabe: o mais modesto se sente o primeiro da classe, um mandão se reputa imperador.

Diga alguma coisa. Sim. Um passadista como o Bardi, o qual, batizado pelos estetas circundantes, nos tins dos anos '40 e comecinho de '50, adquiria (veja-se sua fixação em história), obras de Rafael, Mantegna, Bellini, Rembrandt, Velazquez, Goya etc., e também mestres do Impressionisino desde Manet, Monet até Cézanne e, dulcis in fundo: Picasso, Léger, (doação da senhora Carolina Penteado da Silva Telles) Calder, Wols, Max Ernst etc.

Nos meus tempos como cronista, dava-se o relatório das mostras, examinando obra por obra. Estou lendo algumas páginas de Mário de Andrade, informando sobre uma exposição de Hugo Adami: pintura por pintura descrita, indicando seu número de catálogo entre parênteses. Então: aqui, por onde vou começar? Como posso me curvar 2400 vezes para decifrar o cartáozinho de cada delícia?

Armadíssimo de boa vontade, começo. Penso nos professores acadêmicos que, para um nu, prescreviam pintar até a sujeira das unhas. O boom agora é a figura despida a plantar batatas. Vale o enigma decorativo, aliás as quinquilharias.

No armazenamento tem de tudo, amassado, como vier vem. E cansa descobrir, 
percorrendo os sete-oito quilômetros de cooper. Há várias salas e, de vez em quando, alguma coisa singular. Todavia, o convite é embrulhado pelas gags insuportáveis que minha Coetânea e complicada dona-de-casa que nunca montou uma expô, aprontou em desordem: retrato do seu caseirismo barato e prepotente.

Assim, para os futurólogos que sabem mexer com eletrônica, a sala Ciência-Ficção é de ser vista. Lógico que é uma útil ocasião o contato com Lam, Botero, Caulfield, Hockney e boas peças do grupo "Cobra," sendo insignificantes as de Expressionismo.

Por que não se pensou em ajudar o visitante anônimo oferecendo-lhe uma adequada informação sobre a origem do movimento que se formou na Alemanha, atitude espiritual que refletia a profunda crise dos valores emergentes após a Primeira Guerra?

É desoladora a apresentação dos Expressionistas. Quando eu soube que a Bienal queria mostrar em seu recinto aquela agitaçáo, logo pensei: agora a Rainha Taitu, talvez, sabendo que o balbucio da pintura de ruptura está naquela revirada, recorre ao Masp para o empréstimo de algumas obras. Previsão acertada: despacha suas vassalinhas para parlamentar. Pedem peças “impressionistas." Esclarecida a confusão.

não impressionistas, mas expressionistas, eu informo que obras de Van Gogh, Gauguin, Toulouse-Lautrec, Daumier, náo podiam sair do Masp...

As enviadas replicaram que aqueles eram impressionistas e que elas queriam o empréstimo de telas que não sei bem como definir: de Boi, Branningan Graciano e de Fiori, o único a valer.

O cooper continua. Felizmente meus pés não têm calosidades. Percorro os condenados corredores da "Grande Tela:" impossível ver e julgar. Propositadamente anulador, velório da Pintura?

No que se refere às bandeiras dos países participantes o resultado é de um salão, aparecendo as tendências, desde o Verismo historicista ainda acadêmico até sofismas de folclore, primitivismos caboclos, múltiplos baratos de cerâmicas, geometrismos, a novidade de espalhar trapos de roupa e objetos quaisquer, até empilhamento de caixas vazias, historietas em quadrinhos, esqueletos que abrem a boca à maneira dos robôs: inflaçáo de instalaçóes de destino dúbio, gaiolas e apartamentos burgueses com banheiros e WC sem água, insuportáveis alinhamentos de fotos.

O ponto quadrado é uma preten-

dida escultura de borracha, um antro funéreo, pesando dezessete toneladas. Outro ponto: uma profana capela com altar, crucifixo e ingredientes votivos.

Diria: um desprezar, até mesmo ansiedade, escárnio, ataque contra a normalidade. É um fato que tem sua realidade caricatural, o avanço de uma nova "cultura"?

Parece-me honesto reproduzir o juízo do responsável pela Quadrienal de Kassel, o colega Schneckenburger: "No todo, a mostra me agradou, mas tenho dúvidas sobre a concepção de uma exposiçáo gigante como esta, porque a partir da diretriz que se escolher chega-se a um resultado. Aqui a seleção é mista, através das embaixadas dos países e dos convites particulares feitos pela curadoria." Em palavras não de cortesia diplomática acrescentou: "O resultado só poderia ser heterogêneo." E o trombeteamento que gastou a heterogeneidade?

Para concluir: Status é, agora, uma revista de discussóes. O defensor de uma Estética ainda náo pitanguiteada, admitindo a peremptoriedade das novidades em relação às situaçóes emergentes morais, políticas, científicas, modésticas, se permite abrir uma para, sem pêlos na língua, discutir o seguinte: há necessidade de continuar as Bienais? Em caso afirmativo, como gastar o próximo milhão de dólares para desanuviar o paulistano?

Legenda

Bardi: falta vassoura para tanto lixo 
Opinião de Brasileiro, p.8o-8I

Texto de Marcelo Tas; cf. Anexo B, p.653

Marditas meninas, p.82

Texto de Reinaldo Moraes; cf. Anexo B, p.654

Línguas de fogo, p.83

Texto de Arrigo Barnabé; cf. Anexo B, p.655

Senhor \#242, 6 de novembro de 1985, p.88 (P.M. Bardi)

A SAÚDE DO PATRIMÔNIO

$O$ acervo cultural corre perigo em todos os paises, mas já

existe um esforço inicial para mudar a situação

Tutto il mondo è paese, repetem os italianos para constatar que aquilo que acontece,

por exemplo, no Brasil, verifica-se também em outras naçóes. $\mathrm{O}$ ditado logo me veio à cabeça lendo a manchete de um dos últimos números de Il Giomale dell'Arte sobre uma declaração oficial do ministro dos Bens Culturais e Ambientais da Itália: "Vou absolutamente proibir os desperdícios, do Estado, das regiôes, das entidades locais, e também das empresas privadas... Não podemos permitir uma destruição do patrimônio artístico como se deu com o paisagístico, deixado nas mãos dos aproveitadores... Os museus estão fechados, não temos guardas, guias, falta alarme e segurança, pagamos ordenados irrisórios e os funcionários melhores vão embora. Por quê? Porque não temos verba. Temos uma pretensão tipicamente italiana, mas náo temos um outro país que pague para nós. $\mathrm{O}$ dinheiro necessário não podemos inventá-lo.”

Esta foi a resposta do ministro ao redator que lhe lembrara ser o seu ministério considerado como a "gata borralheira” do governo. As declaraçóes eram causadas pela explosão da opinião pública interessada numa tomada de posição frente aos bens culturais devido ao agravamento dos problemas de conservação definidos como dramáticos.

$\mathrm{Na}$ entrevista, o ministro Nino Gullotti insistiu na falta de verba: "Nosso balanço é de dar risada, indigno até de um país mais pobre do que a Itália. Mas os bens culturais não podem deflagrar greves." Acrescentou que se passou de um conceito de pura tutela, quase em senso estático, ao conceito de recuperação, e deste à reutilização do patrimônio histórico-artístico-arqueológico, um bem de investimento de grande importância também por seu valor econômico que não deve acabar como o patrimônio paisagístico, "desfeito de uma maneira impressionante.”

Deve-se anotar que a posição da Itália no gráfico europeu de despesas com a cultura foi, em I984, de 30 mil liras per capita, (uma lira vale cerca de Cr\$4) contra 49 mil da Alemanha, 66 mil da França, 7I mil da Áustria, 135 mil da Suécia e 192 mil da Suíça.

Parece que uma das possibilidades para encontrar recursos e evitar a lamentada decadência é a de sempre, e a mesma que no Brasil estamos desenvolvendo, sistema que pode ser, se não o único, pelo menos o mais certo: recorrer aos patrocínios dos generosos que podem contribuir. Para nós não acontece como na Itália, onde alguém comparou os pedidos à mendicância de quem pede sentado num saco de ouro.

A novidade da sponsorização na Itália suscitou algumas oposiçóes, pois, na falta do ministro, "os interesses particulares são sempre muito defendidos," todavia continua, por parte das empresas, a destinar aos patrocínios vultosas disponibilidades publicitárias. Mas não deixa de ser uma das providências para salvaguardar o imenso patrimônio acumulado em três mil anos, um achado indispensável para proteger as antiguidades ameaçadas pelos danos materiais, a incúria, o desinteresse e a violência das pessoas. Está inclusive para ser aprovada uma lei para armar os guardas dos bens ambientais e culturais.

Isto tudo não é novidade para nós brasileiros. Constata-se, de ano para ano, uma sempre mais profícua participação das indústrias e dos bancos nas manifestaçóes culturais. Atualmente, por exemplo, o Banco Itaú S.A. está expondo cem obras de seu acervo no Museu de Arte de Sáo Paulo, 
permitindo assim que um grande publico conheça aquele patrimônio, normalmente restrito à diretoria e altos funcionários. Além de incrementar a atuação dos museus e fundações, estas beneméritas empresas contribuem para divulgar a cultura e a história. Tudo somado, creio que o Brasil está no caminho certo. E no setor tutto il mondo é paese, vai-se distinguindo, no estabelecimento de uma política cultural bastante promissora.

\section{Legenda}

Povoado na planície, de Frans Post: da colação do Banco Itaú para o público

Senhor \#243, I3 de novembro de 1985, p.88 (P.M. Bardi)

EzRa POUnD: EVOCAÇÓES

No centenário do poeta, retalhos de uma velha amizade

Comemora-se o centenário do nascimento de Ezra Pound. Pode ser interessante, num complemento aos numerosos ensaios dedicados à sua poesia, o depoimento de alguém que teve ocasião de conhecê-lo intimamente.

Pound, nos anos 30, quando morava em Rapallo, na Ligúria, foi me procurar em Roma, fautor da polêmica por mim desencadeada em favor da nova arquitetura, então apelidada de racionalista, cujo cônsul era Le Corbusier. Ele veio me ver na Galleria d'Arte onde, poucas semanas antes, tinha apresentado de improviso a Mesa dos Horrores, ridicularizando o modo de proceder da arquitetura italiana, vigorando o estilo "romano imperial modernizado," uma espécie de post-neoclassicismo que tinha seus expoentes coroados na Academia Real da Itália, sendo o mais famoso Marcello Piacentini, autor também da mansão que o conde Francisco Matarazzo mandou construir aqui, na avenida Paulista.

Pound havia acompanhado aquilo que, meio século depois, este cronista se permite definir a audácia de uma exposição, (uma das minhas pichações) e vinha, sem saber de mim, para me abraçar e se solidarizar. De fato cumprimentava alguém que, como diretor de uma entidade oficial, tinha denunciado o atraso estético do regime, tendo a cara de bronze de convidar, para inaugurar o grupo Movimento Italiano Arquitetura Racional, o próprio Mussolini.

Pound, que, história velha e em parte mal contada, era um admirador fanático do ditador, queria saber como ele havia encarado o desafio. Expliquei ao Poeta, como de resto se observa nas fotografias do evento, a reaçáo de surpresa de Mussolini diante da desconcertante fotomontagem, cheia de obras públicas repletas de arcos, tímpanos e águias caricaturadas com embalagens de chocolate e inscriçóes pungentes. Disse-lhe que o manda-chuva compreendeu o significado da denúncia dos jovens arquitetos manifestando-se favorável a acabar com o culturalismo, isto é, o uso dos estilos do passado.

Um parentêse: o ditador não era o fulano comumente descrito; entre os handicaps próprios dos donos do poder, jogava esperando contar com a sorte. Calculou mal a última e desgraçada carta. Devo dizer que, naquele tempo, eu já sofrera a supressão da revista Quadrante que dirigia com o acadêmico d'Itália, Massimo Bontempelli, devido a um meu entrefilet ridicularizando a escola para formar hierarcas fascistas.

Mussolini tinha aderido à proposta de mudar a direção no construir, ordenando oficialmente a publicação de meu manifesto polêmico, síntese do meu livro Rapporto sull'Architettura.

Com Ezra Pound ativei ampla correspondência que um dia irei publicar. ${ }^{72}$ Trata-se de longas e pitorescas cartas. Li uma carta dele endereçada a Mussolini, saída dos sequestros dos arquivos italianos feitos pelos aliados, em que o Poeta o incita a prestigiar minha campanha em favor da renovaçáo da arquitetura.

Ezra Pound ia frequentemente a Roma. Era fascista demais, às vezes intransigente, não tolerando discussóes sobre atos do seu ídolo. Vi-o pela última vez quando, em Roma, entregou ao doutor Francesco Monotti, do meu Studio d'Arte Palma, uma corpuda mala de manuscritos que, infelizmente, se perdeu.

O resto se sabe. Queria, hoje, lembrar, acima das tragédias, o Poeta amigo,

72 Essas cartas não foram publicadas e não se sabe o paradeiro delas. 
o entusiasta por tudo quanto era novidade, polêmica e futuro.

\section{Legenda}

Cartaz da cantata cênica executada no Masp com música da Lívio Tragtenberg e regência de Oswaldo Caruso. O poeta era um entusiasta por tudo o que era novidade, polêmica e futuro, e muitas das suas cartas pessoais permanecem inéditas

Senhor \#244, 20 de novembro de 1985, p.96 (P.M. Bardi)

NOTA IO OU NOTA ZERO?

O labirinto dos julgamentos sobre arte

Não é da competência de cada visitante da exposição de pintura e escultura italiana contemporânea, apresentada no Masp, estabelecer o "intelectualismo" de cada um dos nove autores: um momento complicado quando nos cabe julgar. De resto, é o que acontece na apreciaçáo da arte destes últimos trinta anos no mundo inteiro.

Penso nos noventa mil pintores que trabalham em Manhattan e nos pelo menos dois ou três mil ativos na Pauliceia, todos vanguardistas natos, às vezes improvisados, crescidos, bem ou mal originais ou seguidores de modos divulgados em outras praças. Escrevi entre aspas a palavra "intelectualismo" pois é esta a insígnia típica do urbanismo dos ateliers à arte atual. Aliás, afirma o press-release da Secretaria de Estado da Cultura e do Masp, patrocinadores do evento: “... Um elemento decisivo na mudança do panorama artístico dos anos 70 e 80; do intelectualismo da última arte conceitual à sensualidade da nova pintura. Uma nova pintura que tinha espessuras de sedução, de bizarria, de comunicatividade também ligadas a uma configuração quase que antropológica da arte italiana."

As motivaçôes são intelectuais, inteligíveis ou não, de qualquer jeito a serem indagadas para descobrir o que pretendem comunicar.

É notória a existência de duas categorias no julgar. Sempre foi assim, desde os tempos antigos: os inteligentes e os idiote, como os apelidavam os romanos nos tempos de Cícero. Isto é: aqueles em condição de dar nota Io, ou, ao contrário, nota zero, ou um dos tantos números para premiar ou não, caso que ainda acontece nos melhores salóes. Conheci um artista possuidor de 84 medalhas que nem está no Benezit.

Parece-me que tudo, no julgar, depende do próprio saber, independência das inúmeras sugestóes e pressôes, valor monetário, simpatias e antipatias. Os fatores para definir a arte moderna e pós-moderna e mais, as últimas bizarrias, atingem o infinito.

Entre os jovens italianos mais conhecidos estão Chia e Cucchi, articulando o figurativo na maneira disfarçada do nebuloso e suas influências estão presentes na mostra. Outro canal é navegado por Pizzi Cannella e Luzzi, como diz o crítico apresentador, professor Flavio Caroli, da Universidade de Bolonha, "uma fascinante pintura barbárica e mágica... Quase um arquétipo de imagens míticas e primordiais.” Ragalzi e Nunzio, em vez, se distinguem pelas imagens de imediata dramaticidade.

A crítica, hoje, é exercício inútil se não for discutida in loco, diante das obras. Antigamente, era a temática compreensível que ajudava a entender. Pergunto-me: quantos são os observadores atentos com possibilidade de entender a mensagem de cada autor?

Nesta performance, há elementos ligados a ideias e sentimentos dignos de interesse. Todavia, constato como o público continua se esquivando às comunicaçóes que demandam compreensão. Foi o mesmo caso que se deu na passagem do verismo, quando Gauguin dizia não saber pintar um anjo, pois náo o via. Hoje, em vez de anjos, pinta-se o abstrato que ninguém vê. Tudo, moralmente, está mudando. Pouco a pouco, o pessoal estará em condiçóes de distinguir e de se aproximar das propostas do Informal e do Neo-Informal. Para um dos italianos, Caroli escreve: "Na realidade seu desafio é completamente lúcido: recapturar as seduçóes de uma deslumbrante relação com a natureza, aceitando, aliás, declarando, as inevitáveis e grandes premissas da história da arte nesta direção." É o que se espera da parte dos pintores. 
Legenda

Tudo ao redor, óleo sobre tela de

Pizzi Cannella (1983-1984): em arte, tudo está mudando e desafiando os critérios de quem é convocado para fazer a análise desse produção

Senhor \#245, 27 de novembro de 1985, p.II2 (P.M. Bardi)

A ESTÉTICA INTERNACIONAL

A geleia geral da arte, vista pelos seus mais importantes incentivadores

Uma das obrigaçóes que atendem os tais curiosos nos casos e problemas das artes é acompanhar as publicaçôes dedicadas àqueles assuntos, hoje complexíssimos e abagunçados lazeres. Considerando que na praça estas ainda não circulam, a leitura se limita às da Europa e dos Estados Unidos, mais acessíveis por causa das línguas, enquanto que o máximo de interesse seria estar a par do que se passa também nos países do Oriente. Assim, sobre a agressiva Exposição de Tsukuba no Japão, já visitada por vinte milhóes de pessoas, e que vários redatores comparam à Universal de Paris de I900, cujo símbolo, a Torre Eiffel, é considerado a porta de ingresso no século 20 tem-se notícias nas revistas do Ocidente. Vejo algumas em Modo, em um comentário de Mário Bellini: surpreso com os ofuscantes robôs que sobem escadas, dançam, tocam órgão, executam retratos, traduzem; mas, o que o impressionou foi "um efêmero monstruoso pé de tomate em condições de produzir, graças ao emprego da cultura hidropônica, quinze mil frutos por ano.”

É impossível registrar o que se passa neste fim de século, inclusive na área da estética, o tema que mais ou menos se tenta discutir nesta página. Como acenei no último número de Status, ${ }^{73}$ nasceram e vão-se agitando os Pitanguys da estética, conseguindo fragmentar ainda mais o campo do pós-moderno, eclipsando os valores das propostas e imposiçóes dos anuladores do Racionalismo, Le Corbusier, Gropius e tantos mestres que, nos livros alemães, são definidos como "malditos arquitetos," responsáveis pelo aparecimento de "um universo de objetos frios, espigados... Um mundo hospitaleiro, em presença de um homem-modelo, ao qual se oferecem produçóes que, por servir bem a todos, não servirão a ninguém."

Há na estética, a partir da arquitetura, uma advertência de revisóes aliás, reaçôes contra o fetichismo do simples, do linear, do utilitário condenaçóes ao decorar, ao pingo de artificismo: um possível retomo ao culturalismo?

Leio, na mesma revista, uma entrevista com um arquiteto dos mais renomados dos Estados Unidos, Stanley Tigerman, de Chicago, autor de livros polêmicos. Apreende-se que na América do Norte a arquitetura recupera a linguagem neoclássica. Declarou: "Quando se projeta, se projeta sempre para o hoje, não para ontem, nem para amanhá. Dizendo isto sou, talvez, muito americano, programático e eclético; a arquitetura americana é híbrida, pesca em muitas memórias, porém sempre esteve em transformação.”

Em outra página se dá espaço ao make-up artístico: operadores visuais tratam de cores para carrocerias de veículos; em outras, a um conjunto de fatos que também nós no Brasil temos, estudamos e resolvemos. Transcrevi alguns, para me perguntar: por que o Brasil internacionalmente está ausente nas publicaçôes dedicadas à estética?

Depois da fundação de Brasília, de nossa portentosa engenharia que opera nos vários continentes, diria, depois do Masp e de tantas outras conquistas, que seria a hora de se pensar nisto.

\section{Legenda}

Estéticas: fechada da Biblioteca Imperial do Rio de Janeiro, projeto de Grandjean de Mintigny, o arquiteto da Missão Francesa. I Engenharia: construção do anel rodoviário "Cebolão," de São Paulo

Cf. Anexo A, p.48o. 
Senhor \#246, 4 de dezembro de 1985, p.9I (P.M. Bardi)

O BOOM DOS CATÁLOGOS

As empresas fazem o levantamento peça por peça, dos acervos dos museus brasileiros

Continua se verificando o generoso interesse pela cultura por parte das grandes empresas que contribuem decisivamente para a estruturação do Brasil. Hoje esta participação colabora para o reconhecimento e a difusão do que se realiza, às vezes com muita dificuldade, no setor das artes e das ciências. Têm sido numerosos os patrocínios das indústrias e dos bancos para atividades culturais. Várias vezes, nesta página, as referências não faltaram, e hoje vou focalizar uma das mais importantes: a do Banco Safra, que acaba de lançar o Catálogo Geral do Museu Nacional de Belas Artes (MNBA), depois de já ter publicado o do Masp, ao Museu de Arte Sacra de São Paulo e do Museu Paulista; da USP, mais conhecido como Museu do Ipiranga.

Finalmente, após todos estes anos, quatro das maiores entidades culturais do Brasil contam com publicaçóes à altura dos seus acervos, numa contribuição notável, pois a tiragem dos volumes cobre milhares e milhares de destinatários.

Com a edição dedicada ao MNBA é possível finalmente se saber o valor do mais antigo museu brasileiro que, como se vê na ilustração da fachada principal em memória, leva a data fatídica de I808: lembrança dos primeiros passos do nosso neoclássico, consequência do Reinado, estando ainda vivo o Aleijadinho.

As vicissitudes do hoje grandioso prédio são bastante conhecidas: hospeda um acervo considerável que o volume ilustra peça por peça.

Vê-se desde um Crucifixo atribuído a Giunta Pisano do século 13 até obras do famoso Grandjean de Montigny, coleçôes de arte popular nacional e africana, mobiliário, cerâmicas, jades, medalhística, glíptica e várias outras seçóes.

A parte de maior peso do acervo do Museu Nacional de Belas Artes é a incomparável coleção de pintura brasileira, o registro do que se passou no País ao longo do tempo, o conjunto das obras realizadas por iniciativa dos colonizadores. Os diretores daquele museu, desde o inicio até hoje sempre escolhidos por mérito, como confirma o atual dirigente do estabelecimento, professor Alcídio Mafra de Souza, bastante conhecido como competente estudioso do avanço da arte brasileira, atento e dedicado aos problemas de conservação. Para ele, o lançamento do monumental catálogo do MNBA representou o reconhecimento da importância histórica da nossa representativa galeria. Mais uma vez: parabéns ao Banco Safra, que assim vai resolvendo o problema da necessidade dos museus pátrios, publicando catálogos dignos da sua importância.

O lançamento reuniu no Rio de Janeiro, representantes da imprensa carioca e paulista, convocada por José Roberto Marcellino dos Santos, do Banco Safra, que atende com singular competência a participaçáo de sua empresa nos vários setores da cultura artística, sempre contribuindo com iniciativas de interesse coletivo na propagação da difusão cultural.

Mais uma vez se constata o quanto tem sido decisiva a colaboração das empresas no progresso das artes: as manifestaçóes de uma certa importância foram possíveis graças àquela intervenção.

Este cronista aproveita a ocasião para anunciar aos seus leitores que, no próximo mês de março, São Paulo terá a oportunidade de apreciar, no Masp, uma mostra excepcional: "Toda a gravura de Pablo Picasso." Será apresentado o conjunto ainda conservado pela família do Mestre em exposição que será possível através do patrocínio da Câmara de Comércio e Indústria Franco-Brasileira, sediada em São Paulo.

\section{Legenda}

Detalhe da arquitetura do Museu Nacional de Belas Artes, no Rio, indicando a data de I808: lembrança dos primeiros passos do nosso neoclássico 
Senhor \#247, II de dezembro de 1985, p.92 (P.M. Bardi)

A MUlTipliCaÇÃo DA NOVIDADE

A improvisação e a astúcia nos negócios artísticos

É surpreendente apreender na praça, e até em praças internacionais, que obras de arte às quais eu não atribuiria valor foram e continuam sendo disputadas no mercado improvisado destes últimos tempos em que o decreto Morte da Arte vai recebendo sempre mais carimbos, e o registro de nascimento da enigmática supervanguarda idem.

Não sei quem ainda é tolo a ponto de frequentar as antigas escolas de belas-artes, agora que valem as academias da libertação, os templos da decoração informal, abstrata, pobre etc., a estética e o assim dito bom senso no julgar e apreciar uma tela ou um acrílico senão confinados á gaiola dos quatro gatos pintados.

O mecanismo arte é de outra envergadura: vale mesmo o trombetear, o publicitar, o convencer os Peter Sellers do Muito além do jardim, os quais, diante de uma obra quase ou não aparentada com a arte, exclama:"É bonito, eu compro." dentes de que o autor é celebrado como nunca se viu em casos superados de mistificação como Rafaéis, Leonardos, Cézannes etc., frutos do atraso, do figurativismo que já era.

Parece-me que também na praça aconteceu, nestes últimos vinte anos, por dependência imitativa, aquilo que, após o Modernismo, emergindo uma avalancha de nulidades, (salvo, naturalmente, vários mestres) conseguiu se apoderar do mercado, acumpliciado aos sistemas que o sustentam, chefiados pela publicidade que nos impóe beber Coca-Cola e usar computador.

"Desde os antigos tempos, vivendo ainda Santo Agostinho, náo faltavam os falsários e impostores que distribuíam ás pessoas por demais crédulas relíquias adulteradas de santos e, o que é pior, vendiam-nas concluindo um ímpio mercado e lucravam com tais espertezas..." relatava Ludovico Antonio Muratori no terceiro volume das Antiguidades Itálicas.

Descubro o guarda-chuva, sei disso. As maneiras de negociar, servindo-se da astúcia e do engano, fizeram sempre parte das crônicas. Hoje, o rocambolismo sabe como usar subterfúgios e eventuais contos-do-vigário num mundo impacíente por novidades, eventos surpreendentes, exageradas pretensôes. Outra coisa do mundo pagão. Lê-se, porém, com curiosidade, o similar de certas companhias que perambulavam pelos lugarejos e castelos levando num andor uma pretensa Dea Siria, ao som de trombetas, encenando espetáculos, chegando a se ensanguentarem para iludir com malabarismos e fictícios milagres o povo e os capatazes, sendo depois os espertalhóes aplaudidos e recompensados com "óbulos e dinheiro, figos secos, queijo, frascos de vinho e grão e cevada para o burro," como conta Luciano de Samosata.

Não sei a razão, mas estou pensando numa credibilidade daquele tipo: o fascínio atual por uma outra deusa, a da Arte Último Grito, jogando às urtigas a tradicional. Vale, e é exaltada, a improvisada e lançada por fraternidades de vendedores hábeis no convencer que a recém-desenfornada mercadoria dá lucro de cem por cento, aliás, de cem por mil. Não mais os figos secos do tempo pagão, não mais o povinho boquiaberto, mas a burguesia abastada. $\mathrm{Na}$ praça vê-se uma precipitaçáo de novatos, pois o boom se tornou fantástico. Tudo se multiplicou: produtores, críticos, estando em cena como atores os donos de galerias e os corretores. Esta novidade esteve e está vencendo no consumismo típico do capitalismo: o objeto de arte sendo instrumento de comercialização em vez de instrumento de satisfação e prazer cultural.

A atividade mercantil acompanha e determina as correntes da produçáo aviadas no facilismo provocando a multiplicação das peças estando presente uma outra estética passivamente aceita, valorizada pelos empreendimentos de repercussão mundial como a Quadrienal de Kassel e a sua imitadora, a I $8^{\text {a }}$ Bienal paulista. Seria ingênuo assumirmos o papel de conservadores.

Todavia, um certo sabor de Dea Siria vai-se notando: cabotinismo, credibilidade, aceitação indiferente da política 
de vendas. A improvisação, os contatos com mercado que náo entendem bulhufas, criam um quadro sociologicamente curioso: a descoberta da Dea.

\section{Legenda}

Yves Klein em 1956: um dos precursores da ousadia e da vanguarda, elementos que hoje proliferem em todas as galerias

Senhor \#248, I8 de dezembro de 1985, p.I22 (P.M. Bardi)

UMA REALIDADE INDIGESTA

O pioneirismo do Masp no esforço de mostrar a arte brasileira

no que ela tem de mais contundente e representativo

Logo após a Segunda Guerra Mundial, no Brasil, no que se refere ao transcorrer da atividade dos produtores da mercadoria Arte, a situação parecia mais estática do que dinâmica. Tendo desaparecido o mito da Semana de 22, os participantes daquela incrível reação pareciam desconfiados e operavam isolados, pelo que pude constatar ao recolher algumas de suas obras para a Pinacoteca do Masp então em formação.

$\mathrm{O}$ artista mais em evidência daquela época era Cândido Portinari. Todavia, este ficou surpreso quando lhe propus adquirir o tríptico dos Retirantes, pois pensava ser aquele conjunto mais uma reação social sua ao que "peça para museu." Minha ideia era outra. Pensava em escolher e apresentar o mais espontâneo, apesar de, às vezes, ser indigesto: a realidade nacional, possivelmente o desabafo mais do que convencional dos artistas. Náo se pretendia oferecer uma impressão partidária, porém dar notícia do que se produzia, aderindo a um plano imparcial da realidade.

Foi por isso que no Masp se fizeram depois exposiçóes bastante representativas da realidade brasileira juntamente às manifestaçóes convencionais. Às vezes se quebrou o andamento informativo revelando, é a palavra, até o fazer dos camponeses, primeiros usos de máquinas, contribuiçóes das imigraçóes. Foi quando, ao lado de obras-primas de Bellini, Rafael, Ticiano, El Greco, o público examinou a exposição "A mão do povo brasileiro," título que surpreendeu e provocou até a discussão de um historiador de alto valor como Sérgio Buarque de Holanda.

Apresentar aquela produção em um centro de cultura sugeria um interesse por tudo quanto fazia parte ou pelo menos se apresentava com o significado da palavra Arte. Lembro isto para afirmar que, no desenvolver da política, se assim pode ser classificada essa ação, procuramos ampliar e sustentar o princípio geral do fazer humano, até descobrindo valores onde nem se pensava encontrar, naquele setor que chamam "arte menor."

Isto serve para justificar várias extravagâncias que foram apontadas no novo centro cultural. A longa lista das manifestaçóes que apresentaram muitas vezes provocou reaçóes dos museólogos conservadores, sem falar dos críticos do cotidiano os quais perguntava que o Masp quer fazer saber com um desfile de moda desenhada por Christian Dior, as manequins dando voltas, na Pinacoteca, entre antigas pinturas e estátuas. É verdade que, usando de um pingo de astúcia, tinha incluído no desfile um modelo de autoria de Salvador Dali.

Apesar de tudo, a novidade do recém-inaugurado centro de cultura recebeu, naqueles tempos pioneiros, muitas críticas, havendo quem escrevesse: "Museu ou circo equestre."

O que relato nesta página serve para anunciar aos eventuais leitores que estamos trabalhando para inaugurar o ano de 1986 com uma exposição de novíssima novidade, dedicada ao Jornal da Tarde. Evidente: continua a nossa convicção de considerar como espírito e pratica de arte tudo quanto a vida produz. Náo foi por acaso que, no começo dos anos 50, o Masp criou as duas primeiras escolas brasileiras design e propaganda.

\section{Legenda}

A exposição "A mão do povo brasileiro," realizada no Masp em 1969: contradiçóes de um país cheio de desafios 
Senhor \#249, 25 de dezembro de 1985, p.92 (P.M. Bardi)

REUNIÂO DO MESTRE DISTANTE

Minibiografia afetiva de Lasar Segall e sua obra

Transferindo-me para o Brasil em I946, depois dos encontros com Portinari e Di Cavalcanti, que se deram no Rio de Janeiro, visitei em Sáo Paulo o pintor do qual já conhecia a história: Lasar Segall. Fui procurá-lo em sua casa, nos primeiros dias quando discutia com Chateaubriand a organização do Masp. Tive a impressão de um veterano de vida isolada, dedicado a reflexôes, poucas palavras medidas saborosamente num pensar que logo se descobria reflexivo, gestos pausados, atenção cordial, confiança em si, todavia reserva inclinada a possível surpresa.

Ao seu lado sua esposa, dona Jenny, uma senhora esplêndida em sua dedicação: cada um, falando, dirigia o olhar para o outro para acertar e compartilhar pensamentos. Andava anotando dois caracteres singulares: minha curiosidade palmilhava as origens dos Lasar. Surpreso pela inexistência de uma monografia dedicada ao Mestre conversamos a respeito, combinando que o novo Museu se interessaria por editá-la.

Foi uma das primeiras iniciativas colocadas no calendário. Consequência: resultou num assíduo contato com Segall, para mim, então, uma informação correta sobre os tempos, grosso modo, correndo entre a Semana e a decisão aventureira de Chateaubriand de abrir um museu numa capital onde a arte pouco, para não dizer pouquíssimo, parecia interessar.

Lasar, dona Jenny, Gregory Warchavchik, Geraldo Ferraz e depois o valente Flávio de Carvalho, muito contribuíram para me ambientar na cidade. Mais complicados, e nunca compreendi o motivo, foram os contatos com o pessoal do Santa Helena. Segall os considerava ainda em posiçóes pós-acadêmicas. De fato o lituano, de origem expressionista, rompia no Brasil uma situação, modernista sim, todavia contida no status quo. Lasar me contava sua vida, examinando todo o material antigo ainda total ou quase totalmente em seu ateliê. O que me interessava era sua primeira estada em Sáo Paulo em I9I3, e a exposição em Campinas.

Desde o primeiro encontro, fora espontâneo pedir a Lasar que me mostrasse sua pintura dos tempos em que trabalhava em Berlim, Dresden, Amsterdã, Paris. Andava então, recompondo seu itinerário, parecendo-me o mais vivo o período da capital alemá, com o encontro e descoberta da Secessão.

Mas o que mais me impressionou, no convívio com Lasar, foi sempre a expressão da cor. Para ele, um estado de espírito, revelação de sentimento, no severo limite das formas aproximadas ao saber que lhe ministrou seu pai, escriba do Torah. O proceder de Lasar dependia da sua educação espiritual, do senso da ortodoxia próprio de um centro como Wilna, a Jerusalém lituana.

Estava revendo, nestes dias, um livro que o Masp editou pelo cinquentenário da Semana de 22I dando conta dos antecedentes e suas consequências. Numerosos os pintores, raros os arquitetos ativos, os escultores. No conjunto ficava evidente, por singular destaque, um mestre, Lasar Segall. Imigrando para o Brasil, tive a sorte de conhecê-lo intimamente e de ser quem escreveu a primeira monografia dedicada à sua arte.

Esta lembrança é para alertar o próprio Museu Segall, hoje tão ativo e amparado pela Pró-Memória, a tomar a iniciativa de documentar numa completa publicação a obra do Mestre.

\section{Legenda}

Guerra, de Lasar Segall: uma rica experiência exposta num acervo que precisa de divulgação integral

Senhor \#250-25I, 3I de dezembro de 1985, p.80 (P.M. Bardi)

O NERVOSISMO DAS VANGUARDAS

Um trabalho difícil para historiadores e criticos

Numerosos, para não dizer inúmeros, são os pintores que, após os primeiros vagidos do Informal, deixaram de ser figurativos para se disporem a mexer no Abstrato, 
tentando uma possível originalidade, descobrindo composiçóes combinadas, entre o geométrico e o mosaico, buscando nos amplos, aliás, no infinito do invisível, possíveis articulaçóes de linhas e cores, signos excêntricos, às vezes espontâneos ou descobertos por sugestão, outras vezes repetitivos, puras e simples imitaçóes.

Não é aqui o caso de lembrar o aparecimento do Abstracionismo e nem as origens que se interligaram aos acontecimentos normais, numa época de progresso científico e até mesmo de desenvolvimento civil. Como quando se olhava sob o ângulo verista, vindo depois de quebra a reformulação figurativa, o aparecimento do ver independente de modelos reais teve, e tem, sua presença.

Existem críticos que lamentam o exercício do Informal, o que leva a uma pergunta: o trabalho da crítica é de simples registro? É natural que no registrar se possa demonstrar o próprio favor ou negá-lo a uma ou outra tendência. Competirá aos historiadores a avaliação. As mesmas causas e efeitos foram notadas depois dos vários e variados romantismos. De qualquer jeito, o historiador, e isto já se verifica, vai considerar a predominante maneira do Informal. Nesta definição pode ser incluído não sei qual arsenal de manifestaçóes consagradas nas exposiçóes do mesmo teor de Kassel e suas derivaçóes.

As tarefas do historiador do século que se aproxima serão repletas de problemas, como de resto o foram no começo deste, quando se tratou de considerar inquietudes das vanguardas. Foi preciso desenfornar novas justificativas, prosas convenientes de decifração, recorrer às simbioses da poesia. Deve-se lembrar que Baudelaire, em Le Voyage, já advertia: "Se imergir no fundo do abismo.| Inferno ou Céu, que importa?| No fundo do não conhecido para encontrar a novidade." (Encontro esta citação numa prosa de João Pessoa. )

As novidades neste século apareceram ao infinito. Quem for historiar deverá engenhar-se, principalmente, no distinguir, pois os tempos futuros se delineiam por um desejo de síntese. Pensa-se que a cultura caminha para uma reduçáo cada vez maior de informaçóes sobre o passado, as pessoas mais presas à tevê do que à leitura. De resto, como já se observa agora.

Confissão: foi complicado para os interessados nas plásticas contemporâneas, habituado ao Figurativo, aceitar o labor informal. Recentemente estava lendo um livro mediúnico dedicado ao que acontece em Marte na área da Pintura, capítulo que leva a pensar no Informal. Ramatis responde a uma pergunta dizendo que naquele planeta o "grau evolutivo do seu povo" conhece uma pintura fosforescente que provém da mistura de um elemento estranho à cor criando-lhe luminosidade artificial. Em Marte, o artista dotado de visão psíquica incomum; penetra no mundo "etéreo-astral" e "consegue captar nuanças fascinantes que parecem refletir a magia de invisível projeção de luz."

É surpreendente ler este relatório de $A$ vida no planeta Marte, psicografado por Hercílio Maes. Preanunciam os abstracionistas algum fato sideral?

\section{Legenda}

O Cavaleiro Azul, de Wassity

Kandinsky uma ruptura que deu início ao Informal, no começo do século

\section{Casa Vogue \#I, janeiro-fevereiro de I986, p.48 (P.M. Bardi)}

ARQUiteTURA E ENGENHARIA NA CONSTRUÇÃO

Desta vez na página que o diretor me destina devo anunciar que publiquei um livro. Intitula-se Arquitetura e Engenharia na Construção e foi editado pelo Banco Sudameris, na coleção "Arte e Cultura," na qual já apareceram vários outros trabalhos meus. Sendo o assunto a Arquitetura e também contemplando aquela profissão táo ligada a ela, me parece ser este o local apropriado para dar a notícia.
As primeiras páginas se interessam pela cabana e as tentativas de moradia. Logo depois é o momento, aliás, os séculos, ilustrados pelo nosso Barroco, que tem a mesma importância que o mexicano e o peruano. O nosso é extravagante, a manipulaçáo da voluta, negação da lógica renascentista preocupada com a ordem e a parcimônia das formas. A pintura, ao invés, atinge menos o teatral, prevalecendo a compostura tradicional. 
Enquanto na Colônia o Barroco está no seu período de exaltaçáo, na Europa a Arquitetura torna-se objeto de revisão num sentido renovador. Em Veneza a mansão do cônsul inglês Smith, na metade do Setecentos, tornou-se um cenáculo de intelectuais que deram às discussốes relativas a construção amplos e profícuos tratados. Entre os doutos iluministas: o abade Carlo Lodoli, ao qual se deve a afirmação dos princípios "racional" e "funcional," condenador dos abusos dos arquitetos barrocos.

Para Lodoli, propulsor da "Arquitetura Orgânica," valia a razão e não c capricho, a começar pela forma de uma cadeira, provendo um assento em que o corpo se instale comodamente, dar destinação a formas úteis, funcionando para uma realidade natural vivente. Propunha um esquema orgânico para uma construção erguida num terreno propício, desfrutando soluçôes práticas e racionais, a reflexão, diria, engenhosa, contra as soluçóes empíricas: proposiçóes do movimento que será chamado racionalista por Le Corbusier. Iluminismo no Brasil? Nada de notável ao longo do século que na Europa se passa entre a revolução inglesa de 1688 e a francesa de 1789 . O que se produz no antigo continente, aqui nem se sabe o que é. Lá começavam a ser acesas as "luzes da razáo," revolta contra o misoneísmo e as conservadores, a ignorância, o fanatismo e as injustiças, o que se definiu depois como obscurantismo.

No Brasil era mesmo obscurantismo. Raros até os reflexos utilitários das descobertas da ciência através de Portugal. Seria interessante saber se o Dictionnaire raisonné des sciences, des arts et des métiers, enciclopédia de Diderot e D’Alembert, veio por acaso de contrabando. O livro informa sobre contrabandos de tendências e casos de presença de elementos que discutem o Barroco, como ocorreu com a chegada, naturalmente via Lisboa, do arquiteto italiano Antônio Giuseppe Landi, que deve ser citado como antecipador do Neoclássico, construindo em Belém, a capital descrita por um viajante francês como de "ruas bem alinhadas, casas alegres, igrejas magníficas," nos novos modos "pombalinos."

$\mathrm{Na}$ condiçáo de Colônia, era fatal que os ditames estéticos viessem do Reino, como também de outros países que tentaram ocupaçóes territoriais de breve duração, ou de missóes chamadas expressamente, como a francesa: todas as influências que no Oitocentos se juntaram e se entrosaram como as experiências dos imigrados e das raças já estabelecidas, como a moura. É desta combinação de variadas atividades que surge o estilo que vale na Europa e também nos outros países: o Culturalismo, isto é, o se basear em todas as maneiras históricas, como se vê por exemplo em São Paulo: a catedral de formas góticas, o Ipiranga renascentista etc.

E os engenheiros?

A falta de instrumentos era o drama da produção. Até os utilizados na mineração de ouro e de diamantes eram improvisados. Bastará dizer que para lavar a areia, a fim de se encontrar pequenos grãos de ouro, os garimpeiros usavam o prato de estanho em que comiam. Somente em I722, através da vinda da África de mestres na arte de minerar, é que começa o emprego de processos mais aperfeiçoados.

Os engenheiros da construção eram os militares. No livro conto a atividade desta categoria, a qual no Nordeste erigiu as grandes fortaleza ainda visitáveis. Praticamente são eles os responsáveis pela construção na Colônia.

Quando se póe a pena neste tipo de livro, vai-se daqui para lá, afastando-se do argumento, distraindo-se em divagaçóes talvez não tão inúteis no interligar duas ciências, ou artes não só afins, mas unitárias, diria a mesma ciência, ou arte, da construção.

Senhor \#252, I4 de janeiro I986, p.73 (P.M. Bardi)

A REDAÇÃO VAI AO MUSEU

As artes do Jornal da Tarde expostas no Masp

Cada pessoa aceita ou decide envolver-se nas tarefas mais complicadas, talvez por hábito ou vício. Hoje este cronista se mete a expor no Masp - cujo principio é o de

considerar a arte uma simples coleta de novidades da vida, para nelas descobrir pechinchas ou imensidóes relacionadas com aquelas problemáticas que alguns 
eruditos ainda inscrevem na filosofia da estética - uma mostra singular.

Acostumado a receber na cabeça até desaforos por ter realizado exposiçóes que nada tinham a ver, como declaravam os detratores, com as maravilhas da Arte, tive a audácia, certa vez, de desmontar a Pinacoteca conservadora desde um afresco do Quatrocentos até estupendos Van Gogh e Picasso, para dar lugar a corriqueiros instrumentos de trabalho dos artesãos do antigo Brasil.

A nova manifestação se refere a um jornal, para este redator particularmente grato, pois foi editor-chefe, no início de seu aparecimento, Mino Carta, ingenique largitor, que muito prestigiou o Masp. Refiro-me ao Jornal da Tarde, o qual festeja este ano os seus vinte anos. Ao mesmo tempo, páginas de história, recapitulação de atividades, inteligência no comunicar, explicar, comentar, polemizar, absolver, condenar, distribuir votos de mérito, censuras e tudo que compóe os noticiários, tópicos, artigos pesados e brilhantes que brotam de uma redação, inclusive as figuras e aquele modus vivendi da publicidade.

Pode-se dizer que se vivifica o jornal para extrair uma síntese de uma operosidade muito complicada, aquela que o leitor que nunca pisou nos pavimentos de um cotidiano nem pode imaginar ou, se habituado às produçóes industriais, esteja em condição de estabelecer, a grosso modo, o funcionamento. Compilar um jornal não é somente fato técnico: é especialmente um fato de cultura e, naturalmente, de política.

Trata-se de informar se o tal líder no governo de uma das muitas circunscriçóes políticas é ou não valente até estabelecer se o tal partido presta ou não presta. Ao lado uma massa de notícias do que se passa não só entre os confins nacionais, mas também fora. $\mathrm{E}$ dos acontecimentos mais importantes expressar um parecer.
Abram um jornal: quantas as seçóes? Cada leitor tem suas preferências, o que mais lhe interessa na hora, penso que, por exemplo, a Economia, ou "seu dinheiro" como diz o JT, atraia os olhos. Mas deve haver os usuários do Esporte, os habitués do "Divirta-se." Para quem mexe nos problemas das artes se torna leitor do crítico, do Jacob Klintowitz, que considero o mais independente da praça e o mais inteligente. E por que, até pouco tempo atrás, não lembrar os assíduos do colunista Telmo Martino?

Logo se perde o fio da meada, tentando uma aproximaçáo com todo um mundo de elementos, os quais conseguem oferecer a cada tarde uma folha vivaz, repleta de novidades, esta Cinderela senhora Cultura admitida principescamente em nossa mesa.

A técnica da exposição é, penso, curiosa, ou pelo menos ligada à variedade que compóe um jornal. Este é visto na sua intimidade. Vai funcionar no recinto uma redação e paginadores, serão vistas colunas simbolizando diversas matérias, espaços dedicados à gráfica, a original e pioneira gráfica do cotidiano, caricaturas, inclusive personagens de destaque estilizados plasticamente num tablado circular representando o globo terrestre. O Masp conseguiu a grande tela de Cândido Portinari, Os fundadores de $O$ Estado de S.Paulo, uma obra de tal importância que foi colocada, em homenagem aos fundadores do Jornal da Tarde e ao próprio Mestre, na Pinacoteca. Tudo somado: uma manifestação dedicada aos homens de imprensa como Ruy Barbosa, que assim se definia: "E jornalista é que nasci, jornalista é que sou, de jornalista é que não me hão de demitir, enquanto houver imprensa, a imprensa for livre e esse resto de liberdade nos indicar que a Pátria respira."

\section{Legenda}

Os vinte anos do JT: uma virada na imprensa a partir do número I

Senhor \#253, 2I de janeiro de I986, p.68 (P.M. Bardi)

As VESTES DE UM PIONEIRO

Uma noite inesquecivel na Universidade Mackenzie

O cabeçalho desta página é um convite para noticiar, e às vezes comentar, acontecimentos pessoais. Assim, eis uma ocasião para anotar um de certo interesse. 
Numa destas noites o Bardi foi convocado, na Universidade Mackenzie, para ser o patrono dos formandos da Faculdade de Comunicação e Artes, (I6 alunos para Artes Plásticas, 39 para Comunicação Visual, 59 para Desenho Industrial) dirigida pelo prof. Itajahy Martins. Sendo novidade, confesso minha surpresa, e também timidez, ao seguir a ordem do cerimonial, quando me convidaram para vestir uma beca, ajustar a lapela rendada, colocar uma faixa azul na cintura, atribuindo-me, então, uma distinção de professor, o que tumultuou minha cabeça com sérias interrogações.

A vestimenta, própria para os outros componentes da banca, encabulava-me seriamente, pois me parecia impróprio o improvisado papel, para mim que possuo o seguinte currículo escolar: repeti a terceira série primária três anos e, pela lei italiana, fui eliminado das elementari. $\mathrm{Eu}$, então professor? Sim, me chamam de professor, mas é bondade das pessoas. $\mathrm{O}$ que demonstro de saber é simples fruto do autodidatismo. Sim, participei de uma banca examinadora na USP, porém, sem a farda, e, então, mais à vontade.

De qualquer jeito, vestido, compóe-se a mesa, a cortina se abre, o auditório repleto de familiares dos formandos, um grandioso espetáculo de público. Entram em duas filas os laureados, aliás, as laureadas, pois os poucos moços desaparecem num esplêndido desfilar Feminino sorrindo, todas vestidas de branco, e vão sair no palco. Refletia-se também a respeito do avanço da mulher nas profissóes: uma mudança decisiva no setor das comunicaçóes visuais e, em geral, nas artes. Depois da solenidade do Hino Nacional e do juramento, o cordial recebimento dos graus: beijos aos professores homenageados e aos que entregam o diploma, alegria, assobios, até confetes, além dos discursos.

Entre outros, o deste redator: foi para expressar minha emoção, manifestar meus votos de um bom futuro à talentosa juventude que vai ingressar em profissôes ligadas às artes. Fiz questão de lembrar, e foi a razáo de eu ser escolhido como patrono, que em I950, num tempo de iniciativas precursoras, que tomei a decisão de criar no Brasil duas novas e inexistentes escolas, indispensáveis para o desenvolvimento das artes: a de Design e a de Propaganda.

Foi no Museu de Arte de São Paulo: um simples semear que teve como consequência, entre outras, esta inesquecível noite no Mackenzie, confirmação de um Brasil em mudanças e vitorioso.

Lembrava a presença de raros alunos no Masp, conscientes, porém, do futuro das profissóes ligadas às artes nas novas funçôes impostas pelo desenvolvimento industrial. Para acentuar o nascer de uma nova estética interligada ao progresso, consegui trazer para lecionar no Masp, Max Bill, da Bauhaus. Tempos, pode-se dizer, de pioneirismo.

\section{Legenda}

Entre os professores, o discurso e as memórias de um autodidata

Senhor \#254, 28 de janeiro I986, p.72 (P.M. Bardi)

A FANTASIA DO COTIDIANO

$A$ renovação histórica das atividades culturais

Pode ser que eu esteja errado. Todavia, em minha atividade de museólogo ou museógrafo, apelidos que distinguem os que mexem na conservação de produçóes consideradas de interesse histórico, sempre procurei superar esta tradicional tarefa. Além desta, no caso do Masp, desde sua inauguração apresentaram-se exposiçôes periódicas de artistas e artesãos e também de produçôes de evidente parentesco com a prática, com o renovar, com a fantasia do cotidiano. Assim, realizaram-se na Pinacoteca desfiles de moda, colocou-se na Vitrina das formas, juntamente com as peças antigas, uma máquina de escrever, para representar o design contemporâneo; aliás, criaram-se as escolas pioneiras desta importante novidade, além da de propaganda etc.: um museu não bem museu, mas um centro cultural contendo uma Pinacoteca.

Operando neste sentido, chegou-se, no começo deste ano, a abrir uma mostra que num certo sentido causou sensação: a dedicada ao Jornal da Tarde. Numa das páginas precedentes justifiquei a iniciativa 'jornalística.' Por que um museu, no sentido moderno, não pode 
ser até um fato jornalístico? Registrar o quanto se destaca, estética e tecnicamente, no correr do tempo?

Hoje a imprensa e a televisão participam intensamente na comunicação das artes, através da crônica, discussão, reproduçóes, desenho, gráfica, sem contar que o próprio teatro se transmite por via eletrônica com as telenovelas.

A renovação da função museográfica é evidente. Levar em conta a realidade é oportuno. A tradicional e burocrática celebração da "beleza," como ciência e arte do produzir, não está mais em cena, pois o "bonito" foi posto de lado. O que vale agora é um outro critério, pois o gosto é levado para outros caminhos.

Lembro-me das polêmicas suscitadas por Lionello Venturi ao publicar seu livro Gusto dei Primitivi, atribuindo mais valor aos artistas do Medieval tardio, em contraposição aos da arte renascentista e barroca. Quando então se discutia a respeito de beleza clássica e de espontaneidade, pureza e religiosidade dos pintores do Duzentos e do Trezentos, as vanguardas e transvanguardas afirmavam um novo gosto que nada tinha a ver com a "beleza." Hoje, na Pinacoteca do Masp, Rafael, Ticiano e Tumer estão ao lado de Leger, Max Ernst e Picasso.
Então, nada mais singular que um museu de arte se interesse por acontecimentos relacionados e determinadores das mudanças da estética hodierna, considerando fato de arte o redigir um cotidiano, naturalmente pensando até em criatividade. A palavra estética, que vem do grego, significa fatos sensíveis. Benedetto Croce a definia como a "ciência do aprendizado sensível, teoria das artes liberais... Arte do bem pensar, arte do raciocínio por analogia.”

Também a palavra arte é polivalente e própria para não se sabe quantas possibilidades. Depende dos que a usam. Por exemplo: os redatores de arte de $O$ Estado de S.Paulo relegaram a matéria da exposição do $J T$ às páginas de crônica local, entre limpeza de córrego e cinofilia: não é um caso de arte a ser comparado às duas colunas que se consagram a um pintorzinho. Em vez disso, os redatores do jornal exposto, a caracteres vistosos, são explícitos e escrevem: "A arte do JT."

Pessoal da mesma família: vejam só onde começam as discussôes.

\section{Legenda}

A Virgem e o Menino Jesus, de Giovanni Bellini (I430-1516) e detalhe de Crucificação, de Deodato

Orlandi: mutaçóes de um tema

\section{Senhor \#255, 4 de fevereiro de 1986, p.95 (P.M. Bardi)}

UM HOMEM CORDIAL

$A$ arte do encontro, segundo o embaixador Jayme de Barros

O que prevalece no livro de memórias do embaixador brasileiro Jayme de Barros não é tanto a relação das atividades diplomáticas, mas o que conta dos seus encontros com os adeptos da produçáo das artes: ele circulou pelo mundo, despenhando ativamente sua função, procurando sempre, porém, a conversa com artistas. Suas relaçóes tom esta categoria começaram quando era jornalista no Rio de Janeiro, amigo de Cândido Portinari, do qual revela fatos curiosos para sua biografia, como de vários outros pintores dos tempos da Semana de 22, e os seguintes, no Brasil e no Exterior.

O realmente interessante está nas páginas, onde faz a relação dos contatos com elementos da Escola de Paris, especialmente os com Vlaminck; Waroquier, ao lado do qual recebeu o presidente da República Auriol, numa arranjada exposição de brasileiros em 47 no Salão de Outono; Van Dongen, que vinha da terra de Erasmo, possuidor da ironia, a irreverência, o prazer de exercitar o espírito no malabarismo das ideias e na malícia das frases;" e quantos outros, até Vollard, o mercante de Renoir e Monet.

O arquiteto do qual Jayme escreve é Le Corbusier, confirmando o que denunciei em meu livro sobre o Mestre: sua obstinação em declarar que em 36 não recebeu os honorários do risco para o Ministério de Educação e Saúde no Rio. De cada personalidade encontrada, singulares os retratinhos através dos quais é possível completar as opiniōes. Faz saber, por exemplo, $\mathrm{da}$ "ferina reciprocidade a propósito da pintura de cada um” entre Di Cavalcanti e 
Portinari; Vlaminck descreve Modigliani: "Magro, extremamente pálido, a pasta de desenho sob o braço"; Calambour sobre Derain: "Seu mal é que ele vai muito ao Louvre; eu também vou, mas não entro." Nas memórias aparecem quantidades de competiçóes inéditas ilustrando comportamento e operosidade dos mestres amigos: uma autêntica antologia enriquecida de fotografias, desde a do seu bisavô, barão de Sáo Sebastião, que recebia principescamente, na sua fazenda dom Pedro II, até a sua ao lado de Sarney, documentaçáo de uma longa vida de um diplomata que trata com chefes de governo e também com intelectuais dos países visitados. De residência em residência, o embaixador recompóe sua notável coleção de arte contemporânea estrangeira e brasileira, autêntica rara avis no setor.
Notável seu relato a respeito de um visionário de quilate, Assis Chateaubriand, e a simpatia pelas performances do Masp no Exterior : crônicas que se estão tomando objeto de memória. Parece pré história a da série das exposiçóes do acervo do Masp que Jayme presenciou em Nova York, na inauguração, em 54, no Metropolitan Museum of Art.

São mais de meio milheiro de páginas ricas de informação, também no quadro político e social, de um observador em seu Chão da Vida, (assim intitula a obra editada pelo ativo e empreendedor editor carioca Léo Christiano) anotando lembranças familiares, rígidas incumbências do oficio e um entendimento cordial com a gente da cultura.

\section{Legenda}

O diplomata com os pais e em seu escritório: anotaçôes sobre múltiplas experiências

Senhor \#256, II de fevereiro de 1986, p.68 (P.M. Bardi)

UM MUNDO EM MUDANÇA

Do abstrato ao concreto: desafios da arte contemporânea

Já se vão produzindo, neste final de século, os balanços das artes contemporâneas. Ainda não é bem uma história da arte, porém contribuição para quem um dia vai estudar o que se realizou, o que não será fácil.

O Museu de Arte Moderna de Nova York, o Moma, ao qual a cultura das artes plásticas deve a iniciação de interesses estéticos de positivos resultados, apresenta um volume que, sem dúvida, vai servir ao futuro historiador: uma esplêndida resenha do seu acervo de arte abstrata, incluindo a da Riklis Mac-Crory Corporation, recentemente recebida por aquele museu em doação. É uma extraordinária seleção de obras particularmente dedicada ao "abstrato geométrico." (Falando em doaçôes: onde estão os doadores da Terra de Santa Cruz?)

O volume tem por título Cantrast of Form, de autoria de Magdalena Dabrowski, e pode ser considerado o vade-mecum mais completo referente a um capítulo da arte mais discutida deste século. Suas informaçôes, referências críticas e bibliográficas, oferecem a ocasião de considerar a tendência que, como aconteceu com todas as rupturas, teve extraordinário reflexo no Brasil, produzindo alguns elementos a serem apontados pela originalidade das propostas; e, naturalmente, a massa dos repetidores, imitadores, copistas dos modos atuais.

O Brasil continua sendo pouco considerado no Exterior pelas suas atividades artísticas. Infelizmente, quando aparecem as possibilidades de exposiçóes, as panelinhas impedem que sejam mostradas as personalidades que mais se destacam. Por outro lado, na própria última Bienal Internacional, não foram convidados os que valem, consequência do tradicional sistema dos serviços particulares.

Recitada nossa, digamos, litania, voltemos à edição americana, um volume que dá conta das origens da revolução do não-objetivo que despertou em estetas e artífices a negação da figura, a tradição não só negada mas ironizada: alguém tinha descoberto que a comunicação podia desenvolver-se numa linguagem de signos, talvez inteligíveis para iniciados, mas de qualquer jeito, o rabiscar, a mancha, o geométrico geraram uma nova academia, dita do “informal," um jogar de formas, aliás, o comunicar mais insondável da consciência, 
a realidade natural excluída. Depois o abstrato passou a ser denominado concreto.

Muitas foram as resistências à novidade, todavia agora ela passa a ser considerada e estudada na sua história. O volume do Moma relata o passado de um inciso muito importante do operar de mestres desde Kandinsky até Vasarely: sem dúvida um conjunto de várias dezenas de pintores e escultores que generosamente se aplicaram por uma renovação das artes, em companhia de músicos e poetas, para marcar o espírito tremendamente inovador da vida contemporânea, cancelador de presenças do realismo, provavelmente não mais representáveis nos modos tradicionais. Um mundo em mudanças.

\section{Legenda}

Fernande Léger, Ballets russos, I9I4, coleção Museu de Arte Moderna de Nova York Wols, Harmonia em vermelho-branco-preto, 1947, coleção Masp

Senhor \#257, I8 de fevereiro de 1986, p.70 (P.M. Bardi)

SOCORRO ECOLÓGICO

Um banco, um poeta e um alerta sobre o Pantanal

Multiplicaram-se as publicaçóes distribuídas como brinda para festejar o ano de 86. As indústrias, as grandes empresas e os bancos alegraram a editoria de comunicação cultural num surpreendente conjunto abrangendo nossa história, a operosidade das artes, do artesanato, da música e, um bom achado, a fauna e a ecologia.

Estes dois últimos itens, ligados á natureza, receberam do Chase Banco-Lar uma edição em que poesia, ciência, arte, comunicado gráfica e fotografia compóem uma autêntica obra-prima onde a inteligência, o espirito de amor ao tema representa uma exceção na editoria.

A obra é dedicada ao Pantanal mato-grossense, uma contribuição de extraordinário empenho a favor da "campanha mundial da preservação das áreas úmidas.” O Chase convidou o poeta Carlos Drummond de Andrade para evocar a indispensável urgência para que "todo um mundo natural” seja "compreendido, amado, respeitado," em benefício de "um Brasil que cé teu e desconheces| São as árvores,| Os bichos,| As águas,| Os crepúsculos $\mid$... Este livro te convida| A zelar pela maravilha desta planície em que tudo emerge| Do sétimo dia da Criação e tudo é novo como o primeiro raio de soll| Ao amanhecer."

O Pantanal é terra, água, floresta e animais que inspiram poetas, mas também os poetas da objetiva, como Luiz Claudio Marigo, o qual ilumina a paisagem daquela região com imagens, consequência de uma alenta contemplaçáo e de uma escolha em que a observaçáo decide obter a figura num átimo de feliz compreensão. Saíram assim "coisas imensas e pequenas coisas misteriosas," como anuncia Drummond, desde o vagar do gado no levantar das águas até os fantásticos inquilinos: as arborícolas preguiças, os cervídeos, o grão-vizir, isto é, o jacaré, o cachorro-do-mato, o jaguar, infelizmente caçado por canalhas, todo um voo de bichos rasteiros, gavióes, socós-bois, seriemas a povoarem o ar: "Mergulha em sonho a mente deslumbrada."

Poesia, ilustração e texto no Pantanal são paginados pela perícia de Eugênio Hirsch, um mestre do visual, criativo e bastante conhecido deste redator, pois foi ele que, por conta da Editorial Codex, realizou o primeiro volume de coleção Mundo dos Museus dedicada ao Masp. Esplêndido livro este sobre o Pantanal.

Concluindo: uma oportuna e básica publicação, diria até uma das numerosas advertências para salvar um dos tantos impérios naturais dor Brasil, ameaçado por uma lauda de contraventores às leis que existem por aí, leis estas cuja transgressão é por demais convidativa. De fato, as notícias dos atentados já fazem parte do cotidiano. Por mais que se tente proteger a natureza e os animais náo se consegue acabar com a destruição. Nem se pensou, no que se refere aos crocodilos, em experimentar o sistema de salvamento da espécie utilizado no Nilo, feito através da retirada dos ovos e sua incubação.

Espera-se que o livro dedicado ao Pantanal provoque uma maior fiscalização para que não se torne letra-morta, simples motivo de lembrança para outros poetas se inspirarem naquele mundo de sonho. 
Legenda

Em vias extinção: o jacaré, caçado

pelos contrabandistas..

... e a

Senhor \#258, 25 de fevereiro de 1986, p.97 (P.M. Bardi)

UMA TELA ESFAQUEADA

As relaçôes entre as vanguardas e a pintura regional

Cada país, neste atarefadíssimo final de século, produz sua arte, não através das maneiras tradicionais, que permitiriam caracterizá-la nacionalmente. Hoje, o operar das artes tende a participar da corrente internacional, nos modos e nas finalidades, sendo difícil, às vezes impossível, descobrir as naçôes de origem. No Brasil, por exemplo, como de resto ocorre também na Itália, como individualizar os pontos de referência nacional no labor de nossos pintores e escultores, considerando, para náo recuar demais no tempo, aqui a voga do abstracionismo, e, para os peninsulares, os anos do Novecentos?

São as consequências da superação das expressóes realísticas o interesse voltado para o Informal, uma libertação, talvez excessiva, um se manifestar, no avanço de uma espécie de reação, aliás, de ruptura com o que já estava periclitante.

Palmilhando a história: não a ruptura pensada e ajeitada como a que os alemáes opuseram ao Gótico, como escreveu Vasari, quase os culpando por fazer "tanti risalti rotture, mensolini e viticci..." Foi nos nossos tempos a tentativa de anular a tradição: uma virada em absoluto.

As vanguardas, pode ser sem pensar em Ovídio, pressentiram que tempus edax rerum e se dispuseram a devorar tudo quanto vigorava neste antigo lazer das artes, parece que acompanhando as descobertas da inteligência artificial.

Foi natural a persistência dos adeptos da inteligibilidade, pouco a pouco eclipsados pela moda invasora do mistério, do ininteligível, afirmando-se um modo ativo em todos os países, o internacionalismo: sintoma de futuros entendimentos políticos?

Seja como o tempo quiser, eis agora um grupo de pintores contemporâneos, autores de telas que ornam a Embaixada da Itália em Brasília, expostos no Masp. É uma pantera-onça, o maior felino do

Pantanal, cuja pele vale ouro mostra de jovens italianos organizada pelo Instituto Italiano de Cultura.

O destaque é uma obra de Lúcio Fontana, que oferece a ocasiáo para observar que o ventilado "fim das artes" é fato a ser registrado. Começou com Ives Klein: uma tela recoberta de uma única tinta, à maneira dos pintores de parede; e naquela unidade o mestre ítalo-argentino desferiu uma, duas ou três facadas. Fontana estava seguindo o pronunciamento de Kasimir Malevich; ("O pintor não está mais ligado à superficie da obra, livre para transferir suas composiçóes da tela para o espaço") assim Lúcio abriu "um novo espaço, uma nova dimensão, ficando em relação com o cosmos que se expande no infinito além da superfície limitada da pintura.”

Não art autre, não art brut, não dada mas minimal, primary e, consequentemente, avalanche de titulaçôes: é a pintura hodierna. No Masp, seguindo uma programação documentadora da arte de hoje, apresenta-se nestas semanas uma exposição bem original: consegue- se expor o grupo de quadros que decora a Embaixada da Itália cm Brasília. A série foi reunida por um dos críticos mais reputados na Itália, Cláudio Bruni Sakraischik, ao mesmo tempo presidente do Sindicato Italiano dos Marchands de Arte Contemporânea, e através do empréstimo possibilitou ao embaixador Vieri Traxler ornar a sede em Brasília com a criação de parte da jovem arte peninsular.

Noto o fato bem singular que me sugeriu salientar, na apresentação do catálogo, a iniciativa do embaixador italiano, indicando-o como exemplo para os nossos diplomatas no sentido de fazer conhecer em outros países a arte brasileira.

\section{Legenda}

Óleo de Pino Reggiani, uma das jovens surpresas do acervo da Embaixada Italiana, em Brasília, ora em exposiçáo no Masp 
Casa Vogue \#2, março-abril de 1986, p.78 (P.M. Bardi)

\section{ATENÇÃo Às PAREDES}

No próximo mês de junho haverá uma significativa presença de designers procedentes de várias naçóes em Sáo Paulo. Numerosos eventos estão programados para a ocasiáo: conferências, debates, projetos. Além disso estes cronistas prepara para o final do ano, mais um livro para a coleção "Arte e Cultura" que há oito anos publica para o Banco Sudameris, desta vez dedicado ao design. O evento de junho é então uma ocasião das mais favoráveis para ouvir ideias e saber das atividades dos mestres convidados, sendo útil para nós, brasileiros, como está o andamento do design além das nossas fronteiras.

Aqui na terra o desenvolvimento minha vai bem, apesar de um ilustre arquiteto e design ter dado uma entrevista afirmando que o design em nosso país não existe. Nessa minha anunciada excursão penso em anotar algumas novidade e conquistas. Sempre me interessei pelo problema. Álias, há quase quarenta ano abri no Museu de Arte de São Paulo,ainda na rua Sete de Abril, primeira escola de design, sendo diretora a arquiteta Lina Bo Bardi e professores: Lasar Segall, Gregory Warchavchik, Roger Bastide, Gian Carlo Palanti, Leopoldo Haar, Klara Hartock, antiga aluna da Bauhaus. ${ }^{74}$ Foi feita uma série de palestras elucidando o que foi a Bauahus, a cargo de Max Bill. Nosso mais preparado aluno, Alexandre Wollner, foi convidado a se aperfeiçoar na Escola de Ulm ${ }^{75}$ hoje um dos mais ativos, se não o mais ilustre designer paulista.

O livro que estou preparando não é nem de história e nem da crônica. Será,

74 Segundo Ethel Leon, há chances da informação sobre Klara Hartoch ter sido aluna da Bauhaus ser equivocada, e que havia, da parte de Bardi, um esforço por "afirmar a Bauhaus num meio artístico ainda dominado pelos franceses.” \{Wollner in Leon, 2006\}

75 Vale lembrar que o convite foi inicialmente para Geraldo de Barros que, impossibilitado de ir, o sugeriu para Wollner. como os anteriores, uma incursão em novidades antiga e atuais, partindo de Platão, o definidor da operosidade do design. Encontrei um bom número de ilustração ligadas ao tema.

Mas não é disto que quero tratar na minha página de Casa Vogue. A ocasiāo enseja comentar algo, não sei se decoraçáo ou ambientação: o dar posição às obras de arte numa parede.

Quem visita a pinacoteca do Masp sabe que as pinturas são colocadas em lâminas de vidro, havendo atrás a biografia do autor. Indicaçôes complementares sobre a obra, reproduçóes de outras do mesmo autor e inclusive curiosidades.

É um sistema que não convenceu ainda os museólogos, aliás os museuários, para usar o neologismo que Gilberto Freyre usa para aqueles intelectuais bon-à-tout-faire: intelectuários Tradicionalmente uma pintura vem à luz num cavalete. Quando os marchands mostram uma obra, ela vem num cavalete. Nos museus é poeta nas paredes.

E é aqui que se chegou: estava revendo um livro editado por Jorge da Cunha Lima, dedicado a São Pauto, com textos e um capitulo fotográfico. Um destes revela a histórica Villa Kyrial. Tem-se uma ideia matemática da decoração: profusão de móveis, quadros, luminárias, tapetes, bibelôs, onde o caçador de kitsch, Olney Krüse, poderia descobrir não sei quantas bugigangas.

Seja como for, são as paredes que surpreendem, com os quadros uns encostados nos outros, horizontal e verticalmente: uma tapeçaria plástica de molduras douradas. Penso sempre nas paredes na Villa Kyrial, quando vejo as paredes da minha casa no Morumbi. Sendo a casa de vidro, são poucas, para não dizer raras, as paredes. Mesmo assim a coleção de quadros é bastante rica. Do outro, devo achar lugar também para as esculturas e, por que não confessar?, a quantidade restrita de objetos. Sempre tive o vício de juntar, como num grande magazine. Assim a sala de estar e o único corredor têm todo o aspecto de loja. Se sabe que minha profissão é de 
mercante de arte (antiga, mais do que "moderna") apesar de ter lá Klee, Picasso e...

Chegam os amigos: há os que gostam, outros que se distraem no bricolage. Se algum hóspede se assusta reevoco a Villa Kyrial.
Voltando ao design: espero que nenhum dos mestres que se reuniráo em junho em São Paulo passa na minha casa. Sei, aliás propus ambientar as paredes virgens, como teria gostado Yves Klein, o inventor de pintura de uma única tinta, imitado por não sei quantos copistas.

Senhor \#259, 4 de março I986, p.76 (P.M. Bardi)

A VOlTA AO ClÁsSICO

Arquiteto vai mudar o que o Beaubourg tem de mais moderno

Todos os que se interessam por esta antiga novidade chamada arte sabem da espetacular sede aberta há alguns anos em Paris para hospedar e assegurar as produçóes contemporâneas: o Centro Georges Pompidou, que deu vida ao Beaubourg, a revolução museológica proposta como o mais concreto resultado destes tempos caracterizados pela corrida em velocidade inusitada ao progresso.

Agora se descobre que a arquitetura é a de "um transatlântico cultural," e Jean Clair, no Il Giornale dell'Arte, dá notícias de transformaçóes que vão ser realizadas, anotando que muitas delas, por sinal substanciais, devem ser feitas para "corrigir" a arquitetura: "O que tende a se assemelhar com um mercado bastante frutuoso de relíquias vai acabar por afundar num naufrágio assim que a fé e a arte retrocederem diante dos lumes da sociedade tecnocientífica."

Constata-se que os princípios dos construtores foram por demais avenirísticos: "É desgostoso ver no edifício os condutores de água, de eletricidade e dos ambientes sanitários, órgáos de uma vida inferior. Esta gigantesca máquina de expurgar não é outra coisa senão o oposto das formas e funçóes de um lugar de culto." E assim por diante.

Ao que parece, o diretor do Centro, Dominique Bozo, vai remediar a situação, confiando ao arquiteto italiano Gae Aulenti a tarefa de construir no interior da "caixa de vidro" um "museu clássico.” É de se esperar que náo se volte ao passado: "Local no qual se recolhem, ordenam, custodiam objetos de interesse histórico, artístico, científico, étnico etc.," e, no caso parisiense, o Templo das Musas de Ptolomeu.

A notícia é das mais surpreendentes, pois marca um repensamento de intençóes, a modernidade a qualquer custo, o mais novo, o mais extravagante para deslumbrar pequenos grupos, distanciando a massa, tomando-se um refúgio particular de adoradores de incompreensíveis.

Jean Clair, no fervor da polêmica, ataca até o sistema da gratuidade do ingresso: "Em Paris, hoje, até o uso das privadas é pago. Manter a gratuidade para entrar em um lugar de cultura é como dizer abertamente que a peregrinação por museus vale menos que satisfazer as necessidades corporais." O combatedor do Beaubourg é obstinado intolerante e dá preferência a muros, portas, definiçóes de espaços tradicionais: a um museu-museu.

Como se vê, a arquitetura dedicada a museus está em discussão Mas não somente a arquitetura. $\mathrm{O}$ problema, no Novecentos, implicou soluçóes mais favoráveis para a educação popular.

Foi reconfortante, aqui, no Brasil, saber, através de uma entrevista à Veja do novo ministro da Cultura, Celso Furtado, do seu interesse pelos museus. A respeito do Pompidou, disse: "Um espaço muito ativo e muitíssimo frequentado, náo recebeu o nome de museu exatamente para que não se veja ali algo cristalizado, mas sim algo vivo e permanente."

As intençôes furtadianas são, então, certas: eis um setor que o ministro de ideias bem abertas, como todos sabem, vai considerar modernamente.

\section{Legenda}

Centro Pompidou, em Paris: um museu de arte ou um transatlântico cultural? 
Senhor \#260, II de março 1986, p.73 (P.M. Bardi)

As BRIGAS COM A ESTÉTICA

A necessidade de pesquisar os movimentos artísticos deste

século e decifrar seus inúmeros labirintos

Às vezes, quem se interessa por uma ou outra surpresa que os tempos nos reservam, contando com o saber tendo a possibilidade de estabelecer conotaçóes de história e sendo pelo menos usuário do abecê de filosofia, devendo definir, grosso modo, o que se passa neste tumulto atual de devastadores progressos, sintetiza: século xx. O que pressupóe saber, se náo tudo, pelo menos o principal no setor de seu interesse, aquilo que registrou, o que lembra: uma atribuição complicadíssima, pois sempre se pisa no aproximativo, sem contar o prevalecer das preferências, simpatias e antipatias, encontros gratos e ingratos. Labirinto inimaginável este do século que se conclui.

Cada um, antes ou recentemente, por lá andou e seu palmilhar foi feito num corredor próprio, sem saída, tendo algumas satisfaçóes, rotinas, adaptaçóes, iniciativas, vaticinando o mais conveniente, a contabilidade da vida à espera de um balancete quase sempre numerado no passivo.

$$
\sim
$$

Disse que cada um, no seu setor, dá o palpite do século xx. Arriscaria, pedindo licença, enunciar o meu no que se refere à Pintura. Talvez seja um depoimento que desperte curiosidade. Para quem não sei, pois hoje em dia me parece que as brigas com a Estética são tão gritantes que cancelam o que se realizou ontem. O que vale não é nem o hodierno, mas o amanhá, ao que parece desligado de qualquer umbigo tradicional, apesar de ser infinito. Sim, há mestres como o meu preferido Francis Bacon, enamorado de Michelangelo, porém, por ser a seu modo figurativo, como de resto ocorria na Renascença, não pode estar na moda.

Volto à primeira década do século. Menino ainda, não sabia o que era este negócio de uma tela reproduzir alguma coisa, e assim falei em casa de um senhor Del Santo que reproduzia cenas da baía de minha cidade, La Spezia. Quando me ocorria ver alguma obra dele me parecia uma fotografia colorida. Acompanhei as reaçôes acadêmicas, apreciei os Impressionistas, as vanguardas, me intrigaram os Informais, os assassinadores da Pintura, os penetras do amadorismo desrespeitoso deste lazer chamado Arte. E assim por diante.

Hoje gostaria de divulgar a ideia de que a paleta não é uma destas guitarras que emitem notas de um exército de cantores, um mais cacete do que o outro apesar de obterem espaço em páginas inteiras de cotidianos. Proporia um retomo ao compreensível da Pintura, e também da Escultura, uma vez que a época do decorativismo está caindo de moda, e notando que o mundo tem problemas estéticos bem mais sérios, com as Pitanguis de prontidão tocando suas guitarras nas Bienais e Quadrienais.

É realmente confortador, para nós mais ou menos fã́s das artes plásticas e um pouco conhecedores, saber da intenção do recém-nomeado presidente da Bienal, Jorge Wilheim, de conceber a nova edição dentro de um sistema mais compreensível para o público, público este que nada tem a partilhar com os gatos pingados que sucumbem à propaganda e à moda, nem com novatas coordenadoras de exposiçôes que custam fortunas ao cidadão, para exibir excentricidades derivadas mais da gozação do que do bom senso.

Como lembrei há algum tempo em Status, a Bienal passada podia ter sido não digo melhor, porém mais instrutiva e informativa para os pagantes. Por que não apresentar uma história da Pintura, de como se chegou às vanguardas: Neoclássico, Impressionismo, Expressionismo, Cubismo etc.?

\section{Legenda}

Paul Cèzanne, Madame Cèzanne em Vermelho, I980 e Pablo Picasso, O Atleta, I909. Obras do Masp 
Senhor \#26I, I8 de março I986, p.76 (P.M. Bardi)

EsTILOS MISTURADOS

A arte encontra a técnica, e vice-versa, na ciranda de revoluçóes estéticas ocorridas neste século

O progresso científico ocorre a cada dia. Existem, naturalmente, épocas de mais precipitaçôes, como a atual, quando temos até a mirabolante previsão de se mexer no espaço, não só para novas contribuiçôes para a Humanidade, mas também para corridas bélicas.

Resumindo: a ciência favorece a vida. Quando vejo o metrô, penso no nascimento do "trem de ferro," no dia em que o Barão de Mauá conseguiu convencer D. Pedro II a viajar naquele sistema, do Rio até Petrópolis. O presente para o imperador inaugurava a ferrovia. Em 1983 dediquei uma excursão àquela novidade. Durante as pesquisas, encontrando continuamente, no Oitocentos, gente praticando arquitetura e engenharia, aventurei-me no considerar a posição das duas profissóes na construção. Eram ainda tempos, na tradição deixada pela Missão Francesa, em que Vitrúvio ditava lei: as colunas de prontidão, a dórica correspondendo ao corpo masculino; a jônica à "gracilidade feminina;" a coríntia ainda à gracilidade, porém virginal. E os engenheiros?

Não funcionando escolas preparatórias, dava-se o título a personalidades que se distinguiam no setor: "indivíduo diplomado em curso superior, habilitado em planejamento ou direção de construçôes, abertura de estradas, instalaçôes hidráulicas, sanitárias e outras especialidades."

Para estabelecer os precedentes fui atrás dos desembarques dos construtores de fortalezas, os engenheiros militares que Portugal destinava à Colônia, e também dos mestres-de-obras: mais uma vez curioso por esta maravilha que é a realidade da arquitetura nacional desde os bairros das cidades hoje declaradas patrimônios da Humanidade por organismos internacionais que cuidam da História.

De Congonhas até Brasília, queria até acrescentar Itaipu, o vencer do construtor brasileiro foi admirável. Incluo na vitória as redes rodoviárias. O pesquisar me permitiu fotografar, no Arquivo dO Estado de S.Paulo, uma carta referente ao realizador, nos fins do Setecentos, da estrada de Lorena, isto é, a Cubatão-São Paulo: o brigadeiro João da Costa Ferreira. Em uma visita minha à embaixada da Itália em Brasília, cujo edifício é de autoria do engenheiro Pier Luigi Nervi, um caro amigo meu e famoso inovador de aplicaçóes do concreto armado, um mestre que até convidei para lecionar no Masp em I950, a magnífica sede desenhada por um engenheiro me entusiasmou ainda mais, e o resultado disso foi um ensaio: Engenharia e Arquitetura na Construção, publicado no fim do ano passado, e que faz parte da coleção Arte e Cultura - é o oitavo volume da série - editada pelo Banco Sudameris.

O leitor compreendeu: são páginas de fatos memoráveis, que levam a argumentar sobre a relação arquitetura-engenharia. Atualmente uma arquitetura, ou coisa parecida, é desenhada por uma pessoa formada naquela arte; o técnico que a calcula é, porém, um engenheiro. Muitas vezes o projeto provém de um daqueles numerosos escritórios dedicados à construção, atividade de engenheiros, arquitetos e de tantos outros profissionais que participam de um projeto, organizaçóes que em São Paulo, Belo Horizonte e Salvador engajam milhares de funcionários e que quase sempre produzem, além de engenharia, obras de arquitetura.

Surge, então, a pergunta: uma barragem, uma fábrica, um plano urbanístico, obras da engenharia não podem ser considerados corno resultado de arquitetura?

\section{Legenda}

Aqueduto no Rio, construído em I723.

Obra de engenharia ou de arquitetura? 
Senhor \#262, 25 de março 1986, p.92 (P.M. Bardi)

O TECIDO DA MEMÓRIA

Datas, nomes, encontros e surpresas: o dificil e gratificante

balanço de experiências entrelaçadas pelo tempo

Parece-me que é Dante a fazer saber que a vida é uma caminhada, e para este andar fixa a barreira final nos 70 anos. Por ali chegaria, cheia de empecilhos, a velhice. A bagagem de lembranças acumuladas na cabeça dá sinais de se desfazer, se confundir, a sala da memória pouco a pouco vai-se esvaziando, através de esforços se consegue agarrar uma ou outra recordação, porém enevoada, com pouca aproximaçáo com a realidade.

Curioso: evanescente tudo o quanto é de ontem ou anteontem, mais claro tudo o quanto é bem mais antigo, talvez porque na infância e na juventude os acontecimentos se sucediam mais impressionantes, marcando o repertório inicial do caminho, seus primeiros encontros e surpresas, o inesquecível.

Ainda hoje, agora, escrevendo, a luz elétrica me parece um milagre, pois nos meus tempos, exilado de qualquer mordomia, a iluminação era a de vela ou de lume de petróleo. Deste começar lembro os detalhes mais insignificantes, em vez que, da moça que veio há dias para arrancar noticias sobre um painel de Giorgione que descobri em Veneza, o qual adquiri e demonstrei ser do mestre, 40 anos atrás, não saberia recordar nem o seu rosto apesar do interesse que sempre demonstrei pelo sexo feminino.

A memória de nós, superadores da meta etária dantesca, joga por brincadeiras que vou te contar! Há meses, elogiava um jovem escultor, nomeando-o, inadvertidamente, Degas; engano que não deu certo pois o rapaz saiu contando que Bardi o comparou ao francês. Mas do mestre eu lembro até, peça por peça, a coleção total, 73 obras que comprei em Paris, há talvez uns quarenta anos.

Uma companheira corrige-me quando me proclamo desmemoriado: "Você é fanático por Degas, o tal plasmou nus e nus. É natural a confusão, a sua memória é boa."

Eu permaneço com aquela opiniáo: os velhos perdem aquela faculdade de reter as coisas. Pode ser, ou não ser. De qualquer jeito, tentando relatar trechos do meu longo caminho, desculpo-me se em algumas ocasióes incorro em erros de data. Nada de extraordinário, pois está atenta uma minha colega (apesar de não ser inscrito no álbum dos museuários, anagrama que adapto daquele cunhado por Gilberto Freyre para os intelectuários, diretora de um destes estabelecimentos a qual me corrige, como aconteceu recentemente por ter escrito que eu descobrira que Brecheret nasceu na Itália e não em São Paulo. Assim, em boa companhia, de gente viva e do passado, aventuro-me contando encontros e desencontros num passeio em que a presença de afiliados das artes está de prontidão. Eu um destes a operar, talvez anotando fatos de um certo sabor.

E aproveito para informar sobre mais um, já que falei em Degas: todo o acervo de bronzes de Degas sairá, daqui a alguns dias, emprestado para a Itália, indo a Florença, "capital da cultura I986," hóspede nada menos que do Palazzo Strozzi, para uma exposição que, depois seguirá para outras cidades Península.

\section{Legenda}

Edgar Degas, Bailarina de I4

anos, acervo do Masp

Senhor \#263, I de abril 1986, p.74 (P.M. Bardi)

O DESTINO DAS CIDADES

A importância da memória nos planos de renovaçâo urbana

Está em destaque agora, na crônica da Metrópole, o destino de alguns bairros envolvidos no costumeiro problema "utilidade pública" e "memória," constantemente conflitantes, preocupaçáo dos que ainda tentam impedir o desaparecimento da fisionomia de zonas tradicionais em oposição aos arautos da renovação, aos quais a "memória" pouco interessa.

Participei, na Secretaria de Cultura do Estado, de uma reunião pública para 
discutir o ameaçado futuro cívico, urbanístico e arquitetônico da regiáo central paulistana, Santa Ifigênia, Ponte Pequena e Campos Elíseos. A discussão caiu no costumeiro problema: conservar, ou seja, o Patrimônio deve tombar as casas que vale a pena manter ou derrubar para verticalizar prédios de arquitetura sem pai nem mãe, cujos idealizadores, os especuladores imobiliários, astutamente estão de prontidão?

Minha intervenção foi, naturalmente, a favor da "memória," lembrando como cidadão imigrado e possivelmente enamorado por São Paulo há 40 anos, a quantidade de sustos urbanísticos que presenciei aqui e as leis urbanizadoras, náo digo desrespeitadas mas malandramente burladas. Apesar do que se registrou, hoje nós vivemos num dos centros mais ativos do mundo, não mais do Terceiro mas do Primeiro.

Para demonstrar as malandragens imobiliárias, conto o que me aconteceu. Recémchegado a São Paulo, desejando morar na periferia, fui atraído por um anúncio enfatizando um aos novos bairros, o do Jardim Morumbi, um lançamento no território situado numa antiga fazenda de chá: duas monumentais colunas, que ainda existem, na avenida homônima então ainda de terra, acolhiam os futuros habitantes. Os corretores prescreviam, por lei: área mínima de dois mil metros quadrados, distanciamento entre a construção e a rua escolhida de dezesseis metros, obrigação de manter o verde etc.

O ingênuo, acreditando nas exigências, se comprometeu até a restaurar, com o arquiteto Gregori Warchavchik, a antiga e demolida capelinha da fazenda, mandou pintar as paredes pela artista
Lúcia Suanê, tentando dar vida à tradicional casa de fazenda etc. Pensou-se num novo bairro residencial etc.

Minha mulher, Lina, construiu a casa num bosque onde viviam ainda duas preguiças, cobras e tartarugas. Tudo foi para frente. Passam os anos: os lotes passam a ser vendidos em mil metros quadrados, depois em quatrocentos metros quadrados, inclusive para campos de esporte. Este ingênuo recuou sua casa da rua os prescritos dezesseis metros; agora arranha-céus avançam ao redor etc.

Fiz a intervenção para afirmar que, infelizmente, o que impera é a especulação sórdida, o burlar as leis, o ajeitar as conveniências. Assim sendo, atenção para com os bairros hoje em vias de ser reurbanizados, principalmente estando neles a lembrança da cidade em seus primeiros e promissores tempos de pioneiros imigrados e que o Condephaat, Conselho de Defesa do Patrimônio Histórico, Artístico Arqueológico e Turístico, intervenha no duro.

$\mathrm{Na}$ reunião a que aludo, estavam representantes dos bairros ameaçados, uma novidade, pois são os próprios interessados que reclamam, invocando a intervenção do Patrimônio.

O presidente do Condephaat, professor Modesto Carvalhosa, chegou a uma de suas difíceis horas uma das suas tantas horas dedicadas a decisóes benéficas para que São Paulo não se torne uma anônima metrópole do século xx.

\section{Legenda}

Um choque de arquitetura na São

Paulo deste século: como opor arte à especulação imobiliária?

Senhor \#264, 8 de abril I986, p.76 (P.M. Bardi)

UMA DECISÃO POLÍTICA

Reflexóes sobre a candidatura Ermírio de Moraes

Por hábito, esta página dá conta de fatos e avança algumas ideias, às vezes polêmicas, referentes ao proceder de assuntos de arte. Pergunto-me se, numa revista política e de discussão de problemas econômicos, tratar de coisas culturais seja serviço que valha.

O colunista não tem prática nos andamentos e manobras da vida política. Naturalmente, como eleitor, atendeu ao seu dever de votar e, para ser franco, sempre votei em branco, deixando à massa escolher os candidatos. Quando os candidatos picharam as paredes do Masp durante uma campanha política, em 1982, escrevi em caracteres cubitais a palavra M., indo parar numa delegacia. Meu refúgio é o Masp. Ao longo de quase quarenta anos na sua direção, procuro dedicar-me a fortalecer a 
entidade fundada por Assis Chateaubriand que, me parece, contribui para afirmar o Brasil no campo internacional da cultura.

Nestas últimas semanas, ocorreu o rebuliço para escolher o candidato a governador. Decidi, no próximo novembro, votar. E assim oferecer minha modesta adesáo ao candidato que, como se diz em italiano, torna a fagiuolo.

Já compreenderam: um possível governador que fala a língua do bom senso e não um profissional da administração pública e sim condutor de empresas poderosas, pontilhando opiniốes sobre situaçóes uma mais carente do que a outra, não faltando os motejos pungentes, as alusóes ao escabroso de gente que emerge na política como profissão, até pregando lutas armadas.

Sei que os boateiros de plantão vão revelar que, nos tempos dos tempos, antes da minha emigração para o Brasil, eu fui fascista. Sim, porém um sujeito que, quando o regime instituiu a escola para formar seus chefinhos, os quais, como vestibular, deveriam atravessar um círculo de fogo, escrevi na revista Quadrante: "Nós estimamos muito os jovens, menos os jovens que estudam como funcionários fascistas." Consequência: fui expulso e maltratado. Nunca tolerei político de profissão, talvez pensando ingenuamente o inverso do certo. Parece-me que uma comunidade deve ser administrada por elementos independentes que não formem cabides de emprego, mas possíveis voluntários. Sei que existem os que podem precisar de retribuições para legislar. É justa, porém, a recomendação de trabalhar, sem se aproveitarem do cargo.

Gosto dos que se apresentam aos eleitores declarando numa entrevista: "É difícil, mas espero ganhar. Eu gosto do cheirinho do povo, foi o povo que me empurrou." $\mathrm{O}$ candidato falava na sede da empresa que dirige há 36 anos, 28 dos quais sem direito a férias. A conversa se deu durante um almoço. O repórter conta que o candidato comia "dois ovos estrelados, um bife acebolado e torradas, num ambiente simples que não dá a dimensão para quem fatura mensalmente um bilhão e quinhentos milhóes de cruzados. Antônio Ermírio de Moraes vai contando seus planos, sua vida mostrando seu jeitão de caipira.”

Que tem a ver nesta página declarar-se ermirista?

Muito: os nossos problemas de cultura, sem dúvida, eleito o casus rarus, vão receber atenção e, juntaria mais, um pingo de incentivo e remodelação.

Não para insistir, mas continuo com minha denúncia: a da possível abertura do Museu da Tecnologia na Cidade Universitária, existe desde as calendas gregas, um vastíssimo edifício, que hospeda os ratos. Estou certo de que o criador da Votorantim vai resolver o problema do qual, ano após ano, os governadores se esquivam.

\section{Legenda}

Um possível governador que fala a língua do bom senso e não um profissional de administração pública

Senhor \#265, I5 de abril 1986, p.68 (P.M. Bardi)

UMA ANTIGA AMIZADE

A participaçấo da Itália na construção do Brasil

No grande auditório do Museu de Arte de São Paulo, há algum tempo, evidenciamos um personagem que, por ser eu um entre tantos, conheço, como se diz lá na terra, a menadito: é o italiano, dalle 'moilte vite, 'ilustrado numa multivisão composta e divulgada pela Fondazione Giovanni Agnelli, de Turim, e patrocinada pela Fiat do Brasil e pela Alitalia:

A multivisão, intitulada "Itália, um pais modelado pelo Homem," é destinada à América e visa a "melhorar as relaçóes culturais entre a Itália e os principais países americanos, bem como instaurar e intensificar as relaçóes com cidadãos americanos de origem italiana... o slogan do programa poderia portanto ser: conhecer-nos melhor para melhor colaborar."

Existe muito pouco para melhorar, pois as relaçôes entre nós e a Itália nunca foram perturbadas, salvo o intermezzo da última guerra, episódio bélico que não ocasionou problemas mais sérios, pois a maioria das pessoas vogliamoci bene 
para aqui emigrada é, hoje, detentora da caderneta de brasileiro naturalizado.

Os italianos sempre se aventuraram pelo mundo, aceitando bem viver nos países que o acolheram. Nada estranharam nesta terra onde árabes, japoneses, europeus de todas as raças e quadrantes se entendem e dão valiosas parcelas para a estruturação da Nação brasileira, portadora de problemas como acontece em tantas outras comunidades, mas que vamos resolver bafejados de um sadio otimismo, depois de um Regente ter descoberto o Trópico, que muito contribuiu para o avanço na senda do progresso.

Lógico que em cada neobrasileiro existe uma viva recordação da origens etnográficas. Porém, a realidade é que a família verde-amarela, sem dúvida, uma das mais acolhedoras, para náo dizer exemplar, está hoje afirmada em forma bem firme e baseada num espaço próprio de terra $e$ de tempo, única língua, nova, para não dizer nascente consciência comunitária depois do cruzado sarneyniano e calcada em elevado espírito afetivo, rica em integração, sentimento e independência.

Assim, é mais que bem-vinda qualquer contribuição cultural, sem preferências, como notamos linhas atrás, todavia felizes por reencontrar a cara Itália que extraordinariamente participou com braços e muitos cérebros para argamassar o progresso nacional.
A manifestação da Fundação Agnelli deve ser vista sob o prisma evocativo da península da qual saíram, ao longo dos séculos os descobridores de outros mundos, os que entoando cançôes contaram que iam "fazer a América:" os braccianti espalhados pelos campos, os ragionieri que criaram comércio e indústrias, os pintores, os filhos da "Mãe das artes" e alunos da poesia.

Assistindo às cenas da multidivisão, brotou espontaneamente em minha mente que da Itália vieram mestres e aqui dos casais italianos outros mestres, entre outros, Portinari, Volpi e Bruno Giorgi; "elencar" todos seria tarefa impossível já que grande é o número. E os que criaram indústrias?

Lembro-me de ter viajado de Nápoles a Santos, em 1933, no mesmo navio em que regressa ao Brasil um passageiro ilustre: o conde Francesco Matarazzo. Quando desembarcou, uma multidão de funcionários das suas empresas veio dar-lhe as boas vindas, proporcionando um espetáculo inédito para mim: aplausos e gritos. Era o Brasil da arrancada que saudava um contribuidor italiano singular.

Legenda

Assis Chateaubriand e o conde

Francisco Matarazzo em 1936

Senhor \#266, 22 de abril 1986, p.76 (P.M. Bardi)

SEM A AJUDA DOS CRÍTICOS

As mil atividades do povo, decantadas pelos artistas de aldeia

que agem simplesmente, dispensando os currículos

$\mathrm{Na}$ gíria italiana, quem se interessa por um determinado assunto, diz-se que tem um pallino na cabeça, vicioso, incorrigível. $\mathrm{O}$ redator não teve nem tem somente um, mas inúmeros. Entre eles, o interesse pelas artes plásticas, sem dividi-las em artes grandes e artes menores.

Aliás, devo confessar que, se alguma virada me é atribuída, foi pela consideração que sempre demonstrei pelas artes classificadas nos manuais de "menores." Por exemplo, o artesanato, o que de maravilhoso o povo, sem ajuda dos críticos, realiza numa e em mil atividades.
Foi como consequência do pallino que organizei no Masp não sei quantas exposiçóes de produtos populares brasileiros, todas manifestaçôes pontualmente ignoradas, até que os órgãos burocráticos do design industrial descobrem que o artesanato é o pré-design, como se vê numa publicação da Federação das Indústrias de São Paulo, Artesanato e Desenho Industrial. Afinal, o Masp não só produziu o que de mais documentado se refere ao artesanato, como abriu a primeira Escola de Desenho Industrial no Brasil, em I950.

Desabafado o pallino, passo ao motivo da página. 
Trata-se de mais uma exposição no Masp, o museu que prestigia a arte menor, a de artistas que não exibem currículos de três páginas, o inflacionário do amador-abstrato, mas sim artistas de aldeias que simplesmente operam. São cerca de mil objetos que o arquiteto franco-carioca Jacques Van de Beuque conseguiu recolher no imenso Brasil, com inteligente compreensão para instituir um museu não-ocasional, mas meticulosamente ponderado, atribuindo valores estético-culturais ao que andou colecionando: autêntica museologia.

A apresentação do conjunto, patrocinada pela Esso, proporciona aos visitantes do Masp saber à perfeição qual o extraordinário labor anônimo do que é possível definir arte nacional, aquela que não foi atrás das atitudes vanguardistas e, agora, supervanguardistas europeias e, pior, americanas, negadoras até da arte e caricaturistas até da clássica pintura de Leonardo.

Nas vilas, nos casebres ao ar livre, o artista popular brasileiro consegue manifestar espontaneamente sua estética. Cada um deles mostra sua individualidade e, como escreve no ensaio do catálogo Jacob Klintowitz: "Mantêm uma acentuada feição individual. Esta afirmação da personalidade é ainda mais espantosa quando observamos os produtores e a sua ausência de competitividade e a sua desprentensão. Aparentemente é mais forte a expressão individual entre aqueles que mal se apercebem dela e, em praticamente todos os casos, não utilizam as suas habilidades para o destaque individual, a afirmação social e modificaçóes no padrão de consumo.”

A observação e a interpretação do real, a redundância da fantasia, o curiosar, dão vida a um fazer arte à maneira dos primitivos, uma representação genuína, às vezes miraculosa, e um senso vital autônomo brasileiro.

Depois aparece o mestre que recebe três colunas nos jornais, conseguiu descobrir um $p \circ p$ qualquer, naturalmente pop-art.

\section{Legenda}

A paciente museologia recolhida pelo arquiteto Jacques Van de Beuque, exposta no Masp

Senhor \#267, 29 de abril 1986, p.68 (P.M. Bardi)

O FIASCO DA APOSENTADORIA

A informação não ó raio laser, mas apenas simples saber

O Estado de S.Paulo, há uma semana, enriqueceu-se de um caderno que divulga as matérias ditas culturais. O Masp, considerado, por força das circunstâncias, matéria do ramo, de vez em quando é objeto de lembrança. Sem dúvida, a última materiazinha mais saborosa foi um trequinho referente a este paginista, diretor há quarenta anos da entidade, funcionando, bem ou mal, não sei, porém considerada como o único museu de arte europeia desta novata no setor América do Sul.

Quem se incomodou em redigir o sermãozinho não se preocupou em escrever, digamos, sobre a exposição de Picasso ou a esplêndida mostra de arte popular brasileira, nem sobre a mostra dos bronzes de Degas, do acervo do Masp, ora em exposição no Palazzo Strozzi, em Florença. A preocupação é substituir seu diretor, considerado, por força das coisas, aliás da tenra idade, no ponto de se retirar para uma casa de repouso.
A reclamante é nada menos do que a senhora Sheila Leirner, crítica de arte do cotidiano, esta sim merecedora de aposentadoria numa casa de repouso para coordenadoras de bienais locais, depois do fiasco conseguido na última edição, apesar da inundação, aliás inflação, publicitária obtida, e o gasto de um volume de cruzeiros, com zeros à vontade.

A respeito da performance ibirapuerana, ela é manipulada ainda - saiba o senhor leitor - segundo o regulamento da Bienal de Veneza de I892, descoberto pelo saudoso Cicillo Matarazzo, caro amigo, porém entendedor de bulhufas e não de problemas de arte; e sobre esta manifestação ninguém soube revelar que a moça tentou imitar a Documenta de Kassel, importando até técnicos alemães. Mas é assim: copiar parece o destino da improvisação de incalculáveis elementos diretores de bienais e também da museografia local, sendo fatal assim que não tolerem que funcione, bem ou mal, o Masp. 
Retorno à coordenadora que espalha o boato que o Bardi náo entende de arte. Não perco tempo em pedir perdão à Aluna das Musas por ter tentado me pôr ao seu lado como simples contínuo. A sua fama é por demais regurgitante para um simples penetra náo se curvar e considerar o sermãozinho encomendado ou não.

Ainda não faço parte do batalhão que guerreia lançando pedras e escondendo o braço: náo entendo de arte, todavia sou professor de análise e verificador deste sistema do intervir nos fatos dos outros por fulanos que deveriam se interessar mais pela própria cozinha, não mais a do fogão, mas a eletrônica da última moda, templo da Aluna.

Sheila: o problema da cultural das artes não é descobrir o raio laser que o demonstrador lhe mostrou como último grito; mas dedicar-se à informação, à didática, ao simples saber. Nenhum carro antes dos bois, mas cultores puxando o carro. Então, tenha paciência e me suporte até o próximo ano, para eu comemorar, em nome do inimitável Assis Chateaubriand, os quarenta anos de um museu fundado quando a senhora nasceu.

Porquanto se refere ao meu sucessor, não é tarefa dos despachantes de nomes, como outro jornal, já fez. Será a diretoria do Masp que vai decidir: trata-se de um pessoal ponderado, salvo um maratonista social demissionário. É uma diretoria que sabe o que, bem mal, consegui realizar, tanto que me propôs receber o título de presidente honorário do Masp. Dei risadas.

Pelo amor de Deus: não sou ainda medalhável, apesar das cruzes e bronzes já recebidos. De qualquer jeito direi ao meu sucessor, esperando que seja um latinista: "Feci quo potui, faciant meliora potentes." 6

\section{Legenda}

O Masp na Orangerie do Louvre em 53: museografia para valer

76 Fiz o que pude; que façam melhor os que puderem.

\section{Casa Vogue \#3, maio-junho de 1986, p.80 (P.M. Bardi)}

EXCESSIVAMENTE KITSCH

O Kitsch é fenômeno bastante generalizado, não se circunscrevendo somente a manifestaçóes bibelotescas mas a qualquer outra, não excluída a política.

Quando ocorrem pleitos eleitorais, (diretos ou indiretos) os candidatos a salvadores da pátria e os comitês que se encarregam de promover e veicular as afirmaçóes, produzem safras generosas de Kitsch: cartazes, bilhetinhos, chapeuzinhos, legendas, faixas de ruas, slogans, discursos laudatórios, promessas de bicos e cabides, sem contar as fotografias dos postulantes aos vários cargos, em que aparecem maquiladamente bonitos, engravatados, sorrisos giocondescos ou esparramados, certos de que representar o povo implica em firmeza, austeridade, alto espírito público e consciência cívica, enfim, todas aquelas virtudes próprias do jogo eleitoral.

Existem políticos que conseguiram o curral, ou o perderam, recordistas de Kitsch: arranjaram as mais estranhas (naturalmente no juízo de quem pensa em política-coisa-séria) novidades comunicatórias para fazer saber ao coitado do possuidor de título eleitoral sua "plataforma."

Falando-se de Kitsch há que lembrar outro ato que deixou São Paulo curiosa: $o$ kitschismo de proprietários de terra especulativa que vale mil cruzados o metro quadrado, os quais decidiram demolir casarôes da avenida Paulista, destruindo a Memória da qual tanto se fala, fala-se demais e pouco se faz para salvá-la.

O espetáculo oferecido por certos argentários paulistanos foi Kitsch, pois, como se disse linhas acima, o atributo estilístico não se circunscreve somente ao bibelô que consideramos de mau gosto. O fenômeno é generalizado, e nunca houve tempo (alegre) como o deste fim de século em que se está kitschiando.

Bastará refletir sobre os campeonatos de futebol para se formar uma ideia da corrida às atitudes e atividades mais imprevistas e o fora do comum descontrolado, a torcida exagerada, o ver nas coisas os lados de moda: kitschianos que passam 
com o carro ornamentado com bandeiras e vidros cheios de inscriçóes prenunciadoras de vitórias: gente até séria dando entrevistas assegurando 3 a I, 6 a 2 etc.; jornais seriíssimos que abrem espaços na primeira página com grandes manchetes, dando a sensacional notícia que um craque teve uma distensão muscular; seguem-se anomalias, piadas sérias, diversóes e tudo que satisfaça aos aficionados.

Esta nota poderia ser extensa como uma enciclopédia a fim de divulgar que recebemos em doação de Olney Krüse uma riquíssíma coleção de objetos expressivos deste fenômeno típico do começo do século, coleção que completaremos com alguns Kitsch de nossa aquisiçáo.

O discreto mas famoso sociólogo Kurt Kurtmann, estudioso do Kitsch, chegou à conclusão de que o mesmo outra coisa não é senão um vírus ainda não devidamente estudado e portanto sem condiçóes de ser combatido Comparou-o ao vírus que provoca esta coisa banal mas cacete que é o resfriado e que às vezes perdura ao ponto de tornar-se crônico. De fato existem artistas que parecem mesmo inoculados com aquele vírus, pois produzem invariavelmente um achadinho temático, sem nunca sair dos limites, pedantes, obstinados, cacetes.

Ignorando a bela carta de Gauguin em que este afirma ser dever dos pintores produzir somente para os amigos e não para quem compra quadros, repetem o achadinho temático até o mesmo kitschiar. Um exemplo: o bravo Pedro Alexandrino que pintava sofregamente aqueles tachos de cobre polido com bombril.

Aconteceu que num dado momento o vírus $\mathrm{KK}$ se ausentou ou saiu de férias, o bom artista pintou um suculento bolo, talvez de noiva, obra mais tarde indo parar na galeria de um marchand.

A "natureza morta" ficou na parede ao longo de anos. Perguntado ao dono o motivo da invendabilidade, explicou que sua freguesia, apesar da ilustre assinatura e absoluta autenticidade do quadro, preferia pintura com tachos de cobre como Alexandrino habitualmente fazia, rejeitando qualquer outra composição do mestre.

$\mathrm{O}$ que nos convida a considerar o fato de que o vírus KK se insere também no assim dito, "consumidor de arte," podendo ser ele o responsável pelo Kitsch pictórico que campeia por aí afora.

Senhor \#268, 6 de maio de 1986, p.90 (P.M. Bardi)

COMO OCUPAR O ESPAÇO

Preencher paredes, sem critério, pode transformar-se num problema estético de difícil solução

As exposições que se inauguram são numerosas, aliás, numerosíssimas. A arte tornou-se moda. Não passa um dia sem que novas galerias surjam para desenfornar pintores e escultores de nomes novos, sem dúvida uma corrida à procura das musas, como se dizia na época dos gatos pingados denominados artistas.

As artes plásticas andaram despertando interesse, através de colaboraçóes indispensáveis também na comunicação, além da contribuição do design, e, especialmente, da televisão.

Os artistas que operam na tevê, geralmente anônimos, produzem criaçóes singulares, combinando motivos de fantasiosas vinhetas e publicidade, enfrentando com invençóes plásticas uma infinidade de probleminhas cujas soluçôes atingem aquela motivação genericamente dita estética, em palavras mais apropriadas: o gosto.

Estava observando no álbum $O$ Caderno de São Paulo, editado em 1979, pela Rhodia, onde escrevi uma lembrança intitulada "O mito São Paulo,” um capítulo dedicado à Villa Kyrial, um dos palacetes mais famosos na cidade que se dispunha a crescer e tornar-se uma metrópole. Nilo é um capitulo e um capitulo escrito, mas organizado singularmente com páginas de fotografias, ambiente por ambiente, denunciando veristicamente o gosto do antigo proprietário.

O problema das paredes hospedeiras de quadros foi resolvido de um jeito nunca registrado: urna colossal quadraria, uma pintura encostada na outra, aliás, grudadas, uma verdadeira e inédita tapeçaria plástica, onde era impossível descobrir um simples espaço. 
Uma coleção por demais volumosa, ou melhor, uma confusão espetacular. Certamente não foi um serviço de decorador, pois os móveis, as luminárias, os tapetes e o bric-à-brac obedeciam à ideia de quanto mais melhor: se tem lugar na parede, vamos aproveitá-lo.

Quando se tratou de compor a Pinacoteca do Masp, no novo edifício da avenida Paulista, naturalmente o sistema utilizado foi outro, diria, o oposto: cada pintura fixada numa placa de cristal temperado, encontrando-se na parte posterior as legendas, biografia do autor e outras eventuais reproduçóes, pois sempre pensei que, em um museu visitado por amplas camadas de público, um toque didático não fazia mal.

É verdade que em todos os museus a declaração da obra é posta numa plaquinha: nome do autor, datas de nascimento e morte, título, técnica. Isto pode ser justo para um estabelecimento tradicional na Europa, apesar das minhas dúvidas, pois me parece que, em Paris ou em Londres, quem pisa num museu gosta de saber para apreciar melhor mestres e seguidores.

Para passar do Louvre ou da Tate Gallery e do próprio caçula Masp às residências, na decisão se apresentar minimuseus ou minicoleçôes, ou simplesmente decoraçãozinhas, condenado o sistema bagunceiro da Villa Kyrial, vamos oferecer alguns conselhos aos preparadores das paredes de mansóes e de apartamentos, neste momento de excepcional fervor imobiliário.

A pintura tornou-se, em São Paulo, mercadoria de uso comum: passados os tempos dos Salóes de Belas Artes, agora é a vez de centenas de galerias comerciais num constante oferecimento de quadros e esculturas. A arte não é mais negócio de ricos, sendo finalmente predileção da média e pequena burguesias. $\mathrm{O}$ mercado à disposição de todas as Bolsas: a produção dos criadores, seguidores de estilos já inventados, copistas, até falsificadores, tomou um vulto excepcional. Exposições, leilóes, mercantes sérios e notável quantidade de intermediários oferecem pinturas, gravuras, bronzes etc. sem parar.

As escolhas estão aí, a cada momento, para satisfazer todos os gostos, nos vários setores de escolas e personalidades. Tente náo encher as paredes, desconfiando do pessoal ligado ao marketing, que geralmente entende só de preços e insiste, deblaterando, na palavra investimento.

Sim, é justo aplicar convenientemente o próprio dinheiro. Todavia, se você quer ornar suas paredes, decida-se com cuidado, antes de tudo para satisfazer o próprio gosto, harmonizar arte com ambientação, considerar seriamente propostas para não transformar casa numa agência de especulação, nem num empório de arte.

\section{Legenda}

No Masp, a maneira original de expor as obras

Senhor \#269, I3 de maio de 1986, p.76 (P.M. Bardi)

O CAÇADOR DE TEMAS

O rastro de Picasso nos 360 desenhos apresentados no Brasil

Depois de cerca de dois meses desde a abertura, conclui-se a exposição dedicada à gravura de Pablo Picasso, que o Masp conseguiu oferecer a Sáo Paulo graças ao patrocínio da benemérita Câmara de Comércio e Indústria Franco-Brasileira, tendo estado presente à inauguração Claude Picasso, um dos filhos do Mestre. Foi um acontecimento bastante singular, especialmente pela participação de uma massa de público que confirmou o interesse que aumenta cada vez mais com relação às manifestações de arte. Dezenas e dezenas de milhares de visitantes, grande participação de estudantes, de comitivas vindas de outros Estados, uma ampla cobertura da imprensa, do rádio e da televisão confirmaram que a Metrópole não é mais aquela onde, há quase 40 anos, o presidente Dutra inaugurava, na sede ainda em construção dos Diários Associados, o Museu que devia conquistar paulatinamente sua reconhecida posição internacional e, em consequência, nacional. As primeiras mostras que fizemos, apesar dos nomes de Calder, Max Bill, Steinberg, De Fiori e Portinari, recebiam uns vinte gatos-pingados. 
Na ocasião da abertura da Exposição Picasso, na minha qualidade de anfitriâo, não esqueci de pronunciar o nome do fundador da instituiçáo, antes de agradecer aos patrocinadores: Assis Chateaubriand. Sem a decisão deste faladíssimo batisseur d'avenir, superador irônico dos conversadores que murmuram realizar alguma coisa e náo a criam, ou a combinam para dar risadas, repito, sem este taumaturgo o Brasil não teria hoje este centro cultural em condições de hospedar estas 360 obras de Picasso.

E no caso do espanhol-francês deve-se fazer saber que, desde a abertura, se podia admirar no Masp, na improvisada sede da rua 7 de Abril, três obras-primas do mago de todas as tendências da vanguarda, dos períodos rosa, azul e cubista, três pinturas que, na exposiçáo das gravuras reveladoras da incisiva potência de Pablo, testemunhavam seu impetuoso domínio do se expressar.

A mostra permitiu que se notasse o inédito interesse dos visitantes, observadores atentos de um figurativismo engendrado por um espírito renovador, inquieto caçador de temas, sua segurança na manifestação desde um meticuloso anatonismo até o fácil riscar, às vezes brincar com formas e cores, o propor tumultuante até de gags, todavia sempre mestre dos mestres.

Picasso é considerado, numa graduação que não lhe parecia correta, o número $I$ do século no inovar, desbaratar a impressão pela impressão, inventar e surpreender com a enormidade de sua produçáo de uma variedade sem limite: um complicado indagar para o futuro historiador.

O Museu Picasso que a França lhe dedicou em Paris continuará como meta indispensável para o conhecimento do que aconteceu na Europa das duas Guerras. E um centro polêmico, se considera as acrobacias do Informal, o convite a qualquer fulano ou fulaninha se abstratizar ou concretizar o indecifrável. As mais recentes pesquisas confirmam que o perder tempo do novo academismo já era.

Picasso persuade, hoje, neste frenesi do não pintar mais o homem, justamente porque se compreende, nos seus 360 desenhos, a vivência humanidade.

\section{Legenda}

A Toalete e Retrato de Mulher

na acervo do Masp: invenção e surpresa de uma enorme produção com variedade sem limite

Senhor \#270, 20 de maio de 1986, p.72 (P.M. Bardi)

BRASIL-LTÁlia, uM ESPAÇO CULTURAL CADA VEZ MAIOR

Um entendimento já disseminado no cotidiano e que agora alcança

dimensóes inéditas com a programaçâo de múltiplos eventos

Numa das mais recentes páginas de Senhor, tive ocasião de lembrar uma manifestação que a Fondazione Giovanni Agnelli e o Museu de Arte de São Paulo realizaram para mostrar a Itália num belíssimo espetáculo de multivisão. Além disso apresentamos no Museu, em 1980, a mostra Itália-Brasil, dedicada às relaçóes culturais entre os dois países, incrementadas principalmente após as imigraçóes da segunda metade do Oitocentos e primeiras décadas do Novecentos.

O embaixador da Itália, Vieri Traxler, de uma certa maneira recordou este intercâmbio cultural ao inaugurar, no último dia Io, uma nova exposição dedicada à confraternização das duas naçôes, no stand que o Instituto de Cultura Italo-Brasileiro, presidido pelo dr. Amedeo Bobbio e dirigido pelo professor Angelo Manenti, abriu como parte da I Expo Brasil-ltália, no Parque Anhembi. O local demonstra a dinâmica operosidade do Instituto na difusão da cultura italiana em nosso país.

Uma das prerrogativas de São Paulo é, para usar um vocativo italiano, città dalle molte vite, tendo acolhido gente de todos os quadrantes e raças, conciliando-as na arrancada de um progresso construtivo. É normal então recordar os laços de intercâmbio, reconhecer amizades com a meta de contribuir para fortalecer os vínculos étnicos.

O empresário Lemos Britto teve uma boa ideia reunindo industriais, comerciantes e artistas para celebrar este entendimento já existente, confirmação ainda mais 
oportuna quando se considera que ofereceu dois espaços para apresentaçóes culturais.

$\mathrm{Na}$ área do Instituto, duas singulares iniciativas: o lançamento de livros de autores italianos editados no Brasil. Trata-se de Os Próximos 6.00o Dias, de Savério Avveduto, diretor-geral de intercâmbios culturais do Ministério da Educação da Itália, e de $A$ Cidade Moderna Entre a História e a Cultura, de Riccardo Mariani, professor de História da Arquitetura na Universidade de Genebra, experiente estudo sobre o decifrar mitos que se desenvolvem para tornar a vida urbana mais suportável, conhecer as formas que o poder assume para a sua representação: intuitos ao autor, visando uma melhor compreensão do urbanismo contemporâneo à luz da história e da cultura.

O lançamento reuniu muitos intelectuais que tiveram oportunidade de apreciar também uma exposiçáo individual do pintor siciliano Franco Cilia. Italianos e brasileiros especialmente interessados em consultar a coleção exposta de livros do Instituto, aproveitaram para reevocar a história dos antigos contatos, aprendendo na palestra do professor Rangel as vivências da espetacular intervençáo do corpo de combatentes napolitanos comandado pelo Duque de Bagnoli, responsável pela defesa da Colônia no tempo das tentativas de invasão dos holandeses à Bahia.

Os italianos, além de presenças esporádicas durante o domínio português, retornaram ao Brasil em maior número com a imigração, chegando não só trabalhadores mas também empresários, comerciantes e artistas, contribuidores do desenvolvimento cultural.

O outro stand cedido para o Museu de Arte de São Paulo, permitiu que os visitantes da Feira apreciassem uma série de obras de arte, pinturas, esculturas, objetos de autoria de artistas peninsulares. $\mathrm{Na}$ entrada do recinto se lê: "Você pode ver na Pinacoteca do Masp obras de Bellini, Mantegna, Raphael, Tiziano, Bernini e outros mestres da arte italiana, inclusive a famosa Coleção Imbert de cerâmica italiana da Renascença. O Museu de Arte de São Paulo participa da exposição Brasil-Itália para testemunhar as relaçôes culturais entre as duas naçóes. O Masp foi criado pelo senhor Assis Chateaubriand, grande amigo da Itália, na sede dos Diários e Emissoras Associados em 1946 e inaugurado em 47 pelo presidente Eurico Gaspar Dutra, sendo transferido em 1969 para a sede definitiva na avenida Paulista. Tanto a ambientação da primeira sede como o projeto do prédio da avenida Paulista foram de autoria da arquiteta Lina Bo Bardi. O Masp é dirigido desde a sua fundação por P.M. Bardi, imigrado para o Brasil em I946 e naturalizado brasileiro em I950."

Legenda

Alegoria à América do SuL de Nicolò Frangipane, no Anhembi

Senhor \#27I, 27 de maio de I986, p.68 (P.M. Bardi)

A ESTÉTICA DO FAVOR

Uma viagem à irrealidade dos textos de apresentação das obras artísticas

Reli nas páginas de Viagem na Irrealidade Cotidiana, de Umberto Eco, um seu artigo publicado em I980, em L'Espresso: irônico, dedicado à creche dos críticos de arte, os bebês que atendem ao ofício de "como apresentar um catálogo de arte," seja de artista vivo ou falecido há dois séculos. Referia-se então aos que empunham a caneta para evidenciar a obra de amigos, inoportunos, amadores e partícipes do círculo galerístico, de mercado, de sociedade: um ambiente bem conhecido por este paginista.

O tal que pega na cabeça os lances do autor é um pintor. Pena que os tradutores não passaram para o português seu nome: prosciuttini, isto é, "presuntinhos." Eco desenvolve à sua maneira filosófico-caricatural o traseiro do porco num mirabolante prenda ancora una fetta, è tanto apettitosa!, pretexto para massacrar o coitado apresentador do pintor, que na opiniáo ecoana é um bon-à-tout em ajeitar para justificar seu parecer favorável, valendo corrupção, amizade, presente de peça, vários desejos interesseiros, correspondência sexual, ideologias, estética, comércio etc. Registra o crítico ADG, "possuidor de um telefone em seu nome, gozando de uma certa lama." Quanto ao consumidor do texto 
com escassos conhecimentos culturais: o senhor colecionista, ou melhor, investidor.

Eco examina uma das numerosas situaçôes imaginárias do "presuntinho," o qual, depois de trinta anos, pinta fundos ocre e acima dele, no centro, "um triângulo azul isósceles azul com base paralela à borda sul do quadro, à qual se sobrepóe, em transparência, um triângulo escaleno vermelho, indicando na direção sudeste à base do triângulo azul.”

Desenvolve-se a partir daí, uma série de interpretaçóes das mudanças de "estilo do perseguido intercalada às suas relaçôes com o crítico, de hilariante ficção, imaginando intervenções de críticos de outras formações, por exemplo científica: um vaivém de opinióes, caçoando dos modos da pintura à la mode.

Apesar das aventuras contadas por Eco eivadas de tantos riscos que me fazem pensar no Millôr quando se manifesta sobre a política brasileira, ocorre-me opinar como dos fuzileiros do batalhão dos prefaciadores de catálogos, o mais ativo no Brasil por posição não de fama, mas pelo constante exercício profissional.
Apresentar um artista é tarefa complicadíssima, pois implica enorme quantidade de compromissos, exigências lavradas do convidado, sugestóes, o ver como distribuir alguns adjetivos, subentender reservas, o explícito mascarado; uma apresentação é sempre um favor e está encalhada nas relaçóes que Eco relata e que estão acima resumidas.

O que realmente atrapalha hoje o número dos "presuntinhos" que inflacionam a arte-pintura, os seus triângulos possivelmente definidos, como conta Eco: "A representação do próprio ato do tencionar que constituindo regióes eidéticas, faz das mesmas formas puras de geometria uma modalidade da Lebenswelt."

Essas notas são para assinalar o livro de Umberto Eco, o qual deve ser lido para que haja uma revolta contra as inúmeras irrealidades do momento, inclusive a estética.

\section{Legenda}

Charges da Cham Amédée de Noé: Pintura assustando pessoas, de 1877 Caricatura do pintor impressionista Le Charivari, de 1879

Senhor \#272, 3 de junho de 1986, p.65 (P.M. Bardi)

UMA NOVA RUPTURA

Copiar velhas vanguardas é academismo barato.

Mas optar pelo figurativo pode ser um gesto polêmico

O noticiar exposiçóes de arte, tarefa do assim apelidado crítico, deve ser de complicadas soluçóes, hoje que as tendências se multiplicaram, surgindo a cada dia a proclamação de uma novidade, excêntrica, para os assim distinguidos amadores de arte, uma surpresa divertida, provocando comentários e maravilhas. Para o crítico, os casos resultam, como disse, complicados, pois no se orientar no exploit de indescritíveis novidades as bússolas são instrumentos inúteis, e quem deve opinar está proibido de usá-las; porém, tendo a obrigação de pronunciar o parecer, trabalha em prosas de conveniência, quase sempre legível a simpatia por igrejinhas, aliás, galeriazinhas amigas.

Digo isto para anotar que a crítica se tornou aventura partidária, às vezes interesseira. Assim, se eleva ao olimpo sujeitos passeando no terreno dos amadores, através de lançamentos em páginas inteiras de cotidiano: a publicidade denunciando as manobra. Na verdade, não é bem o crítico, mas um redator qualquer, amigo do exaltado a totalizar a página. Hoje a informação do produzir arte é de não importa qual assinatura, o preenchimento da matéria confiada a gregos e troianos. É inflacionária a divulgação das artes, como de resto é inflacionária a produção.

A São Paulo que eu conheci aos tempos do Grupo Santa Helena, órfã de galerias, o Salão escondido, jornais que não dedicavam nem urna linha ao surgir do Masp, era uma cidade $\mathrm{cm}$ que se tratando de arte tudo estava por realizar. Agora aqui se tem a impressão de que todo mundo pinta e esculpe: o mesmo que acontece em Manhattan com a invasão dos artistas, consequência do tempo futebol, dos torcedores, do rock etc.: um resfriado Zico dá matéria de primeira página, com título em corpo 32. 
$\mathrm{Na}$ confusão, cada vez mais me sentindo uma peixe fora d'água, ingenuamente pensando que permaneço um metido no assunto arte como sujeito ainda do Oitocentos, recebo um convite para a inauguração da exposição de um pintor, rara avis, figurativista: Mino Carta, na Galeria Seta. Já o tinha apresentado no Masp há alguns anos. Fui à inauguração, porém quis ver antes, na galeria sem visitantes, as pinturas. Reencontrei o pintor perseguindo seu modo de expressar o que se compreende: sentimento, ideia, o que sempre se denomina temática, referência, suas metáforas, iluminação de significados; uma manifestação de um solitário que se encontra com a figuração na verdade representável, o fazer saber e imaginar o que romanticamente alude na tela.

No momento que acima se tenta definir, da despaginação do figurativo, excluindo o 'acadêmico,' estou certo de que tomadas de posição de pintores como Mino devem ser registradas como polêmicas: o empenho de uma virada para superar uma ruptura que valeu na açáo dos criadores das vanguardas históricas, que repetida agora é academismo barato. $\mathrm{O}$ informal vale seu proposto por um mestre, autêntica invenção formal; recozinhado ao acaso é perda de tempo.

Assim, julgo a exposiçáo de Mino como um gesto polêmico. Está no ar um retorno à pintura na corrente da compreensibilidade. $\mathrm{O}$ enorme interesse das pessoas pelo figurativo notou-se recentemente na exposição "Picasso" no Masp: desde o acadêmico até o arbitrário, porém comunicação. $\mathrm{O}$ próprio Marinetti preferiu a locomotiva à Victoria de Samotracia, vindo de lá a confusão.

É lícito então ver numa mostra como a de Mino uma contribuição para uma nova ruptura em favor do tema figurativo na pintura.

\section{Legenda}

Sabedoria, de Mino Carta Vozes, outra obra do autor exposta na Galaria Seta, de São Paulo

Senhor \#273, IO de junho de I986, p.68 (P.M. Bardi)

UM RESGATE POLÊMICO

Restaurar obras de arte incomoda sempre os conservadores. Mas o processo é irreversivel

Nos jornais italianos continua a discussão provocada pelo restauro da Capela Sistina. Michelangelo, passado a limpo, entusiasma seus fâs: finalmente as cores do mágico, tais e quais quando foram desmontados os andaimes, nos permitindo admirar o afresco. Mas há também ataques peripatéticos dos do contra, denunciando a operação como muito radical, oferecendo um outro Miquelângelo, não o que depois de séculos se tomou familiar aos visitantes do Vaticano, valendo a ilegibilidade, o resultado da memória.

As consequências de um restauro são sempre as mesmas em arquitetura, escultura ou pintura: há quem torça para deixar as obras o fascínio do tempo, até mesmo seus aspectos negativos, e quem queira o restauro para ver como um mestre trabalhou. Os pontos de vista são consequências de qualquer restauro.

Quem não se extasia ao entrar no Coliseu? O que resta, até mesmo uma pedra tombada na época das demoliçôes, quando eram arrancados do estádio materiais para as construçóes decididas pelos papas, é uma mirabolante surpresa. Mas quanto desgosto, no Setecentos e no Oitocentos, aliás, quanta literatura, especialmente inglesa, quando o Anfiteatro foi liberado da vegetação que no andar do tempo o recobria de plantas e flores, dando-se um polimento para deixá-lo como era antes.

O problema, mutatis mutandis, pode ser reconsiderado agora em Sáo Paulo com o caso do bairro de Santa Ifigênia: tem razão Niemeyer ao querer demolir aquelas casas de um século de existência, encobertas por velhas manipulaçóes, como placas de lojas, paredes sem suas cores originais, numa palavra, a memória; ou tem razão o Patrimônio paulista, que polemiza para que a zona seja preservada como sinal dos pioneiros e dos capomastri que a arquitetaram?

Quando em 1933, em companhia de Le Corbusier, estava passeando entre as colunas do Parthenon, surgiu espontânea uma conversa sobre os criminosos que tentaram destruir o templo, nos perguntando também se foram previdentes os ingleses que 
levaram friso inteiro da fachada que agora se admira no British Museum.

A discussão pode recomeçar, a retirada britânica, por mais absurda que pareça, enriquece a história do monumento que, como está, apresenta ainda seu encanto. De acordo com a teoria de Viollet-Le-Duque: um monumento é como o tempo o conserva, inteiro ou em ruínas, os escombros têm sua nostalgia.

Não é o caso da Capela Sistina: lá se trata de um toalete. De qualquer modo as críticas não param. Publicam-se ensaios, autênticas choradeiras, adeus ao Michelangelo que se foi, pois desapareceu a pátina que preservava, alias, escondia a pintura.
Deve-se observar que hoje em dia a técnica do restauro pictórico dispóe de meios sofisticados, havendo condiçóes de se tirar da superfície as sujeiras da fumaça das velas que iluminavam as cerimônias religiosas e, pior, a fumaça dos braseiros aquecidos para os conclaves.

À fuligem são ainda acrescentadas antigas e inábeis pinceladas de irresponsáveis praticantes de restauro, categoria ainda presente nas praças.

Então, Michelangelo revive. Deixemos viver também nosso bairro de Santa Ifigênia, como parte da memória de São Paulo.

\section{Legenda}

O Parthenon, em Atenas, e o bairro de Santa Ifigênia, em São Paulo: tudo é história e respeitá-la nos parece um dever

Senhor \#274, I7 de junho de 1986, p.68 (P.M. Bardi)

UMA INJEÇÃO PUBLICITÁRIA

A campanha da DPZ para o Masp: a confluência de atividades comuns no território da arte

Hoje em dia tudo está na mesa da propaganda, desde o comunicar até fazer saber que isto ou aquilo existe e pode ser comprado. Abra um jornal: se você quer mover uma folha, vai aprender qual é a folha; se deve comprar um apartamento, naquelas páginas lhe indicam, e até lhe aconselham a ver no teatro a comédia ou a tragédia tal. Da publicidade ninguém escapa. Até no caso de se eleger um candidato, ou para encontrar uma empregada doméstica.

Raciocinando sobre propaganda, ocorreu-me, quando fundamos o Masp, considerando que em São Paulo o seu andamento era, não digo modesto mas deliciosamente provinciano, organizar o primeiro Salão da Propaganda, e assim ver o que, na nossa indústria, ocorria.

Foi tal a desilusão que tomei a iniciativa de criar e inaugurar a primeira Escola de Propaganda no Brasil. É a mesma, hoje bem organizada, que se chama Escola Superior de Propaganda e Marketing. O ensino, especialmente pelo interesse de Rodolfo Lima Martensen, seu diretor, deu certo. Foi mais uma novidade do Museu, um incentiva- dor de fatos positivos, apropriado para puxar o carro Arte em termos de vida.
Como se sabe, as atividades do Masp não é que gozem de boa saúde administrativa. Funciona bem ou mal o cérebro, porém a musculatura econômica precisa sempre de injeçôes de remédios fortificantes.

Quem poderiam ser os injetores? É preciso descobri-los. Como? Simples: fazendo saber como está a situação. Consequentemente: propaganda, uma campanha publicitária.

Os amigos da DPZ, informados do problema, incumbiram-se do trabalho. Afinal, a propaganda tem parentesco com a Arte, utiliza muitos desenhos, vinhetas de tevês, editando desde folhetos ou cartazes até dépliants e livros.

Eis então o diretor do Masp no papel de um publicitário. Quando se abriu nosso centro de cultura, naturalmente tentei lançar, dentro do possível, novidades de comunicação. Aliás, eis aqui uma das peças daquele tempo que já vai para os quarenta anos. O cartaz de Roberto Sambonet ficou como um documento de valor. $\mathrm{O}$ designer, agora, trabalha na Itália, considerado um dos mestres de sua profissão.

Voltando à campanha da DPZ: o Museu de Arte de Sáo Paulo que, desde sua fundação, sempre demonstrou sua boa vontade com os profissionais da Publicidade, dirige-se às agências pedindo compreensão, e 
anunciando que, no próximo ano, no programa das grandes exposiçóes dedicadas aos 40 anos do Masp, uma delas será "A propaganda no Brasil.” Apela-se assim a todas as agências para que colaborem para demonstrar este progresso, é bom que se diga, espetacular, da comunicação. Esta nota é para anunciar a proposta, esperando que o museu que lançou o primeiro Saláo e instituiu a primeira Escola de Propaganda receba apoio e contribuiçóes.

\section{Legenda}

O cartaz de Roberto Sambonet e a primeira escola da propaganda do Brasil: o incentivo pioneiro para um trabalho múltiplo

Senhor \#275, 24 de junho de 1986, p.68 (P.M. Bardi)

UM GESTO ILUMINADO

Evocaçóes da participação fundamental de um empresário nos eventos culturais

No meu setor, talvez não esteja tão certo, o das artes plástica, nestes últimos tempos, deu-se merecido destaque a um nome para mim conhecido ab antiquo: Giovanni Agnelli, o dono da Fiat, que mecenamente fez restaurar o famoso Palazzo Grassi de Veneza e ai providenciou uma exposição histórica dedicada ao futurismo, o principio da ruptura que culminou nos anos 30 , sendo ainda hoje objeto de discussão e de tentativas, se não de conclusão, do que se poderia apelidar de "estilo," mas pelo menos da maneira como genericamente chamamos de Informal, ou Abstrato e Concreto.

Para mim é prazeroso evocar o nome de Agnelli - é como recordar gratas lembranças dos começos de uma carreira iniciada no campo da arte, nos anos 30 , quando realizei com o serviço de comunicação da Fiat algumas atividades, grosso modo relacionadas com os problemas da estética: propus uma novidade propagandística bem fora do usual - lançar o novo carro Ardita Sport através uma série de artigos. No referido plano me imaginava um profissional ao qual o médico recomendava dedicar-se a um esporte; preguiçoso, a escolha recaiu em andar de automóvel. Conseguindo passar pela prova de aprendizado, parti para um passeio fazendo um giro pela Itália. Contei as inumeráveis aventuras, prazeres e surpresas muito próprias de um novato no cotidiano Il Messagero, de Roma: um reportagem tendo como título La strada e il volante, mas tarde enfeixada em livro.

Mas o que tem isto a ver com Agnelli? Naqueles anos tive prazer, não permitindo a qualquer um, de ser recebido pelo fundador da Fiat, o venerando então ainda presente na fábrica por ele fundada. Tratou-se de novidades, entáo pouco comum: de design, e, mesmo que pareça estranho, até de borboletas, das suas cores e agilidade, pois o pioneiro era fã delas.

Isto posto, desde então o nome Agnelli, a começar pelo capitão de indústria, tornou-se um símbolo, e, ao receber o monumental catalogo Futurismo, enchi-me de satisfação pensando na grande exposiçáo organizada em 1980 com a Fundação que leva tão ilustre nome localizando o binômio Itália-Brasil. Outro motivo de satisfação, neste ano de 86 , em que a Fiat comemora dez anos de sua instalação no Brasil, foi o de saber que aquela industria automobilística vai continuai sua participação em eventos culturais.

Eis, agora a exposição do Futurismo, uma palavra que envolve, como animador, Marinetti, figura que conheci muito bem, na sua fase de renovação da atualidade, não mais se agitando com relação ao amanhá, membro da Academia d'Itália, ele colega de companheiros arquitetos responsáveis pelo Barroco e pelo Neoclássico, eu iniciando-o a participar da campanha que então conduzia contra os ecléticos. Todavia o autor do manifesto, de I908, agora acadêmico, repousa da charmosa façanha tornando-se assim um acomodado.

Belíssimo o gesto de Giovanni. Penso que Agnelli deveria ser evocado por seu gesto iluminado, tendo em vista a única virada da Itália em favor das vanguardas. Recordaria ainda a soberba virada que o neto do precursor deu à industria italiana. Aqui estou a me lembrar da exclamação de Le Corbusier quando lhe mostrei, na Lingotto da Fiat, a pista de corrida na cobertura da fábrica, obra pioneira do engenheiro Matté-Trunco: C'est Futurisme.

Deixo aos críticos de arte tarefa de escrever sobre a grande manifestação 
veneziana. Entretanto, quero anotar que no catálogo está presente também no Brasil. Lembrou-se que em São Paulo, em 22, poetas e artistas nacionais marcaram o desejo da modernidade, abrindo debates sobre o futuro naquela Semana que continua sendo a empresa mais viva da nossa atualidade.

\section{Legenda}

F.T. Marinetti: prancha "parolibera" (II de fevereiro de I9I5) - as vanguardas têm inúmeros pontos de contato com a indústria moderna

\section{Casa Vogue \#4, julho-agosto de I986, p.I6 (P.M. Bardi)}

A MODA OBJETO DE ARTE

No último Casa Vogue, numa correspondência americana, se aprendeu qual o "drama" de se criar uma decoração hoje; que o gosto não tem uma única orientação, mas uma infinidade de sugestóes desde a obediência ao que prescreveu as vanguardas dos pintores da ruptura até a volta aos tempos do romantismo; as flores secas entre as páginas; vasos e luminárias art-nouveau.

A decoraçáo vai aceitando tudo e de tudo. Francamente, o velho lobo do mar que neste século registrou tudo e de tudo, quando a amiga Orietta veio ao Masp propor uma exposiçáo de quimonos "tanto para vestir como para pendurar na parede, como objeto de decoração," ficou surpreso. De qualquer jeito, capaz das mais estranhas aceitaçóes por parte dos artistas, torci o nariz e respondi: "Vamos ver."

$\mathrm{O}$ que pretendem os expositores ao mostrar publicamente as próprias produçóes? Muito retorno, sendo o principal deles o sucesso. E Orietta o obteve através do rádio, televisão, imprensa e, o que me convenceu ser tudo possível, de venda. Uma senhora da sociedade adquiriu um quimono e na conversa afirmou: "Compro tanto para vesti-lo, quanto para depois não escondê-lo no armário, colocando-o numa parede." Pensei seriamente num problema de decoração: às vezes, nos desfiles de moda se admiram trajes de singular valor, autênticas obras-primas, desenhados e confeccionados pelas mãos de estilistas. Geralmente passam à história através de fotografias. Pensava: por que náo adaptá-los em mostras? Sei que se estuda ou se projeta um Museu do Costume. Informo: conservo religiosamente, encaixotados, no Masp, dois vestidos do desfile Christian Dior que organizei em 50, além de outros que a Rhodia nos doou em 1972. Sem falar no Vestido para a mulher do ano 2045, de Salvador Dalí, que de vez em quando é exposto na Pinacoteca. Como acontece agora. Mesmo para quem é do setor e se adaptou às mais curiosas surpresas, esta de roupas, quimonos que se tornam tapeçarias é um fato estranho a ser escrito nas crônicas das mudanças até ontem consideradas impossíveis.

De fato, eis a última notícia: uma artista que se fez notar como produtora de joias recentemente teve uma exposição no Museu de Arte de São Paulo para apresentar uma série de quimonos de extravagante concepção, juntando a este tradicional elemento do vestuário modos decorativos cujo espírito implica excentricidade, cada peça caracterizada por um gosto cativante.

A performance mostrava os quimonos também pendurados, tanto no espaço como nas paredes. Aqui ilustramos um objeto que pode ser classificado de tapeçaria pela interessante confecção, cheia de elementos coloridos. Está implícito um duplo uso: vestir ou apresentar como enfeite de parede. O Masp não é novato no apresentar produçóes de moda feminina: desde 1950, suscitou curiosidade neste museu-não- bem-museu convocar a São Paulo interessada no problema para assistir a um desfile de elegantes modelos criados por Christian Dior, entre os quais o excêntrico Vestido para a mulher do ano 2045, especialmente desenhado por Salvador Dali que desperta grande interesse entre as esculturas de um lado e as pinturas de outro. Além da moda francesa que então imperava no mundo ocidental, o Masp tentou a proposta de desenhar, costurar e apresentar uma moda brasileira, tentativa esta que, na verdade, pouco interessou nossa distinta grande e média finesse. Com franqueza, pode-se falar em fracasso.

Eis agora, outra vez, moda nestas salas que abordam a arte na vida mais do que nos ateliers isolados: são os quimonos 
de Orietta em sua variada série. Uma novidade nesta época de novidades uma após a outra, surpreendentes às vezes. Trata-se de uma produçáo que serve para duas funções. No caso: vestuários para a mulher elegante usar e, ao mesmo tempo, até pendurá-los como objeto de arte.

Dois usos atribuídos às capas geralmente chamadas de quimonos, mas que quimonos não são: saíram da fantasia de uma artista, talentosa e devotada a discutir os cânones da estética, audaz, inovadora. Eu tive ideia de apelidar a trouvaille "rouparte." É agora comum palavra wearable. Não significam simples modismo, nem é um emblema mercadológico.

No Modo de Vida do Jornal da Tarde, observou Helô Golbspan: "O wearable surgiu nos Estados Unidos nos anos 70, espalhou-se pela Europa e pelo Japão. Ocupou museus e galerias, e ganhou adeptos no mundo inteiro, entre artistas descobriram uma nova fonte de criação."

Penso que Orietta, com ideias realmente singulares, é da turma, como de resto outros elementos que serão apresentados no Masp, um local aberto a novas descobertas, não precisamente um santuário da arte-arte.

Senhor \#276, I de julho de I986, p.68 (P.M. Bardi)

Os PAROQUIANOS DA CULTURA

O voo rasteiro dos candidatos que não conhecem as verdadeiras necessidades de uma área desamparada

A futura Lei que descobriu a existência de um certo lazer genericamente definido Cultura ao que parece aqueceu o costumeiro fogo de palha, ativado até pelos candidatos ao governo de São Paulo, considerado o Estado número um daquele setor. Três dos aspirantes vestiram os balandraus de músicos e de escritores, confirmando aos repórteres que, uma vez segura a caneta autorizada a assinar decretos e portarias, darão ao povo o que ele quer. Prometem aculturá-lo, custe o que custar.

Como aquele lazer depende de verbas, tanto Maluf que se fez fotografar tocando piano, Quércia de guitarra no peito e Suplicy com as mãos na máquina de escrever, fizeram promessas de amparar entidades e talentos, especialmente de rock e de samba, isto é, os sujeitos que, além de agradar, dispóem de votos para eleger. De passagem falou-se nas elites, circularam na conversa, naturalmente, alguns nomes famosos de fora, fizeram algumas confissões bem interessantes, úteis para registrar o quadro da tão propalada Cultura. Pouco se tratou do Ministério da Cultura e do seu titular, em cuja gestâo se deu a iniciativa da Lei que vai ou deveria amparar quem mais precisa de auxílios ou patrocínios. Estes, na ideia do ministro, ao que parece, são os necessitados mesmo e não os que, após feitos os balanços; pouco precisam.

Para dar um exemplo: São Paulo possui uma sociedade civil sem fins lucrativos, com decreto assinado ainda apor
Getúlio Vargas como de "utilidade pública.” Falo do Masp, o qual somente este redator, na sua qualidade de diretor a instituição, sabe como tira avanti.

Num centro geográfico, "cultural” no qual qualquer cantor, como de resto qualquer jogador de futebol, é distinguido com páginas e páginas de cotidianos, alem dos artistas das panelinhas cozidas não a fogo lento, mas com incêndios e disparos, não se notou que nestes meses de outono brasileiro a imprensa italiana deu colunas de crítica para a mostra de nossa coleção completa de bronzes de Degas que emprestamos para o Palazzo Strozzi, de Florença, e que agora está sendo vista no Palazzo Forti, em Verona, indo depois para uma das salas do Campidoglio, em Roma.

Entre os tantos ramos da Cultura, há também este da área museológica, de circulação internacional, as grandes instituições fazendo este tipo de intercâmbio. O Masp assim demonstra que o Brasil está presente em manifestações de países em que a Cultura é realmente prezada.

Acrescentaria que, no ano passado, muito se falou em Paris do Brasil quando emprestamos cinco de nossos treze Renoir para a retrospectiva do mestre. Atualmente de nossos Monet está em Madrid, um Fragonard irá para,a França para uma mostra no Louvre que continuara no Metropolitan de Nova York e, nas últimas semanas, acabamos de enviar para o Japão 
três Manet, um Picasso e um Renoir. Para demonstrar que não se descuida da arte nacional, informo que acabamos de receber de volta obras de Portinari, Anita Malfaltti, Rego Monteiro, Di Cavalcanti e Alfredo Andersen, que emprestamos para a exposição "Pintura Pan-Americana," apresentado no Museo de Arte

Contemporâneo de Caracas, na Venezuela.

O que quero enfatizar: nada de informação pública, como se os fatos citados não fossem novidades culturais. $\mathrm{O}$ que pode gerar perplexidade para quem tenta evidenciar que não somos nação do Terceiro Mundo, mas do Primeiro.

Conclusão: vamos aguardar que as providências clamorosamente exaltadas motivadas pela nova venham também ajudar quem não corre aos jornais para divulgar minúcias pseudoculturais, considerando seriamente a Cultura, numa estrutura nacional e não paroquiana.

\section{Legenda}

Lembram-se disto? [Maluf tocando piano] Ele promete mais $A$ bailarina de Degas: o Masp viaja

Senhor \#277, 8 de julho de I986, p.68 (P.M. Bardi)

UMA SEMENTE NO RECIFE

O papel dos museus nas invençóes culturais

Foi um prazer ir ao Recife há alguns dias para abraçar Gilberto Freyre e participar de um debate, na Fundação Joaquim Nabuco, dedicado a museus, abordando o Museu de Arte de Sáo Paulo e sua ação pouco canônica, pois em quarenta anos os desvios e as viradas na tradicional entidade paulista foram numerosos e nem todos aprovados. Tive ocasião de visitar e fazer elogios ao "Museu do Homem do Nordeste" da própria Fundação, uma resenha completa e abrangente da epopeia que se concentrou em Pernambuco ao longo dos séculos coloniais e depois, do Reinado até a Abolição, da qual Joaquim Nabuco foi um dos batalhadores.

Naquele museu cada visitante se informa sobre o que, há quase vinte anos, no Masp, tentamos mostrar cm síntese, na exposição "A mão do Povo Brasileiro:" dar evidência à capacidade e à genialidade do homem que no campo, patrão, colono, boia-fria ou escravo criou na complicada empresa de formar uma nação.

No Recife minha antiga iniciativa magnificamente estruturada, através de informações técnicas, familiares, até íntimas, trazendo da História as provas mais evidentes, sem nada deixar de fora, cada fato mostrado através do braço e da inteligência inventiva, própria de quem deve resolver problemas existenciais. Instrumentos da lavoura: consequência de reflexão e de bom senso; ver certos arados primitivos de madeira leva a pensar numa tecnologia primária industriosa e eficiente, dando ao caipira extraordinário merecimento.

Particular emoção se sente na saga do açúcar: maquinários, meio de transporte, habitaçóes, aparecem ao lado do trabalhador junto com a participação religiosa, o cotidiano, o lazer: uma série de objetos que, além do sabor etnográfico, valem como relíquias. A cada século, começando naturalmente pelos donos da terra, membros de uma civilização que costumamos chamar pré-colombiana, até os primeiros desembarcados, a Historia é ali contada passo a passo, desde a Senzala até a Casa Grande, estando presentes as páginas de Gilberto Freyre.

O debate acima citado teve o velho mestre, codificador da nossa antropologia, a presidi-lo: sua palavra constantemente precisa na, definições, o senso de um humanismo cordial, caseiro: um olho na ciência, outro na vida. Tratou de museus, de posiçôes nordestinas e paulistas, evocando nosso sempre amado Assis Chateaubriand. $\mathrm{Na}$ minha apresentação, naturalmente associei o fundador do Masp à realidade da Fundação Joaquim Nabuco, provocando vários depoimentos sobre a atualidade daquele importante centro de estudos. $\mathrm{Me}$ parece que os debatedores foram unânimes em atribuir à função dos museus, acima da conservação de obras, o dinamizar da informado intervindo para animar a cultura.

No caso de museus de arte, o interesse pelo Masp foi intenso, e alguém notou que as programaçóes da entidade paulista, em vários setores, foram antecipadoras. De fato, 
fomos o primeiro museu a instituir escolas, algumas inexistentes no Brasil, como a de Design e a de Propaganda, além de desfiles de moda que apresentamos em I950 etc.

Foram duas horas de debates, incluindo problemas de restauro, sendo lembrado o nome de Deoclécio Redig de Campos, o brasileiro ex-diretor dos Museus do Vaticano. Estava presente também o abade superior da Ordem dos Beneditinos sabendo que eu fora escolhido, em 1978 , para a reconstituição da imagem de Nossa Senhora Aparecida, complicado restauro levado a termo pela chefe de conservação do Masp, Maria Helena Chartuni.
Após o debate fui levado pelo beneditino para visitar o seu mosteiro, em Olinda, para examinar um antigo painel italiano, o qual será restaurado no Masp. Eis a que pode levar um debate positivo de um paulista no Recife. Seria o caso de falar, o que talvez faça no futuro, do quarto centenário da chegada dos beneditinos em Olinda, tema de uma monografia a ser editada pela Sanbra da qual serei o prefaciador.

\section{Legenda}

Ora de Lula Cardoso Ayres no Museu do Homem do Nordeste

Senhor \#278, I5 de julho de 1986, p.68 (P.M. Bardi)

RESPEITO À MEMÓRIA

$O$ difícil trabalho de conservação dos centros históricos, um

desafio para todas as cidades do mundo

Uma exposição, aberta no Museu de Arte de São Paulo, demonstra como, na Itália, nas grandes e pequenas cidades, se encara o problema dos centros históricos, isto é, o respeito, acima das questóes urbanísticas, por tudo que se refere à memória, numa palavra: a conservação, ocorrendo eventuais adaptaçóes e ajustamentos arquitetônicos.

Vários visitantes questionaram se o assunto se restringe somente à Itália ou a toda a Europa. Explicou bem o diretor do Instituto Italiano de Cultura, Angelo Manenti, que o caso dos centros históricos é de todas as cidades, pois todas apresentam a necessidade de conservaçáo daquilo que representa o passado. Em cidades milenares ou de centenas de anos, naturalmente os casos são mais complexos do que nos centros urbanos menores. No Brasil mesmo há exemplos bastante numerosos. E por isso que a manifestaçáo realizada durante um seminário feito em Cuba nos interessa. Até mesmo pode ser encarada como uma profícua aula para nossas faculdades de Arquitetura e profissionais que enfrentam este tipo de trabalho. Funciona como um vade-mecum notável e, também, advertência cívica para os que consideram que a atualidade tem direito de demolir o passado, até certo ponto para a comodidade do presente.

Quando se pensa, aqui mesmo em São Paulo, em descuidos inconcebíveis, como por exemplo, o abandono do Teatro Municipal um dos centros históricos da nossa cultura, se compreende qual a importância do problema da conservação, resolvida com sabedoria em tantas cidades italianas. A exposição é uma chamada à ordem, sugestão válida também para nós que, recentemente tivemos a novidade da decisão do município de intervir num bairro histórico, memória paulista entre as poucas que ainda existem. Como se sabe, através da disputa entre o município e o Patrimônio, pode-se estabelecer como os interesses econômicos podem interferir no respeito à memória.

O complicado é estabelecer e, mais, conseguir tombar um centro histórico. Por exemplo, em São Paulo, a antiga estação rodoviária, na praça Júlio Prestes, de I96I, pode ser um centro histórico? Para incontáveis cidadãos que lá embarcaram, - parece um bilhão de pessoas que dali viajaram para todos os cantos do Brasil em mais de quarenta milhóes de ônibus - para este pessoal sim. Para as autoridades, não. É complicado resolver: interesses imobiliários, razôes viárias, sentimentalismo interferem nas decisóes.

A exposição aberta no Masp suscitou várias discussóes e documentou como, num país interessado na conservação do que representa a história, se zela e se defende os direitos dos patrimônios históricos. A mostra circula por várias cidades da América Latina onde, em algumas nações, as situaçôes são semelhantes ás da Itália, 
por exemplo, ou o México, onde existem culturas de valor universal e não somente estádios para espetáculos de futebol.

Se uma crítica pode ser feita à manifestação, é a de não conter, além dos desenhos técnicos, uma série de fotos de grande formato para o público admirar algumas vistas de cidades peninsulares interessadas na conservação dos seus centros. Um outro relevo que se pode notar é que esta mostra deveria conter uma série de vídeo-teípes para ser melhor a comunicação. De lamentar também que o catálogo, bastante sintético, nos seja oferecido em língua espanhola.

Legenda

Em Veneza, a História está

presente na cidade inteira

Senhor \#279, 22 de julho de 1986, p.68 (P.M. Bardi)

UM HOBBY HISTÓRICO

Os colecionadores de antiguidade e sua colheita minuciosa da peças esquecidas

Este colunista, ou melhor, paginista tem, como qualquer colega de profissão, suas manias. Sabe-se que as minhas são de me envolver naquele lazer que um dos historiadores que às vezes evoco, o quinhentista G.P. Lomazzo, considerava, junto com São Tomás, razão das coisas que se tem a fazer, em que possivelmente implica a Beleza. Com as vicissitudes, talvez anomalias do Novecentos, a arte tornou-se até "pobre," "nuclear," etc., sendo patroa de não se sabe quantas tendências. Lê-se sobre "arte informática," "não arte," "arte pichatória," esta última uma tendência que anos atrás me levou a escrever uma palavra censurável nos muros do Masp, o que me fez comparecer a uma delegacia.

Envolvido no setor, sou frequentador da clássica Feira de Antiguidades no belvedere no Masp, e sempre adquiro em uma ou outra barraca alguma "beleza.”Tornando-se moda o art-nouveau, como hobby de colecionador, inúmeros são os que o procuram também para colocar as peças em leilóes. Assim, já se considera histórico o começo do Novecentos, ainda mais estando esta decoração em moda.

Pode ser até que já tenha sido publicada, porém, desconheço, uma pesquisa meticulosa dedicada à vida familiar dos primeiros dois decênios deste século, auge do art-nouveau, decoração que foi largamente importada no Brasil. Penso que este trabalho seria um presente grato para se saber mais como esta estética se andou desenvolvendo.

Pessoalmente procurei encontrar documentaçóes, interessei-me pela aquisição de objetos daquele estilo, perguntando aos comerciantes a respeito das origens, Foi em São Paulo, no fim dos anos 40, que encontrei uma quantidade significativa de peças, especialmente estatuetas de bronze. As famílias abastadas, indo a Paris, evidentemente voltavam com lembranças daquele estilo singular, às vezes até de valor, como as de Gallé. Nenhuma concordância com os estilos arquitetônico: salvo raros casos, ali não havia nenhum interesse pelo art-nouveau. É curiosa a discordância entre o interior e a fachada dos palacetes no começo do século. Ainda hoje, em pleno racionalismo arquitetônico, com sinais de pós-moderno, não se constata a presença de mobiliários vieu-jeux?

O enfeite floreal, então, voltou a ser considerado. Penso que não por simpatia estética, mas por conveniência colecionista-especulativa Isto faz parte dos mistérios da decoração e de ser a arte considerada como moeda de troca: nas capitais não assistimos autênticas disputas para se comprar obras de artistas nacionais, de mercado exclusivamente local? É escasso, para não dizer nulos, o interesse por mestres estrangeiros.

Volto a recomendar um ponderado ensaio sobre a decoração e sintoma de gosto nas primeiras duas décadas do Novecentos. O material inerente é o fotográfico. Há documentação de interiores de palacetes bastante ilustrativas e ainda casas antigas conservadas como eram: é uma memória que pode fornecer elementos da estética bastante singulares. Enquanto moda, a documentação é abundante e oferece a possibilidade de estabelecer também regras de comportamento. Achei-me afortunado por adquirir a fotografia aqui publicada: uma demonstração de como um grupo se compunha para as comemoraçóes de uma ocasião memorável e nacionalista, o 7 de setembro de 1907 , 
no quartel-general de Salvador Tudo é ficção. Documento encantador que guardo com o mais cordial interesse, lembrança de um Brasil histórico. O passo para diante é engolir as novelas de tevê.

\section{Legenda}

Memórias da estética do Brasil de I907: uma ficção decorativa

Senhor \#280, 29 de julho de 1986, p.68 (P.M. Bardi)

A CORRIDA PARA O DIPLOMA

Observaçóes de um penetra no mundo mágico do jornalismo, onde um canudo pode valer mais do que a sensibilidade

Muito divertidas as polêmicas que alegram, nas colunas dos cotidianos e, agora, nas páginas das revistas, o seriíssimo problema dos diplomas. Parece que, não sei desde quando, para o futuro, no Brasil ninguém pode exercer a profissão de jornalista sem pendurar, na parede onde presta seu trabalho, o diploma de uma escola considerada, por lei ou portaria, autorizada a investir o fulano no mandato de informante ou comentarista dos fatos do dia.

Os, pardon, colegas possuidores do pergaminho emoldurado vistosamente em cornija dourada, estilo barroco, protegido por placas duplas de cristal, orgulhosos por terem conseguido o instrumento, defendem os próprios interesses profissionais, conclamando que os não possuidores do brevê de sapiência são gentinha que, numa redação, pode ser incumbida somente da limpeza. O que define o talento para comunicar que o preço das cebolas viola o pacotão, ou que o partido $x$ é o que deve vencer a eleição, é o diploma.

Sem diploma, o fulano pode ser até diretor do Time, porém deve jogar sua caneta no lixo. O paginista foi um dos que passou por jornais de grande tiragem, escreveu em periódicos bastante conceituados e até os dirigiu: penetra sem diploma. E nesta difícil hora está perturbado, esperando que a nova lei invocada tenha um artigo que permita o exercício do jornalismo aos colaboradores adiplomados.

Mas não é este tipo de diploma que me traz ao assunto. É que, agora, o problema do diploma aumenta e está na mesa das diretorias das associaçóes dos "críticos de arte," "professores de história da arte," "museógrafos e museólogos" e de outras formandas congregaçóes, todas pretendendo que um parecer sobre uma pintura, escultura e objetos relacionados deve ter pronunciamentos somente de exibidores de um diploma, enrolado na gaveta ou resplendendo na parede.

Não me interessaria pelo negócio se não tivesse lido o trecho de uma carta de uma das agremiaçóes dos Solons, afirmando que o que vale para se julgar arte é o saber diplomado e não a eventual sensibilidade de alguém sem diploma.

O marginalizado que corra a uma faculdade ou escolinha, consiga seu diploma e aplique, se tiver, a sensibilidade. Mas sem diploma não se atreva a dar um parecer, digamos, numa tela do Quinhentos ou numa "não-arte" do Novecentos. Esta função é prerrogativa de quem cursou a tal escola que dá direito a opinar.

Assim todos os aventurados no mercado das coisas de arte que, justamente favorecidos por esta singular experiência da sensibilidade, pagando do próprio bolso a possibilidade de vencer ou perder, estão proibidos até de trabalhar. Para saber adquirir, vamos dizer, uma porcelana do Setecentos de escola chinesa, não emita parecer: dirija-se ao diplomado que entra em campo oferecendo seu cartório enfeitado com miniaturas de diploma.

Ao que parece, o bom senso foi futricar com a ignorância, e desta relação, no setor do comércio das artes, está nascendo agora o bebê diplominha. Corram para consegui-lo, também os que confiaram na "sensibilidade" para se movimentar no facílimo círculo das artes, inclusive os fulanos que estabelecem a autenticidade ou a falsidade das obras citadas nas crônicas da polícia.

\section{Legenda}

Gostaria de ver os diplomados em museologia opinarem a respeito da autenticidade destas duas telas, uma de Hans Hoffman e a outra da Lichtenstein: valor por volta de US\$500 mil 
Senhor \#28I, 5 de agosto de 1986, p.68 (P.M. Bardi)

ARTE, CORAÇÃO DA INDÚSTRIA

$A$ alquimia das cores no território da tecnologia

Leio: "O homem no coração de todas as coisas - este é o emblema do centenário da Sandoz. O perfil arcaico, que se encontra nas grandes civilizaçóes do Antigo e do Novo Mundo, encarna a energia humana, a vontade de bem utilizar as forças impetuosas da mudança. Os raios que saem do perfil humano simbolizam o esforço criador e a confiança com a qual nós trabalhamos, nós também a modelarmos um futuro digno de ser vivido." A declaração se encontra numa publicaçáo comemorativa dos cem anos da Sandoz, popular empresa suíça que conta sua história de uma maneira espartana, baseada nas biografias daqueles que, de decênio em decênio, comandaram o grupo surgido de um modesto laboratório produtor de corantes, passando depois para outras atividades que o progresso sugeria empreender. $\mathrm{O}$ iniciador da indústria nos interessa, pois além de ser um caçador de novidades na área dos corantes, casou-se com a neta do pintor Emile-François David, tendo com ela um filho, ÉdouardMarcel [Sandoz], escultor e pintor. Era uma família na qual as artes estavam em casa.

Corriam os tempos em que as fábricas eram barracôes onde se tomavam decisões para dominar as aventuras da química, os suíços disputando novidades e patentes com os alemães, sabendo descobrir nas Américas centros de futuro e de ampliação da produção. Em resumo, partindo de uma pequena fábrica, a Sandoz é hoje uma das maiores produtoras não só no campo da química, mas de inúmeros outros elementos numa diversificação fiel à declaração que motiva esta página, com o ideal de superar meios em busca de inovaçôes.

Aqui se nota um paralelo com outro centenário que está sendo celebrado na história das artes. São várias as datas hoje indicadas como o começo do propor novidades, justamente como o senhor Sandoz procurava no emocionante campo das cores: as mesmas brigas entre fabricantes repetia-se entre os pintores. Basta pesquisar nas discussôes dos Impressionistas para estabelecer que, ao lado do progresso tecnológico, existiu a ruptura e o dar valor a inéditos do "bem utilizar as forças impetuosas da mudança."

Estava vendo também o último número de Humboldt, cuja capa reproduz uma roda de locomotiva, porém quantas publicaçóes, neste 86, despertam curiosidade com as rodas do primeiro automóvel do senhor Benz? Eis um estudo a ser feito: como nasceram a nova pintura e a nova escultura dos tempos das propostas da tecnologia, e o quanto as duas atividades acompanharam o desenvolver da humanidade. Os raios observados na marca da empresa suíça se dirigem a todas as direçôes. Parece a justificativa do infinito de posiçóes que a arte hoje assume, desprezando o figurativo, em substância a figura do homem, vai procurar o inconsistente abstrato, às vezes indicado como concreto.

$\mathrm{O}$ assunto se destina aos sociólogos mais do que aos historiadores ou críticos de arte: convencer-nos de que as possíveis alquimias do senhor Sandoz no campo das cores correspondiam às rupturas da Secessáo de Viena ou à Bailarina de I4 anos de Degas, como hoje a um microcomputador correspondem as linhas retas de Mondrian.

\section{Legenda}

A capa do último número da Humboldt e o emblema do centenário da empresa suíça Sandoz: a complexa relação entre engenharia e arte, um assunto que merece a atençáo dos estudiosos

Senhor \#282, I2 de agosto de I986, p.68 (P.M. Bardi)

A ESTÉTICA DAS VITRINAS

A popularidade de uma arte delicada

As estradas e as vielas que levam à Praça das Artes são infinitas agora que este lazer invadiu tudo o que move a vida. Nesta página, de vez em quando, nos interessamos por problemas à primeira vista estranhos, como quando nos dedicamos a descrever como fato singular da estética o supermercado Pão de Açúcar Especial, concluindo num elogio a Abílio Diniz, dizendo: "Penso nele, mutatis mutandis, 
como num dos príncipes de Florença que embelezaram a cidade com uma das arquiteturas que admiramos. Os monumentos surgem pela vocação de quem decide. São os beneméritos das artes.”

A arte então é e ao mesmo tempo não é mais o resultado de quem a produz nos ateliers: seu valor semântico andou de mudança em mudança, de atribuição em atribuição, acabando em nossos dias até na ambientação de centros comerciais.

Ambientar e decorar são verbos que derivam dos termos góticos garedan, ter cuidado, e radfan, aparelhar. Para considerar esteticamente a mercadoria apresentada numa casa comercial, dando ordem a manufaturas ou produçóes industriais as mais variadas, evidenciando os respectivos designs, é preciso disposição e particular senso de atenção. Não pertenço ao ramo, porém, quando, por razóes de conservaçáo, inaugurei o sistema de não pendurar as pinturas do Masp em paredes, mas isoladas em placas de cristal, as críticas foram numerosas, típicas do conservadorismo que dominava o ambiente.

Bem mais simples é ajeitar a composição de um mobiliário numa casa, prática em que, além do decorador, qualquer um pode se improvisar. Diria o mesmo no dar ordem numa loja, pequena ou espaçosa, caracterizando grandes vitrinas, recorrendo a elementos de atrativo chamariz.

Recebo agora um livro muito bem organizado, dedicado ao assunto: Vitrina, de Sylvia Demetresco. Reproduz uma série de amostras atrás de vidros: relógios Rolex, um esplêndido "cenário e figurino" de Celina Balloni e Ernesto Garcia, uma composição "astrologie" de Laura Falzoni e muitas outras figuras intercaladas por opiniôes de vários escritores e arquitetos. Entre estas, uma de Maria Bonomi, a mestra da gravura e da discrição: "Se quisermos entender a essência da comunicação, que é hoje básica em todo o viver contemporâneo, somos impelidos violentamente para o tema da sedução."

Eis um livro inteligente: aborda o problema estética + marketing mostrando casos e soluções. Uma série de vitrinas, mais arte de vários "objetos" pseudo-escultóricos: da própria autora, de Jorge Valle, Heloisa Cardoso, Maria Isabel F. Alves de Lima, Laura Falzoni, Fulvio Nanni, Marion Cymes e Regina Strumpf, além de outros. Parece que os vitrinistas na Metrópole estâo em plena atividade. Me esquecia de registrar uma observação de um famoso mestre, Mies van der Rohe: "Mostrar a efemeridade da vitrina as suas facetas, como uma pele delicada e etérea. Mostrar a essência do vitrinista, talvez como um filtro que absorve informaçôes e as recria num mundo fantasioso, criando uma arte que rege o subconsciente, atraindo o consciente.”

Para não ultrapassar os limites de minha página: um livro, este de Sylvia, oportuno, contribuindo para a afirmação de uma nova estética que vai ganhando popularidade a cada dia

\section{Legenda}

Vitrinas de Sylvia Demetresco e de Mário Sampaio Telles e Scassa Arquitetos: a sedução de um trabalho cheio de surpresas

Senhor \#283, I9 de agosto de I986, p.68 (P.M. Bardi)

UM ESCÂNDALO AMERICANO

Um exemplo artístico do começo do século que deveria ser imitado nos nossos tempos de provocaçóes vazias

Uma moça quebra a moral que impede qualquer ato reprovável, condenado até por leis, considerado indigno, como afirmam os que pensam e agem pontualmente dentro da rotina. Quem quebra este comportamento é Georgia O'Keeffe, pintora, educada, séria, que, em I929, escandaliza os Estados Unidos deixando-se fotografar completamente nua: horror para o puritanismo americano.
Tornou-se o modelo preferido do célebre fotógrafo Alfred Stieglitz e, mais tarde, com ele se casou. Não era manequim, mas uma artista, colega de Pollock, Rothko, Kline, Kooning, Motherwell, o grupo dos novos norte-americanos que sofrem a influência europeia.

Georgia é considerada uma figura isolada na pintura dos Estados Unidos. Desaparecido o marido, refugiou-se no 
Novo México, interrompendo uma carreira celebrada por etapas significativas. A glorificação foi sua individual no Museum of Modern Art de Nova York, em i946. Afirma um seu biógrafo que, no México, "diante daqueles horizontes ventosos, sua pintura de paisagem amadureceu, reduzindo-se a um essencial de linhas, indiferente a qualquer problema de perspectiva, preocupada somente em manifestar um espaço ilimitado repleto de luz, virtualmente abstrato, porém reconhecível na divisão entre céu e terra, uma paisagem, digamos assim panteística, com as improvisações de Kandinsky." Nos anos 20, dedicada às vistas nova-iorquinas, tinha o influxo, em seu trabalho, de um artista que tive ocasião de apresentar no Masp, o fantasioso Paul Strand, o qual foi uma das minhas ilusóes-desilusóes quando, na tentativa de quebrar o gelo da incerta estética paulista, convidei elementos como ele, Calder e Max Bill para exposiçóes, todas pouquíssimo visitadas.

Por que esta lembrança de artistas americanos e, em particular, de Georgia? É que vejo no Giomale dell'Arte uma fotografia sua, náo uma das tantas que lhe tornou Stieglitz, mas de Gianfrancesco Gorgoni, ${ }^{77}$ tirada pouco tempo antes da belíssima

77 A grafia correta é Gianfranco Gorgoni (Roma 194I-) e é desse fotógrafo, também, a série mais reproduzida de imagens da Jetty velha nos dar seu adeus, pertinho já dos cem anos. A cada dia são editadas, freneticamente, fotos de belezinhas em qualquer posição provocadora. Não sou ainda do contra, ao contrário, porém quanta serenidade, nobreza, quanta beleza emana deste vulto: ali esplende o belo que "pelo aspecto exterior e por qualidades intrínsecas provoca impressóes agradáveis," como teria dito São Francisco.

Georgia O'Keeffe, no final do existir, perdeu a vista: a "luminosidade, a luz exterior ao seu redor, espaço e luz, sua visão," na cegueira imaginava, não mais podendo reproduzi-la, mas somente na lembrança que se goza na meditação. Viveu os últimos tempos feliz: não lhe interessava nada além do recordar. Nunca mais voltou à cena seu gesto de I929, e o comentário dos inscritos na ordem dos castos. $\mathrm{O}$ protesto sensacional de Georgia porém é que, enquanto as crônicas registram as famélicas atuais por sensacionalismo, um dos seus quadros White Rose, New Mexico, foi vendido por US\$ I.265.000.

\section{Legenda}

Georgia O'Keefe fotografada por Gianfranco Gorgoni: uma pintora educada e séria que em 1929 provocou o horror dos puritanos dos Estados Unidos e que dedicou sua vida à verdadeira arte

spiral, de Robert Smithson, na época de sua execução.

Senhor \#284, 26 de agosto de I986, p.68 (P.M. Bardi)

O JOGO DOS Estilos

As oscilaçôes da arquitetura no território brasileiro

Há cerca de meio século, o Brasil ingressava na novidade que alguns estetas europeus e norte-americanos andavam propondo para superar o andamento das construçóes, as quais depois de sempre eram tributárias daquela maneira pseudo-estilística denominada pelos críticos Culturalismo. Esta palavra levava a recorrer à cópia, aliás, ao pastiche de elementos tirados dos álbuns da história da Arquitetura e recompostos, sendo normal então São Paulo admirar ou náo compreender uma Catedral de gosto Gótico, ou um Museu do Ipiranga em Neoclássico.
Finalmente, desembarca nos anos 20, o arquiteto Gregori Warchavchik, russo ${ }^{78}$ que tinha exercido sua juvenil experiência profissional na meca do Culturalismo, isto é, Roma, campo do "imperial romano modernizado," um ridículo que este paginista, enfrentando pessoalmente o ditador Mussolini, caricaturou esteticamente no Tavolo degli Orrori e em um livro.

Depois de Warchavchik, entre as duas guerras, tivemos a ação de Flávio de Carvalho, e a vinda de Le Corbusier, em I936, para traçar o risco do Ministério

78 Warchavichik nasceu em
Odessa, Ucrânia. 
de Educação e Saúde, na linha do estilo Racional ou Funcional, que se tornou o estilo do momento. Surgiu Brasília, que fez as contas com o Pós-modernismo, e assim por diante num novo Culturalismo. Desta confusão não é fácil, agora, uma definição, pois ao que parece às componentes variam a cada dia, não sendo possível estabelecer qual é o estilo em auge no Brasil, como de resto no mundo. Idem para a pintura e a escultura.

Faço esta premissa porque recebo de Salvador um grupo de fotografias de um edifício perfeitamente racional. $\mathrm{O}$ prefeito de lá, Mário Kertesz, precisando construir sua sede para resolver um problema urbano-político e por não poder usufruir do Palácio do Rio Branco, confiou ao arquiteto João Filgueiras Lima a construção: necessidades de urgência, despesas e praticidade contribuíram para criar um edifício de singular caráter. Fez-me lembrar um famoso dístico de um arquiteto do Seiscentos: "Deveu-se unir Fábrica e Razão, e seja resultado a Representação.”79

79 O arquiteto do seiscentos em questão é (mais uma vez) Carlo Lodoli. A citação é tradução de devonsi unire fabbrica e ragione e sia funzion la rappresentazione.
O jovem construtor optou pela pré-fabricação metálica, prevendo que o edifício poderia atender, no futuro, a uma transferência para outro local, utilizando materiais e sistemas industriais: vigamento longitudinal, pilares em dois níveis, seção tubular para conduzir as águas pluviais da cobertura; todos os elementos estruturais são em aço, autoprotegidos pela própria oxidação; o ar condicionado sendo conduzido pelo conjunto que se vê na parte superior; a plataforma interligando o primeiro pavimento e o térreo previsto com palco para festividades cívicas, funcionando também como marquise de proteção para veículos; as fachadas voltadas para o mar, protegidas por brises-soleil de chapa pintada.

Se algum leitor for à Bahia de Todos os Santos, e se interesse por Arquitetura, dê um pulo na Praça Municipal para ver um prédio de destino oficial construído não para chamar a atenção, ou diria, para se pavonear, mas para funcionar: uma retomada do Racionalismo, o estilo que devia ser o do século xx e que, ao invés, cede o passo ao Pós-moderno, porta aberta ao Culturalismo.

\section{Legenda}

Dois ângulos da sede transitória da Prefeitura de Salvador, do arquiteto João Filgueiras Lima: uma obra feita para funcionar

\section{Casa Vogue \#5, setembro-outubro de 1986, p.I06 (P.M. Bardi)}

\section{O MERCADO DAS ARTES}

Nesta página dão-se opinióes, às vezes não entendidas, pois, em geral, costumam alegar que o redator é do contra, sujeito não-conformista, um fulano que, em vez de aceitar sem discutir o que se passa no círculo, protesta ou exprime pareceres contrários, sendo apontado, como se diz na minha língua materna, de bastiancontrario.

São várias as prosas que emito para anotar que na São Paulo, centro de todas as aventuras econômicas, dizem que responsável por dezenas de bilhôes de dólares de juros anuais que o país deve no estrangeiro, o comércio das produçóes da arte está ainda no status do palavrão que, anos atrás, escrevi em cima de uma pichação de um político aspirante a deputado estadual feita num muro do Masp.
O mercado do qual trato é circunscrito, curiosamente, ao que circula na praça, quase um tributo nacionalístico, nem mesmo provinciano, mas paroquial: desenvolvido em camera cavitatis, ${ }^{80}$ onde aparecem as falsas pinturas, uma depois da outra, a polícia, intervindo, advindo daí o silêncio, para depois, então, recomeçarem as produçóes ludibriadescas. E, no que se refere às cotaçóes, é uma sorte que o ridículo não mate mais, caso contrário os óbitos inflacionariam as pompas fúnebres. Não se quer dizer que a arte local não tenha seus mestres: todos os conhecem, os avaliam, os prezam, porém as contas, pois se trata de contas, das obras

80 Em tradução livre: "ambiente restrito." 
de pintores e escultores devem ser combinadas internacionalmente. A presença dos nossos artistas no mercado de fora é nula, excetuando-se algum caso de nascidos no Brasil mas considerados parisienses. Diversas vezes alguns ingênuos tentaram colocar peças de artistas locais em leilóes de New York: naturalmente, entraram por um cano no qual podia-se até voar.

O mercado das obras de arte é complicado e inatingível pelo improviso. Todavia penso que seja possível abordá-lo, com o passar do tempo e a seriedade, como peça indispensável.

Lembro-me de que nos tempos do deus-ex-máquina, ${ }^{81}$ Assis Chateaubriand, este queria sacudir a adormecida Sáo Paulo, que nem se lembrava da Semana de 22, e tentou incentivar um mercado de objetos de arte. Resultado: zero. Quantas vezes, para completar alguns motivos brasileiros, eu propus adquirir obras de Frans Post, pois no pós-guerra eram baratas, até demais, custando uma pintura mil dólares, sem encontrar nenhum destes maratonistas sociais que trinta anos depois as adquiriram com o preço multiplicado por quinhentos. Cansei-me de comprar Post para o Masp. Hoje temos

8I Deus ex machina, em sua grafia aportuguesada, um dos inúmeros apostos-homenagem de Bardi a Chateaubriand. cinco. Como de resto me cansei também de juntar os Portinari temos dezesseis.

Minha ideia não era bem especular. $\mathrm{O}$ pacto com Assis era adquirir para o Masp tudo quanto julgava de valor favorável, visão de possíveis altas futuras. No meu iminente livro 40 anos de Masp intitulo o capítulo dedicado à pinacoteca de "Uma pinacoteca que deve ser equilibrada," isto é, através de trocas de obras de autores que possuímos em excesso, obter obras de autores que náo temos. Por exemplo, de Renoir alinhamos treze, quando numa pinacoteca como a nossa bastariam os cinco prestamos à recente retrospectiva do mestre em Londres, Paris e Boston, sem modéstia, todas com obras-primas.

No Brasil, dizem meus companheiros de diretoria, ainda é cedo para agir assim. Inútil mostrar um recorte recente que informa a venda de obras de museus como o Metropolitan de New York, Guggenheim, Philadelphia, Nelson Atkins e o Los Angeles County: a Sotheby's liquidou quatro Renoir, dois Degas e várias preciosidades.

São Paulo ainda não participa da vida das artes, da paróquia sim, até demais diga-se de passagem, estando a internacional ignorada. Só nos resta esperar...

Senhor \#285, 2 de setembro de 1986, p.68 (P.M. Bardi)

O ClIMA DA ARQUITETURA

Como abrir as janelas da arte para o sol

Os dois princípios da Arquitetura, desde sempre, pelo menos nos casos de favorecer quem habita, têm sido a função e a estética, ficando a função bioclimática restrita a deixar o ar circular ou remediar o frio com o uso de lareiras. Com a invenção da energia elétrica tudo mudou, ficando resolvido o assunto bioclimático. Porém, com as novas pesquisas e realizaçóes, outras mudanças vão sendo propostas com novas e surpreendentes fontes de energia, como a nuclear, o petróleo etc., para melhorar a saúde do homem e dar ao ambiente outras delícias, afirmando-se assim no contexto construtivo a "Arquitetura bioclimática," título de uma mostra que o Masp insere em sua programação regurgitante de pinturas e esculturas.

Este não é mais o tempo em que Rafael incita os arquitetos a soluçôes tecnológicas que podem ser definidas "bioclimáticas," como a Loggia Vaticana, cheia de janelas orientadas para o eixo solar leste-oeste, permitindo um aquecimento mais conveniente. Não era novidade mas simples bom-senso o que já se notava na arquitetura das Termas de Ostia: a energia solar utilizada funcionalmente, no inverno através de fornos e no verão através da circulação do ar. Os construtores deveriam interessar-se pelo problema de base, e assim nos transmitiram soluçôes inteligentes, até 
que a eletricidade facilitou, sendo notável o advento do "ar-condicionado" e agora se inclui nas mesas dos arquitetos a energia nuclear controlada até por computador.

A exposição nos vem da Itália, organizada por um instituto que investiga o problema, de grande interesse para os Trópicos que enfrentam os caprichos da natureza: calor e secas ou chuvas intensas. Mas o assunto interessa a todo o mundo. A Itália, por exemplo, é um caso particular, pois a crise energética determina um consumo anual equivalente à queima de 142 milhóes de toneladas de petróleo, o qual é importado e representa $66 \%$ das necessidades energéticas. É justamente o comitê nacional que estuda a energia nuclear e suas alternativas que intervém neste processo. $\mathrm{O}$ catálogo que acompanha a mostra esgota o tema, abrangendo a história até as recentes aquisiçóes ligadas à energia nuclear, infelizmente consideradas com muita reserva pelo que contém de aspecto bélico, ligado ao pavor que circunda a área das usinas, como se observa entre nós, em Angra dos Reis, encarada com temor pela população depois do desastre da Rússia. ${ }^{82}$ Trata-se agora de aceitar uma realidade que se impóe. Diz o texto: "A escolha, proposta pela exposição e que é a de não dissimular numa tranquilizadora diretriz mas, pelo

$82 \quad$ Acidente nuclear da usina de Chernobyl, em abril de 1986, da antiga URSS, local hoje em território ucraniano. contrário, de registrar fielmente as heterogeneidades e os saltos de continuidade cronológica na procura do bem-estar habitacional, tenciona exatamente documentar como o problema fica aberto.”

São bem-vindas estas mostras que alertam os arquitetos e as imobiliárias sobre o ponto de partida de qualquer construção. Às vezes vê-se nos anúncios de jornais plantas de apartamentos que obedecem mais à beleza e a uma mordomia insultuosa quando coroada pela expressão "máxima," do que à funçáo, o bioclimatismo deixado fora da porta de entrada. É uma ocasião para refletir sobre a necessidade que Le Corbusier, na sua pregação racionalista, não se cansava de insistir: definia o sol como um "instrumento da arquitetura." Veja-se sua teoria do brise-soleil que lhe custou intermináveis e minuciosas verificaçôes sobre orientação. No Brasil somos ricos no instrumento principal do bioclimatismo, o sol. A exposiçáo nos chama a atenção para outro instrumento, o neon, neste momento em que o ministro das Minas e Energia convida-nos a limitar o consumo da energia elétrica, para que a nuclear nos socorra. Como se vê, a manifestação que o Instituto Italiano de Cultura nos proporciona é atual e, como se diz na península, pane per i nostri denti.

\section{Legenda}

O "trullo," construção típica da Puglia, Itália... I ...e a escola de Bolonha: arquiteturas bioclimáticas

Senhor \#286, 9 de setembro de 1986, p.76 (P.M. Bardi)

O BARRIL DOS PEIXES

$O$ árduo trabalho de costurar conceitos adversos na obra

comum da arte: afinal, quem são os primitivos?

De vez em quando recebo cartas vindas de fora de São Paulo, discutindo algumas ideias aparecidas nesta página, cartas de aprovação e até de contestação. O que, para um velho, aliás velhíssimo publicista, como me reputo (por ter publicado meu primeiro artigo em 1917) é íntima satisfação.

Os temas da página são geralmente dedicados aos movimentados problemas das artes e das várias vicissitudes que se interligam àquelas atividades. Um leitor me escreve, do Nordeste, perguntando-me se para mim foi fácil dirigir o Masp.
Não. Caminhou-se a passos muito lentos, batalhando, com algumas açôes de bravura. Somando tudo, foi um duro trabalho.

Decidi-me a orientar o pessoal que reuni para dar vida à empresa. Sem muita prática nas relaçóes, talvez por timidez mas desejoso de cordialidade, havia também o empecilho de não falar bem a língua. Mas me esforcei e a situação foi sendo mais favorável.

Ajeitava-me de qualquer modo para fazer amizade com o pessoal buscando buon viso a cattivo giuoco. No balanço geral, o 
princípio resultou mais pesado no passivo com raros registros de alguns ativos.

Às vezes, para andar contra a corrente, considerando simples populares como excelentes pintores, fui até malconsiderado. Por ter exposto uma obra de Agostinho Batista de Freitas, um artista que descobri traçando desenhos no passeio em frente do prédio da Light, recebi muitas críticas.

Após um tempo suficiente para estabelecer um plano de comportamento, deixando de lado quem antipatizava comigo, disfarçando a cara e os protestos de amizade, comecei a dar atenção aos mais idôneos.

Foi um trabalhão. Tive de me ajeitar no "barril dos peixes." Explico-me: na Itália, aqueles que preferem viver isolados, sem entrar em discussóes, esquivando pareceres, inquilinos do anonimato com esperança de serem ignorados, eram chamados de "peixes do barril."

Devo dizer que minha mais delicada incumbência no Brasil foi justamente esta de me convencer do real valor dos artistas, merecedores de atenção, procurando uma distinção da massa dos amadores penetras do jardim das artes. Trata-se de uma massa de elementos que se agita, consegue evidência usando de todos os meios, de um espetáculo mundanesco para outro, tomando posição, manobrando: uma categoria de produtores de objetos, geralmente imitaçóes ajustadas nos modos dos mestres estrangeiro, como se observa nos Salóes e nas Bienais e, às vezes, até em distintos museus. Para ser franco, de vez em quando, também no Masp.

Parece-me honesta esta confissão de aceitação de exposiçóes nas quais se acredita até um certo ponto, pois o período que se está atravessando comporta também uma certa incerteza no opinar. Doutro lado a história da Pintura, depois do aparecimento dos Impressionistas, náo é pontilhada de julgamentos negativos que se tomaram positivos?

Lembro sempre que Cézanne foi, já velho, para Paris, suas telas enroladas, para sua primeira mostra; que Modigliani e vários outros mestres viveram miserissimamente. Julgar arte é difícil. Não se exclui que numerosos sujeitos hoje menosprezados possam vir a se tornar significativos campeóes. $\mathrm{O}$ que sugere: muita reflexão e ponderação. Tudo somado. Considerando tudo, é certo que atualmente para conter a quantidade de aproveitadores do fácil exercício da arte serão necessárias, em vez de barris, caldeiras.

\section{Legenda}

São Paulo de amanhã e Vale do

Anhangabaú, de Agostinho Baptista

de Freitas: o talento popular

Senhor \#287, I6 de setembro de 1986, p.76 (P.M. Bardi)

UM SARAU NA Alemanha

Obras de artistas brasileiros viajam graças ao apoio de uma empresa que já aplica a Lei Sarney

Discute-se muito sobre a Lei Sarney, que deveria resolver o problema dos recursos financeiros indispensáveis para oferecer um certo avanço à cultura nacional. A intervenção das grandes empresas produtoras e os bancos e, em geral, os capitalistas, dariam apoio às iniciativas das artes e das letras, merecendo em troca substanciais descontos fiscais. No entanto, pelo menos na rica São Paulo, há alguns anos estas intervençóes já representam um fato tradicional. É notória a participação de bancos e de indústrias nas iniciativas culturais.

De uma entre as mais recentes se dá conta nesta página: está aberta no Museu de Arte de São Paulo uma exposição de três pintores nacionais a qual, depois de vista em São Paulo, será transferida para a Alemanha. O local escolhido para a realização do evento naquele país é o Feierabendhaus, um espaço cultural criado pela Basf promotora da manifestação, em I9I3, em Ludwigshafen, cujas atividades iniciais eram semelhantes, à época, às nossas antigas casas de sarau.

A mostra é dedicada a três pintores-escultores, Miguel dos Santos, José Zaragoza e Maria Helena Chartuni e a Basf, uma das maiores multinacionais que operam no País, tem em seu ativo, tradicionalmente, reconhecidas promoções culturais.

Para estabelecer a importância da manifestação, bastará folhear o catálogo, com texto em alemão e português, todas as obras reproduzidas em cores, constatando-se o significativo empreendimento que 
aquela empresa se propóe fazer conhecer na Alemanha a existência de bons artistas do Brasil. Não somente no que se refere às artes plásticas mas também está prevista uma semana de música brasileira, com concertos do pianista Roberto Szidon, um espetáculo de dança com o Ballet Folclórico apresentando Brasil Tropical, além de uma exposição de livros dedicada ao nosso país.

Os três artistas foram escolhidos por este paginista, com o conselho do crítico Jacob Klintowitz, na intenção de oferecer uma mostra com elementos de diferentes tendências, sendo Miguel dos Santos o mais característico, pois sua temática denuncia o sabor, a um só tempo popular como evocação dos mitos nordestinos e de singular marcação dos modos expressivos próprios das correntes atuais, inclusive um certo geometrismo e abstratismo.
É de se assinalar Maria Helena como personalidade que se destaca no figurativo, conseguindo articular, num emotivo conjunto de cenas, as peripécias humanas, momentos imaginários do viver cifrados em poética simbologia. E Zaragoza, inquieto e incontentável descobridor de vicissitudes sociais, descrevendo acontecimentos típicos da jornada dos executivos, mostrando sua visão de fatos da vida contemporânea, às vezes até operando no abstrato. Enfim, elementos que por um motivo ou outro representam modos de expressão a serem notados na arte nacional, todos sem dúvida fora da rotina neoacadêmica "modernista" das maneiras invasoras de origem europeia ou norte-americana.

Legenda

Praia, de Maria Helena Chartuni, e Guerreiro, de Miguel dos Santos

Senhor \#288, 23 de setembro de 1986, p.68 (P.M. Bardi)

CONTRASTES DA FORMA

Uma exposição que é um banquete modernista

Eis uma exposição que representaria um extraordinário exploit para a iminente Bienal internacional de São Paulo, evento que infelizmente é regulamentado desde sua fundação nos moldes oitocentescos, ou melhor, imitação da de Veneza e, nas ediçóes recentes, copiando pedantemente a Documenta de Kassel; exploit também para um dos numerosos museus locais de arte moderna. A mostra "Contrastes da Forma," ao invés, está sendo apresentada pelo Masp.

A importante manifestação provém do Museum of Modern Art de Nova York e agrupa a famosa coleção de arte que vai de I9IO a I980, nas fases do geometrismo e abstracionismo: enfim, um banquete para os cultores do modístico modernismo.

A manifestação é de tal importância que o próprio Masp vai mostrá-la em sua Pinacoteca, devidamente desmontada, aproveitando-se a oportunidade para proceder a uma verificação de tudo quanto de antigo lá é conservado, a costumeira revisão técnica, obra por obra, atendendo ao sistema corrente de uma consciente museografia. Como se sabe, este acontecimento, qual o de hospedar exposiçóes de notável valor, como outras tantas vezes foi realizado no Masp, notadamente as retrospectivas de Cândido Portinari e de Lasar Segall, a mostra "Arte no Brasil, uma História de Cinco Séculos" e outras mostras singulares.

A atual, "Contrastes da Forma," documenta muita coisa do que foi produzido no mundo ocidental, desde as vanguardas históricas que despontaram e que ensejaram a primeira ruptura com a arte figurativa tradicional até as mais representativas tendências ainda em curso. A escolha foi bem meditada. Como poderá ser visto no volumoso catálogo editado por ocasião do evento, em português, as várias escolas estruturadas no século são registradas através de nomes em evidência, desde Kandinsky, Mondrian e Klee.

O título da mostra é bem apropriado ao operar deste novo artificiar, são os produtores do que se vai acumulando na busca da novidade. Quem se inscreve neste fazer participa, isolado ou em grupos, seguidor de movimentos, determinações individuais ou envolvido nas problemáticas que no tempo e no espaço vão encontrando razóes de ser, discussóes, propostas e aceitaçóes e repúdios. Deste labor acumulador de talentos, de todos os valores prorrompe a ciência que até há pouco se denominava "beleza," jeito de recente contestaçáo que impôs as revisões, 
andanças, contrastes, negaçóes no indefinido avançar, vencer e buscar o gosto.

Depois do pronunciamento do Futurismo, os "ismos" ao longo dos decênios tornaram-se uma embrulhada de modos que se subdividiram em outros "manifestos:" um repartir incrível.

A exposição deu-me motivo para uma apresentação que denota uma certa participação museológica: recolhi na entrada da Pinacoteca uma síntese das escolas agrupadas em nossa coleção, desde os Italianos do Quatrocento, Flamengos, Espanhóis, Franceses até os Brasileiro da "Semana de 22," na intenção de contrastar a atualidade com a tradiçáo, notando como este comportamento exibido sempre constituiu um fato normal na história da arte, isto é, uma demonstração das várias personalidades em que cada uma inventava expressóes formais, naturalmente nos modos do figurativo ou do realismo. $\mathrm{Na}$ seção, o visitante poderá arguir como, desde Turner até os Impressionistas, a Escola de Paris até Picasso, Léger, Matisse e ainda as propostas de Miró, Max Ernst, Calder e quantos outros, ultrapassando o tempo da tradição-tradição, denunciam o advento de novidades mais coerentes propondo um reflexo das conquistas científicas.

A exposição nova-iorquina dá conta da história dos contrastes da forma na operosidade dos artífices do século.

\section{Legenda}

Uma obra de Max Ernst

O Atleta, de Picasso: de Nova York

Senhor \#289, 30 de setembro de 1986, p.68 (P.M. Bardi)

PÓS-MODERNO PARA QUÊ?

Um tema entre a excessiva superficialidade e a promessa

de humanizar as manifestaçóes artísticas

Sabe-se, não é preciso explicar, o que é o modernismo, superador, para não dizer liquidador, de tudo quanto se produziu antes de seu aparecimento no conclave das artes. Nosso século foi, sem dúvida, o que mais se prestou a uma safra de modernismo, deglutindo as mais heterogêneas novidades. Ainda hoje vale aquele procedimento estilístico e, pelo que se sabe, são inúmeros os artistas prontos a inscrever em suas obras aquilo que o pintor Solsternus frisou, em I2O2, num mosaico da fachada do Duomo de Spoleto, na Itália: Summus in arte modernus.

Todavia hoje se fala mais de pós-moderno, tanto que a pergunta "que é o pós-

-moderno?" continua atual. Livros e ensaios não cessam. Várias são as respostas de críticos, sociólogos e artistas analisadores do comportamento, possível estilo, excentricidades das propostas representativas dos pluralismos em ação, uma mais indecifrável do que a outra, impossíveis de serem relatadas, pois a definição das produçóes representa singularidade de concepçôes, às vezes por demais polêmicas, sejam transvanguardistas ou farejantes ao futuro. Todos falam deste amanhã, e já falavam desde o Manifesto de F.T. Marinetti, de I909, articulador da caminhada dos mais curiosos passos estéticos, hoje nem mais lembrados.
Os altivos que mexem no pós-moderno preanunciam novidades, não para situá-las no século às vésperas do fim mas no XXI, como antecipadoras de incógnitas que nem se pode imaginar. Café pequeno o "automóvel que corre como uma metralhadora, mais bonito do que a Vitória de Samotrácia," no proclame marinettiano. Hoje é o momento das inteligências artificiais, dos computadores que desenham e escrevem poesias, ao pessoal que vai descansar na Lua e o próprio “automóvel rugidor” é uma simples vassourinha parada. No ano 2000 nem será revolução, mas caos de açốes e outros ingredientes do futuro?

Para voltar ao pós-modernismo, o destas últimas semanas: leio em Istoe $e^{\beta_{3}}$ um exaustivo artigo de José Castello analisando a miscelânea de temas, citaçóes, épocas que destroem qualquer intençáo classificadora, citando uma opinião da professora Heloísa Buarque de Holanda: "Ainda não sabemos o que é. Mas, se estamos sentindo como pós, é porque é pós mesmo.” Tinha afirmado antes: "Virou uma modinha, um

83 Nesta época, a Istoé era publicação da Gazeta Mercantil: Bardi se referia também a publicaçóes de outros grupos. (Talvez para dar o exemplo.) 
sinônimo de caretice. Mas não é nada disso, o pós-moderno é irreversível."

De acordo. Mas que é, então? É o ponto final pelo que fizeram os antigos, incluindo no setor os próprios "modernos," desde Baldassare Peruzzi ${ }^{84}$ que apresentou, para a fachada de São Petrônio, em Bolonha, um projeto “à moderna," até Le Corbusier da machine-à-habiter, para lembrar que as rupturas existem sempre, através de emergências, desvios das tradiçóes, criatividade, tudo isto sintoma de renovação próprio do fazer das artes avançando para o futuro. Por exemplo: Salvador Dali, de quem apresentei, em I950, e conservo no Masp, o vestido para a mulher do ano 2050.

$\mathrm{O}$ pós-moderno não tem datas. $\mathrm{O}$ que se propóe agora é caso de história, registrável como tentativa de proposta para um tempo que se prevê anarquista com as artes, se existirem, em novos exercidos: uma interpretação não de ars amula nature ${ }^{85}$ mas de artes servirent vitae ${ }^{286}$

84 Baldassare Tommaso Peruzzi (Siena I48I-Roma I536) foi arquiteto e pintor.

85 Trecho da Metamorfose, (Asinus aureus) de Lucius Apuleius, (Argélia C.I25-I80), a única novela latina que sobreviveu em sua integridade: ars aemula naturae veritati similes explicunt, em tradução literal: "a arte, invejando a natureza verdadeira, mostra sua astúcia” ou, em tradução livre: "Arte que imita a natureza."

86 "Artes servissem à vida" (tradução literal, mantendo-se o subjuntivo) ou "artes que serviriam a vida" em tradução pelo contexto.
Não a vida como é mas de um jeito não previsível. Se neste 1985 as vanguardas que se denunciam pós-modernistas competem expondo nas bienais frangos assados e bicicletas aéreas, pensar em representaçôes de hipopótamos guisados, e serpentes espaciais será o prazer das vanguardas, se ainda existirem, para o progresso ou o recuo das culturas, outras ideologias nascendo, declinando e morrendo. Não se possui um horóscopo para discursar.

Já temos um pós-moderno histórico, marcadamente na Arquitetura e no próprio Brasil. Algumas das construçóes de Brasília de Niemeyer podem ser assim consideradas - se moderno eram o racionalismo ou o funcionalismo lecorbusiano. Uma indicação: o destaque do Palácio do Planalto e, mais, da Catedral parecem superar o que na metade do século representava o estilo da época. Por outro lado a Capela de Ronchamp do Mestre é já pós-moderno.

Cada desvio, licença, pretexto de novidade estrutural, material à vista, acréscimo de elemento à nudez dão sabor à tendência. Então, nada de novo no desenvolver da criatividade, cuja tarefa é justamente a da desconsideração do que se toma acadêmico e conservador, casos de falta de vitalidade.

José Castello ${ }^{87}$ reporta uma definição do paulista Julio Plaza: "O modernismo desumanizou; o pós-modernismo quer recuperar a humanização," colocando então outra perspectiva. Poderia ser a correta?

\section{Legenda}

Vestido de Dali para 2050: quem antecipa a estética está certo?

87 José Guimarães Castello Branco (RJ 195I-) é escritor e jornalista.

Senhor \#290, 7 de outubro de 1986, p.64 (P.M. Bardi)

A RENOVAÇÃO DA ARTE

A didática histórica sobre manifestaçóes artísticas que podem mudar velhos conceitos

Na Pinacoteca do Masp, agora, é exposta uma mostra singular: "Contrastes da Forma," vinda do Museum of Modern Art de Nova York. Apresenta o registro das tendências da pintura feita de I9IO a I980, mostrando a renovação da arte e dando uma ideia do que será, ou deveria ser, na alvorada do terceiro milênio, este lazer que começou, se os arqueólogos estáo certos, na gruta de Altamira com os famosos bisontes.

Para dar um espírito didático à exposição, o Masp, como preâmbulo, apresenta uma parte da sua Pinacoteca, resumo de como se desenvolveu, através dos tempos, a arte pictórica, com seus contrastes de modos, desde o século XII até o que nos deu as novidades do futurismo, do 
cubismo e tudo quanto o MoMA recolheu: a infinidade de tendências, o anseio dos transvanguardistas do mundo todo.

É função museulógica registrar História e Atualidade, lembrando que o Masp, quando da sua abertura, nos anos 40, ao lado dos artífices do passado, mostrou as vanguardas e intervençóes julgadas estranhas e excêntricas.

Interliga as duas manifestaçóes a que nos vem do MoMA novaiorquino e a do Masp, nossa tradicional Vitrina das formas, elemento museológico precursor que, nos idos de 47, abrigava um conjunto de objetos de arte dos séculos passados ao lado de uma máquina de escrever, símbolo da corrente modernista, inaugurando então a primeira Escola de Design no Brasil.

A composição da Vitrina das formas, hoje, reúne produçôes da cerâmica renascentista, a prestigiosa Coleção Imbert de Paris que o Masp adquiriu nos anos 50.

Geralmente, quando se observa e se julga, a memória não enquadra as produçôes na realidade histórica. É então oportuno encarar esta exposição, relacionando-a como procedente de um período dos mais trágicos que o mundo sofreu, aquele entre as duas Guerras, os fatores que aceleraram as espetaculares conquistas $\mathrm{da}$ ciência e da tecnologia que culminaram na destruição de Hiroshima vindo até este decênio, expressão dos mais discutidos vanguardismos que nos encaminham às perplexidades de um futuro antevisto como uma soma de problemas políticos e sociais de complexa solução.

Ao lado das interpretaçóes filosóficas, das contribuições literárias, das continuas indagaçóes da ciência, na vasta estrutura da Cultura, a participaçáo das artes, notadamente de comunicação visual, deve ser considerada como espelho das profundas mudanças da vida. A corrida tecnológica pode ser um símbolo das mudanças e a Pintura revela um evidente contraste com a estética no auge no fim dos Oitocentos: pondo-se de lado o Realismo, superar suas maneiras, se lançar para frente, além do aparente das coisas, negando-o, radical repensamento, ansioso sondar o futuro, propondo uma linguagem ainda em elaboração.

E o protagonista de qualquer pensamento, descoberta, açóes justas ou erradas, a figura que deixamos no preâmbulo dedicado ao Passado?

Será que algum dia voltará?

Mais um contraste?

Ver o catálogo que documenta "Contrastes da Forma:" um acerto de interligaçôes entre o tempo das produçóes e os moventes das inspiraçóes dos Inovadores.

\section{Legenda}

Landscape at Ceret, (I9II) de Picasso: prévia da loucura que iria conquistar o século 20 Uma obra de Max Bill (1967)

Senhor \#29I, I4 de outubro de I986, p.68 (P.M. Bardi)

CONSElHo AOS INVESTIDORES

$O$ delicado terreno do mercado de arte, onde deve prevalecer a sensatez e a sensibilidade

Já, e várias vezes nesta página, nos referimos ao surpreendente desenvolvimento por que passam as artes, marcadamente a pintura; produto de marketing, numa escala jamais vista no Brasil. O número de galerias comerciais, o aparecimento do investidor, a notável atenção dada pela imprensa contribuem espetacularmente em favor da afirmação e da colocação dos quadros pintados pelos contemporâneos como também pelos artistas do passado, o passado de anteontem. O mercado ainda não saiu do recinto nacional; geralmente uma exposição de mestres estrangeiros não produz nem calor nem frio.
Até aqui se alude mais aos artistas merecedores da denominação, inscritos ou não nas associaçóes profissionais, os tais que operam na inflação do amadorismo que também serve para enfatizar o momento

Uma indagação acerca do mercado de obras de arte ensejaria surpresas bem curiosas, por registrar quais os meios de que se valem os produtores para comercializar sua produçáo junto à clientela.

Qualquer interessado sabe que o mercado de arte, como, aliás, qualquer outro mercado, apoia-se muito na publicidade, através da promoção insistente do nome de certos pintores em jornais e 
revistas, habilmente inseridos nas crônicas sociais, livro de ouro dos que, presumivelmente, têm capacidade ou desplante para tanto. Muitos deles são magníficos agentes publicitários. Inútil alinhar nomes; porém, bastará ver a nutrida produção de press-releases e fotografias e as amplas reportagens dedicadas a um único elemento que francamente não é dos mais originais, apesar do contínuo se renovar como maneira, para confirmar eloquentemente tudo aquilo que aqui alinhamos.

Existem conservadores que se queixam deste sistema: artistas confiam a agências de publicidade a divulgação dos seus trabalhos. É preciso que se diga a eles que os tempos são outros, e não aqueles em que as vanguardas eram humilhadas e ofendidas. Por outro lado, hoje, as praças estão cheias daqueles que se metem num setor para vencer, ganhar, brilhar.

Deve-se registrar que a história das artes nos informa que os produtores $\mathrm{da}$ arte, no passado, mais badalados, e dos quais se falava insistentemente, considerados "reis do pincel," acabaram esquecidos. Um exemplo famoso nas crônicas de seu tempo: Meissonier.

Geralmente foram os desprezados que no futuro conquistaram as praças, pois o mercado sempre foi celebrados no bottage, da imprensa, ou os reis dos salóes de belas-artes. Confirmando esta tese, lembremo-nos dos Impressionistas, sem falarmos dos Futuristas e afins que em certo momento foram ridicularizados.

No que se refere ao Brasil, bastará registrar o fiasco da Semana de Arte Moderna de 22. Há uns dois decênios aquelas obras dos pioneiros eram vendidas a preços de banana e, hoje, quem as detém sabe que alcançam vertiginosas importâncias monetárias.

A história sempre se repete: também nos anos que nos conduzem ao próximo século dá-se o mesmo. Os produtores de peças para o comércio festejam as alegrias do país do carnaval, ao passo que operam solitários alguns artistas de real valor. É preciso que se desconfie dos tais que se promovem, montando exposição atrás de exposição até mesmo em galerias-mirins nas metrópoles de fora, importunando as redaçóes para se gloriar, de olho no mercado local, o comerciar, alias, o marketing em atividade permanente.

Temos um conselho a dar aos precipitados investidores, pois se trata agora de um pseudocolecionismo com escopo nitidamente especulatório: devem os mais sensatos procurar elementos independentes do mercado-mercado, pois a arte está nos ateliers não badalados. Apelar à sensibilidade, meditar sobre a compra, possivelmente descobrir os verdadeiros talentos.

\section{Legenda}

Alegorias, de John Graz, (I895-1980)

um pintor que merece mais atenção

Senhor \#292, 2I de outubro de 1986, p.84 (P.M. Bardi)

O ARREPIO DO INÉDITO

Estamos próximos a uma revoluçâo, que poderá jogar o modernismo para o espaço. O que será?

Numa destas páginas já tive ocasião de assinalar que, na cidade de Nova York, vivem e operam algumas dezenas de milhares de artistas, um conglomerado de pintores, escultores, arranjadores de decoraçôes e vários outros serviços inerentes ao lazer arte. Nada de extraordinário numa metrópole que, há pelo menos um século, atribui àquela atividade um rigoroso prestígio, a partir do interesse verificado no fundar, enriquecer, conservar museus e ativar famosas instituiçóes de pesquisas e estudos, participando espetacularmente da vida das artes.

Assim, nada de estranho que, ao redor do Museum of Modern Art, farol deste assunto "modernismo" que está embriagando náo sei quantas novatas em nossa praça, mais devotadas a passatempos amadorísticos do que profissionais; digo, nada de estranho que dezenas e dezenas de milhares de cidadãos (parecem ser oitenta mil) tentem a sorte de se tornar artistas, abraçando uma das inúmeras tendências hoje facilmente abordáveis.

Anotada a situação nova-iorquina, é oportuno, agora, situar a paulista.

Quando imigrei para São Paulo, e tive a ocasião única de encontrar Chateaubriand, e com ele dar vida ao Masp, decidindo nos inspirar na arrancada estadunidense, 
a presença de artistas estava ainda quase circunscrita àqueles que a Escola de BelasArtes licenciava, poucos, para náo dizer raros, os grupinhos independentes, como o heroico Santa Helena, alguns vindos da Europa armados de pincel, martelo e cinzel, falta absoluta de galerias comerciais, gatos-pingados,os primitivos e assim por diante: uma espécie de desconsideração total pela arte, apesar de São Paulo ter sido palco de uma tentativa generosa, a Semana de 22.

Bem ou mal instituímos o Masp, ponto de partida de um renovamento e vivaz animação, logo imitado sem graça e talento por outros estabelecimentos que, bem ou mal, contribuíram para gerar um ambiente promissor. Com a lentidão própria de quem belisca uma novidade, as Bienais do Cicillo ajudando, São Paulo se esforçou para descobrir uma realidade, da qual não podia fazer pouco. Deu certo, até se desenvolveram os negócios com o marketing das produções de arte: são já uns dez anos que a metrópole se enriquece com galerias comerciais, novos museus, leilóes a cada semana, aparecem até associaçóes de artistas e de críticos, criando um ambiente favorável para algo que, cedo ou tarde, dará certo.
Para confirmar que hoje, agora mesmo neste ano de 1986, estamos no auge de um ressurgimento, reservo ao leitor a comunicação de uma novidade no item das previsóes do avanço cultural. Leio na Gazeta de Santo Amaro o seguinte anúncio publicitário: "Exponha sua arte. (Escrito em caracteres negrito acentuado.) Feira do Artista sem Nome. Amadores e Aprendizes. Participe - exponha e venda suas obras. Será realizada em I3/I2 a 2I/I2 com o objetivo de promover o artista anônimo no Palácio das Convençóes do Anhembi.”

O anúncio conclui: "Estamos convidando você que é um artista mesmo sem ter estudado artes, a participar desta exposição. Para maiores informaçóes comunique-se conosco."

Comentários?

O único: alguma coisa, de novo, aliás de inédito, está surgindo na nossa capital das artes.

\section{Legenda}

Mestres como Gauguin e Van Gogh nunca conseguiram um posto em nenhum Anhembi de Paris

Senhor \#293, 28 de outubro de 1986, p.75 (P.M. Bardi)

A VOCAÇÃO DA MEMÓRIA

Quarenta anos do Masp: o resumo de um trabalho que entrou

em contato direto com os museus do Exterior

O autor desta página, de vez em quando, em lugar de enfocar assunto propriamente jornalístico, em substância aquela temática de interesse geral, ou quase, pode ser indiciado como alguém que despacha, talvez demais, questóes de fatos pessoais. Longe de mim a vocação para as memórias, todavia desculpo-me por alguns casos. Como este de agora que pode ser interessante na praça, pois a Lei Sarney agitou a periferia da cultura.

Dia 28 de outubro, no saguão do Banco Crefisul, em São Paulo, presentes algumas obras-primas de Ticiano, Rubens, Velazquez, Goya e nosso Victor Meirelles, será lançado meu livro 40 anos de Masp, prefaciado por Gilberto Freyre.

Nas páginas e, mais especialmente, nas ilustraçóes, conto a crônica da, possivelmente, relevante vitória da entidade que projetou o Brasil na museologia internacional. Foi em 46 que o discutido e indiscutível diretor dos Diários e Emissoras Associados, Assis Chateaubriand, confiou-me a tarefa de dar vida, saindo de um zero bem redondo, ao Museu de Arte de Sáo Paulo.

$\mathrm{O}$ que aconteceu todos sabem, menos os nossos cotidianos que não deram ainda nenhuma notícia sobre o marcante sucesso da exposição itinerante da nossa famosa coleção de 73 bronzes do Edgar Degas, que deverá ser exibida entre outros locais, nada menos que no Museu Marmottan de Paris. Todos já ouviram falar das aventuras, jogadas financeiras, do batismo do nascente museu na rua Sete de Abril, ministrado pelo então presidente Dutra, da obtenção do edifício da Paulista junto ao Município, da sua inauguração peia rainha Elizabeth II, evidente homenagem ao antigo embaixador em Londres, Chaieaubriand, e quantos outros furos, inclusive um que vale a pena 
lembrar. Em 53, fomos convidados ${ }^{88}$ pelo governo francês a apresentar na Orangerie do Louvre cem obras-primas do Masp e, não conseguindo que nossa Embaixada convidasse o presidente da República francesa, Vincent Auriol, para a festa inaugural, obtive esta presença através de amigos parisienses. E, náo estando presente nenhum representante diplomático do Brasil, e nem o dr. Assis, que interpretou às avessas meu telefonema para apanhar o primeiro avião e precipitar-se para Paris, eu mesmo dei as boas-vindas, em nome do nosso país, àquela personalidade.

88 Passível de verificação. Nas outras versóes dessa história, a inicativa parece ter partido do próprio Bardi, que buscava comprovar a autenticidade do acervo, dadas as acusaçóes de falsificação que vinha sofrendo.
Penso que o livro, editado pelo Crefisul, representa uma contribuição para as vicissitudes da cultura brasileira, e também o devido reconhecimento ao grande visionário Assis Chateaubriand.

Além das dificuldades, trapalhadas e afirmaçóes ocorridas na organização deste museu-não-museu, conto da abertura de escolas, entre as quais as pioneiras de design e da propaganda, das centenas de exposiçôes periódicas ligadas não somente a arte mas também à história e à sociologia, organização inclusive de uma orquestra juvenil.

Enfim, um resumo destes quatro decênios onde se manteve ainda um intenso intercâmbio com museus do mundo inteiro.

\section{Legenda}

Um livro que procura contribuir para a solução dos problemas da cultura brasileira

\section{Casa Vogue \#6, novembro-dezembro de 1986, p.II4 (P.M. Bardi)}

\section{REVISANDO AMORAL}

Por ocasião do protesto que lavrei contra os pichadores eleitorais, em particular manchando as paredes do edifício do Masp, acabei lançando a moda do palavrão, por sinal uma expressão hoje muito natural. O impacto foi táo grande, a ponto de chegar às minhas mãos uma enorme quantidade de mensagens jornalísticas, telegráficas e envelopadas. Inclusive recortes de jornais e revistas com ilustraçóes configurando imagens presumidamente ofensivas à moral e ao pudor.

A acusação com que a autoridade policial me incriminou era a de desrespeito à lei que prescreve não se usar em público palavras ignominiosas e nem mesmo registradas em dicionários. Entre a correspondência recebida certo tempo atrás estava um recorte de uma revista onde a ilustração em cores configura uma formosa moça, de costas, na pinacoteca do Masp, olhando uma tela de Turner, despida da cintura para baixo, exibindo belíssimas e rotundas formas. Foi sorte o delegado não conhecer o documento erradamente dito pornográfico, pois só assim escapei de ser acusado de permitir atos "obscenos" no Masp. Ignorava o acontecido, evidente produto de um fotógrafo e de uma modelo penetras que eu gostaria de conhecer para com eles me congratular pela ideia.
O fato me sugere tratar de um assunto inédito, o das calcinhas, não elas em si, mas sua história. Afinal, quem se interessa pelas artes deve mexer em todos os setores interligados à vida. Um dos principais é o pudor, os escaninhos, os truques, as maroteiras que pintores e escultores arquitetam para disfarçar, circunscrever, cancelar órgãos hipocritamente desconsiderados, perturbadores da placidez de um corpo humano. Inventaram até mesmo uma faixa para a figura de Cristo e a folha de parreira para Heitor.

O uso de calças e calcinhas não foi constante ao longo dos tempos e muito menos entre todos os povos. As romanas, as tinham nos seus guarda-roupas, sofisticadas e volumosas, pois nas escavaçóes de Pompeia foram encontradas vítimas do Vesúvio com as molezas centrais cobertas por aquelas indumentárias. Eram prescritas por motivos morais aos teatrantes, como lembra um trecho de Cícero no De Officiis: por decore o ator deve ser apresentar guarnecido de subligatulo. O mesmo valia para acrobatas, vendo-se em vasos gregos flores indicando calcinhas rendadas. Marcial, num epigrama xinga um esportista jogando a bola, que se esqueceu de cobrir aquilo que não podia ser exposto em público. 
Transcorrem os séculos e com eles mudam os costumes, as civilizaçóes bem conformadas perdem os hábitos da decência Grécia e Roma tornam-se mitos, a Idade Média mergulha na barbárie, como dizem os historiadores, e homens e mulheres perdem de vista a decência De calcinha nem falar, à espera do renascer, da reconquista de posiçóes mais próprias e apropriadas. Em baixo das saias aparecem "pequenas calcinhas de tecido." Nos inventários femininos aparecem as proteçôes em número razoável, algumas até de seda.

As coisas relacionadas com o assunto às vezes chegam às raias da extravagância, como o caso de uma senhora da sociedade francesa que, durante uma recepção, não teve dúvidas em levantar o longo para mostrar que na calcinha tinha mandado bordar o retrato do cardeal Mazarin. Evidente que a peça de antanho era de grande tamanho e não a microscópica feita agora.

A pantalona passa por tempos difíceis nos Seiscentos e nos Setecentos, acompanhando o vaivém da moda. Vestem-na mais as levianas de profissão que as damas. A história da calcinha é riquíssima e cheia de episódios galantes, especialmente quando exibidas devido à queda do alto de um cavalo. Ou então quando os que se dedicam a observaçóes indiscretas, por hobby, se postam em frente às carruagens de onde descem as senhoras que, para não se enroscarem nas saias, levantam-nas, aparecendo então suas calcinhas.

Mais afortunados foram os colegas medievais, que assistiram episódios retratados tấo bem num romance de cavalaria: as três princesas capturadas por um galante aventureiro, as mãos amarradas nas costas, as saias costuradas acima das cabeças, com uma pequena abertura para olhar o caminho para o castelo, e Orlando Paladino, resgatadas as belezas, corre a desafiar o vulgar antifeminista.

Eu me pergunto: o que teria acontecido se a tal derrière fotografada na pinacoteca tomasse o elevador, descesse no belvedere do Masp e caminhasse tranquilamente ao longo da avenida Paulista?

Américo Scarlatti no ensaio dedicado às mutande, do qual pinço anedotas, encontrou num manuscrito da Biblioteca Vittorio Emanuele, de Roma, e datado de Io de setembro de I798: "Na manhã uma jovem descoberta até a cintura, passeando no Corso, o povo lhe se jogou contra, zombando e carregando-a de injúrias." Penso que não aconteceria o mesmo à moça da pinacoteca. Teria recebido entusiasmados aplausos?

Ao que tudo indica as conveniências e as inconveniências vão reclamando revisôes, a moral se despojando de pedantismos por demais estreitos e superados pela circulação de novas práticas e esclarecimentos. $\mathrm{O}$ momento parece propenso à retomada de posição neste campo desleixado do comportamento.

Estas ideias ocorreram-me no momento em que me identificava na delegacia, gravando minhas mãos besuntadas de tinta naquelas fichas de Bertillon para identificar criminosos, por ter desrespeitado Código Penal.

Senhor \#294, 4 de novembro de 1986, p.72 (P.M. Bardi)

A CULTURA DAS RAÍZES

Por que não um Globo Cultural, para divulgar e incentivar uma produção ainda marginalizada pela mídia brasileira?

Quando, aos domingos pela manhã, se assiste pela tevê ao "Globo Rural" e se aprendem soluçóes, às vezes surpreendentes, para os problemas da agricultura abrangendo desde o Amazonas ao Rio Grande do Sul, o interessado nos problemas da Cultura se pergunta: - Como seria útil um "Globo Cultural," informando a respeito dos problemas deste outro campo, também assunto nacional, e, talvez, o básico.
Imagina-se, por exemplo, um repórter entrevistando algumas pessoas com prática em assuntos relacionados com as artes: as plásticas, as literárias, a música, teatro, cinema, artesanato, colocando até mesmo amadores e intrusos nos colóquios. Seriam notáveis certas conversas com novatos e ignorantes dos problemas culturais para ver seus pontos de vista.

É verdade que nossas emissoras sempre dão conta, mais ou menos, das novidades 
culturais, porém as comunicações dependem de ocasióes e aparecem intercaladas nos jornais. O que se propóe é um programa reservado exclusivamente à Cultura, de espírito bem jornalístico, organizado com inteligência. Pela potência da tevê teria penetração nas famílias.

Por exemplo, o Canal 2, TV Cultura, que não tem os intervalos publicitários, poderia dedicar não uma hora, mas algumas horas ao assunto, possivelmente sem aquela insistência de cantores e guitarristas.

Alude-se a programaçôes de caráter cultural mesmo, não a diversóes, e nisto se inclui a discussão, críticas, reportagens, descobertas, curiosidades para o telespectador, justamente como já ocorre para os agricultores. Existe um certo público para a divulgação de assuntos culturais? Afinal não se armou um ministério para cuidar desta atividade que não depende de leis, decretos, censuras, verba etc., sendo consequência de tudo que ocorre na sociedade, inclusive as manifestaçôes basicamente populares.

Por exemplo: quando explode o Carnaval. É este um caso de Cultura? Certamente, pois implica arquitetura, visto que se constroem sambódromos, em cenografia, roupagem e também nudez, música e, à maneira antiga, até premiações e tudo mais que exige um espetáculo. E devem ser considerados também os espetáculos futebolísticos, especialmente agora que vem aí a competição mundial. Seria o caso de juntar também a Loteca?

Quando se compóem secretarias estaduais os títulos são quase sempre "cultura, esportes e turismo," numa evidente confusão de atividades. Por outro lado o setor cultura não se interessa por esta num modo como se desejaria.

Para voltar à tevê, além das diversóes, existe a Cultura propriamente dita, na acepção latina, no sentido de civilização. Como se lê num dicionário "a cura assídua para obtê-la, a mesma do agricultor.”

Foi justamente assistindo ao "Globo Rural" que surgiu a ideia de um programa cultural naquele modo: sublinhar fatos que valem a pena anotar nesta fértil planície da Cultura, a representação mais íntima de uma Nação.

\section{Legenda}

O Rei Momo voador da cidade da

Bahia e a mística do Sambódromo: a arte popular invariavelmente contribui para a cultura de um país ainda envergonhado de suas origens

Senhor \#295, II de novembro de 1986, p.84 (P.M. Bardi)

O RESGATE ROMÂNTICO

O novo edifício de esportes do Sesc Pompeia enriquece o esforço brasileiro em favor da memória

Eis uma observação correta de Eduardo Subirats Rüggeberg em Projeto, tratando da salvaçáo e da reconstrução da Fábrica da Pompeia: "O europeu que chega ao Brasil... se assombra pela sua beleza, sua força, pelo colorido e pela variedade de formas que reúnem suas cidades e suas povoaçóes, surpreendendo-se pela criatividade que neste país tem o homem, as plantas e a terra. Mas se surpreende também que tudo isso possa ser destruído de uma maneira tão rápida e tão bárbara.”

Vem mais uma vez à mesa o problema da conservação no Brasil, e justamente os seus fautores são mais numerosos entre os imigrados, diria até os imigrados recentes, do que entre os nativos. Quantas vezes se reclamou contra as destruiçóes bárbaras, adjetivo apropriado, do paraíso da Amazônia e, para nos transferirmos da floresta para a cidade, a defesa dos bairros antigos ameaçados de eliminação em São Paulo tem sido constante nesta página.

Pode ser que um europeu, não ignorando que também no continente do ditado estético, (o próprio Subirats, justificando o trecho acima, se atém ao sentido de Schiller) as destruições foram inúmeras se pensarmos no Parthenon ou no Coliseu romano, todavia este pensar de um europeu no Brasil é bem registrado. Afinal o que nos encantava, ao percorrê-lo inicialmente, era a floresta.

Eu próprio, adquirindo no tempo dos tempos uma área no Jardim Morumbi, um bairro que hoje é desprovido de verde, deixei-a com seu mato original, encantado em hospedar duas preguiças e não sei quantas cobras ao redor da casa: um romantismo exótico, um Brasil que se imaginava antes de para cá vir. 
Ainda hoje se protesta porque caçam os jacarés. Todavia se deve aceitar a vida como ela se desenvolve, com suas situações destrutivas e tudo o mais.

Quando fecharam o tradicional Círculo do Trianon e depois o destruíram, este paginista ficou triste. Pensou-se até num projeto para o edifício do Masp que pudesse conservar o Trianon, lembrança da São Paulo dos ricaços do café. Romantismo exagerado?

A vida prossegue. No Masp, de vez em quando se apresentam restos do passado. $\mathrm{E}$ justamente nestes dias abriu-se a Exposição dos Antiquários, o que leva a pensar que a vida tem suas mudanças. É uma quantidade enorme de objetos salvos e oferecidos aos cultores do passado. É emocionante ver um alambique gigante que nos transfere para um engenho de açúcar nordestino do Oitocentos, ou a um rústico confessionário de não se sabe qual aldeia.
São os europeus que mais gostam destas antiguidades, mas é confortador saber que também aqui se vai formando uma consciência, sempre mais firme, pela memória, os românticos sendo recrutados num número sempre maior, o esplendor da nossa história conquistando adeptos.

Para voltar à observação do professor Subirats, foi uma boa ideia a do antigo presidente do Sesc, José Papa Júnior, e do diretor Renato Requixa, salvarem da destruição um marco da antiga São Paulo, a Fábrica da Pompeia, transformada em centro de lazer graças a um projeto de Lina Bo Bardi baseado em valorizar o que ainda existia, ajeitando com recursos atuais, criando ao lado um monumental edifício destinado aos esportes: respeito pelo antigo neo-cotidiano.

Os românticos satisfeitos? Sem dúvida.

Legenda

Memórias do engenho e o conjunto do Sesc: a ordem é preservar

Senhor \#296, I8 de novembro de I986, p.84 (P.M. Bardi)

O PODER ECONÔMICO DA ARTE

O mercado brasileiro deve abrir os olhos para o potencial que existe nos

objetos artísticos. Para isso, é preciso optar pelo comércio de alto nivel

Em Senhor, tratar de problemas de economia é fato normal. Às vezes, nesta página, abordou-se temas relacionados com o mercado de arte, registrando-se que no Brasil, nestes últimos tempos, despertou-se para o setor, uma vez que a pintura ou a escultura passaram a ser objeto de valor. O que é gratificante é que se vai desenvolvendo um certo movimento para dar valor a artistas nacionais, alguns deles cotados hiperbolicamente, ensejados por consequências paroquiais e não por estimativas técnicas. Temos já um colecionismo atento, empenhado na valorização correta, porém juntam-se aos conscientes amadores formando notável grupo de improvisados que correm atrás de possíveis especulações, sem ao menos saber que o adivinhar neste campo hoje tấo complexo do mercado das artes é negócio de perspicácia, visando o que vai acontecer proximamente.

Fácil notar que é preciso sabe fazer as contas com o futuro ou pelo menos num futuro próximo.
Quem tem experiência sabe que atender aos chamados publicitários, as pressóes dos improvisados marketings náo leva a um lucrar certo. Precisa mesmo que seja do setor, armado de conhecimentos e de uma infinidade de dados para chegar ao negócio, como também ter audácia suficiente e conhecimentos não apenas superficiais, como de resto ocorre em quaisquer outros empreendimentos financeiros.

O fato é que todo o mercado nacional é exclusivamente baseado naquilo que é produzido por aqui, com exclusão até das obras da América do Sul, continente que tem mestres de ampla circulação internacional. Isto demonstra uma falta de visão. Nosso mercado pode ser considerado como uma das atividades ainda de pouca penetraçáo ou pelo menos ensaiando adentrar no chamado Primeiro Mundo, onde a arte se estrutura num autêntico ramo da economia. Na Europa existem casas de leilóes dedicadas aos objetos de arte abertas desde os começos do Setecentos e contando hoje com sucursais e representaçóes nos principais 
centros, mesmo em São Paulo. Funcionam ativamente, concentrando suas atividades comerciais através de leilóes que incluem mercadorias procedentes de vários países.

O Brasil pouco, para não se dizer quase nada, participa daquela disputas leiloísticas. Todos sabem que as únicas presenças ocorreram no após Segunda Guerra, pela visão de um brasileiro que tinha o dom de saber ver grande. Sonhando uma nação operante em sentido universal e, assim sendo, juntou um patrimônio, o acervo do Masp, hoje tombado pelo Patrimônio, que normalmente é emprestado a museus da Europa, dos Estados Unidos e do Japão, num eloquente testemunho de que o Brasil tem também riquezas de arte. Nos séculos passados a grande riqueza nacional era o ouro que era enviado para a Europa.

Queria observar que, no tocante a riquezas, esta da arte, o Brasil sempre teve a sua.
Fácil prever que, antes ou depois, também as produçóes nacionais antigas e as atuais serão objeto de justa avaliação, porém tudo depende da organização mercantil, não deixando de fora a valorização histórica e crítica, com as devidas decisóes de importação e exportação, numa palavra, o comércio. Primeira providência: a despersonalização do mercado, e continuar com estes leilóezinhos sempre na mesma toada, sem nunca se mostrar mais abrangente. Uma pergunta: quando teremos uma manifestação de âmbito internacional, já que o Brasil está maduro também no campo da economia? Venceram-se tantos complicados empreendimentos e, assim sendo, será que não podemos enfrentar este do mercado de arte?

\section{Legenda}

Detalhe de uma tapeçaria de Gobelins baseada em desenho de Albert Eckhout g Obra de Frans Post: alta cotação

Senhor \#297, 25 de novembro de 1986, p.92 (P.M. Bardi)

\section{UMA ARTE AMAZÔNICA \\ Um livro sobre o Museu Goeldi, de Belém, para os brasileiros conhecerem melhor seus mistérios}

Em I894 o criador do Museu que representa a formação amazônica escrevia: "Desejo ver o Museu Paraense grande e digno do seu nome, respeitado nos círculos científicos e com o papel que lhe compete no certame internacional dos bens intelectuais da humanidade." Eram os votos de Emilio Augusto Goeldi, nascido na Suíça, em Ennerbuhl, em I859, e morto em Berna em I9I7. Ele deu vida ao Museu Paraense e ali reuniu as iniciativas pioneiras de brasileiros interessados nas pesquisas científicas.

O Banco Safra dedica ao Goeldi, agora, um suntuoso volume, a última edição da coleção que ilustra nosso museu, tornando-se, como escreve o diretor da instituição, Guilherme M. de la Penha, ${ }^{89}$ um dos patronos das ciências devotadas à Amazônia. As ilustraçóes relembram o trabalho contínuo das indagaçôes sobre a multifacetada realidade desta Terra e a vida dos primeiros povoadores.

De seção em seção, de peça em peça, (etnologia, arqueologia, geologia, zoobotânica, botânica, ciências humanas) vê-se

89 Guilherme Marcos de La Penha no volume o resultado de inúmeras, às vezes complicadas, pesquisas conseguidas ao longo de mais de um século, museologicamente bem expostas e comentadas para os visitantes, através de exposiçóes temporárias e itinerantes, cursos e palestras que beneficiam escolas e curiosos, sem contar a possibilidade do uso da famosa biblioteca da instituição.

Quem vai a Belém logo visita este painel do mundo amazônico: notável grupo de cientistas ali está ativo, dando vida a inúmeras produções, oferecendo no museu a extraordinária visão de um acervo de incalculável valor.

A par de todas as instituições de caráter básico, também o MPEG, sigla do "Goeldi," tem seus problemas e um aceno a estes está na monografia em que se prevê o futuro insistindo num "especial esforço e empenho do seu corpo funcional adaptando linhas de ação destinadas a aprimorar o 'plano de metas' para o próximo triênio e anos seguintes.”

A estrutura do "Goeldi” é sólida, seus ideadores e operadores conseguiram aprimorá-la. Pense-se somente nestes dados: a 
etnografia, esplendidamente documentada no livro, tem 13.370 peças que confirmam a inteligência e o dinamismo das povoaçôes encontradas pelos colonizadores; milhares de pecas arqueológicas; vinte mil de botânica exsicatas; quantidade enorme de exemplares de vertebrados e invertebrados; cinco mil amostras geológicas. Sáo todos materiais, fato que no futuro se pretende aumentar e estudar mais, atendendo às novas descobertas científicas e históricas.

Alguém com prática em conservação museográfica pode avançar uma ideia: por que o "Goeldi" não organiza uma grande exposição itinerante de parte do seu acervo a ser exposta não só no Brasil, mas também no Exterior, com o particular propósito de oferecer uma documentação da estética, muitas vezes de resultados singulares em numerosos trabalhos manuais, objetos que documentam como as tribos amazônicas anteciparam várias tendências, presentes hoje nos comentários das artes?

O volume, publicado pelo Banco Safra, dá esta ideia. Todos conhecem mais ou menos a arte das culturas indígenas, porém uma manifestação bem escolhida do acervo custodiado em Belém serviria também para falar e repensar sobre a maravilhosa região amazônica e os problemas ali enfrentados.

\section{Legenda}

Um centro de criatividade muito ativo

Senhor \#298, 2 de dezembro de 1986, p.76 (P.M. Bardi)

O OURO DA NATUREZA

O difícil garimpo da Arte, entre a emoção e a História

Foi aberta em Roma, na Galeria Nacional de Arte Moderna, uma importante exposição dedicada a Edward Burne-Jones, um dos mestres do pré-rafaelismo, movimento a ser considerado como uma das primeiras rupturas antiacadêmicas. A manifestação, possibilitada pela intervenção do British Council e favorecida por empréstimos de vários museus, resultou extremamente significativa, oferecendo a ocasiáo de estabelecer a singularidade da poética e do idealismo do Mestre, evocando também a operosidade dos seus companheiros de ação, como Walter Morris e Dante Gabriel Rossetti, para lembrar os mais ativos. $\mathrm{O}$ movimento, que depois tomou o rumo do simbolismo, não se limitou às artes plásticas, tendo influenciado, e muito, a literatura inglesa, em especial Walter Pater, J. Ruskin, George Frederick Watts, Henry James, A. C. Swinburne e outros escritores.

$\mathrm{Na}$ atmosfera do movimento deve-se incluir os colecionadores, como o famoso Agnes Graham, protetor também de Burne-Jones. Este, nascido em I833, filho de um moldureiro, foi companheiro de estudos, em Oxford, de William Morris; em I87I tem sério atrito com Ruskin devido a opiniôes contrastantes sobre Miquelangelo; naquele decênio é notável sua presença no "Morris" e só em I886 faz sua primeira exposição. No final de sua vida recebe o título de barão, sendo reconhecido universalmente.
A fonte deste fervoroso interesse pela renovação da arte inglesa é a Itália, para onde se ia para redescobrir a grandiosidade da Renascença pois ali, nas palavras de Pater, "todas as coisas naturais eram urdidas com fios de ouro.” Burne-Jones viajou à vontade pela Península à procura do seu modo de expressão, atraído e entusiasmado tanto pelo clássico como pela cristianidade, recompondo imagens e espírito e reinventando figuraçóes.

Os tempos na Europa são de agitação para encontrar novos rumos para as artes maneiristicamente rotineiras do Belo tradicional.

A Inglaterra se enriquece com reaçôes singulares, a França vence com o novo realismo dos Impressionistas que em Albion era considerado obra de pintores sem ideais. As vanguardas, ao despontar o novo século, desfechavam as revoltas tabula rasa de qualquer novidade e, nos últimos decênios, contrastes que anulavam o passado.

A exposição romana é documentada por um volumoso catálogo da Editora Mazzotta que reúne uma série de ensaios, semelhante ao editado este ano na Itália para as mostras dos bronzes de Degas do Masp realizadas em Verona, Florença e Roma. Os textos sobre o evento inglês formam uma recapitulaçáo do operar, das preferências e resultados do pintor inglês nos ambientes europeus por ele habitados. A capa reproduz uma das obras de Burne-Jones: A cabeça funesta, emprestada 
pela Staatsgalerie de Stuttgart, Alemanha, sobre a qual os historiadores estabeleceram uma nutrida informação, em que a iconografia recorda fontes medievais e do Renascimento, até mesmo mantegnescas, o ideal fatal da feminilidade ligado à imagem da Medusa, o horror mesclado à graça. São observaçóes das exímias curadoras da mostra, Maria Teresa Benedetti e Gianna Piantoni, às quais se deve atribuir particular elogio pelo extraordinário trabalho crítico e museográfico.

Não parece que estes problemas do cultivo da história da arte, numa página como a nossa, podem parecer impróprios? Todavia recordá-los tem um significado, o de fazer saber que no Brasil também há interesse por estes estudos, não somente em termos nacionais, como comprova a próxima fundação um instituto dedicado àquele setor, sem contar o acervo do Masp, internacionalmente conhecido.

E Burne-Jones?

Esta ocasiāo me oferece a possibilidade de assinalar aos estudiosos europeus uma obra deste artista, conservada nos trópicos, aqui pela primeira vez reproduzida, Alep, a bela pelerine, já exposta na mostra Drawings and Studies by Sir Edward Burne-Jones no Burlington Fine Arts Club em i899, isto é, uma das primeiras homenagens que recebeu o artista após sua morte, ocorrida um ano antes.

\section{Legenda}

A cabeça funesta, de Burne-Jones 9 Alep, a bela pelerine, também de Jones

Senhor \#299, 9 de dezembro de 1986, p.68 (P.M. Bardi)

A VERDADE É UMA ESCULTURA

Memórias de dois artistas pouco reconhecidos

Intercalo em minhas crônicas ligadas a um setor que vai recebendo inesperado destaque no Brasil, a lembrança de uma personalidade que, na Arte nacional, considero o número um da Escultura, e ainda não reconhecido na posição que lhe compete: Victor Brecheret.

Quem passa pelo Ibirapuera, sabe que o monumento às bandeiras é dele, todavia não conhece seu singular trabalho, seu produzir intimo, o que seu talento criou e, como fizeram outros mestres, escondeu.

Confirmo isto com um caso em que, como diretor do Masp, tive e continuo tendo curiosa participação: no período em que reuni o acervo do Museu tive a inesperada sorte de adquirir a obra escultórica completa de Edgar Degas, inédita, pois o artista a criara isolado, tanto que somente foi encontrada após seu desaparecimento entre os mortais. Degas expusera a famosa Bailarina de I4 anos, no Salão de I88I, sem repercussáo alguma, sendo considerada obra de um pintor que se tentava expressar nas formas sólidas. Mesmo assim ele continuou, sem ninguém saber que esculpia.

Não foram raras as críticas que recebi assegurando ao Brasil uma das coleçóes de 73 estatuas fundidas e editadas pelos herdeiros. Agora o Masp está emprestando esta coleção, infelizmente aqui ainda pouco apreciada, a museus europeus, suscitando um verdadeiro rebuliço. O entusiasmo é tanto que a coleção foi solicitada para ser exposta, nada menos que em Paris, no Musée Marmottan, para que aquela capital possa finalmente ver Degas escultor no total de sua obra.

O caso de Brecheret, por certos aspectos, semelhante. Conhecido por seus monumentos, é escassa a divulgação de sua obra miúda. Só agora, 3I anos depois de sua morte, é exposta em São Paulo, numa das mais prestigiosas galerias, a Millan. A família decidiu mostrar o quanto este italiano de Farnese, desembarcado criança no Brasil, operou, resultando o mais importante escultor brasileiro deste século.

Conheci muito bem Brecheret: certa vez. levou ao Masp algumas peças geométrico-abstrata que mostrava, segundo disse, a um "crítico europeu." Lembro de ter-lhe dito: "Brecheret, você é o revelador de um infinito de sentimentos e de memoráveis heroísmo humanos: continue assim."

Vi agora, na Galeria Millan, numerosas obras suas, de tal vivência, um exuberante envolvimento no espírito e nos gestos humanos que me veio espontânea a exclamação: "É o esplêndido mestre que devemos divulgar no Exterior, obtendo assim a posição que lhe compete.” 
Declaro (publicamente) à filha de Brecheret: não se preocupe com novidades valorizativas; dedique-se à gloriosa memória de seu Pai; faça com que todos possam admirá-lo. A arte não é das famílias; quem a cria, destina-a a todos. E proponho sensatamente: o Masp esta disposto a consagrar um fabuloso espaço a Victor Brecheret.

Sou especialista em lançar palavras ao vento, porém penso que as ditas poderiam evitá-lo, revelando um fato exemplar, superador de ligaçôes modestas ao princípio pouco brilhante de acumular e amontoar meios. Sei que são necessários, é claro. E numa família de artistas podem perturbar.

Falava, acima, de Degas: era generoso, desinteressado. Também podia vencer vendendo suas bailarinas e seus cavalos: preferiu conservá-los para si. Pensava em Brecheret concluindo peças de imenso valor: valor maravilhoso do espírito. E afirmo: queremos trabalhar pelo nosso grande Mestre.

\section{Legenda}

Uma bailarina de Degas e

o auto-retrato de Brecheret:

glória, só na morte

Senhor \#300, I6 de dezembro de 1986, p.84 (P.M. Bardi)

Os SEGREDOS DA ESTÉTICA

Um acervo que funciona como impulso e revelação

Como já se observou aqui, as artes plásticas no Brasil estão despertando um interesse sem precedentes. Quase toda a atenção é reservada à produção nacional, comercialmente falando, seja dos pintores oitocentistas, seja dos pioneiros de 22 e seus seguidores “modernistas." Há observadores, inclusive este redator, que preveem um futuro interesse internacional, isto é, penetrar e participar do mercado exterior também, sendo fato singular a recente venda de um Picasso num leilão de Renato Magalhães Gouvêia. $9^{\circ}$

$90 \quad$ No artigo "Um lance de Cz\$ 30 milhóes," em Senhor \#297, (25 nov. 1986) mais precisamente no encarte Senhor S.A. \#28, p.22-25, são anunciadas as principais peças do referido leiláo, que aconteceria entáo dias 24 a 27 de novembro e I e 2 de dezembro, no Museu da Casa Brasileira. A obra de Picasso a que se refere Bardi, vendida no leilão, foi Martenité cubiste, guache e nanquim sobre papel, déc. I9Io, com preço base de Cz\$90o mil, preço estimado na venda de $\mathrm{Cz} \$ 3$ milhóes e ela o foi, por $\mathrm{Cz}$ 3,3 milhôes, conforme anunciado na edição de Senhor \#300, também no encarte Senhor S.A. \#3I, p.28. Renato Magalhães Gouvêa declarou, entretanto, que, neste leiláo, o investidor foi mais criterioso em relação ao leilão acontecido em junho do mesmo ano, dado que apenas $70 \%$ das obras
De qualquer modo, é auspiciosa a formação de grandes coleções de patrícios, sendo um exemplo, por escolha e composição, a do senhor Júlio Bogoricin, nome bastante conhecido no campo imobiliário. Seu acervo, e uso um termo de técnica museológica por ter o conjunto boa representaçáo, poderia ser exposto numa entidade conservadora da memória, e pode ser visto no Masp, até 2I de dezembro. O título, atribuído ao catálogo da mostra, abrangendo desde os pioneiros até os elementos mais destacados da atualidade, é "Dacoleção" e oferece uma visão razoavelmente completa do nosso modernismo. O texto é de Frederico Morais, o qual soube nos dar um panorama do quando operaram veteranos e jovens, não faltando promessas que deveriam dar certo: a tentativa foi fixar modos e gosto da nossa pintura através das vicissitudes de um período em que emergem inúmeras tendências.

De cada uma destas, desde o figurativo até o geométrico, está na exposição um exemplo, com a história de tentativas, tomadas de posição, rupturas, retomo ao passado, explosóes novidadeiras para encontrar caminhos às vezes sem saídas: uma síntese de quanto se conseguiu neste campo complicado e desconhecido da estética.

Num texto lúcido, Morais acompanha nosso saber, as generosas conquistas,

foram vendidas, arrecadando $2 / 3$ do valor esperado. Em junho, 90\% das obras haviam sido vendidas. 
audácias e reflexôes, elemento por elemento, aliás, território por território, tendendo a nos oferecer a realidade de uma situação, apontando cada autor em seu manifestar.

Para certos pintores, a definição é singular. Vejamos a de Miguel dos Santos: “...é sertão, seco e áspero, cortante e despojado. No vazio sem fim do sertão, na monotonia do tempo e do espaço é a imaginação que cria a paisagem, melhor, é ela que cria seres fantásticos, os mesmos que frequentam sua pintura: encapuzados, mascarados, heróis e reis destronados, carregando sua ancestralidade e mistérios..." Ou para Ernesto de Fiori: "Mesmo abordando em seus quadros o society paulista da época, deixa transparecer um certo tédio, ou seja, participa deste clima triste dos anos $40-$ anos de guerra." (A respeito de De Fiori não vejo citado, na bibliografia, meu livro sobre o artista, o único, publicado na Itália em 1950, como também não vejo vários ensaios que dediquei a outros artistas.)

Mas o singular de "Dacoleção" é a divisão das várias fases, formação de grupos, destaque de personalidade, vertentes das quais não se sabe quem, qual será o futuro, pois as origens parecem imitação de vanguardas atuantes fora do Brasil.

$\mathrm{Na}$ coleção faltam vários artistas, os quais, por não darem importância a Salóes, Bienais e currículos, pouco aparecem nas crônicas, mas encontrá-los será tarefa de colecionador e seus conselheiros. O que, doutro lado, é típico de todas as coleçôes. O notável é que, finalmente, se começa a reunir obras.

É convincente observar nas páginas do livro vários pintores que este paginista incorporou à Pinacoteca do Masp, logo após a inauguração, como José Antonio da Silva que, nos anos 40, era um desconhecido. Sempre foi esta a tarefa de quem se dedica a reunir coleçóes: ver e apreciar antes que os outros o façam.

\section{Legenda}

Colheita de algodão, de José Antonio da Silva Guerreiro, de Miguel dos Santos

Senhor \#30I, 23 de dezembro de I986, p.68 (P.M. Bardi)

Os MITOS DA ARQUITETURA

Qual a diferença entre admirar o Partenon e dormir embaixo da ponte?

A arquitetura, se for ainda válida a teoria da "figuração espacial," comporta a série de problemas que o estimado Bruno Zevi indicava: condiçôes políticas e sociais, vontade dos comitentes, costumes civis, aspirações religiosas, conhecimentos técnicos, interpretaçóes culturais, psicológicas, simbolistas, funcionais e tecnicistas, além de outras implicaçóes que o arquiteto precisa levar em conta quando se mete a imaginar uma construção a ser colocada num determinado espaço. Toda esta problemática acompanha a arquitetura desde a construção de uma cabana, o mítico começo do construir, conforme nos ensina Vitrúvio. Durante a passagem deste refúgio até o Partenon, o crescimento do arquiteto foi maravilhoso, como de resto se deu no transcurso entre o Partenon e uma catedral gótica e desta a um prédio de vinte ou trinta andares, chegando-se aos apartamentos atuais cheios de conforto e mordomias numa civilização que ainda mantém as favelas e, pior, os que dormem embaixo das pontes.
Quantos os mestres que mexeram nesta arte-ciência-técnica chamada arquitetura? Não há possibilidade de contar, nem pelos resultados monumentais nem pelas práticas advindas ao morar do dia-a-dia.

Para não infligir numa história sintética, vemos neste século, considerando as conquistas do concreto armado, quais as inovaçóes que, grosso modo, foram apelidadas funcionais: a arquitetura saindo da prancheta de desenho, onde a regra era eliminar os enfeites das fachadas, pois estes acréscimos à de construção e de decoração sempre foram consequência da estética, restringindo-se à sua história.

Superou-se o hábito de embelezar fachadas com colunas sem função, molduras em janelas, aplicaçôes de materiais decorativos, o que chamamos culturalismo ou ecletismo, pois os arquitetos utilizavam os registros do passado para usar as novidades já vistas e revistas. Soou a hora da renúncia; paredes lisas, aberturas ligadas ao geometrismo surgindo o que foi chamado de "estilo hospitalar." 
Todavia, a renúncia provocou suas alternativas. Nos anos 40, ocorreu-me projetar, participando de um concurso, em Roma, com o engenheiro Pier Luigi Nervi, um dos número um da arquitetura italiana, um museu destinado a documentar os vinte séculos da arte da Península. Como se observa na planta, que representou minha participaçáo, tudo aparecia claro: cada século num triângulo, separaçóes estritamente funcionais, divisórias para mostrar as diversas artes e artesanatos. Nervi tinha projetado uma cúpula em cimento armado: tudo cem por cento funcional.

Porém, uma arquitetura é vista de fora, e quando se tratou de desenhar o exterior, o próprio Nervi sucumbiu, dizendo: "Agora, aqui na entrada, precisa dar certa monumentalidade, precisamos de algumas colunas." Como, na prática, eu era o técnico do museu e também por respeito a Nervi, limitei-me a comentar: "Então o funcionalismo vai a carte quarantotto." (Traduzindo na gíria: "pras cucuias.")

Isto me dá ocasião de pensar no funcionalismo hoje dito pós-moderno. O próprio Le Corbusitr, do qual vou celebrar o centenário no Masp, no próximo ano, caiu na armadilha quando desenhou a Capela de Ronchamp. Sem falar nos seus seguidores de Brasília. Conclusão: parece que a arquitetura náo pode renunciar ao decorativisimo? Foi sempre discutida e superada a famosa norma do padre Lodoli, do Setecentos: "Nada se deve acrescentar à construção que não seja verdadeiramente função.”

\section{Legenda}

Projeto do Museu dos Vinte Séculos

da Civ. Italiana, de Nervi e Bardi 9

Capela de Ronchamp, de Le Corbusier

Senhor \#302-303, 30 de dezembro de 1986, p.68 (P.M. Bardi)

UM CRIADOR DE IMAGENS

A exposição de Wesley Duke Lee é um milagre no meio

da infinidade de ofertas do mercado artístico

A metrópole, entre a quantidade sem fim de novidades que cada dia nos impinge, apresenta agora algo inédito: a indigestão das exposiçóes de arte, prática que quando eu comecei a inserir no Masp, no pré-histórico 47 - foi preciso explicar aos raros visitantes que a função de um museu não é somente conservar relíquias, mas também mostrar as possíveis relíquias em produção.

Transcorridos quarenta anos, o sistema nos museus continua, mas agora os sintomas são de indigestão, pois é assunto dos galeristas, bancos, clubes, espaços mais ou menos onde pintura, escultura e derivados dos futuros mestres locais são oferecidos ao público.

Não e possível agradar a todos os paladares. De vez em quando, todavia, conseguem-se algumas digestóes. Cada um de nós, alçados nos trilhos das artes, sabe como se dirigir. Finalmente, neste final de ano, três milagres num único acontecimento: um mestre, uma apresentação condigna, um catálogo esplêndido. Os encontrados: o velho, apesar do desenvolto toque juvenil, Wesley Duke Lee; a prosa inauguradora de um sistema de crítica legível e relegível de Cacilda Teixeira da Costa; páginas ilustradas maliciosamente, espiritadas de bom gosto.

Outra vez o Wesley, isolado, genial, inovador, está na crônica: sua exposição na Galeria São Paulo é o marco firme de um pintor que desafia as facilidades do modismo incentivador de um academismo sem letras. É uma proposta com todo o ar polêmico: volta à tradiçáo, valendo as liberdades no se manifestar, um retomo figurativo, indicação de futuros entendimentos, até mesmo consequência da vitalidade tecnológica.

Desde que o conheço, Wesley não desistiu de provar e reprovar, de abrir e seguir caminhos atuais. Bastaria o seu Retrato de Tiradentes que está na Pinacoteca do Masp, para documentar um espírito superador de modos e maneiras, realizador de anseios espirituais, evocativos de história.

$\mathrm{Na}$ mostra paulista, eis o dinâmico mais uma vez se servindo de um personagem memorável para nos oferecer, a um só tempo, através de uma das suas técnicas singulares, folhas de magistral atualidade: desta vez desenhando sobre xerox obtido da quinhentesca figura gloriosa de Maximiliano I. Ali Wesley nos dá 
desenhos sobrepostos de vibração, animosidade e excentricidade convincentes. Vale sua citação, tomada de empréstimo a Casanova e anotada no texto crítico adequadíssimo de Cacilda: "Vencer, por força ou por engano, vencer sempre foi uma coisa louvável." Wesley quis tecer um rendilhão! Diz Cacilda: "Um descarregar de vida," juntando cultura, sensualidade, intuiçôes a mundos fantásticos, um certo descaso próprio de um criador de imagens.

Nesta página são assinaladas exposições, quando se acredita que vale a pena. Esta do Wesley, sobre a qual meditou vinte anos antes de soltá-la, pode ser vista.
Aconselha- se reler sobre Maximiliano I numa enciclopédia, antes de ir ao seu encontro. Encontro? Não, mas descoberta de uma porçáo de fatos, um mais atraente do que o outro, todos concorrendo num visualizar cheio de motivos gratos pois se movem numa história exuberante de eventos, manipulados por um dos mais representativos elementos da arte no Brasil.

\section{Legenda}

Duke Lee: mostra dedicada a Maximiliano I, com desenhos e aquarelas sobre lembranças de gravuras dos Quinhentos

\section{Casa Vogue \#I, janeiro-fevereiro de 1987, p.64 (P.M. Bardi)}

\section{A PROPÓSITO DOS TAPETES...}

Os editores no Brasil são muito ativos.

Prevalece, naturalmente, a edição de livros de ficção, porém a história tem seu lugar, especialmente a nacional. Os textos que não parecem suficientes são os que tratam de problemas específicos de história da arte. Para dar um exemplo: vemos agora publicado Tapetes Orientais, um manual de identificaçấo de autoria de um técnico de renome internacional, Ian Bennett, o perito da Sotheby's neste setor. O volume acaba sendo uma abreviada história das atividades de várias regiôes. ${ }^{91}$

Este campo é de uma vastidão tão grande que sua dominação deve ser feita por alguém experiente justamente em comércio, no caso um conhecedor operando em uma empresa empenhada em acertar origens, datas e qualidades. Diria ser um caso parecido com o julgar pinturas e esculturas, as dúvidas e os dilemas se multiplicando dia a dia, as emboscadas das atribuiçóes constituindo um pesadelo para os avaliadores. Bennett deve ter amontoado em sua carreira não sei quantas aventuras, as mesmas de um especialista envolvido no comércio de materiais de séculos ainda não satisfatoriamente aclarados, as numerosas

9I O título original de autoria de Ian Bennett é Oriental Carpet Identifier. London: New Burlington Books, impresso em 1984 e reimpresso em 1986. O título de Bennett, traduzido no Brasil, ficou Tapetes Orientais: Manual de identificação, Rio de Janeiro: Jolan, 1986. falsificaçóes e determinaçóes de autorias provocando discussóes intermináveis.

O editor do volume é a Jolan, do Rio de Janeiro, com o apoio do marchand Renato Magalhães Gouvêa, que nos seus faustosos leilóes inclui também tapetes antigos, procurando as diversificaçóes técnicas indispensáveis para estabelecer os valores, fato este implícito na saída das peças, objeto não mais de decoraçóes em moda, mas de investimento, o que de resto se tornou comum para a pintura.

Aqui, uma observação: o nosso improvisado adquirente de arte concentrou seu apetite nos quadros dos artífices locais, (considerados mestres, sequazes, imitadores, obras às vezes falsificadas ou não) convencido de que o amplo mundo da produção de arte não é nem local, mas paroquiano. É por isto que maravilhou, em um recente leiláo de Renato, a venda de nada menos que um Picasso, além da presença de mobiliário de épocas passadas e objetos singulares: inauguração de novos tempos?

O mercado dos tapetes orientais é um sintoma. Também porque, especialmente no Rio de Janeiro e em São Paulo, é uma mercadoria que se encontra nas casas, já se notando um nascente colecionismo. O manual agora editado vai contribuir para despertar a atenção, o mesmo interesse meio clandestino que os práticos de história da arte sabem próspero para a prata, a porcelana e a bibliofilia antigas. Bennett ensina, então, a distinguir o que genericamente se classifica bukaras através 
de uma preciosa série de quadricromias, que nos transferem a países asiáticos e a tantos outros onde a fantasia nos leva a uma infinidade de desenhos e a paciente técnica a um patrimônio de sutilezas e ajeitamentos de trama urdiduras: a humanidade devotada a celebrar a vida na espetacular beleza. Os tapeceiros, desde primitivos até os atuais, nos encantam por sua inventiva sem pausas de nós, riqueza de cores, anseios de juntar formas figuradas ou sínteses geométricas, seguindo um miniaturismo obsessivo, as maravilhas fluindo na espontaneidade instintiva do labor.

Eis, portanto, um livro que vai enriquecer nossa vida das artes, auspiciada como sempre mais ativa, emergente na espiritualidade, valendo o colecionar como fato básico.

\section{Legenda}

Desenho de Regina Graz, executado pelas Manufaturas do Tapete Santa Helena.

Senhor \#304, I3 de janeiro de 1987, p.68 (P.M. Bardi)

Cultura AlÉM DA PARÓQUiA

Depois da Lei Sarney, esta é a hora de os nossos editores levarem ao Exterior a cultura brasileira

Sáo comuns as queixas sobre o andamento da Cultura, e para sossegar os reclamantes tivemos agora o apoio da Lei Sarney e disposta a assaltá-la já está predisposto nada menos que um marketing, embastido num simpósio de interessados que, para discuti-lo, pagaram até uma inscrição de Cz\$ 3 mil. Não se denuncia isto por discórdia: excomunhóes já tivemos tantas que mais uma seria inconveniente.

Ocorre que nós, talvez com mentalidade e comportamento ajustados nos cânones dos séculos passados, pensaríamos numa Cultura que surja e se envolva em empreendimentos de um nível realmente digno do significado da palavra, e não no culturalismo bon à toui faire.

Sei que se abre uma discussão a respeito do que se entende por Cultura. De qualquer jeito, a esperança é que manifestaçôes de importância para o Brasil também recebam as ajudas, aliás os incentivos para que se desenvolvam. Pensei neste problema recentemente, ao receber da Suécia a publicação La Revista del Sur, corpuda e com uma rica resenha de assuntos literários e artísticos dedicados à América Latina, com redação no Uruguai. Descobri ali referências a numerosos periódicos similares, que se publicam no Chile, México, Cuba, Colômbia e outros países, inclusive um interessante ensaio de Carlos Espinoza Dominguez sobre Macunaima, e outro, incisivo, de Pablo Neruda lembrando os mestres Orozco, Rivera, Tamayo e Portinari "que formam a estrutura andina do continente," para evocar a fantástica inventiva do equatoriano Guayasamín, ${ }^{92}$ ganhador do prêmio de melhor pintor sul-americano na Bienal paulista de i957. A revista leva a refletir sobre um problema fundamental da cultura brasileira: nossa falha no ilustrar o quanto aqui se produz neste campo. $\mathrm{E}$ os leitores sabem que os valores são muitos em todas as áreas, desde a literatura além do ultratraduzido Jorge Amado, da quitetura, além do consagrado Oscar Niemeyer e das outras artes, há muitos elementos a serem divulgados, inclusive na ciência.

O curioso é que a necessidade de uma publicaçáo periódica, tendo como tema o Brasil cultural é reclamada continuamente no Exterior, e até indicam a língua em que deve ser redigida. Além do português, pedem resumos em inglês e francês como é hábito em certas publicações técnicas europeias. Por ai fica evidente ser indispensável a participação do Brasil no panorama cultural mundial. Páginas atrás, tratando do nosso mercado de artes plásticas, considerava-se a necessidade de nos interessarmos também por obras estrangeiras, deixando de gastar fortunas paroquialmente. Quer-se um Brasil ativo e inserido no mundo.

Hoje, cada nação depende de sua presença lá fora, procuremos então penetrar, para nos fazer conhecer, compreender, nos introduzindo no mecanismo cultural internacional, especialmente nos países com quais comerciamos produtos industriais e agrícolas. Assim estaremos

92 Oswaldo Guayasamín, ganhou o prêmio das Bienais da Espanha e de Sáo Paulo. (Equador I919-I999) 
mostrando, em termos internacionais, o quanto e como valemos. Por outro lado, as falhas já começam aqui, na própria imprensa que ignora o que, bem ou mal, o Brasil realiza culturalmente no Exterior.

Pessoalmente constato que importantes manifestaçóes de arte brasileira no Exterior acabam ignoradas em nossos cotidianos, como ocorreu na recente semana brasileira na Alemanha, compreendendo música, e artes plásticas, patrocinada pela Basf, sem contar as exposiçóes com que o Masp colabora com peças de seu acervo no Exterior, como por exemplo agora estamos com todos os 73 bronzes de Edgar Degas sendo vistos na Itália

Eis um outro lado da questão: finalmente dar um sistema ao conhecimento da cultura nacional nos seus diversos setores, aqui e no Exterior. Por que entâo, com as vantagens da Lei Sarney, alguns de nossos editores não resolvem modificar esta situação?

\section{Legenda}

$\mathrm{Na}$ contracapa da revista uruguaia, [La Revista del Sur] desenho do equatoriano Guayasamín

Senhor \#305, 20 de janeiro de 1987, p.65 (P.M. Bardi)

LABOR PARA HISTORIADORES

Se é trabalhoso decifrar Vênus e Cupido, o que estará

reservado aos pesquisadores de um Kandinsky?

De vez em quando, penso na complicada tarefa do historiador de arte, não tanto no destes nossos babélicos tempos quanto no do futuro, o qual deverá elucidar a criatividade dos artistas das tendências geométrica e abstrata. A reflexâo me ocorreu observando e adivinhando modos para relatar o que foi exposto na retrospectiva enviada ao Masp pelo Museu de Arte Moderna de Nova York: formas em contraste entre aqueles próprios mestres e seus seguidores, linhas, riscos, cortes, interferências, até uma única camada de tinta, mais compreensíveis os extremistas do impressionismo, isto é, os cubistas, sem contar o palpável dos escultores.

Descrever uma destas obras é ainda complicado, pois a temática é indecifrável para os historiadores interessados nas produções de até o fim do século passado, habituados com o tradicional figurativo. Eu mesmo, acostumado a dar conta de obras de Velazquez ou de Segall, tentei esclarecer a pintura de Manabu Mabe ou de Tomie Ohtake. Desde sempre, na minha coleção, estão obras de Paul Klee e de Torres-García.

Porém, continuo a considerar um amanhã que paira no ar: as novidades e as excentricidades vão ganhando pontos, por imposição ou por aceitação. Vamos ver no que dá. Talvez possa até ser previsto um retorno à realidade, pois imagino que, como abandonaram a figura, os pintores venham a abandonar o modismo. Doutro lado, no superado operam mestres do figurativo, como por exemplo um
Francis Bacon, sem dúvida a insubstituível expressão da arte do século.

Penso nos futuros historiadores, decifradores dos mistérios matemáticos do geométrico absoluto de Mondrian, ou do corte na tela de Fontana, nos anos 30, rigidamente figurativo. Serão inseridos no cataclismo das bombas atômicas?

Mais conveniente para os historiadores do antigo era interpretar uma pintura, descobrir intençôes uma a uma, mistérios, esconderijos. Por acaso, averiguando significados do Banho de Diana de François Clouet da Pinacoteca do Masp, ocorreu-me ter informaçóes sobre uma Vênus e Cupido atribuída ao próprio Clouet. Qualquer leitor vê o que o cortês pintor dos reis da França sintetizou e fez alusóes nas duas figuras: a acolhedora de cupido seria Diana da França aos quinze anos? Através de seu casamento, ainda menina, em I553, com Orácio Farnese, uniáo exigida pelo papa Paulo III para coroar com Paris uma coalizão anti-imperial, a pintura nos encaminha por crônicas saborosas. Interessa o encontro, o abraço de Amor: seus braços num gesto envergonhado, pele arrepiada, fascínio poético abrindo a porta aos líricos da Plêiade, chegando ao entusiasmo fora do comum de François de Billon, que na sua obra Le Fort Inexpugnade de L'honneur duneur du Sexe Féminin póe Clouet na mesma fileira dos Miquelangelo.

Então, uma simples peça, parece que procedente da quadraria de Joaquim Murat, rei de Nápoles, pode acender o 
fogo de pesquisas, até indagaçôes minuciosas, pode ser que supérfluas aos olhos dos não interessados neste recinto.

Trata-se de história da arte, publicam-se volumes sobre deduçóes aparentemente cabíveis, para saber de um pintor que póe detalhes em seu fazer, motivos que suscitam perplexidades para compreender seu ânimo. Também os inovadores das vanguardas históricas dissimularam pensamentos. Como é hoje laborioso decifrar um encontro de Vênus e
Cupido, amanhã será laborioso descobrir ideias e espírito de um Kasidinsky.

Este paginista foi acusado de ter desmontado a Pinacoteca para apresentar Constrastes de forma, quase colocando de castigo os Daddi, Rafael, Ticiano, Goya, Matisse. Os antigos formaram na exposição o primeiro contraste com os geométricos-abstratos. Um museu deve registrar, como se fez, as realidades atuais.

Legenda

Vênus e Cupido, de Clouet

Pontos Pretos, de Kandinsky

Senhor \#306, 27 de janeiro de 1987, p.65 (P.M. Bardi)

O CASO REMBRANDT

Testemunho pessoal sobre uma leviandade

Redijo esta página para contar um caso pessoal, que por outro lado é de interesse geral, visto, o barulho que causou.

Em 1948, na condição de responsável pela aquisição das obras da pinacoteca em formação do Masp, não tive dúvida alguma em comprar na Galeria Knoedler, de Londres, uma pintura que logo que me foi apresentada impressionou-me muito, ficando ainda mais certo de sua importância quando examinei sua ampla documentação, além de ter sido publicada por eminentes historiadores e ter feito parte de coleçôes de importantes conhecedores. Tratava-se do Auto-retrato com a barba nascente, de Rembrandt.

A história do painel começou em I829, quando foi exposto no The British Institution, de Londres. Foi por mim mesmo incluído na mostra que a convite do governo francês inaugurei na Orangerie do Louvre, em 1953 - a "Cem obras-primas do Masp," que representou a participação do Brasil na vida artística internacional, que desde então continua a se desenvolver esplendidamente.

Aquela exposição foi levada a Londres, Bruxelas, Berna, Dusseldorf, Miláo, também a Utrecht, no Centraal Museum, onde a obra em pauta foi especialmente admirada. A tournée se encerrou no Metropolitan Museum de Nova York, tendo sido uma consagração.

Por ocasião do terceiro centenário da morte de Rembrandt, várias foram as referências para o Auto-retrato, numerosas as matérias, sendo que a mais viva resultou da revista Veja: quatro páginas, com detalhe da obra etc.

Noto esta circunstância, pois, na última semana, esta mesma revista, com o título do artigo lembrado na capa, vem contar que a pintura náo é de autoria de Rembrandt, que não é auto-retrato, devendo ser atribuída a um aluno seu. Esquecendo o precedente panegírico, Veja se baseou no veredicto de uma comissáo holandesa que deliberou a mudança de autoria do painel: uma obra da mesma época, realizada possivelmente no ateliê do mago, talvez até assinada por ele para premiar um aluno. E não é só isso: não é auto-retrato por causa do tipo do chapéu do retratado, e sim um retrato de um burguês etc.

Como também a Holanda se delicia com um regime democrático, as opiniôes, também discutíveis, são livres e o leão não as morde. Diz-se que a comissão sabetudo sobre Rembrandt, todavia não identificou o aluno. $\mathrm{O}$ mesmo fato ocorreu a outros museus, entre eles o Metropolitan Museum, de Nova York, tendo seu espertíssimo diretor recusado o parecer dado a um de seus Rembrandt. Como de resto fez este diretor do Masp, que ainda não recebeu o decreto, até agora não oficial, mas sim resultado de uma simples conversa com um repórter.

A conversa foi transformada em matéria escandalosa. O Jornal do Brasil, por exemplo, diz ser o Auto-retrato uma obra 
“falsa." Esta observação não é tanto para revelar um fato ultracomum no nosso setor, (na Itália, discute-se, neste momento, a autoria de quatro obras de Caravaggio) mas para denunciar a ignorância de nossos cronistas: falso significa algo bem diferente de autoria não aceita, de nova atribuição. Falso é um ato criminoso.

Por outro lado, onde se encontra o preto no branco da declaração da comissão? Levianamente, ou por motivos estupidamente denegridores, Veja despachou um repórter até Amsterdá para ter uma antecipaçáo do parecer sobre o nosso Rembrandt, o mesmo que exaltou nas quatro páginas, anos atrás.

Quando o parecer for publicado num catálogo de Rembrandt, anunciado pela comissão, o diretor do Masp terá a mesma atitude de Philippe de Montebello, diretor do Metropolitan: continuar a compartilhar a mesma opiniáo dos historiadores que vem desde i829. Quanto à comissão, aparenta mais ser um grupo de voluntariosos armados de instrumentinhos que, evidentemente, não são capazes de usar.

\section{Legenda}

O Auto-retrato e um dos atestado; de sua autenticidade (Veja, 1969)

Senhor \#307, 3 de fevereiro de 1987, p.65 (P.M. Bardi)

UMA CONVIDADA ESPECIAL

Ela se chama propaganda. Começou a ser ensinada no Maspe

estará na festa de seu quadragésimo aniversário

No programa de exposiçóes que o Masp vai apresentar este ano, para lembrar que festeja os seus quarenta de atividade, está prevista uma manifestação dedicada à Propaganda. Será em colaboração com a Escola Superior de Propaganda e Marketing, a entidade que foi criada no próprio Masp em r950, sob o simples título Escola de Propaganda, um ensino então inédito no Brasil que deu resultados singulares e convincentes, como qualquer um sabe.

Incumbido de dar vida ao Masp, pois em São Paulo faltavam numerosos bairros no setor arte e suas periferias, sendo o meu "museu-não-museu," propulsor de fatos novos, foi lógico instituir o ensino de matérias nunca antes enfrentadas. Entre outras, a da Propaganda. Abri o primeiro salão desta atividade e, com a ajuda indispensável de Rodolfo Lima Martensen, conseguiu-se inaugurar a Escola. Contando com a participaçáo de vários profissionais, ganhando alunos, instruindo elementos, afinal servindo como se diz na Itália alla bella e meglio, até que uma participante levou a escola para outros lares e, de desenvolvimento a conquistas, tornou-se escola superior.

Agora é com seu diretor, o professor Francisco Gracioso, que estamos preparando a exposição comemorando seus 35 anos de existência. O Masp vai verter nas salas um pingo de memória e, possivelmente, ideias e a coreografia própria dos eventos dos quais somos praticantes. Numa primeira reuniāo recomendou-se aos voluntários um acréscimo de trouvailles. Penso na Propaganda com P maiúsculo, fora dos rotineiros que sequestram páginas para lançar a produçáo pós-Cruzado dos edifícios apartamentisticos, a Propaganda inventiva, o espirito saltitante do idear, o chamariz que convence e brilha trazendo ao Masp, que lhe vai oferecer três grandes salas, um fato a ser lembrado.

O Brasil é rico, hoje, em agências multinacionais e nacionais, com alto potencial de divulgação, adequado à estupenda vitória da indústria. Então o que se pede é a fusão do produzir e do fazer saber. Penso numa manifestação reveladora do como é encarado, como novidade, o operar da Propaganda. E toda a parafernália que a envolve: gráfica, som, televisão, eletrônica e, naturalmente, aqueles argumentadores, malabaristas de vivacidades na TV, anunciadores de mil produtos. Para tanto será preciso obter fatos de época.

Será, talvez, uma contribuição à estética 87. Eu ficaria corado de vergonha por apresentar num cantinho fotografias do primeiro saláo em 50. Mas era preciso começar. Posso confessar: foi uma grata iniciativa manipular o Masp. Começamos sem press-release, quarenta anos depois eis uma notícia furo: vieram do Japão redatores e fotógrafos do Asahi 
Shimbun, jornal com tiragem de doze milhóes de cópias, para nos atribuir uma reportagem. Valeu a pena começar, também nos dedicando à Propaganda.

\section{Legenda}

Pelo pioneirismo do Masp no ensino da propaganda, em 1950, o Brasil chegou ao longo dos anos a trabalhos como estes

Senhor \#308, io de fevereiro de 1987, p.65 (P.M. Bardi)

O DIREITO A MEMÓRIA

Discute se nacionalmente, na Itália, a conservação de museus.

Um tema, aliás, que também afeta o Brasil

Em um dos últimos números do Il Giornale dell'Arte, iniciou-se uma discussão nacional a respeito de um foto básico em uma nação rica, aliás, riquíssima de memória. Foi apresentada entre outras teses, a da reestruturaçáo dos museus, senão de todos pelo menos da maioria dos administrados pelo governo central ou pelos municípios, que resultam em gestóes insatisfatórias, a burocracia tomando sempre mais conta, as críticas denunciando deficiências.

Na polêmica, indicou-se, consequentemente, o factível e inteligente funcionamento dos museus dos Estados Unidos e a estreita relação destas entidades com seus usuários. Natural que origem e experiência não têm nada a ver com a situação italiana. $\mathrm{Na}$ América do Norte, aqueles centros culturais surgiram por iniciativa particular, por espírito mecênico, exigências universitárias, e continuam progredindo espetacularmente, sempre mais abundante a transferência para lá de material de grande importância histórica, com um mercado próspero, praticamente o mais opulento.

$\mathrm{Na}$ lembrada discussão, ocorreram até provocaçóes, como a proposta de até se vender tudo: "Veneza aos americanos, Milão aos gnomos de Zurique, Pompeia aos suecos que entendem de arqueologia, Nápoles ao socialista espanhol Gonzales, Turim a Chirac, Florença a Thatcher...” ou pelo menos alugar tudo por 99 anos. O tom das disputas para obter recursos e instituir uma nova atençáo para os bens culturais tornou-se um problema político, o acanhamento dos partidos demonstrando o interesse da naçáo, cujos balanços destinados à conservação e valorização da memória não chegam à altura do indispensável.

A leitura dos protestos peninsulares nos leva, por analogia, a dedicar algumas linhas ao que se refere ao Brasil, tendo especialmente presente que estamos as vésperas da Constituinte, a qual, sem dúvida, irá considerar o futuro da Cultura, implícita uma atenção aos museus e aos vários estabelecimentos concentradores e incentivadores da realidade do pensamento e das artes.

Também no Brasil, os centros culturais que se propóem a ativar a cultura, em particular no setor das artes, não são ligados a órgãos governamentais, mas instituiçóes privadas ou fundaçóes.

Lembro-me que quando Assis Chateaubriand criou o Museu de Arte de São Paulo, buscando sim meios governamentais, determinou a constituição de uma "sociedade civil sem fins lucrativos." O resultado é sabido: hoje o Masp é considerado o mais importante museu de arte ocidental da América Latina, ao passo que outros persistentes organismos do ramo acabaram quase vegetando.

Agora, em vista da Constituinte, este paginista auspicia um interesse amplo, até mesmo através de um debate público, como o que se está desenvolvendo na Itália pelo Ministério dos Bens Culturais. A Cultura é uma matéria de absoluta urgência, e particularmente a realidade museológica deve ser estudada a fundo pelos legisladores.

Precisamos de leis para pôr às claras uma quantidade significativa de casos, partindo de uma realidade que um polemista italiano define de profissionalismo galileano, invocando seriedade, competência, firmeza de convicçóes e trabalho.

\section{Legenda}

O Museu do Ipiranga, o mais antigo de Sáo Paulo projetado por Tomasso Bezi: ecletismo e relíquias históricas 
Senhor \#309, I7 de fevereiro de 1987, p.68 (P.M. Bardi)

FLASHES DO FUTURO

Entre o excesso de novidades, algumas obras são exemplos

do avanço das artes em múltiplas direçóes

Quando os renovadores da arquitetura reagiram ao culto do pseudo-estilo chamado "ecletismo" em que o construir utilizava modos do passado, a proposta foi radical resumindo-se em desnudar as paredes de qualquer lembrança antiga, reduzindo tudo ao mais simples possível. Tratou-se de um acontecimento formidável, do qual todos se beneficiaram.

E surgiram as primeiras construçôes "peladas" e quem mais as desnudava mais aplausos obtinha como pioneiro. Inútil repetir a história recente e dar mais crédito à tríade Wright-Gropius-Le Corbusier, pois todos conhecem os fatos e também sabem que, a uma certa hora, se distinguiram os protagonistas do "funcionalismo-a-todo-transe," com os ortodoxos cedendo às pressôes dos comitentes que não gostavam da ironizada "arquitetura hospitalar." O que se via nas praças, não somente do Brasil, mas do mundo inteiro, se sabe. Hoje se diz que certos prédios de Brasília podem ser indicados como irracionais e até não funcionais.

Isto é o que se passou. Agora estamos vivendo uma época de um novo ecletismo: as propostas e até as esquisitices poluem cidades grandes e pequenas. É a volta a um modo em que o teorema de Pitágoras não funciona mais, sendo tudo confiado a um computador liberado para os resultados que quiser. Vale? Não vale?

Se o tempo produz estes "ecletismos" é porque assim deve ser. Seria insensato aliás, impossível reagir mesmo porque o nosso tempo é de uma tal avalanche de encantadoras novidades, de individualismos, de procura do especializado e de interessados em incrementá-lo que náo há limites. Teve críticos que se escandalizaram quando o Masp apresentou uma exposiçáo sobre o kitsch, id est, do mau gosto, outra partilha do ecletismo, pois esta maneira de arte inclui produçóes dúbias se julgada por aqueles mestres que se colocam numa cátedra e assinam decretos de comportamento. Refiro-me sempre às "artes mecânicas," isto, arquitetura-pintura-escultura, um conjunto de atividades que, na atualidade, cede a popularidade a outras artes como a música, cinema, esporte e tudo o mais que se vê festejado nas páginas de nossos jornais.

É no recinto da arquitetura que está circulando um conceito projetual bon-à-tout-faire, assunto mais para periódicos de classe do que de cotidianos. Quem segue nossas revistas de arquitetura vê o contínuo surgir de novas formas, permitindo prever um futuro estético marcado por trouvailles em que não faltará a monumentalidade. Em São Paulo já podemos ver antecipaçóes, como se observa na revista Projeto. Para citar um caso, a transformação da antiga fábrica da Pompeia num Centro Cultural pela arquitetura Lina Bo a qual, dos modos racionalistas do Masp, na avenida Paulista, parece interessada no futuro da construção.

\section{Legenda}

Aspectos do Centro Cultural da

Fábrica da Pompeia, do Sesc, verdadeira celebração da arquitetura gerada do racionalismo mais ortodoxo

Senhor \#310, 24 de fevereiro de 1987, p.67 (P.M. Bardi)

EVOCAÇÓES DE UM MONUMENTO

Um conjunto bancário recentemente inaugurado sintetiza a comunhão

da arquitetura com técnicas urbanas sofisticadas

Foi inaugurado, no bairro de

Conceição, um conjunto bancário de três blocos de escritórios que se insere na grande São Paulo como a maior obra particular construída: mais de cem mil metros quadrados de área.

É uma arquitetura a ser considerada não somente no específico da aparência exterior mas também no urbanismo do desenvolvimento metropolitano. Recruta ampla participação de técnicos para a multiplicidade de suas atribuiçóes, sendo evidente a demonstração de que a arquitetura, hoje, depende sempre mais da tecnologia, resultado de um complexo de novidades, por sua vez recorrendo a outras 
novidades pois o século é de uma inventiva e de mudanças contínuas. A esplêndida publicação Centro Empresarial Itaú Conceição, aos cuidados de Ricardo Ohtake, documenta a construção colocando em cena, numa incomum grandiosidade, a Arquitetura: uma arte que eu próprio historiei, como divulgador da reação do mestre polêmico a cujo lado estive e ao qual dediquei meu livro Lembrança de Le Corbusier: Atenas, Itália, Brasil.

Numa certa época eram as fortalezas, agora são os empreendimentos que satisfazem nosso operar, esperança de concórdia e entendimento entre os povos. Valem o espírito e as conquistas em favor da paz?

Sou viciado no evocar a sapiência dos antigos. A propósito me vem esta sentença: "Devem-se unir fábrica e razão: seja sua função a representação.” É do profeta do Funcionalismo, Carlo Lodoli, o teórico que no auge, aliás, no exagero decorativo do Barroco e do Rococó, preconizou o Racionalismo: construçóes originadas da função, a estética como consequência.

O que logo chama atenção, após a primeira vista do Itauplan é a escolha de sua localização, favorecida por metrô, terminal rodoviário e aeroporto em suas proximidades. Foram previstos os problemas inerentes para dar vida ao trabalho de dez mil funcionários, o que implica providências logísticas para uma série de soluçóes e combinaçôes que facilite toda a complexidade das atribuiçóes. Os responsáveis pela ordem administrativa contribuíram perfeitamente, como de resto os técnicos que trabalharam na realização da obra, projetada pelos arquitetos, do Grupo Itaú: [João Eduardo] de Gennaro, [Jaiver] Judas y Manubens e [Jaime] Marcondes Cupertino.

Além disso, na elaboração do projeto interviram grupos de colaboradores de diversas areas que incluíram sugestóes e indicações, entre os quais Wesley Duke Lee e este redator. Sabe-se que a arquitetura vai-se afirmando na simplicidade das formas, exigindo porém, como de resto sempre aconteceu, as complementaçóes das outras

“artes mecânicas" como pintura, escultura e, acrescentaria, a ecologia, com o paisagismo que esteve a cargo de M.L.O. Martins e $S$. Darwiche que se utilizaram de espelhos e jatos d'água. Assim, o Centro se apresenta agora com a estética própria destes tempos onde se integram obras de Bruno Giorgi, Caciporé Torres, Carlos Fajardo, Franz Weissmann, Takashi Fukushima e Sérgio Camargo, em proporçóes calculadas, consequência de harmonia dos espaços.

Assim escreve Olavo Setúbal no prefácio: "O Itaú está orgulhoso de ter oferecido à comunidade de São Paulo e a seus funcionários uma obra do porte do Ceic... ao mesmo tempo que deseja constituir a busca determinada do crescimento... com objetivos bem definidos, a melhor resposta ás épocas de crise."

\section{Legenda}

Detalhe do Centro Empresarial Itaú

Conceição: exemplo de grandiosidade

\section{Casa Vogue \#2, março-abril de 1987, p.56 (P.M. Bardi)}

\section{As cadeiras}

Como descrever os modelos de cadeiras que, ao longo dos tempos, foram objeto de uso? O máximo que pode acontecer é lembrarmos certos casos em que o móvel foi considerado esquisito ou de um certo interesse, sem contar naturalmente o design do mobiliário da própria habitação.

Se para os leigos é assim, imagine-se o que não ocorre com designers, fabricantes, historiadores, citando alguns profissionais, de maneira especial nestes últimos tempos em que o mobiliário apresenta constantes mudanças estéticas e práticas.
Eu mesmo, mais ou menos chegado ao campo em pauta, me lembro de ter gostado ou criticado vários assentos produzidos por arquitetos contemporâneos: fatos rotineiros, sem contar que, às vezes, ainda faço confusão, lembrando-me de um modelo como o de Mackintosh e alguns imitadores de seu encosto para gigantes.

Casado com uma arquiteta, o problema das cadeiras lá em casa é da ordem do dia, pois ela gosta de desenhar estes móveis. Aliás, o primeiro ideado foi a cadeira para o auditório da primeira sede do Masp, na rua 7 de Abril, em 46, quando precisamos resolver um problema básico: o ambiente, 
devido ao espaço restrito do museu, servia não só para conferências, mas também para outras atividades. Era necessário termos uma cadeira dobrável. Não foi possível encontrá-la no comércio local e, então, Lina a desenhou. Não havendo quem a fabricasse, a confecção foi confiada a um marceneiro italiano recém-chegado a São Paulo, que se desincumbiu muito bem do feito. Vejam na ilustração o resultado.

Lembro esta cadeira, da qual restam alguns exemplares e que há algum tempo está sendo produzida novamente por uma empresa paulista, pois esta nota focaliza uma outra dobrável de Lina, aqui apresentada pela primeira vez.

$\mathrm{Na}$ minha casa o mobiliário abrange várias épocas e, pelo gosto de colecionar, temos curiosos modelos. Um deles é uma cadeira dobrável italiana, do século I6, provavelmente vinda de um convento de franciscanos, exemplar antecipa dor do funcionalismo mais rigoroso: leve, resistente, agradabilíssima.

Foi esta peça que sugeriu à arquiteta realizar uma semelhante, batizada Frei Egidio, em homenagem a um frei franciscano de Uberlândia (MG). Realizada em 87 para o Teatro Gregório de Mattos, de Salvador (BA), a nova dobrável contou também com a colaboração dos arquitetos Marcelo Ferraz e André Vainer, tendo sido executada no laboratório do arquiteto Marcelo Suzuki.

De uma ideia nasce outra: sempre cogitei mostrar no Museu de Arte de São Paulo uma História da Cadeira, considerando que, sem dúvida, este é o móvel que provocou o mais excepcional dilúvio de modelos. Poderia ser comparada nos tempos contemporâneos, à produçáo dos desenhistas de rodas de automóvel, numa variedade de propostas das mais excêntricas já vistas, levando a pensar nas rodas do carro de boi, depois substituídas pelos eixos e seus componentes. Penso numa exposição que para começar, deveria mostrar um primitivo assento de pedra e, em contrapeso, um de nave espacial: seria uma interessante manifestação, riquíssimas antigas novidades.

Têm sido várias as exposiçóes dedicadas ao assunto, todavia há sempre um modo de apresentar alguma novidade, pois o assunto é praticamente inesgotável. $\mathrm{O}$ pessoal, antigo e contemporâneo, se utiliza da cadeira e da poltrona movimentando as produçóes e, por outro lado, a concorrência dos fabricantes de móveis é constante. Parece que a maneira de apresentar os últimos gritos também é infindável, com o caprichar presente, aliás dono do serviço.

Este, como qualquer outro depende do andamento da moda. Neste setor que estamos abordando, a cadeira mais discutida apareceu na Itália, entre as duas guerras, quando foi lançado o assento portátil com medidas e peso convenientes para ser transportado numa bolsa a tiracolo, ocasionando charges humorísticas as mais curiosas. Numa delas se indicava até a possibilidade de se sentar sem nenhum assento por meio de sistemas eletrônicos.

\section{Legenda}

Cadeira dobrável feita em 1946 para o antigo auditório do Masp 9 A nova cadeira dobrável também desenhado por Lina BoBardi, em 1997, para o Teatro Gregório de Mattos, em Salvador

Senhor \#3II, 3 de março de I987, p.68 (P.M. Bardi)

UM MODESTO CRAQUE

A medalha de ouro da Itália, por benemerêncta cultural: uma vitória da obstinação e do trabalho

Talvez alguns dos leitores desta página tenham visto nos jornais que o Ministério da Educação da Itália me honrou, em ata assinada pelo presidente da República, com a medalha de ouro por benemerência cultural.

Se penso que entre os últimos condecorados estavam Renato Gutuso e Alberto Moravia, minha surpresa pode ser compreendida em comum com a satisfação. Emigrei para o Brasil há 40 anos. Pode ser que a decisão tenha levado em conta o quanto consegui realizar no preparo, ideação e desenvolvimento da ação do Museu de Arte de São Paulo, pode ser também consequência do meu insistir no intercâmbio cultural entre nós e a Itália. 
Neste momento lá circula, com extraordinário sucesso, a exposição de nossa coleção de bronzes de Degas, já apresentada no Palazzo Strozzi de Florença, no Forti de Verona, no Campidoglio de Roma e agora no Museu de Capodimonte de Nápoles: o Brasil mostrando os 73 bronzes do Mestre que era ligado familiarmente a ascendentes napolitanos.

Doutro lado, já em 54 eu abri no Palazzo Reale de Miláo a mostra de nossas Cem Obras Primas. Era um dos últimos pontos da tournée que, de Paris, se concluiu no Metropolitan Museum de Nova York. Aliás, não eram mais Cem Obras mas havia uma a mais, a Ressurreição de Rafael que entrementes eu adquirira em Nova York. Foi para mim uma espécie de, como dizem os italianos, o va o spacca, ${ }^{93}$ pois a descoberta daquele inédito, a minha atribuição ao grande Mestre, contrariando a opiniấo de Bernard Berenson, causou não simples reação da crítica europeia. Foi proposital minha tentativa de obter o abraço do mestre dos mestres da história da Renascença, Roberto Longhi, o qual publicou logo em seu 'Paragone' o ensaio consagrador da minha façanha. A repercussão foi tão famosa que a própria Veja há poucas semanas, discorrendo sobre o Autoretrato da Barba Nascente de Rembrandt, por ocasiáo de urna nova atribuição, para mim grotesca, (assinatura do Mestre, porém pintura de um dos alunos, pois ele assinava também obras deles...) a Veja lembrou que o Bardi tem, em seu ativo, a atribuição reconhecida daquele Rafael.

Estou divagando, porém pode ser que casos como este tenham contribuído para receber esta distinção? Em minha idade, não mais juvenil, a soma de fatos é naturalmente pesada, se náo de particulares

93 "Ou vai ou racha” (tradução nossa) vitórias, pelo menos no conjunto. Estava para escrever: quantidade. Prêmios como este que recebo obrigam a rever o currículo: é longo considerando o que foi feito na Itália e no Brasil, quase meio a meio.

Mas quero confessar que realizei com prazer nesta minha nova Nação velhos sonhos entrevistos na antiga pátria: aqui as ocasióes, a facilidade de atingir os propósitos, esta onda de cordialidade com polêmicas e até batalhas possibilitam propósitos e convicçóes. Digo isto por Lina, a arquiteta com quem sou casado. Afinal, os dois construímos, do nada, um museu, bem ou mal, fazendo-o reconhecido no Exterior ativando intercâmbios como disse, com a Itália, França, Inglaterra, Estados Unidos e Japão, já é algo. E este ano será com a China.

É fácil para um felizardo perder o rumo da conversa, mas queria dar algumas notícias novas ao leitor: virá da China um fabuloso acervo; de Nova York os modelos, construídos pela IBM, das máquinas desenhadas por Leonardo da Vinci; de Brasília o cinquentenário da sPhan; da grande São Paulo a celebração da Abril Editorial; de Paris, dois centenários: Le Corbusier e Marc Chagall; e outras manifestaçóes, todas no Masp.

Que tem isto a ver com a medalha de ouro? Afinal, em nossa época, como de resto nas anteriores, pois sempre foi assim, saber de premiaçóes interessa tanto aos que as recebem quanto aos da plateia. Me parece neste momento ser um modesto craque de futebol, o qual conta os episódios do último match. Os leitores então que desculpem a arenga, em italiano papardella.

\section{Legenda}

O reconhecimento pelo paciente esforço de aproximação entre os dois países

Senhor \#3I2, Io de março de I987, p.68 (P.M. Bardi)

A veZ Do FIGURATIVO

Com a mostra do pintor Franco Cilia, o Masp abriu mais um espaço na discussão que envolve o complexo panorama da pintura neste final de século

Eis uma mostra de pintura que sugeriu várias consideraçóes, geralmente apelidadas de crítica. Seguindo o hábito de não me promover a indicador da arte, mas somente seu divulgador, - e, por sinal, agradecendo à Associação Paulista de Críticos de Arte que outorgou ao Masp a distinção de ter realizado a mais interessante exposição do ano passado, "Contrastes da Forma," vinda do Museu de Arte Moderna de Nova York, 
e a do melhor pintor, o mato-grossense Adir Sodré - como dizia, nesta simples veste de divulgador cultural, encaro a manifestação que nos proporcionou o Instituto Italiano de Cultura, apresentando o artista Franco Cilia, como ocasião para mais uma anotação sobre o complexo panorama da pintura neste final de século.

A moda que corre desenfreada, sem obstáculos, as polêmicas silenciadas no começo, o favor prepotente dos patrocinadores empolgados em apontar seus favoritos, os galeristas atrás dos vencedores das corridas, esta moda é para oudiders que, esquecidos de qualquer modo figurativo, produzem geometrismos e abstracionismos às vezes conjugados com elementos curiosos - novidades que talvez maravilhavam no kitsch da "Trama do Gosto," custoso prefácio da iminente bienal, a performance internacional local que depende das diretrizes estéticas do Exterior.

Um visitante do Masp me perguntou, quase agressivamente: como vocês apresentam "Contrats of Form," a estupenda resenha modernista, e agora um acadêmico? A confusão causada pela adjetivação está na ordem do dia. Cilia é figurativo. Os canônicos do geométrico-abstrato são sectários, convencidos em incluir Klee e Mondrian nas categorias que tradicionalmente reverenciam Rafael e Michelangelo.

Assim, em cada encontro se procura historiar, admitindo a personalidade dos vanguardistas da reação e, no caso, justificando um pintor que, com capacidade expressiva, encontrou na grandiosa obram de Goya sua fonte de inspiração. Cilia pertence à resistente escola dos figurativos: independentes e solitários que querem comunicar para serem entendidos. Esta exposição envolveu momentos da vida, fatos de crônicas onde medo, sentimentos, repulsa, propósitos se interligam na tragicidade própria com que Goya se manifestou na mais viva fase de sua pintura, bastante dedicada a retrar a corte e a burguesia. Basta ver-se, no Masp, os quatro retratos sendo que o de Don Juan Antonio Llorente foi-nos agora solicitado em empréstimo para figurar numa grande mostra que o Museu do Prado, de Madri, está organizando.

Pela longa convivência com quem se interessa por pintura, sei que são louvados os artistas que fogem do real ou enxergam seu lado trágico, abandonando o distrair concentrando atenção no despreocupado, até mesmo no impossível de ser reconstruído naqueles signos e alusóes, mistérios do compor modístico.

Estou convicto de que, no labor da criatividade, todas as tendências têm direito à apreciação. O diretor do Instituto Italiano de Cultura, professor Angelo Manenti, neste ano, nos proporcionará a mostra de três pintores de tendência inovadora: Tadini, Pozzati e Rossello. Também eles são apreciados na Itália, como de resto Cilia, confirmando que lá, como em todos os países, a pintura divide os julgamentos. Outra exposição que devemos receber será a do "Novecento Italiano" apresentando De Chirico, Carrà, Soffici, Marussig e outros mestres que inverteram o juízo a respeito das artes plásticas, até os anos 30, tempos empelegados de academismo.

Sobre o "Novecento" poderei contar episódios inéditos, pois os vivenciei e que, talvez, sejam de interesse para os leitores.

Legenda

Pintura de Cilia: o desejo de comunicar para ser entendido

Senhor \#3I3, I7 de março de I987, p.65 (P.M. Bardi)

MEMÓRIAS DA REVOLUÇÁO

Um livro sobre o Impressionismo procura levantar as dificuldades iniciais do movimento

As revoluçóes, isto é, tentar virar de cabeça para baixo a normalidade aceita, no setor da pintura de cavalete, ao longo da história, foram numerosas, a ponto de se contar no computador, aproximadas a um infinito ao qual, depois de um século, os acréscimos são incalculáveis pois o modismo traz novidades, uma após a outra, como de resto acontece na Escultura e, um pouco menos, na Arquitetura.

De qualquer jeito, o singular da Arte é este contínuo renovar. A pintura mais antiga de que se tem notícia é a da gruta de Altamira. Desde então são milênios de operosidade, milênios de propostas e conquistas; é reservada ao século $\mathrm{xx} \mathrm{a}$ 
palma, pelo mais intenso agito, sendo o senhor Marinetti um dos príncipes. A ele, no ano passado, dedicaram uma colossal exposição no Palazzo Grassi, em Veneza. Não a intitularam "Futurismo," mas especificaram "Futurismos."

O relevo serve justamente para informar que as tendências continuam a diversificar sendo admitidas quaisquer novidades, aliás revoluçóes. A mais notável na Pintura dita moderna permanece a do Impressionismo: reproduzir sim a realidade, porém por impressão, sem os detalhes que os veristas se esforçavam por particularizar, modo que depois se relegou à máquina fotográfica, com suas lentes adicionais capazes de fixar um pelo num ovo.

O preâmbulo serve para dar conta de um volume inglês intitulado The Impressionist Revolution, editado por Bruce Bernard. Considera que os revoltosos foram somente sete possíveis conjurados. O livro anuncia que as reproduçôes que apresenta "estão entre as mais apreciadas obras de arte já criadas porém algumas talvez tenham sido tomadas por certo e a forte história de suas gênesis tem sido meio esquecida.”

A escolha dos mestres é a genérica dos manuais, os consagrados que agora recebem sua ovação, mas que sofreram a hostilidade dos inimigos $\mathrm{n}^{\circ} \mathrm{I}$ : os enfurecidos acadêmicos envolvidos em exercer a profissão observando escrupulosamente as regras das beaux-arts cortejadas pelas comunidades.

Para lembrar um caso de preferência, eis o seguinte: num país como a Itália, a ser apontado como o reinado da Pintura, o Impressionismo náo produziu absolutamente nada: foi totalmente ignorado, aliás considerado desvio ao qual não deram o mínimo peso, e tanto é verdade que ainda nos anos 30, na Península, a circulação daquelas telas estava na estaca zero. Nacionalismo? Não, mas ignorância, um pouco como ocorre, por exemplo, aqui em São Paulo onde se pensa, náo sei se seriamente ou visando a propósitos de tapeação, que uma composição (notável, tão notável que eu mesmo fui seu primeiro apreciador, isto é, quem a adquiriu da autora quando na praça ninguém mais a queira, nem a preço de banana) vale não Cz\$ 3 milhôes, mas US\$ 3 milhôes! ${ }^{94}$

Seja como for, quando o senhor Assis Chateaubriand confiou-me a formação do acervo do Museu de Arte de São Paulo, além das antigas escolas europeias, tive a ideia de reunir a soberba série dos Impressionistas. Entre eles estão os mestres revelados na publicação em pauta. Pela ordem que o autor lhes dá: Monet, “o essencial;" Manet, "o respeitável rebelde;" Renoir, "o princípio do prazer"; Degas, "o que se dirigiu ao presente;" Sisley, “a força branda;" Pissarro, "o da honesta visão;" Cézanne, "insistindo nas estruturas."

Bruce Bernard, como conclusão da resenha, compôs um catálogo das 135 principais pinturas. E dá prazer a um diretor de museu constatar que o Masp é possuidor de várias das telas citadas, de Manet, Cézanne e Renoir, pinturas impressionistas que estáo ao lado dos nossos Van Gogh, Gauguin, Courbet, Toulouse-Lautrec etc., geralmente incluídos no panorama dos Impressionistas. A propósito: o Masp está para enviar à Itália, quando voltarem as nossas 73 esculturas de Degas, uma mostra de Impressionistas, além de uma de cinquenta obras antigas. Brasil docet.

\section{Legenda}

$O$ artista, de Manet, e O negro Scipião, de Cézanne: o Masp na antologia

94 Em março de 1987 , a cotação era de vinte cruzados por um dólar, de modo que Us\$ 3 milhóes seriam Cz\$ 60 milhóes.

Senhor \#3I4, 24 de março de I987, p.68 (P.M. Bardi)

A DESCOBERTA DO PASSADO

Uma exposição para comemorar o cinquentenário da Secretaria do Patrimônio

Histórico e Artístico Nacional, marco da recuperação da memória brasileira

Celebra-se, este ano, o cinquentenário da sphan, Secretaria do Patrimônio Histórico e Artístico Nacional, a entidade que magistralmente trabalha na conservação da memória brasileira com leis, intervençóes para a conservação e inúmeras iniciativas para ampliar o respeito ao nosso passado, instituindo museus e 
tudo o mais que contribui para a defesa e valorizaçáo de nossos monumentos.

Para comemorar este evento, o Museu de Arte de Sáo Paulo organizou uma grande exposição, inaugurada no último dia I2 pelo ministro da Cultura, Celso Furtado. A mostra é dedicada à memória de Rodrigo Mello Franco de Andrade, o mineiro que, junto com nosso Mário de Andrade, fundou a SPHAN, em I937.

Quem redige nasceu na Itália, um país que desde o Renascimento se interessou pela Memória, tornando-se o Antigo, fundamental no impulso às Artes. $\mathrm{O}$ que me faz lembrar que, atraído a Roma, ainda repleta de tudo quanto o império havia deixado, Rafael foi um dos mais ativos elementos no promover o respeito, a conservação, o restauro e a glorificação do passado. Desde o Quinhentos então a Memória mereceu atenção particular, e ainda hoje as Superintendências dos Bens Culturais desenvolvem rigorosa ação, semelhante ao que faz aqui a SPHAN, e algumas entidades de caráter estadual, como o Condephaat em São Paulo.

A exposição que o ministro inaugurou no dia I2 reúne uma série de objetos emprestados por museus e colecionadores, como os beneméritos João Marino e José Mindlin, os quais, cedendo importantes peças de suas ricas coleções, ajudaram a reforçar o objetivo do Masp de evidenciar a importância da história. Despertam curiosidade e admiração as bonitas peças em prata de lei e imagens religiosas dispostas na exposição e causa emoção a leitura de vários documentos originais do início da tipografia brasileira, e mais, alguns escritos de próprio punho, pelos inconfidentes Tomás Antonio Gonzaga e Marília de Dirceu.

Uma das seçôes é dedicada à conservação e preservaçáo das peças, sendo destaque um painel do altar do Convento dos Beneditinos, de Olinda, recuperado no laboratório do Masp, o qual há alguns anos foi responsável pela restauração da imagem de Nossa Senhora Aparecida que um alienado reduzira a pedaços.

Grandes painéis explicam outros trabalhos de recuperação de monumentos arquitetônicos levados a termo, ou em execução, pela arquiteta Lina Bo Bardi e sua equipe, no Solar do Unhão e no centro histórico de Salvador, Bahia, na Fábrica da Pompeia, no teatro Politeama de Jundiaí e no bondinho do Pão de Açúcar, no Rio.

Passando do objeto de arte em si aos monumentos, as atribuiçóes da conservação constituem um labor decisivo. As antigas arquiteturas: igrejas, fortalezas, prédios públicos, são o cartão de visitas do passado. Basta lembrar os conjuntos mineiros, baianos, pernambucanos, para refletir sobre a importância do nosso Antigo.

Mas o que é interessante, se alguém que há quarenta anos acompanha o desenvolvimento do gosto paulista pode opinar, é a crescente consideração provocada pelos objetos do passado, o surgimento constante de novos antiquários, a atividade dos colecionadores, a feira do belvedere do Masp aos domingos, as colunas que a imprensa dedica à descriçáo e edifícios do passado próximo ou antigo propriamente dito. E agora mais um fato: a discussão animada que a decisão municipal de criar garagens debaixo das praças provocou. A população está descobrindo a ecologia, como se observou no ano passado ao se manifestar sobre a possível mutilação de antigos bairros centrais.

Todos estes sintomas mostram que a Memória está recebendo atenção e superando critérios contemplativos comuns no Oitocentos, mais dependentes da realidade da renovação edil. No Oitocentos? E no Novecentos não se destruiu a avenida mais "histórica" de São Paulo, a Paulista? Seja louvada então a atitude de José Papa Júnior que, presidente do Sesc, transformou a abandonada fábrica de tambores da Pompeia num centro cultural e esportivo.

A exposição dos 50 anos da SPHAN é um remember: colocar na ordem do dia a prioridade de popularizar a Memória para sempre mais tornar-se este um fato nacional: a história sempre presente pois, afinal, nós somos resultado do que nos precedeu.

\section{Legenda}

Mário [de Andrade] e Rodrigo Mello

Franco de andrade, fundadores do SPHAN 
Senhor \#315, 3I de março de 1987, p.68 (P.M. Bardi)

O PICASSO DA ARQUiteTURA

Memórias de Le Corbusier e a sua obra cheia de contradiçôes

Nas páginas da seção The Economist, sempre instrutivas também para leigos em economia, em recente edição de Senhor, descubro um artigo dedicado a Le Corbusier: muito sensato, quase um instantâneo desta personagem que Pevsner, justamente, comparou com a de Picasso, manipuladores de ideias, fabricadores de imagens seja de concreto como de pincel, polêmicos de nascimento, batalhadores em não importa qual continente, persuasivos e discutidos, elevados aos céus, ou lançados ao fervor do inferno.

Repito: o retratinho é a síntese do responsável pela revolução da arquitetura deste século, juntamente com Wright, Gropius, Mies van der Rohe, para citar alguns dos mestres que desnudaram as fachadas das decoraçóes recolhidas nos álbuns dos estilos do passado.

The Economist lembra um dos pontos de partida das teorias inovadoras, apelidadas racionalismo ou funcionalismo, hoje prática dominante do Novencentos: $\mathrm{o}$ Congresso de Atenas. Lá se redigiu o manifesto propondo que "as cidades deveriam ser rigidamente divididas em zonas, - industrial, residencial, comercial e de recreaçáo - com cinturóes verdes em cada zona.” Mas Brasília náo deu certo.

Este paginista, em 32, estava presente naquela reunião, tornando-se bom amigo de Le Corbusier, ao qual dedicou o livro Lembrança de Le Corbusier, Atenas, Itália, Brasil, Editora Nobel.

Estou preparando, para o centenário do suíço considerado não sei porque francês, uma exposição, oferecendo aos interessados em história da arquitetura curiosas parcelas da vida artística de nosso Brasil. Le Corbusier passou pela Terra em 29, mas volta em 36 para fazer algumas conferências, e é então que os jovens futuros construtores do edifício do Ministério da Educação e Saúde conseguem valer-se, ma non troppo, do "risco" do então popular renovador, convencendo o ministro Gustavo Capanema a cancelar o resultado do concurso para a obra, ganho pelo arquiteto Arquimedes Memória em estilo nada menos que "marajoara."

Então Lucio Costa, Niemeyer etc. foram encarregados de resolver a ereçáo do prédio, inaugurador do início do cancelamento, quase total, do ecletismo no Brasil. O ecletismo, ou culturalismo, que tinha sua demonstração mais famosa na fileira, aliás duas, de palacetes dos donos da produção ao café na avenida Paulista, repertório de gótico, renascimento, rococó e pastiche, definindo o momento do gosto local, comparado por Levi-Strauss a uma rua da estação de águas europeia.

Diga-se entre linhas que os autênticos inovadores aqui foram Gregori Warchavchik e Flávio de Carvalho, naturalmente Le Corbusier inspirador, tudo dependeu da série de conferências do Picasso da Arquitetura, no Rio. Estranho, porém certo: os grandes desenhos de paredes que ilustravam a palavra inflamada do convidado, pela primeira vez publicados no meu livro, acompanhando os textos das conversas, são de minha propriedade, pois os adquiri de Le Corbusier. Depois da anunciada comemoração do centenário do Amigo, os doarei à Secretaria do Patrimônio Histórico e Artístico Nacional/Fundação Pró-Memória.

Mas há mais notícias: o Masp, onde celebraremos a data, foi informado que a Fundação Le Corbusier conseguiu reunir todas as documentaçóes referentes ao Brasil e, com toda possibilidade, reconstituiremos na projetada exposição tudo que se passou entre nós e o Mestre. Espero que se tenha encontrado um projeto para uma fazenda que Geremia Lunardelli deveria implantar no Sul. Se juntará, na mostra, outra lembrança: duas aquarelas, pois em consequência da insistência do Amigo, o Masp, em 1950, apresentou Corbú pintor, sendo oportuna a recordação em The Economist da "pipa funcional," caricaturada por Magritte: Ceci n'est pas une pipe. Le Corbusier era pintor ao seu modo: reprodutor de impressóes, desmanchador de realidades, pintava o que lhe passava pela cabeça, como de resto despachava arquiteturas, as mais contraditórias, antes caracterizadas pela 
função, depois quase pós-modernas, como a Capela de Ronchamp.

\section{Legenda}

Uma aquarela do mestre, o que

desmanchava a realidade

Senhor \#316, 7 de abril de 1987, p.67 (P.M. Bardi)

Chega DE ROTINA

Romper com o pesadelo da mesmice resgata o papel da arte e reinventa a emoção de estar vivo

Às vezes aproveito esta página para falar de iniciativas no setor artístico das quais sou promotor. Obter um espaço adequado em cotidianos não é algo que ocorra todos os dias. Não se culpa imprensa, pois o coleguismo ainda permanece firme, e, por outro lado, sabe-se que neste momento as atençóes estão mais dirigidas aos problemas políticos, sem se falar nos econômicos.

Gostaria agora de tratar de uma exposição singular entre as inúmeras realizadas nesta metrópole: não de pintura de cavalete, a qual se tornou atualmente o cavalo de corrida de milhares de novatos, descobridores de tal quantidade de rabiscos para centenas e centenas de também novatos comerciantes venderem. Realizou-se no Masp uma mostra sui generis: uma daquelas que, me permito dizer, representam um modo diferente, uma ruptura da costumeira rotina, pelo tema e pela própria montagem. Vem colaborar para o avanço dos interesses culturais, sempre mais vivos no Brasil, como a música popular, cinema e teatro, ficando na chefia das preferências as novelas e a "Mônica." As artes plásticas, pintura e escultura, ainda não obtêm muitos favores. Este show tinha parentesco com estas reunindo dois setores que estava, no passado, no auge: a tapeçaria e a moda. Perdão: a moda, como sempre, ainda causa furor.

Recentemente publiquei em Casa Vogue uma matéria sobre um livro dedicado a tapetes antigos, ilustrando-a com uma peça de Regina Graz, ${ }^{95}$ devendo esta artista e seu marido, John Graz, ser considerados pioneiros neste campo nos dias em que, depois da Semana de 22, se tentava, nas ondas da Secessão, acabar com o desinteresse do público pelos problemas ligados às artes.

95 P.M. Bardi, "A propósito dos tapetes...” em Casa Vogue \#, janeiro-fevereiro de 1987, p.64. Cf. p.547.
Os tempos mudaram. Contamos hoje, nas artes ditas aplicadas, com dominadores no artificiar, elementos cuja fama já percorre o estrangeiro, caso que se dá com o mestre da tapeçaria Norberto Nicola, renovador, aliás, revolucionador de modos no seu trabalho. Participa das tendências que animaram a novidade, eclipsando na arqueologia os panos figurados. Nesta exposiçáo Nicola se associou a Ugo Castellana, um mestre costureiro cujas intençôes de vestir mulheres aproximam-se aos modos nicolianos. Um traz às superfícies cores vibrantes, nós, cordôes, anéis; Ugo persegue em seus trajes similar movimentação, despertando surpresa.

As duas maneiras de manejar os fios tendem ao espetacular: o não, aliás, o nunca visto. Alegram a união num anúncio de estética-página-virada. A montagem, uma arquitetura funcional, era ritmada pelo trio Vértice, interpretando variações de compositores clássicos; a iluminação equilibrava e definia a visão do que estava nas paredes e nos manequins. Cada detalhe despertava atenção para o inédito, talvez uma prerrogativa do Masp, que procura sair daquele pesadelo de paredes maçantes que está por aí, até mesmo nas Bienais, expondo pinturas como livros numa biblioteca, sem interrupçóes, destaques, surpresas.

Eis um motivo para propor o remanejamento da rotina: sugere-se interferir nas fileiras de obras. É também um convite para o arranjador de espaços consagrados ás artes mecânicas de se dar um soco na cabeça para atualizar, inventar novas formas.

É gostoso notar a relação entre tapeçaria e moda, a incidência entre as duas manifestações, até de requintados elementos, ao intercalar manequins entre as paredes onde se encontram os trabalhos de Nicola. Este espaço é ambiciosamente anunciador de sinais inovadores, a abertura de momentos de substanciais mudanças. Neste fim de século tudo está sendo refeito, talvez até 
de cabeça para baixo, tudo porém justificado, pois o reinado é o da novidade, até excêntrica, provocando perplexidade. Não são as polêmicas que tomam conta da vida?

\section{Legenda}

No Masp: traje de Ugo Castellana...

I...e tapeçaria de Norberto Nicola

Senhor \#317, I4 de abril de 1987, p.68 (P.M. Bardi)

O DELÍRIO DAS ARTES

Um fenômeno comercial? Mas há bons sinais por trás disso

Estamos vivendo um tempo, um momento mesmo, em que o praticar arte (produção, consumo, aproximaçáo, negócios e tutto quanto pertinente) evidencia sintomas de um interesse quase delirante. Pelo menos é o que nota o cronista desta página, por estar na incômoda direção do que os eternos invejosos chamam de Beubourg local. (Sejamos claros em dizer que o Masp não se casou com a "novidade" parisiense, uma ideia francamente provincial, tipo Bienal etc., criando ao invés de um Centre Pompidou, uma simples instituição de didática e de divulgação das artes.)

O extraordinário interesse registrado nestes últimos dois decênios verificou-se, além da música, especialmente na pintura de ou sem cavalete. Antigamente as academias tinham vagas limitadas, os amadores reclusos no recinto familiar, os salóes restritos; hoje as academias com ou sem mestres pululam,desenfornando adeptos a cada semana. Digo adeptos apenas para indicar os que cultivam na cabeça a ideia de manipular a arte. Nota-se uma inflação desmedida: participa das mudanças da vida deste fim de século, popularizadora do lazer, e criadora de interesses sociais que estão democratizando tarefas antes atribuídas às elites.

Muito natural que a crítica tenha tomado um certo impulso, como consequência das mesmas circunstâncias da produção. Temos os julgadores que se manifestam do alto dos tronos, arrepiados pela invasão pictórica, decretando nas colunas em que legislam lanças e bênçãos para alguns, e vade-retro para quantidades náo indiferentes de elementos de valor. Mas isso tudo faz parte do jogo: no xadrez os peóes são movimentados intencionalmente, tanto que é frequente a exaltação publicística de pessoal medíocre que pensa mais em marketing do que em arte.

Mas também isto faz parte do excepcional interesse do que se discute. normal que nas pregas deste interesse se desenvolva o tirar partido pecuniário, mais uma vez evidente que as contrataçôes da arte sejam praticadas, como de resto se dá no futebol, no automobilismo e quantos outros esportes.

Lógico que nenhum pintor será contratado por especuladores: campeões, só Pelé ou Sócrates.

Todavia, voltando à contínua afirmação da simpatia para com as artes é de notar o quanto esta arrancada contribui também para reconsideração da memória. Bastaria lembrar que em seguida a intervenção popular finalmente se salvou da demolição a primeira casa modernista construída em São Paulo, a de Warchavchik, em Vila Mariana, resolvendo um dos problemas a um só tempo de urbanismo, memória e de ecologia. Outro dado é a renovada atenção para com as coisas do passado: o leitor deve ter visitado aos domingos a Feira de Antiguidades no Belvedere do Masp, uma autêntica quermesse de gente à caça de objetos. Juntaria mais: o público juvenil e as escolas que a cada dia visitam as exposiçóes do Masp são uma gratificante demonstração do quanto a instituição representa na vida cultural da cidade e do País.

Para concluir, afirmo que o momento é altamente favorável à difusão cultural. Saibam ainda que quando inauguramos o Masp em 47 a situaçáo no campus dos exercícios artísticos era simplesmente deplorável: o cônsul dos Estados Unidos patrocinou uma exposição de jovens, reunindo apenas I9; inexistiam galerias comerciais; os remanescentes da Semana de 22 não estabeleciam mais nenhuma polêmica, e assim por diante. Mas, hoje, podemos dizer que a batalha foi vencida.

\section{Legenda}

Feira de Antiguidade no Masp: a memória nacional agradece a esta quermesse de compra e venda 
Senhor \#3I8, 2I de abril de 1987, p.68 (P.M. Bardi)

EVOCAÇÃo ROMÂNTICA

Ao falar dos velhos edifícios de São Paulo, os cronistas

mostram a arte no início da industrialização

A cada dia que observo na Folha de S.Paulo a seção dedicada aos velhos prédios de São Paulo, na maioria das vezes edifícios de habitação e que nem sempre podem ser considerados arquiteturas mas sim consequência da maneira que no Oitocentos e Novecentos classificamos "culturalismo" ou "ecletismo" dos estilos do passado, me convenço de que naquele tempo o gosto não era dos mais cultivados. Em geral, o cronista reproduz as fachadas e dá notícias da conservação e das eventuais alteraçóes no interior. É um evocar romântico, uma oportunidade para se fazer uma ideia de como andaram as coisas. Talvez sem querer, aquelas figurinhas nos tracem um panorama da realidade da arte no momento da arrancada industrial, a era da cafeicultura, que tinha seu bairro na avenida Paulista: as preocupaçóes estéticas cívicas não eram nem cogitadas, uma vez que a arquitetura, digamos, da Catedral da Sé, não brilha pelo seu aparente gótico, pescado aqui e ali nas ilustraçôes de álbuns, sendo suas vítimas os artífices encantados com o eco do revival do estilo medieval que tinha triunfado na Inglaterra, espalhando-se pela Europa e, como se vê, também pelas Américas.

Não se pretende desvalorizar um estilo que, todavia, numa carta atribuída a Rafael e dirigida a Leão X, já era assinalado negativamente: "Os edifícios dos tempos dos godos são tão falhos de qualquer graça, sem maneira nenhuma, dissímeis dos antigos e dos modernos." O gótico verdadeiro é esplêndido, nem os revivals e nem suas caricaturas são aceitáveis.

Doutro lado, para náo deixar os limites da São Paulo desinteressada pelos problemas arquitetônicos, e, se da religião passarmos à política, como julgar a híbrida arquitetura do Palácio do Governo, com aquela fachada pseudo-neoclássica coroada com um tímpano ornado com três estrelinhas? Já em ' 36 Le Corbusier havia sido chamado por Gustavo Capanema para projetar o Ministério da Educação e Saúde no Rio de Janeiro, além de as primeiras propostas do "racional" ou do "futurismo" terem sido aqui lançadas por Gregori Warchavchik e Flávio de Carvalho.

Se constata que a Capital não quis mesmo refletir sobre a monumentalidade. Uso uma palavra clássica que sempre teve valor. Ocorre-me uma opiniáo do setecentista J. de Lalande, no seu Voyage d'un fraçais en Italie: "A conservação dos monumentos não é um fato de preconceito, convencional e nem de interesse: a Filosofia e a Política devem nos induzir a conservar o que se deve a pessoas ilustres, como um germe para reproduzir-se em outros..."

Não parece que nem a Catedral e nem o Palácio ao Governo possam inspirar arquitetos, os quais agora estão mais empenhados em criar prédios de apartamentos, conjuntos bancários, universidades e, naturalmente, palacetes. Sáo estes os monumentos da contemporaneidade? As últimas arquiteturas que podem ser julgadas monumentos se concentram em Brasília. Os exemplares acima indicados podem ser vistos como ilustraçóes nas muitas páginas publicitárias dos nossos cotidianos, de vez em quando oferecendo legendas como esta: "Fachada que se destaca na paisagem da cidade... Requintada fachada de vidros espelhados, caixilhos e granito negro... Acabamento personalizado."

Em termos de monumentalidade, hoje deve-se pensar numa barragem, numa ponte, numa fábrica etc.

\section{Legenda}

Catedral da Sé: símbolo gótico

Senhor \#319, 28 de abril de 1987, p.68 (P.M. Bardi)

A DESORDEM TOLERADA

Os que querem rever o pós-moderno das vanguardas históricas criam confusóes na arte

Num interessante ensaio de crítica teórica intitulado Da Vanguarda ao Pós-Moderno, 
do professor Eduardo Subirats, ${ }^{96}$ leio uma indagação analítica do momento da produção e da atualidade da arte, reportando uma declaração de Charles Baudelaire, como sempre profética: "A modernidade é o transitório, o fugidio, o contingente, a metade da arte, da qual a outra metade é o eterno e o imutável."

Os assim denominados modernistas continuam-se manifestando em vanguardismos que, às vezes, ultrapassam os limites das possibilidades de compreensão, propondo amontoados de formas que, bem ou mal, aspiram a permanecer na outra "metade da arte," superando o ocasional, a gag, o extravagante. Os empenhados no revirar o pós-moderno das vanguardas históricas, apoiados até em utopias, não param, determinando as confusôes a que estamos assistindo. Não bem confusôes, mas caos: a desordem tolerada, aliás incentivada até pelas grandes exposições internacionais concorrendo entre si para mostrar o mais singular.

As produçóes nem podem ser encaradas como um maneirismo, pois falta o agente coordenador que as origina sendo mais uma variedade de trouvailles, o mexer numa infinidade de novidades características da época, inversóes até mesmo irônicas.

Aliás, tudo começou da reação, da ironia. Foi a apresentaçáo de um ferro de passar roupa com pregos soldados no plano, de Marcel Duchamp ou sua roda de bicicleta que só gira manualmente, fixada num suporte. Os ultras utilizam agora o computador para reconstruir a figura de um bicho, e não faltará alguém que fabricará um robô para pintar. Pode ser que na próxima Bienal de São Paulo seja apresentado este robô,

96 Subirats, Eduardo. Da vanguarda ao pós-moderno. Tradução de Luiz Carlos Daher, Adélia Bezerra de Meneses e Beatriz A. Cannabrava. 2a Ed. São Paulo: Nobel, 1986. naturalmente para justificar o momento que, sempre imitando o que se faz lá fora, se interessa pela novidade "arte e ciência."

Não existem normas, teorias, limites de expressão.

A distinção, a separação dos figurativos e dos informais nas diversas áreas do geométrico, do abstrato, do concreto, do pobre etc., já são um modo de julgar, sendo o figurativo considerado a outra metade do "eterno e imutável" de Baudelaire e as transvanguardas o "transitório e fugidio." Todavia, a diferenciação não é hoje de fácil averiguação, pois entram fatores sociais a serem considerados: recentemente a exposição "Contrastes da Forma," vinda do Museu de Arte Moderna de Nova York e do Guggenheim, apresentada no Masp, testemunhou uma realidade significativa. Vale também um outro fator: o interesse do público que se pode definir como uma afeição, se não total, pelo menos notável.

Não se deve desconsiderar também o interesse comercial. O momento é de tal perplexidade que tudo quanto se produz acaba sendo vendido. É um processo como no jogo do bicho: tenta-se e pode ser que o número saia. Conhecem-se casos parecidos, até de grupos que se propóem a especular, apostando num único artista. $\mathrm{Na}$ própria São Paulo formam-se até consórcios de arte, como os de automóveis. ${ }^{97}$

\section{Legenda}

Nos trabalhos de Marcel Duchamp se traduz a vanguarda de sempre.

Entre eles, destaca-se, por exemplo, a sua Roda de bicicleta, que só gira manualmente, fixada num suporte

97 Pouco tempo antes, em Senhor, um artigo descreve um sistema em que os artistas garantiriam remuneraçáo periódica, o organizador do consórcio geraria um acervo e o associado no final de um semestre ou ano, teria uma gama de obras à sua escolha.

Senhor \#320, 5 de maio de 1987, p.68 (P.M. Bardi)

A sínDROME DOS GÊNIOS

O que há por trás da santa loucura dos artistas

Juan Antonio Vallejo-Nágera publica pela Editorial Dossat de Madrid um livro de grande interesse, Locos Egrejios, o mesmo uma significativa homenagem, também por ter sido aquela edição um best-seller. 
A obra trata da "enfermidade criadora" daqueles privilegiados que devido aos seus comportamentos extravagantes são conhecidos como loucos geniais. Os dois casos mais comentados são de Van Gogh e de Modigliani. O curioso no caso do holandês é reler as numerosas cartas enviadas ao seu irmão, Theo, escritas parece que por um sujeito equilibrado. No caso de Amedeo, basta ver o retrato que executou de Diego Rivera quando os dois tinham juntos um ateliê em Paris: igual a qualquer outro, absolutamente o oposto dos retratos de pescoços compridos. Adquiri esta pintura por uma importância miserável, já que não poderia ser do italiano devido a forma do pescoço, e mais tarde, através de correspondência com Rivera estabelecia a autoria, e hoje esta obra pode ser admirada no Masp.

E quanto às telas de Van Gogh que também podem ser vistas no Masp sem se estabelecer a analogia com a loucura? Negócios de psiquiatria et similia.

Falei de dois casos. Um terceiro conclui esta página, pois o ensaísta espanhol desenvolve um capítulo ricamente documentado sobre La supuesta psicosis de Goya, examinando uma obra do mestre que anos atrás eu mesmo comprei para minha coleção. O Infante Dom Sebastian Gabriel de Bourbon e Bragança.

A data da pintura tinha suscitado reservas por parte da crítica, que geralmente vai atrás dos lugares comuns, de besteirinhas e até de boatos. A peça, então genericamente atribuída a Esteve, apareceu no mercado por uma quantia irrisória. Comprei-a (foi um pouco como o afortunado caso duvidoso do Rafael e de outras obras-primas do Masp) e logo demonstrei através de documentos que o retratado era o neto de dom João vi, filho de sua filha casada com um almirante português, exposto oficialmente em Estocolmo em 1959, em Mestres da Pintura
Espanhola, depois catalogado em todas as monografias como de autoria de Goya.

Eis, agora, a tese daquele eminente ensaísta sobre a variedade das fases de um artista: "Parece difícil aceitar a simultaneidade das pinturas negras da Quinta do Surdo (I82I-23), como Saturno, com obras do tipo do retrato de Dom Sebastian (1822), que com maior sabedoria e leves variantes do ofício poderia ser atribuído ao mesmo autor quarenta anos antes. A inconfundível agilidade mental necessária para pular o abismo que separa estas duas obras seria motivo de pasmo em qualquer idade, e é testemunho da juventude espiritual deste ancião de quase oitenta anos. Daí a absoluta injustificação da manobra, tão falsa e tão repetida, do contraste entre as pinturas 'negras' com as das tapeçarias e querer 'demonstrar' a divisão da obra e da vida de Goya em duas etapas." Citando o apodítico Hipócrates, (“A arte é ampla, a vida breve") VallejoNágera pensa que talvez Goya, competindo com a morte inevitável, procurou chegar a ideais essenciais de vida valendo-se da fantasia e, lembrando a Fecunda velhice do japonês Hokusai, ("é penoso morrer agora que estou empenhado em compreender") acrescenta a deslumbrante sobriedade de Ticiano no final de sua vida.

Goya escreve, na última carta que dirige a seu filho, em I828: "Caro Javier, não posso te dizer outra coisa senão que de tanta alegria me sinto um pouco indisposto e estou de cama..." E Nágera assim termina seu nutrico ensaio: " $\mathrm{Na}$ cama, poucos meses antes, tinha morrido, em singular coincidência, Beethoven, o outro grande surdo com o qual a humanidade está em dívida.”

\section{Legenda}

No Sabá das Bruxas e no retrato do Infante Dom Sebastian, neto de João vi (coleção particular de P.M. Bardi, c. I8I6) dois momentos da sublime extravagância de Francisco Goya

\section{Casa Vogue \#3, maio-junho de I987, p.26 (P.M. Bardi)}

\section{O ASSUNTO É MOBILIÁRIO}

São numerosas as ocasiôes para redigir esta nota, procurando sempre novidades para que a mesma não resulte corriqueira. Recentemente o assunto do mobiliário tomou-se prato do dia, e agora, por ter recebido da National Gallery, de Washington, um volume monumental cujo tema é American Furniture from the 
Kaufman Collection, ${ }^{98}$ a conversa retorna a cadeiras, armários, mesas, espelhos etc.

Nos Estados Unidos, os beneméritos que colecionam desde tempos remotos não descobriram precipitadamente apenas a pintura local, como se verificou e ainda se verifica aqui, onde, aliás, os negócios a ela interligados determinam até escândalos por avaliaçóes em que a ignorância é sufocada pelo ridículo. Lá, na República da Liberdade, os coletores de objetos de arte ampliaram os interesses culturais, motivando pesquisas importantes sobre a história, não só de seu pais, pois as estenderam ao mundo inteiro, tendo sido investigados todos os setores, como bem o demonstra a riqueza dos museus americanos.

E agora a National Gallery coloca em cena a coleção Kaufman, motivo de uma indagação, diria total, sobre a fabricação local de fino mobiliário, entre as últimas décadas do setecentos e as primeiras do oitocentos. Vários historiadores especializados nesses períodos estudaram a fundo o assunto através de ponderados ensaios. Nossa recensão pretende somente assinalar o livro aos cultores da história do mobiliário, sugerindo algumas reflexóes pertinentes ao Brasil.

É normal quando surgem assuntos de história das Américas, com referência aos séculos em que vão se formando os sentimentos libertários dos domínios coloniais, observar casos de desenvolvimento das produçóes das artes: no Norte, um franco intercâmbio com a Europa; no Sul, a contínua obediência ao rigor colonial. No Brasil tivemos, em plena presença conclusiva da obra do Aleijadinho, a tentativa de d. João vi de dar renovaçáo a tudo quanto descobria de "atrasado," através da chamada Missão Francesa comandada por Le Breton. Bem outra a situaçáo nos Estados Unidos, o que fica evidente ao folhearmos o catálogo da recente exposição de Washington, apresentando um conjunto de mobiliário que reflete as relaçóes com o operar europeu. Afirma justamente

98 Flanigan, J. Michael. American furniture from the Kaufman collection. Washington: National Gallery of Art, 1986
J. Carter Brown, diretor do museu, que uma das manifestaçóes das artes nos Estados Unidos foram as formas do mobiliário, de fato um excepcional e requintado artesanato, inventivo e caprichado, que poderia ser de Londres: "Como nossos antigos edifícios à maneira georgiana, e mais tarde nos estilos federal e neoclássico, grande parte da arte decorativa de interiores mistura a estética com a funcionalidade, resultando um impulso particularmente próprio do espírito democrático da cultura americana, a busca tanto de um refinamento de formas como de utilidade." As maneiras procedem dos estilos em atividade na Europa Chippendale, Hepplewhite e Sheraton - porém as intençôes dos desenhistas americanos, nas várias regióes, se revelam de singular autonomia. É evidente a presença de cabines makers, imigrados que trabalham usando técnicas tradicionais e até novos sistemas resolver problemas construtivos, favorecendo o desenvolvimento de uma mão-de-obra local que servia para náo importar. Surgem assim estilos bem americanos, sendo notável a variedade dos materiais lenhosos, com os quais se obtêm resultados finíssimos. Deve ser evidenciada a variedade dos espaldares das cadeiras, uma inventiva que leva a pensar no interminável repertório de modos dos designers de hoje quando se propóem embelezar as rodas dos automóveis. O catálogo da exposição documenta, meticulosamente, num trabalho exaustivo em que colaboram historiadores e outros especialistas, as diversas várias vicissitudes do artesanato e seus vários estilos e aproximaçôes, especialmente na Pensilvânia, onde se nota a alternativa das variaçôes com acréscimos góticos ou chineses, como de resto se deu também na Inglaterra.

As oportunidades para o artesão aproveitar a própria engenhosidade determinam uma série de soluçôes. Nesta manifestação, característica da inventividade, fica evidente o gosto por se destacar dos protótipos contribuindo com inovaçôes e, quando aparece a ocasião de se distinguir, os resultados surpreendem. Como se observa nesta poltrona, encomenda de uma loja maçônica, onde os símbolos são aplicados com singularidade e respeito à vontade do cliente. 
Legenda

Massonic Armchair 9 Card Table, Filadélfia

Senhor \#32I, I2 de maio de I987, p.68 (P.M. Bardi)

O ESPAÇO DO GESTO CRIADOR

Visita ao repousante caos de um ateliê de artista

Não é sempre que alguém tem a possibilidade de considerar tudo o que contém o ateliê de um pintor, mexer nas telas, colocá-las em posiçóes mais favoráveis à luz, juntar duas ou três peças para compará-las, pedir datas, ideias, casos, com a finalidade de redigir uma página de apresentação.

A possibilidade me foi dada ao escolher um grupo de pinturas para serem enviadas à Alemanha, quando o artista em questão, junto com Miguel dos Santos e Maria Helena Chartuni, participou de uma exposição representativa da arte figural brasileira, patrocinada pela Basf.

O visitado: José Zaragoza, no seu posto de trabalho no bairro do Itaim, um vasto ambiente repleto de obras, numa colocação que dá sabor ao espaço, uma ordem incerta que reflete o modo de manifestar-se do pintor, suas preferências por formas e temáticas que alegram a sala, às vezes com sintoma de censura social, e também de repouso da natureza. De um conjunto se destaca uma ampla tela: personagens atarefadas, ar de um sentenciar solene com lances dramáticos, e outras vezes em extravagantes posturas.

Insiste-se para ver mais, saber dos princípios, gosto do fantasiar, virar e revirar, perpetuidade de um fazer e refazer, conseguindo o que se imagina. E o mexer nas pinturas não impede o contornar figuras recortadas no metal, e gessos em formação, ao fundo desenhos de pessoas em tamanho natural, e sempre a presença de obras e mais obras ao se transitar entre pinturas e esculturas e objetos em torno.

O ateliê de um artista é sempre novidade, porém este de Zaragoza tem uma novidade a mais: ao percorrê-lo, uma calma que no momento esconde o movimento do pintor durante o seu fazer.

Antes, eram os modelos que podiam observar o pintor operar, sem porém ver o que era posto na tela. $\mathrm{O}$ pintor gosta de solidão. Deve-se imaginar sendo hoje mais complicado formar uma ideia pois o trabalho implica um liberar emoçóes, rabiscos, surpresas, certezas e arrependimentos que surgem a cada momento, o indecifrável de composiçóes à procura do inédito, do particular, do inesperado.

Imaginando, se satisfaz o próprio pensar porém não se dá ao leitor a realidade do que está exposto. Mas se demorou para chegar ao assunto para dizer que tudo vem de um ateliê singular, de um artífice que escolhe, no dia a dia, um condicionar que vai de um a outro conjunto de fatos, num saltitar de pousos caracterizados pela originalidade, num intenso apego a um senso deliberado em liberdade, com um instinto bem além das fronteiras do lícito.

Zaragoza, como se disse, foi um dos três pintores escolhidos para uma exposição na Europa. A lembrança ocasiona esta nota, registrando alguém empenhado na pintura, diria, à maneira tradicional, uma realidade que não sei quantas vezes o redator desta página andou descobrindo em não sei quantos países: a agitação de um ateliê leva a pensar em quantos outros elementos estáo ativos no dar vida a ideias, reflexóes, palpitando momentos de íntimo prazer no resumir visóes, fixar sentimentos, enfim, se manifestar.

\section{Legenda}

Zaragoza e seu universo de rabiscos e cores, em São Paulo

Senhor \#322, I9 de maio de I987, p.68 (P.M. Bardi)

UMA VISITA DE LEONARDO

A IBM anfitriona o comovente encontro de um gênio do passado com a alta tecnologia de hoje

A IBM, para comemorar os 70 anos de sua intensa e profícua atividade no Brasil, teve a feliz iniciativa de nos trazer Leonardo Da Vinci para uma visita. Aliás levou-o antes a numerosos países, a começar, lógico, pelos Estados Unidos e, surpreendendo, até à Itália, através de uma exposição que o mundo continua a discutir, e que o 
Museu de Arte de São Paulo apresentou. O tema escolhido foi Leonardo engenheiro, criador de máquinas. A reprodução e o comentário dos desenhos, contidos nos Códigos, são apresentados em protótipos, fruto de um delicado trabalho que se deve ao estudo e à capacidade, diria até à superprecisão, de Roberto Guatelli.

$\mathrm{O}$ inédito empreendimento provocou não só curiosidade mas a mais agradável surpresa, tanto para os que sabem entender o produzido quanto para os leigos que assim têm ocasião de admirar uma mostra exemplarmente pensada e realizada. A própria montagem, numa rede de armaçôes tubulares onde se afixam os desenhos e manuscritos ampliados fotograficamente, impressionou o público do Masp, como já ocorrera quando da apresentação das gravuras de Pablo Picasso, no ano passado.

Não se tratou de oferecer uma visão das obras do gênio, mas uma faceta do seu espetacular inventar, interessado por tudo quanto o homem até então inventara, e prevendo o futuro em termos de progresso.

Para todos os mais ou menos familiarizados com o andar das artes, Leonardo era identificado pela Mona Lisa, especialmente popularizada nos tempos que se costuma definir como modernos, quando o célebre sorriso foi estupidamente ironizado por Salvador Dali aplicando-lhe bigodes: em graça, suscitando à banalidade um sucesso digno dela. A popularidade tivera um outro fato clamoroso, pois a pintura foi roubada do Louvre por um italiano que pretendia vê-la de volta a Florença provocando um escândalo que possibilitou evocar o pintor.

Uma das maiores indústrias mundiais, justamente empenhada no progresso da tecnologia, foi, agora, a responsável pela vinda de Leonardo. Sua faceta tecnológica é vista como previsor de modos novos de vida: seus desenhos realizados em modelos, para melhor compreensão da singularidade dos inventos.

$\mathrm{Na}$ base da grandiosa obra de Leonardo, autodidata, independente e solitário, sem participar dos duelos e polêmicas das nascentes universidades em vias de substituir com a ciência a alquimia praticada pelos heréticos, está a observação instintiva e meditada da natureza e dos modos de dotá-la de favor material. Seu leque de interesses náo tem limite: tudo lhe interessa, desde uma planta até o sonho de voar, indagador no ignoto de não importa qual problema humano. Arquiteto, músico, pintor e quantas outras práticas o envolveram, sendo a pintura o ponto alto de sua personalidade. Digo pintura englobando o desenho pois seu manifestar neste campo com o miraculoso que admiramos nos seus Códigos expressa sua máxima: "A experiência é a mãe de cada certeza." Interpretando o espírito das máquinas através dos modelos pode-se descobrir qual a compreensão, a genialidade das suas intervençóes cinéticas, dando origem a surpreendentes resultados onde matemática, cálculo de forças e a sempre onipresente fantasia conseguem milagres.

Viu-se na exposição, que do Masp segue para o Rio de Janeiro, Brasília e depois México, uma série mirabolante de inventos aperfeiçoados para obter precisão, soluçóes estáticas e funcionais, dominando um pensar, uma metodologia teórica e técnica que parece um dos pontos máximos que a Renascença nos oferece. Compendiaria uma outra ideia de Leonardo a definição da função da máquina, um positivismo antilitera: "Nobilíssima e acima de todas as outras utilíssima, para que todos os corpos animados que possuam um moto o exerçam em todas as suas operaçōes."

A IBM dotou as manifestaçóes de um filme didático sobre a vida de Leonardo que as enriquece ainda mais, além de uma publicação explicativa sucinta sobre aquele grandioso momento da Renascença, da descoberta das Américas, da nova filosofia e do vencer próprio do Homem.

\section{Legenda}

O helicóptero, no traço de Da Vinci...

I ...e no protótipo de Guatelli 
Senhor \#323, 26 de maio de 1987, p.68 (P.M. Bardi)

O MERCADO ENLOUQUECEU

Quantos Abaporus vale um Van Gogh?

As últimas notícias no campo das artes são, nos dois centros mais importantes do País, Rio e São Paulo, indicadoras de momentos críticos para o cruzado, e as que se referem ao mercado, desanimadoras pelo que se lê em página inteira do Jornal do Brasil, onde a palavra pessimismo é soberana. Denunciam-se acontecimentos através de entrevistas com marchands, marcadas de desolação: acabou um período de euforia em que se vendia de tudo e quase tudo apresentado nas exposiçôes individuais, abertas num ritmo inédito, não só em galerias, mas também em inúmeras sedes improvisadas, às vezes de novatos neste complicado exercício de vender pintura de cavalete.

Das artes plásticas é a pintura que se recomenda às pessoas interessadas em colecionar ou, diga-se sem reservas, intencionadas a entrar no negócio que hoje domina as duas praças, carioca e paulista, negócio que deve ser assinalado como de especulação, em alguns casos.

Numa época de pacotes e de incertezas no decidir como fortalecer as próprias economias ou sobra de capital, os felizardos opinavam entre barras de ouro, open-market e outras possibilidades, quando se descobriu também, fomentado pelos leilóes, o refugio de investir em pinturas.

E de fato, através das habilidades dos galeristas e o favor das crônicas dos jornais, se assistiu a verdadeiros e até incríveis movimentos: preços que rapidamente andaram juntando os zeros, conseguindo impor-se. Já houve referência, nesta página, a uma obra de Tarsila do Amaral, O Abaporu, importante sem dúvida. (Tanto que fui eu mesmo que a adquiri da autora, em tempos bem antigos, quando os compradores de Tarsila não se contavam nem nos dedos da mão) Todavia, quando se leu num impressionante battage de imprensa, constante e continuado, que a tela estava avaliada em 3.500.000, não em cruzados mas em dólares, ficou evidente um dos dois raciocínios: ou o vendedor precisava internar-se numa clínica, ou o atrevimento aproximava-se à ignorância das mais grossas. Andava-se à procura de alguém que a adquirisse

para doar a um museu, beneficiando-se dos então vagos artigos da Lei Sarney.

Foi o consequente fracasso do negócio que começou a denunciar o mercado de arte em posiçóes irregulares. E a fazer raciocinar os compradores, aliás os investidores, que o exagero escondia especulaçóes a serem escritos com o giz branco. O mercado deu uma parada, os investidores que tinham reunido mercadoria procurando vender o que compraram na alta, mas sem êxito. Agora se espera assistir ao resultado dos próximos grandes leilóes.

A respeito dos quais é bom fazer uma observação, depois da famosa, aliás famosíssima venda de um Van Gogh em torno de US\$ 40 milhóes. Será que os girassóis do mestre que durante sua vida vendeu um único quadro ao irmão, vale esta fortuna naquela moeda ainda forte? O jogo dos leilóes é uma incógnita, e se presta a interpretaçóes com não se sabe quantos esconderijos.

Então, vamos ver como se dará o futuro dos leilôes, os quais deveriam estabelecer os valores locais. E daí passar ao indispensável valor de cunho internacional, é lógico. Gostaria de ver uma obra de um de nossos mestres, aqui vendida por US $\$ 500$ mil, quanto alcançaria num leiláo em Nova York. Assim se descobrirá que a especulação deveria ser realizada no mercado estrangeiro. Os verdadeiros valores são ainda os internacionais. No mercado de arte, o nacionalismo não funciona, se a finalidade é saber o justo valor.

Legenda

Os girassóis de Van Gogh e a criatura de Tarsila: no mercado da arte, nacionalismo náo vale nada 
Senhor \#324, 2 de junho de 1987, p.68 (P.M. Bardi)

SOLIDÁRIO Às VAIAS

Como Hugo Borger, diretor do museu de Colônia,

o diretor do Masp é a favor do intercâmbio de exposiçóes

Recentemente, em Colônia, Alemanha, realizou-se um congresso que teve por título "O Museu." Muitos participantes, como se lê no Die Welt, criticaram tenazmente o sistema, hoje comum no mundo inteiro, de intercâmbio de exposiçôes. $\mathrm{O}$ professor Hugo Borger, diretor-superintendente dos museus de Colônia, foi fortemente vaiado por definir este intercâmbio como uma espécie de "carnaval" promovido para as instituiçôes receberem prestígio e momentâneos aumentos de visitantes.

Se, por acaso, o diretor do Masp estivesse presente, teria também recebido vaias, pois penso que estas iniciativas são bastante favoráveis à difusão da cultura, especialmente nas naçóes ainda distantes da vivência dos grandes museus e da facilidade para frequentá-los. Inclusive a América Latina, rica em museus de arte tradicional, porém sem entidades de arte ocidental e oriental. Bastará afirmar que a única coleção de material artístico do Ocidente é a do Masp, o qual aliás participa desde sua fundação em mostras internacionais.

Prudentes oradores do citado congresso demonstraram preocupação no que se refere à periculosidade da transferência das obras, devido a possíveis incidentes. É esta sem dúvida uma razáo mas se deve reconhecer que os danos são registráveis também nas sedes, a fatalidade ocorrendo às vezes tâo repentina e imprevisível como aconteceu no desastre do Museu de Arte Moderna do Rio de Janeiro, onde foi destruída a mostra inteira de TorresGarcía. A este caso pode-se juntar os danos causados pelas guerras, os roubos e até os atos de vandalismo. Para ficarmos no Brasil, basta lembrar a redução a I6o pedacinhos da imagem de Nossa Senhora Aparecida, recomposta depois no laboratório de restauro do Masp.

Somados os fatos negativos, em contrapartida, devem ser estimadas as vantagens dos intercâmbios, para nós do Masp acontecimentos comuns e, diria, em certos casos obrigatórios, quando nos pedem pinturas para completar retrospectivas de mestres. Para anotar os mais recentes pedidos: o envio de cinco Renoir para a celebração do impressionista em Londres, Paris e Boston; o empréstimo de obras de Van Gogh, Cézanne, Monet, Matisse e Diego Rivera para os Estados Unidos, Japão e Europa.

Por outro lado como dizer não a dois recentes pedidos, um do Museu do Louvre que quer exibir o nosso Fragonard, L'éducation fait tout, e outro do Museu de Arte de Zurique pedindo as Estaçóes, de Delacroix, quatro telas da maior importância?

Assim, no congresso de Colônia, o Bardi teria recebido as vaias mais fragorosas, inclusive por ter enviado, neste mês a Milão, para as salas do Palazzo Reale, através de um oficio daquele município, a mostra "De Rafael a Goya... de Van Gogh a Picasso," com cinquenta obras comentadas em grandioso catálogo e com um sucesso espetacular de público. Devo acrescentar: a manifestaçáo se abre com uma sala dedicada ao Brasil, onde estão expostas paisagens de Frans Post, Debret, Bruggemann, ${ }^{99}$ Peixoto, além de um Panorama de São Paulo, de Agostinho Batista de Freitas. Nesta função de realizar exposiçóes no Exterior, nunca se esquece de mostrar, quando possível, a arte aqui produzida.

Aliás, o próprio Ministério da Cultura está organizando para Paris a exposição "Modernidade," uma mostra de arte brasileira da qual o Masp participará com mostras de Cândido Portinari, Emiliano Di Cavalcanti e Flávio de Carvalho.

Para voltar ao congresso de Colônia: foi discutido outro assunto de peso e que se refere à conservação dos patrimônios. Lamentou-se que, na Alemanha, muitos museus não tenham recursos para restauro de obras, sendo proposta até criar uma confederação para disciplinar esta profissão, problema que interessa também ao Brasil. Por exemplo: o Masp tem em seu acervo a série de tapeçarias de Gobelins, também

99 Joseph Brueggmann (Alemanha I825-I894) permaneceu no Brasil por quase duas décadas 
chamadas das Índias, alegorias ao Brasil seiscentesco, obras que nunca foram expostas por precisarem de uma grande restauração, cujo alto custo necessitaria do patrocínio de alguma benemérita empresa.

\section{Legenda}

Panorama de Sáo Paulo, de Agostinho

Batista de Freitas: o Masp em Milão

Senhor \#325, 9 de junho de 1987, p.84 (P.M. Bardi)

A UNIẤO PELA ARTE

$\mathrm{Na}$ Nigéria, onde existem 200 dialetos diferentes, as manifestaçôes

artísticas refletem uma unidade cultural

Uma exposição recentemente aberta no Masp apresentou um panorama da história, arte e costumes da Nigéria, organizada pela senhora Virgínia da Silva, brasileira residente naquele país. É uma das tantas manifestaçôes que considero úteis para, através de intercâmbios internacionais, mostrar a cultura de outros povos. Neste sentido apresentamos também a da arte dinamarquesa e temos planejadas exposiçóes sobre a China e o Líbano, além de outras naçóes, centralizadas sempre em seus aspectos culturais.

Na Nigéria, uma república federativa onde se falam mais de duzentas línguas, cuja característica é a multiplicidade societária das diversas regiôes, as artes constituem o espírito unitário, tradicional da civilização africana.

As produçôes, especialmente relacionadas aos intrincados e complexos ritos sociais e religiosos, singulares como inspiração e execução, encantam pela variedade e sofisticaçáo, desde a arquitetura que se sobressai na construçáo de mesquitas até as figuraçóes próprias do Islamismo, praticado na Nigéria atual. Originais os objetos domésticos, os musicais, os rituais e a série de longos trajes chamados kaftans e agbadas, túnicas tecidas a mão e maravilhosamente bordadas, os ornamentos femininos, as joias de marfim, conchas, coral, vidro e prata.

Todos estes ornamentos têm ligação com as grandiosas celebraçóes dos ritos reservados aos nascimentos e às funçóes fúnebres, cerimônias requintadas para festejar o aparecimento de crianças e assegurar aos defuntos o descanso eterno.

Estavam expostas antigas esculturas em bronze, em barro e madeira, figuras ajeitadas num expressionismo fantástico, reflexo dos ritos que assumem a comunicação no desfile das máscaras, invocando a presença do sobrenatural, efetuado em alegorias grotescas combinadas com o colorido dos trajes: um simbolismo de misteriosos seres da mitologia da terra, onde predominam os fenômenos da natureza como o trovão, todos de significado mágico-religioso.

Geralmente, da arte desta na da África se conhece os bronzes de Benin, no passado representando os monarcas: formas de esmerada modelagem, custodiadas agora em museus europeus e americanos.

As relaçóes que o Brasil manteve com a Nigéria originam-se no período colonial, tendo sido aquela regiáo fornecedora de conspícuas massas de escravos, de modo que nossa formação étnica tem a participação daquele país.

Uma documentação fotográfica evocou esta procedência através de um ensaio do arquiteto italiano Massimo Marafatto, cujo tema é Habitaçôes Brasileiras na Nigéria, parte de uma publicação do Instituto Italiano de Cultura de Lagos, acontecimento aqui já estudado há algum anos por Mariano Carneiro da Cunha no livro Brazilian Architecture in West Africa.

Trata-se das construçôes feitas por grupos de antigos escravos da Bahia que, repatriados para a Nigéria no século passado, contribuíram como planejadores e construtores, ali repetindo os modos arquitetônicos que conheceram no Brasil. Através de relatórios da época fica evidente que a maior parte dos escravos trabalhava com técnicas conhecidas, o que determinou este transplante de construçóes para a África. Já Pierre Verger, o conhecido antropólogo e fotógrafo que dedica sua vida às relaçôes entre Brasil e África, observara esta simbiose na publicação Flux et Riflux de la Traité des Negres entre le Golfe de Benin et Bahia de Todos os Santos. 


\section{Legenda}

Uma casa nigeriana, que lembra

uma fazenda brasileira, e o expres-

sionismo do bronze de Ife

Senhor \#326, I6 de junho de 1987, p.79 (P.M. Bardi)

Os EMPRESÁRIOS TÊM CULTURA

Sarney disse o contrário e se equivocou. Confundiu inculto

com maus administradores de indústrias

Às vezes, no riquíssimo discursar da vida política, notam-se afirmaçóes francamente, aliás democraticamente, discutíveis, apesar de serem vozes que vêm do alto. Neste caso: o fazer saber à Nação que o empresariado náo tem cultura.

A referência se ligava mais a um acontecimento econômico do que à realidade e significado que se dá geralmente à palavra. De qualquer jeito o uso em questão, para os não-filólogos, aquele pessoal - e são muitos - que dos quilométricos artigos da imprensa costuma ler somente o cabeçalho, atribuir aos industriais brasileiros "não terem cultura" provocou surpresa, além de reclamaçóes.

Como este paginista gosta um pouco, sem saber se vale a pena, de verificações linguísticas, uma pesquisa foi feita para indagaçóes. O presidente queria acusar a classe de não levar em conta, no momento de caça à "união de todos os cidadãos," de esperanças de "pactos sociais," num tempo de "pacotes e gatilhos," certas complicadas decisôes administrativas, deflagrando a palavra a ser interpretada num sentido que nada tem a repartir com a Cultura. Parece-me, então, justo liberar a classe empresarial do relevo em pauta, dando notícia de que em Minas Gerais, por ocasião da recente "Semana da Indústria," entre outras manifestações, houve uma no dia 22 de maio, no grande auditório da Fiemg, quando foram outorgados prêmios significativos a elementos que se distinguiram como "construtores do progresso," em seçóes denominadas cultura, pioneirismo, operariado, comércio exterior, agroindústria, tecnologia, integração nacional, fraternidade, arte e memória nacional. Aliás, fui um dos distinguidos como construtor de progresso, pela "contribuição ao esforço brasileiro de desenvolvimento na área de contribuição à memória nacional," sendo considerado o Museu de Arte de Sáo Paulo como um destes fatores. Entre os agraciados, o arcebispo de Belo Horizonte, a primeira pilota de Minas, Anésia Pinheiro Machado, o ministro Aníbal Teixeira, o historiador Câmara Cascudo, a pianista Marina Fernandes e João do Pulo.

Participando do evento tive chance de constatar o interesse que uma federação de indústrias tem pela Cultura, as adesôes em discursos ao objeto que se celebrava, ou como leio numa citação seiscentesca de Davanzati: "Complexo de cogniçôes, tradiçôes, procedimentos técnicos transmitidos e usados sistematicamente, característico de um grupo social, de um povo de toda a humanidade."

Evidentemente o castigador queria acusar a "cultura de administração de empresa," pois de fato os recebedores são cidadáos que contribuem no campo da Cultura de maneira exemplar.

Então a interpretação é outra pois não foi o próprio presidente que, finalmente, instituiu o Ministério da Cultura, egregiamente conduzido por Celso Furtado? Aliás, fez mais: a Lei Sarney que representa um incentivo à categoria industrial, favorecida no abatimento de impostos. A Lei Sarney é um auxílio à Cultura, reconhecendo que, praticamente, é a indústria que tem o poder de destinar meios para atividades literárias, artísticas, musicais e científicas. Prevê-se naturalmente um certo tempo para regulamentá-la, distinguindo os assaltos equívocos a lei das verdadeiras possibilidades de utilização. Em resumo: uma justa distinção e remédios às evidentes falhas, como por exemplo a de excluir as universidades dos benefícios, pois é naqueles ambientes que se determina a Cultura.

Voltando à indústria: sua participação na realidade da difusão cultural está visível tanto na edição de livros, patrocínios de notáveis exposiçôes e grandes eventos musicais. Recentemente, o Masp apresentou a espetacular mostra sobre Leonardo 
Da Vinci, uma iniciativa patrocinada pela IBM. E há pouco o Museu recebeu, da Cia. Iochpe de Participaçóes, uma escultura de Francisco Stockinger. Eis uma das tantas intervençôes culturais feitas pelas indústrias. E pelo Masp pode-se informar que já se preparam outras, esperando novas filas de visitantes. Lançamos há pouco um concurso de pintura cujo tema é "São Paulo," patrocinado pelas
Tintas Acrilex. E assim por diante. Então, descartemos o relevo presidencial aos industriais de não terem cultura num senso geral, para restringi-lo a um resultado de prática de trabalho em relação ao desenvolvimento e custos de produção, sendo Cultura um outro negócio.

\section{Legenda}

Peça de Stockinger: doada pela Iochpe

Senhor \#327, 23 de junho de 1987, p.84 (P.M. Bardi)

PRINCÍPIO DE CONVERSA

O Ministério da Cultura, que nasceu sob suspeita, mostra que está ai para ficar

Dar andamento, ou melhor, sistematizar a cultura nacional é tarefa bastante complexa, pois compreende os setores mais anônimos e diversos, sendo preciso decisóes diplomáticas mais do que portarias, naturalmente não deixando de lado a prática de decisôes impostas e às vezes defesa de princípios irremovíveis.

O Ministério da Cultura está nos seus inícios, baseado na responsabilidade de um titular que, além do passado político independente, exemplarmente democrático, é dotado de um espírito de ampla e experiente capacidade internacionalista tanto que, nos capítulos de uma recente publicaçáo oficial, O Ministério da Cultura em I986, a palavra intercâmbio surge como se esperava: de modo marcante.

A respeito de intercâmbio com o Exterior, o que o Masp realiza é notório, e talvez represente no campo das artes plásticas o que de mais consistente se realiza. Começamos nos anos 50, quando a coleção de pinturas, incluindo uma seção dedicada à nossa vida cultural, reunida em São Paulo sob os auspícios de Assis Chateaubriand, foi levada ao estrangeiro, conseguindo-se abrir a série na Orangerie do Louvre, a convite do governo francês, depois na Tate Gallery e entre os demais museus visitados estava o Metropolitano de Nova York.

O relatório do Ministério dirige-se ao público e dá conta do que se realizou nas entidades que dele dependem, sendo a seção das artes a mais vistosa.

Dá prazer ver ao lado da importância dos museus tradicionais, destacando-se o Nacional de Belas Artes, a notícia do tombamento, pelo Patrimônio, do Hotel Copacabana Palace, lembrança da arquitetura e da vida carioca antes da construção do então Ministério da Educação e Saúde pela clarividência de Gustavo Capanema - que apelou a Le Corbusier para um parecer decisivo para a estética local.

A publicação do Ministério decidido por Tancredo Neves supera e eclipsa o sistema burocrático oficial. Afinal, eis um documento fixado em excelente apresentação gráfica que, desde a atualidade da capa, singular foto de Glória Ferreira, até os textos informativos, dão uma impressão de modernidade. Vale e atrai atenção a síntese dos capítulos ligados aos fatos essenciais do que se realizou os quais colocam o Brasil, como diz o texto "na fase de reencontro com a democracia... conciliando um autêntico desenvolvimento; preservar e enriquecer o legado da nossa História e valorizar a criatividade contemporânea abrindo canais para a eclosão das energias renovadoras.”

Trata-se de um panorama do que o Brasil representa no recinto da cultura que, não há dúvida nenhuma, iremos desenvolver, diria até equilibrar, incentivando, como já se faz, o apoio da iniciativa privada. Sua participação, especialmente hoje com o predomínio da televisão e outros meios de comunicação, deve ser intensa. Declara o prefácio: “É dever do Ministério da Cultura buscar o perfeito equilíbrio entre as responsabilidades que lhe cabem e as iniciativas que nascem da própria sociedade..."

Muitas das intervençốes se darão com o uso da Lei Sarney, uma arma notável para a cultura, de cujo uso veremos os frutos nos balanços deste 1987, após terem sido superados, como se viu recentemente, 
os primeiros assaltos improvisados ligados ao marketing improvisado.

Deixando, então, as conversas, náo de lado, mas na cabine do esquecimento, deve-se citar o informativo com a maior satisfação, esperando que também a imprensa o faça, no mínimo com o espaço reservado a um jogo de futebol, pois cultura é a realidade mais significativa do Brasil e se deseja a participação de todos na sua área.
Finalizando, gostaria de assinalar um outro trecho do relatório: “...promover o intercâmbio cultural com outros países, numa política de mão dupla que divulga valores brasileiros no Exterior e possibilita a vinda ao Brasil de manifestaçóes culturais de outros povos."

\section{Legenda}

Um boletim oficial pode não ser tolo

I Furtado: o passado recomenda

Senhor \#328, 30 de junho de I987, p.84 (P.M. Bardi)

A ARTE DE FAZER "CLIC"

Em seu livro, Notas, Stefania Bril interpreta a criação dos principais fotógrafos do mundo

As artes plásticas quase sempre têm, nesta página, a parte do leão pois arquitetura, escultura e pintura, rodeadas de filiaçóes e parentescos, formam legióes, motivando informaçōes e comentários. Agora, mais um parentesco, a fotografia, pois acaba de sair um livro que tem por título Notas, de Stefania Bril, a mais distinta crítica do invento que, com discussão, se deve ao pintor Daguerre, o qual queria, ao que parece, criar um aparelho reprodutor $\mathrm{da}$ mesma imagem. Se afirma, não ser verdade que desejava liquidar o pincelar sobre telas.

Seja como for, a novidade, já pensada pelo “engenheiro" Leonardo da Vinci, aliás também por Aristóteles, e que atormentou físicos e artistas ao longo de séculos, tornou-se nossa companheira do dia-a-dia, hoje no auge, através de continuas invençôes e aplicaçóes enquanto Akio Morita, o Mister Sony, anuncia uma câmera obscura que vai funcionar sem películas.

Quem nunca experimentou fotografar? Eu mesmo já me meti neste operar. Aliás a ele vou dedicar um dos meus próximos livros da coleção Arte e Cultura que há uns dez anos edita o Banco Sudameris. Assim, a leitura do que Stefania tem escrito resultou implícito, especialmente crônicas e perfis de fotógrafos estrangeiros no $O$ Estado de S.Paulo: prosas de sabedoria, diria apaixonadas pelo trabalho dos que se dedicam ao clic, indagaçóes e estudos conduzidos com insistência e sentimento.

Falei poucas vezes com Stefania, sempre aprendendo e gostando dos conhecimentos, julgamentos certos, indicaçóes convenientes, gosto pensado e instintivo. É o que se descobre nestas 29 Notas que interpretam o fotografar de um grupo de mestres entre os de maior renome internacional. De cada um, a autora escolheu uma imagem, comentando-a e evidenciando o caráter criativo implícito no fotografar, preferências étnicas e sociais, ficando evidente até o senso poético.

É fácil pensar na pintura naturalmente figurativa, a humanidade em cena, oferecendo motivos de comentário. Stefania compreendeu, sujeito por sujeito, o espírito de cada personalidade, penetrando no modo de ver e considerar o momento de colher um fato ou uma simples fisionomia, fixá-los na objetiva, convidando quem observa para descobrir o que transparece, o mesmo caso de quando se observa uma pintura.

Stefania, neste seu livro, tem a posição de um crítico de arte, isto é, examinar uma obra, descobrir o significado, eventuais alegorias, relaçóes com a sociedade. Hoje, que a fotografia tem um valor de documento das andanças da vida e de acessório do lazer, por que não ganhara posição de arte?

$\mathrm{O}$ artista intui e funde os elementos que considera no projetar sua obra; por que quem se dedica à fotografia não pode intuir e captar o que suscita seu interesse? Stefania nas suas Notas quer demonstrar esse paralelo.

\section{Legenda}

Encontro entre o cego e o fotógrafo 9 Paris: "Séria, zangada, carinhosa, indiferente" G Borges: pálpebras teimosas 
Casa Vogue \#4, julho-agosto de 1987, p.36 (P.M. Bardi)

FOTOGRAFIA: ARTE MECÂNICA E FIGURATIVA

Os argumentos desta página são geralmente ligados às "artes mecânicas," definição antiga que abrange arquitetura, escultura e pintura. Esta última, mais ou menos, domina a praça como a manifestação mais popular e, dito entre parênteses, a mais fácil de produzir, hoje que o figurativo foi eclipsado pelo geometrismo, abstracionismo e parentes próximos. Uma arte figurativa e mecânica por excelência, a fotografia, pouco se discute, mas um volume de David Drew Zingg me sugere esta nota. Não se trata de edição recente, porém, pelo tema, o Mato Grosso, permite recapitular velhas novidades sobre paisagismo. No oitocentos, especialmente os pintores, não mais interessados na religiáo, mitologia, retrato, natureza morta como temas cotidianos tomaram de assalto a paisagem que teve grande sucesso popular. Aqui no Brasil a paisagem, como finalidade, teve um cultor singular quando os holandeses tentaram se apoderar do Nordeste e Maurício de Nassau trouxe consigo Frans Post, encarregando-o de reproduzir os territórios conquistados. Suas telas são genéricas vistas do campo, de vez em quando pontilhadas com lembranças de animais ou raros personagens.

Tratava-se de documentação territorial.

Como se disse, é no oitocentos que a paisagem brasileira começa a ser considerada na sua ainda modesta realidade, inclusive no que se refere à construção e seus habitantes. Em nosso século, os fotógrafos, passando a ser artistas, tomaram o lugar dos pintores, pelo menos no diversificar o que reproduzem.
Eis então Zingg, que vai ao Mato Grosso para apresentá-lo nos seus múltiplos aspectos, também e principalmente, o da presença humana. A gente daquela regiấo tem o singular dom da adaptação e a iniciativa de empreendimentos variados, busca de operosidade desconhecida em outros territórios, fazendo história como pioneiros, quase como novos bandeirantes. É preciso descobrir o que de curioso e excepcional aquela vida apresenta: tarefa para o fotógrafo.

A obra de David DrewZingg tem composiçóes que podem ser comparadas a momentos pictóricos de mestres, descobertas num momento de reflexão, do átimo servindo ao imediato; outras calculadas e fixadas na objetiva por escolha, resultado evidente de um gosto próprio, personalidade no colocar a obra, remarcáveis chapas em que a surpresa é parte do fotografar desde o voo de um pássaro a animais em seu habitat, camponeses em suas casas, recantos de lojas, cenas de campo e aldeias, visóes de antigas arquiteturas, pichações maravilhosas, superfícies aradas vistas do alto. Mas o que apaixona é o povo construindo, vivendo.

E fica realmente fácil comparar fotografia com pintura, pelo menos com a figurativa, o que interessa conhecer. O fotógrafo ocuparia hoje, então, o papel do pintor?

\section{Legenda}

Cena típica de Mato Grosso, em foto de David Drew Zingg I Paisagem com jiboia, obra do Frans Post do acervo do Masp.

Senhor \#329, 7 de julho de 1987, p.82 (P.M. Bardi)

A PROPAGANDA MERECE

Os 30 anos da MPM e lembranças dos tempos pioneiros

As sugestôes para redigir esta página aparecem na própria crônica diária; desta vez aqui mesmo em Senhor, que dedica aos 30 anos da nossa maior agência de publicidade o espaço que merece, bastante instrutivo para os que leem estes relatórios, demonstração do desenvolvimento do País que ilustra a operosidade de um grupo de empreendedores decididos que, de Porto Alegre vieram para a região central, conseguindo celebrar o aniversário de fundação de uma empresa em permanente caminhada, diria mais do que vitoriosa, como atestam os números da MPM: em 1957, um escritório, sete clientes, nove atendentes ao serviço; hoje: catorze escritórios, trezentos clientes, novecentos profissionais. Pouco a pouco, a empresa ganhou volume e eficiência.

O que tenho a ver com este negócio? Explico e justifico minha intervenção, 
não casual e até propícia para uma queixa justamente no labor publicitário. Na programação deste ano no Masp, refugium pecatorum das artes e, às vezes, revelador de fatos de um certo interesse, estava prevista uma imponente exposição dedicada à Publicidade, atividade proeminente hoje em dia na vida nacional, como justamente atestam as citadas páginas de Senhor sobre a MPM.

A manifestação tinha também um precedente: na verdade foi este paginista, nos primeiros anos de vida do Masp, o fundador da primeira Escola de Propaganda no Brasil: i950. A atual Escola Superior de Propaganda e Marketing é a continuação da pioneira.

Fui eu mesmo que, de acordo com Geraldo Lima Martensen, abriguei no saguão dos Diários e Emissoras Associados o primeiro Salão de Propaganda, origem da Escola. Quando comuniquei a iniciativa a Assis Chateubriand, ele me cumprimentou pela trouvaille, afirmando que a propaganda, na época, era exercida por quatro ou cinco gatos pingados.

Mas é bom chegar às lamentaçóes: logo que tive a ideia de festejar a data da fundação, comuniquei-a à direção da Escola. Encontrei pronta aceitação, promessas de marinheiro e finalmente recebi uma turminha de possíveis organizadores, enviada pelos professores. Todavia, visto que minha intenção casava mal com as ideias dos enviados, aliás estavam no oposto daquelas, decidi renunciar à façanha.

Penso que uma exposição dedicada à Publicidade seja uma proposta válida e oportuna num museu de arte, pois se poderia dar evidência a tudo que de arte envolve o setor, desde as palavras até o desenhar.

Posso estar errado, aliás é um dos meus handicaps, mas no Brasil, e pode ser que seja certo, não se atribui importância que se deveria ao passado próximo. Estou constatando um caso prático: neste ano de 1987 faz quarenta anos que brasileiro mais autêntico teve a decisão de fundar o Masp, com este redator ao seu lado. Se eu mesmo náo editasse um livro, patrocinado generosamente pelo Crefisul, o aniversário teria passado sem nenhuma recordação. Como de resto não se deu espaço às três grandes exposiçóes que o Masp apresentou na Itália no decorrer de um ano: a coleção completa dos bronzes de Degas por várias cidades, a mostra "De Rafael a Goya, de Van Gogh a Picasso” em Milão e a dos "Impressionistas" que será aberta nos próximos dias em Verona.

Sim, os jornais se preocuparam em publicar até minha cara para anotar um veto que recebi da SPHAN para a saída das obras, fato já solucionado, porém nem uma pintura publicada, nem uma nota, nenhuma entrevista.

Decididamente, reconhecer o que se produz no setor das artes plásticas não é o forte dos jornais. Pelo menos em Senhor tem-se ocasiáo de lembrar estas coisas, a fundação da primeira escola de Publicidade e algumas outras.

\section{Legenda}

Acesso ao primeiro Saláo de

Propaganda, no Masp, em 1950

Senhor \#330, I4 de julho de 1987, p.83 (P.M. Bardi)

ARTE PARA VER E USAR

$O$ design precursor da mulher do futuro

Quando tive carta branca do fundador Assis Chateaubriand para organizar o Masp, sem pensar em um museu na velha tradição que vigorava em São Paulo, (Pinacoteca do Estado e Museu do Ipiranga) inaugurei uma série de novidades, concentrando na nova instituição iniciativas extramuseu, com a organização de manifestaçôes que um amigo italiano, naquele tempo, definiu: c'entramo come i cavoli a merenda.
Entre as couves que servi à mesa estava a moda feminina. Deu-se depois de um encontro, em I950, com o costureiro Paulo Franco, dono da Casa Vogue, elemento número um no setor, com ideias bem abertas, todavia fatalmente interligadas ao que lhe sugeriam suas viagens a Paris. Combinei com ele um exploit e a grã-finagem se precipitou ao Museu para assistir a um desfile das criaçóes batutas de Christian Dior: um sucesso. Desde aquela noite, a moda é 
de casa no Masp. E justamente nestes dias mais uma performance com a mostra "Traje: um objeto de Arte?"

Um parêntese: estava escrevendo esta página quando fiz uma interrupção para assistir ao Globo Rural, aos domingos meu programa preferido, tendo até colaborado na revista homônima. Este se concluiu com uma reportagem dedicada a três cativantes senhoras beirando os oitenta anos, chamadas as três Marias, que dirigem um sítio estupendo que nos transfere para o Brasil antigo. A repórter as seguiu durante toda a jornada delas, e, concluiu o passeio mostrando-as como teceiras: desde a colheita de algodão na planta, o processo para obter o fio, confeccionando maravilhosos tecidos, ricos em desenhos abstrato-geométricos de fazer empalidecer qualquer mestre contemporâneo dedicado àquela novidade. Minha reação natural foi telegrafar para apresentar um aspecto dessa produção na atual exposição.

Vão ser apresentadas na mostra várias peças criadas por um grupo de estilistas norte-americanos, lançadores da wearable art, e de elementos nacionais que foram notados nos últimos anos, em exposiçóes individuais no próprio espaço do Masp, como os autênticos mestres designers de ornamentos Romuald e Jacque, do Rio de Janeiro, Orietta del Sole, a sensível idealizadora de trajes entre o excêntrico e o singular, e Glaucia Amaral de Souza, da qual vai-se admirar uma roupa de particular gosto, além de criaçóes inéditas de Liana Bloisi, Fernando Marques Penteado e Andrea Castor Kramer. O Museu Histórico Nacional do Rio de Janeiro emprestou gentilmente para a exposição algumas peças históricas de seu acervo, e trabalhos de artistas de renome que além de suas produções normais se interessaram de alguma maneira, em outras épocas, pelo vestuário, como Lina Bo Bardi, Aldemir Martins, Aldo Bonadei, Norberto Nicola, Flávio Império e Berenice Gorini, também fazem parte desta apresentação.

A mostra deve ser vista, pois resume talentos do modismo feminino nas fases $\mathrm{da}$ renovação perpétua de modelos, em geral considerados utopia estética nesta filosofia do exibir-se para ser diferenciado, estética que neste século colocou à vista do transeunte uma originalidade de tal exceção que às vezes é amoralística, até apontada como sinal dos tempos pelos perseguidores dos princípios da normalidade.

Assim, é fácil imaginar hoje até o passadismo de Salvador Dali, autor do vestido para a mulher do ano 2045 , também presente na exposição, modelo que foi desenhado para nosso desfile de 1950, francamente corriqueiro se imaginarmos a mulher do futuro.

\section{Legenda}

Wearable de Fernando Penteado

g Wearable de Liana Bloisi

Senhor \#33I, 2I de julho de i987, p.84 (P.M. Bardi)

TELAS QUE VALEM OURO

As companhias de seguro descobrem um belo negócio: o mercado de arte

Envolvido que sou há muitos anos com o intercâmbio de obras de arte com instituiçóes estrangeiras, trato e às vezes contrato seguros para empréstimos que somam dezenas e dezenas de milhóes de dólares. Assim, pode-se dizer que tenho bastante prática neste indispensável negócio que andou crescendo de valor e continua a chamar atenção, pois os objetos de arte registram a cada ano pulos monetários espetaculares.

Tivemos há uns meses a surpresa dos Girassóis de Van Gogh, alcançando num leilâo cerca de quarenta milhóes da moeda norte-americana, e nestes dias um Monet superando os US\$2 milhóes.
Acrescente-se a isto os respectivos seguros contra perdas ou danos e se terá uma ideia de como e quanto as artes representam no plano dos negócios mundiais.

Também aqui no Brasil temos valores que correspondem aos que anotei no parágrafo anterior. As obras do acervo do Masp, que tive a sorte de ver nascer nos anos de sua constituição pela generosa e futuróloga iniciativa do senhor Assis Chateaubriand, hoje propriedade de uma sociedade civil sem fins lucrativos que em caso de liquidação passa tudo quanto possui ao governo do Estado, são solicitadas, quase que mensalmente, em empréstimo por famosos museus do mundo inteiro, a fim 
de participarem de manifestaçôes, curiosamente pouco registradas pelas crônicas locais, a não ser que se trate de escândalos.

O assunto, hoje, é seguro. Aconteceu-me dias atrás de ser convidado pelo Instituto de Resseguros do Brasil para participar, juntamente com o marchand Renato Magalhães Gouvêa, de uma reunião para informar o que sei a respeito de seguro de obras de arte, operação financeira que está tomando vida no Brasil, acarretando na prática numerosos casos a respeito de determinação de valores, sistemas de controle, elementos em condiçóes de fazer identificaçôes e outras medidas relacionadas a seguro.

A discussão foi interessante e devo dizer instrutiva no que se refere às declaraçóes de Renato e minhas: casos expostos sobre a salvaguarda, conservação, restauro como perda de valor e até possibilidades de malandragem etc., foram todas informaçóes que esclareceram possibilidades e práticas de seguro de obras de arte no Brasil.

Começa-se a colecionar, são realizados constantemente leilóes que arrecadam quantias vultosas: é lógico que a intervenção dos seguros constitui uma realidade, providência hoje normal em qualquer transação.

O interesse do governo, então, pelo resseguro é a demonstração de que o recorrer ao seguro para obras de arte significa a presença de grandes organismos bancários se dedicando à divulgação e acerto dos negócios. Recentemente notei que as capas de apólices de seguro das companhias internacionais que acabam custodiadas nos cofres do Masp trazem impresso: "seguro de obra de arte." Isto demonstra que o setor se tomou comum.

Acho graça de uma quantidade de outras indicaçóes de seguro que tentei explicar na reuniáo promovida pelo IRB, constatando que no Brasil, lançado o seguro de obras de arte, os mercados relativos progrediram desde os tempos em que nós no Masp acumulávamos altos valores internacionais, na verdade nem pensando em eventuais seguros.

No avanço de uma nação, tudo muda, felizmente.

\section{Legenda}

A canoa sobre o Epte, de Claude Monet, e Passeio ao luar, de Van Gohg, do acervo do Masp: quanto valem?

Senhor \#332, 28 de julho de 1987, p.84 (P.M. Bardi)

\section{CONVERSA PESSOAL \\ Recordaçōes de uma antiga amizade com Gilberto Freyre}

De vez em quando se percebe nesta página que a conversa é por demais pessoal, até memorialista. Desta vez é impossível não ser assim, pois lembro Gilberto Freyre.

Fomos apresentados, há quarenta anos, por Assis Chateaubriand, o qual falava bem o italiano: "E lo scrittore che ha rivelato a noi il Brasile. "’o Gilberto Freyre estava em São Paulo e o Assis aproveitou para convidá-lo a pronunciar uma conferência no Masp: reuniu toda a intelectualidade. Com pouca prática ainda do português, recorri, depois, à tradução de Casa Grande e Senzala, adquirindo os primeiros conhecimentos dos nossos séculos: o comportamento dos colonizadores, a ação das tribos primitivas, a resignaçáo dos africanos: prosa independente de qualquer espírito nacio-

IOO "É o escritor que nos revelou o Brasil." (tradução nossa) nalista, de uma liberdade de juízo às vezes severa. Revelava um caráter de exceção.

Quando fui admitido à leitura da língua nacional, correndo especialmente as notas dos capítulos, me surpreendia a sua erudição total. A história, para Gilberto, tomava-se lapidar: as minúcias das vidas, sentimentos, amores, lutas, tudo exaustivamente decifrado. $\mathrm{Na}$ minha antiga carreira na reportagem jornalística que me acompanha até hoje pensava sempre em um pesquisador que não renuncia a indagar os mais complicados acontecimentos.

Não é que a nossa tenha sido uma relação contínua. Às vezes em São Paulo vinha a minha casa: gostara do meu interesse imediato pelas antiguidades brasileiras. Em I948, jantando conosco, ficou surpreso ao usarmos um faqueiro de prata dos que El Rei doava aos conventos jesuítas, dizendo que em Apicucos tinha um 
igual, e contou- nos minuciosamente a história. Ousava-lhe remeter catálogos do Masp e algumas publicaçóes.

Recentemente, adquiri a $25^{\text {a }}$ edição José Olympio da sua obra-prima, relendo os prefácios das anteriores e admirando a atraente capa dupla do caro Cícero Dias, síntese do contraste social entre as posiçóes dos patróes e dos escravos. Gilberto, nos artigos que publicou até alguns anos atrás no jornal O Estado de S.Paulo, fez várias citaçôes de minhas opinióes sobre assuntos de arte, elogiosas, a ponto de me persuadir de não ter gasto inutilmente meu fazer. Dediquei-lhe há algum tempo meu livro Comunicação, Notícias de Cabral à Informática e, no ano passado, tive a honra de ver meu livro 40 anos de Masp prefaciado por ele. Foram para mim reconhecimentos de tal valor que me fizeram pensar num outro grande brasileiro que acreditou neste cronista e que lhe ofereceu a possibilidade de assegurar ao Brasil o museu que, hoje, vai afirmando entre nós uma realidade cultural digna do decantado Primeiro Mundo. Honro-me de ter sido quem reconheceu em Assis o implantador do Masp. A ele dediquei meu livro Sodalício com Assis
Chateaubriand e na página "Tendências/ Debates" da Folha de S.Paulo invoquei que um historiador resuma a obra do fundador dos Diários e Emissoras Associados.

Falei sobre isto na última vez que conversei com Gilberto e ele aprovou. Foi no ano passado, quando me convidou para falar de Assis e do Masp, no Recife, na Fundação Joaquim Nabuco. Fez questáo apresentar a conferência: suas consideraçóes foram compensadoras minha gratidão além dos limites. Antes do almoço, Gilberto me mostrou em sua biblioteca, deixando transparecer em seu rosto um certo prazer, as últimas traduçóes de Casa Grande e Senzala numa língua oriental. Caro Mestre, você agora repousa, depois de uma vida exemplar culminada no deixar tudo que reuniu do saber humano e da nossa história para a Fundação com seu nome no esplêndido solar de Santo Antônio de Apicucos:

"A Casagrande; a senzala; inda aos remorsos mais vivos,| tudo ressurge e me fala,| grande Gilberto, em teus livros," como canta Carlos Drummond de Andrade, na

"Viola de bolso novamente encontrada."

\section{Legenda}

Cícero Dias, Casa grande e senzala, 1933

Senhor \#333, 4 de agosto de 1987, p.79 (P.M. Bardi)

O BENEFÍCIO DA CONFUSÃO

$A$ arte incorpora o computador, ao mesmo tempo em que sente saudades do figurativo. Quem vencerá: a vanguarda ou o academismo?

Raramente visito ateliês de artistas, todavia às vezes os convites para um encontro são tão curiosos que a decisão de aceitar é natural. Eis que chega um pintor que se apresenta como à antiga. Curioso, aceito. Encontro as paredes repletas de "belas artes," mostrando desde os costumeiros nus até paisagens e marinhas de todos os tamanhos, composiçóes com e sem figuras pois, segundo ele, entre os compradores há os que preferem quadros sem ninguém à vista. Não faltavam até vistas de interiores, retratos, temas ligados ao surreal: enfim, uma variedade incrível. Ele me explica: "Faço tudo que me encomendam."

Meu primeiro pensamento foi para os fotógrafos pois a eles também se faz encomendas. Logo depois da descoberta do daguerreótipo se decretou a superação da arte do pincel. Isto não aconteceu e continuou firme o academismo que não foi liquidado nem pelos impressionistas. E o impressionismo não provocou o cubismo e várias outras maneiras? Além das que se seguiram abrindo novos caminhos? Há pinturas para todos, diria até inflação, inclusive o academismo mais absoluto, seu figurativo ainda interessando quem náo quer saber, agora, de abstrato, geométrico, pop e o infinito das tendências que conquistam mercado.

O obsoleto cultor do academismo me confirmou que estava certo de que logo as academias se tornaráo os centros propulsores da pintura.

Acontecem no setor das artes tantas mudanças que seria arriscado duvidar. De fato, nas escolas, o ensino das beaux-arts continua. Foram criadas, têm seus organismos e professores. O mesmo se dá com os salóes: existem. Mas o profissional 
em pauta me mostrou diplomas de salóes exclusivamente de arte acadêmica.

É uma forma de polêmica. Pode ser até a polêmica do futuro: o pessoal vai cansar-se do modernismo? Pode ser que façam uma limpeza nas produçôes de vanguarda? Então onde se refugiar? Provavelmente na atividade mais intensa o tradicional realismo, que permite até manifestaçóes com veios de sensibilidade quando o executor os possui.

Hoje, os trânsfugas do academismo, seguindo os tempos e o interesse, pois o que se vende é a "arte nova," denominam os que produzem telas figurativas de "acadêmicos." De fato, os veristas náo têm os favores dos interessados em arte? $\mathrm{O}$ momento é de divagaçóes incompreensíveis. Se o passar dos tempos marca as mudanças, assim deve ser.

No mês passado, uma fábrica de tintas, a Acrilex, lançou um concurso de paisagens de São Paulo para iniciantes. Aderiram centenas de pintores. De acadêmicos à maneira tradicional nenhum, a maioria presa ao sonho de considerar a metrópole com visôes modernistas, fabulosas, excêntricas, São Paulo vista por pintores presos à infinidade de mudanças típicas hoje da arte da pintura.

O trabalho destas centenas de pintores se multiplicou de tal modo que não dá mais para considerar os figurativos, fato que de resto já se notou depois da afirmaçáo do abstrato. Todavia os figurativos existem junto daqueles que pescam nos temas predominantes em moda. Como também existem agora os que pintam por computador, até ali cozinhando figuras.

O momento é de incrível confusão. $\mathrm{O}$ paginista, como membro da comissão premiadora do concurso Acrilex, teve, mais uma vez, oportunidade de ver de perto este momento de confusão na Arte.

\section{Legenda}

A fotografia documenta o número de participantes do concurso Acrilex: filas e filas de candidatos-pintores

Senhor \#334, II de agosto de I987, p.82 (P.M. Bardi)

O Estillo FARAônico

Brasilia toma ao pé da letra, na sua arquitetura, o padrão de vida local

O Brasil teve de construir uma capital ex-nova, pensada num funcionamento tradicional sim, todavia concentrando em sua realidade todos os recursos que a moderna arquitetura estava naquele tempo prescrevendo. Mais do que na arquitetura, o empenho se deu na concepção urbanística. Não vale aqui repetir o elogio a Lúcio Costa, projetista do plano: idealização universalmente apreciada, correspondente ao que o País precisava. Doutro lado, Oscar Niemeyer se dedicou a obter da arquitetura o significado vanguardista esperado, consequência da influência que o risco de Le Corbusier havia impresso em 1936 na construção do Ministério da Educação e Saúde no Rio de Janeiro, o marco da mudança da arquitetura nacional que, como em todas as naçóes, estava acomodada no repetir banalmente os estilos do passado. Um exemplo: a catedral gótica de São Paulo.

É justamente em Brasília, o caso mais curioso para não dizer bastante estranho, que um retomo daquele acomodamento está sendo notado, começando-se a notar fatais quebras no estilo funcional ou racional. Um sinal parece estar sendo dado pela presença de construçôes que não somente não se dispóem a segui-lo, mas ostensivamente o contrastam, quando náo o caricaturam.

Parece-me caricatura um edifício com nada menos do que a forma de pirâmide, apesar de apresentar paredes lisas, janelas e portas sem molduras. A mesma observação vale para outros prédios, por exemplo, uma reprodução da fachada da Casa Branca de Washington ou uma residência semelhante à mais baixa imitaçáo dos modos de Gaudi em Barcelona. E mais: são destacadas construçóes como a catedral das Assembleias de Deus, já apelidada de "baleia," ou a Igreja de Fátima, chamada de "intestino grosso" etc. Tudo isto está na revista Habite-se, de São Paulo, com fotografias de Salomon Cytrynowicz, através de uma bem documentada denúncia de Stella Galvão, que revela uma situação que, sem dúvida, terá deixado de cabelo em pé Lúcio Costa e Oscar Niemeyer. 
Os novos fatos da estética de Brasília são realmente surpreendentes. $\mathrm{O}$ acontecido é justificado pela falta de disposição ou interpretação de leis por parte das repartiçóes às quais é atribuída a tutela da harmonia urbanística. Neste caso a harmonia comporta estreita fiscalização não tanto no exame e aprovação dos projetos, como nas possíveis alteraçóes dos mesmos.

É o caso de se lembrar aqui como, nos anos 20, Gregori Warchavchik conseguiu construir em São Paulo sua casa na Vila Mariana, apresentando um projeto que mostrava uma fachada decorada à maneira antiga, eliminando depois na construção os ornamentos, oferecendo-nos assim o primeiro exemplo de racionalismo.

Se os burocratas de Brasília não ficam surpresos quando recebem e devem aprovar um projeto de um edifício-pirâmide, como também de outras construçóes estranhas, é sinal que gostam de trouvailles.

O que é de se esperar é que as trouvailles náo tomem o rumo de um pseudo-estilo. É verdade que, pelo que se conta de Warchavchik, o andamento de uma mudança estilística pode ser consequência de propostas não imediatamente compreendidas e apreciadas. A superação do "culturalismo" dependeu do longo trabalho dos arquitetos inovadores como Wright, Gropius, Le Corbusier e, no Brasil, os que venceram autênticas barreiras depois da inauguraçáo de Brasília.

Deve ser encarada com suspeita a ocorrência de tal extravagância na própria Capital Federal.

Recentemente, a respeito da "maioridade" de Brasília, a Rassegna di Architettura e Urbanistica, de Roma, reproduziu um texto manuscrito de Oscar Niemeyer que celebrava Juscelino Kubitschek. Ao lado se escrevia que em nossa Capital estão presentes muitos dos problemas das nossas outras megacidades: "O mais grave que a cidade deve enfrentar e, se não controlado em tempo pode comprometer... os ritmos... da linearidade das soluçóes urbanísticas originárias." A alusão dirigia-se para as favelas; mas vamos incluir também os "pastiches" aqui assinalados.

\section{Legenda}

Sugestão para a reforma arquitetônica de Brasília (Arquivo do Masp)

Senhor \#335, I8 de agosto de I987, p.84 (P.M. Bardi)

SÃo José NÃo É CANUdOS

Visita à cidade onde Euclides escreveu Os Sertōes e construiu uma ponte

Quando alguém sai de São Paulo e viaja para o Norte do Estado, percorre uma das grandes auto-estradas, encontrando depois caminhos de mão dupla, fica com os olhos presos àquela imensidão de planalto onde verdeja a riqueza da nossa agricultura. Há dias fiz este trajeto em direção a Sáo José do Rio Pardo: um passeio para mim surpreendente. Fui participar da semana dedicada ao famoso pintor local Germinal Arteses que coincidiu este ano com a semana euclidiana, pois naquela cidade é venerada a memória do autor de Os Sertôes, que lá escreveu sua saga.

Os organizadores fizeram a entrega de duas medalhas, uma a este cronista e outra ao doutor Osvaldo Galotti, médico aposentado, profundo conhecedor e estudioso da obra de Euclides da Cunha, numa simpática cerimônia presidida pelo prefeito daquela cidade, Silvio França Torres.
Os dois dias que lá passei foram para mim esplêndidos, na companhia da artista Maria Helena Chartuni, da jovem Patrícia Inácia de Paula, do colega Luiz Hossaka e também do professor Francesco Tentori, da Universidade de Veneza, Itália. Ele é hóspede do Instituto de História da Arte do Masp, a entidade que estamos constituindo para, possivelmente, dar vida a uma série de levantamentos de crítica, na intençáo de aprofundar o estudo do patrimônio da Pinacoteca do Masp, cuja parte mais notável, neste segundo semestre, está sendo apresentada no Palazzo Reale de Milão e no Palazzo Ford, de Verona, além de algumas peças emprestadas a museus de Zurique, Washington e Londres.

Os amigos de São José do Rio Pardo quiseram festejar também o Masp pela sua atuação internacional fazendo conhecer o Brasil lá fora e nos reservaram uma acolhida especial, diria até típica do nosso interior. Fomos hospedados numa antiga 
fazenda, do casal Eduardo e Maria Olívia Roxo Nobre, espetáculo, para mim, respeitosíssimo de tudo que representa o passado, pois vi como ali se conserva, aliás se venera a memória brasileira: na casagrande há uma encantadora coleção de instrumentos dos avôs, bisavôs e predecessores, cada um resumindo histórias, ou melhor, o mito dos construtores da terra. Relíquias como uma peça de maquinário de engenho, em madeira originária do próprio parque florestal nativo que é conservado intacto na fazenda, contornado por plantaçôes de café e de alho. Tudo nos deixou boquiabertos, principalmente diante de um exemplar monumental de Jequitibá-rosa centenário.

Foi grato para nós e para o hóspede italiano passar a manhá de domingo na grandiosa fazenda e apreciá-la de seu ponto mais alto, tendo ao fundo o cenário esplêndido da Serra da Mantiqueira e um rio de águas cristalinas. No sábado já havíamos admirado a ponte construída por Euclides da Cunha, seu casebre de trabalho e depois sua casa, agora museu: inesquecível recordação, pois os cortêses guias contaram suas façanhas.

De Canudos se evocou o heroísmo eternizado nas páginas de Euclides, nos discursos feitos na Casa da Itália, no domingo. Tivemos ali oportunidade de aprender que os italianos emigraram em massa para São José do Rio Pardo. Num breve agradecimento, declarei-me um imigrado feliz. Depois, na saída, velhas senhoras, filhas dos bravos contribuidores da lavoura, falaram comigo. Posso dizer que a reuniáo, com as duas bandeiras hasteadas, a brasileira e a italiana, foi de fraternidade, igual a várias outras de que já participei pelo Brasil afora.

A ocasião serviu também para se dar início a um intercâmbio entre o recém-nascido museu de São José e o de São Paulo. O que me lembra uma velha ideia museológica nacional: a do incentivo, pelos museus que têm mais possibilidade, aos centros que estão começando.

E quero concluir esta simples crônica com uma proposta que me está intrigando e à qual acenei no livro 40 Anos de Masp: a capital da República deve ter um Museu de Arte digno, o que náo existe. Porque o ativo governador José Aparecido não propóe aos que podem colaborar, desde o Goeldi de Belém, aos numerosos de arte sacra, ao Museu Nacional do Rio de Janeiro, ao próprio Masp e a alguns mecenas, que façam empréstimos e doaçóes?

Eu próprio me declaro um dos possíveis contribuidores quando a proposta passar da previsão a uma efetiva realidade.

Voltando a Sáo José: a viagem, as visitas, a hospitalidade na Fazenda Tabaca e a casa datada de i870, os anfitrióes Eduardo e Maria Olívia, o sol esplêndido, tudo concorreu para não se pensar em crise e em política e sim num país que vai para frente.

Legenda

De Os Sertóes, de Alfredo Aquino

Senhor \#336, 25 de agosto de 1987, p.82 (P.M. Bardi)

A INSUBMISSÃO DO "RADICAL"

Abramo, que nunca aderiu aos poderosos, nos convidava a

refletir sobre a realidade em que vive o ser humano

É fatal assistir ao desaparecimento dos companheiros da imprensa, e mais penoso quando a notícia é repentina. Para quem lia o artigo "Cotidiano" de Cláudio Abramo na Folha de S.Paulo, a impressão é ainda mais desconcertante. No velório sua figura ainda juvenil, serena, lembrava a simpatia com que transmitia seus ideais, levando-nos a evocar também o que de construtivo manifestava no seu entender. Seus artigos afirmavam sua intransigente persuasão, deixando transparecer um incitamento ao leitor para que refletisse sobre realidades sociais e políticas, atitude que agora vejo recordada como de um espírito "radical." No adeus ao caro Cláudio, um repensamento sobre o que ele escrevia, sua constante crítica, um combater contra moinhos não de vento, mas barreiras, torna-se presente e cada um de nós que acompanhava sua sintética prosa sem desvios, mais uma vez atribui-lhe um "bravo."

Eu nunca tive com ele contatos muito frequentes, todavia sabia bastante de sua formação cultural e, naturalmente, política. Esta, nos seus tempos de começo de vida, sendo um daqueles que compreendiam a urgência das 
mudanças, não tinha outra referência: fazer compreender as vozes que apregoam a última reação a um estado de contrastes sociais que o século 20 deveria liquidar.

Eu mesmo já fui jovem, na geração anterior à dele. Devo confessar que, antes de ser recrutado para a guerra que a Itália tinha declarado contra a Áustria, os ideais eram sugeridos por uma arma que, por inexperiência cultural, não se sabia muito bem em que consistiam. Por entusiasmo juvenil tive a coragem de enviar o manuscrito de um ensaio meu dedicado às possessóes colonialistas inglesas de Geremia Bentham, à editora L'Avanti!, órgão do Partido Socialista. O livrinho foi publicado e logo, na vida militar, deu-me as primeiras dores de cabeça, pois me ficharam como "subversivo."

Penso que Cláudio, nos tempos do seu noviciado trotskista, mesmo sem guerras permeando o cenário, deve ter tido também seus arrebatamentos. Os jovens que se lançam na vida, se não têm índole de puxa-saco, são atraídos pela contra- corrente. E Cláudio, pelo que sei, empenhou-se em manter-se em posiçóes claramente de crítica, de consideraçóes de justo senso popular. Sua palavra, no exercício da profissão, sempre venceu, alinhada a um caráter inflexível. Permito-me fazer uma constatação como velho, aliás, de idade própria dos aposentados, sobre a imprensa nacional: a liberdade de pensamento que, naturalmente quando se tem, é permitida.

Como se sabe, fui amigo e colaborador dos jornais de Assis Chateaubriand, e fiquei surpreso quando, por um incidente que terminou em socos dados por mim em pleno auditório do Masp, fui reprovado, não somente pela assistência mas pela imprensa dos próprios Diários Associados, veementemente acima do diretor do então nascente Masp.

Caro Cláudio Abramo, desculpe-me se nesta página divaguei, queria te mandar uma saudação: sempre te considerei um colega exemplar e de caráter, o que em nossa profissão é o alicerce do noticiar e comentar.

\section{Legenda}

[Foto de Cláudio Abramo]

Bravo! Bravo! Bravo!

\section{Casa Vogue \#5, setembro-outubro de 1987, p.34 (P.M. Bardi)}

\section{Questáo De estilo}

Estamos sempre assinalando casos de arquitetura, tratando geralmente de seus projetistas e também dos determinadores das construçóes. Recentemente, numa série de artigos para a Folha de S.Paulo dedicados à arquitetura paulista, me ocorreu lembrar o comendador Giuseppe Martinelli que em 22 ideou e desenhou o mastodonte que muito justamente, há alguns anos, a Emurb náo se atreveu a eliminar, restaurando-o, pois faz parte da São Paulo voltada para os arranha-céus.

Falo do edifício Martinelli. Poucos sabiam que seu autor, imigrante italiano, aqui trabalhou como açougueiro antes de acumular o ingente patrimônio que gastou na sua obra- prima. Pode ser que cortando carne, ele já pensasse em construçóes, recordando-se que, afinal, era licenciado na escola de belas-artes da cidade natal, a esplêndida Lucca, na Toscana. Desenhou o edifício, gigantesco sim, porém devemos lembrar que naquele pós-Primeira Guerra os estilos estavam concentrados na mais cômica situação: o ser ou não ser do ecletismo o mais curioso. Sim, tinha alguns raros precursores do proposto "racionalismo," como o voluntarioso Gregori Warchavchik e o endiabrado Flávio de Carvalho, porém o pessoal preferia ainda os palacetes "culturalistas," o pseudoestilo que copiava do antigo, aliás pseudocópias também como se vê na Catedral da Sé que apresenta o gótico mais manipulado, sem ofensa a nenhum credo confessional, pelas mãos de construtores patenteados sim, porém militantes no cômodo sistema de cozinhar qualquer estilo. Nem se pensou que o gótico estava até fora de moda. Seria interessante reportarmos as justificativas dos proponentes de um estilo já então obsoleto apesar de que em São Paulo seus exemplos aparecem até na avenida Paulista, meca então da mais curiosa confusão arquitetônica combatida depois por gente como Le Corbusier, Gropius e Frank Lloyd Wright, que conseguiram pô-la de castigo, não tolerando nem o floreal, o art-déco e outras tentativas de encontrar modos mais 
coerentes com o século que começava a viajar de avião, às vésperas da informática.

São pelo menos uns cinquenta anos que se trabalha pela liquidação do "culturalismo." Antes lembrei o comendador Martinelli, cerra-fila dos adeptos daquele pseudoestilo. Pertenci à turma que, na Itália, reagiu contra o projetar náo importa com qual estilo do passado, condenando os pseudorrenovadores que apresentaram como moderno o "neoclássico."

Fui responsável por ato irreverente bastante famoso contra o excesso de neoclassicismo, quando os arquitetos ligados a Mussolini, para promover um novo vulto para Roma, tentaram impor um estilo "romano imperial modernizado," alguns exemplos chegando até Sáo Paulo, como o palacete Matarazzo na avenida Paulista, projeto do arquiteto Morpurgo do atelier de Marcelo Piacentini, então o caporione.

Por que conto tudo isso? Voltando ao que declarei no início, lamento que sempre se dê importância ao arquiteto, sem falar do engenheiro que é quem dá estabilidade à construção, nem do comitente. Aqui quero lembrar este último, aquele que encomenda a obra. Um deles, Leonard Gianadda, o qual determinou o complexo da Fundação Pierre Gianadda, na Suíça, será objeto de longo artigo meu no próximo número de Casa Vogue: è um senhor suíço que se dedica à construção civil em Martigny, sendo engenheiro civil formado na Universidade de Lausanne. Diz sua biografia que somente em Martigny realizou notável quantidade de prédios, obras públicas e industriais e mais oitocentos apartamentos. Como veremos, Leonard, atravessando singulares acontecimentos os quais relatarei, realizou seu desejo, exemplo de civismo, pois reverteu parte de sua fortuna para uma obra de prestigioso valor, como se pode ver na ilustração. A arquitetura depende do comitente, de quem decide criá-la. Neste caso, oferecendo-a como bem de toda uma comunidade. A lembrança vale para incentivar, também no Brasil, estes gestos altruísticos. E aqui aproveito para fazer saber que dona Lina e este redator estão fazendo doação testamentária dos seus próprios bens ao Museu de Arte de São Paulo, em memória do senhor Assis Chateaubriand, deliberador daquela instituição.

Aceitam-se outras doaçôes para o Masp.

\section{Legendas}

Uma visão da arquitetura da Fundação Pierre Gianadda Parte interna. No vão, os resultados das escavaçóes arqueológicas

Senhor \#337, I de setembro de 1987, p.I06 (P.M. Bardi)

Os sucessos DA ANTIARTE

Paul Klee na carroceria de um automóvel. Por que não?

A palavra Arte (se escreve em maiúscula, pois atende ao mais alto conceito espiritual) manifesta-se numa miríade de casos de complicada para não dizer impossível determinação, modos e regras nas quais se baseava hoje subvertidas, quando não negadas. A fantasia interveio juntando ao conceito tradicional referências, porque não, estimulantes, a criação e a expressão propondo enormes amplidóes.

Os nascimentos contínuos das novidades etiquetam tendências rapidamente aceitas e superadas, numa época se dizia no panorama do modernismo, hoje num autêntico caos em que tudo vale, gerando dúvidas e repulsas. Aliás, quanto mais reprovadas, mais admitidas e, às vezes, coroadas de consenso. Os sucessos, especialmente da antiarte, estão na ordem do dia. A duração é breve, quase instantânea. As adjetivaçóes exauriram as definiçóes: desde "degenerada," "feia," "brutal" etc., até "sublime," "periférica," "intelectual," alternando-se os lançamentos. Encontrar passagens no labirinto é operação tão complicada que o mais conveniente é se resignar a náo procurar saídas.

Ainda no recinto das artes plásticas, correr atrás dos significados e das classificaçóes é empresa complexa: tudo é convencional e impreciso, a evolução dependendo das mais imprevistas intervençóes.

Hospedei no Masp, contemporaneamente, no mês passado, uma exposição de arte "degenerada" alemã, (um esplêndido panorama do desenho que discutiu o conceito da realidade classicista, Hitler de prontidão) outra em que se via a 
ação do raio laser, (propondo relações entre ciência e pintura) e outra intitulada “A arte do automóvel.” É sobre esta última que farei brevemente um relato.

Desde a inauguração do Masp sempre tive a ideia de oferecer ao visitante exemplos da interferência da arte na vida, tomando do dia-a-dia alusôes a circunstâncias estéticas. Foi maravilhoso quando reuni centenas de simples instrumentos de trabalho na exposiçáo "A mão do povo brasileiro," ou quando apresentei as esplêndidas "Embalagens japonesas," e assim por diante.

A atual manifestação, cujo tema é o automóvel, tenta notar como o aspecto desta popular máquina pode mudar, aliás evoluir, usando a arte da pintura. Foram, de fato, expostas carrocerias e seus elementos pintados. A colaboraçáo veio de uma grande fábrica de tintas, a Glasurit. Admiram-se chassi harmoniosamente decorados com composiçóes, por exemplo, de Paul Klee, o mestre que em seu "caderno de esboços pedagógicos" propóe a aproximação das formas abstratas no processo criativo, figuraçóes de Tarsila do Amaral, Maria Helena Chartuni, e até de primitivos, de vivência realística ou simplesmente decorativa.

A pintura poderá considerar como meio de comunicação o exterior do automóvel? Por que não? Num tempo em que vai crescendo a afirmação do individualismo, a fuga do standard, a posição do personalismo, nada mais fácil que começar a ver nas ruas, algum dia, carros caracterizados por algumas pinturas.

O objeto de uso doméstico pertence, hoje, ao designer, sendo marcado como produto de arte, evidente o empenho de oferecer-lhe uma fisionomia diferenciada, participando das conquistas da estética própria do século. Notar e mesmo propor isto numa exposição pode ser um caso novo no setor. Quando inaugurei o Masp em 47, além de fundar a primeira escola de design no Brasil, numa vitrina de objetos pré-históricos e históricos coloquei também uma máquina de escrever para testemunhar que o Novecentos era rico em novidades com a presença da tecnologia.

\section{Senhor \#338, 8 de setembro de 1987, p.84 (P.M. Bardi)}

UM VOO PELA MEMÓRIA

De Bartolomeu de Gusmão a uma precursora crônica em defesa do aeroporto de Cumbica

Dá prazer a um cronista reler um dos seus artigos depois de certo tempo, vendo confirmadas algumas das opinióes, emitidas mesmo quando contêm um certo espírito polêmico. Algumas vezes tive este prazer e o caso do qual estou escrevendo representa tal contentamento que me parece valer a pena recordá-lo.

Foi recentemente editado um volume de certo interesse dedicado a Aeroportos: do Campo de Aviação à Área Terminal, ${ }^{\text {1or }}$ de autoria de Rubens Rodrigues dos Santos, editado pela Contar. Curioso pelo assunto, inclusive no mesmo dia descobrira no arquivo do Masp a fotografia abaixo publicada. Abro o livro e após o frontispício leio duas notas de jornais. Uma, de I9I2, dizia: "Pilotando um avião Blériot, o glorioso patrício Edu Chaves

IOI Rubens Rodrigues dos Santos. Aeroportos do Campo de Aviaçao à Area Terminal. Sao Paulo: Contar, I985. pousou no primeiro campo de aviaçáo de São Paulo, aberto em cem metros de pasto aplainado da fazenda de seu pai, em Guapira, pouco além do bairro de Santana;" a outra, de 1979, esclarecia que "A área terminal de São Paulo é constituída não por um, mas por vários aeroportos..."

Viro as páginas e, surpreso, vejo reproduzido, como prefácio, um longo e antigo artigo meu dedicado a Cumbica, escrito quando se continuava na imprensa a criticar, aliás, a condenar a construção do Terminal que hoje atende, juntamente com os outros aeroportos, a seis milhóes de passageiros por ano. Comparava Cumbica a Itaipu, as duas empresas que projetaram o Brasil nos caminhos do futuro.

Inspecionando a obra colossal, ainda durante sua construção, com o major-brigadeiro Theodósio Pereira da Silva, presidente da Comissáo Coordenadora do Projeto Sistema Aeroportuário da Área Terminal de Sáo Paulo, e o arquiteto Jorge Michirefe, chefe da Divisão de Estudos e 
Projetos, entusiasmado pelo que já dava para ver me veio à mente o "compasso dentro dos olhos," o juízo confiado ao ver, como acena Michelangelo numa carta a Benedito Varchi: "Esquecer para imaginar, o encanto tomando- se estupor pelo que de incalculável representavam as conquistas técnicas, adendos do espírito, diria mesmo a nova vivência deste final de século."

Relendo minha prosa, noto que, para uma crônica, me deixei levar demais pela empolgaçáo como aspirante a literato, pois evocava, no começo, uma advertência de sir Charles Eastlake: "O nome designa mais um hábito de familiaridade com os fatos do que com a verdade, hábito de considerar mais as aparências e os resultados do que as causas dos fatos..." Era para julgar a meditada arquitetura do Terminal que, revista agora na sua função, convence sempre mais na sua grandiosidade.

Posso confessar que a crônica me convenceu. Mais do que tudo pela conclusão: “... o novo aeroporto é símbolo do otimismo que, custe o que custar, devemos continuar e peremptoriamente propagar, acima das contrariedades. E mais uma vez me refiro ao inglês acima citado. Acena à 'verdade,' à 'aparência' e mais, à “capacidade de distinguir.' O que me leva a distinguir entre crise econômica, que de resto cada nação tem a sua, pior até se a crise é de egoísmo monetário, e aquela que supera o transitório, valendo o resultado. Neste caso, o Brasil construtor e vitorioso."

O esplêndido livro é uma história, muito ilustrada, de quanto o Brasil contribuiu para o desenvolvimento da aviação: desde Bartolomeu Lourenço de Gusmáo, passando por Santos Dumont, até chegar a Cumbica.

\section{Legenda}

Aeroporto de Congonhas, São

Paulo (1940)... I...e seu imprescindível sucessor (1987)

Senhor \#339, I5 de setembro de 1987, p.84 (P.M. Bardi)

Mão dupla para A África

Pierre Verger, em livro e numa mostra em preparação, antecipa os Ioo anos da Libertaçâo

Os problemas da Cultura são inúmeros. Inúmeros mais um: complexos e complicados, num labirinto de momentos e ocasiōes. Recentemente alguém abordou o setor intelectual latino-americano, anotando resultados de ordem geral de um certo interesse.

Geralmente, quando se trata do assunto, são os intelectuais, como categoria representativa, que acabam carregando o peso das queixas feitas pelos que ignoram a realidade das atividades culturais. Parece estarmos lendo "cartas dos leitores," cada um se queixando que sua rua tem a calçada em pior estado. O pessimismo, de vez em quando, toma conta de conversas e discussôes, sendo a política o tema mais saboroso.

Para não desviar do semeado, sabendo que se não se semeia não se colhe, em vez de anotaçóes negativas gostaria de falar de uma esplendidamente positiva, para assinalar um acontecimento que na Cultura brasileira representa um ponto máximo.

O Setor de Difusão Cultural e a

Secretaria de Atividades Sócio-Culturais do Ministério da Cultura acabam de publicar Fluxo e Refluxo do Tráfico de Escravos entre o Golfo de Benin e a Bahia de Todos os Santos, dos séculos XVII ao XIX, de Pierre Verger, pela Editora Corrupio. Verger dedica o livro a Fernand Brandel, Arlete Andrade Soares, Rubens e Marisa P. Ricupero, informando que "sem os esforços dos quais" a publicação não teria sido possível. Reproduzimos a nota para mostrar que há os que agem positivamente.

Sobre os problemas da história colonial, também apresentamos no Masp uma mostra sobre a Nigéria com uma seção sobre a arquitetura que os escravos brasileiros, depois da libertação, construíram naquele país, com fotos de Massimo Marafato.

Agora, a história dos africanos no Brasil é, final e totalmente, enfrentada e documentada pelo mestre francês Pierre Verger, radicado na Bahia, revelador de inúmeros eventos dos séculos da Colônia. O antropólogo do "Musée de l'Homme," com doutrina e uma indômita e exemplar tenacidade, oferece nestas setecentas páginas o resultado das pesquisas levadas a termo nestes últimos quarenta anos. 
Sediado em Salvador, Verger esteve em todos os cantos para reconstruir fatos do nosso passado, perlustrador incansável inclusive fora do Brasil, participando dos ritos negros, para a compreensão dos mitos, não como anotador mas como babalaô: uma fraternidade em que o estudioso dava provas do próprio espírito

O volume é um monumento de saber, de obstinado interesse no historiar que me faz pensar em Casa-Grande e Senzala: a exigência do averiguar, a certeza que se propóe escavar no escondido. É um dote, não faltando o socorro da intuição, aquilo que poucos possuem e em Pierre é das mais notáveis: a ciência casada com a paciência, com amor ao oficio, diria miraculosidade, pois lendo logo transparece a dedicação quase religiosa de Verger.

É um dever assinalar Fluxo e Refluxo..., assunto reservado aos antropólogos e, todavia, de amplo interesse para quem tenta se informar sobre a formação do Brasil. Deve-se ter presente que no ano que vem será comemorado o centenário da Libertação, e que na povoação nacional o africano foi elemento da laboriosa atividade.

O Masp, como já contei, dedicou uma exposição a um curioso caso da Nigéria. Estamos estudando, agora, a organização de uma memorável manifestação paia celebrar o centenário dos providenciais fluxos e refluxos migratórios de negros e brancos ao Brasil, o qual vai para frente apesar dos lamentadores da "crise." A mostra estará aos cuidados de Lina Bo Bardi e de Pierre Verger.

\section{Legenda}

O babalâo [Pierre Verger] com Lina Bo Bardi: uma dedicação quase religiosa

Senhor \#340, 22 de setembro de 1987, p.IOo

A "ESCOLINHA" DEU CERTO

Trinta anos de ensino de propaganda e marketing

Quando se planejou dar vida ao Masp, na São Paulo que parecia mais obstinada a se tomar capital do trabalho do que o centro de arte previsto antecipadamente pela Semana de 22, foi indispensável levar em conta as condiçóes das escolas dedicadas aos ofícios inerentes e providenciá-las. Pensei logo, entre as várias disciplinas, em me interessar pelo problema da propaganda, e com a colaboração de voluntariosos participantes abri a primeira exposição para constatar sua modesta realidade. Daí passar a instituir uma escola foi decisão consequente.

Artistas, psicólogos, sociólogos, sob a direção do dedicadíssimo Rodolfo Lima Martensen, instituíram um ensino que deu certo, tão certo que, através de um desenvolvimento realizado esplendidamente por profissionais ad hoc, veio a ser a atual Escola Superior de Propaganda e Marketing que, por meio da insígnia "Agora é tarde...," segunda-feira dia 3I de agosto, celebrou, no Masp, sua casa de origem, mais uma formatura.

O folhetim de convite levava várias escritas como "O passado distante. O passado próximo. $\mathrm{O}$ passado da escola, e atrás dela. $\mathrm{O}$ passado do Bixiga. O passado no bar do Abel, na cantina da Tia, na biblioteca com o Maurício. O passado dos briefings, da mídia, dos shares." O convite, já peça de cunho profissional, avisava sobre o futuro "tela grande e transparente," esperança, agência, empresa e "o futuro no cliente."

Como boutade da turma, este paginista foi convidado a presenciar a cerimônia na qualidade de "patrono geral," ao lado dos dois paraninfos: no marketing, Paulo de Laurentiz; e Ricardo Ramos, na publicidade. Presente, lógico, o diretor da Escola, prof. Francisco Gracioso, o qual aproveitou para me convidar a ver em Vila Mariana o início da construção do edifício que espera inaugurar no próximo ano como nova sede. $\mathrm{O}$ avanço é exemplar: já funciona a pós-graduação, e se pensa numa filial no Rio Grande do Sul.

Entre uma informação e outra, encontros, cumprimentos e abraços, o auditório se povoava de juventude: um espetáculo que os organizadores do show inaugural andaram preparando em plena animação. Tornei-me cronista. Deslumbrante movimentaçáo, para mim acostumado aos coquetéis de inauguração, compassados e cerimoniosos: um verdadeiro encantamento. Os formandos etiquetados em 
preto, as formandas endossando um chique modístíco do mais alto padráo, todos exaltados por um público legal: crise e política, e até Constituinte sem representantes.

Ataca a música, naturalmente jazz dos mais sonoros, a alegria incontida, duplicada em abraços daqueles que o rapaz ergue a moça, beijando-a até a assistência pedir para parar.

Como publicitários do futuro, projetaram na tela exemplos surpreendentes de boa propaganda. E quando se tratou da cerimônia? Teatralidade pensada, provada, insistentemente marcada de cordialidade, incluindo até brincadeiras. Como "patrono geral," abolida finalmente a mesa de honra, fui o primeiro a ser convocado ao palco, conseguindo não sei como improvisar um discursinho, dizendo que estava comovido e que não me arrependia de ter fundado uma escolinha de propaganda no comecinho dos anos 50.

\section{Legenda}

No auditório do Masp, a formatura da Escola Superior de Propaganda e Marketing

Senhor \#34I, 29 de setembro de 1987, p.IO8 (P.M. Bardi)

A MELODIA DO UKIYO- $\hat{E}$

Exatidão, detalhes, inspiraçâo: a gravura japonesa em sua melhor expressão

O intercâmbio cultural com o Japão continua intenso, o Brasil recebendo extraordinárias exposições de instituições e museus daquela próspera e ativa nação. A mais recente que aqui aporta, realizada no Masp, veio de Atami, uma pequena cidade náo muito distante de Tóquio, e pertencente ao acervo de uma entidade bem singular pelas suas múltiplas atividades. A Associação Mokiti Okada, conhecida internacionalmente pela sigla MOA e seu nome popular, e que mantém um Museu de Belas Artes, nos envia uma esplêndida mostra dedicada aos trezentos anos da gravura japonesa conhecida por ukiyo-ê. A instituição, porém, não se dedica somente às artes plásticas; interessa-se, igualmente, no âmbito internacional, por numerosos outros temas desde os assuntos religiosos até a expansão de empreendimentos culturais, educacionais, filantrópicos e a agricultura natural, seguindo, assim, os ensinamentos de seu mestre fundador Mokiti Okada. Nessas atividades não faltam laboratórios dedicados às pesquisas para a preservação de ecossistemas, aos problemas de ordem industrial e econômica, ao reflorestamento e à preservação florestal e da respectiva fauna - problemas comuns a todos os continentes e metrópoles. Assim, difundindo os ensinamentos de seu fundador: construção de um mundo ideal consubstanciado na Verdade, no Bem e no Belo, Mokiti Okada é lembrado no prefácio do catálogo que apresenta essa mostra ao público brasileiro.

O ukiyo- $\hat{e}$, a arte de xilogravura japonesa, testemunha a vida popular: tudo é documentado à perfeição como as paisagens, os costumes, os fatos cotidianos, ideias e humores. Ukiyo-ê significa "estampas do mundo flutuante." Sua origem foi o sinal de ruptura aflorado no Seiscentos contra a arte convencional de agrado dos nobres e dos samurais, com um anseio de liberdade, pode-se dizer, surgido através do intercâmbio que o comércio com o Ocidente favorecia, novidades que o teatro concentrava. Do teatro surgiram as figuraçôes impressas em imagens muito agradáveis, uma espécie de press-release com ampla difusão: produção artesanal, barata e aceita pelo povo, destacando-se artistas de talento, autores de cenas ricas em protagonistas e fatos do dia-a-dia numa maravilha de expressóes, atenção nos traços, um operar mantido através dos séculos num estilo concebido pela espontaneidade popular no Novecentos, continuado e realçado por mestres de alto valor, que conciliam realismo e espiritualismo, como ensina o Mestre: "o homem relacionando-se com a arte poderá elevar sua alma, encontro à Salvação através do Belo." Ele, depois da Segunda Guerra, construiu o Jardim Shinsen-Kyoen, nos arredores de Tóquio, mantendo o Museu MOA que se tomou famoso por suas atividades educativas acima mencionadas.

É em consequência do Mestre que São Paulo se informa sobre a arte mais representativa do Japão, que começa no período Edo, admirando Masanobu Okumura que oferece um movimentado panorama do teatro kabuki, plateia e palcos lotados e de atores em representação. Na Europa, naquele Seiscentos, não há nada comparável: este instantâneo 
magistralmente desenhado e colorido impressiona os artistas do Barroco. Mas foi somente no Oitocentos que as considerações dessas figurações foram não só compreendidas, mas serviram aos Impressionistas como possíveis novidades, van Gogh entre os primeiros.

Toda a história da xilogravura japonesa é uma marcação de tal exatidão que surpreende pela previsão de gestos e referência dos detalhes, inspiração de composiçóes que superam o fato de ser um trabalho artesanal, para entendê-lo como resultado da arte nacional. O bem documentado catálogo que ilustra a mostra constitui um livro de exaustiva demonstração dessa arte japonesa.

\section{Legenda}

Goyo Hashituguti, Marrecos. Era

Taisho (agosto de I920)

Senhor \#342, 6 de outubro de 1987, p.84 (P.M. Bardi)

Os 40 ANOS DE UMA OUSADIA

Como é que o Masp, graças a Assis Chateaubriand, garimpou ouro na terra do café

A última sexta-feira, 2 de outubro, representou uma data singular para este paginista, pois lembrou um acontecimento todo especial para mim e, ouso dizer, para a cultura nacional. Foi naquele dia que, quarenta anos atrás, o presidente da República, Eurico Gaspar Dutra, presidiu a festa de inauguração do Museu de Arte de São Paulo, a convite de Assis Chateaubriand, seu fundador e inigualável animador.

Planejado para surgir no Rio de Janeiro, depois de várias consideraçóes, o fundador optou por trazer o Museu para a Pauliceia, pois, no seu entendimento, "na terra do café" encontraria os meios para lhe dar vida e, muito provavelmente, servindo-se, como fez, da sede em construção dos Diários Associados na rua Sete de Abril, para abrigar a instituição.

Assim, em 1946, tendo combinado com ele os termos de minha tarefa de realizador, discutimos a programação, iniciando tudo de uma oportuna estaca zero. Como foi estabelecido mais tarde, tratou- se de um caso único e inédito no setor museográfico, favorecido pela cordial amizade que existia entre nós. $\mathrm{O}$ que deu certo, como está demonstrado na realidade cotidiana do Masp e, como constantemente se faz saber, na excepcional vontade do idealizador, descobridor e, quando não, fabricador de mecenas na cidade em vias de se tomar metrópole.

No meu livro, 40 anos de Masp, editado pelo Banco Crefisul, dou conta das aventurosas peripécias do nascimento do Museu que incluiu brilhantes momentos de perplexidade, discussóes e boatos. Estes tão malévolos a ponto de eu propor ao patrão permissão para, em I953, iniciar uma tournée de cem obras da recém-constituída pinacoteca, apresentando-as em grandes centros museológicos da Europa e dos Estados Unidos. Assim respondia de uma vez por todas ao mexerico de que as obras reunidas eram falsas. Inaugurei as manifestaçôes na Orangerie do Louvre, encerrando as no Metropolitan Museum de Nova York.

Na volta, continuamos a programação que não planejei no tradicional andamento dos museus de arte, criando em torno do patrimônio um conjunto completo de escolas, inclusive duas novas no Brasil: a de Design e a de Propaganda, além de uma orquestra juvenil, salas de comunicação didática, mostras periódicas de artistas nacionais e estrangeiros, propiciando assim contatos com a arte da vanguarda internacional. Na verdade, um Museu novo, ideado como um centro cultura que logo atraiu a juventude, afirmando-se no Exterior e hoje conhecido como o maior de arte europeia da América Latina.

A atividade continuou, próspera e produtiva, porém, em 1960, o fundador foi vitimado por séria doença. Mesmo assim o pessoal dos "Associados" continuou a manter as programaçóes, enquanto o Masp se transferia para a nova sede da avenida Paulista, projetada por Lina Bo Bardi com cálculos do engenheiro José Carlos de Figueiredo Ferraz, prédio da Prefeitura cedido ao Masp em comodato, construído em terreno que o governador Adhemar de Barros destinou ao Museu.

Inaugurado em 1968 pela Rainha Elizabeth II, que assim homenageou Assis Chateaubriand, que fora embaixador em Londres durante o governo de Juscelino 
Kubitschek, todos sabem qual a posição e a constante contribuiçáo do Masp à cultura, o que seria supérfluo evocar.

A página de hoje é escrita para consagrar a data e a figura do decidido fundador do Masp que no discurso da abertura, em 47, afirmou:. "Nosso duce, no Museu de Arte, professor Bardi, que é um impetuoso sarraceno, filtrado pela península italiana, uma índole afeita aos prelos, em lugar da tribuna..."

De certa maneira, nestes 40 anos tentei fazer jus a estas palavras do meu saudoso amigo Assis.

\section{Legenda}

O prédio que a rainha Elizabeth inaugurou, em i968... g ...e um saudoso amigo do Masp [Assis Chateaubriand]

Senhor \#343, I3 de outubro de 1987, p.92 (P.M. Bardi)

CEM ANOS, COM EXCLAMAÇÃO

O Museu de Arte de São Paulo comemora o centenário de nascimento do arquiteto Le Corbusier

Os centenários dos grandes mestres têm esta utilidade: convocam pesquisadores e estudiosos para revelar fatos até então desconhecidos, interpretações, até revelaçóes de segredos. Enfim, tudo quanto eles conseguiram acrescentar de original ao patrimônio da vivência humana. No caso do de Le Corbusier, que está sendo celebrado no mundo inteiro, inclusive no Museu de Arte de São Paulo, numa mostra que irá até 30 de outubro, os fatos inéditos de sua vida e obra constituem uma infinidade de surpresas, a ponto de não se saber por onde começar a reconstruir sua personalidade não só de arquiteto como também de pensador interessado e presente nos mais variados campos da arte e da filosofia.

Eu mesmo, tendo conhecido o Mestre, com uma certa intimidade, dediquei-lhe em 1984 o livro Lembrança de Le Corbusier: Atenas, Itália, Brasil, Editora Nobel, documentando encontros, discussões, correspondência, desenhos e até suas pinturas. Era um vulcão em perpétua erupção: esta opiniāo é de todos os que o conheceram e dos que leram suas prosas insurrecionais. Mas isso tudo deixo, agora, com os comentadores do aniversário de seu nascimento, entre eles os membros da associação "Le Corbusier tem Ioo anos!": singular o ponto de exclamação. Esta associação, em Marselha, promoveu manifestaçóes muito bem organizadas, centradas no interesse do Agitador pelo Mediterrâneo. $\mathrm{Eu}$, que tive a sorte de atravessá-lo com ele em 1932, para em Atenas participar do Congresso Internacional de Arquitetura Moderna-CIAM, admirava como ele era de casa por lá. A bordo do Patris II, todos nós ao redor de um evocador da história, à qual queria juntar renovações, outras arquiteturas, que figurassem tão esplêndidas quanto as dos gregos e dos romanos. Não era uma ilusão, era certeza. Surpreendiam-nos suas conversas e os desenhos que fazia para nos esclarecer. Transcorreu-se mais de meio século e cada definição permanece na memória.

Mas não é do passado que esta página vai tratar. Descubro na publicação Le Corbusier et la Méditerranée, ${ }^{\mathrm{I} 2}$ ilustradora da exposição de mesmo título, o nome de uma brasileira, Philomena Miller-Chagas, professora na Escola de Arquitetura de Estrasburgo, radicada na França há 2I anos.

Os centenários servem, então, para se descobrir eminentes brasileiros lá fora e, como neste caso, estudiosos de alto valor. No catálogo, Philomena é registrada como redatora de Le Jeu du Soleil. O problema da luz no urbanismo de Le Corbusier é complexo e envolve o aprofundamento de uma doutrina a ser considerada de base para a edificação: o dimensionamento e a orientaçáo de quanto constitui um conjunto, sua construção e sua posição relacionadas com a luz. Citam-se prerrogativas do Revolucionário: "Rebuscar, reencontrar, redescobrir a unidade que gera as obras humanas e aquelas da natureza... o sol que comanda..."

Saindo desta citação, a professora convence no seu ensaio, oferecendo uma interpretação exata das afirmaçóes do Mestre,

IO2 Centre de la Vieille Charite (Marseille, PACA), Le Corbusier et la Méditerranée. [Marseille]: Editions Parenthèses, Musées de Marseille, [27 jun-27 set I987]. Catálogo de exposição. 
sublinhando seus princípios fundamentais do slogan "sol, espaço, verdor." Esta nota náo se constitui numa crítica sobre o trabalho. É somente para assinalar a excelente participação da brasileira nos estudos dedicados à obra do criador da arquitetura que apelidamos de "racional," aquela que representa a eloquente motivação da arte do Novecentos.

\section{Legenda}

Projeto de Le Corbusier para urbanizar Argel

Senhor \#344, 20 de outubro de 1987, p.78 (P.M. Bardi)

"CANSADO DE QUÊ?"

As homenagens dos amigos nos 40 anos do Masp retemperam a alma de um velho galerista

Minha intenção era não promover movimentaçóes demais pelo aniversário do Masp, velho já de quarenta anos, porém se tomaria indelicado não registrar aqui um acontecimento que repercutiu na crônica paulista pela singularidade, desta vez de exceção e, me parece estar certo, único no fazer rotineiro da vida das artes, refugiada no "Acontece esta semana" dos cotidianos das segundas-feiras.

A caprichá-lo o talento galerístico de Sabina de Libman que, em sua [galeria] Arte Aplicada, quebra continuamente a usança daquele corriqueiro expor, considerando os objetos de modo atraente, numa escolha pessoal que se torna fato de arte. Escrevi caprichar para distinguir o que há de excêntrico, de pensado de vez em quando com fantasia, com o propósito de interferir no convencional. Na Arte Aplicada, que sempre encantou o diretor do Masp, o qual tenta diferenciar as exposiçóes que quinzenalmente oferece, a mise-en-scêne é o que de mais recomendável é possível encontrar na praça: desde a arquitetura requintada até o mais simples objeto apresentado. Diria mais: a recepção amigável, sem a qual o que é exposto sofre de isolamento.

O fato é que Sabina descobriu uma foto impertinente de Olney Krüse: o Bardi abraçando a estátua de Assis Chateaubriand. Ordena, então, ao jovem escultor Rodolpho Veríssimo que a traduza em bronze. Daí, a multiimaginadora encomenda um conjunto de retratos deste que ainda não viajou para o lugar que lhe convém no Purgatório. Recruta um grupo de jovens pintores. (Sabedoria + liberdade + novidade que ao impenitente historiador relembra o vocativo do Cavalheiro Marino: "Quem não sabe maravilhar, que passe a ser almofaçado como um cavalo:"103 já no nascente Barroco se recomendava o maravilhar.) Os recrutados: Gregório, Gretta, Paulo von Poser, Kutka, Newton Mesquita, Granato, Aldir Mendes de Souza, Wesley Duke Lee. (Wesley, você sabe que te reputo o mais moço.)

Mas Sabina não se satisfaz quando recebe minha cara decifrada e denunciada anatômica e cordialmente, e resolve produzir um vídeo, aos cuidados de Geraldo Anhaia, o qual me espia no Masp, eu discutindo, cortejando e comandando. O comportamento é entáo reproduzido num televisor no último dia 7 , as pinturas mostradas com jeito e, numa parede, meus desenhos, antiquíssimos, dos quais Sabina tinha editado um esplêndido álbum, há anos. $\mathrm{O}$ conjunto todo enseja uma reuniấo de amigos e até personalidades, um quarteto tocando e gente, muita gente, abraços, beijos, Olney, rei das explosóes, trazendo flores, os velhos, aliás senhoras de cabelos brancos me perguntando se não estava cansado. Cansado de quê?

A homenagem, mais uma vez, para o Assis, ponto de partida do milagre do Masp. Sim, foi uma generosa e justa deliberação a lápide que a Câmara dos Vereadores mandou colocar no edifício de Lima e de José Carlos de Figueiredo Ferraz, tendo

I03 Giovan Battista Marino (Napoli I569-1625) "È del Poeta [artista]il fin la meraviglia.| Parlo de l'eccellente, e non del goffo,| Chi non sà far stupir vada a la striglia." (Fischiata XXXIII. La Murtoleide fischiate del cavalier Marino con la Marineide risate del Murtola. Aggiontovi le Strigliate a Tomaso Stigliani e l'Innamoramento di Pupolo, e la Pupola. Et altre curiosità piacevoli. Frankfurt: Giovanni Beyer, I6I9, p.35.) 
sido para mim uma orgulhosa satisfação receber o título de "cidadão paulistano" no último dia 4, por iniciativa de Marcos Mendonça. Foi tudo excelente, porém, a noite organizada na Arte Aplicada, reevocando meus passos iniciais de galerista, e o quanto recebi da gente de bem de Sáo
Paulo e do Brasil é uma compensação que, nesta página, atribuo à cara Amiga Sabina, aos artistas por ela convocados e a todos os demais presentes naquela festa inesquecível.

Legenda

Sabina e seus recrutados fizeram

maravilhas a partir desta foto

Senhor \#345, 27 de outubro de 1987, p.84 (P.M. Bardi)

FRAGMENTO POR FRAGMENTO

A escultura de Margarida de Brabante é recomposta em Gênova

Em Miláo se edita uma revista de arte que pela originalidade, competência na escolha dos textos e das ilustraçôes, além da gráfica impecável, deve ser considerada iniciativa única na Europa. Trata-se de $F M R$, iniciais que correspondem a seu idealizador e diretor, Franco Maria Ricci, e que, publicada em italiano, inglês, francês e alemão, conquistou notável difusão.

Cada número revela fatos inéditos, retornos históricos, comentários e indagaçóes redigidos por autores de reconhecida fama. Não é publicação para todos, porém os interessados no estudo da arte têm obrigação de acompanhá-la. No número de julho-agosto se informa a respeito de algumas exposiçóes-surpresa, rememorando personalidades que raramente aparecem. O princípio é o de desencavar o que menos se conhece, o submerso no tempo.

Do calendário das manifestaçóes em evidência nos centros de cultura (aliás, eis ali anotadas as exposiçóes do Masp em Miláo e em Verona, esta "estreitamente ligada à mostra milanesa, ...propóe notáveis obras-primas dos impressionistas...”) é extraído um artigo sobre a reunião dos fragmentos do monumento a Margarida de Brabante, de Giovanni Pisano, esculpida no começo do século XIV. Como uma recensão da recomposição dos pedaços exigiria muitas páginas de Senhor evocando o mestre que com Giotto registra a universalidade da arte preparadora da Renascença, penso ser interessante destinar meu espaço a um período cheio de movimentaçóes na Europa. É quando Arrigo viI, no comando de três mil homens fortemente armados, desce à Itália para, a ferro e fogo, pôr ordem no bordel político, e se fez coroar titular do Sacro Império Romano.

Em Gênova a peste lhe mata a esposa, Margarida, sua virtuosa conselheira e moderadora de suas açóes. Desesperado, Arrigo, para quem Dante guardou o símbolo do Veltro, confere a Giovanni Pisano a tarefa de eternizar a memória da mulher no Sepulcro da Capela de São Francisco, em Castelletto. O velho escultor atende ao chamado. Pouco depois Arrigo vai para o Céu e seu túmulo, de Tino de Camaino, ainda pode ser visto no Domo de Pisa.

Os mármores de Margarida, em vez disso, por causa de guerras, descuidos, destruiçóes, se fragmentaram e agora, na recomposição, a crítica de arte está escrevendo um romance em capítulos de magistral tensão e de um final ainda em aberto, como diz o reconstrutor Max Seidel: um pedaço aqui, outro acolá e hoje se tem uma visão da obra mutilada, e se contam as vicissitudes que empenharam os conhecedores. É somente em I804 que soa a hora de pensar em possíveis descobertas, pois um presidente do Magistério das Finanças de Gênova decide a venda de todas as esculturas da Capela. Assim se repetia o que aconteceu em Roma com os mármores do Coliseu e em Paris com os mármores da fachada de Notre-Dame, comprados por um senhor Bertrand para servir na construção de alicerces de prédios. Desde então a memória de Margarida de Brabante vem à superfície. Há os que compram e revendem, alimentando o mercado e assim, fragmento por fragmento, individualizados, idealmente recompostos, acertadas as atribuiçóes, chegou-se a esta exposição com sede na Commenda de San Giovanni de Pre na mesma Gênova que náo conservou uma das produçóes mais famosas de Giovanni Pisano.

Escreve Vittorio Sgarbi, um dos convocados para lembrar o mestre: "As obras de arte abrem muito longos e nunca 
concluídos diálogos do autor com a sua imagem, mas também de um testemunho, de um sobrevivente que, através do autor, atribui os seus sentimentos, suas paixôes, suas recordações e a memória viva daquilo que foi, do próprio mito, a um simulacro de pedra ou de madeira que continua a falar."

Pisano continua a ser, provocando emoçôes: "Todas as formas mais altas da arte têm procurado reconhecer em um rosto, num movimento de corpo, num olhar voltado para o Céu a clara expressão da alma..." Compreende-se assim a figura aqui reproduzida.

\section{Legenda}

A rainha Margarida de Brabante, esculpida por Giovanni Pisano, no início do século XIV

\section{Casa Vogue \#6, novembro-dezembro de 1987, p.38 (P.M. Bardi)}

\section{A CONSERVAÇÁO DA MADEIRA}

Quem não acompanha os trabalhos que se desenvolvem em um museu de arte não sabe qual o empenho na conservação das obras, especialmente nos trópicos, onde as condiçôes climáticas representam, às vezes, casos desesperadores. A conservação depende de cuidados constantes, mesmo que os ambientes sejam equipados de ar-condicionado e a umidade seja permanentemente controlada.

As peças que necessitam mais de atenção e intervenção são as de madeira, geralmente deterioradas por agentes biológicos, por exemplo os cupins, insetos que se alojam na madeira e dela se alimentam, cujo combate é feito através de preservativos complicados, nem sempre conseguindo-se resultados satisfatórios.

No ano passado, encontrando-me em Olinda, depois de uma conferência em que se discutia também conservaçáo, fui convidado pelo abade-mor do Convento dos Beneditinos para ver um painel pintado no século I6 na Itália, em condiçôes realmente sérias, pois os cupins tinham dele tomado conta ao longo de séculos: a madeira tomando-se um reticulado de cavernas embaixo da película pictórica e da douração.

Aceitei fazer no laboratório de restauro do Masp um exame e uma tentativa de reparo. Quando a pintura chegou aqui, foi providenciado seu ensacamento num plástico, injetando-se substâncias químicas que, por prática, se sabe que penetram nas galerias, eliminando os devoradores. O tratamento durou meses e meses, para depois finalmente se passar à aplicação de injeçóes, destruir as partes que se tornaram vazias, solidificando o que fosse possível da madeira.
A referência deste caso serve para assinalar a edição de um oportuno Manual técnico I: Madeira, características, determinação, tratamento, redigido pelo Ministério da Cultura, a Secretaria do Patrimônio Histórico e Artístico Nacional e a Fundação Nacional Pró-Memória. Trata tanto da madeira em geral como das edificaçóes e de seus agentes destrutivos, pois, além dos cupins, agem também coleópteros, fungos e brocas marinhas, comuns nos ambientes em que o calor e a umidade favorecem a ação dos destruidores.

Fornecidos os elementos que constituem a madeira, dando conta das condiçóes de crescimento e dos ambientes variáveis das espécies, são resumidas as propriedades físicas e mecânicas das madeiras brasileiras, para entrar na descrição dos cupins, que vivem em vastas colônias, semelhantes às das abelhas, com rainhas, reprodutores, bandeirantes à procura de novos territórios, atacantes vorazes e destruidores dos alimentos retirados. $\mathrm{O}$ cupim não suporta a luz. Como combatê-lo? O Manual técnico oferece uma série de normas, também de proteção para quem aplica substâncias para agredir os insetos. Trata-se de produtos tóxicos, chamando atençáo para náo se reduzir a resistência da madeira.

No caso de restauro de mobiliário, se constata que agentes químicos podem danificar os acessórios metálicos. O restaurador deve cuidar sobretudo da madeira e o Manual aconselha os modos de ação geralmente escolhidos conforme as experiências, pois ainda não se descobriu um produto correspondente às exigências e, por outro lado, as soluçóes sáo sempre sugeridas mediante os casos apresentados.

Interessante a pesquisa do Manual referente à idade da madeira. Nossa experiência 
pode acertar que madeiras muito antigas apresentam a açáo, às vezes rápida $\mathrm{e}$ imperceptível, do cupim. Uma pintura sobre madeira do quinhentos foi achada em tal estado que se optou pelo transporte da película da pintura: operação delicada e laboriosa. Ocorre também o desenvolvimento de fungos, organismos vegetais que se apresentam em milhares de espécies, dependendo da umidade, além das brocas marinhas, outro inimigo.
Enfim, a natureza oferece uma quantidade de benefícios e ao mesmo tempo uma quantidade de danificaçóes, determinando pesquisas tecnológicas para defesa, distinguindo-se o IPT paulista, presente no Manual com seu fichário dedicado às madeiras nacionais. Completa o Manual o trabalho da SPHAN, Secretaria do Patrimônio Histórico e Artístico Nacional, sem dúvida uma séria iniciativa para a preservação do patrimônio, especialmente dirigido a museus, indicando até os fabricantes de remédios.

Senhor \#346, 3 de novembro de 1987, p.84 (P.M. Bardi)

A ARTE DO COTIDIANO

Ela está nas ruas, nos prédios... Não visa lucros a seu criador mas servir à comunidade

Recentemente, na exposição de xilogravuras japonesas 300 anos de Ukiyo-e, patrocinada pela Fundação de Arte e Cultura MOA, do Japão, mais divulgada pela imprensa como publicidade do que como fato cultural, o presidente daquela famosa instituição, Takaaki Nakano, concordou comigo, num dos discursos oficiais, de que a arte se encontra na vida do dia-a-dia. É o que, geralmente, se procura parafrasear nestas páginas. Na de hoje, por exemplo, fazendo referência a uma entrevista que leio no Suplemento Cultural do Jornal da Bahia sobre problemas técnicos do concreto armado. O entrevistado é João Filgueiras Lima, o Lelé, um discípulo de Niemeyer, arquiteto que se especializou na produção de "argamassas" - um sistema de engenharia da maior importância. Já com um currículo de realizaçóes que determinaram sérias conquistas na construção popular na administraçáo Leonel Brizola e Darcy Ribeiro, no Rio. Agora o arquiteto opera em Salvador, na arrancada edil que seu prefeito Mario Kertesz está promovendo.

A arte inclui a arquitetura, esta abrange a política, envolvendo polêmicas de tema social, etiquetando-as de esquerda. $\mathrm{O}$ João, ou melhor dizendo, o Lelé, consumado cultor do xadrez em que se jogam as disputas do momento, defende através do seu trabalho argamassiano princípios humanos básicos em benefício do povo, combate a galopante miséria envolvendo quantidade de decisóes naturalmente não do agrado da estabilidade do poder.

O inovador dirige a Fábrica de equipamentos comunitários da Prefeitura de Salvador que, barateando os custos, atende ao máximo de construçóes, especialmente as destinadas a favorecer a administração, pondo em prática um sistema tecnológico que possibilita atingir suas finalidades. Trata-se de uma maneira de trabalhar o "pré-moldado."

A entrevista deve ser registrada entre as corajosas, custe o que custar, denunciadora e, em certos aspectos, severa. Criticando habitual corrida especulativa ao negócio, de realizar não para servir à comunidade mas visando os próprios interesses, às vezes descritos até em crônicas policiais, o arquiteto vai contra, como diz, "aqueles que querem ter lucros em cima da miséria” deixando de lado o trabalho honesto. "Se isso desagrada a algum grupo de empresários eu acho que é ótimo, até fico muito satisfeito em desagradá-los e os objetivos deles são inteiramente opostos aos meus."

Lelé justifica seu modo de resolver alguns aspectos da arquitetura, especialmente nas áreas que define "transitórias:" construir habitaçóes populares, usando os pré-moldados, que são mais leves, tornando o custo de construçáo bem reduzido, pois chegam a pesar cinco vezes menos do que as construçóes convencionais. $\mathrm{O}$ resultado tem se mostrado eficiente. Disse ele: "A atuação tem de ser extremamente delicada, para que nossa intervenção realmente tenha uma absorção social. Considero as intervençóes que temos feito através da fábrica como transitórias, em áreas transitórias dos grandes centros urbanos. São assentamentos muito precários, mas como solução imediata acho que nós, profissionais, 
precisamos nos ater a esse problema. É preciso melhorar um pouco a condição de vida dessa gente enquanto não há uma reforma política, estrutural e social que nos permita atingir a sociedade como um todo."

E daí se volta ao problema que sempre é tratado nas conversas e que, no aspecto prioritário que é realizar, Salvador dá um exemplo. Seria oportuno segui-lo também nas megalópoles sulinas empobrecidas demais e que não resolvem a questão do não-habitar de milhóes de brasileiros. Nas declaraçóes de Lelé deve-se notar a palavra transitórias para entender que o problema é de extrema atualidade e tem em conta a realidade da urgência de soluções, superando os murmúrios sobre "beleza," deixando-os para a arquitetura que se vê por aí. As acusaçóes, por parte dos situacionistas, são de esquerdismo. Incrível.

\section{Legenda}

Os artistas engajados moldam até concreto

Senhor \#347, Io de novembro de 1987, p.83 (P.M. Bardi)

Rumo Às ARTES DO Sul

Na visão subjetiva dos artistas de Santa Catarina, a transformação histórica da sua gente

Uma novidade editorial, que acredito seja de interesse geral, levou-me a Florianópolis. A esta capital foi dedicada uma esplêndida monografia de autoria de Glauco Carneiro, iniciativa do Banco Bandeirantes e do Museu de Arte de São Paulo, favorecidos pela Lei Sarney de incentivo à Cultura. Constitui o primeiro volume de uma série que se quer editar dedicada à origem, história e atualidade de várias cidades brasileiras, através de textos de agradável leitura, complementados por ilustraçóes e fotografias, como este primeiro que se refere à capital de Santa Catarina.

O lançamento do livro se deu na recém-inaugurada sede do Banco Bandeirantes, em Florianópolis, com a presença do governador de Santa Catarina, Pedro Ivo, diversas autoridades e grande público, numa noite de fraternal encontro entre paulistas e o pessoal da Ilha, como sempre hospitaleiro. O livro, destinado ao grande público, revela um passado rico em acontecimentos, desde os primeiros povoadores, a defesa do território pelos portugueses diante das invasóes, até as sucessivas determinaçóes da República. Acontecimentos geralmente bem conhecidos apenas pelos estudiosos, expondo-se passado e realidade numa precisa prosa informativa; e por intermédio de ilustraçóes, que prendem o leitor, documentando amplamente o que se registrou no Desterro e depois em Florianópolis, onde hoje admiramos um desenvolvimento surpreendente, as várias imigraçóes acertando progresso e brasilidade.

Durante o lançamento desta primeira monografia, unanimemente aceita e favoravelmente comentada, até surpreendendo pelo espírito cordial com que foi redigida, baseada numa bibliografia ainda não exauriente, porém utilizada inteligentemente pelo autor, este paginista, como coeditor, também pronunciou algumas palavras. Aproveitei a ocasião para notar a magnífica atividade que se vai afirmando no setor das artes no Sul, observadas in loco: museus e instituiçóes culturais demonstram singularidades e factível ação: Museu de Antropologia, na Cidade Universitária, que apresenta a laboriosa formação daquele litoral, admirável obra do famoso professor Franklin Cascaes, que nos dá a visão e o conhecimento dos maquinários pré- industriais na vida dos ilhéus e colonizadores; o Museu da Ordem dos Jesuítas, conservador e documentador de arqueologia e zootecnia; o Museu de Arte Contemporânea. Uma fundação se empenha em reunir e incentivar os vários setores das artes num amplo edifício que abriga departamentos, sob a denominação de Oficinas, onde se desenvolvem atividades no campo da pintura, escultura, cerâmica, gravura, comunicação, música, dança, conseguindo resultados exemplares.

Ao comentar sobre o quanto a visita tinha-me impressionado, dizendo que considerava o conjunto como único no Brasil, provoquei aplausos de consentimento que não esperava. Em Santa Catarina, notadamente em Joinville e Blumenau, as artes são bem exercidas, e através das informaçóes que tive da doutora Lygia Roussenq Neves, superintendente daquela entidade, de como funciona a Fundaçáo que promoveu e ativou os trabalhos, pensei nos meus tempos paulistas, 
quando no Masp lançamos a iniciativa de dar vida às artes, conseguindo algo semelhante numa nova estrutura, diria exemplar. O lançamento de Roteiro da Ilha Encantada, de Glauco Carneiro, propiciou que se constatasse naquela capital um centro de cultura de alto gabarito.

\section{Legenda}

O universo imaginário dos

ilhéus, por Franklin Cascaes

Senhor \#348, I7 de novembro de 1987, p.I08 (P.M. Bardi)

PARADO NO TEMPO

Para o arquiteto Manuel Siqueira Marques, a fotografia é uma arte menor

Sendo por tradição mais ou menos metido na prisão das artes, aproveito a ocasião de um escândalo registrado na Folha de S.Paulo (a fotografia: arte ou arte menor?) para informar que vou lançar, na coleção Arte e Cultura, editada pelo Banco Sudameris, o livro Em tomo da fotografia no Brasil, onde ouso considerar o clic uma arte sem adjetivaçóes. $\mathrm{O}$ escândalo foi o seguinte: no jornal da Funarte, órgão do Ministério da Cultura, foi suprimido um artigo que classificava a fotografia "arte menor," sendo refeita a edição. O texto clamorosamente censurado era de autoria do arquiteto Manuel Siqueira Marques, o qual bombardeava: "E hoje, quando as artes plásticas se veem atropeladas pela fotografia - o que não deixa de ser uma forma menor de arte - compreende-se que as tradicionais ditas artes maiores, para sobreviverem como tal, terão de enveredar pelo caminho onde elas se tornam insubstituíveis: o da capacidade de transmitirem sentimentos não passíveis de serem totalmente apreendidos por palavras ou fotos."

O invento de Daguerre é, então, atropelador das artes plásticas maiores? No conceito do fuzileiro, seriam capitais a Arquitetura, a Pintura e a Escultura, pois estas "transmitem sentimentos." Afirmar isto, hoje, significa permanecer imóvel nas páginas dos manuais de Belas Artes do Oitocentos. Trata-se de um tão culturalista disparate que o próprio diretor do Instituto Nacional de Fotografia, Walter Firmo, não considerou a prosa como uma tragédia. Valem hoje no setor as afirmaçóes consideradas de ruptura. O sentimento agora está refugiado na sensibilidade e se exerce em qualquer "trapalhada."

Nossos críticos não se comoveram, na Bienal, descobrindo o sentimento que Marcel Duchamp descarregou numa roda de bicicleta, ou no "bigodear" a Mona Lisa? Sem recorrer aos luminares que sempre distinguiram o que um artista compreende e sente e o que exprime através do que tecnicamente está à sua disposição, é pacífico que um fotógrafo, a par de um pintor, possa expressar um sentimento, posição hoje incerta para um arquiteto genérico ou um escultor que se comunica com uma ou duas chapas de metal.

Curioso, muitas vezes a fotografa consegue sensibilizar uma destas formas através de imagens próprias.

Assim as "trapalhadas" do fotografar me parecem um inadvertido escaramuçar. E se me permite o presidente Evaldo Correa Lima, deixe escrever na Programação Funarte os últimos resíduos de mentalidades destinadas à amortização. Não é a única besteira: numerosos outros têm direito de se manifestar, e os contrários de reagir.

Caro presidente da Funarte, vou mandar-lhe meu livro sobre fotografia: vai ver ali que o Brasil reúne elementos, e não foi possível arrecadar todos, de singular sensibilidade. (Sentimento de conotação, às vezes, romântica.) $\mathrm{O}$ último adjetivo me faz lembrar Eugène Delacroix, um pintor do qual tive a sorte, há quarenta anos, de adquirir para o Masp suas famosas Quatro Estaçôes, hoje em empréstimo ao Kunstinstitut de Frankfurt, Alemanha, na retrospectiva do Mestre. Dizia ele em seu Diário, já na metade do Oitocentos: "O sentimento faz milagres. Graças a ele uma incisão, uma litografia produzem na imaginação efeito da própria pintura." Eu juntaria: a fotografia, arte não menor.

\section{Legenda}

Fotografia de Pedro Vasquez: uma exposiçáo de sucesso no Masp 
Senhor \#349, 24 de novembro de 1987, p.84 (P.M. Bardi)

SOS MORUMBI

Do bairro que nasceu com vocação para santuário ecológico sobrou

um bosque, onde queriam erguer uma delegacia

Não é em todos os anos, nem em todos os decênios, que os habitantes de uma regiáo conseguem preservar um determinado ambiente.

Quem escreve participou recentemente de um abaixo-assinado em defesa de quanto restava de um propalado "jardim" que nos anos 30 foi divulgado como o non-plusultra de um dos novo: bairros da Pauliceia. Tão decantado foi pelos lançadores, prometedores de encantos e alegrias, que a arquiteta Lina Bo, minha esposa, se convenceu, após visitas e consultas, a adquirir até mais do que a área necessária para construir uma casa.

O jardim se denominava Morumby e se chegava até lá percorrendo uma descomposta pista de terra, aquela que muitos anos depois foi asfaltada, sendo hoje a avenida onde espacia o Palácio dos Bandeirantes.

O sítio ou fazenda de chá foi sacrificado, à altura do atual número 5000: conservava até sua casa-grande e nas proximidades sua derrocada capela, e mais adiante outra lembrança de Deus. Na entrada, nos limites que marcavam o acesso ao "bairro residencial mais tranquilo de São Paulo,” as imobiliárias mandaram erigir duas volumosas colunatas de estilo vagabundo, ainda hoje monumento do empreendimento.

Os recém-chegados Bardi, atendendo a todas as imposiçóes dos cedentes, autêntico exagero, apesar de termos sido os inauguradores das construçóes, construíram a casa de vidro, hoje tombada pelo patrimônio estadual. As imposiçóes foram: afastamento de quinze metros da rua, deixar os limites do terreno sem muros etc. A natureza encontrada era ainda florestal, tanto que não foram raras as cobras descobertas quando se decidiu abrir estreito caminhos para aproveitar o verde, onde no alto pulavam até duas vivazes preguiças.

Foi uma aventura a construção, ocorrendo atolamentos de carros e consequentes quebras dos veículos, porém, construída a casa, maravilha das maravilhas viver rodeado pela floresta, até uma serpente visitando o progresso, sendo gentilmente remetida de volta ao mato. Hobby inesquecível foi contribuir com o amigo arquiteto Gregori Warchavchik no restauro da setecentesca Capela, eu chamando pintora Lucia Suané para afrescar algumas paredes. Tudo corria à perfeiçáo: chegava a luz, se providenciava a água e o esgoto e, jeitosamente, um telefone. $\mathrm{O}$ menor lote era de dois mil metros [quadrados], que depois passou a mil e dali a quinhentos, sendo abolido o distanciamento obrigatório da construção da rua General Almério de Moura. E surgiram muros, minhas preguiças emigraram, desapareceram as cobras, tendo própria sede da fazenda sido descaracterizada por um desses restauros caros à burguesia etc.

O bairro de luxo ficou como se vê hoje, até com bancos e indústrias, e os arranha-céus do Real Parque às portas. Continuo a história, retomando o que conto no primeiro parágrafo: havia no conjunto territorial ainda um bosque, felizmente propriedade do município, e a uma certa hora nós do maltratado bairro descobrimos que fora decidido lá construir uma delegacia de polícia. Faltava só isto! Fizemos, então, um abaixo-assinado dos moradores da região para fosse ocupado por uma praça pública. Foi proposto até a quem dedicá-la. Eu indiquei Gilberto Freyre. Mas, foi escolhido o nome de Carlos Drummond de Andrade: magnífico. Em minha qualidade de primeiro habitante do abandonado bairro, permito-me louvar a deliberação do prefeito Jânio Quadros, acolhendo a proposta que o secretário Cláudio Lembo lhe levou. De vez em quando se consegue preservar.

\section{Legenda}

Breve, neste vestígio da exuberância perdida, a praça Drummond 
Senhor \#350, I de dezembro de 1987, p.8I (P.M. Bardi)

LEMBREM-SE DE DELACROIX

A burocracia dos salóes desfavorece a arte

As mudanças operadas na pintura ao longo do Oitocentos foram bem decisivas: transferi-las da herdade do Romantismo, de espírito ainda rococó para o Impressionismo, tendência que abriu caminho para manifestaçôes de mais livre expressão, para dialogar em singulares afirmaçóes individuais, foi transferência lenta e laboriosa.

As mudanças se desenvolveram polemicamente contra o status quo da Academia, sempre imperando no gosto por tradição. Nasceu com livre linguagem generalizada. Vale a pena nos referirmos a um episódio do qual indiretamente este cronista se encontrou envolvido: Eugène Delacroix, pelos idos de I86I-62, pinta quatro grandes telas representando as quatro estaçóes. Pretende apresentá-las no Salão de Paris, mas dois meses antes descobre que o Salão não admite mais que três obras por artista. Ocupado com outras composiçóes deixa as quatro estaçóes incompletas. Um ano após, em i863, Delacroix morre e as obras fazem parte do seu espólio.

As quatro telas acabaram mercadoria parisiense, sem encontrar compradores, pois foram julgadas mais esboços que pintura acabada. Para encontrar adquirente, um marchand as confia a um amanuense acadêmico, o qual, servindo-se de Delacroix como inventor dos temas, as repinta à maneira escolástica.

Passados alguns decênios, as telas foram encontradas por alguém que descobre a aventura: são libertadas da repintura e voltam ao mercado como obras-primas do mestre. Dáo muitas voltas pelo mercado para finalmente acabar no Museu de Arte de São Paulo, por decisão do cronista desta página.

As mesmas telas estiveram até agosto passado no Kunsthaus Zürich, na Suíça, participando de uma grande exposição dedicada a Delacroix, a qual se encontra atualmente no Städtische Galerie im Städelschen Kunstinstitut, Frankfurt, Alemanha.

As peripécias por que passaram estas quatro telas dão uma pálida ideia dos gostos e dos sistemas dos Salóes. Devo lembrar que essas instituições sempre desfavorecem a vida dos artistas. Já em I79I se discutia a "liberdade das exposiçóes," quando uma delegação da "Comuna das Artes" vai expor na Assembleia, em Paris, a necessidade de deixar livre a participação das manifestações artísticas; o Salão, então aberto no Louvre destinado ao Palácio das Ciências e das Artes, pediu a eliminação das dificuldades impostas pelas autoridades acadêmicas. Obtiveram um decreto que sancionava a liberdade de expor o que quisessem; todavia, o júri de aceitação era então composto também de não-acadêmicos. Existiram também os antiacadêmicos. Tem início naquele ano o operar em favor da liberdade reservada às artes.

Mas o caso Delacroix que pintou as quatro estaçóes e não conseguiu expô-las, pois somente três foram exibidas, confirma como os Salóes sempre travaram as mudanças burocráticas.

A lembrança é apenas para que nos perguntemos: será que, depois, de dois séculos, também no Brasil, se continua incentivando o estabelecimento "Saláo de Belas Artes," hoje que a liberdade de exposiçôes é um fato adquirido?

Antes cada Estado, excluído alguns, tinha seu salão, outorgando suas medalhas de ouro, grandes, médias, pequenas, de prata, de bronze, mençóes honrosas, diplomas de participação do certame etc. Agora se sabe que até pequenas cidades se ornam deste superado sistema de incentivar pintura e escultura.

Verdadeiramente, porém, as "belas" artes devem evoluir um pouco mais.

\section{Legenda}

Uma das telas de Delacroix: O veráo:

Diana surpreendida por Acteon 
Senhor \#35I, 8 de dezembro de 1987, p.84 (P.M. Bardi)

A SÁTIRA PELA IMAGEM

Quando a fotografia serve à polêmica e à provocação

Esta página, também como os amigos de Senhor quiseram intitulá-la, vai reunindo mais memórias do redator e pontos de vista que, em recentes discussóes, dão a ideia de um conservador. Pode ser que eu seja conservador neste marasmo das artes, na poluição de novidades uma mais excêntrica do que a outra, na corrida incontrolável de extravagâncias, divertidas, sim, porem não classificáveis no espaço que nos meus tempos era reservado às vanguardas.

Naturalmente, apoiava-se o pessoal da ruptura contra o academismo que se tornava insuportável. Considerava-se válida a produçáo dos seguidores de Marinetti. Mas foi por um período breve, diria de reconsideração, de qualquer modo as reservas se manifestavam. Alguém começou a desprezar as obras-primas, por exemplo, a Monalisa, pondo na berlinda Leonardo da Vinci.

Mas as artes deviam ir para frente. $\mathrm{O}$ ponderado manifesto do Futurismo de I920 declarava estar bem distante dos plágios deduzidos de tudo quanto um museu representava, todavia era favorável a novos rumos para os valores plásticos e que deviam conquistar novos.

Se participou, como estava dizendo, do espírito das vanguardas, e uma vez que, meio século atrás, me interessava por arquitetura, foi lógico na Itália combater o estilo "romano-imperial-modernizado," como já escrevi outra vez, uma subespécie de um neoclássico maldigerido, aliás, ludibriado pela onda exaltadora do fascismo.

Uma das minhas ações, além de propor que a Itália acolhesse Gropius e Bauhaus, defenestrados pelo nazismo, foi o caricaturar com uma certa audácia, naqueles tempos difíceis de ditadura, o estilo então em pleno andamento, numa "Mesa dos Horrores"

Por que recordo a iniciativa?

Simples: porque vejo agora reproduzida a "mesa" no importante livro de Dawn Ades, do Departamento de História e Teoria das Artes na Universidade de Essex, na Inglaterra. Trata-se de uma monografia completa sobre Photomontage, editor
Thames and Hudson de Londres. É, sem dúvida, o trabalho mais completo desta singular manifestação do comunicar através do emprego da fotografia, consequência de uma meticulosa pesquisa.

É no começo do século que a imagem fotográfica é utilizada em composições para dar ênfase ao Surrealismo, depois para estabelecer alegorias, e também para polemizar, como foi o meu caso. A propaganda política teve também na fotomontagem elementos de notável valor. Sob o ponto de vista arte, no livro se notam dadaístas, emergindo mestres como El Lissintzky, Max Ernst, Magritte, George Grosz, Schwitteers, Heartfield, Picabia, André Breton, Man Ray, Marcel Duchamp, Paolozzi, Moholy-Nagy, Malevich, para recordar os nomes mais conhecidos.

A história deste meio de comunicação, que hoje é prática comum, é exposta pela autora com riqueza de elementos. Parece que a novidade pode ser datada em I9ı6, em Berlim. Escreveu George Grosz sobre ele e Heartfield: “...Não tínhamos ideia das imensas possibilidades ou da penosa mas bem-sucedida carreira que esperava a nova invenção. Num pedaço de papelão nós colamos uma confusão de anúncios de cintos para hérnia, livros de cançóes estudantis e comida para cachorro, rótulos de bebida e de garrafas de vinho, e fotografias de publicaçóes cortadas à vontade, à maneira, digamos, de quadros, o que teria sido proibido pelos censores se nós o tivéssemos dito em palavras."

Nos anos 30, a fotomontagem teve sua ampla difusão. Naqueles anos saiu a minha "Mesa dos Horrores" que Dawn Ades comenta no livro assim: "Uma fotomontagem satírica de P.M. Bardi, Mesa dos Horrores (I93I) foi montada para uma exposição de arquitetura racional e pretendia mostrar a visão retrógrada e a atitude retrógrada e enferrujada da "política construtiva oficial italiana."

\section{E no Brasil?}

Em meu livro, Em Torno da Fotografia no Brasil, edição Sudameris, publico duas fotomontagens de Valério Vieira, 
de uma originalidade singular, da primeira década deste século. Será uma surpresa para Dawn Ades.

\section{Legenda}

Fotomontagem pioneira do

paulista Valério Vieira (1906)

Senhor \#352, I5 de dezembro de I987, p.IOo (P.M. Bardi)

LE CORBUSIER, MODERNISTA

Rabiscos inéditos de uma visita ao Rio de Janeiro e uma conferência que abalou o Brasil

Somos centenas, aliás milhares de redatores que cotidianamente ou casualmente preenchem colunas e páginas da imprensa nacional, cada um na própria seara ou especialidade: todo um escrever que compóe a parte mais documentada da opinião pública.

Também este paginista faz parte da turma, agitando de vez em quando alguma ideia. Desta vez é um fato concreto que tem por argumento problemas de estética ou dependentes desta que dizem filosofia, referente à arte. Da arte são múltiplos os andamentos do gosto, das novidades sensíveis e de quantas outras exigências e ilusóes, propostas, rupturas, colaboraçóes etc.

Cada um se interessa e sentencia a respeito da beleza, sendo esta a finalidade primordial ou última da jornada estética, se bate na informação, crítica ou um simples julgar para que, a seu modo naturalmente, as coisas se encaixem em princípios válidos.

Neste século, as contribuições foram extraordinárias, sendo notadas intervençóes, como se sabe decisivas. Para ficar em casa, vale a pena registrar que um grupinho de vanguardistas combinou na Semana de Arte Moderna explodida no Teatro Municipal de São Paulo, em 1922. O propósito foi liquidar um certo operar concentrado nas escolas de belas-artes, revelando a um público extremamente ligado ao academismo e às novidades que $a b$ antiquo foram proclamadas por Marinetti no seu manifesto futurista.

De vez em quando pesquisei sobre as consequências da Semana, apontando até em livros a escassa repercussão do generoso empenho. A arte que devia refletir a Semana, a náo ser a vinda e a ação de Gregori Warchavchik e os disparos de Flávio de Carvalho ficou acomodada no ecletismo compositivo até, praticamente, a chamada de Le Corbusier em 1936 para dar as ideias básicas para construção do Ministério da Educação e Saúde: o "risco" dele servindo como ponto de partida da renovação. Além do "risco," o Mestre do funcionalismo em arquitetura pronunciou uma série de conferências às quais se deve atribuir a substância do mexer no setor, através de justificaçóes críticas do maior valor.

Quando este paginista se interessou pelas consequências da Semana, ficou surpreso com o seguinte: Le Corbusier nas conferências, conforme seu sistema, desenhou uma série de pranchas para ilustrar seu discursar. Eu logo pensei em escrever um livro de recordaçôes dedicado a Le Corbusier, do qual fui bom amigo desde o Congresso de Atenas em 1933. Fui ao Rio de Janeiro à procura dos grandes desenhos, mas ninguém sabia de nada. Dirigi-me ao Mestre e soube que as folhas, enroladas, voltaram para Paris, pois a ninguém ocorreu a natural ideia de lhe pedir para deixá-los na praça, também porque as conferências foram pagas regiamente.

É lógico que o curioso pesquisador se dirigiu a Le Corbusier para obter as peças. $\mathrm{E} \mathrm{o}$ arquiteto que nunca foi contrário a negócios, me disse que os cedia através de pagamento. Breve: paguei as peças, juntei-as ao material que vinha reunindo: cartas e desenhos dele. Reentelei os grandes desenhos e sempre pensei que este documental se havia arquivado no Brasil

Confesso aos meus leitores que o rolo do precioso material vai ser doado à Secretaria do Patrimônio Histórico e Artístico Nacional, justa homenagem ao Polemista e ao mesmo tempo minha homenagem ao Brasil onde tive a possibilidade de contribuir para abertura e organizaçáo do principal museu de arte europeia da América Latina, juntamente com Assis Chateaubriand.

\section{Legenda}

O Mestre vê o Rio (material doado ao Patrimônio Histórico Nacional) 
Senhor \#353, 22 de dezembro de 1987, p.65 (P.M. Bardi)

A LeITURA PELO DESENHO

A pedagoga Angela Lago não usa texto em seus livros. E ensina

às crianças o mundo real através da fantasia

De vez em quando se descobrem os fatos mais escondidos do Brasil, e a descoberta se dá não em nossos confins, mas lá fora. E desta vez de modo bem singular: chegando às minhas mãos um catálogo da Slovenska Narodna Galeria, de Bratislava, Tchecoslováquia, dedicado à Bienal de Ilustraçôes de 83, leio uma página dedicada a Angela Lago, intitulada Baroque and Brazilian Children's Book Illustrations.

Tive ali o prazer de conhecer uma artista que se dedica a publicar livros de alto interesse social pois tem como campo de ação a criança. Praticamente se trata de histórias sem o acompanhamento de legendas, usando basicamente figuraçôes, o oposto das historinhas em quadrinhos que através da palavra ajudam o pequeno leitor a compreender o que se quer fazer saber. Nos livros de Angela o observador infantil deve imaginar, despertar, intuir, encontrar soluçôes do conto, com a ajuda da fantasia.

A pedagoga mineira apresenta publicaçôes que despertam a inventividade, a participaçáo da criança numa visão atraente, ampliadora da imaginação.

A sua experiência tornou-se particularmente rica através de suas participações em universidades e estabelecimentos estrangeiros: estudou em Denver, Edimburgo e na Escola Guignard, em Belo Horizonte, tendo lecionado em Puerto Ordaz, na Venezuela.

Em seus livros, Angela consegue desenhar assuntos a serem recapitulados a seu modo pelas crianças, programando visualmente argumentos de interesse infantil, ora explorando temas de caráter brasileiro como a divertida "Chiquita Bacana e outras Pequetitas," e também a "Festa do Céu," um conto folclórico nacional que vai ser editado na série World Picture Books por uma editora de Tóquio.

Em vários depoimentos que Angela fez, em debates com especialistas, é possível anotar posiçôes, digamos, pedagogicamente novas. Declarou, por exemplo, que a fantasia, vista como mediadora da realidade, não é oponente desta, pois sua posição quanto à adequação da linguagem é uma possibilidade de falar a um leitor especial. Demonstrou: "Tenho visto crianças pequenas solicitarem a seus pais ou outros adultos que lhe leiam livros," assim o livro se toma um intermediário na relação entre pequenos e adultos, atribuindo à criança posição diversa do sistema comum.

As ideias de Angela são certas quando afirma: "A criança neste fim-de-século é capaz de manipular as mais sofisticadas tecnologias, muitas vezes com mais facilidade que os adultos, não se acomoda mais no protótipo do bom selvagem. Trata-se de negar um mundo patriarcal, autoritário, caduco, que está falido.”

É evidente seu desejo de atender à educação dos futuros cidadãos de uma maneira que supere o habitual e que se pode resumir na leitura dos quadrinhos para dar à formação da cultura outras diretrizes, como esta de conseguir saber através da ilustração, com a ajuda do raciocínio, da imaginação e da fantasia.

\section{Legenda}

Com a imaginação e o raciocínio... 9 .... a criança conta a história para si mesma

\section{Casa Vogue \#I, janeiro-fevereiro de I988, p.I8 (P.M. Bardi)}

\section{ESPERANTO ARQUITETÔNICO}

Le Corbusier, quando se referia ao estilo predominante na arquitetura depois do neoclássico, usava o termo culturalismo. A definição acabou conhecida também como ecletismo, a meu ver termo impróprio, pois a palavra se refere mais à filosofia: a admissão de princípios mais prováveis, escolhendo nos diversos sistemas um preceito supremo. De qualquer maneira, a segunda metade do Oitocentos e a primeira do Novecentos cozinharam os mais curiosos estilos da construção, na confusão estética que todos conhecem.

Sob o título que descarto, foi lançada agora um interessante livro de ensaios, que se referem ao quanto no Brasil os arquitetos 
andaram realizando, desvairadamente, valendo-se do acato de maneiras do passado. A edição é da Nobel, que vai se afirmando no setor da história e realidade da arquitetura, com a contribuição da Editora da Universidade de São Paulo, Ecletismo na arquitetura brasileira, idealizado por Carla Milano Benclowitcz, teve por colaboradores os eméritos professores Luciano Patetta, que se interessou pelo ecletismo na Europa; Giovanna Rosso del Brenna, sobre o Rio de Janeiro; Carlos Lemos, São Paulo; Heliana Angotti Salgueiro, Minas Gerais; Jussara da Silveira Derenji, Pará; G. Gomes da Silva, Pernambuco; J. Liberal de Castro, Ceará, Gunther Weimer, Rio Grande do Sul; e, finalmente, O ecletismo à luz do modernismo, de Annateresa Fabris, coordenadora da edição. Cada um dos ensaístas dá conta do que se produziu neste "esperanto arquitetônico," conforme a definição de Monteiro Lobato, sendo o crítico mais citado Mário de Andrade. Um fato significativo: a Semana de Arte Moderna não ter apresentado alguns elementos relacionados com a "modernidade" do construir. Seja como for, o que as ilustraçôes apresentam é sempre o momento conhecido por todos. Praticamente o trio que se costuma considerar como liquidador do ecletismo (Wright, Le Corbusier e Gropius) através de um construir com paredes lisas, geometrizando linearmente, venceu as maneiras fachadescas, coletoras do arsenal decorativo pinçado aqui e ali nos álbuns das antigas arquiteturas. Tivemos no Brasil, como de resto em todos os países do Primeiro Mundo, os reelaboradores dos estilos, recompondo os emolduramentos mais cômicos. O gosto e o fazer vinham de fora. Não faltaram as firmas especializadas em fornecer peças de ornamento pré-moldadas. Em alguns ensaios do volume estão reproduzidos estes adendos. Os textos documentam o profundo empenho dos ensaístas que documentaram historicamente o tempo, especialmente no que se refere à escolha das ilustraçóes.

Finalmente, em I923, chegou da Rússia, depois de uma estada em Roma, meca da aruitetura do "antigo romano imperial modernizado,” Gregori Warchavichik, a quem se deve atribuir a palma da afirmação e difusão do racionalismo entre nós. Foi duro convencer os comitentes, mas, pouco a pouco, tivemos Le Corbusier convidado em 36 para riscar o prédio do Ministério da Educação e Saúde, no Rio.

O livro documenta o estado de coisas vencido. É complicado estabelecer quais os mestres do ecletismo no Brasil: cada Estado tem seus Ramos de Azevedo, construtores de mérito, respeitáveis apesar de superados. Várias vezes nestes páginas deu-se alarme de que estamos às portas de um novo ecletismo em arquitetura. Este não irá recorrer ao gótico ou ao romântico, nem ao liberty, mas sim àquilo que, por diversão, por excentricidade, para se distinguir, os construtores usam para se manifestar num, digamos, novo espírito "artístico." O pós-moderno está aí mesmo. Em várias regióes já é de casa: o funcionalismo, a um tempo decantado, vai sofrendo os processos reformadores da "beleza," consequência das mudanças próprias dos estilos.

\section{Incentivando a cultura}

A Lei Sarney se propóe ser um sério incentivo à cultura, concedendo àqueles que têm a intenção de contribuir neste processo descontos no Imposto de Renda equivalentes às verbas destinadas. É praticamente uma iniciativa da qual as entidades culturais já se beneficiaram inúmeras vezes, pois deve-se afirmar que foram os generosos patrocínios de bancos, indústrias, empresas comerciais e particulares que possibilitaram ediçôes de livros, exposiçôes, espetáculos e tantas outras atividades culturais. É o caso de lembrar o antecipador desta façanha, o mecenas Assis Chateaubriand, que, valendo-se de sua visão de futuro ao prever o avanço da cultura nacional, fundou, há quarenta anos, nada menos que o Museu da Arte de São Paulo, dando ao Brasil algo que nem se pensava ser possível, e certo que não bem através de descontos no Imposto de Reda, mas ajeitando um sistema parecido, sendo ele mesmo o leão.

O recorrer a patrocínios vultosos ou modestos tornou-se praxe, como se vê hoje em inúmeros catálogos, folhetos, convites e depliants, onde é inidcado o "apoio" de uma ou outra empresa. Trata-se, agora que está em vigor a Lei Sarney, de ampliar o apoio, estudá-lo, sistematizá-lo e, possivelmente, conseguir que as verbas não se transformem em acomodaçóes que, bem 
ou mal, acabam mais nas mãos de hábeis postulantes e corretores do que nas caixas de entidades realmente merecedoras. Aprovada a lei, é preciso agora não dar sequência a panelinhas e panelóes, com fiscais instruídos, possivelmente feras em condição de não serem domesticadas e, quando preciso, dispostas a morder.

Já que a façanha deve dar sentido a projetos de notável valor, parece-me dever assinalar uma possibilidade a que já acenei anteriormente: resolver o incrível caso do Museu de Tecnologia da Universidade de São Paulo, sede hoje da indústria nacional. Se problemas ligados à arte são solucionados, nada mais justo do que voltar os olhos e promover a abertura deste organismo museográfico de maior interesse para o público brasileiro. Da mesma maneira pode-se indicar o caso da suspensão das atividades do Teatro Municipal, que enfrenta crise semelhante.

Conhecedor das necessidades de um estabelecimento cultural, sabendo também das dificuldades de se conseguirem meios para iniciativas, sem dúvida, de altos custos, com a vigência da Lei Sarney parece certo que as primeiras soluçóes deveriam atingir o finalmente inaugurável Museu de Tecnologia e também a reabertura do Teatro Municipal: um, indispensável centro de estudos e divulgação de conhecimentos da vida contemporânea; o outro, símbolo da cultura paulistana.

Senhor \#354, 5 de janeiro de 1988, p.77 (P.M. Bardi)

A INTERIORIZAÇÃO DA ARTE

Impressóes de uma visita ao museu de Ribeirão Preto, instalado na fazenda de um "rei do café"

Além de receber o honroso reconhecimento como "Homem de Visão," nada menos que em companhia de eminentes brasileiros como Heráclito Fontoura, Sobral Pinto, Ives Gandra da Silva Martins e Ronaldo Caiado, nestes dias me alegrei por causa de um convite-surpresa: fui convidado para ir a Ribeirão Preto para dar uma olhada no que lá existe de autenticamente indispensável e original no campo da cultura.

Voltei refletindo, e como, sobre o meu encontro com Assis Chateaubriand, o qual, constatando que o Brasil era carente, diria pobre de centros culturais, tomou a resolução de criar o Masp. A saída foi de uma redonda estaca zero. Hoje, depois de quarenta anos, dito sem perífrases, de luta, às vezes desesperada, está não só em pé, mas conquistando novos caminhos, uma vez que conseguimos consolidá-lo e, finalmente, popularizá-lo.

Talvez tenha sido por esta posição que recebi o convite daquela cidade, polivalente nos setores agrícola e industrial, para tomar conhecimento de o quanto seu povo, que monumentalizou numa praça a sua "Maria Fumaça," andou realizando no campo das artes. Fui sempre informado daquele progresso por dois amigos italianos que lá vivem, o pintor Pedro Manuel Gismondi e o escultor Bassano Vaccarini, todavia foi para mim surpreendente visitar o Museu alojado na antiga morada que o "rei do café," Francisco Schmidt, há mais de um século, construiu num parque de um convidativo verde. Dirige-o, felizmente, um sociólogo, o novo amigo Antonio Lorenzato, o qual o estruturou de maneira em que a história local se une à atualidade, vida e arte se integrando num perfeito e utilitário sistema. Mostra-se a origem, as iniciativas, o bandeirismo, etnografia e tudo que compóe sua vivência.

Lorenzato restaurou o casarão do fazendeiro Schmidt, um dos empreendedores da agricultura da região, que andou descobrindo as riquezas da "terra roxa." O meu colega deixou a casa como era em I870, no tempo das grandes fazendas e senzalas à espera das imigraçôes da Europa. O ambiente que mais me interessou foi a sala de estar, de um gosto em que a simplicidade recorda o operar sem parar dos donos da lavoura. Minhas recordaçóes foram logo para o museu de minha cidade, onde se recolhia de tudo. Museu no Brasil é assunto novo. Lembro que, depois do primeiro anúncio do Masp, recebi uma pessoa que oferecia uma xícara de sua bisavó. $\mathrm{O}$ museu de Ribeirão recolheu de tudo, porque a história documenta tudo. Minhas curiosidades: o cofre, a bandeira de mármore e vários instrumentos. A adaptação das salas serve para hospedar exemplares de zoologia, os animais originários da regiấo, os minerais e não sei quantas réplicas de estátuas de bronze de personagens 
condignos, retratos a óleo de administradores e as primeiras paisagens da cidade.

As artes, naturalmente, presentes. No salão debaixo uma exposiçáo dos dedicados à pintura e à escultura. Figurava até um retrato do Bardi. O diretor Lorenzato recebeu o colega paulistano com banda e o extraordinário Coral da USP- Ribeirão, que entoou músicas de Villa-Lobos, descerramento de uma placa, banquete etc. Esta nota náo pode referir quanto a jornada foi exuberante de surpresas. A primeira visita foi ao prefeito Joáo Gilberto Sampaio, articulador do desenvolvimento cultural. Além da entidade da qual falei e do famoso Museu do Café, Ribeirão apresenta no seu esplêndido Bosque dois edifícios de alto interesse: a Casa da Cultura e o novo Teatro Municipal.
Opera na administração o secretário da Cultura Antonio de Pádua Pozini, o qual não deixa em suspenso nada de prático para favorecer os que querem gozar do lazer número I, a cultura.

$\mathrm{Na}$ recepção ao diretor do Masp se exagerou em simpatia e homenagens. Me foi até oferecida uma placa com dizeres muito gentis. E, dulcis in fundo, fui recebido até com outdoors. Conto isso para anotar como as artes penetraram e venceram nas cidades do interior de nosso Estado, sinal de certeza no futuro.

\section{Legenda}

Aqui a história da cidade convive com suas manifestações artísticas

Senhor \#355, I2 de janeiro de 1988, p.65 (P.M. Bardi)

As MARÉS E AS ROCHAS

Nas artes, tudo o que é novo será fatalmente imaturo?

Nestes últimos decênios São Paulo andou inaugurando numerosos conjuntos na área cultural, desde instituiçōes de caráter científico até galerias comerciais, formando uma série de atividades que atribuem a esta metrópole uma posição de destaque. Serão inaugurados, também no Interior, novos museus, novos salóes, novas sociedades; temos editores que se especializaram na produção das artes, a Bienal continuou suas performances, os intercâmbios com as nações estrangeiras são sempre mais numerosos: conseguiu-se uma participação ativa de ano em ano neste setor. A característica destas iniciativas é que elas são quase sempre deliberadas por pequenos grupos, quando não partem de decisóes de particulares, como foi o caso do Masp e da Bienal, isto em tempos pioneiros, numa Sáo Paulo ainda provinciana. Para fornecer uma ideia daqueles tempos, bastará recordar que quando o ex-presidente Eurico Gaspar Dutra inaugurou o Masp, acompanhado de ministros e da intelectualidade local, um jornal deu a notícia somente do almoço que lhe havia sido oferecido em casa de uma destacada família, não citando a outra finalidade cultural da visita.

Como foi dito, o avanço é notável e irresistível, mesmo que este precipitar de eventos, por sinal salutar, estabeleça algumas confusões. Isto é próprio dos tempos em andamento, pois é natural que repentinas mudanças combinem reaçôes. A nós mesmos, às vezes diante de exageros por demais avenirísticos, para não dizer fora de qualquer sentido, nos atribuem a posição de "passadistas."

Fique bem claro que uma reserva contra a realidade das mudanças da manifestação das artes seria imprópria. É impossível ir contra o tempo e suas deliberaçóes. Sendo assim, é normal o respeito pelos mestres, porém o que cria confusão é justamente a avalancha de intromissóes amador-oportunistas. Mondrian, Klee e tantos outros contribuidores das novas invenções são aceitos e distintos, porém a onda que os seguiu não. Inclusive, me desculpem as sheilas da Bienal, o próprio Duchamps que pinta bigodes na Mona Lisa.

$\mathrm{Na}$ confusão existe toda uma crítica não só defensora das últimas trouvailles, mas pronta a atacar os que a desatem: um estilo advocatício que andou encontrando suas pandectas, sabendo interpretar os códigos das novas estéticas, justificaçôes, demonstraçóes que um simples leguleio resolve. É, então, obrigação se adaptar ao que o momento está proporcionando, aliás, impondo? No final de 1987 o que mais venceu como massa estética foi, sem dúvida, a Bienal, usando de suas 
dispendiosas possibilidades de penetraçáo. Foram estampadas camisetas com símbolos e dizeres, um catálogo pot-pourri de imagens em branco e preto, não em cores, indispensáveis para se compreender melhor as intençóes dos abstracionistas, bottoms e uma bagagem propagandista industrializante. Isso tudo não deve surpreender, pois faz parte da situação, do prevalecer de tendências, dizem, próprias ou pelo menos apropriadas ao atual fim de século. Para contar com um certo número de visitantes, a Bienal recorre até à visita de escolas primárias, pretendendo consensos evidentemente imaturos.

Mas isso faz parte dos novos rumos do lazer em distribuição, do qual é complicado falar.

\section{Legenda \\ A Partida dos Barcos (1927) de Paul}

Klee: os maneirismos tornam

o mestre irreconhecível

Senhor \#356, I9 de janeiro de 1988, p.65 (P.M. Bardi)

FORA DAS METRÓPOLES

Piedade, no interior de São Paulo, abre sua Casa da Cultura

Geralmente, nesta página, as referências se reservam às metropoles, pois é onde se dá a ativação da cultura, mais ou menos nosso espaço de discussão. Porém, semanas atrás, este paginista foi convidado a participar de um evento no interior de São Paulo, em Piedade, que seu poeta local, numa amorosa apresentação, descreve comovido: Teu nome é respeito e devoção| és berço de um povo ordeirol que na paz dos teus verdes vales | acolhe o irmáo estrangeiro| com o mais pátrio sentimento | do legítimo povo brasileiro, lembrando uma das sextilhas que compóem o poema do acadêmico Osvaldo Feitosa.

Inaugurava-se naquele município, por iniciativa do artista Paulo de Andrade, a Casa da Cultura, uma grata surpresa. O seu compreensivo prefeito, Artur Hess, pôs à disposição dos poucos mas volitivos intelectuais o edifício que num jornal, imagina-se, teria assim anunciado: "Ontem, dia 4 de novembro de I887, na Pousada de Pirapora, foi inaugurada, com todas as honras, a Cadeia Pública." Esta é a origem da Casa que, de tempos em tempos, já abrigou a Delegacia de Polícia, o Fórum, o Destacamento da Polícia Florestal, e até um escritório do IBGE.

Hoje, um século depois, tomou- se centro de ensino e de manifestaçóes promissoras neste recinto dedicado à insígnia $\mathrm{da}$ Cultura. Heroicamente restaurado, com a contribuição do Rotary local e de numerosos cidadãos, a instituição se destina a ministrar aulas de pintura, cerâmica, música e dança. Há uma sala de exposiçóes e num dos espaços foi adaptado até um teatro com um amplo palco que dá para a praça das Bandeiras. Disse heroicamente, e este é o advérbio certo, pois durante a visita se recapitulou o quanto foi realizado e o quanto ainda está para se fazer.

Por ocasião da inauguração, ocorreu o julgamento de uma série de concursos, tendo sido reservado para o "visitante estrangeiro" o de pinturas. $\mathrm{O}$ artigo único do regulamento prescrevia: "Cada concorrente poderá inscrever até três obras inéditas...” Assim, constituído o júri, foi possível constatar quais as tendências regionais: desde o tradicional dos artífices dedicados aos ensinos acadêmicos e os ainda ligios às polivalências do impressionismo, até as que transfiguram e surrealizam qualquer elemento, uma demonstração que por lá penetraram as tendências do modernismo.

Este foi um dos episódios da visita. O gostoso foi assistir às aulas de violáo, ver uma séria exposição de jovens fotógrafos de Sorocaba, descobrir um ambiente onde se acumulam as primeiras remessas de livros para formar uma biblioteca, e saber de doaçôes de prestígio como a da Academia Piracicabana de Letras, da Câmara Municipal, afinal, um principiar generoso e laborioso que se resumiu em reflexôes no caminho de volta a São Paulo, atravessando Votorantim, Ibiúna, entre $o$ alto dos teus verdes montes contemplo a divina natureza| contemplo a Deus e ao Universo $\mid$ um povo amigo| que cultiva esperança e beleza, no canto de Feitosa.

Então, parabéns a Piedade, pela sua nova exemplar Casa da Cultura.

\section{Legenda}

Nela [Casa de Cultura de Piedade]

já funcionou a Delegacia de

Polícia, o Fórum e o IBGE 
Senhor \#357, 26 de janeiro de 1988, p.8I (P.M. Bardi)

UM TEMPO DE DÚVIDAS

A verdadeira sensibilidade artística sofre a imposição da ideologia da modernidade

Leio numa apresentação que Harry Laus, o brilhante diretor do Museu de Arte de Santa Catarina, faz para o jovem artista Antonio Filipak: "Revela em sua pintura o inconformismo com o preestabelecido e leva suas especulaçóes à estrutura primária do átomo, num atestado evidente da sua filiação à geração da dúvida."

Harry intitula a sua meditada prosa "A geração da dúvida," sintetizando-a: "O sentido maior da arte contemporânea talvez esteja na perplexidade do ser humano entre a justiça e a injustiça, a coerência e a incoerência, a falsidade do discurso político ante as exigências reais da ação. Pertencente a esta geração da dúvida, o artista sensível não pode sujeitar-se a antigos conceitos de beleza, nem desprezar todas as variaçóes e conquistas das artes plásticas no século xx."

De fato, o ser sensível (difícil e complicado hoje descobri-lo) debatendo-se, para não pescar no oceano das novas definiçóes, entre figurativo e abstrato, procura produzir quanto mais lhe convém. Assim, hoje, na praça formigante de mercadores, se despacha o que os seguidores das ideias avançadas chamam de acadêmico, e os do figurativo "nem quero ver," na disputa do vencer, aliás do vender. Quem adquire obras conflitantes com a tradição passa por sabido, até precursor do futuro, aliás já cidadão de mundos mudados. Há exposiçôes que se sucedem, umas depois das outras, que deixam surpresos até o mais aveniristas. Depois que uma roda de bicicleta ou um ferro de passar roupa se tomaram obras de arte, consequência da tecnologia, tudo pode ser incluído no panorama da engenhosidade e do gosto estético.

Naturalmente o inovador, o sujeito que tem a ideia, propondo uma ruptura, é o campeão que recebe o troféu, os imitadores da ideia formando a claque e, como sempre, são responsáveis pela difusão das eventuais besteiras, especialmente quando se reúnem em batalhôes, para não dizer em exércitos.

A crise das artes plásticas é, hoje, o número excessivo dos fabricantes de pintura e de escultura, não excluída a arquitetura. Cada artífice quer se singularizar e, na diferenciação, acaba abraçando qualquer parada. O inconveniente é justamente o número.

No tempo dos salóes existiam as comissôes de seleção que, bem ou mal, eliminavam os principiantes e os copistas descarados. Hoje, mostrar o que se produz, é fato comum.

Para um pintor ex-acadêmico, daqueles que sabem desenhar e usar as cores, seguir a onda da assim denominada modernidade transferindo-se para um dos novos academismos de aceitação burguesa é como saborear um café. Como antes se folheavam álbuns de história agora olham para uma das infinitas possibilidades da moda, e pronto. Do academismo à antiga passam ao academismo do momento. E há também os que pensam ser perfeitamente inútil desenhar, pintar, compor etc. quando a praça que, aliás, exalta qualquer improvisação.

Disse justamente Harry Laus: é um tempo de dúvidas.

Legenda

Dionísio Del santo, 1967: relevo em madeira pintada

Senhor \#358, 2 de fevereiro de 1988, p.65 (P.M. Bardi)

EM TEMPO: LE CORBUSIER

Um livro imprescindivel para lembrar um centenário que já

passou - mas, que importa, se o personagem é eterno?

Não foi possível registrar no ano passado tudo quanto se produziu de textos críticos a respeito do centenário de Le Corbusier. 1987 constituiu-se numa ocasião para lembrar o surgimento de uma arquitetura que tentou instaurar um estilo, pensado e defendido, de expressão do nosso século. Muitos dos textos devem ainda ser comentados. Acha-se necessário recordar aqui um destes trabalhos, pois se trata de uma recapitulação da inesquecível figura do mestre suíço-francês: Vita e Opere di Le Corbusier, de Francesco Tentori, editora Laterza de Roma e Bari, estudo que já está na sua terceira edição. 
Trata-se de um exame pormenorizado dos trabalhos do arquiteto, descrevendo-os e julgando-os no seu tempo, através das mais estranhas definiçóes que recebeu, por exemplo, arquiteto "nazi-soviete-social-fascista" ou "bárbaro destruidor do passado," conforme os protestos que provocava.

O volume indaga cada obra de Le Corbusier, desde a Ville Savoye e a Capela de Ronchamp até as últimas. Diz o autor que "Le Corbusier foi sempre, ao longo de sua vida, de um lado o filho da demanda do mercado da arquitetura (a qual parece depender sempre da haute-couture) e fiel intérprete das aspiraçóes, nunca bem claras, dos atos emergentes. Todavia ele se destacou de jeito tal da demanda de mercado, por exemplo, em seus projetos dos anos 20 e 30, como a cidade-jardimvertical e as immeubles-villas, para determinar muito mais nas inovaçóes da famosa diferenciação marginal, sobre a qual parece se basear o aparecimento de qualquer novidade, no mercado consumidor."

Partindo desta diagnose, o professor Tentori remonta ao exame dos projetos lecorbusianos, consequência do operar num isolamento constante, que lhe permitiu manter uma posição que, naquela época, eu mesmo que o acompanhei posso afirmar, era de fadigosa conquista cotidiana.

É uma honra para o Brasil, assim como para os intelectuais que puderam por isto decidir, ter apelado a ele para conselhos e, substancialmente, para o projeto do Ministério da Educação e Saúde no Rio de Janeiro. Mais uma vez é o caso de lembrar que um daqueles intelectuais foi Carlos Drummond de Andrade, então chefe de gabinete do ministro Capanema, ao qual se deve a decisão de hospedar o fautor do "funcionalismo."

Durante a celebração do centenário, várias vezes foi recordada a posição de Le Corbusier no Congresso Internacional de Arquitetura de 33, em Atenas, quando se reuniram os arquitetos que aderiram à liquidação do "ecletismo," estilo entấo em voga, ocasiáo em que foi deliberada a Carta de Atenas.

Este paginista estava lá, conhecendo e aderindo aos novos princípios, ditados praticamente por Le Corbusier. Foi tornando à mente as definiçóes do mestre que li o livro de Tentori, que facilita o entendimento das obras do mestre, podendo-se apreciar a precisão e, sobretudo, a compreender suas intençóes. A sequência de desenhos e fotografias de suas páginas esclarece exatamente a posiçáo do arquiteto, mesmo para quem não seja um entendido no assunto.

Parece-me certo aconselhar uma tradução deste trabalho. Faria aqui uma alusão aos colegas de Projeto, que conseguiram o mais rico e vivo periódico dedicado à arquitetura. Seria mais uma merecida comemoração do centenário de um dos grandes construtores da história.

Legenda

Viaduto-auto-estrada-residência (projeto para o Rio, I936)

Senhor \#359, 9 de fevereiro de 1988, p.67 (P.M. Bardi)

LEMBRANÇAS DE Assis

O que um livro sobre Chateaubriand tem a oferecer ao Pais

Como não é mais segredo, pode-se informar que Fernando Morais está trabalhando num livro que vai contar a vida de Assis Chateaubriand, de quem em I99I transcorre o primeiro centenário. $\mathrm{O}$ autor vai reevocar a participaçáo de um personagem singular na vida brasileira, atuante no setor de comunicação e na política.

Eu mesmo, pela amizade e colaboração que mantive com o dono de $O$ Cruzeiro e de mais de 35 cotidianos, estaçóes de rádio e lançador da primeira televisão no Brasil, publiquei um livro de lembranças em 1982, Sodalício com Assis Chateaubriand, que não teve repercussão nenhuma. Tratou-se de uma homenagem ao criador do Masp. Penso que todos aqueles que puderem contribuir com Morais, com depoimentos e recordaçóes, devem fazê-lo.

Nesta página me proponho a escrever algumas notas, completando o que já editei. Entre o muito que se pode dizer, transcrevo de minhas velhas anotaçóes. Não se faça caso se meu discursar sobre Chateaubriand venha a se romantizar, natural consequência do envolvimento que 
tive com ele, por sua vez romantizador de tudo que realizava, provocando surpresa.

Muitos fatos realmente aconteceram entre nós, adaptei-os a visões em que a fantasia tem também sua parte, pois contados simplesmente não teriam graça nenhuma. Sem alterá-los, me convenci de que o mais certo fosse contorná-los, às vezes substanciá-los do anedotário próprio da linguagem do Amigo. Não gostava da contradição, nem do acesso às reservas, francamente opondo-se à discussão do quanto afirmava. Se valia de um certo senso ocasionalmente diplomático encontrando convenientes saídas. Em outra página: Peremptório, porém sempre generoso, inflexível numa deliberação aparentemente errada, Assis pertencia a um outro mundo, e por isso nos permitimos isolá-lo no território da fantasia, a nosso modo.

Não me lembro de ter notado no Assis momentos de desânimo, nem mesmo quando a implacável doença o obrigou a ficar quase imóvel na cama. Ia-se à sua Casa Amarela também para receber seu consentimento para empresas pouco canônicas. Era sempre um passo mais para frente do que se ia propor, os olhos do façanhoso se arregalando ao conhecer novidades e propostas arriscadas.

No meu Sodalício conto alguns acontecimentos, mas não tudo, preferindo que o tempo transcorra e liquide divergências que de vez em quando atrapalham o empenho de atracar o projetado barco Masp num cais seguro. Um dos casos de nossa amizade foi ele saber das minhas andanças de jornalista. Ele era curioso pelos meus relatos referentes às atividades redacionais, e talvez por este motivo tenha-lhe vindo a ideia de eu ter capacidade no setor.

Assis tinha enfrentado, composto e recomposto, a seu critério, manejando a seu exclusivo modo, um meio de comunicação que somente sua extrema capacidade e, mais, seu senso de intuição conseguiram vencer. Pode parecer o exercício de simples direção de uma holding, porém somente quem o conheceu de perto sabe como dirigia, impondo e arranjando através de hábeis correçóes, negaçóes e operaçóes até do impossível: um patrão mesmo que decide na hora, pondo na porta qualquer atrapalhador, sua ordem era ordem mesmo.

Com Assis era impossível discutir. Quantas vezes, para não ser insistente, deixei que, no compor a pinacoteca do Masp, emergisse com algumas iniciativas provocadas mais pela repercussão societária do que pela importância da aquisição, como a solene disputa num leiláo londrino para ser dono de uma pintura de autoria de Winston Churchill.

\section{Legenda}

Para ele, ordens eram ordens. Mesmo quando era para entrar num leilão por um quadro de Churchill

Senhor \#360, Is de fevereiro de I988, p.63 (P.M. Bardi)

O ARQuivo E A Constituinte

Para estudar nossa história recente será preciso ir aos Estados Unidos?

Uma discussão, entre as muitas que se desenvolvem na Assembleia Constituinte, interessa à história, aliás aos arquivos que, como se sabe, documentam a vida da Nação. Apareceram por lá constituintes que se manifestaram contrários ao permitir o livre acesso, após trinta anos de sua edição, do que os arquivos conservam ou deveriam conservar: uma espécie de camuflagem do que se processou no Brasil nos tempos mais recentes. A restrição é para qualquer documento e, sem dúvida, tem interesse político, quando se constata que, praticamente, dos acontecimentos tudo se sabe, cada episódio, mesmo escabroso, já tendo sido interpretado, às vezes nos mínimos detalhes, pela imprensa que, sendo livre, não deixou de tocar no assunto.

Por outro lado, num período de 30 anos o que se tem para manter no secreto? Ao que parece, o que todo o mundo sabe, inclusive no estrangeiro, aliás justamente no estrangeiro, que não cuida somente da vida de Pelé, mas em primeiro lugar da nossa vida e dos atos políticos dos quais, com a liberdade vigente, tudo já foi revelado, à maneira própria de cada um, provocando o costumeiro contraste de ideias.

Geralmente, o acesso aos arquivos é reservado a estudiosos, isto é, a elementos práticos no manuseio de documentos. $\mathrm{O}$ 
pedido do vetum poderia ser interpretado contra uma classe benemérita, a qual aliás não é tão omissa, a ponto de não ter conhecimento de como chegar, por uma ou outra via, aonde pretende.

Quem tem prática de arquivos, tanto os gerais quanta os particulares, sabe profissionalmente que a crônica dos fatos políticos acaba quase sempre reservada aos próprios protagonistas. Eles têm o hábito de redigir diários e trocar correspondência: manifestaçóes estas que ficam fora dos arquivos oficiais, complementaçóes da mais alta importância, pois para escrever história tudo vale e tudo serve, às vezes até a revelação de um simples bilhete.

Voltando à Constituinte: seria este dos arquivos um problema pertinente àquela Assembleia? Ao que parece a liberdade de consultar os arquivos deveria ser proclamada apartis verbis e não exposta a críticas e intromissóes que resultariam numa fraude à liberdade, a qual deve ou deveria estar acima de tudo. Se sabe que hoje, com todos os meios em atividade, a comunicação é fatal e praticamente não há "segredos de Estado." Se nos tempos recentes havia algum, tornou-se segredo conhecido, avaliado e discutido, evidenciando os a favor e os contra.

Esqueci de notar que o nobre deputado autor da emenda é o mineiro Pimenta da Veiga, que agita para a sua inclusão na futura Carta Magna. Qualquer cidadão é do parecer que com a sua proibição, ou melhor, seu corte no texto da Constituição, o politicar fica sem garantia, uma vez que para estudar nossa história recente será preciso ir aos Estados Unidos. Se as coisas acontecem aqui é aqui mesmo que têm que ser vistas, estudadas e analisadas, custe o que custar. O texto "podado" mas cuja emenda foi aceita pelo relator Cabral diz textualmente o seguinte: "Não haverá, em nenhuma hipótese, documento sigiloso por mais de trinta anos, a contar de sua produção.” Então, os arquivos acabarão conservando tudo que se sabe e não o que se tem interesse em saber.

Legenda

Paz e Concórdia, de Pedro

Américo: simbologia das relaçôes

entre o cidadão e o Estado

Senhor \#36I, 22 de fevereiro de 1988, p.72 (P.M. Bardi)

A FLOR DA PELE

Também no Brasil a moda já é celebrada como arte

Geralmente, nesta página, os produtores de arte que recebem aplausos (e às vezes reprovaçôes) são os pintores, sendo menos focalizados aqueles que nas inúmeras atividades se mostram parentes próximos dos pintores ou destes procuram aproximar-se, usando ou não aquela criatividade que brilha nos mestres. Porém, quando as ocasiōes se apresentam, tenta-se envolver na magnificência Arte até mesmo exercícios que seus defensores classificam como resultado mecânico, de técnica, ou tecnologia, conforme as circunstâncias.

Hoje, a crônica é dedicada não aos Le Corbusier, Picasso, Moore e companhia, mas aos envolvidos na arte do vestir. Sabe-se que o traje hoje é produzido em série, massificado, fato industrial. Às vezes ao seu lado está a alta costura, consequência do trabalho artesanal que inclusive dita lei na estética.

Quando, no antiquíssimo ano de I95I, apresentei na Pinacoteca do Museu de
Arte de São Paulo um desfile de Christian Dior, o público se resumiu à elite feminina da sociedade paulista, sem repercussão popular. Todavia foi um acontecimento, pois nele inseri, para lembrar os artistas, uma roupa avenirística desenhada especialmente por Salvador Dali. Depois desta manifestação este ingênuo que estava propondo uma museologia não-tradicional (mumificada) teve a inconsistente ideia de lançar nada menos que uma moda brasileira, imaginada com o auxílio de pintores, costureiros etc. Foi um autêntico fracasso. As encantadas peripatéticas eram escravas dos ditames de Paris. Porém em 40 anos de Masp nunca desisti de apresentar moda como fato de Arte, mostrando não sei quantos exemplares do que agora chamam wearable, como os esplêndidos quimonos de Orietta del Sole e, no ano passado, a resenha Traje, um Objeto de Arte?.

O trecho acima é uma espécie de justificativa porque outro dia fui convidado para 
um almoço no restaurante Vecchia Cucina pela ativíssima indústria Alpargatas S.A., revolucionária na fabricação de jeans no Brasil, que assim festejava os primeiros quinze anos da US Top. Estavam em cena quinze personalidades, recebidas pelo diretor daquela indústria, Ivo Miranda Reis. A ideia se liga realmente a este final de '9oo: solicitaram a três artistas do wearable (Liana Bloisi, Heloísa Beldi e Fernando Penteado) que idealizassem trajes em seda para serem distribuídos aos convidados, todos ligados à área da moda: cronistas, modelos, editores de moda, industriais. Cada artista deveria preparar cinco peças de vestuário únicas, exclusivas e atemporais, para serem vestidas ou expostas como obras de arte.

As entregas das peças aos homenageados deram lugar aos aplausos quando eles, espirituosamente, vestiram os casacos, as mulheres mais jeitosas do que os homens. Cada peça foi criada tendo em conta a personalidade do escolhido, desde a sempre elegante Costanza Pascolato a Helena Montanarini, Claudia Berkhout, Denise Orensztjein, Claudia Duarte, Leda Gorgone, Elza Lucchesi, Elda Priami, Isa Smith, Regina Guerreiro, Malu Fernandes, Bia Roig, Roberto Barreira, Beto Simóes e Fernando de Barros.

Há algum tempo se discute a criação de um museu da moda. A ideia é boa, todavia exige uma reflexáo. $\mathrm{O}$ fato enseja lembrar que no acervo de pinturas do Masp várias obras documentam o desenvolvimento da moda, desde o Quatrocentos até o Surrealismo. As exposiçóes periódicas sobre o assunto mostram que há interesse.

\section{Legenda}

Constanza Pascolato e Bardi, alguns dos homenageados na festa da Alpargatas

Senhor \#362, 29 de fevereiro de 1988, p.80 (P.M. Bardi)

O destino dos Estilos

O tempo os apaga numa contínua superposição de formas. $O$

Neoclássico é um caso exemplar dessas transformaçóes

Se existiu um estilo, na Arquitetura, da mais ampla e consenciente aprovação, este foi o Neoclássico: reanimava a história mais popular, deixando Grécia e Roma ao alcance de qualquer voluntarioso que, naturalmente, estivesse em condiçóes de usufruir de uma fachada animada por algumas colunas e tímpanos, com as janelas emolduradas, festa ainda maior se o acesso pudesse receber alguns degraus e várias outras exigências prescritas pelo estilo.

Mesmo os que nunca viram o Parthenon ou qualquer adaptação da famosa construção se lançaram na empreitada, e o surgimento de igrejas e palacetes, na lentidão das aplicaçóes e adaptaçóes, acabou produzindo o carnaval do estilo. Sim, houve a revolta do gótico, logo apagada, mas de vez em quando voltando a interessar arquitetos e comitentes.

Para não ir muito longe, e ficar na nossa São Paulo, projetaram a Catedral no espinhoso estilo do norte, porém, quando as autoridades e os poderosos do dinheiro pensaram em arquitetura, foram os últimos avanços do Neoclássico os vitoriosos. As campeãs no uso, quase inútil repetir, foram as colunas, ornadas ou não de capitel, com ou sem base, na variedade que nossos mestres de obras com a participação até de arquitetos diplomados, andaram oferecendo à cidade-capital, não sem escutar e atender as ordens superiores do comitente.

Tudo somado, se alguém quiser mesmo encontrar o estilo do qual tratamos terá o tempo perdido. Se, porém, houver alguém realmente desejoso deste encontro, precisará tomar um avião e encontrar na Europa as últimas empresas dos neoclassicistas. Se se contentar porém com as larvas a própria São Paulo pode satisfazer as pretensóes com o que sobrou em pé após as demoliçóes. Nos nossos Jardins existem os avanços do estilo a lembrança de uma ideia que não passou nem no Oitocentos, quando ainda havia fábricas interessadas em construir os ornamentos de cimento.

O destino dos estilos é parecido para todos. É o tempo que intervém. Apresentamos há pouco a exposição dedicada ao centenário de Le Corbusier. Todos os visitantes tiveram ocasião de constatar como sua pregaçáo em favor do Racionalismo e do Funcionalismo foi providencial. 
É verdade que os dois últimos estilos acima citados náo conseguiram vencer como se esperava, pois um outro modo de resolver a estética das construçóes andou inundando as cidades e até apareceu em Brasília: o Pós-moderno, praticamente uma readaptação, uma tentativa de salvar o que antigamente se pretendia da arte arquitetônica. Se opinou ser justo e certo utilizar a limpeza das fachadas, porém algumas recordaçóes podem ser usadas para embelezá-las.

Assim foram construídos edifícios cujo aspecto é racional, porém as movimentaçôes das fachadas, algumas introduçôes de elementos ornamentais e até escolha de cores e relativas misturas representam a utilização da fachada como portadora de enfeites, no caso, os do Pós-moderno.

$\mathrm{Na}$ ilustração se apresenta um edifício da metade do Oitocentos que, salvo as colunas, anunciava o Racional, naturalmente mais ou menos. Curioso: foram os ingleses e os norte-americanos que conseguiram se servir do estilo Neoclássico na maneira mais aceitável, recompondo-o em adaptaçóes mas dando-lhes uma ordem até nos elementos utilizáveis.

\section{Legenda da imagem}

Casa de campo irlandesa: exemplo de adaptação do estilo neoclássico

\section{Casa Vogue \#2, março-abril de I988, p.38 (P.M. Bardi)}

\section{REFLEXÓES AO AR LIVRE}

Não há nada de novo: a cada noite, vândalos da pior espécie destroem centenas de telefones públicos nas ruas e nas praças de São Paulo, talvez sem pensar que aquelas cúpulas amarelas representam, além de uma utilidade, um dos monumentos-símbolos desta época.

Quando se fala em monumento, se pensa nas estátuas e nas composiçóes de grupos representando fatos históricos e também nas formas abstratas que querem indicar o quê, francamente, não sei, tanto nas ruas como nos interiores de arquiteturas como shopping centers e supermercados. O retorno da decoração?

É natural pensar nestas esculturas custodiadas em edifícios e nas ruas e praças como um problema carregado de aventuras. De fato, do mesmo modo que um aparelho telefônico pode ser destruído, o mesmo pode suceder com um mármore ou um bronze. As mutilaçôes são conhecidas na própria São Paulo, e até os desaparecimentos das obras, mudanças de suas posições e várias outras situaçóes.

Li, recentemente, o livro de Maria Luisa Tronconi Fuori delle Case, Selezione di Componenti Ambientali, um panorama do que ocorre quando as obras cívicas são de todos e passíveis de atentados, inclusive as esculturas. Se hoje vemos, ou pelo menos ainda era possível ver, estátuas até mesmo decapitadas na Grécia e em Roma, o dano significava o abandono e, naturalmente, o desrespeito aos objetos.
Pouca, para não dizer nenhuma, importância se atribuía à arte ao ar livre. Basta dizer que foi até mesmo demolido o frontão do Partenon, em Atenas, sendo hoje visível num museu de Londres.

Diz Edward T. Hall em seu escrito $A$ dimensáo escondida que "é um grave erro colocar o homem de um lado e as coisas, a cidade, a tecnologia, a linguagem, do outro, como entidades separadas: o homem e o conjunto das suas 'extensóes' constituem um sistema único de interrelaçôes.”

A observação é correta, porém o que se constata, saindo de casa - as dimensóes do que se encontra - é apavorante: é preciso se integrar, se adaptar. Se alguém náo gosta da personagem esculpida numa praça, é capaz de lançar uma pedra contra aquele nariz.

Sem falar na política: quando mudam os regimes, é normal pôr as mãos, ou melhor, pôr fogo nos símbolos que exaltam os efeitos do governo precedente. E nada de extraordinário se, numa mudança da situação política, os antigos celebrados voltarem à adoração. Havendo entâo nas casas liberdade de pensamento, fora é preciso se conciliar com a determinação geral, com liberdade para usar as liberdades de manifestação? E, já que se fala em estética da cidade, é fatal lembrar o exercício da pichação, especialmente nesta virada de tempo em que parece que se determinam trocas de legisladores, altos e baixinhos, para, ao que parece, um melhor governo. 
Sair de casa, então, não é m negócio simples, normal. Já pisando na calçada, os problemas não digo que vêm ao nosso encontro, mas praticamente nos assaltam. E uma das coisas que nos tomam de assalto é a citada pichação, agora com pretensôes artísticas, quando antes era feita por um fulano qualquer que se divertia a desenhar com uma única cor num muro e, por que não?, numa estátua. Agora as iniciativas progrediram. Não mais numa só cor, geralmente usando o preto, mas sim complicadas ilustraçóes de preferência caricaturais sujam, aliás alegram, muros brancos ou de cor que possam receber aquelas produçóes.

Para não ser permanentemente do contra, deve-se observar que estas composiçôes aparecem repletas de humor e não realizadas por simples principiantes, tanto que já se dá um apelido aos autores: grafistas dos muros. No túnel final da Paulista que leva à Rebouças se distinguem alguns que sabem fazer especialmente quando nos oferecem cabeças anormais contornadas de signos e alegorias. Quem sai de casa está servido. Se gosta de figurativo, pode apreciar tudo que lhe preparam para os olhos. Felizmente os pichadores são quase todos figurativos. Raro ver um favorável a abstraçóes ou geometrismos. Eles querem comunicar mesmo. Há alguns que poderiam se dedicar à imprensa, como cartunistas. Náo sei se algum dos nossos editores já descobriu essa mina.

\section{Sobre as esculturas}

Existem também os que, em vez dos muros, assaltam as esculturas. Estes são mesmo piratas, pois, às vezes, levam até pedaços de bronze ou de mármore das obras públicas. Aí não se trata de "artistas" mas de baderneiros. Há algum tempo, levaram, do prédio que fica ao lado do Masp, um toldo de bronze que protegia os que saíam do local. Para fundir a peça e vender o metal.

O que fazer? A rua é rua e, assim sendo, é de todos, tanto dos bons como dos maus. É difícil distinguir, pois todos saem de casa.

Senhor \#363, 7 de março de I988, p.73 (P.M. Bardi)

CASA SEM GOTEIRA

Livre das infiltraçôes de água, o Masp já pode receber de volta o acervo que enviou à Europa

Não tenho prática, aliás estou na estaca zero no que se refere a vida política. No recinto italiano, saindo na juventude como aspirante a socialista, lembrando que em 1917 publiquei um ensaio dedicado ao ético Geremia Bentham, editado pela L'Avanti!; depois aderindo talvez à revolução de Mussolini, sempre usei a liberdade de polemizar, com bastante severidade e irreverência, tanto que acabei sendo posto em desgraça. Vindo, depois da Guerra, ao Brasil, interessado de corpo e alma à criaçáo do Museu de Arte de São Paulo, soube das coisas políticas locais somente lendo os jornais, e, francamente, pouco entendendo.

De vez em quando encontrei personagens da política no gabinete de Assis Chateaubriand, do qual falei numa das últimas crônicas, e que agora o livro de Samuel Wainer pinta como chantagista, exercício, pelo que pude seguir no caso do Masp, não interesseiro. $\mathrm{O}$ meu mais recente encontro de político deu-se com o prefeito Jânio Quadros. Mas não para fatos políticos. Participei de uma reuniáo em que a diretoria do Masp presenciava a assinatura de um contrato para reformar a cobertura do edifício onde estamos instalados: encontro cordial, quase familiar, e ali ouvi o antigo presidente da República discursar de improviso sobre um assunto de cultura.

Não sei se todos sabem, mas nosso edifício da avenida Paulista é de propriedade do Município, que o cedeu em comodato por 40 anos. Quem deve cuidar da sua conservação é a operosa e sobrecarregada Secretaria de Obras. Fica então impossível, para nós, providenciarmos reparos no teto da Pinacoteca repleto de infiltraçóes de água que poderiam prejudicar as telas ali expostas. No ano passado, esvaziamos o local e comunicamos o fato diretamente ao responsável supremo da metrópole. Ele nos escutou e assim que pôde providenciou para se proceder ao conserto, tendo sido há poucos dias assinado o contrato para execução da obra cuja supervisão estará a cargo de um dos diretores do Masp, o engenheiro José Carlos de Figueiredo Ferraz, autor dos já célebres cálculos da complicada estrutura do edifício projetada 
pela arquiteta Lina Bo Bardi, ambos presentes na citada cerimônia oficial.

Depois do agradecimento de nosso vice-presidente, Hélio Dias de Moura, substituindo o presidente, Edmundo Monteiro, que está em férias, a palavra foi de Jânio: calmamente, com sua bem conhecida verve, sublinhou a importância do empreendimento, a presença constante do Masp no campo sempre amplo da cultura, desviando argutamente por vários caminhos deste problema, mostrando um conhecimento preciso e sempre apontando possibilidades, compreensivo com as incumbências fáceis e complicadas que se desenvolvem, e às vezes se engolem, no Masp.

Em resumo, quando saímos, disse aos repórteres que vieram me entrevistar: "Sou hoje o cidadão mais feliz de São Paulo.” Pensava que neste ano, quando receberei de volta da Europa o acervo que emprestamos para museus de lá e cuja última apresentação será na Fundação Gianadda, em Martigny, no mês que vem, com inauguração do presidente da Confederação Suíça, poderei recolocar as obras na sala original, já consertada.

Outra pergunta: "O que pensa do prefeito?" Respondo: "Como administrador desta nossa São Paulo, o admiro pelo que consegue fazer, aliás, defender, em benefício da metrópole, especialmente quando desmancha favelas e quando enfrenta hostilidades ao tentar oferecer possibilidades futuras ao nosso crucial trânsito."

E depois o picante: "E o aumento de tarifas e impostos?” Respondo: “Também eu paguei sem recriminar. Com os cofres vazios vai-se à falência."

Sei que a declaração é impopular, porém quem consegue calar a boca dos descontentes, dos egoístas e dos tradicionais resmungóes?

\section{Legenda}

Masp: propriedade do Município que cedeu o prédio por 40 anos

Senhor \#364, I4 de março de I988, p.65 (P.M. Bardi)

UMA DIFÍCIL MISSÃO

A Bienal de Arte de São Paulo carece de uma revolução que Alex Periscinoto terá de realizar

Dias atrás li um artigo de Alex Periscinoto, no jornal Folha de S.Paulo, dedicado a explicar como é complicada a escolha de um nome para uma empresa, cheio de exemplos curiosos que envolvem o processo até chegar a uma identidade conveninente e proveitosa. Existem até mesmo firmas especializadas para a escolha.

Agora, como aquele articulista tornou-se (felizmente) presidente da vetusta Bienal de Arte de São Paulo, me parece interessante contar como surgiu aquela instituição realmente modesta, para não dizer corriqueira e, por conseguinte, copiada.

No após-guerra, nos anos em que São Paulo, esquecendo que tinha na sua história cultural a façanha da Semana de Arte Moderna de 22, andava atrás de novas iniciativas naquele campo, eu estava com Assis Chateaubriand abrindo um museu. Aliás, se eu, passivamente, tivesse aderido ao título já in pectore do fundador: Museu de Arte Antiga e Arte Moderna, as consequências teriam sido diversas.
Não concordei sabendo que o quilométrico título seria um contra-senso, pois as linhas do estabelecimento não o representavam. Não consegui demovê-lo do uso da palavra "museu," mesmo explicando que a palavra sabia a mofo.

O benemérito Cicillo Matarazzo, fautor não muito prático do significado da "modernidade" tentou até criar um "museu de arte moderna," e tanto insistiu com o Assis, que obteve dele no bloco dos fundos dos Diários Associados (no bloco da frente já funcionava o Masp) algumas salas, uma logo transformada em bar. A partir daí: confusão, quiprocós, Calambours. Eu disse logo a Cicillo: por que o senhor não encontrou um outro substantivo e, em vez de museu, não o chamou por exemplo de artis? Tudo ficou na mesma e, depois de pouco tempo, aquela reuniaáozinha não deu certo, e fechou.

As invenções típicas da província tiveram outros lances de ingenuidade quando o mesmo fervoroso, mal- aconselhado, fundou nada menos que a Bienal. Lembro-me de ter-lhe explicado, 
como dois e dois são igual a quatro, que o batismo estava errado. Falou-me da Bienal de Veneza e, turisticamente, lhe fiz compreender que a Laguna era diferente do Tietê, e mais especialmente, demonstrei-lhes que a palavra "moderno" não tinha mais sentido. Doutro lado, nós da Itália, já nos anos 20, criticávamos severamente a Bienal de Veneza, então sem tanta curiosidade, evento já ultrapassado.

Meus dois mais dois em vez de igual a quatro foram iguais a zero. O Cicillo já estava com aquele regulamento na sacola, traduzido nem em português, mas em paulistano. E surgiu que a nossa Bienal, onde nenhuma menina artista foi recusada e que agora o Alex irá consertar, começando por completar o espaço, tirando-o de seu ponto de inércia.

Em tempos de pós-moderno, para ver arte que ao longo de um biênio se vê em qualquer esquina, andar quilômetros naquele calor é exercício para maratonistas, de preferência da São Silvestre, pontualmente perdidos nos itinerários geralmente errados, especialmente os das últimas ediçôes. O certame tornando-se burocraticamente "moderno" gasta uma fabulosa quantia em dólares. O abacaxi é, para mim, a fruta mais gostosa quando se póe na boca, porém a mais indigesta quando alude à solução de problemas. Pelo menos é o que dizem. No que se refere a nossa Venezinha local, que a última curadora para atualizar ornamentou com arremates da quadrienal de Kassel, o abacaxi presenteado a Periscinoto é até descascável.

Porém, para não continuar na polêmica e feliz por ostentar minha condecoração de cavalheiro do Conservadorismo (contarei um dia porque e como comprei para o Masp seis Modigliani, Picasso cubista, Max Ernst etc.) permito-me felicitar o novo presidente da Bienal, esperando dele a revolução que, volente ou nolente, deverá proclamar. Penso, saindo do titulo, exposição de dois em dois anos, inauguraçóes com fanfarra e outros abacaxis que compóem o mais provinciano fruto de nossa arte, em tempos melhores e efetivas conquistas no nosso (ainda modesto) recinto da Arte.

\section{Legenda}

Cartaz da primeira Bienal de

São Paulo, lançada pelo Museu

de Arte Moderna, há 37 anos

Senhor \#365, 2I de março de I988, p.68 (P.M. Bardi)

Candidatos aO Olimpo

No mercado de artes, investir em nomes consagrados sai caro. Melhor é se antecipar à fama

Falou-se, aliás, escreveu-se muito nestes últimos meses a respeito do mercado de arte. A pintura foi assunto predominante depois da venda de um Van Gogh por US\$ 50 milhóes e de um Modigliani por US\$ 7 ou US\$ 8 milhões.

Naturalmente os acontecimentos me interessaram, não tanto pelo negócio em si, mas porque, quando formava o acervo do Masp, adquiri cinco obras do holandês e seis do italiano, por preços que naquele tempo, apesar do reaquecimento do mercado depois da Segunda Guerra, eram considerados com muita atenção, valendo a baixa.

A retomada das vendas era ainda fraca, a não ser pela possibilidade dos americanos de incentivá-la. Entre estes últimos apareceu o Brasil, então a única nação compradora do Hemisfério Sul.

Contratar, adquirir, prever, estar certo do quanto se andava escolhendo, determinava reflexôes bastante complexas, sem contar as exigências da experiência, o estar seguro de aplicar o dinheiro convenientemente. Andava comprando para um museu, o que era ainda mais complicado, pois se tratava de formar um acervo. Felizmente, descartadas as arapucas, resolvidos os problemas das atribuiçóes, o que aconteceu há quarenta anos deve agora ser comentado.

O critério das aquisiçóes obedeceu à ideia de reunir obras de quase todas as escolas da Europa, partindo do Quatrocentos até a contemporaneidade. Diversos visitantes ficam curiosos ao encontrar no Masp pinturas de Max Ernst, Victor Brauner e da Escola de Paris, além de obras de artistas que naqueles anos não gozavam de consideraçôes especiais. Resultou então, na compra de trabalhos náo só de mestres de renome como também de obras de artistas para os quais a consagração deveria chegar um dia. Entre estes últimos estava Fragonard. 
Foi motivo de contentamento para este paginista receber no ano passado um convite para apresentar $A$ educação faz tudo, do mestre francês na grande retrospectiva que o Museu do Louvre e o Metropolitan Museum, de Nova York, lhe dedicam. Contentamento ainda maior foi receber o monumental catálogo, onde nossa pintura está reproduzida em cores, em página inteira, indicando uma série de informaçôes que, francamente, não conhecia. Mas o que me deu mais prazer foi ler a transcrição deste texto de Les Goncourt: "Faltam poetas ao último século. Eu não falo de fazedores de rimas, versificadores, alinhadores de palavras; falo de poetas. A poesia, que toma expressão na verdade e na altura do seu sentido, a poesia, que é a criação pela imagem, uma elevação ou um encantamento da imaginação, o resultado de um ideal de sonho ou de um sorriso do pensamento humano, a poesia, que eleva e equilibra acima da terra a alma de uma época e o espírito de um povo, a França do século XVIII não os conheceu e seus dois únicos poetas foram dois pintores: Watteau e Fragonard.”
A cena familiar é um festivo jogo de cores, delicado na observaçáo dos pequenos personagens, que resultou na prerrogativa de Fragonard ao representá-lo, como de resto se deu com os pintores franceses do Setecentos. Não observava as imagens, contemplava-as, talvez por timidez.

Tinha experimentado todos os gêneros, mas sua especialidade eram as cenas familiares, além dos retratos e paisagens que tratou de maneira superior. Dedicou-se também a todas as técnicas, cada obra cuidadosamente trabalhada.

Ainda na sua época Fragonard passava por um retardatário, conforme a afirmação de um dos competentes deste século, Walter Friedlaender, pois o comparavam a David, príncipe da nação neoclássica, quando a linha valia mais do que a cor, a reta sobre a curva, o acabado sobre o inacabado, o exemplar sobre a frivolidade, a virtude sobre o amor.

\section{Legenda}

Este Fragonard custou relativamente pouco ao Masp. Hoje vale uma fortuna.

Senhor \#366, 28 de março de I988, p.Ioo (P.M. Bardi)

O DOM DA VOZ

O apresentador e empresário Sílvio Santos conversa nas ruas como fala nos palcos. Foi nas ruas, aliás, que ele aprendeu a ser persuasivo e se convenceu de que o querer oferece o vencer

O leitor de Senhor que eventualmente lê esta página compreende que quem escreve nem sempre fica circunscrito às experiências que, querendo ou não, se aproximam das artes. Às vezes se desvia delas ou procura fazer aproximaçóes, especialmente quando o motivo parece obrigatório para um cronista.

Por isso, visto que até os severos comentários dos solenes cotidianos se interessaram pelo caso Sílvio Santos, e esta revista dedicou-lhe uma capa em que o valente sustentava um globo, é indispensável participar da discussão.

O apresentador, que não sabe precisamente se vai candidatar-se só a prefeito de São Paulo ou a presidente da nossa atribulada República, é personagem bastante digno de atenção, pois é reconhecidamente dono de uma preferência popular náo indiferente em número e eventual potencial de votos, hoje que se olha mais do que os políticos de profissão, o indivíduo, inclusive como condutor de empresas, como se deu na disputa passada para o governo de São Paulo, quando elogiamos Antônio Ermírio de Moraes. Refazer o curriculum de quem, todos os domingos, abre as portas da esperança para seus fãs seria repetir o que se sabe e nem há mais possibilidade de desencavar detalhes daquela vida, começada como camelô chegando à presidência de empresas bilionárias.

Assim, me limito a anotar que conheci Sílvio somente na ocasiáo em que, no teatro Anhembi, dirigiu a escolha de uma beldade brasileira, incumbida de voar para a corrida das misses Universo, e eu, a seu convite, participei do júri. Declarando não ter smoking, o SBT providenciou e me vestiu na fatídica farda, necessária para o julgamento.

Sílvio conversou comigo para agradecer minha presença durante os intervalos: tal qual como é no palco. Sua palavra, descobri, sem um acento a mais nem a menos, a pronúncia simples e arguta como 
de costume na tevê, mostra um domínio calculado de economia nas entrelinhas.

Mas o que mais me surpreendeu em Sílvio foi a trajetória de sua vida e fez com que me aproximasse dele. Em seu programa do dia 13 ele relacionou várias pessoas que também começaram a vida de maneira humilde. Ouvir isto me alegrou, pois confirma que o querer oferece o vencer. $\mathrm{E}$ o vencer de Sílvio teve o dom que Horácio definia ore rotundo, isto é, se o meu latim ainda está certo: voz harmoniosa, para dizer convencedora, persuasiva. Os italianos acrescentariam: cerello fino. $\mathrm{O}$ candidato, se o Tribunal Eleitoral permitir, servirá para adicionar o que a democracia pretende, isto é, a aprovação numérica em votos que permitirá um mandato?

O paginista queria somente lembrar este caso singular surgido neste táo atrapalhado momento político nacional, para cogitar possíveis soluçóes.

\section{Legenda}

Ele pode ter mais votos de que muitos políticos profissionais?

Senhor \#367, 4 de abril de 1988, p.68 (P.M. Bardi)

NotAS DE VIAGEM
Niemeyer lança um olhar inteligente em direção da Ponte Vecchio
e percebe que a contribuiçáo árabe está por toda parte

Num breve mas exuberante ensaio de Oscar Niemeyer se aprendem várias e essenciais recomendaçóes sobre o ensino da Arquitetura. Encontra-se na nova e arrojada revista Ponta de Lança da Fundação Clóvis Salgado, de Belo Horizonte, e tem por título Viagens, Origens e Influências na Arquitetura. Substancialmente, trata de indicaçóes do quanto um olhar inteligente de quem anda estudando construçóes no continente africano e no Oriente Médio pode ensinar. $\mathrm{O}$ arquiteto recorda que Le Corbusier "de caderno em punho percorreu atento a Grécia, o Egito e o deserto africano a tomar nota de tudo que o seduzia... um estudo comparativo da sua obra mostraria certamente por onde ele andou e o que o entusiasmou nas I4 viagens que fez pelas ilhas gregas, pelo Egito ou pelos desertos argelinos - estes últimos seu assunto preferido, como a igreja de Ronchamp e os pilotis do convento de La Tourette evidenciam.”

Também o arquiteto de Brasília namorou aquelas áreas, confessando: "Nesse estado de espírito... surpreso diante das coisas do passado, desse passado fascinante, cheio de grandeza e lirismo que o homem soube realizar." Suas andanças serviram-lhe para referir observaçóes inéditas, por exemplo que em Florença "a Ponte Vecchio sugere um mercado árabe e que na Praça da Senhoria a arquitetura árabe e a escultura grega estão presentes.”

Eis uma maneira de ver quando se viaja ao Exterior para ampliar as possibilidades criativas da invenção arquitetural.

Dirigindo-se aos estudantes brasileiros afirma que isto não é bem compreendido: "Nenhuma medida favorável é considerada pelos órgáos competentes e o estudante mais interessado se limita a conhecer por alto a arquitetura portuguesa, como se nela terminassem as origens da nossa arquitetura."

De fato, especialmente no passado do culturalismo aquela influência está presente, quando não impóe até a cópia. Dias atrás, pesquisando para um ensaio a respeito destas aventuras, encontrei um regimento de João III expedido em I548 a Tomé de Souza, quando governador-geral do Brasil, que ordenava: dar sesmarias para construir engenhos de açúcar, sob condição de levantarem "torres ou casas fortes" para a defesa dos mesmos engenhos e povoaçóes dos seus respectivos limites. A construção de entâo era de fortalezas, uma arquitetura defensiva, pesada, patronal. A maneira continuou.

Para voltar a Niemeyer: suas curiosidades e compreensão da simplicidade e da engenhosidade das construções da Arábia estão visíveis nos seus projetos, onde predominam aquelas suas formas a um tempo ornamentais porém funcionais, que revelam originalidade e confirmam sua cultura de atento observador do passado. Os superficiais apelidam isto de "pós-moderno," genericamente. Ainda é cedo para definiçóes, embora se saiba que a arte de Niemeyer representa um dos fatores da nova construção, já pesquisada e, em parte, acertada. 
Também o texto, que nos dá ocasião de redigir esta nota representa um elemento para julgar a arquitetura do mestre brasileiro. Um dado interessante: lembrando o livro de Garaudy Diálogo das Civilizaçôes, onde o autor se apaixona pelos "grandes monumentos do passado, as Pirâmides do Egito," Niemeyer reprime o "trabalho escravo sob o chicote do senhor... testemunho de um período desumano de opressão e injustiça." É importante considerar na produção do arquiteto o sentimento social, antes de tudo.

\section{Legenda}

Arquitetura árabe na praça de Al-Qatn

Senhor \#368, II de abril de 1988, p.65 (P.M. Bardi)

\section{O tesouro do Caribe}

Fica em Cuba um dos mais ricos acervos artísticos da $A L$

Quando se indicam os museus de arte ocidental da América do Sul, o Museu de Arte de São Paulo é sempre prestigiado como o mais rico e ativo até hoje, sem aplicar as regras da tradicional e burocrática museografia que não considera os intercâmbios com o Exterior. Todavia náo se deve esquecer alguns estabelecimentos de notável importância, entre eles o Museu Nacional de Cuba, do qual pouco ou quase nada se escuta.

Trata-se de uma coleção significativa de obras de pintura, na maioria ocidentais e, naturalmente, cubanas, que se admiram num esplêndido catálogo editado por Letras Cubanas, de Havana, e Aurora Art Publishers, de Leningrado. Editado em russo, espanhol e inglês em I978, vale a pena lembrá-lo dez anos depois, agora que finalmente as relações diplomáticas entre o Brasil e Cuba foram restabelecidas. O museu tem uma imponente sede com amplas salas, contendo um notável acervo. De excepcional qualidade, entre outras, algumas raras pinturas em encáustica denominadas fayum, retratos provenientes do Egito do segundo século da nossa era, e painéis aragoneses do Quatrocentos. Isto demonstra que residiam em Cuba.

As obras que mostram a Renascença apresentam o tríptico de Hans Memling "A Virgem e o Menino adorados por dois doutores," junto com uma "Recepçâo de um embaixador," elaborada por Vittore Carpaccio, um dos mestres italianos. Considerando a variedade do acervo acaba-se refletindo no interesse dos adquirentes na consideração da pintura, circunstância que não tivemos no Brasil onde a arte antiga não teve e ainda não enumera cultores, ao contrário do que aconteceu na América do Norte - onde hoje se conserva um grandioso patrimônio de todas as escolas ocidentais, africanas e asiáticas, sem contar o interesse pela arte contemporânea que tem no Museu de Arte Moderna de Nova York sua meca mais preciosa.

Quando o Masp, em I956, expôs no Metropolitan Museum de Nova York Ioo das suas obras, desmontaram cinco daquelas salas para exibir o que apelidaram de milagre brasileiro, expressão que eu corrigi numa entrevista como "milagre de Chateaubriand."

O acervo do Museu Nacional de Cuba pode ser considerado outro milagre pela excelência das obras-primas: flamengos bem escolhidos com predileção para os acontecimentos memoráveis da Bíblia; espanhóis dramáticos e uma série de mestres do Oitocentos, (decisão de um espanhol?) veem-se as vivas composiçôes de Rubens e de Van Dyck; vários franceses escolhidos com gosto; ingleses formando uma completa reuniáo de retratos evidenciando a sensibilidade de um conhecedor da ilha colonizadora e vários italianos. O importante é a coleção única dos modernos cubanos, participantes das empresas das vanguardas, sobressaindo-se Vitor Manuel Garcia, Mariano Rodrigues, René Portocarrero e o internacionalmente famoso Wifredo Lam. A contemporaneidade está bem composta, alguns da velha escola, como de resto ocorre em todas as naçóes, prevalecendo um espírito de determinação original, espelhando motivos cubanos no figurativo e no abstrato.

O diretor da instituição cubana, Alejandro Alonso, que recentemente esteve entre nós, solicitou uma exposição do Masp naquele país. Parece-me oportuna a ideia que contribuirá para que os dois países se conheçam melhor. 
Legenda

El Tercer Mundo, do cubano Lam, convive no museu com Van Dyck e obras egípcias do séc. II

Senhor \#369, I8 de abril de 1988, p.82 (P.M. Bardi)

O Futuro do PASSADO

$O$ antiquariato: peças antigas, gosto atual

Foi inaugurada no Museu de Arte de São Paulo a Terceira Feira de Antiguidades e Artes Plásticas. Vem confirmar que aos poucos se está contribuindo com um fato de uma certa importância ao colecionismo do passado, apesar de ser com passos ainda iniciantes.

Como se sabe o Masp, desafiando muitas adversidades, há alguns anos hospeda aos domingos a feira de antiguidades, a qual andou criando seu público, sempre mais numeroso.

É desta feira que surgiu a mostra agora inaugurada, que se pode classificar como apresentadora do gosto corrente no que se refere a objetos antigos.

O Brasil, especialmente Rio e São Paulo, sem contar o que se verificava na decoração das fazendas, no Oitocentos andou reunindo coisas de arte. Foi depois da vinda da Missão Francesa e também com a transferência de famílias estrangeiras, que se notou a importação de mobiliário e peças de um certo padrão já neste século. A inauguração do Masp em I947, a atenção que se reservou à história da arte, o intercâmbio com museus de fora, deram incremento a considerar o antigo e especialmente o que o comércio de Paris andava vendendo.

Em 1946, quando este paginista veio para Sáo Paulo, sendo sua atividade devotada ao mercado de arte, não encontrou nenhuma loja especializada em antiquariato. Porém num armazém na rua da Consolação, dirigido pelo senhor Florestano, foi possível, por exemplo, encontrar e, naturalmente, adquirir lotes significativos de art-nouveau, pintura acadêmica e também outras peças de certo interesse.

Depois, abriram-se lojas dedicadas ao antiquariato e, com o desenvolvimento de Sáo Paulo tomando sempre mais impulso, aumentaram os antiquários e, consequentemente, o comércio. Hoje a capital de nosso Estado conta com um complexo de antiquários bastante expressivo. Possuem uma associação, responsável por esta exposição que vai funcionar até o dia 24 de abril. A mostra foi implantada no subsolo do Masp em dezenas de stands muito bem montados e iluminados, que apresentam o que o comércio do antiquariato está em condiçôes de oferecer: objetos de todos os séculos, especialmente do Oitocentos, todos cuidadosamente classificados. Disse que esta feira é o começo, mas já dá uma ideia de um colecionismo mais amplo que se vem integrar ao que já existe dedicado à arte do século passado e princípio do Novecentos.

Quem sabe pescar pode efetivamente obter peças singulares. De notável interesse o mobiliário nacional. Assim mais uma iniciativa do Masp que, sem dúvida, tem um futuro bastante promissor.

\section{Legenda}

Cama d. João v, relógio de pedestal

Luís XIV e cadeira Luís Xvi: De

repente, na avenida Paulista

Senhor \#370, 25 de abril de 1988, p.84 (P.M. Bardi)

A ARTE NA MESA

Um livro mostra o interesse de artistas antigos e contemporâneos

com a não menos nobre arte de cozinhar

Já que me vejo bastante lembrado num livro publicado agora na Itália, dedicado à gastronomia e à arte, penso ser interessante recordá-lo aos leitores de Senhor. É de Roberto Sambonet, com o título L'Arte in Tavola, editor Edizioni del Sole 24 Ore, Milão.
O autor é um dos mais ativos designers italianos e pintor de renome. Passou alguns anos no Brasil, a partir de 1948, como colaborador do Masp. Dele publicamos uma brochura intitulada Massaguassu, localidade por ele documentada em notáveis pinturas, lançada por ocasião 
de uma exposição sua, das primeiras que faziam conhecer elementos de valor.

Depois de alguns anos, Sambonet voltou à Itália, onde se afirmou excelentemente. Viajou muito, e o sabemos ao lado de Alvar Aalto, na Finlândia. Seu livro é bem original: numa série de páginas anota artistas, antigos e contemporâneos, interessados nos sérios problemas da mesa, que não são poucos. Parece que cozinhar depende do conhecimento de complicados ingredientes e de saber manuseá-los. Se o cozinheiro tem renome na pintura e na arquitetura, na escultura e até no design, pode ser ótimo preparador, mas deve também saber convidar, escolher restaurantes, gostar e, às vezes, criticar. Deve sobretudo sintonizar as primazias da cozinha com cores, composição, harmonia.

Às vezes Sambonet imagina, e imagina com fantasia. Mas fique claro que este paginista não é citado nem biografado como gourmet. Geralmente almoço no Degas, o restaurante do Masp, entre centenas de clientes. O Degas oferece mais uma diversão ao nosso público, o qual pode saborear, ao som de música ao vivo pratos de diversos sabores, ao sistema americano self-service, chegando-se a formar filas intermináveis: um sucesso que, infelizmente não vejo citado nas crônicas das nossas grandes revistas e nem nos artigos especializados dos vários Lancellotti.

O nosso restaurante tem o nome de Degas e está sob responsabilidade de Adolfo Gorenstein. Tem como decor uma vitrina que conta nada menos do que com a coleção de todos os bronzes do mestre, bronzes que de vez em quando viajam para grandes museus da Europa e que estáo ao alcance de cada hóspede das dezenas de mesas, de modo que a arte e a gastronomia se dão as máos, como Sambonet gostaria de registrar. Penso até em apertar a máo do chef Sergio Capuzzo, italiano de Pádua, mestre por todos apreciado no Masp, também vindo de famosos restaurantes europeus, onde aperfeiçoou seu talento.

Voltando ao escritor: o livro se distingue por uma série de correlaçóes entre maneiras de cozinhar e apresentar na mesa, vinhos, doces etc., as delícias que saem das panelas e das garrafas, citando especialmente as do pessoal do pincel: de Klee até Leonardo. É um livro divertido e espirituoso, com ilustraçóes selecionadas pelo autor, recolhidas no infinito mundo da produção das artes, antiguidade e modernidade.

\section{Legenda}

A "peixeira” em aço inoxidável, de Sambonet, recebeu o prêmio Compasso d'Oro, em 1970

\section{Casa Vogue \#3, maio-junho de I988, p.84 (P.M. Bardi)}

\section{OBRAS AUTÊNTICAS}

Quem se interessa pelo lazer arte e, consequentemente, pela pintura sabe de uma circunstância se não muito comum pelo menos de vez em quando presente: a autenticidade das obras, relativas discussões, o recorrer aos assim considerados experts, as possíveis consequências judiciais e tudo quanto ocorre quando estáo em jogo valores monetários. As produçóes dos artistas - como sabem os que as possuem, compram e vendem - dependem sempre de avaliaçóes e, infelizmente, neste casos não é sempre que tudo corre bem, sendo as negociatas provocadoras das mais curiosas e às vezes ilícitas combinaçôes.

$\mathrm{O}$ adjetivo falso é um dos mais frequentes. Surgem crônicas a cada dia, quando descobertas as costumeiras trapaças, processos e companhia. E mais: revelaçóes de copistas ou intérpretes da pintura de mestres, por parte de sujeitos de valor, capacitados a reproduzir obras com tal perícia que confundem o mais atento conhecedor.

Isto não é de hoje, pois no passado copistas e imitadores existiram e numerosos. Fácil saber de pintores da Renascença inscritos como ativos no "círculo," para indicar alunos e seguidores: são tão próximos dos originais que podem ser considerados excelentes executores. Tempos atrás ocorreu o típico acontecimento do Auto-retrato de Rembrandt do acervo do Masp: uma comissão holandesa sentenciou que a obra não representava Rembrandt, que a pintura era da mão de um aluno, todavia a assinatura era definida como absolutamente autêntica. Conclusão: Rembrandt assinou a obra de um aluno. Desde as primeiras décadas do Oitocentos a obra era unanimemente atribuída ao mestre 
holandês por todos os números um da história. Improvisadamente, o escândalo. Devo dizer que o quadro é de Rembrandt, tanto é verdade que nas recentes exposiçóes do Masp na Europa a obra está incluída no acervo e continua a ser do seu autor.

\section{Reproduções}

Mas não é bem disso que quero falar nesta página. $\mathrm{O}$ assunto é outro: hoje temos tal progresso fotográfico e de técnicas de reprodução que a cópia em si resulta superada, tornando-se um original ao alcance de todos. A perfeição de uma pintura, também em tamanho natural, é surpreendente, perfeita identidade com que o pintor realmente representou: um fato novo na difusão das artes. Qualquer um tem a possibilidade de emoldurar um Cézanne ou um Picasso, conforme seu gosto, e gozar da obra preferida.

Observo constantemente este fato no balcão de publicações do Masp, através da venda de reproduçóes de obras singulares. Uma conquista da cultura? Sem dúvida. Hoje que as formas são simplificadas, reproduzir, por exemplo, um Mondrian ou um Klee é serviço corriqueiro. E o preço de uma compra dessas é bem conveniente.

Em tempos em que o autêntico custa importâncias espantosas, uma obra célebre pode ser pendurada em todas as casas, deixando a museus e colecionadores com possantes cofres admirar os originais. Tivemos há pouco o caso de um Van Gogh adquirido por cinquenta milhóes de dólares. São exageros, a meu ver. A um certo momento, não se sabe se se trata de real amor às flores pintadas pelo pintor que vendeu um único quadro na vida a seu irmão ou apenas de exibição de quem tem muito dinheiro.

\section{Imagens do mestre}

A respeito de originais e reproduções não-autorizadas, isto é, obras falsas: nos necrológios pela morte do pintor Alfredo Volpi, há pouco falecido, vários foram os acenos a exemplares de sua pintura considerados falsos. De fato, como sempre se verifica na obra de um artista de sucesso e, por consequência, vendável, pode ser que as telas apócrifas do mestre sejam numerosas, especialmente na fase mais recente, a das bandeiras, que resultou a mais característica do antigo participante do grupo Santa Helena.

Nada de inédito: os falsificadores e os embrulhôes do comércio devem dar sinais de vida e concorrer para a celebridade de quem é visitado pela glória. Depois da morte de Volpi, os falsos a irão, sem dúvida, retomar o caminho normal, não sendo simples o trabalho de distinguir entre o original e o falso - e esta tarefa deverá ser reservada a um técnico.

A pintura de cavalete, em especial a dos pintores contemporâneos, é de possível averiguação enquanto se pode contar com testemunhas e documentos.

Há alguns anos, no Museu de Arte de São Paulo, fizemos tentativa de levantar toda a obra de Alfredo Volpi, mas o projeto, por falta de patrocinador, infelizmente não foi adiante.

\section{Legenda}

Rua de Itanhaém, óleo sobre tela, e Casario com Calçada, têmpera sobre tela: obras do grande gênio da pintura brasileira Alfredo Volpi

Senhor \#37I, 2 de maio de I988, p.68 (P.M. Bardi)

O OURO QUE SOBROU

Imagens do apogeu pré-colonial na América do Sul

O ciclo de exposiçóes periódicas do Museu de Arte de São Paulo é, sem dúvida, de um interesse que somente nossa grande imprensa não está em condiçôes de descobrir. Digo isto abertamente, pois noticiada a belíssima manifestação dedicada ao Ouro do Peru os releases obtiveram a mesma acolhida que os da fulaninha que finalmente descobre a arte abstrata.
Neste setor da história da arte, os caminhos que ainda devemos percorrer são inúmeros. A questão é de gosto e saber. E no entanto esta mostra de arte peruana representa um fato sul-americano da maior importância e apreciá-la é uma experiência básica para nos sentirmos cidadãos da América dita Latina. Ali se pode ver o que um dos povos sacrificados pelos brancos realizava no tempo 
das conquistas, com uma civilização de um desenvolvimento absoluto. Cada vitrina do Masp reúne peças que demonstram o que os peruanos criavam numa estética deslumbrante. Simples objetos de uso, os mais simples, adornados com ouro se distinguem como únicos: quem os executava tinha mente e mão de artista, fantasia e técnica exaltadas de singularidade.

A exposição apresenta desde objetos que podiam servir para uma tarefa doméstica até outros para celebraçóes rituais: a variedade é que nos impressiona levando a pensar num povo vivendo de poesia, todos poetas um mais do que o outro.

Quando os espanhóis se precipitaram em nossa América para civilizar, deu-se a devassa da vida peruana: apoderaram-se do ouro, especialmente para fundi-lo, desprezando qualquer produção. Mas felizmente algumas peças resistiram à pilhagem e são muitas delas que hoje formam o acervo do Museo Oro del Peru, reunido por Miguel Mujica Gallo, empresário e colecionador que durante mais de quarenta anos conseguiu resgatar num incessante trabalho, joias valiosas, vasos e outros objetos, dos quais uma parte se pode ver no Masp até 22 de maio, numa iniciativa da Fundação Copasa, entidade com sedes em Buenos Aires e Lima, que promove exposiçóes de caráter cultural.

Com um pingo de fantasia pode recompor-se o romance pré-colombiano, bem diverso do pré-cabralino. Apesar de o Brasil ter tido no Setecentos a epopeia do ouro, este era tirado da terra, mais especialmente dos rios, às toneladas. Só que os administradores portugueses, no festival do ouro, nada entenderam e o desperdiçaram sem o mínimo senso social, até mesmo desprezando os que advertiam contra a injustiça de náo gastá-lo em parte para o desenvolvimento da colônia.

No Peru, o desenvolvimento, como se vê pelas peças, era outro, como se vê pela mostra: desde um par de sandálias femininas enfeitadas com ouro até joias de grande esplendor e uma caixa com a tampa esculpida e modelada. As peças, não só em ouro mas também em prata, pedras, bronze e tecidos, documentam o gosto refinado dos executores, a liberdade de invenção, a continua veneraçáo aos seus ídolos, os quais eram reproduzidos em diversos objetos.

\section{Legenda}

Garrafa de duplo bico cônico, vaso com rosto humano e máscara de uma lâmina só: o Peru vai ao Masp

Senhor \#372, 9 de maio de I988, p.68 (P.M. Bardi)

\section{RELÍQUIAS AFRICANAS}

Com a exposição África Negra, o Masp presta sua homenagem ao centenário da Lei Áurea

Transcorre neste ano o centenário de uma lei que o Brasil promulgou tardiamente em relação aos outros países, tendo o governo brasileiro ao longo de quase todo o Oitocentos tergiversado, adiado, não dando ouvidos a ninguém a respeito: trata-se da Lei Áurea, que libertou os escravos. Nem mesmo os apelos dos vários patriotas abolicionistas que se empenharam fervorosamente nas campanhas pela libertação conseguiram antecipar a decisão final que só ocorreu em I3 de maio de I888.

Diversas manifestaçóes estão sendo organizadas para comemorar o evento, e o Museu de Arte de São Paulo não poderia deixar de participar de alguma maneira dos festejos. Assim, em conjunto com a Fundação Gregório de Mattos, da Prefeitura Municipal de Salvador, valeu-se da personalidade mais expressiva do nosso africanismo: o etnólogo Pierre Verger, estudioso francês que há mais de quarenta anos reside na Bahia, onde, através de inúmeras viagens à África, estudou e documentou os fatos da escravidão no Brasil, de maneira total e abrangente. Antigo organizador do Musée de l'Homme de Paris, Verger é também autor de vários livros sobre a África e o Brasil, tendo lançado recentemente Fluxo e Refluxo do Tráfico de Escravos entre o Golfo de Benin e a Bahia de Todos os Santos.

Foi a este estudioso que o Masp e a Fundação Gregório de Mattos confiaram a organização da mostra África Negra, o qual, com a arquiteta Lina Bo Bardi, decidiu realizar o evento em duas etapas, a primeira em Salvador inaugurando a Casa de Benin, no Centro Histórico do Pelourinho, tombado pela Unesco e cuja recuperação 
está sendo feita sob a coordenação da arquiteta, e a segunda em São Paulo. Para esta manifestação, de caráter artístico, no Masp, de II de maio a 26 de junho, obtivemos, graças a Verger, o empréstimo de 28 peças de arte africana do Musée de l'Homme de Paris, além de outros seis objetos da coleção do Musée des Arts Africains et Océaniens. As peças, cuidadosamente selecionadas pelo etnólogo, representam um oferecimento ao nosso público de singular importância, permitindo que se aprecie a arte do continente africano que, no início deste século, tanto influenciou as criaçóes de artistas como Picasso, Modigliani, Braque, Léger, entre outros.

Lembrar a escravidão significa entrar na história nacional desde o Seiscentos, sem falar no papel que os africanos desempenharam no Setecentos nas minas: todo um trabalho ao qual se deve, em parte significativa, a formaçáo do Brasil. Para citar o escritor que mais penetrou na vida da Colônia, Gilberto Freyre: "Do negro, especialmente em todo o litoral, desde o Maranhão ao Rio Grande do Sul e no Estado de Minas Gerais: influxo direto ou remoto do africano."
Num primeiro momento a exposição do Masp se intitulou África-Brasil, pois se pretendia dar relevo à participação do africano na vida nacional. Passou depois a se chamar África Negra.

A respeito da contribuição na lavra mineira, consulte-se a prosa de um dos documentadores da Colônia, o jesuíta Andréa João Antonil: "Os escravos são as mãos e os pés do senhor porque sem aqueles no Brasil não seria possível fazer, conservar e aumentar fazendas, nem ter engenho corrente."

O supervisor do Santo Ofício, quando se tratou de publicar o livro Cultura e Opulência do Brasil por suas Drogas e Minas, achou-o tão importante dizendo que o mesmo deveria ser imprimido em letras de ouro.

Através das duas exposições, em Salvador e em São Paulo, é possível constatar como o povo africano se distinguiu em sua produção artística, especialmente na escultura, na qual demonstra produção significativa.

\section{Legenda}

Duas das 28 peças africanas do Musée de l'Homme de Paris que integram a mostra do Masp

Senhor \#373, I6 de maio de 1988, p.78 (P.M. Bardi)

PRÊMIO PARA UM AUTODIDATA
Por seu trabalho à frente do Masp, Pietro Maria Bardi
recebe a distinçấo de doutor honoris causa

Sem dúvida, cada leitor, ao longo de sua vida ou carreira, deve ter recebido alguma homenagem: devido a negócios, empreendimentos políticos ou sociais, sucesso na escola, enfim, onde se destacou. Se esta nota tem algum leitor, repense aquele momento e refaça aquele dia em que uma ação sua foi reconhecida e premiada.

Sendo o sabor destas páginas bastante pessoal, peço desculpas por registrar um caso que se insere no lembrado quadro de receber um reconhecimento. Para não ficar nas conversas: no último dia io de maio recebi, no auditório da Universidade Mackenzie a distinçáo de doutor honoris causa.

Para um estudioso, um professor, um político, este título pode ser recebido como rotina no trabalho ao qual consagrou sua atividade. Para mim se trata de um prêmio absolutamente particular. E por um simples fato: eu não provenho de nenhuma escola.

Devo confessar que na minha caderneta escolar do primário, na classe III, tem a séria anotação que repeti o ano três vezes e por isso, de acordo com a lei, não pude fazer uma quarta tentativa. Não me desesperei. Tentei vencer a derrota procurando emprego, sendo o mais fácil o de ajudante operário, naquele tempo - segundo decênio do século - fácil de encontrar devido à guerra que a Itália tinha declarado à Áustria, para reconquistar as províncias de Trento e de Trieste.

Em resumo: imbuído ao máximo de boa vontade, cônscio de que permanecer um "burro," como se dizia então "calçado," não era um bom negócio, teimosamente me propus a aprender tudo quanto fosse possível do saber. Meti-me num 
empreendimento que, soube depois, ser chamado autodidatismo. Naquele tempo, faltando a luz elétrica, durante o dia trabalhando e à noite estudando à luz de velas, consegui somar na cabeça muitas noçóes, a começar da escrita. Depois de ter ensacado na cabeça tudo que pude, em I9I7 fui chamado como soldado na Primeira Guerra. Como recruta, continuei aprendendo, inclusive inutilidades. Impossível exprimir o que tenha sido: penso que cada participante se movimenta no saber como acontece e como pode. Para concluir: depois da guerra, comecei a praticar o jornalismo na província, depois em Miláo, nunca abandonando esta profissáo que me vê agora paginista de Senhor. Esqueci-me de dizer que, no ano em que fui militar, tive a sorte de publicar meu primeiro livrinho dedicado às possessôes coloniais, obra do inglês Geremia Bentham.

É inútil rememorar uma longa carreira em que fiz algumas coisas no campo da arte até chegar à direção do Masp. Neste trabalho a Universidade Mackenzie descobriu, talvez, algum aspecto original, e me outorgou o honoris causa.

Não soube como agradecer, mas nas poucas e emocionadas palavras que disse refletia a comoçáo de ver reconhecido um demais longo e, pode ser, competente trabalho. Aqui vai aos veneráveis, agora colegas, e especialmente à reitora Aurora Albanese, meu agradecimento profundo.

\section{Legenda}

Bardi discursa ao lado de Assis

Chateaubriand, na noite de 2 de outubro de 1947, data da inauguração do Masp

Senhor \#374, 23 de maio de I988, p.68 (P.M. Bardi)

MEMÓRIA NEGRA

Inaugurada há pouco em Salvador, a Casa do Benin será um espaço permanente de reflexão sobre a influência africana na etnografia brasileira

Foi aberta em Salvador a Casa do Benin, no Pelourinho, um acontecimento da maior importância para a Bahia pois consolida seus laços etnográficos com aquela nação africana, de onde vieram grandes contingentes de escravos para cá durante o período colonial. A inauguração foi uma festa de evidente solidariedade, com a presença de uma comitiva vinda do Benin. Na casa, o etnólogo Pierre Verger conseguiu compor uma sintética exposição com peças mostrando muito da produção artística beninense, e a arquiteta Lina Bo Bardi, responsável pela restauração da casa e pela composição da mostra, arranjou, numa série de vitrinas, encantadoras produçóes populares onde se observam o gosto artístico e a criatividade das técnicas: tecidos, instrumentos musicais, objetos de toalete, móveis, elementos de culto, tapeçarias, ornamentos - todo um arsenal demonstrativo da vida africana, inclusive um tear manual.

A Casa do Benin, além de ser um centro de estudos, funcionará como hospedaria pois lá se instalarão os estudiosos que virão do outro lado do Oceano para ativar o intercâmbio cultural. Como diz o prefeito de Salvador, Mário Kertesz, a iniciativa "para nós baianos é uma oportunidade de encontrarmos manifestaçôes culturais incrivelmente semelhantes com as nossas e de nos informarmos sobre as razões deste parentesco.”

É este aspecto cultural a mais palpável consequência do centenário da Lei Áurea que o Brasil celebra neste mês de maio. Assim, mais um aplauso a Pierre Verger, promotor de amizade, entendimento, paz e trabalho entre a Bahia de Todos os Santos e o Golfo do Benin. Ele consagrou sua vida de etnólogo a este entendimento através de seus estudos e pesquisas.

A ele também se deve a interessante exposição África Negra, no Museu de Arte de São Paulo, com uma série de peças procedentes do Musée de l'Homme de Paris e do Musée des Arts Africains et Océaniens: uma amostra do que o continente africano ofereceu à arte universal, dando forma a pensamentos de intensa criação.

O que se espera agora, depois dos festejos, é que o Centenário da Abolição não passe a representar um fato passageiro, impondo-se como objeto da nossa história e da nossa formação étnica. Em geral estas ocasióes servem somente para os oradores se exibirem em discursos, sem pensar que estas datas propiciam a oportunidade de 
se estreitarem os vínculos de fraternidade humana. É hora de o século da eletrônica descobrir um mecanismo, aliás, um robô, para convencer que se precisa, no mundo, não de mísseis, mas de amizade.

Este é um campo de nossa história com uma abrangente presença. Mas é preciso dar um senso à celebração do centenário de libertação de um povo que nos deu braços e abnegação, sem contar os sacrifícios. Náo se pode esquecer que no apogeu da exploração do ouro dezenas e dezenas de milhares de africanos escavaram as minas das Gerais retirando o ouro que, infelizmente, os portugueses despejaram nos cofres ingleses, incapazes de administrarem a inesperada riqueza. Por acaso estou preparando um livro sobre o ouro nacional e a cada página encontro nossos negros. É por isto que a Casa do Benin em Salvador e a grande mostra do Masp têm significados precípuos. Aliás, de um tema se pode passar a outro. E lembrei do seguinte: li num jornal que o palacete da avenida Paulista, antiga residência da família Matarazzo, está a venda. Eis uma oportuna ocasiáo para os ricos italianos o adquirirem para lá fazer a nova sede do Instituto Italiano de Cultura.

Assim, Salvador terá a Casa do Benin e São Paulo, a Casa da Itália.

\section{Legenda}

Um novo ponto de encontro para todos os estudioso da questão negra

Senhor \#375, 30 de maio de 1988, p.94 (P.M. Bardi)

A EMOÇÁO MARCADA A FERRO

Não há equívoco maior do que considerar a gravura uma arte menor.

Estão ai para provar Bonomi, Grassman...

Os pintores de cavalete, isto é, os artífices considerados artistas, consumidores de telas, pincéis e tintas e que preenchem as colunas dos jornais representam a categoria mais falada no recinto do lazer-arte. Pelo contrário, os artífices que se dedicam às técnicas erradamente ditas "menores," por exemplo, a gravura, não gozam do interesse que, em vez, se lhes deve. O que se explica: a pintura andou se popularizando de tal maneira que pôs de lado até a escultura, e a gravura ficou então ainda menos presente, como uma espécie de gata-borralheira.

Apesar do esquecimento e das lacunas, há no Brasil elementos dedicados à incisão de reconhecido valor. E agora temos até uma revista, a Gravura e Gravadores, circulando entre os amantes desta especialidade. É redigida com singular e atraente competência.

Num dos últimos números, o do inverno - pois a publicação é sazonal - aparece uma matéria de curioso sabor de Leonor Amarante: ilustra xilogravuras executadas por soldados do Paraguai, durante a guerra que aquele país travou contra o Brasil, Argentina e Uruguai no século passado. Foram cinco anos, de I865 a I870, de ferozes embates e impressionante soma de mortos. O que resta de tanto sangue sacrificado são alguns jornaizinhos de trincheira que os combatentes paraguaios conseguiam compilar e estampar, enquanto os canhóes semeavam o terror.

Os tempos eram duros se entre as ilustraçôes se descobre a figura aqui reproduzida de uma tartaruga virada que serve de pasto para urubus. Os desenhistas são recrutas da tropa, xilógrafos improvisados escavando placas de madeira com espírito e técnica rudimentares, fazendo pensar no dito "à la guerre comme à la guerre." E a impressão? O papel, as cores? Eram milagres se considerarmos as dificuldades de importação, sabendo que os materiais, inclusive o papel, a uma certa hora, foram criados no próprio front.

Foi publicado no Paraguai um livro de Josephina Plás, Cabichuí, onde se diz: "Os quatrocentos desenhos feitos no quartel-general de Paso Pucú formam um conjunto homogêneo, resultante de duas vertentes: uma com uma solução esquemática em linhas retas, provocando uma dialética entre o dinamismo e o estatismo, e a segunda influenciada pelo expressionismo primitivo, sóbrio e lírico.”

No mesmo número, um crítico de fina intuição como Federico Mengozzi evoca os difíceis passos da gravura brasileira e, tratando dos tempos da guerra com o Paraguai, recorda Angelo Agostini, que na Vida Fluminense "descrevia a irracionalidade da guerra numa composição de 
página dupla Por cima e por baixo do rio Paraguai: por cima, homens que se matam como peixes vorazes, por baixo, peixes que se banqueteiam como homens civilizados."

A reprodução das gravuras paraguaias contrasta com as obras que a revista apresenta de nossos artistas que, como se afirmou acima, devem ser bem considerados. Entre estes, eis as incisóes do solitário Evandro Carlos Jardim, que Frederico Morais define de "uma luminosidade que faz escola e influencia uma geração de novos artistas;" Renina Katz e Djanira, bem expressivas da realidade popular nacional. Alex Fleming, serigrafista excepcional; Roberto Grassman, PerezSola, Selma Dafrée, Sérgio Fingermann, Ubirajara Ribeiro, Darel Valença Lins e vários outros. Mas se deve notar que o Brasil conta também com a autêntica mestra criadora Maria Bonomi, Paulo e Omar Guedes, Laura Salgado, João Rossi, Leon Ferrari, elementos já afirmados, além das galerias, clubes, grupos e marchands que prestigiam a gravura.

\section{Legenda}

Visôes contrastantes à margem da Guerra do Paraguai: no lado dos vencedores, uma cena bucólica; entre os vencidos, a destruição

Senhor \#376, 6 de junho de 1988, p.84 (P.M. Bardi)

A MISSÃO DO SOLITÁRIO

Sugestão à Bienal deste ano: uma bela homenagem a Volpi, silencioso revolucionário

Volpi nos deixou, de improviso, levando consigo para a eternidade sua solidão. ${ }^{104}$ A lembrança da trajetória deste criador é das mais caras. Morreu depois de noventa anos, quase um escondido, como foi sempre, nunca avançando nem quando um certo reconhecimento da sua arte finalmente o prestigiava.

Uma das mais significativas homenagens Volpi recebeu recentemente no seu próprio Cambuci. Foi quando o pintor Julio Pequeno, ao longo de dois muros próximos à Igreja Nossa Senhora da Glória, naquele bairro, teve a afetuosa ideia de dedicar-lhe todas as pinturas que realizou no local, evocando o quanto o mestre tinha produzido nos últimos decênios.

O Masp foi convidado para participar das homenagens. Eu mesmo lá acorri, vendo a fanfarra tocar alegre e, ao lado da filha do pintor, Maria Eugênia, desatei a fita verde-amarela que impedia o trânsito da rua ao lado dos muros, inaugurando-os, enquanto as televisóes filmavam, ouvindo os comentários do povo que circulava discreto. Quem conhece um pouco da história italiana, logo lembrou que aquele tributo a um pintor tinha o mesmo espírito das antigas solenidades da entrega de afrescos de uma igreja. Agora os murais, que contaram com o apoio das Tintas Coral, eram de origem cívica, para exaltar a arte. São de livre concepção, porém

IO4 Volpi faleceu dia 28 de maio de 1988. devotas evocaçóes do Alfredinho que aos dois anos desembarcou proveniente da Itália, sua família uma das tantas imigradas que povoaram nosso Brasil. A história do menino, os jornais recompuseram: moço operário, depois pintor de paredes, mais tarde participa do Grupo Santa Helena, no qual se andaram formando os elementos de uma escola, não bem uma escola, mas um conjunto de obstinados operadores que, sucedendo à Semana de Arte Moderna de 22, se incumbiu de melhorar as artes plásticas paulistanas, cada participante pondo no próprio paisagismo signos de individualidade, ajeitados no modernismo que então estava fervilhando nas iniciativas parisienses.

Penso que a próxima Bienal deveria documentar o trabalho de Volpi, para mostrar a mais expressiva pintura de um brasileiro, consequência do próprio engenho, inserido na bem falada tendência da "modernidade," um pintor que não se andou inspirando no trabalho de fora, espontaneamente dedicado a sua atividade, formas e doutrinas próprias, sem espelhar em ídolos, dando vida a um modo que lhe vinha naturalmente, de um espírito popular, congênito a partir dos primeiros encontros com murais. A trajetória de Volpi, para quem sabe precisar criticamente, é inconfundível, desde o início dos momentos pictóricos até as últimas casas e bandeiras ou alusão às bandeiras. Seria então certo mostrar, no ninho de Perissinoto, algo que se fez neste século no Brasil, sem recorrer aos facilismos 
abstratos ou geométricos ou de tantos outros ismos. A estranheza às circunstâncias que o cercaram e, em certo modo, deixar definir a tendência do seu pintar e possíveis comparaçôes, foi uma característica de Volpi. Viveu realmente como um solitário, sua tarefa única executar telas como as imaginava, como lhe passava pela cabeça, recusando o nominativo de revolucionário: silencioso, um sorriso irônico ao saber de atribuiçôes, não interessado no receber premiaçóes e merecimentos.

Fechava-se no atelier, não para satisfazer os últimos chegados do mercado nem os improvisados pseudocolecionadores que descobrem e arquitetam monetariamente: um solitário empenhado na sua missão. Difícil tirar-lhe da boca palavras e conceitos, Volpi era um permanente ativador da barreira do silêncio para se defender dos assaltos dos interessados. Exemplo de artista independente e, a seu modo, mestre desta nossa arte do Novecentos.

\section{Legenda}

Paisagem de 1922, já a caminho da libertação do acadêmico, e Bandeirinhas e barco, obra dos anos 70 e da irriquieta maturidade

Senhor \#377, I3 de junho de I988, p.92 (P.M. Bardi)

Mestre do Figurativo

Mal compreendido à sua época, Lasar Segall nada fica a

dever aos maiores expressionistas alemães

Quando cheguei ao Rio de Janeiro, em 46, minha primeira visita a um artista foi reservada a Cândido Portinari, adquirindo uma sua pintura, a qual tive a infeliz ideia de doar à Galleria d'Arte Moderna de Miláo, ${ }^{\text {105 }}$ junto a uma de Di Cavalcanti e a outra de Lasar Segall.

Boa ocasião esta para confirmar a pouca estima que manifesto pelos museógrafos-cabides de emprego, pois nunca soube se as três obras foram expostas e posso afirmar que são bem notáveis. Mais tarde reclamei o fato até com o próprio prefeito de Milão. Sou de opinião que o vaivém na direção de uma entidade cultural é nocivo ao seu funcionamento. Mas sobre isto: ponto e basta. Hoje quero lembrar Lasar Segall, pois a Metal Leve patrocinou a publicação de uma monografia dedicada a ele, compreendendo seu trabalho de gravador. Pouco a pouco, aliás, de decênio em decênio, agora que a Segall está consagrado um museu bastante ativo, se começa a dar a César o que é de César: o reconhecimento de seu valor, diria único, à medida que se descobre aquela historieta da "modernidade." De fato, Lasar, que de vez em quando descobrem como elemento brasileiro nesta ou naquela exposição

IO5 Bardi conta desse episódio que nunca recebeu de volta da Galeria nenhuma manifestação de agradecimento, nem mesmo resposta às cartas que enviava perguntando se as obras chegaram. REF? oficial, é o artista mais notável deste século no recinto nacional, mestre emigrado para a Pauliceia no tempo dos tempos, na centúria em que aquela fabulinha da modernidade nem articulava a letra "a."

Natural que, logo instalado com o Masp no edifício em construção dos Diários Associados, pensei em escrever e publicar um longo ensaio sobre Segall, no meu italiano que o caro amigo carioca Mário da Silva traduziu para o português. A repercussão foi pontualmente modesta. Não valia a pena registrar: o silêncio se devia à hostilidade pela abertura do Masp, náo museu mas antimuseu, e a um certo mau humor por saber que a entidade era dirigida por um estrangeiro que se estava batizando brasileiro. Espero, aliás estou certo, que dona Sabina Libman, intencionada em historiografar os fatos da Bienal, passe no Masp para conhecer de perto a precipitada decisão do amigo Cicillo em abrir o "museu de arte moderna” no próprio prédio do Masp.

Mas aqui se queria recordar a monografia da gráfica segalliana: revela um mestre do expressionismo alemão, segurança de gravar o quanto pensava, despreocupado de qualquer consideração, um amor no se manifestar, espontâneo resultado. Um figurativo que pode estar ao lado de qualquer mestre seu contemporâneo.

A arte de Segall foi a de um isolado, e no Brasil sentiu-se como na Europa, independente, sem poder falar com alguém que 
o compreendesse. Reputo-me afortunado por ter aprendido muito da sua palavra e de ter tido o prazer de publicar a primeira monografia a ele dedicada. Estou bem feliz, agora, pela edição das suas gravuras. Falei acima de isolado. Bastará recordar que Lasar não foi convidado para a Semana de Arte Moderna em 22, acontecimento grandioso, também este quase esquecido, e me prezo de tê-lo evocado, no Masp, no seu cinquentenário, em 1972.

\section{Legenda}

Mãe e filho, xilogravura de I92I Mulher do mangue com cactos, de 1926 , em ponta seca

Senhor \#378, 20 de junho de I988, p.67 (P.M. Bardi)

ARQUITETURA PRÊT-À-PORTER

O uso de pré-moldados nas obras públicas de Salvador

Já tive ocasião de lembrar, nesta página, um acontecimento baiano no setor do urbanismo e da arquitetura, de inédito sabor: o prefeito de Salvador, Mário Kertesz, enfrentando com decisão o problema de, em continuidade, prover medidas indispensáveis para dar um novo vulto à sua cidade, deliberou criar uma fábrica de produçôes edis, elementos em concreto fabricados em série, destinados a construir escolas, hospitais, centros comunitários e de lazer, enfim tudo quanto se inscreve no serviço de obras de um município.

A tarefa surgiu do encontro do prefeito com o arquiteto João Filgueiras Lima, carioca, que todos conhecem pelo apelido, Lelé: um personagem saído do grupo que, sob a direção de Oscar Niemeyer e Lúcio Costa, ideou e construiu Brasília onde ele, depois de tocar obras, foi convidado pelo próprio Niemeyer para secretário-executivo do Centro de Planejamento da Universidade.

Lelé, ao mesmo tempo, é um técnico e um inovador. Conseguiu bolar um extraordinário sistema de edificar, superando as maneiras convencionais, descobrindo novos meios. Sua ideia predominante é simples, porém o obrigou a resolver uma infinidade de problemas a serem estudados na teoria e na prática. A insígnia do seu trabalho é uma máxima que se insere no futuro da construção: economizar tempo no realizar e no custo. Isto sem menosprezar a mão-de-obra, a qual é sempre necessária.

Para a produção dos materiais a prefeitura criou uma fábrica, a Faec, Fábrica de Equipamentos Comunitários. Foi desenvolvida ali uma tecnologia de pré-moldados de "ferro cimento" ou "argamassa armada," em colaboração com a Universidade de São Carlos que realiza pesquisas científicas ligadas à Faec. A denominação de "argamassa armada" é mais utilizada do que "ferro cimento" porque aqui a quantidade proporcional de argamassa, areia, foi aumentada e a de ferro, diminuída.

O estabelecimento da Faec situa-se num dos bairros de Salvador. Fomos visitá-la num sábado: a produção faz pensar em toda a longa história da arquitetura que sempre se valeu do pré- fabricado, a começar pelo glorioso tijolo.

As peças que saem da fábrica representam uma certa quantidade de tijolos concentrados num bloco de cimento, calculado como componente, por exemplo, de uma parede, fundaçóes, escadas, tudo com a resistência prevista. Um ovo de Colombo que náo admite discussóes, agora que podemos constatar as surpreendentes consequências do sistema.

É a engenharia a desfrutar de novos materiais, a tecnologia permitindo esta espécie de robô surpreendente. Mas também deve-se anotar a confiança e a decisão de um prefeito animador para concluir o empreendimento.

No canteiro: 2500 operários no trabalho; notável o acúmulo de seriados dispostos no espaço destinado à produção. Uma parte deste material será empregada na construção do Hospital de Medicina do Aparelho Locomotor, em Salvador. Também ali está em preparo um outro hospital para São Luís e outro para Curitiba.

Uma seção de pré-moldados está pronta para o restauro da Ladeira da Misericórdia, na capital baiana, plano-piloto para a futura recuperação do seu centro histórico.

A Bahia dá um exemplo que, sem dúvida, será considerado no futuro da arquitetura para edificaçóes de caráter social, dado que desde já se verifica o comportamento 
da produção, considerado de consistência, além do aspecto estético, pois Lelé é arquiteto de visão, como se vê em Salvador, na implantação de três passarelas feitas na Faec, de uma simplicidade, funcionalidade e elegância que saltam aos olhos.

\section{Legenda}

Funcionalidade, baixo custo e beleza combinados na passarela de Filgueiras

Senhor \#379, 27 de junho de 1988, p.92 (P.M. Bardi)

INSPIRAÇÃO ORIENTAL

$A$ arte japonesa está em exposição no Masp

Uma autêntica festa, prestigiada pela presença do ministro da Cultura, Celso Furtado, marcou a inauguração, no último dia I8 de junho, no Museu de Arte de São Paulo, da exposição "Arte da Colônia Japonesa no Brasil,” comemorando a passagem dos 80 anos da imigração nipônica no País. A mostra, patrocinada pelo Banco América do Sul, tradicional entidade financeira ligada à colônia japonesa, cujo presidente Yosuki Yoshida usou a palavra após o discurso do ministro Furtado, reúne obras de pintores e escultores japoneses aqui radicados bem como de descendentes dos imigrantes.

O Masp não poderia deixar passar em branco esta comemoração pois há muitos anos temos com o Japão um intenso intercâmbio cultural. No ano passado se recebeu daquele país uma esplêndida exposição dedicada à xilogravura tradicional, cujos começos datam do século XVII, sempre retratando aspectos do cotidiano popular ou de encenaçóes teatrais, numa inventiva bastante singular e que obteve grande aceitação. Através dessas gravuras se pode acompanhar o que lá aconteceu ao longo destes séculos até a atualidade, possibilitando ao visitante acompanhar também a evolução da arte plástica.

Este intercâmbio é constante pois o Brasil, por intermédio do Masp, desde 1973 tem enviado ao Japão exposiçóes de seu acervo de arte europeia e também de obras brasileiras. Outra das manifestaçóes que apresentamos dentro deste espírito foi realmente sui generis e teve um tema aparentado ao design. Explico-me: durante minhas viagens ao Japão tinha percebido a originalidade que caracteriza naquele país as embalagens. Assim tive ocasião de recolher inúmeros objetos constatando como eram apresentados, admirando a praticidade e a arte desta apresentação. Anos depois finalmente se conseguiu uma mostra, trazida pela
Fundação Japão, mostrando as técnicas da embalagem japonesa, de simples execução e aparência atraente. Desde o embrulho de cinco ovos com palhas de milho até volumosos pacotes, o empenho dos japoneses é o de agradar a vista, compondo linhas de uso rápido e fácil, em harmonia com o gosto tradicional, as variantes sempre contidas numa mesma estética. Após percorrer vários locais no país, o acervo desta exposição foi doado integralmente ao Masp pela Fundação Japão.

O intercâmbio com o Japão nos proporcionou um cordial entendimento com os artistas japoneses, hoje aqui muito ativos, fazendo parte de nossa comunidade. Nomes famosos como Manabu Mabe e Tomie Ohtake fazem parte de exposiçóes brasileiras no Exterior.

Por ocasião de aniversários, São Paulo não deixa de lhes atribuir importância: afinal somos uma metrópole de imigrados que, sem esquecer as origens, gostam de se reencontrar e confraternizar.

Assim, tendo sido espontâneo o patrocínio do Banco América do Sul, organizou-se o evento documentado por um livro, apresentando aspectos da vida do imigrante no Brasil, e um catálogo contendo todos os artistas participantes da mostra. No que se refere à cerâmica recebemos do Japáo uma excepcional amostragem de peças feitas com técnicas tradicionais e que realmente surpreendem o visitante. Durante três dias apresentamos ainda uma série de arranjos em Ikenobô, uma das técnicas de arranjos florais típicas dos japoneses.

Outra importante mostra que de certo modo se integrou nestes festejos foi a retrospectiva do gravador japonês radicado nos Estados Unidos, Yozo Hamaguchi, também no Masp.

E sendo o assunto Japão, não poderia faltar a fotografia, com a comunicação 
de Taku Aramassa, um veterano profissional que se dedicou aos imigrantes japoneses na América do Sul, retratando os antigos pioneiros, numa documentaçáo de grande valor, patrocinada pelo Mainichi Shimbun, um jornal japonês com o qual mantemos também excelentes contatos. Todos estes eventos representam uma resenha da presença nipônica em nosso país, caracterizada pela organizaçáo e seriedade onde se cultivam além dos interesses econômicos os espirituais.

\section{Legenda}

Manabu Mabe ajudou o Brasil

a decifrar a alma japonesa

\section{Casa Vogue \#4, julho-agosto de I988, p.84 (P.M. Bardi)}

ARTE AO AR LIVRE

A pintura dita de cavalete é a consagrada por aqueles senhores que pretendem ornar as paredes de suas casas, para os encomendadores de retratos destinados a figurar nos palácios oficiais, enfim para as mais variadas, e às vezes curiosas, aplicaçôes. Mas há, no setor, uma outra manifestação: a dos pintores primitivos, os quais espontaneamente se ajeitam e produzem figuras e objetos, não excluindo as paisagens urbana e rural: artistas à maneira deles, às vezes escondendo extraordinários talentos.

Quem se dedica à observação dos elementos produtores de obras-primas ou secundárias raramente atribui algumas palavras a estes simplórios, relegando-os ao esconderijo dos amadores. Este cronista deve confessar que os primitivos sempre foram objeto de sua consideração. Aqui se descobriram elementos de valor e, de resto, como se sabe, a arte francesa tem até pintores deste setor reputados como mestres.

As linhas acima servem para justificar esta página dedicada a um grupo que está, hoje, em evidência em São Paulo, geralmente confundidos como emporcalhadores de muros, pois a criação deles é feita no espaço das ruas e das praças e, aliás, até das colunas do museu que dirijo.

Pode ser que as figuraçóes descarregadas nestas colunas sejam provocação, pois entre as muitas aventuras de minha não curta vida tive, alguns anos atrás, uma reação bastante dura contra emporcalhadores verdadeiros de parede, escrevendo em caracteres grandiosos a palavra merda sobre uma banal propaganda vereadorística. Acabei preso, sendo denunciado por escrever palavra imoral e por perturbar a comunidade. E o delegado de polícia mandou tomar minhas impressóes digitais, não me colocando na cadeia, pois, devido aos meus já suados 80 anos, era qualificado de irresponsável.

A provocação dos pintores noctívagos, usando como cavalete os muros do museu foi, provavelmente, feita para sondar minha reação. Resposta natural: não houve reaçáo nenhuma, pois achei o que lá pintaram interessante, como fato de estética deste convulsionado século, em que cada um, em arte, se comporta como melhor ou pior quiser. A obra é de um grupo impertinente e sabido que os leitores de São Paulo certamente já notaram nos túneis que da avenida Paulista levam aos bairros: deslumbrantes e, às vezes, extraordinárias e irônicas comunicaçóes. Parece que a prefeitura de vez em quando manda apagar as pinturas, mas os pintores rapidamente usam de novo as paredes, como os profissionais utilizam como base telas e painéis de madeira. Estamos diante de uma maneira de pintura mural sui generis; e eu, como entendido no assunto, acho-a rica em saber técnico e exuberante em fantasia, e, como já disse, irônica. Ela ironiza, penso eu, os conservadores, castigando-os como gente da ordem estabelecida e do quanto esta prescreve. Mas repito: alguns têm talento. Gostaria de conhecê-los de perto. Um deles até poderia ser aceito numa exposição individual no Masp. Apelidam-nos de grafiteiros, mas eles fazem parte da áurea confusão por que a pintura está passando, acima de BienaisI895, Trienais-I950 e Quadrienais-Kassel. 
Senhor \#380, 4 de julho de I988, p.65

A FUSÃO E A CONFUSÃO

O Ecletismo na arquitetura nem sempre dá uma boa mistura

$\mathrm{Na}$ Europa, geralmente, o Ecletismo da Arquitetura se indica como Culturalismo, pois se refere ao uso dos álbuns dos vários estilos do passado para compor recursos, que ganharam favores dos profissionais do edificar no mundo inteiro. As cidades foram invadidas por uma monumentomania fachadesca, quase sempre inspirada em exemplos antigos, de prontidão especialmente o Gótico e o Barroco, ou os dois misturados.

Há algum tempo a Editora Nobel/USP publicou um livro dedicado ao Ecletismo em vários Estados do Brasil, compilado por vários arquitetos e bastante ilustrado. ${ }^{106} \mathrm{~A}$ escolha dos edifícios depende dos diversos modos de encarar e apreciar o Ecletismo, mas se trata de uma série de ensaios que resumem as manifestaçóes mais aparentes do "estilo" que representou, logo depois do Racionalismo-Funcionalismo de Le Corbusier e dos outros mestres do século, o alvo das reaçóes para afirmar, possivelmente, um sistema arquitetônico coerente com o espírito do tempo.

Também o Brasil transitou pela estrada culturalista, sendo a Catedral de São Paulo o exemplo mais evidente pela variedade dos enfeites que a embelezam. Cito um exemplo, porém na própria São Paulo não faltaram outros em todos os bairros, como de resto em não sei quantas outras capitais e até cidades fin-de-siecle.

Recentemente, em Milão, dei uma olhada naquele Ecletismo, tendo em companhia alguns arquitetos com os quais fui rever, em visita de obrigação, a suntuosidade de Santo Ambrosio, onde notei de lado uma construção "parecida" ou respeitosamente "imitada”: um princípio do Culturalismo, desenhada por um arquiteto de Novecentos, que tentou restabelecer o Neoclássico na Itália.

O Neoclássico foi o estilo que mais empolgou, naturalmente, a Itália. Caso curioso: apareceu na Pauliceia, quando o

Io6 Annateresa Fabris. Ecletismo na arquitetura brasileira. São Paulo: Nobel/Edusp, 1987 conde Matarazzo encomendou sua mansão na avenida Paulista ao venerável Marcello Piacentini. Assim, pousou no centro dos cafeicultores um pedacinho do estilo que o Príncipe Regente tentara impor nesta Terra, onde os capomaestros, não entendendo nada de nada, o abastardaram na profusão de colunatas e tímpanos: o Parthenon devidamente caricaturado.

A avenida Paulista foi o purgatório do Ecletismo. Alguns palacetes ainda estão de pé. Tinha razão Levi-Strauss ao defini-la uma rua de estação de águas da Europa: cada um interessado em aparecer, em se destacar. Um estudioso, como Carlos Lemos, deveria propor-se preparar uma monografia sobre o assunto, dando conta também das planimetrias, para demonstrar como viviam os do poder, os corresponsáveis pelo Ecletismo. Seria um trabalho socioeconômico muito importante para a história de São Paulo, metrópole de "hábitos e costumes singelos da sociedade, singelos e ultraconservadores, plenos de fetiches, de tabus, de persistências e fixaçóes culturais," como o autor escreve no seu claro ensaio no volume da Editora Nobel.

\section{Legenda}

O exibicionismo desfilava na avenida Paulista 9 Detalhes do Neo-Barroco em Belo Horizonte 
Anexo B

Outros autores em colaborações regulares de P.M. Bardi 
Senhor Vogue \#6, set 1978, p.IO6-II3

VALOR DA ARTE É FUNÇÃO DO DESEJO DE TÊ-LA, p.IO6-IO7

Amin Brunetti Atta

Pedimos a Amin B. Atta, antiquário, profundo e esclarecido conhecedor do ramo, um depoimento sobre o mercado de arte.

Tenho uma ideia precisa sobre o valor das antiguidades e objetos de arte. Baseio-me em dados concretos fáceis de verificar. Parto do principio que existem Informaçôes certas sobre cotaçóes de imóveis, matérias-primas, manufaturados, açóes, cereais e também para objetos de arte.

Todos conhecem publicaçôes especializadas que descriminam as flutuaçóes das diversas bolsas, e as razóes pare as oscilações, assim como as previsóes dos peritos, a curto e a longo prazo, além de comentar o que se espera do futuro e qual o comportamento previsto no mercado.

Esta definição é minha ideia assumo a paternidade e engloba qualquer tipo de conceito objetivo ou subjetivo: "O valor de um objeto de arte é diretamente proporcional ao desejo que temos de possui-lo." No caso especifico das antiguidades e objetos de arte toma-se como base negócios já realizados em lojas ou leilóes, tanto nacionais como internacionais, e estes fornecem suficientes parâmetros para definir ume avaliação correta.

A raridade de um modelo, a época, o estado de conservação, as qualidades decorativas, todos estes detalhes devem ser computados no valor de um objeto, além das particularidades do mercado e da conjuntura econômica, da oferta e da procura.

É lógico que um maior appeal decorativo e artístico exerce Influência flagrante.
Não há Improvisação, como alguns leigos querem fazer crer, quando se fala em cotação. Desconhecer este fato é total desinformação.

O profissional categorizado e experiente é a maior garantia que o mercado pode ter. Vivência é o fruto de muitos anos de pesquisas, observaçóes, que tornam o profissional competente um verdadeiro médico, confessor e consultor técnico.

Um investimento em objetos de arte deve ser dirigido por profissional de reconhecida responsabilidade, que conheça não só o mercado nacional, mas que o situe comparativamente no âmbito internacional, pois conhece e leva em consideração fatores e sutilezas que o leigo desconhece.

O mercado brasileiro tem imensa vitalidade e está em crescimento. A renovação apresenta-se sob forma do impressionante interesse que a juventude manifesta por arte e antiguidades.

O exemplo evidente é a fantástica frequência em tropel, no melhor dos sentidos, que visita o Museu de Arte de São Paulo, verdadeira célula viva de cultura, apresentando exposiçôes temporárias, acervo Permanente, cursos de vários níveis, exemplo único em território nacional, instituição inteiramente dedicada à formação artística de nossa gente.

Isto é muito, muito mais importante que preços, cotaçôes, valores pecuniários, é a difusão da arte em beneficio do aprimoramento do homem.

A ARTe É Negociada, p.IIo

Paulo Vasconcellos

Paulo Vasconcellos é antiquário e ao mesmo tempo pesquisador e conservador de patrimônio de arte. Conhecido como colecionador de cerâmica de Saramenha, cuja mostra no II Salão de Antiquários recentemente realizado no Masp suscitou muita curiosidade e admiração. Falando-nos, disse:

São pouquíssimas as pessoas interessadas, honestamente, em perpetuar o que os nossos antepassados puderam nos legar com multo amor. Lamentavelmente a arte é negociada, pois existe o mercado e ela passa a ter um preço, e como podemos julgá-la sem feri-la?

Só os museus deveriam abrigar o que foi bem feito. Só o colecionador respeitoso deveria possuir, para preservar e divulgar, através de exposiçóes, o seu acervo. 
As decoraçôes deveriam ser feitas de xerox, pois amanhá, quando a moda se transforma, as peças ficarão sob a escada, junto à enceradeira, garrafas vazias e jornais já lidos.

A arte não deve ser adquirida e somada a outras, como notas, para produzir dividendos: ela náo foi feita para ficar em cofres, como riqueza. Ela precisa ser vista para ser amada. Não é preciso comprá-la para possui-la e sim respeitá-la para ser apreciada.

Já cansei de ver pessoas comparando o valor de uma obra de arte com cabeças de gado ou alqueires de terra.

Como educar os ricos que compram e satisfazer os pobres que apreciam? Como inventar sensibilidade em ampolas, para distribuir aos que visitam museus, galerias e antiquários? Como engendrar uma bolsa de valores, comparando diariamente o valor do dólar, da libra e do cruzeiro com a obra de arte?
O dinheiro compra, regateia, suborna, mas nunca poderá ser comparado com a arte, que extasia. Ela náo custa nada, só o direito exclusivo de sua propriedade é que tem preço, pois a sua real posse é eterna, é de quem a fez e de quem a aprecia e respeita.

Aos bons artistas, críticos, museólogos, colecionadores, restauradores e marchands, os meus sinceros respeitos. Vocês realmente sentem o que existe além do palpável da vida. Meus respeitos, pois, àqueles que souberam preservar o que é bom.

O mercado brasileiro, já em seus estertores há alguns anos, só foi disfarçado com a revoluçáo social em Portugal, que inundou nosso país, enchendo as vitrines de peças, para completar o cenário já quase vazio, e assim mesmo, poucas sobraram, ou já voltaram para o pais de origem.

O que realmente está faltando são as peças boas, que felizmente algumas já estão preservadas em museus e coleções particulares, às quais muito me dediquei.

UM DESTAQUe (MERECIDO) p.III

Amim Brunetti Atta

O dr. Plácido Gutierrez merece um destaque. Em linguagem quase jornalística, isto é, atendo-se aos fatos, é difícil dar uma ideia dele. É engenheiro, mineiro, estudou no Rio e é casado com d. Helena Silveira Lobo Gutierrez. O casal tem como sólido traço de união o amor comum à arte, ao estudo e à pesquisa da história que envolve os objetos.

Eclético basicamente em seu gosto, o Plácido, no entanto, tem nítida preferência pelo objeto, móvel ou pintura que de alguma maneira diga respeito à História do Brasil. Senhor de imensa biblioteca de arte, na qual estuda sem cessar, divide seu tempo entre a magnífica casa da Tijuca, rodeada por antigas árvores, e sua senhorial fazenda do Pau Grande, em Avelar, distrito de Vassouras.

Conhecedor profundo do nosso mobiliário e prataria, consegue ser um mestre em porcelanas da China, que ama e decifra totalmente à vontade, seguro dos longos anos de vivência e carinho que lhes dedicou.

Senhor Vogue \#7, outubro de I978, p.98-I05

Problemas COMUNS, SOLUÇÓES ARTístiCAS ORIGINAIS, p.IOO, IO2

O segredo: não mexer no trabalho do artista

José Hugo Celidônio

"Os jesuítas seguiram o caminho dos indígenas, nas veredas que percorriam e também no sistema de viajar: caminhavam descalços e mais raramente se deixavam levar em redes, numa e noutra circunstância não no comum e diário, conforme contam." Esse trecho de Caminhos e Estradas no Brasil, revelado com exclusividade por Senhor não faz parte de nenhuma publicação de história, como se poderia pensar. Mesmo pertencendo a um livro de história.

É apenas uma parte da exceção, peça publicitária de fim de ano da Rhodia, uma das poucas empresas no Brasil que têm uma publicidade realmente criativa. A exceção de que falamos é a seguinte: a Rhodia resolveu levar às últimas consequências a ideia de basear sua publicidade na cultura brasileira. Ela não foi a primeira 
nem vai ser a última empresa a tentar essa fórmula de marketing, que não é das mais fáceis. Na maior parte das vezes, o que acontece é a confusão entre empresa e cultura, com enorme prejuízo para ambas.

O fato de ser uma multinacional a conseguir esse resultado náo deixa de ter seu ar de mistério, principalmente porque ainda tem muita gente que pensa que as multinacionais são uma espécie de corpo estranho, incapazes de se adaptarem com firmeza ao novo terreno onde passaram a atuar.

A Rodhia é francesa, o que talvez pudesse explicar a ligação com a preocupação cultural, já que os franceses amam tanto sua cultura. Em todo caso, não seria suficiente a ideia. Dificilmente um estrangeiro poderia estar por trás de um álbum sobre Capitanias de Mar e Serra e muito menos contrataria um cronista tão respeitado e sobretudo nacionalizado como Luis Fernando Veríssimo para escrever as famosas Estórias do Povo Brasileiro. A propa-ganda da Rhodia tem muitas histórias e surpresas.

A Rhodia está no Brasil desde I919, quando começou a fabricar lança-perfumes. E veio vindo, vindo, até montar indústrias em dezessete setores e se transformar numa das dez maiores empresas privadas do país. Mas só de uns anos para cá conseguiu firmar pé na terra onde está. Essa boa imagem se deve às bem boladas campanhas institucionais e principalmente a uma atividade no campo da cultura, táo marcante que muitíssimo poucas empresas nacionais ousam se comparar a ela. Pode tranquilamente se gabar de ter chegado muito próxima do objetivo. Para completar o processo, seria preciso ainda alguma coisa mais séria do que simples propaganda, mesmo institucional. Mas isso é outro caso.

A primeira surpresa da Rhodia aconteceu no final de 1976 , justamente naquela época em que todo mundo faz questão de atulhar nossas salas com algumas centenas de litros de uísque, cheveirinhos, agendas, canetas, calculadoras e outros mimos menos votados. Naquele ano, a Rhodia deu um livro. Um livro já era novidade bastante para pelo menos merecer exame, mas não suficiente para escapar do almoxarifado pessoal. O inacreditável é que o livro é muito bom.

Para criar Capitanias de Mar e Serra, a Rhodia foi procurar o conhecido pintor Thomaz Ianelli, não para fotografar uns três ou quatro quadros mais conhecidos e depois botar muita propaganda embaixo, mas com a seguinte proposta: vai pintar por aí que a gente publica. Como ele não estava obrigado a fazer uma aquarela do logotipo da firma, saiu por mar e serra, feliz e pintando como nunca. Depois foi só fazer um texto - onde não aparece uma só vez o nome Rhodia - e o trivial variado: impressão em papel importado, capa gravada e outras banalidades.

No Brasil, país que apesar do progresso ainda considera gasto e investimento a mesma coisa, isso seria o suficiente, mesmo não sendo muito, para botar diretor de propaganda em hospital psiquiátrico. Afinal das contas, onde já se viu fazer propaganda sem falar diretamente da firma ou pelo menos de alguma coisa ligada ao ramo?

No ano seguinte, a ideia maluca cresceu. Durante a comemoração do trigésimo aniversário do Museu de Arte de São Paulo a Rhodia voltou a promover o trabalho de artistas nacionais, ainda com a filosofia de deixar a criação totalmente por conta de quem entende do riscado. Hoje, enquanto ainda não existe um Museu da Roupa Brasileira, o Masp guarda algumas das roupas mais bonitas do país, feitas por gente como Aldemir Martins, Manabu Mabe, Nelson Leirner e mais dez artistas.

É claro que essas iniciativas funcionavam apenas em ambientes mais ou menos restritos. Para grande parte da opinião pública, a Rhodia ainda era apenas mais uma firma estrangeira. Era necessária uma campanha institucional para ligar a Rhodia ao Brasil. Claro que isso já foi feito muitas vezes. Tantas que é até possível fornecer algumas das fórmulas mais comuns:

Foto de uma grande fábrica chafurdando o ar de fumaça. Ao fundo, alguns operários limpinhos entrando sorridentes no serviço. Título espetacular: Estamos trabalhando para o progresso do Brasil. Ou então foto de uma imensa linha de produtos com sensacional título: Estamos aqui. Material imaginativo o 
suficiente para Nelson Rodrigues produzir umas três ou quatro crônicas sobre sua grande descoberta, o óbvio ululante.

Um pouco acima, se é que existe acima, ficariam aquelas propagandas que dizem sempre: "Indústria é cultura brasileira," mostrando que a invenção de um novo tipo de parafusos permitiu que fossem construídas carteiras escolares melhores e que por isso a cultura nacional deu um grande salto que só poderá ser avaliado no futuro.

Deixando de lado a propaganda, a Rhodia encontrou uma solução bastante criativa e de uma simplicidade estrondosa. Largar a coisa na máo de quem entende do assunto, mesmo que para isso o trabalho de divulgação não fosse tão direto. Com isso, ela conseguiu produzir uma das campanhas mais fortes do ano passado, recuperando para nossa tấo desgastada memória alguns tipos e situaçôes deliciosas: circo mambembe, papo de vendedor de bilhete de loteria, maria-fumaças e maquinistas de cara preta, serenata e polícia. Tudo escrito por Luís Fernando Veríssimo, sem nada a lembrar alguma coisa sobre as atividades da empresa. Quando era moço e trabalhava no Brasil, Levi-Strauss dizia que os países da América passaram diretamente da barbárie para a decadência, sem conhecer o sentido do período de civilização que existiu entre uma e outra. E citava o exemplo das cidades: na Europa, os séculos que passam se constituiriam numa espécie de promoção para a paisagem, enquanto na América, bastavam alguns poucos anos para dar um ar irremediavelmente deteriorado para a mais bela cidade. Tudo isso, para dizer que sua maior perplexidade em São Paulo (a São Paulo de 1934 que ele conheceu, é bom que se diga) era a de náo encontrar vestígios de que ali houvesse qualquer espécie de ocupaçáo anterior. Náo foi è toa que os anúncios da Rhodia soaram um tanto estranhos, assustando muita gente com suas lembranças. Mas até nisso a Rhodia conseguiu acertar no Brasil, entrando, graças à criatividade de Veríssimo, num mundo que lutamos cotidianamente por destruir a cada prédio que fazemos. Instaurou-se o paradoxo: uma firma francesa mostrando ao país aquilo que houve entre a barbárie e a decadência, tirando afora nossas vergonhas tão saradinhas.
E claro, houve os muitos que tentaram seguir a trilha descoberta pela Rhodia infelizmente apenas no campo da propaganda - já que, como reza o ditado, tudo que deu certo merece uma cópia. Como a ideia era boa, as cópias vieram de montáo. Como não podia deixar de ser, a Xerox fez tudo igualzinho, só-que-em-preto-e-branco. Depois, a Mercedez fez alguns layout muito parecidos, a Volkswagen usou uns temas idem e a Comind umas fotos tal-e-qual. Para coroar tudo, a Sharp resolveu fazer também sua campanha de nacionalização, só que com textos assinados. Essa ainda continua sendo a maior prova de sucesso no país.

Por causa dessa campanha, o livro que a Rhodia fez sobre o mobiliário na época colonial só assustou aqueles que conhecem o assunto por ter sido tão bem feito dentro de uma empresa. A agência MPM cuidou da parte de arte e acompanhou o trabalho de pesquisa. O texto ficou por conta de Luís Seraphico e a pesquisa foi de Joáo Carlos Maciel. Bem verdade que o mobiliário colonial continuou tão abandonado como no tempo de Levi-Strauss, muito embora bem fotografado. Melhor dizendo: pelo menos fotografado, porque até hoje só se publicou um livro específico sobre o assunto, do qual deve existir ainda um exemplar na Biblioteca Nacional, se não choveu muito. (Para os que não sabem, não há verba para consertar as janelas do prédio, e a cada chuva se perdem alguns volumes.) Afinal das contas, o livro é de 1944.

Graças a catástrofes culturais desse tipo, um trabalho que em qualquer lugar civilizado seria considerado apenas uma forma um tanto elegante de propaganda, acabou se transformando numa peça de real significação cultural. Esse fato permitiu que a Rhodia lançasse num projeto ainda mais ambicioso. Um livro, mais uma vez um livro, mostrando a história das vias de transporte no Brasil. Obviamente a Rhodia não é empresa transportadora nem fabrica veículos. Tanto melhor, mais uma vez ela evita a retórica. Principalmente para quem gosta de ler coisas interessantes.

Talvez isso seja mais que uma exceção, sinal de novos tempos mais modernos: nos Estados Unidos e nos países europeus não há firma que se preze que não 
tenha uma fundação realmente ativa.

Se isso isso acontecer, pode até ser que

a gente conheça certa civilizaçáo.

Senhor Vogue \#I2, março de I979 p.83-97 (Senhor e as artes)

Documento, AVIDA NUM ÁlbUM DE FAMÍlia, p.92

Dulce Soares

Pode-se ler no Time Life Books:

"Documento fotográfico: uma descrição do mundo real pelo fotógrafo cuja intenção é comunicar algo de importância - fazer um comentário - que possa ser entendido pelo conservador."

A princípio pode parecer uma explicação do óbvio falar sobre o porquê de documentar. Se observarmos mais atentamente podemos descobrir que se torna quase uma necessidade se falar em documentação quando tudo muda tão rapidamente, quando o consumo nos estimula a querer novos objetos, novas emoçóes, novos conceitos, novas imagens. O tempo é pouco, os conflitos são muitos e as angústias nos distanciam dos valores reais do indivíduo e da sociedade. O trabalho artesanal é substituído, a tecnologia toma novos caminhos, a eletrônica revoluciona o mundo e em consequência a arte se modifica. Da mesma forma que o progresso nos beneficia, nos ameaça. E nós, como qualquer ser humano, apesar de admirar o crescimento do homem, precisamos de raízes, de história, de uma identificação com o passado ou de segurar o presente que nos escapa como água na mão.

A rotina do cotidiano nos cega e embota os sentidos. Cabe ao artista, qualquer que seja sua forma de expressão, retirar deste cotidiano gasto e sofrido as imagens ou sentimentos significativos, conduzindo o observador à uma leitura fácil e de acesso imediato. Assim foram feitas as músicas que, transmitindo um desabafo ou uma necessidade social, fizeram o país cantá-las. Quantos livros e peças teatrais foram censurados através dos tempos por abordar as verdades do momento. São documentos de uma época. Não documentos frios e impessoais como os que estamos acostumados a nos referir quando se fala de documentação, mas arte, porque ali estão envolvidos através da realidade do momento, a sensibilidade e a visão do autor.

Com o nascimento da fotografia, que veio preencher uma necessidade do homem de documentar a família e pessoas queridas, surgiu o álbum de família que, se poderia dizer, foi o primeiro documentário fotográfico. Entretanto, o termo só começou a ser usado nos Estados Unidos durante os anos de depressão, quando as fotografias, que mostravam a pobreza dos fazendeiros, alertaram os americanos da necessidade de uma reforma social. Daí em diante a fotografia de documentação teve um papel atuante na sociedade, seja para um alerta ou para um registro através da linguagem e expressão do fotógrafo.

\section{Legenda}

Arquitetura na Barra Funda, São Paulo; antiga casa da Chácara do Carvalho; Salão São Paulo Chic: detalhe de fachada. Fotos de Dulce Soares

UM PRÉdio PARA SER VISTO: DePOIMENTO: Miguel Juliano, p.93

Miguel Juliano

Estamos distanciados 34 anos do dia 8 de maio de 1945. Duas geraçóes inteiras não presenciaram e não sentiram, de nenhuma maneira, a guerra, simplesmente por lhe serem posteriores.

Dificilmente podemos chamar nossa época de pós-guerra. No entanto, estamos ainda presos a modelos (melhor dizendo, utopias) que se formaram num conjunto de ideias desenvolvidas antes e durante a Segunda Guerra Mundial. Nossa formação vem de arquitetos como Le Corbusier,
Gropius e Mies, que se viam também como profetas e legisladores. $\mathrm{O}$ que nos toca de um passado mais distante?

O mundo cresceu enormemente. Não temos cidades bem comportadas, e a vida nelas é o que conhecemos: o ruído, o envenenamento do ar, o desemprego, a violência. $\mathrm{O}$ conjunto se assemelha a um grande hospício do qual náo se escapa.

Eis São Paulo. Sua paisagem é absurda, um aglomerado de sólidos de todas as formas e 
dimensóes, coloca-dos em todos os rumos e direçóes, cada vez mais próximos e juntos, podendo-se sempre construir outros iguais ou diferentes em todos os interespaços.

A grande especulação sobre a terra, da qual o próprio poder público participa, e a mais disparatada e injusta distribuição de renda, numa competição de espaços, subdivididos cada vez mais em trincheiras de faixas sócio-econômicas, por sua vez, cada vez mais estratificadas.

Pressionada pela mídia e pelo marketing, a promoção social é a grande meta de todos. A mudança de status é seguida de uma mudança de endereço, ou começa por ela.

Grandes áreas urbanas se deterioram: veja-se o Centro, o Brás, Campos Elíseos etc., enquanto se promovem outras em direção ao Sul e Sudoeste, num desperdício incontrolável de recursos.

Até quando crescerá assim conformada, contida, não-participante, sem esperanças, sem lutar? Infelizmente não se procuram mais perfeitos "urbanistas" para torná-las ensolajardinadas, (perdão) afluentes e felizes. Ninguém como Pereira Passos, que o Rio teve.
Nada a ver com a estética-ética de sua vida. Mas simplesmente administradores, empresários como sabem, que lutem com o seu orçamento, com as enchentes, com o tráfego, a marginalidade, a violência, a burocracia, que lhe controlem, principalmente a dívida.

A dívida. Olhemos bem para isto, bebendo desse caldo os ensinamentos que precisamos para as próprias transformaçóes.

Não está nada fácil para os prefeitos.

Como não está para os arquitetos, os médicos, os jornalistas.

É neste exíguo espaço físico e dentro daquela estreita faixa de manobras administrativo-financeiras que trabalham hoje os arquitetos e todos os demais. Não é, já se vê, nenhuma fase heroica.

O que é pior, estamos, há alguns anos, acostumados a decisôes verticais, fechadas, centralizadas ao máximo, e que convêm extremamente ao cume da pirâmide social brasileira.

A cultura e a ciência aguardam a vez. Como aguardam a sua vez a pesquisa e a própria Universidade brasileiras.

Senhor Vogue \#I3, abril de I979, p.IIO-I2I (Senhor e as Artes)

As OpÇóEs CUlTURAIS DO DESIGN, p.IIO-III

\section{Lina Bo Bardi}

"Em casa faltava dinheiro. Fui obrigado a fazer gravuras e desenhos. Lembro em particular os ovos de Páscoa. Redondos, rodavam sobre si mesmos e rangiam como portas. Vendia-os numa boutique de artesanato da rua Neglinnaja. Dez, quinze copecas a peça. Desde então odeio sem limites as aquarelas das Senhoras, o estilo Russo e $o$ 'artesanal.'”- Wladimir Majakovskij

Estas consideraçóes poderão ser julgadas "óbvias" ou "superadas." A resposta é: há julgamentos que definem como "óbvio" e "superado" tudo aquilo que toca diretamente interesses de casta bem definidos.

As tímidas conclusóes do XII Congresso Mundial de Arquitetos, Madri, maio 75, dedicado à idealização e tecnologia na arquitetura, são a demonstração do medo do óbvio e já superado. Neste caso o óbvio e superado é a posição do arquiteto frente à coletividade. No campo específico da arquitetura a mais flagrante traição aos princípios que informaram todo o movimento moderno, interrompido pela Segunda Guerra e abandonado, depois, como superado.

$\mathrm{Na}$ avalancha-câncer da desorientação tudo é englobado e desvanece obsolescência total, num rápido envelhecimento e perda de sentido, numa completa perda de metáfora. Assim a arquitetura "selvagem" pulveriza Gaudí, os "acrílicos" e os "metais" pulverizam Pevsner e Arp. Para individualizar os valores verdadeiros do pavilhão da Exposição Barcelona I929, de Mies van der Rohe, é necessária uma bem precisa operação histórica, o significado original da arquitetura de Le Corbusier é engolido e Frank Lloyd Wright se salva apenas pela boa vontade de alguns críticos. Mas a Casa da Cascata está a caminho para a perda total de sua violência de comunicação originária. 
A arte não é tão inocente: a grande tentativa de fazer do desenho industrial a força regeneradora de toda uma sociedade faliu e transformou-se na mais estarrecedora denúncia de perversidade de um sistema. A tomada de consciência coletiva de mais de um quarto da população mundial, aquela que acreditou no progresso ilimitado, já começou.

A desmistificação do Design como arma de um sistema, a procura antropológica no campo das artes contra a procura estética, que informou todo o desenvolvimento da cultura artística do Ocidente, desde a antiguidade até as vanguardas, está em curso, num debate lúcido que exclui a volta a situaçôes romântico-artesanais, à visão de Ruskin e Morris; um reexame da história recente do fazer nas artes. Não uma recusa em bloco, mas um cuidadoso processo de revisão.

O esforço contra a hegemonia tecnológica, que sucede no Ocidente ao "complexo de inferioridade tecnológico" no campo das artes, esbarra na estrutura de um sistema: o problema é fundamentalmente político-econômico. A regeneração através da arte, credo da Bauhaus, revelou-se mera utopia, equívoco cultural ou tranquilizante das consciências dos que não precisam e as metástases da incontrolável proliferação em massa, arrastaram junto às conquistas básicas do movimento moderno, transformando sua grande ideia fundamental - a Planificaçáo - no equívoco utópico da intelligentsia tecnocrática, que esvaziou com sua falência a "racionalidade," posta contra a "emocionalidade," num fetichismo de modelos abstratos que encarava como iguais o mundo das cifras e o mundo dos homens.

Se o problema é fundamentalmente político-econômico, a tarefa do atuante no campo do Design é, apesar de tudo, fundamental. É aquilo que Brechet chamava a capacidade de dizer "náo." A liberdade do artista foi sempre, "individual" mas a verdadeira liberdade só pode ser coletiva. Uma liberdade ciente da responsabilidade social, que derrube as fronteiras da estética, campo de concentração da civilização ocidental; uma liberdade ligada às limitaçóes e às grandes conquistas da
Prática Científica. (Prática Científica, não tecnologia decaída em tecnocracia.)

Ao suicídio romântico do "não-planejamento," reação ao fracasso tecnocrático, é urgente contrapor a grande tarefa do Planejamento Ambiental, desde o urbanismo e a Arquitetura até o desenho industrial e as outras manifestaçóes culturais. Uma reintegração, uma unificação simplificada dos fatores componentes da cultura.

Qual a situação de um país de estrutura capitalista dependente, onde a revoluçáo nacional democrático-burguesa não conseguiu se processar, que entra na industrialização com restos de estruturas oligárquico-nacionais? O Brasil entra em último na história da industrialização de marco ocidental, portador de elementos de pré-história e da África, rico de seiva popular.

Todas as contradiçóes do grande equívoco ocidental se apresentam contemporaneamente ou em tempo curto no seu processo de modernização, com os traços violentos de uma situação falimentar. Um processo que nas naçóes industrializadas demorou séculos para se processar, leva aqui poucos anos. A industrialização abrupta, não planificada, estruturalmente importada, leva o país à experiência de um incontrolável acontecimento natural, não de um processo criado pelos homens.

Os marcos sinistros da especulação imobiliária, o não-planejamento habitacional-popular, a proliferação especulativa do desenho industrial: gadgets, objetos na maioria supérfluos, pesam na situação cultural do país, criando gravíssimos entraves, impossibilitando o desenvolvimento de sua verdadeira cultura autóctone. Uma tomada de consciência coletiva é necessária, qualquer divagação é um delito na hora atual, a desculturação está em curso. Se o economista e o sociólogo podem diagnosticar com desprendimento, o artista deve agir, como parte ligada ao povo ativo, além de ligado ao intelectual.

O reexame da história recente do país se impóe. O balanço da civilização brasileira “popular" é necessário, mesmo se pobre à luz da alta cultura. Este balanço não é balanço do Folclore, sempre paternalisticamente amparado pela cultura elevada, é o balanço "visto do outro lado," o balanço 
participante. É o Aleijadinho e a cultura brasileira antes da Missão Francesa. É o nordestino do couro e das latas vazias, é o habitante das Vilas, é o negro e o índio, é uma massa que inventa, que traz uma contribuição indigesta, seca, dura de digerir.

Esta urgência, este não poder esperar mais, é a base real do trabalho do artista brasileiro, uma realidade que não precisa de estímulos artificiais, uma fartura cultural ao alcance das mãos, uma riqueza antropológica única, com acontecimentos históricos trágicos e fundamentais. O Brasil se industrializou, a nova realidade precisa ser aceita para ser estudada. A "volta” a corpos sociais extintos é impossível, a criação de centros artesanais, a volta a um artesanato como antídoto a uma industrialização estranha aos princípios culturais do país é errada. Porque o artesanato como corpo social nunca existiu no Brasil, o que existe é um pré-artesanato doméstico esparso.
O que existiu foi uma imigração rala de artesãos ibéricos ou italianos e, no século I9, manufaturas. Artesanato, nunca.

O levantamento cultural do pré-artesanato brasileiro podia ter sido feito antes do país enveredar pelo caminho do capitalismo dependente, quando uma revoluçáo democrático-burguesa era ainda possível. Neste caso, as opçóes culturais no campo do desenho industrial podiam ter sido outras, mais aderentes às necessidades reais do país. (Mesmo se pobres, bem mais pobres que as opçóes culturais da China e da Finlândia.) Precisa recomeçar, saindo de uma nova realidade, mas uma coisa está hoje bem clara e definida: os que se ocupam das necessidades de uma parcela bem reduzida da sociedade, os autores da serena tomada de anotaçóes dos fatos, os que náo fazem escândalo, estão, com certeza, do outro lado.

O HOMEM É O FIM, p.II2

Sônia Levy

A produção do desenho industrial brasileiro pelas indústrias nacionais em larga escala é ainda muito pequena. Hoje há uma lacuna, entre nós, de desenhos de bom nível, (linguagem plástica contemporânea, sentido de industrialização, material compatível com o nosso habitat) cujo lugar está ocupado basicamente por linhas estrangeiras (anteriormente importadas e agora copiadas) ou por linhas que se submetem aos modismos.

O desenho industrial aqui produzido, ainda em pequena escala, é dirigido a uma classe limitada. De certa forma isto nega o próprio desenho industrial que nasceu com a finalidade cultural e social. Moholy-Nagy, um dos mestres da Bauhaus, já afirmava: "Não é o produto, mas o homem o nosso fim."

É necessário, portanto, que o desenho industrial no Brasil tenha um sentido mais amplo, para que possa atingir o maior número possível de pessoas. Assim, do ponto de vista cultural, deve ser afirmado, pois existe um imenso potencial: do ponto de vista didático, deve ser estimulada a formação de profissionais; do ponto de vista de divulgação, deve ser difundido para que aumentem as condiçôes de produção e de conquista de mercado. Finalmente, cabe às indústrias um maior interesse e apoio, pois sem elas os bons projetos nunca poderáo ser executados.

EMBALAGEM, UM MUNDO, p.II4

José Luiz de Paula Paiva, da Associação Brasileira de Embalagem-ABRE

Vivemos num país tropical. E o calor se faz notar quase que o ano inteiro. Nosso povo tem todas as características de um povo tropical, improvisador, criativo e versátil.

Os projetos gráficos mais do que nunca deveriam enfatizar estes aspectos, pois se não o fizerem, estarão contradizendo o seu slogan mais comum que é: a transformação da linguagem oral em visual.
Vemos e vivemos em meio a esta atmosfera alaranjada e radiante, portanto, nossas cores deveriam ser quentes e alegres.

Quanto à embalagem de consumo, se obedecer a estes preceitos estará de certa forma completando o consumidor, pois a embalagem é mais do que um envoltório de produto, é um registro de um povo, documento de uma época. A cor está 
diretamente ligada ao comportamento do homem e, sendo tropical, é claro que as cores frias da Europa, aplicadas atualmente nas embalagens, principalmente de cosméticos, de certa forma se incompatibilizam com as características tropicais do povo brasileiro.

A nossa indústria gráfica teve um infeliz desenvolvimento. Infeliz no tocante à sua evolução histórica, pois passamos da xilogravura de cordel para o sistema offset, sem explorarmos o potencial do sistema tipográfico, que agiria como um intermediário do desenvolvimento. Atualmente, esse espaço gera, de certa forma, um problema de organização e programação de trabalho. É comum uma indústria gráfica que imprime livros, de repente passar a imprimir embalagens (cartucho) e vice-versa.

Se o desenvolvimento histórico tomasse outro rumo teríamos: um sistema tipográfico para editora, mais especificamente textos e livros de arte, um sistema offset para cartuchos e serviços gerais desde que programados, um sistema rotográfico para grandes tiragens de laminados, plásticos e editoriais, quando programadas.

A minha proposta, além de enfatizar as cores e as formas tropicais, tenta também reduzir o custo do processo de confecção, pois o resultado posterior seria também uma redução no custo final do produto, e, com isto, o mesmo poderia atingir uma maior faixa da população.

$N$. da R. - O autor vem tentando defender a tese de mestrado em Comunicação Visual na Faap, onde se formou, porém sem êxito, pois naquela escola não existem pós-graduados na área, configurando o costumeiro absurdo da nossa precária inteligência universitária.

Tecnologia Vai aO POVO. Através De um Museu. p.II5

Francisco de Paula Machado de Campos, presidente da

Fundação Museu da Tecnologia de São Paulo

A ciência e a tecnologia no tocante a cientistas e tecnologistas náo são elementos improvisados, mas o resultado de acumulação da cultura e da técnica e a consequência de um processo contínuo e perseverante do trabalho de geraçóes. Existem à disposição, principalmente dos jovens, várias modalidades que lhes permitem acelerar sua educaçáo por processos diretos e expeditos, práticos e interessantes, que servem para estimular a criatividade, que são os oferecidos pelos Modernos museus e centros dedicados à ciência, tecnologia e indústria.

Em todos os países industrializados e em numerosos outros em esforço de desenvolvimento, esses centros culturais "exploram" de forma direta e atrativa os principais fenômenos e princípios da ciência aplicada.

São estabelecimentos de educação popular, verdadeiras escolas experimentais postas ao alcance direto dos visitantes, permitindo-lhes participar de provas e experiências que ativam o desejo inato de conhecimento latente para a escolha de vocaçóes profissionais. A finalidade principal desses museus e centros é exatamente a de contribuir, facilitando e aperfeiçoando a educação das grandes massas populacionais para os caminhos da ciência e da técnica.

O sucesso desta modalidade de ensino é tão notório e destacado que oferecendo esses atrativos á sua população, que dispóem de toda sorte de diversóes e entretenimentos, nos Estados Unidos cerca de um quarto de toda a população, isto é, mais de 50 milhóes de pessoas visitam anualmente os seus 350 estabelecimentos desse gênero. Idêntico sucesso é verificado em todos os demais países industrializados no mundo, onde já existem mais de 700 museus similares, e onde quer que eles existam, atraem anualmente milhóes de visitantes. Com exceção apenas da América do Sul e Central e dos países africanos, todos são dotados de centros de ciência e tecnologia.

No Brasil, recentemente estão sendo anunciadas a abertura dos primeiros museus desse gênero: em Salvador, na Bahia, no Rio de Janeiro e em Belo Horizonte, enquanto que em São Paulo, a nossa querida, "supercap" onde uma população 
de mais de Io milhóes de habitantes é carente de alternativas para suas horas de lazer, a Fundação Museu da Tecnologia de São Paulo, entidade educacional sem fim lucrativo, vem há 9 anos trabalhando para a instalaçáo do Museu da Tecnologia, sem que até o presente tenha conseguido os recursos necessários para esta realização.

Entretanto, agora as expectativas são favoráveis. Recentemente, a atual administração municipal de São Paulo deu um valioso apoio que permitirá à Fundação prosseguir com as obras de construção do seu primeiro edifício, destinado às instalaçóes desse Museu, obras que estão sendo executadas em grande e privilegiada área de terreno situada junto à Universidade de São Paulo, à avenida Engenheiro Billings. (Marginal do rio Pinheiros)

Porém, é de todo necessário que além dos poderes públicos também as entidades particulares participem ativamente desse empreendimento que, concluído, constituir-se-á certamente no ponto de maior atração da população de toda a região de São Paulo.

A construção e a instalação de moderno Museu dessa categoria exigem vultosos recursos que, entretanto, são largamente compensados e remunerados pela utilização maciça que decorre

Os RISCOS DE UM DESIGN AUSENTE, p.II6 Francisco Augusto Sememaro Júnior

Refiro-me ao Design em máquinas e equipamentos industriais. Tem-se notado que os fabricantes vêm encetando os caminhos de ligação homem- máquina de maneira a que ambos sejam mais produtivos e seguros, representando o Design elemento básico do binômio produção-segurança. Por exemplo, nas máquinas injetoras de plástico, pelas quais minha firma se interessa, onde a produção é alta, faz-se sentir mais fortemente a necessidade do uso de Design para a construçáo delas.

Pode-se observar: I. Quando a máquina tem uma paralisação por defeito o efeito do uso do Design é sentido à medida em que sua localização e posição seja de lógica simples e funcional, não necessitando brainstorming para solução. Paralelamente, o acesso do homem e suas ferramentas aos locais de manutenção deve ser fácil; 2. da visitação pública, justificando-se, assim, os investimentos necessários.

A colaboração das empresas e de particulares, sobretudo dos homens de negócio de São Paulo, é quase um dever cívico, pois constitui-se na forma prática e direta de se acelerar o desenvolvimento e o progresso do país pela difusão dos conhecimentos científicos e tecnológicos criadores de riquezas, tal como ocorre em nações desenvolvidas.

Recursos financeiros e de bens, e também petrechos representativos da nossa tecnologia, antiga e moderna, representam contribuiçóes de enorme valia para a constituição do acervo patrimonial do nosso Museu. É uma oportunidade para quantos tenham condiçóes de fazê-lo em benefício das geraçóes que virão.

A Fundação Museu da Tecnologia de São Paulo tem sua sede à avenida Paulista, Ioo9, $\mathrm{II}^{\circ}$ andar, conjunto IIor, e aí espera que as indústrias, os comerciantes, as entidades financeiras e outras organizaçóes congêneres, bem como, individualmente aqueles que se sintam atraídos pelo empreendimento, vinculem suas organizaçóes e seus nomes, de modo permanente, à uma organizaçáo educacional de âmbito popular que se constituirá num valioso instrumento de valorização do povo brasileiro.
Quando a máquina estiver em operação a indicação dos valores utilizados em tempo, pressão, velocidade etc., consoante ao Design, o operador, da máquina fará os ajustes necessários rapidamente; e, 3 . Levando esta situaçáo do homem junto à máquina 9,6 horas por dia, (fora os sábados e horas extras) 2I dias por mês, ou seja, 202 horas/mês, se a composição construtiva não for simples, desmistificada de respostas rapidíssimas, ter-se-á problemas de produtividade oscilantes com média baixa e uma alta taxa de risco de acidentes, seja a dano do homem como da quina e seus complementos .

Tudo isto quer dizer uma "bela máquina," máquina aprovada e indicada pelos industriais, que produz muito e dá eficiência e eficácia aos resultados da empresa: o resultado de um dos seus ingredientes. 
Na ilustração o modelo PPIS-6o/40, fabricado sob licença da Triulzi S.P.A.,
(Milão-Itália) cujas características de Design são a concretização da exposição acima.

FORMA, MATERIAL E COR, p.II7

Carlos Chitl, presidente da diretoria das Indústrias Romi S.A.

No desenho industrial de uma máquina-ferramenta, como um torno caracterizado por enormes variaçóes em termos de dimensóes, há a necessidade de respeitar as funçóes a que se destina a máquina. A forma deve ser funcional e o uso de materiais e cores devem respeitar as características técnicas do produto. Um eficiente desenho industrial será mais válido, quanto mais contribuir para a redução dos custos de fabricação.

Condicionado a estes aspectos, o designer deve criar formas que conciliem a função da máquina a uma estética moderna e inovadora, procurando dar ao produto harmonia, beleza e perfeita funcionalidade.

A Romi, consciente da sua liderança na fabricação e comercialização de máquinas-ferramentas, sempre se preocupou em aplicar em seus produtos os recursos de um desenho industrial atualizado, o que lhe tem garantido o domínio crescente dos mercados, nacional e internacional.

Diante da necessidade constante de renovaçáo dos produtos que fabrica e da criação de novos Designs para seus lançamentos, a Romi mantém uma bem estruturada equipe de designers e, quando necessário, recorre à colaboração de reputados mestres internacionais.

Devido a esta orientação, a Romi é hoje a única empresa no mundo a fabricar uma grande variedade de máquinas-ferramentas com desenhos industriais que lhes permitem funcionalidade perfeita, estética de vanguarda, constituindo, portanto, conjuntos harmoniosos e de sóbria beleza.

AlÉm Do BELO, O FUNCIONAL É O DESIGN, p.II7

José Olavo de Azevedo, diretor da Pereira Lopes-Ibesa

A nossa maneira de apreciar o campo do desenho industrial tem sido voltada muito mais para o aspecto utilitário que estético dos produtos que fabricamos, considerando fundamentalmente o objetivo básico de oferecer ao consumidor mais conforto e durabilidade do produto.

A mais profunda experiência que tivemos foi em $1974 / 75$ quando a Pereira LopesIbesa convidou especialistas em Design para preparar a nova linha de geladeiras. Naquela época éramos os primeiros a adotar no Brasil o uso da espuma de poliuretano expandida para isolação térmica. As hoje conhecidas geladeiras de paredes finas traziam um novo conceito de espaço útil, de extraordinário poder de isolamento, sensíveis benefícios para o custo industrial, peso específico e valor de conforto.

Externamente o produto sofreu o despojamento dos features que o Design classificava como supérfluo e até desprezível, tendo em vista as tendências da época. As cores bem analisadas obedeciam as recomendaçóes.
$\mathrm{O}$ impacto inicial junto à rede de revendedores foi satisfatório. $\mathrm{O}$ resultado de vendas ao consumidor náo aconteceu.

Pesquisamos o campo e verificamos que o produto, diante do contraste de aparência externa com os concorrentes, sofria perda, um captis diminutio:

$\mathrm{O}$ aspecto estético estava ofuscando toda a inovação tecnológica.

Considerando que nossa linha de produtos tem seus padróes de forma universalmente estandardizados, a nossa preocupação, repetimos, tem sido sempre voltada para o aproveitamento interno, o espaço útil e os materiais qualificados para uma melhor performance de durabilidade da geladeira e as técnicas de aperfeiçoamento do rendimento e versatilidade das nossas máquinas de lavar. 
TODAS AS INTENÇÓES DO ENVELOPE, p.I2O Fred Jordan

Depois de provocar as mais injustas suspeitas, a proposta do envelope para discos foi mantida na íntegra: oferecer proteção. A proteção se estende ao próprio consumidor, pois quem carrega discos ostensivamente está imune contra assaltos. Pelo menos, o assaltante dificilmente leva os discos. A subproposta foi projetar a imagem das lojas como Centros Discômanos. Observe-se, a propósito, as letras subliminais C e D do Design.

Este, aliás, inspirou-se nas pinturas rupestres da Granja Viana. A pesquisa junto ao público foi bastante auspiciosa, pois três entre seis pessoas identificaram os círculos; duas hesitaram entre luas-crescentes e minguantes e uma não tinha opinião formada.

As cores são antiestáticas e resistentes ao álcool após as 22 horas, sugerindo ainda o gosto aromático do sorvete de baunilha.
$\mathrm{Na}$ forma externa optou-se por quatro cantos vivos, por valorizarem melhor o aspecto tântrico do produto. A eficiência máxima do envelope foi obtida com álbuns de Mahler e Chico Buarque. Wagner requer um saco especial.

A funcionalidade é permanente, pois o envelope serve para guardar o dinheirinho que o discômano vai juntando escondido da mulher durante o trimestre, antes de procurar uma loja especializada. Finalmente, é a embalagem/presente ideal para passar para frente aquela Primeira de Brahms, onde a entrada da flauta, na introdução più andante do IV movimento, não foi muito feliz.

\section{Legenda}

Envelope para discos: as novas propostas de Fred Jordan

PRESENÇA DO DESIGN NA BIENAL, p.I2O Lais Moura

Como de costume nossa classe da critica, numa exposição, não tem o mínimo interesse sobre o fato em si, isto é, da apresentação do conjunto de elementos que compóem a manifestaçâo sob um ponto de vista arte, arte de representaçáa. Foi o caso da última Bienal. Como a composição de uma exposição é Desing, torna-se oportuno esse comentário.

O projeto de comunicação visual na Bienal Latino-Americana baseou-se em um sistema de codificação de cores, identificando países, eventos e serviços. Foram utilizados três tipos de suportes: placa de madeira pintada com faixa de cores horizontais codificando país, artista e classificação da obra; bandeiras verticais de tecido colorido identificando os países participantes e material publicitário, (outdoors, anúncios, TV-spots, cartazes, catálogo etc.) onde as cores são aplicadas segundo faixas inclinadas.

O tipo de informação veiculada nas placas identificadoras das obras não é convencional, uma vez que deveria grifar o conteúdo da própria exposição.

Nestas circunstâncias, o projeto, visando à máxima resposta do público, optou pela adoção da escala de cores natural do meio ambiente brasileiro, em substituição à forma de sinalização mais usual no Brasil, caracteristicamente neutra, em tons de cinza, preto e branco. Tal atitude implicou ainda no risco de que as cores vibrantes dos meios de comunicação interferissem nos trabalhos expostos, o que na realidade das obras e do espaço físico desta Bienal não se verificou. Além de identificação, as cem placas suspensas horizontalmente a $210 \mathrm{~cm}$ do chão, desempenharam a função de humanizar a arquitetura, atuando como elementos para a construção uma nova proporção ambiental, chegando, em algumas situaçôes, a criar um rebaixamento ilusório na altura descomunal do pé direito dos salóes.

Foram responsáveis pelo projeto montagem e de comunicação visual da Bienal LatinoAmericana de São Paulo, o designer Alexandre Wollner, como coordenador; o arquiteto Pierluigi Bagini, como assistente, e Guimar Morelo, pela montagem. 
Senhor Vogue \#I4, maio de 1979, p.94-I07 (Senhor e as Artes)

UM PINTOR INÉDITO: RosáRIO BERNAUDO, P.99-IOO

Edimar Soares

A descoberta de novos valores no campo das artes é fato normal, pois existem produtores solitários náo integrados no ambiente do tempo em que operam. Assiste-se comumente à recuperação de artistas até ontem rejeitados pela crítica e consequentemente pelo mercado. Assim, elementos que não tiveram a devida consideração recebem atenção e passam a mudar de posiçáo na história.

Recentemente os americanos deram nova posição a Greuse, organizando uma exposição levada também à Europa: um pintor no oitocentos, detestado, está recebendo muitos aplausos, redescobrindo-se em sua arte novos significados, até mesmo de crítica social. Este é um dos tantos casos. Lembramo-nos dos La Tour, Magnasco, Archimboldi, Monsu Desidério, para não falarmos na recuperação dos pré-rafaelitas, dos neoclássicos e dos acadêmicos do Segundo Império. $\mathrm{O}$ mesmo se verificou com personalidades menores e de tempos bem mais recentes.

Cada país apresenta vários destes casos, inclusive o Brasil, onde a pesquisa continua atraindo estudiosos empenhados na reconstrução da história da arte nacional. É frequente a consideração de pintores, escultores e arquitetos escondidos nas dobras do tempo colonial, não faltando no grupo artistas desaparecidos há poucos decênios, às vezes personalidades de notável interesse. Bastante amplo é ainda o trabalho a ser feito.

Eis, agora, uma redescoberta: Rosário Bernaudo, um italiano que operou em São Paulo, poeta, dramaturgo pintor.

Recentemente um pesquisador interessado nos tempos do Modernismo, encontrou na família do artista um grupo de pinturas que surpreendem.

A pintura de Bernaudo pode ser inscrita no fazer post-romântico que, na Sáo Paulo onde ele viveu e teve família, representava num certo sentido a tendência conservadora, em oposiçáo aos inovadores do Modernismo, porém a ser considerada contribuidora deste movimento que englobava os mais variados modos, como se viu na Semana de Arte Moderna conciliadora do delicado espírito art-nouveau de Paim, do expressionismo de Tarsila, do purismo de Brecheret e do caricaturismo de Di Cavalcanti.

Rosário é um romântico, tanto na poesia como na dramaturgia: autor de líricas ricas de emoção, quando pintava procurava expressar um senso de intimidade, o bucólico que vemos nas paisagens, as composiçôes de figuras inspiradas em motivos sentimentais, a retratística que procura definir o caráter. Romântico é também o não abusar das cores violentas, adaptando-as a tonalidades calmas e harmoniosas. Bernaudo elaborava suas telas com extrema consciência: eram os tempos da volta do Impressionismo, gosto do plein-ar sintético, o da mancha, mas ele procurava resolver a pintura na solidão do atelier.

Ele veio ao Brasil de Nápoles, trazendo aquele consagrado da pintura partenopea do começo do século.

Bernaudo nasceu em Cosensa, na Calábria, em i888. Órfão, aos dez anos se encontra em Nápoles, seugutzzo, vendedor de jornais. Vive precariamente, desenha e escreve versos ingênuos nas calçadas, chamando a atenção do filósofo Giovanni Bovio que o leva para sua casa e o faz estudar. Mais tarde o inscreve no Instituto de Belas Artes, na classe de pintura.

Um dia, no palácio do príncipe de Sirignano, o jovem improvisa um acróstico para o anfitriâo e o ilustra com um retrato dele; estava presente a famosa escritora Matilde Serao que, no jornal que dirigia, publica uma nota sob o título Un astro che sorge.

Em I3, Rosário expóe na Bienal de Veneza. Deixa a Itália e se aventura para o Brasil. Reside em São Paulo, expóe no Rio, é premiado, expóe em São Paulo, estimado e querido pela coletividade italiana, escreve os dramas Il Tunnel, Da l'Abisso alle Stelle, dedicado ao seu benfeitor Bovio, comédias, sátiras, poesias. 
Músico, estudou canto em Nápoles, bom tenor, conhecedor de partituras.

Anotou um biógrafo: "Era psicólogo e intuitivo. Era de coração aberto, franco, sincero. Extremamente sensível, amoroso e gentil, e de outro lado, explosivo. Apesar de viver atormentado pelas dificuldades financeiras, com períodos desesperadores, era de índole alegre. Via o lado trágico e sentimental da vida e o lado cômico e alegre. Sentia-se deslocado, incompreendido, com algumas exceçóes. Exercia sobre as pessoas verdadeiro fascínio e tinha muitos amigos. Dizia que tinha em mente produzir outros quadros e escrever muito, e que para tanto almejava um pouco de sossego de espírito, o que nunca teve.

Morreu pobre e sem realizar o seu sonho. Tinha saúde sólida, mas nos últimos anos teve o coraçáo abalado desse mal veio a falecer.
Pressentiu a morte e no bolso do último colete que usou estava um pequeno pedaço de papel e quase ilegível estas palavras: "Fra poco passerà per questa porta la bara che pur terrà il mio cadaver. Irto, supino, immobile, ingliallito, diretto a la Necropole." Isto se deu em i950. As últimas palavras confirmam que Rosário era um romântico, como bem o atesta toda tua obra ainda à espera de um diligente pesquisador que, estudando o caso, oferecerá uma contribuição não indiferente a reencontrar o tempo que passa à história como o dos modernista, especialmente no setor da participação dos Italianos na formação cultural brasileira.

\section{Legenda}

Rosário Bernaudo. Depois do Réveillon, óleo sobre tela, 57 x 94,5 cm. Coleção particular, São Paulo g Rosário Bernaudo, Pacífico e Malandro, óleo sobre tela, $80 \mathrm{x}$ $80 \mathrm{~cm}$. Coleção particular, São Paulo.

Senhor Vogue \#I5, junho de 1979, p.94-I06

DefEndendo uma POLÍTICA NACIONAL DO LAZER, p.97-99

Renato Requixa

Preconizamos uma política nacional de lazer, ou, em outras palavras, uma nova política educacional que considere outros tempos, inclusive o tempo livre; outros espaços, inclusive os equipamentos de lazer; outros recursos humanos, inclusive os animadores sócio- culturais; e que atenda à especificidade ias diferentes faixas etárias, ao longo ia vida dos indivíduos.

\section{Conceito de lazer}

Uma ocupação não obrigatória, de livre escolha do indivíduo que a vive e cujos valores propiciam condições de recuperação psicossomática e de desenvolvimento pessoal e social.

\section{Recuperação psicossomática}

A primeira imagem que nos vem à mente ao estímulo da palavra lazer parece ser a de repouso, após um esforço, a de recuperação após os desgastes de natureza física ou de natureza nervosa. Na verdade, hoje, é através das atividades de lazer que o indivíduo tem ocasiáo de recuperar as energias gastas em seu trabalho, ou nas demais obrigaçôes que enfrenta na vida cotidiana. Especialmente quando tratamos da vida do trabalhador nos centros urbanos é que podemos avaliar mais concretamente a série de obrigaçóes que enfrenta, não apenas as obrigaçóes do trabalho, mas as obrigaçóes dele decorrentes e as demais obrigaçôes a que se na contingência de enfrentar e satisfazer para viver numa sociedade cada vez mais urbanizada. As obrigaçóes, porém, dão origem a tensôes que, por sua vez, provocam deterioraçóes físicas ou nervosas. Entende-se então, a recuperação psicossomática como a liberação da fadiga física ou nervosa decorrente das obrigaçóes que os indivíduos enfrentam em sua vida diária.

Sabem-se dos efeitos negativos do trabalho parcelado na vida do trabalhador, desempenhando tarefas simples, fracionadas até seus últimos limites, sem grande esforço físico e sem necessidade de qualificação para executá-las. Ora, uma das funçôes do lazer é a de liberação do homem dos efeitos negativos do trabalho especializado e fragmentado, através do divertimento que se pode alcançar com a prática de ocupaçóes de lazer.

Por outro lado, uma ocupaçáo de trabalho em nossa atual sociedade nada tem em comum com o trabalho de um artesão ou 
de um camponês de outrora. Desaparece a satisfação e mesmo o orgulho de um trabalho bem feito. Daí a importância do lazer para a expressão humana. $\mathrm{O}$ lazer funcionaria, então, como antídoto contra o tédio causado por um trabalho monótono e enfadonho.

\section{Desenvolvimento social}

O que se pode notar, de pronto, é a participação social mais ampla que as atividades de lazer permitem ao indivíduo. Convivendo em novos grupos primários, o indivíduo vai alargando as fronteiras de seu mundo, intensificando suas comunicaçôes nos contatos que mantém com novos grupos humanos, o que certamente lhe trará a natural ampliação de seu sentimento de responsabilidade. Além disso, o lazer cultural incentiva o indivíduo ao seu próprio aperfeiçoamento técnico e profissional, o que manifestamente se refletirá em seu melhor desempenho como agente econômico, sentindo-se ao mesmo tempo mais responsabilizado pelo desenvolvimento social e pelo desenvolvimento econômico do país. São as atividades de lazer cultural, suscitando novos interesses intelectuais, que também permitem o autodesenvolvimento. Desenvolvendo-se culturalmente, o indivíduo tem condiçôes de melhor dominar-se e está mais bem equipado para enfrentar e dominar os fenômenos da natureza. Os valores do lazer permitem-lhe ainda desenvolver uma experiência interior, íntima, subjetiva, que lhe enriquece a personalidade na medida que lhe desenvolve uma de suas faculdades. Uma experiência conscientemente vivida é um perfeito exercício de uma faculdade humana.

Ora, tais experiências e tais vivências formam o verdadeiro conteúdo sócio-educativo das atividades de lazer, lembrando-nos que a educação é hoje entendida como o grande veículo para o desenvolvimento, e o lazer o excelente e suave instrumento para impulsionar o indivíduo a desenvolver-se, a aperfeiçoar-se, a ampliar seus interesses e sua esfera de responsabilidades, inclusive sua responsabilidade social como cidadão.

\section{Desenvolvimento pessoal}

$\mathrm{O}$ indivíduo, através da prática de uma atividade de lazer, é capaz de adquirir novos conhecimentos que lhe permitem uma compreensão diferente daquela que tinha, até então, a respeito de determinados fenômenos. Essa compreensão diferente poderá impulsioná-lo a uma nova atitude frente àquele fenômeno. Poderia sua antiga atitude ser já condicionada. Ele, então, liberou-se desse condicionamento e alargou sua compreensão do mundo. Pode-se dizer, com isso, que as atividades de lazer, fomentando novas atitudes em face da sociedade, estão, ao mesmo tempo, suscitando o desenvolvimento da personalidade. A participação em uma equipe esportiva pode despertar no indivíduo o reconhecimento do valor de um esforço em conjunto, do sentido de lealdade para com o grupo, do prazer pelo companheirismo e pela solidariedade.

A simples fala de uma determinada personagem numa peça teatral ou num filme, reagindo a uma certa motivaçáo provocada por uma situação social que o espectador já viveu ou está vivendo no momento, poderá servir-lhe como verdadeira revelação. Através daquela personagem o autor pôde, penetrando com acuidade a alma humana, ou retratando uma situação social, com aguda sensibilidade artística, apontar elementos, descobrir ângulos, revolver emoçôes que se transformam em formidável revelação para o espectador. Ele sente que descobriu algo até então desconhecido ou não discernido. Essa revelação poderá marcar de forma indelével sua maneira de articular-se com as outras pessoas, com as coisas, com a natureza. Enfim, sofreu uma experiência e através dela captou um determinado conhecimento que lhe escapava, pois estava preso a certos automatismos de conduta ou de pensamento. A obra revelou-lhe algo que ele desconhecia e cujo conhecimento acrescentou alguma coisa que fez com que ele próprio se compreendesse melhor, compreendesse mais os outros, e compreendesse mais o próprio mundo.

A propósito, o professor Antônio Cândido afirma: "Neste ponto tocamos uma das funçóes capitais da ficção que é a de nos dar um conhecimento mais completo, mais coerente do que o conhecimento 
decepcionante e fragmentário que temos dos seres. Mais ainda: de poder nos comunicar este conhecimento.

As atividades de lazer oferecem ocasiāo para que as pessoas externem suas faculdades criadoras, exercitem seus dotes artísticos ou estimulem a realização de suas virtualidades estéticas; facilitam ao indivíduo a contemplação e o prazer de admirar criaçóes artísticas de outros. As atividades de lazer exercem assim a função de condutores, de encaminhadores, dirigindo o indivíduo ou indicando ao indivíduo o caminho através do qual ele também pode encontrar e alcançar o sentimento de prazer, de alegria de viver, de felicidade, pela descoberta de valores estéticos e pela fruição desses valores.

I860: 85 horas. I960: 48 horas

Ambas as noçóes confundiam-se nas civilizaçôes mais remotas. "Trabalho," palavra de origem recente em comparação com a idade da humanidade, lembrava punição e dor e era desprezado pelas elites. Esse desprezo, posteriormente, restringir-se-ia apenas ao trabalho manual. Na Idade Média não só o trabalho ganhou dignidade, como os dias festivos ganharam importância. A revolução religiosa do início do século 16 inicia o processo de supervalorização do trabalho e de condenação dos tempos livres. O lazer perde terreno. A economia se dinamiza e inicia-se o processo da revoluçáo industrial, quando se exacerbam as ideias da importância do fator trabalho e o trabalhador se vê privado do seu lazer e de suas incipientes vantagens sociais.

Essa posição utilitarista do tempo naturalmente encontraria críticas contra o lazer. Não se aceitava mais o exagerado número de dias santificados pela Igreja, como também não eram bem vistas as ordens religiosas contemplativas. O lazer perdia terreno, ao mesmo tempo que o trabalho era moralmente supervalorizado. A humanidade iniciava-se no que veio a caracterizar- se mais tarde como civilização industrial. Nesta, o binômio lazer-trabalho apresenta-se com contornos mais nitidamente diferenciados.
Para os trabalhadores a resultante foi uma situação seriamente agravada com duplo prejuízo, pois a civilização industrial, durante sua fase inicial, além de não ter podido satisfazer as necessidades materiais imediatas dos trabalhadores, ainda privou-os do lazer e de certas vantagens sociais que estavam acostumados a desfrutar na civilização pré-industrial. Basta lembrar que no começo da era industrial o proletariado urbano na Europa trabalhava, em média, 85 horas por semana. Este excessivo número de horas de trabalho, não apenas para os homens, mas também para mulheres e crianças, e a carência de condiçóes ambientais aceitáveis, quer para trabalhar, quer para viver, aliavam-se à generalizada insegurança de emprego e à incerteza na obtenção de meios e recursos para prover as necessidades vitais. As condições apontadas, obviamente, não poderiam favorecer a colocação do tema lazer.

Curiosamente, foi o próprio desenvolvimento da civilização industrial, acompanhando-se de continuados progressos tecnológicos, que veio estimular a recolocação da temática do lazer no século 20.

Se a industrialização, em sua fase inicial, sugeriu muito mais a continuidade agravada da situaçáo do homem no trabalho do que a eliminação da miséria e da infelicidade para milhóes de seres humanos, por outro lado representou e representa ela, manifestamente, a mais apropriada solução encontrada pelo homem em sua busca pelo bem-estar social. De uma época, na França, por exemplo, em que a média semanal de trabalho era de oitenta e cinco horas, em I860, chega-se, em I960, a quarenta e oito horas. Nos Estados Unidos, no mesmo período, a média desceu de setenta para quarenta e uma horas.

\section{A democratização do lazer}

Chega a humanidade a um formidável momento de sua história, em que as massas passam a existir como realidade social significativa e, superando preconceitos, também se voltam para a fruição do lazer, que deixa de ser um privilégio de classe para ganhar uma extraordinária dimensão social. É cada vez maior o número de pessoas com disponibilidade de tempo e em condiçóes econômicas adequadas 
para usufruírem os valores do lazer, ao mesmo tempo em que o lazer passa a corresponder à aspiração de milhóes de indivíduos. Praticamente inaceitável, como vimos, numa época de supervalorização moral do trabalho, converte-se, como lazer, num valor em si mesmo, o que representa uma das mais importantes modificaçóes na história social do homem.

É esta ampliação social do lazer que nos leva a indagar se os homens - beneficiários diretos da democratização do lazer - estarão dela fazendo o uso mais adequado ou, em outras palavras se os homens estarão sabendo utiliza as horas liberadas do trabalho, empregando-as na satisfaçáo de suas aspiraçóes mais autenticamente humanas, ou estarão apenas desvirtuando-as, na medida que procuram preenchê-las com novas formas de comprometimento em respostas meramente condicionadas; ou ainda, se, em face do tempo livre e por falta de habilidade para usá-lo, ou náo encontrando nas atividades que empreendem a plena satisfação almejada, não acabam por defrontar-se com o enfado, a angústia ou o tédio dos momentos desesperançadamente vazios.

\section{Menos neuroses e angústia}

São funções intrínsecas às atividades de lazer e cuja prática beneficia de forma direta e individual as pessoas que delas participam. Há uma recompensa física ou psíquica pelo fato de terem praticado uma ou mais atividades de lazer que se traduz, como dissemos, ou pela diminuição ou mesmo pela superação de problemas que afetam individualmente e de forma preponderante o homem urbano. Assim, a decorrência da prática de uma atividade de lazer é aqui entendida como "preponderantemente individual.” Ela beneficia individualmente o homem habitante da grande cidade. Mas o benefício não é apenas individual, porque o homem, afetado pelos problemas urbanos apontados, age socialmente de forma diferente. Aqueles problemas se refletem em seu comportamento social. Daí dizermos que a decorrência da prática das atividades de lazer é "preponderantemente" individual porque supera ou diminui problemas diretamente sentidos pelo ser humano individualmente considerado. Mas essa superação, indiretamente, também beneficiará a coletividade como um todo, na medida que os componentes dessa coletividade apresentarem menos problemas, menos neuroses, menos angústia, menos ansiedade.

\section{Nos países em desenvolvimento}

Em primeiro lugar, cabe, realmente, a indagação sobre a oportunidade da introdução do tema lazer nos países em desenvolvimento, como o Brasil. Num primeiro momento, desacostumados à temática, somos assaltados pela dúvida quanto à validade dessa colocação, ou mesmo quanto à existência do problema lazer nesses países. Nada há a questionar sobre a urgência para a solução de problemas como o da alimentação, saúde, da habitação, da educação que inegavelmente configuram prioridades impositivas e desafiadoras. Entretanto, as concepçóes há pouco apontadas, relativas ao aproveitamento das ocupaçóes de lazer com objetivos sócio-educativos, sugerem outras consideraçôes que permitem reconduzir e validar a proposição, mesmo para os países em desenvolvimento, pois trata- se, a nosso ver, de realista discernimento de possibilidades.

Nos países onde já se conseguiu um alto nível de vida, aliado ao menor número de horas semanais de trabalho, o problema "lazer" pode apresentar-se como prioritário; nos países em desenvolvimento, o assunto deve ser abordado tendo-se em vista, em primeiro lugar, a importância do lazer para todos aqueles que trabalham, independentemente do maior ou menor grau de desenvolvimento já alcançado, e, em segundo lugar, considerando também as possibilidades de aproveitamento de disponibilidades, tendo em vista o objetivo maior que é o próprio desenvolvimento.

Trazemos essas consideraçóes para estímulo de nossa própria imaginação, para que possamos refletir sobre o significado do lazer em nosso país, onde já nos parece plausível encará-lo como assumindo foros de problema social, principalmente em nossas grandes cidades, onde os aglomerados humanos crescem em porcentagens de explosão demográfica. 
Não é de surpreender a preocupação demonstrada com relação aos equipamentos e áreas destinados ao lazer em possas cidades, o que vem refletir a situação que as cidades brasileiras estão apresentando. Por outro lado, os formidáveis índices de nosso desenvolvimento econômico só nos devem alertar para o tema, pois seria voltarmos as costas à realidade se, numa averiguação do presente e numa antevisão do futuro, desde já tal fato não fosse considerado. Parece-nos, se nos permitirem uma advertência, que aos técnicos e profissionais do campo social e educacional não deverá estar ausente a predisposição necessária para, ocupando-se imediatamente dos problemas que a futura "civilização do lazer" começa a colocar entre nós, evitar que ela se imponha desacompanhada dos mais altos valores inerentes à humanidade. As reservas que podem ser levantadas quanto à validade da temática do lazer Para os países subdesenvolvidos é plausível admitir serem oriundas primeiramente de um natural desconhecimento do assinalado quanto às funçóes do lazer; e, em segundo lugar, pelo fato de a imagem mais direta e simples do lazer estar ainda, de certa forma, impregnada de ideias preconceituosas originadas da confusão entre as noçóes de ócio e de lazer.

O primeiro aspecto a considerar é aquele que para todos os técnicos, profissionais e estudiosos do social pode ser aceito como o mais essencial e o mais provocante pela riqueza de possibilidades que oferece. Referimo-nos às concepçóes relativas ao aproveitamento das ocupaçôes de lazer como instrumento de educação para consideráveis parcelas da coletividade. Nesta dimensão, o lazer não é apenas um bem de consumo, mas também centro de convergência da atenção dos especialistas interessados em conceber novas formas de educação que a prática das ocupaçôes de lazer propicia. Um livro intitulado Educação de Jovens Delinquentes, editado na França em I962, relata os processos de reeducaçáo de jovens delinquentes, através de ocupaçôes de lazer, fator considerado como realmente privilegiado para a readaptação social.

São facilmente discerníveis as possibilidades que a utilização das horas livres oferece quando se tem em vista o desenvolvimento individual, grupal ou comunitário. Pode-se já verificar que, em diversos países e em instituiçôes dedicadas à promoção do lazer, as novas estratégias programáticas levam em conta o emprego das horas livres para, simultaneamente com a recuperação individual, promover e ampliar a consciência individual e social a respeito da sociedade e de si mesmo, aguçar a sensibilidade com relação às manifestaçôes culturais, desenvolver a criatividade e fomentar sentimentos de solidariedades e cooperação humanas.

Em nosso país o lazer vem sendo claramente reconhecido como de relevante importância educativa, destacando-se ainda sua função de recuperação psicossomática, principalmente tratando-se dos habitantes das cidades. É assim entendido que o lazer constitui hoje uma das diretrizes operacionais básicas da ação sócio-educativa do Serviço Social do Comércio (Sesc) em todo o Brasil.

O segundo aspecto educativo a salientar a respeito do assunto é o da necessidade de educação para o lazer.

A falta de habilitação apropriada para a utilização do lazer é lembrada por Robert Mclver, quando, em seu ensaio, The Great Emptness, diz: "Para muitos homens, o trabalho tornou-se uma rotina não muito onerosa, não muito compensadora, e de forma nenhuma absorvente - uma rotina diária até que a sineta toque e os torne novamente livres. Mas livres para quê? É uma liberação maravilhosa para aqueles que aprenderam a usá-la; e há muitas formas de fazê-lo. Mas é também um grande vazio para aqueles que não aprenderam a usá-la.”

Aprender a usar o tempo livre significa, em última análise, educar-se para o lazer. É o duplo aspecto educacional do lazer; educar através do lazer e educar para o lazer.

\section{Educação para o lazer}

Mesmo nos países plenamente desenvolvidos apresentam-se sintomas de carências da educação que vise especificamente ao lazer. Em primeiro lugar nota-se a falta de dispositivos mais racionais para o correto aproveitamento do tempo livre. Ainda não foram tentadas soluçóes inovadoras, ou são poucos os exemplos de soluçôes 
inovadoras, para o aproveitamento mais racional do tempo ou facilitadoras da criação de mais tempo livre para o lazer.

Lembra-nos Jean Fourastié, em seu livro Des Loisirs pour quoi Faire? "Ignorando o verdadeiro repouso, como o verdadeiro trabalho, chega-se a transportar para o lazer os ritmos e nervosismos do trabalho: leva-se consigo a intoxicação da vida trepidante e ritmos dos quais não se pode desfazer. Isso pode ser observado no Japão, onde o popular jogo Patchenko (caça-níqueis,) praticado diariamente por milhóes de homens, reproduz os gestos sacudidos de um trabalho industrial acelerado." Essa observação de Fourastié alerta para a falta de preparação para o lazer. Muitas vezes o homem se sente em tédio, em depressão, frente ao tempo vazio. O mesmo autor, na mesma obra diz: "Quando se vive o tempo de trabalho fechado numa fábrica, num escritório, deve-se normalmente procurar um equilíbrio, uma compensação nos lazeres ao ar livre; enquanto que as pessoas que exercem atividades exteriores, como a agricultura, deveriam procurar distraçóes de natureza intelectual. Mas isto é uma solução teórica; por mais surpreendente que pareça, o homem é geralmente prisioneiro de um número limitado de interesses, ele é mesmo, o mais das vezes, totalmente preso, orientado por uma ideia única. É assim que o camponês ocupará seus lazeres na caça e na pesca, ao passo que o professor mergulhará voluptuosamente nas suas garatujas.” Daí a importância de facilitar-se a iniciação para o aprendizado de atividades de lazer. Aqui entram em função os técnicos nas diversas especialidades. O despertar ou o aprimorar do gosto artístico, por exemplo, para melhor apreciação das grandes manifestaçóes de arte, o fornecimento de conhecimentos técnicos para que o indivíduo possa melhor praticar certas atividades de lazer são tarefas essenciais dos especialistas. É através delas que o indivíduo iniciado disporá de melhores condiçôes e de maior incentivo, ou para escolher entre as possibilidades que se lhe oferecem, ou para aprimorar-se e melhor usufrui-las. É uma aprendizagem que naturalmente se faria com a aprendizagem dos próprios valores do lazer.

\section{A POBRE RELAÇÃo ENTRE LAZER E LEITURA, p.IO3}

\section{Cláudia Marino Semeraro}

Seja pela falta de hábito ou precariedade de nossas bibliotecas, a verdade é que a leitura ainda não foi incorporada ao cotidiano do brasileiro. A relação lazer-leitura é insignificante se comparada à do lazer-televisão, esta última fadada a crescer cada vez mais.

Interessante seria em se analisar a primeira relação, a qual certamente trará resultados surpreendentes. Certamente um dos elementos levantados seria o do difícil acesso aos livros, ou seja, o número reduzido de bibliotecas e instituiçóes.

É assustador constatar-se que, segundo dados oficiais para o ano de I976, da Secretaria de Planejamento da Presidência da República e Fundação Instituto Brasileiro de Geografia e Estatística, o Brasil, em seu imenso território, conta apenas com 3519 bibliotecas, (federais, estaduais, municipais e particulares) das quais 900 localizam-se no Estado de São Paulo, seguindo-se Minas Gerais, com 565 e Rio de Janeiro, com 336.
Em São Paulo, 534 bibliotecas populares, sendo 337 municipais, responsáveis pelo maior número de leitores por ano. Se pensarmos que São Paulo compreende 57I municípios, constrangidos verificamos a inexistência de uma biblioteca popular para cada município: isto ocorre no Estado que mais possui bibliotecas...

Náo se trata de acusar este ou aquele como responsável por esta situação, mas acredito que muito mais que a simples falta de interesse, a desinformação é grandemente responsável: a populaçáo, em sua maioria, desconhece as bibliotecas existentes, principalmente as infanto-juvenis, tão importantes para a formaçáo do nosso jovem.

O pessimismo do quadro justifica-se em exemplo recente. Durante os meses de março e abril deste ano, o Masp realizou exposição dedicada à História da Tipografia no Brasil, despertando interesse por seu ineditismo e pela qualidade dos materiais expostos. Visando a esclarecer especialmente aos estudantes, 
colocou-se pranchas explicativas do assunto, situando-o historicamente, além das legendas para cada obra em exposição.

Apesar deste cuidado, não foram poupadas informaçóes aos interessados. Foi surpreendente constatar que alunos, geralmente de nível universitário, solicitavam um resumo do que era a exposição, assim como do assunto tratado. À indicação das pranchas como quadros explicativos, o desaponto era total: insistiam em uma explicação abreviada.

Resta-nos alertar para este problema, acreditando que uma contribuição à formação cultural seria o incentivo à utilizaçáo de bibliotecas, e mais, desacreditar a relação tida como verdadeira, que lazer é ócio.

Istoé \#I42, I2 de setembro de I979, p.65 (Artes: Grande vexame)

Xv Bienal de São Paulo

Jacob Klintowitz

[mencionado por Bardi em Senhor Vogue \#20, novembro de 1979, p.I07]

A grande atração desta Bienal, a se iniciar em dias, o Congresso Internacional de Críticos de Arte, cujo tema era a função das bienais na sociedade contemporânea, (tristemente cancelado num ataque de ineficiência aguda) já tem um novo local: Barcelona. Enquanto isto a Bienal informa a "aquisição" de dois novos conselheiros culturais, Wolfgang Pfeiffer e João Cândido M.G. Barros. Com os dois, a gestão Rodrigues Alves acaba de bater o recorde mundial da incompetência pomposa, já que. na sua laboriosa gestão, teve os seguintes aconselhadores culturais: Casimiro Mendonça. Pedro Manuel Gismondi. E. von Launstein Massarani, Geraldo Edson de Andrade, Radha Abramo, Alberto Beutnmüller, Romeu Mindlin. Maria Bonomi, Yolanda Mohaly, Marc Berkowitz, Esther Emílio Carlos, Clarival Valladares, Leopoldo Raimo, J. KJinlowitz, Olívio Tavares de Araújo, Lizeta Levi. São dezoito conselheiros, e, para o nosso orgulho, nem a corte do Rei Sol teve tantos... Nos dois meses de Bienal deverão ser gastos exatamente Cr\$ 9.353.240,00.

Senhor Vogue \#I8, setembro de I979, p.99-IIO

AMERICA LATINA, SER OU NÁO SER: ESTE MUNDO EXISTE ALÉM DO GEOGRÁFICO? p.IO4-IOS Felipe Herrera, presidente do Conselho Administrativo do Fundo internacional de Promoção da Cultura do México

Precisamos definir exatamente o que seja a identidade cultural latino-americana. Vários ensaios filosóficos, históricos e sociológicos sobre a América Latina como um todo,têm questionado a validez de um conceito globalizado do hemisfério e, em alguns casos, até mesmo negado a existência da América Latina como uma entidade especial e consistentemente válida.

Contudo, pondo-se de lado as muitas distinçôes sutis e as definiçóes emaranhadas que têm inflamado a controvérsia, permanece o fato de que ela constitui uma presença histórica, econômica, política e cultural no mundo de hoje, que se vem gradativamente afirmando, e de que essa presença é a expressão de uma essência latino- americana.

Tal afirmação poderia ser refutada à base da aparente incapacidade na consecução de níveis mais elevados de integração regional em todos os aspectos. Poderse-ia também alegar que os vínculos de dependência que nos ligam aos centros de hegemonia da ordem internacional se tomam cada vez mais fortes. E também que a dicotomia hispano-lusitana não só está longe de ser resolvida, como, na opiniáo de muitos pessimistas, as perspectivas para uma aproximação são hoje menos favoráveis do que nunca.

Esses pontos de vista emanam daquilo que poderíamos chamar de lenda negra, uma sombra permanente que tem pairado sobre nosso Continente. Essa lenda foi concebida por países política e economicamente mais avançados e pelos próprios intelectuais e dirigentes latino-americanos, os quais masoquistamente, enfatizam nossas falhas inerentes. Este último tipo de crítica paralisadora é, sem dúvida alguma,o mais perigoso. Os centros 
industrializados avançados, agora mais sensíveis por causa da emergência do Terceiro Mundo, tendem a atribuir um valor mais elevado ao papel da América Latina. Noto, pela minha própria experiência, que, do ponto de vista econômico, a importância da América Latina como um todo e das suas naçóes individuais tem aumentado muito nos últimos 20 anos.

A maior importância de nosso Continente vem sendo também reconhecida por outras regióes do Terceiro Mundo.

O fato de que, há mais de cento e cinquenta anos, virmos lutando para projetar uma vigorosa imagem nacional, numa jornada em que outros países só deram os primeiros passos nas últimas décadas, é um fator que pode muito bem ser considerado um dos nossos pontos fortes, numa época em que se procura uma nova ordem internacional.

A essência latino-americana adquiriu uma conotaçáo própria, graças a um impulso intrínseco na direção de uma integração cultural coesa, que remonta ao primeiro desembarque de navegadores ibéricos no Novo Mundo. Desde o século I6, vem-se desenrolando, em escala maciça, contínua e até mesmo monumental, um processo ininterrupto de fusão dos valores

\section{Status \#I36, novembro de I985, p.78-84}

Texto de Rubem Braga

Quem disser que viu toda a Bienal estará quase sempre mentindo. Eu andei por lá umas três vezes e vi apenas alguma coisa, mesmo porque esse negócio de pintura a gente tem uma capacidade limitada de consumir; a certa altura os olhos ficam enjoados, cansados. Além disso eu não tinha compromisso de escrever um artigo sobre a Bienal como um todo; queria apenas selecionar alguns trechos para a Neide Duarte, da TV Globo, focalizar em pequenas reportagens depois. Deixando de lado coisas que já tinham sido mostradas, como aquelas pilhas de pneus gigantes do norueguês, e a "Casa da Rainha do Frango Assado" do brasileiro Alex Vallauri, por exemplo.

Minha escolha foi mais ou menos arbitrária. Logo de cara (comecei a visita de cima para baixo, ao contrário do que é correto) culturais de vários grupos étnicos, em diferentes graus de desenvolvimento.

A verdadeira definição da América Latina poderá ser encontrada em seu papel de cadinho dinâmico, no qual tem se processado a absorçáo cultural mútua dos subtratos [sic] ibérico, indígena e africano, no decorrer dos últimos três séculos. Embora os espanhóis e portugueses, aparentemente, tivessem podido determinar ou definir tangivelmente a fisionomia dessa fusão, a realidade é que a influência nativa possuía tal força determinante que influenciou o modelo europeu transladando modos culturais indias para a Península Ibérica. Essa situação, que prevaleceu nos séculos I6 e I7, foi enriquecida pelas novas levas de imigrantes europeus, que continuaram a aportar ao Novo Mundo durante o século I9 e até mesmo neste século.

É interessante notar que essas novas migraçóes geralmente obedeceram à tendência histórica de fluída assimilação indiscriminada. Em outras palavras, a emergência de minorias raciais a constituírem grupos distintivos e até mesmo blocos de poder, como se deu nos Estados Unidos, não se coadura com a experiência latino-americana. fiquei encantado com as xilos de cordel e mais ainda com aquelas gravurinhas do Paraguai do tempo da guerra; mas aquilo não dava para televisáo. $\mathrm{O}$ primeiro pintor que me chamou a atenção foi Ole Sporring, um dinamarquês. Ninguém mais tropical. Seus quadros são sempre paisagens ao ar livre, cheias de coisas e figuras em grande animação, com aves, ilhas, mares, piqueniques. Títulos assim: "Anda sobre a água, borboleta", "Almoço barato ao ar livre", "Crianças no jardim". Tudo meio caricatural, sarcástico, lírico, de cores alegres, muita vida, talvez ameaças de catástrofes atômicas, mas, enfim, o que se leva desta vida é esta vida que a gente leva. O Ole é bom.

Cuba compareceu na Bienal com belos quadros picassianos de Wilfredo Lam e umas paisagenzinhas de um rapaz chamado Thomas Sánchez. Não tem nada 
demais. Água, muita água, parece um lago, um estuário, e uma nesga de terra com árvores. Parece fotografia. Não é; Sánchez não aderiu a esta moda moderna de usar fotos para economizar desenho. Aquela floresta não é fotografia, é uma floresta remada por ele, com suas palmeiras reais ou imperiais, suas árvores de folhas miúdas, árvores de beira d'água e, mesmo, de dentro d'água, como em nossos igapós. Aí é que está: o que me seduziu em Thomas Sánchez foi essa capacidade de enfrentar um tema que parece assustar os nossos pintores modernos: a floresta. Desde Batista da Costa e Parreiras náo se fez nada, ou quase nada. Com uma extrema delicadeza Sánchez nos dá uma lição.

Uma terceira reportagem que encomendei foi sobre o espanhol Francisco Leiro. Também não é nenhum gênio, mas faz grandes esculturas em madeira - geralmente pinho ou nogueira - às vezes pintadas, às vezes não, que me parecem muito expressivas. No Brasil quem faz isso é artista popular do Noroeste, que por sinal usa tronco de jaqueira.

No primeiro andar fui encontrar um artista que todo mundo conhece porque suas figuras são inesquecíveis: Fernando Botero, o pintor das gordinhas. Ele inventou essas donzelas gordas, esses bispos gordos, essas árvores gordas, esses legumes gordos. O importante é que ele pinta essa gordura toda com uma espécie de carinho, com delicadeza suprema. A menina gorda de colher na mão, boquinha pequena e olhinhos tristes parece estar dizendo: "o senhor acredita? - no fundo eu sou uma pessoa fina..."

E ora me direis; mas que bonita Bienal que v. viu, sem abstratos gestualistas violentos, sem minimalistas nem transvanguardeiros, nem bad paiting! Não viu nem a Grande Tela?

Respondo que vi. A certa altura avancei alguns metros por aquele corredor, entre imensos quadros carregados de gordos traços de óleo. Olhei; o fim do túnel longe, e aquilo me confrangia, me sufocava; recuei alguns passos e enveredei por trás de um painel para uma nave lateral, prometendo a mim mesmo voltar outro dia.

Não voltei. Se eu morasse em São Paulo voltaria muitas vezes. A Bienal tem muita coisa interessante para a gente ver - embora tenha, justiça lhe seja feita, muita bobagem também.

Legenda

p.8o Braga: Bienal de fim de semana

OpINião DE Brasileiro, p.8o-8I

Texto de Marcelo Tas

A fotógrafa da STATUS iria me encontrar às $\mathrm{I} 7$ horas, em frente às bilheterias $\mathrm{da}$ Bienal. Ela deveria levar duas cadeiras de rodas motorizadas com as quais eu e um brasileiro (este eu me encarregara de levar) iríamos percorrer a $18^{a}$ Bienal Internacional de São Paulo. Ora, brasileiro a gente encontra em toda parte. Mas, qual não foi minha surpresa diante da dificuldade que tive em convencer um dos muitos "guardadores" de automóvel ali do Parque do Ibirapuera a abandonar temporariamente os seus afazeres e dar uma olhadinha comigo nas coisas que acontecem lá dentro do Pavilhão. Depois de me comprometer em ressarcir o prejuízo de sua ausência junto aos fregueses, convenci um deles a me acompanhar: Natalino de Melo, 38 anos, brasileiro, mulato, "guardador" de automóvel, curso primário completo e morador do ltaim Paulista (periferia da cidade). A fotógrafa estava um pouco desapontada, pois não havia conseguido cadeiras motorizadas. Natalino e eu não nos importamos. Sentamos e entramos usando a força braçal mesmo. O brasileiro me dizia que nunca passou pela sua cabeça a ideia de entrar ali. Primeiro andar: deslizamos em silêncio por toda uma sequência de pinturas abstratas. No final, Natalino arrematou: "Olha, não me diz nada. Esse é um tipo de quadro que só tem tinta!" O brasileiro gostou das telas do peruano Herman Braun-Vega, especialmente uma que mostra "uma gordinha simpática na praia. Parece até Caraguatatuba", completou o Natalino. Ali no $\mathrm{I}^{\mathrm{O}}$ andar, a última obra que mereceria a atenção do brasileiro foi a escultura de um uruguaio onde três figuras jogam "truco" em volta de uma mesa: "Gostei. Olha só 
a cara de sossegado desses caras, Pito na boca, aposentado, tranquilo, jogando o seu baralhinho, não tão nem aí com a Hora do Brasil, comentou. Subimos a rampa para o $2^{\circ}$ andar. Uma velhinha bem vestida nos interrompe no meio do caminho. Ela insiste em alugar uma das nossas cadeiras de rodas. A fotógrafa fica dando as explicaçôes, eu e Natalino rodamos até as Instalações. O brasileiro estranhou a maioria delas — "mas, se tudo isso está aqui deve ter importância para alguém, né?", disse Natalino de Melo. Depois de brincarmos com os objetos de Guto Lacaz, visitarmos a Casa da Rainha do Frango Assado de Alex Vallauri, chegamos à enorme borracharia do norueguês Bjorlo, onde pedi pro brasileiro verbalizar as suas sensaçôes e ele me devolveu: "Sem legenda! O cara que financia uma coisa dessas é mais louco do que o cara que fez". E agora deslizamos um cinquenta metros em silêncio pelo enorme corredor branco malhado de telas enormes, chamado pelos organizadores da Bienal de “GRANDE TELA”. Pergunto ao brasileiro se ele sabe por que as pessoas usam telas táo grandes para pintar. Ele arremata da sua cadeira: "Deve ser para chamar a atenção. Isso daqui pra mim é só borrão. Não diz nada. Isso é quadro pra executivo, pra quem é bacana. Pra mim é só tinta espalhada!" Mas, no final do corredor, Natalino encontraria a primeira e única tela que realmente gostou e que, diz ele, levaria para casa: um quadro do berlinense Helmut
Middendorf que mostra um macaco com alguns edifícios ao fundo. $\mathrm{O}$ brasileiro analisa: "Esse é um macaco que está perdido numa cidade grande.” Pergunto: "Ô Natalino, tem muito macaco perdido aqui pelo Brasil?" - "Vixe se tem. A maioria deles é da política”, completa. No $3^{\circ}$ andar, mesmo com os braços já cansados, o brasileiro Natalino se entusiasmou bastante com o seu primeiro contato com uma holografia e também com as fotos, máscaras e objetos na sala $O$ Turista Aprendiz, da fotógrafa Maureen Bisilliat. "Aquele véio ali parece o Jânio Quadros”, dizia Natalino apontando uma das bizarras máscaras bolivianas. Diante das enormes fotografias, comentou: "Isso daqui parece gente lá do Maranhão", observando que só conhecia até então as cidades de São Paulo e Rio de Janeiro. "Deve ser muito bom conhecer o Brasil”, completou. Chegamos ao final e conforme combinado, a fotógrafa pagou cinquenta mil pelas duas horas de serviço perdidas pelo brasileiro, que fez questão de finalizar: "Não é verdade que o brasileiro não se interessa por arte, cultura, essas coisas... é que depois de um duro danado o dia inteiro, ônibus lotado, ninguém teria a manha de enfrentar condução e sair de casa. Mas, vou avisar pros meus colega lá do estacionamento que vale a pena dar uma entradinha. Gostei sim.”

\section{Legenda}

p.8I Marcelo e o Brasileiro diante

do corredor dos horrores

\section{Marditas MEninas, p.82 \\ Texto de Reinaldo Moraes}

Ele entrou na Bienal, talvez a décima da sua vida, figurando no desejo um encontro patrocinado pelo acaso safado com uma daquelas mulheres-que-passam fantásticas, das que se demoram na retina uns segundos tramando tesôes abstratos com enredos velozes de romance pop, enquanto correntes eletroestáticas percorrem a marvada carne da gente.

Aliás, pode não ter nada a ver, mas é um barato esse filme do André Klotzel, $A$ Marvada Carne. A dicção, o "idioma," o lendário, a malícia malazartiana da caipiridade paulista, tấo bem flagrados no filme, me fizeram lembrar das saborosíssimas férias da infância e primeira adolescência nos arredores da Serra de Botucatu, com autênticos caipiras de pé no chão e trouxas de pano na máo, pitando fumo de corda enrolado na paia e liberando pesadas cusparadas no chão de terra, e o meu tio dizendo "carcule..." coa sua pachorra zen-rural, ao volante do forde-bigode lírico pelas estradinhas peidorrentas que cortavam o mato bonito cheio de bichos eventuais. Tabus e totens eram mais belos e terríveis ali.

Esse tio meu do forde-bigode chamava filme de fita e era (e é) um grande sujeito, cheio duma alegria marota, tendo sido dono dum cinema assombroso lá na cidade dele, onde vi, de graça e chupando bala piper, muito policial e 
bangue-bangue de Rays e Fords e Walshs e Wises, conforme viria a descobrir com orgulho godardiano bem mais tarde, já leitor sabido dos Cahiers du Cinema.

Dez paus pra entrar e a primeira cerveja no bar da Bienal e as primeiras meninas cruzando a linha oscilante do seu olhar. Ele queria uma paixãozinha ao cair da tarde, mas era um querer sem urgência suficiente pra atirá-lo de velas pandas à conquista duma daquelas adolescências deambulantes. Ele tinha um amor, mas o amor dele estava a milhas marítimas do Ibirapuera navegando no mar disciplinado da produção. Sim, enquanto ele boiava na superfície ondulada do dia útil, seu amor trabalhava. E enquanto seu amor trabalhava, ele considerava com simpatia sua própria carência de uma paixãozinha, já que o seu amor era um amor estabelecido com casa, comida, roupa lavada e sexo sossegado (doce privilégio dos amores que queimam devagar), e a tal paixãozinha por uma menina da Bienal, além de não cair nada mal, era até que bem legal, como diria o seu Paschoal, chefe do pessoal.

"Sem um mínimo de carência sexafetiva sou capaz de perder de vez o interesse pela humanidade", ele ponderou. E tendo assim ponderado, tomou de si e foi consigo rampa acima, disposto a percorrer os pavilhóes do Niemeyer que abrigavam a loucura multinacional organizada em imagens miscelâneas. Arte. As meninas subiam e desciam com arte a rampa. Ele ia de olhos acesos e sexo adormecido, preguiçosamente a caminho de tanta tentação/confrontação/ informação/masturbação visual. Os olhos são os órgãos sexuais do espírito. Então, a beleza talvez lhe acenasse do ponto de fuga de uma perspectiva ou do fundo oco de uma escultura, e ele ficaria em eterna suspensão no espaço da grande galeria, como aquele outro personagem de braços e pernas abertos, um suicida em pleno êxtase do voo final, que pairava sobre as vistas visitantes bem em cima dos humanóides blablablativos de bocas mecânicas. Apenas, em vez dos fios de náilon que sustentavam o vôo interminável do boneco suicida, ele se veria atado aos tão tênues quâo tesos fios da sua libérrima imaginação.

\section{Legenda}

p.82 Reinaldo uso o banheiro da Casa da Mulher no Frango Assado

LínguAS DE FOGO, p.83

Texto de Arrigo Barnabé

A grande atração da semana de abertura da Bienal foi um artista dos sons: John Cage, o compositor norte-americano de vanguarda. O fã Arrigo Bamabé foi pedir-lhe um autógrafo e ganhou, além da assinatura, um desenho do hexagrama $n^{\circ} 30$ do I Ching, denominado Li-O Fogo. Ao voltar para casa, abriu vários livros prediletos na página 30 e, inspirado em Maiakovski, Adorno, Barthes, hitónas em quadrinhos e o dicionário, entre outros, escreveu o texto que segue, dentro da mais pura técnica cagiana.

Se fosse um brasileiro fazendo isso eles jogavam pedra. Acotilo (Adi. Zool.) Diz-se do animal desprovido de vértebras, boca central e cavidades laterais. Droga! Eu não faço nada certo mesmo! - O robô vai nos atacar agora. Visão! — Sim! Mas eu já estou recuperado! Apesar de ainda não estar bem, o andróide ataca! Mas felizmente... seu plano falha! A única pergunta que se faz neste momento é esta: quando e onde será o próximo ataque? A preocupação dos

usineiros da região aumentou ao tornarem conhecimento de que havia um formulário de cadastramento correndo pela cidade. A reforma agrária ficou mais próxima deles, apesar das garantias do presidente Sarney de que as terras produtivas náo seriam atingidas sob pretexto algum. Não seria o caso de lembrar que a sequência de proposições arbitrárias dos livros de Alice acabam, ambas, num lance compulsivo, num ato de violência? - Eu não sei se é isso mesmo que eu quero, Isolda... você merece o amor de um HOMEM que possa... - Quer parar de se preocupar com o que eu MEREÇO e pensar no que eu DESEJO? E o que eu quero é ficar com VOCÊ! É conhecido e tem sido confirmado por outros o relato de Humboldt sobre a capacidade de olfato que os indígenas da América do Sul possuem. Beleza radiante. A persistência correta traz recompensa. Sucesso! Criação de vacas - boa sorte. Por aqui passou, no cavalo baio. José Francisco 
Lopes, o Guia, mineiro de Pium-i, de sertóes exatos e da tenência e transatos, da lealdade e da força. Por ele conduzidos e nutridos do seu gado, vieram os homem da expedição, para vinda e volta - sob bandeiras, serra acima, boi berrante.

$\mathrm{O}$ indiano dissipou os ciclos; o cristão rompeu-os: tudo acontece somente uma vez. Tempo e eternidade, Meu novo olhar é de quem já sabe. Tinhas pouco, antes que eu viesse para ti, e agora tornaste-te rico; e o Senhor te abençoou com a minha vinda. É, pois, justo que eu pense também agora a minha casa. A ausência é a figura da privação; desejo e preciso ao mesmo tempo. O desejo se abate sobre a carência: aí está o fato obsedante do sentimento amoroso.

Este hexagrama simboliza o fogo subindo em duas línguas de chamas. Seria útil, antes de começar pormenorizadamente o estudo do pensamento musical atual, lembrar que princípios lógicos se deve respeitar, se não os malentendidos se instalam, e em abundância - temos disso exemplos recentes; entre tantos outros, a confusão entre acaso puro e relatividade no universo dos sons e das formas, enquanto que essas duas noções, longe de se subentenderem, náo obedecem, em momento algum, às mesmas leis estruturais. Então o discurso vacila e as palavras se póem a dançar. Roçamos as fronteiras do poético ou, com mais frequência, da oratória. Só o retomo ao concreto, ao palpável, com os olhos do corpo e da alma, devolve à prosa o seu equilíbrio. Há primeiro um estado de espírito emocional predisposto, um estado de prontidáo ou consciência, talvez um senso de disponibilidade momentânea dos níveis inconscientes da mente. Significa dizer que, perante uma multiplicidade de mensagem, parece possível e útil definir cada uma delas utilizando os mesmos instrumentos e reduzindo-as portanto a parâmetros semelhantes. As vacas são animais mansos e que exigem atençóes; esta frase significa que a boa sorte pode ser conseguida se ajudarmos quem precisa de ajuda.

\section{Legenda}

p.83 Hexagramas tremulam sobre a cabeça de Arrigo 
Anexo $C$

Sobre P.M. Bardi 
Casa Vogue \#28A, setembro de 1977, p. 5 I

PONTO DE VISTA

Luis Carta

A tomada de consciência de que somos uma nação sem memória foi responsável pelo aparecimento de uma autentica preocupação com nossos bens culturais. Aos poucos, a história e a arte brasileiras vão assumindo o seu lugar e valor. Nesse sentido, algumas coleçóes particulares têm se colocado como verdadeiras trincheiras de luta contra a evasão de nossos documentos literários e artísticos. Entre estas, devemos incluir a biblioteca de José Mindlin, o acervo de artes plásticas de Gilberto Chateaubriand e a imaginária de João Marino, todas elas franqueadas aos especialistas e interessados, o que lhes confere uma dignidade ainda maior. Este mês Casa Vogue apresenta João Marino, um colecionador exemplar.

Istoé \#45, 2 de novembro de 1977, p.59

MasP: TRINTA ANOS aO LAdO DE Pietro Bardi

Moacir Jupiassu

Nesses anos todos, a única queixa do velho mestre Pietro Maria Bardi é o Masp carregar o sisudo nome de "museu." Ele diz, carrancudo, o rosto talhado de um nobre de Lucas Cranach: "isto aqui é mais um laboratório; museu dá sempre a impressão de coisa estática, e o Masp é dinâmico, vivo.” Bardi não pára um instante há meses, preparando os festejos dos trinta anos do Masp, que ele comemora como se fosse seu próprio aniversário. Afinal, é diretor do museu desde a fundação, em i947. E há quem diga que, pela ordem de importância, as primeiras aquisiçóes feitas pelo fundador, Assis Chateaubriand, foram um Rembrandt, um Picasso e Pietro Maria Bardi.

$\mathrm{Na}$ tarde de terça-feira, dia 25 de outubro, o primeiro andar do Museu de Arte de São Paulo está tomado por menores de dezoito anos, os olhos atentos nos painéis da exposição "Masp ano 30.” Nesta segunda-feira inicia-se a montagem da exposição "Artistas e Artífices do Brasil, do Século Xvi ao século XIx." São 240 objetos de 7I colecionadores - prataria, mobiliário, esculturas, pinturas e talhas. No subsolo do prédio da av. Paulista, desde o dia 2I formam-se filas imensas para a $I^{\text {a }}$ Mostra Internacional de Cinema. Tudo sob a vigilância do professor que, aos 77 anos, trabalha o dia inteiro, recebe várias pessoas ao mesmo tempo, em várias salas, engatando os mais variados assuntos, pedidos, queixas. Nos minutos vagos e fins de semana Pietro Bardi escreve artigos, pesquisa e dá os últimos retoques num livro a respeito de Assis Chateabriand. A figura do "dr. Assis" sempre foi motivo de fascínio para o professor, desde os primeiros contatos no início de 1947, quando foram apresentados pelo embaixador do Brasil na Itália, Pedro de Morais Barros. Chateaubriarid fazia planos para a criação do museu e queria um italiano para dirigi-lo. Morais Barros indicou-lhe o nome de um jornalista, crítico, diretor da Galleria dell'Arte de Roma - Pietro Maria Bardi. No dia 2 de outubro de 1947, ele e o dr. Assis abriam as portas do Museu de Arte de São Paulo, instalado no prédio ainda em construção dos Diários Associados, na rua 7 de Abril, 230.

A noite de inauguraçáo foi o acontecimento social do ano em Sáo Paulo. $O$ Diário de S. Paulo abriu grandes fotos, o crítico Geraldo Ferraz escreveu um artigo emocionado: "Estamos com as chaves dos horizontes nas mãos."

Dramas e riscos. As primeiras telas foram de Picasso e Rembrandt; em I948, chegou um Cézanne e um raríssimo Montegna; em I950, nove telas de Toulouse Lautrec; em I95I, El Greco e Goya; em I952, Van Gogh. A ordem do dr. Assis era "primeiro comprar, depois pensar em como pagar.” Assim, o museu exagerou na ousadia e chegou a disputar $A$ banhista e o cachorrinho, de Renoir, com Nelson Rockefeller. E ganhou! Tanto foi o sucesso que começaram a falar mal. O Masp estava cheio de belas obras, pena que fossem todas falsas. Aquilo deixou o velho Bardi doente e ele resolveu calar a boca dos caluniadores. E levou cem das mais importantes obras para uma exposição no Louvre (1953). "Cada obra aqui exposta tem uma história de drama e 
risco," escreveu Marcondes Filho, um dos presidentes do Museu de Arte de Sáo Paulo.

Democracia. Em 1967, quando a rainha Elizabeth II inaugurou o prédio da av. Paulista, a sede da 7 de Abril já não servia mesmo para nada. Os quadros amontoavam-se pelos cubículos apertados, o espaço era mínimo. Hoje, o Masp possui um acervo de mais de mil obras, que o professor expóe em rodízio permanente, "para náo cansar os visitantes.” As exposiçóes periódicas são feitas dentro daquela tese de museu-laboratório, que tanto encanta o velho Bardi.

Nas mãos desse agitado italiano de La Spezia (perto de Gênova), o Masp sempre foi assim, um centro ativo para a difusão da arte, criado para abalar a sonolência do Museu do Ipiranga e da Pinacoteca do Estado. O jovem Masp abriu uma escola de propaganda, dança, deu cursos de balé. O primeiro desfile internacional de moda organizado no Brasil (Christian Dior) aconteceu no Museu de Arte de São Paulo. Há cem milhóes de dólares em telas de grandes mestres, não existe nada igual na América Latina. Uma pesquisa de opinião mostrou que o público costuma ir ao Masp com certa frequência e em número cada vez maior. "Precisamos democratizar isso aqui, abrir todas as portas," afirma o velho Pietro Bardi. E ele mesmo vai abrindo as enormes portas de vidros, como para ilustrar o que diz.

\section{Legenda}

Bardi, a poetisa Rosalina Coelho e o Dr. Assis: 2 out. 1947 g Bardi: democratizando a arte

Casa Vogue \#32A, fevereiro de 1978, p. 24-33

Lew Parrella apresenta O universo do professor Pietro Maria Bardi

Um universo povoado de História da Arte

"Construída há quase trinta anos nas alturas do Morumbi, uma espécie de caixa de vidro levitando no meio da selva." Foi assim que Mino Carta descreveu a residência de Pietro Mana Bardi, projetada por sua mulher, Lina Bo Bardi, também autora do arrojado projeto do Museu de Arte de São Paulo, do qual o professor Bardi é diretor. A casa funciona como um abrigo ideal para todas as artes. É que o professor, além de dirigir o Masp, é marchand, crítico e historiador da arte. Dos seus is livros já publicados, cumpre destacar o riquíssimo e absolutamente indispensável História da Arte Brasileira, vasto e colorido painel das nossas artes, dos tempos coloniais ate nossos dias.

De olho atento a todas as manifestações artísticas, sem preconceitos, sem fronteiras, em sua casa podemos encontrar esculturas gregas do século 5 a.C. ao lado de imagens paulistas de barro, quadros de pintores célebres ao lado de pintores principiantes edesconhecidos, (desde que sejam bons) um armário florentino servindo de fundo a uma mesa mineira rústica onde sempre é servida deliciosa pasta. Personalidade internacional, autoridade reconhecida no mundo inteiro, com livros e catálogos traduzidos em diversas línguas, o professor Pietro Mana suas portas pela primeira vez a uma revista. Eis o seu universo.

\section{Legenda}

p.24-25 Diana, de Bernardo Strozzi

p.26-27 Abrigo ideal para todas as artes. A sala de jantar, mesa mineira rústica com tampo de mármore, cadeiras certosianas dobráveis do século I5; na parede, pinturas de Figari, Torres García, Tito de Alencastro, Miguel dos Santos, José Maria Reis Junior, Roberto Matta e Toledo Piza

S Sopeira de prata e marfim de Puiforcat, aparelho de café art-nouveau de preteiro japonês, pote para doces prata e lápis-lazuli, sucessão de Viena, Novecentos Arranjo de peças e quadros de um dos recantos da sala de jantar Fachada da casa vista do portão principal: a caixa de vidro parece flutuar acima das copas das árvores, o que lhe confere uma grande sensação de leveza e refrigério - trata-se de um projeto de Lina Bo Bardi, datado de 1950 . Lina é também autora do projeto do Masp, tendo ainda assinado algumas restauraçóes célebres, como a do Museu do Unhão, em Salvador

p.28-29 Escultura de vários países sobre um armário florentino. Um detalhe da Nossa Senhora de Vestir, escultura do século I9, provavelmente oriunda da provícia de Sáo Paulo grande armário de madeira entalhada e dourada, artesanato florentino da metade do século I6, sobre 
ele, prof. Bardi fez um arranjo de pequenas esculturas lembranças de suas viagens

\section{p.30-3I O sagrado e o profano. Só a aura}

da Beleza. Santa de vestir, artesanato napolitano, século ig Arcanjo, artesanato mineiro do século I8 Floreira, cerâmica siciliana caricatural de Garibaldi e Cristo, escultura italiana de madeira, século 17 o conjunto de lembranças de viagens em cima do armário

\section{p.32-33 Olhar atento a todas manifes-} taçóes artísticas. Algumas esculturas expostas na lareira do living: Voltaire, mármore de Rosset Fils, figura de cerâmica policromada de Ernesto de Fiori, de I9I7, Retrato de Eleonora Duse de Lovatelli, cerâmica amazonense do século I9 representando Nossa Senhora; vaso art-nouveau de prata repoussé, de artesão italiano do início do século Buda, escultura chinesa de madeira, século I8; à direita, outro Buda I Samovar inglês art-déco, sobre mesa de mármore, em mosaico, desenho variegado

Senhor Vogue \#II, fevereiro de I979, p.47 (Ponto de Vista)

DE LIBERALISMO, IRONIA, ARTE

Luis Carta

Não foi por acaso que nas últimas ediçóes fiz notar que Cláudio Lembo tinha me tocado pelo esforço de sua campanha, pela sinceridade de sua postura e pela honestidade de seu pensamento. Não é por acaso que há dois meses venho batendo numa tecla um tanto antiquada em termos do mundo lá de fora, mas estranhamente nova em termos de postura política de um certo tipo de público local: o Radical Chic. Notei até que a definição tem aparecido em colunas de jornalistas célebres, quase para rebatê-la - como se tivessem sido atingidos - ou em estéreis apresentaçóes de artistas mundanos - como se estivessem querendo aproveitar a vaga. (Vaga mesmo.) $\mathrm{Ou}$, finalmente, em colunas de jornalistas que tentam misturar o mundano e o célebre numa constante troca de pequenos favores e pequenos deslumbramentos.

Nesta edição, continuando na tecla, solicitei que o próprio Lembo explicasse o que é o seu neoliberalismo que, segundo ele mesmo diz, é a mais revolucionária das ideologias, tanto em sentido político quanto econômico, a única a permitir o pleno debate e a verdade mais sincera. Para completar a matéria, Cláudio Abramo, um profissional acima de qualquer suspeita, traça o perfil do jovem professor-político. Oliveiros S. Ferreira define historicamente o liberalismo e Paulo Mendonça e Jorge Cunha Lima cuidam da entrevista.

Mas tudo o que está dito acima, e o que representa, é mais uma prova de que a vida é na verdade algo a ser encarado com extrema ironia: juntar numa só matéria elementos tão díspares e conflitantes como o próprio entrevistado e os jornalistas citados requer também uma dose de senso de humor. Qualidade aliás das mais raras, com raras exceçôes. Exceção para mim definitiva é a de um homem que entra nestes dias no seu octagésimo ano de vida: Pietro Maria Bardi, a quem o Brasil muito deve (e esta é a típica frase da qual ele ri com sardônica indiferença) e que a partir deste mês mudou sua seção de artes da revista Casa Vogue para Senhor.

Dedicamos a Bardi a capa da revista e uma matéria que ele - com medo de más interpretaçóes - escreveu de próprio punho contando de sua vida e - desculpe, professor - de sua obra: uma carreira absolutamente fulgurante e altamente movimentada. Na Itália, primeiro, onde ele se apresentava como inovador na arquitetura e na pintura. Sua resistência ao estilo neotriunfalista do fascismo e que ele combateu até a hostilização total. Depois o convite de Chateaubriand, o museu e o marco que é na vida deste país, as compras - controvertidas às vezes - que fez em benefício do nosso patrimônio artístico e, finalmente, sua preocupação constante em dar oportunidade aos novos e ter uma visão da arte não como um exercício gratuito, mas sempre ligada às coisas práticas da vida. É o que Bardi mostra na espetacular exposição que pode ser vista hoje mesmo no Masp. Um promotor, um animador, um renovador. Um homem com senso de humor, acima de tudo. 
Istoé \#III, 7 de fevereiro de 1979, p.40-4I

LeVantando A SAIA DA Semana DE 22

Pietro Maria Bardi lança mais dúvidas sobre o "modernismo"

Jacob Klintowitz

Nunca um pequeno acontecimento, afinal uma modesta semana de artes e conferências, provocou tanta celeuma, estudos, louvação e críticas. Mesmo aqueles alegres rapazes não imaginavam que a repercussáo seria tão grande e demorada. Corria o ano de 1922 e a jovem e inquieta inteligência paulista se movimentava para realizar uma semana de agitação artística - que terminou conhecida como a Semana de Arte Moderna de 22. A pretensão era sacudir o sonolento ambiente da província, mexer com a academia artística que rejeitara a pintura de Anita Malfatti e os projetos escultóricos de Victor Brecheret e - quem sabe? - brincar um pouco com os hábitos de uma sociedade dominada pelo caipirismo.

Eram bons rapazes o Mário de Andrade, Menotti Del Picchia, Oswald de Andrade, Di Cavalcanti, Guilherme de Almeida, Villa-Lobos, Ronald de Carvalho, Sérgio Milliet, Graça Aranha... Este último, um escritor já famoso, embaixador, bem-relacionado, foi quem conseguiu o patrocínio político e financeiro do culto e influente Paulo Prado.

Depois de sua alegre e agitada irreverência, a Semana não deixou mais de ganhar corpo, adesóes e paternidades. Nos últimos tempos, porém, inúmeras análises procuraram determinar sua verdadeira dimensão. A mais violenta delas corporificou-se no livro de memórias de Yan de Almeida Prado, um dos artistas participantes. $\mathrm{O}$ seu relato pintou um Oswald maníaco, um Mário medíocre, um pobre $\mathrm{Di}$, mas era demasiado raivoso, foi posto à conta de ressentimentos pessoais e teve repercussão limitada. Agora, entretanto, Pietro Maria Bardi, diretor do mais importante museu brasileiro, o Museu de Arte de São Paulo, também investe contra a Semana - acaba de publicar um livro, O Modernismo no Brasil? (*), no qual vaia quase tudo o que viu e sabe a respeito do movimento.

(*) O Modernismo no Brasil, de P.M.Bardi, Sudameris-Banco Francês e Italiano para a América do Sul S.A., São Paulo, 1978
Um perito no Brasil. Pietro Maria Bardi é um especialista em arte, respeitado internacionalmente. Jornalista, crítico de arte, museólogo, historiador, dirigiu uma das mais importantes revistas europeias, viveu a luta do italiano pela arquitetura moderna, organizou o catálogo geral das obras de Velazquez e, com a II Guerra Mundial, a convite de Assis Chateaubriand, criou no Brasil o nosso maior museu. Para isso, aproveitando o seu conhecimento do mercado de arte internacional, comprou o mais valioso e importante acervo de obras de arte existente hoje na América do Sul.

Entre nós, ele conquistou imediatamente as simpatias e antipatias pertencentes ao seu hospedeiro, o controvertido Chateaubriand, criador dos Diários Associados. Nada, todavia, o impediu de travar a sua própria luta, de criar uma arena particular de debates e se tomar, por sua vez, uma figura igualmente controvertida. Bardi escreveu muitos livros, centenas de artigos, promoveu artistas, insuflou uma atividade vertiginosa ao seu museu, patrocinou o desenho industrial, a moda e a propaganda, escreveu a primeira História da Arte Brasileira, fundou revistas e, durante todo este tempo, com o seu estilo franco, agressivo e invidualista, estabeleceu polêmicas e fez furiosos e eternos inimigos. Diga-se de passagem que ele está preparando a sua grande memória do período - e promete contar tudo o título é sugestivo: 30 Anos Entre os Brancos. Para seu prazer especial, os seus furiosos e eternos inimigos usam como quartel-general a coluna de Zózimo Barroso do Amaral no Jornal do Brasil. É de lá que saem os dardos, as denúncias, os boatos. Pietro Maria Bardi considera tal fato uma bela vitória. Pois foi essa polêmica e discutida figura que, agitando os seus 79 anos, com o seu sorriso feliz e irônico, resolveu levantar as saias da veneranda senhora Semana de Arte Moderna de 22.

Pés de barro. Parece indiscutível que algumas famosas figuras da Semana estão em baixa. A irregularidade qualitativa de Di Cavalcanti, por exemplo, é constrangedora. E, além disso, o grande animador 
da Semana foi nos seus últimos anos severamente fustigado por acontecimentos que independeram da qualidade de seu trabalho. Primeiro, há dois anos atrás, houve o escândalo dos falsos Dis. E a suplementar verificaçáo de que o artista assinava telas produzidas por pintores contratados. Agora, aparece o professor Bardi a apontar Di Cavalcanti como invejoso carreirista. Essa a razáo pela qual artistas que lhe eram superiores - e são tantos! - não foram convidados a participar da Semana. Por exemplo, ficaram de fora Belmonte, J. Carlos, Voltolino, chargistas muito melhores que o caricaturista Di. E mais Tarsila do Amaral, Eliseu Visconti, Selinger, Theodoro Braga, José Maria dos Reis Jr.t Gastão Worms, pintores muito melhores do que ele. Como? Ora, cabia a Di Cavalcanti selecionar os artistas e fazer os convites.

Dizia Bardi: "Di Cavalcanti é um caráter um pouco prepotente... Belmonte, é incompreensível não ter sido convidado... o selecionador do elenco de artistas evidentemente estava mal-informado a respeito da essência e dos limites do modernismo... Di era caricaturista: por que não pensou em seus colegas? Egoísmo ou porque considera o desenho de humor uma arte menor?"

Mário de Andrade, caráter inatacável, o grande ideólogo e organizador do modernismo brasileiro, é apresentado por Bardi como fanático religioso, hipócrita e malvisto até por seus pares. Mário diria de Graça Aranha, que viera da Europa com o seu livro Estética da Vida: “... Nós nos ríamos um bocado da Estética da Vida, que ainda atacava certos modernos europeus de nossa admiração...” E sobre Oswald: "Oswald caiu em admiração idiota por tudo quanto é brasileiro." E sobre Villa-Lobos: "...O coitado que tem feito umas musiquinhas para agradar, duma bestice palmar."

Fio condutor. Evidentemente, o farsista Oswald não deixaria Mário de Andrade incólume. Eis a sua descrição: “...Um jeito gozado: careca, de óculos, carregando uma tocha e cantando em procissáo..." Mário, aliás, retrucou com recursos estranhamente modernos: “...O Oswald é um comunista em que o Partido não acredita que seja, e a polícia também não.”
Quanto a Oswald, Pietro Maria Bardi foi procurar o seu ponto mais forte, a sua pretendida competência. Descobriu um cortês e terrível texto do mestre Carlos Drummond de Andrade, de I925: "A grande tolice do meu amigo Oswald de Andrade é imaginar que descobriu o Brasil. Absolutamente não descobriu tal. O que ele fez foi descobrir-se a si mesmo. Verificou que era brasileiro, achou graça na história e acabou levando a sério a ideia da prática. Hoje é um dos nossos bons poetas, se bem que não entenda uma palavra de anatomia do verso. Náo passou pelo serviço militar da métrica. Ora, eu acho isso quase indispensável. A gente só se liberta daquilo que não prende. Ninguém nasce livre."

O fio condutor do pensamento de Pietro Maria Bardi define que o movimento de 22 foi exclusivista, burguês, nacionalista e xenófobo. Consequência: o nacionalismo xenófobo estava inspirado em ideias europeias e acabou redundando em formas políticas reacionárias. (Que em alguns casos sobrevivem até hoje.) E, pior ainda, a Semana foi tíbia demais, quando comparada com as respostas e os acontecimentos verdadeiramente políticos da época

Cabotínismo. Revolução? Ninguém se engane. Segundo Bardi, em nenhum momento do modernismo houve motivos para preocupaçóes: afinal tudo se passava entre burgueses. A sociedade paulista apenas observava, divertida. Náo poderia ser perigoso, afinal, um movimento patrocinado por Paulo Prado, secretariado pelo conservador René Thiollier e desfilado nos requintados salóes de dona Olívia Guedes Penteado ou nos fumoirs do Automóvel Club ou do Cube Athletico Paulistano. Do Rio de Janeiro pegou-se o hábil Graça, que chegou a virar avenida. O próprio Menotti Del Picchia, poeta, pintor e líder da Semana, conferenciou: "Somos o escândalo com duas pernas, o cabotinismo organizado, na escola julgam-nos uns cangaceiros da prosa, do verso, da escultura, da pintura, da coreografia, da música, amotinados da jagunçada do Canudo Literário da Paulicéiá Desvairada. Que engano. Nada mais ordeiro e pacífico que este bando de vanguarda..."

É bom lembrar também, insiste Bardi, que a própria ideia da Semana nasceu na cabeça 
de uma dama de alta sociedade, dona Marinetti Prado, o que já foi afirmado por outros autores. A sugestão: "Por que vocês não fazem como nós, em Deauville, durante a temporada: uma semana de atividades intelectuais, com exposiçóes de pintura, recitais de canto, musicistas e artistas exibindo-se em concertos etc.?" Resposta de Di Cavalcanti: "É isso mesmo: vamos fazer uma semana de loucuras!"

$\mathrm{E}$ as vaias, as tão famosas vaias com que a burguesia teria recebido, no teatro Municipal de São Paulo, os "modernistas"? Para Bardi, tudo não passou de uma brincadeira, de uma coisa sem importância.

Um nacionalismo? O nacionalismo, versão modernismo, encarnado principalmente em Mário de Andrade, não agrada ao polemista Bardi. Mário não viajava ao exterior para não se influenciar, e recebeu as visitas de Blaise Cendrars, o famoso poeta francês, e de Marinetti, líder do futurismo, com extrema desconfiança. Depois de sua morte, porém, soube-se que reunira uma biblioteca especialmente fornida e informada sobre tudo o que se passava no mundo. Tarsila do Amaral, nacionalista? Nem se fala disso. Era amiga e filha da cultura europeia, admiradora (como se pode ver em seus quadros) das formas de Léger. Quanto a Oswald de Andrade, bebia suas ideias nos salóes da cultura internacional, especialmente os de Paris. Bardi vai ao ponto de imaginar que a antropofagia - uma das fases daquela cultura que se sucedeu ao modernismo e que foi tão característica de Oswald e Tarsila - tenha sido diretamente inspirada na revista Cannibal, do pintor espanhol Abel Picabia. E mais: o arquiteto Gregori Warchavchik, que depois construiria as primeiras casas modernas, era europeu. O pintor John Graz, de tão larga influência, um artista europeu maduro. Em suma, o tal de nacionalismo xenófobo era diretamente bebido em fontes europeias.

Espera-se, obviamente, uma resposta às afirmaçôes bardianas. Mas os inúmeros estudiosos e admiradores do modernismo e da Semana encontrarão a resposta adequada? Aí está este senhor Bardi, nos seus irrequietos 79 anos, colocando-se em questão e na arena e lançando dúvidas e luzes providenciais sobre o mais famoso acontecimento da arte brasileira.

\section{Legenda}

p.40 Tarsila, Anita Malfatti, Oswald

e Mário de Andrade: nacionalistas à la europeia; Bardi: irônico e desconfiado

p.4I Um desenho de Belmonte e uma caricatura de Di (ao lado, Paulo Prado): quem foi melhor?

Senhor \#36, março de I98I, p.I5

Nos MUSEUS, OS VERDADEIROS TESOUROS

Inclusive aqui no Brasil. Tanto que mestre Bardi acaba de ganhar mais um prêmio por Jacob Klintowitz

Quem é o verdadeiro dono dos tesouros artísticos da humanidade? Será possível que alguém conteste a posse das magníficas coleções de arte e antiguidade que estão expostas no Museu do Louvre, no Museu Britânico ou no Museu do Vaticano? É realmente possível que isto aconteça. Mesmo porque, já aconteceu. O que representa a posse de uma soma inimaginável de dólares. E mais do que isto, do que o representado num praticamente inimaginável valor de mercado, significa alguma coisa mais grave ainda, a própria imagem de tantos países. Ou seja, tem mais valor mercadológico ainda. Quem é que deseja depenar, desta maneira tấo cruel, países como a França e a Inglaterra, outrora indepenáveis? Ora, os países que produziram estes tesouros. É claro. Acontece que as grandes coleçôes de arte dos mais famosos museus do mundo são constituídas por peças trazidas de outros países. O que possibilitou esta transferência foi o poder imperial dos países europeus. O Museu Britânico tem uma tão grandiosa coleção egípcia - múmias, sarcófagos, joias, objetos - que é fonte permanente de atração. E tem, igualmente, templos gregos, templos assírios, inscriçóes sagradas de povos antigos etc. Estes objetos foram conseguidos no período em que a Europa tinha a sagrada missão de civilizar os vários continentes. Como se sabe, este tempo terminou. E as relaçóes entre os diversos países têm se modificado tanto que possibilitou, mais de uma vez, que representantes do chamado 
Terceiro Mundo, usassem dos tribunais oficiais (Unesco, ONU) para reivindicar a devolução destes tesouros. O que tem significaçôes profundas. A ideia central e que as produçôes artísticas e culturais voltem para os países onde foram produzidas.

Uma imagem. Ocorre que esses tesouros ajudam a manter a imagem dos países hospedeiros. (Vamos chamar assim...) A França, por exemplo, tem a imagem de um país libertário. E de um país culto. Isto porque ela teve em seu território um movimento artístico chamado impressionismo. E porque ela tem instituiçóes como o Museu do Louvre. Com esta imagem de cultura, liberdade e bom gosto, a França tem mais facilidade para disputar mercados para os seus vinhos, moda, perfumes, indústria gráfica, tecidos, automóveis etc. Ainda que o seu vinho seja excessivamente "químico," a sua moda antiquada, o seu design inferior ao de outros países europeus. Há uma imagem dando cobertura à atividade francesa. $\mathrm{O}$ que se estende aos seus artistas atuais. Mesmo que o seu melhor escultor, César, saiba principalmente amassar metal ou se apropriar de produtos químicos expansivos. Enfim, uma imagem. Quem dera o Brasil investisse na sua imagem...

Evidentemente, estas questôes de posse não se resolverão facilmente. E o mais provável, aparentemente, é que todos os países descubram sistemas de troca. Know how tecnológico em troca da posse definitiva das obras. Ou troca de metodologia arqueológica e custeio de novas exploraçóes pela posse definitiva...

De qualquer maneira, o mais interessante da história toda é que aquilo que parecia um processo natural, um status definitivo, não é mais assim. Perigo que não correm as nossas boas coleções de arte. Caso do Museu de Arte de São Paulo e do Museu de Arte Contemporâneo. Lá tudo foi comprado com dinheirinho contado, doaçóes de milionários e com a ajuda conhecedora e esperta deste jovial Pietro Maria Bardi que, aos 80 anos, acaba de ser escolhido como a personalidade artística do ano. Foi mesmo quem mais contribuiu para o desenvolvimento das artes neste terrível ano de 80.

\section{Legenda}

Bardi: sempre jovial

\section{Casa Vogue \#I, janeiro-fevereiro de I982, p.82-87}

O PEQUENO GRANDE MUSEU construído em 20 anos

Entrevista a Ugo di Pace por Andrea Carta

Não muito tempo atrás, talvez um ou dois anos, tive meu maior contato com Ugo di Pace. Acho que a simpatia bateu logo no primeiro instante; um fato náo táo estranho por se tratar de uma pessoa interessante como ele. Foi uma experiência de trabalho, a nossa, e lembro que sempre dentro do prazo, entregava sua matéria Antiquariato; explicava e mostrava com carinho as peças fotografadas. Tinha muita preocupação em como seria feita a paginação. Uma vez, por falha nossa, uma de suas fotos recebeu um corte mal dado e a mesa teve seu pé esquerdo amputado. A tristeza nos olhos de Ugo, sua náo conformaçáo com o fato, fizeram-me sentir e ter certeza que arte, para este homem, é uma, se náo a coisa que mais ama. Ugo, uma pessoa sensível, é muito verdadeiro, não esconde o prazer em ver pessoas de que gosta. Fala com ternura e saudades das coisas boas que aconteceram em sua vida e que, diga-se, não foram poucas: "No fundo nada importa, se não se tem alegria em sorrir."

Sua vida no Brasil começa com vinte anos e algum dinheiro dado por seu pai. Voltemos, entáo, para 1948 quando se instala no Copacabana e começa sua vida tropical: "Vittorio Gobis, sem dúvida, é um pintor de que todos ainda vão ouvir falar muito; deixa alguns de nossos pintores tão falados, muito atrás."

É em 1948 que nasce sua grande amizade com Gobis; o dinheiro aperta e ele se muda para a casa do pintor, onde começa seu aprendizado na área das artes: "Sua maneira em descrever, sua euforia no falar torna-se algo muito especial.” Ugo se despede do Copacabana e caminha para uma grande e decadente casa no Rio, onde moram Gobis, uma velha que não se sabe de onde veio e uma menina de catorze anos, que na história tem as mesmas referências da velha: "Gobis, com 
seus quase dois metros e seus $120 \mathrm{~kg}$, falava muito, sentado em sua poltrona, que o sustentava diretamente pelas molas que eram todas aparentes. Um quadro digno a ser pintado por ele.”

Foi um período em que a necessidade começava a falar na frente. Gobis era um mestre e fazia Giovanni Battista Castagneto e outros, táo perfeitos quanto os autênticos. Foram postos muitos Gastagnetos de Gobis em paredes de casas ilustres em São Paulo. Mas este período maluco, romântico, dura pouco. Em São Paulo, Ugo, com Fernando Medeiros, que considera um monstro de sabedoria na área das artes, abre a Antiqua, um verdadeiro sucesso. Tudo vai bem, mas a vontade de crescer bate forte. E, logo depois, em Roma, Ugo, P.M. Bardi e Wallinho Simonsen abrem o Studio A. Roma assistia a uma explosão causada pela sua nova galeria. Instala-se em pleno coração das artes, num magnífico prédio do quatrocentos: "A nova galeria fazia com que todos os jornais comentassem sempre sobre nós, 'os loucos brasileiros.' E como éramos!'

Simonsen lotava avióes da Panair do Brasil com peças de arte da Europa para a Antiqua, que a esta altura já era Arte Hispânica, de Sáo Paulo. O acervo estava dividido em dois: Arte Hispânica, em São Paulo, e Studio A, em Roma, onde Ugo chefiava e estava sempre presente, pois aparecer por lá Giovanni Gronchi ou mesmo o embaixador da França, era bastante comum: "Foi uma época muito movimentada, mas em que nós nos divertimos muito. Lembro-me de uma das peregrinaçóes com Bardi, (compramos muito juntos) em seu Fiat SS, (eu guiava) indo de Firenze para Barcelona, dois dias de carro, para encontrar as cinco mulheres mais lindas do mundo, em uma das 'casas' mais luxuosas da Europa! Bardi, comigo, também conheceu algumas maravilhas de Napoli."

Ai Ugo passa para outra história, nos anos 70, e lembra de um telefonema de Adolfo Lindenberg: "Ugo, qual é este seu estilo, que todos agora estão comentando? Como se chama?" "Mediterrâneo," respondi depois de pensar um pouco. "E assim ficou. Lindenberg começou a fazer o Mediterrâneo, que eu até hoje desconheço ser."

Correndo mais um pouco chegamos em seu escritório-casa e sentamos em sua sala-museu: Ugo, meu pai ${ }^{\mathrm{r}}$ e eu. Sua casa hoje, mas não a de amanhã, mesmo com sua coleção já estando instalada, seu quarto sendo um genuíno quarto italiano, com a fonte sob sua janela; fotos antigas e todo o resto. Pois Ugo está por terminar o trabalho que diz ser o mais incrível, maluco e completo que já fez. Diz ser o último, que está em liquidação. Sobre este ponto discordo, pois seu espírito e sua criatividade são os de um homem de 30 anos. Quem sabe, por isto, ele é Ugo di Pace!

"Os valores perdem o sentido rapidamente," diz Ugo.

E para ele perderam realmente. Trocar seu Jaguar por duas arcas, é hoje não só permissível, como absolutamente normal. E mais que isto, chegar ao Gallery com seu fusca amassado, passou a não ter tanta importância desde que lá no bar estejam dois de seus guaches para dar prazer a quem gosta de arte.

Sua sala-museu é responsável por seus projetos. À noite, Ugo assiste a um espetáculo único, reunido em vinte anos de trabalho, com suas luzes de efeito ligadas sobre peças, que tem um encanto e uma beleza únicos, incapazes de serem descritos: sua coleção. Os projetos nascem à noite e são postos no papel, na manhã seguinte. Não é possível esquecer do quadro que esteve à nossa frente, dos que mais gosto, um Nicolas Maes, que foi o primeiro aluno de Rembrandt, nem do cheiro afrodisíaco de ervas vegetais que está guardado em uma caixa de marfim do século I7, nem dos pequenos desenhos pornográficos de Rembrandt que ele tira da parede para nos mostrar, nem de todo o resto. A vontade de estar em seu paraíso, seu local inspirador, é enorme. Poderíamos ficar la, sentados, olhando, por horas. Nos levantamos. Ugo tira um Gobis da parede e estende para meu pai, que gosta muito. Ugo, mais por sentir isto, e a partir deste momento, já determina que o quadro não é mais seu. A sensibilidade com que

I Luis Carta. 
capta me emociona. Um homem, que se manteve simples. No topo da escada dá seu beijo de padrinho, com um sorriso, e entra em sua sala, a número um.

O que é a coleção Di Pace, segundo ele mesmo, p.86

É o meu hobby e investimento. É uma coleção eclética, composta de quadros, esculturas, objetos, tapeçarias, móveis e tapetes, quase tudo de proveniência europeia, desde o século I5 até nossa época. Como peças brasileiras, as mais importantes são os "Aleijadinhos." O critério de escolha é condicionado à minha afinidade com esta ou aquela escola, com esta ou aquela época, mas também a dificuldade que o mercado proporciona no sentido de oferta que dia a dia se refaz com referência a peças boas de bons autores. Dizia-me um grande marchand de Firenze que as peças de artes são o melhor investimento que existe. A condição é de que sejam da melhor qualidade. É a pura verdade! Um dia o meu amigo Pietro Maria Bardi escreveu, se referindo à minha coleção que ela poderia estar esplendidamente num museu; honestamente é também a minha opinião! A matéria fala sozinha: quem quiser poderá apreciar e opinar!

\section{Legenda}

p.82-83 Ugo sentado em meio a seu paraíso onde estáo: I. Madonna e menino Jesus, século I5, estuque policromado, moldura a tempietti (arte florentina) 2. Philip Wouwerman, I616-I668 (escola holandesa). 3. Giuseppe Maggiolini, Papeleira, século i8 (escola italiana) 4. Francesco Bassano, I549-I592 (escola italiana) 5. David Teniers, I582-I649 (escola flamenga). 6. Lisboa, Antonio Francisco, O Aleijadinho, escultura I730-I8I4 (escola brasileira) 7. Nicolas Maes, I632-I693 (escola holandesa) s Quarto de Ugo, o genuíno italiano p. $84-85$ Vemos ainda: I. Paul Von Ravenstein, I854 (escola alemã) 2.Lorenzo Lotto, I480-I556 (escola italiana) 3. Bernadino Licinio I490I565 (escola italiana) 4. Charles Lebrun I600 5. Tapeçaria, série "Ecole D' Equitation" (Bruxelles, I633) manufatura de Henry Keydams Antigos mármores brasileiros e italianos p.86 Em algum ponto da casa, Leão de Pedra, arte mineira do século I8 e antigos potes brasileiros de engenho Ainda alguns potes brasileiros de engenho

\section{Vogue Brasil \#II5, fevereiro de I985 [Edição especial: P.M. Bardi] p.II5-I62}

\section{Đe Carta para Bardi, Ponto de Vista, p.IIs}

Luis Carta

Caro professor,

Vogue comemora, neste ano, dez anos de vida. Foram longos, trabalhados com seriedade, deram resultados positivos, amigos e inimigos.

Escolher o "autor" da edição de fevereiro de 1985 foi, devido à data e ao início de nossas comemoraçóes, uma tarefa particularmente delicada.

Procurei alguém que unisse à densidade de sua vida e ao valor de sua obra e de seu trabalho, uma marcada carga de sensibilidade e de ironia.

P.M. Bardi encaixou-se como uma luva nesta rápida pesquisa íntima.

Gostaria de ter seu senso de humor - tão evidente para os que lerem esta edição especial - para fazer uma apresentação que, respeitando a importância da personagem e da ocasiáo, soubesse colocar ambos, personagem e ocasião, na luz mais adequada.

Precisaria ter seus fartos conhecimentos para dar consistência a estas linhas que vão testemunhar apenas admiração e carinho.

Deveria ter sua jovem idade para lhe contar algo que não fossem as banalidades de que você foge com absoluta galhardia.

De qualquer modo, caro professor, uma coisa é certa: comemorar com você seus primeiros 85 anos de vida e os primeiros Io de Vogue no Brasil, neste 2 I de fevereiro de 1985 , é algo que me dá prazer, emoção, justificação e compensação de tantos outros momentos menos gloriosos. 
Pietro Maria Bardi, p.II6-I35

Pietro Maria Bardi

Eis, como dizem os italianos, um fulmine a ciel sereno que me desconcerta: falar do Bardi, isto é, de mim mesmo; alguns dados, calculadas confissôes, esconder não sei quantas desventuras, procurar parecer o que efetivamente sou, mais pessoa simples lio que promovido a personagem, mais elemento de crônica dia-a-dia que da social.

\section{$\mathrm{Eu}$, professor?}

Não sei bem por onde começar. Todavia o que me preme é desmentir o título que me atribuem de professor. Declarei isto quando um reitor da USP me convidou para fazer parte de uma banca e decretar um diploma, parece-me que de doutor, a um candidato. Disse-me que eu era professor de "clara fama.” Encabuladíssimo, aceitei. Meu papel não foi dos piores. Tratava-se de questionar história da arte, os colegas me incumbiram de indicar dez assuntos, as "pequenas teses," uma para ser escolhida e discutida pelo rapaz. Relacionei dez assuntozinhos: o candidato viu e me declarou que se tratava de temas difíceis. Juntei mais um, bem banal: aceitou. Curioso: quando cada examinador escreveu o próprio parecer, descobri que os professores de verdade divagavam em longas prosas. Mortificado, também por ter ouvido conversas casuais, me limitei à aprovação em meia linha. Daquele momento em diante comecei a ter alta consideração pela classe dos professores, surpreendendo-me cada vez que me atribuem o título. O leitor (se vou ter algum) vai ver em seguida os motivos.

\section{De palo in frasca}

Aproveito para me desculpar pelo proceder pop destas páginas. (É fatal que um fale como Francis Bacon no pintar: a confusão ocorrendo até usando no parágrafo um título "aventurier." As desconveniêcias têm justificativas até históricas. Pesco: ainda não atribuíram a Bacon os versos que Boileau, três séculos atrás, em L'Art Poetique, dedica à desordem: "Son style impétueu souvent marche au hasard,| Chez elle un beau désordre est un effet de l'art.") É um castigo à cronologia, e talvez um certo exagero no contar vantagem. Sou um "scavezzacollo:" fúria, precipitada com gotas de audácia, os escrúpulos postos de lado, cada vez que o se tornar indispensável é imperioso.

"De paio in frasca" significa em italiano passar de um argumento a outro por volubilidade. Ocorre-me assinalar uma lembrança: há um meio século, em Roma, no sabor de uma das inúmeras confissôes de Le Corbusier, almoçando, escutava suas novidades gênero "curriculum-vitae." O interrompi: "Por que você não as escreve?" Resposta: "Je vais le faire à l'instant!" Chamou o garçom, pediu papel e começou a escrever. Publico as três páginas, em fac-símile, no livro que lancei há dois meses no Museu de Arte de São Paulo: Lembrança de Le Corbusier: Atenas, Itália, Brasil, editora Nobel, tendo a Indústria Du Pont adquirido mil exemplares.

Recebida a ordem-convite do Luis Carta, logo me assaltou a advertência de Virgílio "horresco referens," conjugada a outra advertência "horros habet onus," esta me parece de Plínio. (Não se pense que sou latinista.)

Seja como for, aqui me permito contar minha historieta, usando meu criticado português italianizado e confessando minha modéstia, se me comparo aos autênticos personagens aos quais Vogue dedicou realces: Tónia Carrero, fascinante por simpatia e fantasia; o caro Jorge Amado, mestre dos mestres, revelador do nosso polivalente povo; Ivo Pitanguy, o mágico recriador da aparência da gente; e Paulo Autran, popularizador de personagens imaginados que náo se esquecem.

Deveria dar conta das minhas andanças à maneira de Corbú: sínteses, redução a duas linhas dos romances e fatos, ignorar momentos sem importância, o olho considerando um esqueleto em vez que o polpudo da carne, refletir em Esparta, dizer o que serve. Deve haver ainda alguns curiosos. Conto então um punhadinho de notícias para estes pacientes.

\section{Uma família Bardi}

Nasci, há 85 primaveras, na cidade de La Spezia, num golfo encantador, entre a Ligúria e a Toscana, pai e mãe da 
pequena burguesia. A conversa mais repetida: nossa família com possíveis antepassados florentinos, os banqueiros Bardi, que emprestaram dinheiro aos reis da Inglaterra, agiotas que nunca receberam o capital e os juros de volta.

De herança em herança, no palavrear, nós, os Bardi de La Spezia, deveríamos ter amealhado fortunas. Contrariava-me o contínuo esperar por possíveis chuvas de libras esterlinas. Fui ver, recentemente, nos livros: os Bardi eram mandóes metidos em campanhas mercantis e bancárias de peso na Europa toda, com filiais nas capitais, a serviço até do Vaticano para a coleta dos décimos pontificiais. Eram seus fregueses os príncipes da França e da Inglaterra, e deles, como garantia de vultosos empréstimos, tinham em penhor as próprias coroas nobiliares e o controle das alfândegas. Em casa se algebrizava sobre os contos dos financiamentos a Eduardo III, para ele empreender as primeiras campanhas da Guerra dos Cem Anos. O curioso é que só se dava valor aos traficantes, e nenhuma atenção ao poeta Giovanni Bardi. o Conde de Vernio, o humanista renovador da música da Renascença, magnificado cultor do "dolce stil nuovo."

Um caso, aliás, casos

Minha cidade era mesmo provinciana. Os únicos fatos discutidos: a tipografia de Pasquale Binazzi, que publicava um semanário dos anarquistas, difuso no estrangeiro, e uma represália popuiar que quase acaba tragicamente - a senhora do dentista assaltada porque saiu na rua trajada de jupe-culottes, improvisada evasão das mesquinharias cívicas, ignorando o bovarysmo, talvez sabendo do escândalo de Mademoiselle Provost no palco da Comédie Française. No restante, tudo normal.

Voltando ao assunto biográfico: este rampollo vai à escola elementar, consegue a duras penas (duríssimas, diria) se promover até o terceiro ano. Repete esta classe por três vezes e, de acordo com o regulamento, é jogado fora, como "rei dos burros."

Se emprega: contínuo no escritório de um causídico. Envergonhado, descobre que, pelo menos, precisa na vida saber ler e escrever: assim se ajeita numa estranha espécie de autodidatismo. Um dia, tendo caído e batido a nuca, maravilhado, depois de limpar o sangue, percebe que conquistou de improviso aquela faculdade que apelidavam, então, de inteligência. É promovido a office-boy.

(Às vezes dá prazer ler nas autobiografias dos valentes, casos semelhantes aos nossos: uma consolação. Assim, fiquei feliz por ter lido isto de J.P. Eckermann, o confidente de Goethe: “....as imperiosas necessidades do meu estado exigiam que encontrasse logo um trabalho, para poder me sustentar... a ocasião favorável apareceu: um oficial de justiça me propôs uma ida ao seu escritório para ajudá-lo a escrever e a fazer alguma modesta função. Aceitei com prazer...” Deu-se o mesmo comigo: foi um advogado que me empregou como escrivão e office-boy.)

O machucado descobre os livros do advogado, se mete na leitura, aprende a escrever a máquina, até rabisca, se considera não mais o coitado que era, e torna-se artesão do próprio amanhá. Se impóe uma disciplina: trabalhar para se sustentar, economizar, um pouco de esporte para náo se reduzir a um palerma, amizades, nada de cigarros, comida o quanto fosse suficiente e, naturalmente, minutos contados de namoricos.

De empregadinho, logo que atinge a idade, torna-se operário-aprendiz no Arsenal Marítimo, continuando sem saber trafegar em assuntos da inexistente cultura.

$\mathrm{Na}$ cidade se publica uma das mais inovadoras revistas italianas, L'Eroica, de Ettore Gozzani, o lançador da renovada xilogravura.

Breve: aos 17 anos, (não banco, há os documentos) brincando com coetâneos no setor meio primitivo das artes, escreve seu primeiro artigo na revista Gazzetta di Genova, objeto o pintor Francesco Gamba, e no mesmo ano envia (notar a coragem) um manuscrito seu à Casa Editora Avanti!, de Milão, referente ao filósofo inglês Geremia Bentham: um texto do anticolonialista e o comentário do debutante.

Foi minha primeira publicação, até elogiada e paga. 
(Foram as primeiras incursóes, puramente ocasionais, em livros de Gian Domenico Romagnosi, um humanista operante na conjunçáo do Setecentos e do Oitocentos, possível articuladordo pensamento político do quase nascente Estado italiano. Repito ocasionais para alguém que andava em barafustando no possível saber, lendo, amedrontado, que Bentham aos três anos de idade lia correntemente, e aos sete opinava sobre assuntos literários.)

Outra notícia breve: no mesmo período sou chamado às armas. A Itália está em guerra contra a Áustria. É o tempo da derrota de Caporetto, e o imberbe spezzino veste o uniforme de soldado da artilharia de montanha. É promovido a caporale e, depois, a caporalmaggiore.

A experiência foi reveladora do que nem imaginava: conviver na minha bateria, onde me improvisaram instrutor, com jovens na maior parte analfabetos, cuidar das mulas em cujos dorsos transportávamos canhóes, suas peças e muniçóes, obedecer até a ordens obscuras, compreender o povo, disciplina medieval, oficiais bons porém rígidos, o espectro do inimigo, a morte sempre de prontidão. Torno-me consolador, escrivão público, redator das cartas dirigidas às famílias em nome de quem não sabia escrever, juntando na correspondência a fotografia do recruta apresentando a arma, não a verdadeira que pesava um quintal, mas a de madeira, em dotaçáo para nos instruir.

Foi uma experiência favorável à formação do meu caráter.

Fui dispensado, com medalha, nada menos que em 2I, na cidade de Bergamo. Tinha então conhecido os jornalistas locais, e me promovo em um deles. Consigo um lugar de repórter no vespertino Il Giornale di Bergamo.

\section{Honro-me de um gesto}

1922. Um dia antes da "Marcia su Roma" de Mussolini, os fascistas locais obrigam o diretor do cotidiano, Francesco Scarpelli, e o redator-chefe, Alfonso Vajana, o engolir conspícuas doses de óleo de rícino, por serem os dois seus opositores políticos. A dupla se tranca em casa, aliás, no wc: telefonam ao colega principiante para que redija o jornal, o qual era da oposição.

Agora falo na primeira pessoa. Estava preparando a edição quando um tropel de fascistas armados irrompe na redação bradando ordens peremptórias: exaltar a revolução. Respondo pacífico: "Pois não!" Os prepotentes saem satisfeitos. Eu então reflito e decido abrir o número, em vez de com o costumeiro comentário, o "artigo de fundo," com o primeiro romântico capítulo do Promessi Sposi, de Alessandro Manzoni; cozinho com outros textos: a vida de uma santa, clichês de música, outras brincadeiras, páginas de um humor sui-generis. Tinha o imperativo da liberdade de imprensa. Apesar de simpatizante da ação de Mussolini, não tolerava a intervenção.

Resumo: chegam os strilloni, entrego-lhes as cópias e sigo com eles até o centro da cidade. Logo que os insurretos percebem a molecagem, me assaltam e me quebram na cabeça um sifão de água gasosa. Levam-me ao hospital. A nova ferida, ao que percebo, melhorou ainda mais minha inteligência, à parte uma aureolazinha de herói.

\section{Não sou um peixe no barril}

Defunto o vespertino, o cronista se ajeitou vivendo de colaboraçóes, lançou um semanário humorístico, Il Fischietto, tornou-se correspondente do Il Secolo, de Milão, aparecendo, afinal, o momento de demonstrar seu profissionalismo. (Conto-o no próximo verbete.)

Um jornal estrangeiro, comentando a façanha, escreveu que o B. "não era um peixe no barril.” Gostei: desde criança ouvia falar que um tal era um peixe no barril. Criança, se não completamente, mas com sintomas, como já lembrei, de retardamento mental, náo compreendia: os tais peixes, para mim, eram as sardinhas que se via, alinhadas e prensadas, no botequim ou na feira. Afinal consegui, diria, paralelizar: sujeito circunspecto registrado no mapa dos cautelosos, o prudente que antes de se aventurar num passo mede o comprimento. $\mathrm{Na}$ cidade o chamavam também de "homem de borracha," pois podia se precipitar da torre campanária e náo se machucar. 


\section{Jornalista metido nas artes}

Alguns práticos do papel impresso sentenciavam ser o B. um batuta na floresta do jornalismo. Meu exploit foi numa certa noite: saía do teatro, e vendo movimentação de polícia e bombeiros, apreendi que a barragem do Gleno havia se rompido, as águas invadindo o Val Seriana, centenas e centenas de mortos. De smoking e sapatinhos de verniz, me jogo num carro de socorro.

Breve: fui o único jornalista, por meio de um telefone oficial, no município de Clusone, disfarçando-me de oficial de gabinete não me lembro de qual ministério, a registrar o desastre no Il Secolo. Furo dos furos: a primeira página assinada P.M.B.

(Diverte-me pescar nas prosas das pessoas famosas. A ocasião, nesta linha, é de levantar o anzol, pescando, por me convir, ao invés de uma sentença bíblica, uma confissão de Shirley MacLaine: "As pessoas progridem de acordo com aquilo para que estão prontas a agarrar." Uma solução sem meditaçôes, reflexôes e cálculos precipitou-se imediata: “va o spacia.”)

Seria muito longo e, talvez, inútil contar. De simples correspondente do antigo órgáo milanês, eu operando na terra de Bartolomeo Colleoni e Caetano Donizetti, sou promovido a chefe da crônica. Deu dor de cabeça aos colegas cronistas do concorrente Corriere della Sera, assim me contratam nesta Meca.

Descubro a burocracia do noticiar e do comentar. Logo após uma discussão a respeito de um probleminha de vocabulário com o diretor Ugo Ojetti, ele me afastou do emprego. Tinha usado, para descrever a festiva decoração de um monumento a São Francisco, a palavra "pinnacolo," e o filólogo gritava que se devia escrever "antenna," juntando: "Lei si dà le arie di esteta..."

Meu "pallino," isto é, obsessão, sempre foi este "conjunto de coisas combinadoras da Beleza" ou, como se repetia então: "método para criar uma obra usando certas regras," isto é, "a arte pela arte." Porém, timidamente, existiam os espantalhos da Vanguarda.

Começo minha carreira, diria, de galerista, o que deve ter sido no ano de 25 , me parece. Adquiro a Galleria L'Esame do renomado escritor Enrico Somaré, e abro a Galleria Bardi. Debuto no inarticulado mercado da arte contemporânea, depois no da arte antiga, e, pelo vício do papel impresso, fundo meu quinzenal de arte, Belvedere (disseram-me que uma coleção deste jornal foi vendida recentemente por mil dólares) devotado às mudanças.

Inauguro as atividades com uma exposição excepcional: "Carlo Carrà e Ardengo Soffici," publicando um livro polêmico dedicado aos dois antigos futuristas. Para se ter uma ideia da situação das artes na Itália: foram vendidas duas únicas pinturas, adquiridas por Lionello Venturi, o ilustre historiador que estava compondo a Coleção Gualino, distinta por ter importado a primeira tela de Amadeo Modigliani.

Completo a situação: a exposição foi invadida fanaticamente pelos alunos da Academia de Brera, sob incitação dos professores conservadores, a rapaziada expulsa a socos e pontapés por parte dos dois pintores e do tal que agora se autobiografa.

\section{Curiosidades e sorte}

Era um curioso pelas coisas, valessem elas ou não, exceçôes e quinquilharias. Não me interessa possui-las, prefiro balançá-las nas mãos, indagar, descobrir seus itinerários, imaginar outros B. que tiveram o mesmo prazer, se encantando ou comerciando. Além dos objetos deveria reservar um parágrafo para os livros raros, os que pus de lado quando doei ao Masp minha biblioteca iniciada em I9IO. Revejo neste momento muitas raridades, para dar uma ideia: a Epistola di Frate Hieronymo da Ferrara Dellordine de Frati Predicatori a Tuctilli Electi di Dio e Fedeli Christiani, de Savanarola, publicada por Bartolomeo di Libri, em Florença, datada de 8 de maio de 1497. Comprei a raridade por um montáo de libras esterlinas em Londres. Pergunto-me: a quem pode interessar no Brasil?

Desde menino tenho outros vícios. Visitador assíduo de vendedores de ferros-velhos, de feiras, de botecos. Gosto de mexer num arsenal de antiguidades e de novidades. (O fotógrafo Andreas registrou 
coisas na minha Bacon-house.) Não sei me explicar: desde uma quinquilharia fabricada à perfeição até uma pintura que agita coração, nervos, olhos, memória, sangue e pele. ( $\mathrm{O}$ veterano do mercado local, José Claudino da Nóbrega, quis que o aspirante a veterano B., apresentasse as memórias do peregrino, do qual comprei não sei quantas mercadorias, entre elas minha escrivaninha do Seiscentos, encontrada numa igreja do rio Tocantins.)

Minhas andanças são maratonas afortunadas. Deixem-me divagar. Há muitos anos, em Veneza, estive numa casa: era para adquirir uma tela, aqui reproduzida. Estava suja, temática quase irreconhecível, quando sou atacado de agitação. Pego-a, não a limpo, entrego-a à transportadora Gondrand, com ordem de apresentar à obrigatória exportação governamental, obedecendo às leis, declaro-a "pintura de anônimo do século ı6" e dou meu endereço em New York, valor 200.000 liras. A comissão de exportação carimba o êxodo da obra.

Nos Estados Unidos, libero a tela dos antigos restauros e então descubro um esplêndido Giorgione. Anos depois a crítica o revela com páginas e mais páginas. Inquérito da direçáo das Belas Artes de Roma. Num domingo de manhã, minha casa no Morumbi é invadida por jornalistas: uma comunicação oficial me acusa, simplesmente, de exportação clandestina. Exibo os documentos de exportação regular; desculpas italianas pela besteira. Comentário do Bardi: "Era para dar uma patente de incompetência à comissão julgadora.”

\section{Um "Tavolo degli Orrori"}

Volto aos meus tempos de noviciado: nos primeiros anos da década de 30 me chamam da Capital para dirigir a "Galleria d'Arte de Roma," oficial. Para ter minha plataforma de discussáo, fundo e dirijo com Massimo Bontempelli a revista Quadrante, e promovo a campanha da arquitetura racional.

O que P.M.B. faz?

Descubro que Baudelaire prescrevia: "Le critique doit être partial, passionnée, politique, c'est-à-dire faite à un point de vue exclusif..."

Componho a fotomontagem Tavolo degli Orrori, caricatura da Roma incorporadora de construçóes surgidas em consequência do Culturalismo, valendo o estilo "antigo romano modernizado." Escrevo o livro Rapporto Sull'Architettura per Mussolini, editado pela revista Critica Fascista, de Giuseppe Bottai, sendo este político o número um da inteligência e da independência da época, codiretor Gherardo Casini, hoje ativo editor em Roma. No periódico eu publicava a coluna "Battifuoco," um cabeçalho que denuncia o jeito polêmico da matéria. No mais absoluto sigilo organizo a exposição do "Movimento Italiano per l'Architettura Razionale," e convido o Duce para inaugurá-la.

Colpo di scena: Mussolini aceita o convite. Explico-lhe e, surpreso, compreende e aceita meu Manifesto. Na Itália a página da miséria arquitetônica está fechada, a nova página é aberta. Estranhamente, meio século depois todos estão de acordo que o B. foi, afinal, quem rompeu a moleza estética da Itália. (Digressão: este é um dos fatos que será documentado na próxima Triennale Internazionale de Milão, organizador o professor Riccardo Mariani, catedrático de História da Arquitetura na Universidade de Genebra. Ele prepara até um livro, que será publicado pela Mondadori, baseando-se no arquivo do B. abarcando o período 1917-46, arquivo que foi doado a uma Fundação italiana, rico em correspondência, ouso dizer, preciosa: Mussolini, Ezra Pound, Le Corbusier, Léger, Pirandello, Zavattini, Bontempelli, Morandi, para citar apenas alguns.)

Há muito tempo insistia na polêmica para a renovação da arquitetura peninsular. Meu opositor mais feroz era Roberto Farinacci, o fascínora diretor do cotidiano Cremona Nuova, o qual apelidava, por sua reação ao Racionalismo, "quello que usa le mutande con i legacci," à moda oitocentesca.

\section{Studio d'Arte Palma}

De 23 até a Segunda Guerra promovi e movimentei coisas demais: livros, transaçóes no mercado de arte dando certo, iniciativas propagandísticas, 
uma delas bastante nova para a Fiat, viagens pela Europa até a Rússia, para a África e América Latina.

Não dormi, faço graça ao leitor dos sonhos. É bom saber que, por não concordar com certas novidades do fascismo (acreditava nos seus princípios) era dissidente cada vez que vinham à tona sujeitinhos insuportáveis e decretaram-me fora do partido. (Parênteses: imaginar o quanto me divirto sabendo das fugas e improvisados amores dos deputados e senadores do PDS.)

Uma outra molecagem: Mussolini inaugura na Farnesina uma escola para formar dirigentes da caserna do partido. Para ser admitido, o postulante devia passar dentro de um circulo de fogo, fogo mesmo, para demonstrar que estava pronto para tudo. Então, na minha revista Quadrante, número 24, assinando, escrevi o seguinte: "Nós temos muita confiança nos jovens, menos nos jovens que estudam para secretário federal."

Não se abriu o céu, mas o inferno. Para não parar, abro em Roma um empreendimento particular o "Studio d'Arte Palma," então o mais importante centro da Itália dedicado ao mercado de arte, exposiçóes, restauro e editoria Meus colaboradores: Mário Modestini e Francesco Monotti.

Pode-se ver a página dedicada ao Estúdio para se ter uma ideia.

\section{Depois da guerra me transfiro}

Vem a guerra. (No próximo mês de outubro vou descarregar todo meu ódio contra as carnificinas, dedicando uma exposição à Paz, no Masp.) A Itália buscava alianças que, por causa da sua posição ditatorial não conseguia, ou conseguia sem franqueza. Não vale a pena reevocar: a Península entra tarde na guerra, os aliados vencem, assina-se a paz, a Europa retoma outro caminho. Os italianos se empenham em recompor a pátria, a vida é outra. Muitos cidadãos se propóem a mudar de país, ou melhor, de continente.

Por isso este redator, logo que apareceu a ocasiāo, embarca num dos primeiros piroscafos, o "Almirante Jaceguay," que tinha como rota o Rio de Janeiro.
As novidades da terra que, esperava, poderia me acolher da mesma maneira humana que a milhares de italianos, conheci na travessia discursando com famílias de emigrantes que para cá retornavam. Do Brasil já conhecia Recife, Salvador, o Rio, Santos e Sáo Paulo, visitadas em 33 por ocasiấo da viagem no Oceania que me levara a Buenos Aires, onde apresentaria no Museu Nacional de Belas Artes, uma exposição dedicada à arquitetura italiana, inaugurada pelo presidente da República, general Agustín Justo.

Desembarquei na Capital. Com a benevolência e a orientação do caro amigo Mário da Silva me ambientei. Obtive a possibilidade de expor duas coleçóes no salão do Ministério da Educação e Saúde, uma de arte antiga italiana e outra de arte contemporânea também italiana, manifestações de seguro interesse cultural, porém fracasso de venda.

\section{Encontro o dr. Assis}

Encontro-me com Assis Chateaubriand, o qual sabia das minhas atividades através de Pedro de Moraes Barros, o primeiro embaixador do Brasil em Roma, depois de assinada a Paz. Convida-me para um jantar em sua casa em Copacabana e me contrata para ser o organizador de um "museu de arte antiga e moderna," não se sabendo se o mesmo seria no Rio ou em São Paulo.

Se parlamenta e discute-se por alguns meses. Finalmente a decisão: São Paulo, “porque lá está o café.” A combinação se deu por várias circunstâncias: B. podia ceder várias obras-primas da exposição mostrada no Ministério e também por ser considerado um perito no mercado de arte. Começaram logo as aquisiçóes. (Não dá para registrar todas as, ao que dizem, audaciosas, com as quais a Pinacoteca do Masp agora se enfeita: foi rotina para quem se dedica à tarefa usando um pouco do seu saber, muitos pingos de experiência e, por que náo?, de chances e de ocasióes a serem tomadas no ato. Devo declarar no setor, compras concluídas com a ajuda do ditado sírio: "a sorte é mais útil do que a prudência." Ao reunir a coleção do Masp e, não escondo, a minha particular, uma boa estrela me ajudou.) 
Voamos com Assis para São Paulo. Primeira cortesia: eu e minha segunda esposa, Lina, batizamos dois "paulistinhas" doados a um aeroclube e que foram denominados "Garibaldi" e "Mazzini," dois dos mil e tantos avióes conseguidos durante a campanha promovida pelo endiabrado diretor dos Diários Associados.

Visita à futura sede do museu, do qual eu tinha modificado o título: Masp. Era no edifício ainda em construção dos Diários, trabalho do arquiteto Jacques Pilon. Una se encarrega de estudar o planejamento: devia surgir no primeiro andar, então cavado na armação de concreto. A planta permite saber como o Masp foi idealizado: a entrada era feita pela rua Sete de Abril; subia-se por uma escadinha, um tapume indicando a novidade.

Inauguração: dia 2 de outubro de $47 . \mathrm{Na}$ entrada: um arbusto de café. doado por Geremia Lunardelli. ("Ma come lei fa ad avere tante fazende di caffè?” Resposta do rei: "Basta vedere se la terra dà bene!")

O convidado de honra foi o presidente Dutra, acompanhado de vários ministros, muitos discursos, sendo o mais brilhante o do caro Menotti del Picchia. A festa deve ser descrita usando-se carvão branco.

No dia seguinte, excetuando o Diário de S. Paulo, houve na imprensa um silêncio tumular. Aliás, O Estado de S. Paulo registrou a presença do marechal Dutra, noticiando, sem titulo, entre um tópico e outro, em corpo seis, somente que tinha almoçado no palacete dos Prado.

Deixo de lado a crônica. A associação com o dr. Assis calcava-se em confiança, sem interrupçóes, apesar de alguns contrastes cordiais de posição. Passado um decênio, sabendo de meu penchant pelo Jornalismo, o Amigo me nomeia diretor-geral dos Diários Associados, cargo que ocupei por breve tempo, por não me sentir à vontade.

Neste momento da atenção (não sou um ingênuo ou ignorante para não saber qual a fama que às vezes me atribuíram: "cupincha do Chateaubriand") me permito evocar mau protetor, transcrevendo um trecho da minha revista Mirante das Artes de 67: “...Chateau, ilustre tanto como Jornalista como homem público e, muito especialmente, como aquele que acionou a alavanca que pôs em movimento a máquina da artes, conquistando para o Brasil uma posição tão talada no campo dos museus, do ensino artístico a da promoção cultural. Assis Chateaubriand, sempre presente na luta das ideias há já mais da meio século, com inteligência viva e cintilante, com a energia telúrica, o mais patriota no grupo daqueles que anteviam as necessidades básicas do país, me ensinou uma infinidade de coisas, conduzindo-me através da 'selva escura' da histórica aventura do Museu de Arte de São Paulo, dando-me um empurrão toda vez em que pressentia que o espírito europeizante, em mim inato, observava e utilizava a respeito em certos casos como método de conduta. $\mathrm{O}$ caro dr. Assis é uma figura situada num plano fora do comum, síntese de uma raça originária dos Aborígenes e dos Pioneiros, dono de uma cultura autóctone e, ao mesmo tempo, entrosada do essencial que a História acumulou no altíssimo obelisco do espírito humano; capitão de prodigiosa força de vontade, sempre pronto, e seguramente também neste mesmo instante, em realizar uma nova façanha. Indômito como quando menino ainda, em uma fazenda, não largou as rédeas de um cavalo furioso: arrastado pela terra, fatigou o animal e o domou, apesar de sangrar nessa luta..."

\section{Nova museografia}

Pode ser que a singularidade do Masp tenha sido a antecipação de um sistema mais tarde adotado na museografia não só no Brasil, como também no exterior: se interessar e relacionar todas as artes, as plásticas, a música, o teatro, a fotografia, o cinema e tantas outras atividades em combinaçáo com a cultura.

Dois volumes dedicados a um antigo museu me abriram os olhos, convidando-me a superar o restringir ou repartir os assuntos. Note Overo Memorie del Museo del Conte Lodovico Moscardo..., editado em Verona em I672. O colecionador juntava tudo do que gostava, desde pinturas e esculturas, até pedras, metais, conchinhas, coisas da antiguidade e do seu tempo. O conde escrevia no prefácio: "Não falo com Aristarcos, mas com alguém que saiba compreender 
quem escreve com a finalidade de gozar de maneira honesta o ócio..."

A ação do Masp não tem a finalidade elitista, mas a da informação, de preferência a didática. Bastará dizer que foi no Masp que se deu o lançamento da primeira televisão no Brasil, o mexicano frei José Mojica cantando.

Num recente seminário na Folha de $S$. Paulo, presidido por Jean Maheu, presidente do Centro Georges Pompidou, me permiti lembrar que em 47 o plano do Masp foi, em menor proporção, o mesmo ativado pelo Beaubourg, apropriado às circunstâncias daquele tempo em São Paulo, caracterizadas pela necessidade de começar, se não do zero, pelo menos do um. A uma certa altura das "trouvailles" apresentei na Pinacoteca um desfile de moda de Christian Dior, passeando entre obras de Goya e de Toulouse-Lautrec, as quatro mais chiques manequins de Paris. Clou: um vestido desenhado expressamente por Salvador Dali, para a mulher do ano 2050. Era a primeira vez que a moda desfilava num museu.

De outro lado: oferecer as tendas dos revendedores de antiguidades, aos domingos, no belvedere do Masp. E tantas outras rupturas. (A palavra virou moda, pois neófitos bienalescos descobriram que a arte brasileira se substancia de tradição e de maçadas. Maçada por maçada reputo que a mais certa não foi a da Semana de 22, mas a dos Simbolistas. Importação por importação, me veio natural, quando acima citei Baudelaire denominador da mudança do modernismo: as "Flores do Mal" revolucionando as cabeças dos tradicionais.)

Volto ao Masp. A procura dos acompanhantes dos primeiros passos foi uma caminhada repleta de dificuldades num terreno cheio de percalços, como se fossem pregos que os assaltantes agora usam para furar os pneus dos carros-fortes. Minha primeira descoberta (um guarda-chuva fora de série) foi a tomada de posição diante do grupinho dos opositores, lançado ao assalto do Escolhido para implantar o "Museu dos Quadros Falsos." O pelotãozinho era guiado por simplórios formados não sei em qual cantinho, por terem defendido a tese "Invidus alterius macrescit rebus opinis," a horaciana sentença que, em palavras pobres quer dizer: os invejosos emagrecem, quando o visado progride. (Meu jocoso divertimento era ver emagrecer o pessoal da cobiça.)

Procurou-se utilizar os meios favoráveis para suscitar a participação do público, especialmente da juventude, pondo em prática as experiências que haviam me ocupado na direção de galerias na Itália, a difusão de publicaçóes sendo essencial: lanço a revista Habitat, entáo muito mais difundida no estrangeiro do que no Brasil; anos depois a Mirante das Artes \& etc. e, finalmente, a tentativa da Arte Vogue, periódicos por mim dirigidos, sendo este último de um padrão agora próprio da Casa Vogue.

A novidade de tantas iniciativas, depois de ter superado os paredóes que sempre se erguem para obstaculizar os percursos, acabou produzindo satélites: já se perdeu a conta dos maspinhos, galerias, salas de exposição em bancos e instituiçóes. São Paulo agora regurgita arte.

Não tenho nenhuma reclamação a fazer. Penso que foi normal compensar as agruras do jejum com as delícias dos banquetes. Se houve desacertos, há o superávit de artistas empenhados. (Sim, há confusão, mas onde não mexem os que atrapalham?)

\section{Molecagem com o sistema}

Aqui dou conta de duas molecagens para interromper a crônica por demais contozinho. Penso da preferência em Bertrand Russel: "Precisa-se enfrentar a vida com alegria, bom humor a Ironia, pois sem estas qualidades nos tornamos ressecados e azedos." Porém, às vezes, a ressecação e a acidez liquidam qualquer graça.

A primeira infração deu-se no antigo auditório do Masp. Continuo colocando na frente da batalha o Marechal Chateaubriand. Dizem-me: sem você o Assis náo teria feito nada. Náo é verdade: naquele tempo a metrópole estava transbordante de ativistas aspirantes à implantação do Masp. O Assis me confiou a incumbência de agir, sabendo das naturais oposiçôes de improvisados pretendentes, os quais ficavam náo digo maravilhados, mas irritados ao tomarem 
conhecimento que um estrangeiro etc. fora o escolhido para realizar a grande saga.

A murmuração foi de calibre excessivo. Até os chauvinistas de prontidão desfechavam protestos. Para documentar esta espécie de "compte-rendu," eis o caso: uma noite, durante uma conferência de Flávio de Carvalho, o italianinho (queria escrever com I maiúsculo, mas isto representaria imodéstia) foi provocado estúpida, gratuita e banalmente por um redator de arte do Estadão, que me definiu aos gritos: "É um dos Italianinhos (aqui com I maiúsculo) que vêm fazer fortuna no Brasil, encurralados no porão da terceira classe.” Não engoli, não quis discutir, mas demonstrar o contrário: minha cabina no navio era da primeira classe, e recorri à lei de Moisés desferindo um soco na cara do tal. Estava evocando esta defesa-combate em dezembro passado, quando vi na Senhor, a revista que semanalmente publica a página "P.M.Bardi," meu semblante ao lado dos de Carlos Drummond de Andrade, Sobral Pinto, Cora Coralina, Chico Xavier e até do Papa. (Motivo: personalidades indicadas, através da uma pesquisa realizada ouvindo-se donas da casa, para indicar sujeitos ad-hoc.) $)^{2}$ Evidente que o episódio briguento que relato náo honra minha biografia. Não estou mais em condiçóes de ruborizar-me. Provocou a revolta entra os assistentes: ao invés de aplaudir quem não tolerava injúrias, se dirigiram ao gabinete

2 Pesquisa realizada por Rose Saldiva com donas de casa das classes A, B e $\mathrm{C}$, que fornecia uma longa lista de personalidades de diversas áreas para as participantes escolherem as mais representativas, dentro de algumas categorias. Na categoria "Santo," "líderes que se destacam porque estão acima das coisas materiais. São líderes espirituais, os que não têm pecados" foram selecionados Carlos Drummond de Andrade, o Papa, Sobral Pinto, Chico Xavier, Pietro Maria Bardi e Cora Coralina. "O que diferencia a liderança dos santos é a posse de traços adimrados por todos. Neles, as donas-de-casa encontram apoio moral, fibra e esperança." \{Saldiva em DUCLÓS, Senhor \#194, 5 dez. 1984, p.68-69\} do dr. Assis, pretendendo a cabeça do inesperto pugilista. O Supremo apareceu e, informado da ocorrência, me apertou a mão. Disse-me, já que às vezes falávamos em latim: "Invidia gloriae comes est."

Continuei então meu trabalho, na verdade nada fácil: tratava-se de criar escolas, ensinar, animar o ambiente local, formar uma pinacoteca (a diretora do MAM de Paris, senhora M.O. Briot a definiu "un petit Louvre") e não sei quantas outras incumbências. O resultado está na avenida Paulista, no prédio inaugurado no dia 7 de novembro de I968 pela rainha da Inglaterra, Elizabeth II, que aceitou o convite lembrando de Assis, que fora embaixador do Brasil em sua corte. $\mathrm{O}$ edifício, marco da arquitetura nacional, foi projetado por Lina Bo, sua estrutura calculada por José Carlos de Figueiredo Ferraz, singular resultado da nossa operosa e vitoriosa engenharia.

A avenida Paulista me leva a contar a segunda gaiatice, um pouco inconveniente, pois resultou na minha prisão, mas não algemado, e castigado por um simpático titular de delegacia, numa manhã, durante as arrojadas campanhas políticas para eleiçóes locais de 82. (Pela última vez uma citação latina: "Nomina stultorum scribuntur ubique locorum," isto é, os nomes dos coitados se encontram escritos nos muros.)

Insistiam, náo sei a a oposição ou a situação, em pichar os muros do Masp. Pacientemente mandava limpar, porém certa manhã, o saco cheio explodiu: cancelei a escrita referente a não me lembro mais qual candidato, a pichei em cima um palavrão. Estou receoso de escrevê-lo em páginas tão cem por cento. Consequência: denunciado, depois da ter estampado minhas impressóes digitais e declarado meu curriculum limpíssimo no que se refere a crime, pedi desculpas por minha improvisada tarefa de "perturbador da ordem pública” por ter escrito, em caracteres cubitais, o substantivo.

Liberado da delegacia, me tornei personagem, pois jornal, rádio, TV, boatos etc. me celebraram como intérprete da opinião pública. 


\section{Meu monumento à pizza}

Procedo o conto alla Carlona, isto é, a vanvera: Vogue me proporciona uma ocasiāo que me parece a de um felizardo, ao qual fazem beber mais um copo para ele se comportar até inconvenientemente. Como voltar ao estilo dos verbetes dos dicionários biográficos? Sou mencionado num número por demaia graúdo de taia enciclopédias.

Um informa:

BARDI, Pietro Maria, writer; b. La Spezia, Italy, Feb. 2 I 19oo; s. Pasquale and Elisa (Viggiani). B.; m. Bo Lina Aug, 1946. Dir. Museum of Art of São Paulo, 1947 - redactor Il Secolo, Milan; editor art mags. Belvedere, Quadrante. Author: Carrà e Soffici, Rapporto Sull'Architettura, Giorgio Morandi, Lasar Segall, The Arts in Brazil, Profile of the New Brazilian Art, The Tropical Gardens; L'Opera Completa di Velazquez. Address: São Paulo Mus. Caixa Postal 6789, São Paulo, Brazil.

Todos os citados em verbetes de um Who's who in the world são idôneos? Devo acrescentar que tenho defeitos e cultivo manias que os cidadãos "per bene" condenam. Sei do espanto destes senhores ao verem reproduzido aqui o lote de condecoraçóes, medalhas, obelisquinhos, e até o manto de Cavalheiro de Sáo Paulo. A distinção mais cobiçada é, todavia, a medalha de ouro que ganhei há sessenta anos na corrida ciclista Milano-Miradolo. (Deixei o passatempo esportivo quando constatei que os atletas se inscreviam no quadrante dos negócios. Apesar de ter sido um não desprezível center-half, depois de ter figurado no último match como capitão de um time militar, me aposentei: era muito velho para jogar futebol, 2I anos!) Conservo as condecoraçóes no mesmo armário em que venero minha única escultura. Um caso que se deu quando o proprietário de uma pizzaria que estava para ser inaugurada me pediu que inventasse um troféu para sua propaganda. Disse-lhe: "Farei um monumento à pizza." Náo compreendeu. Apresentei o trabalho, e disseram que eu era um diretor de museu como se deve e não um destes colegas que pensam em arte chupando balas. ${ }^{3}$

3 Comentário de Bardi, encontrado em legenda da fotografia do mencionado

\section{Publiquei muitos livros}

Cada caso que me ocorreu me levou a romancear. O Luis Carta, acostumado a honrar batutas de primeira em Vogue, me recomendou: nenhuma traição à linha da revista; não que tudo seja feito na ponta do garfo, todavia nosso leitor exige atençôes. É por isso que deixo de lembrar fatos fora da linha, desculpando-me por alguns que já contei.

Deveria falar dos meus livros. Afinal, não me aceitaram em nenhum clube de escritores. Não sou tal. (Os que respeito são os que conseguem ocupar as páginas dos cotidianos e apêndices dos domingos, textos que, às vezes, me lembram o "Il compilait, compilait, compilait," a sátira de Voltaire no Pauvre Diable.)

Sinto-me um inoportuno em fatos de letras. Tento resistir como periodista.

Um pouco de blague: como todo jornalista, eu também faço confissóes. Não mencionei Bacon por acaso. Abuso de neologismo, desrespeitando Voltaire, enérgico contra este praticar.

Confissão: me instruí com os irmãos Edmond e Jules de Goncourt pelo gosto, mais reação que capacidade de situá-los no Decadentismo; pelo bizarro, por pretender escrever como um pintor se serve das cores, a decantada "écriture d'artiste." O periodismo distanciava, distancia o modo. Não me falta reler, agora, excelentes prosadores nacionais, todavia não ouso citar, por medo dos professores de verdade, que poderiam censurar a ousadia de alguém que se banca.

Os meus livros são consequência do interesse que devoto (demais) às questôes de arte. Por exemplo, o volume

armário, p.I47: "Conservo as condecoraçôes no mesmo armário em que venero minha única escultura." Sei que é ambicioso, porém se não aproveito esta ocasião para surpreender o leitor e lhe comunicar que, afinal, não sou um "peeme" qualquer, devo fotografar as medalhas e condecoraçóes que recebi, o que serve, sociologicamente, para estabelecer o man gosto com que se fabricam estes negocinhos premiadores, ao que parece, de gente que vale. 
dedicado a Corbú é consequência de uma amizade bem marcada em muitos pacotes de cartas que dele recebi. (Por mais incrível que possa parecer, comprei daquele pão-duro todos os desenhos de paredes e os textos das conferências que pronunciou no Rio de Janeiro em 36, época do risco do edifício do Ministério de Educação e Saúde, quando chamado por Lúcio Costa e Gustavo Capanema.)

Publiquei, repito, muitos livros. Além de alguns já mencionados, para me confirmar como um metido em questóes de história: namorado da Renascença, dediquei à Primavera de Botticelli um ensaio bem aceito até por mestres do setor. De um certo interesse a monografia sobre a obra de Velazquez, na coleção "Classici dell'Arte," da editora Rizzoli. Foi consequência da aquisição do quadro Conde-Duque de Olivares, resultando num trabalho científico de uma certa importância, dedicado ao Mestre; tive assim a honra de ver no mesmo frontispício, como coautores, o nome do Prêmio Nobel Miguel Angel Astúrias ao lado do meu, no livro La Obra Completa de Velazquez, publicado em 70 pelo citado editor Rizzoli. Estabeleci a biografia e exame das obras do pintor de As Meninas.

Alternava o prazer de me esconder em questôes históricas com contos de viagens, como a da Rússia, e até de propaganda industrial, por exemplo o La Strada e Il Volante, para o lançamento do "Ardita-Sport," quando tive a oportunidade de conhecer o criador da "Fiat," o venerado Giovanni Agnelli. (A que não leva o ser periodista?)

Revelei em inglês, editares "Il Milione" de Milão e a "Abrams" de New York, meu encontro e tomada de posiçáo no país de minha escolha: The Arts in Brazil: A New Museum at São Paulo, o livro do qual mais me gabo. Outras publicaçôes de interesse brasileiro? Numerosas. Para ser breve cito as monografias dedicadas a Lasar Segall e a Roberto Burle-Marx.

Não sei quantos são os catálogos, na Itália, Brasil, América, e até no Japão, que levam meus ensaios ou prefácios. Apresentei um batalhão de artistas. (Parênteses para me desabafar acusado, sei, de falar um pouco ou discretamente de muitos: é verdade. Inscrevi-me na companhia dos divulgadores, incentivadores, propagadores.) Repito: não sou nem historiador nem crítico, mas um simples conhecedor, avaliador também dos que chutam na assim chamada critica. Mas isto deve ser computado na confusão da qual falei acima: na horta florescem as plantinhas que servem à farmacopeia da verba não volant.

Não odeio nem mesmo os pernilongos que me sugam o sangue, porém guardo reserva em relação àqueles artistinhas que descobrem que o $\mathrm{B}$. pode ser-lhes útil e funcional para alongar seus passos no jardim em que vão colher os frutos; esta gentinha sim, me irrita; não a odeio, mas procuro diminuir os perturbadores. De qualquer jeito, quando um tal me leva a observar que também Caravaggio era postulante, a raiva aflora: Vá à m...!, grito.

E, de boato em boato, acabo quase sempre tido como nervoso, histérico, insuportável, superado. (Sorrindo, aceito quando me censuram com a sentença que a Angélique, no Le Malade Imaginaire, joga na cara do pretensioso velho Tomas: "Les anciens sont les anciens, et nous sommes des gens de maintenant.” Justo: cada um é anciâo do seu tempo.)

Com relaçáo ao tempo o que me comove é o seguinte: quando, em 1957, Giorgio Morandi comemorou seus setenta anos, a Galleria del Milione (a sucessora da Bardi, em 33) perguntou ao Mestre quem escolheria como autor de um livro-brinde dedicado a ele. Respondeu: "Bardi."

Telegrafam-me, embarco para a Itália, e escrevo a lembrança. Obrigado, Morandi! Nestes últimos anos o morandismo é até insuportável, pois chegam a lhe dedicar um museu, as cotaçóes de suas obras no mercado sobem ao nível do exagero, as mesmas precipitaçóes dos recém-chegados, possíveis peixes no barril, o que faz pensar que quando o B. viajava de Miláo para Bolonha, e almoçava com Morandi na trattoria da Cesarina, aprendia; "Sa? Ieri al'Accademia (onde ensinava gravura) sono andato a uma ricorrenza: mi sono portato l'orbace e l'ho vestito lá, non mi pareva bello attraversare la città vestito di nero." 4

"Sabe? Ontem na Academia [de Belas Artes] percebi uma coisa: 


\section{Intermezzo para Assis}

Lamento o silêncio dos contemporâneos para com Assis. De vez em quando recebia no Masp pessoas eminentes alegando, por conveniência, um ou outro motivo, desenformando receitas moralísticas, para retirar seus nomes como doadores de quadros: não queriam ser considerados em relaçóes com o Exator. Pela minha posição de cúmplice em várias caçadas de dinheiro para erguer o monumento (a palavra é muito apropriada) do Masp, era procurado também para estas estratégias.

O panteão dos mecenas do Masp foi uma das boas açôes do Singular, incluindo os generosos que recrutamos demonstrando a realidade do empreedimento, povoando-o de participaçóes não digo obrigatórias, mas certas de serem registradas como combinaçóes de favores, o "do ut des" que na vida antiga e muito mais na contemporânea é praxe inamovível.

$\mathrm{O}$ dr. Assis me dizia ser ele consumado professor do sistema e de ter formado o patrimônio dos Diários Associados e depois das estaçôes de rádio e de TV, através de negociaçóes de conveniência, ao mesmo tempo de utilidade para o contraente e para sua cadeia. Só um contabilista sem preconceitos teria capacidade para reconstituir como um único empresário conseguiu ser o dono de 35 cotidianos, espalhados nas capitais, desde o Amazonas até o Rio Grande do Sul: um domínio singular à maneira de Hearst nos Estados Unidos.

\section{Resultados de um aprendizado}

Uma das liçóes que o B. aprendeu com Chateaubriand foi a de conseguir dos capitalistas responsáveis por indústrias, fazendas, comércio e tantas outras empresas, meios para serem aplicados na cultura. Para Assis as pressóes tinham o respaldo de seu poderio.

Todos sabem como foram deflagradas as campanhas de Assis: aviação, evento em que quem não doava pelo menos um avião de treinamento aos aeroclubes podia esperar sua efígie na primeira página

levei o casaco xadrez e o vesti lá. Não me pareceu bonito atravessar a cidade vestido de preto." (tradução nossa) de um Jornal vestido de penitenciário, como se deu com o conde Chiquinho.5 A novidade era: todos deviam contribuir para as iniciativas do Empreendedor.

O Luís me pediu para não esquecer de contar os meus pecados. A safra mais punível resultou nas participaçóes museográficas. A lista não poderia ser contida neste número inteiro da Vogue, tantas são minhas infraçôes ao "tabu," como católico batizado; não são brincadeira, e se vale me envergonhar (também pelo descuido do iniciador Adão) declarando o meu ato de contrição pelas impurezas praticadas, me dá alívio esperar peto eventual perdão do Divino. Espiritualmente, se disso é permitido falar, me definiria um "terra-terra," isto é, incapaz, talvez temeroso, de refletir sobre os fantasmas do Além, imaginando de diálogos ao longo das mil vezes previstas para vir habitar o Planeta. Num seminário, acenando ao caso, me chamaram de besta. É, então, besta Goethe, que é deste parecer "Estou certo que já estive aqui, como estou agora, mil vezes antes. Espero voltar mais mil vezes...”

Sobre pecados é melhor não mexericar.

Fala-se sobre mecenas

Então o penitente aprende com o Mestre como se arranjar. Exerce o possível dever-direito com as luvas: persuade possíveis doadores. Sabe que às vezes se doa sem gosto. (Falo na primeira pessoa: doei em 48 três obras de Lasar Segall, Emiliano Di Cavalcanti e Cândido Portinari à Galeria de Arte Moderna de Miláo, para que soubessem que no Terceiro Mundo existem bons pintores; aquela galeria nem ao menos responde quando escrevo pedindo fotografias dos quadros.)

Conclusão: nem sempre dá vontade de doar mais nada. Viva os colegas do Museu de Arte de Mie-ken, Japão, felizes da vida quando em 82 , por ocasiáo da inauguração deste museu, doei seis quadros de artistas contemporâneos brasileiros: Glauco Pinto de Moraes, M.H.

$5 \quad$ Francisco Matarazzo Júnior (São Paulo 1900-I977), era filho do patriarca Conde Matarazzo. 
Chartuni, E. Nardin, Celso Suetake, J.A. Van Acker e Evando C. Jardim.

É-me grato, muitíssimo grato mesmo, aproveitar esta ocasião para constatar quanto o interesse pela cultura por parte dos mecenas, em São Paulo, teve generoso incremento, compreensão e participação.

Ao longo dos anos as atividades desenvolvidas pelo Masp no campo de exposiçôes, cinema, música, ensino, documentação e biblioteca, sofreram avanços difíceis dada à exiguidade de verbas à sua disposição. Os poderes públicos náo conseguem incluir em seus orçamentos (federal, estadual e municipal) verbas suficientes para a arte e a cultura, e as entidades mais atingidas são as que se dedicam às atividades culturais, principalmente as não oficiais. Embora essas dificuldades persistam e anunciem-se como crônicas e eternas, o Masp vem conseguindo ajuda de empresas nacionais e multinacionais que apoiam direta ou indiretamente algumas de suas promoçóes. Devo lembrar os que contribuíram para a realização de exposiçóes e de publicaçóes de livros e catálogos. Para começar cito o Banco Safra, que ofereceu ao Masp o primeiro catálogo geral digno do acervo, oferecendo depois o mesmo ao Museu de Arte Sacra e ao Museu Paulista da USP.

Particular registro para o Banco Sudameris que já publicou sete livros de minha autoria na "Coleção Arte e Cultura," dedicados a O Modernismo no Brasil; Arte da Prata no Brasil; Arte da Cerâmica no Brasil; Mestres, Artifices, Oficiais e Aprendizes no Brasil; A Madeira, Desde o Pau-Brasil até a Celulose; Lembrança do Trem de Ferro; sendo o último $A$ Comunicação, de Cabral à Informática, com notável vantagem econômica para o Masp. Um outro banco, o Francês e Brasileiro, nos patrocina os "Concertos Sinfônicos ao Meio-dia,” duas vezes por mês. Várias são as contribuiçóes que recebemos, entre elas destacam-se da Kodak Brasileira, American Express, Hoechst, Lufthansa, Banca Commerciale Italiana, Pirelli S.A., Banco Itaú, Fondazione Giovanni Agnelli da Itália, Estúdios Eldorado, Fortuna Com. Internacional Ltda., IM Arte e Artesanato, Associação Brasileira de Cimento Portland, Rhodia, Consulado Geral da França, MPM Propaganda,
Cromex Resinas, e também as doaçóes vindas através de serviços prestados a particulares pelo Departamento de Restauro e Conservação do Masp, além da atuação deste relator como garoto propaganda, revertendo o cachê para a caixa do Masp.

Tudo extremamente profícuo para a administração do Museu e, entre doaçóes, as mais providenciais foram as recebidas do Japão. Em 1973, por solicitação da empresa Matsuzakaya e do jornal The Mainichi Newspaper de Tóquio, o Masp concordou em emprestar obras do seu acervo de arte ocidental, complementada por trabalhos de artistas brasileiros contemporâneos, para uma série de apresentaçóes no Japão. O roteiro foi o seguinte: Tóquio, Osaka, Nagoya, Shizuoka e novamente Tóquio, no encerramento da mostra. $\mathrm{O}$ Interesse foi muito grande, filas extensas aguardavam a hora da abertura da mostra. A Casa Imperial do Japão, por intermédio do príncipe Akihito e da princesa Michiko também foram à exposição para conhecer a coleção vinda do Brasil.

Mais tarde, em 78 , por ocasião das comemoraçóes dos 70 anos da Imigração japonesa no Brasil, o Masp enviou a sua coleção de todos os bronzes de Degas, sob os auspícios da Associação de Museus do Japão e, em seguida, uma seleção de suas pinturas. Mais recentemente, por ocasião da inauguração do Museu de Arte da Prefeitura de Mie, o Masp enviou novamente uma seleçáo de obras do seu acervo, complementada com obras de artistas brasileiros contemporâneos. A exposição foi apresentada em Mie-ken, Gunma-ken, Fukuoka-ken, Yamaguchi-ken e Tóquio, com amplo sucesso. Em todas essas oportunidades os promotores das mostras sensibilizaram-se pelo trabalho que o Masp vem desenvolvendo no campo da arte e da cultura, tanto no âmbito brasileiro como no do intercâmbio internacional e, assim, fizeram generosas doaçôes, as quais permitiram estabilizar, embora dentro de estreitos limites, a vida financeira e econômica do Museu. Além do lado cultural e artístico dessas mostras no Japão, outro fator positivo foi o despertar o interesse dos japoneses pelo Brasil, interesse já natural devido ao grande número de imigrantes no país, mas que cresceu incrivelmente, pois 
paralelamente à exposição foram apresentados painéis sobre o Brasil, sua gente e seus costumes, além da intensa divulgação através da televisão, revistas e jornais.

\section{Saper stare a tavola}

O diretor de Vogue me recomendou não esquecer minhas preferências gastronômicas. Começo pelo vinho. Não sou degustador deste líquido, pois desde mocinho aprendi no Livro dos Provérbios (anotei até o capítulo: 3I, 6-7) que o nectar se "dá aos aflitos... aos que estão amargurados de coração, para que eles bebam e se esqueçam da sua pobreza..." Achando-me em forma, sem precisar de aquecimentos, náo digo que me devotei à abstinência, porém a uma moderação que os amigos consideram exagerada.

O mesmo se deu com o fumo, sempre caçoando pelos que lhe jogam na cara: "Você não sabe o que perde!"

Nunca fui guloso. Leio os cardápios do Sílvio Lancellotti com gosto, porém me reputo avesso à sapiência da cozinha. Gastronomicamente me reduzi a representar a negação de um buongustaio medíocre. Não carnívoro, tendência aos farináceos. Aqui sim, me sinto alguém: pizza pasta-asciutta, ravioli, lazanhas, pão e companhia representam a delícia da mesa.

\section{Rotina do Masp}

O Masp é um organismo sem doenças graves. Procurei sempre mantê-lo de acordo com o amigo Edmundo Monteiro, o presidente, evitando as picadas daquela que sabe como se infiltrar e gerar o que lhe interessa. Estes casos das apariçóes e desapariçóes de senhoras e senhores proveitosos pro-domo-sua é outra croniqueta que o diretor maspiano vai contar nas suas "memórias."

Ainda não passei ao computador o número de assinantes num intenso vaivém que me ajudaram ou que tentaram me injetar vacinas marca "atrapalha." Bem ou passavelmente, continuo na ação e na defesa, sabendo, como candidato a centenário, quando dá para engolir e, com boas ou más maneiras, não deglutir o indigesto.

Desmancharam tantas vezes meu prazer que me parece normal, aliás, justo, desmanchar também o de outros. Outros para indicar aqueles aproveitadores que, disfarçados de peixes no barril, serviçais, encobridores, esperam o momento de se apoderar do cargo ambicionado.

Sabe-se de numerosas intervençóes minhas denunciadas como ditatoriais. Fui sempre, em várias ocasióes, mais um comandante do que um subalterno. Mas enquanto dar, dará.

Entre os tais, estão não sei quantos mecânicos das artes. Sei que os fanáticos do "se deve absolutamente ser atual" (definição de Courbet) me apelidam de "acadêmico," porque às vezes torço o nariz diante de uma placa de espuma de nylon dada à luz em cesariana, apresentada num dos recintos das senhoras lançadoras do excêntrico, de um qualquer "maior do mundo" na ginecologia das artes paulistas. Nestes casos até eu me reputo acadêmico, procurando não me agregar às mafiazinhas dos ingênuos.

\section{O Masp em Paris}

Retrocedo aos idos de 53 quando os que atiravam pedras e escondiam o braço continuavam a espalhar os velhacos boatos, dos quais já falei. Precisava reagir. De acordo com o Chefe que se recusava a processar certos malandros, decidi escolher um conjunto de obras do Masp e organizar uma exposição na Europa, para mostrar a cultura do Terceiro Mundo.

$\mathrm{Na}$ época em que visitei o Oriente, uma astróloga chinesa, fazendo confusão sobre minhas datas e status, me atribuiu este horóscopo: "Siga os impulsos do seu dinamismo, creia na sua estrela, em você mesmo, e não tema perder a cabeça, ou o comando: você tem o poder de levar à ebulição as águas paradas.” Agradou-me. Porém, quando fui verificar sua exatidão, descobri que não era Rato/ Peixe, isto é, meu signo, mas Cavalo/Água. Todavia, já que me convinha, o considerei válido, gostando da salada à chinesa.

Meu signo é Peixes. Convém-me mais que seja, observando o horóscopo chinês: Rato. Antes de tudo porque as pessoas deste signo são "extremamente charmosas e encantadoras,” o que se não é verdade, é pelo menos um ponto a meu favor. Testemunha o horóscopo, o que me parece certo: 
"Embora à primeira vista pareça tranquilo, equilibrado e alegre, o rato esconde dentro de si uma perpétua agitação e uma agressividade sistemática. Basta observá-lo mais detalhadamente para descobrir seu nervosismo, sua inquietação e um temperamento por vezes colérico. Costuma criar casos, esmiuçar problemas, chegando inclusive nas situaçóes extremas a tornar-se um maníaco. Muito esperto e imaginativo, manifesta, às vezes, surpreendente criatividade. Destaca-se também por sua habilidade. Mas é por ser excelente crítico que se faz notar na maior parte das vezes."

Assim, a decisão foi rápida. Em Paris era o ano em que se falava, discutia-se e lamentava-se os recessos do "Terceiro Mundo," locuçáo lançada no ano precedente, pelo demógrafo Sauvy e que alcançou ressonância mundial. Imaginei uma repercussão-boutade.

A estrela deu certo. Consegui um convite da direçáo geral dos Museus da França, sendo o local da performance a Orangerie do Louvre com o título "Cem Obras do Masp." Confiando no horóscopo, porém pouco acostumado com os hábitos diplomáticos brasileiros, conhecendo todavia os comuns de sempre, fui à embaixada informar da façanha que tinha conseguido, ousando pedir nada menos que convidassem o presidente da República para a inauguração. Não me deram, não digo bola, mas nem bolinha.

Confiando ainda mais na estrela, contando com Germain Bazin, diretor do Louvre, e o saudoso George Wildenstein e outros amigos parisienses, não sei de quais ramos de relaçóes, consegui que o presidente Auriol e senhora inaugurassem a manifestação. Por mais que possa parecer inverossímil, as boas-vindas foram dadas ao sr. Auriol por um neo-brasileiro recém-naturalizado. O próprio fundador do Masp chegou no dia seguinte, lágrimas nos olhos: não tinha entendido meu telefonema, certo de que eu estava brincando, pois lhe parecera impossível o achado.

A imprensa parisiense exaltava o fato de que o malandro que aqui escreve tinha alinhado na mostra os quatro retratos das filhas de Luís Xv, de Nattier, e o retrato de "Luís Xvi e Luís XviıI crianças," de
Drouais Fils, cinco pinturas arrancadas do Castelo de Versailles durante a Revolução. Então: páginas e páginas de entrevistas. Naturalmente, na festa, alegrada pelas bandeiras verde-amarelas e o cartaz do "Escolar" de Van Gogh em toda Paris, não compareceu ninguém da embaixada e do consulado, sendo notada a estupefação pelo espetáculo, digo sem falsa modéstia, espetacular mesmo. Filas de visitantes me consolavam dos raros gatos pingados visitantes da sala, mais tarde das salas dos outros três andares, na sede da rua Sete de Abril, fazendo votos para que o emagrecimento dos invejosos chegasse aos ossos.

O sucesso provocou numerosas visitas de colegas de museus europeus, os quais queriam combinar para que as "Cem Obras” fossem apresentadas nas capitais e cidades do Continente do Primeiro Mundo.

A mostra foi, então, apresentada no "Palácio des Beaux-Arts" de Bruxelas, "Tate Gallery" de Londres, "Central Museum" de Utrecht, "Kunstmuseum" de Berna, "Kunstverein" de Dusseldorf e, finalmente, na minha terra: "Palazzo Reale” de Milão. Outro caso: descobria-se que o "Retrato do Cardeal Madruzzo," de Ticiano Vecellio, fora retirado do Castelo "Del Buon Consiglio" de Trento. De lá, através de itinerários clandestinos, foi descoberto por mim em New York, porém valendo a lei da prescrição dos crimes, resultava que tudo estava em ordem.

(A vaidade do relator deve registrar o seguinte: no dia anterior à inauguração veio ao Palácio, expressamente de Florença, Roberto Longhi, mestre número um da crítica histórica. Depois de examinar o conteúdo de sala em sala, disse-me: "Bardi quà la mano.")

Levei depois a coleção para o Metropolitan Museum of Arts, onde foram desmontadas cinco salas para que New York a visse. Depois da exposição em Ohio, Toledo, voltei ao Brasil, retomando a guerrilha.

\section{Como concluir?}

Tenho a impressáo, agora que pela primeira vez tento um balancete, de ter me aventurado por muitos caminhos, deixando, no narrar, a meu modo não canônico, de abrir várias veredas. 
Escrevendo e ilustrando preocupei-me em não exagerar e não impacientar o leitor.

\section{Nota}

Este depoimento foi escrito à medida que vinham à mente os retalhos esparsos da minha vida. Relendo-o, ocorre-me ter deixado de registrar náo sei quantas pequenas empresas. Todavia, não quero mexer, nem suprimir alguns trechos encolerizados, o que me leva a pedir perdão aos eventuais desinteressados.

As descobertas de Pietro Maria Bardi, p.I36-I37

Pietro Maria Bardi

Alguém que insere em seu currículo esta surpresa da Vogue, como atividade quase emergente, deveria resumir afortunadas descobertas de obras de arte, náo para se destacar no seu comércio e no cargo de diretor do Masp, mas para contar as numerosas aquisiçóes, geralmente de objetos sem habituais "documentaçôes de autenticidade." Isto levaria a ocupar muito espaço, últil talvez somente para especialistas no assunto. Já dei noticia, no rascunho biográfico, do caso do Giorgione, agora escolhe-se uma peça de Rafael. Cada obra do Masp, como de resto cada obra que adquiri ao longo da carreira, tem seu currículo. A obra do Masp que, me parece, possa despertar a curiosidade do leitor, é o painel de Rafael. Em 54 eu devia expor a mostra "Cem Obras-primas do Masp" na Tate Gallery. Chegando em Londres, adverti o diretor que devia acrescentar mais uma, pois tinha adquirido a "Ressurreição," pintada pelo Mestre de Urbino. Foi na manhã de Páscoa, na Knoedler, em New York, a loja excepcionalmente aberta naquele dia para três brasileiros (dr. Assis, Walter Moreira Salles e B.) tomarem conhecimento da existência de uma pintura absolutamente desconhecida: tinha vindo no dia anterior da Inglaterra, achada em Rossie Priory, proposta à National Gallery de Londres, e por este museu recusada, pois lá as peças da Renascença italiana deviam ser aprovadas por Bernard Berenson, o qual negou a autoria.

$\mathrm{O}$ veto do mestre suscitou as reservas imagináveis. Conseguiu-se, todavia, juntar às cem pinturas do Masp a "Ressurreição," declarando-a de autoria de
Rafael. Sozinho, pesquisando, descobri então que a pintura era lembrada por Crowe e Cavacasell e numa monografia, de I884, dedicada ao pintor, e mais: no Ashmolean Museu de Oxford existem, no patrimônio Lawrence, os desenhos preparatórios de duas figuras da pintura.

A crítica europeia perplexa: Brasil docet?

Até que o mestres do mestres, mestre mesmo, Roberto Longhi, celebra a descoberta brasileira no documentado ensaio na revista Paragone.

Várias obras que o visitante do Masp encontra colocadas nos painéis de cristal (talvez seja uma novidade museográfica: o prazer de libertar a pintura do suporte da parede para, na parte detrás, poder se ver e ler dados biográficos e notícias de peça) provêm de felizes picadas na selva do inédito e pode ser este um prazer para o investigador, o qual aproveita da lembrança para se justificar por um fato que várias vezes lhe foi repreendido: a presença às vezes excessiva de alguns mestres, como é o caso por exemplo dos treze Renoir, seis Modigliani e dezesseis Portinari.

Justificativa: o entendimento com o inesquecível sr. Chateaubriand, quando juntos formamos a Pinacoteca, era de reunir pinturas de alguns autores cujo custo era bem conveniente, para em um segundo tempo aproveitar da alta dos valores, vendendo ou trocando com telas de outros artistas para equilibrar o acervo. Desaparecido o Fundador, a diretoria do Masp não quis dar sequência à ideia dos iniciadores na iniciativa.

MASP, O NúMERO UM DO BRASIL, p.I38-I39

\section{Jacob Klintowitz}

O Masp é o principal instituto cultural do Brasil. É uma afirmação espetacular. Como pode um museu de arte, situado na

avenida Paulista, representar tanto para o país? Será que é o seu acervo, hoje avaliado em quinhentos milhóes de dólares, a causa 
desta importância? Não é, ainda que um acervo deste tenha um valor cultural inestimável. Hoje seria quase impossível formar um núcleo cultural e o acervo deste porte. As obras não estão mais disponíveis no mercado de arte internacional. Não se trata, portanto, de dinheiro, mas de oportunidade. Somente circunstâncias especiais permitiram a formação do Masp na América do Sul. Mas a sua real importância vem apenas em parte da guarda deste tesouro da arte ocidental.

O Masp, mais tarde chamado de Museu de Arte de São Paulo Assis Chateaubriand em homenagem ao seu fundador, o jornalista Assis Chateaubriand, foi um elemento formador fundamental na consolidação do modernismo brasileiro. O Masp foi fundado em 2 de outubro de 1947. Logo após o fim da Segunda Guerra Mundial. Chateaubriand era, na época, o proprietário de uma cadeia de comunicação, jornais, rádios, revistas e, posteriormente, canal de televisão, como ainda não houve outra entre nós. A sua força de convencimento e influência era imensa. E ele tinha ligação, à sua maneira, com o desenvolvimento nacional.

Chateaubriand, como é próprio dos grandes empresários da área da comunicação, fez várias campanhas, como a da aviação e formação de aeroclubes. O Masp foi a sua principal campanha, o que realmente deixou o seu nome na história cultural brasileira. Após a guerra, Chateaubriand procurava alguém capaz de implementar a criação de um museu brasileiro. Pietro Maria Bardi era um intelectual destacado no mundo europeu, diretor de revistas importantes, jornalista, diretor da Galeria de Roma, fundador do Estúdio Palma, introdutor da arquitetura moderna na Itália. O encontro dos dois, propiciado pelo embaixador brasileiro, foi curioso e determinante do futuro destas relaçóes afetivas e produtivas. Assis: "O senhor vai encontrar muita gente no Brasil que vai dizer que eu sou um aventureiro. Eu sou um aventureiro. O Senhor por acaso, é também um aventureiro?" Bardi: "Sim. Eu sou um aventureiro."

Estava selado um pacto que duraria por toda a vida e começava a nascer o nosso Museu de Arte de São Paulo.

\section{A vocação da modernidade}

A história da formação deste museu foi tumultuada. Acusaçôes falsas, leviandades, pressôes, luta política. Os quadros, adquiridos por preços vis no mercado de uma Europa arrasada pela guerra, foram acusados de serem falsos. Foi necessário, para afirmar a autenticidade, uma excursão do novo acervo pelas capitais e museus importantes. O Metropolitan, em New York, a Tate Gallery, em Londres e o Louvre, em Paris, assistiram, com grandes pompas, a apresentaçáo dos novos tesouros brasileiros. As obras-primas da coleção do Masp. Mesmo assim, ainda se duvidou muito, entre nós, da excelência do material. Como poderia o Brasil ter um acervo cobiçado pelo mundo culto? Nós náo éramos uma colônia? Havia, é claro, ciumeira e luta política, na qual Assis Chateaubriand estava profundamente envolvido.

Mas o Masp, em sede provisória, estava definitivamente implantado. E vieram as atividades renovadoras. Formação de uma orquestra juvenil, criação da escola de publicidade, criação da escola de desenho industrial, desfiles de moda, cursos de arte, história da arte, discussão de arquitetura. O Masp ficou na raiz do desenvolvimento industrial brasileiro, favorecendo a discussão e a formação de mão-de-obra sofisticada na área cultural. Desta maneira, formaram-se as técnicas baseadas na aplicaçáo das artes, favoráveis ao surto industrial que modernizou o país.

O desenvolvimento brasileiro deve muito ao Masp. Bastaria estas atividades para colocar o seu nome na nossa história cultural. Mas esta atividade foi só o impulso inicial. Quase nada foi feito, na área visual e semelhantes, sem a atividade e o estímulo permanente do Masp. No nosso país, onde se menospreza a memória, é importante assinalar a atividade pioneira deste museu que náo se colocou como um museu, mas como um instituto de artes e ofícios pioneiro em escala mundial.

\section{A ânfora e o helicóptero}

Foi infinitamente divulgada a reinauguração do Museu de Arte Moderna de New York. 
Em todas as matérias, causou um espanto deliciado o helicóptero pendurado no teto. Que ousadia do grande museu, símbolo da participação do império americano na arte. Mas, em I948, o Masp fez uma famosa vitrine das formas, na qual constava uma ânfora grega e uma máquina de escrever Olivetti. Equiparava-se a produção industrial à criação das formas clássicas. Vale dizer, todos os objetos construídos pelos homens são igualmente importantes. Ânfora, máquina de escrever ou helicópteros. Este pioneirismo do Masp teve um efeito notável, entre nós. Ele foi um elemento detonador. A diferença, neste caso, está no fato do Brasil ainda não ser capaz de defender mundialmente a sua produção cultural.

O conceito museológico de P.M. Bardi foi pioneiro. O Masp, desde o seu início, se propôs náo como uma guarda privilegiada de tesouros, mas como um estimulador de cultura. É por isto que ele pode perceber as mudanças do país e se oferecer para suprir as necessidades emergentes. Por estar voltado para o futuro, e não para o passado, o Masp foi capaz de se antecipar à tradição de sua função e inventar novas funçóes que hoje, com o avanço dos institutos culturais, estáo disseminados por boa parte do mundo.

\section{O museu do Bardi}

A atividade do Masp está indissoluvelmente ligada à personalidade de Pietro Maria Bardi, esta figura eternamente polêmica. O Bardi foi e é a sua mola propulsora. Ele estabeleceu o conceito de sua função, ele organizou o museu, ele comprou o acervo, ele conservou o acervo, ele orientou a construção do prédio definitivo, em fantástico projeto arquitetônico de Lina Bo Bardi, ele tocou o museu até os nossos dias. Aos 85 anos, Bardi é o mais dinâmico diretor de museu do Brasil.

É comum as pessoas referirem-se ao Masp como o Museu do Bardi. São parte de um mesmo conjunto, imagens associadas, interpenetrantes. É difícil imaginar o museu sem o P.M. Bardi, seu diretor técnico, como é impossível imaginar o Bardi sem o Museu de Arte de São Paulo. Parecem como os relatos das histórias românticas. Um foi feito para o outro. Esta integração das imagens do homem e do produto de seu trabalho dá bem uma indicaçáo da dedicação absoluta que o historiador Pietro Maria Bardi doou ao museu mais importante do país. E, sem esta dedicação de um homem deste nível e energia, o Masp não seria o instituto cultural mais importante do país. Para se ter uma ideia, basta ver os outros museus brasileiros que, mesmo sem um acervo tão valioso, poderiam ter resultados interessantes.

O Masp recebe, diariamente, seis dias por semana, 2500 pessoas. Esta média de público não impede que, em certas ocasióes a frequência alcance piques de até dez mil pessoas. O Masp, com cerca de dez mil metros quadrados, é tocado por uma equipe de 4I pessoas, incluindo aí a segurança, o departamento de restauração, marcenaria, contabilidade, e a própria direção. O prédio está sempre escrupulosamente limpo, o ambiente é calmo e tudo funciona como se fosse uma pacata empresa de porte médio.

\section{$\mathrm{O}$ acervo único}

Completa este instituto cultural o principal acervo de arte ocidental da América do Sul. Foram peças escolhidas com a mão do mestre. Pinturas cobiçadas no mundo inteiro que já foram expostas nos principais centros culturais do planeta. E que, como no caso japonês, proporcionam ao Masp polpudos rendimentos como "contribuição espontânea." Este acervo inclui os grandes nomes da arte ocidental. Mas não é um museu de arte moderna. Bardi não aceitou este nome para não comprometer a aquisição do acervo com um rótulo. É simplesmente museu de arte, porque tudo é arte, moderna ou não.

Esta decisão acertada em relação ao nome, permite que o público brasileiro entre em contato com autores como Giovanni Bellini, Andrea Mantegna, Rafael, Ticiano, Tintoretto, Chardin, Fragnard, Ingres, Corot, Daumier, Delacroix, Manet, Degas, Cézanne, Renoir, Monet, Gauguin, Van Gogh, Toulouse-Lautrec, Utrillo, Bonnard, Vuillard, Matisse, Vlaminck, Léger, Picasso, Larionov, Soutine, Lipchitz, Modigliani, Max Ernst, Wolls, Brauner, El Greco, Velásques, Goya, Memling, Holbein, Frans Hals, Bosch, Cranach, o 
velho, Rembrandt, Turner, Frans Post. E os brasileiros, pois os há em bela quantidade e qualidade, Facchinetti (italiano de nascimento), Benedito Calixto, Victor Meirelles, Almeida Júnior, Castagneto, Visconti, Di
Cavalcanti, Flávio de Carvalho, Anita Malfatti, Portinari, Lasar Segall, José Antonio da Silva, Maria Helena Chartuni, Ermelindo Nardin, Israel Pedrosa, Wesley, Rubens Gerchman, Felícia Leirner.

Merlin, Digamos, TINHA OS Olhos DE BARDI, I4O-I4I

Mino Carta

Conheci Pietro Maria Bardi há 38 anos, quando usava calças curtas. Ele não, eu. Ele já estava para emplacar 47 anos, e esta é uma idade que, para quem usa calças curtas, costuma se parecer bastante com a velhice. Mas a imagem que se fixou na minha cabeça infantil não foi a de um velho, porém de um camarada especial, de idade indefinida e aptidóes mágicas.

Hoje sei que Bardi estava fadado, por um jogo insondável do destino, a carregar vida adentro, sem alteraçóes sensíveis e vincos mais profundos, o semblante adquirido nos anos verdolengos. De hábito, os homens ficam com o rosto que merecem quando a juventude se vai. Bardi pertence a uma categoria extraordinária de pessoas que cedo ganham feiçôes definitivas, imutáveis, apesar das intempéries da vida e da força da gravidade. Nelas, o rosto se toma perfeito emblema de uma indomável resistência aos assaltos do tempo e das fraquezas humanas, aos agravos das paixôes, dos humores destilados entre o fígado e a alma. E se trata de uma resistência tanto mais valiosa quanto mais discreta, disfarçada atrás de um sorriso cético.

Assim é, eu creio, uma das faces possíveis da sabedoria, a qual, no caso de Bardi, alguém poderá tomar como bruxaria, por causa dos olhos do próprio, tão plausíveis em feiticeiros. Merlin, digamos, tinha os olhos de Bardi. Tendo a achar que tal foi o motivo do meu imediato interesse por ele na noite de Natal de 1946, sem neve para surpresa dos recém-chegados ao Brasil que se reuniam com suas perplexidades na casa de estilo colonial de outro italiano, estabelecido aqui há mais tempo, com notável conforto e esposa do lugar. Ela era loura, de olhos muito transparentes e ria muito com a certeza, plenamente justificada, de decorar, de forma no mínimo admirável, qualquer ambiente. A mulher de Bardi, Lina, moça formosa, ardentemente morena, diante da exuberância da dona da casa, permitiu-se um gesto entre a generosidade e a compaixão, e apagou o fogo do seu olhar, suntuosamente negro, e dos seus pensamentos, criticamente progressistas, num canto sombreado da sala, de resto propício ao abandono da mastigaçáo forçada do tender de praxe. Em plena luz, exposto, eu vi Bardi sorrir como o mago Merlin das gravuras de um dos meus livros preferidos, e considerei confirmada a impressão, aliás muito forte em mim desde sempre, de que encontros com magos são mais prováveis em lugares onde menos os esperamos. De sorte que não excluí a possibilidade de que todos nós fossemos personagens inventadas por Bardi, naquele exato instante.

Esta sensação da magia bárdica, ou bardiana, permanece, 38 anos passados. Mas o tempo pretendeu conferir uma arrumação lógica, racional, aos meus espantos. Direi, portanto, que Bardi é apenas um mortal muito sábio, com a consistente colaboração de um agudo senso da ironia e da auto-ironia, sem detrimento de súbitos mergulhos em vagalhóes de indignação dispostos a se aplacarem bonança num piscar de olhos. Nunca o vi enfurecido, nem colhi depoimentos a respeito dos seus mais candentes momentos de mau-humor, mas sinto que Bardi pode entregar-se a fúrias gloriosas, relampejantes e criativas. Criativas porque conscientes, quero dizer, responsáveis. Quem sabe, até, programadas. Não disse fingidas, encenadas. Não, não, rigorosamente autênticas, mas não me engano ao intuir que, quando navega pela breve roda da crise, da faiscante explosão, Bardi mantém o controle da situação, sabe o que faz, planeja gestos e palavras enquanto os circunstantes náo nutrem a mais pálida sombra de dúvida quanto ao fato de que ele perdeu as estribeiras. Nisso, é um interprete de si próprio, Bardi no papel de Bardi, o que faz sentido, porque ninguém é mago sem ser ator. 
Agora, forte nele é também a vocação política. É um mourejador da estética, está claro. Sabe tudo de Velazquez e Morandi, escreveu dezenas de livros sobre as coisas da arte. Mas o Masp, que é a sua segunda maior obra (a primeira é o seu estilo de vida), é bem mais do que o mais importante museu do hemisfério sul, do que uma pinacoteca respeitável em termos mundiais, com três Goya e quatro Cézanne. O Masp é um exemplo empolgante de como se pode realizar magias, grandes, incomensuráveis mágicas, com esperteza e picardia, aproveitando as qualidades e defeitos das personagens à mão, organizando e conduzindo a bom termo uma commedia dell'arte que, aparentemente, está longe de contar com interpretes adequados.

E no outro dia fui visitar a pinacoteca do Masp na companhia de um velho amigo. Antes avisei o Bardi, e ele se prontificou a servir de cicerone, e serviu, por toda uma manhá, contando histórias de cada pintor e da sua obra, exposta ali no espaço projetado pela ardente Lina. E, sobretudo, contando a história da captura daquele quadro, e daquele outro, comprados, um a um, com o dinheiro arrancado (há outros verbos possíveis) de senhores paulistas que, de outra forma, o gastariam em uísque pelos bares mais diversos, incluindo o internacional bar do Plaza-Athenée, ponto turístico preferido destes mesmos cavalheiros. O meu amigo visitante, moço de 73 anos, deslumbrou-se com o cicerone-anfitrião, e riu muito das suas histórias, e, enquanto ria, na memória as guardava, com razão, como exemplares e exaltantes.

Bardi jamais diria que se expropriou grana de ricaço para dar a Sáo Paulo um museu melhor do que o Brasil. Isto não seria político, à luz daquilo que, neste pobre país onde poucos têm tanto e a maioria não tem nada, se supóe ser a política, ou seja em lugar da arte do possível, a arte do engodo. Agora, entendam bem: Bardi fez política, no sentido mais correto, mesmo quando as aparências diziam da sua aliança com leopardos, ou gattopardi que fossem. E se na nossa selva esse gênero de felinos ainda está mandando, Bardi não é culpado por isso, ainda que se aproveite deles, com o seu ar deliciosamente sonso. Como convém a um mago.

O CARÁter de Pietro NÃo É dos MAIS DOMÁveis, p.I42-I43

Lina Bo Bardi

O caro amigo Luis me pede para participar desta improvisada festinha para o Bardi, sugerindo-me o tema: como aguentá-lo. De fato, o caráter do Pietro não é dos mais domáveis. Sabia disto desde garota de soquetes, quando estudava no Liceu Artístico, na via Ripetta, em Roma, onde se falava do B. então diretor da Galleria d'Arte, numa repercussão da estrondosa polêmica dedicada à Arquitetura. Era definido como "louco."

O título, atribuído a alguém que, para censurar o mau gosto de Mussolini, tinha fotomontado um Tavolo degli Orrori, vinha misturado aos comentários mais picantes, inclusive pelo seu mulherenguismo.

Meu tio Natalino, então redator-chefe do cotidiano L'Impero, considerado do partido ligado a Giuseppe Bottai, Curzio Malaparte e aos futuristas Mario Carli e Emilio Settimelli, conhecia o B. Uma vez o levou a um círculo denominado "La Spensierata" que nós, da Academia de B.A., tínhamos aberto numa antiga garagem onde apresentamos uma mostra de trabalhos escolares de arquitetura e de outras artes. Pelas cores, onde emergiam o verde e o branco, foi definida por F.T. Marinetti, convidado para a inauguração, como "pastasciutta con gli spinacci."

Era a Roma dos anos trinta: os jovens eram de casa na lembrada Galeria onde encontravam com o B., Massimo Bontempelli, Luigi Pirandello e seus filhos, Ezra Pound, De Sicca e praticamente com a inteligência do tempo.

Passados alguns anos, com a guerra e a derrota, Roma se tornou a capital das "signorine," Bruno Zevi tinha fundado a Associação da Arquitetura Orgânica, nascia o cinema neorrealista de Rosselini e tantas outras novidades. Eu, então já formada em Arquitetura, me transferira para Miláo, redatora da revista Stile: o diretor Gio Ponti me manda à Capital para entrevistar B. sobre um conjunto de casas-coletivas. Finalmente falava de igual para igual com um jovem que julguei um tipo 
oriental, elegante, gentil. Andei com ele, para a entrevista, através de ateliers e obras edis e, voltando a Miláo, continuamos mantendo relaçóes. Deram-se outros encontros: namoramos e em 46 casamos, decidindo nos transferir para o Brasil. No Rio de Janeiro o B. se entendeu com absoluta amizade com Assis Chateaubriand. Eu colaborei no nascimento do Masp, como arquiteta, cujo resultado está na lembrança do museu de 47, na casa que construímos no Morumbi em 50 e na sede da avenida Paulista, onde tive a honra de ter como responsável pelo complicado cálculo do edifício o engenheiro José Carlos de Figueiredo Ferraz. Continuo meus trabalhos, sendo o mais recente o Centro de Lazer da Fábrica da Pompeia, do Sesc, aqui fotografado pelo Andreas.

Arte e mulheres. As PreferênCias de Bardi, p.I44

\section{Pietro Maria Bardi}

Quais são os artistas nacionais que mais gosto?

\section{Do passado-próximo}

Tarsila do Amaral, Ismael Nery, Vicente do Rego Monteiro, Brecheret e alguns outros. Destes mestres o B. náo esperou a alta do mercado mas procurou adquirir suas obras ainda quando a noite nebulosa não permitia vislumbrar os inexistentes investidores. Comprei de Tarsila o Abaporu vinte anos atrás; de Nery tudo que encontrava; de Vicente, que descobri em Paris, quando organizei sua individual no Masp visto que ninguém comprava nenhum desenho, adquiri a exposiçáo completa.

\section{Dos de hoje}

Todos indistintamente. Os que pintam e esculpem para pintar e esculpir bem ou mal, os que seguem mais ou menos a Tradição ou tentam ser das Rupturas, (de scatole) os amadores, as senhoras que pintam para enfrentar e matar o tempo, caboclos e semicaboclos primitivos, pichadores de rabiscos nos muros cívicos, alunos das escotas primárias obrigados a honrar a Arte, também os trinta mil que se inscrevem neste ou naquele Salão para tentar a sorte etc.

\section{Menos}

Os que pescam no riacho turvo das Modas (a de meio século atrás ou a última de New York ou da cidadezinha do Oregon) e procuram surpreender as senhoras que têm galerias, as quais, náo tendo na loja obras de Picasso para vender, proclamam que "Picasso já era."
Vai o Menos também para os que se investem o manto de "ipso dicti," amoladores de críticos e simples periodistas que a ignorância local honorifica com este título, contratadores de agências de publicidade para aparecer.

Caso o Festejado tivesse de apresentar seu vulto, seu retrato completo, desde a pré-história até ser medalhão, não seriam suficientes as páginas deste número pois, por ter ele se metido na confusão da pintura, inúmeras são as folhas e as telas em que sua fisionomia resultou "bolada." O redator pediu a ele que indicasse um retrato seu, no qual se vê na intimidade: escolheu este, de Maria Helena Chartuni, de três caras, na companhia do senhor Tigre.

\section{Legenda e comentário}

p.I44 Confissão por confissão: por que não escorregar para o recinto, inexplicavelmente proibido, do ideal físico feminino? Quem se interessa por problemas de estética, e o homenageado está entre os primeiros, coloca em cena aquela castigada palavra Beleza. Quer-se desvelar as preferências que ele andou catalogando na cabeça: as Vênus e aspirantes ao título às quais dedicou ensaios, lembranças, palpites, olhadinhas de estúpida honestidade. Não são todos do mesmo parecer, pois ainda inflaciona o setor alguns antifeministas. Todavia, a verdade é soberana: é a Mulher, quando tal, que dá ao homem o senso do presente e do infinito. E, pois náo tem idade, o galante de turno evoca seus antiquíssimos ideais femininos: homenagem às Senhoras de todos os tempos, com carinho de um amador que em qualquer ocasiāo reverenciou e reverencia a Mulher.

( $\mathrm{Na}$ outra página, ideais femininos de $\mathrm{B}$. em seus tempos: dois modelos, pensando 
na obra-prima de Ticiano Vecellio, o "Amor Sagrado e o Amor Profano;" embaixo: visita ao "Studio" de José Duarte de
Aguiar, acolhido por Ana Christina Souza

Dantas e Maria do Céu Mota Camargo.)

O PACIENTE ORIENTADOR, p.I47

Maria Helena Chartuni

Em meados de 64 lia em um jornal que a Associação Amigos do MAM pedia aos artistas que doassem obras para serem leiloadas com a finalidade de reforçar a caixa da entidade. Eu ensaiava os primeiros passos na pintura, e já havia participado da vir Bienal, além de ter apresentado uma exposição individual naquele ano na Galeria Selearte. Peguei dois quadros e parti rumo à rua Sete de Abril, onde estava o MAM, no mesmo edifício do Museu de Arte de São Paulo. Lá chegando subi direto para o saguáo do Masp, confundindo as portas. Disse ao porteiro que queria doar os trabalhos para o leilão. Momento de confusão: ninguém sabia de nada, e eu rubra de vergonha queria que o chão se abrisse. Mas, de repente, surgiu, na minha frente, o diretor do Masp, o Prof. P.M. Bardi, que eu conhecia só através de livros e aprendera a admirar e compactuar com suas ideias sobre arte.

Viu os quadros, pediu um em doação ao Masp, e assim nasceu uma amizade-admiração que dura até hoje.

Foi por suas mãos que quatro anos mais tarde iniciei-me no restauro, tendo nele um orientador paciente e competente.
Participei da transferência do acervo da antiga sede da Sete de Abril para a sede da avenida Paulista, onde criamos o Departamento de Restauro. Nesta aprendizagem diária, passaram-se dez anos. Corria o ano de 78 e uma noticia repercutiu em todo o Brasil: um louco havia quebrado a imagem de Nossa Senhora Aparecida, reduzindo-a em I65 fragmentos. Depois da tragédia os padres comunicando-se com o Vaticano, para melhor se orientarem, receberam a informaçáo que a pessoa indicada para opinar e resolver o problema era o Bardi. Assim, a imagem chegou às nossas mãos e o resultado é já conhecido. Este fato extraordinário popularizou o Departamento de Restauro do Masp, e até hoje cuidamos da conservaçáo dos acervos de várias igrejas do Brasil, além de algumas peças para colecionadores particulares. Cada intervenção no acervo do museu é feita sob a orientação do diretor, e procuramos seguir sua ideia de que se restaura somente em último caso, quando é absolutamente necessário. Assim foi com obras de Rafael, Bellini, Turner, Goya, para citar algumas.

p.I49 Chez lui un beau désordre est un effet de l'art. Beaulieu

O SENHOR COLECIONA? O QUE COLECIONA? P.I5O-I5I

Juntar objetos de arte ou que têm a ver com ela; para satisfazer o prazer da sua companhia, coloquiar, relembrar visitas, encontros e aventuras; evocar a descoberta de algumas peças, tentar fixar possíveis autorias, sonhar e delirar, trafegar, especular, avançar valores, comprar e vender: é o que se define colecionar. Gosto quando possível de particulares, sujeitos de todas as marcas: sabidos, iludidos, maníacos, às vezes malandros.

Quem se confessa nesta Vogue sempre foi um destes. Menino ainda juntava selos, figurinhas da Tobler, conchas do mar; mais tarde, a presa passou a ser objetos de arte: xilogravuras, rabiscos, fotografias; depois, de emoção em emoção, metido na pintura, na escultura, naquele mundo infinito que é o antiquariato, a mania tomando-se furor. Para documentar o jeito nas paredes e nas vitrinas numa sala do Masp, eis um resumido mostruário do meu hábito de juntar coisas, das já doadas ao meu Museu, à minha biblioteca, e um pouco dos itens que ainda me alegram.

Sinto-me de casa no Brasil, assim, em vez de disfarçar minha mania recorrendo ao famoso dito de Vasari, me justifico com um verso do poeta alagoano Sabino Romariz, o qual não teria dado sua estrela "nem por um império."

Senhor leitor desta Vogue: o Senhor coleciona? O que coleciona? 


\section{Legenda}

Sempre fotografam a arquitetura iluminada pelo Sol. O Andreas Heiniger sugeriu apertar o botão de sua máquina num momento em que o astro ainda está escondido para que os poetas façam seus versos. $\mathrm{O}$ resultado, pelo que se vê, deu certo.

p.IS2 "Reputo-me acadêmico, procurando não me agregar às mafiazinhas dos ingênuos."

p.IS3 “A sorte é mais útil do que a prudência." (ditado sírio)

Quem se meteu no setor das Artes, fatalmente, por ter manipulado obras de artistas contemporâneos e mais, de mestres antigos, acabou possuindo pinturas, esculturas e muitos outros objetos referentes ao campo por ale cultivado e, muitas vezes, arado.
Aliás, uma de suas particularidades foi a pesquisa, não tanto a livresca mas a da descoberta. Nestas duas páginas revela-se alguns dos casos mais emocionantes desta fantástica e aventurosa carreira.

FAZ E FEZ TANTO QUE SÓ FALTA VIRAR ENREDO DE ESCOLA DE SAMBA, p.I54 Eugênia Gorini Esmeraldo

Conviver com o Professor é uma aventura constante: alternados o presenciar explosóes com alguém que "satura" sua paciência e a contagiante alegria e bom-humor.

Ganhamos pouco, é verdade, e ele mesmo reconhece, mas aprendemos muito. É fascinante vero Professor cuidar de detalhes mínimos do museu, sua "menina dos olhos." Desde a embalagem de uma peça delicada de cerâmica até a fiscalização das caixas dos quadros do acervo para exposiçóes no exterior: com tudo ele tem atenção. A mesma atenção que, por sinal, reserva às mulheres bonitas. É impressionante ver seu contentamento e interesse quando aparecem as moças, sinal de juventude e vitalidade.

E respeitoso com todos que o procuram. Responde a todas as cartas que recebe. Atende, se for preciso, a quem vem pessoalmente. Às vezes somos obrigados a pedir a compreensão dos mais insistentes, pois ele fica tão assoberbado com seus mil planos que precisa de tempo para "ajeitar tudo," como gosta de dizer.
Se isto é assim agora, fico imaginando como era no início do Masp, esta locomotiva que puxou os vagóes de todas as escolas de arte (de música à ecologia) das quais São Paulo era tão carente nos anos 50.

Mas não lhe falem em férias. Para ele é pura perda de tempo. O museu vicia, entra no sangue. E o Professor sempre lá, das nove às cinco.

Agora, porque até dois anos atrás, ficava até as seis. Âs vezes ainda chega as seis da manhã! Sempre pensando na frente, para daqui a dois anos. Faz e fez tanto que não vou me espantar se um dia destes o vejo como inspiração para o enredo de alguma escola de samba. O que seria uma surpresa enorme para ele e o maior golpe nas suas implicâncias, pois para ele o tríduo momesco e os campeonatos de futebol são o maior desperdício que, ainda por cima, nos festejos feitos na Paulista, póem em ameaça o seu museu.

Mas se este enredo acontecer, ele merece... E muito mais!

DANDO NOTAS E ESPERANDO TAMBÉm, p.I55

Pietro Maria Bardi

Nos manuais dos tempos em que Arte e Beleza eram a mesma sopa, uma dependendo da outra como gêmeas inseparáveis, havia a distinção entre Arte maior e Arte menor. Nesta última massificação se cozinhava o que não apresentava audácia, fama, grandiosidade. Foi assim que um dos interesses aos quais Bardi se dedicou foi a Arte Menor: as coisas que geralmente passam despercebidas, objetos de artesanato, populares, de produção industrial, procurando descobrir neles um senso, um gosto, um motivo engenhoso, agradável na forma, um prazer, uma simpatia estética.

Reservo ainda nota Io, nas páginas de Vogue, às mulheres bonitas e às vezes cannonate que consagram nossa juventude; Io também às páginas publicitárias que confirmam a originalidade do design brasileiro, lembrando-me que eu 
fundei, em 50, a primeira escola deste setor básico da arte; nota 5 (às vezes com um -) ao desfile social; notas menores não dou. Esqueci de dizer, reservo IO+, aliás Io++ aos números de Vogue que entronizam Pitanguy, Jorge Amado e outros valentes, esperando um voto deles para este número. (Omnia vanitas?)

Legenda p.I58 Os objetos que cumprem seu destino Cada cantinho da casa recolhe o que o dono pensa ser útil para satisfazer seu gosto: junta objetos, às vezes de valor, outras de simples curiosidade, até minúcias, as quais talvez suscitem surpresa no leitor de Vogue, com pontos de interrogação se acumulando um em cima do outro. Na lareira eis um delicioso mármore, que retrata Voltaire, do escultor Rosset. Quando se pergunta a respeito da procedência, as narrativas são as mais singulares, concluindo-se em estranhas circunstâncias: colecionar dá prazeres sempre afortunados, parecendo que o destino do objeto era acabar nas máos do B.

\section{p.I59 As aventuras de Diana para}

chegar no seu lugar Eis um mármore representando Diana que soma um longo percurso de viagens e aventuras as mais curiosas. Originalmente no Palazzo Spada, em Roma, restaurada no Setecentos por Bartolomeo Cavaceppi, foi levada para Inglaterra. De propriedade de lorde Egremont passou depois ao duque de Buckingham e, finalmente, para o castelo de Lowther, em Cumberland, onde B. a adquiriu no leilão de 47 , trazendo-a para São Paulo. Bloqueada na alfândega do Rio de Janeiro durante quatro anos, foi finalmente liberada através de uma intervençáo governamental.

p. I6o "Sou mais um comandante do que um subalterno."

p.I6I "Desmancharam tantas vezes meu prazer que me parece normal, aliás, justo, desmanchar também o de outros...” 
Anexo D

Arte Vogue 


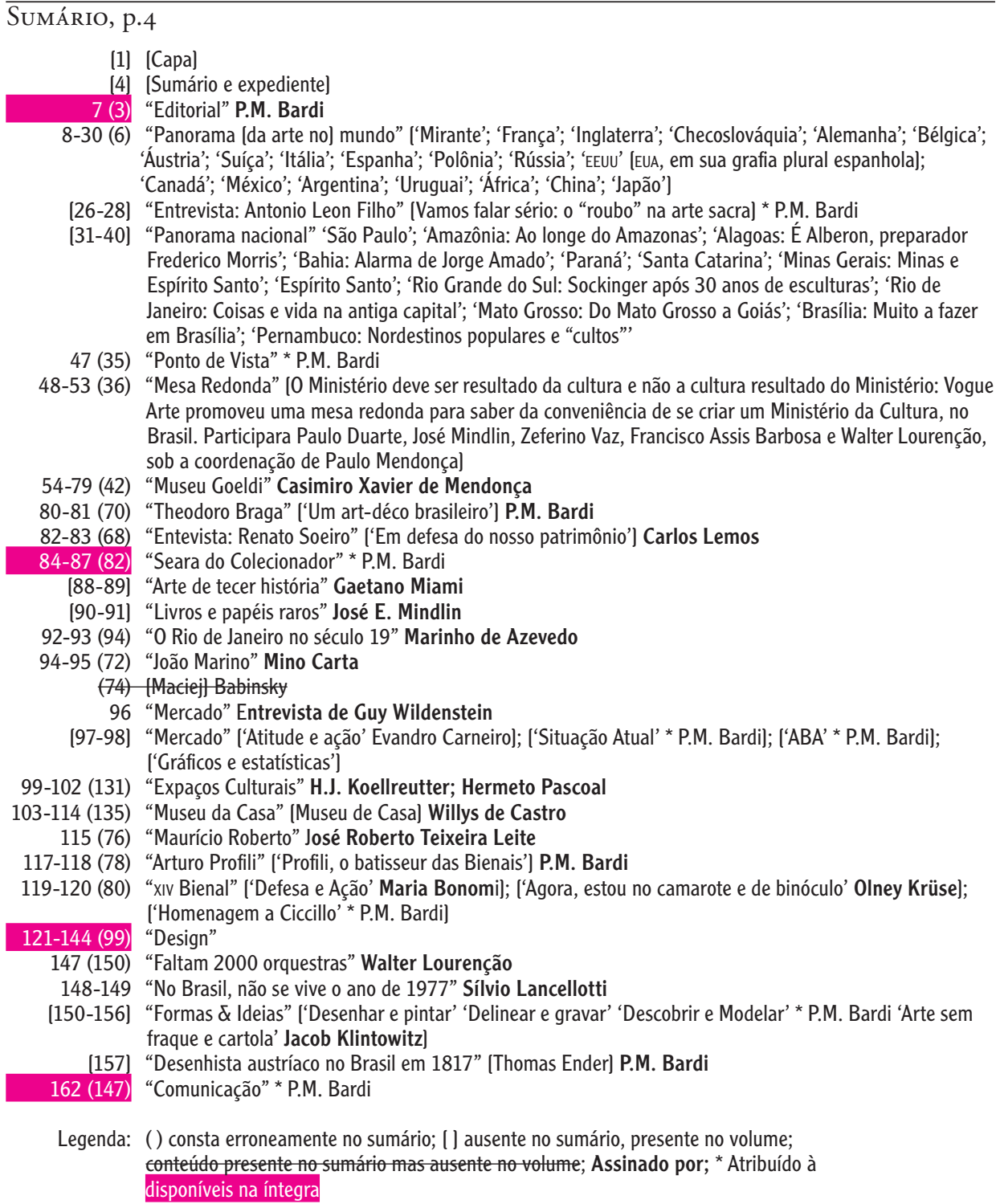
Frederico Morris'; 'Bahia: Alarma de Jorge Amado'; 'Paraná'; 'Santa Catarina'; 'Minas Gerais: Minas e Espírito Santo'; 'Espírito Santo'; 'Rio Grande do Sul: Sockinger após 30 anos de esculturas'; 'Rio de Janeiro: Coisas e vida na antiga capital'; 'Mato Grosso: Do Mato Grosso a Goiás'; 'Brasília: Muito a fazer em Brasília'; 'Pernambuco: Nordestinos populares e "cultos"'

47 (35) "Ponto de Vista" * P.M. Bardi

48-53 (36) “Mesa Redonda" [0 Ministério deve ser resultado da cultura e não a cultura resultado do Ministério: Vogue Arte promoveu uma mesa redonda para saber da conveniência de se criar um Ministério da Cultura, no Brasil. Participara Paulo Duarte, José Mindlin, Zeferino Vaz, Francisco Assis Barbosa e Walter Lourenção, sob a coordenação de Paulo Mendonçal

54-79 (42) "Museu Goeldi" Casimiro Xavier de Mendonça

80-81 (70) “Theodoro Braga" ['Um art-déco brasileiro'] P.M. Bardi

82-83 (68) “Entevista: Renato Soeiro" ['Em defesa do nosso patrimônio'] Carlos Lemos

84-87 (82) "Seara do Colecionador" * P.M. Bardi

[88-89] "Arte de tecer história" Gaetano Miami

[90-91] "Livros e papéis raros" José E. Mindlin

92-93 (94) "0 Rio de Janeiro no século 19" Marinho de Azevedo

94-95 (72) “João Marino" Mino Carta

(74) (Maciej) Babinsky

96 "Mercado" Entrevista de Guy Wildenstein

[97-98] “'Mercado” ['Atitude e ação' Evandro Carneiro]; ['Situação Atual’ * P.M. Bardi]; ['ABA' * P.M. Bardi]; ['Gráficos e estatísticas']

99-102 (131) “Expaços Culturais" H.J. Koellreutter; Hermeto Pascoal

103-114 (135) "Museu da Casa" (Museu de Casa) Willys de Castro

115 (76) “Maurício Roberto" José Roberto Teixeira Leite

117-118 (78) "Arturo Profili” ['Profili, o batisseur das Bienais'] P.M. Bard

119-120 (80) “xiv Bienal” ['Defesa e Ação' Maria Bonomil; ['Agora, estou no camarote e de binóculo' Olney Krüse); ['Homenagem a Ciccillo' * P.M. Bardi]

121-144 (99) "Design"

147 (150) "Faltam 2000 orquestras" Walter Lourenção

148-149 "No Brasil, não se vive 0 ano de 1977" Sílvio Lancellotti

[150-156] “Formas \& Ideias” ['Desenhar e pintar' 'Delinear e gravar' 'Descobrir e Modelar' * P.M. Bardi 'Arte sem fraque e cartola' Jacob Klintowitz

[157] “Desenhista austríaco no Brasil em 1817" (Thomas Ender] P.M. Bardi

162 (147) “Comunicação" * P.M. Bardi

Legenda: ( ) consta erroneamente no sumário; [ ] ausente no sumário, presente no volume; conteúdo presente no sumário mas ausente no volume; Assinado por; * Atribuído à disponíveis na íntegra

\section{P.M. Bardi}

Depois da Vogue dedicada à mulher e à moda, da Vogue dedicada à casa e da Vogue dedicada ao homem, chega a vez, no Brasil, da Vogue Arte A revista chega para intervir num campo fértil de atividades, inovaçôes, extravagâncias e discussóes tấo intensas que parecem anuviar o semblante tradicional da contínua busca do conceito e do tabu da arte - o belo.

Nos tempos correntes, quando a antiga redução filosófica do manifestar da arte tornou-se simples curiosidade, o labor-lazerilusão-conforto continua companheiro do indivíduo, mais último e indispensável, condicionando qualquer dos seus atos através dos inevitáveis usos e modismos, das oscilaçôes da moral. Mais, fazendo subir à tona aqueles ingredientes que participam do necessário e do supérfluo, das utilidades e inutilidades, das certezas e das perplexidades da vida. O homem precisa, cada vez mais, de informaçáo e, ao mesmo tempo, do convite à livre e espontânea discussão de uma larga gama de assuntos, inclusive aqueles não circunscritos à arte, mas que com ela intercambiam.

Cada qual à sua maneira, mesmo o habitar, o comer, o se comportar, o amar 
e até o guerrear podem ser classificados como formas de arte. Sem a pretensão de descobrir tesouros e sem prometer maravilhas, Vogue Arte se propóe a oferecer a um leitor curioso, exigente, uma revista como até agora jamais foi possível editar no Brasil. Vai basear-se especialmente numa variada e elaborada trama de informaçôes. A comunicação visual às vezes prevalecerá sobre a escrita - em função, é claro, das novas preferências impostas pela mudança dos gostos e pelo desejo de ver, mais do que ler. E como uma nação é parte do mundo, não deixaremos de sintetizar fatos, problemas e ações havidos no estrangeiro, ainda que mais páginas, naturalmente, falarão das coisas da vasta, laboriosa e ansiosa casa brasileira. Está aqui a arquitetura conjugada com progressos do urbanismo e as alarmantes exigências da ecologia. Estão a pintura, a escultura, ofícios aventurados, dizem as Sibilas, nos limbos do sobreviver. Está o invento popular, resistente às inclementes tentaçóes do folclore. Está tudo o quanto concorra na estruturada vida das formas.

Não instituiremos repartições visando a fórmulas da possível unidade das artes. Assim, saltando fora do âmbito das artes ditas plásticas, anotaremos coisas do palco e do vídeo, a música, a publicitária potência da comunicação integrada no cotidiano, a gráfica e o livro.

Lugar preferencial daremos, também, a outros capítulos da arte: a fotográfica, expressão de individualidade. E a tantas mais ocorrências e novidades que representarem parcelas da nutrição cultural. Vogue fará um registro independente, inaugurando um sistema de balança aferida com uso de pesos cordialmente medidos, aberto as propostas que produtores $\mathrm{da}$ criatividade e seus consumidores puderem avançar, até os limites do bom-senso.

Nestes tempos em que o historcismo não está sendo levado na devida conta, teremos todo o respeito e a consideração para com o passado, pois dele somos a consequência e a síntese, negando firmemente a ignorância que hoje diz ter a arte começado com Picasso, Mies e Giacometti. Por isso as páginas de Vogue Arte abrigam uma reportagem dedicada ao Museu de Belém do Pará, o mais elevado patrimônio daqueles que aqui estavam antes da descoberta e ao seu fundador, o sábio Goeldi, e ao esquecido Theodoro Braga, que tentou o revival do estilo marajoara, a única contribuição brasileira ao art-déco.

Os assuntos são numerosos e desafiantes. Neste primeiro número, a matéria central é dedicada ao design, tema vivo de um setor que consideramos como um sério problema nacional. Depois da escassa consideraçáo e das raras experiências que o envolveram o design reclama a atenção do próprio governo como elemento expressivo e a generalizado de cultura. Um automóvel, uma geladeira, um cartaz, uma caixa de fósforos assumem alentado significado estético, são produtos e implicaçôes da civilização industrial e do jeito que condiciona o dia-a-dia de hoje. Nesse sentido, um grupo de pesquisadores, aos cuidados de Lais Moura, realizou um documento de crucial interesse, com as opinióes de quem se preocupa com os problemas - e os debates. Foi também por isso; que decidimos abrir a revista com uma mesa redonda dedicada à necessidade de se pensar num Ministério da Cultura. Mas, digressionemos, pois este é um meio de evitar a cacetice dos editoriais, e voltemos à História. Outra secção que enfocaremos é o setor genericamente dito do antiquariato e o interesse que ele vem despertando, depois de alguns anos, um sintoma da evidente conscientização nacional que favoreceu o aparecimento de colecionadores e, consequentemente, de um mercado, setor este atentamente referido e tecnicamente analisado, procurando noticiar a realidade, sem empalmar sugestóes.

Destaque, é óbvio, igualmente estamos dando aos participantes da vida das artes, sendo pinçados, desta vez, um pintor, um colecionador e um arquiteto.

A realidade brasileira das artes não é mais como há algum tempo, que dependia dos modos de fora. Estão surgindo novos pontos de vista a respeito do fazer internacional, e por isso alinhavamos um amplo relato ao que observamos lá fora, avaliando-o com consideraçôes para uma melhor compreensão não passiva e, por que não dizer, decididamente crítica.

Ocasionalmente, o relevo dedicado à futura Bienal Paulista faz parte do contexto. 
Pois, sendo o Brasil o organizador do tradicional certame, é oportuna uma informação e, ao mesmo tempo, uma lembrança saudosa daquele que muito operou para o êxito daquela empresa.
O leitor encontrará vários enfoques. Caso discorde, poderá escrever à Vogue Arte. Como já foi dito, a revista está com suas portas abertas e gosta de mergulhar em discussões. Não custodiamos na gaveta a pedra filosofal.
SEARA DO COLECIONADOR, p.84-87 atribuido a P.M. Bardi

Em casa de um colecionador, culto e inteligente, reuniu-se um grupo de amigos para apreciar peças recentemente por ele adquiridas. $\mathrm{O}$ encontro originou algumas observaçóes relacionados com o valor, necessidade e prazer em recolher, discutir sobre o gostar e estudar coisas e problemas da arte e história. O informal simpósio foi gravado. Da troca de ideias e consideraçóes escolhemos alguns trechos que abaixo reproduzimos, assim inaugurando esta Seara.

\section{O hobby de colecionar}

Alguém frisa que pessoas tranquilas e até de certa forma possuidoras de cultura, convencidas de que conduzem suas vidas nos trilhos da normalidade corrente, costumam declarar que não entendem de arte. Talvez para que outras não as apontem como excêntricas, ou para impedir que surjam as perguntas do gênero: "Mas por que você coleciona? Você tem prazer nisso?” Muito natural que uma réplica seja difícil de ser formulada, pois quem coleciona o faz para satisfazer um prazer invariavelmente inexplicável. Um hobby, surgido em circunstâncias nem sempre recordadas: ocasiáo, diversão como tantas outras que surgem sem que se saiba, às vezes, os motivos.

Um exemplo oferecido por um senhor que se declara colecionador de objetos mecânicos antigos: "é muito comum os moços se tornarem filatelistas, como é comum eles desistirem de tal prática. A desistência, porém, não impede que esse hobby seja extraordinariamente difundido pelo mundo inteiro, aliás, rico de adeptos a ponto de jornais lhes dedicarem colunas diárias, do mesmo modo que o jogo de xadrez e as palavras cruzadas, as historietas em quadrinhos e a previsão do tempo. No que se refere ao antiquariato, os jornais só registram roubos ou falsificaçóes, pensando mais em escândalo do que em outra coisa.
O interesse dos curiosos se volta para um tipo de colecionismo mais emocionante, com objetivos mais culturais que a mecânica da manipulação dos selos. (Um colecionador de pinturas, que é também filatelista e numismata, protesta contra o adjetivo 'mecânico;' de fato admite-se que qualquer tipo de colecionismo tem suas emoçóes e prazer.) Concorda-se que, recolher obras de arte, o interesse é bem mais variado já que o antiquariato é um inesgotável campo de aventuras. $\mathrm{O}$ homem outra coisa não faz senão produzir apetrechos de uso, de ornamento e de culto, um mundo, real e fantástico, corriqueiro e imprevisível, que desperta curiosidade e admiração e, consequentemente, o gosto de possuir partículas daquele universo, o prazer de remexer e descobrir pedaços da história e também voltar a atenção para o trabalho dos contemporâneos. No caso, o prazer de contribuir em favor da operosidade dos artistas."

\section{$\mathrm{O}$ respeito pelo tempo}

Agora vêm à tona as origens. Nota-se que uma vez que um povo leva a bom termo seu labor existencial, sistematizando-se, ajeitando a nação, espontaneamente se empenha na elucidação do seu passado, investigando-o, estudando-o, considerando-o com amor. É a extensão do respeito e do carinho que devotamos aos pais, retroagindo nos decênios, nos séculos, ampliando o encontro com o tempo e o espaço. Observa-se: também em 1977 continuam as comemoraçóes do segundo centenário da independência dos Estados Unidos, particularmente as exposições que se tornaram possíveis graças à compreensão dos cidadãos e de constituiçóes culturais preocupadas em registrar os vestígios da história, artes e signos da vida nacional. Naquele país, favorecido pela opulência econômica e também pela curta mas intensa tradição e intercâmbio 
cultural, (um convidado lembrou que Goethe ofertou suas obras à Universidade de Harvard, escrevendo na dedicatória que desejava sentir-se mais perto da admirável nação que chamou para ela a consideração de todo o mundo) o gosto do colecionismo teve e continua a ter excepcional número de elementos. O norte-americano se interessa pelo colecionismo de qualquer tipo de coisas desde que tenha significado histórico, ou que pensa tê-lo no futuro. Qualquer cidade, por menor que seja e mesmo que acontecimentos em nada ou pouco contribuíram para determinar crônicas memoráveis, têm seus museus, seus antiquários, suas galerias, seus cultores. O colecionismo é moda, é lazer e, consequentemente, um labor que apaixona ou, num sentido mais venal, elemento de poupança. (Comenta-se: defesa contra a inflação.) Leilóes e intensa tratativa mercantil, animadoras trocas e barganhas entre colecionadores, formação de clubes, recrutamento de participantes são comuns nesta atividade. $\mathrm{O}$ mais exemplar espetáculo é que os objetos guardados no recesso dos lares, um dia ou outro, acabam doados aos museus. $\hat{E}$ quando civismo é civismo. (Lembra-se que o sr. Samuel Kress, um dos maiores doadores da National Gallery de Nova York, dizia: "O dinheiro me veio do povo, ao povo volta.")

\section{Aconteceu nos Estados Unidos}

Como nasceu o colecionismo?, indaga um dos presentes. Ninguém pode precisar, mas há quem lembre do diletante de arte, de conchas, de minerais, nos idos dos anos setecentos. A conversa se anima, e se registra o que aconteceu nos Estados Unidos nos últimos anos do século ig e no começo deste: numerosos marchants europeus se transferiram para Nova York, desenvolvendo lá ação fortemente persuasiva junto aos bigs das finanças e da indústria, conseguindo convencê-los do certo e permanente valor das obras de arte. Citou-se o caso do mágico sir Duveen, famoso como um Buffalo Bill, conseguindo transferir de além oceano fortunas incalculáveis, despertando a emulação entre os que podiam enriquecer suas casas com tesouros que valiam mais que ouro e diamantes. Foi assim que nasceram os Pierpont Morgan, Frick, Mellon, Kress, Chester Dale. Um lembrete: este Senhor aliás grand seigneur, doando uma bela natureza morta de Antoine Vollon, o mestre de Pedro Alexandrino, ao Masp, se congratulava com o sr. Chateaubriand, dizendo-lhe: "Faça como nos Estados Unidos; convença os ricos a investirem em arte."

O Brasil não tem, por enquanto, a história dos Estados Unidos. No que se refere a investimentos em obras de arte, porém, parece aos presentes mais capacitados em assunto de economia, que ainda não adentramos na fase inteligente, isto é, o considerar o problema da arte. Começou-se a concentrar esforços para a valorização das coisas nacionais, mas as atençôes precisam voltar-se para a ampliação dos interesses em senso universal.

$\mathrm{Na}$ oportunidade vem à tona uma informação: alguns dos mais vivos propulsores do mercado internacional, notadamente de países europeus mais afetados por crises políticas, visitaram recentemente o Brasil para estudar, na base de marketing, as possibilidades de uma ação, mutatis mutandis, no tipo americano implantado no período mencionado linhas atrás. As conclusôes a que chegaram foram negativas. A opinião geral é de que ainda em 1977 náo teremos o ano propício, porém, continuando o interesse para com a arte nacional.

\section{Uma estória antiga}

Certamente que os americanos aprenderam dos Europeus, o que nos faz pensar que este modo de guardar vem de longe. Objetos eivados de afeição chegaram ao Novo Mundo levados pelos emigrantes, muitos deles amadores, alguns possuidores de cabinets, maníacos inoculados com o vírus colectio (termo latino, no Brasil de amena memória pelas travessuras de um megalômano) isto é, pessoal, desejoso de deitar as máos nas raridades e nas curiosidades. Um participante do colóquio, amigo de colecionadores de parcos recursos, mas dedicados à tarefa, lembra os que colecionam figurinhas de caixas de fósforo ou de cigarro; outros de rótulos de garrafas de pinga; de brinquedos antigos. As searas do colecionismo são reservadas às mais imprevisíveis safras. (São recordados o instituidor de um museu do sapato nas Casas Eduardo, os ajuntadores de relógios, de arte popular, de instrumentos musicais e cirúrgicos; 
qual o objeto que não tem o seu valor? Lembrar os bibliófilos é coisa pacífica.)

A Europa, não no tempo das descobertas de novas terras, mas no tempo dos gregos, foi realmente mestra na ideia de conservar e classificar. A Idade Média, depois das convulsóes determinadas pela exaustão do Império Romano, consegue evitar a destruição de boa parte do patrimônio espiritual artístico das civilizaçôes, que as sucessivas geraçóes vão considerar, insaciáveis de descobrir história. É colecionismo? Alguém entre os presentes avança: providencial iniciativa do homem, afinal bastante consciente do seu viver. As guerras, os terremotos, o fogo, as inundaçóes, os roubos, enfim toda sorte de calamidades, destroem. Sempre existe, porém, quem salve obras de arte.

A referência ao Brasil brota naturalmente: aqui o gosto pela salvação, é a palavra certa, de monumentos e materiais de sua breve história, não passa de atividade recente. Bom será lembrar o carinho de uns quantos idealistas que, durante o reinado de d. João vi, naquela heroica empresa de sair dos séculos da degradação colonial, se empenharam em dar base a uma cultura visando à preservação. Porém, não faltaram às destruiçóes, pena, o desprezo pelo patrimônio do passado. Ao longo dos anos oitocentos, raras são as coisas que foram preservadas. Alguém enumera os culpados. Por exemplo: o clero que deveria conservar as relíquia alinhou, infelizmente, membros que foram os primeiros a despojar das Casas de Deus, trocando imagens preciosas por outras de gesso pintado. E a prata e o ouro fundidos? Os arquivos registrando a infância, a adolescência da nova pátria, serviram e servem de pasto para a cupinzada, deixando infelizes os responsáveis pelo patrimônio e, portanto, reclamando mais memória para a história do país. Um otimista presente pondera: "Na verdade, as coisas melhoraram." Redargui o pessimista: "Ainda hoje as crônicas acusam o desinteresse do próprio governo, pois este não intervém em casos penosos com leis e açôes enérgicas."

Poderá parecer romântico, mas os presentes acham que algum basta já foi dado no sentido de pôr cobro à delapidação das nossas igrejas e à destruição do palácio onde viveu o consolidador da nação brasileira, o duque de Caxias.

\section{Os colecionadores}

Uníssonos são todos no mesmo parecer: aleluia ao labor do colecionador, que deve ser incentivado e elogiado. O colecionador é um conservador de coisas merecedoras de sobreviverem para não serem eliminadas pelo abandono e pela exportação, pois mesmo no estrangeiro existe quem se interesse. Um observador compara a funçáo dos colecionadores e dos comerciantes de objetos antigos brasileiros aos monges que conservaram, no período mais obscuro da era Medieval, os palimpsestos gregos e romanos, conjuntamente com a tradição da cultura. Um dos convidados aparteia diante de comparaçáo um tanto paradoxal. Resposta: "Os paradoxos servem para ressaltar fatos senão de cunho universal pelo menos importantíssimos para nós." Outro lembra que Bernard Shaw dizia que a história que lhe interessava mais era a de sua tia.

Alguém recorda que, quando da morte do saudoso Marques dos Santos, tido no Rio como o príncipe dos antiquários, e que depois foi o apaixonado diretor do Museu Imperial de Petrópolis, os preciosos manuscritos por ele recolhidos ao longo de meio século, de brava operosidade, acabaram dispersos no comércio e, hoje, felizmente, se encontram em mãos dê brasilianistas que são numerosos e ativos, quando na verdade deveriam estar recolhidos na Biblioteca Nacional. (É verdade que o governo náo pode comprar tudo, porém, como são mixurucas nossos museus, a verdade é que também as doaçóes de particulares sáo raras autenticas moscas brancas.) Certamente algum colecionador vai conservar e estudar aqueles documentos, praticando assim um verdadeiro gesto de benemerencia e patriotismo.

Outro assunto em pauta foi o da inauguração de um mercado. No momento mais interessam os nomes da pintura nacional, os chamados clássicos. (Portinari, Di, Neri, Rego Monteiro Pancetti, Guignard, Tarsila, Anita, Volpi, o décimo nome cada um pode alinhar conforme sua preferência e conveniência.) Melancolicamente, o mercado anda menos interessado em 
outros valores não somente da pintura, uma vez que existe a escultura e quantas outras produçóes de arte. Nota pitoresca: em consequência deste boom a gente que olha agora as paredes da casa, reconsidera bibelôs eliminados pelos avós por estarem fora de moda, desempoeira velhos móveis e logo salta a já clássica pergunta: qual o seu valor? Cada cidadão pensa ter um tesouro e logo correra às casas de comércio. Alegando que vai mudar de habitação ou outra deslavada mentira, pede uma avaliação, faz uma pesquisa de preços, frequenta leilóes e, farto de bater nas portas tupiniquins, escreve ao Louvre para saber o quantum da sua preciosidade. O resultado de todo este trafegar é que o colecionismo acaba por ganhar novos materiais.

\section{A descoberta do Brasil}

Não tenhamos dúvidas; no instante em que a situação internacional se acomodar, veremos o Brasil dar mais algumas passadas na senda do colecionismo. Estamos encaminhados. Um dos presentes se lembrou de um dos tópicos em matéria divulgada pela revista Exame, de alguns meses atrás: "O problema, na verdade, é um problema de cultura." (Não é por acaso que Vogue Arte debate, nesta sua primeira ediçáo, a urgente necessidade do desdobramento do Ministério da Educação e Cultura em dois pois o país precisa organizar, definir e dinamizar um plano de cultura. Sem desmerecer profetas, políticos, intelectuais, burocratas e mais cabeças pensantes e de coraçóes generosos, precisamos estruturar uma cultura mais em consonância com os destinos de um Brasil potência emergente.)

Neste último decênio, para voltarmos às discussóes do simpósio amical (as digressóes são naturais, pois o assunto comporta alguns termos paralelos), numerosas e positivas foram as conquistas até aqui alcançadas. Cumpre coordená-las. O colecionismo vai marcar com seu de contribuidor. Bom será se diversificado, certo sentido, desnacionalizado, cuidando-se de incentivar os estudos históricos e as pesquisas. Numa palavra: o colecionismo é uma base para fortalecimento da cultura, enfrentando o preocupante desafio representado pelo panem em novelas.

\section{Legenda}

p.84 Capitel talhado em madeira, atribuída a Aleijadinho, fins do século I8, 45 x 48. Col. Paulo Vasconcelos, São Paulo g Vaso de vidro encamisado e tratado a jato de areia, assinado Gallè. Col. particular, Curitiba PR g Coroa de "Bumbameu-boi," arte popular do Maranháo. Col. particular, São Paulo g Compoteira em pedra sabão, originária de Ouro Preto, MG, alt. $35 \mathrm{~cm}$. Col. Paulo Vasconcelos, São Paulo 9 Prato de cerâmica florentina com inscrição "Gentil e Bela," século I5, diam. I9 cm. Col. particular, São Paulo I p.87 Jukebox, Wurlitzer, toca-disco com seleção automática, mod. no 750 , em perpex, caixa de madeira em arco e metal niquelado, datadodel939. Alt. de $145 \mathrm{~cm}$. Col. Fulvia e Adolfo Leirner, São Paulo g Locomóvel gerado a vapor. A composição tem 3 m. Col. Paulo Vasconcelos, São Paulo Ventilador gerado a álcool, em ferro fundido, alt. $5 \mathrm{I} \mathrm{cm}$ e diam. $33 \mathrm{~cm}$. Col. Paulo Vasconcelos, São Paulo g Taxímetro fabricado em Berlim, dotado na parte posterior da máquina de adicionar, 1915. Col. particular, São Paulo g Caçaníquel fabricado pela Bunker, I900, 49 x $29 \mathrm{~cm}$. Col. particular, São Paulo

p.87 Prato com as armas da família Carvalho e o grande colar da Ordem da Rosa, da Chamberlain's Wororcester. Royal Manufacturers, Londres, quepertenceu ao barão de Penedo (Alagoas I8I5-Rio I906,) Col. EldinoBrancante, Rio de Janeiro 9 Naveta-caravela e turíbulo, prateirobrasileiro doséculo I7. Col. Sandro Mancurti, São Paulo G Claude-François-Marie Rosset, dito Rosset (I780-I828), Voltaire, mármore assinado, alt.. Coleção particular, São Paulo 9 Serviço de chá e café com figuração, chinoisemestilo George III, prateiro W. Fountain, I8I6 bandeja estilo vitoriano, prateiro W. Bernard I896. Col. particular, São Paulo

\section{Design, índice, p.I2I}

Para coordenar este caderno dedicado ao Design, Vogue Arte solicitou o empenho de um dos críticos mais bem informados do país: Lais Moura. A qual vem seguindo com atençáo e compreensão os nascentes e nada fáceis problemas das artes no 
Brasil e, mais especificamente, o do design representando e condensando ampla quantidade de outros problemas que atingem inúmeros casos interligados à vida e consequentemente à cultura.

Nestas páginas não se propóe nem historiar nem ilustrar o problema em todos os seus aspectos, mas táo-somente indicar possíveis soluçôes. A intenção é provocar ampla discussão e, ao mesmo tempo, despertar a atenção governamental, já que o design é um entre os inumeráveis casos da cultura nacional à espera de melhor consideração, como se poderá inferir de depoimentos de autores responsáveis.

Convidamos para prestar depoimentos, tratando-se de um assunto próprio do setor, elementos realmente em condiçôes de opinar. Certamente não são todos que desejaríamos publicar. Repetimos: nosso propósito é de abrir e ativar uma discussão que, certamente, nas próximas edições, terá continuidade.

\section{Histórico}

Graz-Gomide

Selos-Visconti

\section{Crítica}

Design-designer

Abertura crítica

Normas técnicas

Formato padrão

Equipamentos urbanos

Operação-bicicleta
Metrô de São Paulo

\section{Depoimentos}

Aloísio Magalhães

Alexandre Wollner

José Ephim Mindlin

Lina Bo Bardi

Lúcio Grinover

Jornais

Última Hora

Correio da Manhá

Jornal do Brasil

Jornal da Tarde

Programa de identidade empresarial

Indústria

Desenho radical?

Moda

Polêmica: Design brasileiro

Marcas

IAC

Emilie Chamie

Alexandre Wollner

Antonio Maluf

Aparício Basílio da Silva

Ludovico Martino

Maurício Nogueira Lima

Design: DecoraÇão GraZ-Gomide, p.I22

$\mathrm{Na}$ década de 20, alguns artistas brasileiros, ao retornarem da Europa, traziam em seu universo visual o vocabulário do art-déco. E porque eles se dedicaram predominantemente às artes decorativas, a tendência parece mais nítida na obra de Regina e John Graz, embora também se faça notar no trabalho de Antônio Gomide. A produção destes artistas pode mesmo ser considerada como uma síntese das tendências da vanguarda europeia e do art-déco. Atuam como elo de ligação entre pintura ou arquitetura e artes aplicadas, traduzindo a estética do cubismo, futurismo, neoplasticismo, construtivismo em termos ambientais. Mas, pouca coisa chega até nós das artes decorativas do casal Graz e de Antônio Gomide. Em alguns casos, por trabalharem os três com materiais perecíveis. Em outros, por integrarem residências ou edifícios já destruídos. $\mathrm{Ou}$, ainda, por mero desconhecimento.

Assim que voltou ao Brasil, Regina se dedicou ao artesanato de tapetes, panneaux, almofadas, tapeçarias, dividindo-se entre as encomendas e o ensino desse ofício às senhoras da sociedade. O seu volume de pedidos aumentou tanto que, por volta de 1950, ele abriu uma fábrica de tapetes e tapeçarias. A geometrização cubista está sempre presente nas suas composiçóes 
abstratas ou figurativas. Regina trabalhou com vários tipos de veludos, fios de metal, tapeçaria. Fez um estudo da tecelagem indígena do alto Amazonas, cujo resultado apareceu em algumas de suas tapeçarias. Esta ordem de preocupação é típica do art-déco, com toda a corrente de interesse pelas artes arcaicas, exóticas ou primitivas. Mas a produção de Regina não se fazia isoladamente - participava de um trabalho de equipe, onde todos os integrantes compartilhavam dos mesmos ideais. Caso, por exemplo, de sua colaboração na decoração da Casa Modernista de Grigori Warchavchik, em I930.

Embora pintor, a obra de John Graz abrange o que poderia chamar de arquitetura de interiores, uma vez que ele projetava a distribuição espacial, o mobiliário, os aparelhos de iluminação, além de realizar painéis, murais e vitrais. É importante notar, no casal Graz, a preocupação com o design total, conceito que estava presente tanto nos ideais da Bauhaus, quanto nos designers art-déco. Nesse sentido, seu trabalho pode ser considerado como início, ainda a nível artesanal, do design brasileiro.

A atuação de Gomide no campo das artes decorativas é menos conhecida, embora tenha ele realizado um número considerável de afrescos, murais, vidros gravados, azulejos, painéis de mármore e principalmente cartóes para vitrais. $\mathrm{O}$ vitral era então um elemento decorativo bastante utilizado, aparecendo tanto nas residências mais abastadas como nas mais simples.

Em São Paulo, quase todos os desse período foram realizados pela firma Conrado Sorgenicht, que elaborou inúmeras encomendas aos Graz-Gomide. Os vitrais do portal do Parque da Água Branca, projetado em 1928 por Gomide, talvez possam ser considerados como o primeiro exemplo de integração arte/indústria no Brasil. Conrado Sorgenicht, através do contato com artistas e intelectuais da época, teve uma compreensão muito lúcida de seu tempo. Ao proporcionar a possibilidade de trabalho de parceria entre o artista e a indústria, ainda que em pequena escala, estava timidamente colaborando para que o objeto industrial se tornasse significativo dos valores culturais da época.

\section{Legenda}

Sala de estar da Casa Modernista projetada por Gregori Warchavchik, em exposição de 26 de março a 30 de abril de I930. Móveis prateados a duco, quadros de Tarsila do Amaral e Lasar Segall. O tapete é um original das oficias da Bauhaus, Dessau, Alemanha

\section{Design: Selos, p.I23}

Brasil foi o segundo país do mundo a adotar o selo postal, dois anos após sua invenção, ocorrida em I840, na Inglaterra. O desenho do primeiro selo brasileiro deveria ser semelhante ao do modelo inglês, com a efígie do imperador reinante. Entretanto, o provedor da Casa da Moeda, naquela época, Camillo João Valdetano, argumentou: “... permita-me V. Excia., que aproveitando a oportunidade, observe que quer se façam selos, quer chapas, será mister adotar modelos que dificultem a falsificação e sejam conforme nossos costumes". Daí os Olho de Boi terem usado como elemento gráfico apenas o número, para indicação do valor do porte, sobre um fundo geométrico, gravado mecanicamente. Seu caráter original deveu-se, portanto, à iniciativa de um funcionário da Casa da Moeda e não dos responsáveis pela implantação da reforma postal e do selo no Brasil. Hoje seria necessário que outro funcionário de bom-senso alertasse seus superiores quanto ao caráter do selo postal, como produto industrial de função específica, onde não cabem soluçôes gráficas arbitrárias, mas, ao contrário, exigem a elaboração de projetos que venham a atender suas características atuais como veículo de comunicação, além de sua função original de portear correspondência. Projetos de Eliseu Visconti premiados em concurso realizado em 1904. Frederico Barata em Eliseu Visconti e Seu Tempo, I944, escreveu: "Toda a imprensa, na Europa e na América, festejou os novos modelos de selos brasileiros, felicitando o governo por ter sabido incumbir um verdadeiro artista da execução dos desenhos ... Até o presente, porém, aguardam os filatelistas a ordem de 
impressão para estes selos que deviam ter enriquecido a coleçáo nacional, ao invés de, perdida toda a oportunidade, amarelecerem os seus modelos em algum dos empoeirados arquivos da repartição postal".

"Pena que o artista, imbuído dos ensinamentos da escola francesa de entáo, não se tenha orientado por uma senda nacionalista", diz Frederico Barata em Eliseu Visconti e Seu Tempo, - pois, em comparação com a pintura, "um caráter brasileiro só pode ser conseguido pela arte decorativa”, uma vez que ela "penetra em todos os recessos do povo. Reflete-se, pela indústria têxtil, nas roupas que esse povo usa, pela cerâmica que vai ao palácio do potentado e à cabana do humilde; seus motivos tanto se gravam nas calçadas das ruas como no mosaico dos salóes, nos azulejos dos templos ou nos móveis dos lares. As artes gráficas, nela inspiradas, veiculam-se aos mais longínquos pontos do território nacional. É este infiltramento, esse poder de expansão, rápido e educativo, que lança em um país jovem as bases de uma arte nacional".

Enfocando o selo do ponto de vista do design gráfico com rigor metodológico, a tese defendida na ESDI, em I972, por Maria Carmen C. de Magalhães Ribeiro e Suzana Valadares Fonseca, é trabalho de indispensável consulta para todos os que se propóem a desenvolver projetos de selos postais.

\section{Legenda}

Única carta com três Olho de Boi; foi mandada 22 dias após a saída do primeiro selo brasileiro. Provavelmente a carta mais antiga do continente americano. Cedida por gentileza do sr. Ralf Harold Meyer

Design: CRítiCA, p.I24-I27

\section{Design e Designer}

Os propósitos e a esfera de atuação de design foram controvertidos desde suas origens. A predominância do exercício da profissão em dados setores e durante períodos específicos, porém, permite o traçado de uma trajetória apresentando pontos de inflexão - ou seja, mudanças de direção significativas. São muitas as variáveis que determinam tal trajetória. Têm maior peso, contudo, as de ordem ideológicas, intimamente vinculadas à política e à economia.

A Segunda Guerra Mundial marca o início de uma curva de inflexão, segundo orientação que, só a partir dos anos 60 , tem sido reconhecida e engrossado fileiras. Até então o design se limitava a projetos para a determinação da forma, tendo em vista a função de objetos ou sistema de objetos industrializados. No Ocidente, este tipo de atuação condicionou a adoção pelo design dos objetivos mercadológicos da indústria capitalista. Nestas circunstâncias, o objeto, ou melhor, a imagem do objeto a ser consumido, era a preocupação predominante, em detrimento do homem só considerado em termos de consumidor, caso ele o fosse, ainda que potencialmente; caso contrário, ele náo participava do universo do designer. Nesta época, portanto, a influência de fatores de caráter humanista ou antropocêntrico na trajetória do design, atinge ao mínimo de seu decréscimo progressivo verificado a partir de valores máximos alcançados nos momentos iniciais da industrialização, ainda no século i9. Particularmente, se nos lembrarmos da preocupaçáo de William Morris com o destino do homem da era da máquina, e mesmo neste século, a manifestação gradativamente mais rara, impotente e utópica de ideais visando ao estudo das reais necessidades do ser humano e da utilizaçáo da capacidade de produção em massa para dar a todas as pessoas, condiçóes dignas de existência.

A aceleração do desenvolvimento tecnológico nas últimas décadas e os consequentes problemas e ameaças que começaram a pairar sobre a aldeia global, determinaram que o design, sofrendo processo análogo a várias outras disciplinas, fosse questionado quanto ao seu papel no mundo contemporâneo. Resultou a volta à consciência de que esta profissão deve prioritariamente cuidar das condiçóes de vida do homem, seja qual for seu habitat, suas condiçóes de industrialização, seu poder econômico, político ou social. Ou ainda, à consciência da necessidade da instituição ou preservação dos direitos humanos, não 
no sentido restrito atualmente em voga, mas no seu mais amplo significado.

Resta a pergunta: por que caberia, hoje, ao profissional do design tal responsabilidade? Teoricamente, o designer tende a atuar na confluência de áreas com poder de decisão político-econômica e com autoridade ou capacidade para esclarecer e educar o indivíduo - áreas estas representadas pelos sistemas governamentais, produtivos e seus canais de ligação com as populaçóes, a comunicação de massa. Por outro lado, nos melhores currículos de formação do designer convergem disciplinas, em sua maioria surgidas ou revalorizadas recentemente - tecnológicas, exatas e humanas que têm permitido ao pensamento contemporâneo, digamos, enxergar a situação da humanidade de hoje. São exemplos: a linguística, antropologia cultural, teoria da informação, ecologia, bioengenharia, gestalt, ergonomia, entre outras. Com tal formação, este profissional teria condições de coordenar os fundamentos teóricos e o ferramental (métodos e técnicas) concebidos e colocados à disposição pela idade atual para a resoluçáo de seus problemas. Assim, conforme comprovam várias iniciativas internacionais, o designer não seria especificamente o projetista, mas o planejador de soluçóes visando a salvaguardar a qualidade de vida nos nossos tempos.

\section{Abertura crítica}

Usos e costumes de uma sociedade acabam participando do sistema de crenças dos elementos do grupo, em todos os setores e a toda os níveis. Fundamentam premissas da filosofia e da política locais, condicionam peculiares processos lógicos e, na prática, manifestam-se no enfoque e tratamento dado aos problemas tanto no plano do individual quanto do coletivo. Tais usos e costumes raramente são questionados, devido mesmo ao envolvimento dos indivíduos no ser coletivo e à dificuldade de distanciamento da situação vivenciada, que certamente conduziria a uma reflexáo crítica quanto ao significado e à verdade desses condicionamentos sociais.

O preâmbulo é para dizer que, nos grandes centros urbanos brasileiros, estabeleceram-se hábitos de trabalho que se arraigaram profundamente, tornando-se característicos e assumidos como parte da realidade brasileira.

Um deles é o devagar como são recebidos os problemas que invariavelmente conduzem, no minuto final, às soluções de urgência. Isto em todos os aspectos. Seja na reflexão de um assunto a resolver, levando a atitudes precipitadas, marcadas pela ausência da maturação necessária ao bom-senso, seja nos métodos de desenvolvimento de trabalhos, obrigando o passar ligeiro sobre etapas, ou mesmo a saltos pulos, superando-as na consideraçáo de que etapas intermediárias entre início e fim de trabalho são dispensáveis, e aquelas posteriores ao fim, isto é, da aplicação dos resultados, da continuidade e da manutenção das intervençôes representadas por qualquer trabalho, são consideradas totalmente desprezíveis.

E isto ocorre, com maior ou menor frequência e intensidade, no decorrer do desempenho das atividades de cada um dos que estão neste mesmo barco. Porém, cabe-nos alertar - ao depararmos com casos ao alcance de nossa avaliação -, para que também sejamos alertados em nossos escorregóes.

\section{Normas técnicas}

Talvez agora, quando o Brasil se lança maciçamente à conquista do mercado externo, crie-se no país a consciência de que normas técnicas e controle de qualidade são fatores de venda e não meras exigências teóricas. Porque é certo que o importador, ao receber diferentes remessas de qualidade extremamente oscilante, estranha o fato e cancela os pedidos, como frequentemente tem ocorrido.

Não é possível conceber projetos industriais quando não existe a possibilidade de especificação unívoca de materiais. $\hat{E}$ antieconômico, por outro lado, projetarem-se todos os elementos sob medida - por não existirem componentes padronizados, nem mesmo matéria-prima normalizada.

O problema, embora grave, tem soluçôes como a de educar consumidores, comerciantes e industriais, instruindo-os quanto à necessidade e às vantagens advindas da normalização técnica. É preciso criar e aplicar dispositivos, programas de 
esclarecimento e incentivo que só virão em benefício do produto industrial brasileiro.

Basta observar o exemplo da indústria automobilística. Os fornecedores de autopeças foram conscientizados da obrigação de fabricar seus produtos segundo normas especificadas e rigoroso controle de qualidade. $\mathrm{O}$ fabricante passou então a exercer total observância a ambas as exigências. Ninguém se queixa, o que prova ser possível trabalhar sob normas.

Longo é o caminho a ser vencido na corrida desenvolvimentista e de nada adianta pular etapas neste processo sem a imprescindível infra-estrutura da qual fazem parte as normas técnicas e o controle de qualidade.

\section{Papel formato padrão}

Após cinco anos de vivência do decreto federal adotando o A-4 como o formato padrão para os papéis das repartiçóes públicas, estas continuam exigindo que os requerimentos dos usuários sejam no chamado formato ofício, abolido por ser antieconômico.

Agora, os Correios vêm de padronizar o formato dos envelopes para permitir a leitura eletrônica do código de endereçamento postal. Seria necessária a aplicação de programa eficiente de esclarecimento e instrução ao público quanto às novas normas, a fim de diminuir a frequência do acender das luzinhas vermelhas das leitoras automáticas, acusando a rejeição dos envelopes.

Em nossa metrópole reina o caos visual. Não há, por exemplo, normas ou códigos regulamentando a colocação de material publicitário e de seus equipamentos de suporte. Em consequência, verifica-se uma atitude de desrespeito ao público e às obras arquitetônicas, inclusive por parte dos órgãos públicos, ao aceitarem, na base de permuta, o fornecimento de equipamentos urbanos com agregados publicitários, como são exemplos as placas de rua e os pontos de ônibus.

Compreende-se que esta prática ainda vigore nas pequenas cidades do país, cujas pracinhas são equipadas com bancos doados por casas comerciais locais, sujeitando-se aos critérios de escolha das mesmas. Não se entende, contudo, que isso persista na metrópole onde se concentram as forças culturais, produtivas e econômicas do país. A colocação de tais equipamentos acrescida pelo acúmulo de out-doors que proliferam na cidade, interferem na leitura das informaçóes úteis e necessárias à população.

Agravando um pouco mais a poluição visual, surge no verão causticante deste ano, um out-door da Nestlé, referindo-se a produto impróprio às altas temperaturas ambiente e cuja primeira leitura nos leva a crer que se trata de material publicitário de alguma fábrica de linguiça, em consequência da proporção inadequada do produto representado.

Quando compreenderão os nossos publicitários e respectivos clientes que um layout de 30 x $90 \mathrm{~cm}$ é diferente de um painel de 32 folhas colocado no contexto urbano?

\section{Equipamentos urbanos}

A reurbanização da nova avenida Paulista, os calçadóes e a criação do Museu de Rua (fotos de Sáo Paulo antiga) demonstram a preocupação, positiva, dos poderes públicos com o meio ambiente urbano. Entretanto, a desordenação, a falta de planejamento e objetividade levaram à implantaçáo inadequada de equipamentos que não atendem à sua finalidade de servir à população.

Apesar da disparidade entre os tratamentos dispensados às três obras - desde a alta sofisticação desnecessária à pobreza material e formal - um ponto é comum aos projetos: ausência de conceitos precisos para avaliação das necessidades e de racionalização no emprego dos materiais construtivos. No caso da Paulista o excesso de sinalização compromete a legibilidade do sistema. Nos calçadóes evidencia-se a desorganização do espaço, a falta de proporçáo entre os elementos (a infeliz escultura de Vlavianos na confluência das ruas D. José de Barros e 24 de Maio, mimetizada no ambiente, acaba por desaparecer) e o conflito de pseudoestilos. Lado a lado, coexistem postes de iluminação fin de siècle, luminárias dos anos 60 , bancos da década de 70 e floreiras do ano 2000.

Quanto ao Museu de Rua, a adição de mais um equipamento agrava a 
circulação de pedestres, porquanto o elemento suporte faz-se mais presente que as próprias fotografias.

Mais uma vez fica patente que para a execução de boas ideias é imprescindível o prévio estabelecimento de diretrizes seguras, de parâmetros que garantam a uniformidade aos diversos equipamentos urbanos e de prazos compatíveis com a amplitude dos projetos - e, portanto, independentes de falsas prioridades políticas. E mais: os programas urbanos não podem sofrer solução de continuidade para ajustarem-se aos ciclos políticos.

\section{Operação bicicleta}

Suponhamos que concursos de projetos de desenho industrial contem com o decisivo apoio de órgãos governamentais e sejam instituídos com a finalidade exclusiva de atender objetivamente a problemas reais e específicos da comunidade. Particularmente quando se tratar de caso como o brasileiro, carente de soluçôes eficientes para o desenvolvimento tecnológico e consequente melhoria da qualidade de vida.

A aplicação de verbas para organização e distribuiçáo de prêmios em concursos, visando tâo- somente a generalidades do tipo estímulo ao desenho industrial no Brasil, não se justifica após várias experiências que demonstram não terem os certames assim organizados, contribuído para o desenvolvimento do campo em questão. Ao contrário, tornaram-se desacreditados e desgastados perante os profissionais, e acabaram por contar apenas com a participação de trabalhos que não chegam mesmo a preencher requisitos mínimos como os exigidos pelas universidades em nível de pós-graduação. Na década de 6o surgiram várias oportunidades para promoção de concursos e entre elas foram mais significativas as relacionadas ao Salão de Utilidades Domésticas e ao Salão de Automóveis. O concurso da UD era de incentivo à produçáo anual de nossa indústria neste setor, através da concessão de certificado de boa forma aos produtos vencedores. O outro, de maior importância, era o prêmio Lúcio Meira, concedido ao melhor projeto de equipamento automotor. Propunha-se a descobrir talentos para atuarem junto à jovem indústria automobilística em implantação no país. Ambas as experiências, se analisadas hoje, mostram-se inconsequentes em seus resultados. Produtos que obtiveram certificado de boa forma, não se firmaram no mercado em decorrência, inclusive, da ausência de maiores esclarecimentos ao público consumidor quanto ao significado de tal atribuição. Projetos premiados nos nove Salóes do Automóvel não tiveram, sequer, seus protótipos desenvolvidos ou seus autores contratados pela indústria automobilística.

No entanto, erros e acertos do passado não têm sido devidamente considerados e assimilados em tentativas recentes, como bem exemplifica o concurso Operação Bicicleta, do Programa de Alternativas de Desenvolvimento, promovido em outubro de 1975, pelas secretarias de Economia e Planejamento e de Cultura, Ciência e Tecnologia do governo do Estado de São Paulo e Associação Brasileira de Desenho Industrial.

Isto, apesar do tema bicicleta ter sido motivo de exaustivos estudos no exterior, tendo em vista, particularmente, o International Cycle Design Competition, organizado pelos órgãos competentes do Japão, em 1973 e, posteriormente, em maio de 1975, o Second International Bicycle-Pedestrian Planning and Design Seminar, realizado em Amsterdã.

A indefinida conceituação do concurso, agravada pela não participação das indústrias de bicicleta, obviamente indispensável em empreendimentos desta natureza, e ainda pela exiguidade do prazo de cerca de dois meses para a elaboraçáo do projeto, determinaram o caráter amadorístico dos trabalhos apresentados, obrigando o júri a conceder prêmios condicionados ao detalhamento e até à complementação da ideia proposta nos anteprojetos.

$\mathrm{O}$ alto valor do primeiro prêmio, na mesma ordem de grandeza do prêmio internacional instituído pelo Japão, justificaria a participação de profissionais nacionais e mesmo internacionais, caso o concurso fosse conceituado e organizado, considerando essa categoria de concorrentes.

A intenção deste comentário é a de conscientizar nossas instituiçôes, inclusive 
quanto à oportunidade de realizaçáo de concursos internacionais, que podem resultar na invenção de novas soluçóes tecnológicas, como ocorreu no Japão, com a bicicleta sem corrente, a ser industrializada e lançada no mercado internacional.
Design: Metrô de Sáo Paulo, p.I28

Antes da implantação do sistema metroviário de São Paulo os veículos públicos urbanos eram projetados e fabricados com surpreendente negligência quanto à aplicação de soluçóes do desenho industrial, principalmente nos interiores dos carros. Ao romper com tal tradição, o metrô contratou designers para o desenvolvimento de uma série de projetos, adotando uma atitude pioneira no Brasil.

Conforto, segurança, ambiente dos interiores e velocidade são fatores que tocam particularmente os usuários. Procurou-se criar atmosfera atraente e amistosa nos recintos destinados aos passageiros, além de distribuição de equipamentos que permitisse simplicidade e economia de manutenção.

A partir de parâmetros técnicos e estruturais definidos, fornecidos pelos fabricantes, a equipe de Verschleisser/Visconti, ex-alunos e atuais professores da Escola Superior de Desenho Industrial, desenvolveu projeto que não só considerou os aspectos mencionados mas também as exigências, contingências e especificações nacionais, numa tentativa de padronização para os futuros projetos que irão surgir em outras cidades brasileiras.

Um sistema de transportes coletivos tão complexo, como é o caso dos trens urbanos, deve comunicar-se visualmente com o público, marcando sua presença e fornecendo coordenadas para orientação dos usuários. Para tanto será preciso que o sistema, no caso o metrô, encontre um só modo de apresentar-se para ser mais facilmente identificado. Criada tal unidade visual, a simples menção da palavra metrô passa a imprimir na mente das pessoas uma imagem clara e bem definida, que lhes permite reconhecer qualquer dos componentes do sistema, desde as estaçôes até um simples bilhete, de modo inconfundível. E isso aconteceu, através da arquitetura das estaçóes, do design dos equipamentos e da sinalização, insere-se no contexto da cidade como uma rede de referenciais redutível a uma imagem única, a um signo. Digno e definitivo.

As cabeceiras dos carros foram projetadas sem a preocupação de enfatizar as formas aerodinâmicas, uma vez que a frente da composição deve funcionar como pistão a fim de produzir boa ventilação do túnel, forçando o ar com o avanço dos carros.

No interior dos veículos, as paredes, tetos com luminárias, ventiladores, molduras das janelas e bancos foram desenvolvidos em fibras de vidro para maior simplicidade de fabricação, montagem, peso, manutenção, flexibilidade de cores, além do aspecto ergonômico. No projeto dos bancos foi dada especial atenção às dimensóes com vistas às proporçóes médias do corpo humano padrão brasileiro.

$\mathrm{Na}$ cabina do operador dos trens foi otimizado o desenvolvimento do console tanto no que se refere à forma quando à disposiçáo do equipamento de controle e leitura, facilitando ao máximo a operação do carro.

Nas salas de comando operacional das estaçôes, a participação dos designers foi dupla. Uma, no desenvolvimento da forma dos consoles e das caixas dos monitores de televisão; a outra, na distribuição da grande quantidade de botóes de comando, chaves, relógios, monofones e microfones nos painéis. Nos móveis dos consoles foi considerado o aspecto da modulaçáo e da produção em série, visando a uma futura extensão. $\mathrm{Na}$ organização das botoeiras foi estudado um esquema de uso, baseado na filosofia de operação própria do sistema metroviário, sempre considerando os aspectos ergonômicos específicos, como também facilidade e rapidez de manejo, visualização correta e sonorização perfeita.

Para a linha leste-oeste serão redesenhados os interiores dos trens, desde o recinto dos passageiros até a cabina do operador, como também, a frente dos trens. Novidade: as passagens de ligação entre um carro e outro. O projeto que pretende reduzir os custos de produção e manutenção está sendo desenvolvido pelo Grupo Associado 
de Pesquisa e Planejamento, GAAP, de Sáo Paulo, contando com a assessoria dos designers italianos Rodolfo Boneto e Alessandro Massina, que consideram o forte impacto cultural que o metrô exerce sobre o povo e a necessidade da validade do projeto a longo prazo. Recomendam, portanto, soluçôes simples, limpas e naturais, evitando a tentação do espetacular, do streamlined, vazio de sentido e de lógica, que tende a uma rápida obsolescência.

No que se refere ao metrô de São Paulo eis dois fatos incontestáveis:

I O real empenho da Companhia do Metropolitano de São Paulo em aumentar o índice de nacionalização em todos os seus setores.

2 A alta qualidade da Comunicaçáo Visual no Brasil, que lhe permite competir em nível internacional.

Um fato inconciliável diante de dois fatos incontestáveis:

Design: Depoimentos, p.I3O-I3I

\section{Aloísio Magalhães Programador Visual}

Pode parecer estranho e até mesmo pouco usual como procedimento que os primeiros passos para a formaçáo de um pensamento brasileiro sobre o desenho industrial, tenham sido dados na direção da rigorosa metodologia suíça-alemá. Mais facilmente se imaginaria que tais passos tivessem sido tomados na direção de um apoio metodológico mais conforme com a exuberância e o calor, para dizer desordem, do temperamento brasileiro.

Hoje, entretanto, parece claro que intuitivamente fomos levados àquela opção na medida em que carecíamos justamente de contrapor aos nossos valores tropicais uma postura diametralmente oposta - e, através de uma dialética entre aqueles elementos, intuitivos e os do método, saíssemos enriquecidos com um posicionamento original e próprio.

Acrescente-se que tal rigor trouxe-nos uma base de pensamento globalizante, muito correto para situaçóes de culturas em desenvolvimento como a nossa. A maior parte dos países desenvolvidos e industrializados
3 A execução, em Chicago, do projeto de Comunicação Visual relativo à sinalização do metrô de São Paulo, pela Unimark International.

Moral da história:

I O metrô de São Paulo não pôde marcar mais um ponto para sua vitória em prol do desenvolvimento nacional.

2 Os profissionais brasileiros não participaram da mais importante obra de Comunicação Visual do país.

3 O Departamento de Arquitetura do metrô foi obrigado a reformular o projeto da Unimark, uma vez que esta multinacional não se ateve à realidade da indústria nacional. Finalmente: por que teria a Companhia do Metropolitano de São Paulo suspendido repentinamente a solicitação de proposta orçamentária e conceituação dirigida a três escritórios especializados de São Paulo, decidindo-se definitivamente pela Unimark International?

oferece uma gama muito fragmentada de profissionais de design; desenhistas de cerâmica, de móveis, de tecelagem, gráficos, estilistas de automóvel, desenhistas de moda. Tudo muito conforme com o desenvolvimento relativamente homogêneo e dirigido ao consumismo daqueles contextos.

Ao contrário disso, o posicionamento de rigor metodológico pelo qual optamos, preconiza, para o problema de design, uma visão abrangente, tendo como base dois grandes campos, onde a atividade normativa e coordenadora do design se exercem: a Comunicação Visual e o Desenho de Produto. A bidimensionalidade no plano e a tridimensionalidade dos objetos.

Curiosamente, estas noções nos foram trazidas pelas mãos de um artista-designer, Max Bill, através do Masp e do мам do Rio.

Posteriormente, com a ida de Alexandre Wollner para a escola de Ulm e sua volta com Karl Heinz Bergmiler, concretizaram-se as premissas da atividade entre nós.

Tal posicionamento, exercido por profissionais com formação homogênea e de nível universitário, criou uma base sadia para o 
exercício dialético ao qual nos referimos antes. Igualmente, novos e necessários ingredientes foram acrescentados. De um lado, os profissionais de formação heterogênea e abrangente como eu e Rubens Martins, por exemplo, e, depois, os de formação basicamente em arquitetura.

\section{LINA BO BARDI}

Arquiteta, antiga diretora da revista Domus e fundadora do Museu das Artes Populares da Bahia

$\mathrm{O}$ design tradicional (e com a palavra design queremos definir não somente o Industrial Design, mas tudo aquilo que a palavra desenho significa, desde arquitetura e urbanismo até os comportamentos) está chegando à asfixia. Consumidas as raízes positivo-racionalistas, debate-se, sem mais oxigênio, nas poucas águas daquilo que foi um oceano.

É preciso criar novas imissóes, entender profundamente a luta do homem contra as dificuldades ambientais: a situação de indigência é a solicitação básica para a criatividade: os tempos ricos são criadores de produçóes espúrias. Para fugir à asfixia precisa recorrer a experiências originais, criar uma nova consciência. Este novo patrimônio cultural não pode ser inserido no mundo do Industrial Design e do consumismo, no mundo da cultura-comopoder, como arrogante mandato-social de poucos contra muitos. É necessário reunir todas as faculdades criativas atrofiadas pela sociedade do trabalho-produto-consumo gerada pelo capital. Alcançar a liberdade: a liberdade coletiva, não a liberdade individual. Substituir ao eu o nós. A América Latina tem mais possibilidade do que a Europa, ligada a esquemas e tradiçôes culturais de elite, difíceis de ser totalmente superados. Através das atividades manuais, (artesanato somente como documento: é impossível voltar no tempo) através da participação do corpo (corpo como totalidade do homem), isto é, de todo um comportamento, uma pesquisa coletiva começa a descobrir um caminho, entre novidades efêmeras e resíduos culturais.

\section{Alexandre Wollner \\ Designer, professor da \\ ESDI/RIO e MACK/SP}

À frequente indagação a respeito do significado da programação visual no contexto do design, respondo tratar-se de planejamento de meios de comunicação, através da determinação de estrutura ou linguagem visual básica, metodologicamente desenvolvida no todo e nos detalhes. No caso de empresas, por exemplo, são programadas estruturas e código visuais, a partir dos quais se projetam marcas, papéis administrativos, folhetos, publicidade impressa e filmada, uniformes, frota de veículos, sinalização diretiva de fábrica e escritórios, códigos luminosos para comunicação eletrônica. Para a execução de tal planejamento é importante o trabalho em colaboração de programadores visuais e artistas gráficos (ilustradores, fotógrafos, letristas, tipógrafos). Aliás, persiste ainda, no Brasil, a confusão em relação a estas duas categorias profissionais.

Desde o início da década de 60 existem, entre nós, faculdades de comunicação visual (ESDI/UERJ; PUC/RJ; MACK/SP; FAAP/ $\mathrm{SP})$, que formam especificamente programadores visuais. Esta época coincide com a fase de atualização das empresas gráficas, graças a incentivos governamentais para importação de equipamentos, resultando melhoria técnica e qualidade de impressão, notadamente em jornais e revistas. Paralelamente, a televisão no Brasil sofreu processo semelhante, evoluindo em termos de emissão e recepção. Em síntese, a formação de programadores visuais, o parque gráfico e a TV condicionaram a existência de mercado de trabalho para os gráficos, o que lhes permitiu desenvolver a técnica, o potencial criativo e alcançou nível internacional, como mostra a revista especializada suíça, Graphis, em número recente dedicado à produção dos artistas gráficos brasileiros.

Tal situação também favoreceu o trabalho do programador visual, permitindo-lhe estender seu campo de atuação para além dos programas de identificação empresarial e institucional. Surge então a sinalização, ou seja, a codificaçáo visual de informaçóes dentro do contexto das necessidades dos aglomerados urbanos, e também 
rurais - hoje já bastante comum nas vias públicas, sistemas de transportes, entidades coletivas (hospitais, escolas, indústrias).

Nestas circunstâncias, torna-se necessário que empresários e governantes tomem conhecimento do potencial de trabalho nesta área, a exemplo do que acontece nos países industrialmente avançados, onde existe um consenso quanto à necessidade do recurso de profissionais especializados neste setor para a realização de obras comunitárias.

José E. Mindin

Presidente da Metal Leve, foi Secretário de Cultura, Ciência e Tecnologia do Governo do Estado de São Paulo

Felizmente está despertando no Brasil a consciência da importância do desenho industrial. Um grupo expressivo de empresários deu seu apoio à ABDI, e a instalação de um Centro de Desenho Industrial, sob os auspícios da Federação e Centro das Indústrias do Estado de São Paulo, mas visando a congregar todas as entidades e pessoas interessadas no assunto, está em vias de concretização, num programa que conta com a colaboraçáo do Museu de Arte Moderna de Nova York.

Já existe muita gente, tanto no campo de profissionais como de usuários, perfeitamente consciente de que o problema náo é apenas de satisfação estética, e que o bom desenho pode ser uma contribuição essencial ao bom produto. $\mathrm{O}$ alcance dessa conscientização é muito grande, pois vai permitir a formação de um vasto campo de trabalho para profissionais especializados (hoje ainda é grande o número de arquitetos que se dedica ao desenho industrial), contribuirá para o desenvolvimento tecnológico nacional, e proporcionará maiores probabilidades de aumento de nossas exportaçóes de produtos manufaturados.

Estamos saindo da fase da cópia para a da adaptação e criação. É um desafio aos profissionais, que têm pela frente um esforço muito grande a realizar, mas é também um desafio às autoridades e ao empresariado, que têm de reconhecer o valor desse esforço e a importância de apoiá-lo. Isto sem falar no papel que devem representar as universidades na formação desses profissionais, e os museus na divulgaçáo de trabalhos aqui realizados.

É uma nova etapa no processo de desenvolvimento brasileiro. Cheia de problemas, com muitas dificuldades a vencer, mas de cujo sucesso não tenho dúvidas.

\section{LÚCIO Grinover}

Arquiteto, diretor da Faculdade de Arquitetura e Urbanismo da USP

Superada uma determinada fase da industrialização brasileira, faz-se necessária a formulação de uma política de desenho industrial autônoma. Os esforços que nossos desenhistas industriais empreenderam para alcançar aquele objetivo, não foram insignificantes. Entretanto, algumas reflexóes nos parecem oportunas a fim de que possam ser traçados rumos, corretos e realistas.

Vejamos rapidamente qual a situação em que nos encontramos.

Via de regra, o design no Brasil movimenta-se em posição bastante precária. As empresas industriais ou que mantêm setores de desenvolvimento de produtos que recorrem aos profissionais são exceçóes. Isto por razóes óbvias: acreditam ser mais fácil e barato copiar desenhos estrangeiros do que investir em desenhos elaborados com recursos próprios daqui.

Esta posição evidencia o esquema de uma industrializaçáo "reflexa" segundo o qual, nos países periféricos é implementado o desenvolvimento de uma capacidade tecnológica reprodutora, porém, não inovadora. Num certo sentido, a capacidade de poder reproduzir desenhos estrangeiros pressupóe um maior nível tecnológico; entretanto, não é por causa disso que se supera a dependência tecnológica e cultural.

Dessa forma, a formulação e implementação de uma política tecnológica autônoma - onde é incluído o desenho industrial - é colocada em perigo pela tendência a uma nova divisão internacional do trabalho: deslocamento de certos processos produtivos à periferia e concentração de atividades de pesquisa e, portanto, de inovação, nos países desenvolvidos.

Não podemos pecar de ingenuidade considerando a fácil realização de uma 
mudança radical nesse processo. Entretanto, algumas políticas podem ser adotadas. Em primeiro lugar, esclarecer a opinião pública, o governo e as indústrias. Em seguida e, consequentemente, se o design há de adquirir um maior significado social e econômico, deve-se dirigir a imaginação projectual para os problemas reais do país; por exemplo, colaborar para a criaçáo de uma infra-estrutura pública adequada (equipamentos escolares, equipamentos hospitalares, meios de transporte, equipamentos para a produçáo agrícola etc.), colaborar para a solução do déficit habitacional (componentes para a construção de habitações econômicas), colaborar para atender outras necessidades, outras prioridades. Eis aí uma "política" e uma série ampla de programas que podem ser desenvolvidos por nossos governos, por nossas universidades e por nossas associaçôes de classe.

\section{DESIGN: JORNAIS, p.I32-I33}

O design de jornais diários reflete o nível tecnológico, cultural, social, econômico e político de um país, de um estado, de uma cidade e até de um bairro. Através de evolução bastante lenta foram-se definindo características estruturais como as que conhecemos ainda hoje - formato, papel, aspecto gráfico e técnica de informação. Em meados dos anos 6o, porém, vários jornais se reestruturaram em função dos novos recursos tecnológicos, como impressão em offset, composição a frio por computação, gravação de clichês pelo sistema scanner em chapas plásticas, e assim por diante. Paralelamente, os grandes jornais internacionais, através de seus suplementos culturais e de lazer,desenvolveram verdadeiros laboratórios não só de comunicação visual mas também de técnicas de informação, pesquisando novas linguagens visuais e verbais que, gradativamente, foram introduzidas no caderno principal.

Exemplo ostensivo é o The New York Times, cujos cadernos especiais são melhorados constantemente e as experiências resultantes, que possam valorizar a qualidade da informação e de sua leitura, são aplicadas lenta e metodicamente, no corpo do jornal.

No Brasil existiram e existem tentativas de acompanhar o processo evolutivo da técnica jornalística.

\section{Última Hora}

Em meados dos anos 50, Samuel Wainer lançando no Rio e depois em São Paulo o vespertino Última Hora. Paginado pelo artista Guevara, incorporou novos conceitos verbais/visuais aplicando manchetes, fotos, ilustraçóes e cores, resultando efeitos de cartaz, em sua página de rosto. Os métodos de impressão da época, porém, não permitiram bons resultados, Influências: France-Soir, Daily Mirror, Bild Zeitung.

\section{Jornal da Tarde}

O Jornal da Tarde, de São Paulo, por influência do jornalista-editor Mino Carta, veio quebrar a monotonia de nossos diários e de suas acanhadas tentativas de atualização, introduzindo características inusitadas no design jornalístico brasileiro: atribuição de arte gráfica aos editores e criação de linguagem verbal/visual própria. Este último fator é o principal responsável pela identidade do jornal, destacando-o dentre as demais produçóes da imprensa nacional. Influências: The Times, Herald Tribune, The Observer.

\section{Jornal do Brasil}

O Jornal do Brasil no início dos anos 60 lançou o caderno B, que sob a responsabilidade de Reynaldo Jardim e Amílcar de Castro, constituiu-se em experiência para a mudança das características do matutino, dando ênfase à fotografia como força visual. Influências: New York Herald Tribune,

Sunday Times, cadernos Art an Leisure e Week in Review do The New York Times.

\section{Correio da Manhã}

Em fins de 1958, o entáo prestigioso matutino carioca Correio da Manhá procurou reformular-se através de uma sistemática visual objetivando a interação do aspecto gráfico e jornalístico, técnico e econômico. Os responsáveis pelas modificaçóes, o empresário-jornalista Paulo Bittencourt, o jornalista Luiz Alberto Bahia e o designer Alexandre Wollner, respeitaram a tradição do matutino e introduziram 
técnicas modernas de percepção condicionadas ao equipamento técnico existente no jornal. Influências: New York Herald Tribune, Frankfurter Allgemeine.

Design: Programas de Identidade Empresarial, p.I34

Alexandre Wollner

Como consequência da revoluçáo industrial, por volta de 1880 o produto passou a ser o principal objeto a ser comunicado. A partir de 1900 acrescentou-se o fator distribuição, gerando o tratamento visual da embalagem. Nos anos 20, ao produto e à distribuição agregou- se mais um item, a publicidade, criando outros tipos de requisitos para a comunicação visual. A década de 40 introduziu o marketing, iniciando-se as pesquisas com o objetivo de condicionar o comportamento do consumidor, utilizando os novos recursos visuais, particularmente a televisão. E finalmente, nos anos 6o, o referencial a ser comunicado passou a ser a própria empresa, como ocorreu com a Westinghouse, IBM, Ciba-Ceigy, Olivetti, Swissair, Braun, Lufthansa e tantas outras.

A escola de Ulm, na Alemanha, constituiu-se no laboratório para o desenvolvimento da metodologia de programação de identidades empresariais, que culminou com a concretização do modelo de design global, quando da concepção da imagem das Olimpíadas de Munique em sua totalidade - arquitetura, comunicação visual, desenho industrial, planejamento, divulgação dos eventos esportivos e culturais.

Qual será a tendência dos anos 80 ? Teremos que tratar de grupos multinacionais e da adequação à automação dos meios de comunicação?

A tendência atual das empresas, bem como dos governos, é a de centralizar serviços para o atendimento das diversas indústrias do grupo (holdings) ou dos vários órgãos governamentais, verificando-se, então, a necessidade de identificar tais serviços às instituiçóes a que pertencem.

O equivalente histórico do processo de codificação visual das partes em função do todo, embora empiricamente desenvolvido, é encontrado especialmente na Idade Média, nos procedimentos de identificação das ordens religiosas e dos exércitos.

No Brasil dos anos 20, havia indícios da fase produto/embalagem no comportamento da Manteiga Viaducto, Café
Paraventi, Odol para higiene bucal, Cafiaspirina, entre outros. Posteriormente, em meados de 30, Bernard Rudowsky, ex-aluno de Bauhaus, em visita ao Brasil, criou a marca da Fotoptica e, no final dos anos 40, o designer americano Raymond Loewy, através de seu escritório no Brasil, dirigido pelo eng. Bosworth, implantou programas de marketing identificando produtos: calçados Clark (logotipo e lojas); sabonete Fantasia, das Indústrias Matarazzo (embalagens e promoção de vendas); sabonete Gessy (embalagem e projeto do edifício-sede); Indústrias Pignatari (logotipo). Em fins de 50, a solicitação da Argos Industrial possibilitou a implantação do primeiro trabalho de identificação empresarial no Brasil, por mim realizado, aplicando a experiência adquirida nos projetos da Braun e Lufthansa, desenvolvidos em Ulm.

A partir de então, com a mesma metodologia, várias empresas tentaram implantar um completo programa de identidade empresarial. Pelas diversas razóes da realidade brasileira, porém, não chegaram a aplicar mais de $45 \%$ do programa total. Contando com o trabalho de diversos designers nacionais, figuram entre elas Argos Industrial, Equipesca, Grupo Santista (têxtil e alimentícios), grupo Light, Metal Leve, Eucatex, grupo Villares, Leco, Banco Nacional, Comgás, grupo Pereira de Castro, grupo Fenícia, Companhia Vale do Rio Doce, grupo Hansen.

Hoje, as empresas brasileiras, estendendo seu parque industrial por todo o território nacional, compreenderam que a simples elaboração de um programa de identidade empresarial, sem a preocupação de adotar um sistema gráfico codificado para seus produtos, seus meios de comunicação e suas informaçóes impressas, não poderão manter o controle da unidade visual. Daí ser necessária não mais a criação de um sinal, que torna-se secundário, porém, a definição da malha estrutural, base de toda uma constelação de sinais codificados e início do novo relacionamento empresa/público. 
O projeto de reformulação da imagem

Brasilit é exemplo de programa

completo de identidade empresarial.

Design: Desenho Radical? p.I36-I37

Marco Antonio Amaral Rezende

Em outubro de 1975 , realizou-se em

Moscou o X Congresso do ICSID

(International Council of Societies of

Industrial Design), o organismo que reúne todas as associaçóes de classe. O tema proposto foi o "Design para o Homem e a Sociedade". Durante os trabalhos procurou-se ressaltar a necessidade e o levantamento de algumas formas de como o designer pode contribuir para a restauração da qualidade ambiental e a instauração do bem-estar social.

O conclave marcou uma reviravolta nas consideraçóes de muitos desenhistas industriais. Tradicionalmente, sempre foram profissionais preocupados com os aspectos formais, com a boa forma, integrada a certos requisitos de funcionalidade. Através dos debates de Moscou, revelou-se que uma nova consciência de projetos já está presente nas intervençôes, nos produtos de muitos desenhistas, isto acontecendo principalmente nos países em vias de desenvolvimento que buscam encontrar modelos próprios, evitando os males de muitos países ditos "desenvolvidos".

Logo após o Congresso de Moscou, em abril de 1976, o Royal College of Art, o mais importante centro de pesquisas de desenho industrial da Europa, organizou o simpósio Design for Need, quando foram apresentados mais de quarenta projetos (inclusive do Brasil) voltados para os problemas das necessidades básicas das comunidades humanas. No Japáo e nos Estados Unidos outros eventos similares aconteceram. Verifica-se, assim, que esta tendência é irreversível, pois talvez seja o único caminho para que os desenhistas possuam um mínimo de consciência e responsabilidade social.

Fazendo uma análise deste novo conceito de design, que alguns chamam de radical, percebe-se uma nova forma de projetar. $\mathrm{O}$ desenhista deixa de criar projetos isolados e passa a conceber sistemas de produtos inter-relacionados, coletivamente relacionados às necessidades essenciais de grupos humanos ou do meio ambiente. Em outras palavras, destinados a elevar os índices de qualidade de vida. O desenhista deixa de trabalhar no sentido da proliferação irracional de objetos isolados e passa a atuar no sentido de controlar quantidade e qualidade. Passa a exercer o design para $o$ controle, na expressão de Tomás Maldonado, um dos recém-convertidos teóricos do design radical, a fazer projeto de sistemas.

Este trabalho tem mostrado mais resultados exatamente em países mais necessitados, isto é, nos subdesenvolvidos. Até mesmo no Brasil. Infelizmente, ainda pouco expressivos. Seu número, contudo, tende a aumentar pela própria situação de periferia - como tais países são também chamados.

Para melhor entendimento deste quadro vejamos o exemplo brasileiro, onde os setores de máquinas de escritório, de aparelhos eletrônicos e de comunicação, de material de transporte, mecânica, borracha e derivados - para apenas citar alguns sáo dominados por empresas estrangeiras. Evidentemente estas não se interessam em gerar uma tecnologia ou muito menos um design brasileiro, e se limitam a reproduzir modelos e projetos de fora, avidamente devorados por nosso manipulado mercado.

Com tal estrutura nosso atraso tecnológico só tende a aumentar. Consequentemente é difícil ser otimista em relação à expansão do mercado de trabalho do nosso designer, pelo menos junto às grandes empresas que não se interessam pelas necessidades básicas de nossas comunidades, principalmente daquelas que não têm acesso ao mercado de consumo, 60\% de nossa população, algarismo que se verifica na grande maioria dos países subdesenvolvidos. São milhóes de pessoas tentando sobreviver sem alimentação adequada, carentes de condiçôes de saúde, educação e habitação, isto para náo se falar de outros aspectos que constituem a qualidade de vida.

O primeiro problema realmente mais grave é o de produzir comida a preços 
mínimos e em quantidade suficiente. $\mathrm{Na}$ índia, Arvin Merchant e Alir Mullich, do National Institute of Design, desenvolveram um sistema intermediário para colheita de arroz e trigo, a fim de substituir obsoletos instrumentos de três mil anos de idade. Seus componentes tornam a colheita manual mais confortável, menos cansativa, sem implicar em sacrifícios de emprego dos trabalhadores do campo ou de fabricantes de ferramentas. No Chile, durante o governo de Salvador Allende, o Grupo de Desenvolvimento de Produtos de Tecnologia, coordenado por Gui Bonsieppe, criou um sistema de colheita mecânica capaz de permitir a superação do atraso dos equipamentos deste tipo.

Outro importante problema é o do equipamento de saneamento básico, que tradicionalmente exige imensos investimentos, superiores à capacidade dos organismos responsáveis. Investigam-se, então, novas tecnologias. O National Environmental Engineering Research Institute of Nagpur, Índia, tem uma longa e bem sucedida história de desenvolvimento de técnicas apropriadas às condiçôes indianas. Estas técnicas incluem métodos simplificados de rede de esgoto.

No campo das chamadas tecnologias náo ortodoxas (ou alternativas ou intermediárias) as pesquisas abundam em todo o mundo. Por aqui, inclusive, já são feitas algumas experiências, principalmente no campo da geração de energia e da construção de habitações. Tecnologias não ortodoxas são aquelas que se caracterizam pela escala reduzida, pelo intenso uso do trabalho e náo do capital, pela recuperação dos recursos, pela não poluição, pela adequação aos valores antropológicos de quem a utiliza.

O transporte é um dos campos que mais tem atraído a atenção dos designers radicais. Aqui, o Grupo da Secretaria de Tecnologia Industrial do Ministério da Indústria e do Comércio realizou a pesquisa Aspectos Ergonômicos do Ônibus Urbano, visando a definir critérios que possibilitassem um mínimo de conforto a milhóes de pessoas que se utilizam deste meio de transporte.

No campo da habitação, pesquisam-se técnicas construção que permitam combinar a pré-fabricação industrial de componentes com as técnicas populares de mutirão e autoconstrução. Estas são apenas algumas amostras deste esforço geral dos designers mais conscientes, preocupados em adequar o mundo dos objetos às reais necessidades dos usuários.

Legenda p.I36 Instrumento de colheita projetado pelo National Institute of Design, da Índia Máquina de colheita desenvolvida por Gui Bonsieppe, no Chile 9 Unidade sanitária para vilarejos projetada pelo National Enviroment Engineering Research Institute of Nagpur, Índia g Pesquisa ergonômica sobre ônibus urbano promovida pela STI/MIC

\section{Design: Moda, p.I37 \\ De uma entrevista com Augusto d'Azevedo, idealizador e coordenador do Centro Brasileiro da Moda, diretor do Guia Oficial da Moda Brasileira.}

Três são os estágios característicos que marcam a evolução de um país em termos da moda do vestuário: cópia direta, adaptação e lançamento próprio. O Brasil situa-se predominantemente no estágio de adaptação do desenho criado no exterior, não se excluindo a possibilidade de que venha a atingir a fase do lançamento próprio, no âmbito da moda caracteristicamente tropical.

Ao falar-se de moda brasileira cabe, logo de início, uma advertência: a moda não é regional; hoje é internacional, universal.
E aí está sentenciado o fato de que jamais existirá uma moda brasileira.

Como resultado de contribuiçôes diversas e fatores heterogêneos, configura-se em momentos específicos, nos grandes centros europeus, particularmente na França, Itália, Suíça e Alemanha, o que se convencionou chamar de "tendência internacional".

Os demais países, inclusive os desenvolvidos como os Estados Unidos e o Japão, pesquisam a "tendência internacional", adaptando-a às condiçóes locais, onde são considerados os recursos industriais, usos 
e hábitos do consumidor, fatores climáticos, poder aquisitivo da população etc. Assim, as modas nacionais, excluídas as dos países lançadores, podem ser consideradas genericamente como caracterizaçóes da moda internacional. No tocante à relação figurinista indústria, estudos e pesquisas que resultam nas criaçóes da alta costura fornecem os elementos básicos sobre as quais se estruturam a moda industrializada.

No Brasil, entretanto, se por um lado a maioria das fábricas de confecção mantém ainda uma estrutura familiar auto-suficiente, dispensando o trabalho de figurinistas, por outro, a ausência de formação e profissionalismo destes, com raríssimas exceçóes, vem reforçar o círculo vicioso que assim se estabelece. Mesmo no caso de indústrias interessadas na contratação de figurinistas, subsistem dificuldades em virtude do individualismo exacerbado peculiar desta classe profissional, agravado ainda pela negligência quanto aos requisitos estruturais básicos dos métodos de produção, isto é, quanto ao desenho industrial propriamente dito, criando peças inviáveis para a indústria.

Assim, figurinistas de talento incontestável, com a capacidade criativa de um Dener ou um Clodovil, não chegaram a consolidar experiências de colaboração iniciadas com fábricas de confecção nacional.

Em face de tais circunstâncias, verifica-se que as indústrias organizam-se visando à utilizaçáo de seus próprios técnicos para a realização de pesquisas no campo da moda. E o figurinista passa a ser considerado, em termos industriais, simplesmente como estilista.

No que se refere ao incremento da exportação de produtos do vestuário fabricados no Brasil, torna-se imprescindível o desenvolvimento de uma série de iniciativas, tais como: I. participação sistemática e incisiva do Brasil nas grandes feiras internacionais; 2. apresentação das coleçôes utilizando veículos de informação eficientes (filmes, audiovisuais, materiais impressos etc.); 3. pesquisa prévia relativa à orientação geral e às demais participaçóes na feira em questáo; e 4. seleção das indústrias participantes, segundo critérios de qualidade, capacidade de produção, infra-estrutura para exportação etc.

Providências desta ordem são necessárias a fim de que seja evitada a repetição do fracasso de venda ocorrido na última Feira Internacional de Munique, na qual estiveram presentes 32 indústrias brasileiras de confecção. O Centro Brasileiro da Moda, com o objetivo de proceder à avaliação dos resultados da referida feira, enviou questionário ao Itamaraty para a obtenção dos dados necessários. Não havendo resposta, elaborou hipóteses alternantes que pudessem explicar os resultados negativos ocorridos: inadequação dos modelos apresentados; participação de indústrias não capacitadas para a exportação; ausência de divulgação/ promoção eficiente; ou ainda, localização desfavorável do estande brasileiro.

Se em termos de mercado interno o Brasil se situa no estágio de adaptação, as características da demanda externa nos têm conduzido a procedimentos da primeira fase, ou seja, à cópia de desenhos estrangeiros conforme especificaçôes do cliente.

A primeira escala da viagem de negócios do importador é sempre Hong Kong; no caso de não encontrar ali condiçôes favoráveis para a assinatura de contratos, este cliente dirige-se ao Brasil, motivado pelo baixo custo da mão-de-obra neste país. Ocorre, entretanto, que a produtividade desta máo-de-obra é cerca de 50\% inferior à média dos países desenvolvidos, em decorrência principalmente das condiçóes de saúde, alimentação, transportes etc. do operário brasileiro. Em consequência, o preço do produto fabricado no Brasil torna-se necessariamente elevado, deixando de ser competitivo no mercado internacional.

Outro fator negativo, responsável pela elevaçáo de preços, relaciona-se com o depósito compulsório determinado pela política de contenção da importação de equipamentos e matérias-primas. Exemplo bastante significativo desta situação é $o$ alto custo das fibras sintéticas nacionais. Entretanto, deve-se observar que apesar das condiçôes adversas a qualidade da confecção brasileira equipara-se ou mesmo supera, a dos demais produtores do mercado internacional. 
Quanto a lançamento próprio ocorrem esporadicamente casos isolados, sendo praticamente único o fenômeno tanga,

DESIGN: IndúsTRIA, p.I38

Jorge Zalszupin

Para ampliar seu mercado de trabalho, o designer terá que atuar em todos os ramos industriais e não se deixar confinar, por exemplo, no mobiliário - terá também que encontrar meios de viabilizar o seu trabalho com as possibilidades e realidades de um maior número de indústrias brasileiras, vale dizer não só as grandes (das quais muitas são transnacionais e usam produtos desenhados fora) mas justamente as médias. A fim de que isto possa se dar em condiçóes aceitáveis para todos, a qualidade de trabalho precisara ser garantida através da formação de departamento de produto, isto é, equipes mais complexas e estruturadas em volta do designer, envolvendo engenheiro de produto, desenhistas projetistas, modelistas, e todo um departamento de protótipo.

Evidentemente, um departamento assim montado é mais caro do que as possibilidades de uma indústria média. Mais ainda, este grupo de trabalho não só deve ter um nível teórico de preparo para atuar eficientemente e com uma margem mínima de erro, como também deve conhecer intimamente as condiçóes de equipamento industrial futuramente responsável pela

Design: Notícias, p.I38-I39

\section{[Braun]}

Uma exposição no Masp, em I974, apresentando produtos da Braun, marcou o início das atividades comerciais da empresa no Brasil. Atualmente multinacional, a Braun está-se estruturando para produzir sua linha de eletrodomésticos em São Paulo, em consequência da política nacional de restrição à importação.

\section{[Indústria Itália-Brasil]}

Experiência altamente gratificante é a de se deparar com um produto industrializado brasileiro em pleno Museu de Arte Moderna de Nova York. Lá está o Talher Camping, da Hércules, projetado por José Carlos Bornancini e Ivan no setor da moda-praia, que em 1974 obteve repercussão internacional. produção. Digo “intimamente" para afastar o simples conhecimento teórico como sendo suficiente. Trata-se, na verdade, de um conhecimento que envolve máquina por máquina, e homem por homem, as verdadeiras possibilidades e limitaçóes do conjunto fabril, podendo avaliar os limites do mesmo em matéria de precisão, absorção de novas ideias, controle de qualidade, margem de erro, eficiência etc. Muitas situaçóes de incompreensão e conflito resultam deste pouco conhecimento recíproco. Permito-me (e isto baseado numa experiência própria) sugerir uma fórmula de difícil mas não impossível realização: fazer com que um grupo de indústrias de porte parecido e náo concorrentes custeie, em conjunto, um departamento de produto completo. $\mathrm{O}$ rateio pode ser estabelecido de várias maneiras, mesmo na base de horas trabalhadas para cada uma delas. Não só se viabilizará, assim, a existência de um departamento de produto, como ainda se transferirão experiências tecnológicas de uma para outra. E o designer terá finalmente acesso a uma convivência real e diária com a produção e isto em variados setores de atuação.
Petrold. Foi selecionado, em I975, dentre a produção internacional de objetos representativos do bom design, para ser integrado na exposição permanente de desenho industrial do museu. Devido ao seu caráter, função e dimensóes, o produto gaúcho figura também entre os objetos colocados à venda pelo MoMA, podendo ser adquirido na loja/livraria do anexo.

\section{[Brazilina design in NY]}

Uma das grandes indústrias italianas, Alessi Fratelli de Crusinallo, Novara, produtora de objetos de mesa em aço inoxidável, fez um acordo com a Metalúrgica Bellini S.A., de Caxias do Sul, para a transferência de tecnologia de estampagem a frio do aço, e para a reproduçáo de seus modelos. $\mathrm{O}$ 
acordo prevê o desenvolvimento de energias criativas brasileiras visando a criar amplos programas dedicados a produzir, além de mesas, a cozinha, dentro da linha e do espírito nacional, contemplando o uso de outras matérias-primas como a madeira, a pedra e os nossos minérios. Pelo renome da Alessi, que conta com designers de notória fama e está presente com suas produçóes em mais de setenta países, certamente este acordo entre italianos e brasileiros dará os mais fagueiros resultados.

\section{[F-004/I976]}

Eis um carro para competiçóes esportivas desenhado no Brasil por Ricardo Divila. Um verdadeiro desafio, pois cada corrida de que participa constitui-se num teste para o aperfeiçoamento da forma e do equipamento técnico, tendo em vista o modelo definitivo. Este é o F-004/1976.

[Designer italiano, estagiário brasileiro]

Num país em fase de afirmação de seu parque industrial como é o caso do Brasil, é muito importante que uma indústria com a capacidade da Romi importe designers italianos para desenvolver o projeto do Torno Imor - uma vez que dificilmente se encontraria profissional brasileiro com know-how suficiente para este tipo de equipamento. O coroamento da iniciativa poderia ser a participação de desenhistas brasileiros no projeto, através de estágios ou de colaboração como assistentes do departamento de novos produtos daquela indústria.

\section{[Geladeira Grinover]}

A geladeira projetada por Lúcio Grinover teve por base estudos antropométricos, levantamento das necessidades de mercado, análise das dimensóes nas embalagens brasileiras, e a utilização do pioneiro processo de polieretano expandido, que permitiu aumentar a cubagem útil interna.

\section{[Design superficial]}

Uma linha de eletrodomésticos mantendo a mesma unidade formal em todos os seus produtos, resulta em economia e mesmo em identificação e promoção empresarial. As indústrias brasileiras ainda não tiveram condiçôes de adotar um tal comportamento, assim como não superaram a proliferação de formas diferentes para a mesma função de uso, ou a diferenciação de modelos standards, luxo, superluxo, baseadas em modificaçóes de superfície e não legitimamente estruturais. Em termos culturais precisamos tomar cuidado, porque as utilidades domésticas têm uma certa vocação para a sustentação do mito do status social.

\section{[Luminária urbana Livio Levi]}

De relevante importância para a leitura dos logradouros públicos de uma cidade (ruas, avenidas, alamedas e praças) são as luminárias industriais distribuídas no contexto urbano. Diversificando o design de forma sistemática, as luminárias são suscetíveis de significado semiótico na cidade. Um dos designers brasileiros que mais se preocupou com este tipo de problema foi Livio Edmondo Levi, cuja morte prematura, porém, não impediu o progresso da trajetória da iluminaçáo arquitetônica, uma vez que seus assistentes têm desenvolvido novos projetos para as indústrias de luminárias.

\section{[Azulejos]}

A volta à utilização do azulejo, considerado como o material mais adequado ao caso brasileiro, principalmente no revestimento de cozinhas e banheiros, foi calorosamente defendida em recente reuniáo de designers e arquitetos, por Janete da Costa, arquiteta de interiores da firma Borsoi, de Pernambuco. A atual posição em prol da recuperação deste material do repertório da arquitetura tradicional brasileira, deve-se aos resultados obtidos pelos irmãos Brennand em uma nova linha de azulejos, utilizando padróes projetados pelo designer italiano Enzo Mari. Neles são aproveitados diversos recursos do material, inclusive as juntas, como elemento integrante do desenho. Segundo Francisco Brennand, artista e industrial pernambucano, as várias tentativas de utilização de projetos brasileiros, resultaram em padrôes decorativos, mantendo a velha tradição portuguesa e negligenciando detalhes, que foram posteriormente resolvidos por Mari. Isto significa que, neste caso particular, os brasileiros assumiram a atitude de designers de prancheta, não se preocupando em 
resolver o problema técnico e a função de superfície requeridos por este tipo específico de revestimento. O que não ficou claro, e isto viria em defesa de nosso design, é se o relacionamento comercial entre os Brennand e Enzo Mari conservou a mesma base daquele mantido com os artistas e designers brasileiros que participaram da experiência nordestina de encontrar soluçôes válidas para as superfícies azulejadas.

\section{[Avião Bandeirante]}

Financiado com recursos provenientes da política de incentivos fiscais, o avião Bandeirante, desenvolvido pela engenharia brasileira, representa uma vitória de nossa indústria aeroespacial. Teria sido esta uma oportunidade para a realizaçáo de desenho nacional, absorvendo profissionais brasileiros das áreas competentes, a exemplo dos Estados Unidos onde, principalmente no setor aeronáutico, se verifica desde o início do projeto um perfeito entrosamento entre engenharia e design.

Design: MóveIs, p.I4O-I4I

\section{Linha 8}

A Linha 8 resulta de uma nova concepção de design em móveis para escritório, a começar do dimensionamento de seus elementos, todos eles projetados mediante os cânones da Proporção Áurea.

No desenvolvimento das mesas Linha 8, a Securit-Tecnogeral, no design dirigido por Sandro Magnelli, reduziu as formas a um ponto tal de despojamento que chegou à funcionalidade pura e simples. Analisou-se, por exemplo, a tradicional mesa de escritório como uma herança das antigas escrivaninhas. A partir disso, foi desmembrada a mesa em suas unidades funcionais, ganhando flexibilidade. Sob o tampo de mesa tem-se um vão livre para ser usado da maneira que for mais prática. Os gaveteiros foram concebidos em duas formas: aplicáveis (que se fixam por encaixe sob o tampo), podendo ser trocados sempre que necessário e móveis com rodízios, os quais podem, por sua vez, ser usados por mais de uma pessoa, não precisando estar sob a mesa, fazendo com que uma mesa possa ser de reunião ou vice-versa. Afora estes fatores, as mesas da Linha 8 apresentam outras características de flexibilidade: a retaguarda pode ser removida ou aplicada livremente, e a mesa é inteiramente desmontável. sem o uso de qualquer ferramenta.

\section{Forma}

Indústria de móveis de São Paulo, a Forma tem em sua coleção os maiores nomes do design internacional. Foi criada em 1952 e, paradoxalmente, naquela época fabricava apenas móveis de design brasileiro. Martin Eisler e Carlo Hauner foram os primeiros a desenhar para a nova firma, com sucesso, recebendo alguns prêmios internacionais, entre eles, o Compasso d'Oro e o Die Gutte Form.

Isso tudo não era suficiente para manter uma firma. Havia a necessidade de lançarem novos modelos, a dificuldade de encontrar no Brasil um design de alto nível e, assim, a Forma voltou-se para o mercado internacional, começando a fabricar, sob licença, a coleção da Knoll International (Mies, Saarinen, Bertoia e Florence Knoll).

Se até hoje o nome Forma está ligado a este design originário de Bauhaus, a realidade que começa a transparecer já é bem outra. De uns anos para cá a empresa voltou à primeira posição, isto é, ao design brasileiro, através de Adriana Adam, à frente do seu departamento de design. Depois de lançar uma linha de escritórios de luxo e uma linha de dormitórios, agora se arremessa a um projeto mais ambicioso: um sistema de cadeiras baseado em dados ergonômicos. Um trabalho sério e ousado para o qual foi feita uma pesquisa antropométrica do homem brasileiro e um levantamento biomecânico das funçôes da cadeira ligadas a seu usuário.

\section{Escriba}

Este conjunto de móveis, projetado pelo designer Karl Heinz Bergmiller, para a Escriba, deixa claro que racionalidade e design não são sinônimos de padrôes sofisticados e ideias importadas. Afirma, ao contrário, a necessidade de conceituar o mobiliário segundo referências 
contemporâneas compatíveis com a realidade técnica e industrial brasileira; definir um caráter próprio à produção e ao produto; não se dirigir apenas a um segmento esclarecido do mercado; fornecer critérios de opção ao consumidor, sem mistificações ou artifícios formais; evitar compromissos com a massificação vulgar; considerar que o produto industrial não é hoje elemento passivo na vida do ser humano, mas suscetível de modificar o modo de sentir e pensar das pessoas, o que implica em responsabilidade social.

\section{Lina Bo Bardi}

$\mathrm{O}$ assento tem suas origens perdidas na noite dos tempos e ninguém até hoje pôde estabelecer o seu início - que certamente vai desde os bancos de pedra até as sofisticadas poltronas de Mies van der Rohe e tantos outros mestres do design, que nos autoriza a ver o quanto têm sido mutáveis as formas e irrefreável a busca do aperfeiçoamento da tecnologia daquele simples objeto. Lina Bo Bardi, da qual publicamos dois assentos (Cadeira dobrável para o auditório do Masp, I947, e assento de dois elementos, 195I) realizou, no jardim de sua casa, esta cadeira ajustável, armação de galho de aroeira e assento de sisal, 1967.

Em 1947, o nascente Museu de Arte de Sáo Paulo necessitava de umas duzentas cadeiras para compor seu auditório. Foram convocadas as principais firmas da cidade para participarem de uma concorrência; foram apresentadas várias amostras com formas que náo levavam em conta a existência do design. A arquiteta responsável pela instalação do Masp, Lina Bo Bardi, desenhou, então, uma cadeira que nenhuma das fábricas convidadas quis produzir. Foi um simples artesão italiano recém-chegado Brasil que as realizou. É incrível, mas realmente aconteceu.

\section{Senta}

A fórmula da mini-indústria se tornou muito válida no caso brasileiro. Com reduzida mão-de-obra, simplificação e desburocratização dos processos de fabricação e administração, a mini-indústria não se caracteriza como artesanato; trabalha em regime de produção em série, permitindo que o designer participe das etapas do processo de fabricaçáo. Para o profissional, constitui-se em método de trabalho bastante satisfatório. E para os países em desenvolvimento, uma opção viável. Poltrona, projeto e execuçáo Senta, São Paulo, designer Michel Arnaudt.

\section{Linha Eurit}

Partindo do clássico desenho com tubos e recriando-o segundo exigências contemporâneas, a Securit vem de criar a linha de cadeiras e poltronas Eurit, nas versóes fixa e giratória, cuja leveza amplia a dimensão do conforto para o campo sensorial. $\mathrm{O}$ conforto não se limita às características físicas do corpo mas também se entrosa à percepção e ao conforto. Daí a opçáo pela suspensáo do conjunto assento-encosto em estruturas de tubos cromados de peso visual equilibrado num prolongamento contínuo da própria estrutura.

Presentemente, a Forma se defronta com os resultados do concurso, significativo pelo fato de haver o júri valorizado projetos em que se percebe a preocupaçáo com uma temática ligada à realidade sócio-cultural e econômica brasileira.

\section{Probjeto}

Resultante de estudos antropométricos, a forma de concha da cadeira de plástico, funcionando em monobloco com a estrutura, é projetada visando à otimização do fator elasticidade em função da forma e dos movimentos naturais do corpo humano. Produto da Probjeto, São Paulo.

Presentemente, a Forma se defronta com os resultados do concurso, significativo pelo fato de haver o júri valorizado projetos em que se percebe a preocupação com uma temática ligada à realidade sócio-cultural e econômica brasileira. 


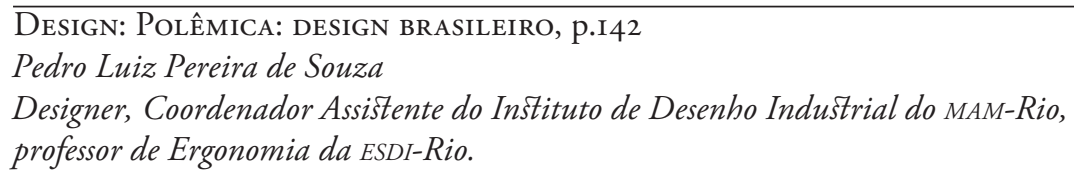

"Busca-se um esquema bipolar: aos paises desenvolvidos a produção de microscópios eletrônicos e, aos subdesenvolvidos, a fabricação de cinzeiros de barro"- Gui Bonsiepe

A vida sempre se serviu do pensamento técnico, como de uma chave mágica. Em nossa civilização, em nossas grandes cidades, já surgiu uma fase em que a crítica técnica está farta de servir à vida e já se arvorou em tirania. Hoje as técnicas são encaradas como um fim em si mesmo, como códigos que têm, em princípio, soluçóes para nossos problemas e, cada vez mais, é isso que se espera do design a julgar pela atitude didática emergente nas escolas.

Mas o design não é uma ciência.

Apresenta-se muito mais como um processo, um empenho imposto, que como uma disciplina acabada. $\mathrm{O}$ conhecimento no processo do design é algo que só cresce autenticamente, na medida em que se investiga; e saber investigar significa, na maior parte das vezes, saber esperar. Numa época, porém, em que só é real o que vai depressa e pode-se manipular com rapidez, a própria investigação torna-se alienação, algo que não vale a pena levar em conta ou esperar, pois torna-se "teoria”, "subjetividade", e não um número, uma quantidade "objetiva” e pragmática.

Uma atividade colocada num impasse dessa natureza, tende a fugir de seus elementos e buscar uma compensação valorizando-se como técnica, isto é, instrumentos de formação, para com isso se transformar em atividade acadêmica.

O design vem aos poucos se transformando em mera técnica de fabricação, em instrumento da tecnologia como um todo, ao contrário de uma ordem material onde o inverso deveria acontecer. Nesse caso já não se pensa em design; ocupa-se de design. Essa atitude hoje em ascensão é a principal responsável pelo que se pode chamar destroncamento entre o design (interpretado apenas como uma técnica auxiliar) e os fatores humanos envolvidos obrigatoriamente na concepçáo de produtos e sistemas de produtos industriais.
Desconhecendo qualquer limite a mal-entendida objetividade se expande e o design, sob sua particular ditadura, é colocado apenas a serviço dos meios de troca, transformando-se em mera especulação operacional e metodológica, pois de antemão, independente dele já foi decidido até mesmo pela publicidade, o que é compreensível, útil e necessário e o que deve ser rejeitado como incompreensível e supérfluo.

Talvez até já se tenha decidido o que é caráter nacional e toda a discussão em torno desse assunto já não é senão uma investigação e o conhecimento resultante cairá no vazio.

Quando se fala em caráter nacional é necessário definir bem o que se quer dizer. É preciso, pelo menos em design, diferenciar o que seja nacional, de folclore e artesanato.

Não raro se ouve dizer que no folclore e no artesanato se encontram as raízes para um estudo real do homem brasileiro e, consequentemente, elementos úteis e essenciais para o design. Folclore e artesanato são com efeito excelentes raízes para estudos sociais e antropológicos e, através desses estudos é que devem chegar ao design. Antes de ser um "curioso" o designer tenta ser mais coerente com suas principais vias de criatividade: os métodos racionais e o pensamento crítico. Apropriar-se do folclórico e do artesanal sem senso crítico significa introduzir elementos de pura espontaneidade e náo de direção consciente num trabalho. A necessidade real é muito mais de estudar e elaborar os elementos da psicologia popular de forma histórica, isto é, ativamente e não descritivamente, e nesse ponto reside o que se pode chamar de distanciamento entre os profissionais das ciências humanas com a especificidade própria do design.

Com relação ao artesanato, que não é necessariamente arte popular, deve-se pensar objetivamente no seguinte aspecto: Como salienta Guy Bonsiepe, há uma grande diferença entre o desenho artesanal e o desenho 
industrial. A própria complexidade de dados, característica de cada uma das atividades, pressupóe métodos de trabalho qualitativamente diversos.

O caminho de uma contribuição do desenho industrial no Brasil, para o desenvolvimento econômico e social, passa obrigatoriamente por uma metodologia científica operativa.

Não se podem fazer comparaçóes absurdas com o design de países escandinavos, estes sim certamente baseados em sua qualidade artesanal, quando se propóe caminhos para o nosso design. Em primeiro lugar, não temos a mesma tradição de artesanato industrial desses países. Em segundo lugar, pelo menos em tese, devemos resolver problemas para cem milhóes de habitantes e náo dez ou vinte milhões, com necessidades, anseios e níveis culturais totalmente diferentes.

Isso não quer dizer, obrigatoriamente, que $\mathrm{o}$ artesanato seja irracional, primitivo etc. Significa, porém, que ao contrário do que propóe, talvez a saída para o nosso artesanato, hoje convertido em artigo de luxo e decoração em butiques e casas de mau gosto, esteja numa aproximaçáo com o design.

Talvez o que se devesse fazer fosse industrializar ou semi-industrializar o artesanato e não colocar o design brasileiro diante de mais um problema a confrontá-lo com sua indústria que cada vez exige menos qualidade artesanal.

Isso tudo leva a uma última diferenciação entre o trabalho artesanal e o industrial enquanto projeto: a relação com o consumidor. Ela é sempre direta, pessoal no caso do artesão, sempre indireta, anônima no caso de desenhista industrial. De qualquer forma, tentativas de incorporação decorrentes de um ao outro são em princípio perigosas e não podem ser encaradas do ponto de vista parcial. Mas o que seria então um "caráter nacional" no design? Que critérios permitem sua definição? Evidentemente, deveríamos antes de nos preocupar com características ou materiais autenticamente brasileiros, um tipo de formalismo enfim, em definir quais seriam as necessidades brasileiras sobre as quais o designer poderia atuar, através de que métodos e com que propósitos. Levar em conta as necessidades da maioria da populaçáo, inclusive, é claro, as de caráter cultural, ainda parece ser o melhor caminho. Um trabalho mais útil ao invés de tentar definir superficialmente padrôes do senso-comum ou concepções tradicionais de determinados extratos sociais. Muito mais importante que a "coleção de borboletas" que se possa fazer em tomo disso é a definição das necessidades reais, para determinar com clareza o que seja caracteristicamente nacional. Não se pode esquecer que para uma atividade que se diz um processo como o design, é essencial levar em conta o conceito de contemporaneidade. E esse conceito não é obrigatório em atividades como o artesanato e o folclore. Algo que seja caracteristicamente nacional em design, portanto, não é necessariamente ligado ao anacronismo ou ao provinciano.

Se d. Pedro I revivesse hoje, no Brasil, com suas maneiras extravagantes seria mais folclórico do que nacional. Porém, em seu tempo não tinha as características pelas quais assim seria qualificado, pois todo o Brasil era anacrônico e provinciano e, por isso, ele era nacional e contemporâneo.

Em resumo de um fato constatado, pode-se chegar a um princípio de análise e fica faltando uma síntese.

A ausência da determinação do que seja caracteristicamente brasileiro em design deve-se principalmente aos distanciamentos mútuos e desconfianças entre o design e as ciências humanas e sociais. A culpa desses fenômenos pode ser atribuída desde a má-formação acadêmica passando pelo sistema de ideias que condiciona a profissão em seus objetivos, pela falta de informação e análises superficiais e formalistas da profissão, feitos por elementos de outras áreas, fatores que reunidos impedem, em última instância, a possibilidade de determinar de forma real as necessidades existentes sobre as quais o designer deveria atuar, transformando-se naquilo que realmente deve ser: uma atividade de interesse social. 
Design: Marcas, pi43

\section{[NBC]}

Em janeiro de 1976 , quando a NBC, uma das maiores redes de TV dos Estados Unidos apresentou sua nova identidade visual criada pelo conceituado escritório de design Lippincott \& Margulies Inc., teve a desagradável surpresa de um protesto por parte da TV Educativa de Nebraska, alegando apropriação indébita do seu sinal em tudo idêntico ao da NBC. A TVE, de Nebraska veiculava sua imagem com antecipação de seis meses. Naturalmente criou-se a maior polêmica profissional entre os envolvidos, provocando, inclusive, debates e revisão de comportamento, cuidados de registro e de uso. Tudo isso através de revistas especializadas, sem entrar em campo de agressóes pessoais.

Cá entre nós, em caso semelhante se levantariam primeiramente suspeitas de provocaçóes pessoais, o que evita o teor educativo e debates construtivos apontando trabalhos em desacordo com suas finalidades. Temos lutado contra essa posição e nosso intuito é elevar conceitos críticos no sentido de educar, através de diálogo, não somente entre profissionais do design, mas com o público a que se destina e, principalmente, com os executivos que avaliam e compram tais serviços. Somente neste caso poderemos informar claramente o que seja desenho industrial e comunicação visual. Esta revista está aberta a qualquer diálogo, polêmica e contestação.

Sabe com quem está falando?

Nossas instituiçóes governamentais pouco ligam, ou não estão informadas, com o trato visual de seus meios de comunicação. Geralmente é com grande dificuldade que distinguimos, a priori, o remetente dos ofícios, impostos e brochuras que recebemos. Essa atitude é altamente antieconômica, não acompanha as premissas e exigências dos novos meios de comunicação. As imagens são ligadas a um passado de morosidade que não se coaduna com os esforços de nossos governantes em criar reformas administrativas sem fazer acompanhar uma implantação de um programa estrutural dos seus meios de comunicaçáo.

Um é bom, dois é demais, três...

A escolha de profissionais não especializados algum dos campos da comunicação visual e, principalmente não tendo informação de que especializados em programas de identidade empresarial são os programadores visuais (não confundir com engenheiros, arquitetos ou decoradores) geralmente resultam a apresentação de soluções já existentes, sem a mínima preocupação com uma pesquisa mais aprofundada. Nesse caso os exemplos se repetem, ad infinitum. E o que é pior, em certos casos alguns serviços, empresas adquirem um significado totalmente errado de suas funçóes. Por exemplo: bancos com tratamento de boutique e assim por diante.

Está chegando a hora.

Por que será que algumas indústrias insistem em manter status de tradição em detrimento de uma comunicação mais efetiva? Gastam enormes verbas em comunicaçóes perecíveis (publicidade) sem se importar com os meios ou conotaçóes negativas que a sua imagem representa. Veja a poluição da IRFM. Vamos eliminar as chaminés antes que a Secretaria do Meio Ambiente mande uma intimação.

Design: IAC, p.I44-I4

\section{Emilie Chamie}

Na década de 50 fiz o curso do IAC, no Masp. Naquela época praticava pintura, dedicando-me também à criação de cartazes, chegando a ganhar o Prêmio iv Centenário de São Paulo.

Passei enfim a me interessar pela arte gráfica e, em seguida, à programação visual propriamente dita. Trabalhei na equipe de Rubem Martins, de 1964 a 68, realizando na Formiform trabalhos individuais e de equipe que iam desde marcas e logotipos até a criação e racionalização de materiais visuais do grande complexo de Aratu, na Bahia. Mais tarde, fundei a minha própria empresa, denominada Semáforo, em 1969. Essa experiência foi 
interessante e valiosa, mas de certo modo me obrigava a algumas concessóes que deformavam a qualidade e o objetivo final do próprio trabalho. Infelizmente, pela falta de uma tradição maior, no Brasil, no campo do design e da programação visual, minha empresa se viu diante de pressóes de clientes que acabavam por limitar a criatividade. Por isso mesmo, e também para eu poder escolher o trabalho ao invés de ser escolhida por ele, resolvi atuar autonomamente. E, somando todas as fases, desde os anos 50 até hoje, diversifiquei minha produção. Em I974, a convite do Masp, realizei uma exposição retrospectiva, ganhando o Prêmio de Melhor Artista Gráfico do Ano, conferido pela APCA.

\section{Antônio Maluf}

Em termos de processos de criatividade, considero-me alfabetizado pelo Instituto de Arte Contemporânea, seja através da assimilação de um acúmulo de informações de ordem cultural, seja na absorção de conhecimentos relativos à prática artística - ou, ainda, na aprendizagem dos procedimentos básicos do trabalho de pesquisa. Por utilizar métodos didáticos extremamente avançados para a época, marcou-me profundamente o curso de Elementos de Arquitetura, organizado e desenvolvido com muita inteligência por Lina Bo Bardi, onde eram colocados problemas de organização de espaços e praticados exercícios de linguagem visual. Onde, enfim, o ponto, a linha e a cor adquiriram significados novos para mim.

O mesmo ocorreu com relação ao curso de artes plásticas, de Roberto Sambonet, rompendo com todos os esquemas das aulas de arte daquele tempo, a ponto de apresentar, por exemplo, uma simples lata para que os alunos descobrissem seus valores plásticos e semânticos, codificando-os posteriormente, no desenho ou na pintura. $\mathrm{Na}$ opção de minhas futuras atividades profissionais, o IAC foi mais uma vez decisivo, incentivando-me em minhas buscas de maior abertura, a posicionar, no lugar da engenharia que entáo cursava, o design como núcleo de meus projetos de vida.

Posteriormente, circunstâncias de ordem várias, entre elas a atuação no mundo das relaçóes empresariais, determinaram meus caminhos e descaminhos profissionais. Por um lado, ativaram-se minhas realizaçóes puramente artísticas, quando então, como artista integrado no espírito da chamada arte concreta, participei de vários salóes e bienais.

Paralelamente, desenvolvi as minhas atividades de designer no campo da estamparia de tecidos e projetos de murais para obras de arquitetura. Considerei a estamparia de tecidos como uma espécie de styling - ou melhor: antidesign - pois o design propriamente dito está no tecido em si. Isto é, sua trama e urdume resultantes da programação do trabalho da máquina. A estamparia do tecido é um processo de beneficiamento através do silk-screen, semiartesanal. Esses poucos processos foram por mim utilizados na produção de padróes, dos quais destaco os dos lançamentos da Rhodia daqueles tempos. Os que mais me alegraram, porém, foram aqueles executados diretamente sobre os tecidos, desligados dos problemas do rapport definidos pelos quadros do silk-screen. A partir do final dos anos 50, passei a produzir painéis integrados na arquitetura - e isso se constituiu no campo de aplicação de meus conceitos de design.

Em meados de 60 projetei logotipos e marcas trabalhando inclusive em planejamento empresarial, dada a minha formação também em administração de empresas. E hoje, como marchand e proprietário de uma galeria, continuo designer, criando uma estrutura, uma referência, uma marca, através de processos seletivos, baseados na compreensão do que é o Brasil cultural de hoje, do ponto de vista da forma e da função.

\section{Alexandre Wollner}

O Instituto de Arte Contemporânea foi decisivo em minha formação profissional. Até entáo atuava no campo da arte como gravador e desenhista, condicionado unicamente por elementos intuitivos e artísticos, sem nenhuma função objetiva. O IAC, e principalmente a vivência e a convivência no ambiente do Masp daqueles anos (I95I-53), aprimoraram minha capacidade intuitiva e permitiram-me perceber a possibilidade de participação social do artista através do design. Tal percepção 
confimou-se por volta de 1953, quando da exposição do pintor, escultor e designer suíço, Max Bill, no próprio Masp.

Tal exposição veio de encontro às minhas tendências, ainda potenciais, no sentido de fundamentar minhas criaçóes em raciocínio lógico e de participar de realizaçôes objetivas e eficientes no âmbito social. Informou-me ainda sobre o projeto de Max Bill relativo à organização de uma escola de design, de nível equivalente ao da Bauhaus, em Ulm, na Alemanha Ocidental. Orientado quanto à escolha definitiva da profissão, nada mais natural que considerasse a Alemanha como meta a ser alcançada para a minha formação, o que consegui através de bolsas de estudo da escola de Ulm, do Capes e de ajuda de custo do Itamaraty.

Após minha formação na Alemanha, onde realizei a síntese do intuitivo e do racional, e após 17 anos de atividade profissional e educacional no Brasil, constato hoje a lenta evolução da nossa estrutura industrial, econômica, social e cultural. Por isso creio oportuna a revisão dos conceitos do design, compatibilizando-os à realidade brasileira, independentemente de modelos externos e guardando as nossas devidas proporçôes.

Caso não se modifiquem as atuais condiçôes de indefinição, as novas geraçôes de designers estarão sujeitas à necessidade de atuação em outras áreas de atividades, repetindo-se progressivamente a situação dos meus colegas do IAC, excluídas as raras exceçôes.

\section{Aparício Basílio da Silva}

A época do IAC foi de grande entusiasmo em termos artístico-culturais. Apesar do desenvolvimento ocorrido nestes 25 anos, não mais se repetiu a experiência do início da década de 50. Naquela época tínhamos museus vivos, cursos de prática e teoria artística, com orientadores competentes, ao lado de exposiçóes e acontecimentos culturais altamente significativos. Havia então uma esperança; tínhamos a impressão de estar construindo um futuro cultural. Hoje, por exemplo, vejo a inexistência de um atelier de escultura, onde os interessados, como é o meu caso, possam desenvolver-se.
Quanto ao design de moda, sua evolução é bastante problemática, devido à mentalidade do industrial-empresário, do mercado, e, às vezes, do próprio figurinista. Há também a competição com as marcas estrangeiras e a ausência de uma infra-estrutura, particularmente no campo da confecção. A única solução para elevar o nível dos produtos de vestuário, seria o apoio governamental aos profissionais e o incentivo às atividades na área.

Paralelamente às minhas atividades como perfumista. estou atualmente partindo para um segundo negócio: a estampa para tapeçaria. Exige um esquema um pouco mais compatível com a situação brasileira, não necessitando renovação trimestral, como no caso do vestuário. Mas também neste campo persistem problemas devido à ausência de profissionalismo, de controle de qualidade, da falta de desenvolvimento tecnológico e know-how neste país.

Paralelamente às questóes da técnica, coloca-se o problema da coerência do desenho com o sistema de valores culturais da realidade brasileira. Raramente as pessoas se indagam: Quem somos nós? O que devemos usar? Do que necessitamos? Nosso sistema de vida não é europeu nem americano. Nossas casas são muito diferentes das deles, são muito mais despojadas, têm colorido característico, têm um clima e um gosto próprios e a vida dentro delas é também extremamente diferente. Por exemplo, agora está usando muito rosa-choque e turquesa. Pode-se imaginar entrar num ambiente aqui no Brasil todinho rosa-choque e turquesa sem ser no carnaval? Mas para perceber estas e todas as outras coisas, só mesmo provocando o milagre da elevação do nível cultural desta terra.

\section{Ludovico Martino}

Histórica iniciativa do Masp, o Curso de Desenho Industrial, em I95I, pode ser considerado como um dos marcos iniciais do nosso design. Além de suas evidentes funçôes didáticas, um dos principais resultados daquele curso foi o de afirmar a integração entre a comunicação visual e o desenho industrial, entre o projeto gráfico e o projeto do produto. Vigente durante mais de 25 anos, na formação e na 
prática dos profissionais brasileiros, hoje, esta integraçáo mais e mais se afirma.

Em nosso escritório, Cauduro/Martino Arquitetos Associados, como naqueles de muitos outros colegas, raros são os trabalhos que envolvem apenas uma destas especialidades. Pelo contrário, quase todos os nossos problemas de projeto abrangem aspectos de ambas. Para citar um exemplo desta integração, lembramos o Programa de Identidade Visual Villares. Complexo projeto (cobrindo o planejamento das mensagens visuais das diversas empresas daquele grupo), com seus subsistemas de sinalização interna, identificação externa e equipamentos, apresentou inúmeros problemas de desenho industrial.

Outros projetos nossos, como a sinalização da avenida Paulista, e de diversos Shopping Centers, o programa de Identidade Visual Banespa, confirmam a importância desta integração, que é um dos principais aspectos positivos da prática do design brasileiro.

\section{Maurício Nogueira Lima}

O ensino no IAC era muito bem fundamentado nas novas teorias vindas da extinta Bauhaus, preconizando um enfoque contemporâneo no desenho de objetos e mensagens ligadas à sociedade industrial. O curso tentou de várias formas um contato com a nascente indústria nacional. Mas, não obtendo êxito, voltou-se mais para a formação cultural dos alunos, e a única forma de design possível na época, isto é, ao aprimoramento das artes gráficas, o que hoje chamamos de programaçáo visual, tendo alguns de seus estudantes sido pioneiros da moderna comunicação visual.

$\mathrm{Na}$ época, o IAC, através de seus alunos, produziu modernos desenhos de estamparia, cartazes, folhetos, marcas de fábrica, capas de livros e revistas, diagramaçóes, projetos de vitrinas e estandes promocionais, além de sinalizaçấo urbana e desenho do vestuário.

O desenho dos equipamentos ficou a cargo de alguns arquitetos, por vezes talentosos, porém despreparados para o trabalho exigido pela indústria. Basta ver que a construção civil no Brasil encontra-se ainda hoje em um estágio semiartesanal.
Mesmo com a criação, na década de 60, da Escola Superior de Desenho Industrial, no Rio e, posteriormente, dos cursos de Desenho Industrial e Comunicação Visual na FAAP e no Mackenzie, e também da introdução nos currículos das faculdades de arquitetura de disciplinas relacionadas com o desenho do objeto e comunicação visual, o design brasileiro evolui no sentido da programaçáo visual, muito mais do que no sentido do desenho de objetos, eletrodomésticos e viaturas.

IAC

O Museu de Arte de São Paulo, pouco depois de sua fundação em I947, abriu um grupo de escolas que representavam, naquela época de escasso interesse e não poucas incertezas em relação aos rumos das artes, um fato bem aceito pela juventude, oferecendo também apreciável contribuição para o desenvolvimento da cultura em Sáo Paulo. As escolas mais concorridas eram a de História da Arte; a de propaganda (atualmente com a denominação de Escola de Propaganda e Marketing); dos vários ofícios das artes plásticas ministrados por Roberto Sambonet e Gastone Novelli, personalidades que nos anos seguintes granjeariam na Europa notável afirmação; de cinema, onde ensinava Alberto Cavalcanti o qual, a convite do Masp, voltou ao Brasil após três decênios de ausência; de artesanato, aos cuidados de Clara Hartock, do Bauhaus; de música, com a criação da orquestra juvenil, regida pelo maestro Mário Rossini, do Maio Musical Florentino; de balé, dirigida por Yanka; ecologia, comportamento, moda e inúmeras outras, entre as quais a do design, talvez a iniciativa mais importante. Se denominava Instituto de Arte Contemporânea, dirigido por Lina Bo Bardi, com resultados concretos, apesar das dificuldades de entrosamento com a indústria. Agrupava alunos oriundos de vários centros e admitidos após testes. Quase todos os elementos se distinguiram depois nos mais variados setores de atividade interligada nas artes, sendo que alguns deles oferecem, nas páginas de Vogue Arte, um depoimento. 
FIESP

Um centro de desenho industrial, em São Paulo, inaugurado com exposição organizada pelo Museu de Arte Moderna de Nova York será acontecimento em 77. A iniciativa é da Federação das Indústrias do Estado de São Paulo, que instalará o centro nos $800 \mathrm{~m}^{2}$ do primeiro andar do novo edifício-sede do Senai, à avenida Paulista. O objetivo da Fiesp neste empreendimento é conscientizar os empresários brasileiros das possibilidades do desenho industrial. Iniciando o acervo do centro, a exposição doada pelo MoMA, ilustra a evoluçáo do desenho industrial no século 20, através da apresentação de 170 objetos, peças de mobiliário, utilidades domésticas, equipamentos de trabalho e lazer, ferramentas e acessórios os mais diversos. Ambas as iniciativas contarão ainda com a colaboração de várias indústrias brasileiras.

\section{Prêmio Philips}

O projeto que for considerado pelo International Council of Societies of Industrial Design como a mais válida contribuição aos países em desenvolvimento, receberá, através de concurso anual, no período de 1976 a I979, prêmio no valor de 125 mil cruzeiros, instituído pela Philips. O objetivo é estimular o desenho industrial nos países em desenvolvimento para que seja possível a concepção de produtos e sistemas a eles adequados e, consequentemente, a melhoria da qualidade de vida de suas populaçóes. Outra finalidade é a de favorecer a compreensão do desenho industrial como profissão suscetível de contribuir para a solução de problemas sócio-econômicos dos países em desenvolvimento.

[Embalagem, Design e Consumo]

A exposição itinerante "Embalagem, Design e Consumo", o Curso e o Manual para Planejamento de Embalagens, provocaram no ano passado amplo debate sobre o assunto em Recife, Salvador, Rio, São Paulo e Porto Alegre.

Trata-se de um conjunto integrado de trabalhos sobre embalagem, desenvolvido pelo Instituto de Desenho Industrial do MAM do Rio, contando com o apoio do Ministério da Indústria e Comércio, através do Programa o6 de incentivo ao desenho industrial brasileiro.

\section{Compasso d'Oro}

Criado em 1954, o Prêmio "Compasso d'Oro" é talvez o mais importante da Europa, em seu gênero. Organizado pela ADI, Associazione per il Disegno Industriale, bienalmente, distingue os vinte melhores produtos italianos, bem como programas de identidade visual, pesquisas de desenho industrial, estudos teóricos e projetos de promoção do desenho industrial.

\section{Prêmio Braun}

Alunos de cursos de desenho industrial e designers com menos de dois anos de atividade profissional serão os candidatos ao Prêmio Braun 77, no valor de 220 mil cruzeiros. O prêmio visa a estimular a formação de novas geraçóes de designers e difundir conceitos de bom desenho. Embora o tema dos trabalhos seja de livre escolha dos participantes, os critérios de julgamento foram previamente estabelecidos e divulgados. Sabe-se que - quanto ao objetivo dos projetos - serão considerados os graus de inovação, complexidade, dificuldade e importância. Quanto à pesquisa preliminar será levada em conta a profundidade, amplitude e sistemática. Quanto à solução proposta, serão avaliadas a originalidade, os modos de funcionamento de utilizaçáo, como também, o estudo de processos e custos. Em relação à exatidão para concretização da solução, importarão os detalhes, as características ergonômicas e funcionais e a qualidade do design, tanto nas partes como no todo. $\mathrm{Na}$ apresentaçáo serão levadas em conta a clareza e a qualidade da execução.

\section{Selo da Boa Forma}

Um positivo sinal de desenvolvimento de nosso desenho industrial acaba de ser dado pela Secretaria de Cultura, Ciência e Tecnologia do Governo do Estado de São Paulo com a criação do "Selo de Boa Forma”. Destina-se a identificar produtos industriais que se destaquem por suas características de bom design como já existe 
em outros países. Por outro lado, esse selo objetiva a oferta de melhores produtos aos consumidores em geral, através da elevação da qualidade do design nacional, promovendo-o junto aos empresários.

\section{Comunicação, p.I62}

Como conseguir o título de crítico de arte? Simples: existe uma associação paralela, a dos artistas, e basta pedir a inscrição anexando como comprovante um recorte de jornal que tenha publicado algumas colunas sobre o assunto. Obtida a caderneta prossegue a compilaçáo de pareceres, que é facílimo, pois a demanda das bienais, salóes, salóezinhos, galerias é tão inflacionária que tem lugar para todos. Constituído seu mini-império, dispóe e organiza sua estratégia, (sempre através da publicidade) conquista posiçóes na imprensa que lhe permitem a emissão de bulinhas e bênçãos, às vezes - genus irritabile criticum - censuras e anátemas, de acordo com as amizades e os interesses. No mês de abril, no Rio de Janeiro, os anais da crítica registraram um caso inédito e que vale a pena ser comentado: Frederico Moraes, elemento em geral manso, culto, curriculado, emergente entre tantos clérigos, desencadeou tremenda reprimenda contra Sepp Baendereck, réu náo por ser pintor, mas por pertencer a uma outra tendência repelida pelo colunista.

De fato, o grande Frederico, ao invés de despachar o Sepp para o inferno na sua qualidade de pintor, o atirou nos dannati, pois descobriu que ele pertence à categoria que opera na "atividade diabólica que nos corrói por dentro a cada momento, a cada segundo, com slogans e ideias altamente perniciosas de efeito negativo irreversível..., uma espécie de ditadura que nos impóe uma filosofia de consumo que aliena até a morte..." O crítico, apoiado no fantasma de Maquiavel e, naturalmente, no diabo trapalhão, descarrega sua repulsa contra a "impregnação publicitária” elevando à milionésima potência seu Vade retrum, de sorte que bem se pode apreender, o pessoal metido naquele nefasto negócio não é digno de ser sepultado em cemitérios de animais.

O curioso da desconsideração é que o jornal onde o texto apareceu é veículo de
Para implementação deste programa a Associaçáa Brasileira de Desenho Industrial (ABDI) e a SCCT, estão mantendo contatos visando a definir suas condições operacionais.

publicidade, (serve também à publicidade do crítico) isto é, comunicação de gente, produtos, ideais. Cuspinhar na folha em que se escreve, deblaterar em termos ofensivos a toda uma classe operosa e que faz parte da engrenagem da vida assim como é, nos parece tratar-se de matéria, não pertinente à crítica de arte. Pode talvez ser crítica de costume, mas então seria mais honesto renunciar a viver inter impares. Aflora, ainda, um outro perigo: se o Frederico contraria, por exemplo, a classe média, arrasaria com o Burri.

Concluindo: atenção artista que vai expor no Rio e por acaso exerceu ou exerce uma profissão que não seja do agrado do crítico, que tome suas precauçóes, pois o Frederico é o guardião da Porta Inferi das mil profissóes, e talvez no dia do vernissage ele, não reverenciado ou mal-humorado, corra ao $O$ Globo e, genus irritable criticum desabafe não contra o que você apresenta, mas contra a profissão exerceu ou ainda exerce, pois ele acredita na fórmula superada da Arte pela Arte, identificando o pintor no personagem confeccionado por Henri Murger. 


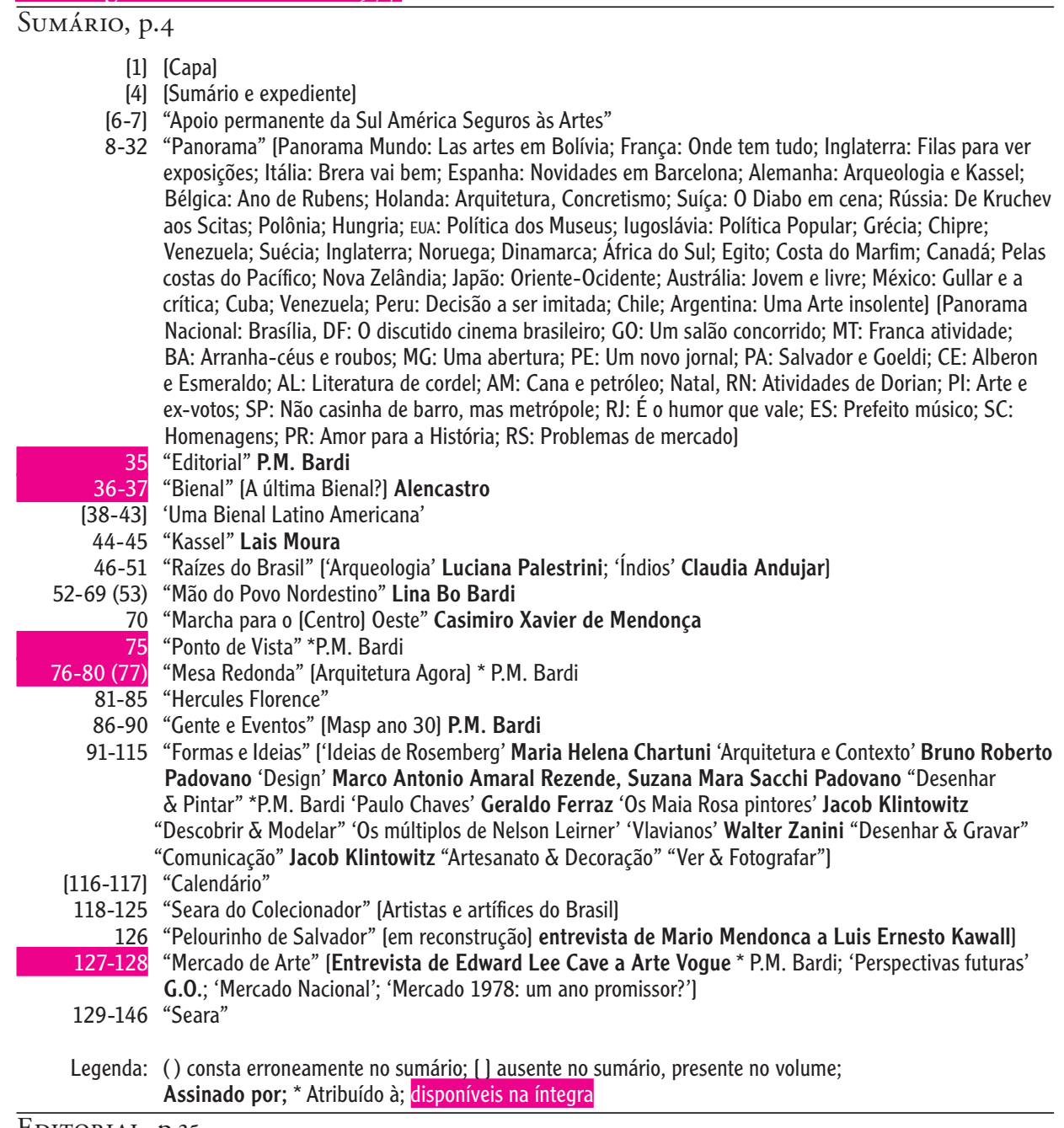

EDITORIAL, p.35

No editorial de Arte Vogue n ${ }^{\circ}$ I convidamos os leitores para discutir e exercitar a crítica ou criticar, o que não é a mesma coisa uma vez que entendemos a crítica como uma atividade que implica experiência, preparo e saber para onde encaminhar uma opinião; além disso, criticar é atividade dependente de um simples gostar-não-gostar, do julgar negativo quando se diverge do resultado, o avançar pareceres. Numerosos foram os pareceres referentes à tentativa de oferecer uma visão das artes ao público nacional, através uma revista que quer registrar fatos e problemas. E parece que atingimos a meta, pois alentado foi o número de cumprimentos que recebemos pela edição de número inaugural. Deu para constatar que a nóvel publicação não foi somente compulsada com olhadelas, mas sim inteiramente lida, determinando opinióes pró e contra e, mais confortadoramente para nós, pró. Seria ingênuo (mesmo sendo provincianamente usual) estandardizar os aplausos tão comuns nos catálogos que enfeixam "críticas" entusiásticas para o expositor, e ignorar as desfavoráveis, geralmente raras. Vamos, no entanto, protocolar as gratas observaçóes contrárias, algumas das quais nos chamaram, proveitosamente, a atenção. Tópicos de jornais e numerosas cartas, chegadas desde o Amazonas até o cone Sul, acham que Arte Vogue deveria relatar mais à vida artística dos Estados da Federaçáo brasileira. Dois destaques: uma carta de Mato Grosso e uma nota de um jornal de Curitiba, bem como outros comentários vindos, de longe, insistindo sobre a necessidade de considerar mais o que fica fora do eixo formado por São Paulo e Rio de Janeiro. É de se observar que Arte Vogue pretende ser uma publicação de caráter nacional; 
mas há que se admitir que pela magnitude da extensão territorial do país, não é fácil dar conta dás centenas e centenas de manifestaçóes que se realizam, sendo que em muitos Estados já começam a se publicar periódicos dedicados às artes, (o Jornal das Artes, do Recife e o MARGs, de Porto Alegre) sem contar a nova revista Arte Hoje, iniciativa de Roberto Irineu Marinho, do grupo Globo. Um leitor apreciou a reportagem focalizando Belém e o seu Museu Goeldi; já neste número aparece um museu da Bahia e c extraordinário labor do homem do Nordeste, numa reportagem rica de inéditos. Proximamente trataremos da vivaz atividade de Curitiba, Belo Horizonte e outras capitais brasileiras Os leitores podem e devem continuar nos ajudando, oferecendo opinióes que serão cordialmente recebidas. Será uma maneira de desmentir a história de que o brasileiro é epistolarmente preguiçoso, particularmente no que se refere às coisas da Cultura. Aos que se queixaram de que o próprio Estado teve "noticiário por demais reduzido” respondemos de que não é porque nos envelopes náo colocaram elementos dignos de serem considerados pela redação. Estamos conscientes de que nem Sáo Paulo nem o Rio significam o país como um todo. Não. Mas precisamos da ajuda de todos aqueles que realmente se interessam pelos problemas da Cultura brasileira e, dentro desta, a Arte no seu sentido mais amplo. Mandem-nos notícias, correspondam-se conosco, sem acanhamentos, e ajudem-nos a fazer de Arte Vogue, aquilo que tanto ambicionamos: a revista das artes do Brasil.

Os principais assuntos deste número são o monográfico, que focaliza alguns aspectos das origens e das raízes do Brasil: arqueologia, agora em desenvolvimento, presença sempre mais inquietante dos índios, inventiva do povo nordestino e realidades dos territórios longínquos das metrópoles muito mal conhecidos.

Arte Vogue oferece aos seus leitores um inédito da mais alta importância, a "Ordem Palmiana," ideada pelo poliédrico artista e inventor Hércules Florence, desenhista da Expedição Langsdorff, do Tietê ao Amazonas por via fluvial na segunda década do Oitocentos. Sempre no campo da História: uma antecipação da exposição Artistas e Artífices do Brasil, séculos I6 e I8, a ser realizada em novembro no Masp, tentativa de um panorama sintetizado de quanto se produziu no período colonial, adaptando o barroco, inovando-o, às vezes saindo por caminhos originais. Arte Vogue quer registrar o mais possível assuntos pouco ou mesmo desconhecidos, evitando calcar no demais retórico e até, às vezes, no por demais batido. Por isso, mais uma vez apelamos para os leitores na intençáo de estreitar uma colaboração que visa a revelar fatos e personalidades que por esta ou aquela razáo ainda náo tiveram ocasiáo de ser conhecidas.

Uma exceção é feita pelos 30 anos do Museu de Arte de São Paulo, para lembrar a iniciativa de Assis Chateaubriand e, sem falsa modéstia, por mim, tentativa hoje de uma esplêndida realidade e apesar dos inumeráveis empecilhos muito próprios das instituições culturais. Falar de si próprio não deixa este escriba muito à vontade; porém, o diretor do Masp, que festeja este ano três décadas de devotamento à causa da cultura, e, dentro desta, as artes em geral, sente-se gratificado como, ao olhar para trás e contemplar o longo caminho percorrido, vê que cumpriu seu dever e viu realizadas muitas das suas esperanças.

A última Bienal?, p.36-37

Alencastro

Um passo à frente foi dado pela Bienal de São Paulo ao estabelecer um regulamento que, finalmente considera as artes como síntese de diversas linguagens e processos, e um "tudo vale" que vai colocar o público diante de expressóes antitradição, uma iniciativa que vinha sendo lançada e prepotentemente proposta há tempo pela coirmã de Kassel. Mais uma vez, o Brasil vai se alinhando face às supremas decisóes dos que na Europa e nos Estados Unidos ditam as leis da moda. Nos primeiros anos, a Bienal paulista espelhou-se, parágrafo por parágrafo, na de Veneza, que foi a sucessora das exposiçóes que complementaram as internacionais do industrialismo, por sua vez essas liquidantes dos Salóes que tiveram o batismo em Paris nos fins 
do século I8; agora, a renovada Bienal se amolda às novidades internacionais, para não se inferiorizar diante da competição do iffaut être absolument moderne.

Mais uma vez os organizadores da Bienal local querem que as crônicas não apontem um não-frentex, pois o país vai para a frente, mesmo sabendo que "é feito por nós.” (Nenhum entre centenas de autocadernetados artistas participantes ou deixados no gramado pelo Conselho de Arte e Cultura "reunido durante 24 dias, num total de 25 horas de trabalho," como se lê nos comunicados à imprensa, pensou em apresentar um pouco de blank art, projetando no infinito aquelas estrelinhas que na tv no final se conglobam numa única grande estrela que seria a síntese do Cruzeiro do Sul, isto é, positivamente o nosso caro Brasil.)

Como a Constituição não proíbe a discussão dos problemas rubricados na pauta arte, é o caso de registrar o erro de base que os senhores e senhoras que tutelam a Bienal, mais uma vez produziram para um certame digno de melhor sorte: o erro de base, em nosso parecer, é o genérico da condução da vida brasileira, o olhar demasiado para fora e náo prestar atençáo no que se faz, o que se quer e o que se pode inventar aqui dentro das fronteiras pátrias. A observação nada tem a ver com o espírito de nacionalismo - fato superado nos tempos que correm, apesar de apresentar nocivas acentuaçóes emanadas de naçóes imperialistas - trata-se na verdade em se pensar e resolver (tesourando, naturalmente, o que de bom e útil se produz lá fora) com a própria cabeça e conforme as exigências das próprias necessidades morais e materiais. Antigamente foi proposto ao chefe da Bienal adaptar a manifestação a um sistema mais conveniente para uma informação correta do que se passava no campo internacional das artes, recomendando acabar com os convites a qualquer país para receber pacotes fechados sem que se soubesse o teor do seu conteúdo, tomando a decisão de confiar a uma comissão brasileira a seleção do realmente válido e representativo de cada nação: e acabar com aquela marmelada dos prêmios que, por absurdo acabou dando por duas vezes o prêmio internacional a um artista local, mas sem maior foro de fama, se bem que prestativo. (Fato inédito neste tipo de disputa.)

Assim, também na XIV edição da Bienal, reformada e arejada, continuaram os convites a todos os países e a bandeirada dos prêmios. A participação não é mais com aqueles poróes cheios de caixas, o que permitiu bolar o singular slogan de: “7 quilômetros de pintura:" agora vários países se abstiveram, alguns dos higs se retiraram deixando voluntariamente extraoficial arranjar participaçôes de comando, enquanto outros nomearam comissários membro da própria diretoria da Bienal. São todas determinaçôes que pesam sobre um organismo por demais envelhecido. $\mathrm{Na}$ verdade os nossos organizadores compreenderam o erro de base e procuraram nos limites do possível ajustar as participaçôes estrangeiras a uma nova realidade, que seria de compor panoramas representativos, superando o antigo sistema que era mais feirístico do que crítico.

Deve-se agradecer aos responsáveis pela tentativa de um transplante, feito em moldes, como se disse, frentex, admitindo nos pavilhóes do Ibirapuera novos elementos, grande parte daqueles que, na defunta Bienal Nacional, foram englobados sem passar por um júri, pois os componentes do tribunal um certo dia se cansaram de opinar, abrindo as comportas diante da avalancha daqueles que vinham descobrindo que a arte não é um hobby sério.

O boletim de 30 de maio da Fundação Bienal de São Paulo informava solenemente que 93 artistas nacionais tinham sido admitidos para colocar nas salas suas "propostas", devidamente divididas nas categorias "Arqueologia do Urbano", "Recuperaçáo da Paisagem”, "Arte Catastrófica”, "Vídeo Arte", "Poesia Espacial", "Muro como Suporte de Obras", "Arte Não-Catalogada”. Sáo mais uma centena de novos produtores se não propriamente de arte, certamente de ideias, gestos, danças, sons, brincadeiras e, possivelmente, novidades que a história poderá até registrar.

Diante destas várias manifestações deve-se oferecer cordialidade e consideração. É bom lembrar que os Dadaistas inauguraram este 
tipo de comunicação-choque há mais de meio século, a bondade de Tristan dando frutos consideráveis, através de vivíssimas personalidades. Naquele Cabaret Voltaire, de Zurique, em I916, se reuniram uns poucos gatos pelados; na Bienal e em todas as exposiçóes internacionais a filiação dada alinha milhares de artífices. Não é de se escandalizar: é a marcha do Tempo, é a mudança ao encarar o fenômeno do desvio para caminhos diferentes. Escândalo também faz parte da estrutura da arte.
Precisamos nos acostumar ás surpresas. Por acaso o Cubismo não foi surpresa?

\section{Legenda}

p.36 Tempos amigos: a I ${ }^{a}$ Bienal de São Paulo Orensanz (Espanha), Esculturas

p.37 Ramon de Vargas (Espanha)

Assassinado, óleo sobre painel, 2,40 x

6,30 m 9 Alfred Jensen (EUA) Mr. Faraday's

Diagram, óleo sobre tela, I $\mathrm{m} \times 2 \mathrm{~m}$ g

Miguel dos Santos, Três das pinturas exis-

tentes na sala dedicada ao pintor paraibano

Uma Bienal Latino-Americana, p.38-43 atribuido a P.M. Bardi

Em lugar da Bienal Nacional, cuja última edição não passou de uma feirinha de amadores, a Fundação decidiu lançar uma Bienal Latino-Americana. Perguntamos ao dr. Oscar P. Landmann presidente da entidade, como via o novo empreendimento e ele nos respondeu: "Deixarei em fevereiro do próximo ano o cargo de presidente e assim será meu sucessor e a equipe nova quem vai preparar aquela Bienal. Eu tratei deste assunto já em 1975 com representantes da Argentina, Colômbia, Peru, México e Uruguai, sendo aceita com enorme entusiasmo a ideia de fazer da Bienal a grande vitrina da arte latino-americana perante o mundo. Alberto Beuttenmuller, membro do Conselho de Arte da Bienal, teve em junho do ano passado, esta excelente ideia, com a qual todos os membros da diretoria e do conselho concordaram plenamente. De minha parte, já iniciei os primeiros passos, isso há dois anos, buscando apoio em diversos países e expondo minhas ideias que são as seguintes: em primeiro lugar, sou de opinião que para cada país latino-americano, ou pelo menos regionalmente para vários países, temos que nomear conselheiros de nosso Conselho de Arte, no exterior. Estou pensando em nomes como Juan Acha, no México; Martha Traba, na Venezuela; Carbonel, na Colômbia; Angel Kalenberg, no Uruguai, e outros, sendo que eles deveriam vir a São Paulo pessoalmente durante os preparativos, para assistir a uma reunião do Conselho. Vejo a Bienal Latino-Americana de uma forma completamente diferente da Internacional. Creio que cada país deve propor uma participação com algo que seja totalmente típico."
O que aconteceu durante o ato de comunicação dos premiados da XIV Bienal é por demais conhecido graças ao noticiário da imprensa em geral. Portanto, náo vale a pena retornar ao assunto. A culpa não é do júri que fez o possível para contentar os vários países participantes; a culpa reside no sistema de premiaçóes, superadíssimo. Os artistas não são cavalos de corrida. Chagall é melhor que Léger, ou mesmo que Braque? Só o defunto ingênuo dono das Bienais (não deixou um centavo para a entidade que presidiu durante anos e que lhe deu fama de mecenas, justo ele que era riquíssimo) poderia ter pensado em graduaçóes stakanovistas. Nos tempos em que os júris opinavam sobre pinturas e esculturas figurativas o critério funcionava, incorretamente, mas funcionava; hoje com aquela onda, aliás tempestade, de conceitualismos, pensar em primeiro, segundo ou terceiro valor, é ridículo. Assim e diante do ocorrido, só resta esperar que o próximo conselho diretor da Bienal suprima aquele sistema obsoleto e sem interesse.

Naturalmente os itens a serem suprimidos são numerosos, porém este dos prêmios é o mais urgente.

Para quem tenha tido oportunidade de visitar a Bienal durante sua abertura, ziguezagueando por entre as caixas, muretas em construção, tapumes, cheiro de tinta, expositores atarefados e lépidos, nuvens de poeira e de espirais fumageira, a imaginação sugeria que aquela representava comunicaçáo válida para um panorama da arte dos dias de hoje. Não é gozação. $\mathrm{O}$ que o repórter afirma o faz 
com convicção: vendo um amontoado de entulho misturado a lixo intelectual de livros, fotografias, restos de coisas caseiras, é lícito pensar que se o negócio é apresentado como "produto da arte" todos os amontoados de entulho cotidianamente deixados aqui e acolá, são "produtos de arte." E pode ser, se organizadores patenteados de exposiçóes internacionais os consideram como tais. Por isso, indo fotografar na Bienal, encontrando o carrinho para transporte interno de "telas já eram," abandonado num canto, o dignificamos como obra de arte. Náo pense o leitor que brincamos. E deixe seriamente pensar que algumas coisas no setor estão mudando.

\section{Legenda}

p.38 O último Carro, de João das Neves, é o ponto alto da Bienal: a premiadíssima peça teatral escrita nos anos 60 e apresentada ao longo de um ano no Recife, está em cartaz diariamente num teatro de arena onde o espectador está no palco e os atores na cena Paulo de Andrade e Zeca Rodrigues, natureza morta, caixão contendo natureza-viva engaiolada.

p.39 Rufino Tamayo: cómo pinto yo: 1 En general, trabajo directamente sobre la tela, sin hacer notas previas, y procediendo inmediatamente a la transposición de las formas reales que molivan el cuadro. 2 Comienzo mi trabajo diseñando la estructura general del cuadro, y sobre ella construyo con la pintura. 3 Nunca he trabajado con luz artificial, pues considero que sólo la luz natural da a los colores su justo valor tonal. 4 Aunque he pintado sobre toda classe de materiales, creo que la tela, por su extraordinaria textura, es el material que ofrece más posibilidades para el manejo de la matéria pictórica. 5 Mi paleta es lo más limitada posible, pues creo que el secreto del color no está en la ulilización de todos los colores existentes, sino por el contrario, en el manejo de unos cuantos, extrayendo de ellos todas sus posibilidades tonales. 6 Pinto utilizando toda clase de instrumentos de trabajo, pues cada uno de ellos produce una textura diferente, logrando así, una mayor riqueza de la materia pictórica. 7 Uso las telas preparadas de mejor calidad que se pueden obtener en el mercado. Creo que son realmente buenas, y se pueden obtener de la textura y grado de absorción que uno desee. Por lo que respecta a los colores, como en muchos casos los que se compran ya manufacturados, no tienen suficiente cuerpo, preparo los míos al punto conveniente. 8 Hasta ahora, sólo he trabajado en una sola tela hasta terminarla, mas como en mi nuevo trabajo estoy ensayando texturas nuevas, para las cuales es necesario dejar secar las telas de vez en cuando, y antes de superponer nuevas capas de pigmento, estoy ensayando también, pintar dos cuadros paralelamente, con el objeto de no interrumpir mi ritmo de trabajo. 9 Rufino Tamayo, Retrato de Olga, I964, óleo sobre tela, 2,IO m x I,35 m. Col. Olga Tamayo, Mexico. I Rufino Tamayo, Vendedores de Peixe, 1972, óleo sobre tela, 0,95 m x I,35 m. Coleção Jacob B. Noble, Roslyn, Nova York Rufino Tamayo, Homem Subindo a Escada, 1973, óleo sobre tela, I,45 m x I,Io m. Col. arq. Manuel Reyero, México.

p.40 Sala de Juan Romero (Espanha) Sala de Manuel G. Raba (Espanha) Martín Naylor (Inglaterra), Comunicação de ideia

p.4I Sepp Baendereck que fora convidado para participar conjuntamente com Olívio Tavares de Araújo, em sala especial, dentro do tema Recuperaçáo da Paisagem, teve sua exposição "cassada" pelo simples fato de ter Olívio desistido de participar com o filme que começou a rodar na Amazônia, sobre a pesquisa e a pintura de Sepp, muito embora a obra deste independa do outro. Eis duas das telas, I,35 x I,80 m que náo foram apresentadas. 9 Juan Gomilda (Espanha), arqueologia do Urbano g Mário Cravo Neto, Ninho em fiberglass construído por pássaros.

p.42 Alberto A. Carneiro (Portugal), Ambiente Franz Erhard Walther (Alemanha), Halbkreis II Josef Lukomsk (Polônia), Environment II, I973-77 Lee, Kang-So (Coreia),

I Bardi critica a curadoria dessa exposição “Todos estão lembrados da $14^{\text {a }}$ Bienal quando foi oferecida uma visão quase total da obra de Rufino Tamayo, que resultou num autêntico desastre sob o ponto de vista da formação de uma ideia da personalidade do mestre mexicano." 
Coca-cola, 7722 Adib Tabach, Passaporte

g Kurt Sinrist (Suíça), Comunicação

p.43 Camille de Taque (Bélgica), $L a$

vision du Sentiment, 1976, 2 × 2 m. Col.
J.P. Pestian Alírio Palácios (Venezuela)

g Bernard e Hilla Becker (Alemanha),

Tipologia, 1963-75, I,40 x I m
Ponto DE VIsTa, p.75

atribuido a P.M. Bardi

Recentemente a Rede Globo de Televisão realizou, nas principais capitais europeias e na cidade de Nova York, uma pesquisa de opinião pública cuja principal pergunta era saber o que se pensava do Brasil. Autêntica Waterloo, pois o pessoal demonstrou nada saber ou, como consolo para os entrevistadores, lembravam-se do país grande produtor de café, aliás um produto de preço alto e de que Brasília era a sua nova capital, e algumas outras noticinhas tropicais. Para quem, de vez em quando, recebe correspondência postal endereçada "São Paulo, Argentina," ou entáo apreende num dos tratados de arquitetura mais reputados, o do Lurçat, que nossas metrópoles pertencem à vizinha república platina, o informe do Canal 5 não constitui novidade; todavia, ele serve para que voltemos, mais uma vez, ao assunto para dizermos da necessidade de se fazer saber no estrangeiro o que é o Brasil, especialmente o de hoje, quando situaçóes e casos de política interna se prestam, aos menos informados e simplistas, a interpretaçôes deformadas, alterando com isto a imagem nacional além do necessário.

Naturalmente não é possível delinear um retrato político do Brasil, em molde tão requintado que motivaria telegramas de congratulaçóes do presidente estadunidense, tão pouco de Brejnev ou de outros chefes de naçóes que estejam mais ou menos, no tocante à política, nesta condição: se Esparta chora, Micenas não ri, ou vice-versa.

O ponto de vista exarado não conta que se pise em terreno eivado de armadilhas dos complicados negócios do xadrez internacional, agravados pela posição do Brasil face a uma serie de fatos por demais complexos: somos um imenso, rico e feroz território que suscita não poucos apetites dos imperialistas de todos os quilates, potentes e impotentes e portadores de dores agudas de cotovelo; ser um país - como repisa o slogan que substituiu outro, sinceramente primaríssimo (ir para a frente) feito por nós."

Trombetear um produto industrial náo constitui problema: boas e de motivar risadas ("a voz é a mesma, mas os meus cabelos...” etc.) servidos em panaceias publicitárias que se amontoam, mal distribuídas na tv, contribuindo egregiamente para fortalecimento da incultura dos curtidores de novelas e de cantantes; porem quando o assunto se torna fato de interesse nacional, as responsabilidades devem ser encaradas com seriedade.

Asseguramos a todos que não foi para encher páginas e páginas que Arte Vogue $\mathrm{n}^{\mathrm{o}}$ I veiculou matéria referente a uma mesa redonda quando foi discutido um tema ao qual deve ser atribuída a mais alta importância: a necessidade da criação de um Ministério da Cultura. Os convidados, com total liberdade e plenos de autoridade, opinaram sobre casos interessantes. Vários leitores acharam que ninguém pegou o touro pelos chifres.

Um amigo de Arte Vogue, na ultima hora impedido de participar do conclave, confiou-nos seu ponto de vista nos seguintes termos: "Se existe uma bagatela que deve ser encarada já, com urgência e o máximo de polêmica, custe o que custar, sem olhar nas caras de ninguém, altóes e baixinhos, destruindo até mesmo o último cabide (desde os de molas para adoçar a função até aqueles revestidos de veludo perfumado ou mesmo aqueles simples de arame usados pelos tintureiros) a bagatela, repetimos, é a Cultura, certamente não a física, na qual estão engajados batalhões de Matheus que vão desde os preparadores, os massagistas até aos milhóes de coitados, aflitos, para o maná da Loteca. por sinal esta e o seus aficionados, em franco desenvolvimento. Quero falar de cultura da mens e não do músculo, até sem protestar pelo custo astronômico do inválido cooperçucar, através do qual o Brasil vende 
menos açúcar no mercado. Desculpem-nos os colegas se aparento um certo ar de radical, isto é, filiado a uma atitude que no Brasil se tornou sinônimo de moleza. Sem contestar para não ser confundido com os que mais o são, austeros Capaneus, permanentemente do contra, quero dizer em síntese que a cultura brasileira está declinando. Burocratizada num melecar de acomodaçôes e amadorismo, do deixa está para ver como fica, reduzida aos mal redigidos e insossos abaixo-assinados do pessoal - salvo uns poucos - que se proclama intelectual, cientista e artista (autocadernetados). Devemos reagir diante de situaçáo estranha como esta em que vemos o MEC patrocinar lautamente jogos de futebol, enquanto deixa agonizar por inércia os institutos que servem para fortalecer e animar o que realmente vale para impelir o país para a frente. Muitos são os governos que apregoam constantemente o slogan de "justiça social." Evidentemente a fórmula não é circunscrita ao setor econômico que, sem dúvida, é a base de tudo: implica certamente no setor Cultura. Aliás a Economia é consequência da Cultura.

Mesa Redonda: Arquitetura agora, p.76-8o atribuido a P.M. Bardi

Convida-se um, convida-se outro para participar de uma mesa redonda quando será discutido um assunto da maior atualidade e relevância: "Arquitetura agora;" cada um, no instante do convite, promete participar do encontro, mas ulteriormente, ao serem convidados a confirmar suas presenças, estranhamente oferecem um leque de desculpas pouco convincentes, exonerando-se do compromisso. (Na mesa redonda dedicada a proposta para verificar-se da necessidade da criação de um Ministério da Cultura, conforme publicamos em nossa edição $n^{\circ} I$ aconteceu o mesmo: várias personalidades que na opiniāo de numerosos inscritos no Clube da Inteligência, teriam chance de debater o problema com competência e ênfase, negaram-se a dar sua desejada contribuição, oferecendo rica série de excusas.)

Por experiência é sabido que a discussão não é lá muito da preferência da parte daqueles que se interessam pelas vissicitudes da Cultura sendo, pelo contrário, o prazer, às vezes excessivo, pelos que se dedicam à política. (Curioso: estes últimos, imersos em suas atividades, não incluem as dos outros nas discussóes que se desejaria ver agitadas nos conclaves em que sáo elaborados os princípios e as doutrinas do comportamento entre os homens e, parece, os povos.) Se "esporte é saúde" a Cultura é a "geologia da alma" e, em última análise, é política. Foi pensando na definição de Bacone que promovemos a mesa redonda sobre um órgáo político que deveria ser incumbido de considerar a Cultura em si, e não como apêndice da Educação.
É fácil não sermos compreendidos e, como dissemos acima, acabar desencontrando-se e, por consequência, discutir em solilóquio. Foi por isso que a mesa redonda programada para examinar a situação "Arquitetura agora" resultou num simpósio entre personagens imaginários: um estudante, um Velho Profissional, um Urbanista, um Radical, um Imobiliarista e um Morador.

Encontrado um Moderador, que fez questão se conservar no anonimato para evitar eventuais dores de cabeça, deu, em primeiro lugar, a palavra ao

Velho Profissional Fui escolhido profissional, portador de títulos e diplomas pendurados nas paredes de meu escritório, e por ser o decano de numerosas escolas, de abrir este debate que visa a discutir o problema da arquitetura, neste momento em que nossa querida arte-ciência é posta em questão. Não vou recapitular sua história mais recente, pois vocês todos a sabem, se não com conhecimentos preciosos, pelo menos de orelha. Assim, sem mais delongas, darei a palavra ao colega Radical que vejo muito gesticulante e impaciente. Ele falara depois do Morador, o qual acena-me pedindo um aparte.

Morador Justamente. Sabendo a história do que se passou, quero deixar bem claro que minha presença visa simplesmente a saber qual será o destino de nós moradores. Em minha qualidade de inquilino, autêntico consumidor de arquitetura, , bode expiatório e por que não dizer, às vezes, arquiteto. Não se surpreendam: quando o estimado profissional está por 
demais ocupado em projetar pescoços de girafas e mansóes, nós projetamos e construímos barracos em favelas.

Velho Profissional Peço o favor de não escorregarem em terrenos mais pertinentes à classe política, já que aqui estamos reunidos mais para opinar sobre matéria artística e, se quiserem, científica; longe desta mesa avançar qualquer insinuação demagógica.

Radical O senhor é por demais contorcionista. Protesto, antes de desenvolver meu pensamento, contra a ideia de que arquitetura não é negócio político. Então o $\mathrm{BNH}$ seria manejado por poetas? As permissóes para embaralhar as cidades são dadas por pintores conceitualistas? Então os planos diretores, quando existem, são elaborados pelas Musas? Se existe uma atividade que depende da política, $\operatorname{com} p$ minúsculo, é a arquitetura, também com $a$ minúsculo.

Morador Proponho a outorga de um $R$ maiúsculo ao senhor Radical.

Velho Profissional Recomendo um comportamento mais tranquilo ao ilustre representante das ideias de 68, apreciando a generosidade dos moços, iconoclastas por natureza.

Estudante Muito obrigado pela parte que me toca.

Urbanista Por que não começar pelo terreno, pelas ruas, pelo encanamento de água, esgotos, serviços afins, numa palavra, pela urbanística, a ciência que predispóe o viver como o que seria muito facilitado se adotada a proposta de Jaime Lerner de instituir um Ministério do Desenvolvimento Urbano.

Morador Recomendo a todos que se mantenham dentro do proposto deste mesa redonda.

Velho Profissional O tema é arquitetura, mas penso que o nobre colega, sem aflorar assuntos por demais políticos, pode dizer a sua.

Urbanista Associo-me ao nobre representante da onda Radical que afirmou tratar-se de política porém com $p$ minúsculo. Como urbanista de uma grande cidade quando proponho, para exemplificar, o alargamento de uma rua, antes de ver o projeto, a Câmara indefere; depois devo engolir um tobogã qualquer já que ele serve ao interesses de um chefão, ou mesmo de um chefete; e se por acaso alguém fica sabendo que escolher um local para nele implantar uma nova estação rodoviária, os políticos se mexem e exercem terríveis pressóes em nome de "forças ocultas." - no dizer de um ex-presidente eleito por elevada soma de votos, mas que não teve peito para liquidá-las preferindo arrepiar carreira - e só depois de terminada a briga entre eles é que se fica sabendo da solução, naturalmente errada. Nós urbanistas somos uns marginais, dependentes dos jogos políticos. $\mathrm{O}$ arquiteto tem uma posiçáo mais cômoda: não se preocupa com os arranjos da infra-estrutura; dão-lhe uma área de tantos por tantos metros é sua tarefa é desfrutá-la, com a expressa recomendação de tapear ò mais possível o "Código de Obras. Se o terreno é destinado a um prédio de apartamentos ele deve tirar o máximo proveito dos metros cúbicos que sua imaginaçáo criadora pode amontoar sem a preocupação de incomodar vizinhos e a circulação. Sua tarefa e mais artística, não é social como a do urbanista.

Radical Preocupa-se, a seu modo, com a estética. Em geral trabalha em "riscos" de fachada capazes de justificar os slogans a serem usados pelos "consultores" de imóveis: "luxo", "alto luxo," "luxuosíssimo," "altíssimo padrão" etc. Muitos conhecem aqueles apartamentos onde a área destinada à vivência da empregada não passa de um cubículo sem janela. Felizmente nos blocos de casas populares náo existe quartinho de empregada, mas em compensação os dormitórios da casa se equivalem ao que seria destinado à dita criada.

Velho Profissional Calma moço, estamos discutindo sem paixão, e não devemos nos arvorar em reformadores de usos e costumes. O arquiteto não é um "mestre da vida”, mas um profissional que recebe e executa encomendas, devendo se adaptar à vontade daqueles que oferecem trabalho...

Radical Os especuladores...

Moderador Náo vamos generalizar. Seria ingênuo não admitir a presença dos especuladores; escarlatina que sempre grassou em quase todas as 
épocas, mas deve-se reconhecer que existe gente que sem pensar em especulação emprega muito bem seu dinheiro

Velho Profissional E o nobre debatente conhece por acaso gente endinheirada que joga a gaita pela janela? $\mathrm{O}$ arquiteto deve conciliar sua arte com a situação, uma vez que ele é participante do mecanismo.

Estudante Até aqui fiquei calado. Nunca francamente falando, ouvi tamanha heresia: então aprendida a arte-ciência, com ouvir dizer, me tornaria um instrumento do Senhor Comitente?

Imobiliarista $\mathrm{E}$ se nós não lhe dermos trabalho como o arquiteto irá viver? De sonsos?

Estudante Sonhos. Sim sonhamos, mas com cidades harmoniosas, se não com a Beleza, pelo menos em termos do Bonito, se não a Justiça Social uma Minijustiça, ocasióes e encontros que nos permitam oferecer contribuição para edificação de uma sociedade interessada na Estética. Pode ser sonho, convenhamos, porém penso, se for lícito pensar, que o perfil das cidades, está mascarado como a cara de um palhaço, e isso por culpa dos arquitetos, do urbanista e, em ultima análise, por culpa da política, com p minúsculo Nossa classe é sempre acusada de ser agitada. $\mathrm{O}$ mestre que nos concede a palavra classificou sessentaeoitoescas as afirmaçôes do senhor Radical. Bem sei que estamos aqui para encontrar soluçóes pacíficas; de qualquer jeito parece-me que o problema da arquitetura precisa, antes de tudo, de uma definiçấo por parte do senhor Comitente ou do senhor Imobiliarista.

Imobiliarista Seu radicalismo é aéreo. Imagine uma greve de Comitentes, com capital letter vocês arquitetos de joelhos implorariam a revisão de tão drástica decisão. Afinal vocês dependem de nós, são nossos assalariados. Jamais rimos suas associaçóes de classe protestar contra $o$ nosso legítimo poder, mesmo quando nosso gosto náo seja do gosto do Morador.

Radical É verdade. É a classe dos arquitetos que náo reage. Como classe, democraticamente, poderia intervir para que as cidades não se transformassem numa salada de pseudoestilos. Parece-me que este deveria ser um empenho da classe, visto não ser exigência municipal. Antigamente, para ser mais preciso, há uns cinquenta anos, Warchavchik não pôde construir sua casa em São Paulo porque projetara o palacete com paredes lisas, fato entáo considerado como ofensivo à Estética. Tudo devia ser decorado. Era um critério. Hoje, porém, estamos esteticamente em pleno carnaval. As autoridades se desinteressam, e cada imobiliarista pode construir à vontade. Se fulano quer um palacete ou um prédio em estilo $\mathrm{M}$ ou estilo $\mathrm{P}$, encontra sempre profissionais dispostos a desenhá-los e, caso não seja possuidor de carteira profissional não há impecilho, pois sempre encontra alguém inscrito no Crea que assina a meleca. Cadê moral para falar ou protestar?

Moderador Quero mais uma vez chamar a atenção...

Radical ... que aqui estamos reunidos para examinar a situação para afinal deixá-la como esta.

Moderador Veja: caso o senhor persista nesta linha de raciocínio, serei obrigado a aplicar-lhe o Ato $n^{\circ} 6$ e cassar seu convite. A classe dos arquitetos é heterogênea, como qualquer outra, com seus problemas de arroz e feijáo, de locomóvel, de aposentadoria. É profissão liberal, o que significa liberdade. Assim, se uma Fulana quer um palacete em estilo Mediterrâneo, não se configura um fim do mundo quando encontra centenas de profissionais que aceitam a encomenda.

Estudante Vamos ver se conciliamos as coisas. Afinal os brasileiros já foram “conciliadores," levamos na conversa muita gente, como também nos deixamos levar na conversa. Nós jovens, é natural, gostamos de discutir, mas às vezes gostamos de trilhar nas paralelas de Euclides, as quais a certa altura acabavam se encontrando. Queria, em nome do bom-senso que esta mesa redonda considerasse o tema sob a perspectiva da Estética.

Urbanista A Estética depende da Ética. Insisto: o caso que estamos discutindo implica em fatos práticos, e sei lá se não seria melhor descobrir quem nasceu primeiro: o pintinho ou a galinha. $\mathrm{O}$ caso é político, por uma urbanística conveniente, por uma arquitetura transpirante 
de consequências sociais, e, no entretanto, até agora só vejo resultados comprometidos com situaçóes políticas, por sinal insatisfatórias. Parece-me que o tema da mesa é por demais genérico. Presta-se às mais clamorosas manobras, interesseira por um ou por outro. Ouvi dos nossos colegas, desculpem, ingenuidades lapalissianas, brados de guerra que podem provocar derramamento de biles, como ouvi patéticas declaraçóes. Estamos aqui para realisticamente discutir o tema "arquitetura agora" evidentemente com risos de melhorar a qualidade do viver, como bem o disse o ilustre Urbanista...

Morador Estamos afinal chegando ao busillis.

Urbanista Sei o que quer dizer: os ricos moram sempre bem, enquanto os pobres mal. Sei que as gaiolas de ouro da Gávea ou do Morumbi panoramizam quarteirôes de favelas.

Radical Quero acabar com as favelas!

Velho Profissional Eu também, e penso que todos são da mesma opinião.

Imobiliarista Até eu.

Velho Profissional Entre o dizer e o fazer existe um abismo que cumpre superar. Devemos admitir que as soluçôes não são mais dos profissionais. Por outro lado a fórmula "Arquitetura, arte de Estado", resultaria num complexo de leis e uma evidente ingerência da burocracia, cujo resultado final seria a saudade pelos tempos hodiernos.

Radical Então é deixar as coisas como estão, e não mais discutirmos para evitar perda de tempo.

Velho Profissional Não; ao contrario, precisamos discutir, pois nós arquitetos segundo ouvi dizer, somos responsáveis não só pela moradia da humanidade como também pela arte ou estética, que distingue uma civilização.

Radical Pelo amor de Deus: lembro que nosso encontro não deve espraiar-se demais nos limbos da estética, pois diferente estaremos perdidos. Deixem os arquitetos desenhas suas janelas ovais, redondas, triangulares, trapezoidais, pois isso não interessa visto que existem coitados que namoram essas gostosuras fechadescas, como um negócio particular. Admiramos o Pantenon de Roma, porém sabemos que o povo ao redor viva nos tugúrios. O problema para mim é menos "monumento" inúteis e mais habitaçôes para todos. Parece-me ser este o voto que deveria resultar desta reuniáo. Comportaria: combinaçóes com a ecologia, a economia, a educação, e quantas outras coisas.

Urbanista Justo. O senhor certamente já andou pela periferia de alguma cidade. O senhor saberá, por exemplo, que só em 78 é que se vai fazer o cadastramento aerofotogramétrico da Grande São Paulo? Conheço bem as vilas periféricas, por força da profissão que exerço sou seu frequentador e nunca vi por lá um arquiteto. Este eminente colega não me parece preocupado com os seríssimos problemas da periferia. A classe dos arquitetos, como foi lembrado, já se intitulou de "mestre da vida," e deveria olhar para além dos jardins e da selva dos arranha-céus, dos Portais, da Vertentes etc., faraônica invencionices do imobiliarismo ou então olhar para fora do perímetro central.

Estudante Ouvi dizer que aplicando o valor de um arranha-céu em construçóes populares seria possível ...

Imobiliarista Náo toque nesse assunto, pois ele é inteiramente pertinente ao $\mathrm{BNH}$; pode dar galho. Por outro lado, aqui na mesa, meu protesto contra o hábito de bater na cabeça do benemérito capitalista que, construindo, assegura trabalho a numerosas turmas de nordestinos, participando do milagroso vaivém econômico.

Morador Os nordestinos não poderiam ser empregados nas obras públicas em benefício da comunidade, sustando o boom edilício?

Velho Profissional Obra pública é arquitetura?

Estudante Um dos meus professores demonstrou, numa aula, que a arquitetura envolve hoje em dia o total das construçóes, classificando de inútil a presença nelas do arquiteto. Lembrou que o grande engenheiro Pier Luigí Nervi classificou o arquiteto de "pedreiro que sabe o latim." Disse que é absurdo o fato dela projetar um prédio e que o engenheiro seja o 
responsável pela estrutura. $\mathrm{O}$ arquiteto seria então um decorador? Já vimos decoradores que vestem a manto do arquiteto, com a fiança do engenheiro, pois é ele quem garante a construção para que não desmorone. Queria saber, como estudante, se a arquitetura é o organismo interno, lembrado da acusação do Urbanista, quando acenou para os cubículos das empregadas nos apartamentos propalados nas publicidades dos jornais como de luxo. Arquitetura em questão: quem se forma nas faculdades, sérias e semissérias, nesta arte, ou arte-ciência como disse o Patriarca presente nesta reunião, será um profissional de utilidade social? Duvido, visto que o campo é tão carente de soluçóes sociais. O arquiteto deixará o posto ao engenheiro civil que também é arquiteto, sem previsóes estáticas?

Imobiliarista $\mathrm{O}$ Estudante toca num ponto certo, na maioria das vezes, por um único produto, pagamos $\mathrm{x}$ para $\mathrm{o}$ arquiteto, $\mathrm{x}$ para o engenheiro calculista. Por isso gostaríamos da simbiose das duas profissóes, para economizar.

Velho Profissional Mas o engenheiro não sabe nada de estilos, enfeites, arranjos, beleza, jardinagem e quantos outros adendos pertinentes à Estética.

Radical Veja as pontes de Maillord, as centrais nucleares e, para irmos mais longe, o Coliseu: obras de engenheiros. Por minha conta fundaria numa única escola a engenharia e a arquitetura. Antigamente a divisão tinha uma razão: o engenheiro projetava e o professor a fachada. Depois eis o compromisso, no ensino: $\mathrm{O}$ arquiteto projeta, o engenheiro calcula. Anacrônico.

Morador Se eu quiser construir uma casa em estilo Ilhas Gregas ou Jorge III ou transição do $\mathrm{V}$, ou, obedecendo às novas tendências, Brutalista, Brutalista-masnon-troppo, ou aquele pavilhão de Sérgio Prado que vi publicado na edição ${ }^{\circ}$ I de Arte Vogue, preciso de um artista. Será que o encontraria numa das safras de uma das escolas politécnico-arquitetônica?

Radical E por que o senhor não constrói no estilo mais apropriado aos tempos correntes, o Desvairado?
Velho Profissional Não gosto de ironia Lembro-lhe que estamos discutindo em São Paulo, metrópole famosa por ninguém brincar em serviço, muito menos no humorístico. Queria reconduzir a mesa, depois dos senhores terem tomado o décimo cafezinho, à circunscrição correta do tema: arquitetura agora. Compreendo que cada convidado puxa a água para o seu moinho, todavia, o que se espera deste confronto é um cordial exame dos vários problemas, se bem que conflitantes: o Urbanista querendo ditar lei ao arquiteto; este distribuidor de panaceias estéticas; o Imobiliarista amarrado ao jogo capitalista onde o rico faz e consegue o que mais lhe convém; o estudante com suas interrogaçóes e perplexidades; e enfim o Morador, certamente a vítima, à espera de soluçóes. Aqui, daria a palavra a cada um dos presentes para dizer em síntese o próprio pensamento. Vou por ordem de idade, ao contrário, pois o futuro está mais para ele. Com a palavra o Estudante.

Ele Estou encabulado. Meu ponto de vista é que quando recebemos o diploma e nos inscrevemos nos numerosos órgãos de classe, procuramos trabalho, competindo uns com os outros. $\mathrm{Na}$ escola não nos ensinaram a ser intransigentes, isto é, sermos firmes nas convicçóes assaz convenientes para professar arquitetura com espírito coerente com a realidade de uma sociedade equilibrada em suas exigências morais e existenciais. Muitos de nós, fatalmente sugados nas construtoras, acabamos perdendo de vista a pouca estética aprendida, para nos tornarmos, como dissemos antes, um instrumento. Outro, encontrando, as possibilidades que nunca faltam numa sociedade, onde a cultura é pobre e o gosto não tem a chancela de quatro estrelas, vão desenhar o caprichado para uma burguesia que gosta de distinçáo, do barroco fachadesco que me parece seja o condenado pelo exuberante Radical, quando em aparte falou de estilo Desvairado. Sei que gustibus non est disputandum, ${ }^{2}$ mas que os arquitetos como classe deixem afogar as cidades no ridículo, isso é lá verdade, vibrante, estampada em Arte Vogue n ${ }^{\circ}$ I, dedicada a um desejado Ministério da

2 A expressão em latim é um dos indícios da autoria de Bardi. 
Cultura, que poderia se interessar pela arquitetura e, natural, da Urbanística, não Urbanística-Urbanística das cidades, mas de um plano nacional, não "planejamento," um lugar comum abstrato dos profissionais de hoje, em todos os sentidos, enfim, um plano global, ainda em mente Deis.

Urbanista Associo-me às conclusôes do Estudante que vê claro o problema. Não se trata de fato isolado da arquitetura, mas vai além do construir, para investir uma consideração em absoluto determinada pela política, desta feita com P maiúsculo. Ficaremos aqui dias e dias opinando, até brincando, sem contudo demover a Esfinge, grosso modo, dita, arquitetura e sua coorte da sua granítica imobilidade. Disse o Radical que o desejo é deixar as coisas como estão para ver como ficam. Parece-me que a situação é esta, salvo os inúmeros paliativos enrolantes do problema: um calçadão aqui, um semáforo acolá, uma comissão de inquérito para constatar as sacanagens de uma empresa, o zoneamento favorecedor de interesses, uma fábrica porque polui e outra mais poluidora inauguradas no mesmo dia, uma devastação do verde aqui, uma inundação acolá, e assim por diante. Que fazer?

Morador O meu problema é urgente. Sou um cidadão de recursos modestos, sempre em luta para ter o almoço e o jantar, o patráo retirando pontualmente meus encargos sociais, sou um brasileiro médio e gosto de sê-lo. Aspiro, como todos os meus companheiros, possuir um teto próprio, mas não nas colmeias do BNH, teto com um pouco de verde. $\mathrm{O}$
Estudante falou de caprichos. Não quero o capricho das colunatas que intimidam quem as olham nas mansões, todavia, de um capricho bem caipira, eis o que gostaria. Será que estes senhores que são apelidados de arquitetos, com bem disse o senhor Urbanista, não poderiam dar uma olhadela em nossas vilas?

Radical Se um dia me tornar presidente da Federação, fiquem sossegados que tratarei dos casos em pauta com energia de reformulação e de duras reformas, tábula rasa de uma estrutura obsoleta sob todos os pontos de vista. A arquitetura é mesmo arte de Estado, precisando de leis inteligentes, por sua vez leis que só podem sair de Congressos constituídos por licurgos à altura. Porém, onde encontrá-los?

Velho Profissional Último anagraficamente, resumo o debate com a esperança de que surgirão mais discussóes, não sem recomendar que nosso país finalmente se decida a pensar no problema Cultura, além dos problemas Esporte e Lotecas.

O Moderador, a certa altura, deu por encerrada a mesa redonda, lamentando apenas não ter alcançado os resultados esperados, remetendo ao repórter confidencialmente estas notas que, devidamente purgadas dos excessos cometidos pelo Radical, são aqui ajustadas para o leitor de Arte Vogue refletir sobre um tema que reputamos da máxima importância, sendo a arquitetura, na definição de Vitruvio, a Princesa das Artes.

Legenda

p.76 Horácio Nobre, de Millôr Fernandes

\section{Masp ano 30, p.86-90}

P.M. Bardi

\section{São Paulo, 3 de Outubro de 1947}

Parece que foi ontem. Abro o Diário de $S$. Paulo e vejo como os repórteres registraram o ato inaugural do Museu. Foi à noite. Todos os amigos de Assis Chateaubriand estavam presentes para aplaudir os oradores, convocados para cerimoniar, segundo a ordem disposta pelo anfitrião radiante que dedicava uma palavra e um abraço a cada um, desde o governador Adhemar de Barros (que recebeu muitos tapinhas nas costas) até um dos muitos "meu-filhocomo-vai-você?” Lá estavam elegantes senhoras (sabia das transas com o Paulo Franco, da Vogue, na vizinha rua Marconi então apelidada de "rue de la Paix," apesar de possuir salóes de barbeiro e engraxates), os baróes da produçáo do café todos de smocking, alguns uniformes militares de gala: os manda-chuvas da capital, em vias de crescer mais que todas as outras do mundo inteiro, apesar dos desserviços que cada administração transmitia (com solenes discursos) às sucessivas.

Todos, curiosos por entrar na última invenção do príncipe da opinião pública 
alcançam o primeiro andar do edifício dos Diários ainda em construção, subindo por uma escadinha quintalesca, ainda fresca de reboque (as senhoras de idade desconveniente foram de elevador, aos cuidados do mestre de obras, gentilmente desembarcadas no fundo de um corredor onde eu tinha arranjado o "gabinete da direção." (O dr. Assis é um querido prepotente irracional: sua vontade é lei; pronto a mudar de ideia ou a contrariar a dos outros, tanto assim que ontem lhe disse; Dr. Assis, o senhor "é mobile qual piuma at vento, muta di accento e di pensier." Iato por causa da casaca. Ele decidira: - Professor, a festa será de casaca. — Não tenho casaca. - Vá ao Carnicelli, ali na Barão de Itapetininga, grande alfaiate. Anteontem, contra-ordem: - Smocking!... e o Chateaubriand apareceu de terno escuro.)

Os convidados pararam diante dos quadros, sustentados nos suportes fixados em tubos de alumínio, que o Baby Pignatari havia nos presenteado, como homenagem da sua laminação. (Não foi possível colocar as pinturas nas paredes, pois estas ainda lacrimejavam de tão úmidas que estavam.) As telas, reunidas para a solene abertura, eram poucas para constituir o que pomposamente dávamos o título de Pinacoteca (com surpresa e um certo receio dos colegas que governavam a Pinacoteca do Estado, ainda nos moldes de uma tradição honestamente oitocentesca, porém superada pela novidade de um museugrafismo mais em dia) constituíam um anedotário de temas conformados com uma comunicação não problemática quanto ao gosto-não-gosto. Fui avisado de que não adiantava se abrigar nas asas bamboleantes do Moderno visto que naquele ano nem se falava mais da Semana, destruído que fora o pavilhão de dona Olívia, pintado por Segall, o Lasar recusado e isolado no atelier da rua Afonso Celso; Warchavchik já fora do jogo racionalista e, assim por diante, no impasse de uma estagnação estética pobre de eventos. (Tarsila não mais pensando no Pau Brasil, Oswald apagado, Anita produzindo folclore que nada tinha a partilhar com a "Estudante russa”, Di desiludido e não compreendido, olhando sua antiga obra-prima Cinco moças de Guaratinguetá, que eu tinha recebido de presente do maravilhoso amigo
Frederico Barata, diretor dos Associados, biógrafo de Elyseu Visconti, colecionador e estudioso da Civilização Marajoara, da qual se vangloriava ser descendente.)

Incumbido de instituir um "museu," procurei com a arquiteta Lina, adaptar da melhor maneira o primeiro andar do edifício em construção dos Diários. Não era novato neste mister: nos anos 20 tinha implantado minhas galerias em Milão, criei nos anos 30 a Galleria de Arte de Roma que dirigi e, nos anos 40, o Studio d'Arte Palma de tamanho idêntico ao que inaugurávamos naquela noite. Foi no Palma que se realizou o que o público começaria a ver a partir de amanhã: grande parte da coleção é de minha propriedade como aquela soberba mesa atrás da qual os oradores falaram, é lá de minha casa (é do século i6, vem do palácio Barberini, e foi um presente de núpcias, entre um Barberini que tinha por brasão nobiliárquico as abelhas daqueles príncipes e uma Della Rovere, com as armas representadas por árvore) e a exposição didática de história das artes foi preparada, em Roma, chez moi. É esta a secção principal do Museu de Arte (o dr. Assis queria apelidá-lo de Arte Moderna; fui contra, pois este adjetivo cheirava a amadorismo, e ninguém pode prever os galhos futuros que iráo dar ao copiar o MoMA de Nova York) e tenho a firme esperança de que o boato que ouço da intenção de se criar uma Bienal, cópia da de Veneza, Deus a tenha bem longe de Piratininga que, com o goal dos Diários Associados, vai reforçar seu status de Atenas do Brasil.

Já cedo, ao alvorecer, recebi os primeiros parabéns pela "noite de arte," e — pela crônica — também alguns desaforos, motivados por eu ter, segundo os cronistas, desmerecido a cultura local: sustentavam, intelectuais de alta valia, que aquela Exposição Didática era uma afronta, pois todos sabiam (de cor e salteado) que Carlos Magno fora coroado imperador do Ocidente pelo papa Leão III e que Rafael era personagem familiar, se não de todos, pelo menos para $98 \%$ dos transeuntes. Ofereci minhas desculpas, protestando que a iniciativa pedagógica náo era para sábios, mas para a juventude que gosta de aprender. Nesta defesa contei com a ajuda do meu primeiro assistente Flavio 
Motta, espirituoso rapaz que, sem dúvida fará esplêndida carreira. Partidários do professor também os alunos do rápido curso de história que continuava ministrando, despretensiosamente, para preparar monitores; ao século Nidia Pincherle (parece-me que a bela triestina inteligente e vispa, leva a sério jeito de teatrante), Gabriela Borchardt, reflexiva e rica de saber, e dois outros italianos: Enrique Camerini, pintor que queria abraçar a carreira de publicitário (uma cartomante o prediz como um futuro diretor da filial de Miláo da McCann Erickson) e um estudante de arquitetura fora de série, Jorge Wilheim. (A mesma adivinhadora o descreveu como um urbanista muito capaz, e o prevê ocupando cargo no governo.) Apelidavam a turma de "máfia italiana," mas sei muito bem que o vírus da dor de cotovelo é bastante difundido também aqui, com sintomas de epidemia. Falei disto com o dr. Assis. Comentou: — ... E o senhor pensa que o vírus também não se espalhou pelas redaçôes dos jornais, que me adoram como fumaça em seus olhos?

Folheando os cotidianos de fato, não vejo notícias da façanha; dou-me ao luxo de ficar admirado, pois estou certo de que ontem havíamos lançado as bases do maior museu sul-americano. Trabalharemos no isolamento?

Um velho amigo brasileiro, meu conhecido de Berlim quando Hitler começava a chatear, literato de cultura de peso e que estudara na Itália, vem me procurar. Conta-me que alguém soltara um boato velhaco atribuindo, às obras apresentadas no Museu, o honorífico apelido de falsas; outro boato mais benevolente espalhava que se tratavam de cópias: é o costumeiro sistema de atrapalhar a vida dos outros, atirando a pedra e escondendo a mão. Dou risadas, mas o dialogante me explica que devo absolutamente recorrer-me à defesa.

Já sabia que numa metrópole sem metrô o mexerico é hábito. Se alguém contar que um Pégaso pousou na praça da Sé, todos correm para lá para ver o burro alado. E se não o encontram, são persuadidos de que ele se recolheu na Catedral para repousar. Se eu desse ouvidos às bisbilhotices sobre o meu chefe, deveria correr para Congonhas e embarcar no aviáo para a Itália. Aliás, distinto miniescritor, pode ser mini mas sempre bem na crista, pois frequenta porção notável da sociedade carioca, escreveu que o Brasil deve me devolver já à Península.

Reflexão: ficar atento, medir os passos e, importante, passear com um olho atento às costas. ( $\mathrm{O}$ Chateaubriand carrega consigo duas pistolas uma delas no coldre à cintura, às costas, e viaja acompanhado de um guarda-costa grandalhão, olhar reluzente denotando possíveis intervençóes. Pergunto ao meu Senhor: — Mas, e o Brasil não é um país cordial? Respondeu: - Até um certo ponto.)

Hoje estou descansando do meu agitar de ontem no preparo da festa. Foi deslumbrante. Que oradores estes poetas paulistas: Guilherme de Almeida bombardeou: Milagre! Milagre! Milagre! O pacto, firme, bonario Menotti del Picchia resumiu o significado do gesto do seu amigo íntimo Assis. Rosalina Coelho Lisboa, fantástica na elegância e no charme, foi o ponto alto do palavrear à mesa. Infelizmente eu mesmo, apontado como deus ex-máquina do Museu, fui obrigado a me pronunciar e, incapaz de discursar, nem me lembro do que falei, porém recordo-me de ter elogiado os operários e os contínuos que me ajudaram a armar o ambiente. (Um pouco chocante para muitos possuidores de casas decoradas com as coisas dos Luíses I4, I5 e I6.) Falou-se bem da arquitetura de interior? Não me lembro. De qualquer jeito é uma proposta. Foi, naturalmente, para quem esperava se sentar em poltronas ao invés de em cadeiras simplérrimas desenhadas por Lina, e que nenhuma fábrica quis executar. (Foi um tapeceiro patrício quem se incumbiu do negócio.)

Não me resulta se os convidados apreciaram a ideia, nova em folha, de um museu-não-museu. Tinha lutado, em vão, com o dr. Assis para que a empresa se chamasse de Centro de Arte; mas ele insistiu em fazer um Museu com M maiúsculo. (Suspeito da intençâo de arrumar uma "Chateaubriand Collection," ingrediente utilíssimo para se ingressar no Society international.) Logo que desembarquei no Rio - mas isto como turista, em 1934, quando ia para Buenos 
Aires lecionar - alguém me advertiu: faça, no Brasil, das tripas coração.

O ditado é tão apropriado que encomendei a uma das inúmeras organizações herádicas o meu estema: representa um coração (como aquele que os paqueradores inscrevem nas cascas das árvores) em campo de ouro (alusão à minha independência econômica) acima de uma barriga em campo azul, denotando o tudo-azul que jamais me abandonou nos meus cinquenta anos.

Confiando no êxito desta insígnia. (A de minha família, não sei se florentina ou spezzina, era uma mão empunhando a espada e a sentença Io son gentil, benchè di spada armato.) Os futurólogos dizem que vou pedestrar bastante na vida, especialmente se meu temperamental caráter se acalmar. (Viajo, agora, com a garrafinha de bromuro na sacola.)

\section{Legenda}

p.87 1947: inauguração do Masp, sede dos Diários Associados; discursando o ministro Clemente Mariani - da Educação.

p.87 inauguração de novas salas no Masp. Entre os presentes: presidente Eurico Gaspar Dutra, Nelson Rockefeller, Clouzot, Samuel Ribeiro, Edmundo Monteiro, atual presidente do Masp.

p.87 A Rainha Elizabeth II inaugura, em I968, a nova e do Masp, à av. Paulista.

p.88 Gente e Eventos

p.89 Quando e finalmente vai se dar o golpe expositivo do Millór em São Paulo? Boato confirmado: no próximo ano de 1978.

p.89 Rebolo, o pintor que na juventude corria com outros colegas piratininga-trotters a periferia, morador naquela fazenda do Morumby, hoje perdida ao progredir citadino da megalópolis paulistana, está festejando 70 anos do que os mundanistas apelidam de nat: o mesmo entusiasmo, o mesmo bom-senso e a mesma simplicidade.

p.89 Villanova Artigos festejado no Clubinho dos Artistas pelo prêmio recebido nos Estados Unidos pela sua valiosa contribuição à arquitetura contemporânea.

p.89 Felícia Leirner está preparando, com o patrocínio da Secretaria de Cultura,
Ciência c Tecnologia, uma exposição que será ambientada no Belvedere do Masp. Da sua escultura original e conhecida por todos os amadores Arte Vogue vai falar proximamente num depoimento de Sheila Leirner, sua neta.

p.89 Com José Geraldo Vieira desaparece um dos últimos cultores do romance calcado nos moldes do século 19. Maior perda é para as artes plásticas que tiveram sempre nele o crítico arguto e vivaz que nos mostrava em trabalhos, publicados na Folha de S. Paulo e na revista Habitat, o penetrante conhecedor das tendências estéticas do nosso tempo. Exercitava uma crítica fundada em segura erudição e sua maneira de estabelecer comparaçóes procurava inserir os artistas numa determinada filiação, enfim, num contexto generoso e amplo.

p.89 A Arte Global de São Paulo festejou seus 16 anos de existência publicando uma brochura que elenca as numerosas exposiçóes apresentadas não só em São Paulo, mas também no país e no estrangeiro. Na ilustração uma vista da galeria à al. Santos, quando da exposição de Rubens Gerchmann.

p.89 Notícias de Nova Jerusalém, PE, informam não ser verdadeira a versão de que os escultores locais deixaram de produzir a estatuária que um espirituoso cronista de coisas de arte apelidou "de cordel." Nunca no Brasil se viu empreendimento tão poderoso.

p.89 Há vinte anos Lasar Segall nos deixava. Sua lembrança é constante.

p.89 O maestro Camargo Guarnieri, nascido há 70 anos, em Tietê, SP, é senhor de vasta bagagem musical que abrange todos os estilos, desde pequenas miniaturas vocais e instrumentais, até grandes formas da ópera e da sinfonia. Mais de 600 obras em sua maior parte inéditas, ou não executadas. Sua ópera $O \mathrm{Homem}$ Só, por exemplo, nunca foi executada em Sáo Paulo. (O texto é de Gianfrancesco Guarnieri, que aliás não é seu filho como muita gente pensa, mas sim do falecido Edoardo de Guarnieri.) "Poucas de minhas obras - disse-nos o Maestro - têm sido editadas, porque poucos são os que sabem ler música, e que se interessariam 
em comprá-las para estudo ou execução". Nos Estados Unidos e na Europa, porém, suas obras são freqüentemente executadas. Exatamente como acontecia e ainda acontece com Villa-Lobos. Comemorando seus ativos 70 anos. Camargo Guarnieri dirige a Orquestra Sinfônica da USP.

p.90 Entre as perdas que o setor das artes lamenta é a do acadêmico Luís Arrobas Martins, dedicadíssimo como administrador de todos os casos da cultura. Foi ele, no governo Abreu Sodré, quem criou o Museu de Arte Sacra e o Museu da Casa Brasileira, e no governo Paulo Egídio enriqueceu o Palácio dos Bandeirantes de uma série de obras de arte que levantaram o aspecto daqueles ambientes frios e desajeitados.

p.9o Israel Pedrosa, fundador da cadeira de história da arte na Universidade Federal Fluminense e conhecido pintor dedicado às pesquisas da cor, publica o volume Da Cor à Cor Inexistente, Leo Christiano Editorial, Rio. Trata-se de uma diligente gramática das cores, científica e, todavia, de agradável leitura.

p.9o Quirino da Silva, o popular crítico de arte do Diários Associados que ao longo de 40 anos recusou expor suas pinturas, esculturas e cerâmicas, chegando aos 80 anos afinal permitiu que o Masp apresentasse sua retrospectiva. Será na Pinacoteca para homenagear o famoso autor da estátua de João Caetano, aqui ao seu lado e há meio século.

p.9o Maninha, a pintora amazonense revelada em exposição na Petite Galerie carioca, há uns dez anos depois de várias andanças volta a ser notada, e muito bem, pelas ilustraçóes que desenhou para um antigo livro, muito discutido em sua época e também ainda hoje, de De Quincey.

p.90 Eis um evento: abertura de Papier um show-room que vende papéis personalizados, na São Paulo onde há esta insigna-chamariz que parece evocar os bons tempos em que a caligrafia era uma arte.

p.90 Almir Mavigner, o gráfico carioca que depois de dois decênios ensina na Universidade de Hamburgo, foi escolhido para projetar o selo comemorativo do grande pintor Philipp Otto Runge; encomenda do governo federal alemão. Além do selo, Mavigner desenhou o carimbo.

MerCAdo DE ARTE, p.I27-I28

\section{A Sotheby chegando a nós}

Não é a primeira vez, desde o após Guerra, que as grandes firmas do mercado das artes internacionais vêm ao Brasil para sondar as possibilidades de desenvolver suas atividades ao lado das nacionais. Por quanto se sabe, as pesquisas foram até aqui pouco favoráveis, mas não tão negativas a ponto de induzir um ou outro big do mercado a pensar sempre em estudar o caso brasileiro, aliás, paulista, pois é nesta metrópole que reside à força monetária do país.

Cumpre lembrar que se observa o mesmo fenômeno de Nova York nos fins do século passado, quando as grandes casas parisienses e inglesas descobriram a mina que teria dado os máximos índices de compreensão para com a cultura e, por reflexos, as artes. (A situação entre o Brasil e os Estados Unidos é comparada tendo-se em conta uma situação absolutamente diversa: quando Goethe homenageava
Harward com sua opera omnia e com a famosa dedicatória, a cultura no Brasil ainda estava no começo de sua articulação.)

Algumas circunstâncias análogas, tímidas pelas razóes facilmente imagináveis, se registravam entre nós recentemente. Estando há pouco no Brasil, o sr. Edward Lee Cave, vice-presidente da Sotheby Parke Bernet de Nova York, nos permite inferir como a inauguração do reconhecimento de que o Brasil pode começar a se mexer no campo internacional em termos de mercado de arte, hoje restrito exclusivamente à pintura nacional dos vinte nomes mais propagados.

O ingresso da Sotheby no Brasil?

Para dar boas-vindas à bicentenária casa à nossa terra, Arte Vogue teve oportunidade de ouvir o dr. Edward Lee Cave. Eis o diálogo: 
AV O senhor está informado sobre o que está acontecendo atualmente na América Latina, no que toca ao desenvolvimento das artes em geral. Assim, após sua breve estada no Brasil, gostaríamos de saber, em poucas palavras, sua opiniáo a respeito.

ELC Durante minha breve visita ao Rio e a São Paulo tive oportunidade de conhecer colecionadores e artistas brasileiros. Fiquei muito impressionado com o entusiasmo que existe no país por assuntos de arte. As coleçôes de antigos móveis brasileiros, arte religiosa e prataria são extraordinárias. A atividade dos colecionadores são de altíssimo calibre. Minha única desilusão reside no fato de não ter visto melhores coleçóes de arte antiga e moderna europeias.

AV Em sua qualidade de diretor da Sotheby Parke Bernet conduz os maiores leilóes de arte espalhados por várias partes do mundo como Londres, Nova York, Zurique, Amsterdã, Monte Carlo, Hong Kong, Toronto, Los Angeles e Melburne; o único continente onde ainda não organizamos vendas é aqui a América do Sul.

ELC Gostaríamos de ser o instrumento para incrementar o fluxo da arte europeia para a América do Sul e, assim, atrair a atenção mundial para a arte latino-americana.

AV Quais os acontecimentos que prevê em termos de mercado para a arte brasileira? ELC O Brasil é um país muito rico com um inato interesse pelas artes. Infelizmente poucas são as coleçóes importantes, com exceção, é lógico, do importantíssimo acervo do não menos soberbo Museu de Arte Assis Chateaubriand de São Paulo. Não vemos razóes contrárias para que o Brasil deixe de reunir importantes coleçóes de arte europeia e nacional, pelos setores públicos ou privados, nos próximos vinte anos. Dinheiro e interesse é que não faltam.

AV Sabemos que a Sotheby com seus bem sucedidos leilóes propiciou a vitalização de todo o mundo da arte. O senhor acredita que será possível organizar proximamente um leiláo de caráter intercontinental aqui em São Paulo?

ELC Sáo Paulo é o mais importante centro comercial da América do Sul. Será lógico que a Sotheby realize seu primeiro e importante leiláo aqui. As vendas de pinturas modernas e ao mesmo tempo arte brasileira dariam ao fato uma dimensão internacional.

AV Arte Vogue está à sua disposição para tal eventualidade. Estamos certos de que um leilão desse nível irá vitalizar o mercado nacional. Que acha o senhor?

ELC Nós, da Sotheby, ao longo de dois séculos, nos tornamos em estimuladores do colecionismo de obras de arte em muitos países. O maior exemplo para reforçar este ponto foram as vendas propiciadas pelos leilóes realizados em Nova York no começo do século, com a formação dos núcleos de grandes coleçóes como as de Morgan, Hearst e Mellon. Se a Sotheby realizar vendas no Brasil, certamente irá acrescentar um maior interesse pelas artes no país. Os brasileiros poderão formar importantes coleçóes que seráo parte apreciável de seu patrimônio nacional.

AV O senhor teria algumas sugestôes a formular e de interesse para os leitores desta revista?

ELC A verdade é que o Brasil sempre foi motivo de nossas preocupaçóes e interesses. De fato, há dez anos, mantemos um representante no Rio de Janeiro, o senhor Walter Geyerhann e, mais recentemente, destacamos em São Paulo o senhor Cornelius Reicheneim. Vocês fazem parte de um país jovem com um brilhante futuro pela frente. Já são líderes mundiais em termos de indústria e de agricultura. Desejo sinceramente que a Sotheby traga a sua contribuição capaz de fazer do Brasil também um líder no mundo internacional da arte. Como agradeço em meu nome e no da Sotheby a amistosa acolhida com que fomos recebidos.

Os jornais de São Paulo, registrando a presença do senhor Cave, avançaram algumas hipóteses com visos de futurologia. Nosso ponto de vista é de otimismo, pois alguma coisa vai acontecer. Arte Vogue quer colaborar para a desprovincializaçáo de nosso mercado de arte.
Perspectivas futuras
G.O.
O Brasil será em futuro próximo um mercado bem interessante no que se relaciona com as artes em geral, e muito particularmente no que toca às artes contemporâneas. 
Indubitavelmente serão colhidos os frutos de que foi semeado há uns trinta anos, época da organização dos primeiros museus e das grandes exposiçóes internacionais, contando-se, ainda, com o surgimento das galerias e dos vários grupos de colecionadores. O período situado entre o fim da última guerra e os dias de hoje pode ser comparado com o último decênio do século passado e os primeiros vinte anos deste nos Estados Unidos, isto é, na época em que foi estruturada a divulgação dos problemas de arte, dando-se particular incentivo ao mercado. As iniciativas da sra. Gardner e dos srs. Fríck, Kress e Johnson, para citarmos apenas alguns, mudando as origens sociais, culturais e econômicas - correspondem, de certo, à iniciativa do sr. Assis Chateaubriand que, em 1947, promoveu a criação do Museu de Arte de São Paulo, realmente um ponto de partida para que fossem criados novos museus e formadas várias coleçôes, favorecendo o aparecimento de um grande movimento em favor da arte antiga nacional até então desconsiderada sem se contar, ainda, com a valorização dos artistas participantes da Semana de I922, que viram fraudados os esforços tendentes a oferecer a arte uma posição adequada ao desenvolvimento do pais. Paralelamente à profissão de artista, antes limitada aos poucos professores das Escolas de Belas Artes, tomou novo rumo, com o aparecimento de numeroso e qualitativo grupo de artistas, sendo que vários dos melhores elementos transferiram-se para o exterior.

Deve-se ressaltar que o desenvolvimento da: artes, especialmente da arquitetura, acompanhou o da indústria e o da cultura com um ritmo sincronizado, naturalmente com as inevitáveis falhas e as improvisaçóes próprias de qualquer labor na América Latina, para conquistar as posições a que aspira alcançar.

No élan desenvolvimentista, o mercado das artes foi sendo organizado de maneira um pouco tumultuada dado o ambiente de então. Mas é confortador constatar um interesse sempre mais vivo em relação à vida artística apesar do índice inflacionário que interfere na vida financeira da nação. Apesar da persistência da inflação e a espera de uma melhoria na economia em geral, guardamos as melhores esperanças de que proximamente teremos um firme mercado de arte do tipo norte-americano. Os atuais museus, e mesmo aqueles que vão sendo organizados, deverão formar seus acervos, com o favor da lei que prevê o desconto na declaração do Imposto de Renda, das doaçôes aos museus; paralelamente os amadores de arte aumentarão as próprias coleçôes, como surgirão novos interessados na onda da divulgação, resultando assim em um natural incremento do mercado e relativa seleção dos adeptos. Este desenvolvimento somente será possível através de um vivo intercâmbio com os países estrangeiros, considerando-se também o fato das contínuas imigrações de capitalistas, técnicos, empresários, diplomatas etc. Teremos um intercâmbio hoje tấo comum entre a Europa e a América do Norte. Será assim favorecida a exportaçáo das obras dos sul-americanos com uma consequente circulação entre nós das produçóes dos estrangeiros, como aliás já timidamente acontece.

O problema, simples no seu enunciado, apresenta dificuldades em sua solução. A princípio, o mais importante é o investimento, com uma boa massa de capitais necessários ao lançamento e à adequação da iniciativa; fato tão igual em relação aos variados ramos da indústria e do comércio, pois o Brasil continua carente de recursos financeiros; consequentemente deve recorrer àqueles que de fora desejam participar de um empreendimento que, além do mais, diz respeito à vida cultural do país.

\section{O mercado nacional}

$\mathrm{O}$ mercado de arte continua interessado no setor pintura, dando preferência acentuada aos mestres que passaram a ser apelidados de "clássicos." Nos últimos dez anos andaram atribuindo aos tais "clássicos" valores bem significativos a ponto de surpreender os analistas, sendo a articulação da alta atribuída à ação da empresa Collectio, introdutora no mercado de um sistema de marketing e de um insistente battage publicitário, conseguindo resultados apreciáveis. O empreendimento se desenvolveu especialmente através dos leilóes, superando os modos tradicionais até então conduzidos em termos caseiros. Tivemos, como em Buenos Aires, onde 
os arremates constituem acontecimentos sociais, reunióes brilhantes alegradas com boas bebidas e gentis leiloettes, conseguindo concentrar notável assistência em condiçōes de competir nos lances: pessoal em grande parte novato na consideração dos problemas da arte, interessado no decor, algum com propósitos de colecionar, mas intencionado na especulação. Eram os tempos em que a Bolsa de Valores, depois das euforias artificiais, andava mal, a inflação galopava e a falsa ideia do milagre econômico poluía ilusóes: todos componentes que favoreceram o boom do mercado de arte.

O agitador da Collectio, amparado pelo cronista Roberto Pontual, faturou espertamente a situação, originando o nascimento de capitalistas que consideraram o investimento em objetos de arte como uma operação segura. Assistiu-se assim a uma rotatividade de obras totalizante de valores bem compensativos, intervindo os bancos com generosos créditos, incentivando assim as vendas a prestaçóes, sem contar com maciças ajudas ao inventor do negócio que, poucos anos depois, não deu certo, pois a honestidade não era o seu forte.

A corrida determinou um interesse geral pela arte, aliás pelo seu valor pecuniário: quem tinha nas paredes alguns quadros de autor ou não, valorizou-os, contribuindo assim em favor de um processo de consideração pelas coisas até então não muito apreciadas. $\mathrm{O}$ pedido de mercadoria foi tal que foi necessário recorrer ao estrangeiro para recolher o pouco de arte brasileira lá importada como souvenir. Logo que os proprietários lá de fora souberam dos preços aqui alcançados, venderam aos marchants nacionais tudo que possuíam. Até Nelson Rockefeller e Helena Rubinstein se desfizeram dos Portinari que compraram bem barato, mais como finalidade public-relations.

A herança do boom deve ser hoje avaliada com serenidade. Aliás, há um ano que o problema está sendo discutido. Fala-se em crise no mercado. Não é bem de crise que se trata, mas é justo falar-se em redimensionamento. Tem colecionadores que compraram e continuam comprando pelo prazer de ter obras do seu agrado: para esta categoria as preocupaçóes náo existem. Quem adquiriu com propósito de puro e simples investimento sabe que precisa esperar tempos mais favoráveis, os quais sem dúvida vão vir, pois os que conhecem a história antiga e contemporânea do mercado da arte sabe que, quando se trata de obras originais, o valor vai sempre aumentando.

Uma preocupação pelo índice dos valores relativos aos mestres nacionais julgados por alguns analistas são por demais altos, quando comparados com os estrangeiros. É de se observar que o fenômeno de nacionalidade no campo da arte é próprio de todos os países e, sob certo ponto de vista "de pátria”, é lógico que o brasileiro goste mais de um Di Cavalcanti do que de um Derain, pois a temática do pintor das mulatas lhe é mais afim. Há quem venha afirmando ser o valor alcançado pelos dois artistas, mutatis mutandis, análogos é o mesmo, porém tendo o francês uma cotação internacional, e o Di somente local. Isto é verdade, todavia, se um amador quer possuir um EM deve se sujeitar ao mecanismo do mercado nacional, isto é, o mesmo que se dá em outras naçóes, marcadamente nos Estados Unidos onde os nacionais do Oitocentos são muito bem pagos. Deve-se convir que o mercado brasileiro está em seu começo. Pouco a pouco irá apreciar também a arte de fora. Já foram vistas, nos últimos leilóes, vendas de obras de estrangeiros, sendo quase nulo o interesse pelos autores antigos os quais, por outro lado, são raros não ser a pintura colonial espanhola a qual interessa bastante. Trata-se de amadurecimento da cultura e do gosto, o mesmo fato ocorrido nos Estados Unidos nos fins do século, quando lá abriram filiais as casas parisienses e inglesas. Cultura e compreensão das artes não andam rapidamente. O importante é que o Brasil tenha começado a se mexer no setor. No que se refere mais especificamente ao mercado pensa-se que os valores alcançados pelos Portinari, Di, Segall, Anita, Rego Monteiro Soruide, Tarsila, Neri, para lembrar apenas os desaparecidos, em consequência da raridade das produçóes e da constante procura, irão atingir sempre mais altos valores. Para os escalóes subsequentes será o mesmo, dependendo da estabilização do mercado e dos leilóes que estão interessando agora a Estados até aqui refratários. (É significativo 
saber que em Ribeirão Preto foi realizado um leiláo e que em Juiz de Fora um marchant comprou uma igreja desativada para transformá-la numa galeria.)

Falar em crise é certamente errado; os pessimistas e as cassandras devem se convencer de que o mercado de arte náo poderá acompanhar a conjuntura experimentada pela economia brasileira durante algum tempo, mas agora em franca recuperaçáo graças a medidas governamentais.

Concluindo, devemos assinalar que ainda o investidor brasileiro em arte não descobriu a presença no Brasil de pelo menos dez artistas de futuro, elementos que irão representar o que hoje representam os "clássicos." Estes últimos, quando começaram, não tiveram o conforto do ambiente e foram desconsiderados. Hoje a situação mudou; todavia, precisa melhorá-la para efetivamente ser considerada como fato cultural. Afinal quem se mete neste hobby e nos negócios de arte deve ativar a arte dos jovens. Serve para o Brasil definir uma posição no campo da arte.

\section{Mercado 1978: Um ano promissor?}

Para o próximo ano são anunciadas novas iniciativas no setor das galerias, sempre mais numerosas, não somente nas duas principais metrópoles do país, mas também nas capitais de vários Estados. $\mathrm{O}$ que parece mais promissor é o intercâmbio, o que provoca maiores possibilidades para um plano (inexistente) de "nacionalização" das artes. Trata-se dos primeiros passos, pois ainda temos territórios numa fase de expectativas de eventos culturais de certo porte. Por enquanto são as iniciativas particulares que animam o desenvolvimento como foi verificado no Recife, Bahia, Belo Horizonte, Curitiba e Porto Alegre: tivemos lá pioneiros obstinados e, na verdade, os próprios governos não deixaram de incentivar a solução dos problemas inerentes. Os observadores calculam que a arrancada se deu nos últimos dois decênios, regulada ou desregulada, como sempre acontece, pela falta de programaçóes, intromissóes políticas e polêmicas entre fautores de academismo e fautores de modernismo. Todavia, o passo foi notável, nem de jumento nem de veado: o normal prescrito pela situação e pela falta de experiência.

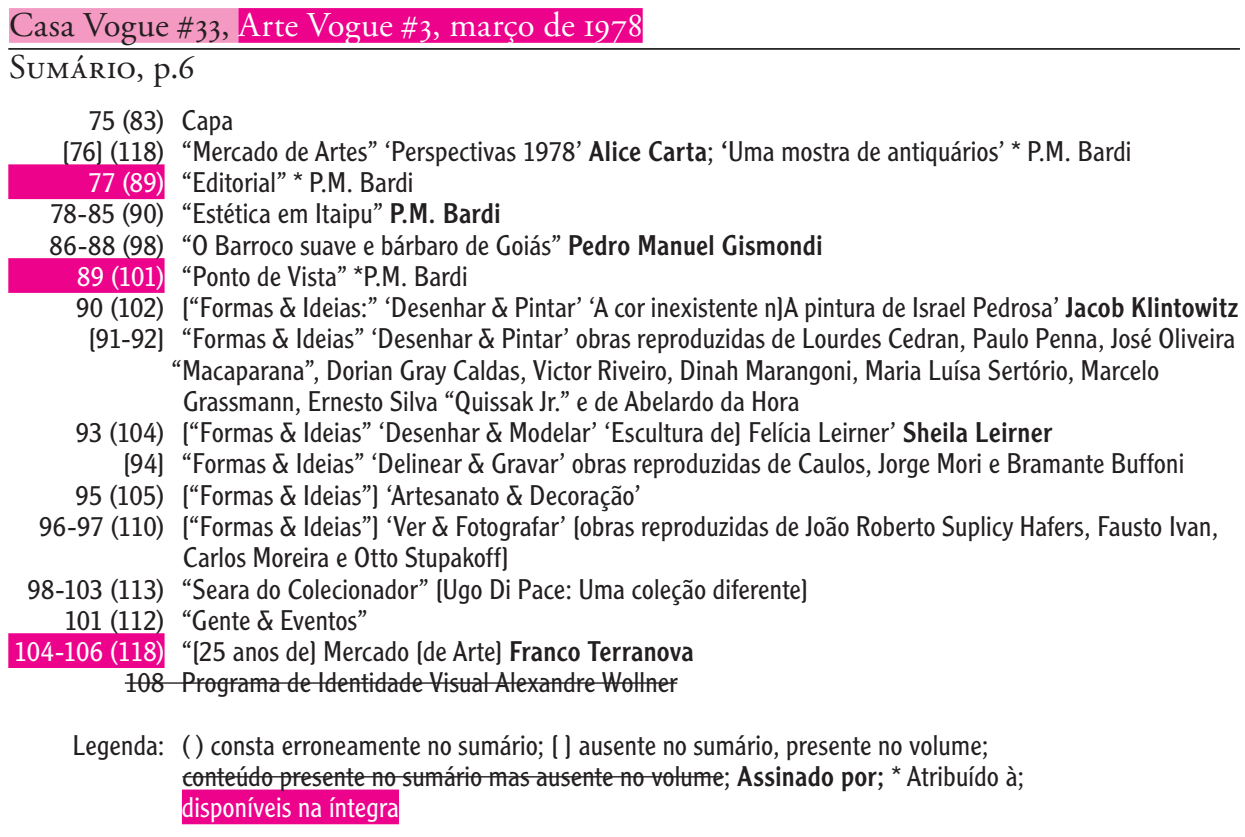

EDITORIAL, p.77

aribuido a P.M. Bardi

Novidades no campo Vogue. Esta revista que em 77 apareceu duas vezes, teve oportunidade de apresentar ediçóes com marcado caráter monográfico e dedicadas mais ao enfoque de problemas da arte do que da crônica. As pesquisas nos 
confirmaram que os tempos ainda não são totalmente favoráveis a um gênero de publicação conforme o planejado, mas acima de tudo pensado. Assim, o editor decidiu mudar a periodicidade da revista: Arte Vogue sairá em 78 trimestralmente e será oferecida ao público em companhia de sua coirmã Casa Vogue, uma publicação que se interessa em divulgar assuntos pertinentes ao seu próprio título. Pensamos que as duas revistas, sem perder as características de cada uma, podem e vão se integrar. Na Casa Vogue se compendiam os labores das artes, a começar pela arquitetura, ainda se afirmando como a revista das arquiteturas de interiores, envolvendo o amplo processo de renovação dos ambientes, registro da intensa atividade desenvolvida pelos decoradores, antiquários e galerias. Arte Vogue se propôs em apontar outros assuntos de interesses mais amplos, como por exemplo, a consideração da história das artes, a indicação de novos valores, desempenhando uma certa ação que visa a incentivar o colecionismo, discutindo casos de política da cultura, às vezes saindo do êxtase do situacionismo, chegando até às raias da polêmica.

O leitor, em geral, não gosta de se aventurar na senda das questóes que impliquem em participação, opinióes, julgamentos. A maioria das poucas publicaçóes que se interessam pela arte não toma posição, nem mesmo diante de fatos provocatórios da própria opinião pública, como foi o caso da última Bienal de São Paulo. Habitualmente o pessoal aceita as coisas que os encarregados do assunto produzem, registra sem exercitar o uso da crítica, atividade esta que parece náo gozar da popularidade que mereceria; e não só no trato de problemas afinal correlatos, se considerarmos o básico, isto é, o político. Arte Vogue em suas duas primeiras ediçóes publicou textos que bem demonstram um vivo desejo de dar crédito à discussão, particularmente no concernente à arquitetura, que nesta edição apresenta uma reportagem sobre a maior obra que o Brasil está levantando no momento, o fabuloso complexo de Itaipu. Eis definido mais uma vez o espírito de Arte Vogue: a consideração por empreendimentos que representam os autênticos fatos da arte, dos quais pouco se fala por serem considerados obras de engenharia. De qualquer jeito, ao passo que Casa Vogue - agora sua irmá siamesa - pretende ilustrar os acontecimentos da vida artística nacional que afinal fazem parte de uma definição da arte mais atual.

Estética EM ItAipu, p.78-85

\section{P.M. Bardi}

\section{Itaipu, janeiro}

Ao longo de minhas andanças pelas alamedas do jardim das artes, tive ocasião de me surpreender com as inúmeras oscilações do gosto tão característico do século, das propostas e contrapropostas, das secessóes, enfim da instabilidade deste fato apelidado estética. Às vezes não me conformando com o aplauso que certas mudanças vinham recebendo por parte dos fruidores das floraçóes daquele jardim, tentei reagir nos limites do possível, quase sempre inquinado de um autêntico dom quixote mirim. Carente de regular inscrição num dos conciliábulos denominados de associaçôes de críticos, acabei me envolvendo em algumas polêmicas que vejo, nestes últimos anos, lembradas pelos historiadores italianos interessados em descobrir papéis datados de há meio século.
Referem-se opinióes sobre arquitetura, a um tempo em que, na península assim chamada de "Mãe das Artes e Aluna da Poesia," aquela atividade era ainda exercida e mais prerrogativa de artistas devidamente licenciados nas academias na matéria “desenho arquitetônico;" o engenheiro civil (nunca entendi este adjetivo) construía, o artista aplicava na fachada os ornamentos que o comitente podia escolher à vontade nos álbuns ilustrados de desenhos dos diversos estilos. O século I9 passava ao sucessivo a herança inaugurada depois do período neoclássico: qualquer estilo utilizado para a maquilagem das cidades, e não só os modos europeus eram tomados como exemplo, mas também os exóticos, contribuindo para o ecletismo desvairado que também andou de moda no Brasil.

A situação era tão aceita que surgindo o art-nouveau os ditos licenciados, 
acostumados a não inventar nada de novo, tiveram de se adaptar, fornecendo material a bizzeffe $e^{3}$ aos humoristas. Os ofícios continuaram: o engenheiro construía, desinteressado no vulto do seu labor, o ornamentista juntava "arte."

Nos fins dos anos 20 eu dirigia, em Miláo, o jornal Belvedere, em cujas colunas comecei a notar que o panorama da arquitetura nacional era uma $\mathrm{m}$., desfechando logo depois no cotidiano L'Ambrosiano uma veemente polêmica contra o caput magister de um novo "estilo novo", o "romano modernizado" dos arcos e das colunas, Marcello Piacentini. Fui castigado pelo PNF, como filo-comunista, pois pronunciando-me favorável ao racionalismo, funcionalismo e outros princípios antirretóricos fui considerado um perigoso gastador de festas.

Por que esta breve introdução para iniciar uma reportagem dedicada a Itaipu?

As polêmicas atrás invocadas eram em favor de uma arquitetura coerente com o espírito do tempo, simpatizando com os reformadores, desde Le Corbusier até Mies van der Rohe, Rietveld, com simpatia pela Escola de Viena e quantos isoladamente contribuíram para a renovaçáo mais que polêmica, garibaldinismo juvenil, irritação contra a situação em que era aprisionada a princesa das artes na Itália.

Por acaso um dia descubro em Florença que se estava construindo um estádio: obra-prima, plenamente funcional, escadarias parcialmente cobertas por uma pensilina ${ }^{4}$ lançada no espaço. Quando publiquei e comentei, com destaque, aquela arquitetura, o construtor veio me procurar para declarar que náo se tratava de arquitetura, mas de engenharia, pura consequência de satisfação de exigências práticas, cálculos de comportamento do concreto, análise de materiais e assim por diante, insistindo o projetista e construtor em não querer nem ouvir falar de arquitetura, pronunciando no final da peroração uma sentença apodítica: "O arquiteto é um mestre de obra que sabe latim.” A definiçáo era de Pier Luigi Nervi. Daquele dia em diante

$\begin{array}{ll}3 & \text { Em abundância. } \\ 4 & \text { Cobertura pênsil. }\end{array}$ a amizade e a estima por essa hoje famosa figura foi, para mim, uma diretriz na consideração dos problemas da arquitetura, tendo o privilégio até de associar meu nome ao dele no projeto para o Museu da Civilização Italiana. Daí a origem da minha admiração pelos engenheiros.

Vim até aqui para ver uma obra de engenharia, a barragem do complexo hidrelétrico de Itaipu que será uma das mais fabulosas arquiteturas de todos os tempos, a par das Pirâmides, da Muralha da China, do Parthenon, do Coliseu e dos Aquedutos de Roma.

Foz do Iguaçu, apesar do calor senegalesco, tem suas ruas e avenidas que mais parecem formigueiros, turistas, num vaivém contínuo em demanda às Cascatas. Todos extasiados com aquele soberbo e sem fim precipitar de água, o ruído ritmais monótono e irritante.

Os caçadores de sensaçóes da Natureza, trajando shorts e chapéus de palha, a vagarem ao longo dos caminhos panorâmicos, os guias indicando onde é Argentina e onde é Brasil, quantos são os metros de altura das águas que vão, depois de tanto barulho, calmamente para o Paraná. (Curioso: vinte e cinco anos atrás aqui estive para filmar o lugar. Parte de "Magia Verde" que realizei com os amigos Leonardo Bonzi. Giangaspare Napolitano e Mario Craveri, tive uma desconcertante impressão deste doce inferno de águas. Agora, me parece um cartão postal.) $\mathrm{O}$ turismo ofende às vezes a Natureza. Não compreendo por que o interesse dos que percorrem milhares de quilômetros para chegar às Cataratas, sem percorrerem mais umas dezenas para ver o que acontece em Itaipu.

Há dois anos que a barragem está me intrigando. Tive uma proposta do Museu de Arte para ordenar uma Exposição de Itaipu a fim de que o grande público fosse informado das proporçóes do audacioso empreendimento que vai transformar uma vasta regiáo: um leque de problemas ecológicos, econômicos, sociais e inclusive estéticos sem precedentes como 
amplitude, marcadamente no que se refere ao futuro rico de incógnitas, caso o Mundo continue a porfiar em progressos tecnológicos esquecendo-se de que o único progresso é o moral.

A proposta da exposição (esperamos que ainda seja válida) além de apresentar os planos técnicos numa comunicação simplificada e de fácil leitura, capaz de determinar uma participação popular no empreendimento de orgulho nacional, proporcionaria aos responsáveis a possibilidade de ver descobertos e discutidos variados assuntos bem significativos, particularmente no que toca ao status atual e o destino dos milhares de operários que estão agora participando dos trabalhos do desvio do rio Paraná e, depois de outubro, do erguimento da barragem.

Em torno de Itaipu, como ocorreu com outras grandes barragens, está nascendo um novo centro urbano que será bem maior do que aquele surgido em Ilha Solteira. Fácil será imaginar qual a situação de uma população vinda de todos os Estados do Brasil e, em parte, do fronteiriço Paraguai. Arrasado o matinho, foram construídos alojamentos com características semiprovisórias, sem adaptaçôes urbanísticas que melhor atenderiam aos usuários. Trata-se, é verdade, de habitações para servir a um canteiro, porém ao longo de pelo menos seis anos. Um estudo mais acurado desta cidade operária, sob o ponto de vista comunitário, notadamente no que se refere aos serviços mais indispensáveis para o viver material, e mais, o cívico e o espiritual teria, não resta a menor dúvida, proporcionado resultados bem mais satisfatórios. A Urbanística poderia ter um tratamento mais correto. Francamente, aquelas filas de casas geminadas, plano diretor em que a fantasia parece não ser amiga não convence, e não corresponde às exigências do viver das famílias.

Percorrendo as "avenidas" dos quarteirôes nota-se que já alguns dos inquilinos se industriaram nas correçóes e na procura de animar o ambiente, formando hortas para ver se dá um pouco de verdura e flores, hábito típico do popular que face às contingências desfavoráveis, corrige a falta de atenção do urbanista e de seu partner, o arquiteto.

Pode ser que o relevo seja o mus dos mons, todavia, penso que uma solução mais pertinente aos tempos para os quais estamos caminhando seria confortante para os vinte mil, um dia trinta mil, da barragem. A Urbanística é hoje um de primeira plana; conjuntamente ao design e à comunicação de massa determinam uma estética que contribua a servir para a solução do problema vida das gentes. A história da arte contemporânea, nesta quadra em que ela interfere, ou melhor, sofre interferência da economia e da sociologia é, na realidade, a crônica de um contraste dialético, levado às mais imprevisíveis consequências, entre o pitoresco da tradição e as inerentes necessidades de uma mudança de panorama.

Por isso, vendo construída, em folha uma cidade, procura-se observar se os serviços, sociais existem, e se a proporção e a fartura são convenientes. Parece-me que o planejador do conjunto é de opinião que o que serve é pensar nos dormitórios.

Engenharia: resultado dos inventos e suas aplicaçóes técnicas, das descobertas da ciência, da disciplina que condensa contribuiçóes e inúmeras funçóes, sempre novas, alcançando soluçôes cada dia mais carregadas de surpresas, dominadas, distribuídas, harmonizadas neste lazer e labor obcecante que o homem apelida de progresso.

Para nós, os leigos, contempladores ignorantes dos eventos, consumidores dos resultados, ciência e técnica constituem um poliedro de mistérios, e mais: perplexidade por não saber reconstruir nem o mais simples dos processos de uma ou outra façanha da engenharia. O mesmo se dava com o sublime da engenhosidade, a arte; todavia, este manifestar deixava intuir os moventes e os sentimentos, quase sempre expressão de singulares personalidades, apesar de ser síntese de ambiente. Uma obra de arte, por quanto bocejante nas diversidades que antecipam o inédito de outras formas e ideias era, até há algumas dezenas de anos legível e compreensível, ao passo que o mesmo se dava, a grosso modo, com a regalia dos inventos mais comuns, como as máquinas que mudaram 
a tradição milenar, da navegação marítima, o inovar da aviaçáo, o transporte terrestre e quantas outras aquisições.

Mas hoje a humanidade está impelida numa corrida de ambição apocalítica, e mesmo a própria e tradicional sua companheira, a arte, sacudida por aquele tumulto de progressão sem uma meta definida, incontestável no produzir, consumir e destruir, ressente do abalo, o campo chegando a ser um carroussel de confusóes e delírios. Refletimos, sem perder mais tempo em busca de esperanças de um retorno à ordem, na antevisão de Hegel, isto é, que a atividade arte vai morrer.

Se vaga pelo imenso canteiro das obras, entre uma e outra trovoada consequente das explosóes nas encostas das colinas que cada dia perdem fatias das suas rochas, (ígneas mesozoicas compostas de basaltos, brechas de basalto e arenitos) os cascalhos arrancados e recolhidos pelas escavadeiras, trinta toneladas por lance, encaçambadas e levadas para moagem na usina de concreto; passado o ruído, se veem subir grossas colunas de poeira, para tudo em seguida voltar a uma calma relativa, cadenciada da batucada dos motores. Transitar-se aquém das bandeirinhas vermelhas, o olhar confuso por não saber onde pousá-lo. Viciados de história é só imaginar, recorrendo a Dante: um engenheiro afiançou-me que iria ver "algumas coisas de dantesco."

Não é só a barragem a nos convidar a pensar nas quizílias da estética. Itaipu é uma das tantas obras levadas a efeito pelo homem, a mais grandiosa entre suas similares que estão transformando os cursos dos rios espalhados pela terra; aqui pode-se inferir como o máximo da perfeição técnica de um sistema que tem seu precedente nas rosas e nas pás dos moinhos. Estamos assistindo a um evento rico de vitalidade humana. Penso, então, naquelas plataformas combinadas para produção e estocagem que o consórcio anglo-holandês Andoc mandou construir em Rotterdam para extrair e armazenar óleo no mar do Norte, uma espécie de "caixão" de IO4 x IO4 x 32 metros, sobre o qual se elevam quatro torres de II2 metros, obra rebocada até um fjord norueguês para receber seu complicadíssimo maquinário, para depois ir desafiar a impetuosidade das ondas e dos ventos bem assim das correntes e das marés. Também a Plataforma Dunlin-A é de concreto: noventa mil toneladas, dez mil de aço reforçado, duas mil de aço protendido, seis mil de aço estrutural.

Nossa barragem será encravada na rocha, a Plataforma vai flutuar nas águas. Pontilha no rápido panorama mental que sobreponho ao realista, ao lado deste trecho do Paraná, também a forma cilíndrica da Usina Nuclear de Angra dos Reis, outra espetacular obra de engenharia.

Curioso: se um arquiteto, naturalmente não um qualquer, entrega um prédio, jornais, revistas ou qualquer outro veículo de comunicação exaltam o acontecimento, entrevistam o autor, numa palavra o produto recebe sua propaganda. (O móvel é que se trata de arte.) Em contrapartida, a obra dos engenheiros, mesmo que resulte em arquitetura, isto é arte, pouco se sabendo, geralmente, quem é o seu autor; as loas vão sempre e mais para os círculos especializados. (Vejam Itaipu: um colosso de projeto. Sua autoria passará à história como sendo do Consórcio formado pela International Engineering Company de São Francisco da Califórnia e da Electroconsult de Milão-Elc, que desde I970 trabalham nos estudos de viabilidade, levantamento de campo, análises hidrológicas, investigaçóes geotécnicas, estimativa de custo, operaçóes simuladas, análises econômicas em busca da solução mais econômica e vantajosa para o aproveitamento energético: um conjunto de açóes e responsabilidades enormes. Será como o Coliseu, do qual se sabe somente que foi planejado por engenheiros romanos.)

A obra do engenheiro é sempre pessoal, mesmo quando projetada em equipe, como é o caso da Itaipu, fruto mais de intuição do que do raciocínio anônimo, consequência de um labor considerado fruto da ciência e de técnica, mas de que se serve da ciência. Geralmente confunde engenharia com os costumeiros procedimentos matemáticos do cálculo. Os procedimentos matemáticos são os meios para o conhecimento dos estados físicos da matéria, como indispensável ponto de indagação, não estando aí toda a engenharia. O telescópio em si não é a astronomia, apesar de ser o meio da pesquisa. Queria ver mais 
apreciada a figura do engenheiro, guia das atividades humanas, solucionador de problemas, inclusive os da estética.

Voltemos ao caso da arquitetura. Itaipu, Dunlin-A, conjuntamente com não sei quantas outras obras: arquiteturas. Será difícil convencer os exegetas encabulados na distinção estética entre moradia e obra industrial.

Náo contei o caso do meu encontro com o engenheiro Nervi, numa época em que a arquitetura era privativa, como disse, de "artistas." No Congresso de Atenas, com a reunião da nata das vanguardas entre os quais Le Corbusier, Aalto, Giedion, Terragni, Morthon Shand, Sirkus, [Cornelis] van Eesteren, Sert, Bottoni, Charlotte Perriand, [Gino] Pollini, Léger e quantos outros, o repórter integrava a delegação italiana (devidamente considerada não representativa da Itália então nas mãos, em termos de arquitetura, dos mais ilustres pompiers).

Convencido de que no Congresso uma comunicação sobre obras industriais que deveriam ser consideradas como criatividade de formas, seria aceita com entusiasmo, tentei o lançamento. Porém, não pude apresentar a documentaçáo da Barragem do Tirso, na Sardenha, de autoria do engenheiro Savério Kambo, uma construção de arcos múltiplos de extraordinária composição, nem também uma ponte dos engenheiros irmãos Damioli, nem o projeto do saneamento das Paludes Pontinas e consequente urbanizaçáo.

Por quê?

Porque arquitetura era casa de rico, palácio, igreja, arco de triunfo e, como último interesse, hospitais, casernas e outros estabelecimentos utilitários. Também à Urbanística tocava o mesmo pensamento: circunscrita à cidade, mais para remediar os entraves da viação, para adaptar o que servia na calmaria oitocentesca às exigências da vida contemporânea.

Parece-me que neste sentido, em termos da zona da Barragem, a Urbanística como infra-estrutura poderia merecer melhor atenção. Já me referi às habitações semiprovisórias do operariado. Ao lado vejo uma cidadela para técnicos de um certo grau de especialização. Mais distante, um grupo de casas-jardins dos dirigentes da Binacional.

Agora: a poucos quilômetros vive, especialmente hoje, do movimento ativado por Itaipu, a cidade confusa e caótica de Foz do Iguaçu. É evidente que uma consideração urbanística de uma certa amplitude teria encaminhado a regiāo para uma solução digna do evento que vai determinar seu futuro. A urbanística deve ser, no mínimo, regional. O ideal seria um plano urbanístico nacional, mas até lá é complicadíssimo chegar. Achamos que não seria demais estudar-se um complexo envolvendo as Cataratas, o Parque Nacional, o Reservatório. Foz do Iguaçu, enfim, criar a região.

Não é este o local para uma informação técnica mais ampla sobre Itaipu, que me dispus a ver em companhia de meus assistentes do Masp. O propósito era para que eles examinassem, de visu a viabilidade de uma exposição dedicada à barragem número um do mundo.

Lá pelos anos 30 fui ver a Barragem Dnieprogres, na Rússia, (760 metros de comprimento, 60 de altura) detendo-me em Alexandriaska vários dias: para jovem que tinha visto pela primeira vez um destes diques, infelizmente estraçalhado (foi a tragédia do Gleno, cuja barragem cedeu, deixando esvair um volume de água que arrasou o vale e encheu de cadáveres o lago de Iseo) a impressão foi daquelas que jamais se esquece. Como foi a Yaroslav, no Volga, onde o engenheiro italiano Omodeo construiu a represa. No Dnieper minha referência foi Piranesi, mas em Itaipu? Não sei. Tudo está mudando para que se possa fazer comparaçóes estéticas. Aqui em Itaipu o repórter revive aquelas distantes jornadas na Rússia dos tempos em que os Slogans políticos repetiam: "Um povo que constrói é um povo que vive," e o insistente: "Eletrificação + soviet = socialismo," assinado: Lenin.

Jornadas de outros tempos. O rio agora é o majestoso e turbulento Paraná. Os problemas não são somente de engenharia ou de economia, alcançam a área política, pois aqui as águas de um lado banham 
terras paraguaias enquanto mais abaixo costeiam a Argentina. O que importa é que a barragem já se constitui em fato irreversível, e que o Brasil vença mais esta nova etapa na senda de seu desenvolvimento, na verdade uma das bases para o fortalecimento de seu necessário sistema elétrico.

Itaipu tem outras coirmãs: no Norte, Tucuruí e Couto de Magalhães; no Nordeste, Paulo Afonso IV e Sobradinho; nas regióes do Sudeste e Centro-oeste, Divisa/Itapebi, São Simão, Água Vermelha, Itumbiara e Emborcação; no Sul, além de Itaipu, Salto Osório, Itaúba, Foz de Areia e Salto Santiago, todas em construção para produzir um potencial hidrelétrico nacional que na alvorada do ano 2000 servirá para contribuir e prover a todas as necessidades regionais.

Estas simples notícias implicariam, agora, na ilustração da obra; porém, isto é assunto assaz complexo que foge aos propósitos que levou o Masp até aqui para estudar a possibilidade da Exposição de Itaipu, visando a combinar uma comunicação bastante acessível, enfocando um conjunto de dados e os fatos correlatos, e até sua breve, mas já emocionante história, desde os primeiros riscos, os estufe de viabilidade, as alternativas dos convenientes para represar o Paraná (foi escolhido o tipo de gravidade aliviada que resulta no mais adequado, pelo menor volume de concreto e a menor subpressão sob a barragem) os fatores segurança, o desvio do rio, a criaçáo usina de concreto, o cronograma, a redução do custo que deve preocupar cada engenheiro no resolver os problemas a ele confiados, empenhando-se em obter o máximo de rendimento. (O leitor que se interessar por Itaipu, pode recorrer à ediçáo especial de Construção Pesada que, apesar de ser revista de circulação entre engenheiros, é de leitura bem compreensível e rica de desenhos-síntese de leitura não complexa.)

A mais corriqueira notação, e se ouve de gente que pouco afina com a história, é a comparação das Pirâmides face a Itaipu Porém, sabe-se que os egípcios, desde o faraó até o povinho, confortavam a construção com diuturna atenção, tudo sabendo, realidade e mistérios. Da barragem a gente pouco sabe, ou melhor, nada sabe.
Numa das mais recentes Bienais foi exposta a maqueta do Metrô paulista, porém, não se compreendeu se a iniciativa era para mostrar uma obra de arte ou para simplesmente fazer propaganda do novo meio de comunicação. De qualquer jeito os visitantes acharam aquela apresentaçáo uma intrusa num recinto da arte propriamente dita, ou no máximo, um brinquedo de trenzinho para a criançada se divertir.

A lembrança é para insistir no problema de ordem geral que interessa à arte, considerada na sua realidade atual, hoje sempre mais estruturada na democratização, atendendo às imensas necessidades da vida, com prioridade para a urbanística e a ecologia, o design, a comunicaçáo de massa, passando para um plano acessório as produçóes individuais das vanguardas, às vezes, retrovanguardeiras que se tornaram espetáculo penoso, como vimos na última Bienal e na própria Documenta, de Kassel.

A estética de como antigamente parece no ocaso. É o que se pensa voltando de Itaipu.

Comunicar Itaipu: Uma proposta, p.79

O Museu de Arte de São Paulo tem tradicionalmente encarado a arte como algo vivo e atuante. Tem-se interessado, assim, pelas principais manifestaçóes contemporâneas da cultura e do labor humano. Poder-se-ia citar, a titulo de exemplo a exposição "A Mão do Povo Brasileiro" ou, mais recentemente, uma sobre a Grande São Paulo cobrindo os múltiplos aspecto de uma metrópole e outra a denominada "Metas e Limites do Progresso."

A usina hidrelétrica de Itaipu não é apenas uma obra gigantesca, e uma Presença, é uma presença física em implantação num ambiente natural e num contexto muito particular, como também uma expressão do amadurecimento técnico e cultural de duas naçóes amigas. A obra, além da sua finalidade primária de produçáo de enormes massas de energia barata e sem poluição, permanecerá como exemplo ímpar de cooperação internacional que a tornou possível.

O Masp considera Itaipu uma expressiva realização do gênio criador humano e uma afirmaçáo da capacidade realizadora das naçôes promotoras devendo, por isso, ser 
divulgada em todos os seus aspectos: material, econômico, social, cultural etc.: do planejamento ao acabamento arquitetônico.

Como todas as grandes realizaçóes humanas o interesse da obra ultrapassa as vantagens econômicas diretas e os próprios limites geográficos das naçóes que a promove. Constitui o testemunho vivo de uma época e implica numa infinidade de opçôes, detalhes e aspectos particulares de grande interesse geral.

Assim o Masp, com a eventual participação de uma entidade congênere do Paraguai, propóe associar a uma exposição (de interesse binacional e internacional) dois outros aspectos que julga de interesse direto da obra. Trata-se de um local permanente, junto ao canteiro, para demonstraçóes sobre o trabalho e de sistematizar algumas contribuiçóes aos programas culturais de lazer para a comunidade dos técnicos e operários do canteiro e respectivas famílias.

Uma grande obra de engenharia é um fato de arte. Modernamente talvez deva ser considerada entre as realizaçóes de significado artístico fundamental. O Masp tem sustentado este ponto de vista ao longo de anos e sente que é de interesse público essa divulgação sobre Itaipu e a gente que a constrói. Através de demonstraçôes de vários níveis. (Um centro deste tipo tem sido muito útil às grandes obras hidrelétricas, como no caso de Assuá, no Egito.)

Estimando-se que a população do canteiro chegará a cerca de cem mil habitantes, existirão, como em todas as cidades-acampamentos, os problemas sociológicos relacionados ao lazer e à identidade coletiva. Mas o maior fator de identidade coletiva é, justamente, a obra em si. A organização de uma exposição acessível, que demonstre e acompanhe a obra, pode contribuir para um melhor relacionamento entre os componentes desta população.

A exposição pode, facilmente, ser aliada a uma espécie de Museu de Campo, onde tenham lugar manifestaçóes culturais de vários gêneros. Além de exposiçôes várias em conjunto com museus brasileiros e paraguaios, pode-se prever manifestaçóes no setor da música, do cinema e do teatro.
Em vista de tais fatores poder-se-ia estudar uma exposição modular e flexível, de interesse geral; transferência da exposição para uma construção apropriada junto à obra; possíveis extensóes sucessivas, espaços modulares adicionais para outras atividades culturais no canteiro.

Quem executa Itaipu, p.8I

Além do gerenciamento global de todas as operaçóes do empreendimento, as demais atividades do projeto e construção estão assim distribuídas: Coordenaçáo técnica do empreendimento Consórcio International Engineering Co. Inc. e Electroconsult SpA—IECO-ELC; Projeto Consórcio IECo-Elc: projeto do desvio do Rio, barragens, Enrocamento M.E. Especificação dos equipamentos permanentes, Consórcio Promon Engenharia Grupo Consultor Alto Paraná-GCAP: projeto da Barragem principal. Consórcio Themag-GCAP: projeto da casa de força. Consórcio Engevix- GCAP: projeto de vertedor e barragem lateral direita. Consórcio Hidroservice-GCAP: Barragem da Terra M.E., Sismologia reservatório, do reservatório, estudo de viabilidade das obras de navegação; Estudos de Canteiro e Planejamento geral da obra Consórcio Logos-Enge-Rio-gcap Ensaios com modelos hidráulicos Centro de Estudos Hidráulicos da Universidade Federal do Paraná-CeHPar; Ensaio com modelo estrutural Instituto de Pesquisas Tecnológicas do Estado de São Paulo_- IPT, Instituto Sperimentale Modelle e Strutture SpA-ISMES

Empreiteiro civil principal Consórcio unicon-CONempa, (Diretor: eng. Gabriel Paes de Carvalho), constituído pelas seguintes empresas: Andrade Gutierrez S.A., Barrail Hermanos S.A., Construçốes e Comércio Camargo Corrêa S.A., Cetenco Engenharia S.A., Cia. de Obras de Engenharia Civil SRL, Cia. Brasileira de Projetos e Obras- Свро, Cia. Genral de Construcciones SRL, ECCA S.A., Ing. Civil Hermann Baumann, Ing. J.C. Wasmosy Asociados, Jiménez Gaona Y Lima, Mendes Júnior S.A. 
Quem dirige Itaipu, p.83

A diretoria executiva de Itaipu Binacional está assim composta: Diretor geral Gen. José Costa Cavalcanti, Brasil; diretor geral adjunto Enzo Debernardi, Paraguai; diretor técnico John R. Cotrim, Brasil; diretor técnico adjunto Hans W. Krauch, Paraguai; diretor jurídico Antonio Colán Rodriguez, Paraguai; diretor jurídico adjunto Paulo José N. da Cunha, Brasil; diretor administrativo Victorino Vega, Gimenez, Paraguai; diretor administrativo adjunto Aluisio Guimarães Mendes, Brasil; diretor financeiro Moacyr Teixeira, Brasil; diretor financeiro adjunto Fidencio Juan Tardivo, Paraguai; diretor de coordenaçáo Carlos A. Facetti, Paraguai; diretor de coordenaçáo adjunto Cassio Paula Freitas, Brasil.

\section{Legenda}

p.8o As habitaçóes daqueles que trabalham em Itaipu: A cidade dos operários Casas dos técnicos Recanto

PONTO DE VISTA, p.89

atribuido a P.M. bardi

Nada de mal, nos tempos em que os vasos comunicantes da informação governam a vida, ao pescar nas searas as ideias, as técnicas, as modas e inúmeras outras coisas que se calculam úteis importar. No campo das artes o pegar lá, no que se refere à balança moral e comercial no Brasil, é praxe notória. É lícito que um pintor recompile os esquemas dos colegas novaiorquinos que se encontram na crista: a história, o dia do juízo final, vai se encarregar de colocar os fatos nas suas devidas posiçóes. O mesmo se dá com os arquitetos, não se esquecendo dos decoradores que vivem com o "House and Garden" colocado na mesa.

Fala-se do genérico que ocorre na área das artes, do acontecimento corriqueiro, pois o copiar e o imitar sempre foram atividades correntes. Nem todos, no Quatrocentos, tinham o elã de um Bramante ou, como no Seiscentos, o éstro caprichado de Borromini, ou ainda, mais tarde, o brilho do Aleijadinho, isto para inserir na conversa um mestre brasileiro. O genérico desta arte é o 'mass' que as construtoras erigem nas cidades, aquela mediocridade do centro habitacional dos dirigentes A igreja que serve Itaipu p.8I As máquinas, protagonistas da obra: uma escavadeira e uma caçamba Pirâmide de pneus

p.82 Momento da obra (todas as fotos e reportagens de Luiz Sadaki [Hossaka])

p. 83 Gráficos comparativos do volume da barragem Planta de Situação Comparação com o Museu de Arte de São Paulo (comprimento $80 \mathrm{~m}$ ) e o edifício Itália Comparação com a avenida Paulista

p.84 A engenhosidade dos inquilinos está mudando a "arquitetura" das moradias, buscando melhorias, como também tentando a produção de hortaliças.

p.85 Meninos à espera de um centro de lazer todas as instalaçóes que servem para ajeitar a vida da comunidade foram previstas e se encontram em fase de execução 9 Um Louvre para o povo [fotografia de um mercado]

de prédios de apartamentos e refúgios minifamiliares do $\mathrm{BNH}$, verdadeiras ofensas.

O pessoal que despacha os edifícios, ignorante como é, sabendo que vai fazer contrato com ignorantes, lança o produto imobiliário com etiquetas marketingamente apropriadas e golpistas, como é o caso do assim chamado estilo Mediterrâneo, atualmente o mais popular entre as classes que andam de galaxies e das que andam de ônibus, executivos ou não. Quando, em São Paulo, começou-se a falar deste "estilo" talvez o proponente tenha querido referir-se à "arquitetura sem arquitetos" que, nas costas do Mediterrâneo é bastante comum, o mesmo se dando na África e em outros Continentes, resultado de espontâneas soluçôes de forma e de racionalidade popularescas, não se levando em conta os condicionamentos próprios da arquitetura codificada nos manuais do clássico, esquecendo a simetria, a composição da fachada dela derivante, o tabu prospéctico e inúmeras outras imposições da tradição do movimento grego e romano. Pode ser que o introdutor do estilo Mediterrâneo no Planalto que nasce no Atlântico tenha 
querido polemizar contra a "arquitetura dos arquitetos," epígono do classicismo (sem mesmo saber o que isto significa:) uma chamada à ordem, para ativar o processo de linguagem coerente com os tempos em contraste com o borboletear das tipologias anacronisticas.

O tal que se deu à pena e à glória de introduzir o mais famoso "estilo" pode ser, ironicamente, congratulado: se sua iniciativa foi a de embaralhar nossas grandes cidades (e já o interior está ansioso em imitar) com modos helênicos, a façanha deu certo. O cúmulo é que os jardins se ornam de frentes devidamente providas de colunatas, mini-Partenons tão apreciados pela classe A: sinal de que a Atenas do Brasil homenageia Péricles, Ictino e Fídias.

As consequências "mediterrâneas" são visíveis.

A ideia, num certo sentido justa, de construir sem os empecilhos formais da tradição, foi logo arrasada pelos faturadores. Eles ajeitaram a novidade em negócio e bolaram o costumeiro pastiche para paulistas ricos verem, gostarem e comprarem. Os modos característicos na "arquitetura sem arquitetos” no Mare Nostrum podiam, muito bem, ser adaptados nos Trópicos: tridimensionalidade antiprospética, decomposição quadrimensional. (Típicas nas casas de Capri ou das ilhas gregas.) Era o recomendar de náo continuarem a repetir os mitos de Procuste da tradição, a liberdade de projetar ao invés, nas mãos dos primários imobiliaristas, a proposta foi interpretada e manipulada no costumeiro aproveitamento decorativo cujo símbolo hoje - incrível - é um mixuruco arquinho acima das janelas, como se pode ver naqueles pescoços de girafa ou nos maciços corpos de elefante que surgem aqui e acolá, classificados "mediterrâneos" (ao invés de "africanos") em virtude das prescritas janelinhas, que um dia ou outro também veremos nas colmeias do BNH, concluindo o ciclo de determinação da última importação estética.

25 ANOS DE MERCADO DE ARTE, p.IO4-IO6

Texto de Franco Trranova

Há alguns anos (poucos) a imprensa brasileira começou a se interessar pelo mercado de arte no Brasil e, em 1978, quando a Petit Galerie comemora seus vinte e cinco anos de existência isto nos faz, muito diretamente, responsável deste mercado que, como o famoso feitiço, virou-se contra o feiticeiro.

O sentido cultural, se já teve um, não existe ou se esgotou em 1964, quando organizamos o primeiro leiláo de arte moderna no Brasil, nos salóes do Copacabana Palace, no Rio de Janeiro. E queremos aproveitar, antes de entrar em números e dados técnicos, do convite que Luís Carta nos fez para dizer (ou repetir) algumas verdades (as nossas pelo menos) sobre todo este processo mercadológico que nós começamos e sobre o qual temos a autoridade e o dever de falar.

Num mundo sempre opaco, onde o smog cultural e a falta de sensibilidade concorrem com a poluição atmosférica, está sempre mais difícil reconhecer os verdadeiros valores: as mistificaçóes são quase normalidade no mercado de arte. (E, em verdade, em outras atividades humanas, também.)
Cada geração, como já repito há muito tempo, tem apenas uma dúzia de bons artistas e dois ou três grandes criadores; e isto vale para cada país do mundo e excluindo-se a autêntica arte anônima popular, o resto é apenas decoração de bom ou mau gosto, de maior ou menor talento.

Quando começamos a nossa atividade de marchand, no início dos anos 50, acreditamos nos artistas brasileiros e expusemos, pela primeira vez, um Volpi desconhecido, um Pancetti, um Marcier, um Dacosta, uma Leontina, um Krajcberg, um Agnaldo, um Vergara, um Wesley, um Roberto Magalhães, uma Wanda Pimentel e tantos outros que nos deram alegrias e orgulho e nossa pretensão foi a de criar um mercado firme para todos eles: conseguimos em parte isto e conseguimos criar uma geração de colecionadores, cuja sensibilidade foi aos poucos melhorando e cujas coleçôes fazem, hoje em dia, inveja a qualquer museu e conseguimos naquela época heroica o apoio da crítica, dos artistas e intelectuais para que náo desistíssemos da nossa luta: toda esta nossa 
experiência tinha um sabor diferente e nós tínhamos as ideias claras em nossa cabeça.

Hoje o mercado de arte que ambicionávamos não foi, em verdade, por nós alcançado e nos sentimos culpados por isto: por não ter podido evitar a especulação absoluta que invadiu este nosso mercado. É justo que numa sociedade capitalista, marchands, artistas, colecionadores e até museus, tenham lucros em suas atividades; mas não desejamos que este mercado se transforme em exclusivamente especulativo, temos de afirmar os verdadeiros valores da arte brasileira, esta arte brasileira que, bem ou mal, estamos todos contribuindo um pouco para que se faça sua história.

Não podemos confundir as ideias: temos que dar a informação correta ao público e temos que ser claros e honestos.

Não podemos permitir que se desencave do passado pintores secundários, que podem até ter sua importância histórica, para alcançar preços absurdos sem lógica nenhuma ou se lançar jovens como pintores e que poderiam ser úteis à sociedade em outras atividades e que não têm e nunca terão valor artístico; e, em verdade, não está é se dando as chances devidas aos jovens valores da arte brasileira que existem e trabalham, quase em surdina, neste Brasil grande. Agora mesmo a Galeria Arte Global, em São Paulo, está expondo alguns destes artistas de que falamos: baianos quase desconhecidos, que merecem ter uma chance.

Sem dúvida é um trabalho lento como foi o dos nomes já hoje reconhecidos e não basta somente expor, é preciso acreditar neles, falar deles e dar-lhes todo o apoio, inclusive o oficial. como já vem fazendo a Funarte, timidamente, por enquanto. Desejamos que surjam marchands jovens, com ideias novas e sangue novo que possam dar um gabarito melhor e alento a este mercado em demasia confuso para desmistificar as artes plásticas brasileira e este é um trabalho que hoje não pode mais ser executado sozinho, precisa da colaboraçáo dos melhores: artistas, críticos, marchands, museus, colecionadores e órgãos culturais do governo.

Somos otimistas: a falta de preparo cultural, a falta de seletividade no mercado fazem parte de uma crise de crescimento e o futuro será mais claro e sadio para as geraçóes a seguir e para a cultura brasileira. Quando será efetuada verdadeira história crítica das arte do Brasil, os verdadeiros valores do nosso povo permanecerão e os blefes e as mistificações desaparecerão por completo.

E agora, caro Luis Carta, vamos aos números. As vendas totais no Rio de Janeiro, pelas informaçóes coletadas, giraram, em 1977, em torno de Cr\$ 50 milhóes' e a Petit Galerie esteve em redor do Cr\$ I5 milhóes. As obras mais caras vendidas pela Petit Galerie durante este ano foram estas:

Relação de obras vendidas (algumas para demonstração de preço)

Di Cavalcanti Serenata, óleo, 89 x II5, Cr\$ 600 mil [aprox. Us\$ 42,I mil]

Di Cavalcanti Mulata, óleo, I970, 92 x 65 Cr\$ 518 mil [aprox. Us\$36,4 mil]

Portinari Composição, óleo, 25 x 19, Cr\$ 200 mil [aprox. Us\$ I4 mil]

Portinari Composição, óleo, 25 x I7, Cr\$ I90 mil [aprox. Us\$ 13,3 mil]

Volpi Bandeiras, têmpera, 70 x Ioo, Cr\$ IOo mil [aprox. Us\$ 7 mil]

Volpi Bandeiras, têmpera, 70 x IoO, Cr\$ I4O mil [aprox. Us\$ 9,8 mil]

Bonadei Casarios, óleo, 40 x 32, Cr\$ 70 mil [aprox. Us\$ 5 mil]

Eliseu Visconti óleo,

Cr\$ 85 mil [aprox. Us\$ 6 mil]

Escola Cuzquenha óleo, 205 x I70, Cr\$ I70 mil [aprox. Us\$ I2 mil]

Facchinetti óleo, I875, 93 x 53,5, Cr\$ I50 mil [aprox. Us\$ I0,5 mil]

Picasso Téte, óleo, 26,7 x 21,4, Cr\$437,5 mil [aprox. Us\$30,7 mil]

Artista mais vendido (liquidez imediata) [Enrico] Bianco Em I977, a cotação média do dólar foi Cr\$ I4,244. O mercado deve ter girado, portanto, algo em torno de Us\$3.5IO mil ao longo daquele ano. A seguir, os valores aproximados em dólar foram calculados a partir dessa cotação média. 
Casa Vogue \#36, Arte Vogue \#4, junho de 1978

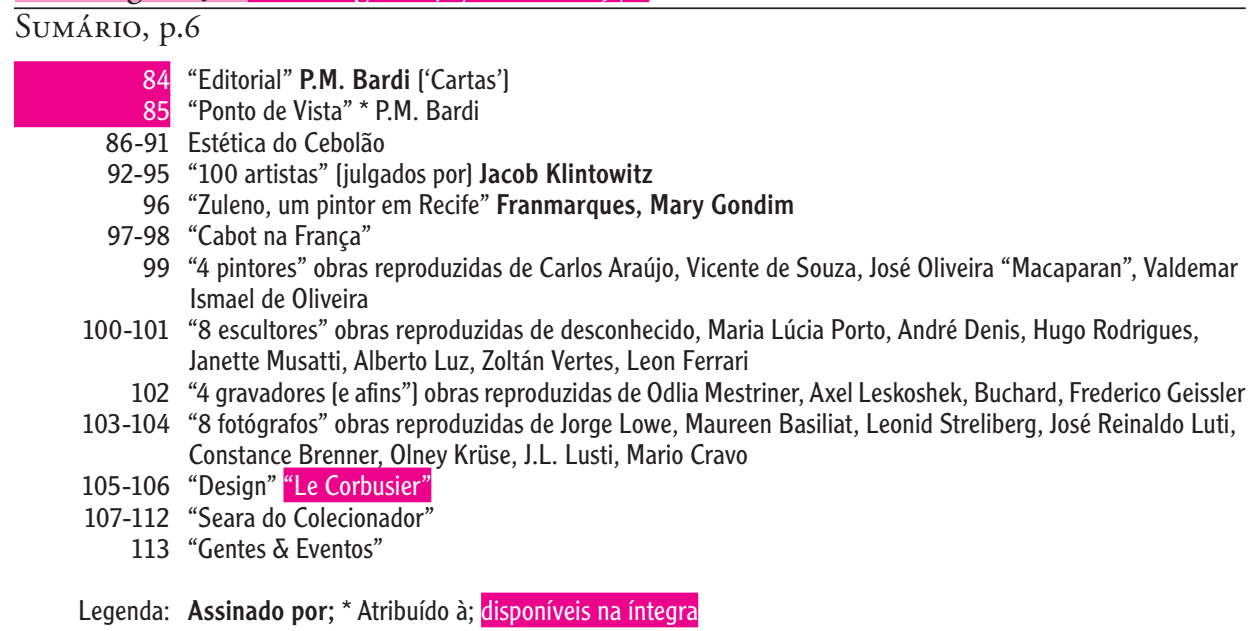

\section{EDITORIAL, p.84}

Trocar de cenário é próprio da arte teatral; ou era, pois hoje os diretores minimizam a montagem do espetáculo, do qual se tem em conta agora quase exclusivamente nas peças antigas. Trocar de cenário é próprio também da prática jornalística, pois quando se notam oportunidades e necessidades de mudança e lícito se libertar de diretrizes habituais ou inadequadas para apresentar outro espetáculo, em novo cenário. No jornalismo também constituem espetáculo as fusóes para unir forças e são fatos comuns, notadamente entre periódicos de caráter literário e artístico afins. Recentemente L'Ocil e Realite se fundiram num único mensário, mais vivo.

Arte Vogue, iniciativa que alguém apelidou de empresa quixotesca, depois da edição $\mathrm{n}^{\circ} 3$ teve de mudar de fundeiro e de bastidores, seguindo os mais recentes rumos da cenografia sempre mais endereçada ao sintético e ao simples, tornando-se parte integrante de Casa Vogue.

É justo que o leitor saiba dos motivos que aconselharam a transformação: pensávamos que uma revista não fútil, de um certo modo dedicada a informaçóes e trato de problema de ordem geral, não-situação, (a corrente favorita no campo da cultura nacional) e consequentemente, polêmica, predisposta a denunciar acontecimentos e resultados, a nosso ver, carentes de intervenção, ou pelo menos necessitados de debates; uma revista assim planejada, pensávamos, poderia ter um robusto agrupamento de leitores. Constatou-se que as previsôes eram por demais otimistas, para não dizermos erradas. Cuidadosas pesquisas revelaram que o público consumidor de periódicos que tratam de coisas das artes em geral e em particular apreciam mais o azul das coisas como são do que o vermelho das coisas como possivelmente deveriam ser. As pesquisas confirmaram que o pessoal prefere aceitar as coisas normalmente ao invés de contestar, felizes por poderem mergulhar nas águas poluídas do que apelidaram de Arte, ingrediente da Cultura tal qual como é, com seus anexos e conexos.

A tentativa, na primeira edição de Arte Vogue de discutir a urgência da constituição de um Ministério da Cultura, naturalmente não para aumentar um gigantesco número de cabide de emprego, mas para afinal resolver um dos problemas fundamentais do país, não teve a mínima repercussão.

Os próprios participantes da mesa redonda, promovida para uma troca de ideias, se limitaram, com prudência, a mandar o assunto para tempos melhores. Parece que o brasileiro culto tem mais vocação para passear pela arena das palavras eivadas de politicaria. É verdade que a política implica cultura, porém é suficiente observar o que a política conseguiu fazer do ensino, para nos erudlr a respeito de como deve ser encarada a renovação de uma nação em marcha acelerada para alcançar no próximo ano 2.000 o status de grande potência. 
Culturalmente falando parece que tudo está concentrado nas empolgantes alternativas da Bola, endeusada nos ritos espirituais dos campeonatos locais e internacionais, sem se falar da veneração reservada aos autódromos, justamente reclamados também pelas cidades menores. E quantas são as esportividades pelas quais se pretendem estádios não mais de IOO, mas de 220 mil torcedores?

No espraiar desta cultura seja sempre mais acantonada e marginalizada, monopólio do funcionalismo e do amadorismo. Aludimos a situaçóes que poucos conhecem tão bem e que a generalidade aceita inerte, até achando estranho que aqueles poucos se queixam, considerando-o um punhado de pessimistas.

Sem ter na sacola nenhuma pedra filosofal adaptável para horoscopar a soluçáo do problema cultura, no setor artes, apontamos a convicção de continuar, nos limites o alto propósito enunciado no editorial

\section{Cartas}

\section{Senhor Diretor,}

Terra de difícil amanho esta da arte, apelidado também e impropriamente de jardim. Às vezes semeamos com a antevisão de que vai dar bons frutos e para favorecer sua rápida germinação deita-se adubo na terra, escolhendo não um estrume qualquer, mas sofisticadérrimos produtos oferecidos pela tecnologia do setor. Porém, a terra tem um humus esquisito, rejeita, endurece; não satifaz. (Ao contrário do último tipo de cigarro fino, cuja propaganda na tv conclui com a frase "e precisa?) Vivemos épocas não bonançosas no campo, pois ele faz parte do latifúndio da cultura governada pelos baróes da política, as barreiras vigiadas e, se alguém quiser entrar, sua sacola é previamente revistada. Ao passo que o latifúndio tem dono, o campo das artes também não faz por menos, e justamente, são aqueles que controlam as eventuais penetraçóes, proibindo plantios não canônicos piorando quando se usa fertilizates vetados, isto é, os que poderiam sem dúvida transformar o campo não num jardim, mas talvez numa horta onde os abacaxis prosperariam, separados dos chuchus. As tentativas de ingresso por parte de postulantes numa convenção de igualdade de tratamento naquela lavoura publicado na edição n ${ }^{\circ}$, Arte Vogue, qual o de manter as paginas da revista aberta a discussôes. As portas abertas poderiam ficar fechadas, pois como já o dissemos, a preguiça, o contornismo, o não se declarar sempre aconselham a que se fique dentro da própria casca para náo se comprometer, e não ter implicaçóes e muito menos complicaçôes. E realmente triste receber a carta de um artista ilustrado no Arte Vogue, mais por caridade patriótica do que por méritos reconhecidos, carta para reclamar que o tamanho do clichê era demais modesto. A facilidade com que qualquer recruta ou caporal consegue alcançar publicidade, de coronel ou general, e outro assunto que deverá merecer certa atenção.

Voltando à mudança de cenário: esta junção de Arte Vogue com Casa Vogue será periódica, isto é, trimestral, nos meses de junho, setembro e dezembro de 1978. É mais uma tentativa para não abaixar uma bandeira. P. M. Bardi.

a pretensão de agriculturalidade num recanto, seja o menor possível, são pontualmente indeferidos pelos oficiais de gabinete dos proprietários sem escrituras registradas no Cartório da Inteligência, às vezes indeferidas por simples datilógrafos, quando não por pacatos porteiros que obedecem disciplinadamente às disposiçôes cupulares.

O campo é nosso, para dizer deles, os donos. Em vão foi quase ganha a representaçấo contra os ocupantes, posseiros que nem sabem o que e usucapião, prepotentes impunes práticos somente de como contornar situaçóes, manobradores profissionais, usuários do soltar boatos, fortes na expedição de alvarás para conferir direito de posse fictícia. Um sociólogo examinador do caso (disse que no campo da sociologia se dá o mesmo) afirmou, naturalmente em sede privada, pois não é conveniente a divulgação franca do que passa na cabeça, de que se trata de máfia. $\mathrm{E}$ acrescentou: "uma máfia sem um $\mathrm{Al}$ Capone," para dizer que se trata de grileiros sem espírito, sem trouvailles, sem elã; muito ao contrário, associação de pequenas criaturas adoutoradas em marketing e em cabidismo empregatício. O sociólogo em pauta não deve conhecer com precisão o 
que é máfia, mas informamos que a melhor definição é "igrejinha," para não espraiar-se além dos limites provincianos; ou, para acompanhar os tempos de opulência gozada e esperada: "Catedral," também em homenagem à última praça melhoradora da estética paulista, fruto esta do campo da terra acima lembradas terra árida. A incomensurável realidade: espelhar o enjoativo Gótico da Sé nas ondas artificiais das águas ajudada pelos monstrengos escultóricos que reabilitam a beleza dos anôes de concreto pintados, aqueles que os prefeitos do interior costumam usar para enfeitar os jardins da praça municipal ou o sagrado da matriz. Que o campo das artes pertença a posseiros e posseiras desta categoria parece ser por demais, na Cidade troca o apelido de Athenas do Brasil por
Cidade da Semana de Arte Moderna. Não sei se Arte Vogue vai publicar esta carta. Sei muito de suas alquimias para comunicar ideias e propor discussóes neste momento em que as acomodaçóes, os entrosamentos de interesses, os pactos, o empreguismo, as rever não incomodar e o acomodar determinam um modus vivendi com o qual é prudente não ter problemas; todavia, tendo lido recentemente que temos liberdade de imprensa, me arrisco em tentar ver esta carta publicada, declarando que não faço alusóes aos posseiros do campo em que Arte Vogue está exilada.

Atenciosamente e com os protestos da minha mais sincera admiração,

Fernando dos Silvas e Mattos

Ponto de Vista, p.85

atribuido a P.M. Bardi

Uma das falhas mais sérias na estrutura da fortaleza chamada Bienal, desde sua fundação, foi a certeza de seus fabricantes terem descoberto o meio de serem infalíveis. Copiada em letras de forma da Bíblia da Bienal de Veneza, dada à luz pelo sr. Fradeletto nos primeiros anos da década de i89o, o saudoso sr. Ciccillo Matarazzo, (passado à história como alguém que "consagrou 40 anos de sua vida em benefício da cultura de São Paulo, do Brasil e do mundo," como diz o Boletim do Conselho Federal de Cultura, n. 27, pág. 30) sem nada saber que o século foi testemunha de duas guerras e que a panela das artes cozinhava o minestrone a duzentos graus. E então? Generosamente obteve dos cofres públicos os mais conspícuos meios para armar a nascente cidade de Piratininga de mais um ponto turístico para. ser visitado conjuntamente com o Butantã e o Gótico Doméstico da Catedral. Através de conversas macias, nos coquetéis, com os cônsules (de carreira ou honorários) conseguiu apresentar a arte que 50, 60 ou mais países produziam no setor. Nobre iniciativa, sem dúvida alguma. Mas a dúvida, avançada pelo oposicionista, era esta: será que um público jejum de problemas de história e vivência das artes poderia compreender toda aquela pintura geralmente, por nossos bem pensantes, relegada na fórmula:

"também o meu menino sabe pintar assim?"
Colocar o carro antes dos bois funcionou à perfeição, pois o sr. Ciccillo sabia obter dos cofres públicos o máximo de verbas; e tantas foram a verbas que, desaparecido o chamado Mecenas, o continuou aflorando, apesar da Bienal resultar naquilo que se observou em suas últimas ediçóes.

Parece que agora, só agora, uma vez computado o fracasso da fórmula veneziam acomodada no binômio política-turismo, descoberta a fórmula de Kassel, acomodada no binômio sensação-turismo amadurecidos os tempos e as larvinhas da crítica se movendo; parece que a Bienal vai mudar de rumo, especialmente contando com o conspícuo legado (não em cruzeiros) moral deixado por seu fundador.

Que o objeto de arte represente principalmente um valor pecuniário todos sabem; para alguns pode representar também um valor espiritual, mas para a generalidade, art is money.

(O conservador de um museu poderia contar que a primeira pergunta do jornalista sempre se refere aos valores dinheirais.) Não é para se escandalizar, pois o rumo da vida é materialista e, num certo sentido, achamos surpreendente e mais justo que o minúsculo retrato Benci, de Leonardo da Vinci custar tanto quanto cinco ou seis mil automóveis: significa que o produto do gênio é considerado. 
Mas estes são casos do Ocidente propriamente dito, da Europa e da América do Norte, onde o mercado de arte é paralelo ao das bolsas de valores. Lá é ativa uma cultura que vem de longe, predisposta ao apreço a tudo que é novidade ou historia, sem discriminações de tempo e de territórios: qualquer objeto de arte encontra adquirentes, pois os que colecionam ou comerciam compóem legiốes capazes de manter em funcionamento cotidiano inumeráveis casas de venda em leilóes, galerias e antiquários em cada bairro de pequenas cidades (no Hotel Drouot num único dia se desenvolvem pelo menos cinco ou seis leilóes em diversas salas.

Obras de pintores, escultores, gravadores, de passado recente e da contemporaneidade, objetos antigos, curiosidades e quantas outras coisas suscitam interesse e determinam valores sem sofrer da volubilidade do gosto-não-gosto por parte daqueles que se metem nesta transas, característica notada em outros pontos do hemisfério, o nosso, por exemplo.

São normais as alternativas da moda. É um dos condicionantes da vida, propulsão da criatividade.

Assim são normais os revivais de adventos formais e ideais que o tempo eclipsou, voltando a ser reconsiderados e apreciados. Trata-se das oscilaçóes do gosto, das preferências por uma ou por outra manifestação, e devem ser inscritas no constante e movente sentido de propor, cancelar, repropor da atividade humana.

É justamente dos revivais que queremos falar. Depois da primeira Guerra o art-nouveau definido prontamente como algo de mau gosto, foi vilipendiado; apareceu o art-déco que também lá pelos anos 30 foi desconsiderado. Recentemente os dois estilos na Europa foram desempoeirados, reavaliados, passando a ser "últimos gritos." O Brasil, eco neste setor dos que se decidem além dos Odeanos, limpou os bric-à-brac e teve momentos de corrida em direção àqueles objetos. Porém, como sempre, corridas momentâneas, à espera de uma nova onda que veio quando, sempre no rastro do exótico, apareceu a moda do Oriente que já está acabando, à espera de um novo "último grito."

O fato é normal. O que não é normal é que os revivais (o mesmo acontece com os pintores brasileiros ditos clássicos, que passam com rapidez da glória dos altares ao refúgio das sacristias) náo determinam um interesse cultural, propósito de estudos, pesquisas. Sim, tivemos algumas iniciativas e algum ativo, mas geralmente é aquela mixuroquice que domina: o Brasil é ainda pobre de obras de arte com o agravante das barreiras alfandegárias, a concentração das preferências $99 \%$ pelas coisas nacionais, museus órfãos de ajuda, e assim por diante, de quejandos para chegar-se a um total não confortante.

\section{Estética do Ceboláo}

\section{P.M. Bardi}

Curioso: é difícil encucar no pessoal metido com problemas de estética que a arquitetura é a arte das formas tomadas num sentido mais geral, e não somente o resultado de edifícios de habitação ou mesmo de convívio. Assim nossa nota dedicada a Itaipu (edição $\mathrm{n}^{\circ} 3$ desta revista) surpreendeu até os engenheiros que em sua maioria não se conformam em ser curriculados com os arquitetos. É que a confusão gerada pela diversificação, quase antinomia, das duas atividades continua, e tudo indica que sem alguma solução à vista. A impossibilidade de considerar o que se denomina "obra de engenharia", como arquitetura permanece. É um tanto estranho se considerarmos a evolução e a radical mudança da definição arte própria dos tempos de hoje. O progressivo e veloz desligamento dos conceitos oitocentescos do Belo e Companhia, repartição das artes em nobres e aplicadas, primárias e secundárias, a atual permanente presença do design, as denúncias da desordem do urbanismo com a cumplicidade de tanta pseudo-arquitetura nada disso atinge a arte do construir, reserva ainda em colossal preponderância nas mãos de empresas e de profissionais, pensando mais e quase exclusivamente em faturamentos do que em responsabilidades sociais.

O caso é antigo. Pode parecer ingênuo quebrar lanças nas paletas de aço de 
um moinho de vento que, forte, desafia qualquer furacão. Nossa ingenuidade, teimosia ou não, aponta nesta edição de Arte Vogue uma outra grande obra de arquitetura, o Ceboláo, um complexo sistema viário que foi construído nas margens do rio Tietê, em São Paulo.

$\mathrm{Na}$ lembrada reportagem dedicada a Itaipu, tivemos ocasiāo de considerar o ciclópico empreendimento to sob o ponto de vista da estética. Curiosamente obtivemos manifestaçóes de perplexidade por parte de engenheiros, o que mais uma vez nos deixa convencidos de quanto vai custar chegar a definir-se e afirmar-se um conceito coerente em relação àquela ciência filosófica que, grosso modo, ainda está amarrada à "doutrina do conhecimento sensível", de Baugartener, uma doutrina aplicada às artes como produto de beleza, circunscrito especialmente à arquitetura, escultura e pintura, sendo a arquitetura atribuída às construçóes monumentais e as moradias principescas, excluindo as obras assim classificadas de engenharia. Parece que as tentativas de separar uma "ciência da arte" da "doutrina do belo," na intenção de instituir uma "ciência geral da arte," ainda não obteve apreciáveis resultados. Esta ciência deveria ter por objeto a arte em seus aspectos técnicos, psicológicos, morais e sociais, deixando à estética, no sentido tradicional, o julgamento do belo, evidenciando o superamento e a insuficiência para se interessar pelos fenômenos ditos artísticos, desde os grafitos pré-históricos até o empacotar montanhas de Christo, fatos que fogem à categoria do belo. Frente ao projeto de uma barragem e por incidência ao canteiro, à paisagem em vias de transformação, ao maquinário empregado, à gente que labora e a quantos outros acontecimentos, a noção do belo cai por terra, pois a consideraçáo estética se alimenta de novidades que determinam uma poética mais coerente com o modo de pensar contemporâneo. A arte não reproduz o existente, mas propóe sempre alguma novidade, afirmando uma nova situação espiritual e material. Tem sido árduo superar a definição do belo em relação, por exemplo, a obras de pintura que representam coisas ou pessoas náo propriamente aceitas como gratas. (Alguém lembra que um membro de uma banca examinadora, na USP, para julgar um doutorando, disse ser os retratos dos bufóes de corte pintados por Velazquez não obras a serem inscritas na categoria canônica do Belo.)

Como se vê, estética é definição em período de conjuntura. Pensa-se que a palavra pode continuar a servir para uso corrente, reconhecimento das formas e das ideias como consequência de sensibilidade, utilidade, ordem, engenhosidade e tudo quanto concorre no ato de criar. Todos estes termos podem servir perfeitamente para definir o assim chamado Cebolão.

Antigamente eram as catedrais que concentravam o labor dos construtores. Naquelas obras eram reunidos arquitetos, pedreiros, canteiros, serventes, escultores, gente do povo que supervisionava o progredir do monumento, vendo o assentamento de pedra sobre pedra, contribuindo ainda, com óbulos, como ajudando, imaginando e sonhando com o dia da consagração e entregue ao culto. Os materiais eram trazidos das jazidas e dos bosques, às vezes situados em locais bem distantes, ao longo de estradas de terra batida, carros de boi gemendo ao peso das coisas transportadas, cada esforço feito por braços vigorosos os andaimes de madeira amarrados com cordas, os desenhos feitos e refeitos para acompanhar o serviço e corrigir os planos gerados por empecilhos surgidos um após outro: todo o viver, durante decênios, às vezes por séculos, de uma obra grandiosa pela mole e, particularmente, pela espiritualidade.

Vendo aqui no Cebolão a leve armação de aço que sustenta formas para receber concreto, por analogia, me faz pensar na linha sutil das coluninhas que correm ao longo das paredes e convergem para o centro dos tetos das igrejas do Gótico, ponto alto de estética, resultante por intuição: tudo certo, maravilhosos, como todas as grandes catedrais do passado, como a Cúpula de Brunelleschi da qual hoje tanto se discute ao ensejo do centenário. Não é fora de propósito imaginar que Messer Felipe gostaria de estar aqui embaixo das pontes do Cebolão para contemplar conosco sua linha qual flecha parada no ar, gostando também de uma novidade para ele: as curvas que levam em si o movimento, articuladas como 
numa fuga musical, um desdobrar de linhas sem fim que altera a solidez do concreto na mobilidade de uma onda.

O mestre dos mestres gostaria da soluçáo que os engenheiros deram à ponte $\mathrm{da}$ Fepasa, que aqui representa a romântica presença da estrada de ferro, lembrança das locomotivas que abriram as comunicações do imenso e inexplorado Brasil. O Cebolão, conjunto de dezoito quilômetros de pistas, viadutos e pontes que permitem a passagem de trezentos mil veículos por dia, tem uma via reservada à Fepasa.

Vive-se hoje tempos de centrais elétricas, de gasolina, enquanto o invento nuclear vai ajeitando suas vitórias de paz, após os fatos desastrosos da guerra.

A estrada une as gentes. Aposentada a mula, (dignificante o gesto da antiga diretoria da Antarctica que cuida amorosamente dos últimos e velhos animais que puxaram pelas ruas de São Paulo seus carros de entrega) chegando à era do motor, o Brasil enfrentou o problema viário, mais tarde, muito tardiamente, o básico dos metrôs. Foi um empenho, um desafio, dando origem à extraordinária atividade das empresas nacionais e especializadas que operam hoje também em outros continentes.

Nos anos 30, quando a Itália construía as primeiras auto-estradas, o redator destas notas lembra ter percorrido a antiga São Paulo-Santos ainda tresandando a ranços da aventura colonial; hoje a Imigrantes é uma das vias mais comentadas sob o ponto de vista da engenharia, a par de outras numerosas que, desde o Amazonas até o Rio Grande do Sul, interligam nosso território com uma vasta rede viária com bons rendimentos e, todavia, necessitante de conspícuo aumento e ao mesmo tempo carente de obras complementares, como é esta do Cebolão.

A rede, ainda objeto de remanejamentos e novas aberturas, deve ter em conta o máximo dos patrimônios, a ecologia e, inerentemente, a estética, dois fatos integrados, confluência de responsabilidade que não se deve subestimar. Bom seria termos um plano rodoviário mais relacionado com aquelas imprescindíveis exigências. Se vemos no Brasil estradas e projetos bem estudados sob o ponto de vista técnico (por exemplo, o trecho entre Ubatuba e Paraty, para citar apenas um caso, onde a Secretaria dos Transportes colocou, mal, uma estátua de bronze no baixio de uma cachoeirinha: ainda uma estética superada) se vêem também traçados onde o fator custo quanto mais não seja a validez do atendimento a pressóes especulativas, sacrificou bastante a estética, sem falar de certos castigos ao paisagismo, evidente falta de entrosamento entre as autoridades do Departamento de Rodagem e prefeituras. (Como foi possível permitir de construir, sempre na Santos-Rio numa colina, um conjunto de prédios de apartamentos, só os partícipes de marmeladas devem saber.)

O Cebolão se apresenta como uma persuasiva solução de problemas, tendo em conta o que nos interessa particularmente, a estética. A tendência da urbanística e da arquitetura metropolitanas é, hoje, pelo exemplo norte- americano, voltada para o gigantismo, provocando o achatamento do horizonte visível, isto é, a privação do cidadão de ter um espaço conveniente para desfrutar da paisagem urbana. Convence esta harmônica fusão de estruturas onduladas, pois esta rede suspensa permite espaciar na paisagem, para quem as percorre e para quem as observa, alguma coisa de bem diferente em relação, por exemplo, ao Minhocão paulista, espremido entre paredes e muros, exemplo gritante de pequenez de quem o projetou e que deu sobejas mostras de nada saber de urbanismo.

Finalmente a urbanística, neste caso a ecologia urbanística recebe pela primeira vez uma atenção inédita: intuição de formas e intuição das possibilidades de integração das mesmas no sítio onde foi implantada, fruto de imperceptíveis atos de invenção, experimentações, provavelmente discussóes para achar o mais acertado resultado a obra é de grupo de engenheiros cujos nomes envoltos no anonimato, passando por ser obra do Departamento de Estradas de Rodagem de São Paulo. Num tempo mergulhado no ecletismo em todos os campos, em que a arquitetura sofre a crise da destruição das regras e da ordem tradicionais para afundar-se nos diversos, numerosos e contraditórios maneirismos, é 
lógico dar-se crédito à compostura racionalista de um projeto de engenheiros, os quais, talvez nem o saibam, operam para a afirmação de uma cultura arquitetônica que venha em defesa da própria arquitetura.

Penso que os engenheiros deveriam operar mais no próprio setor da arquitetura, pois representam papel decisivo no programar dos sistemas racionais regulando, a um tempo, a função e a estética, também para intervir nas tentativas de comprometer a arquitetura com articulaçóes formalísticas e com o cenográfico escultórico.

Doutro lado a responsabilidade estática de uma construção é atribuída aos engenheiros. E também este é outro fato, que me lembra um caso significativo: quando começou a projetar-se em concreto armado, não poucas foram as dúvidas no tocante à esteticidade, particularmente quando
Le Corbusier filosofa, em termos de arquitetura, com um senso universalístico, propondo o "racionalismo" como fato utilitário para o homem de qualquer quadrante da terra, reduzindo a um mínimo denominador comum as necessidades do viver. Quando ele lançou a fórmula da "machine-à-habiter" e depois o "modulor," numerosas foram as críticas recebidas, muitas das quais apontando especialmente a diversidade dos costumes e dos usos de cada povo, porém sem jamais se perturbar. Alguém presente no Congresso de Atenas lembrou que nos debates definiu o princípio deste seu universalizar o consumidor das habitaçôes, evocando outra fórmula naqueles tempos corrente entre os arquitetos qual o de ser este profissional um "mestre de vida," isto é, não somente o projetista de paredes, tetos, assoalhos, janelas e portas, mas a combinação destes elementos num plano moral e pedagógico assim e assim.

Le Corbusier viajava constantemente e, como todos sabem, esteve também no Brasil. Dele é o risco sobre o qual foi projetada a sede do Ministério da Educação e Saúde no Rio de Janeiro. Daquela visita à antiga capital do país restou a série dos grandes desenhos, executados durante suas conferências, após trinta anos numa coleção particular, e uma se tratou de pontes de uma única arcada. Em igII a ponte sobre o Tibre, patente Hennebique, provocou tal perplexidade, que seu responsável, o engenheiro Mosca, decidiu entrar num barco acompanhado de sua família e passar várias vezes sob a ponte para demonstrar sua absoluta confiança no feito, ao passo que se verificava a resistência sob o peso de areia que os bombeiros iam molhando. Inaugurado o Cebolão deverá agora prover e manter e, em alguns casos ajeitar ecologicamente seu espaço, eliminando a invasão de presenças marginais, vigiando severamente, pois o crescer de São Paulo é prepotente e se caracteriza pelo fenômeno da improvisação e do remendo das falhas, sem controlar uma orgânica disposição das construçôes e do espaço. As necessidades cívicas, nas mais das vezes sofrem das intervençóes especulativas dos grupos encarapitados no poder.

série de cartas nas quais existem referências à urbanística do Rio de Janeiro.

Recentemente tivemos mais uma visita lecorbusiana: a fabricação no Brasil dos seus famosos móveis graças à cessão de suas patentes a um dos pioneiros da renovação do móvel no Brasil: Leo Seincman. Leo sempre foi o animador do estar em dia em termos de mobiliário. Em 5I fundou a "Ambiente," para fornecer móveis contemporâneos à nova arquitetura brasileira, dando início ao design nacional, lançando os móveis de Giancarlo Palanti e de Lina Bo Bardi. Em 1959 lançou o "Prêmio Ambiente" para projeto de móveis, um dos marcos da história de nosso desenho industrial. Fundada a "Probjeto", lança a "cadeira dinamarquesa;" liga-se à firma italiana Cassina, mundialmente reconhecida como a mais viva produtora de mobiliário contemporâneo, proporcionando ao Brasil o ingresso do móvel brasileiro em um novo estágio.

Como a Cassina inteligentemente se dedica em produzir o design dos mestres do século, como Mackintosh, Rietvel, do Bauhaus e de Le Corbusier, eis então o encontro através de simples objeto com o mestre ao qual todos os arquitetos devem algum ensinamento ou uma inspiração: a arquitetura que vale no mundo inteiro 
é um aporto de Le Corbusier desde o "brutalismo" do concreto ao "formalismo" da escola brasileira que dele deriva.

O conceito de Le Corbusier em relação móvel de suporte era "objeto-membros humanas” visando ao racional (proporção, elasticidade etc.) para conter comodamente um corpo objeto, resultando quase uma forma em negativo. $\mathrm{O}$ mestre, ponto de partida as inovaçóes de Thonet e de outros designers do Oitocentos aceitos na linha do seu maquinismo, tendo em conta a funcionalidade, conseguiu produzir assentos clássicos, tão clássicos que hoje vêm sendo usados com satisfação.

Mais uma vez Le Corbusier está entre nós; e dele nós nos recordamos como um amigo do Brasil.

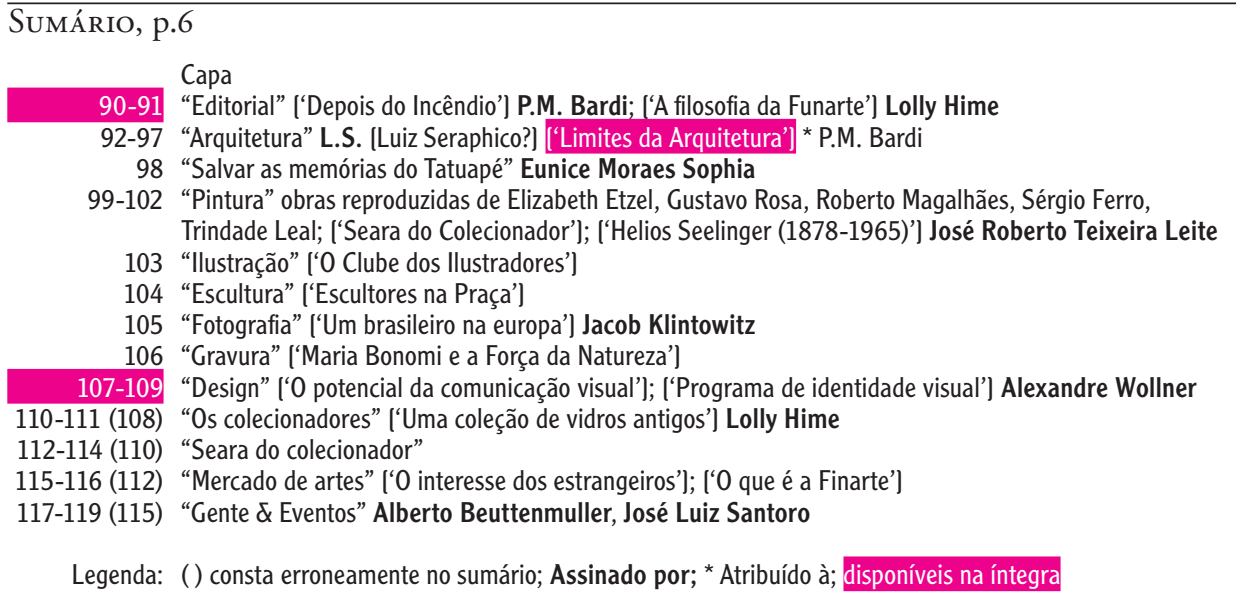




\section{EDITORIal: Depois do incêndio, p.9o} P.M. Bardi

O americano é notoriamente de muita inventiva quando se trata de promover fatos e ideias, chegando mesmo a recorrer à teatralidade para chamar atenção. Esta configuração é mais pertinente ao americano do Norte. No Sul o sistema não proliferou, porém temos as nossas manifestaçóes de praça as quais não passam de pálidas representaçóes quando comparadas, por exemplo, com um desfile na Fifth Avenue tomada pelos irlandeses.

Por isso não deixou de surpreender a concentraçáo com visos de apoio levada a efeito, dias após ao famoso incêndio, quando um alegre e tamborilante desfile de uma escola de samba se concentrou na avenida Beira Mar, não faltando os indefectíveis cartazes e discursos do veterano Mário Pedrosa e da senhora Lustosa; um extemporâneo grito de carnaval, uma festa para chamar a atenção para as chamas destruidoras de mil obras de arte mas também para clamar aos céus para que, qual nova fênix, o museu ressurja em todo o seu esplendor das cinzas e restolhos. A parada foi organizada por artistas que exibiam cartazes reproduzindo pinturas de Torres-Garcia., homenagem à maior das vítimas do desastre. A iniciativas burocráticas de apoio e de socorro serviram, na verdade, para alertar a opiniáo pública sobre os constantes problemas que envolvem a vida dos museus, que representam apreciável parcela da cultura brasileira?

Seria imprudente dar-se uma resposta agora. Pela experiência que os práticos têm do ramo, não é lisonjeira nem otimista a previsão. Todos sabem que os poucos museus nacionais de uma certa vivência foram instituídos por particulares, obtendo alguns apoios dos poderes públicos através da alta e da baixa das marés políticas, valendo os do ut des transados com personagens mais ou menos interessados em cultura, porém com as mãos no timão do poder.

A cultura brasileira, no setor arte como no setor ciência, poderia merecer melhor atenção, sem que com isto se pretenda uma equiparação à cultura pebolística ou às outras culturas de vírus torcidísticos, cujas criaçôes também custam ao Erário público vultosas quantias.

O caso do incêndio do MAM, dizem seus dirigentes, deveu- se mais à falta de apoio verbaresco à instituição que, quase semanalmente, proclama a precariedade das suas finanças, os celebrados sete ou oito milhóes de cruzeiros de déficif, obrigando sua diretoria a uma vexatória ginástica para conseguir dinheiro, chegando a ponto de alugar suas dependências até para exposição de vinho.

O homem da rua se pergunta: Por que toda aquela grã-finada que vai almoçar no mais caro e luxuoso restaurante carioca, o do MAM, não custeia a instituição? Este é o ponto onde queremos chegar. O desinteresse pela cultura do pessoal que a cada instante abre um banco ou se queixa de que a portaria número tal não lhe permite ganhar mais do que julgam merecedores, numa palavra, o desinteresse dos mesmos é inerente e característico de nosso subdensenvolvimento.

Depois da guerra o se meter nas aventuras da arte por parte de gente de negócios, visando cinicamente à promoção pessoal, tornou-se tiririca: o pessoal penetra nas instituiçóes culturais onde se encarapitam em cargos de diretoria sem jamais assinarem um cheque em favor da entidade. Fundam museus (naturalmente modernos) e quantas outras novidades, transferindo o custeio e realizaçóes à conta dos cofres públicos, pouco se importando se o público frequenta, pois bastam-lhe os bares e os restaurantes de luxo. O público visitante, este tem que morrer com generosa taxa de ingresso para ver, nas mais das vezes, uma mostra sem importância.

Será que o incêndio do MAM vai chamar a atençáo dos que podem, propondo enfim uma reformulação dos direitos e deveres inerentes ao fato cultura?

Como sói acontecer quando a arte produz escândalo, a imprensa abriu largas manchetes e copioso espaço para registrar o incêndio que devastou o MAM carioca. Da pletora de comentários, Arte Vogue escolheu 
o mais sintético e o mais correto, aquele registrado por Istoé: "Misturar espetáculos com obras de arte pode ser uma boa ideia cultural, mas pode ser também a porta aberta para uma tragédia. Pelo menos foi o que aconteceu no Museu de Arte Moderna do Rio de Janeiro: a sala 'Corpo e Som' (de espetáculos) foi colocada no mesmo bloco da sala de exposição de pinturas. Uma ponta de cigarro, na primeira saia, causou o incêndio, que se espalhou para o setor de exposiçóes, causando a devastação conhecida. É a conclusão de laudo do Instituto Carlo Éboli. o erro foi admitido pelos diretores do MAM, como Ivo Pitanguy: 'O erro foi flagrante, e o sistema de segurança náo era o ideal.'”

Outro comentário do qual gostamos foi o do Jornal da Tarde, de Sáo Paulo, de Telmo Martino sob o titulo "Proveito próprio:" "O Museu de Arte Moderna do Rio de Janeiro só pode estar atônito com tão grande e tão repentino interesse por sua existência. A indiferença das pessoas até mesmo pelas maravilhas de obra-prima da sua arquitetura já tinha habituado o MAM a viver num esplêndido isolamento. De repente, transformado em vítima por um incêndio, o MAM vem sendo usado como pretexto para manifestos e comícios, onde as palavras são tão exaltadas que as intenções deixam, às vezes, de ser veladas. Há muitas sugestôes para uma reformulação do museu e muitos nomes apressadamente associados às medidas para socorrê-lo em seu infortúnio. Daqui a pouco, já sem surpresa, deverão surgir indicaçôes de pessoas cogitadas para a formação de uma nova diretoria. Tanto para sua reconstrução como para seu funcionamento, o MAM precisa muito mais de novas verbas do que novas comissóes e novos diretores. Há mesmo quem diga que o MAM renascido deveria ser um museu crítico. É bem possível que o MAм incendiado já o fosse. Talvez tenha usado todo esse fogo como uma crítica ao desinteresse geral. Um desinteresse tão geral que a perda de seu acervo não mereceu as dimensóes de uma tragédia lamentável. O acervo destruído do мам era táo pobre que até o seu Picasso tinha apenas a raridade de ser muito feio."

Agora que o festival armado após a tragédia do MAM carioca se apagou, chegados os tempos da quaresma, parece-nos que o caso de expressar não uma opiniáo sobre as causas do desastre (cada um ou cada uma deu a sua, palpiteresca ou interesseiresca) mas uma opinião sobre a situação física dos museus nacionais, (federais, governamentais, estaduais, municipais e particulares) isto é, sobre um adendo da cultura nacional do qual várias vezes nestas páginas tivemos ocasiáo de abordar e lamentar a progressiva decadência.

O Brasil tem poucos museus, isto é, instituiçóes incumbidas de conservar materiais da história, possivelmente reunindo- os com iniciativas úteis à difusão de uma cultura. É um setor do qual a Federação pouco se preocupa, deixando o que se herdou do Oitocentos praticamente como estava como, por exemplo, o Museu Nacional de Belas Artes, o equivalente à National Gallery de Washington, ou a outras instituiçôes que deveriam representar o cartão de visita de uma nação.

\section{A filosofia da Funarte \\ Texto de Lolly Hime, com a colaboração de Iara Vaz}

A proposta para a criação da Fundação Nacional de Arte, Funarte, há alguns anos, decorreu mais de uma constatação feita pelo Ministério de Educação e Cultura de que os instrumentos da ação cultural vigentes no país eram bastante precários, notadamente sob o ponto de vista prático. Assim, para a Funarte o incentivo à pesquisa se configurava como um dos caminhos de apoio, ainda que indireto, à produção artística em quatro grandes áreas: teatro, música, artes plásticas e folclore como arte popular.
Apenas como atividades complementares daquelas quatro áreas, ação nos setores de artesanato, cinema, dança, ficando de fora o cinema, já que a Embrafilme coordena de maneira satisfatória.

Numa palavra, a Funarte surgiu para dar cumprimento à política nacional de cultura. Passados alguns de sua criação, lembramo-nos em ouvir seu diretor, dr. Roberto Parreiras, a fim de que dissesse a Arte Vogue algumas observaçóes sobre as realizaçóes da Funarte. 
Arte Vogue Quais as regióes onde existe maior interesse artístico fora do eixo Rio-São Paulo?

Roberto Parreiras Quando começamos nosso trabalho, antes mesmo da Funarte, a regiáo Sul tinha marcante presença em termos de cultura de consumo. Sinto, hoje, que se desenvolve um grande esforço também nos Estados do Nordeste através suas universidades.

AV Qual a quantidade de visitantes às exposiçóes organizadas pela Funarte? RP Propusemos transformar nossa sede numa casa de cultura adaptada à vivência brasileira. Não pensamos em imitar as experiências estrangeiras, mas apenas utilizá-las como um ponto de referência. Hoje a Funarte tem uma frequência bem superior a I.5OO pessoas por dia, destacando-se estudantes e o público frequentador de teatro que utilizam as diversas galerias e o museu.

AV Como a Funarte vê as exposiçóes em praça pública?

RP Com muita atenção a ponto de patrocinar várias dessas exposiçôes. Achamos que a arte não deve confinar-se a nenhum espaço físico. Tem que ser integralmente aberta.

AV A Funarte pensa abrir escolas de arte para crianças?

\section{atribuido a P.M. Bardi}

Com este caderno de Arte Vogue promovemos mais uma incursão palmilhando o gramado onde, saindo da rotina centrifugadora dos setores próprios da "arte pela arte," procuramos espargir sementes de alguma planta de espécie diferente daquelas já conhecidas, para com estas se entrosarem e, enfim, conviverem em perfeita harmonia. Uma das iniciativas já enunciadas nas ediçôes precedentes foi a de propor que as grandes obras públicas (Itaipu e o Ceboláo) se constituíssem mais como resultados de arquitetura.

Tais enunciados motivaram náo poucas interpelaçóes, alguns com ranços de protestos; estes, em nome da arte (“...se trata de obras, por quanto importantes e excelentes, sejam de engenharia, onde o computador tudo resolve: forma, materiais,
RP Não. A Funarte pensa em termos de educação artística, mas julga não ser sua atribuição criar escolas de arte para crianças.

AV A Funarte concede bolsas de arte para artistas jovens?

RP Não. Mas cria condiçóes para esse artista expor suas obras, não lhe cobrando despesas de galeria. Auxilia, ainda, de várias maneiras, notadamente junto ao Itamaraty, com relação às bolsas no estrangeiro .

AV Como se deu a restauração do prédio onde está a Funarte?

RP Foi-nos possível em pouco tempo colocar o prédio a serviço do público. $\mathrm{Na}$ verdade as condiçóes eram as mais precárias após a Escola de Belas Artes o deixar. Dotamos o prédio de condiçôes mínimas de segurança, (fiação elétrica e telhado) obedecendo rigorosamente à orientação do IPHAN e, posteriormente, adaptamos o prédio para cumprir sua função cultural.

AV Em sua opinião qual a atividade artística que desperta maior interesse no público brasileiro?

RP Pela experiência de hoje com o projeto Pixinguinha não há dúvida de que é a música. tempo etc;") outro, alegando o fato de que o leitor gosta mais de considerar arquitetura a "casa propriamente dita em que a fachada indica ser ela fruto do talento de um artista, e não o resultado de um cálculo.”

Sei por experiência que é sempre difícil, se não mesmo impossível, contentar a totalidade dos leitores, certamente de gostos e preferências as mais díspares. Sei também que cada um, o que é incontestável, tem o direito de manter as ideias que digeriu ou não assimilou. Se não divulgamos em toda sua extensão as missivas protestatórias é porque elas são carentes de informaçóes; elas poderiam ser escritas como nos tempos em que Paris se escandalizava com a novidade da Galerie des Machines, com todo aquele ferro de sua cobertura. 
Muita água já rolou por baixo da Ponte da Estética, sendo que esta construçáo de século em século deve ser consertada e ajustada em face das exigências do trânsito; e no século que vai findando com vistas ao novo milênio, parece ser carente de uma solução satisfatória em termos de conserto.

De fato as coisas mudaram no gramado. Em vão os herbicístas teimam em semear para que a germinação desponte com rapidez. Não é fácil acompanhar a "marcha dos tempos," que vai deixando para trás o pessoal, notadamente aqueles que se envolvem no manto da critica. Como é lógico também nos incluamos na turma, já que estamos convencidos de que a certeza do que é arte, hoje, na verdade é negócio incerto.

O que não nos impede de voltar ao assunto, pois afinal a arquitetura considera as obras ditas edificadas em termos de engenharia, no seu lato valor estético. A história da arte, em geral, julga o próprio Coliseu como obra de engenharia, e o Partenon como obra de arquitetura, quando na verdade os dois monumentos têm as mesmas características técnicas e estéticas.

Tudo isto é anotado, pois Arte Vogue, na presente edição, volta a um assunto de engenharia-arquitetura, ou melhor, de arquitetura, enfocando um engenho de açúcar que vai ser (providencialmente) salvo da destruição.
Mercado de Artes, p.II5-II7

$O$ interesse dos estrangeiros, p.IIS

Senhor Vogue publicou em sua edição $\mathrm{n}^{\circ} 4$ de julho passado ampla matéria dedicada ao mercado de arte no Brasil, oferecendo uma sintetizada história que começa quando aqui desembarcaram os primeiros vendedores de quadros e de esculturas, logo após a Primeira Guerra.

A reportagem enfocando a tímida abertura das primeiras galerias paulistas e cariocas, anotando o boom dos chamados clássicos nacionais que terminaram com a quebra da Collectio, do surpreendente José Paulo Domingues, no século o italiano Paolo Businco, conclui com um apelo para uma melhor reformulação dos critérios do colecionismo, visando a atender a realidade da cultura no Brasil: considerar o labor dos artistas que vem surgindo.

O mercado de arte entre nós vai, sem dúvida, ganhando terreno, especialmente depois da abertura de considerável número de galerias e da organização dos leilóes.

Leilóes: é justamente este setor que nos parece ainda carente de melhor atenção, mas que todavia dá sinais de consideraçóes vindas de fora, provocando comentários. Nos ambientes do setor, tivemos a recente visita do presidente da Sotheby's Park Bemet (é a segunda que vem ao Brasil um representante da famosa empresa que monopoliza, com a Christie's, as vendas internacionais.
Por ocasião da primeira visita Arte Vogue registrou o fato.) Após a prospecção, tem-se a impressão de que as conclusóes do pessoal da Sotheby foram a de considerar um possível trabalho no Brasil ainda um tanto negativo, não por falta de meio nem pela ausência de um real interesse para com a obra de arte, quando comparado, por exemplo, a Austrália, onde as casas londrina e novaiorquina mantêm de há muito filiais.

Arte Vogue manteve, recentemente, entrevista com o dr. Casimiro Forro, diretor da "Finarte," de Miláo. Perguntamos ao dr. Porro: - O Senhor após vinte anos e atividades, pode nos transmitir um conceito deste ramo tão complicado que é o de comerciar obras de arte.

Respondeu-nos: - É um ramo com características bem difíceis de serem compreendidas. Muitas são as motivaçôes e nem todas fazem parte de transaçóes puramente econômicas.

De fato, se a moda, o gosto, o costume, a cultura e a psicologia são fatores que têm um preciso elenco nas atividades humanas, tais fatores se tomam determinantes no campo do mercado da arte.

Outra pergunta: - Por que as pessoas colecionam obras de arte?

Resposta: - É somente um desejo de posse ou então um propósito de afirmação do próprio ego, de distinguir-se, 
de qualificar-se em qualquer campo? As respostas podem ser as mais variadas, ao passo que a importância do colecionismo nunca estará situada em sua real magnitude. Quem quer que esteja interessado na história da arte está em condiçóes de constatar que somente o grande colecionador pode se permitir formar coleçóes, tanto quanto os museus, como é também na conservação da arte como instrumento de pública utilização e fato de cultura.

Dr. Porro: o que pensa o senhor dos tempos atuais em que o mercado de arte suscita tanto interesse em termos de investimentos e especulaçôes?

É um dado mais que evidente no mercado moderno, e isto náo somente na Itália, do excessivo senso de especulação ocorrido nestes últimos anos, especulação que provocou notáveis desproporçôes de valores, marcadamente em relaçáo às cotaçóes das obras de arte antiga, particularmente as do Oitocentos; todavia, à parte a crise generalizada da arte moderna, o mercado ainda é muito vivaz. Na Itália, o mercado está orientado especialmente para as obras dos mais famosos mestres do Novecentos, bem assim da arte figurativa em geral.

- Na Itália, como em outros países, nestes últimos dez anos se nota uma crise econômica. Quais suas consequências?

- O renovado gosto pelo colecionismo, os exames da situação e a justa reflexão necessária ante cada aquisição, às cotaçôes mais acertadas são os pontos mais que evidentes de que a notória crise do setor propiciou ao mercado italiano. Como base na experiência por mim adquirido ao longo de vinte anos, sou de opinião e com a maior crença possível de que apesar das crises econômicas, o interesse para com o colecionismo e pelo investimento em obras de arte no sentido lato da palavra, poderá subir e redimensionar, mas não mais ou menos. Sem dúvida vai se ampliar sempre e mais a atração pelas coleçóes de obra de arte.

- Dr. Porro: o senhor vem ao Brasil evidentemente porque pensa que nós estamos tendo muito futuro neste setor do colecionismo.

— Quando falo de ampliaçáo dos mercados logicamente que penso neste pais onde atualmente se processa promissora ascensão social e notável estimulo cultural.

É fatal que a curto prazo isto provoque uma maior propensão pela aquisição e conservação de inumeráveis bens que constitui a parte mais importante da nossa vida cultural.

Um seguimento à nota publicada na edição $\mathrm{n}^{\mathrm{o}} 3$ de Arte Vogue, que apontava o constante aparecimento de obras falsificadas de Alfredo Volpi, um grupo de colecionadores, em perfeita sintonia com o artista, tomou a iniciativa de publicar o catálogo geral das obras do pintor. O comitê dos iniciadores, formado por João Marino e Marco Antonio F. Mastrobuono, se dirigiu ao Museu de Arte de São Paulo Assis Chateaubriand para realizar o catálogo. Cada pintura do mestre será examinada, fichada fotografada em doas copias, uma das quais assinada pelo autor e que será entregue ao proprietário como documento de autenticidade.

O trabalho de catalogação já começou. Os interessados podem se dirigir ao Masp. à avenida Paulista, I578, a fim de obter fichas para serem preenchidas,

Espera-se que outros grupos e entidades se dediquem à catalogação de obras de outros artistas brasileiros, para porem um paradeiro a difusáo de falsificaçôes que nestes últimos anos tornou-se um problema preocupante.
O que é a Finarte, p.II6

Idealizada e acionada por Gian Marco Manusardi, economista e apaixonado pelas coisas da arte, em 1959 constituía, em Miláo, o Instituto Finanziario per l'Arte-Finarte S.p.A.

O estatuto da sociedade se propunha operar exclusivamente no setor de obras de arte, e determinando expressamente o financiamento das operaçôes de caráter econômico, o comércio por conta de terceiros e finalmente as vendas por meio de leilóes.

A realização de tão ambicioso programa, nos anos 50, na Itália, parecia uma empresa verdadeiramente difícil de ser realizada, pois era fato inédito e porque 
inexistiam bases tanto em termos públicos quanto privado, capaz, assim, de criar um mercado de arte em termos técnicos, modernos e culturalmente aberto.

As pesquisas e estudos da Finarte muitas vezes antecipou a crítica e o gosto dos colecionadores italianos. Desde o começo foram organizadas mostras de jovens pintores contemporâneos, os quais atualmente registram as mais elevadas solicitaçôes do mercado, e apresentando nos leilóes artísticos notadamente as vanguardas internacionais. Tais antecipaçóes do mercado bem como estas propostas resultaram do conhecimento direto dos autores e dos movimentos de que faziam parte.

Coerente com as promessas firmadas no programa de trabalho proposto, a
Finarte desenvolveu intensa atividade ao longo de vinte anos em suas sedes de Miláo e Roma, contando com a colaboração de equipes de experts de nível internacional, propondo ao público de pinturas antigas e contemporâneas, mas também esculturas, peças arqueológicas, desenhos, gravuras, móveis, prataria, maiolica, porcelanas etc. Significativo testemunho de um trabalho desenvolvido são as numerosas obras de arte que sob a tutela da Finarte foram transferidas e formam hoje as mais prestigiosas coleções particulares bem como em numerosos museus italianos e do estrangeiro.

\section{Legenda}

$\mathrm{O}$ dr. Casimiro Porro diretor

da "Finarte" de Milão

Design: O potencial da Comunicação Visual, p.IO7

As primeiras manifestações da comunicação visual no Brasil limitaram-se à criação de simples monogramas ou simbologias imediatas.

A partir do desenvolvimento econômico, da importação da tecnologia, a comunicação visual popularizou-se através da divulgaçáo de boas marcas do ponto de vista puramente estético, restrita em sua potencialidade como implantadora de sistemas racionais de informação.

A transmissão de mensagens pela imagem e sua compreensão fascinaram Norberto Chama e Fernando Diederichsen Stickel desde a FAU-USP, onde formaram-se em 73. Deste então, estiveram ligados à comunicaçáo visual, adquirindo experiência no setor.

Em princípios de 78 associaram-se a arquiteta Íris Di Ciommo e, formando uma equipe de profissionais, fundaram a Und S/C Ltda., onde a comunicação visual é exercida como organizadora de sistemas, rompendo com o tradicional academismo da criação.

A equipe procura encontrar resposta a problemas, baseada no levantamento criterioso da realidade. Definem necessidades e organizam informaçôes a serem transmitidas, sem fórmulas pré-estabelecidas.

Mais organizadores que dese-

nhistas, preocupam-se com todos os aspectos de um projeto, em busca de uma coerência de linguagem, sem inibir a liberdade de criação.

Seus conhecimentos técnicos são utilizados tanto para o planejamento visual de uma máquina, visando a oferecer segurança ao operário que vai manejá-la, quanto para a criação de um programa de identidade visual para um conglomerado de empresas.

Um exemplo claro de suas propostas está no planejamento gráfico desenvolvido para usuários do sistema de transportes urbanos. Partindo de mapas concebidos pela Secretaria Municipal de Transportes para o Pro Uso (serviço de orientação ao usuário e transportes coletivos) a Und implantou uma padronização gráfica, através de normas para uso de alfabetos, estabelecendo convençóes, tornando os mapas uniformes e rapidamente perceptíveis pela população.

Uma padronização de linguagem também foi elaborada para os pictogramas contidos nos mapas. O caminho para esta padronização foi estabelecido através da utilização da linguagem popular e observou como característica primordial o profundo respeito aos valores culturais do usuário.

A imagem de uma cobra para identificar o Butantã ou de uma locomotiva antiga para identificar estaçóes ferroviárias, são extraídos do conhecimento 
popular e identificáveis até pelas pessoas mais desinformadas.

"Facilitar a vida da comunidade é a nossa missão," define simplesmente um dos integrantes da equipe.

\section{Legenda}

Selo da Boa Forma, Secretaria de Ciência, Cultura e Tecnolgia do Estado de Sáo Paulo, Concurso: $\mathrm{I}^{\mathrm{o}}$ prêmio, Colaboração de Eliana Cesar 9 Rodolfo Mahle, Abel Augusto Freitas Toller, Bebedouro SP 9 Filmar do Brasi S.A., São Paulo SP

Programas de Identidade Visual, p.io8-Io9

Alexandre Wollner

No seminário organizado pela ABDI sobre Programa de Identidade Visual, em novembro do ano passado, no Masp, foram apresentados vários trabalhos nacionais, inclusive um executado no exterior para a Olivetti. Porém, o mais aplaudido dos case history nos chegou de Pernambuco. João Roberto Nascimento (Peixe), que vive e trabalha como designer em Recife, desenvolveu um projeto incluindo a totalidade das etapas de uma programação de identidade empresarial para um grande supermercado do Recife, o Bom Preço, e ainda conseguiu implantá-lo integralmente.

Este feito, decorrente sobretudo de uma eficaz interação designer/cliente, colocou-se como a grande surpresa do seminário. animando os profissionais da plateia. Isto porque todos sabem das dificuldades de implantar, mesmo nos centros mais avançados como Sáo Paulo e Rio, tais projetos em sua globalidade, mesmo quando possuem qualidades conceituais e gráficas, como é o caso do trabalho exposto por Peixe, que alias atinge nível internacional. Trata-se de uma batalha por vencer: tanto o profissional brasileiro ainda precisa vender o conceito de design ao empresário, quanto devem os críticos de design gráfico alertar os profissionais para o fato de que ainda não logramos criar uma linguagem própria para a identidade visual, como o fizeram, por exemplo, os japoneses, os americanos, os alemães, os poloneses, os suíços. Conseguimos realizar trabalhos gráficos no gênero dos executados nos países desenvolvidos, porém até hoje não ousamos aproveitar oportunidades como seria bem o caso do supermercado do Recife - para o desenvolvimento de uma comunicação visual dirigida especificamente à nossa gente, em termos culturais visual e, portanto, funcionais.
No atual estágio da comunicação no Brasil, é compreensível que para o público consumidor dos grandes centros, participando de uma cultura predominantemente alienígena, se utilizem signos internacionais: porém, em se tratando do Nordeste, talvez fosse culturalmente mais verdadeiro e, portanto, mais eficiente procurar comunicar-se com o público através de elementos gráficos oriundos de sua rica tradição visual. (xilogravura dos cordéis etc.) Desta forma, o projeto de João Roberto Nascimento teria acrescentado à sua qualidade intrínseca, o mérito de uma linguagem apropriada aos seus consumidores, dando assim o primeiro passo para cobrir o furo maior de nossa comunicação visual. 


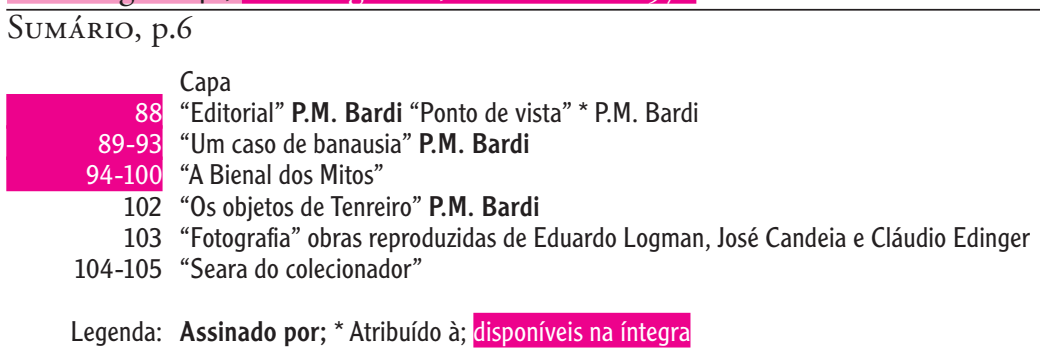

Editorial, p.88

P.M. Bardi

Depois de um ano, bem agasalhado em suas páginas, deixo o espaço que Casa Vogue me cedeu para, com saudade, partir para pousar em outra morada, uma saudade peculiar como convém, aliás, a um bom inquilino que fez de tudo para não chatear o dono, não reclamando dos empecilhos tão comuns nas casas, procurando observar o regulamento, agradecendo a liberdade total que sempre desfrutei a partir do instante em que o patrão me acolheu com um cordial abraço dizendo-me "A casa é sua."

Como saltitamos pelo campo evitando um e outro boato (se o pessoal não boatar, como poderia ser beato e feliz, convencido de saber tudo de fonte absoluta, utilizando um aparelho para aumentar a audição e usando uma pastilha para facilitar a emissão da voz?) bom será especificar, com a franqueza habitual, que a cultura nacional ainda se encontra num estágio que não permite contar-se com um bom número de revistas dedicadas às artes, que na verdade os quase cento e vinte milhóes de brasileiros bem merecem. Estamos ainda nos tempos das tentativas, do vaivém, do alicerce.

Confesso aos leitores que é a terceira vez que tento publicar uma revista de arte: a primeira foi a Habitat, em 50; a segunda foi Mirante das Artes \& etc. e a terceira Arte Vogue. Todas as ediçôes fazem parte de tentativas levadas a efeito com as melhores das intençôes; pode ser que náo lograram êxito por motivos ou erros de consideração daquilo que geralmente se espera de uma publicação: badalação, otimismo, exaltaçôes, tudo bem; nada de reservas, críticas, dúvidas. Mas devo confessar, não sem uma ponta de orgulho, que as experiências foram interessantes e válidas.

Foi um generoso aporto que deu para conhecer a mentalidade dos que se agitam no rodopio do problema arte: emerge o espírito individualista, envaidecidos da própria altitude e prenhes de desconsideração para com os outros. Numa palavra: a falta de ambiente. (De resto o mesmo se verificou nos belos tempos dos modernistas, os quais operando num ambiente mais concorde e cordial podiam preparar uma situação favorável a entendimentos úteis às geraçóes vindouras.)

Há muito o que fazer com vistas a criar possibilidades de entente entre quem produz e quem consome, superando rivalidades, panelinhas, dores cotovelares e tudo quanto mais obstacularize o melhoramento de uma situação incerta.

Para não salientar, como não é de meu feitio, aviso que a luta, apesar dos percalços, vai continuar; a partir do ano próximo, no coirmão Senhor Vogue, mensalmente, em quase duas dezenas de páginas, vamos desfilar problemas gerais e não apenas informaçôes; e virtualmente informação também, pois sem esta não se discute.

Adeus Casa Vogue! E até fevereiro de 79, em Senhor Vogue. 
PONTO DE VISTA

\section{atribuido a P.M. Bardi}

Para fruir de um ponto de vista é preciso, diria La Palisse, estar dentro do mesmo. Consequentemente, é necessário achá-lo primeiro, considerá-lo adequadamente para exercer o trabalho, assumir a posição e a disposição. Em geral o trabalho, é exercido com benevolência, contornando, un colpo al cerchio e uno alla botte como dizem os italianos que, por viverem numa península um tanto vulnerável, ao longo dos séculos depois da aposentadoria dos imperadores, articularam a fórmula como mestres.

Raramente o pontista perde a paciência, pois está no alto e tem condiçóes de panoramizar as coisas de forma serena, distanciado das discussóes, imerso na solidão que concilia a boutade e o perdão.

Assim sendo nos desculpamos pelo fato deste ponto de vista não ser canônico. Acontece que um Tal (ainda existem alguns) teve a excelente ideia de prestar extraordinário serviço à nação, por ocasião das festas comemorativas dos 70 anos da imigração japonesa para o Brasil, através uma exposição de obras-primas da arte ocidental (naturalmente incluindo brasileiros numa proporção não criticável) a ser apresentada em Tóquio, sem um centavo de despesa para nós, patrocínio do grande jornal Mainichi Shimbum, tendo como presidentes de honra o irmão de S.M. o imperador do Japão e o presidente Ernesto Geisel. Tudo pronto, tudo combinado, expectativa excepcional no Japão, pais no qual já tínhamos levado à apreciação do nobre povo oriental manifestaçáo semelhante em 73, sempre organizada pelo Tal, sem qualquer despesa para o Brasil, com uma afluência da ordem de meio milhão de visitantes, fato que conferiu ao nosso país o titulo de nação culturalizada, visto possuir um museu a nível internacional. Como dissemos, tudo estava pronto para que obras viajassem; e eis que surge um simples burocrata, de referência modesta, um desses fulanos que encarapitado num cargo, sadicamente, para atrapalhar a vida dos que realizam alguma coisa de bom e útil (falta o carimbo, a assinatura deve ser tabelionada, a numeração está errada e não confere, o guiché está fechado), enfim alguém com calosidade no cotovelo, sentencia: veto a exposição.

Ponto de vista? Para que o leitor forme uma melhor ideia sugerimos a leitura da reportagem que se segue, náo sem antes pedir desculpa ao pontista que certamente desta feita vai perder a paciência.

Um CaSo DE BanaUsia, $p .89-93$

\section{P.M. Bardi}

Um dia, se a história ainda for alguma coisa que valha a pena ser invocada, ando alguém remexer papéis pertinentes à cultura nacional dos tempos hodiernos, particularmente os relativos ao setor arte, não restará menor dúvida de que todos ficaráo perplexos ao tomarem conhecimento de certos fatos de banausia, particularmente um ocorrido em i978. (Por banausia entenda-se um antigo conceito de relação cidadão-Estado: o cidadão considerado como o executor das artes mecânicas, atividade considerada vulgar. Aristóteles dizia que os do poder senhorial não praticam as artes mecânicas, atribui mais aos servos, artes que não devem ser nem de longe aprendidas "nem pelo bom político, nem pelo bom cidadão," duas figuras que no mundo grego eram os mandachuvas que levavam as maiores vantagens em relação aos que se danavam em bem cumprir seus trabalhos. Mais um, isto é, referente à banausia: permitia a divisão da sociedade em duas classes: a dos que viviam do trabalho manual, obrigados a obedecer sem bufar e a dos que comandavam sem dar maiores satisfaçóes, um conceito que perdurou ao longo da Idade Média e que a Renascença procurou revisar inaugurando o conceito de dignidade do trabalho manual.)

Feita esta premissa passemos a narrar um caso de banausia ocorrido, como já foi dito, neste dealbar de século.

\section{Uma ideia de japoneses}

Todas as coisas corriam normalmente numa instituição cultural, no caso o Museu de Arte de São Paulo (programação em 
execução normal: pinacoteca aberta aos visitantes na mais perfeita ordem, exposiçóes periódicas sucedendo-se uma a uma cada semana; visitas guiadas de estudantes de níveis primário e secundário; três a quatro audiçóes de música por semana; realização da II Mostra Internacional de Cinema com a participação de 25 países e com a projeção de 30 filmes inscritos sem que a Censura, por muitos criticada, impugnasse quaisquer um deles etc.), quando uma comissão de amigos do Japão se apresentou para propor ao museu de se organizar a exposição de um grupo de obras do seu acervo, a fim de ser mostrada em cinco cidades japonesas.

A proposta era similar àquela realizada em 1973, promovida pelo Matsuzakaya e pelo Mainichi-Shimbum (o primeiro um dos maiores departament-stores do Japão, e o outro famoso jornal cuja tiragem diária é da ordem de 7.500.000 exemplares). Os japoneses, lembrando o sucesso do Masp quando apresentou 45 pinturas mais a escultura Bailarina de I4 anos, de Degas (sucesso que pode ser configurado em mais de meio milhão de visitantes, ampla divulgação pela tv mostrando as obras expostas, uma por uma, inclusive os brasileiros Portinari, Di Cavalcanti, Visconti, Mabe, Wesley Duke Lee, Segall, Ismael Nery, comentadas por historiadores de arte; inauguração presidida pelo príncipe Misaka, irmáo do imperador, reunindo, na oportunidade, intelectuais, artistas, empresários, banqueiros, enfim, a elite intelectual e as mais altas expressóes das classes produtoras do Japão) os amigos do Mainichi fiados naquele extraordinário sucesso demandavam a São Paulo a fim de obter do Masp a anuência para mais uma exposição.

$O$ pedido se calcava em um caso sentimental, qual o de registrar a passagem dos 70 anos da imigraçáo japonesa no Brasil. Diziam eles que o Masp possuía um rico acervo, merecedor de ser apresentado também fora do país.

\section{Reflexões de um diretor}

Durante as conversaçóes contamos com a ajuda do amigo Kei Kimura, que gentilmente servia de intérprete. Eu escutava, refletindo, levando meu pensamento ao nosso fundador Assis Chateaubriand, o qual, lá da Eternidade, me enviava uma mensagem: "Professor, aceite já. Não fique bancando o papalvo." Pensei, depois, na felicidade de Rafael, Ticiano, Cézanne, Matisse, Picasso, Portinari, Tarsila e outros que seriam vistos e apreciados por centenas de milhares de japoneses, vivamente interessados a ponto de pagarem ingressos da ordem de 200, 300 ou 500 yens, variando de estudantes, a grupos organizados de visitantes ou mesmo isoladamente, sem contar com as visitas programadas para os portadores de defeitos físicos e escolas, com acesso gratuito ao recinto da mostra. Meus pensamentos estavam voltados para o fato de que enquanto os japoneses pagavam de bom grado para conhecer obras de arte do mundo ocidental, aqui, o visitante nada paga para conhecer o acervo da nossa pinacoteca. Voltavam ainda minhas recordaçôes à média de IOo mil visitantes quando, entre 53 e 56 , levei à Europa (mostras no Orangerie do Louvre, Palais de Beaux-Arts de Bruxelas, Kunstmuseum de Berna, Kunsthalle de Dusseldorf, Centraal Museum de Utrecht, Palazzo Reale de Milão, Tate Gallery de Londres) e aos Estados Unidos (exposiçóes no Metropolitan Museum of Art de Nova York e Art Museum de Toledo, Ohio) cem obras-primas do Masp, manifestaçôes estas que organizamos com o deliberado propósito de sufocar o boato espalhado de que eu, em parceria com Chateaubriand, estávamos importando nada menos que quadros falsos, enquanto parte da imprensa, gratuitamente, criticava, numa evidente demonstração de estarem cultivando dores de cotovelo, já que o Masp tinha sido criado pelos Diários Associados.

Curioso: foi nessa ocasião que os cotovelos doloridos adquiriram calosidade a ponto dos alfaiates terem de criar nos paletós mangas bem amplas, bufantes mesmo, a fim de minorar as dores dos néscios. $(\mathrm{O}$ triste é que os tempos não mudaram.) Os japoneses continuaram falando, o Kimura traduzindo, enquanto eu me abandonava nas reflexóes tendo por tema as vicissitudes do Masp, lamentando a ausência do Fundador, que tudo resolvia como mágico fiscal, obrigando cordialmente as beneméritas classes produtoras a participarem pecuniariamente para dar ao Brasil um museu não provincialesco. Natural que, 
como bom banausiano, me afloravam algumas alucinaçóes decorrentes dos espectros do poder. Por mais que se viva num regime cordial, uma entidade (com foro de sociedade civil, sem fins lucrativos, reconhecida há mais de 30 anos como de utilidade pública e considerada filantrópica), além de ter suas contas submetidas ao crivo dos tribunais competentes, quando se trata de corresponder com o estrangeiro para intercâmbio cultural deve transar com dois órgãos do poder público, no caso os Ministérios das Relaçóes Exteriores e da Educação e Cultura; o primeiro, por se tratar de manifestaçáo no exterior e por lhe competir zelar pelo bom nome do pais; o segundo por se ocupar da tutela das coisas de arte. Mergulhado em minhas reflexôes, eis que os hóspedes, com aquela objetividade que tão bem os caracteriza, insistem em concluir as tratativas. Se parlamenta. (Um parêntesis: em 73, os anfitrióes Matsuzakaya e Mainichi doaram ao Masp a quantia de cem mil dólares. Também agora prometeram uma doação.)

Os pensamentos do diretor evoluíram para as trapalhadas sempre enfrentadas pelo Masp, quando procura demonstrar que o Cruzeiro do Sul é formado por cinco estrelas, ou que o Hino Nacional é um dos mais lindos do mundo. Em geral é difícil conseguir-se uma autorização favorável para enviar, temporariamente, obras de arte ao exterior para uma exposição que carreia para o país prestígio e provoca ampla repercussão internacional.

\section{Um precedente}

Entre os vários casos em que o poder público fez emperrar a roda do carro do Masp foi o seguinte, me dispondo a narrar a fim de denunciar um fato incrível que geralmente golpeia nós banausianos.

Corria o ano 70 e veio planando e aterrando na Atenas do Brasil uma comissão de historiadores de arte japoneses incumbida de escolher, na Pinacoteca (não a do Estado) do Masp algumas pinturas que deveriam figurar na secção dedicada à Arte Ocidental na concorrida exposição de Osaka, conhecida internacionalmente por Osaka-70. Os peritos, após atento exame e acurada observação do nosso acervo, solicitaram o empréstimo de algumas obras, para juntar às dos museus europeus dos quais tinham obtido a colaboraçáo. O Brasil teria estado presente e em muito boa companhia, e nossa inteligência teria faturado a atenção de milhóes de visitantes, especialmente porque nós estávamos participando da manifestação com um eminente pavilhão. Como de praxe, comecei as demarches, como dizem os diplomatas, dirigindo-me às autoridades competentes a fim de obter a licença de exportação temporária das obras. (Desnecessário dizer que estavam cobertas por seguro total em seu valor comercial.)

Não entro em pormenores para não repetir o que se passou com outro caso e que motiva este desabafo; de qualquer jeito nas demarches tudo estava em vigor (Constituição, leis, regulamentos, portarias, miniportarias, ordens-de-serviço-internas etc.) foi explicitado justamente como deve fazer qualquer cidadão face ao Estado. As repartiçóes, conforme usos e costumes, para início de conversa, antes de tudo se preocuparam em náo considerar o pedido, transferindo o processo de uma mesa para a outra, sem ao menos lear em conta as solicitaçóes do Masp e da embaixada do Japão no Brasil. Práticos, os responsáveis sabem muito bem como se engaveta um processo e, assim sendo, a Expo-7o se inaugurou sem a presença das pinturas escolhidas do Masp que muito teriam ajudado em mostrar aos orientais um panorama da arte ocidental. Nas aparedes destinadas às pinturas que deixaram de ser apresentadas, foram afixados cartazes informando da proibição branca às obras que o Brasil deveria ter enviado. Justa reprimenda ao nosso país que, assim, perdia excelente oportunidade para informar que aqui existem banausianos em condiçóes de preocupar-se com cultura em termos não caseiros. Naturalmente, sempre seguindo a praxe, nunca se soube dos motivos que levaram a quem de direito a sonegar nossa participação no evento de Osaka. A repartiçáo é aquela incumbida de zelar pela conservação da história e da arte nacional, a mesma que recentemente permitiu a demolição do palacete do Duque de Caxias, para em seu lugar erigir um arranha-céu. Tempos depois, no país dos boatos, numa reunião coquetelesca, foi possível saber-se que uma dama que se autodenomina mecenas das artes, havia sussurrado no 
ouvido da ingênua autoridade que o Masp, com dívidas no exterior, fatalmente teria suas obras sequestradas pelos credores; assim, desaconselhava permitir a saída de tão formidável acervo. Tomando a sério a maldosa invencionice da fulana para quem tudo é cor-de-rosa, as telas não viajaram.

Que uma dama boatize é normal; anormal é que ao ouvir tão graves inexistentes afirmaçóes. a autoridade não tenha se preocupado em proceder a uma averiguação para saber a verdade.

Configura-se um triste produto do ambiente que depende da leitura das crônicas sociais de um proustianinho aldeiano, digno de ser aferido na balança do prof. Denis P. Burkitt, o descobridor do linfoma que leva o seu nome, e famoso estudioso de escrementos humanos.

\section{Voltando à bomba}

Combinamos, então, com a missão do Mainichi que o Masp, uma vez aprovada a proposta pelas respectivas diretorias, concordava em enviar 45 obras de mestres europeus e mais 5 de autores brasileiros. Foram escolhidas as obras dos seguintes artistas: Piero de Cosimo, Rafael, Frans Hals. El Greco, Nattier, Fragonard, Delacroix, Courbet. Renoir, Degas, Van Gogh, Modigliani, Mantegna. Tintoretto, Bosch, Gainsborough, Poussin, Pater, Drouais, Vuillard, Daddi, Paris Bordone, Rubens, Van Dyck, Franz Post, Lawrence, Goya, Le Moine, Corot, Manet, Gauguin, Toulouse- Lautrec, mais os nossos Di Cavalcanti, Segall, Tarsila, Portinari e Tomie Ohtake, esta última já consagrada na pintura brasileira, apesar de sua origem nipônica.

Deu-se início aos trabalhos acionando-se os canais de comunicação com as entidades vinculadas ao caso: imediatamente o Itamaraty foi informado; o Mainichi comunica-se com a embaixada do Brasil em Tóquio. Efetua-se o seguro das obras, risco total, como se solicita a competente autorização ao IPHAN, enquanto paralelamente era providenciada a documentaçáo necessária junto ao Banco do Brasil.

O tempo flui e se aproxima a data da inauguração. O Mainichi anuncia em primeira página de suas ediçóes, nos idiomas japonês e inglês, o evento a ser inaugurado sob a presidência do príncipe Mikasa. irmão do imperador Hirohito. O presidente Ernesto Geisel aceita a presidência de honra, juntamente com o príncipe Mikasa: o chanceler Azeredo da Silveira e o governador de São Paulo Paulo Egydio escreveu mensagens para o catálogo da comemorativa dos 70 anos da imigração japonesa. O Brasil, através tal manifestação. torna-se assunto diário. Enquanto tal expectativa é mais que manifesta, a permissão dos burocratas não vem. Todos os preparativos são feitos pelos banausianos das artes mecânicas: caixas especiais e individuais são confeccionadas nas oficinas do Masp; praça reservada em avióes da Varig, também ela patrocinadora.

Começam as preocupaçóes face ao inexplicável retardamento da permissão governamental. Os japoneses telefonam do outro lado do mundo para saber o que está acontecendo. O IPHAN continua mudo. A embaixada do Japão em Brasília é acionada para verificar o motivo da demora da autorização.

Diante de tão justa intervenção diplomática, finalmente o IPHAN dá seu parecer: negativo.

Após insistentes solicitaçóes fica-se sabendo que uma comissão que cuida do Patrimônio (talvez a mesma que autorizou a demolição do palacete do patrono do nosso Exército) opinou negativamente pela saída das obras para o Japão, porque (risum teneatis) o incêndio do MAM carioca tinha castigado o patrimônio nacional com fortes perdas e, portanto, náo se deveria correr o risco de se perder outras obras (como se o transporte das obras fosse o mesmo que incendiá-las): que o Masp tinha vendido obras de sua coleção (as costumeiras velhuscas calúnias alimentadas monetariamente por especializado cronista social); de qualquer jeito a exposição deveria ser reformulada da seguinte maneira: o conjunto de 50 pintores (incluídos 5 brasileiros) se invertesse, isto é, 5 estrangeiros e 45 brasileiros. Solicitado a que desse seu parecer por escrito, a fim de que o Masp respondesse e chamasse à responsabilidade o autor das calúnias, naturalmente tiraram o corpo, a alma e o espírito de porco. Repito: espírito de porco, possivelmente com peste suína. 
É bom fazer saber que a exportação temporária necessita de uma licença, conjugada com uma de importaçấo. Fiscal da Cacex verifica caixa por caixa, munido de fotografias de cada obra. A alfândega procede de igual maneira. Assina-se um termo de responsabilidade pelo retorno das obras, pois o não retorno de qualquer peça implica em multa da ordem de três vezes seu valor, além de processo judicial intentado tanto pelo Banco do Brasil quanto pela Alfândega, numa palavra, pelo Ministério da Fazenda. No retorno as obras são verificadas uma a uma e, somente quando as formalidades são devidamente satisfeitas é que o Banco do Brasil dá baixa ao termo de responsabilidade.

\section{Status das fofocas}

Até hoje o Masp aguarda explicaçôes da origem das fofocas. O banausiano, conhecidos os itens da negaçáo, tomou então a primeira providência, correndo célere a uma casa de umbanda a fim de comprar os apetrechos destinados ao esconjuramento: quanto à venda de obras o que fazer? Morder-lhes as orelhas? Matar?

Quanto ao formar, à L'instant, uma coleção de 45 pintores brasileiros, mesmo superando a incompetência dos órgãos oficiais, convida a quem? Possui o país 45 artistas em condiçôes de provocar algum interesse internacional? Nacionalismo é atitude lógica, porém, força convir, nacionalismo barato é irritante.

Vislumbrando o fracasso da exposição, o Masp pede ao amigo Kimura para informar ao presidente do Mainichi que, possivelmente, a manifestação não vai se realizar. De Tóquio, no mesmo dia, partem dois diretores daquele grupo editorial, um deles desembarca em Brasília enquanto o outro aterrissa no Rio de Janeiro. (Por que o Instituto do Patrimônio Histórico e Artístico Nacional mal legisla sobre o patrimônio cultural brasileiro das ardentes praias cariocas e não do Planalto Central, sede do governo, até agora ninguém conseguiu saber.) Os executivos do Mainichi parlamentam com a direçáo do IPHAN, como o Ministério da Educação e Cultura, com o pessoal do Itamaraty para buscar uma solução positiva, ou seja, a efetivação da mostra ansiosamente aguardada pelos japoneses. No Japão são habituais as exposiçóes de coleçóes de museus de todo o mundo, sendo que uma das últimas foi a que no momento se encontra exposta no Metropolitan de Nova York: os tesouros de Tutankamon, do Museu do Cairo. Também já visitaram o Japão a Mona Lisa, de Leonardo, e a Vênus de Milo: a Arte Italiana Antiga dos museus de Roma; as obras-primas de Rembrandt do Hermitage de Leningrado; a exposição de Delacroix; os Goya do Museu do Prado; as relíquias do Tibre-Eufrates do Museu do Iraque: os tesouros arqueológicos da China; os tesouros incas, do Museu do Ouro do Peru, e inumeráveis outras mostras do mais elevado valor cultural que os museus e as coleçóes do mundo preservam e emprestam para serem vistas por outros povos.

Retornando aos emissários do jornal japonês, registramos que trouxeram todo o material já impresso (cartazes, catálogo, revistas, folhetos), tudo preparado para a exposição do Masp. A Missão Diplomática japonesa acreditada junto ao governo do Brasil então se movimenta. Finalmente chega a notícia de que o Conselho do IPHAN (integrado pelos srs. dr. Renato de Azevedo Duarte Soeiro, presidente e diretor feral do órgáo; prof. Geraldo Brito Raposo da Câmara, diretor do Museu Histórico do Rio de Janeiro; prof. Luiz Emydio Mello Filho, diretor do Museu Nacional do Rio de Janeiro; prof. Edson Motta, diretor do Museu Nacional de Belas Artes, Rio de Janeiro; prof. Lourenço Luiz Lacombe, presidente da Fundaçáo da Casa de Ruy Barbosa, Rio de Janeiro; prof. Afonso Arinos de Melo Franco; prof. Pedro Calmon, prof. Paulo Ferreira Santos, prof. Alfredo Galvão, prof. Gilberto Ferrez, prof Ciro Ilídio Correia de Oliveira Lina. Paraná; prof. Fernando Bueno Guimarães, diretor da Funarte/Fundação Nacional de Arte, e prof. comandante Max Justo Guedes, diretor do Serviço de Documentação Geral da Marinha do Brasil) tinha mudado de parecer.

Curioso, muito curioso. Mas o curioso mais curioso é que na ilustre comissão, São Paulo não tem representação. Não somos municipalistas, porém, como bons banausianos, rogamos que São Paulo seja imediatamente admitida numa comissão 
que opina sobre conservação e destino das artes, pois São Paulo, sem bairrismo, é a roda dianteira do carro nacional.

Seria demasiado longo narrar todos os lances que ocorreram desde a comunicação do IPHAN ao Masp náo permitindo o empréstimo de suas obras ao Japão até o momento em que, cortando a fita verde-amarela / verde-branca, o príncipe Mikaas, e o embaixador Ronaldo Costa, chefe da Missão Diplomática do Brasil em Tóquio, inauguravam a exposição na presença de ministros, embaixadores. intelectuais e artistas, manifestação que tinha como presidente de honra o chefe de Estado do Brasil, Ernesto Geisel, numa mostra de evidente simpatia e amizade para com o povo japonês.

A solução foi possível graças à firme e pronta intervenção de um estadista paranaense (um dia nomearemos seu nome), o qual conseguiu sacudir as mesas do pessoal dos guichés. Assunto superado e esclarecido, as calúnias e as imbecilidades soltas ao vento são examinadas e chega-se à conclusão, que uns tantos, no seu apoucamento caipiresco e falta de patriotismo, por um triz não póem em cheque o prestigio do Brasil, quase arranhando as ótimas relaçóes felizmente existentes entre nosso país e o Japão.

O telefonema anunciador da concessão do placet para a viagem da exposição (devidamente segurada), peça por peça, de todos os riscos, num valor global de nada menos que vinte milhóes de dólares) chegou três dias antes da abertura da exposição. Em tempo recorde foi concedida autorizaçáo, bem assim a licença da exportação da CacexBanco do Brasil. Graças à compreensão e à boa vontade desse extraordinário pessoal (Banco do Brasil, Alfândega. despachantes aduaneiros) os dois corretos executivos nipônicos se animaram. Todas as providências foram tomadas, buscando-se a melhor cooperação e o devido apoio para que as obras chegassem a tempo em Tóquio, para a abertura da mostra. Um verdadeiro milagre. Milagre também foi o excelente trabalho executado pela Varig, que arranjou espaço na aeronave que partiu dia i9 de setembro do Galeão com destino a Tóquio. Os banausianos respondem ao recado.

\section{Tirando conclusões}

O leitor deve tirar suas próprias conclusóes. Para melhor entendimento do caso devo dizer que por indiscrição de um membro da comissão, parece que o pretexto para negativa foi o fato do Masp ter informado o Itamaraty antes do iphan. Ciúmes? Se foi, de fato, esse o pretexto para negar, creio que não se pode fazer nada, a não ser lamentar a mesquinhez. Ao longo de decênios toda e qualquer exposição que o Masp realizou no exterior, sempre a primeira informação foi transmitida à chancelaria brasileira, visto ser ela quem cuida dos interesses nacionais lá fora.

O IPHAn é um órgão do MEC destinado a preservar o patrimônio dentro dos limites do país, sendo assim um departamento de assuntos internos. A ingenrência do desenvolvimento da cultura artística no exterior é da competência do MRE, tanto isto é verdade que este Ministério possui um Departamento de Assuntos Culturais e também um de Difusão Cultural. Então, compete ao MrE essas tratativas, enviar e receber exposiçóes de caráter internacional.

Mas o leitor fique atento no seguinte caso. No ano passado o Masp apresentou, com a colaboraçáo de 7I colecionadores particulares paulistas, a exposição Artistas e Artífices do Brasil, séculos i6, i7 e I8, composta de 240 peças, entre esculturas, pratarias, mobiliários, pinturas etc., completada com a publicação de um catálogo adequado ao importante evento o que coroou a passagem do $30^{\circ}$ aniversário de fundação da instituição. Tratava-se da primeira reunião de obras de propriedade de particulares auténticos guardióes e preservadores do patrimônio nacional. Era a primeira vez que essas peças eram mostradas ao público formando um conjunto único de raridades. (Tanto é verdade que várias tinham expertises de funcionários do próprio IPHAN.) A intenção dos organizadores foi a de, além de tornar conhecida a coleção aos visitantes do Masp, proporcionar ao IPHAN a descoberta de peças que aquele órgão desconhecia existir e, naturalmente, esperar alguns processos de tombamento. Os responsáveis do Patrimônio nem se abalaram, preferindo as areias de Copacabana, nem se interessaram 
pelo acontecimento. Como cha mar esse comportamento? Desinteresse? Inépcia?

Muito bem. Ao tomar conhecimento dessa exposição que apresentava um dos ciclos mais criativos da arte brasileira, o presidente do Instituto Ítalo-LatinoAmericano, com sede em Roma, telegrafou ao Masp informando que um seu representante estava se dirigindo a São Paulo para visitá-la. Desejava estudar atentamente a exposição e, eventualmente, promover sua apresentação em Roma e em várias capitais europeias.

O secretário do IILA, prof. Brook, chegou e ficou entusiasmado com a exposiçáo, declarando que finalmente a Europa teria a oportunidade de apreciar uma apresentação do barroco brasileiro. O Instituto oferecia, além de todas as despesas pagas para a ida e retorno da mostra, com o devido seguro, um catálogo técnico, convite para um nosso representante e também convites para conferencistas brasileiros a serem designados a fim de que ilustrassem a exposição. Confirmou, também, apresentaçôes em Paris, Londres e Munique.

Tudo acordado, o Masp dirige-se, como sempre, ao Itamaraty. Se imagina, ingenuamente, que um convite para apresentar uma exposição brasileira, custeada pelos europeus, seria recebida com fogos de artifício.

Escoa-se o tempo costumeiro para a tramitação dos papéis quando (risum teneatis) vem como resposta ao Itamaraty a cópia de um comunicado iphaniano, um verdadeiro medíocre ensaio escolar ditado por catedrática ainda por ser descoberta, no qual são discutidas, usando filologia primária, atribuiçóes técnicas de parte das peças, inclusive as atribuiçóes vergadas por seus mais credenciados colegas e de seu próprio departamento: uma flagrante e indevida intervenção para impedir, como impediu, a concretização da exposição. Manifesta atitude de ciúme?

Para ser franco e sem falsa modéstia posso afirmar que nem eu, nem tampouco a comissão que escolheu os objetos da exposição Artistas e Artífices do Brasil, necessitamos das luzes das fulaninhas do IPHAN, mesmo porque cada macaco deve ficar em seu galho e eu, como macaco velho, posso afirmar que o IPHAN deve aprender a não perder tempo e muito menos fazer com que os demais o percam, com ingerências em problemas atribucionísticos, devendo-se dedicar com afinco ao tombamento de obras que eles julgam de interesse para o Patrimônio Histórico e Artístico Nacional.

\section{Aula para o IPHAN}

E aqui vai um bom exemplo da incorreta atividade do serviço. O que se entende por tombamento de uma obra de arte? Uma vez decidido e aprovado que a obra tal é de interesse para a memória da naçáo, o órgão tutelador tomba a referida peça. (Justamente, ao longo da abertura da exposição Artistas e Artífices do Brasil, esperei por um funcionário do IPHAN para notificação do tombamento de obras de frei Agostinho, Aleijadinho e de inúmeras imagens e objetos expostos forrados de relevante valor.) O funcionário do IPHAN teria sido recebido com cordialidade e tomado um cafezinho com o diretor do Masp, o qual lhe teria explicado que o próprio acervo do Masp também deveria ser tombado pelo IPHAN. Ao dito funcionário, com a cordialidade inerente ao recinto da avenida Paulista, eu teria demonstrado que o acervo do Maap não está tombado.

\section{E por quê?}

Pelo fato de que o ato de tombamento ou é tombamento mesmo, ou então é uma farsa. Ele implica, antes de tudo, numa notificaçáo do órgão competente à entidade possuidora do acervo. (O Masp jamais recebeu notificação, pois jamais o diretor responsável deu contra-recibo de qualquer documento.) Consequentemente a identificação das obras, verificação do estado físico de cada uma, documentação bibliográfica e, como o bom senso e a boa técnica recomendam, um ou mais documentos fotográficos, e tudo devidamente assinado pelo Masp, carimbado etc. etc., de maneira a que cada peça seja perfeitamente identificada, sem margem a qualquer engano. Pelas leia de tombamento vigentes em países europeus, o proprietário de uma obra de arte tombada, uma vez aceita a notificação (na Itália a notificação é feita por caribineiros, ou seja, representantes da Lei) compromete-se a conservá-la e preservá-la, informando as autoridades 
competentes mesmo quando deseja mudá-la de uma parede para outra. Em caso de transferir sua propriedade a outrem, esse ato deve ser precedido de uma autorização previamente solicitada, para que o novo proprietário seja cientificado e notificado pelo Patrimônio de lá que a peça é tombada.

\section{Para concluir}

Para concluir, um pedido: Amigos do Patrimônio, colaborem com todos nós da Baunasia. Garanto-lhes que nós, aprendizes de museógrafos, colecionadores, estudiosos, antiquários (os autênticos valorizadores e conservadores de arte nacional, como bem o demonstrei em duas reportagens publicadas em Senhor Vogue) temos todos melhor boa vontade em contribuir para que o Brasil conserve tudo aquilo que os antepassados nos deixaram de original. (Menos, naturalmente, o colonialismo que considerava a banausia ao modo de Platão o qual condenava a função baixa, fazendo dizer a Callecle, no Georgia: desprezar até os fabricantes de máquinas de guerra, apesar de serem úteis, e "por ofensa o chamará banausianos, e não vai dar tua filha em casamento ao filho dele, nem permitir que seu filho case com a filha dele.")

Amigos do IPHAN: não nos considere simples banausianos. Afinal, se trabalhamos nas artes mecânicas e vocês no alto do poder, todos devemos permanecer unidos para participar $\mathrm{da}$ emergência nacional, eventualmente passando pelo calista para extirpar calos que provocam a dor de cotovelo.

Assim queiram aceitar as mais respeitosas e cordiais saudaçóes de

NB - Um lembrete: o príncipe Mikasa e o presidente Ernesto Geisel, representado pelo seu embaixador em Tóquio, bem assim os organizadores e promotores $\mathrm{da}$ exposição esperam que vocês nunca mais coloquem em risco o prestígio cultural brasileiro, em qualquer realizaçáo de caráter internacional. O Masp espera e tem certeza que vocês se encham de compreensão e, sobretudo, de boa vontade e sejam, da próxima vez, mais inteligentes.
A Bienal dos Mitos, p.94

atribuido a P.M. Bardi

Como dissemos em Arte Vogue que registrou a Bienal da Arte Catastrófica, o certame paulista andou modificando substancialmente seus rumos, esquecendo o sistema inaugurado e mantido pelo seu fundador, derivado, aliás copiado, da exposição-mater de Veneza. Os tempos também mudaram na Europa e assim é fatal que as coisas aqui no continente historicamente ainda jovem, mudem, também, provavelmente ajustando as últimas mudanças com o objetivo de exaurar as ediçôes bianuais destas reunióes de artistas.

Não era fácil arranjar uma manifestação em que os participantes obedecessem a um tema, o que se verificou com a precedente edição internacional. Fatal originar uma desorientaçáo entre os participantes que só em parte concorreram e, às vezes, recorrendo a produçóes sem mitos nem magia. Assim numerosas e corriqueiras foram as salas de pintores genéricos do academismo figurativo e não figurativo superado e cacete.
Resultou, apesar da boa vontade do presidente da Bienal, dr. Luís Rodrigues Alves, uma grande exposição definível e intitulada como caseira, especialmente no tocante aos participantes brasileiros, aqueles que se dedicam aos mitos que no país são comuns, meio África, meio Colônia, meio trouvaille ocasional, não faltando mesmo emergentes pontas de folclore.

Apesar do caso que resultou com tema tão complexo, mais assunto para Bosch ou para Dali, na verdade a exposiçáo foi bem visitada por um público não-Jardim América ou Búzios: multidóes de povo foram ver e se divertir, vendo a troupe de bailarinos baianos de Lea Robatto invadir corredores, salas, rampas, levando som e movimento, alegrando o recinto.

Desmantelada a Bienal tradicional da ambígua linha veneziana, após duas experiências da Catástrofe e da Magia, que tudo precisa ser reformulado.

Como? 
Esta Bienal e a próxima na opinião do presidente

Arte Vogue Todo aquele que conhece o exercício das artes plásticas na América Latina está convencido de que a Bienal dedicada ao continente afirma ser necessário haver um melhor desenvolvimento por constituir um fato de boa vontade e de extraordinário valor. Assim, perguntamos ao presidente da Fundação Bienal se se sentia satisfeito com o êxito.

Rodrigues Alves Estou muito satisfeito em ter realizado a I Bienal Latino-Americana de São Paulo. Quanto ao êxito, esta é uma questão um tanto controvertida. Posso afirmar que houve êxito na aceitação dos países em participar desta Bienal. Temos 23 países latino-americanos, compareceram I3, lamentamos que todos não comparecessem, mas sabemos que - como nós - eles também têm problemas internos de ordem econômica e nem sempre é possível enviar uma delegaçáo. Dentro destes casos está a Venezuela, que nos prometeu uma grande mostra de Reverón, cancelada na última hora por impedimentos internos locais. Xul Solar, que consta em nosso catálogo, não foi apresentado porque sua obra, de propriedade da Galeria Rubbers, exigia um seguro individual que não foi possível cobrir. Outros países, como os das Antilhas, não puderam aceitar o convite. Acredito que a montagem foi muito bem resolvida, encontrando-se uma forma mais racional e mais aberta, evitando-se fechar os vidros com painéis. Com relação ao Simpósio, tivemos um grupo de nomes de alto gabarito, que trouxe uma boa contribuição, além daquela advinda dos debates. Vocês me perguntaram se estou satisfeito com o êxito. Estou satisfeito, apesar de todas as críticas, algumas procedentes, outras absolutamente infundadas, em ter proporcionado e contribuído para que se realizasse, aqui em São Paulo, esta I Bienal Latino Americana, que foi uma abertura, um início de relacionamento cultural entre os países latino-americanos. Nosso objetivo era fazer alguma coisa positiva, mesmo que não perfeita, pois acredito ser melhor fazer algo mesmo com falhas, do que ficar inerte. A nossa abertura continua, principalmente para, aqueles que nos criticaram, esperamos receber propostas, sugestóes e soluçôes para as falhas havidas; o diálogo foi iniciado e nada deverá interrompê-lo.
AV Esquecido o sistema mundanesco da premiação, a Bienal conseguiu lançar uma fórmula mais construtiva e cordial entre os participantes, que afinal não se sentem julgados como se fossem cavalos de corrida e, assim sendo, o senhor pensa que o mesmo critério será adotado na próxima Bienal Internacional?

RA Uma das modificaçóes por que passou a Fundação Bienal foi a criação de um Conselho de Arte e Cultura de caráter normativo e consultivo, atuante. Quanto à premiação, na XIv Bienal Internacional foi feita uma pesquisa junto aos artistas. Nas fichas de inscrição foi incluída uma pergunta referente aos prêmios, cerca de $70 \%$ dos artistas foram favoráveis, portanto os prêmios foram mantidos. Quando da elaboração do Regulamento da I Bienal Latino Americana de São Paulo, concluímos, de acordo com a sugestão do Conselho de Arte e Cultura, que o prêmio fosse abolido e que com a verba destinada a ele faríamos a documentação de todas as obras expostas, bem como publicações, o que está sendo feito. Com relação à próxima Bienal Internacional, o Conselho de Arte e Cultura deverá reunir-se brevemente e estabelecer suas normas. Só então será possível responder a esta pergunta.

AV Sem dúvida, a próxima Bienal vai ser mais complexa como organização, tendo em vista a necessidade de superar o sistema das precedentes ediçóes ainda baseado nos regulamentos da veneziana, que são de I893. O senhor pensa numa nova fórmula, mais consentânea ao público brasileiro? Por exemplo: visto que os manipuladores do produto arte hoje são as grandes casas comerciais de Nova York, Londres, Paris e Milão, o senhor não pensa que a próxima Bienal poderia contar com a colaboração delas, para que assim o público venha a conhecer como são as coisas num determinado setor, e ao mesmo tempo testar o esclarecimento e a prática do colecionismo local, por demais nacionalista, uma vez que o Brasil é pobre de materiais arte e num certo sentido, náo querendo provocar polêmica, provinciano?

RA Como afirmei na resposta à pergunta anterior, até o presente momento estamos recebendo sugestóes para a próxima Bienal 
Internacional. Gostaria de ter permissão para colocar suas sugestóes, e outras mais que possa nos trazer, na pauta de trabalho do Conselho de Arte e Cultura. No momento estou apenas preparando, com meus auxiliares diretos, um plano para a reestruturação total da infra-estrutura da Fundação Bienal de São Paulo, que deverá ser apresentado para aprovação da diretoria. Acredito que com uma organização melhor estruturada, estaremos aptos a corrigir erros fundamentais, que vêm de longa data, e que colocam a Fundação numa posição, em que a critica encontra falhas que não mais deveriam existir em uma entidade com 30 anos de existência. Gostaria, se possível, que Arte Vogue me procurasse antes do fim do ano, pois terei muito prazer em responder a outras perguntas e principalmente em anunciar as normas que determinaráo a próxima Bienal Internacional e também as providências que serão tomadas para um melhor atendimento em todos os setores.

Como sempre acontecia nas Bienais de Veneza e às vezes se repetiu nas domésticas, grupos de artistas inconformados coma organização ou por não terem sido convidados a participar, se declararam contrários ao evento dos "Mitos e Magias"; e democraticamente distribuíram folhetos convidando o público visitador do Ibirapuera para testemunharem o protesto intitulado "Mitos Vadios". Deve-se registrar também este fato, pois ele faz parte da atmosfera polêmica suscitada pela manifestação latino americana. Aqui reproduzi dois dos folhetos distribuídos.

Presente e futuro da Bienal

Após decênios, isto é, depois de sempre, desta vez a Bienal se apresentou planejada em termos aceitáveis e louváveis no que se refere à organização. Bem distribuídas as salas e itinerário bem delineado, indicaçôes das salas bem legíveis, um certo decor na entrada. Bem marcante o planejamento executado por um profissional, no caso Alexandre Wollner.

Wollner soube conciliar, num prédio famoso por seu ambiente assás negativo para hospedar exposiçóes de arte (Oscar Niemeyer o tinha projetado, ao tempo do bengodi ibirapuerano, para apresentaçáo de maquinário), compor a Bienal LatinoAmericana com uma ordem definida, apesar das exigências de numerosas salas propostas e desenhadas por expositores, obtendo o contentamento de todos.

Naturalmente Wollner foi obrigado a fazer das tripas coração para ajeitar salas demais para pintores mais redatores de press-releases que de telas, os quais, curioso, não tinham nada a ver com o peixe mitomágico. De qualquer jeito, foi importante apresentar tudo numa certa ordem.

Se na próxima Bienal, marcada para 1979, o planejamento dos materiais a serem expostos for mais rigoroso, obedecendo efetivamente a um eventual tema, pensa-se que será possível apresentar uma manifestação à altura dos tempos. Um costume menos caseiro como foi a presente, apesar de tudo quanto foi pensado pela diretoria atrapalhada pelo vaivém dos membros das comissóes de arte, conseqüência daquilo que alguém já disse nos anos da euforia cicillesca: São Paulo em termos de arte estava pondo o carro antes dos bois.

A demonstração desta aventura é hoje demonstrada pelo desinteresse do público: convocado pela propaganda incomum acorreu em massa às primeiras Bienais (divertissement mais próprio para centros culturalmente avançados do que para o Brasil), nada compreendendo dos problemas dos ismos, voltando desiludido, desertando regularmente de dois em dois anos as mostras do Ibirapuera, até esta última edição que, apesar da propaganda também pela $\mathrm{TV}$, não recebeu tantos visitantes quanto seria de se esperar.

O sr. Ciccillo pôs o carro antes dos bois. Pensou que a opinião de um grupelho mundano de modestos entendidos de arte justificasse despesas colossais (pinçadas aos erários governamentais), inaugurando uma retardada cópia da Bienal de Veneza. As conseqüências estão aí. 
Bibliografia 
ALTINI, Rosalva Weber. Rosalva Altini-Weber: Autobiografia. Saatchi Online. Disponível em: <http://www.saatchionline.com/rosalvaltini>.

Arte Vogue no Brasil, dá prá fazer? Deu. Istoé\#24, p. 49, 1977.

AZEVEDO, José Olavo de. Além do belo, o funcional é o design. Senhor Vogue \#ı13, p. II7, 1979.

BARDI, Lina Bo. As opçóes culturais do design. Senhor Vogue \#I3, p. IIO-III, I979. . O caráter de Pietro não é dos mais domáveis. Vogue Brasil \#II5, p. I42-I43, 1985.

BARDI, Pietro Maria. ...E, por que não? Os tronos. Casa Vogue \#5, p. 64, 1985. . I5 Bienal. Senhor Vogue \#20, p. I04-II5, 1979.

. A antiguidade da vanguarda: excessos e conveniências da Bienal paulistana. Senhor\#239, p. I00, 1985 .

. A arquitetura da terra: Inspiraçôes do caboclo à disposição da curiosidade urbana. Senhor \#I75, p. IIO, I984.

. A arquitetura do índio. Senhor \#157, p. 79, 1984.

. A arquitetura em Cumbica: algumas soluçóes criativas expostas no Masp. Senhor \#2IO, p. I04, I985.

. A arte antes de Cabral. Senhor \#I5O, p. 83, 1984.

. A arte da falsificação. Senhor \#83, p. 68, 1982.

. A arte da mesquinharia: o cronista reage a "mentiras" e "maledicências" e esclarece uma história que envolve Tarsila, o Masp e o Abaporu. Senhor \# 192, p. $84-85$, I9 84 .

. A arte de colecionar arte. Senhor Vogue \#I6, p. 98-III, I979.

. A arte de conservar com amor: Coleção João Marino. Casa Vogue \#28A, p. 52-55, 1977.

. A arte de fazer "clic": em seu livro, Notas, Stefania Bril interpreta a criação dos principais fotógrafos do mundo. Senhor \#328, p. 84, 1987.

. A arte do cotidiano: ela está nas ruas, nos prédios... Não visa lucros a seu criador mas servir à comunidade. Senhor \#346, p. 84, 1987.

. A arte do tropeço. Senhor \#io8, p. 65, 1983.

. A arte e corpo. Senhor \#24, p. 94-95, 1980.

. A arte é para poucos? Os eternos grupinhos, do informal ao abstracionismo.

Senhor \#160, p. 73, 1984.

. A arte maior de uma ourives. Senhor \#9I, p. 72, 1982.

- A arte na mesa: um livro mostra o interesse de artistas antigos e contemporâneos com a náo menos nobre arte de cozinhar. Senhor \#370, p. 84, 1988.

. A arte nas máquinas: a construção de Cumbica: arte e engenharia andando juntas. Senhor \#202, p. 100, 1985 .

- A aventura da tecnologia: memórias de uma atividade que não pode prescindir do estímulo do governo e das empresas privadas. E que desperta muita curiosidade no público. Senhor \#228, p. 108, 1985.

A Bienal da imitação. Senhor \#69, p. 69, 1982.

. A casa concha que pode ser feita por você mesmo. Istoé \#I6, p. 46, I977. 
A casa do Morumbi: em meio ao verde. Casa Vogue \#3, p. 80-86, I984.

A central de boatos: problemas com um código herdado da Colônia. Senhor \#2I4, p. I04, I985.

A civilização do futuro: A arte do ano 2000 deverá contribuir para a difusão de princípios úteis a uma sociedade contaminada pelo consumo. Senhor \#I80, p. IO9, 1984 .

A comunicação em seus novos caminhos e propostas. Senhor \#23, p. 94-95, 1980.

A conquista do supérfluo. Senhor \#177, p. 93, 1984.

A conservação da madeira. Casa Vogue \#6, p. 38, 1987.

A corrida para o diploma: observaçóes de um penetra no mundo mágico do jornalismo, onde um canudo pode valer mais do que a sensibilidade. Senhor \#28o, p. 68, 1986.

A cultura das raízes: por que não um Globo Cultural, para divulgar e incentivar uma produção ainda marginalizada pela mídia brasileira? Senhor \#294, p. 72, 1986.

A cultura de Alagoas: alguns perfis do Brasil imperial e republicano iluminam a leitura de um aprendiz de História. Senhor \#215, p. 79, 1985.

A decadência do plágio: esforços a favor da criatividade da propaganda no Brasil. Senhor \#I43, p. 79, I983.

A democratização da arte: perguntas da Sociologia para um mercado que se fortalece. Senhor \#132, p. 97, 1983.

A descoberta de novos mundos. Senhor \#163, p. 72, 1984 .

A descoberta do móvel polivalente: cômoda, toucador, escrivaninha, estante e cama. Senhor \#22, p. 94-97, 1980.

- A descoberta do passado: uma exposição para comemorar o cinqüentenário da Secretaria do Patrimônio Histórico e Artístico Nacional, marco da recuperação da memória brasileira. Senhor \#3I4, p. 68, 1987.

À descoberta dos simbolistas: um elo esquecido mas importante na longa corrente da história da arte. Senhor \#30, p. II2-II3, I980.

A desordem tolerada: os que querem rever o pós-moderno das vanguardas históricas criam confusóes na arte. Senhor \#319, p. 68, 1987.

A emoção marcada a ferro: não há equívoco maior do que considerar a gravura uma arte menor. Estão aí para provar Bonomi, Grassman.... Senhor \#375, p. 94, I988.

A “escolinha” deu certo: trinta anos de ensino de propaganda e marketing. Senhor \#340, p. I00, 1987.

A escultura avança. Senhor \#94, p. 64, 1983.

A escultura, sem histeria. Senhor \#59, p. 67, 1982.

. A estética das vitrinas: a popularidade de uma arte delicada. Senhor \#282, p. 68, 1986.

A estética do favor: uma viagem à irrealidade dos textos de apresentação das obras artísticas. Senhor \#27I, p. 68, 1986.

A estética internacional: a geléia geral da arte, vista pelos seus mais importantes incentivadores. Senhor \#245, p. II2, 1985. 
. A fábrica de valores: cada época tem o Sócrates que merece. Senhor \#193, p. II5, I984.

. A fantasia do cotidiano: a renovação histórica das atividades culturais. Senhor \#254, p. 72, 1986.

. À flor da pele: também no Brasil a moda já é celebrada como arte. Senhor \#36I, p. $72,1988$.

. A fusão e a confusão: o Ecletismo na arquitetura nem sempre dá uma boa mistura. Senhor \#380, p. 65, 1988.

. A futilidade é o protoplasma da moda: seja elegante. Homem Vogue \#28/B, p. I4, 1977.

A histeria nacionalista: redutos conservadores arrepiam-se com a "morte" da identidade cultural. Senhor \#I28, p. 89, 1983.

. A Holanda nordestina. Senhor \#I71, p. I06, 1984.

. A importância do cálculo: uma visão "excêntrica:" a arte da matemática na arquitetura. Senhor \#219, p. 92, 1985.

. A insubmissão do "radical:" Abramo, que nunca aderiu aos poderosos, nos convidava a refletir sobre a realidade em que vive o ser humano. Senhor \#336, p. 82, I987.

. A interiorização da arte: impressôes de uma visita ao museu de Ribeirão Preto, instalado na fazenda de um "rei do café". Senhor \#354, p. 77, 1988.

. A leitura pelo desenho: a pedagoga Angela Lago não usa texto em seus livros. E ensina às crianças o mundo real através da fantasia. Senhor \#353, p. 65, 1987.

. A medalha inesperada. Senhor \#162, p. 93, 1984.

. A melodia do Ukiyo-ê: exatidão, detalhes, inspiração: a gravura japonesa em sua melhor expressão. Senhor \#34I, p. I08, 1987.

. A Memória e o egoísmo. Senhor \#68, p. 6I, 1982.

- A missão do solitário: sugestão à Bienal deste ano: uma bela homenagem a Volpi, silencioso revolucionário. Senhor \#376, p. 84, 1988.

A moda é parte da existência coletiva. Senhor \#Io, I979.

. A moda objeto de arte. Casa Vogue \#4, p. I16, 1986.

- A multiplicação da novidade: a improvisação e a astúcia nos negócios artísticos. Senhor \#247, p. 92, 1985.

A obra dos penetras: uma visão otimista sobre a inflação de talentos nas artes. Senhor \#213, p. 73, 1985 .

. A obra que surpreendeu a rainha: cinco séculos de Rafael, um pintor sem mistérios. Senhor \#II6, p. 73, 1983.

. A outra farsa de Hitler. Senhor \#II4, p. 69, I983.

- A pátria dos estrangeiros: um país sem revanchismos antropológicos não pode recriar velhos preconceitos contra os imigrantes. Senhor \#23I, p. 92, 1985.

A pintura como denúncia: a importância da obra de Cândido Portinari. Senhor \#205, p. 73, 1985.

A pintura mural. Senhor \#64, p. 65, 1982.

. A poética da embalagem. Senhor \#I70, p. 72, 1984. 
A possível viagem: novos rumos para o mercado de arte no Brasil. Senhor \#230, p. 76,1985 .

A pouca valia dos concursos. Senhor Vogue \#13, p. II4, 1979.

A prontidão dos penetras: como enfrentar a astúcia aos vendedores de obras falsas. Senhor \#220, p. 76, 1985.

A propaganda merece: os 30 anos da MPM e lembranças dos tempos pioneiros. Senhor \#329, p. 82, 1987.

. A propósito dos tapetes.... Casa Vogue \#I, p. 64, 1987.

. A redação vai ao museu: as artes do Jornal da Tarde expostas no Masp. Senhor \#252, p. 73, 1986.

A renovação da arte: a didática histórica sobre manifestaçóes artísticas que podem mudar velhos conceitos. Senhor \#290, p. 64, 1986.

. A revolução dos brinquedos. Senhor \#I09, p. 88, 1983.

- A safra da arte religiosa: maravilhas do catálogo do Museu de Arte Sacra. Senhor \#I53, p. 84, I984.

A sátira pela imagem: quando a fotografia serve à polêmica e à provocação. Senhor \#35I, p. 84, 1987.

. A saúde do patrimônio: o acervo cultural corre perigo em todos os países, mas já existe um esforço inicial para mudar a situação. Senhor \#242, p. 88, 1985.

. A Semana quase futurista: antropofágias brasileira do mito Marinetti, a partir do evento de 1922 e dos calafrios que o ídolo provocou quatro anos depois, numa visita que trocou o Páo de Açúcar pela favela. Senhor \#182, p. 76, 1984.

. A síndrome dos gênios: o que há por trás da santa loucura dos artistas. Senhor \#320, p. 68, 1987.

A solidariedade urbana. Senhor \#86, p. 65, 1982.

. A trégua chega aos museus. Senhor \#76, p. 65, 1982.

. A uniāo pela arte: na Nigéria, onde existem 200 dialetos diferentes, as manifestaçóes artísticas refletem uma unidade cultural. Senhor \#325, p. 84, 1987.

A Urbanística: reflexão sobre qualidade de vida. Istoé\#I2, p. 44, 1977.

A verdade é uma escultura: memórias de dois artistas pouco reconhecidos. Senhor \#299, p. 68, 1986.

. A vez das enciclopédias: onde está o nosso Giovanni Treccani? Senhor \#176, p. 80,1984 .

A vez de Brasília. Senhor \#98, p. 69, 1983.

. A vez do figurativo: com a mostra do pintor Franco Cilia, o Masp abriu mais um espaço na discussão que envolve o complexo panorama da pintura neste final de século. Senhor \#312, p. 68, 1987.

A vocação da memória: quarenta anos do Masp: o resumo de um trabalho que entrou em contato direto com os museus do Exterior. Senhor \#293, p. 75, 1986.

A volta ao clássico: arquiteto vai mudar o que o Beaubourg tem de mais moderno. Senhor \#259, p. 76, 1986.

Academie-vangarde: ou, como descambar rapidamente para o ocaso. Senhor \#34, p. 72-73, I98I.

. Adhemar e o Masp: sem ingratidão. Senhor \#58, p. 67, 1982. 
. Algumas pistas para cercar o trabalho de Renoir: as cinco obras do mestre, expostas no Masp, são indispensáveis para qualquer retrospectiva internacional. A opiniāo é de experts de Paris e Londres. Senhor \#224, p. 73, 1985.

. Alquimia arquitetônica. Istoé\#25, p. 6I, 1977.

. Ambiguidades da crítica. Senhor \#i8I, p. 80, I984.

. America Latina, ser ou não ser: este mundo existe além do geográfico? Senhor Vogue \#18, p. 104-105, 1979.

. Amor à tipografia. Senhor \#IO2, p. 69, 1983.

Antenção às paredes. Casa Vogue \#2, p. 78, 1986.

. Antiqua, simbiose de dois momentos. Casa Vogue \#8, p. II3, I979.

. Arquitetura. Senhor Vogue \#I2, p. 89, 1979.

. Arquitetura corrente e inteligente: P.M. Bardi fala desta casa. Casa Vogue \#2IA, p. 8I, 1977.

. Arquitetura e Arte. Casa Vogue \#2, p. 76, 1985.

. Arquitetura e engenharia na construção. Casa Vogue \#I, p. 48, 1986.

. Arquitetura prêt-à-porter: o uso de pré-moldados nas obras públicas de Salvador. Senhor\#378, p. 67, I988.

Arquitetura: um passo atrás. Senhor \#II5, p. 93, 1983.

. Arte ao ar livre. Casa Vogue \#4, p. 84, 1988.

. Arte da América Latina, além das bienais e do exotismo: a arte do Continente é caudalosa, e nem sempre as promoçóes oficiais revelam sua dimensão mais profunda. Senhor Vogue \#18, p. 99, I979.

. Arte e mulheres. As preferências de Bardi. Vogue Brasil \#II5, p. I44-I45, 1985.

. Arte na hora do chá. Senhor\#92, p. 68, 1982.

. Arte para encher os olhos. Senhor \#103, p. 67, 1983.

. Arte para ver e usar: o design precursor da mulher do futuro. Senhor \#330, p. 83, I987.

. Arte Vogue. Senhor Vogue \#12, p. 83, 1979.

. Arte, coração da indústria: a alquimia das cores no território da tecnologia. Senhor \#28I, p. 68, 1986.

- Artes de um escrivão público: agradar a artistas e críticos tem sido um dos muitos fardos de um diretor de museu. Mas o importante é saber o momento adequado para investir numa obra pouco conhecida. Senhor \#217, p. 72, 1985.

. As aquarelas-memória de Miguelzinho: nestas aquarelas, um pouco da história de S.Paulo, esquecidas como Miguelzinho, seu autor, num canto deste país sem memória. Senhor \#40, p. 64-65, I98I.

. As artes e o Senhor: arte societária, II Mostra Internacional de Cinema, Tito de Almeida e Millôr. Senhor Vogue \#II, p. 98, 1979.

. As aulas de Le Corbusier: uma evocação dos mestres da arquitetura. Senhor \#197I98, p. IOO, 1984 .

As brigas com a estética: a necessidade de pesquisar os movimentos artísticos deste século e decifrar seus inúmeros labirintos. Senhor \#260, p. 73, 1986. 
As cadeiras. Casa Vogue \#2, p. 56, 1987.

As confusões do "Espaço". Senhor \#62, p. 69, 1982.

As descobertas de Pietro Maria Bardi. Vogue Brasil\#II5, p. I36-I37, 1985.

As frenéticas corridas para se acompanhar a moda: Paris e Nova York nos dizem, antes, o que é bom. Senhor Vogue \#16, p. 106-109, 1979.

As leis do mercado de arte. Senhor \#65, p. 69, 1982.

As luzes de Paris: um debate com o presidente do Centro Georges Pompidou.

Senhor \#196, p. 92, 1984.

As manias do público: quais são os critérios artísticos dos visitantes dos museus? Senhor \#I23, p. 89, I983.

. As marés e as rochas: nas artes, tudo o que ó novo será fatalmente imaturo? Senhor \#355, p. 65, 1988 .

. As memórias da cidade: "paulista não é homem muito dado a diversóes... um homem mais dado à luta que um bom viveur, accomodado às facilidades da terra e da boa fortuna." Senhor \#47, p. 72, I98I.

As quermesses de arte. Arte? As festinhas cheias de medalhas inúteis, e os leilóes regados a whisky e champagne. Senhor \#29, p. I04-I05, I980.

. As trapaças da arte: perdas e danos de um negócio cheio de armadilhas. Senhor \#235, p. 88, 1985 .

As vestes de um pioneiro: uma noite inesquecível na Universidade Mackenzie. Senhor \#253, p. 68, 1986.

Assunto: caricatura: ou, o sucesso de um desenhista brasileiro numa grande exposiçáo em países de além Cortina de Ferro. Senhor \#35, p. 80-8I, I98I.

Astúcias da arte num tempo de política: uma reunião acadêmica na Universidade Mackenzie, com vaias, aplausos, uma medalha e consideraçôes múltiplas sobre a capacidade da cultura de abrir todas as portas. Senhor \#187, p. 77, I984.

Audácias de um Pasquim do Império: A reedição de um jornal pioneiro na sátira política e dos costumes, que sacudiu a São Paulo provinciana de I876. Senhor \#5I, p. $72,1982$.

Aventuras de Manet em São Paulo. Senhor \#II7, p. 73, 1983.

. Balanço de um valente. Senhor \#179, p. 77, 1984.

Bienal, Trienal, Quadrienal.... Senhor \#33, p. 65, 1980.

. Bom gosto (I) e consideraçóes sobre o mau gosto (II). Homem Vogue \#2I/B, p. I6, 1977 .

Brasil 2I: uma revista voltada para o futuro dá 500 mil por seu logotipo. Senhor \#25, p. I7, 1980 .

Brasil, um grande exportador de pincéis: o filho de um madeireiro se propôs um dia a fabricar pincéis. Seu sonho é hoje uma realidade. Senhor \#43, p. 72, I98I.

. Brasil-ltália, um espaço cultural cada vez maior: um entendimento já disseminado no cotidiano e que agora alcança dimensôes inéditas com a programação de múltiplos eventos. Senhor \#270, p. 72, 1986.

Burocracia nacional e arte latino-americana. Um encontro infeliz. Senhor Vogue \#I8, p. I06, I979. 
. Candidatos ao Olimpo: no mercado de artes, investir em nomes consagrados sai caro. Melhor é se antecipar à fama. Senhor \#365, p. 68, 1988.

. "Cansado de quê?": as homenagens dos amigos nos 40 anos do Masp retemperam a alma de um velho galerista. Senhor \#344, p. 78, 1987.

. Cartas extraviadas: as cartas são imaginárias, mas os problemas da arte bem reais. Senhor Vogue \#I2, p. 97, 1979.

- Casa sem goteira: livre das infiltraçóes de água, o Masp já pode receber de volta o acervo que enviou à Europa. Senhor \#363, p. 73, 1988.

. Casas de Cultura? Senhor Vogue \#I5, p. I03, 1979.

. [Catálogo de Objetos Impossíveis de achar]. Senhor Vogue \#15, p. IO2, 1979.

. Cem anos, com exclamação: o Museu de Arte de São Paulo comemora o centenário de nascimento do arquiteto Le Corbusier. Senhor \#343, p. 92, 1987.

. Chega de adular a cultura: a tecnologia brasileira é que está precisando de um museu. Senhor \#I42, p. 77, 1983.

- Chega de rotina: romper com o pesadelo da mesmice resgata o papel da arte e reinventa a emoção de estar vivo. Senhor \#316, p. 67, 1987.

. Cinquenta retratos do Brasil. Senhor \#III, p. 73, I983.

. Coisas da indústria antiga e moderna. Senhor \#75, p. 63, I982.

. Coisas do patrimônio. Senhor \#78, p. 69, 1982.

. Coleção Arte Brasileira. Casa Vogue \#5, p. I44-I47, 1983.

. Como desenhar uma cadeira? Casa Vogue \#3, p. 78, 1985.

Como ler a fórmula de Einsten? Homem Vogue \#23/B, p. I4, 1977.

. Como ocupar o espaço: preencher paredes, sem critério, pode transformar-se num problema estético de difícil solução. Senhor \#268, p. 90, 1986.

. Como salvar os museus? Uma atividade que sofre tanto quanto os acervos. Senhor \#I78, p. 75, I984.

. Comunicação no Brasil. Casa Vogue \#3, p. 62, 1984.

. Conselho aos investidores: o delicado terreno do mercado de arte, onde deve prevalecer a sensatez e a sensibilidade. Senhor \#29I, p. 68, 1986.

. Conselhos ao colecionador: num documento sobre a arte russa de vanguarda, um "expert" publica as suas regras para se formar um acervo. Senhor \#55, p. 72, 1982.

. Conservar, para sobreviver. Senhor \#93, p. 72, 1982.

. Contrastes da forma: uma exposição que é um banquete modernista. Senhor \#288, p. 68, 1986.

. Conversa pessoal: recordaçóes de uma antiga amizade com Gilberto Freyre.

Senhor \#332, p. 84, 1987.

. Cresce o mercado de arte. Senhor\#ı38, p. 76, 1983.

. Cuba libre. Mas a sua produção de arte um tanto prisioneira. Senhor Vogue \#18, p. 106, 1979 .

. Cuidado ao destruir. Casa Vogue \#5, p. 92, 1984.

. Cuidado! O passado quebra. Senhor Vogue \#6, p. IO6-II3, I978. 
Cultura além da paróquia: depois da Lei Sarney, esta é a hora de os nossos editores levarem ao Exterior a cultura brasileira. Senhor \#304, p. 68, 1987.

. Cultura não é sobremesa: a importância do intercâmbio artístico para o desenvolvimento das relaçóes entre o Brasil e o Japão. Senhor \# I84, p. Io6, I984.

Cultura, recursos. Senhor Vogue \#18, p. I07, 1979.

. Dando notas e esperando também! Vogue Brasil \#II5, p. I55, 1985.

. Das raízes para o universal. Senhor Vogue \#18, p. Io8-I09, I979.

Deixa comigo que eu vou mostrar uma novidade: a magia de Wesley, do tufão da Rex ao mapa-mundi de agora. Senhor \#27, p. 22, 1980.

Dentre os premiados pela Associação Paulista dos Críticos de Arte, versão-8I, o escriba que assina esta seção:justa homenagem a três artistas solitários, inquietos, contestadores. E ao velho professor, que diz: “grazie”. Senhor \#37, p. I28-I29, I98I.

Design. Senhor Vogue \#I3, p. IIO-I2I, 1979.

Design italiano, exemplo para o Brasil. Senhor Vogue \#I3, p. II2, I979.

. Design: o vôo dos pioneiros: uma conferência no Instituto Tecnológico da Aeronáutica desencadeia reflexôes sobre a arte de projetar avióes. Idéias que vão render uma exposição no Masp. Senhor \#221, p. 73, 1985.

Dilema. Senhor Vogue \#I4, p. 94, 1979.

. Direita, esquerda. A arte sublima a política. Senhor Vogue \#18, p. I06, 1979.

. Disciplina em vias de expansão. Senhor Vogue \#I3, p. II3, I979.

. Dois homens do lazer: José Papa Jr. e Roberto Requixa. Senhor Vogue \#15, p. 96, I979.

Don Cicillo, um Matarazzo nas artes. Istoé \#I8, p. 40-4I, 1977.

. E como sobremesa, uma bíblia do massacre: No álbum de cartuns de Hugo Corrêa, o julgamento do gosto humano pela criminalidade guerreira implica uma condenação carregada de ironia. Senhor\#i69, p. 65, 1984.

E nenhuma escola de design. Senhor Vogue\#I3, p. I20, I979.

. E os leilóes, chegar ao fim? Se não chegarem, que o comprador inexperiente se acautele. Mas o "boom” deve entrar em baixa fatal. Senhor \#39, p. 96-97, I98I.

. Em tempo: Le Corbusier: um livro imprescindível para lembrar um centenário que já passou - mas, que importa, se o personagem é eterno? Senhor \#358, p. 65, 1988.

Emoções de um colecionador: uma arte contra muitos preconceitos, à procura das obras esquecidas dos brasileiros anônimos do passado. Senhor \#134, p. 84, 1983 .

Engenharia, arquitetura e arte. Casa Vogue\#4, p. 76, 1985.

Entre a Arte e o Design. Senhor Vogue \#13, p. II6, I979.

. Espírito de vitória: A força do humanitário Chateaubriand. Istoé Senhor \#I202, p. $75,1992$.

Estética do investimento. Senhor \#99, p. 69, 1983.

Estilos misturados: a arte encontra a técnica, e vice-versa, na ciranda de revoluçóes estéticas ocorridas neste século. Senhor \#26I, p. 76, I986. 
. Estranho, esquisito, indesejável (antes de ser colecionado). Senhor Vogue \#ı6, p. IIO-III, I979.

. Eu, crítico? Vogue Brasil \#I, p. I48-I49,I76-I77, I975.

. Evocação romântica: ao falar dos velhos edifícios de São Paulo, os cronistas mostram a arte no início da industrialização. Senhor \#318, p. 68, 1987.

. Evocações de Le Corbusier no Brasil. Istoé\#29, p. 57, I977.

. Evocaçóes de um monumento: um conjunto bancário recentemente inaugurado sintetiza a comunhão da arquitetura com técnicas urbanas sofisticadas. Senhor \#310, p. 67, 1987.

. Exame radiográfico de pintura. Senhor Vogue\#12, p. 96, 1979.

Excessivamente kitsch. Casa Vogue \#3, p. 80, 1986.

Ezra Pound: evocaçóes: no centenário do poeta, retalhos de uma velha amizade. Senhor \#243, p. 88, 1985 .

Falando de privilégios. Senhor \#IOO-IOI, p. 8I, I983.

Feira não motivou industriais. Senhor Vogue \#I3, p. II3, 1979.

. Flashes do futuro: entre o excesso de novidades, algumas obras são exemplos do avanço das artes em múltiplas direçóes. Senhor \#309, p. 68, 1987.

Fora das metrópoles: piedade, no interior de São Paulo, abre sua Casa da Cultura.Senhor \#356, p. 65, 1988.

. Fotografia: arte mecânica e figurativa. Casa Vogue \#4, p. 36, 1987.

. Fragmento por fragmento: a escultura de Margarida de Brabante é recomposta em Gênova. Senhor \#345, p. 84, 1987.

. Gente e eventos. Senhor Vogue \#I4, p. I06, I979.

. Gente e eventos: Aposentadoria; Unicamp. Senhor Vogue \#13, p. I2I, I979.

. Gentoteca: uma solução? Casa Vogue \#I, p. 54, 1985.

. Hábito, vício, mania da simetria. Homem Vogue \#29/B, p. 28, 1977.

. Histórias de falsários. Senhor \#79, p. 69, 1982.

. Inéditos de Modigliani: o centenário de um mestre descobridor dos segredos pláticos, que, na sua época e em sua própria terra, sofreu também a injustiça do esquecimento e da incompreensão. Senhor \#I55-156, p. 89, 1984.

. Inspiração oriental: a arte japonesa está em exposição no Masp. Senhor \#379, p. 92, 1988.

. Intervenção na arquitetura: um exemplo de recuperação artística e histórica em Gênova. Senhor\#218, p. 76, 1985 .

Itália de todos os mundos: no Masp, plano geral de um país de descobridores. Senhor\#133, p. 69, 1983.

- Joaquín Torres-Garcia, o mergulho na alma latino-americana: um complexo artista plástico, de raízes peculiares, atinge o universal. Senhor Vogue \#I8,

p. IOO-IO3, 1979.

. Labor para historiadores: se é trabalhoso decifrar Vênus e Cupido, o que estará reservado aos pesquisadores de um Kandinsky. Senhor \#305, p. 65, 1987.

. Le Corbusier, modernista: rabiscos inéditos de uma visita ao Rio de Janeiro e uma conferência que abalou o Brasil. Senhor \#352, p. Ioo, 1987. 
Lembrança de Le Corbusier: como surgiu uma estética anti-sensual de um olhar fascinado? Senhor \#188, p. 80, 1984.

Lembranças de Assis: o que um livro sobre Chateaubriand tem a oferecer ao País. Senhor\#359, p. 67, 1988.

Lembrem-se de Delacroix: a burocracia dos salóes desfavorece a arte. Senhor \#350, p. 8I, 1987.

. Luigi Vietti, arquiteto e urbanista. Resistente, conciliador, criativo. Senhor Vogue \#5, p. I8, 20, 1978 .

. Made in England: em São Paulo, o lirismo de um estadista cáustico e a crítica de um pintor lírico. Senhor \#25, p. IIO-II3, I980.

Mais uma viagem do Masp. Senhor \#80, p. 64-65, 1982.

. Manchas e rabiscos: Wallinho Simonsen, a revelação de uma maturidade. Senhor \#85, p. 69, 1982.

Mão dupla para a África: Pierre Verger, em livro e numa mostra em preparação, antecipa os IOo anos da Libertação. Senhor \#339, p. 84, 1987.

. Marketing: arte e agilidade. Senhor \#I6I, p. 69, I984.

. Memória negra: inaugurada há pouco em Salvador, a Casa do Benin será um espaço permanente de reflexão sobre a influência africana na etnografia brasileira. Senhor \#374, p. 68, 1988.

. Memórias da revolução: um livro sobre o Impressionismo procura levantar as dificuldades iniciais do movimento. Senhor \#313, p. 65, 1987.

Memórias do "rei dos ventos:" as aventuras dos trens brasileiros e sua galeria de heróis. Senhor \#I44, p. 79, 1983.

Mercado. Senhor Vogue \#I4, p. IO2-I05, 1979.

. Mestre do figurativo: mal compreendido à sua época, Lasar Segall nada fica a dever aos maiores expressionistas alemães. Senhor \#377, p. 92, 1988.

. Mestres do retrato. Senhor \#70, p. 69, 1982.

. Michelangelo, séc. XX: Sérgio Ferro recaia um mestre, descobrindo novas interpretaçôes, numa proposta singular e polêmica. Senhor \#42, p. 70, I98I.

. Milagres da arte popular: o Masp faz uma exposição de pintores primitivos, apesar da má vontade de certos especialistas. Senhor \#172, p. 72, I984.

Molecagem com o Belo. Senhor \#167, p. 97, 1984.

. Mudanças no ensino das artes: aprender com liberdade, uma opção capaz de romper com o pedantismo. Senhor \#135, p. 72, 1983.

Museus, um cabidão de empregos? No lançamento da correspondência de dois pioneiros da abertura cultural, um alerta para o abandono de nossos museus. Senhor \#4I, p. 70, I98I.

Na sala de espera de Franz. Senhor Vogue \#I7, p. I09-III, I979.

Não temos Design. E de quem é a culpa? Há muitas dificuldades a definição de um design brasileiro, segundo Alexandre Wollner. Senhor Vogue \#13, p. II8-II9, I979.

. Nas fachadas, a nova moda foliona. Istoé \#15, p. 46, 1977.

. Natureza viva: a arte do ikebana nos arranjos florais do mestre japonês Sen'hei.

Istoé Senhor \#982, p. I26, 1988. 
. Neurose no começo do século. Senhor Vogue \#17, p. II2, I979.

No baile das artes. Casa Vogue \#6, p. 36, 1985.

. No campo movediço da Cultura. Senhor \#60, p. 67, 1982.

. No coração do passado. Senhor \#I73, p. 72, 1984.

No decor matrimonial. Homem Vogue \#25/B, p. I0, 1977.

. No Masp, mais uma exposição fundamental: os arquivos de São Paulo, enfim livres dos ataques do descaso, do pó e dos cupins. Senhor \#38, p. 96-97, I98I.

. Nos jardins da memória. Senhor \#77, p. 65, 1982.

. Nos labirintos da estética: a difícil missão de escrever sobre arte numa época confusa. Senhor \#I39, p. 93, I983.

. Nossa memória pede socorro. Senhor \#158, p. 89, 1984.

. Nosso tempo livre: o lazer e seus negócios encarados como uma obra de arte.

Senhor Vogue \#15, p. 94-106, 1979.

. Nota Io ou nota zero? O labirinto dos julgamentos sobre arte. Senhor \#244, p. 96, 1985 .

. Notas de viagem: Niemeyer lança um olhar inteligente em direção da Ponte Vecchio e percebe que a contribuição árabe está por toda parte. Senhor \#367, p. 68, 1988.

. Notas meridionais: sobre um artista em dois mundos. Senhor \#I95, p. 92, 1984.

. O Antigo e nós: os problemas do tempo na cultura e as fórmulas que usamos para solucioná-los. Senhor \#32, p. 96-97, 1980.

. O aprendizado do ursinho: as memórias de um jornalista íntimo dos homens que mandaram no Brasil nas últimas décadas. Senhor \#24I, p. II6, 1985.

. O arquivo e a Constituinte: para estudar nossa história recente será preciso ir aos Estados Unidos? Senhor \#360, p. 63, 1988.

. O arrepio contemporâneo: o que é o novo e o que é o bom? A arte percorre estranhos caminhos antes de impregnar a sociedade. Senhor \#204, p. 73, 1985.

. O arrepio do inédito: estamos próximos a uma revolução, que poderá jogar o modernismo para o espaço. O que será? Senhor \#292, p. 84, 1986.

. O assunto é mobiliário. Casa Vogue \#3, p. 26, 1987.

. O barril dos peixes: o árduo trabalho de costurar conceitos adversos na obra comum da arte: afinal, quem são os primitivos? Senhor \#286, p. 76, 1986.

. O benefício da confusão: a arte incorpora o computador, ao mesmo tempo em que sente saudades do figurativo. Quem vencerá: a vanguarda ou o academismo? Senhor\#333, p. 79, 1987.

. O boom do tempo livre: criatividade artística agora é moda na sociedade de massas. Senhor \#I2I, p. 65, 1983.

. O boom dos catálogos: as empresas fazem o levantamento peça por peça, dos acervos dos museus brasileiros. Senhor \#246, p. 9I, I985.

. O brilho sagrado da prata: os artífices, motivados pelo culto, produziram muitas obras-primas. Senhor Vogue \#16, p. 104-105, 1979.

. O caçador de temas: o rastro de Picasso nos 360 desenhos apresentados no Brasil. Senhor\#269, p. 76, 1986. 
. O cansaço do figurativo. Senhor \#87, p. 73, 1982.

. O caso Rembrandt: testemunho pessoal sobre uma leviandade. Senhor \#306, p. $65,1987$.

O clima da arquitetura: como abrir as janelas da arte para o sol. Senhor \#285, p. 68, 1986.

O colecionador salva do esquecimento aquilo que no futuro representará a história. Casa Vogue \#36A, p. 80-8I, 1978.

O conflito no lazer. Senhor Vogue \#15, p. I06, 1979.

O crime das cinco letras. Senhor \#84, p. 65, 1982.

. O delírio das artes: um fenômeno comercial? Mas há bons sinais por trás disso. Senhor\#317, p. 68, 1987.

O destino das cidades: a importância da memória nos planos de renovação urbana. Senhor \#263, p. 74, 1986.

O destino dos estilos: o tempo os apaga numa contínua superposição de formas. O Neoclássico é um caso exemplar dessas transformaçóes. Senhor \#362, p. 80, I988.

O dinheiro da arte: o mecenato e a formação do patrimônio do Masp. Senhor \#226, p. 85 , 1985 .

O direito a memória: discute se nacionalmente, na Itália, a conservação de museus. Um tema, aliás, que também afeta o Brasil. Senhor \#308, p. 65, 1987.

. O direito histórico da Arte: no Brasil, um problema idêntico ao dos mármores da Acrópole. Senhor \#II9, p. 92, 1983.

O dom da voz: o apresentador e empresário Sílvio Santos conversa nas ruas como fala nos palcos. Foi nas ruas, aliás, que ele aprendeu a ser persuasivo e se convenceu de que o querer oferece o vencer. Senhor \#366, p. I00, 1988.

. O encanto das pequenas obras. Senhor \#189, p. I40, I984.

O erotismo de Zaragoza: e o texto lúcido e lógico de Jacob Klintowitz. Senhor \#28, p. II2-II3, I980.

O espaço do gesto criador: visita ao repousante caos de um ateliê de artista. Senhor \#321, p. 68, 1987.

O estilo faraônico: Brasília toma ao pé da letra, na sua arquitetura, o padrão de vida local. Senhor \#334, p. 82, 1987.

O exemplo da Sul América. Senhor Vogue \#16, p. 99-IOI, I979.

. O fiasco da aposentadoria: a informação não ó raio laser, mas apenas simples saber. Senhor \#267, p. 68, 1986.

O futuro do passado: o antiquariato: peças antigas, gosto atual. Senhor \#369, p. $82,1988$.

. O Grande Incêndio: São Paulo, 26 de maio de 2089. Homem Vogue \#25/B, p. 92-96, 1977 .

O jogo dos estilos: as oscilações da arquitetura no território brasileiro. Senhor \#284, p. 68, 1986.

O labirinto da comunicação: um balanço de Pero Vaz de Caminha à informática. Senhor \#200, p. 88, 1985. 
. O manifesto de Piracicaba: os salóes de Arte estão-se tornando frequentes no Brasil e refletindo o mundo cheio de labirintos de nosso tempo, inventor de poéticas imprevistas. Senhor \#48, p. 72, I98I.

. O manso leão das artes: o Imposto de Renda e a participaçáo cívica dos empresários na cultura nacional. Senhor \#223, p. IOI, 1985.

. O Marquês não é mais um sádico. Senhor Vogue \#I7, p. I08, 1979.

. O mercado assinatural: comprar para estocar. Essa é a tese do chamado colecionador. Quer dizer, do comerciante. Mas isso não ofende a arte? Senhor \#36, p. 72-73, I98I.

. O mercado das artes. Casa Vogue \#5, p. 106, 1986.

. O mercado enlouqueceu: quantos Abaporus vale um Van Gogh? Senhor \#323, p. $68,1987$.

. O nervosismo das vanguardas: um trabalho difícil para historiadores e críticos. Senhor \#250-25I, p. 80, I985.

. O nó da tradição: a contribuição do artesanato à cultura brasileira. Senhor \#240, p. 80,1985 .

. O novo academismo: um debate sobre as energias e o cansaço do Figurativo.

Senhor \#183, p. 72, 1984 .

. O ofício da crítica: o exemplo das mostras didáticas no Exterior. Senhor \#227,

p. 82,1985 .

. O ouro da natureza: o difícil garimpo da Arte, entre a emoção e a História.

Senhor \#298, p. 76, 1986.

. O ouro que sobrou: imagens do apogeu pré-colonial na América do Sul. Senhor \#371, p. 68, 1988.

O pacifismo e os encantos da mocidade: uma homenagem em meio à Autobiografia, de Bertrand Russell: para meditar sobre a crise e renovar o otimismo. Senhor \#190, p. 88, 1984.

. O pânico do futuro: enquanto os artistas se afundam na abstração, os cientistas preparam o Apocalipse. Senhor \#216, p. 76, 1985.

. O papel histórico da nossa vanguarda: um balanço do trabalho dos pioneiros que colocaram a arte brasileira no rumo da modernidade. Senhor \#20I, p. 84, I985.

. O Picasso da arquitetura: memórias de Le Corbusier e a sua obra cheia de contradições. Senhor \#315, p. 68, 1987.

O poder econômico da arte: o mercado brasileiro deve abrir os olhos para o potencial que existe nos objetos artísticos. Para isso, é preciso optar pelo comércio de alto nível. Senhor \#296, p. 84, 1986.

. O "poster" japonês contemporâneo: Vendo de perto a arte japonesa, os críticos podem analisar sua influência na formação da escola nipo-brasileira. Senhor \#52, p. II, I982.

. O "pot-porri” que se chama de mediterrâneo. Istoé \#17, p. 46, I977.

. O preço da vanguarda. Senhor \#67, p. 69, 1982.

. O purgatório paradisíaco do marquês Von Bayros. Homem Vogue\#29/B,

p. II2-II5, I977. 
O relâmpago dos pincéis: A convivência com uma fábrica que fornece a matéria-prima da pintura na era industrial provoca algumas reminiscências do tempo dos mestres. Senhor \#186, p. 76, 1984.

O resgate romântico: o novo edifício de esportes do Sesc Pompéia enriquece o esforço brasileiro em favor da memória. Senhor \#295, p. 84, 1986.

O senhor coleciona? O que coleciona? Minhas andanças são maratonas afortunadas. Vogue Brasil \#II5, p. I5I, I985.

. O sexo na televisão. Senhor Vogue \#I7, p. II2, I979.

O sonho da cidade ideal: os tumultos do progresso criaram a necessidade de reformas totais no espaço urbano. Mas como adequar desejos e aspiraçóes a uma realidade cada vez mais negativa? Senhor \#234, p. 82, 1985.

. O sono das artes plásticas: Um setor que pouco se envolveu com a denúncia social no Brasil. Senhor \#209, p. 88, 1985.

. O talento em poliedro. Senhor \#97, p. 69, 1983.

- O tecido da memória: datas, nomes, encontros e surpresas: o difícil e gratificante balanço de experiências entrelaçadas pelo tempo. Senhor \#262, p. 92, 1986.

. O terno combate de Segall. Senhor \#I26, p. 69, I983.

O tesouro do Caribe: Fica em Cuba um dos mais ricos acervos artísticos da AL. Senhor\#368, p. 65, 1988.

O tímido respeito ao DI. Senhor Vogue\#I3, p. II5, 1979.

. O vale-tudo dos estilos: indefiniçóes da arquitetura numa época fechada para as reformas estéticas. Senhor\#I29, p. 69, I983.

. O valor da "Arte menor". Senhor \#IO5, p. 82, 1983.

. O verdadeiro milagre da Virgem: uma festa em Aparecida do Norte e algumas reflexôes sobre a permanência da Arte. Senhor \#82, p. 69, 1982.

. O vírus do Kitsch. Senhor \#IO4, p. 8I, I983.

. Obras autênticas. Casa Vogue\#3, p. 84, 1988.

[Observador]. Senhor Vogue \#12, p. 88, 1979.

. Os 40 anos de uma ousadia: como é que o Masp, graças a Assis Chateaubriand, garimpou ouro na terra do café. Senhor \#342, p. 84, 1987.

Os antiacadêmicos do Rio. Senhor \#73, p. 69, 1982.

. Os artistas são pitonisas? O pintor Francisco de Mello une homens e máquinas, com um desenho escrupuloso. Senhor \#54, p. 68, 1982.

. Os caprichos da Arquitetura: uma arte que dificilmente chega ao consenso.

Senhor \#120, p. 73, 1983.

. Os críticos dos trópicos: arte na imprensa, um setor aberto à xingação e ao ataque pessoal. Senhor \#I45, p. IOO, I983.

. Os empresários têm cultura: Sarney disse o contrário e se equivocou. Confundiu inculto com maus administradores de indústrias. Senhor \#326, p. 79, 1987.

. Os escultores-arquitetos. Senhor \#96, p. 69, 1983.

Os especialistas inúteis: a difícil caçada das obras-primas internacionais. Senhor \#208, p. 73, 1985 . 
Os heróicos museus do Interior: esperanças para uma atividade maldita. Senhor \#IIO, p. 85, 1983.

. Os italianos no Brasil: no Museu de Arte de São Paulo, uma comovedora exposição sobre a vida, a arte e a cultura dos imigrantes que ajudaram a fazer o Brasil. Senhor \#3I, p. IIO-II3, I980.

. Os jovens e a pintura: surpresa: nenhuma obra da transvanguarda no Prêmio Pirelli. Senhor \#I4I, p. 95, 1983.

. Os leilóes melancólicos: livrar-se dos preconceitos é um bom início para quem quer modificar a rotina artística em São Paulo. Senhor \#72, p. 69, 1982.

. Os mitos da arquitetura: qual a diferença entre admirar o Partenon e dormir embaixo da ponte? Senhor \#30I, p. 68, I986.

. Os nervos abalados da Crítica. Senhor \#6I, p. 65, 1982.

. Os pára-quedistas da arte: eles existem aos montes, expóem em qualquer lugar, promovendo uma confusão dos diabos com seu amadorismo. Senhor \#44, p. 72, I98I.

. Os paroquianos da cultura: o vôo rasteiro dos candidatos que não conhecem as verdadeiras necessidades de uma área desamparada. Senhor \#276, p. 68, 1986.

. Os possíveis milhóes (de dólares) do nosso mercado de arte. Senhor Vogue \#4, p. 58-69, 1978.

. Os salóes do fim do século. Senhor \#90, p. 69, 1982.

. Os segredos da estética: um acervo que funciona como impulso e revelação. Senhor\#300, p. 84, 1986.

. Os sucessos da antiarte: Paul Klee na carroceria de um automóvel. Por que não? Senhor \#337, p. 106, 1987.

. Os últimos dias do cidadão Chatô. Istoé \#8, p. 80-87, 1976.

. Oscilaçôes do mercado de arte. Senhor Vogue \#II, p. 96-97, 1979.

. Ossos e nervos do Copa: a pesquisa fotográfica de Olney Krüse nas salas e corredores de um edifício-símbolo do Rio antigo ajuda a desmascarar a moda da poluição visual. Senhor \#185, p. 90, 1984.

. P.M. Bardi: O anjo sem asas das artes. Senhor Vogue \#II, p. 76-84, 1979.

. Parado no tempo: para o arquiteto Manuel Siqueira Marques, a fotografia é uma arte menor. Senhor \#348, p. I08, 1987.

. Patrimônio e iniciativa. Senhor \#I48, p. 67, 1984.

. Pela janela do mundo. Senhor \#7I, p. 69, 1982.

. Pelas trilhas de minas: os caminhos da Arte mineira estão no Masp. Lá perfilam-se os figurativos, os românticos, futuristas e até os tradicionalistas. Senhor \#45, p. 70, 198I.

. Picasso para adolescentes. Senhor Vogue \#17, p. II2, I979.

. Pier Luigi Nervi: o mestre do concreto. Senhor Vogue \#I2, p. 84-85, 1979.

. Pietro Maria Bardi. Vogue Brasil \#II5, p. II6-I35 (I62), 1985.

. Pimenta no vatapá: um novo espaço para o debate cultural. Senhor \#233, p. 76, 1985 .

. Pintura. Senhor Vogue \#I4, p. 94-IO7, 1979. 
Pintura para pintura: o prazer dos críticos é descobrir a possível vocação, a intimidade, a emoção, o secreto intransmissível da arte de pintar. Senhor \#53, p. 68, 1982.

Porcelana chinesa, emoção para uns poucos:o requinte branco e azul, de Ming e Ching. Senhor Vogue \#16, p. IO2-IO3, 1979.

Pós-moderno para quê? Um tema entre a excessiva superficialidade e a promessa de humanizar as manifestaçóes artísticas. Senhor \#289, p. 68, 1986.

Prático, leve e lavável. Senhor Vogue \#13, p. II3, 1979

Prêmio para um autodidata: por seu trabalho à frente do Masp, Pietro Maria Bardi recebe a distinção de doutor honoris causa. Senhor \#373, p. 78, 1988.

Princípio de conversa: o Ministério da Cultura, que nasceu sob suspeita, mostra que está aí para ficar. Senhor \#327, p. 84, 1987.

Propriedade, compostura, inteligência. Uma casa do arquiteto Raul di Pace. Casa Vogue \#3, p. 36-4I, 1979.

Quando a arquitetura esquece sua função: é normal surgirem projetos arquitetônicos revolucionários, mas que se esquecem de sua função primeira: servir de abrigo às pessoas. Senhor \#46, p. 70, 1981.

Quanto vale o passado? Senhor \#57, p. 77-78, 1982.

Questão de estilo. Casa Vogue \#5, p. 34, 1987.

Raros tesouros brasileiros. Senhor \#166, p. 73, I984.

. [Reflexão] Pergunta. Senhor Vogue \#14, p. I07, I979.

Reflexos da informática: uma revolução que está isolando os "obscurantistas".

Senhor \#I40, p. 75, I983.

Relíquias africanas: com a exposição África Negra, o Masp presta sua homenagem ao centenário da Lei Áurea. Senhor \#372, p. 68, 1988.

Respeito à memória: o difícil trabalho de conservação dos centros históricos, um desafio para todas as cidades do mundo. Senhor \#278, p. 68, 1986.

Reunião do mestre distante: minibiografia afetiva de Lasar Segall e sua obra. Senhor \#249, p. 92, 1985.

Revisando a moral. Casa Vogue \#6, p. II4, 1986.

Revivals e Histerismo. Homem Vogue \#I6/A, p. 54-57, 1976.

Roteiro de uma ousadia: onde está a história da arte brasileira deste século?

Senhor \#238, p. 84, 1985 .

Rumo à maximetrópole: São Paulo tenta imaginar como vai ser sua cultura, no fim do século. Senhor \#I47, p. 65, I984.

Rumo às artes do Sul: na visão subjetiva dos artistas de Santa Catarina, a transformaçáo histórica da sua gente. Senhor \#347, p. 83, 1987.

. Salvar o Artesanato: na Europa ele está desaparecendo. No Brasil, resiste. Senhor Vogue \#12, p. 96, 1979.

São Jerônimo liberado: a restauraçáo de uma obra com cinco séculos de idade. Senhor \#2II, p. 68, 1985.

São José não é Canudos: visita à cidade onde Euclides escreveu Os Sertôes e construiu uma ponte. Senhor \#335, p. 84, 1987. 
. São Paulo, arte e futuro. Senhor \#I49, p. 9I, I984.

- Seara do colecionador: uma coleção de modernos, de Enrica Profili. Casa Vogue \#7, p. 84-87, I979.

Sem a ajuda dos críticos: as mil atividades do povo, decantadas pelos artistas de aldeia que agem simplesmente, dispensando os currículos. Senhor \#266, p. 76, I986.

Sem abstracionismos. Istoé \#44, p. 80, 1977.

. Sem mais problemas. Casa Vogue\#6, p. 98, 1984.

. [sem título: SP 200o]. Casa Vogue \#4, p. 50, 1984.

. [sem título]. Casa Vogue\#2, p. 68, 1984.

. Senhor e as arte eróticas: Pietro Maria Bardi tira o erotismo de seus envelopes plásticos. Senhor Vogue \#I7, p. IO3-II3, 1979.

. Senhor e as artes: dar crédito aos valores reais. Motivar os que podem e devem ajudá-los. Pensar Brasil. Senhor Vogue \#II, p. 85, 1979.

. Simbolismo, uma escola que sai do esquecimento: Acusada por algum tempo de ser uma cópia malfeita da Renascença, ela só recentemente foi ressuscitada pela crítica e pelo interesse do público. Senhor \#168, p. 72, 1984.

Só o futebol é que merece viajar? Senhor \#63, p. 64, 1982.

. Socorro ecológico: um banco, um poeta e um alerta sobre o Pantanal. Senhor \#257, p. 70, 1986.

Solidário às vaias: como Hugo Borger, diretor do museu de Colônia, o diretor do Masp é a favor do intercâmbio de exposiçóes. Senhor \#324, p. 68, 1987.

. Solidário às vaias: como Hugo Borger, diretor do museu de Colônia, o diretor do Masp é a favor do intercâmbio de exposiçóes. Senhor \#324, p. 68, 1987.

SOS Morumbi: do bairro que nasceu com vocaçã para santuário ecológico sobrou um bosque, onde queriam erguer uma delegacia. Senhor \#349, p. 84, 1987.

. Supermercado de arte. Senhor \#74, p. 68, 1982.

Surpresas nas edições de arte. Senhor \#I07, p. 64, I983.

. Também na meca do design. Senhor Vogue \#I3, p. II2, I979.

. Tambores internacionais: os milagres do Masp, uma sociedade sem fins lucrativos cercada de incompreensão e atacada pelos que justificam gastos públicos exagerados em promoçóes de pequena repercussão cultural. Senhor \#154, p. 96, I984.

. Tecidos que animam e complementam qualquer tipo de ambiente. Casa Vogue \#30A, p. 56-59, 1977.

. Telas que valem ouro: as companhias de seguro descobrem um belo negócio: o mercado de arte. Senhor \#33I, p. 84, 1987.

Tendências da panelinha. Senhor \#I74, p. 72, 1984.

. Tipografia, Design Nascente. Senhor Vogue \#I3, p. I2I, I979.

. TV e comunicação. Senhor Vogue \#I8, p. I07, 1979.

. Um apelo para manter a obra de Chateaubriand: aos 35 anos, o Masp deve continuar recebendo o apoio das classes produtoras, como acontece desde a sua fundação. Senhor \#56, p. 73, 1982.

. Um arquiteto de vanguarda. Senhor \#I5I, p. 67, I984. 
Um artista sem rótulos. Senhor \#164, p. 69, 1984.

. Um assalto estético: as chances do design brasileiro no mercado internacional. Senhor \#225, p. 72, 1985 .

Um balanço da vanguarda: o Chase Manhattan Bank e a renovação das artes plásticas. Senhor \#212, p. 75, 1985.

. Um colecionador autêntico. Senhor \#165, p. 68, 1984.

. Um contato com artes exóticas: na casa de uma designer. Casa Vogue \#2, p. 84-89, 1982 .

. Um convite à aventura: relato de uma viagem ao purgatório tropical. Senhor \#236, p. I24, 1985.

. Um convite à indigestão: a Bienal de São Paulo não imita mais Veneza. Imita a Alemanha. Senhor \#136, p. II8, I983.

. Um criador de imagens: a exposição de Wesley Duke Lee é um milagre no meio da infinidade de ofertas do mercado artístico. Senhor \#302-303, p. 68, 1986.

Um escândalo americano: um exemplo artístico do começo do século que deveria ser imitado nos nossos tempos de provocaçóes vazias. Senhor \#283, p. 68, 1986.

. Um estímulo à criação: a arte do design nos pequenos objetos. Senhor \#19I, p. 92, I984.

. Um faro infalível: histórias do maior editor da Itália. Senhor \#II8, p. 73, 1983.

. Um gesto iluminado: evocaçóes da participação fundamental de um empresário nos eventos culturais. Senhor \#275, p. 68, 1986.

. Um hobby histórico: os colecionadores de antiguidade e sua colheita minuciosa da peças esquecidas. Senhor \#279, p. 68, 1986.

Um homem cordial: a arte do encontro, segundo o embaixador Jayme de Barros. Senhor \#255, p. 95, 1986.

. Um modesto craque: a medalha de ouro da Itália, por benemerêncta cultural: uma vitória da obstinação e do trabalho. Senhor \#3II, p. 68, 1987.

. Um mundo em mudança: do abstrato ao concreto: desafios da arte contemporânea. Senhor \#256, p. 68, 1986.

. Um museu não pode abrigar só pinturas e esculturas: o sucesso da Feira de Trocas do Masp, em São Paulo, com sua exposição de quinquilharias e antiguidades. Senhor \#26, p. IIO-II3, I980.

. Um museu recém-nascido: a Propaganda não pode ser vista como uma arte "menor". Senhor \#I3I, p. 69, I983.

. Um nordeste menos autêntico: a qualidade da cerâmica popular começou a cair com o consumismo. Hoje, há exaustão de fontes anteriormente ativas e originais. Senhor \#49, p. 72, 198I.

Um paisagista em Curitiba: Paul Garfunkel reafirma, em nosso século, uma tradição artística que vem desde Maurício de Nassau e que se tomou, com o tempo, num importante patrimônio da História do Brasil. Senhor \#I25, p. 7I, I983.

. Um passeio pelo Brasil: fotos tiradas antes de 1900 revelam um país desconhecido. Senhor \#222, p. 76, 1985 .

. Um pintor da aventura humana. Senhor \#II2, p. 73, 1983. 
. Um prédio para ser visto. Senhor Vogue \#I2, p. 93-95, I979.

. Um projeto polêmico de Ugo di Pace. Casa Vogue \#38A, p. 84-87, 1978.

. Um pulo internacional: ecos da Escola de Pans, na exposição do Masp. Senhor \#194, p. 76, 1984 .

. Um resgate polêmico: restaurar obras de arte incomoda sempre os conservadores. Mas o processo é irreversível. Senhor \#273, p. 68, 1986.

. Um sarau na Alemanha: obras de artistas brasileiros viajam graças ao apoio de uma empresa que já aplica a Lei Sarney. Senhor \#287, p. 76, 1986.

. Um tempo de dúvidas: a verdadeira sensibilidade artística sofre a imposição da ideologia da modernidade. Senhor \#357, p. 8I, I988.

. Um terremoto artístico: memórias da Trienal Internacional de Milão. Senhor \#232, p. I00, 1985 .

. Um vôo pela memória: de Bartolomeu de Gusmão a uma precursora crônica em defesa do aeroporto de Cumbica. Senhor \#338, p. 84, 1987.

. Uma antiga amizade: a participação da Itália na construção do Brasil. Senhor \#265, p. 68, 1986.

. Uma arquitetura exemplar: bons exemplos de design num supermercado de São Paulo. Senhor \#237, p. 80, 1985.

. Uma arquitetura mais rude. Senhor Vogue \#I2, p. 90-9I, 1979.

. Uma arquitetura tropical. Senhor \#89, p. 76, 1982.

. Uma arte amazônica: um livro sobre o Museu Goeldi, de Belém, para os brasileiros conhecerem melhor seus mistérios. Senhor \#297, p. 92, 1986.

Uma arte quase secreta. Senhor \#I24, p. 65, I983.

. Uma árvore na horta: o mercado de arte no Brasil precisa de uma publicação especializada de interesse público. Senhor \#I46, p. 64, 1984.

. Uma aventura indispensável: a história de um empréstimo em Nova York. Senhor \#207, p. 65, 1985.

. Uma chance para dois estilos: quem se interessa por enfeites decorativos antigos? Senhor \#152, p. 67, 1984 .

. Uma chuva de homenagens: agradecimentos de um paulista assumido no mês do seu aniversário. Senhor \#206, p. 8I, 1985.

. Uma convidada especial: ela se chama propaganda. Começou a ser ensinada no Masp e estará na festa de seu quadragésimo aniversário. Senhor \#307, p. 65, 1987.

. Uma decisão política: reflexões sobre a candidatura Ermírio de Moraes. Senhor \#264, p. 76, 1986.

. Uma difícil missão: a Bienal de Arte de São Paulo carece de uma revolução que Alex Periscinoto terá de realizar. Senhor \#364, p. 65, 1988.

. Uma dupla muito agitada. Senhor \#81, p. 73, 1982.

. Uma exposição: tempo Livre. Senhor Vogue \#15, p. I06, I979.

. Uma Feira precipitada. Senhor \#I06, p. 68, I983.

. Uma história contada de modo diferente. Senhor Vogue \#II, p. 86-95, 1979.

. Uma injeção publicitária: a campanha da DPZ para o Masp: a confluência de atividades comuns no território da arte. Senhor \#274, p. 68, 1986. 
. Uma nova correspondência: nas cartas a Oneyda Alvarenga, as idéias de Mário de Andrade sobre as artes plásticas. Senhor \#130, p. 93, 1983.

. Uma nova pedra: uma resposta a cartas apócrifas cheias de acusaçôes. E uma advertência. Senhor\#203, p. 76, 1985 .

Uma nova política cultural. Senhor \#88, p. 76, 1982.

. Uma nova ruptura: copiar velhas vanguardas é academismo barato. Mas optar pelo figurativo pode ser um gesto polêmico. Senhor \#272, p. 65, I986.

. Uma obra de arte que você só vê pela TV: uma rotina: obras como Itaipu ficam escondidas dos olhos do público. Senhor Vogue \#12, p. 86-87, 1979.

. Uma pesquisa difícil: enquanto a pintura provoca delírios, a escultura continua quase esquecida, reservada apenas aos monumentos públicos e às recordaçóes funerárias. Senhor \#50, p. 72, 1982.

. Uma profissão sem diploma. Senhor \#137, p. 71, 1983.

. Uma questão de prestígio: As viagens internacionais do acervo do Masp. Senhor \#159, p. 89, I984.

. Uma realidade indigesta: o pioneirismo do Masp no esforço de mostrar a arte brasileira no que ela tem de mais contundente e representativo. Senhor \#248, p. 122,1985 .

. Uma saída criativa: o trabalho cultural aos publicitários. Senhor \#229, p. 8I, I985.

. Uma semente no Recife: o papel dos museus nas invençōes culturais. Senhor \#277, p. 68, 1986 .

. Uma síntese da gravura: o gesto criador de uma arte múltipla. Senhor\#199, p. 73, 1985 .

Uma tela esfaqueada: as relações entre as vanguardas e a pintura regional. Senhor \#258, p. 97, 1986.

Uma visão científica da arte. Senhor\#II3, p. 71, 1983.

Uma visita de Leonardo: a IBM anfitriona o comovente encontro de um gênio do passado com a alta tecnologia de hoje. Senhor \#322, p. 68, 1987.

. Usuários falando do Sesc. Senhor Vogue \#15, p. 106, 1979.

. Vanguarda: o Brasil na trincheira: uma infiltração de jovens artistas em Nova York. Senhor \#127, p. 85, 1983.

Vantagens do mecenato. Senhor \#66, p. 65, 1982.

Vênus na casa de massagem. Senhor \#95, p. 64 - 65, 1983.

Verde. Istoé\#32, p. 57, 1977.

Vestir com liberdade: da tragédia do colarinho à democracia dos jeans. Senhor \#122, p. 73, 1983.

Viajando em casa. Senhor Vogue \#15, p. I03, 1979.

. Visita a um antiquário. Casa Vogue\#3, p. I20-I2I, 1982.

Wesley: gráfico e pintor extravagante, cada vez que o artista deseja marcar sua presença ele o faz com uma surpresa. Senhor Vogue \#I4, p. 95-98, 1979.

BARDI, Pietro Maria; CELIDÔNIO, José Hugo. Histórias de um namoro que deu certo: a presença cultural da Rhodia. Senhor Vogue \#7, p. 98-105, 1978. 
CAMPOS, Francisco de Paula Machado de. Tecnologia vai ao povo. Através de um Museu. Senhor Vogue \#13, p. II5, 1979.

CARTA, Andrea. O pequeno grande museu construído em 20 anos. Casa Vogue \#I, p. $82-87,1982$.

CARTA, Luis. De Carta para Bardi. Vogue Brasil\#II5, p. II5, I985. Ponto de Vista. Casa Vogue \#28A, p. 51, 1977. . Ponto de Vista: De liberalismo, Ironia, Arte. Senhor Vogue \#II, p. 47, 1979.

CARTA, Mino. A memória de Bardi: O Brasil silencia a respeito de quem doou um tesouro de valor inestimável ao País. Ou relega ao esquecimento. Carta Capital \#799, p. Editorial 2, 20II. Disponível em <http://www.cartacapital.com.br/ cultura/a-memoria-de-bardi> Acesso em I5 dez. 2013.

. Merlin, digamos, tinha os olhos de Bardi. Vogue Brasil\#II5, p. I4O-I4I, I985.

CELIDÔNIO, José Hugo. Problemas comuns, soluçóes artísticas originais. Senhor Vogue \#7, p. IOO, IO2, 1978.

CHARTUNI, Maria Helena. O paciente orientador. Vogue Brasil \#115, p. I47, I985.

CHITI, Carlos. Forma, material e cor. Senhor Vogue \#I3, p. II7, I979.

DUCLÓS, Nei. Os novos ídolos das mulheres. Senhor \#194, p. 68-69, 1984.

. Um investimento garantido: Empresários e políticos descobrem o óbvio: financiar obras de interesse cultural dá lucro. Senhor \#60, p. 64, 1982.

ESMERALDO, Eugênia Gorini. Faz e fez tanto que só falta virar enredo de escola de samba. Vogue Brasil \#115, p. 154, 1985.

Giannino Carta. O Estado de S.Paulo, 3I out. 1964, p.8.

HEINIGER, Andreas. As aventuras de Diana para chegar no seu lugar. Vogue Brasil \#II5, p. 159,1985 .

Os objetos que cumprem seu destino. Vogue Brasil \#II5, p. I58, 1985.

JORDAN, Fred. Todas as intençôes do envelope. Senhor Vogue \#13, p. I20, 1979.

JUNIOR, Francisco Augusto Semeraro. Os riscos de um design ausente. Senhor Vogue \#iz, p. II6, I979.

JUPIASSU, Moacir. Masp: Trinta anos ao lado de Pietro Bardi. Istoé\#45, p. 59, 1977.

KLINTOWITZ, Jacob. Levantando a saia da Semana de 22: Pietro Maria Bardi lança mais dúvidas sobre o "modernismo". Istoé \#III, p. 40-4I, I979.

. Masp, o número um do Brasil. Vogue Brasil\#II5, p. I38-139, I985.

. Nos museus, os verdadeiros tesouros: Inclusive aqui no Brasil. Tanto que o mestre Bardi acaba de ganhar mais um prêmio. Senhor \#36, p. I5, I98I.

LEON, Ethel. IAC Instituto de Arte Contemporânea: Escola de Desenho Industrial do Masp (195I-I953): Primeiros estudos. Dissertação (Mestrado). Faculdade de Arquitetura e Urbanismo da Universidade de São Paulo, São Paulo : FAUUSP, 2006.

LEVY, Sônia. O homem é o fim. Senhor Vogue \#I3, p. II2, I979.

LIMA, Jorge Cunha. Senhor: entre o poder e a realidade. Senhor Vogue \#Io, p. 98, I979. 
MADIA DE SOUZA, Francisco Alberto. De feminismo e Senhor. Senhor Vogue \#15, p. 29, I979.

MARANHĀO, Carlos. Memórias de um editor. Veja \#2324, p. 94-IOI

MORTEO, Enrico. Roberto Sambonet: do Brasil ao design. A experiêcia do MASP entre Brasil e Itália. In: São Paulo : FAUUSP: [s.n.], 2009.

MOURA, Lais. Presença do design na Bienal. Senhor Vogue \#I3, p. I20, I979.

PAIVA, José Luiz de Paula. Embalagem, um mundo. Senhor Vogue \#13, p. II4, I979.

PARRELLA, Lew. Lew Parrella apresenta o niverso do Professor Pietro Maria Bardi. Casa Vogue \#32A, p. 24-33, 1978.

PAVAM, Rosane. Pintura e Resistência. Carta Capital, I2 ago. 201 I.

REQUIXA, Renato. Defendendo uma política nacional do lazer. Senhor Vogue \#15, p. 97-99, 1979.

SIROTSKY, Nahum. Nascimento, vida e paixão de SR. Senhor Vogue \#I, p. 76-79, 1976.

SOARES, Dulce. Documento, a vida num álbum de família. Senhor Vogue \#I2, p. 92, I979.

SOARES, Edimar. Um pintor inédito: Rosário Bernaudo. Senhor Vogue \#I4, p. 99-100, I979.

STOLARSKI, André. Design e arte: campo minado. Uma antologia de discursos comentados e uma proposta disciplinar. Dissertação (Mestrado). Faculdade de Arquitetura e Urbanismo da Universidade de São Paulo, São Paulo : FAUUSP, 2012.

TENTORI, Francesco. P.M.Bardi: com as crônicas artísticas do "L’Ambrosiano" I9301933. Trad. Eugênia Gorini Esmeraldo. São Paulo: Instituto Lina Bo e P.M.Bardi : Imprensa Oficial do Estado, 2000.

\section{Entrevistado}

Mino Carta, em São Paulo, II de fevereiro de 2014. 